

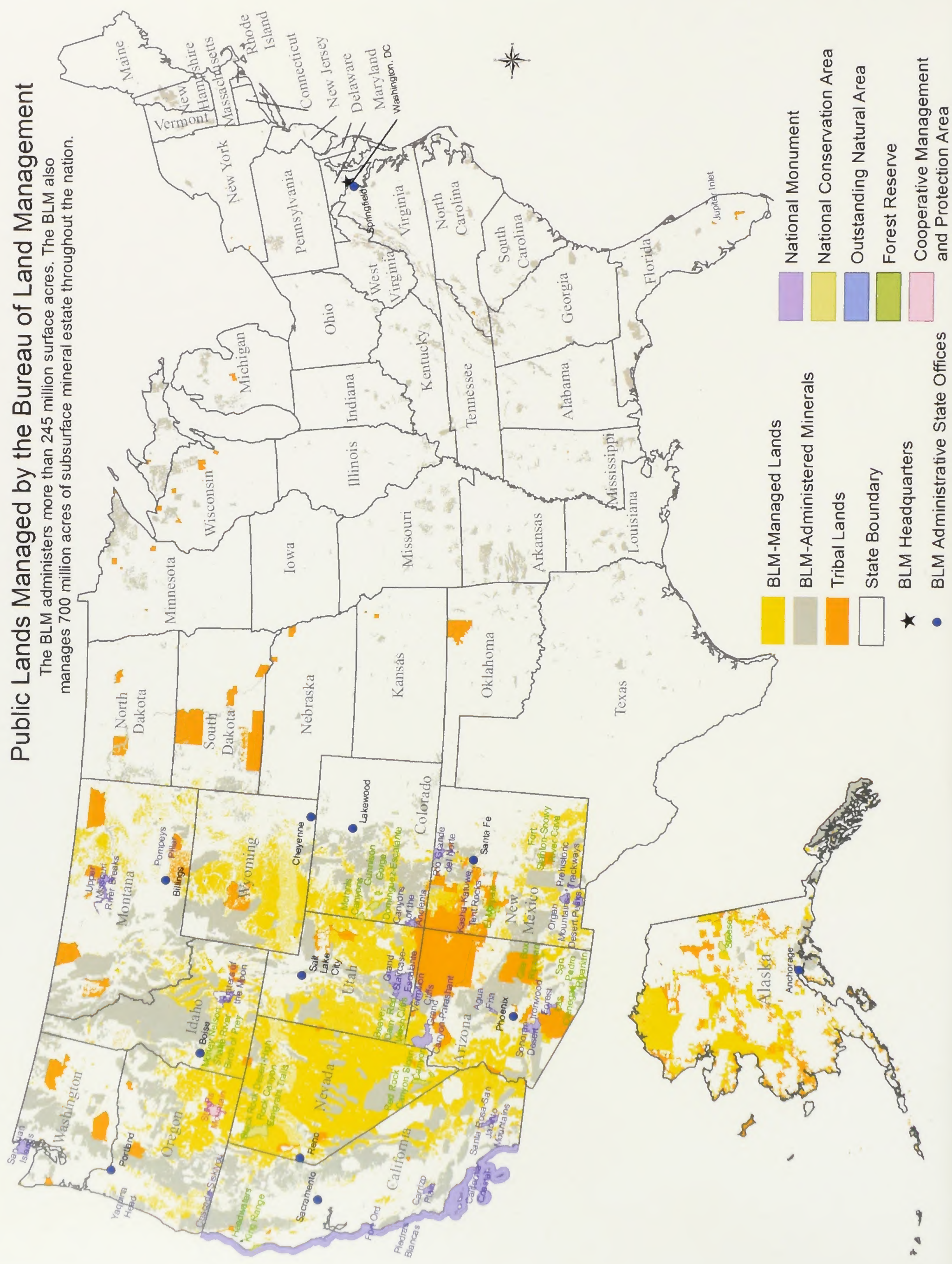




\section{Biological Assessment for Vegetation Treatments Using Aminopyralid, Fluroxypyr, and Rimsulfuron on Bureau of Land Management Lands in 17 Western States}

U.S. Department of Interior

Bureau of Land Management

Washington, D.C.

April 2015

BLM Library

Denver Federal Center

Bldg. 50, OC-521

P.O. Box 25047

Denver, CO 80225 


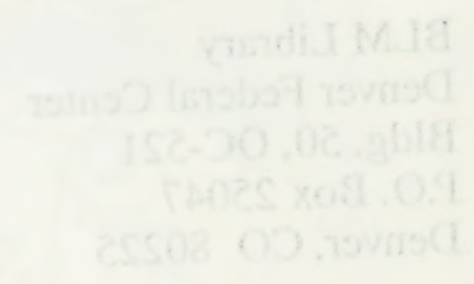




\section{TABLE OF CONTENTS}

Page

INTRODUCTION

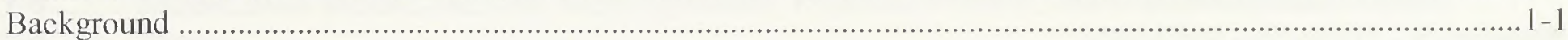

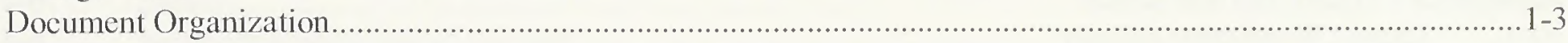

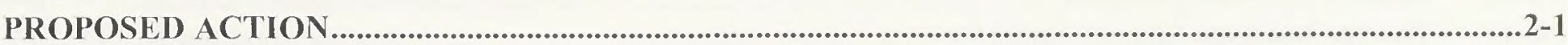

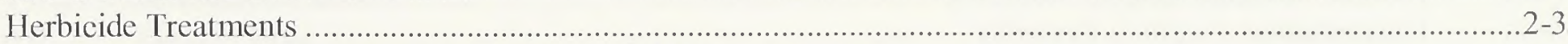

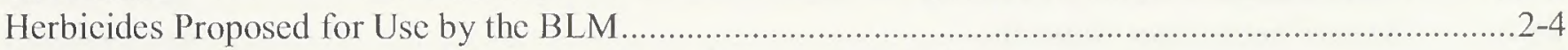

Herbicide Treatment Standard Operating Procedures and Guidelines .............................................2-4

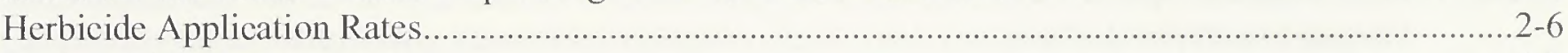

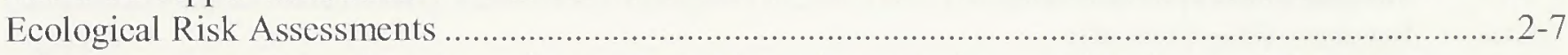

Adjuvants, Degradates, Inert lngredients, Tank Mixes, Formulations, and Endocrine Disrupting

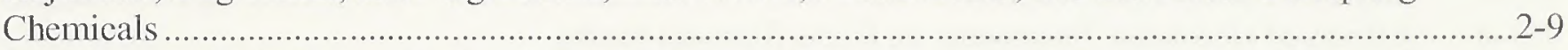

Procedures to be Followed by Local Field Offices to Protect Species of Concern from Herbicide

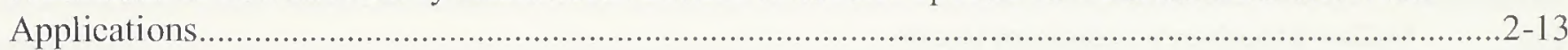

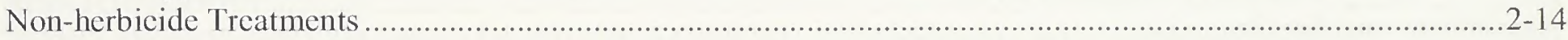

SPECIAL STATUS SPECIES MANAGEMENT CONSULTATION PROTOCOL .................................3-1

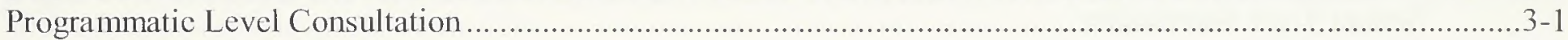

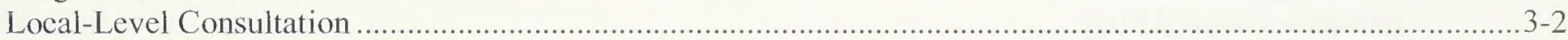

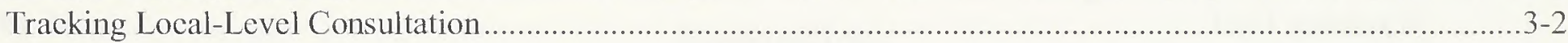

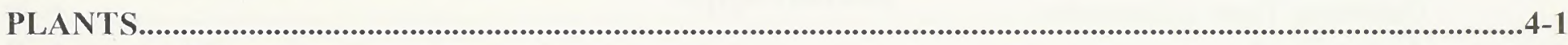

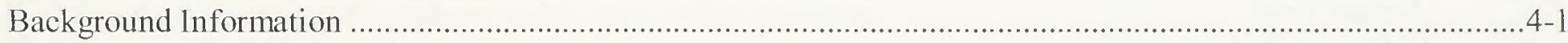

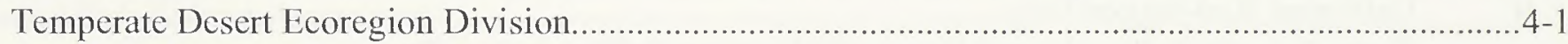

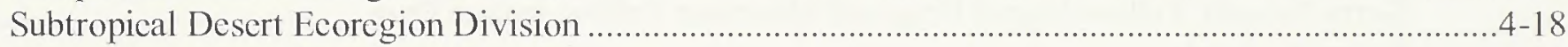

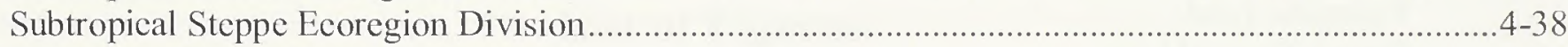

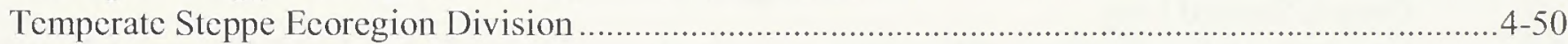

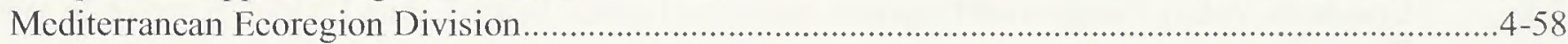

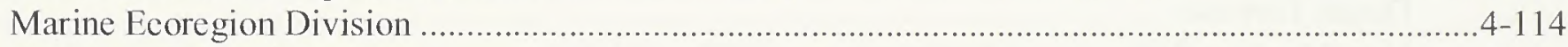

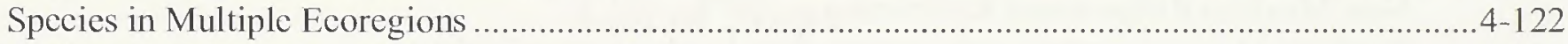

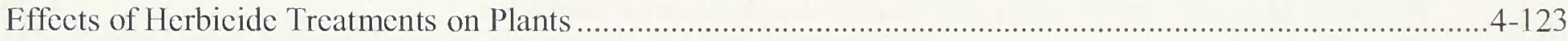

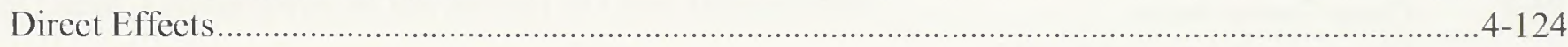

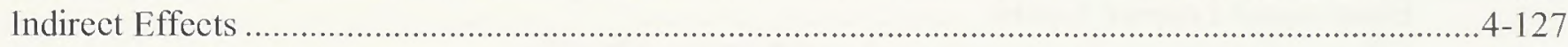

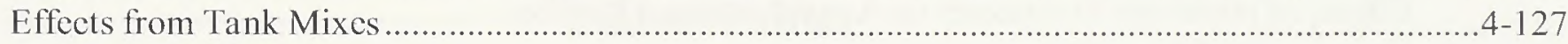

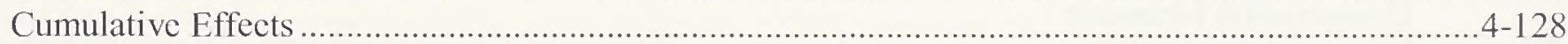

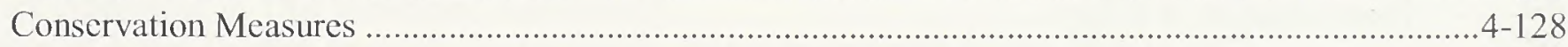

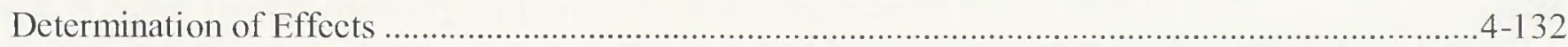

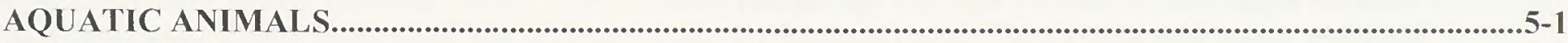

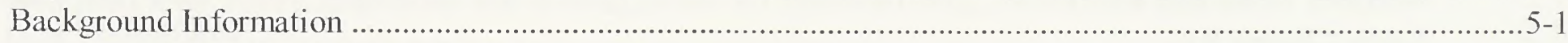

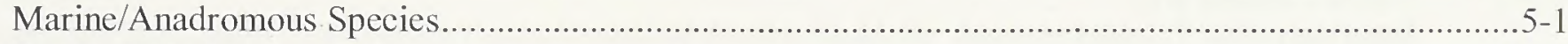

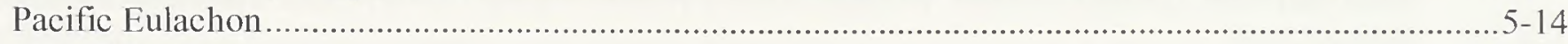

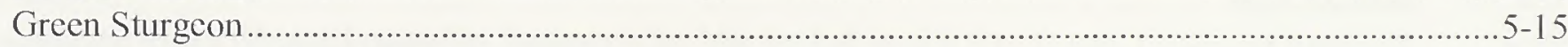

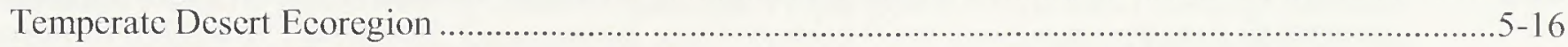

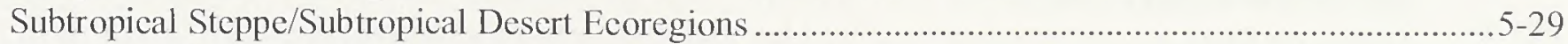

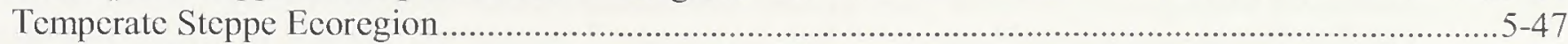

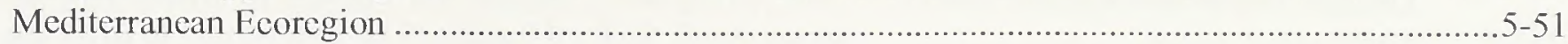

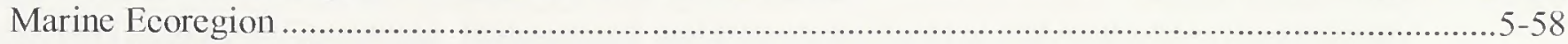

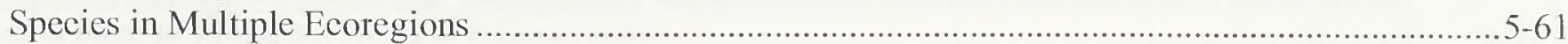

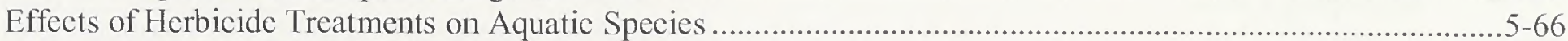

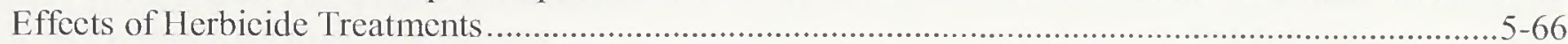

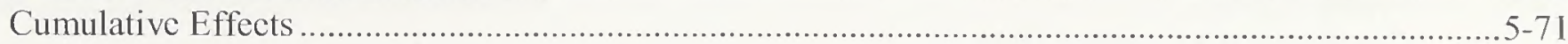


Conservation Measures

Determination of Effeets

TERRESTRIAL ANIMALS.

Terrestrial Mollusks

Morro Shoulderband Snail

Arthropods - Butterflies and Moths .

Carson Wandering Skipper

Pawnee Montane Skipper Butterfly

Uncompahgre Fritillary Butterfly

Quino Checkerspot Butterfly.

Kern Primrose Sphinx Moth.

Oregon Silverspot Butterfly

Fender's Blue Butterfly

Taylor's Cheekerspot Butterfly

Effects of Herbicide Treatments on Butterflies and Moths ................................................6. 611

Arthropods - Other Terrestrial lnsects ..................................................................................6-13

Valley Elderberry Longhorn Beetle ......................................................................6-13

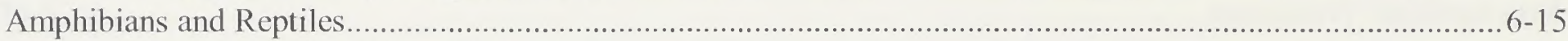

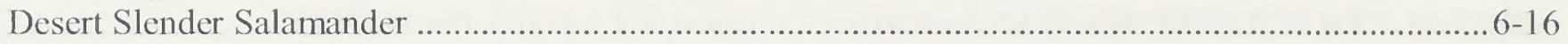

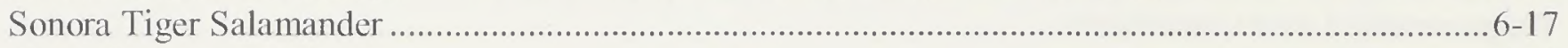

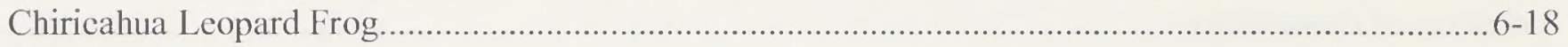

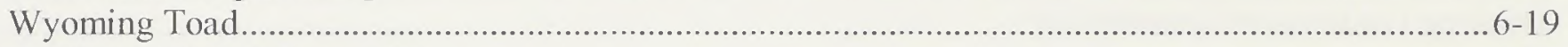

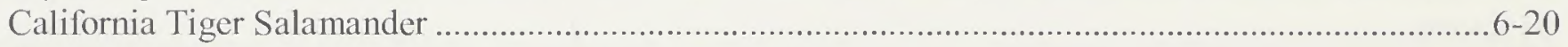

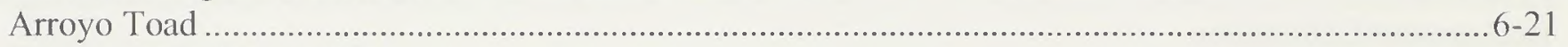

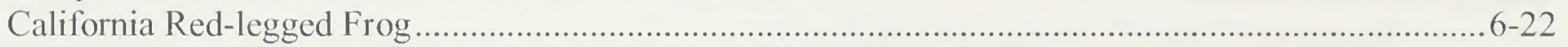

Sierra Nevada Yellow-legged Frog and Mountain Yellow-legged Frog........................................6-23

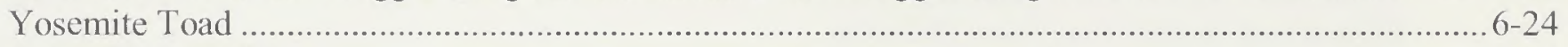

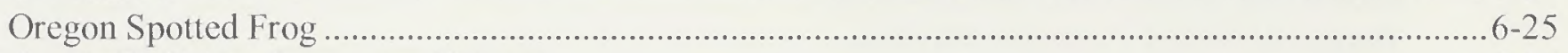

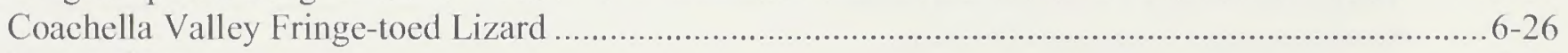

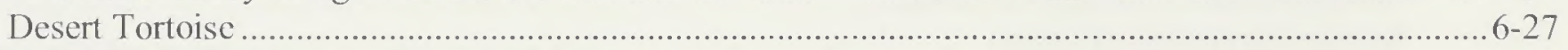

New Mexican Ridge-nosed Rattlesnake................................................................6-28

Northern Mexican Garter Snake and Narrow-headed Garter Snake .............................................6-28

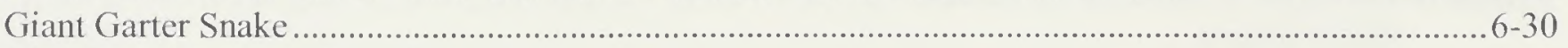

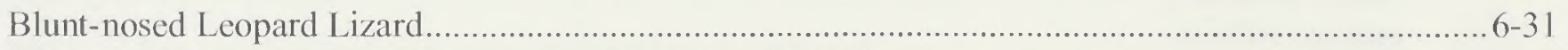

Effects of Herbicide Treatments on Amphibians and Reptiles .................................................6.32

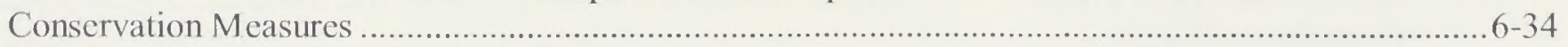

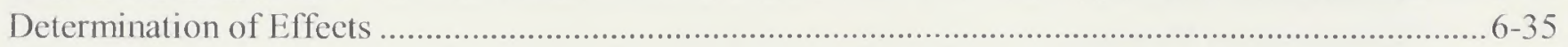

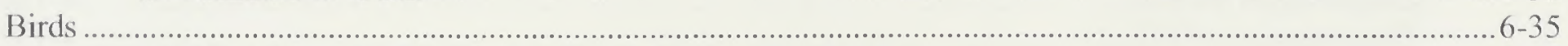

Alaskan Waterfowl: Steller's Eider and Spectacled Eider ...............................................6-36

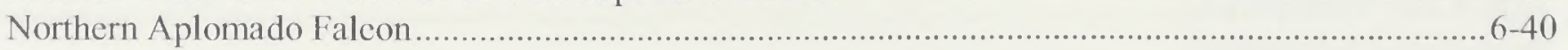

Yuma Clapper Rail .............................................................................................6-42

Sand and Bare Ground Nesters: Western Snowy Plover, Piping Plover, Least Tern, and Streaked Horned Lark ..................................................................................................6.4.

Riparian Species: Least Bell's Vireo, Inyo California Towhee, Southwestern Willow Flyeatcher,

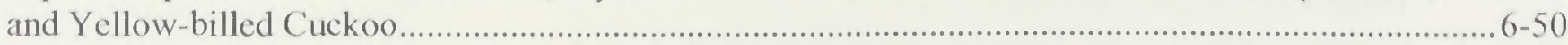

Gunnison Sage-grouse, Greater Sage-grouse, and Lesser Prairie-chicken.....................................6-55

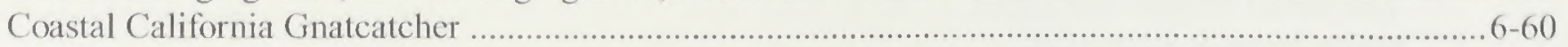

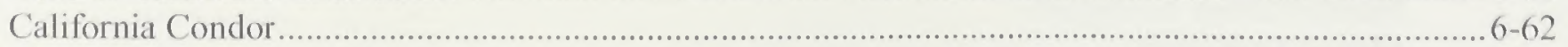

Mature-forest Nesters: Marbled Murrelet, Northern Spotted Owl, and Mexican Spotted Owl............6-64

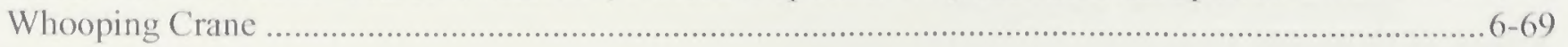

Mammals.

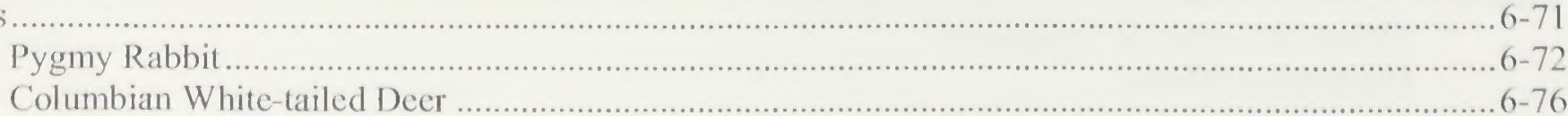




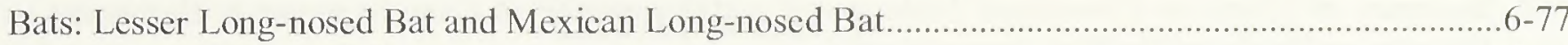

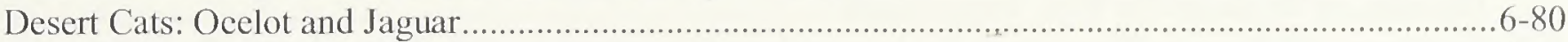

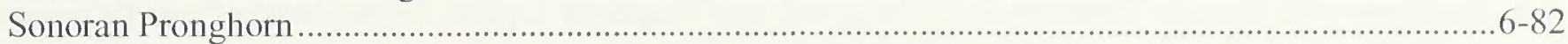

Small Wetland Mammals: Hualapai Mexican Vole, Amargosa Vole, Preble's Meadow Jumping

Mouse, New Mexico Meadow Jumping Mouse, Riparian Woodrat, and Buena Vista Lake Ornate

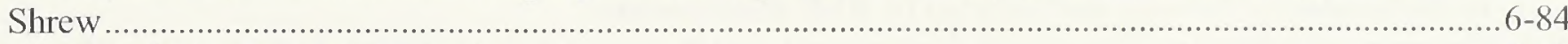

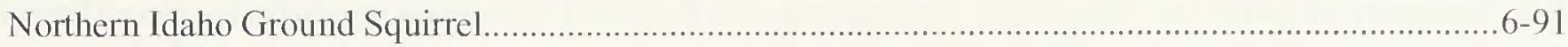

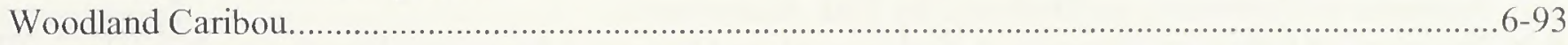

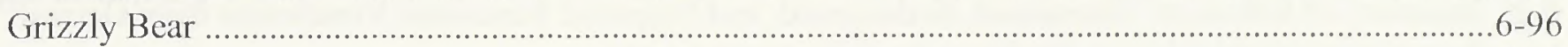

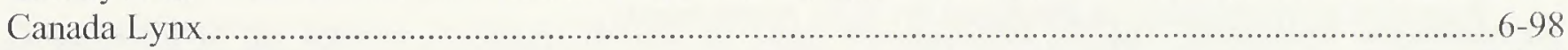

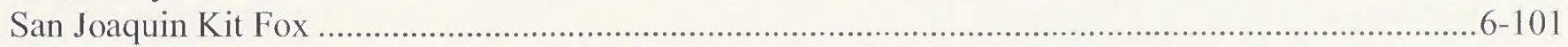

Grassland Ground-Burrowing Mammals: Kangaroo Rats, Utah Prairic Dog, and Black-footed

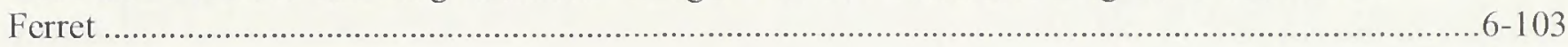

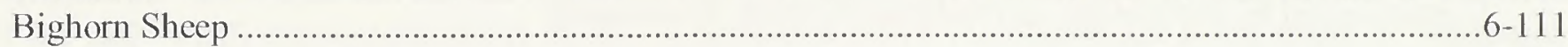

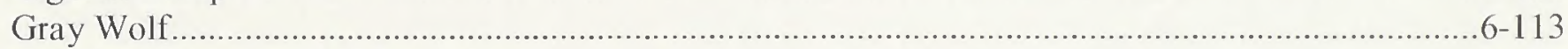

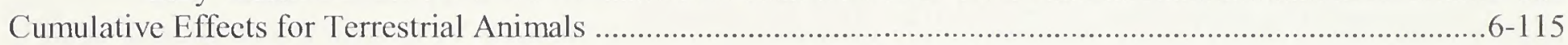

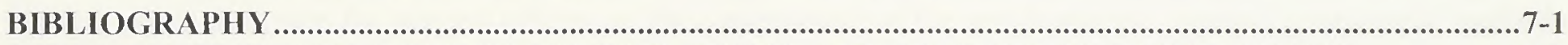

INDEX OF SPECIES COVERED IN THE BIOLOGICAL ASSESSMENT BY COMMON NAME ..................8-1

INDEX OF SPECIES COVERED IN THE BIOLOGICAL ASSESSMENT BY SCIENTIFIC NAME ...............9-1

\section{Appendices}

A Standard Operating Procedures and Conservation Measures ................................................................

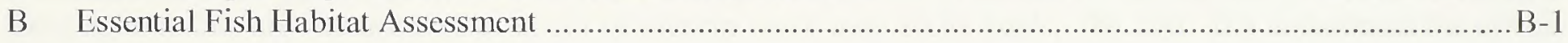

\section{List of Figures}

2-1 Number of Acres of Public Lands Treated Using Herbicides during 2006 to 2012.

\section{List of Maps}

1-1 Public Lands Administered by the Bureau of Land Management

\section{List of Tables}

1-1 Species Addressed in This Biological Assessment

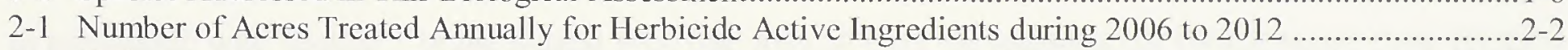

2-2 Herbicides Characteristies, Target Vegetation and Projected Future Use (as a pereentage of all acres treated), and Areas Where Registered Use is Appropriate for Aminopyralid, Fluroxypyr, and Rimsulfuron

2-3 Typical and Maximum Application Rates ldentified by the BLM for Aminopyralid, Fluroxypyr, and Rimsulfuron

2-4 Formulations of the Three Herbicides Proposed for Use on Public Lands

4-1 Summary of Effeets to Threatened, Endangered, and Proposed Plant Species as a Result of Off-site Drift from Aerial Applications of Herbicides, as Predicted by Risk Assessments.....

4-2 Summary of Effects to Aquatic Threatened, Endangered, and Proposed Plant Species as a Result of Off-site Drift of Herbicides, as Predicted by Risk Assessments

4-3 Summary of Effects to Threatened, Endangered, and Proposed Plants as a Result of Surface Runoff of Herbicides, as Predicted by Risk Assessments

5-1 Summary of Effects to Threatened, Endangered, and Proposed Fish From Exposure to Herbicides in Ponds, as Predicted By Risk Assessments .... 
5-2 Summary of Effects to Threatened, Endangered, and Proposed Fish From Exposure to Herbicides in Streams, as Predicted By Risk Assessments

5-3 Summary of Effeets to Threatened, Endangered, and Proposed Aquatie Invertebrates From Exposure to Herbicides in Ponds, as Predieted By Risk Assessments

5-4 Summary of Effects to Threatened, Endangered, and Proposed Aquatic Invertebrates From Exposure to Herbicides in Streams, as Predicted by Risk Assessments

6-1 Summary of Effects to Threatened, Endangered, and Proposed Terrestrial Invertebrates from Dermal Exposure to Herbieides, as Predicted By Risk Assessments

6-2 Summary of Effects to Threatened, Endangered, and Proposed Terrestrial Vertebrates from Dermal Exposure to Herbicides, as Predicted By Risk Assessments

6-3 Summary of Effects to Threatened, Endangered, and Proposed Herpetofauna from Ingestion of Food Contaminated by Herbicides, as Predicted By Risk Assessments.

6-4 Summary of Effects to Threatened, Endangered, and Proposed Birds from Ingestion of Food Contaminated by Herbicides, as Predicted By Risk Assessments

6-5 Summary of Effeets to Threatened, Endangered, and Proposed Mammals From Ingestion of Food Contaminated by Herbicides, as Predicted by Risk Assessments 


\section{CHAPTER 1}

\section{INTRODUCTION}

\section{Background}

The U.S. Department of the Interior (USDOI) Bureau of Land Management (BLM) administers vegetation on approximately 247 million aeres in 17 states in the western U.S., ineluding Alaska (Map 1-1). In 2007, the BLM published the Vegetation Treatments Using Herbicides on Bureau of Land Management Lands in 17 Western States Programmatic Environmental Impact Statement (2007 PEIS; USDOI BLM 2007a). The Reeord of Deeision (ROD) for the 2007 PEIS allowed the BLM to use 18 herbieide aetive ingredients for a full range of vegetation treatments in 17 western states (USDOI BLM 2007b). The BLM also prepared a Vegetation Treatments on Bureau of Land Management Lands in 17 Western States Programmatic Environmental Report (2007 PER; USDOI BLM 2007e), whieh diselosed the general effeets on the environment of the non-herbieide vegetation treatment methods that the BLM uses to manage vegetation: fire use, meehanieal methods, manual methods, and biologieal eontrol. BLM treatment programs utilize a eombination of these methods to treat hazardous fuels, invasive speeies, and other unwanted or eompeting vegetation.

In 2007, the Biological Assessment for Vegetation Treatments on Bureau of Land Management Lands in 17 Western States (2007 BA; USDOI BLM 2007d) was prepared to analyze the effeets of proposed BLM vegetation treatments on Endangered Speeies Aet (ESA)-listed speeies, speeies proposed for listing, and/or eritieal habitat for these speeies that are doeumented or eould be present on or near BLM lands. The 2007 BA eonsidered the effeets of the proposed herbieide treatments, as well as non-herbieide treatments, on 319 plant and animal speeies. All of the 2007 doeuments are available on the BLM's website at http://www.blm.gov/wo/st/en/prog/more/veg_eis.html.

Currently, the BLM is proposing to add the aetive ingredients aminopyralid, fluroxypyr, and rimsulfuron to its list of approved aetive ingredients for use on publie lands. These herbieides would be integrated into the vegetation treatment programs that were assessed in the $2007 \mathrm{BA}$. The total aereage of land treated using herbieides would remain within the limits speeified in the 2007 PEIS and BA. In aeeordanee with the protoeol speeified in the ROD, Eeologieal Risk Assessments (ERAs) have been prepared for the three aetive ingredients proposed for use, and the BLM is preparing the Vegetation Treatments Using Aminopyralid, Fluroxypyr, and Rimsulfuron on Bureau of Land Management Lands in 17 Western States Programmatic Environmental Impact Statement (2015 PEIS) to evaluate the potential effeets of these ehemieals as part of the BLM's vegetation treatment programs.

In aeeordanee with Seetion 7 of the federal ESA (the Aet) of 1973, as amended (19 United States Code [U.S.C.] 1536 [e], 50 Code of Federal Regulations [CFR] 402.14[e]), federal ageneies must "insure that any aetion authorized, funded, or earried out by sueh ageney is not likely to jeopardize the eontinued existenee of any listed speeies or result in the destruetion or adverse modifieation of eritieal habitat of sueh speeies." The purpose of the Aet is to provide a means for eonserving the eeosystems upon whieh threatened and endangered speeies depend, and to provide a program for proteeting these speeies. Under Seetion 7 of the ESA, federal ageneies are required to consult with the U.S. Fish and Wildlife Serviee (USFWS) and/or National Oeeanie and Atmospherie Administration National Marine Fisheries Serviee (NMFS; eolleetively the Serviees) to: 1) determine what speeies and eritieal habitats eould be affeeted by the aetion; 2) determine what effeet the aetion may have on these speeies or eritieal habitats; 3 ) explore ways to modify the aetion to reduee or remove adverse effeets to the speeies or eritieal habitats; 4) determine the need to enter into formal eonsultation for listed speeies or designated eritieal habitats, or eonferenee for proposed speeies or proposed eritieal habitats; and 5) explore the design or modifieation of an aetion to benefit the speeies. When a federal ageney's aetion "may affeet" a proteeted speeies, that ageney is required to eonsult formally with USFWS or NMFS, depending on the partieular endangered speeies, threatened speeies, or designated eritieal habitat that may be affeeted by the aetion. Federal ageneies are exempt from this 
general requirement if they have concluded that an action "may affect but is not likely to adversely affect" endangered species, threatened species, or designated critical habitat, and the Services concur with that conclusion.

As part of this process, federal agencies are required to prepare a BA for major federal actions that modify the physical environment. Because BLM vegetation treatment activities using aminopyralid, fluroxypyr, and rimsulfuron have the potential to modify the physical environment, this programmatic BA was prepared to analyze the potential effects to federally listed threatened and endangered species, and species proposed for listing, and their critical habitats as a result of vegetation treatments using these herbicides. This BA will be used by the Services to facilitate compliance with the requirements of Section 7 of the ESA.

The ESA defines an endangered species as a species that is in danger of extinetion throughout all or a major portion of its range. A threatened species is defined as any species that is likely to become an endangered species within the foresecable future throughout all or a major portion of its range. This BA also address species that have been proposed for listing as either threatened or endangered, but for which a final determination has not been made. Critical habitat is a specific area or type of area that is considered to be essential for the survival of a species, as designated by the Services under the ESA.

This BA addresses the potential impacts to federally listed threatened and endangered species, and species proposed for listing, as a result of herbicide treatments using aminopyralid, fluroxypyr, or rimsulfuron. Potential impacts associated with the 18 previously approved herbicides, as well as potential impacts associated with nonherbicide treatments, are not included in the action eovered under this BA. However, these impacts have been eonsidered as part of the cumulative effects analyses presented in this BA.

The BA also complies with several other rules and regulations that govern threatened and endangered species. These include the Fish and Wildlife Conservation Act of 1980, which cncourages federal agencies to conserve and promote the conservation of non-game fish and wildlife species and their habitats. Executive Order 13186, Responsibilities of Federal Agencies to Protect Migratory Birds, requires that federal agencies that have, or are likely to have, a measurable adverse effect on migratory bird populations develop a Memorandum of Understanding with the USFWS that shall promote the conservation of migratory bird populations. If the USFWS determines that migratory birds could be harmed by BLM vegetation treatment actions, the two agencies would develop a site-specific assessment and mitigation to prevent harm to these birds. The Bald Eagle Protection Act, passed by Congress in 1940, prohibits the take, possession, sale, purchase, barter, or offer to sell, purchase, or barter, export, or import of bald eagles at any time or in any manner. In 1962, Congress amended the Eagle Act to cover golden eagles. The Sikes Act authorizes the USDOI to plan, develop, maintain, and coordinate programs with state agencies for the conservation and rehabilitation of wildlife, fish, and game on public lands. Agency-wide guidance in the protection and management of species of concern, and consultation requirements, is given in $B \boldsymbol{L} \boldsymbol{M}$ Manual 6840 (Special Status Species).

The purposes of this BA are to:

- Evaluate the effects of herbicide treatments with aminopyralid, fluroxypyr, or rimsulfuron on listed species, species proposed for listing, and/or eritical habitat for these species that are documented or could be present within the project area. These effects are being considered as part of this consultation with the Services for herbicide treatment activities at the programmatic level.

- Determine the need for consultation and conference with the Services.

- Meet the requirements of the ESA and the National Environmental Policy Act (NEPA, 42 U.S.C. 4321 et seq., implemented at 40 CFR parts 1500-1508).

- Ensure that the BLM recovers or maintains populations of listed species or species proposed for listing that occur on public lands by outlining conservation measures and standard operating procedures (SOPs) for groups of species that react similarly to vegetation treatments with the new herbicides proposed for use. 
An important overriding assumption of the BA is that each site-specific action that could occur under the proposed action will be analyzed as required by NEPA and the ESA, and that there will be compliance with all federal laws during implementation of the project. Since the 2015 PEIS is programmatic in nature, it does not authorize a specific commitment of resources. Therefore, local-level consultation with the Services is necessary for proposed site-specific activities with a project area that overlaps with one or more listed species. The procedures that the BLM field offices would follow during local-level consultation are summarized in Chapter 3.

During January 2013, the BLM held three public scoping meetings in the western U.S.: in Worland, Wyoming, Reno, Nevada, and Albuquerque, New Mexico. The public scoping period ran from December 21, 2012 through February 19, 2013. During this period, the public commented on issues related to the proposed vegetation treatment activities, including the potential effects of treatments on threatened and endangered species, and species proposed for listing. These comments were summarized in a Scoping Summary Report for the Vegetation Treatments Using Aminopyralid, Fluroxypyr, and Rimsulfuron on Bureau of Land Management Lands in 17 Western States Programmatic Environmental Impact Statement in November 2013 (AECOM 2013).

Ecological risk assessments were prepared for aminopyralid, fluroxypyr, and rimsulfuron, in accordance with the final ERA protocol (ENSR 2004) that was developed by the BLM in coordination with the U.S. Environmental Protection Agency (USEPA), USFWS, and NMFS. Risk assessments were completed in February 2014. Information from the ERAs is included in this BA, including information on likely risks to threatened and endangered species and species proposed for listing (TEP species), and on recommended minimization measures for reducing these risks.

The species addressed in this BA were identified by Endangered Species Coordinators at BLM offices serving each of the 17 states included in the project area. Species included on these lists are TEP species that are known to be located or could potentially be located on public lands, or that could be affected by activities oceurring on public lands. In addition, listed species with designated critical habitat that occurs on public lands or that could be affected by activities occurring on public lands have been ineluded. Although the BLM administers land along the Pacific coast, marine species have not been included in this programmatic BA. The BLM does not propose to treat lands adjacent to the coast with herbicides under its vegetation management programs. Should there be a site-specific need for herbicide treatment in a coastal area in the future, potential effects on marine species would be addressed during local-level consultation.

A total of 341 species or subspecies of plants and animals (including populations that are treated separately) are addressed in this BA, including federally listed species, and speeies proposed for listing. Critical habitat has been designated for 175 of these species, and proposed for 14 additional species, as indicated in Table 1-1. It is important to recognize that because this document is programmatic and addresses species over such a wide geographic range, information on species, listing status, and critical habitat is likely to change over time such that Table 1-1 will become less accurate with time. However, this BA will still be able to provide guidance for local BLM offices, since it presents effects analyses by groups of species, rather than individual species. For local-level consultations involving species not listed in Table 1-1, the BLM could utilize this BA for programmatic-level guidanee if the appropriate group of species is analyzed in the document (such as plants or fish). Species not addressed by any of the group-level analyses in this BA would not be covered by this BA, but would still be considered during local-level consultation.

\section{Document Organization}

This BA contains four main parts: a description of the proposed action and herbicide active ingredients proposed for use on public lands throughout the western U.S.; procedures that the BLM field offices will follow during consultation to ensure compliance with the ESA and mitigation identified in the 2015 PEIS; background information on all TEP plant and animal species that occur or are likely to oceur within the project area; and a discussion of the potential effects of the proposed action on these species. 
Chapter 2 of this BA provides a description of the proposed action, with detailed information about the three new herbicides and how they would be used to treat vegetation on public lands in the western continental U.S. and Alaska. Herbicide treatments using aminopyralid, fluroxypyr, and rimsulfuron would be used by the BLM as part of treatment programs to improve ecosystem health on public lands by reducing levels of fuels and controlling weeds.

Chapter 3 identifies the procedures that the BLM field offices will follow to ensure that field offices comply with the requirements of the ESA; guidance provided in the 2015 PEIS, the 2007 PEIS, PER, and BA and ERAs; and guidance provided in BLM Manual 6840 (Special Status Species Management) and BLM Handbook H-1601-1 (Land Use Planning Handbook). Descriptions of these procedures are presented to make sure that each field office follows similar procedures for ensuring that actions taken by the BLM are consistent with the conservation needs of TEP species, and that these actions do not contribute to the need to list any special status species under provision of the ESA.

Chapters 4 through 6 inelude background information and an analysis of the effeets of the use of aminopyralid, fluroxypyr, and rimsulfuron on the species covered by this BA. "Effeets of the action" refers to the direct and indirect effects of an action on the species or critical habitat, together with the effects of other activities that are interrelated or interdependent with that action, which will be added to the environmental baseline. The environmental baseline includes the past and present impacts of human aetivities in the action area, the anticipated impacts of all proposed federal projeets in the aetion area that have already undergone consultation, and the impacts of state or private actions that are contemporaneous with the consultation in process. In Chapters 4 through 6, species are divided into three main categories: plants (Chapter 4), fish and other aquatic animal species (Chapter 5), and terrestrial animals (Chapter 6). The intention of these divisions is to separate speeies into broad, biologieal groups, because of the large number of species considered in this document, and to facilitate logical analysis. In the first part of each seetion, background information on speeies abundanee and distribution, habitat requirements, reproductive biology and life history, and current status and presence/absence of designated eritical habitat is provided. Potential beneficial, direct, indirect, interdependent, and interrelated threats to the species that are unrelated to the proposed aetion, and that may result in cumulative effects as a result of the use of herbicides, are also presented (for a more detailed discussion of types of effects, see USFWS and NMFS 1998). These effects are defined as follows:

- Beneficial - Effects of an action that are wholly positive, without any adverse effects, on a listed species or designated critical habitat. Determination that an action will have beneficial effects is a "may effect" situation.

- Direct - The direct or immediate effects of the project on the species or its habitat. Direct effects result from the agency action including the effects of interrelated actions and interdependent actions.

- Indirect - Effects caused by or resulting from the proposed action, that are later in time, and that are reasonably certain to occur. Indirect effects may occur outside of the area directly affected by the action.

- Cumulative - The effects of future state, tribal, local, or private actions that are reasonably certain to occur in the action area considered in this BA. Future federal actions that are unrelated to the proposed action are not considered in this section because they require separate consultation pursuant to Section 7 of the ESA.

For presentation of background material, species are organized using Bailey's Ecoregion Divisions (Bailey 1995). These divisions allow species to be separated based on geography and broad habitat types, and are the same as those used for much of the analysis in the 2007 PEIS and PER. In the second part of each section, the potential effects of the proposed action on the species discussed are presented. In many cases, the effects on a logical grouping of species are described, with grouping systems described in the beginning of each of the three sections.

A complete list of SOPs and conservation measures is provided in Appendix A. In addition, information on essential fish habitat (EFH) is provided in Appendix B. In 1976, Congress passed into law what is currently known as the Magnuson-Stevens Fishery Conservation and Management Act (MSA). This law authorized the U.S. to manage its fishery resourees to a distance of 200 miles off the coast. Under this law, all federal agencies are 
required to consult with the NMFS on all actions or proposed actions that are permitted, funded, or undertaken by the agency and that may adversely affect EFH. Essential fish habitat is defined by Congress as "waters and substrate necessary to fish for spawning, breeding, feeding, or growth to maturity." For the purpose of interpreting the definition of EFH habitat, "waters" include aquatic areas and their associated physieal, ehemieal, and biological properties; "substrate" ineludes sediment underlying the waters; "necessary" refers to the habitat required to support a sustainable fishery and to manage the species" contribution to a healthy ecosystem; and "spawning, breeding, feeding, or growth to maturity" eovers all habitat types utilized by a speeies throughout its life cycle.

Because of the vast area covered by this projeet, and the large number of species to be considered by this BA, it was not feasible to inelude preeise information about where listed species or eritical habitat are located on publie lands, and how those populations are eurrently managed. Rather, this BA assumes that all TEP species known to occur or that potentially occur on public lands are present in areas where herbieide treatments with aminopyralid, fluroxypyr, and rimsulfuron could be utilized. This document assesses the potential impaets to all 341 TEP species from herbicide treatments using the three herbieide active ingredients being eonsidered, and identifies management activities (i.e., mitigation) required to avoid adverse impacts to these speeies.

This programmatic BA, together with the $2007 \mathrm{BA}$, analyzes the potential overall effeet of the BLM vegetation management program on the TEP speeies listed in Table 1-1 and diseussed in detail in Chapters 4 through 6 . When the BLM decides to implement vegetation treatment projects, local BLM offiees will still be required, under NEPA, to prepare site- or project-specific analyses of TEP species potentially affected by the project and to consult with the Services. These analyses, which will eover considerably fewer species than this all-encompassing document, are expected to be more detailed in seope than this programmatic document. 


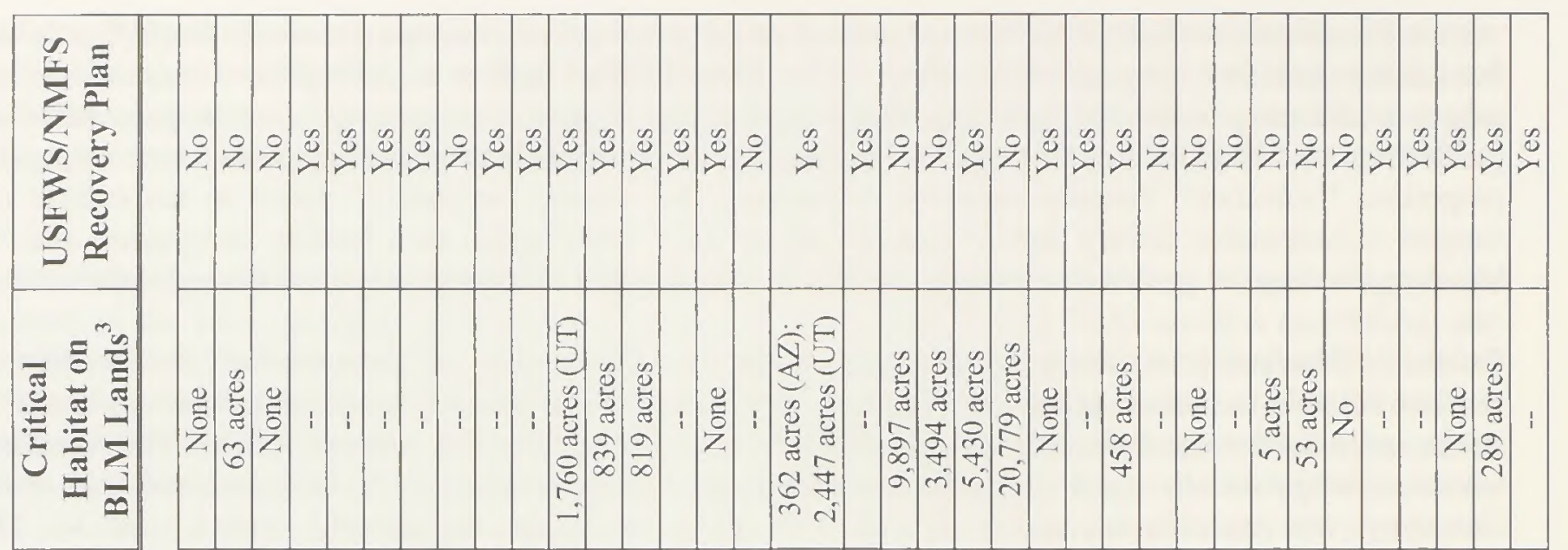

焉焉焉

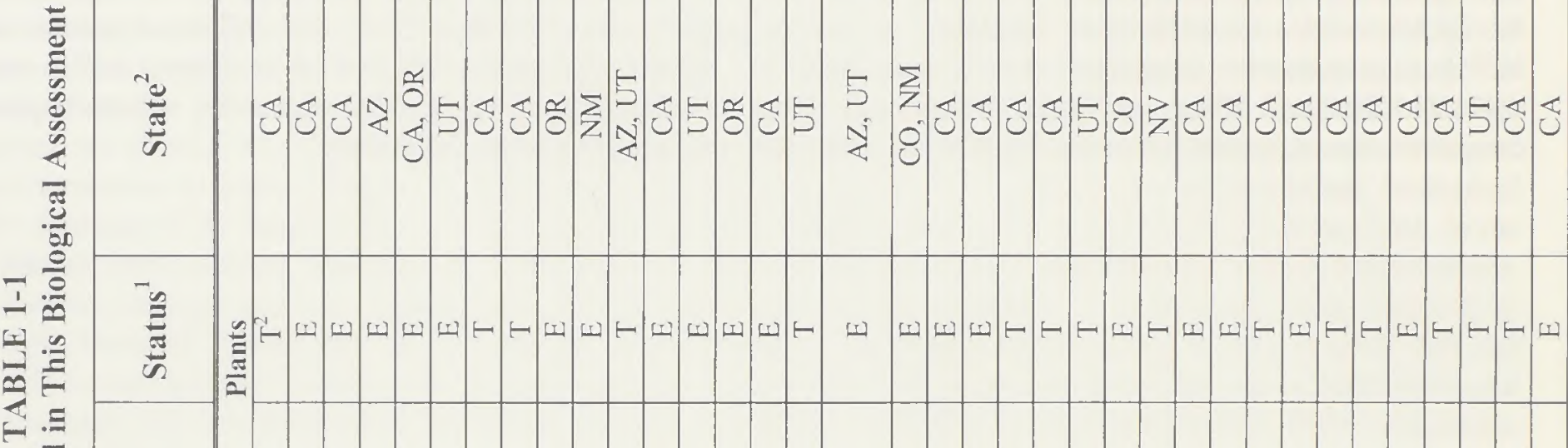

क्ष

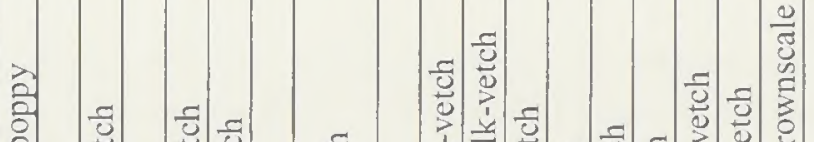

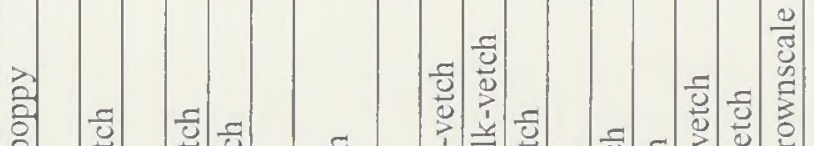

ڤัँ

音 至

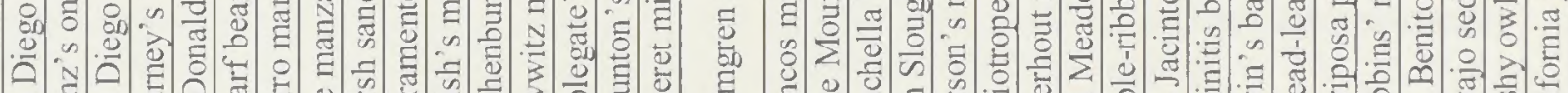

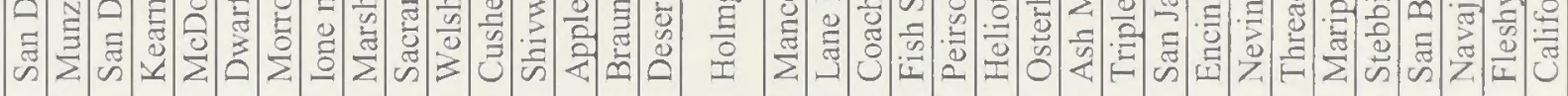

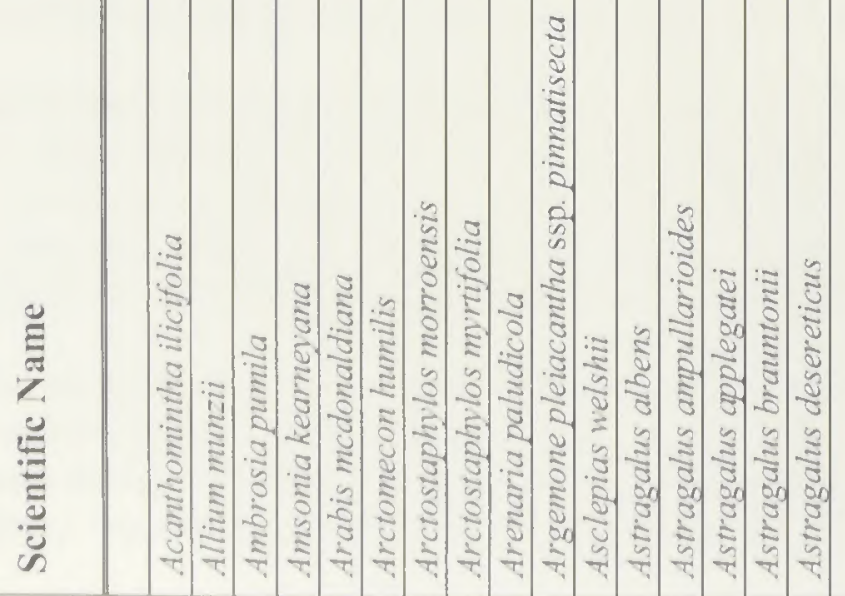

:

$\frac{\sqrt[3]{3}}{3}$

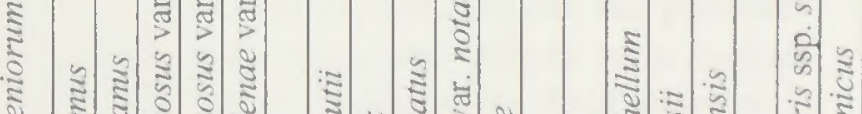

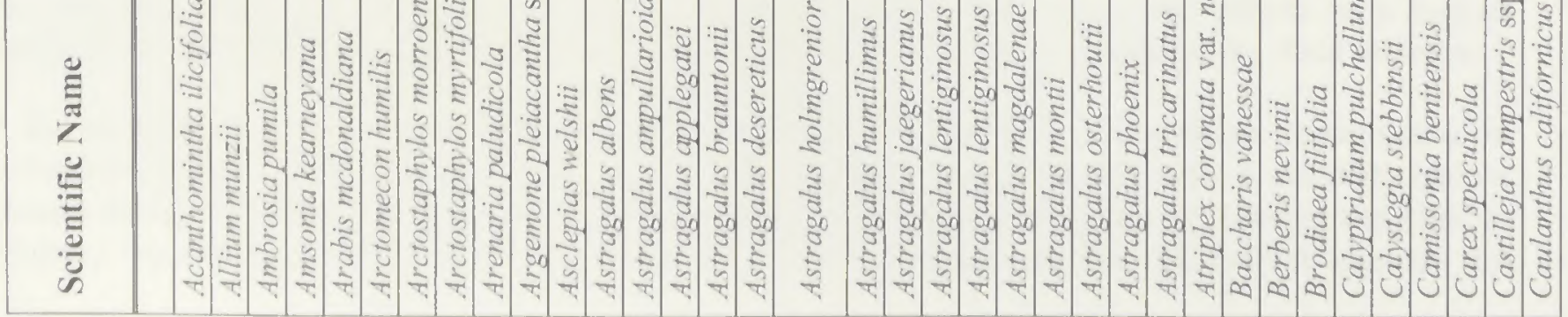




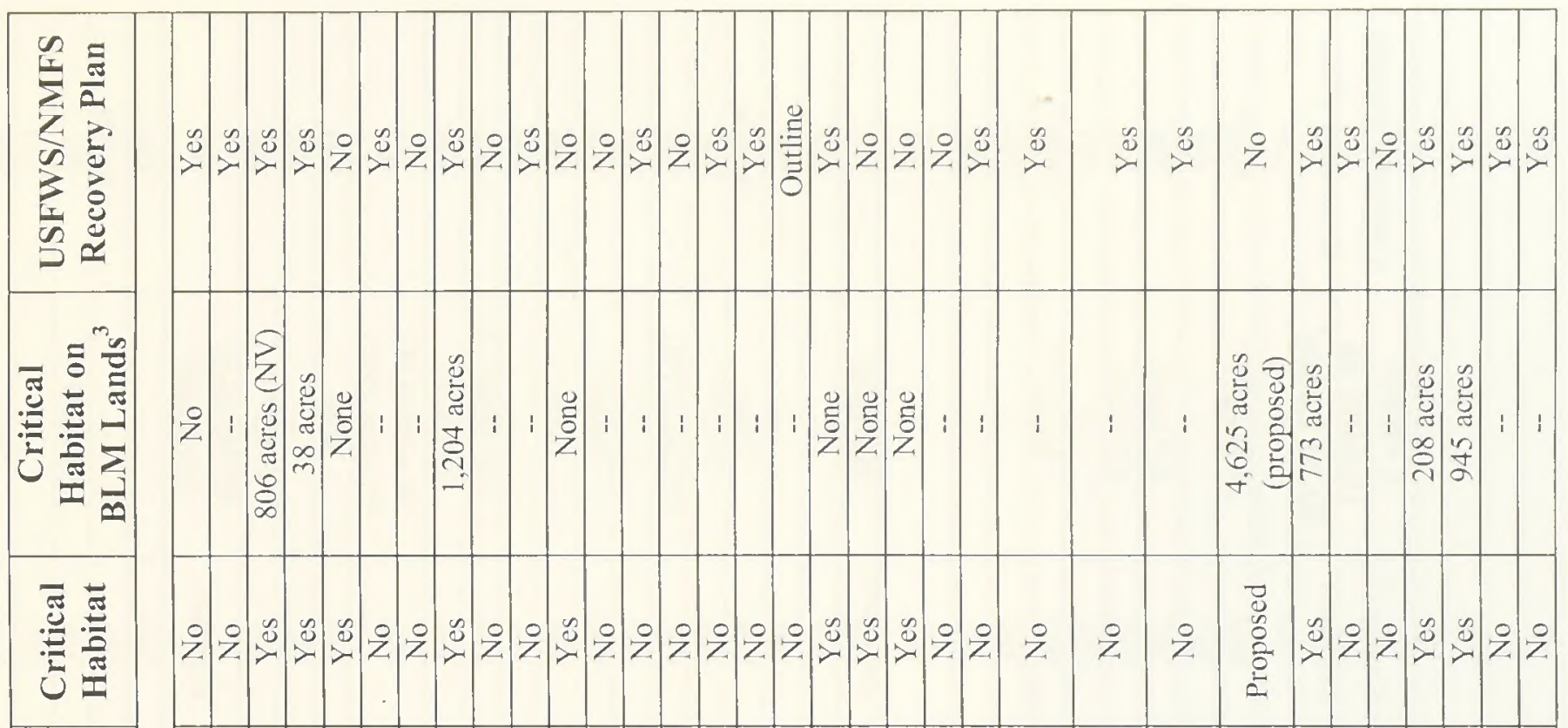

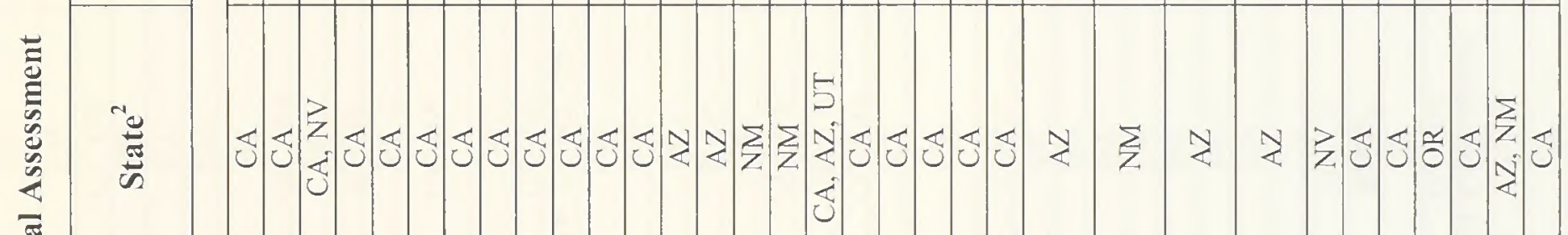

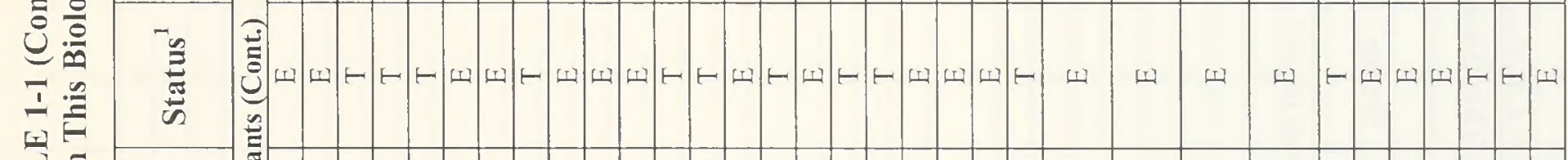
要焉

幽

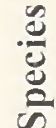

글

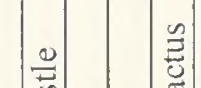

范

|

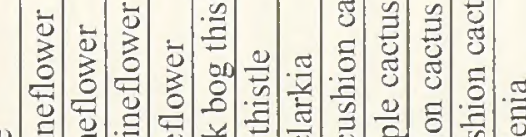

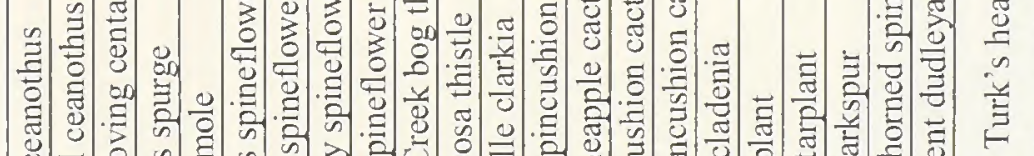

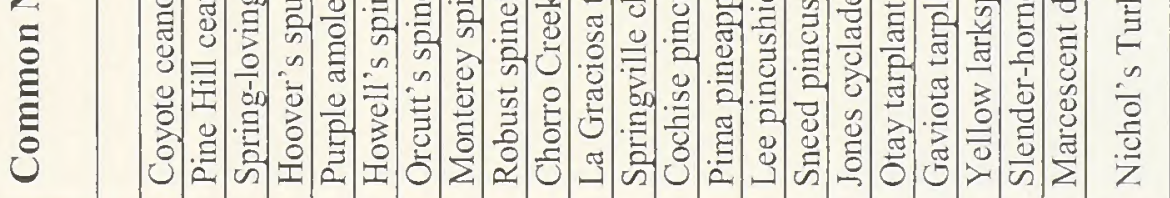

(

$\approx$

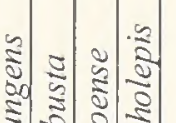

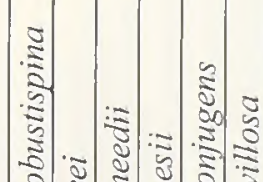

골

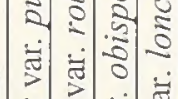

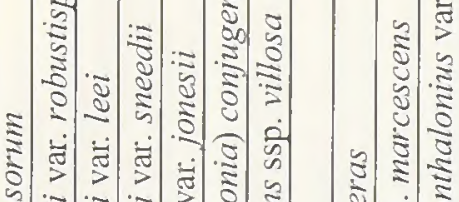

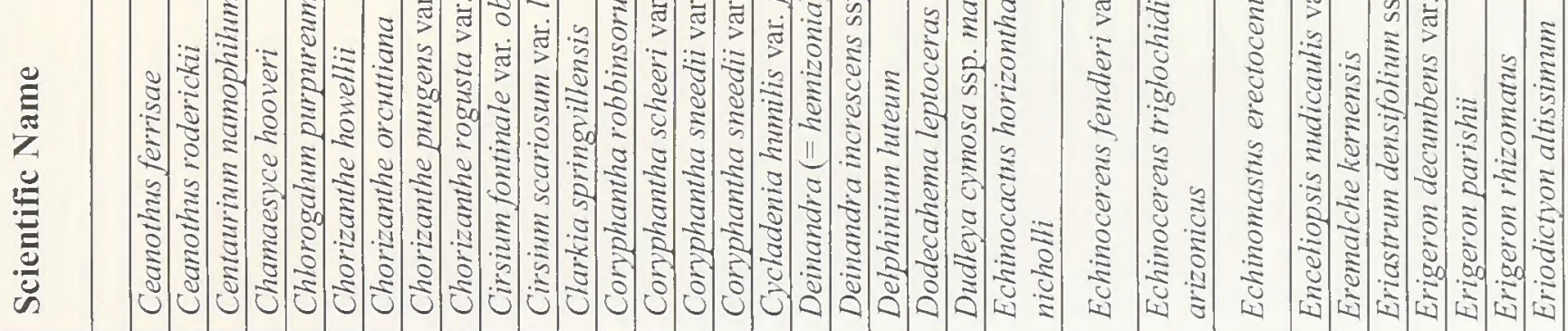




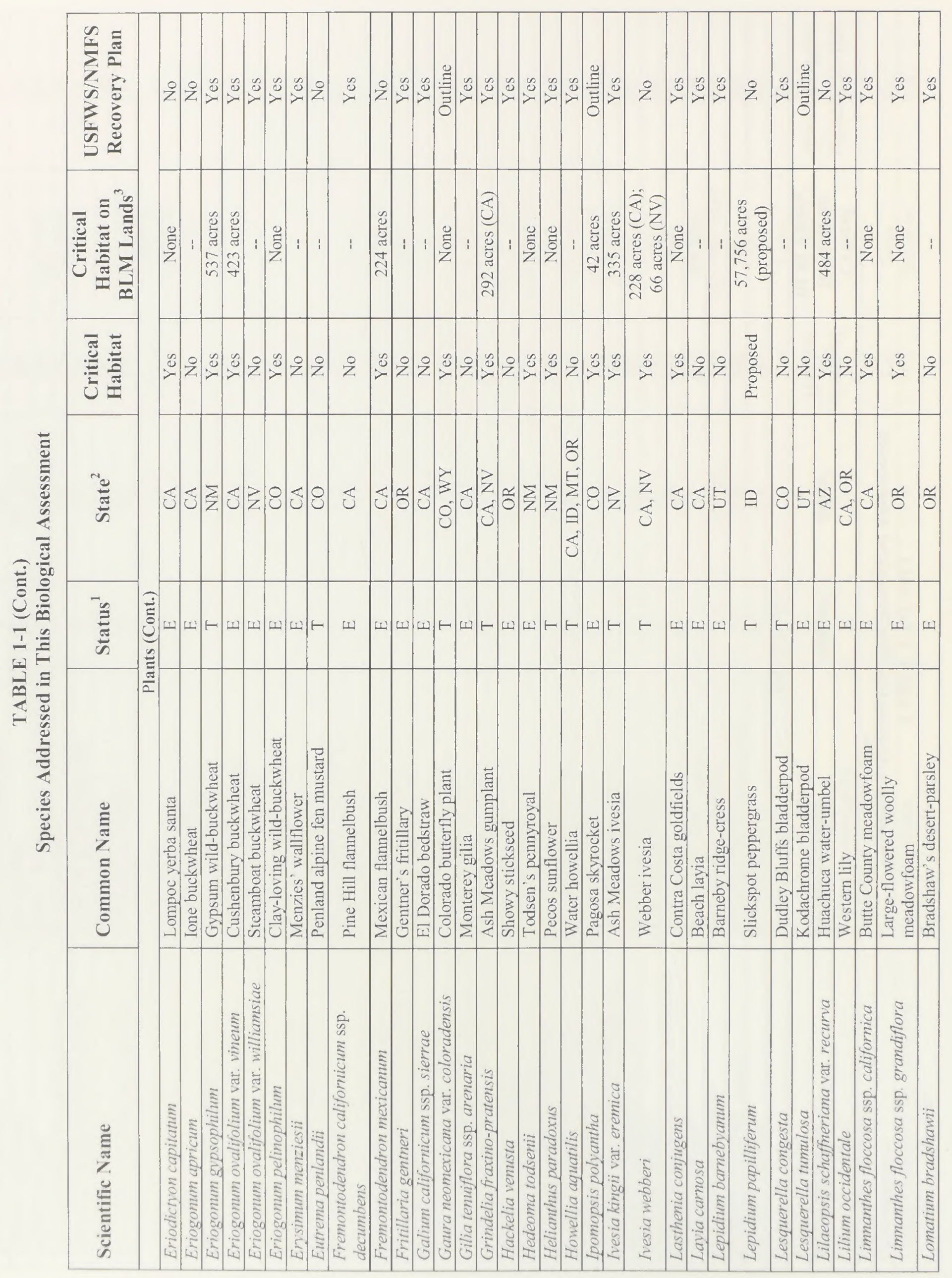




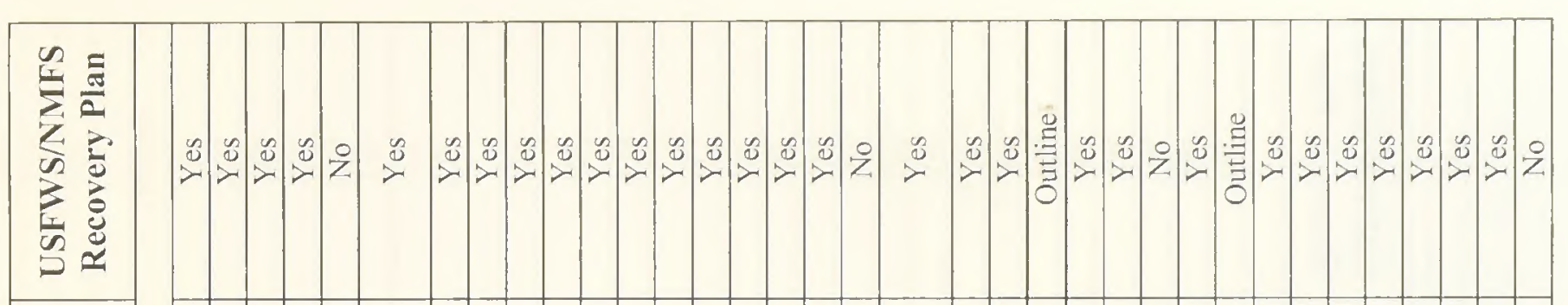

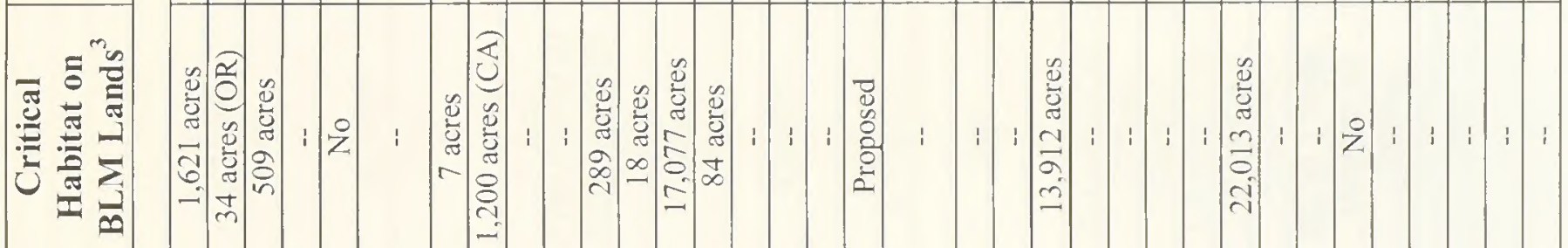

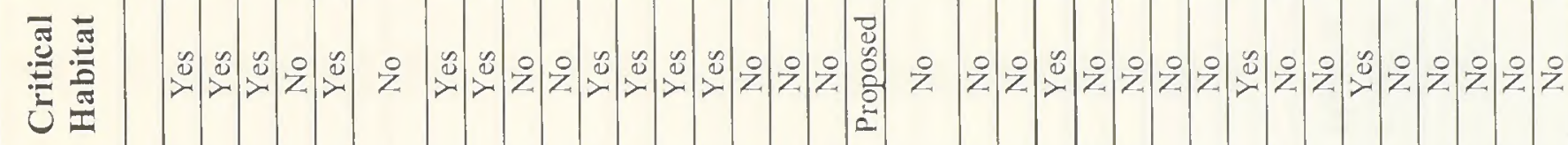

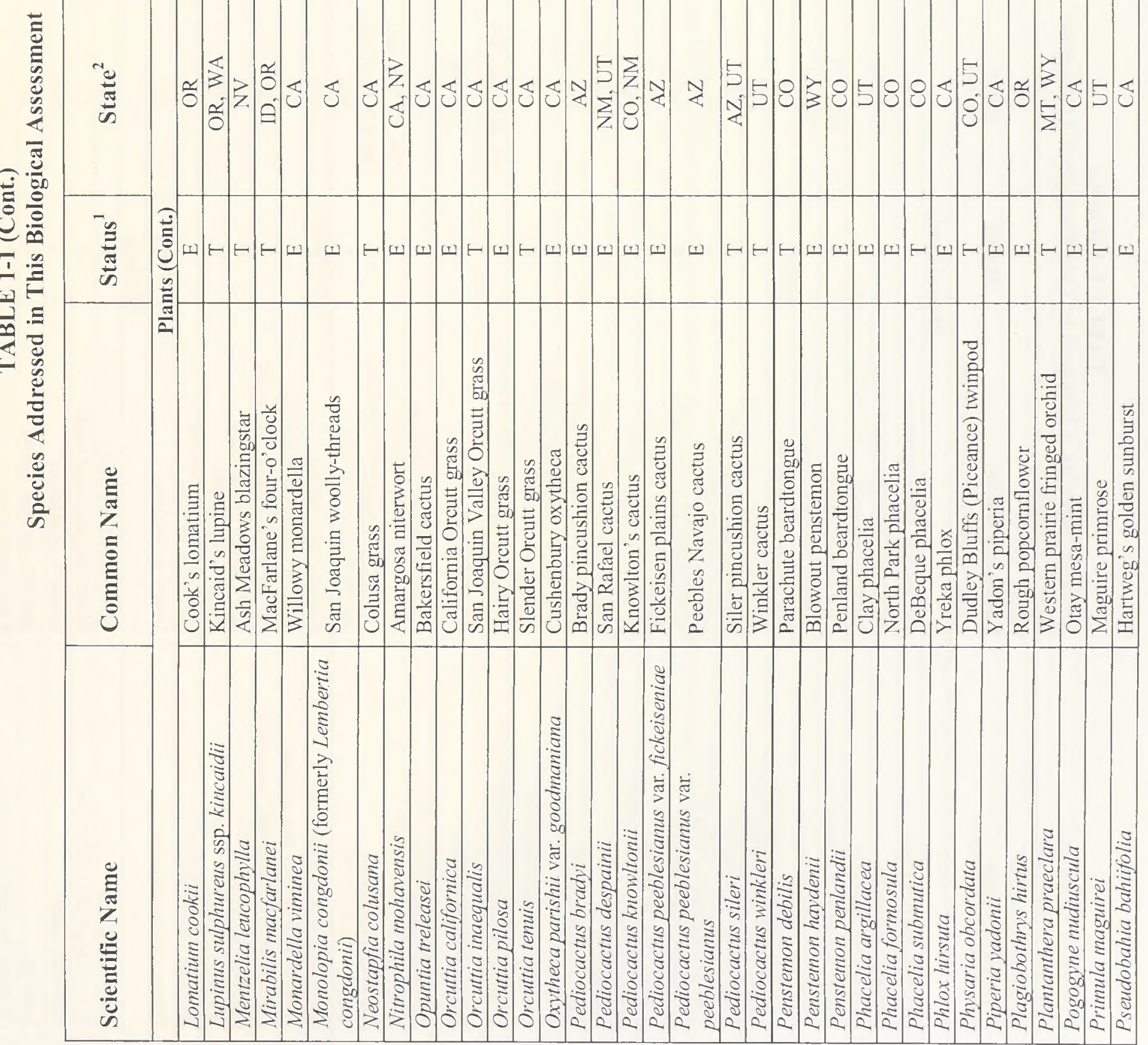




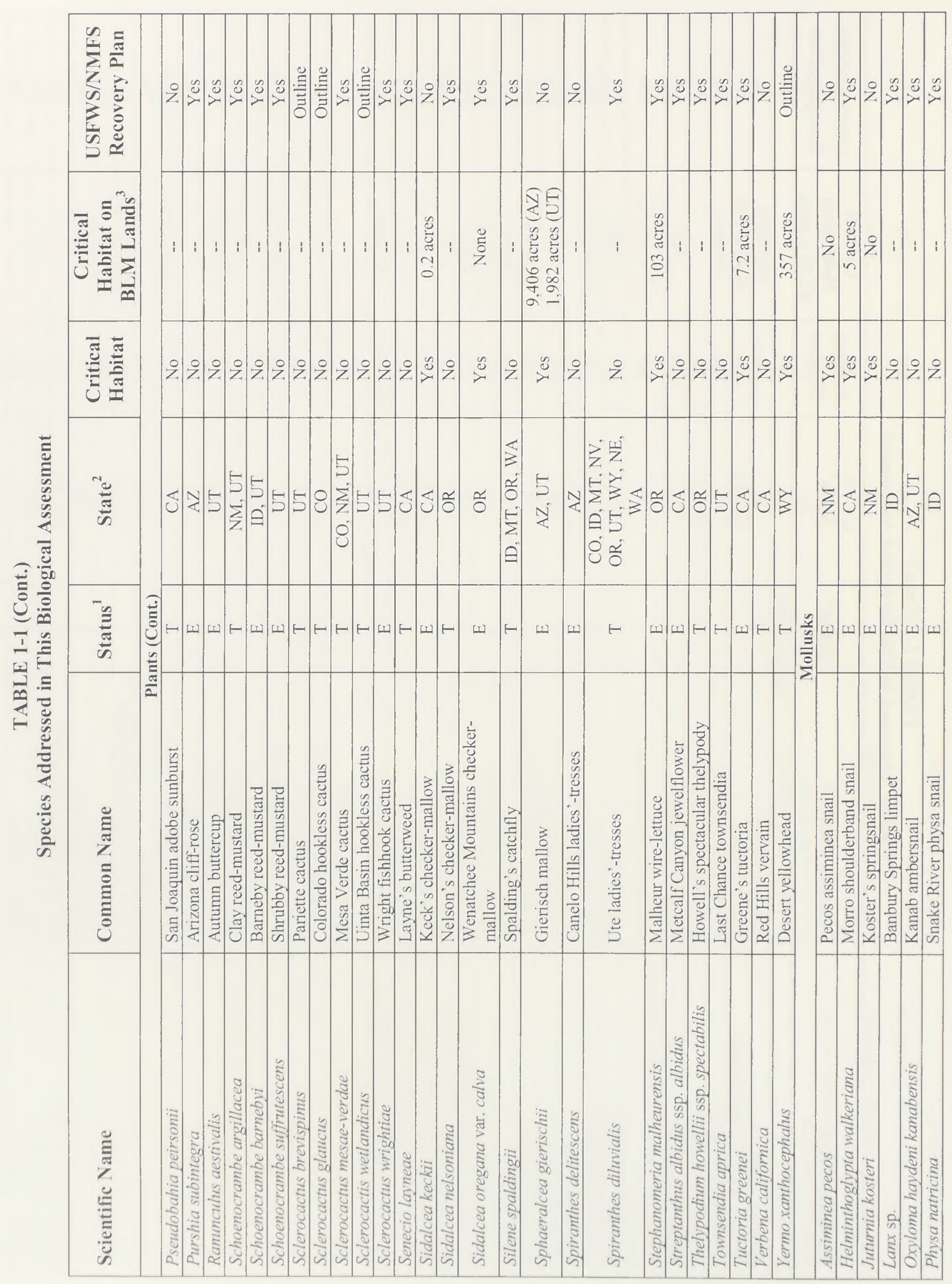




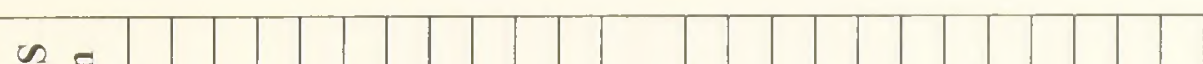

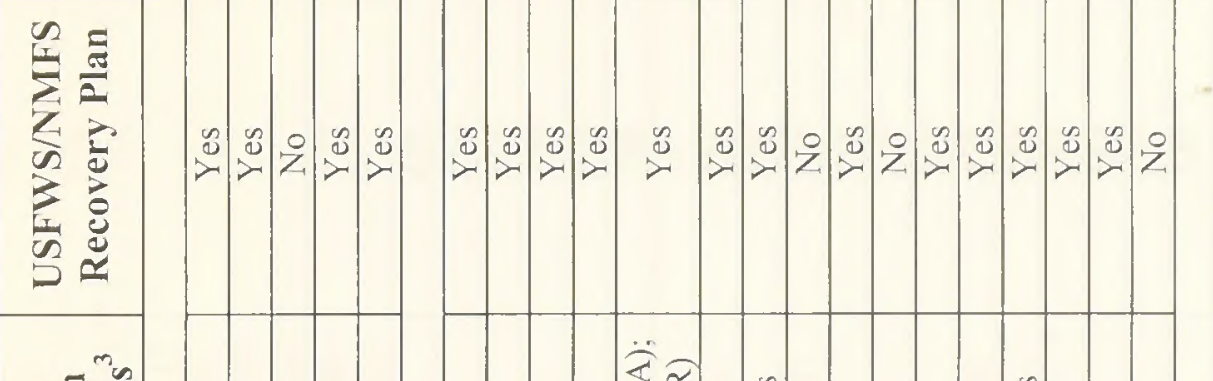

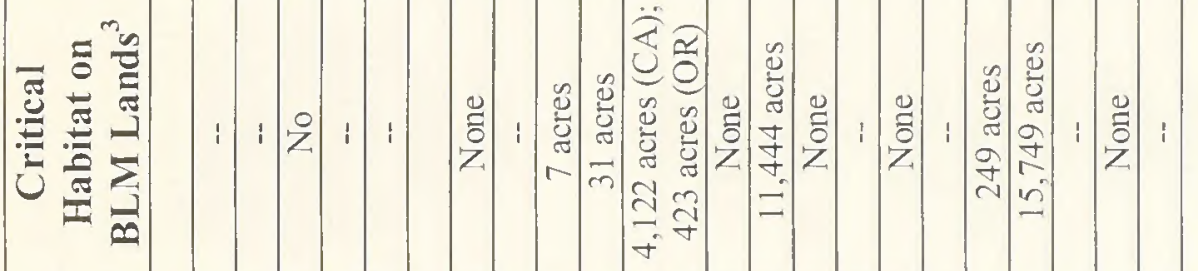

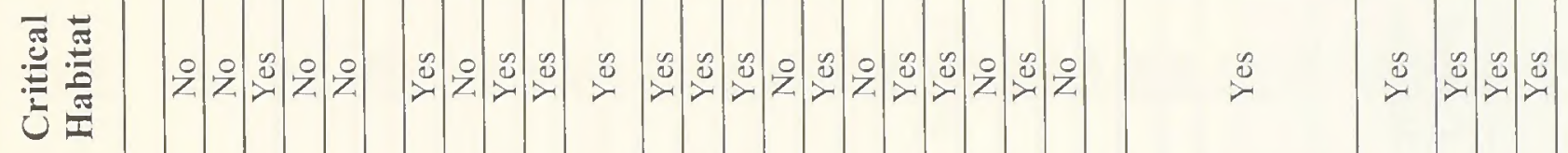

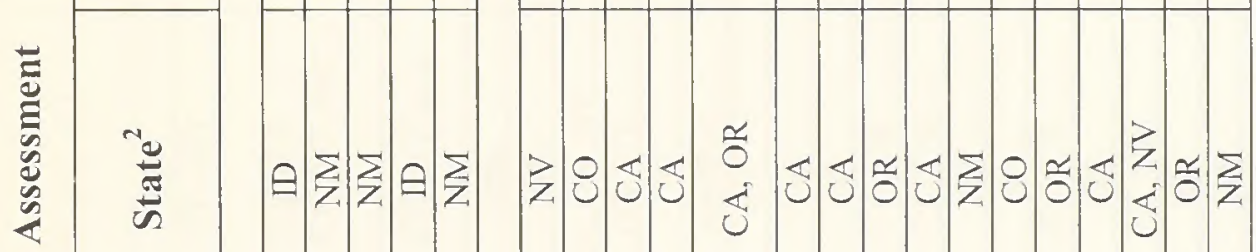

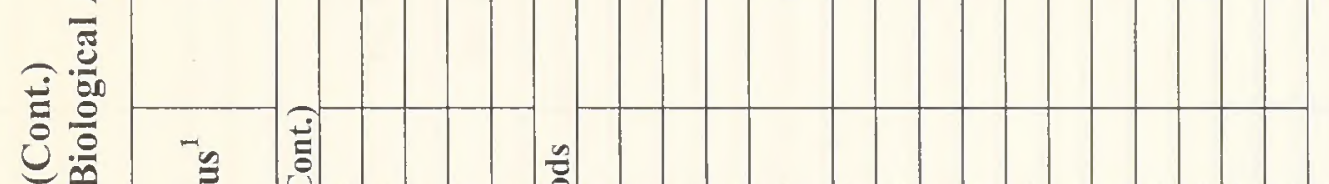

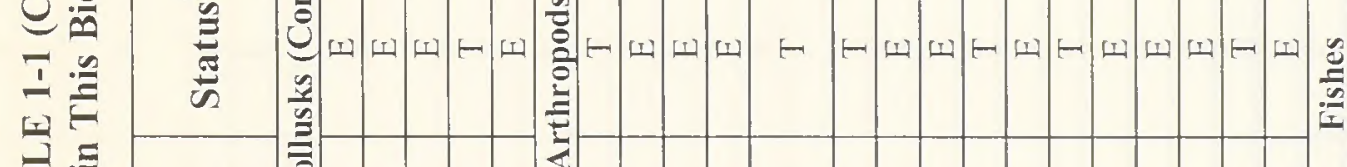

站

프

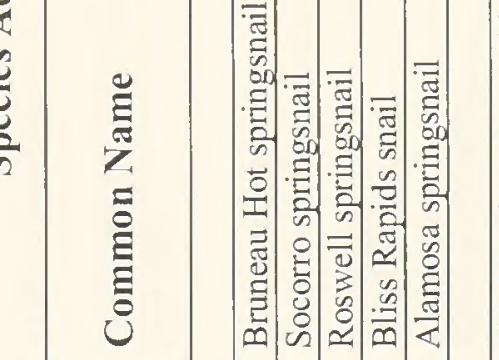

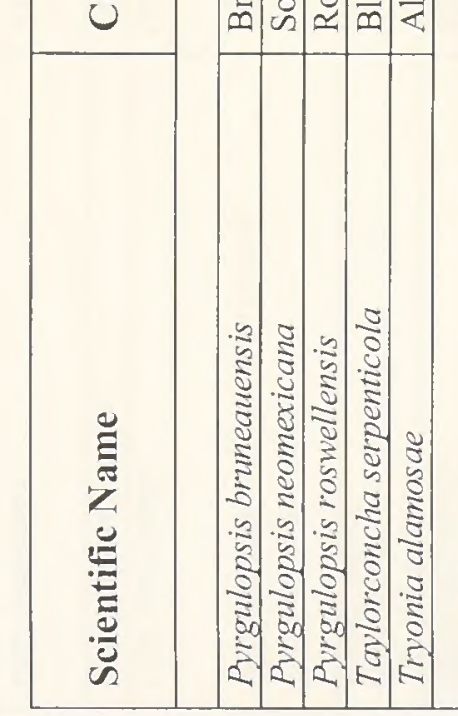

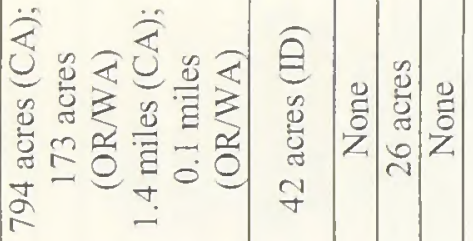

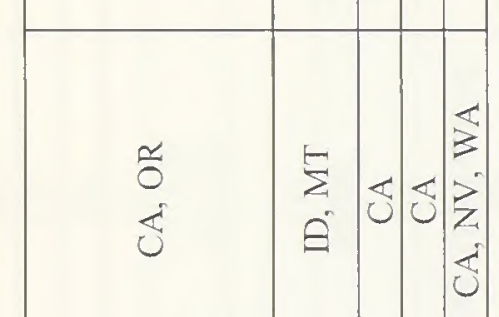
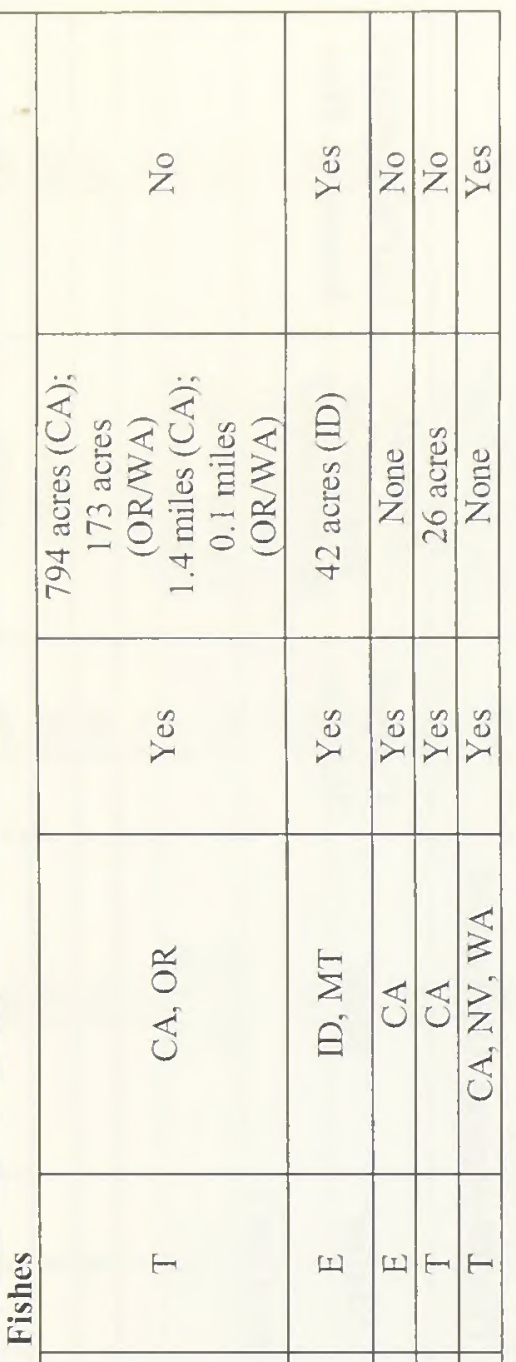

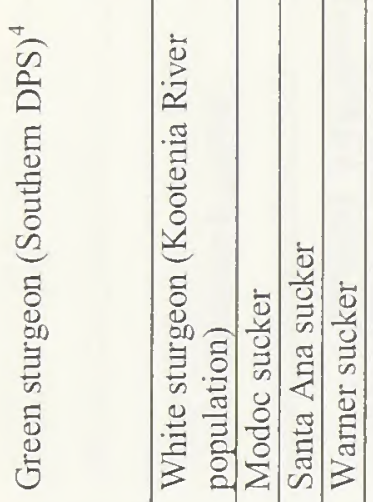

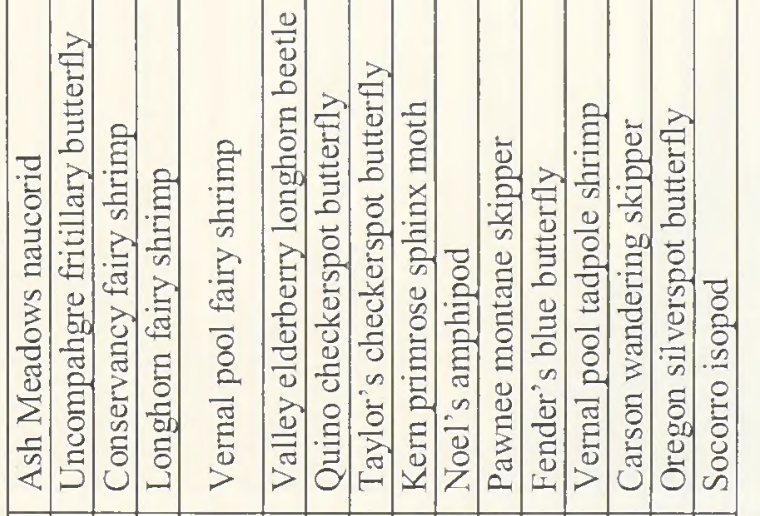

ำ

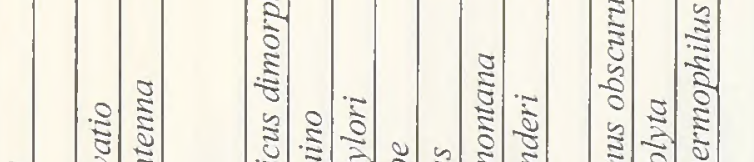

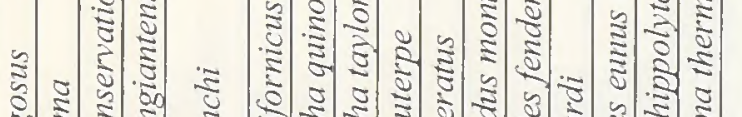

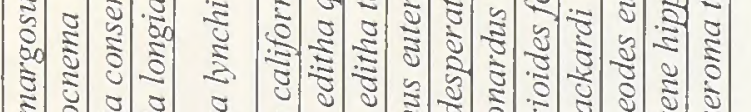

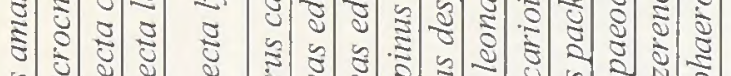

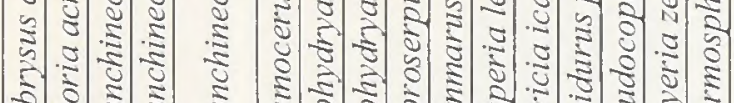

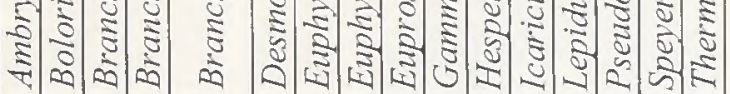
a $=$ 


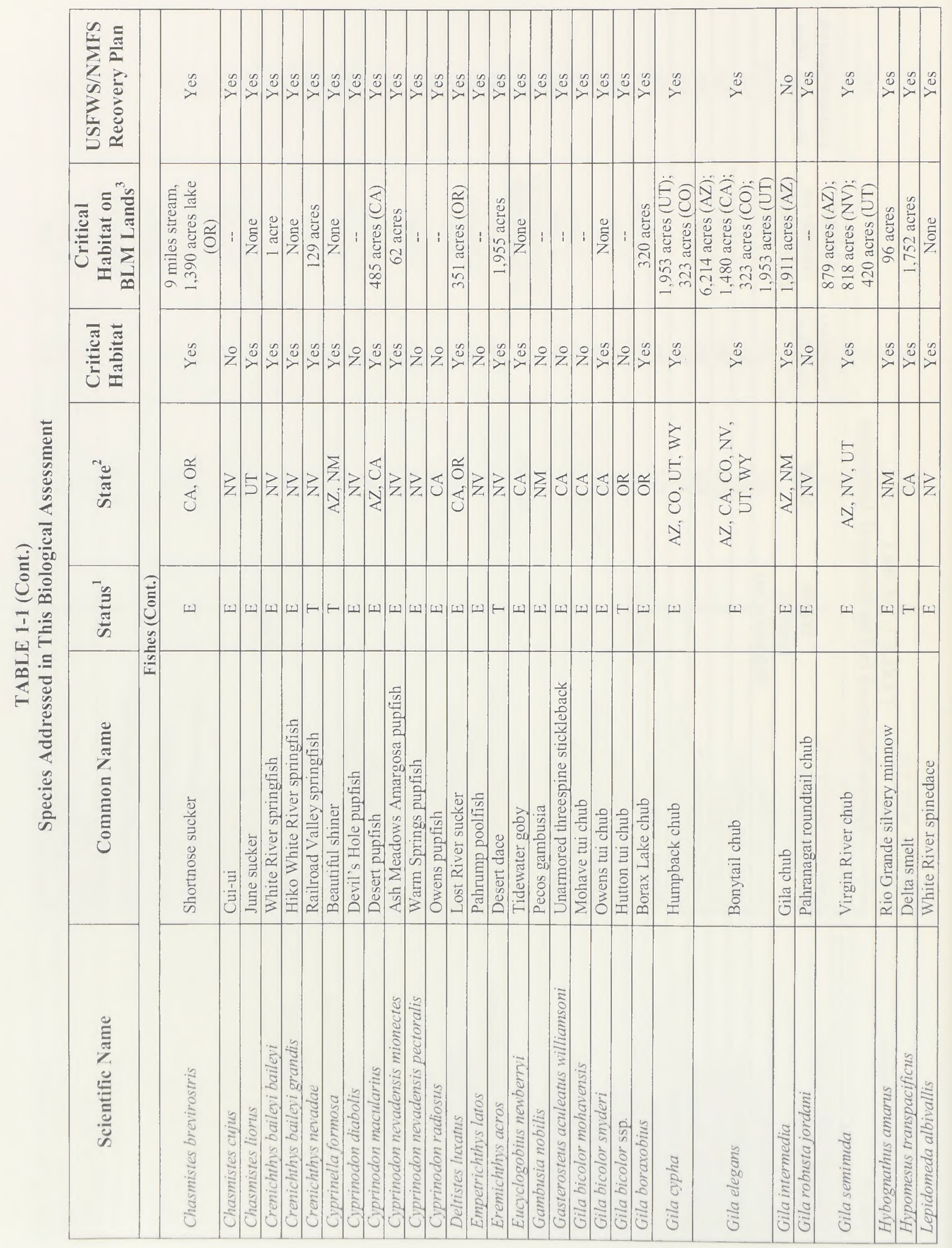




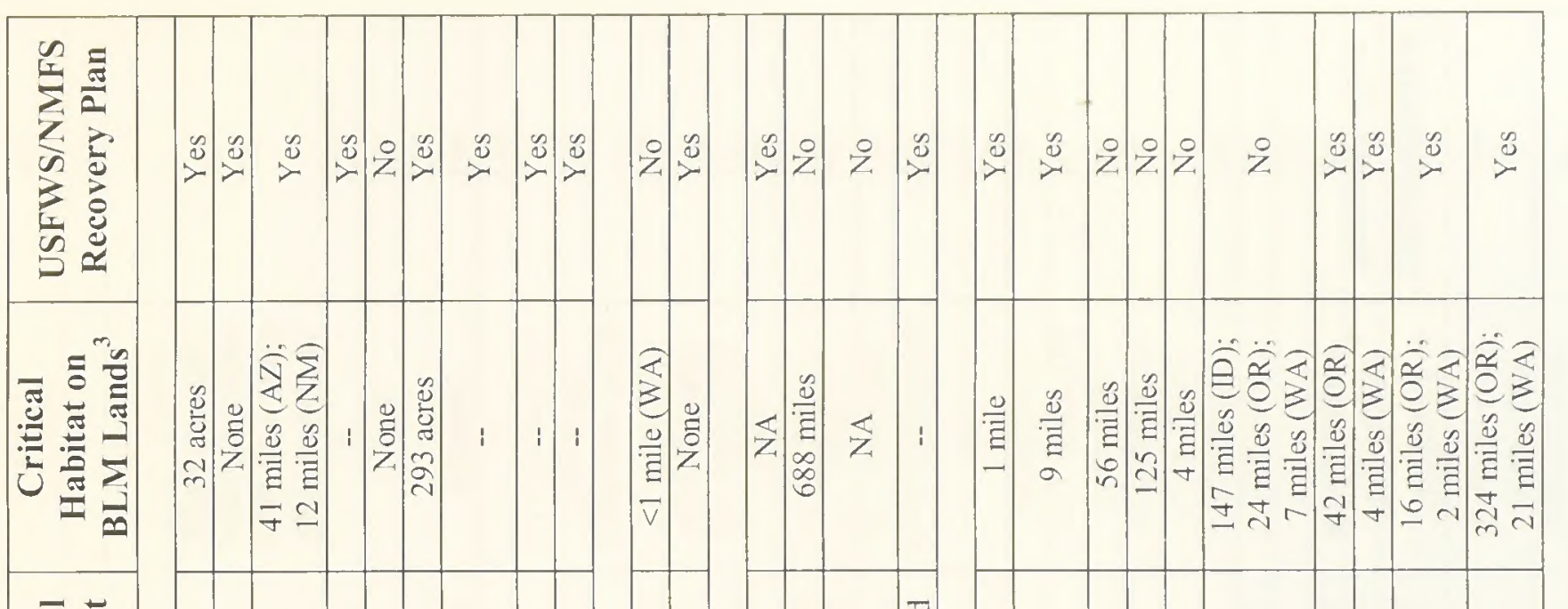

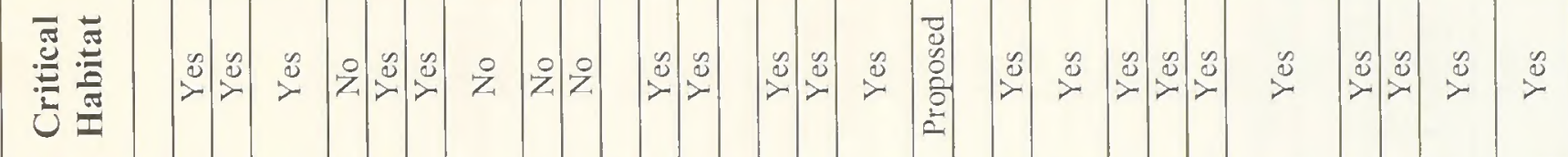

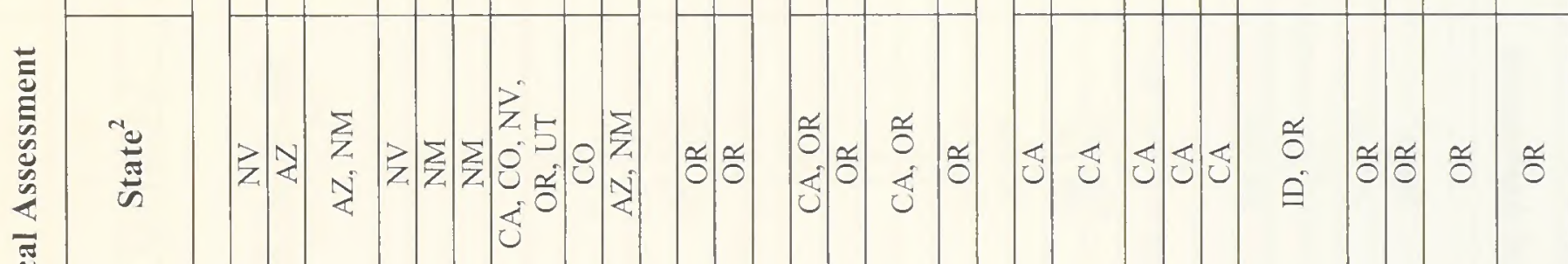

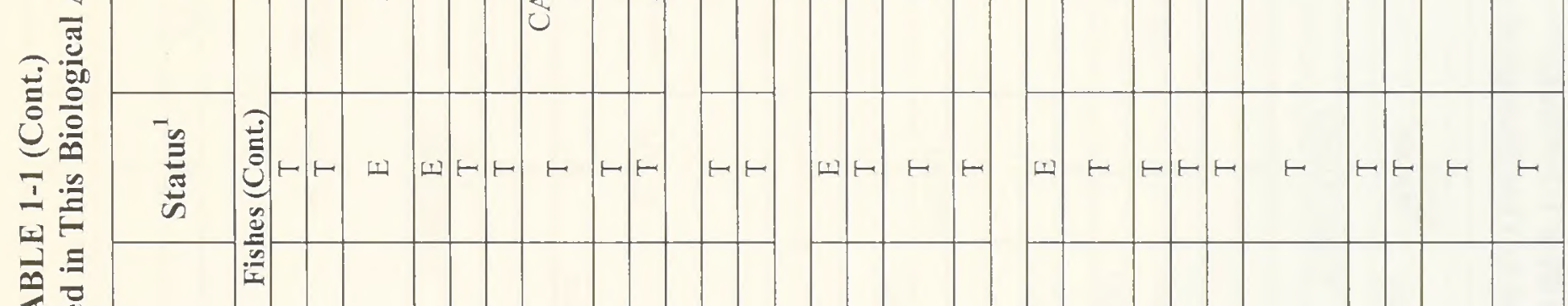

离

竞

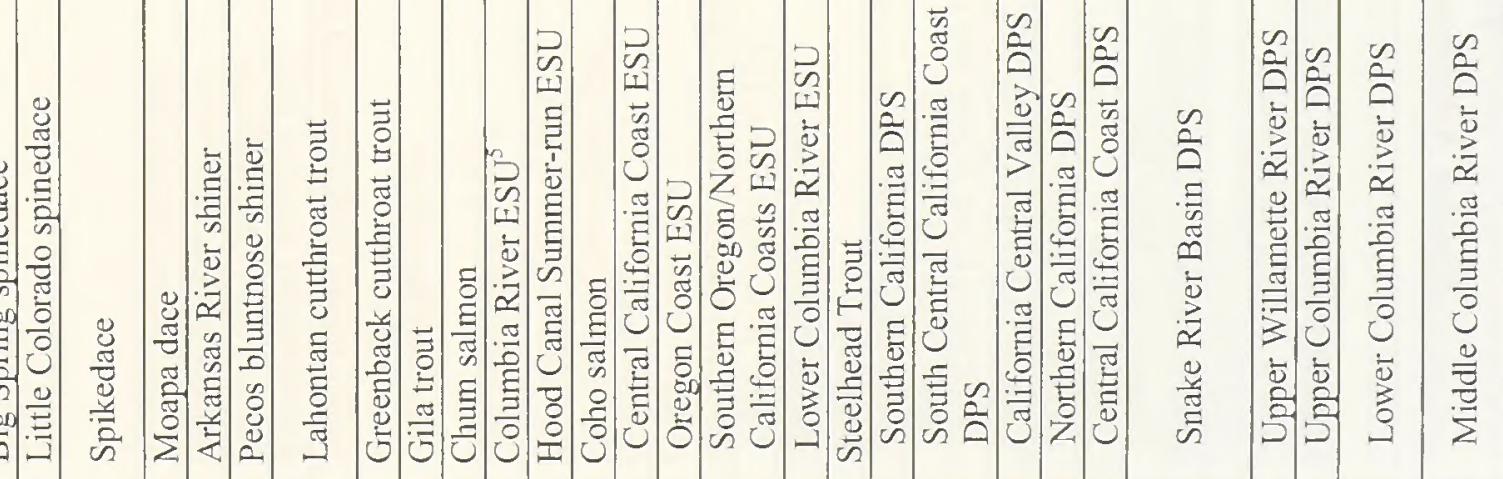

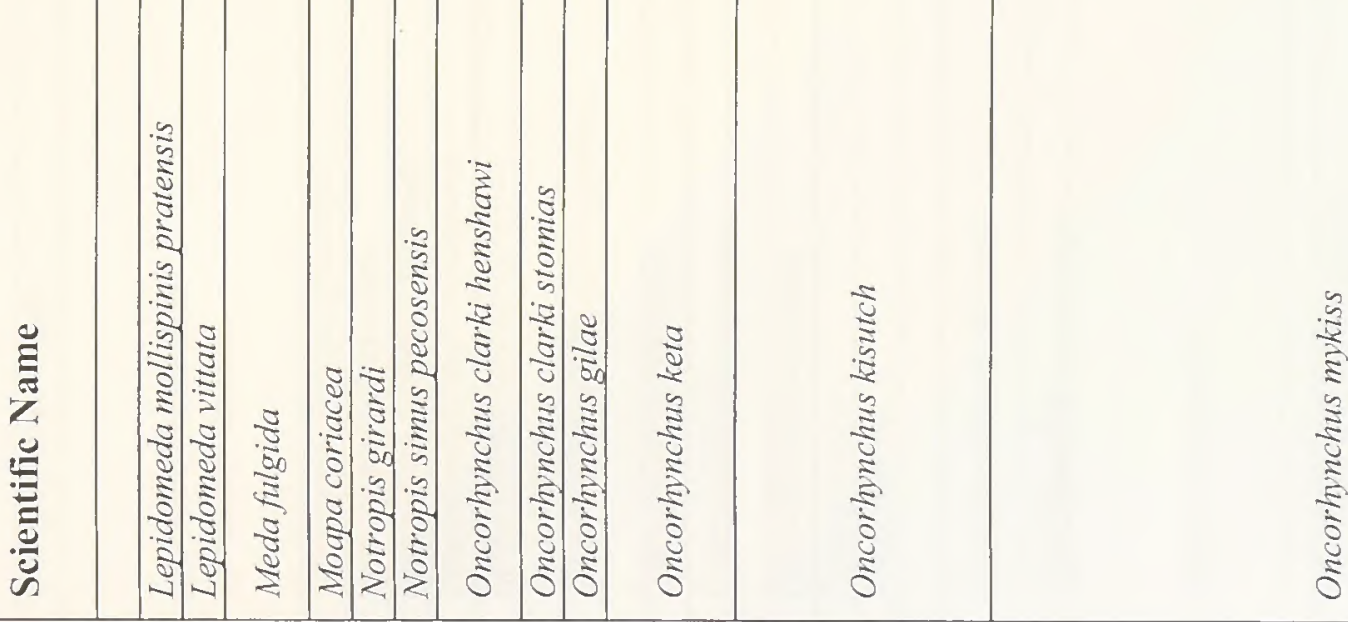




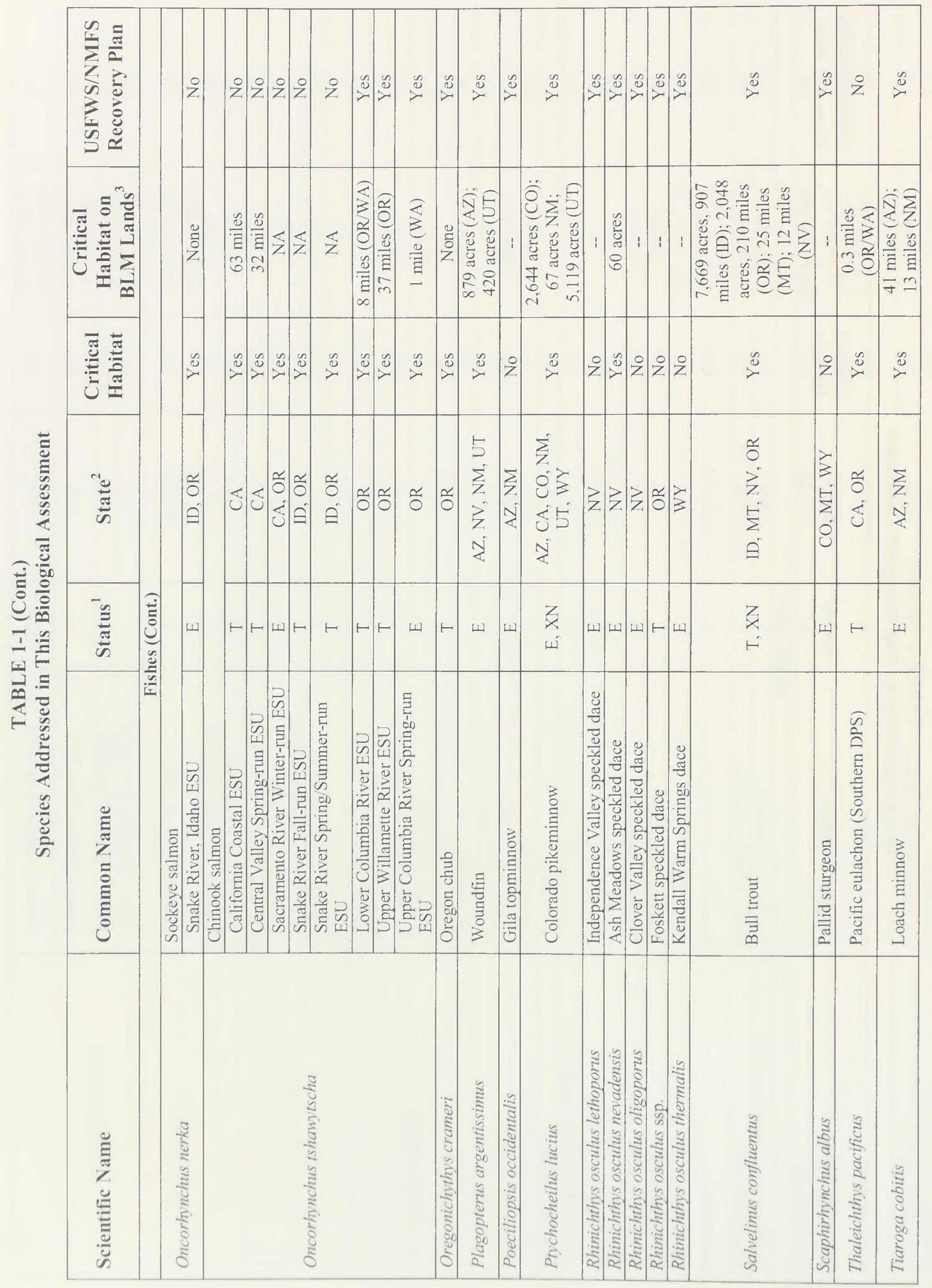




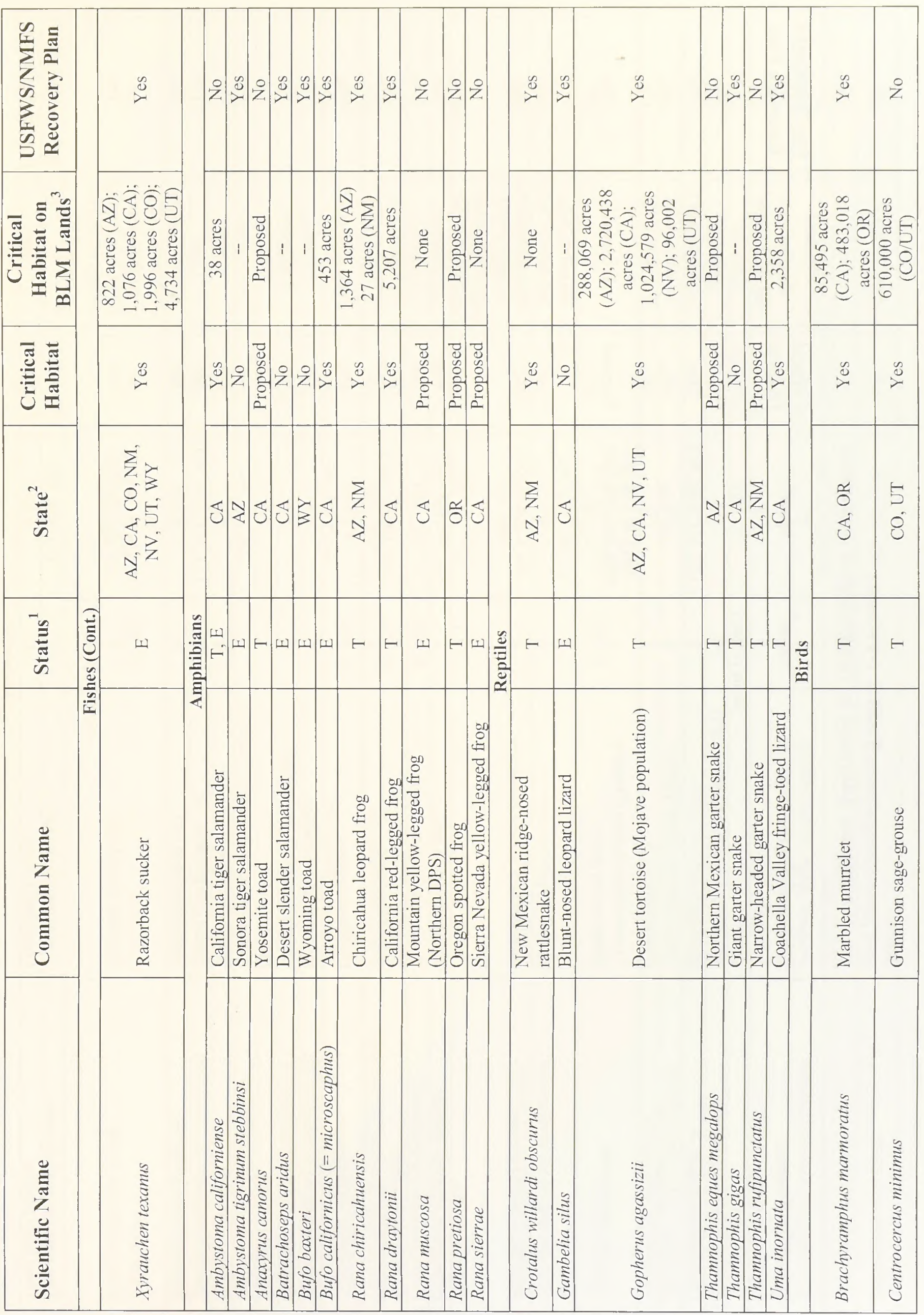




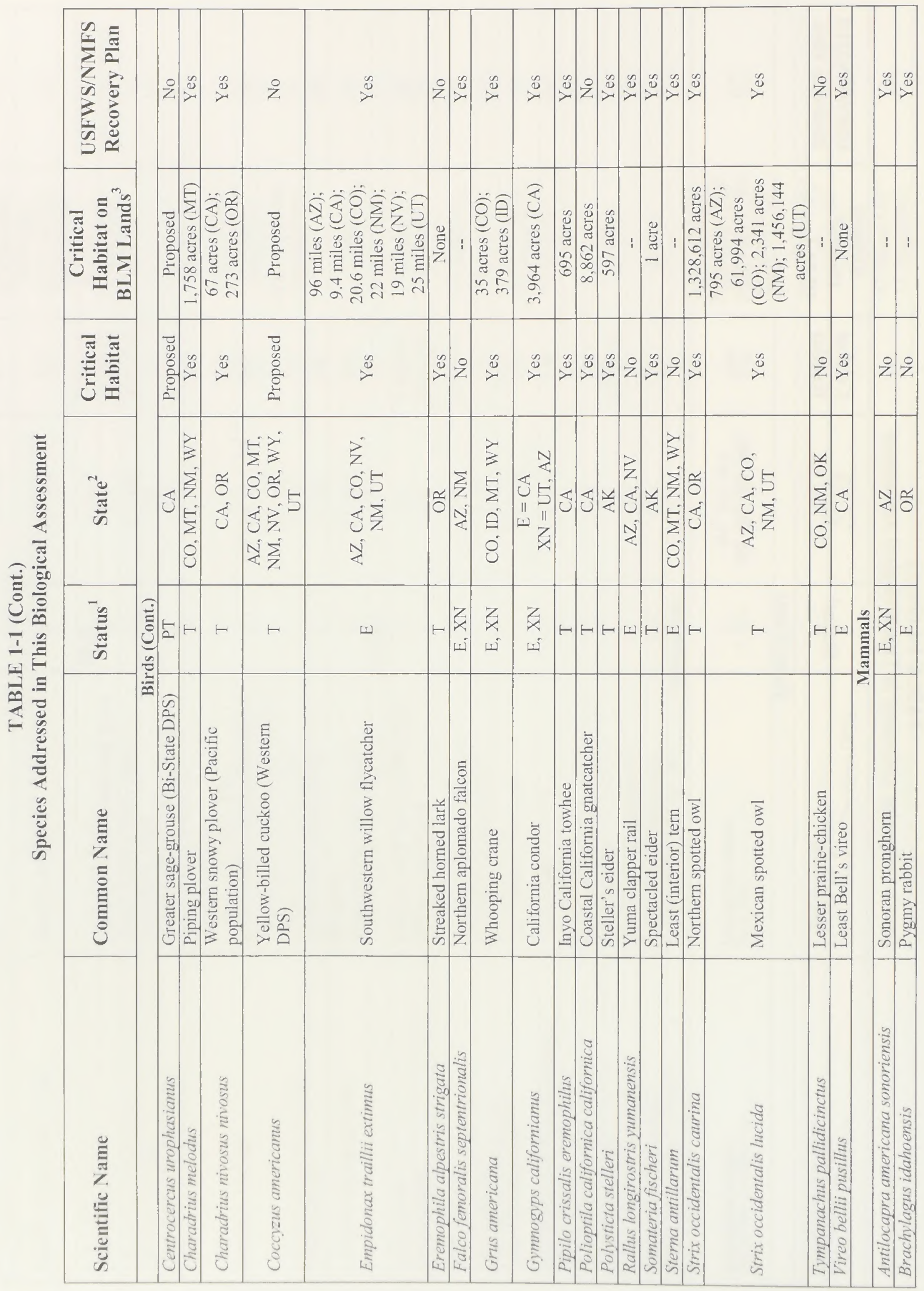




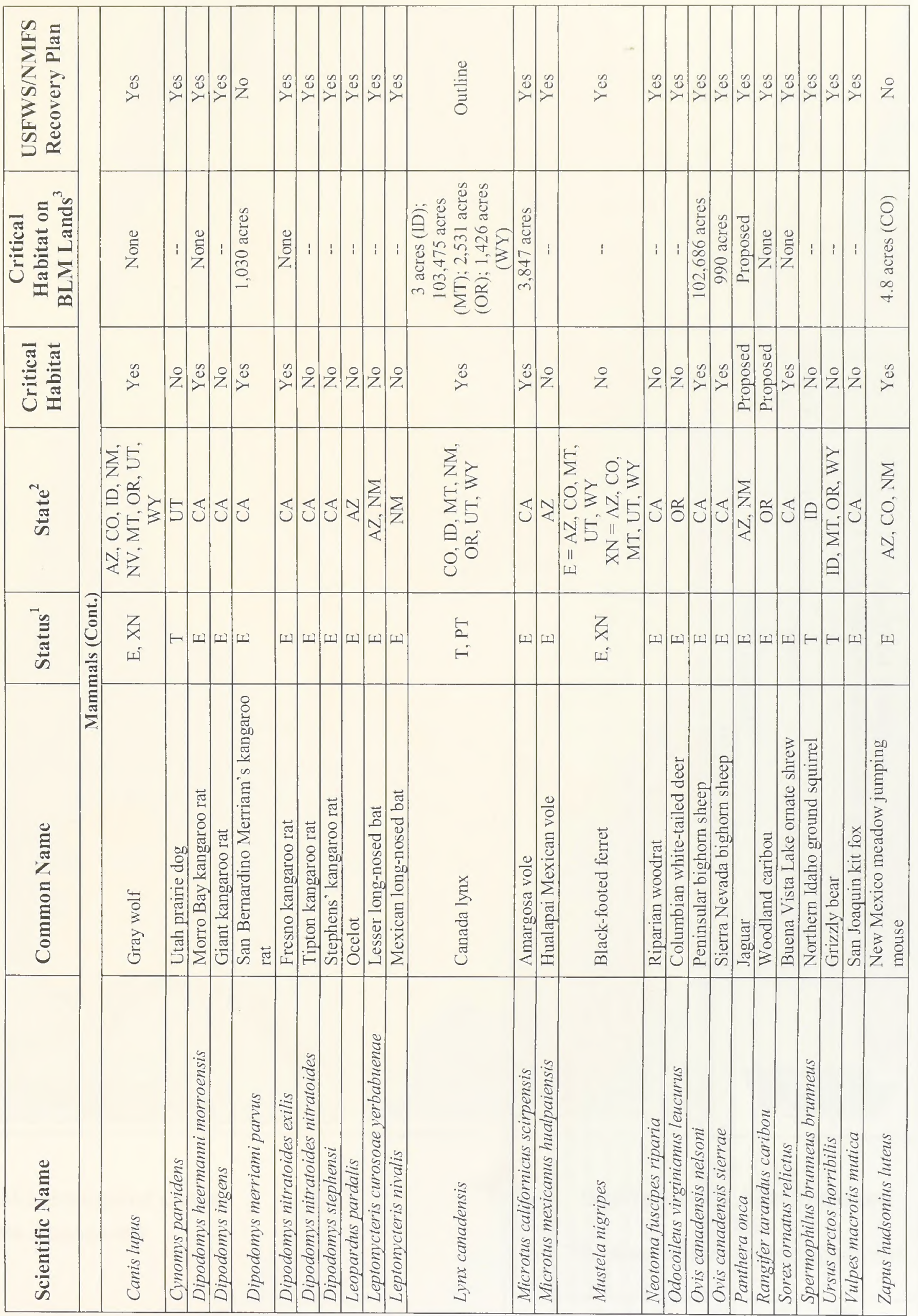




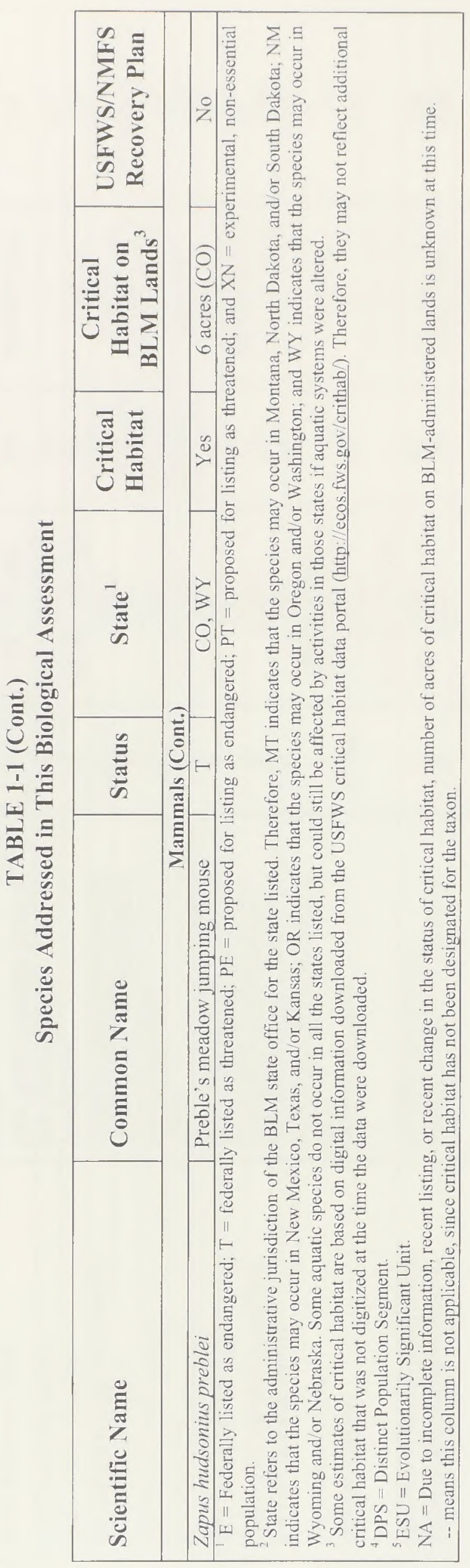




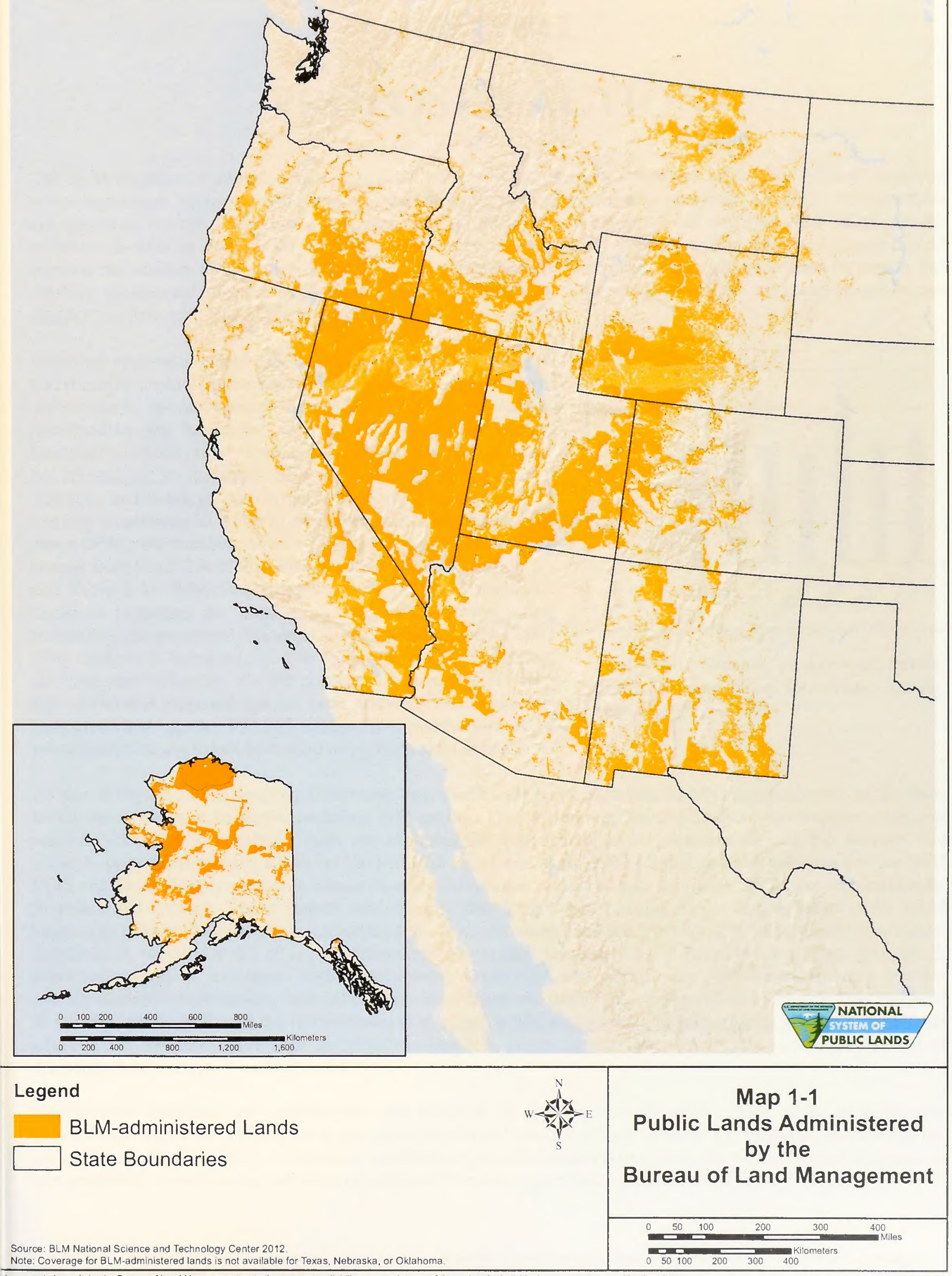





\section{CHAPTER 2}

\section{PROPOSED ACTION}

The BLM proposes to add the active ingredients aminopyralid, fluroxypyr, and rimsulfuron to its list of approved active ingredients for use on public lands as part of its vegetation management programs. Currently, 18 herbicides are approved for use under these programs, as well as non-herbicide treatment methods. The BLM has the authority to treat up to 932,000 acres of public lands annually using herbicides. The proposed project would increase the number of approved herbicides to 21 . The three new herbicides have been registered for use by the USEPA, are deemed cffective in controlling vegetation, and have minimal effects on the environment and human health if used properly according to the herbicide label instructions.

Proposed vegetation treatments using aminopyralid, fluroxypyr, and rimsulfuron could occur anywhere on the 247 million acres of public lands in the western U.S., including Alaska, unless restricted by the herbicide label or BLM guidelines. Actual treatment methods, acres treated, and treatment locations would be determined at the local field level and by Congressional direction and funding. At current funding levels, the BLM is treating an average of 315,000 acres per year using herbicides. Since 2006, the number of acres treated using herbicides has ranged from about 260,000 to 436,000 acres annually (Figure 2-1 and Table 2-1). While the ROD for the 2007 PEIS makes no decisions regarding the number of acres to be treated using herbicides, the maximum treatment acreage assumed in the 2007 PEIS analysis is being carried over to the current 2015 PEIS for the three new herbicides. For the purposes of evaluating effects to ESA-listed and proposed species from herbicide treatments, it is estimated that up to 932,000 (about 0.4 percent of BLM-

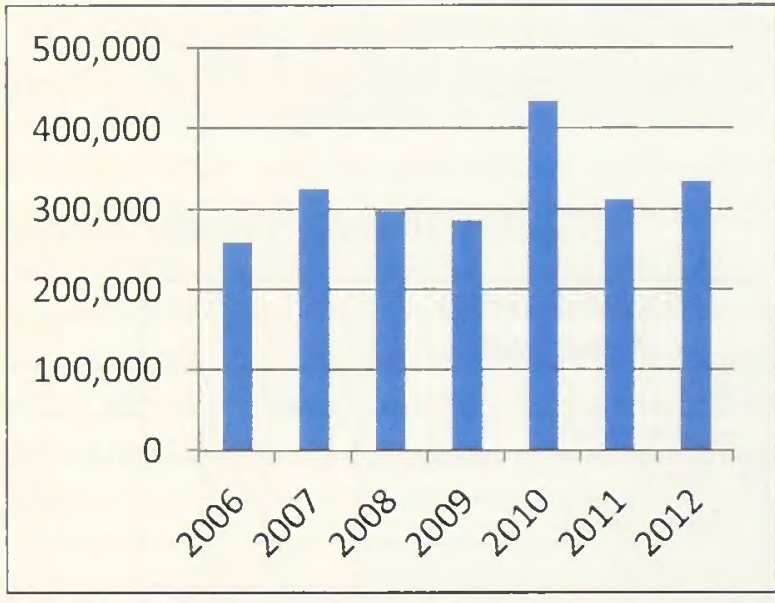

Figure 2-1. Number of Acres of Public Lands Treated using Herbicides during 2006 to 2012. administered lands) would be treated using herbicides annually.

As part of the 2015 PEIS analysis of herbicide use, ERAs were prepared by the BLM to assess the risks of the three herbicides to plants and animals, including TEP species. The methodology used to analyze risks to plants, fish, and wildlife, including TEP spccies, from use of herbicides was developed in collaboration with the Services and USEPA, prior to completing ERAs for the herbicides analyzed in the 2007 PEIS. During development of the 2007 PEIS and ERAs, SOPs, mitigation measures, and conservation measures were developed to further minimize risks to plants and animals. These impact minimization measures would continuc to be implemented under BLM vegetation management programs, including general conservation measures pertaining to all herbicide treatments. Appendix A provides a list of impact minimization measures that apply to all herbicide treatments, and which would also apply to treatments with aminopyralid, fluroxypyr, and rimsulfuron. Additional measures that are specific to herbicide treatments with other active ingredients and other types of vegetation treatments may be found in the 2007 PEIS, PER, and BA (all available at http://www.blm.gov/wo/st/en/prog/more $/ v e g$ eis.html). Additional conservation measures have been developed in this BA, where appropriate, that pertain specifically to use of aminopyralid, fluroxypyr, and rimsulfuron.

Conservation measures are conservative and designed to apply across all public lands. With all applicable conservation measures in place, herbicide treatments would result in effects to listed and proposed species that are insignificant, discountable, or completely beneficial. Applicable conservation measures would include measures in this document, as well as any revisions or additional measures specified during consultation at the local level. 
The proposed action authorizes the use of herbicides, but does not authorize, fund, or carry out any on-the-ground actions that could potentially affect TEP species. The proposed action requires field offices to comply with all SOPs in the 2015 PEIS for TEP species that could be affected by proposed site-specific projects. Prior to implementation of site-specific vegetation treatment projects that utilize aminopyralid, fluroxypyr, or rimsulfuron, BLM field offices would consult with the Services at the local level on any action that may affect ESA-listed resources. Conservation measures provided in this BA represent the minimum standards necessary for a project to fall under this programmatic BA. Local field offices have the opportunity to identify additional appropriate local measures for further reducing potential effects at the project scale if necessary. If the BLM wishes to deviate from/reduce the minimum protections identified in the programmatic BA, they will be addressed during local-level consultation with the Services. SOPs and conservation measures are discussed further in later sections of this chapter, and are listed in Appendix A of this document.

Treatments using herbicides are part of a larger effort by the BLM to treat vegetation on up to 6 million acres each year using fire and manual, mechanical, and biological control treatment methods, in addition to herbicides. Currently, the BLM is treating about 1.4 million acres annually using all methods. The primary objectives of the BLM vegetation treatment program are to manage hazardous fuels, control noxious weeds, and restore fish, wildlife, and native vegetation on public lands.

TABLE 2-1

Number of Acres Treated Annually for Herbicide Active Ingredients during 2006 to $2012^{1}$

\begin{tabular}{|c|c|c|c|c|c|c|c|}
\hline $\begin{array}{c}\text { Herbicide Active } \\
\text { Ingredient }\end{array}$ & 2006 & 2007 & 2008 & 2009 & 2010 & 2011 & 2012 \\
\hline $2,4-\mathrm{D}$ & 35,572 & 39,249 & 44,851 & 50,505 & 30,944 & 38,951 & 33,324 \\
\hline Aminopyralid $^{2}$ & 97 & 11 & 25 & 91 & 391 & 1 & 135 \\
\hline Bromacil & 2,284 & 3,066 & 3,902 & 9,051 & 4,052 & 6,338 & 3,434 \\
\hline Chlorsulfuron & 3,724 & 6,999 & 5,638 & 13,269 & 12,998 & 9,126 & 9,870 \\
\hline Clopyralid & 56,606 & 53,187 & 50,698 & 74,234 & 184,324 & 54,893 & 6,120 \\
\hline Dicamba & 3,348 & 5,709 & 4,969 & 10,929 & 12,676 & 11,172 & 6,540 \\
\hline Diflufenzopyr + Dicamba & 4 & 25 & 293 & 170 & 11 & 38 & 16 \\
\hline Diquat & 0 & 0 & 0 & 28 & 52 & 17 & 0 \\
\hline Diuron & 3,568 & 3,313 & 9,388 & 14,339 & 7,636 & 9,991 & 7,798 \\
\hline Fluridone & 0 & 0 & $<1$ & 0 & 0 & 0 & 0 \\
\hline Glyphosate & 49,422 & 37,827 & 46,741 & 23,838 & 44,420 & 26,796 & 26,390 \\
\hline Hexazinone & 85 & $<1$ & 0 & 2 & 49 & 0 & 353 \\
\hline Imazapic & 36 & 32 & 1,776 & 3,103 & 12,249 & 21,194 & 39,603 \\
\hline Imazapyr & 4,277 & 3,994 & 5,539 & 5,544 & 16,154 & 9,439 & 9,781 \\
\hline Metsulfuron methyl & 8,294 & 11,259 & 11,319 & 8,718 & 18,205 & 11,916 & 8,876 \\
\hline Picloram & 27,847 & 24,764 & 30,917 & 30,086 & 39,740 & 28,843 & 27,401 \\
\hline Sulfometuron methyl & 452 & 1,456 & 710 & 242 & 960 & 1,116 & 230 \\
\hline Tebuthiuron & 55,899 & 172,263 & 119,735 & 88,419 & 72,534 & 73,626 & 147,520 \\
\hline Triclopyr & 54,428 & 52,319 & 53,209 & 78,811 & 189,973 & 109,756 & 9,176 \\
\hline Total & 305,971 & 415,421 & 389,710 & 411,379 & 647,368 & 413,213 & 336,568 \\
\hline \multicolumn{8}{|c|}{$\begin{array}{l}\text { If an acre was treated with a tank mix of two or more herbicides, each herbicide was credited with } 1 \text { acre of treatment. Thus, the total number of } \\
\text { acres treated annually based on herbicide active ingredient may exceed the actual number of acres treated. } \\
{ }^{2} \text { Although not yet approved for use, aminopyralid has inadvertently been used alone or in tank mixes with } 2,4-\mathrm{D} \text {, as reported by contractors when } \\
\text { Pesticide Application Records are submitted. When identified, the BLM has contacted the herbicide applicators to point out the mistake and ensure } \\
\text { that aminopyralid is not used on a larger scale until approved. }\end{array}$} \\
\hline
\end{tabular}

The BLM is seeking to add aminopyralid, fluroxypyr, and rimsulfuron to its list of approved herbicides in order to have increased flexibility and options when designing herbicide treatment programs. These three herbicides have been selected for use based on their effectiveness at controlling certain noxious weeds and other target invasive plant species and their relatively low environmental risks. These herbicides have been identified by BLM field offices as active ingredients that would be useful for providing better control of certain weed species. 


\section{Herbicide Treatments}

Herbieides are chemical formulations that kill or injure plants by disrupting biochemieal proeesses. Typieally, they are applied as liquids or dry formulations mixed with water or oil carriers, which are sprayed onto vegetation. Some formulations are dry granules that are applied direetly to the soil surfaee, where they dissolve and move into the soil and are taken up by plant roots. An herbicide formulation includes an active ingredient, which is the chemical that kills the target plant, and one or more inert ingredients, which make the herbicide more effective. These inert ingredients may improve herbieide effectiveness by improving the solubility of the active ingredient, improving its ability to stick to plants or to penetrate protective layers on plant surface, or by limiting unintended drift of the herbicide mixture when it is sprayed. In this BA, all herbieides that contain a partieular aetive ingredient are referred to by the name of that active ingredient, since it may be found in numerous products that are sold under different names.

Several federal laws govern herbicide use in the U.S. The Federal Insecticide, Fungicide and Rodenticide Act (FIFRA) establishes proeedures for the registration, elassification, and regulation of all pesticides. Before any pesticide may be sold legally, the USEPA must register it. The USEPA may classify a pestieide for general use if it determines that the pestieide is not likely to cause unreasonable adverse effects to applicators or the environment, or for restricted use if the pesticide must be applied by a certified applicator and in aceordance with other restrietions. All the herbieides evaluated in the 2015 PEIS are registered with the USEPA as general use pesticides, and all applicators that apply them on public lands (i.e., eertified applieators or those directly supervised by a eertified applicator) must eomply with the herbicide label rates, uses, and handling instructions. In some cases, applieation rates allowed by the BLM are lower than the label application rates. The Resource Conservation and Recovery Act (RCRA) regulates the disposal of toxie wastes, including the disposal of unused herbicides. The Comprehensive Environmental Response, Compensation and Liability Act (CERCLA) regulates how to clean up spills of hazardous materials and when to notify agencies in case of spills.

The appropriate method for applying herbicides to unwanted vegetation is dependent on a number of factors: pestieide labeling restrietions; the treatment objective (i.e., removal or reduction); the accessibility, topography, and size of the treatment area; the characteristics of the target species and the desired vegetation; the location of sensitive areas and potential environmental impaets in the immediate vieinity; the antieipated eosts; equipment limitations; and the meteorological and vegetative eonditions of the site (USDOI BLM 1991).

Herbicide applications are scheduled and designed to minimize potential impacts to non-target plants and animals, while remaining consistent with vegetation management objectives (National Fire Plan Technical Team 2002). Applieation rates are dependent on the presence of the target species; the condition of the non-target vegetation; soil type; depth to the water table, distance to open water sources, riparian areas and/or speeial status species; and the requirements printed on the herbicide label.

Over very large areas, herbicides may be applied aerially by helicopter or fixed-wing aircraft. Aerial applieations do not disturb the soil or protective organic layers, and are not limited by inaccessibility or rugged terrain. In general, helicopters are more maneuverable than fixed-wing aireraft, more effective in areas with irregular terrain, and more effeetive for treating specifie target vegetation in areas with multiple vegetation types. A common problem associated with aerial application of herbicides is drift of ehemicals off of the target site, which may be diffieult to predict and manage.

Manual applications are suited for treatments of small areas or at sites that are inaccessible by vehicle (USDOI BLM 1991). Manual spot treatments target individual plants through herbicide injections, applieations on eut surfaces, or granular application to the surrounding soil (hand crank granular spreader). Application using backpack sprayers is another means of spot treatment, in which the herbicide applicator directs a spray hose at target plants. To eover a larger number of plants, meehanical equipment is used. In this method of treatment, herbieides are applied using a spray boom or wand attaehed to a truek, all-terrain vehicle (ATV), utility vehicle (UTV), or other type of vehiele. Truek-mounted spraying is primarily limited to roadsides and flat areas that are 
accessible. However, ATVs and UTVs can treat weeds in areas that are not easily accessible by road, such as hillsides.

\section{Herbicides Proposed for Use by the BLM}

The BLM has identified three active ingredients that should be evaluated under the 2015 PEIS and BA: aminopyralid, fluroxypyr, and rimsulfuron. All three herbicides can be applied using both ground and aerial equipment. Table 2-2 summarizes the characteristies of these herbicides and other information related to their proposed use. Additional discussion about each active ingredient is provided in the sections that follow.

\section{Aminopyralid}

Aminopyralid is a post-emergence selective herbicide that is used to control invasive annual, biennial, and perennial weed species. It is applied either aerially or using ground application equipment. It is mobile in both the xylem and phloem of the target plant, and aceumulates in leaf and root meristematic tissue. Species targeted by this herbicide include, but are not limited to, Russian knapweed, musk thistle, spotted knapweed, yellow starthistle, Russian thistle, and tansy ragwort.

Aminopyralid is registered under the USEPA's reduced risk initiative, indicating that the USEPA believes that it poses less risk to human health and the environment than existing alternatives (USEPA 2012). Aminopyralid may be used instead of picloram in certain situations. Although not registered as an aquatic herbicide, aminopyralid is approved for use right up to the water's edge. It is appropriate for use at rangeland, forestland, reereation and cultural resource sites, along rights-of-way (ROW), and at energy and mineral sites.

\section{Fluroxypyr}

Fluroxypyr is a selective, post-emergenee herbicide that is used to control certain annual and perennial weeds, including broadleaf weeds that are resistant to sulfonylurea herbicides, sueh as kochia. It can be used to eontrol weeds while maintaining grass forage species. It is applied to actively growing plants using either aerial or groundbased equipment. Fluroxypyr's mode of action is by mimicking auxins and disrupting plant cell growth. It is mobile in the xylem of the plant, and to a lesser extent the phloem. Fluroxypyr ean be tank mixed with other active ingredients to improve its effectiveness on difficult-to-control weed species. The BLM has indicated that the use of fluroxypyr can help reduce the amount of other herbicide products used in treatments. It is appropriate for use at rangeland, forestland, recreation and cultural resource sites, along ROWs, and at energy and mineral sites.

\section{Rimsulfuron}

Rimsulfuron is a selective, acetolactate synthase (ALS)-inhibiting herbicide that inhibits the biosynthesis of certain amino acids. It is applied both pre- and post-emergence, using both ground and aerial equipment. Rimsulfuron is active in both the xylem and the phloem of the plant, but primarily the phloem. Species targeted by this herbicide include winter annual grasses, such as cheatgrass and medusahead rye. Rimsulfuron has been observed to be more effective than imazapic in certain areas. It is appropriate for use at rangeland, forestland, recreation, and cultural resource sites, along ROWs, and at energy and mineral sites.

\section{Herbicide Treatment Standard Operating Procedures and Guidelines}

The BLM would follow SOPs designed to minimize risks to human health and the environment when conducting herbicide treatment actions. These SOPs include measures to minimize risks to plants and animals, including TEP plant and animal species. They include the following:

- Prevention measures during project planning, development, and revegetation phases to minimize the risk of introducing or spreading noxious weeds. 


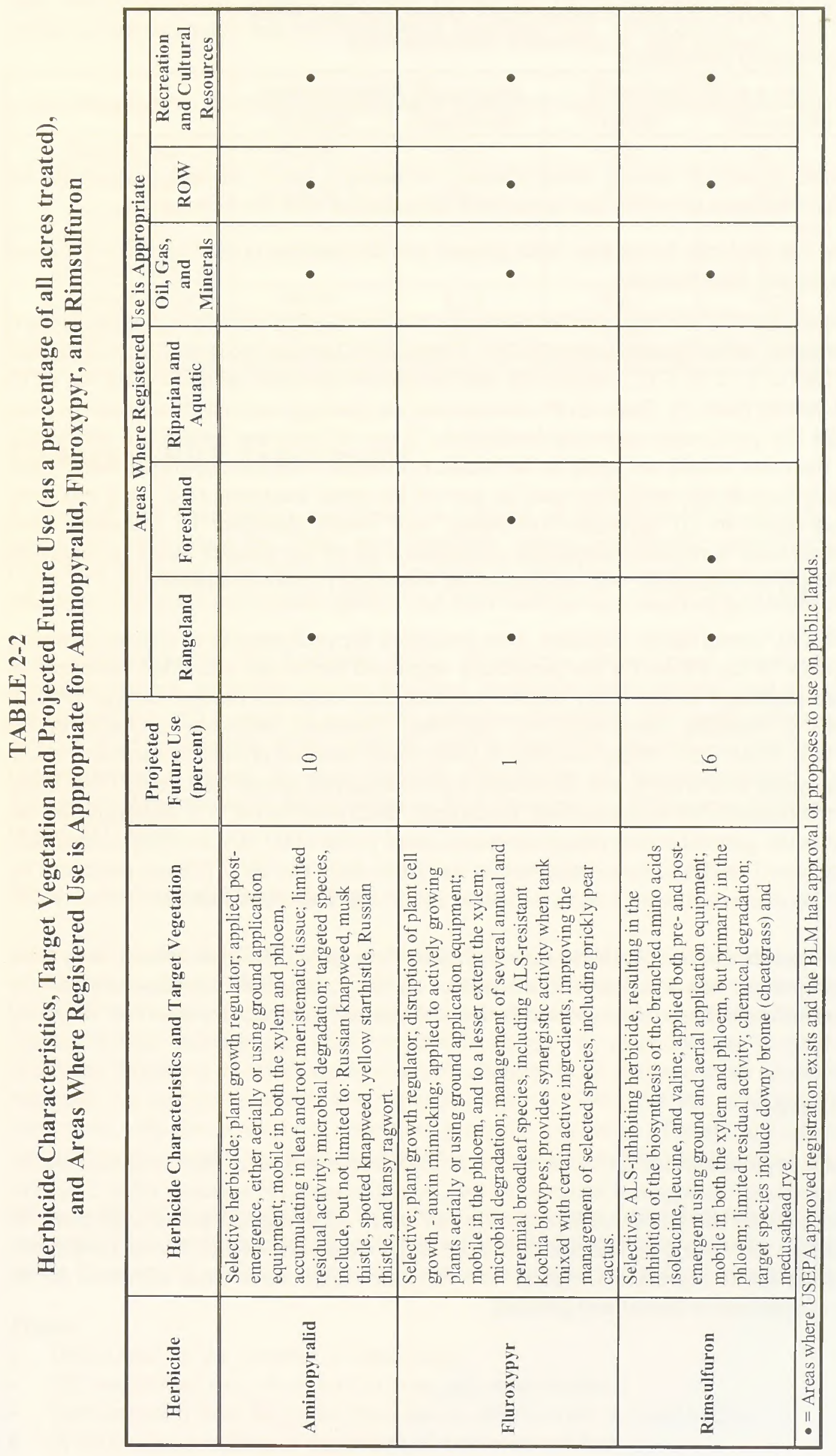


- Herbicide treatment planning, which includes evaluation of the need for ehemical treatments and their potential for impact on the environment, and development of an operational plan that includes herbicide buffers near water bodies; information on project specifications, key personnel responsibilities and communieation, safety, and spill and response; and emergeney procedures.

- Procedures specifie to site revegetation after treatments to promote establishment and/or recovery by the native plant community.

- Special precautions to minimize impacts to special status species, including a survey of each project site for TEP species prior to vegetation treatment activities and associated consultation with the Serviees.

- Standard operating procedures for applying herbieides, both general and designed to protect specific resources elements, including TEP species and their habitats.

The proposed action, as discussed in this BA, assumes that all herbicide treatments with aminopyralid, fluroxypyr, and rimsulfuron would follow pertinent herbicide application SOPs. These SOPs include those that were identified in the 2007 PEIS (USDOI BLM 2007a:2-22 to 2-35, Table-2-8), and mitigation measures developed for the ROD for the 2007 PEIS (USDOI BLM 2007b:Table 2). These SOPs incorporate the findings and recommendations from the ERAs that were completed for the previously approved herbicides. Some of them are specific to previously approved active ingredients, and therefore would not apply to herbicide treatments with aminopyralid, fluroxypyr, and rimsulfuron unless other active ingredients were also used as part of the same treatment (e.g., in a mixture). Others are general practices that apply 10 all herbicide treatments, and would therefore be followed when conducting treatments with the three new herbicides. Appendix A compiles all of the general SOPs for applying herbicides that would potentially apply to treatments with aminopyralid, fluroxypyr, and rimsulfuron.

In the 2007 BA (USDOI BLM 2007d), eonservation measures were presented for each species or species grouping analyzed, based on recommendations in the ERAs for the previously approved herbieides and other information. These conservation measures were identified as the likely impaet minimization measures needed, but do not take into account local site conditions or specific eomponents of individual treatment projeets. As stated in the Biological Opinion for the 2007 BA, BLM field offices are able to tailor these national proteetive measures based on local conditions and the habitat needs of the particular threatened and endangered species that could be affected by the treatments. For herbicide treatments with aminopyralid, fluroxypyr, and rimsulfuron, it is assumed that the BLM would continue to incorporate the general conservation measures listed in the $2007 \mathrm{BA}$, or other comparable measures developed based on local-level analysis. Key conservation measures from the 2007 BA are presented by species group/species throughout this document, with a more complete list provided in Appendix A.

Additional national-level conservation measures specific to aminopyralid, fluroxypyr, and rimsulfuron have been developed for this BA, as appropriate, based on recommendations in the ecological risk assessments for aminopyralid, fluroxypyr, and rimsulfuron. These risk assessments are diseussed in more detail in the following section.

\section{Herbicide Application Rates}

The BLM has identified typical and maximum rates for the three active ingredients, based on their proposed use by the Rangeland, Public-Domain Forestland, Energy and Mineral, ROWs, and Recreation Programs (Table 2-3). The typical application rate is the amount that the BLM would typically use when applying the active ingredient. In certain situations, a higher application rate would be warranted, but the BLM would not exceed the maximum rate identified in Table 2-3. For all three active ingredients, typical and maximum application rates identified in the table would apply to all methods of application (aerial and ground). 
TABLE 2-3

Typical and Maximum Application Rates Identified by the BLM for Aminopyralid, Fluroxypyr, and Rimsulfuron

\begin{tabular}{|c|c|c|c|c|c|c|}
\hline \multirow{2}{*}{ Program } & \multicolumn{2}{|c|}{ Aminopyralid (Ib a.e./ac) } & \multicolumn{2}{c|}{ Fluroxpyr (Ib a.e./ac) } & \multicolumn{2}{c|}{ Rimsulfuron (lb a.i./ac) } \\
\cline { 2 - 7 } & Typical & Maximum & Typical & Maximum & Typical & Maximum \\
\hline \hline Rangeland & 0.078 & 0.11 & 0.26 & 0.50 & 0.0469 & 0.0625 \\
\hline $\begin{array}{c}\text { Public-Domain } \\
\text { Forestland }\end{array}$ & 0.078 & 0.11 & 0.26 & 0.50 & 0.0469 & 0.0625 \\
\hline $\begin{array}{c}\text { Energy and } \\
\text { Mineral Sites }\end{array}$ & 0.078 & 0.11 & 0.26 & 0.50 & 0.0625 & 0.0625 \\
\hline Rights-of-Way & 0.078 & 0.11 & 0.26 & 0.50 & 0.0625 & 0.0625 \\
\hline Recreation & 0.078 & 0.11 & 0.26 & 0.50 & 0.0625 & 0.0625 \\
\hline lb a.e./ac = pounds acid equivalent per acre; and lb a.i./ac = pounds active ingredient per acre. & & \\
\hline
\end{tabular}

\section{Ecological Risk Assessments}

Ecological risk assessments completed in support of the 2015 PEIS identify the risks to plants and animals associated with using the three new herbicide active ingredients: aminopyralid, fluroxypyr, and rimsulfuron (AECOM 2014a-c). The information provided in these risk assessments was used to determine the potential for effects to TEP plant and animal speeies and their habitats as a result of herbicide treatments on publie land.

Risk assessments for the herbicide active ingredients characterized exposures scenarios involving a range of surrogate species, including speeies that have biological characteristies that are similar to those of TEP plant and animal species, and a range of exposure pathways assoeiated with applieations on a variety of upland and aquatie sites. A brief explanation of the methods used to determine the risks to non-target speeies as a result of herbicide use is presented below. A more detailed deseription of this methodology may be found in the Vegetation Treatments Programmatic EIS Ecological Risk Assessment Methodology (ENSR 2004), which is also Appendix C of the 2007 PEIS.

\section{Risk Assessment Methodology}

Surrogate species for TEP plants and animals were evaluated to determine assessment endpoints and associated measures of effect to be used in ERAs. Assessment endpoints, for the most part, refleet direct effects of an herbicide on these organisms, although indirect effects were also eonsidered. Assessment endpoints for non-target species include mortality and negative impaets on growth, reproduetion, or other ecologieally important sublethal processes. Measures of effect are measurable ehanges in an attribute of an assessment endpoint (or its surrogate) in response to a stressor to which it is exposed (USEPA 1998). For the sereening-level ERA, the measures of effect associated with the assessment endpoints generally consisted of aeute and chronie toxicity data (from pesticide registration doeuments and from the available scientifie literature) for the most appropriate surrogate species.

Because the BLM uses herbicides in a variety of programs (e.g., maintenance of rangeland and recreational sites) and application methods (e.g., via aireraft, vehicle, backpack), the following exposure scenarios were considered to assess the potential ecological impacts of herbicides under a variety of uses and conditions:

\section{Plants}

- Direct spray of the receptor or water body

- Off-site drift of spray to terrestrial areas and water bodies

- Surface runoff from the application area to off-site soils or water bodies

- Wind erosion resulting in deposition of contaminated dust

- Aceidental spills to water bodies 


\section{Aquatic Animals}

- Direct spray of the water body

- Accidental spill to the water body

- Off-site drift of spray to the water body

- Surface runoff from the application area to the water body

\section{Terrestrial Animals}

- Direct spray of terrestrial wildlife

Small mammal - 100\% absorption

Pollinating insect - $100 \%$ absorption

Small mammal $-1^{\text {st }}$ order dermal absorption (absorption occurs over 24 hours, taking into consideration the potential for some herbicide to not be absorbed)

- Indirect contact with foliage after direct spray

Small mammal $-100 \%$ absorption

Pollinating insect $-100 \%$ absorption

Small mammal $-1^{\text {st }}$ order dermal absorption

- Ingestion of food items contaminated by direct spray

Small mammalian herbivore - acute and chronic exposure

Large mammalian herbivore - acute and chronic exposure

Small avian insectivore - acute and chronic exposure

Large avian herbivore - acute and chronic exposure

Large mammalian carnivore - acute and chronic exposure

- Ingestion of food items contaminated by surface runoff or off-site drift

Piscivorous bird

For each scenario, applications using both the typical and maximum application rate were considered, so that risks to assessment endpoints could be determined for both. Exposure scenarios involving off-site drift, surface runoff, and wind erosion were not modeled for terrestrial wildlife. All modeled scenarios assume broadeast applications of herbicides, using either ground or aerial equipment. Manual spot treatments target individual plants over a small area, and are highly controlled, so risk can be minimized.

The AgDRIFT ${ }^{\circledR}$ computer model was used to estimate off-site herbicide transport due to spray drift. The Groundwater Loading Effects of Agricultural Management Systems (GLEAMS) computer model was used to estimate off-site transport of herbicide in surface runoff and root zone groundwater transport. The AERMOD and California Puff (CALPUFF) computer models were used to predict the transport and deposition of herbicides adsorbed (i.e., reversibly or temporarily attached) to wind-blown dust. Each model simulation was conservatively approached with the intent of predicting the maximum potential herbicide concentration that could result from the given exposure scenario.

In order to address potential risks to plant and animal receptors, Risk Quotients (RQs) were calculated. To facilitate the translation of RQs into readily applicable estimates of risk, the calculated RQs were compared with Levels of Concern (LOCs) used by the USEPA in screening the potential risk of herbicides. Distinct USEPA LOCs are currently defined for the following risk presumption categories:

- Acute high risk - the potential for acute risk is high

- Acute restricted use - the potential for acute risk is high, but may be mitigated

- Acute endangered species - TEP species may be negatively affected

- Chronic risk - the potential for chronic risk is high 
For the analysis presented in this BA, LOCs for the aeute endangered speeies and chronic risk eategories were used. Wherever the RQ exeeeded one or more of these LOCs, it was assumed that adverse health effeets to the TEP speeies in question eould potentially oeeur under that exposure seenario.

\section{Adjuvants, Degradates, Inert Ingredients, Tank Mixes, Formulations, and Endocrine Disrupting Chemicals}

Herbieide formulations are a eommereial mixture of both aetive and inert (inaetive) ingredients. Inert ingredients are those ingredients that are added to the eommereial produet (formulation) and are not herbieidally aetive.

As part of the ERA, the BLM assessed the general risks to plants and animals from inert ingredients found in herbieide formulations and from adjuvants. The ERAs also addressed potential risks assoeiated with:

- Adjuvants - ehemieals that are added to the herbieide formulation to enhanee the aetivity of the aetive ingredient or to make the aetive ingredient easier to handle. They inelude surfaetants, materials that improve the emulsifying, dispersing, spreading, wetting, or other surfaee-modifying properties of liquids.

- Degradates - physieal or biologieal breakdown eompounds of a eomplex eompound.

- Tank mixtures - the mixture of two or more eompatible herbieides in a spray tank in order to apply them simultaneously.

\section{Herbicide Formulations Used by the BLM}

The BLM generally uses several formulations of eaeh aetive ingredient approved for use on publie lands. Current formulations of the three herbicides proposed for use are shown in Table 2-4, whieh ineludes the USEPA registration number of eaeh formulation. The approval proeess for formulations of the approved aetive ingredients takes into eonsideration eoneerns assoeiated with the inert ingredients and adjuvants.

Before a formulation of one of the approved aetive ingredients ean be approved, the following information is required: 1) a letter from the manufaeturer/formulator stating that the other ingredients found in the formulation are found on the USEPA Food and Nonfood Use or Nonfood Use lists; 2) a eopy of the eurrent label and Material Safety Data Sheet; and 3) a statement indieating whether the formulation is registered in California.

\section{Inert Ingredients}

Herbieide produets eontain both aetive and inert ingredients. The terms "aetive ingredient" and "inert ingredient"/"other ingredients" have been defined by federal law-the FIFRA — sinee 1947. An aetive ingredient is one that prevents, destroys, repels, or mitigates the effeets of a pest, or is a plant regulator, defoliant, desieeant, or nitrogen stabilizer. By law, the aetive ingredient must be identified by name on the label, together with its pereentage by weight. An inert ingredient is any ingredient in the produet that is not intended to affeet a target pest. For example, isopropyl aleohol may be an aetive ingredient and antimierobial pestieide in some produets; however, in other produets, it is used as a solvent and may be eonsidered an inert ingredient. The law does not require inert ingredients to be identified by name and pereentage on the label, but the total pereentage of sueh ingredients must be deelared. Beeause neither the federal law nor the regulations define the term "inert" on the basis of toxieity, hazard or risk to humans, non-target speeies, or the environment, it should not be assumed that all inert ingredients are non-toxie.

As deseribed at http://www.epa.gov/opprd00l/inerts/, pestieide inert ingredients permitted for use by the USEPA, fall into one of three eategories: Food and Nonfood Use, Nonfood Use List, and Fragranee Ingredient List. The BLM requires that inert ingredients found in herbieide formulations and adjuvants must be on the Food and Nonfood Use or Nonfood Use lists. 
TABLE 2-4

Formulations of the Three Herbicides Proposed for Use on Public Lands

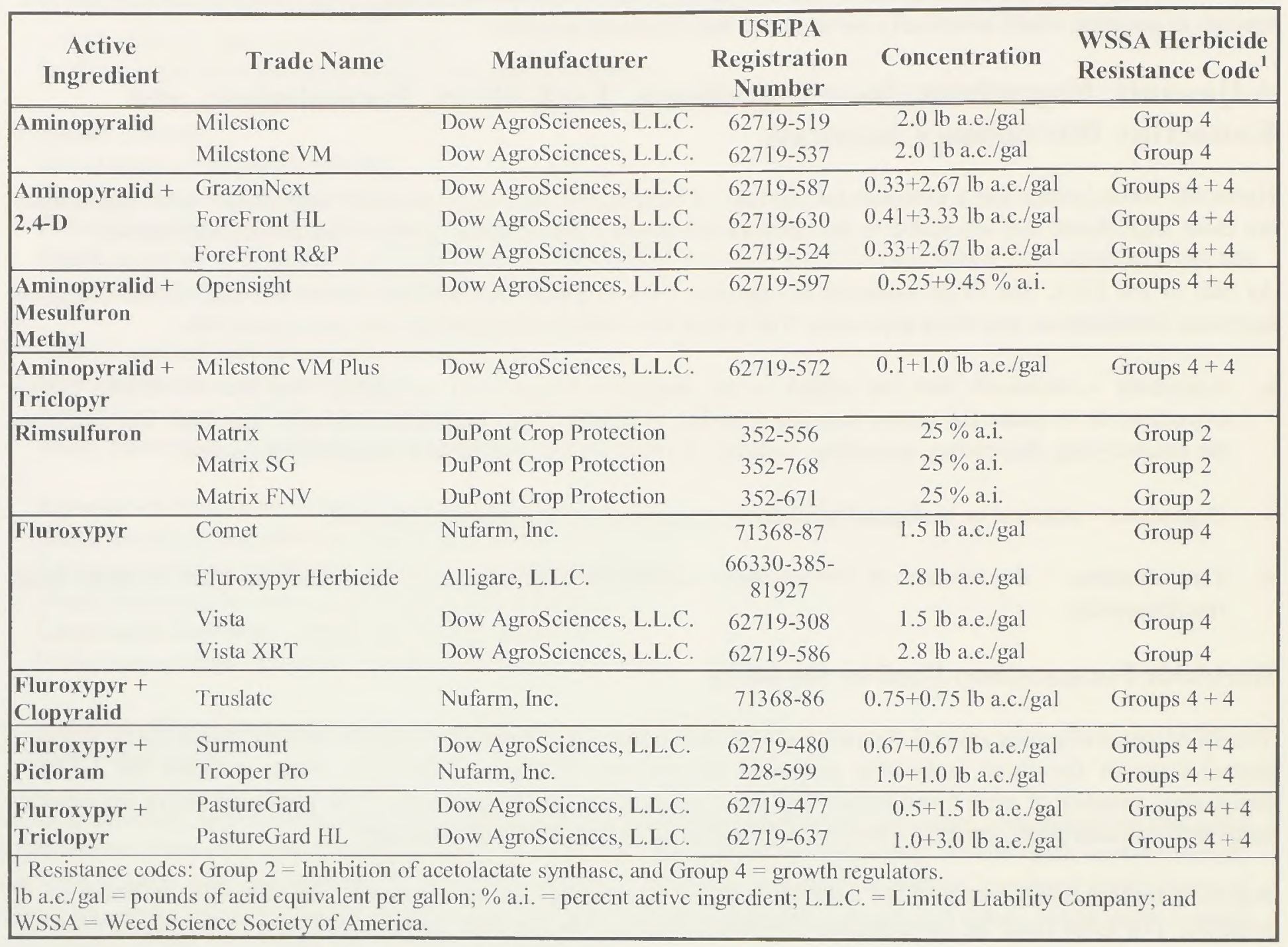

Food and Nonfood Use - inert ingredients approved for pesticide products applied to food. These inert ingredients have either tolerances or tolerance exemptions in 40 CFR part 180, or their residues are not found in food. All food use ingredients are also permitted for nonfood use.

Nonfood Use Only - inert ingredients permitted solely for use in pesticide products applied to nonfood use sites, such as ornamental plants, highway ROWs, rodent control, etc. These inert ingredients may not be applied to food. Manufacturers must identify that inert ingredients found in an herbicide formulation or adjuvant are found on the appropriate list of approved inert ingredients.

\section{Adjuvants}

Adjuvants generally function to enhance or prolong the activity of an active ingredient. For terrestrial herbicides, adjuvants aid in proper wetting of foliage and absorption of the active ingredient into plant tissue. Adjuvant is a broad term that includes surfactants, selected oils, anti-foaming agents, buffering compounds, drift control agents, compatibility agents, stickers, and spreaders. Adjuvants are not under the same registration guidelines as pesticides; the USEPA does not register or approve the labeling of spray adjuvants. Individual herbicide labels contain lists with "label-approved" adjuvants for use with a particular herbicide under specific conditions. Currently, more than 200 adjuvants are approved for use on BLM-administered lands. 
The GLEAMS model was used in the BLM ERAs to estimate the potential portion of an adjuvant that might reaeh an adjaeent water body via surfaee runoff. In addition, sourees (Muller 1980; Lewis 1991; Dorn et al. 1997; Wong et al. 1997) generally suggest that aeute toxicity of surfaetants and anti-foam agents to aquatie life range from 1 to 10 milligrams per liter $(\mathrm{mg} / \mathrm{L})$, and that ehronie toxieity eoneentrations are as low as $0.1 \mathrm{mg} / \mathrm{L}$.

\section{Aminopyralid}

Only nonionie surfaetants have been identified as adjuvants for use with aminopyralid formulations on the herbieide label. Aeeording to ERAs, the maximum predieted eoneentration of the inert/adjuvant eompound would be 0.03 to $0.06 \mathrm{mg} / \mathrm{L}$, based on the reeommended nonionie surfaetant applieation rate and the maximum ground applieation rate for aminopyralid. This value is well below the ehronie toxieity value for nonionie surfaetants $(0.1$ $\mathrm{mg} / \mathrm{L})$, and at the low end of the range for behavioral and physiologieal effeets $(0.002$ to $40.0 \mathrm{mg} / \mathrm{L}$; Lewis 1991).

\section{Fluroxypyr}

Only methylated seed oil (MSO) surfaetants have been identified as adjuvants reeommended for use with eertain fluroxypyr formulations, when used for eontrol of koehia. In the ERA for fluroxypyr, the GLEAMS model eould not be used to estimate the potential portion of MSO that might reaeh an adjaeent water body via surfaee runoff beeause applieation rates are not provided in the eorreet mathematieal unit. Therefore, a literature review was eondueted to assess the toxieity of MSO relative to other adjuvants used in herbieide applieations. Based on this literature review, MSO has been identified as one of the least toxie adjuvants, and aeute adverse effeets to aquatie speeies would be unlikely under a eonservative seenario involving direet applieation of the ehemieal to a pond. However, predieted eoneentrations under this seenario are above the ehronie toxieity value for nonionie surfaetants, and within the range for behavioral and physiologieal effeets. Therefore there are some eoneerns with long-term exposure of aquatie habitats to MSO, partieularly under spill seenarios.

\section{Rimsulfuron}

Based on a review of labels of rimsulfuron formulations, several types of spray adjuvants (e.g., nonionie surfaetant, petroleum erop oil eoneentrate, modified seed oil, ammonium nitrogen fertilizer, and eombination adjuvant produets) were identified as being eompatible for use with rimsulfuron produets. Aceording to the ERA, the maximum predieted eoneentration of the inert/adjuvant eompound would be $0.011 \mathrm{mg} / \mathrm{L}$. This value is well below the ehronie toxieity value for nonionie surfaetants $(0.1 \mathrm{mg} / \mathrm{L})$ and in the low end of the range for behavioral and physiologieal effeets $(0.002$ to $40.0 \mathrm{mg} / \mathrm{L}$; Lewis 1991).

This evaluation indieates that, for herbieides with high applieation rates, adjuvants have the potential to eause aeute, and potentially ehronie, risk to aquatie speeies. However, more speeifie modeling and toxieity data would be neeessary to define the level of uneertainty. The primary use of rimsulfuron would be as a pre-emergenee herbieide, a use for whieh no adjuvant is required. Seleetion of adjuvants is under the eontrol of BLM land managers, and it is reeommended that land managers follow all label instruetions and abide by any warnings. In general, adjuvants eompose a relatively small portion of the volume of herbieide applied. However, seleetion of adjuvants with limited toxieity and low volumes is reeommended to reduee the potential for the adjuvant to influenee the toxieity of the herbieide.

\section{Degradates}

The potential toxieity of degradates should be eonsidered when seleeting an herbieide. However, it was beyond the seope of the ERAs to evaluate all of the possible degradates of the herbieide formulations. Degradates may be more or less mobile and more or less toxie in the environment than their souree herbieides (Battaglin et al. 2003). Differenees in environmental behavior (e.g., mobility) and toxieity between parent herbieides and degradates makes predietion of potential impaets ehallenging. For example, a less toxie, but more mobile bioaeeumulative, or persistent degradate may have a greater adverse impaet due to residual coneentrations in the environment. The laek of data on the toxieity of degradates of the speeifie herbieides represents a souree of uneertainty in the risk assessment. 
During preparation of the 2007 PEIS, the BLM responded to concerns expressed by the public by conducting additional studies to evaluate information on degradates and try and determine if it is likely for degradates to be more toxic than the parent compounds (active ingredients; see Appendix D of the 2007 PEIS). This assessment found that degradates are often not identified or named in registration documents, that the physical and chemical attributes of degradates are often poorly understood, and that assessing the risks from degradates would be an enormous job given the vast number of degradates identified for the 18 herbicides addressed in the 2007 PEIS. For the risk assessments completed for aminopyralid, fluroxypyr, and rimsulfuron, the lack of data on the toxicity of degradates were considered a source of uneertainty in the risk assessment. Differences in the environmental behavior and toxicity between parent herbicides and degradates makes prediction of potential impacts associated with degradates challenging. Numerous degradates of herbicides have a similar or reduced toxicity to the parent herbicide, but some may be more toxic than the parent pesticide (Sinclair and Boxall 2003).

\section{Tank Mixes}

The BLM used a mixture of two or more herbicides to treat approximately 20 pereent of public lands during 2001 through 2011. The use of mixtures of herbicides, along with the addition of an adjuvant (when stated on the label), may be an efficient use of equipment and personnel. However, knowledge of both products and their interactions is necessary to avoid unintended negative effeets. In general, herbicide interactions ean be classified as additive, synergistic, or antagonistic:

- Additive effects oecur when mixing two herbicides produces the same response as the combined effects of each herbicide applied alone. The products neither hurt nor enhance each other.

- Synergistic responses occur when two herbicides provide a greater response than the added effeets of each herbicide applied separately.

- Antagonistic responses oceur when two herbieides applied together produce less control than if you applied each herbicide applied separately.

While a quantitative evaluation of all of these mixtures is beyond the seope of the ERAs prepared for the 2015 PEIS and this BA, a qualitative evaluation may be made if it is assumed that the produets in the tank mix will aet in an additive manner. The predicted RQs for two active ingredients can be summed for each individual exposure scenario to see if the combined impacts result in additional RQs elevated above the corresponding LOCs.

Based on simulations of tank mixes in risk assessments completed for the 2007 PEIS, and a similar exereise completed for mixtures involving the active ingredients being considered in this BA, the combined toxicity of multiple active ingredients is specific to each tank mix. Aquatic plants and TEP terrestrial plants may be at greater risk from the mixed application than from the active ingredient alone. However, in some cases all receptors are at greater risk, and precautions (e.g., increased buffer zones, decreased application rates) should be taken to reduce risk. There is some uncertainty in this evaluation because herbicides in tank mixes may not interact in an additive manner. Thus, the evaluation may overestimate risk if the interaction is antagonistic, or it may underestimate risk if the interaction is synergistic. In addition, other products may also be included in tank mixes that may contribute to the potential risk.

Selection of tank mixes, like adjuvants, is under the control of BLM land managers. To reduce uncertainties and potential negative impacts, it is required that land managers follow all label instructions and abide by any warnings, including conservation measures and SOPs identified in this BA and in the $2007 \mathrm{BA}$. Labels for all products in the tank mix should be thoroughly reviewed, and mixtures with the least potential for negative effects should be selected, particularly for applications with increased potential for risk. Use of a tank mix under these conditions increases the level of uncertainty in risk to the environment. Measures to mitigate for risks associated with use of tank-mixed products, such as buffers between treatment areas and TEP species and their habitats, may require analysis at the local level. These local-level analysis may include use of information in ERAs and local site conditions (e.g., soil type, annual precipitation, vegetation type, treatment method, application rate, and potential 
additive effects from multiple active ingredients) to more precisely caleulate buffer distances to minimize effeets to TEP species.

\section{Endocrine Disrupting Chemicals}

Endoerine disrupting chemicals are exogenous substances that alter funetion(s) of the endoerine (hormone) system and ean cause adverse health effects in an organism, its progeny, or in (sub)populations (World Health Organization 2002).

Endocrine disrupters interfere with the funetioning of the endocrine system, in at least three possible ways:

- By mimicking the action of a naturally produeed hormone, such as estrogen or testosterone, and thereby setting off similar chemical reaetions in the body;

- By blocking the receptors in cells reeeiving the hormones (hormone reeeptors), thereby preventing the action of normal hormones; or

- By affecting the synthesis, transport, metabolism and exeretion of hormones, thus altering the eoneentrations of natural hormones.

The BLM eonducted a search of endoerine disrupter databases, including sourees from the U.S., the European Union, and Japan. The databases included official government lists and lists published by concerned eitizen groups, such as the Pesticide Action Network. It should be noted that the eriteria used to trigger listing are not the same for eaeh list. Therefore, not all lists are the same. In fact, there is no USEPA-approved methodology for defining occurrence and magnitude of potential endocrine disrupting effeet. For this reason, quantitative risk assessment of endocrine disruption is very diffieult.

The USEPA's Endoerine Disruptor Sereening Program currently maintains a Universe of Chemicals list, which includes approximately 10,000 ehemicals that have been identified to undergo some type of sereening for endoerine disrupting effects (USEPA 2014). These ehemicals are prioritized for sereening, whieh is eurrently underway. Aminopyralid is not on the list for future sereening. Based on the available toxieity studies for this aetive ingredient, it does not have estrogen, androgen, or thyroid mediated toxicity (USEPA 2005). Fluroxypyr and rimsulfuron are on the Universe of Chemicals list, but have not yet gone through the screening process. Therefore, there is limited information available for determining whether these active ingredients have the potential to cause endocrine disrupting effects. The BLM conducts periodic reviews of the active ingredients utilized in herbicide treatment programs, and risk assessments are updated every few years. If any new information about the potential for these active ingredients to eause endocrine disrupting effects becomes available in the future, the BLM will review the information and evaluate whether changes in the way the herbicides are used on Public Lands is warranted.

\section{Procedures to be Followed by Local Field Offices to Protect Species of Concern from Herbicide Applications}

An important purpose of the ERAs is to provide guidanee to BLM field offices on the proper method of application of herbicides to ensure that impacts to animals and non-target plants are minimized to the extent practical when treating vegetation. This guidance is also intended to ensure that treatment actions at the local level are not likely to jeopardize the continued existence of a listed species or result in the destruction or adverse modification of designated critieal habitat. This information may also be useful in developing treatment application plans for herbicides that are already approved for use by the BLM.

The information provided in this BA, as obtained from ERAs, will allow the BLM to determine herbicide application methods and amounts that could be used without harming non-listed species. For listed species, additional safety factors have been identified (e.g., reducing the amount of ehemical applied, or requiring a safety 
buffer between the treatment area and location of a listed species) as mitigation. This information may be used to help the BLM determine which herbicides could be applied, and how they could be applied, without jeopardizing the continued existence of a listed species or resulting in the destruction or adverse modification of designated eritical habitat.

Using this information, the BLM will follow a set of procedures to protect TEP species when using herbicides currently approved for use:

- The BLM will identify appropriate application methods, including rate, time, and mode of application (source characterization) for projects involving the use of herbicides.

- The BLM will incorporate mitigation and conservation measures identified in the ERAs and BA, and from analysis of exposure levels based on modeling, to eliminate or reduce risks to TEP species. It is possible that conservation measures would be more or less restrictive than those listed in subscquent sections of this BA if local site conditions are evaluated using the ERAs when developing project-level conservation measures. Measures that are agreed upon by the BLM and the Services at the loeal level will be incorporated into planning documents. The signed Pesticide Use Proposal will include a section identifying applicable measures for listed species, and the BLM will be required to follow these measures once the Pesticide Use Proposal is signed.

- The BLM will use herbicides in a manner that is consistent with labeling instructions, design criteria, the applicable Pesticide Use Proposal, and any issued reasonable and prudent measures with terms and conditions to ensure that unlawful taking of an ESA-listed species does not oecur. The BLM will consult with the Services as per Section 7(a)(2) of the ESA on any action that "may affect" listed resources.

General guidance on exposure levels and on mitigation and conscrvation measures to reduce exposure levels to acceptable levels are provided in Sections 4 through 6 of the BA, in the ERAs, and in the 2015 PEIS.

\section{Non-herbicide Treatments}

A discussion of non-herbicide vegetation treatment methods (fire, mechanical, manual, and biological eontrol methods) may be found in the $2007 \mathrm{BA}$. These methods are not discussed in this BA, but are considered during analysis of cumulative effects. 


\section{CHAPTER 3}

\section{SPECIAL STATUS SPECIES MANAGEMENT CONSULTATION PROTOCOL}

There are typically two "tiers" of action when a federal ageney adopts or approves a management plan or strategy that will be used to guide the development and implementation of future projects. The first tier of action involves adopting the broad management plan or strategy, and the seeond tier involves implementing site-specifie aetions. Both tiers require consultation under Seetion 7 of the ESA.

Consultation with the Serviees is required when any action authorized, funded, or earried out by a federal ageney may affect any ESA listed species or eritical habitat that has been designated for those speeies. This ehapter identifies the steps that will be taken by the BLM at the national and local level to ensure that their actions requiring authorization or approval by the Services are consistent with guidanee provided in the 2015 PEIS, this BA, ERAs (AECOM 2014a-c), Endangered Species Consultation Handbook (USFWS and NMFS 1998), BLM Manual 6840 (Special Status Species Management), BLM Handbook H-1601-1 (Land Use Planning Handbook), and consultation with the Services as part of the preparation of the 2015 PEIS and BA. In particular, the focus of this protocol is to ensure that any action authorized, funded, or earried out by the BLM will not jeopardize the eontinued existence of any listed species or result in the destruetion or adverse modification of eritieal habitat of such speeies. If followed, these steps should ensure that the conservation needs of TEP species and other speeial status speeies are met.

This BA and the PEIS evaluate the potential for herbicide treatments using aminopyralid, fluroxypyr, and rimsulfuron to affeet TEP speeies and designated and proposed eritical habitat on BLM lands in the western U.S., ineluding Alaska. These documents establish standards, guidelines, and design eriteria to which future vegetation treatment actions must adhere. Programmatic consultation inereases the effieieney of the Seetion 7 consultation process because much of the effects analysis is completed up-front and the effeets of future aetions are broadly aceounted for. For example, much of the analysis of the effeets of the use of herbieides on speeies of eoneern has been completed as part of this BA and risk assessments; this information ean be ineorporated into the assessment for loeal projeets. Programmatic eonsultation also minimizes the potential "piecemeal" effeets than ean oeeur when evaluating individual projects out of eontext of the complete ageney program.

\section{Programmatic Level Consultation}

As part of the first phase of consultation, the Services will develop a Biological Opinion that analyzes the potential landseape-level effeets that may result from implementing the proposed action. For the 2015 PEIS and this BA, there is substantial temporal and spatial uneertainty about future aetions, resulting in corresponding uncertainty regarding potential effeets at the loeal level. As a result, a seeond phase is required that involves development of appropriate project-specific documentation that addresses the speeifie effects of individual projeets proposed by BLM field offices.

An important feature of the first phase of eonsultation is the development of design eriteria or standards that ean be used to guide future projects. Design eriteria are developed through a five-step process:

- Identify the conservation needs of each species.

- Identify the threats to each listed species. 
- Identify the speeies conservation or management unit.

- Identify the species conservation goals within the eontext of the BLM's programs and authorities.

- Develop conservation/management strategies for implementing future activities (design criteria; eonservation measures).

These five elements have been ineorporated into this BA This BA helps to streamline the consultation process by completing a portion of the effeets analysis early in the consultation process, and providing conservation measures that reduce potential adverse effects to listed species and which will be applied ageney-wide.

\section{Local-Level Consultation}

Prior to implementation of specific vegetation treatment projects that utilize aminopyralid, fluroxypyr, and rimsulfuron, BLM field offices will consult with the Services at the local level on any action that may affeet ESAlisted resourees. This process will include a site-specific analysis of potential effeets to TEP speeies from proposed vegetation treatment actions. At this level, the BLM will be able to determine more specifieally which species might be impacted by the proposed treatments, the nature and extent of potential impacts, and what conservation measures are needed to reduce potential adverse effects to these species. Using the conservation measures in this $\mathrm{BA}$ as a starting point, the BLM will develop a final list of conservation measures during the local-level consultation. BLM field offices will tailor the national protective measures based on local conditions and the habitat needs of the particular TEP species that could be affeeted by the treatments. The conservation measures in this doeument are the minimum standards necessary for a project to fall under this programmatic BA. If the BLM wishes to modify a project and its conditions and/or parameters while still maintaining the safety of the identified TEP species, the BLM will coordinate with the Services at the loeal level through informal consultation. However, when a project deviates from/reduces the minimum protections identified in the programmatic BA and adequate protections eannot be afforded to the species in question, formal consultation must be initiated.

\section{Tracking Local-Level Consultation}

In order to track whether consultations are occurring at the local level, the BLM is expanding Seetion V of Pesticide Use Proposals ("Sensitive Aspects and Precautions") prepared by field offices to include more specifie questions about coordination with USFWS and NMFS when an herbicide application for vegetation treatments will overlap a site with TEP species or designated critical habitat. The new questions are as follows:

1. Are there "Special Status Species" in the proposed treatment area?

A. If "No" - no further questions.

B. If "Yes" - Are any of the Special Status Species also federally threatened, endangered or proposed?

a. If "No" - no further questions.

b. If "Yes" - Did your Field Office coordinate with the local Fish and Wildlife Service office and/or NMFS?

I. If "No"- explain.

II. If "Yes" - was Section 7 consultation completed?

1. If "No"- explain.

2. If "Yes" - what extent of Section 7 consultation was completed?

"Formal Consultation"

"Informal Consultation"

"Technical Assistance"

(circle one)

2b. Describe the outcome of the consultation.

The BLM enters information from Pesticide Use Proposals into the National Invasive Species Information Management System, where the BLM tracks all pesticide use data on BLM-administered lands and produces a 
yearly report of its pesticide use. This information will assist the BLM in tracking all of its herbicide treatment projects that have resulted on additional site-specific consultation under Section 7 of the ESA. 



\section{CHAPTER 4}

\section{PLANTS}

\section{Background Information}

This BA eonsiders a total of 163 plant speeies that are listed as threatened or endangered, or that are proposed for listing. For this baekground diseussion, these speeies have been arranged on the basis of the eeoregions (Bailey 1995 ) in which they are loeated. These divisions provide groupings that eonsider both geography and broad habitat types, and are the same divisions used for mueh of the analysis in the 2015 PEIS.

Most of the information eontained in this seetion was obtained direetly from Federal Register doeuments, speeies reeovery plans, BAs and biologieal evaluations, and other sourees of information. Where primary referenee(s) was/were used for speeies baekground and listing information, full eitations are listed in the individual seetions for each speeies. In some instanees, eitations were used from the primary referenee(s), and the eomplete eitations were not available from the primary referenee(s) for inelusion in the Bibliography (Chapter 7). In the instanees where eomplete eitations were not available, information on where eomplete eitations ean be found (e.g., USFWS Saeramento Field Offiee, Saeramento, California) is provided in the individual seetions.

\section{Temperate Desert Ecoregion Division}

The Temperate Desert Eeoregion Division ineludes the arid lands loeated in the rain shadow of the Paeifie mountain ranges. Portions of the Great Basin, Columbia Plateau, and the Wyoming Basin are found in this eeoregion division, which supports vegetation that is adapted to summer droughts and eold winters. Plant eommunities oeeurring in the Temperate Desert Division inelude sagebrush steppe, perennial grasslands, evergreen (mostly pinyon-juniper) woodlands, deeiduous shrublands (found in the Great Basin and deserts of the southwest), and evergreen forests.

\section{Malheur Wire-lettuce}

The primary referenee for this seetion is:

USFWS. 2011a. Malheur Wire Lettuee (Stephanomeria malheurensis) 5-Year Review: Summary and Evaluation U.S. Fish and Wildlife Serviee Oregon Fish and Wildlife Offiee. Portland, Oregon.

Malheur wire-lettuee (Stephanomeria malheurensis) is an annual plant that is found at only one 70-aere loeation near Malheur National Wildlife Refuge in Harney County, Oregon. This population is found within the high desert environment typieal of the northern portion of the Great Basin, on top of a dry, broad hill. The substrate at this loeation is an azonal soil derived from the voleanie tuff layered with thin erusts of limestone. By eontrast, the surrounding soils are derived from basalt. The top of the hill is about 500 feet above the surrounding flats, whieh eonsist of sagebrush-rabbitbrush desert. The immediate site itself is dominated by big sagebrush, eommon or gray rabbitbrush, and downy brome. Malheur wire-lettuee appears to be one of the few speeies that is able to survive on and around the otherwise barren harvester ant hills at the site. The area has been feneed to proteet the population.

Beeause the speeies is an annual, the numbers of plants vary greatly from year to year, and depend largely on the amount of preeipitation reeeived prior to and during the spring growing season. Seeds germinate in the fall after a late summer/early fall rain.

The Malheur wire-lettuee was federally listed as endangered on November 10, 1982 (47 Federal Register [FR] 50881), and eritieal habitat was designated on the same day to inelude the 160-aere Seientifie Study Area on publie land administered by the BLM, loeated 27 miles south of Burns in Harney County, Oregon. Beeause of its extremely restrieted range and low numbers, this speeies is vulnerable to even small land disturbanees in and 
around its habitat. Potential future zeolite mining in the area also endangers the continued existence of this species. Other threats to this species include competition with downy brome, grazing by native herbivores, and possible foraging by beetle larvae.

\section{Desert Yellowhead}

The primary references for this section are:

USFWS. 2002a. Listing the Desert Yellowhead as Threatened. Federal Register 67 (50):11442-11449.

and

USFWS. 2010a. Reeovery Outline for Yermo xanthocephalus (Desert Yellowhead). U.S. Fish and Wildlife Service Wyoming Field Office. Cheyenne, Wyoming.

References cited in this section are internal to the above-refereneed documents. They are ineluded in the Bibliography.

Desert yellowhead (Yermo xanthocephalus) is a recently deseribed endemic to the south end of Cedar Rim on the summit of Beaver Rim in southern Fremont County, Wyoming. The species is restrieted to shallow deflation hollows in sandstone outerops of the Split Rock Formation (Van Houten 1964). These wind-excavated hollows accumulate drifting snow and may be moister than surrounding areas. The vegetation of these sites is typically sparse, consisting primarily of low-cushion plants and scattered clumps of Indian ricegrass.

Desert yellowhead is known from a single population widely scattered over an area of less than 50 acres of suitable habitat. This population is located in the BLM's Lander Resource Area, which is rich in locatable mineral resourees, such as gold, copper, and uranium. The total population size varied from approximately 9,000 to 13,000 individuals during the period 1995 to 2003.

Desert yellowhead is a tap-rooted, perennial herb. Flower heads are numerous (25 to 180) and are crowded at the top of the stem. The species flowers and fruits in the spring and summer.

The desert yellowhead was federally listed as threatened on Mareh 14, 2002 (67 FR 11442). On March 16, 2004, the USFWS designated approximately 360 acres of land managed by the BLM in Fremont County, Wyoming, as eritical habitat (69 FR 12278). The species is vulnerable to extinetion from even small-scale habitat degradation due to its small population size and limited geographic range. Although the site is largely protected, potential threats include surface disturbances associated with oil and gas development, compaction by vehicles, weed infestation, trampling by livestock, and randomly occurring, catastrophic events.

\section{Steamboat Buckwheat}

Steamboat buckwheat (Eriogonum ovalifolium var. williamsiae) is a shrub that occurs most commonly on open slopes in gravelly, sandy-clay soil that is derived from hot spring deposits around the Steamboat Springs geothermal area, 10 miles south of Reno, Nevada. The associated plant community is desert shrub, and commonly includes saltbush, greasewood, rubber rabbitbush, snakeweed, and desert saltgrass. The habitat varies from 4,580 to 4,720 feet in elevation. Steamboat buckwheat is largely restricted to shallow to moderately deep (less than 21inch), siliceous hot spring deposits known as sinter, in open areas of relatively low density vegetation (CH2M Hill 1986a). It is a colonizing species on sinter deposits and may eventually be out-competed by other plant species. Steamboat buckwheat is locally abundant, but apparently restricted to approximately 50 acres of plants in an area of approximately 250 to 373 acres on a combination of private and public lands. About half of the lands on which Steamboat buckwheat occurs are under a 30-year lease by the Ormat Technologies Inc. for geothermal power production. The remainder of the population and its habitat are on private property and public lands managed by the BLM (USFWS 2009a).

Steamboat buckwheat grows in low, compact, woody mounds up to 18 inches across, covered with rosettes of small leaves (Nevada Division of Forestry, no date). Pink flowers appear on leafless stems from May through July, 
clustered into tight balls at the tips. The reproductive biology of the speeies is not well understood. Although eaeh plant may produce hundreds of seeds, germination may be less than 1 percent. New plants grow from seeds, and may also grow from the roots of existing plants. Butterflies are potential pollinators.

Steamboat buckwheat was federally listed as endangered on July 8, 1986 (51 FR 24669). Critieal habitat has not been designated. The primary threat to the species is private development. The remaining (and largest) part of the population, however, is owned by a geothermal power plant and is potentially proteetable, but faces continued threats from off-highway vehieles (OHVs) and dumping (NatureServe 2012). These aetivities may alter moisture patterns, a habitat parameter to which this plant is espeeially sensitive. Because of the plant's low reproductive potential, any substantial loss of individuals may severely affeet its survival.

\section{Slickspot Peppergrass}

The primary reference for this section is:

USFWS. 2009b. Endangered and Threatened Wildlife and Plants; Listing Lepidium papilliferum (Sliekspot Peppergrass) as a Threatened Species Throughout Its Range. Federal Register 74(194):52014-52064.

References cited in this seetion are internal to the above-referenced doeument. A eomplete list of these referenees is available from the USFWS Snake River Basin Office, Boise, Idaho.

Slickspot peppergrass (Lepidium papilliferum) oecurs in semi-arid sagebrush-steppe habitats in southwestern Idaho, at elevations of approximately 2,200 to 5,400 feet. This speeies is found along the Snake River Plain and Owyhee Plateau in Ada, Canyon, Gem, Elmore, Payette, and Owyhee Counties. Plants are restrieted to small areas, similar to vernal pools, known as slickspots (also ealled mini-playas or natric sites). Slickspots range from less than 10 square feet to about 110 square feet, within communities dominated by other plants (Maneuso et al. 1998). Sliekspot peppergrass is limited to slickspots covering a relatively small area. These sparsely vegetated microsites are very distinet from the surrounding shrubland vegetation, and are eharaeterized by relatively high eoneentrations of clay and salt (Fisher et al. 1996). The mierosites also have redueed levels of organie matter and nutrients due to a lower biomass produetion, as eompared to surrounding habitat areas. Associated native species inelude Wyoming big sagebrush, basin big sagebrush, bluebunch wheatgrass, Thurber's needlegrass, Sandberg's bluegrass, and bottlebrush squirreltail. Non-native speeies frequently associated with slickspot peppergrass inelude downy brome, tumble mustard, bur buttereup, elasping pepperweed, and crested wheatgrass (Moseley 1994, Mancuso and Moseley 1998).

The restrieted distribution of sliekspot peppergrass is likely a produet of the searcity of suitable habitat, whieh is extremely localized, and the loss and degradation of suitable habitat areas throughout southwestern Idaho. Occurrences of the species ean inelude one to several oceupied sliekspots within an area determined to be suitable habitat. The total amount of habitat eontaining interspersed slickspots that have extant oceurrenees of sliekspot peppergrass is about 12,356 acres. Of 88 known occurrences of the species, 70 are currently extant (exist), 13 are eonsidered extinet, and 5 are historic (Moseley 1994, Mancuso 2000, Idaho Conservation Data Center 2002). Only 6 of the 70 extant occurrences are considered to be high-quality habitat and contain large numbers of the plants (Idaho Conservation Data Center 2002).

Sliekspot peppergrass is an annual or biennial plant in the mustard family that reaches 4 to 12 inches in height. Numerous small, white flowers terminate the branches. Slickspot peppergrass is mainly pollinated by bees (Apidac, Colletidae, and Halictidac families), flies (Syrphidae family), and some beetle species (Dermestidae and Cerambycidae families; Robertson 2001). This species produces small, spherical fruits (siliques), whieh are approximately 3 millimeters long. The primary seed dispersal mechanism is probably gravity, although wind and water may have a minor role (Moseley 1994). Slickspot peppergrass seeds may be viable in the soil for up to 12 years (Quinney 2002). Like many short-lived plants growing in arid environments, the above-ground number of individuals at any one site can fluetuate widely from one year to the next depending on seasonal precipitation patterns (Mancuso and Moseley 1998, Maneuso 2001). Flowering individuals represent only a portion of the population, with the seed bank contributing the remainder, and apparently the majority, in many years (Mancuso and Moseley 1998). For annual plants, maintaining a seed bank is important for year-to-year and long-term 
survival (Baskin and Baskin 1978). A seed bank includes all of the seeds in a population and generally covers a larger area than the extent of observable plants seen in a given year (Given 1994).

Slickspot peppergrass was listed as an endangered species on October 9, 2009 (74 FR 52014) and critical habitat is currently proposed but not designated ( 76 FR 27184). This species is threatened by a variety of activities including urbanization, gravel mining, irrigated agriculture, habitat degradation due to cattle and sheep grazing, fire and fire rehabilitation activities, and continued invasion of habitat by non-native plant species (Moseley 1994, Mancuso and Moseley 1998). Much of the habitat for slickspot peppergrass occurs within a matrix of sagebrush-steppe, a community in which displacement of native plants by non-native species is a major problem (Rosentreter 1994; Office of Species Conservation 2002). Widespread grazing by livestock in the late 1800 s and early 1900 s severely degraded sagebrush-steppe habitat, enabling introduced annual species (espeeially downy brome) to become dominant over large portions of the Snake River Plain (Yensen 1980, Moseley 1994). The invasion of downy brome has shortened the fire frequency of the sagebrush-steppe from between 60 to 110 years, to less than 5 years, as it provides a continuous, highly flammable fuel through which a fire can easily spread (Whisenant 1990, Moseley 1994, Mancuso and Moseley 1998). The result has been the permanent conversion of vast areas of the former sagebrush-steppe ecosystem into non-native annual grasslands. The continued eumulative effects of overgrazing and fire suppression permit the invasion of non-native plant species into slickspot habitats (Rosentreter 1994). Slickspot peppergrass populations typically decline or are extirpated following the replacement of sagebrush-steppe habitat by non-native annuals. Another problem has been the use of non-native perennial species to restore or rehabilitate shrub-steppe habitat after a fire event. Although some slickspot peppergrass plants may temporarily persist in spite of these restoration seedings, most occurrences support small numbers of plants (fewer than five per slickspot) and long-term persistence data are unavailable (Mancuso and Moseley 1998). Habitat degradation, fragmentation, and loss of sagebrush-steppe vegetation have oecurred throughout the range of the species.

\section{Fish Slough Milk-vetch}

The primary references for this section are:

USFWS. 1998a. Determination of Endangered or Threatened Status for Five Desert Milk-veteh Taxa from California. Federal Register 63 (193):53596-53615.

and

USFWS. 2009c. Astragalus lentiginosus var. piscinensis (Fish Slough Milk-veteh) 5-Year Review: Summary and Evaluation. Ventura Fish and Wildlife Office. Ventura, California.

References cited in this section are internal to the above-referenced documents. A complete list of these referenees is available from the USFWS Ventura Field Office, Ventura, California.

Fish Slough milk-vetch (Astragalus lentiginosus var. piscinensis) is found within a 6-mile streteh of alkaline flats paralleling Fish Slough, a desert wetland ecosystem in Inyo and Mono Counties, California. It grows in seasonally moist alkaline flats that support a cordgrass-dropseed association, and is absent from nearby lower areas that are seasonally flooded (Ferren 1991a, 1992). Appropriate alkali habitat covers less than 540 acres of the slough, and portions of this area do not currently support the species, for unknown reasons (Ferren 1991a; Odion et al. 1992). The population is comprised of 8 colonies of varying size totaling approximately 4,500 plants. These eight colonies are grouped in three regions of Fish Slough, with the majority of the plants $(3,300)$ located in the northern portion of the slough, on land administered by the Los Angeles Department of Water and Power, and approximately 1,100 plants in the central zone of the slough, on lands administered by both the BLM and the Los Angeles Department of Water and Power. The remaining plants are in scattered patches downstream as far as McNally Canal. Grazing is not permitted in the habitat of Fish Slough milk-vetch on lands administered by the BLM.

Fish Slough milk-vetch is a prostrate perennial with lavender flowers arranged in loose, short racemes. The plant produces relatively few seeds with narrow germination requirements and low probability of dispersal. Seed scarification is essential for seed germination. Without some form of localized disturbance event, seed germination 
may be a rare event. The establishment, survival, and growth of juvenile plants are strongly influenced by hydrologie eonditions at speeifie sites. The potential life span is estimated at 15 to 35 years, but the median life span appears to be about 10 years.

Fish Slough milk-veteh was federally listed as threatened on Oetober 6, 1998 (63 FR 53596). On June 9, 2005, the USFWS designated eritieal habitat on approximately 8,007 aeres in Mono and Inyo Counties, California (70 FR 33774). The main threat to Fish Slough milk-veteh is lack of reeruitment, possibly eaused by herbivory of seedlings and ehanges in soil hydrology or ehemistry that make the area less hospitable to seedlings. Other threats to the speeies inelude a modifieation of wetlands, and alteration of slough hydrology. A long-term threat may be the expansion of Fish Slough Lake, eaused by natural geologic proeesses or the existenee of Red Willow Dam, resulting in inereased inundation of soils and loss of suitable alkali habitat for this taxon (Ferren 1991b, 1992). Historieal alterations of the Fish Slough eeosystem to enhanee fisherics appear to have eaused similar inereases in seasonally flooded habitats, which are less suitable for Fish Slough milk-veteh. Modifications include creation of dams and weirs in the main slough ehannel, construction of a dirt road through milk-vetch habitat, and soil compaetion and trail ereation by eattle. These activities have altered the slough hydrology by eausing an inerease in permancntly flooded habitats, artifieial ponding, altcration in drainage patterns, and ehanges in seasonal flooding of milk-veteh habitat. These ehanges have in turn resulted in expansion of emergent wetland vegetation and conversion of alkali flat habitats (Ferren 1991e, 1992). More reeent restoration aetivities have partially reversed some of these changes.

\section{Autumn Buttercup}

The primary reference for this section is:

USFWS. 1991a. Autumn Buttcrcup (Ranunculus acriformis var. aestivalis) Reeovery Plan. Denver, Colorado.

Referenees cited in this scction are internal to the above-referenced document. They are included in the Bibliography.

Autumn buttereup (Ranunculus aestivalis) is restrieted to perennially moist soils in wet meadows along the Sevier River, Garfield County, Utah. A single known population grows along the margin of a spring-fed wet meadow at an elevation of 6,440 feet, on an east faeing slope. The habitat surrounding the population is grassland, with the autumn buttereup oceurring on hummoeks at the transition zone between a wet sedge-dominated community and a dry upland meadow. Common assoeiated speeies include beaked spikerush, aster, Nebraska sedge, sea milkwort, Baltic rush, alkali buttercup, and darkthroat shootingstar.

Autumn buttereup is a perennial herb that typically grows to a height of between 1 and 2 feet. Reproduetion of the speeies is by seed. Plants complete their life cycle of flowering to produeing seed between late July and early September. Seeds are generally dispersed in elose proximity to the parent plant, though they eould be transported by animals and water. Flowers are likely pollinated by inseets and/or wind.

Autumn buttereup was federally listed as endangered on July 21, 1989 (54 FR 30550). Critical habitat has not been designated for the speeies. The speeies is apparently highly vulnerable to grazing from domestie livestock, as well as other mammals (e.g., rodents, rabbits, and possibly deer). Modifieation of the hydrologie regime of the speeies' habitat could also affect plants. In addition, the buttereup's small population and restrieted habitat make it very vulnerable to any negative impaet to plants or their habitat.

\section{Clay-loving Wild-buckwheat}

Clay-loving wild-buekwheat (Eriogonum pelinophilum) oeeurs in Delta and Montrose Counties of western Colorado, growing exclusively on substrates high in salt and gypsum derived from the Maneos Shale. This saline, ealeareous, eretaeeous deposit outerops to form nearly barren adobe (elay) hills. Thus, the soils are typieally elays, or have a high elay eontent, and, while having the potential for a high moisture holding eapaeity, have little available moisture. The laek of available moisture is exaeerbated by the low rainfall in the region. Beeause of intense competition for water, the habitat is sparsely vegetated. Speeies able to survive here are xcrophytic (drought tolerant), with primarily woody prostrate or low-growing shrubs as dominants: mat saltbush, shadseale, 
valley saltbush, black sagebrush, and horsebrush. Herbaceous species include winter-fat, wildrye, and wheatgrass. The clay-loving wild-buckwheat prefers swales and bottoms, on all aspects, where the competition for water is somewhat less severe. When found, the species is codominant with other xerophytie shrubs or subshrubs. There are several streams and crecks running throughout the habitat of the clay-loving wild-buckwheat, as are roads and highways. The elevation ranges from 5,180 to $6,240 \mathrm{feet}$, with an average of 5,764 feet. The most recent rangewide population estimate for all clay-loving wild-buckwheat is roughly 278,000 individuals in 12 occurrences, aeross 582 acres. Roughly 46 percent of the acres are in private ownership ( 14 percent of the total acres have conservation easements) and 54 percent of the acres are managed by cither BLM or the Colorado Natural Areas Program (USFWS 2009d).

Clay-loving wild-buckwheat is a perennial woody subshrub. Leaves of this species begin to appear during the last week in April and into the first week in May. Flowers bloom from June through August, and fruit appears anywhere from late June to August. Seed dispersal occurs during late July and August (Reveal 1973; Peterson 1982, 1985; Neese 1984; O'Kane 1985). Seeds of wild-buckwheat species are usually dispersed through passive means, either by being consumed or carried by animals, windblown, or moved by gravity or water. Often, seeds are moved intact in the dying flower. Flowers are produeed over a long period of time; therefore, brief events are not likcly to substantially reduce seed production. Nearly every flower will produce a seed. Over 50 species of insects visited clay-loving wild-buckwheat flowers (Bowlin et al. 1993). Roughly half of these 50 species were native bees, and 18 species were native ants (Bowlin et al. 1993). Habitat severity and a lack of invading species capable of dominating the sites indicate that the communities occupied by the clay-loving wild-buckwheat are stable, climax associations. Reproduction appears to occur as senescent individuals die. Substantial reproduetive episodes may occur during relatively wet years. No data are available on causes of mortality other than observations made on human induced habitat destruction or alteration.

Clay-loving wild-buckwheat was federally listed as endangered with critical habitat on July 13, 1984 (49 FR 28562). Critical habitat was designated in Delta County, Colorado, in an area 3 miles east of Austin. In 2009, the USFWS determined that a revision to the critical habitat was warranted, but funding and resourees were not available to complete the revision. Clay-loving wild-buckwheat is exposed to numerous threats. Much of the habitat for this species has been converted to alfalfa fields and residential sites with accompanying barns, pastures, and corrals. Expansion of the population base in the Montrose and Delta County areas has eaused residential encroachment onto habitats previously occupied by the plant. Tracts of land not directly influenced by homes or pastures is subject to heavy domestic livestock grazing. Thesc clays, which are easily eroded, are especially impacted during wet periods when large and deep impressions are made in the soil by animal hooves. In addition, the known habitat is dissected by roads (paved and unpaved) and railroads. The adobe hills, the primary habitat, are subject to a great amount of OHV use. The sparsely vegetated hills are also prone to severe erosion, as evidenced by deep rills on those hills receiving the heaviest OHV use. The land between Montrose and Delta has an exceptionally dense concentration of irrigation canals and ditches for water diversion. Intensified agricultural uses will necessitate an increased loss of habitat to irrigation projects (O'Kane 1985). Finally, given the nature of the Mancos Shale, and underlying strata, the area has a high potential for oil and gas development. Should the need for these commodities and for gypsum, another component of the adobe hills, increase, the buekwheat's habitat will be subject to use of heavy equipment for oil and gas exploration as well as surface mines for gypsum. Habitat fragmentation and invasion by non-native plants pose additional threats (USFWS 2009d).

\section{Colorado Hookless Cactus, Pariette Cactus, and Uinta Basin Hookless Cactus}

The primary references for this section are:

USFWS. 1990a. Uinta Basin Hookless Cactus (Sclerocactus glaucus) Recovery Plan. Denver, Colorado.

and

USFWS. 2009e. Endangered and Threatened Wildlife and Plants; Taxonomic Change of Sclerocactus Glaucus to Three Separate Species. Federal Register 74(177):47712-47717. 
Referenees eited in this section are internal to the above-referenced documents. A full list of eitations from the Federal Register document is available from the West Valley City Office of the USFWS.

Colorado hookless eactus (Sclerocactus glaucus), Pariette eactus (S. brevispinus), and Uinta Basin hookless eaetus (Sclerocactus wetlandicus) were considered to be the same species (Uinta basin hookless eactus; Sclerocactus glaucus) until 2009, when genetie and morphologieal analysis indieated that they are separate speeies. Colorado hookless cactus is endemie to western Colorado, and the Pariette eaetus is a morphologieally unique Sclerocactus population, oeeurring only in the Pariette Draw in the eentral Uinta Basin in Utah. The Uinta Basin hookless eactus comprises the bulk of the previously termed Uinta Basin hookless eaetus eomplex in Utah.

These speeies are generally found on eoarse soils derived from cobble and gravel river and stream terrace deposits, or roeky surfaces on mesa slopes at 4,400 to 6,200 feet in elevation (Heil and Porter 1994, 2004). Plants oeeur on varying exposures, but are most abundant on south-faeing exposures, and on exposures to about 30 pereent grade. They are most abundant at the point where terrace deposits break from level tops to steeper side slopes. They oeeur in desert serub communities dominated by shadseale, galleta, blaek sagebrush, and Indian rieegrass. Other important speeies inelude strawberry hedgehog eactus, and Simpson's pineushion eaetus.

Reproduetion in the eactus speeies is sexual, with flowering oecurring in April and May, and fruiting oceurring in May and June. The funnel-shaped flowers are pink to violet, and produee reddish fruit when ripe. Bees, flies, beetles, and ants have been observed visiting flowers, though it is not known whieh of these inseets are effeetive pollinators. Seeds are small and dense, with no surface struetures for faeilitating dispersal; rather, they are dispersed by water, gravity, water flow, or possibly inseets and/or birds. Seed dispersal is probably a limiting faetor.

The Uinta Basin hookless eaetus, as S. glaucus, was federally listed as threatened on Oetober 11, 1979 (44 FR 58868). On September 15, 2009 (74 FR 47712), S. glaucus was taxonomically split into three speeies, and the threatened status was maintained for all three. Critieal habitat has not been designated. Threats to the speeies ineluded mineral and energy development, illegal eollection, reereational OHV use, and grazing. Energy development remains one of the largest threats to this species through direet loss of habitat, and it is oecurring in the habitat of these speeies at a rate much greater than existed at the time of the 1979 listing.

\section{Wright Fishhook Cactus}

The primary referenees for this seetion are:

USFWS. 1985a. Wright Fishhook Cactus Reeovery Plan. Prepared in Cooperation with the Wright Fishhook Cactus Recovery Committee. Denver, Colorado.

and

USFWS. 2008a. Wright Fishhook Cactus (Sclerocactus wrightiae L. Benson) 5-Year Review: Summary and Evaluation. U.S. Fish and Wildlife Serviee Utah Field Offiee - Ecologieal Services. West Valley City, Utah.

Referenees eited in this seetion are internal to the above-refereneed documents. They are ineluded in the Bibliography.

Wright fishhook cactus (Sclerocactus wrightiae) oeeurs in the Canyonlands seetion of the intermountain region in Utah (Holmgren 1972), an area of relative geologieal stability and high plant endemism. The range of the speeies follows a low elevation trough around the south end of the San Rafael Swell uplift between the Swell and the Wasateh Plateau, Thousand Lake Mountain, and the Henry Mountains, and extends aeross approximately 860,000 aeres of Utah's western Emery County, southeastern Sevier County, central Wayne County, and a small strip within Garfield County. Plants oeeur primarily on arid sites with widely spaced shrubs, perennial herbs, bunchgrasses, or seattered pinyon and juniper that provide very little surfaee eoverage. Plant eommunity types are salt desert shrub and pinyon-juniper, with the following associated speeies: pinyon pine, Utah juniper, valley saltbush, shadseale saltbush, mat saltbush, and galleta. Population estimates range from 4,500 to 21,000 
individuals. Surveys suggest the species predominately oceurs in small, widely scattered pockets, with most oceupied sites totaling less than 50 individuals (Neese 1987; Kass 1990; Clark 2001, 2002a, b; Intermountain Ecosystems 2002; Clark and Groebner 2003; Clark et al. 2004; Utah Natural Heritage Program 2005).

The limiting factor for Wright fishhook cactus appears to be soil physiology. Most sites where plants are located have three of the following four habitat conditions: 1) close proximity to fine textured, presumably saline and/or gypsiferous strata that have contributed both texturally and chemically to the soil; 2) elose proximity to a sandforming geologic stratum that eontributes to the substrate; 3) fine- or medium-sized gravels, pebbles, or fossil oyster shells in (and particularly littering) the surface of the soil; and 4) level to gently sloping terrain (Neese 1987, Kass 1990). In addition, the eacti are rare or absent where cryptobiotic crusts have been destroyed or are undeveloped.

Reproduction of these small eacti is primarily by seed. Plants begin to flower when they are quite small and, presumably, young. Flowers form on the new growth of the eurrent year. From one to several white to pale pink blossoms eluster at the top of each small barrel. Fruits mature in June, and seeds are generally dispersed near the parent plant, though they may be transported by water or animals. Seedling plants are often collected inadvertently in organic detritus elinging to adult plants. Budding, in which small cacti form at the base of an adult, also contributes to the population. As the summer progresses, and drought stress inereases, the cacti shrink and beeome almost level with the ground surface. The species is almost completely self-incompatible (Tepedino 2000) and the number of flowering individuals in an area is vital for outerossing and reproductive suceess (Steffan-Dewenter and Tseharntke 1999). Pollination is limited by the foraging distance of ground nesting bees.

Wright fishhook eactus was federally listed as endangered on October 11, 1979 (44 FR 58866). Critical habitat has not been designated. Factors that threaten this species include predation by eactus borer beetles, livestock trampling and uprooting of plants, and OHV use. Because the Wright fishhook eactus appears to be associated with the presence of a well-developed eryptogramie crust, it is threatened by any aetivity in which the eryptogramie crust is removed.

\section{Barneby Ridge-cress}

The primary references for this section are:

USFWS. 1993a. Barneby Ridge-cress (Lepidium barnebyanum) Recovery Plan. Denver, Colorado.

and

USFWS. 2011 b. Lepidium barnebyanum (Barneby ridge-cress) 5-Year Review: Summary and Evaluation. U.S. Fish and Wildlife Service Utah Field Office - Ecological Services. West Valley City, Utah.

References cited in this section are internal to the above-referenced documents. They are included in the Bibliography.

Barneby ridge-cress (Lepidium barnebyanum) is a rare local endemic occurring solely on tribal lands and restricted to weathered outerops of an unnamed limestone stratum in the Uinta Formation. The species is known from one population with three separate stands endemic to thin limestone caps on ridge lines near Indian Canyon approximately 3 miles south and southwest of the town of Duchesne, Utah. Plants occur at elevations of 6,200 to 6,500 feet on either side of Indian Creek, with the total known population of the species located within the Uintah and Ouray Reservation of the Ute Indian Tribe. The soil characteristics of Barneby ridge-cress habitat are not common within the species' range, and effectively form "islands" of suitable habitat within a "sea" of unsuitable soil types derived from other differing geologic substrates. The abundance and distribution of the species is limited by its restrictive habitat. The total population is estimated to be approximately 6,000 individuals across approximately 500 acres of suitable habitat.

The vegetation of the shale barrens on which the Barneby ridge-cress occurs is dominated by the stemless fournerve daisy, Hooker's sandwort, table Townsend daisy, Colorado feverfew, and the Barneby ridge-cress itself. 
Other assoeiated plant speeies include Bateman's buekwheat, tufted milk-veteh, and rough Indian paintbrush. The shale barren plant eommunity is a small inelusion within the broader pinyon-juniper (pinyon pine and Utah juniper) woodland eommunity that eharaeterizes the general area (Welsh 1978a, USFWS 1989).

Barneby ridge-eress reproduees entirely by sexual reproduetion. Flowering oecurs from April to May, and fruiting oeeurs from May to June. The speeifie pollination meehanism and veetors are not known.

Barneby ridge-eress was federally listed as endangered on September 28, 1990 (55 FR 39860). Critieal habitat has not been designated. The speeies is vulnerable to any event that eould eause the loeal extirpation of one or more of its isolated stands within its only known population. Past, existing, and potential threats to the speeies and its habitat inelude oil and gas exploration, drilling, and produetion, OHV use, and grazing. The remaining population of the Barneby ridge-eress is underlain by petroleum deposits that are eurrently being developed. The 1993 reeovery plan for the speeies indieated that eontinued OHV use and the future development of oil and gas wells and aneillary faeilities eould lead to extinetion of the speeies in the absenee of appropriate measures to proteet the speeies and its habitat.

\section{Deseret Milk-vetch}

The primary referenees for this seetion are:

USFWS. 2010b. Astragalus desereticus Deseret Milk-Veteh 5-Year Review: Summary and Evaluation. U.S. Fish and Wildlife Serviee Utah Field Offiee - Eeologieal Serviees. West Valley City, Utah.

and

USFWS 1999a. Final Rule to List Astragalus desereticus (Deseret Milk-veteh) as Threatened. Federal Register 64(202):56590-56596.

Referenees eited in this seetion are internal to the above-refereneed doeuments and are ineluded in the Bibliography.

Deseret milk-veteh (Astragalus desereticus) is a narrow endemie oeeurring only on the sandy-gravelly hillsides of the Moroni Formation near Birdseye, Utah, in Utah County. The speeies oeeurs at elevations between 5,400 and 5,600 feet. The plant grows on soils derived from a speeifie and unusual portion of the geologie Moroni Formation, whieh is eharaeterized by eoarse, erudely bedded eonglomerate (M.A. Franklin 1990). The plant eommunity in which the deseret milk-veteh oeeurs is dominated by pinyon pine and Utah juniper. Other assoeiated plant speeies inelude: sagebrush, serub oak, wild buekwheat, Indian rieegrass, needle and thread grass, bitterbrush, and plateau beardtongue. 2008 surveys estimated the population to be between 86,000 and 98,000 mature plants in 6 separate oeeurrenees. The speeies' total range eovers approximately 146 aeres, along approximately 2.8 miles long near Thistle ereek. The majority of the land ( 82 aeres) upon whieh the desert milk-veteh grows is owned by the State of Utah; the remaining 64 aeres are privately owned.

Deseret milk-veteh is a perennial, nearly stemless herb in the pea family. Individual plants are approximately 2 to 6 inehes in height, and arise from a eaudex (the persistent base of an otherwise annual herbaeeous stem). The speeies' flowers are white in eolor with a purple tip on the keel, and borne on a stalk of five to ten flowers. Small bees are thought be the primary pollinators of flowers. The fruit is a seed pod. The speeies appears to be relatively short-lived, with a life expeetaney of about 5 years, although seeds ean persist for many years in the soil.

In 1975, the deseret milk-veteh was presumed to be extinet. In 1981, a population of the speeies was re-diseovered. The deseret milk-veteh was federally listed as threatened on Oetober 20, 1999 (64 FR 56590). Critieal habitat has not been designated. Current threats to the speeies have not been identified, and previously identified threats, ineluding residential development and grazing, have not materialized. The speeies is under eonsideration for delisting. 


\section{San Rafael Cactus}

The primary references for this section are:

Utah Conservation Data Center. No Date(a). Faet Sheet for San Rafael Cactus. State of Utah Natural Resources, Division of Wildlife Resources. Available at http://utahde.usu.edu.

and

USFWS. 2007a. Recovery Outline for San Rafael Cactus (Pediocactus despainii) and Winkler Cactus (Pediocactus winkleri). U.S. Fish and Wildlife Service Utah Field Office. West Valley City, Utah.

San Rafael eactus (Pediocactus despainii) is a narrow endemic with a range centered on the San Rafael Swell and extending into southwestern Emery County, Utah. The species is found in fine-textured soils rich in ealeium that are derived from the Carmel Formation and the Sinbad Member of the Moenkopi Formation. Plants oceur on benches, hilltops, and gentle slopes in pinyon-juniper and mixed desert shrub-grassland eommunities, at elevations ranging from approximately 4,800 to 6,800 feet. The species is known from five populations, ineluding Mussentuchit, MeKay Flat, Wedge, Short Canyon, and Ferron. Most of the habitat and population of the species is on federal lands managed by the BLM, with additional population sites on seattered sections of State of Utah land administered by the School and Institutional Trust Lands Administration.

This species is a small, subglobose to ovoid caetus, with flowers that are born near the tip of the stem during April and May.

San Rafael cactus was federally listed as endangered on September 16, 1987 (52 FR 34914). Critical habitat has not been designated. The habitat of this speeies is vulnerable to surface disturbanee from OHV use, trampling by humans and livestoek, and by mineral resource explorations and development. The limited habitat and small population size make it especially vulnerable to extinetion by natural or human-induced habitat disturbanees. The species is also highly desirable to eactus collectors, and illegal collection is a threat.

\section{Clay Reed-mustard}

The primary reference for this section is:

USFWS. 1994a. Utah Reed-mustards: Clay Reed-mustard (Schoenocrambe argillacea), Barneby Reed-mustard (Schoenocrambe barnebyi), Shrubby Reed-mustard (Schoenocrambe suffrutescens) Recovery Plan. Denver, Colorado.

References cited in this section are internal to the above-referenced document. They are included in the Bibliography.

Clay reed-mustard (Schoenocrambe argillacea) oceurs on fine-grained soils in desert shrub in the Colorado River drainage of eastern Utah. It is found at six locations in the south-central Uintah Basin near the Green River in Uintah County, Utah, including Ray's Bottom, King's Bottom, Long Bottom, Wild Horse Bench, Big Pack Mountain, and Broome Canyon (USFWS 2011e). The eurrent range-wide estimate places the total population at approximately 6,000 plants. The clay reed-mustard grows on clay soils that are rich in gypsum and overlain with sandstone talus, and that are derived from a mixture of shales and sandstones. This species occurs on steep, usually north-facing slopes in mixed desert shrub communities, at elevations ranging from approximately 4,700 to 5,800 feet. Common associates include: Utah serviceberry, western wheatgrass, black sagebrush, Mojave bricklebush, wavyleaf Indian paintbrush, yellow rabbitbrush, Rollins' cryptantha, saline wildrye, granite prickly phlox, fleshy beardtongue, grassy rock-goldenrod, turpentine wavewing, Indian ricegrass, Navajo tea, and various species of rock-cress, milk-vetch, horsebrush, buckwheat, and saltbush (Shultz and Mutz 1979, Franklin 1992). All known populations of the species occur within a limited range of about 19 miles across, from the west side of the Green River to the east side of Willow Creek in southwestern Uintah County, Utah. These populations occur on land administered by the BLM. 
Clay reed-mustard is a perennial herb with sparsely leafed stems 6 to 12 inches tall arising from a woody root crown. The species reproduces entirely by sexual means. Flowering occurs from April to May, and fruiting occurs from May to June. Possible pollinators include native bee species.

Clay reed-mustard was listed as threatened on January 14, 1992 (57 FR 1398). Critical habitat has not been designated. Threats to the species include oil and gas cxploration, drilling, and production, oil-shale mining and processing, building stone removal, small population size and limited distribution, and OHV use. All known populations of the clay reed-mustard are on federal lands leased for oil and gas energy reserves. The species is also vulnerable to surface disturbance associated with cnergy developments within its habitats (USFWS 1990b). Trampling by livestock is also a potential threat.

\section{Barneby Reed-mustard}

The primary references for this section are:

USFWS. 1994a. Utah Reed-mustards: Clay Reed-mustard (Schoenocrambe argillacea), Barncby Reed-mustard (Schoenocrambe barnebyi), Shrubby Reed-mustard (Schoenocrambe suffrutescens) Recovery Plan. Denver, Colorado.

and

USFWS. 2011d. Schoenocrambe barnebyi (Barneby Reed-Mustard) 5-Year Review: Summary and Evaluation. U.S. Fish and Wildlife Service Utah Field Office - Ecological Scrvices. West Valley City, Utah.

References cited in this section are internal to the above-referenced documcnts. They are included in the Bibliography.

Barneby rced-mustard (Schoenocrambe barnebyi), like the clay reed-mustard discussed in the previous species account, occurs on fine-grained soils in desert shrub in the Colorado River drainage of eastern Utah. The species' range is restricted to BLM and Capitol Reef National Park lands in northern Wayne and southern Emery Counties in central Utah. The species grows on cool, steep, north-facing slopes, along mid- or upper-slopes in pinyon pine/juniper communities on the Moenkopi, Chinle, Cutler, Kaibab Limestone, and Carmel formations (Clark 1997, 1999). Typical habitat for this species is sparsely vegetated sites in mixed desert shrub and pinyon-juniper communities, at clcvations ranging from approximately 4,800 to 6,500 fect. Associated plant species include snowball sand verbena, Utah serviceberry, tarragon, Brandcgee's milk-vctch, shadscalc saltbush, rabbitbrush, Torrey's jointfir, Mormon tea, crispleaf buckwheat, woollygrass specics, gallenta, plains pricklypear, dropsced, desert princesplume, and hoary Townsend daisy. The total population of the species is estimated to be approximately 2,250 individuals within four populations containing a total of 15 sites, the majority of which are located on Capitol Reef lands. This includes one population with 2 sites on BLM lands (Sy's Butte/Hidden Splendor Mine population), and three populations with 13 sites located in Capitol Reef (Freemont River [5 sites], Sulphur Creek [ 7 sites], and Horse Saddle populations [1 site]). Approximately 75 percent of the population is on Capitol Reef lands.

Barneby recd-mustard reproduces entirely by sexual means. Flowering occurs from April to May, and fruiting occurs from May to June. Possible pollinators include native bee species.

The Barneby reed-mustard was federally listed as endangered on January 14, 1992 (57 FR 1398). Critical habitat has not been designated. The species is vulnerable to the effects of inbreeding, low reproductive rates, and reduced genetic diversity. In addition, other factors, such as prolonged or more frequent droughts and increased frequency in heavy rainfall events brought on by climate change may threaten the species and its habitat in the future. Limited distribution and threats associated with mining activities on BLM lands and visitor trampling may also impact populations. In addition, the species' highly restricted distribution and very small population make it particularly vulnerable to any activities that disturb its habitat (Spence 1991, Heil 1992). 


\section{Shrubby Reed-mustard}

The primary referenees for this seetion are:

USFWS. 1994a. Utah Reed-mustards: Clay Reed-mustard (Schoenocrambe argillacea), Barneby Reed-mustard (Schoenocrambe barnebyi), Shrubby Reed-mustard (Schoenocrambe suffrutescens) Reeovery Plan. Denver, Colorado.

and

USFWS. 2010e. Schoenocrambe suffrutescens (Shrubby Reed-mustard) 5-Year Review: Summary and Evaluation. U.S. Fish and Wildlife Serviee Utah Field Office - Eeologieal Serviees. West Valley City, Utah.

Referenees eited in this seetion are internal to the above-refereneed doeuments. They are ineluded in the Bibliography.

Shrubby reed-mustard (Schoenocrambe suffrutescens), grows in an extremely limited band of soil derived from an upper member of the Green River geologie formation. This habitat is a disjunet white shale layer resembling small, dry desert islands on level to moderate slopes. The shrubby reed-mustard is found within elose proximity of the Clay reed-mustard, in the south-eentral Uintah Basin near the Green River in Uintah County, Utah, at elevations ranging from approximately 5,000 to 6,850 feet. The speeies oeeurs in seven populations at three loeations: Gray Knolls area (two populations); Paek Mountain area (four populations); and Badlands Cliff area (one population). Sixty-two pereent of the known populations are on BLM land, 21 pereent are on Uintah and Ouray Indian Reservation lands, 6 pereent are on State Sehool and Institutional Trust Land Administrations lands, and the remaining 10 pereent are on private lands.

Prominent associated shrub and herbaeeous speeies inelude pygmy sagebrush, saltbush, mountain mahogany, eryptantha speeies, saline wildrye, Mormon tea, basin fleabane, ephedra buekwheat, spiny greasebush, hyaline herb, winged four o'eloek, Colorado feverfew, shortspine horsebrush, table Townsend daisy, and Spanish bayonet. Many of these species are loeal endemies that are found only in the Uintah Basin.

Shrubby reed-mustard is a perennial plant that grows in elumps from a branehed, slightly woody stem. Flowering for this species oeeurs in April to May and fruiting oceurs May to June. Reproduetion is sexual, and the speeies is eapable of self-pollination (Tepedino 2000). However, seed set is lower in individuals that self-pollinate eompared to individuals that are fertilized by pollen from another plant, and reeent researeh indieates that the speeies may be pollinator limited (Lewis 2010). Possible pollinators inelude several speeies of small to medium-sized, mostly solitary bees (Bartlett et al. 2008; DiTerlizzi et al. 2008). Populations fluetuate greatly over time in apparent response to preeipitation levels, though it is unknown whether the speeies exhibits prolonged dormaney in response to drought.

The shrubby reed-mustard was federally listed as endangered on Oetober 6, 1987 (52 FR 37416). Critical habitat has not been designated. Threats to the speeies include oil and gas exploration, drilling, and produetion, oil-shale mining and proeessing, building stone removal, and OHV use. The shrubby reed-mustard is vulnerable to surface disturbance associated with energy developments within its habitats (USFWS 1990b). Trampling by livestock is also a potential threat. In addition, other factors, such as prolonged or more frequent droughts and inereased frequency in heavy rainfall events brought on by climate change may threaten the species and its habitat in the future. 


\section{Last Chance Townsendia}

The primary referenees for this seetion are:

USFWS. 1993b. Last Chanee Townsendia (Townsendia aprica) Recovery Plan. Denver, Colorado.

and

U.S. Department of Agrieulture Natural Resource Conservation Scrvice (USDA NRCS). 2010. Plant Guide for Last Chance Townsendia. USDA NRCS Idaho Plant Materials Program. Aberdeen, Idaho. Available at: ftp://ftpfe.se.cgov.usda.gov/ID/programs/plant/townsendia_last_chance.pdf.

Last Chanec townsendia (Townsendia aprica) is a low-growing perennial, herbaceous plant that is known from a series of small populations in Emery, Sevier, and Wayne Counties in south-eentral Utah, at elevations ranging from approximately 5,500 to 8,400 feet. Most populations occur in a band about 5 miles wide and 30 miles long, beginning near Interstate 70 at the western edge of the San Rafael Swell to near Fremont Junetion, then south along the Emery-Sevier eounty line to the vieinity of Hartnet Draw. Populations of Last Chanee townsendia generally oceur with galleta and salt desert shrubs, in small barren openings of pinyon-juniper communitics. Commonly assoeiated plant speeies inelude galleta, blue grama, black sagebrush, shadseale, snakeweed, Indian ricegrass, and yellow rabbitbrush. There are 26 known populations with an estimated 6,650 plants extant.

The surface geology in the area where Last Chanee townsendia occurs is highly mixed and contains a wide variety of soils with unusual soil ehemistries. Most known populations of the species grow in soils derived from shale that have a very fine silt texture and very high alkalinities, and that oeeur at the surface in small, isolated poekets. These poekets effectively form "islands" of suitable habitat in a "sea" of unsuitable geologie substrates with their resultant soil types.

Last Chance townsendia is a small, mound-forming perennial in the sunflower family. The plant arises from an underground base and branches at ground level to form a dense mat from 2 to 4 inehes across, with the flowering heads formed tight against the leafy mound. Flowering oeeurs from April to May, and fruiting oecurs in May and June. Self-pollination is virtually non-cxistent; instcad, pollination is accomplished by several species of solitary bees. A few speeies of flies also visit the flowers. It appcars that seed set is frequently limited by pollination. Lack of pollination may be eaused by various factors, including low pollinator numbers, inelement weather affeeting pollinator flight activity, and possibly other unidentified factors.

Last Chanee townsendia was federally listed as threatened on August 21, 1985 (50 FR 33734). Critical habitat has not been designated for this spccics. Beeause Last Chanee townsendia is so restrieted in its distribution, any event that could result in the loss of individuals or habitat within one or more populations is a potential threat to the species' survival. Threats to the speeies eome primarily from mineral and energy development, road building, and livestock trampling.

\section{Maguire Primrose}

The primary reference for this section is:

USFWS. 1990e. Maguire Primrose (Primula maguirei) Reeovery Plan. Denver, Colorado.

Referenees eited in this section are internal to the above-refereneed doeument. They are ineluded in the Bibliography.

Maguire primrose (Primula maguirei) is restricted to cool, moss-covered dolomite eliffs and boulders at the lower elevations (4,800 to 6,000 fect) of Logan Canyon in northern Utah. Plants appear to be dependent on the favorable temperature and moisture conditions of this microhabitat. Plants grow in eraeks or crevices, or in a well-developed mat of moss. Associated plant speeies include pink alumroot, rock spiraea, tadpole buttereup, and narrowleaf wildparsley. The eliff face vegetation grows within a larger mosaic of mountain shrub, montane coniferous forest, and riparian vegetative communitics, charaeteristie of the Wasateh Mountains (Cronquist ct al. 1972). 
Maguire primrose is an herbaceous perennial plant that grows from 2 to 4 inches tall. Flowering typically oceurs from mid-April to mid-May, and fruit development and seed dispersal oecur from May through June. Bees and flies have been observed visiting Maguire primrose flowers (Beedlow et al. 1980; Padgett 1986).

Maguire primrose was federally listed as threatened on August 21, 1985 (50 FR 33731). Critical habitat has not been designated. Threats to the species include road construction, water development, recreation, and collecting (Welsh 1979a, b; Beedlow et al. 1980; USFWS 1985b; Padgett 1986).

\section{Clay Phacelia}

Clay phacelia (Phacelia argillacea) is a narrow endemic to Spanish Fork Canyon, Utah County, Utah. The species is found in fine textured soil and fragmented shale derived from the Green River Formation. It grows on barren, precipitous hillsides in sparse pinyon-juniper and mountain brush communities, at elevations ranging from about 6,040 to 6,170 feet (Utah Conservation Data Center, no date[b]). The dominant species occurring in habitats that support clay phacelia are Utah juniper and Utah serviceberry. The phacelia grows in openings between widely spaced woody plants, which are mostly 2 to 10 feet in height. Other common associates plant species include bluebunch wheatgrass, Indian ricegrass, shortstem buekwheat, smoothstem blazingstar, and gypsyflower (USFWS 1982a).

Clay phacelia is an herbaceous winter annual that grows up to about 14 inehes tall. It germinates in the fall (September and October) if there is sufficient moisture, or as early in the spring (typically late April to early May) as the required moisture is available. Flowers are produced from June to mid-August, fruiting oceurs from midJune to September, and seed/fruit dispersal oecurs from August through September. Flowers are pollinated by the wind and possibly bees or other insects. Seeds are dispersed by birds, gravity, and wind. Seed produetion varies depending on the climatic regimen of any given year. If there is sufficient moisture the number of plants will bc greater and there will be a concomitantly greater number of seeds. Winter annuals tend to have seeds with long viability, so it is inferred that the elay phacelia also has long-lived seeds.

Clay phacelia was federally listed as endangered on September 28, 1978 (43 FR 44810). Critical habitat has not been designated for the species. Construction activities have modified some of this species' habitat, and grazing by native ungulates and the presence of exotic plant species in its habitat are both potential threats (Utah Conservation Data Center, no date[b]).

\section{Heliotrope Milk-vetch}

The primary reference for this section is:

USFWS. 1987a. Final Rule to Determine Astragalus montii (Heliotrope Milk-vetch) to be a Threatened Species, with Designation of Critical Habitat. Federal Register 52(215):41652-42657.

Heliotrope milk-vetch (Astragalus montii) is a narrow endemic of the Wasatch Plateau in central Utah. The species is restricted to Sanpete and Sevier Counties, on outcrop barrens formed from a substrate of partially decomposed limestone. These limestone barrens are of a very limited extent, occurring at or near timberline (elevations between 10,000 and 11,000 feet) on top of the Wasatch Plateau. Heliotrope milk-vetch is found in subalpine communities of cushion plants and other low growing species, scattered within more extensive conifer, forb, and grass communities.

Heliotrope milk-vetch is a perennial herb of the pea family that grows to about $1 / 3$ to 2 inches tall. Plants produce pink-purple, white-tipped flowers that bloom from June to August, and fruits are bladdery inflated pods.

Heliotrope milk-vetch was federally listed as threatened on November 6, 1987 (52 FR 42652). At the time of listing, the USFWS designated approximately 65 acres of federal land in the Manti-LaSal National Forest, in Sanpete County, as critical habitat. Populations of heliotrope milk-vetch are in a general area of active oil and gas exploration. The associated oil and gas exploration and development are a threat to the species. Domestic livestock grazing also occurs within the species' habitat. 


\section{Dudley Bluffs Bladderpod and Dudley Bluffs Twinpod}

The primary references for this seetion are:

USFWS. 1993e. Dudley Bluffs Bladderpod and Dudley Bluffs Twinpod Recovery Plan. Denver, Colorado.

and

USFWS. 2008b. Dudley Bluffs Bladderpod (Lesquerella congesta or Physaria congesta) and Dudley Bluffs Twinpod (Physaria obcordata) 5-Year Review: Summary and Evaluation. U.S. Fish and Wildlife Service Western Colorado Field Office. Grand Junetion, Colorado.

References in this section are internal to these documents. They are included in the Bibliography.

Dudley Bluffs bladderpod (Lesquerella congesta) is endemic to the Piceanee Basin in Rio Blanco County, Colorado. Within the basin, this species occurs along drainages, on barren white oil shale outerops that have been exposed through erosion from downeutting of streams. The species' microenvironment is level surfaces at the points of ridges, and narrow, exposed outerops of level white shale. Plants range from 6,140 to 6,644 feet in elevation.

Dudley Bluffs bladderpod, whieh was diseovered in 1982, is known from seven oeeurrenees on about 201 acres, over a range of about 10 miles on BLM, state, and private lands in the northern Pieeance Basin in Rio Blanco County. As of 2006, the estimated total number of plants was between 550,000 and 610,000 (Colorado Natural Heritage Program 2006). The bladderpod grows only on barren white shale outerops of the Thirteenmile Creek Tongue of the Green River Formation, where it is exposed along downeutting drainages and often overlays thiek oil shale deposits. Plants are therefore vulnerable to impacts resulting from future development and extraction of these oil shale minerals and associated activities.

Dudley Bluffs bladderpod is an extremely small cushion plant in the mustard family, ranging from only 0.4 to 1.2 inches in diameter with a congested mass of bright yellow flowers and narrow silvery leaves rising from a long, thin taproot. The cushion growth habit is an adaptation to erosive badland soils, whieh has evolved independently in several unrelated taxa in this area. Flowering is typically during April and May, and fruit set from late May into June. Pollinators reported for the bladderpod are three species of native, solitary bees that nest in ground holes or in dead wood.

Dudley Bluffs twinpod (Physaria obcordata), like Dudley Bluffs bladderpod, is endemic to the Piceanee Basin in Rio Blaneo County, Colorado. The twinpod oceurs primarily on the Thirteenmile Creek Tongue and on the Parachute Creek Member of the Green River Formation. The Parachute Creek Member ineludes the Mahogany ledge, one of the richest oil-shale zones in the basin, as well as potentially valuable deposits of nahcolite (soda ash) and dawsonite (soda ash and alumina; Decker et al. 2006). Plants grow along drainages on barren white oil shale outcrops that have been exposed through erosion from downeutting of streams. The microenvironment for the Dudley Bluffs twinpod is steep sideslopes. Plants are found at elevations ranging from 5,960 to 7,440 feet.

Dudley Bluffs twinpod, like Dudley Bluffs bladderpod, was discovered in 1982. The speeies is known from 10 occurrences (Decker et al. 2006) covering an estimated total of 142 to 290 acres on BLM, State, and private lands in the northern Pieeanee Basin. As of 2006, the estimated total number of plants was between 18,000 and 28,000 (Colorado Natural Heritage Program 2006). Most sites are on public land administered by the BLM, with the remainder on privately owned land or land administered by the Colorado Division of Wildlife. Plants grow on tongues of White Green River shale within the overlying Uinta Formation, whieh is considered overburden to the thick underlying oil shale deposits. Plants are therefore vulnerable to impacts resulting from future development and extraction of these oil shale minerals and assoeiated activities.

Dudley Bluffs twinpod is an extremely small cushion-shaped plant in the mustard family, reaching up to 1.2 inches in diameter with fruiting stalks up to 0.6 inches tall. It has small, linear leaves and bright yellow flowers. Dudley 
Bluffs twinpod is an obligate outerosser that requires pollinators. The observed pollinators are generalized foraging bees.

Dudley Bluffs bladderpod and twinpod were was federally listed as threatened on February 6, 1990 (55 FR 4152). Critical habitat has not been designated for either species. Potential threats to the species include future underground mining of oil shale and the associated development. In addition, beeause both species are locally abundant on small areas of specialized habitat, they are particularly vulnerable to surface disturbances, despite their high densities.

\section{Debeque Phacelia}

The primary reference for this section is:

USFWS. 2011e. Endangered and Threatened Wildlife and Plants; Determination of Endangered Status for Ipomopsis polyantha (Pagosa Skyrocket) and Threatened Status for Penstemon debilis (Parachute Beardtongue) and Phacelia subrrutica (DeBeque Phacelia). Federal Register 76(144):45054-45075.

References eited in this section are internal to the above-referenced document. A complete list of these referenees is available from the Western Colorado Ecologieal Services Fietd Office, Grand Junetion, Colorado.

The DeBeque phacelia (Phacelia submutica) is an annual plant that is endemic to clay soils derived from the Atwell Gulch and Shire members of the Wasateh Formation in Mesa and Garfield Counties, Colorado. As of 2010, there were nine populations and 22 known oceurrenees of the plant, oecupying a total area of 626 acres (CHNP 2010a). The estimated total number of plants ranges from approximately 7,800 to 68,000 per year, depending on growing conditions. Roughly 80 percent of the occupied habitat is on lands managed by the BLM (USFWS 2011a). The growing town of DeBeque and about 10 miles of Interstate 70 and the Colorado River biseet the speeies' range.

Oecurrenees of the DeBeque phacelia consist of small patehes of plants on uniquely textured, shrink-swcll elay soil separated by larger areas of similar soils that are not oecupied by the species. The species is restrieted to exposures of chocolate to purplish brown and dark chareoal gray alkaline clay soils derived from the Wasateh Formation (Donnell 1969, O'Kane 1987). These soils are found on moderately steep slopes, benehes, and ridge tops adjacent to valley floors of the southern Piceance Basin. There is no precise seientifie deseription of the soil features required to support this speeies, but the natural shrink-swell cracking process ereates the conditions needed for the plants and seed bank to thrive. The DeBeque phacelia grows in a habitat with wide temperature fluetuations, long drought periods, and erosive saline soils.

The DeBeque phacelia is a low-growing, herbaceous, spring annual plant with a tap root. Plants flower between late April and late June, and set seed from mid-May through late June. Individuals finish their life eycle by late June to early July, after which time they dry up and disintegrate or blow away, leaving no indication that the plants were present (Burt and Spackman 1995). The DeBeque phacelia depends on its seed bank to survive for one or many years, depending on growing conditions. During dry conditions, seeds plant themselves by falling into the cracks that close when wetted, thus covering the seeds (O'Kane 1988). Seeds ean remain dormant for 5 years (and probably longer), until the combination and timing of temperature and precipitation are optimal for germination (Colorado Natural Heritage Program [CNHP] 2010a). The life history of the DeBeque phacelia makes it resilient to fluctuating conditions. Although plant sites differ in numbers of flowering plants each year, there have been no observations of site expansion by this species.

The Debeque phacelia was federally listed as threatened on July 27, 2011 (76 FR 45054). On August 13, 2012, the USFWS designated 25,484 acres in nine units as eritical habitat for the species ( 77 FR 48367). The primary threats to the species are destruction and moditication of its seed bank and habitat from natural gas exploration and production, with associated expansion of pipelines, roads, and utilities; development within the Westwide Energy Corridor; increased access to the habitat by OHVs; and soil and seed disturbance by livestock and wildlife. The main reason that the species is vulnerable to energy development is that the plants' annual life cycle only lasts a few weeks before they dry up and blow away, and they may not appear at all for several years if growing 
conditions are not favorable. With such a short life eycle and unpredictable emergence, oceupied habitat may not be recognized as such, so it may be inadvertently destroyed. Protecting the seed bank in the soil depends on avoiding ground disturbance of bare patehes of clay soil where nothing appears to be growing most of the time. About 78 percent of the habitat for the species and 67 percent of the entire range of Phacelia submutica are on BLM lands currently leased for oil and gas drilling (Ewing 2009). An additional 65 acres of habitat (10 percent) may be opened to natural gas development by BLM in the future (BLM 2005, Ewing 2008a).

\section{Parachute Beardtongue}

The primary reference for this section is:

USFWS. 2011e. Endangered and Threatened Wildlife and Plants; Determination of Endangered Status for Ipomopsis polyantha (Pagosa Skyrocket) and Threatened Status for Penstemon debilis (Parachute Beardtongue) and Phacelia submutica (DeBeque Phacclia). Federal Register 76(144):45054-45075.

References eited in this section are internal to the above-refereneed document. A complete list of these references is available from the Western Colorado Ecological Services Ficld Office, Grand Junetion, Colorado.

The parachute beardtonguc (Penstemon debilis) is endemic to shalc outcrops on the Ron Plateau escarpment in Garfield County, Colorado. The historical range and distribution of the species is unknown. All of the eurrently known oceurrences oceupy about 91.8 acres on the Green River formulation in Garfield County, Colorado. The total area of the plant's geographic range is about 2 miles wide and 17 miles long. Of six documented oceurrences, two were no longer viable in 2010 (CNHP 2010a), although the species may oceur in inaccessible areas that have not yet been surveyed. Five oceurrenees of this species oceur on BLM land, although two of these occurrences were considered non-viable as of 2011 .

The parachute beardtongue appears to be adapted to natural physical disturbance. Sites occupicd by this species typically experience continual shifting of the substrate, steep slopes, unstable surface layers of broken shale rubble, and no surface soil (McMullen 1998). The plants grow on steep, oil shalc outcrop slopes of white shale talus at elevations of 8,000 to 9,000 feet. The parachute beardtongue is often found growing with other species endemic to the Green River formation, including the Roan Cliffs blazingstar, dragon milk-veteh, Utah feseue, and sun-loving meadowrue.

The parachute beardtongue is a mat-forming perennial herb with thick, succulent leaves. Plants produce shoots that run along underground, forming what appear as new plants short distances away. They are able to survive on the steep, unstable slopes by responding with stem elongation as leaves are buried by the shifting talus. Flowers bloom during June and July, and plants produce a small number of seeds that are dispersed by gravity. Parachute beardtongue plants require cross-pollination, and have many different pollinators (McMullen 1998).

The parachute beardtongue was federally listed as threatened on July 27, 2011 (76 FR 45054). On August 13, 2012, the USFWS designated 15,510 acres in four units as eritical habitat for the species (77 FR 48367). The primary threats to the species inelude destruetion and modification of habitat by energy development and associated impacts, and the inadequacy of existing regulatory meehanisms to protect the species from these threats. All but one of the four known viable occurrences are on lands wholly or partially owned by energy development companies, and face ongoing threats from oil and gas development, oil shale extraction and mine reclamation, road construetion and maintenance, and vehicle aceess.

\section{Webber Ivesia}

The primary reference for this section is:

USFWS. 2013a. Endangered and Threatened Wildlife and Plants; Endangered and Threatened Wildlife and Plants; 12-Month Finding and Candidate Removal for Potentilla basaltica; Proposed Threatened Species Status for Ivesia webberi. Federal Register 78(149):46889-46897.

References eited in this section are internal to the above-referenced document. A complete list of these references is available from the Nevada Fish and Wildlife Office, Reno, Nevada. 
Webber ivesia (Ivesia webberi) is a low, spreading perennial forb that oceurs in the transition zone between the eastern edge of the northern Sierra Nevada and the northwestern edge of the Great Basin (USFWS 2013). It is currently known to oceupy approximately 165 acres within five counties in California and Nevada. The speeies is known historically from a total of 17 populations, of which 1 has been extirpated and a portion of another is possibly extirpated. Of the remaining 16 populations, the status of 4 is unknown (USFWS 2013). Six of the ten well-documented populations occur on areas that are less than 5 acres each.

Webber ivesia oceupies vernally moist, rocky, elay soils with an argillic horizon that shrink and swell upon drying and wetting. It oecurs in open to sparsely vegetated areas associated with a low sagebrush-perennial bunchgrassforb community. The specialized soils are ivell developed, and take approximately 1,000 years to develop. Webber ivesia has limited seed dispersal and apparent limited reeruitment.

Webber ivesia was listed as a threatened species on June 3, 2014 (79 FR 31878). On the same date, 2,170 aeres in Plumas, Lassen, and Sierra Counties in northeastern California and Washoe and Douglas Counties in northwestern Nevada were designated as critical habitat (79 FR 32126). Due to its restricted range, specialized habitat requirements, and limited reeruitment and dispersal, Webber ivesia is vulnerable to ongoing and future threats. The primary threats are the additive and synergistic effects of non-native invasive plant species and the modified fire regime. Other threats to the species include OHV use and roads, development, livestock grazing, and climate change.

\section{Subtropical Desert Ecoregion Division}

The Subtropical Steppe Ecoregion Division oceurs in the southeastern portion of California, in southern Nevada, Arizona, and New Mexico, and in western Texas, and includes the Chihuahuan, Sonoran, and Mojave deserts. The dry, desert habitats that predominate in this ecoregion support communitics in which xerophytic plants (e.g., small, hard-leaved or spiny shrubs; eacti; and hard grasses) are dominant. The inhospitable environs of shifting sand dunes and nearly sterile salt flats oceur in this eeoregion. The important broad community types of the Subtropical Desert Ecoregion Division are desert grasslands and shrublands, and the higher elevation oak and pinyon-juniper woodlands.

\section{Coachella Valley Milk-vetch}

The primary references for this section are:

USFWS. 2009f. Astragalus lentiginosus var. coachellae (Coachella Valley Milk-veteh) 5-Year Review: Summary and Evaluation. U.S. Fish and Wildlife Service Carlsbad Fish and Wildlife Office Carlsbad, California.

and

USFWS 2011f. Endangered and Threatened Wildlife and Plants; Designation of Critical Habitat for Astragalus lentiginosus var. coachellae. Federal Register 76(165):53224-53254.

References cited in this section are internal to the above-referenced documents. They have been included in the Bibliography.

The Coachella Valley milk-vetch (Astragalus lentiginosus var. coachellae) is restricted to the Coachella Valley in Riverside County, California, with the exception of six outlying occurrences in the Chuckwalla Valley north of Desert Center. Occurrences of this species are known from locations between the One Horse Spring area near Cabazon, to the sand dunes off Washington Avenue, north and west of Indio, in a longitudinal west to east range of approximately 33 miles. Extensive dune systems which once occurred at the base of the Santa Rosa Mountains from what is now the cities of Palm Springs, Cathedral City, Rancho Mirage, Palm Desert, Indian Wells, and La Quinta provided suitable habitat for the Coachella Valley milk-vetch. Today, only scattered remnants of these populations remain in sand dunes south of Interstate Highway 10. 
The preferred habitat for the Coachella Valley milk-veteh has been deseribed as dunes and sandy flats. It is also often assoeiated with disturbanee along the margins of sandy washes, and in sandy soils along roadsides, in areas formerly oeeupied by undisturbed sand dunes. Within dune habitat, this speeies is found in the eoarser sands at the margins of dunes, rather than in the most aetive blowsand areas. Other populations have been loeated on sand substrates in creosote bush serub, where the topography is rolling, stabilized dunes, or in poekets of sandy soil on the valley floor. The speeies may oeeur in loealized poekets where sand has been deposited by wind or by an aetive wash, but would not be expected on roeky alluvial slopes.

Coachella Valley milk-veteh seeds germinate in fall to early winter. Seasonally dormant root erowns sprout new shoots in Deeember and January. The date of first flowering may be as early as Deeember in perennial plants, but usually not until January or February for plants in their first year, and continues into April. Seed production in Coachella Valley milk-veteh is highly dependent on pollinators, and a variety of native bees and non-native honeybees are known to visit flowers of the speeies. Fruits of the speeies are inflated pods, an apparent adaptation for being dispersed by wind. As sueh, wind transport eorridors between populations facilitate gene flow and population growth. As summer progresses, the plants may die or aerial stems may die back and persist through the summer and fall as dormant root erowns. It has been observed that the proportion of plants surviving the summer and fall is dependent upon elimatic conditions. Plants in the northwestern portion of the range where rainfall is higher may survive into their seeond year or longer, while plants that oceur in the southeastern extent of the range which reeeives less rain are primarily annuals (Meinke et al. 2007).

Coaehella Valley milk-veteh populations ean survive prolonged drought periods as dormant seeds in the soil (Sanders and Thomas Olsen Assoeiates 1996). Suitable habitat that laeks aboveground individuals may in faet sustain the speeies through one or more dry years as an undetectable seed bank, and dormant root erowns and may therefore be important to the long-term survival of this taxon. In good years it may oeeur in large numbers, but most reports are of small populations of less than 20 plants. Specific data on population size and dynamies are not available for this species. However, great annual variation in population size has been observed, depending on rainfall.

Coachella Valley milk-veteh was federally listed as endangered in 1998 (63 FR 53596). Critical habitat for the speeies was first proposed in December 2004 (69 FR 74468), but no acres were designated in the final rule. On February 13, 2013 (78 FR 10449), the USFWS designated approximately 9,603 aeres in the Coachella Valley as eritical habitat. The primary threat to Coachella Valley milk-veteh is habitat destruetion by urban development on private lands in the Coaehella Valley. Other impaets to the speeies inelude the results of inereased human aetivity, ineluding OHV use, trampling, and the introduction of non-native plants. Development of wind energy parks has impacted this speeies, although the plants ean persist within wind parks as long as disturbanee to the sandy habitat is minimized.

Fragmentation of the extensive dune systems in the Coaehella Valley has resulted in fragmentation of the existing populations and alteration of the natural processes that maintain the blowsand eeosystem. Development on the dunes has disrupted the flow and replenishment of sand to the remaining fragments. The sand formations provide substrate components and conditions suitable for growth, and wind transport of the sand contributes to seed dispersal and pollinator movement, and helps maintain sand movement and genetie diversity.

\section{Lane Mountain Milk-vetch}

The primary referenees for this seetion are:

USDOI BLM. 2001a. Biologieal Evaluation on Effeets of California Desert Conservation Area Plan as Amended and Proposed to be Amended by the NEMO and NECO Preferred Alternatives and With Other Interim Measures on Ten Threatened and Endangered Plants. California Desert Distriet, BLM. Riverside, California.

and

USFWS. 2008c. Lane Mountain Milk-veteh (Astragalus jaegerianus) 5-Year Review: Summary and Evaluation U.S. Fish and Wildlife Service Ventura Fish and Wildlife Office Ventura, California. 
References eited in this section are internal to the above-referenced documents. They are included in the Bibliography.

Lane Mountain milk-vetch (Astragalus jaegeriamus) is a very rare and highly localized species with a range that occurs entirely within the western Mojave Desert. It is known to occur at elevations of approximately 3,150 to 3,850 feet. This species appears to be confined to granitic substrates in Mojave creosote bush scrub with a few widely scattered Joshua trees. It occurs on rocky, very low ridges, only a foot or two higher than the main bajada slope (i.e., a broad, gently inclined slope), and rocky low hills, 10 to 20 feet high, where bedroek is exposed at or probably near the surface (Lee and Ro Consulting Engineers 1986). Soils are shallow, rocky and coarse sandy decomposed granite (Lee and Ro Consulting Enginecrs 1986; Bagley 1989; Brandt et al. 1997). The serub community at Lane Mountain milk-vetch sites is typically a diverse mix of shrub species including California buckwheat, Nevada Mormon tea, Cooper goldenbush, turpentine-broom, paper-bag bush, Mojave aster, hop-sage, Anderson box-thorn, ereosote bush, and burro bush. California buekwheat, burrobush, turpentine bush, Mormon tea, goldenbush and dead shrubs account for 75 percent of the host plants for Lane Mountain milk-veteh. Twentyfour perennial speeies were recorded in the vicinity of Lane Mountain milk-vetch at one population site on Fort Irwin (Lee and Ro Consulting Engineers 1986). A diversity of annual species may also occur in years with adequate moisture. Creosote bush and burro bush are dominant on the surrounding sandy bajada slopes, but are not dominant on the thin soils where Lane Mountain milk-vetch oceurs (Bagley 1989; Brandt et al. 1997).

About 5,700 plants were reported during surveys in 2001, although population counts are probably higher due to sampling methods, the difficulty of locating the species due to its cryptic growth form, and the tendency of the species to remain dormant during drought years. Overall population trends are declining. The entire known range of this species lies between Barstow and Goldstone, San Bernardino County, in an area of about 21,350 acres. There are four population areas where this species is known to occur: Goldstone (1,250 aeres), Montana-Brinkman (5,500 acres), Paradise (4,790 acres) and Coolgardie (9,780 acres). The majority of the sites are on Department of Defense land, or on land managed by the BLM. A small portion is on private land.

Lane Mountain milk-vetch is a spring-flowering perennial species that typically twines up through a host shrub that it uses for structural support. Although the taproot is perennial, the aboveground portion of the plant is herbaceous, resprouting from the taproot or old stems with the first winter rains, and then dying baek during the drier summer months. In years with little rainfall, taproots may remain dormant, and few plants will be visible. In years with more rainfall, individuals may grow vegetatively and produce seed to varying degrees depending on other factors (Sharifi et al. 2006).

Little has been reported on the growing season of Lane Mountain milk-vetch. However, it is known to grow in the spring and bloom in April and May. Presumably, like other desert perennials, it begins growth sometime in the late fall or winter, going dormant sometime in the late spring or summer when the soil moisture has been depleted in its rooting zone. The infloreseence bears from 5 to 15 dull yellowish-white or lavender-rose flowers. Nothing is known of the reproductive biology of Lane Mountain milk-vetch. The most likely pollinators are leaf-eutter and metal leaf-cutter bees.

The Lane Mountain milk-vetch was federally listed as endangered on October 6, 1998 (63 FR 53596). Critical habitat was proposed in December 2004 (70 FR 18220), but no acres were designated. In May 2011, the USFWS revised the USFWS designated 14,069 acres of land in two units located in the Mojave Desert in San Bernardino County, California as critical habitat, including 9,888 acres of BLM-administered lands, 1,282 acres of land managed by the U.S. Army, and 2,899 acres of private land (76 FR 29108). Because of its small population and small range, the Lane Mountain milk-vetch is particularly vulnerable to extinction as a result of random events (USFWS 1992a). It is threatened by ongoing military activities at the Fort Irwin National Training Center and by the recent expansion of Fort Irwin onto adjacent public lands. The largest population occurs on Fort Irwin, in an area thus far not used for training. Except for the small population on Coolgardie Mesa, the remainder of the plants occur within one of the proposed alternative sites for Fort Irwin expansion (USDOI BLM 1996a). The primary threat to the species is from OHV travel, particularly from heavy trucks and tracked vehicles. Sheep grazing, a minor threat noted by the USFWS (1992a), has been alleviated by closure of the grazing allotments within the 
range of the plant due to eonfliets with the listed desert tortoise. Mineral elaims on publie land eould also potentially pose a threat to this speeies.

\section{Peirson's Milk-vetch}

The primary referenee for this seetion is:

USFWS. 2008d. Endangered and Threatened Wildlife and Plants; Revised Designation of Critieal Habitat for Astragalus magdalenae var. peirsonii (Peirson's Milk-Veteh). Federal Register 73(31):8748-8785.

Referenees eited in this seetion are internal to the above-refereneed doeument. A eomplete list of referenees is available from the Carlsbad Fish and Wildlife Offiee, Carlsbad, California.

Peirson's milk-veteh (Astragalus magdalenae var. peirsonii) is endemie to the Algodones Dunes, also known as the Imperial Sand Dunes, in the Colorado Desert of Imperial County, California. In addition, it is known to oeeur in the dunes of the Gran Desierto in northern Sonora, Mexieo (USFWS 1998a). This speeies has been reported from the Borrego Valley in San Diego County (Barneby 1964), but this loeation has never been eonfirmed. It is also believed that the speeies may oeeur in dunes in southwestern Arizona. Peirson's milk-veteh is distributed as one extensive population of seattered colonies throughout the length of the Algodones Dunes, an aetive dune system stretehing more than 40 miles southeasterly from the Salton Sea to just aeross the U.S.-Mexiean border into Baja California Norte, Mexieo. Management of the Algodones Dunes is primarily by the BLM, with the exeeption of a few privately owned pareels, and is eontained within the boundaries of the Imperial Sand Dunes Reereation Area.

Although Peirson's milk-veteh eolonies are seattered throughout the Algodones Dunes, suitable habitat for this speeies does not oeeur everywhere within the dunes system. The plant oeeurs only on wind-blown hollows and slopes primarily in the western two-thirds of the dunes, (WESTEC Serviees Ine. 1977; USDOI BLM 2000). The plant usually oeeurs on the leeward side of dunes where sand movement is less extreme. Peirson's milk-veteh is eommonly found in association with other dune speeies, partieularly dune buekwheat, sandpaper plant, and Wiggin's eroton. Surveys eondueted in 2006 estimate the population at approximately 83,500 individuals; estimates eondueted between 1977 and 2006 range from a low of 86 plants (2000) to a high of 1.8 million plants (2005).

Peirson's milk-veteh is a short-lived perennial plant in the pea family. Seeds germinate after late summer or fall rains. The large size of Peirson's milk-veteh seeds allows for germination and growth from depths of several inehes (Bowers 1996). After germination, seedling mortality is high as a result of burial and exeavation due to shifting sand. Surviving seedlings grow rapidly and may flower as early as 2 months after germination (Barneby 1964). The taproot is extraordinarily long, often extending more than 6 feet into the ground from a plant 1 foot in height. Typieally, the plant flowers in winter and either dies or beeomes dormant by late spring. It is not known how long plants may remain dormant if they do not reeeive adequate rainfall to resume growth the following season. Small bees have been seen visiting Peirson's milk-veteh and are most likely the pollinators of this speeies.

Peirson's milk-veteh was federally listed as threatened on October 6, 1998 (63 FR 53596). Critieal habitat was first designated in August 2004 (69 FR 47330). The eritieal habitat designation was revised on February 14, 2008 (73 FR 8748), to inelude 12,105 aeres of Imperial County, California, as eritieal habitat. Suitable habitat for this speeies in the Algodones Dunes has been substantially redueed due to impaets from OHV use and assoeiated eamping. Monitoring studies eondueted in 1977 and 1998 show that Peirson's milk-veteh has been eliminated from OHV staging and eamping areas, but it still oeeurs in areas of low to moderate OHV use (WESTEC Serviees Ine. 1977; ECOS, Ine. 1990; USDOI BLM 2000).

The subspeeies is still threatened by OHV use in the Algodones Dunes. The small stature of Peirson's milk-veteh provides little obstaele to riders and the brittle nature of its stem eauses it to break rather than bend when hit by a vehiele (ECOS, Ine. 1990). The laek of lateral roots also reduees its ability to survive vehiele damage (Romspert and Burk 1979). Seedling establishment of this speeies oeeurs during the winter and spring, whieh are the most popular periods for OHV use in the dunes. The young seedlings are partieularly vulnerable to erushing and 
dislodging by vehicles and may be destroyed by being run over by a vehicle. Indirect effects from OHV use such as sand compaction, disruption of hydrologic factors, and changes in community composition may also be responsible for the deeline of this speeies in areas used by OHVs (ECOS, Inc. 1990).

The North Algodones Wilderness was established in 1994, but it protects only 20 percent of Peirson's milk-vetch habitat. The most suitable habitat containing the highest plant numbers for this species occurs in the OHV open area, formerly Wilderness Study Area 362, in the eentral portion of the dunes. (WESTEC Services Inc. 1977, USDOI BLM 2000). Fortunately, OHV use in much of this area has been low due to its remoteness from staging and camping areas, and most of the habitat remains relatively intact (USDOI BLM 2000).

\section{Triple-ribbed Milk-vetch}

The primary reference for this section is:

USFWS 2009g. Astragalus tricarinatus (Triple-Ribbed Milk-Vetch) 5-Year Review: Summary and Evaluation. U.S. Fish and Wildlife Service Carlsbad Fish and Wildlife Office. Carlsbad, California.

References eited in this section are internal to the above-referenced document. They are ineluded in the Bibliography.

An additional souree of information was the Biological Evaluation on Effects of California Desert Conservation Area Plan as Amended and Proposed to be Amended by the NEMO and NECO Preferred Alternatives and With Other Interim Measures on Ten Threatened and Endangered Plants (USDOI BLM 2001a).

Triple-ribbed milk-veteh (Astragalus tricarinatus) is endemic to California and is found in transition areas of the Sonoran and Mojave Deserts from 1,300 feet to 4,000 in southern California (Sanders 1999). Determining the extant range of triple-ribbed milk-vetch is difficult because historically known habitat types within the species' range have been inadequately surveyed, due to the remoteness of sites and difficult topography, and because abundance and detectability can vary significantly from year to year. Plants have been difficult to loeate where they are known to exist because of their life history characteristies (i.e., growing as an annual or short-lived perennial) or the absence of plants during periods of drought. Potential distribution is in a band around the Coachella Valley, in 12 oceurrences or populations totaling fewer than 500 plants. Two oceurrences account for more than 75 percent of the total known population.

Triple-ribbed milk-vetch habitat includes two general types: sandy or gravelly disturbed soils often in washes or at the base of canyon seree slopes (Barrows 1987, Sanders and Thomas Olsen Associates 1996), and established soils with developed horizons on undisturbed upslope ridge tops (Amsberry and Meinke 2007, Avery 2008). The populations on undisturbed upslope ridge tops tend to be larger and persistent, whereas the downslope populations on seree slopes or washes tend to be small and ephemeral. The downslope populations thus are likely small populations that develop when seeds disperse from the upslope areas, and are not large enough to retain genetic diversity and are on too unstable of a substrate to persist long term. Accounts of the soil at the upland source sites describe the fine soils as white or blue-gray in color, though no soil analysis has been performed. Plants oceur at elevations between 1,300 and 4,000 feet. Associated plant taxa include giant ricegrass, bigberry Manzanita, desert ceanothus, bitter snakewood, bush poppy, California buckwheat, hairy yerba santa, giant stipa, and Mojave yucea (White 2004, Amsberry and Meinke 2007) creosote, Schott's indigo bush, rush milkweed, burrobush and deerweed (La Doux 2007, Granite Mountains Desert Research Center, pers. comm.).

Triple-ribbed milk-veteh is a somewhat bushy herb, generally described as a perennial, but apparently more commonly behaving as an annual. At best, it is a short-lived perennial persisting for about 3 to 5 years. Mature plants are usually 2 to 10 inches tall and the stems are erect or ascending. Based on specimen records, the species flowers from February 12 through April 6, though the true range is likely to extend a few days beyond these dates. The inflorescence bears 10 to 15 widely spaced flowers. Fruits appear as early as mid-March and are present until at least early May. Pollinators, germination requirements, seed longevity, and most other aspects of the biology of this species are unknown. The color and form of the flowers suggest that this speeies may be bee pollinated, as many legumes are. 
Triple-ribbed milk-vetch was listed as endangered by the USFWS on October 6, 1998 (63 FR 53596). Critical habitat has not been designated. Known populations are few, small, and highly unstable. Since habitat modifieation within its range has not been extensive, it does not appear likely that human aetivity has been an important factor in its present scareity. The only potential habitat threat to triple-ribbed milk-vetch since listing is residential development. Pipeline maintenanee and unantieipated pipeline ruptures continue to be a potential threat to tripleribbed milk-vetch habitat at Big Morongo Canyon. There are no signifieant range-wide threats to triple-ribbed milk-vetch habitat at this time. The species could be affected by potential increased fire from pipelines ruptures, illegal OHV activity, and wildfire suppression. Threats assoeiated with small population size persist range-wide.

\section{Amargosa Niterwort}

The primary references for this seetion are:

USDOI BLM. 2001a. Biological Evaluation on Effects of California Desert Conservation Area Plan as Amended and Proposed to be Amended by the NEMO and NECO Preferred Alternatives and with Other Interim Measures on Ten Threatened and Endangered Plants. California Desert Distriet, BLM. Riverside, California.

and

USFWS. 1990d. Rceovery Plan for the Endangered and Threatened Species of Ash Mcadows, Nevada. Portland, Oregon.

and

USFWS. 2007b. Amargosa Niterwort (Nitrophila mohavensis) 5-Year Review Summary and Evaluation. U.S. Fish and Wildlife Service Nevada Fish and Wildlife Office Las Vegas, Nevada.

References eited in this section are internal to the above-referenced documents. Full citations have been ineluded in the Bibliography.

Amargosa niterwort (Nitrophila mohavensis) is a small, perennial plant eonfined to highly alkaline, moist, saltencrusted clay soils within the Ash Mcadows region of the Mojave Desert. It is found within an extremely restricted range that contains approximately 56 acres of occupied habitat. The species is eurrently known from two populations in California and three populations on the Ash Mcadows National Wildlife Refuge in Nevada. Roughly 98 percent of the population and distribution occurs at two sites: Crystal Reservoir Reserve and Carson Slough. A small population is also found near Tecopa Hot Springs.

Amargosa niterwort is generally found adjacent to the active stream channel in the Carson Slough, and appears to be adapted to periodic disturbanee related to flooding and sediment deposition. The Amargosa niterwort grows on open, highly alkaline mudflats and low sand deposits in sinks, around alkali sink vegetation. It is an extremely hardy species that is tolerant of high soil salinity and alkalinity (Mozingo 1977). All populations are known from wet alkaline flats lacking appreciable standing water and which support very little vegetation, with extensive salt crust development. The Amargosa niterwort is sensitive to disturbance, and does not reinvade sites where the salt crust overlaying the soil has been disturbed (Reveal 1978a). The species occurs in the open and is generally not found with, or under, any type of cover. It is found at elevations betwecn approximately 1,970 and 2,460 feet. Associated plants include spiny saltbush, Parry's saltbush, Tecopa bird's-beak, short-pedicelled eleomella, pickleweed, and saltgrass. Natural and unaltered hydrology within Lower Carson Slough appears eritieal for the survival of the Amargosa niterwort (California Department of Fish and Game 1990).

Amargosa niterwort is a small, ereet perennial from an extensive, heavy, underground rootstock. The largest population of the species is thought to consist of several thousand individuals (Reveal 1978a), many of which are interconnected via underground rootstocks. Plants can over-winter as underground rootstocks, with new plants starting their growth in March. Flowering is from late April to Oetober. Each flower produces one solitary, shiny blaek sced. Viability, longevity, dormaney and germination requirements of sceds are unknown (Reveal 1978a). 
On June 19, 1985, the Amargosa niterwort was federally listed as an endangered species, with designated critical habitat (50 FR 20777). The restricted range of this species makes it susceptible to natural eatastrophic events such as drought, as well as the genetic and demographic consequences of small populations. A majority of all suitable habitat in California for this species is on public lands. Potential threats to the species include local groundwater depletion; streambed alteration; highway maintenance; mining, including exploratory drilling and claim marker placement; OHV travel; and trampling by wild horses. An additional threat is the potential introduction and spread of the exotic plant saltcedar.

\section{Ash Meadows Milk-vetch}

The primary references for this section are:

Nevada Natural Heritage Program. 2001a. Rare Fact Sheet for Astragalus phoenix Barneby (1970), Ash Meadows Milk-vetch. Available at http://www.state.nv.us/nvnhp/atlas/.

and

USFWS 2009h. Astragalus phoenix (Ash Meadows milkveteh) 5-Year Review: Summary and Evaluation. U.S. Fish and Wildlife Service Nevada Fish and Wildlife Office. Las Vegas Nevada.

Other references used are cited in the text and included in the Bibliography.

Ash Meadows milk-veteh (Astragalus phoenix) is endemic to the Ash Meadows area of Nye County, Nevada, a cienega (desert wetland) eeosystem maintained by several dozen springs and seeps. The species occurs on dry, hard, seasonally moist, white, barren flats, washes, and knolls of ealcareous alkaline soils. Associated species include saltgrass, shadseale saltbush, Ash Meadows blazingstar, alkali goldenbush, and Ash Meadows sunray. Its habitat ean be generally deseribed as warm desert serub. This species has only been known to grow in areas of mineral encrusted soil; no growth of this speeies has been observed in areas that have been disturbed (Reveal 1978b, Mozingo and Williams 1980). However, the species is also found most commonly in open places without any vegetation cover (Reveal 1978b). The maximum range of the species is approximately 7 miles. Most of the known oceurrences are on lands within the Ash Meadows Reserve and administered by the USFWS (45 pereent) or the BLM (50 pereent), as well as on privately owned lands ( 5 percent). The total population at the Ash Meadows Refuge is estimated to be 11,643 plants, with the potential for additional habitat and populations on the adjacent Ash Meadows Area of Critical Environmental Coneern (ACEC).

Ash Meadows milk-vetch is a low, mat-forming, long-lived perennial herb that forms mats of up to 1.6 feet in diameter. Germination is rare, and probably oceurs in the spring or fall but depends on late fall or early winter rains (Reveal 1978b). Leaf-out occurs from March to early April. Flowering occurs from late April through May and requires sufficient rains in the winter or early spring to be abundant, although some flowers are likely produced even during times of drought. Fruiting occurs from May to June with seed/fruit dispersal occurring from May to July (Reveal 1978b, Mozingo and Williams 1980). Sufficient rain is probably necessary for seedling establishment (Reveal 1978b). Plants are small and long-lived, and seed production for this species is relatively low. A species of bee is the most likely pollinator, and wind and water are the primary vectors for seed dispersal.

Ash Meadows milk-vetch was federally listed as threatened on May 20, 1985 (50 FR 20777). At the same time, critical habitat was designated in the Ash Meadows area of Nye County, Nevada, in portions of sections 14, 21, 22, and 26, Township 17 South, Range 50 East; sections 1, 12, 13, and 24, Township 18 South, Range 50 East; and sections 7, 18, and 19, Township 18 South, Range 51 East. Major threats to the species include development, rabbit grazing, horses, and dust from disturbed soil. 


\section{Spring-loving Centaury}

The primary reference for this seetion is:

USFWS. 2009i. Centaurium namophilum (Spring-loving Centaury) 5-Year Review: Summary and Evaluation. U.S. Fish and Wildlife Service Nevada Fish and Wildlife Office. Las Vegas, Nevada.

References eited in this seetion are internal to the above-referenced doeuments. Full citations have been ineluded in the Bibliography.

Spring-loving centaury (Centanrium namophilum) is endemie to the Ash Meadows area of Nye County, Nevada. The range of the speeies encompasses the Ash Meadows Refuge and the Ash Meadows ACEC, as well as adjacent private lands, with nearly all of the known distribution on federal lands (50 pereent USFWS, 45 percent BLM, and 5 percent private). The total estimated population is in excess of 4.4 million plants on USFWS land, and the speeies is widespread throughout the Refuge in habitat that ineludes seasonally flooded wetlands to seasonally moist alkali meadows and the edges of some alkali scrub-shrub eommunities. Currently the species is distributed in six major subpopulations with additional minor subpopulations (Bio-West, Ine. 2008).

Spring-loving centaury grows at elevations between 2,070 and 2,320 feet within the Mojave Desert Eeoregion. The species is adapted to alkaline elay soils of the Ash Meadows Area, and water availability is a limiting faetor to its distribution (Pavlik and Manning 1986). It typically grows in wet saltgrass meadows near springs and streams and occasionally in low uplands at seeps (Reveal et al. 1973). The wet meadow eeosystem occupied by spring-loving centaury is typically dominated by saltgrass with seattered velvet ash and serewbean mesquite trecs. Other associates inelude the Ash Meadows gumplant, Emory baceharis, and yerba mansa. On drier sites, eommon assoeiates inelude Ash Mcadows ivesia and Tecopy bird beak (Reveal et al. 1973).

Spring-loving eentaury is an annual that flowers from July to September (Reveal et al. 1973). Fruiting occurs in Oetober, with eaeh plant produeing thousands of seeds. Sceds may be dispersed by small animals, wind, and water. Little else about reproduction and life history of this speeies is known.

Spring-loving centaury was federally listed as threatened on May 20, 1985 (50 FR 20777). At the same time, 1,840 aeres of critical habitat were designated in the Ash Meadows area of Nyc County, Nevada, in portions of scetions 21, 23, 28, 34, and 35, Township 17 South, Range 50 East; sections 1, 2, 3, 7, 23, and 24, Township 18 South, Range 50 East; and seetions 7, 18, 19, 20, 29, and 30, Township 18 South, Range 51 East. The speeies is threatened by regional groundwater pumping and potential surfaee mining.

\section{Ash Meadows Ivesia}

The primary reference for this section is:

Nevada Natural Heritage Program. 2001b. Rare Plant Fact Sheet for Ivesia kingii S. Watson var. eremica (Coville [1892]) Ertter, Ash Meadows Ivesia. Available at: http://www.state.nv.us/nvnhp/atlas/.

Ash Mcadows ivesia (Ivesia kingii var. eremica) is endemic to the Ash Meadows area of Nevada. The species occurs in barren areas, on moist to saturated, heavy to chalky alkaline soils. Plants grow in meadows on flats, drainages, and bluffs near springs and secps. They are commonly associated with highly alkaline, clay lowlands or depressions where soil moistures remains high from perched groundwater maintained by springs and seeps (USFWS 1985e). The taxon is typically found in saltgrass meadow, shadscale, and ash-mesquite, associated with the following species: shadscale saltbush, saltgrass, Baltic rush, mesquite, Mojave thistle, spring-loving eentaury, velvet ash, Yerba mansa, and iva. The Ash Meadows ivesia is a matted perennial herb/shrub that bears white flowers from August to October. It is aquatic or wetland-dependent, and occurs at elevations ranging from 2,200 to 2,300 feet. There are nine occurrences of the species that cover a eombined total arca of approximately 9 acres, on land administered by the USFWS and the BLM, and on privately owned land.

Ash Meadows ivesia was federally listed as threatened on May 20, 1985 (50 FR 20777). At the same time, approximately 880 acres of critieal habitat were designated in the Ash Mcadows area of Nyc County, Nevada, in portions of sections 21 and 35, Township 17 South, Range 50 East; and sections 1, 2, 3, 12, 23, and 24, Township 
18 South, Range 50 East. This species is threatened by development, trampling and grazing, and the associated large-seale drawdown of water resourees.

\section{Ash Meadows Gumplant}

The primary reference for this section is:

USDOI BLM. 2001a. Biological Evaluation on Effects of California Desert Conservation Area Plan As Amended and Proposed to be Amended by the NEMO and NECO Preferred Alternatives and with Other Interim Measures on ten Threatened and Endangered Plants. California Desert Distriet, BLM. Riverside, California.

References eited in this seetion are internal to the above-refereneed document. Full eitations have been included in the Bibliography.

The 2007 5-year review for the Ash Meadows gumplant (USFWS 2007e) was reviewed for updated information on this species.

Ash Meadows gumplant (Grindelia fraxino-pratensis) is endemic to the Ash Meadows Area in Nye County, Nevada, and Inyo County, California. The Ash Meadows gumplant is concentrated in three main populations and several smaller ones over an area of approximately 2,260 acres (USDOI BLM and USFWS 2000). Most of its distribution is within the Ash Meadows National Wildlife Refuge. One population oecurs outside the Refuge boundary in the Carson Slough, primarily within the Ash Meadows ACEC managed by the BLM in Nevada.

The Ash Meadows area is a distinet ecosystem that supports hundreds of plant and animal speeies, including the Ash Meadows gumplant, that are closely associated with the wetlands and aquatic habitats that are unique features of this area. Over 30 pereent of the Refuge has been mapped as wet meadow and is dependent on flows from several dozen springs and seeps (Otis Bay, Ine. 2006). These springs and seeps are fed by an extensive groundwater system that extends more than 100 miles northeast of Ash Meadows and terminates at local diseharge points including Alkali Flat, the Refuge, and Furnace Creek in Death Valley. Ash Meadows gumplant is found primarily in saltgrass meadows along streams and surrounding pools in the vicinity of ash-screwbean mesquite woodlands and desert shadseale scrub vegetation. It oceasionally occurs sparsely on open alkali clay soils in drier shadseale habitats or in the unique clay barrens which support other Ash Meadows endemies (Cochrane 1981). The wet meadow ecosystem oceupied by Ash Meadows gumplant is typically dominated by saltgrass. Common associates in the saltgrass meadow include the spring-loving centaury, Emory baceharis, yerba mansa, western niterwort, and California loosestrife. Common associates of sites occupied along streamsides and pools include velvet ash and serewbean mesquite. Common associates within shadseale serub include shadscale, alkali sacatone, desert isocoma, alkali rabbitbrush, and seablight (Cochrane 1981).

Ash Meadows gumplant is an ereet, biennial or more often perennial, herb of the sunflower family reaching 25 to 40 inches in height, with yellow flowers with heads measuring 0.3 to 0.4 inches in diameter (Mozingo and Williams 1980). The gumplant genus is so named because of their very sticky (gummy) flower heads. Each Ash Meadows gumplant flower head can produce approximately 30 small seeds, and each branching individual can support several to up to a hundred flower heads. Therefore, in a good year, each plant may produce several hundred seeds (Lane 1993). The Ash Meadows gumplant flowers from June through October (Beatley 1977). Seed dispersal could occur by means of wind/water transportation and possibly by mammals or birds. The pollinators for this species are currently unknown (Cochrane 1981).

Ash Meadows gumplant was federally listed as threatened with 1,968 acres of designated critical habitat in Nevada and California on May 20, 1985 (50 FR 20777). It is likely that before human-caused habitat modifications such as grazing, farming, and water diversions occurred, the distribution of this species was more or less continuous (Cochrane 1981). Surface mining and invasive non-native species continue to be the most important obstacles to long-term protection and delisting. Non-native species pose a threat to Ash Meadows gumplant through competitive exclusion and by changing ecosystem processes, including fire regimes. Fire, facilitated or fueled by non-native species, is also a threat to the Ash Meadows gumplant. 


\section{Ash Meadows Blazingstar}

The primary reference for this section is:

Nevada Natural Heritage Program. 2001c. Rare Fact Sheet for Mentzelia lewcophylla Brandegee (1899), Ash Meadows Blazingstar. Available at: http://www.state.nv.us/nvnhp/atlas/.

References cited in this seetion are internal to the above-refereneed document. Full citations have been included in the Bibliography.

Ash Meadows blazingstar (Mentzelia leucophylla) is endemic to the Ash Meadows area of Nye County, Nevada. It occurs in open areas, on dry, hard, salt-crusted alkaline clay or sandy-clay soils. Plants grow on low bluffs, swales, flats, and drainages, in shadscale vegetation that surrounds spring and seep areas. This habitat can be generally categorized as warm desert scrub. Associated species include shadscale saltbush, alkali goldenbush, Ash Meadows sunray, and Ash Meadows milk-vetch. The Ash Meadows blazingstar is found at elevations of between 2,240 and 2,300 feet. There are eight occurrenees of this species over a range of approximately 6 miles, on land administered by the USFWS and the BLM, as well as on privately owned land.

Ash Meadows blazingstar is a biennial herb with bright yellow flowers that bloom from late May into September. Flowers open only for brief periods in the late afternoon. Observations made in early spring indicate that individuals of this species do not overwinter, and that there was no new growth from previous years (typical of a biennial; Reveal 1978c). Sufficient rain is probably necessary to allow flowering. Since populations of mature plants vary greatly from year to year, it is likely that the total number of seeds produced varies also. The dispersal of this species' seeds is restricted to the sides of gullies and on raised knolls of the flats and lower foothills in the area of the existing populations. Like the Ash Meadows milk-vetch, the Ash Meadows blazingstar is apparently sensitive to disturbance or habitat alteration, as it is not found on any disturbed sites either as seedlings or as established plants.

Ash Meadows blazingstar was federally listed as threatened on May 20, 1985 (50 FR 20777). At the same time, 1,240 acres of eritical habitat were designated in the Ash Meadows area of Nye County, Nevada. This species is threatened by agricultural development.

\section{Ash Meadows Sunray}

The primary reference for this section is:

USFWS. $2011 \mathrm{~g}$. Enceliopsis nudicaulis var. corrugata (Ash Meadows Sunray) 5-Year Review: Summary and Evaluation. U.S. Fish and Wildlife Service. Nevada Fish and Wildlife Office. Reno, Nevada.

References eited in this seetion are internal to the above-referenced document. Full citations have been included in the Bibliography.

Ash Meadows sunray (Enceliopsis nudicaulis var. corrugata) is also endemic to the Ash Meadows area, oceurring in both Nevada and adjacent California. The range of the species encompasses the Ash Meadows National Wildlife Refuge and adjacent Ash Meadows ACEC and private lands. The species oceurs across a broad range of habitats including moist alkaline soils, spring and seep areas, and dry desert washes (Morefield 2001; Bio-West, Inc. 2011), but most often occupies intermittently flooded to upland mesic alkali shrub-scrub habitat in alkali-clay soil and is occasionally a component of salt desert scrub and desert pavement (embedded, tightly packed gravel) habitats (Bio-West, Inc. 2011). Surface and subsurface groundwater is probably an important habitat determinant for this species. Plants are found in spring and seep areas, at elevations from 2,200 to 2,360 feet, in creosote-bursage and shadscale zones. Common associated plant species include shadscale saltbush, alkali goldenbush, saltgrass, broom snakeweed, ratany, basin yellow cryptantha, desert bearpoppy, Ash Meadows blazingstar, and Ash Meadows milkvetch. Population estimates for the wildlife refuge are approximately 80,000 plants in 30 separate oceurrenecs.

Ash Mcadows sunray is a perennial plant in the sunflower family that forms clumps 3.9 to 15.7 inches high, and arises from a stout, woody root-stock that flowers in April and May (Mozingo and Williams 1980). Flowers are 
borne singly on leafless flower stalks. The species attracts numerous potential pollinators, including 19 speeies of bees. Little is known about the reproductive biology and life history of this species.

Ash Meadows sunray was federally listed as threatened on May 20, 1985 (50 FR 20777). At the same time, 1,780 acres of eritical habitat was designated in the Ash Meadows area of Nye County, Nevada. Groundwater withdrawal coupled with solar development is the greatest threat to Ash Meadows sunray. Other threats, both immediate and potential, inelude non-native plant species, wildfire, and predation and herbivory.

\section{Nichol's Turk's Head Cactus}

The primary reference for this section is:

USFWS. 2009j. Nichol Turk's Head Cactus (Echinocactus horizonthalonius var. nicholii) 5-Year Review: Summary and Evaluation. U.S. Fish and Wildlife Service Arizona Ecological Services Field Offiee. Phoenix, Arizona.

References eited in this seetion are internal to the above-refereneed document. Full citations have been ineluded in the Bibliography.

Nichol's Turk's head eactus (Echinocactus horizonthalonius var. nicholii) is endemie to the Sonoran Desert and occurs in isolated mountain ranges that extend from south-central Arizona in Pima and Pinal Counties to a disjunet loeation in Sonora, Mexieo. There are four known populations: the Waterman Mountains and Koht Kohl Hills in Pima County, Arizona; the Vekol Mountains including those near the vieinity of the Vekol Mine in Pinal County, Arizona; and a population in the Sierra del Viejo Mountains in Sonora, Mexico. Surveys conducted between 1981 and 2006 estimated the total U.S. population at fewer than 3,000 plants.

The eactus oecurs within the Upland Division of Sonoran Desert serub at elevations from 2,400 to 4,000 feet on 0 to 30 percent slopes with a north, west, and south-facing exposure (USFWS 1986a). The cactus is found on limestone substrates along disseeted alluvial fans, inclined terraces and saddles, bajadas, and debris flows. The eactus grows in open areas and partially to shaded areas underneath the eanopy of shrubs and trees, or shouldered next to rocks on steep slopes and within limestone outerops. Dominant plant species associated with the species include: creosote bush, foothill palo verde, triangleleaf bursage, white ratany, brittlebush, prickly pear cactus, saguaro, ocotillo, and buckhorn cholla. (USDOI BLM 1986, USFWS 1986a). Extant populations occur on land administered by the BLM, the Bureau of Indian Affairs/Tohono O'odham Nation, and the state, as well as on privately owned land.

Nichol's Turk's head cactus is a small, blue-green to gray-green, barrel eactus. Large individuals range from 16 to 20 inches tall and from 5 to 8 inches wide. The species is very slow growing; on average, individuals grow 0.11 inches in height and 0.07 inches in width per year (McIntosh et al. 2007). An immature cactus takes 11 to 13 years to reach a diameter of 0.8 inches, and individual lifespan is estimated between 35 and 95 years. Germination oceurs in mid-summer, and vegetative growth takes place primarily in March through May. The majority of flowering occurs in late April to mid-July, often in response to the first warm-weather rain, but plants can flower as late as November. Flowers remain open from approximately 10 a.m. to 5 p.m., for 1 or 2 days. Common pollinators include bees and butterflies. One to five bright pink fruits are produced in May and June (Benson 1982), with young plants producing few flowers and older plants producing more. An average of 100 seeds are produced per fruit per year, and seeds are dispersed by birds, mammals, and rainwater. Seeds may require an extended dormancy of 5 to 10 years prior to suecessful germination.

Nichol's Turk's head cactus was federally listed as endangered on October 26, 1979 (44 FR 61927). Critical habitat has not been designated. Direct human interference remains the most important ongoing threat to this subspecies. The cactus continues to face habitat degradation by off-road vehicle use from activities associated with undocumented immigrants, and an increasing fire risk from buffelgrass invasion. On the Tohono O'odham Nation and on private lands, the cactus and its habitat continue to be impacted by activities associated with mining. 


\section{Kearney's Blue-star}

The primary referenee for this seetion is:

Arizona Game and Fish Department. 1997. Amsonia kearneyana. Unpublished Ábstraet Compiled and edited by the Heritage Data Management System, Arizona Game and Fish Department. Phoenix, Arizona.

Kearney's blue-star (Amsonia kearneyana) is an herbaeeous perennial that is limited to the South and Sysamore Canyons of the Baboquivari Mountains in Pima County, Arizona. In addition, there is an introdueed population in Brown Canyon on the east side of the mountains. This speeies generally oeeurs in eanyon bottoms on sandy alluvium, in partial shade under deeiduous riparian trees, at elevations between 3,680 and 6,400 feet. The habitat is not strietly riparian, however, as plants may also be found on hillsides. Plant eommunities that support this speeies inelude the Mexiean blue oak assoeiation, Sonoran desertserub, and semidesert grassland.

Kearney's blue-star flowers from Mareh through April, and fruits ripen from June through July. Hawk moths may pollinate plants at night. Observed predation of seeds by boring inseets has made this speeies largely sterile. Extant populations of this speeies oeeur on land administered by the Bureau of Indian Affairs and the BLM, and on privately owned land. The reintrodueed population is at a site in the Buenos Aries National Wildlife Refuge.

Kearney's blue-star was federally listed as endangered on January 19, 1989 (54 FR 2131). Critieal habitat has not been designated. This speeies is threatened by its extreme rarity, physieal damage from livestoek, and other disturbanees that ean eause mortality to plants.

\section{Pima Pineapple Cactus}

The primary referenee for this seetion is:

USFWS. 2007d. Pima Pineapple Caetus (Coryphantha scheeri var. robustispina) 5-Year Review: Summary and Evaluation. U.S. Fish and Wildlife Serviee Arizona Eeologieal Serviees Offiee Phoenix, Arizona.

Pima pineapple eaetus (Coryphantha scheeri var. robustispina) is sparsely distributed in Sonoran desert serub and semi-desert grasslands of Arizona. Its range extends east from the Baboquivari Mountains to the northeastern foothills of the Santa Rita Mountains, and from near Tueson south into Mexieo. The Pima pineapple eaetus oeeurs most eommonly in open areas on flat ridegetops or areas with less than 10 pereent slopes, and at elevations from 2,400 to 4,200 feet. Preferred sites have silty to gravelly deep alluvial soils. The eaetus does not typieally oeeur in mountainous areas, but is found instead on valley floors and bajadas. Habitats for the Pima pineapple eaetus ean be broken into two major divisions: ridges in what is now or onee was grassland, and alluvial fans in Sonoran Desert serub. On a smaller seale, the plant oeeupies habitats that are relatively flat and sparsely vegetated. In hilly landseapes, the Pima pineapple eaetus is found on flat hilltops, but is missing from slopes or drainages separating the hilltops. It is not found in riparian areas.

Pima pineapple eaetus is typieally a semi-eireular plant with single or numerous stems and spine elusters. Flowers, whieh are yellow to nearly white, appear in early July with the onset of summer rains. With adequate moisture, flowering ean eontinue until August. The fruits are green and sueeulent, and they may be taken quiekly by animals for broad dispersal of the seeds, or they may wither and dry among the spine elusters. Under eonditions of suffieient moisture, these withered fruits disintegrate, seattering seeds into the immediate vieinity of the dispersing eaetus. The major pollinator of the speeies is a ground nesting bee.

Pima pineapple eaetus was federally listed as endangered on September 23, 1993 (58 FR 49875). Critieal habitat has not been designated for this speeies. Threats to the taxon include eolleetion, OHV use, development related to mining and housing, the introduetion and spread of non-native grasses for livestoek forage and the altered fire regime, and use by inereasing numbers of javelinas. 


\section{Huachuca Water-umbel}

The primary reference for this section is:

USFWS. 1997a. Determination of Endangered Status for Three Wetland Species Found in Southern Arizona and Northern Sonora, Mexico. Federal Register 62(3):665-689.

Huachuca water-umbel (Lilaeopsis schaffneriana var. recurva) is an herbaceous, semi-aquatic plant that occurs in healthy riverine systems, eienegas (desert wetlands), and springs in Arizona and Mexieo. In watersheds that generally do not experience scouring floods, it occurs in microsites where competition between plant species is low. At these sites, the plant oecurs on wet soils, interspersed with other plants at low densities, along the periphery of the wetted channel, or in small openings in the understory. In stream and river habitats, it can oceur in backwaters, side channels, and nearby springs. After a flood, the water-umbel is able to rapidly expand its population by oceupying the disturbed habitat, persisting until it is no longer able to compete with other plant species. Huachuca water-umbel oecurs at 19 sites in four major watersheds: San Pedro River, Santa Cruz River, Rio Yaqui, and Rio Sonora. All sites are between 3,500 and 6,500 feet in elevation.

Huachuca water-umbel is a perennial plant with slender, erect leaves that grow from creeping rhizomes. Flowers are borne on an umbel in groups of 3 to 10 . The plant reproduces sexually through flowering, and asexually from rhizomes, with the latter the primary reproduetive strategy. The taxon may also vegetatively disperse when clumps of plants are dislodged from one location and then re-root in a different site along the aquatie system. The density of plants and the size of populations fluctuate in response to both flood cycles and site characteristics. The number of individuals in any given population may be difficult to detect because the creeping rhizomes tend to intermesh, and beeause reproduction is predominantly asexual.

Huachuca water-umbel was federally listed as endangered on January 6, 1997 (62 FR 665). Critical habitat was designated on July 12, 1999, on the Upper San Pedro River, in Garden Canyon of Fort Huachuca and other areas of the Huachuea Mountains, in the San Rafael Valley, and on Sonoita Creek (64 FR 37441). This taxon is threatened primarily by wetland degradation and loss, which reduces the amount of available habitat. Human aetivitics such as groundwater withdrawals, surface water diversions, impoundments, channelization, improper livestock grazing, chaining, agriculture, mining, sand and gravel operations, road building, the introduction of non-native speeies, urbanization, timber harvest, and recreation all contribute to the loss and degradation of riparian and cienega habitat. In addition, limited numbers of populations and the small size of populations make the Huachuea waterumbel vulnerable to extinction through chance events, such as drought, disease, or lightning-induced wildfires.

\section{Canelo Hills Ladies'-tresses}

The primary reference for this section is:

USFWS. 1997a. Determination of Endangered Status for Three Wetland Species Found in Southern Arizona and Northern Sonora, Mexico. Federal Register 62(3):665-689.

Canelo Hills ladies'-tresses (Spiranthes delitescens) is an orchid that is known from five sites in cienega and streamside habitats within the San Pedro River watershed in Santa Cruz and Cochise counties, Arizona. These sites occur in areas where scouring floods are unlikely. Soils supporting the populations are finely grained, highly organic, and seasonally or perennially saturated. Springs are the primary water source, but a creek near one locality contributes near-surface groundwater. The five sites for this orchid oceupy less than 200 acres of habitat near the U.S./Mexico border. Four sites occur on privately owned land. The dominant vegetation associated with Canelo Hills ladies'-tresses includes grasses, sedges, rushes, spike rushes, cattails, and horsetails. The surrounding vegetation is semidesert grassland or oak savannah.

Canelo Hills ladies'-tresses is a slender plant with linear, grass-like basal leaves, which produces a flower stalk of up to 40 spirally-arranged white flowers. Mature plants seldom flower in consecutive years, and in some years have no visible aboveground structures. Although it is presumed that fire once played a role in the life history of this orchid, a full understanding of both fire and other disturbances is lacking. Since little cienega habitat remains, and with so few known individuals, fire events that once may have been beneficial to the species could now depopulate an entire site. 
Canelo Hills ladies'-tresses was federally listed as endangered on January 6, 1997 (62 FR 665), but eritieal habitat has not been designated. The primary threats to this speeies are activities that result in wetland habitat degradation, sueh as groundwater overdrafts, surfaee water diversions, impoundments, ehannelization, improper livestoek grazing, agrieulture, mining, invasive non-native speeies, and reereation. This orehid may also be threatened by colleetion. In addition, the limited distribution and low numbers of individuals leave it vulnerable to extinetion from ehanee events.

\section{Cochise Pincushion Cactus}

The primary referenees for this seetion are:

Arizona Game and Fish Department. 2001a. Coryphantha robbinsorum. Unpublished Abstraet Compiled and Edited by the Heritage Data Management System, Arizona Game and Fish Department. Phoenix, Arizona.

and

USFWS. 2007e. Coehise Pineushion Caetus (Coryphantha robbinsorum) 5-Year Review: Summary and Evaluation. U.S. Fish and Wildlife Serviee Arizona Eeologieal Serviees Offiee Phoenix, Arizona.

Coehise pineushion eaetus (Coryphantha robbinsorum) is a sueeulent perennial that is endemie to desert serub eommunities in southern Arizona and northern Sonora, Mexieo. Arizona populations are limited to southeastern and southwestern Coehise County on both state-owned and privately owned land. Plants are found on the rolling gray limestone slopes of hills in the transition zone between Chihuahuan Desert serub and semidesert grassland, at elevations of 4,200 to 4,650 feet. Plants are rooted in bedroek eraeks or thin soil, where there is an abrupt vegetation ehange. They prefer areas with good drainage, and full sun to light shade. Assoeiated speeies inelude alkali muhly, fairyduster, Palmer's eentury plant, pinkflower hedgehog eaetus, dissodia, spinystar, eaetus apple, and oeotillo.

Coehise pineushion eaetus is a small ( 0.5 to 2.5 inehes in diameter), unbranehed eaetus eovered by white, eottony, areoles, giving the eaeti an overall whitish appearanee. The flowers are pale yellow or light beige and are produeed in late Mareh through early April, with flowers opening around mid-day and pollinated by bees. Fruiting oeeurs from late June through August. There may be short-distanee dispersal year-round, with seeds eoming off the mother plant and germinating below it. In addition, the red, fleshy fruits attraet birds, whieh then disseminate the seeds over long distanees. Most of the stem is underground, with only the top $1 / 2$ ineh visible above ground. During droughts and seasonal dry times, the eaeti shrink or retraet into the soil, making them diffieult to see. Plants tend to be solitary or seattered in diserete sub-populations, rather than randomly spread out.

Coehise pineushion eaetus was federally listed as threatened On January 9, 1986 (51 FR 952). Critieal habitat has not been designated. The speeies is at risk beeause it is a loeal endemie with speeifie substrate requirements. Plants are vulnerable to trampling, and oeeasionally suffer direet damage by livestock uprooting plants. Other potential threats inelude eolleeting, minerals exploration and mining, habitat degradation from livestoek and wildlife, and inereased illegal border aetivity and assoeiated law enforeement.

\section{Arizona Cliff-rose}

The primary referenee for this seetion is:

Arizona Game and Fish Department. 2001b. Purshia subintegra. Unpublished Abstraet Compiled and Edited by the Heritage Data Management System, Arizona Game and Fish Department. Phoenix, Arizona.

Referenees eited in this seetion are internal to the above-refereneed doeument. They are ineluded in the Bibliography.

Arizona eliff-rose (Purshia subintegra) is a low, woody shrub that is endemie to limestone soils in eentral Arizona. The eurrent range of the speeies ineludes Marieopa County (near Horseshoe Lake), Yavapai County (near Cottonwood), Mohave County (near Burro Creek), and Graham County (near Bylas). The speeies oeeurs where the winters are mild, summers are hot, and the rainfall ( 9 to 34 inehes) is evenly distributed between summer and 
winter rainfall periods. The landscape is dissected by ephemeral drainages and is sparsely vegetated. Plants typically grow on rolling, rocky, limestone hills and slopes, within Sonoran Desert serub, at elevations of 2,120 to 4,000 feet. The species requires white tertiary limestone lakebed deposits high in lithium, nitrates, and magnesium. The Arizona eliff-rose tends to be the dominant or codominant shrub on sites where it oceurs.

There are four disjunct populations of Arizona eliff-rose (listed above), which exist along an area of eentral Arizona that is 200 miles wide. The Cottonwood population includes the greatest number of individual plants, including seedlings. Extant populations are found on land under a number of different ownerships: private, BLM, Bureau of Indian Affairs, Forest Service, State of Arizona, and possibly the Bureau of Reclamation.

Arizona eliff-rose was federally listed as endangered on May 29, 1984 (49 FR 22326). Critical habitat has not been designated for this speeies. This species is very vulnerable beeause of its limited number of populations, habitat specificity, and a number of threats. Browsing by livestoek and burros, poor reproduction, mineral exploration and development, construction and maintenanee of roads and utility corridors, recreation, OHV use, urbanization, pesticides, and urbanization are all threats to the species (USFWS 1995a). The relative importanee of each of these threats varies from population to population.

\section{Arizona Hedgehog Cactus}

The primary reference for this section is:

Agyagos, J., A. Telles, and R. Fleteher. 2001. Biological Assessment and Evaluation: Wildland Urban Interface Fuel Treatment. Forest Service, Southwestern Region. Albuquerque, New Mexico.

Arizona hedgehog eactus (Echinocereus triglochidiatus var. arizonicus) oeeurs in interior ehaparral, madrean evergreen woodland, and desert grassland plant communities in Arizona, primarily at elevations ranging from 3,400 to 5,300 feet. Habitat consists of exposed bedrock or boulders in rugged, steep-walled eanyons and boulder pile ridges and slopes. Typically, the eaetus is seattered on open, rocky exposures, rooting in shallow soils and narrow crevices among the boulders. The plant may also grow beneath an understory of shrubs, but moderate to high shrub densities and associated deeper soils tend to preelude its establishment.

Because there are numerous red-flowered hedgehog eacti, which are variously grouped and separated as different species and varieties by different authors, there is some confusion surrounding both the morphology and range of the Arizona hedgehog cactus. As hybridization readily occurs among plants, and isolated populations rapidly evolve slightly different morphological characteristies, defining this variety becomes even more complicated. Investigations condueted between 1992 and 1994 stated that the Arizona hedgehog eactus oceupies a range of 30 square miles, and that a very small distribution of the taxon was readily aceessible to the general public. However, the BLM has identified over 300,00 acres of potential habitat for the Arizona hedgehog cactus on publie lands in east-central and southeastern Arizona. The main distribution is thought to oceur in the vicinity of Globe/Miami, Arizona, though there are likely thousands of plants occurring in satellite populations disjunet from the main distribution.

Arizona hedgehog cactus is a robust, succulent perennial, with dark green stems that occur singly or in clusters of a few to 10 stems, though some plants may have over 100 stems. Flowers erupt along the sides of the stems, and are a brilliant scarlet to deep red in color. Flowering occurs from late April to mid-May. Likely pollinators include insects - primarily bees - and perhaps hummingbirds. Fruits are present from May through June, with several fruits occurring per plant and 100 seeds produced per fruit. The amount of variation in annual seed production, and in seed viability and longevity are unknown. Seed dispersal is likely by birds and mammals. Seeds do not appear to have special germination requirements apart from protection from extended direct sunlight and extreme temperatures (i.e., above 110 degrees Fahrenheit $\left[{ }^{\circ} \mathrm{F}\right]$ ), and germination can occur in mid-summer. Natural insect predators include borers and leaf-foot bugs that attack the stems. Rodents may also gnaw on stems.

Arizona hedgehog cactus was federally listed as endangered on October 25, 1979 (44 FR 61556). Critical habitat has not been designated. Plant collection, mining, and livestock grazing have all been identified as threats to this plant, although it is likely that at present these threats have far less impact than originally believed. A substantial 
portion of the range has been designated as wilderness and receives additional protections. From a biologieal standpoint, it is possible that this eactus is not as in danger of extinetion as was previously thought.

\section{Dwarf Bear-poppy}

Dwarf bear-poppy (Arctomecon humilis) is a narrow endemic to Washington County, Utah, where it is found on gypsiferous elay soils derived from the Moenkopi formation. Plants oceur on low hills, bluffs, and outerops of this formation, or at the bases of ridges and buttes (Welsh and Thorne 1979, USFWS 1982b). These isolated populations are surrounded by ereosote bush-dominated vegetation, but in general the speeies is assoeiated with the mixed warm desert shrub eommunity (Welsh 1978b; USFWS 1979, 1982b; Welsh and Thorne 1979). Dominant plant species include creosote bush and longspine horsebrush (Welsh 1978b, USFWS 1979). Other assoeiated species include Fremont's dalea, burrobrush, Torrey's jointfir, saltbush, erispleaf buekwheat, desert pepperweed, Parry's sandpaper plant, beautiful phaeelia, and Palmer's phaeelia (USFWS 1982b).

Dwarf bear-poppy grows only in clay to sandy or rocky clay soils containing a high amount of gypsum (Welsh 1978b, USFWS 1979, Welsh and Thorne 1979). This soil type is highly alkaline and has shrink-swell properties, whieh allow the soil to become a sticky mud during spring and fall, then extremely hard during summer (USFWS $1979,1982 \mathrm{~b}$ ). The elevation at which the poppy grows varies between 2,000 and 3,500 feet (Welsh 1978b, Welsh and Thorne 1979, USFWS 1982b), and the plant requires a southern exposure, with open sun (Welsh 1978b).

Dwarf bear-poppy is an evergreen, herbaeeous, perennial speeies. Plants flower in mid-April through May, and fruit in May and June. Reproduetion is sexual. The soil seedbank is apparently eritical for the persistenee of populations of this speeies, since mortality rates are high and germination events are widely spaced. Because transplanting and eultivating the poppy is usually unsuceessful, reeovery potential for this species is poor unless its habitat is preserved and proteeted (USFWS 1979, 1982b).

Dwarf bear-poppy was federally listed as endangered on November 6, 1979 (44 FR 64250). Critieal habitat has not been designated. Causes of mortality to the species inelude OHV use, mineral exploration, and land utilization for urban and industrial development (Welsh 1978b; J.L. Anderson 1982). The dwarf bear-poppy has probably always been restrieted to its small range, possibly due to specific soil and elevation requirements. It is estimated that 10 to 20 percent of the species' historic habitat has been destroyed by the development of the cities of St. George and Bloomington, and by the construction of the Interstate 15 freeway (Anderson 1982; USFWS 1982b). Presently, the dwarf bear-poppy is threatened by housing, recreational, and industrial development throughout its existing range (USFWS 1979, Welsh and Thorne 1979). Expanding land use around St. George and exeessive motoreyele and other OHVs use is damaging much of the remaining habitat of the poppy (USFWS 1979, 1982b; Welsh 1979b; Anderson 1982). Although not as great a problem as OHVs, the collection of the poppy for ornamental gardening has oceurred. Mineral exploration, strip mining of gypsum deposits, the Warner Valley Power Projeet, and privatization of public land are all possible future threats.

\section{Holmgren Milk-vetch}

The primary reference for this section is:

USFWS. 2006a. Astragalus holmgreniorum (Holmgren Milk-veteh) and Astragalus ampullarioides (Shivwits Milk-veteh) Recovery Plan. Denver, Colorado.

Referenees cited in this seetion are internal to the above-referenced doeument. Full citations have been ineluded in the bibliography.

Holmgren milk-vetch (Astragalus holmgrenorium) is a narrowly-distributed endemie of the Mojave Desert, restrieted to the immediate vicinity of St. George, in Washington County Utah and Mojave County, Arizona. Holmgren milk-vetch oceurs at elevations between 2,480 and 2,999 feet in areas that drain to the Santa Clara and Virgin rivers. It is typically found on the edges of hill and plateau formations slightly above or at the edge of drainage areas; it occurs on soils characterized by small stone and gravel deposits and where living vegetative cover averages less than 15 pereent of the landscape. The speeies is associated with geological layers or parent materials found within the Moenkopi formation. The species is a prineipal member of a warm-desert shrub 
community dominated by desert goldenhead, white burrobush, and Anderson wolfberry. Also associated with the Holmgren milk-vetch are several perennial and annual forbs and grasses, most importantly the non-native foxtail brome, storksbill, and African mustard (Armstrong and Harper 1991, Stubben 1997, Harper and Van Buren 1998, Van Buren and Harper 2000a). Only four extant populations of the Holmgren milk-veteh are known, ranging in size from 200 to nearly 16,000 plants. The total population size during 2006 surveys was estimated at nearly 40,000 plants; however, the majority of these were seedlings, which have a very high mortality rate.

Holmgren milk-velch is a stemless herbaceous perennial plant that produces leaves and flowers in the spring, both of which die back to the roots after the flowering season. Fruits are pods that eventually dry out and open, releasing seeds, which may persist in the soil for years. Plants are pollinated by native solitary ground-dwelling bees (Tepedino 2000). Fragmented, isolated populations of the species restrict pollinator exchange between occupied population sites. This situation may cause genetic isolation, which potentially lead to inbreeding and local extirpation of isolated populations.

Holmgren milk-vetch was federally listed as endangered on September 28, 2001 (66 FR 49560). In December 2006, the USFWS designated 6,289 acres in Mohave County, Arizona, and Washington County, Utah as eritical habilat (71 FR 77972). Substantial portions of the species' habilat are subject to disturbance from urban development, OHVs, grazing, displacement by exotic weeds, soil compaction, and mineral development. In addition, the introduction of frequent fire into the Mojave Desert ecosystem with the spread of non-natives such as downy brome and foxtail brome and changing elimate and precipitation patterns have been identificd as a threat 10 these species.

\section{Shivwitz Milk-vetch}

The primary references for this section are:

USFWS. 2001a. Determination of Endangered Status for Astragalus holmgrenorium (Holmgren Milk-veteh) and Astragalus ampullarioides (Shivwitz Milk-veleh). Federal Register 66(189):49560-49567,

and

USFWS. 2006a. Astragalus holmgreniorum (Holmgren Milk-veteh) and Astragalus ampullarioides (Shivwits milk-vetch) Recovery Plan. Denver, Colorado.

References eited in this section are internal to the above-referenced documents. Full citations have been included in the Bibliography.

Shivwitz milk-vetch (Astragalus ampullarioides), like the Holmgren milk-vetch discussed in the previous speeies account, is a narrowly-distributed endemic of the Mojave Desert, restricted to the immediate vicinity of St. George, Utah in Washington County. Shivwitz milk-vetch grows only on purple clay soils derived from the Petrified Forest member of the Chinle geological formation, at elevations between 3,018 and 4,367 feet. Native plant speeies associated with Shivwitz milk-vetch include beautiful bluedicks, birdsfoot trefoil, snakeweed, mariposa lily, and several other Mojave Desert plants. However, the most frequently found herbaceous species associated with Shivwitz milk-vetch are the non-natives foxtail brome, downy brome, red brome, cheatgrass, storksbill, African mustard, and bells of Ireland; the latter is of particular concern. (Armstrong and Harper 1991; Van Buren 1992; Harper and Van Buren 1998; Van Buren and Harper 2000b, 2003, 2004; J. Alexander 2004, Zion National Park, pers. comm.). Shivwitz milk-vetch is known from six separate sites in Washington County, Utah, which are distributed over a narrow band of the exposed Chinle formation over a distance of about 45 miles. These populations contain a total of approximately 5,000 plants.

Shivwitz milk-vetch is a perennial herbaceous plant, with flowering stems that may attain a height of 40 inches if not grazed. Each plant produces about 45 small flowers on a single stalk in the spring. Seeds are produced in small pods, and the plant dies back to its root crown after the flowering season. Plants are pollinated by native bees (Tepedino 2005). Fragmented, isolated populations of the plants restrict pollinator exchange between occupied 
population sites. This situation may cause genetic isolation, which can potentially lead to inbreeding and local extirpation of isolated populations.

Shivwitz milk-vetch was federally listed as endangered on September 28, 2001 (66 FR 49560), and 2,181 acres of critical habitat were designated on December 27, 2006 (71 FR 77972). All known Shivwitz milk-veteh populations are threatened by OHV and other reereational uses, invasive plants such as downy brome and foxtail brome and the fires associated with their establishment, prolonged droughts caused by climate change, and grazing. Land development poses an indirect threat to three of the six Shivwitz milk-vetch populations.

\section{Gypsum Wild-buckwheat}

Gypsum wild-buckwheat (Eriogonum gypsophilum) oceurs in Chihuahuan Desert serub in Eddy County, New Mexico, at three known locations: north of Carlsbad at Seven River Hills; south of Black River Village; and in the drainages of Ben Slaughter Draw and Hay Hollow (New Mexico Rare Plant Technical Council 1999). All three known populations contain between 11,000 and 18,000 plants. However, the total acres of occupied habitat are relatively small. At this time, the total known area of habitat occupied by gypsum wild buckwheat is less than 250 acres (USFWS 2007f). The species oceurs on almost pure gypsum that is sparsely vegetated with other gypsophilous plants such as hairy crinklemat, gypsum blazingstar, and southwestern ringstem. Plants occur at elevations of 3,280 to 3,600 feet, on the eroded hillsides and tops of the gypsum hills, as well as on the gypsum colluvial fans at the base of the hills.

Gypsum wild-buckwheat occurs on slopes of 0 to 45 degrees, and does not have an apparent exposure preference (Spellenberg 1977, Wagner and Sabo 1977, USFWS 1984a). There appears to be some correlation between surface disturbance and plant density, with larger numbers of the plant present where the tough surface crust of the gypsum is broken. Hence, plants are often most abundant adjacent to crosion channels on the hillsides, and roadways along the base.

Gypsum wild-buckwheat is a small herbaceous perennial that arises from a persistent woody root erown (Wooten and Standley 1913, Reveal 1977). Budding occurs in early May, flowering occurs from mid-May to early July, and fruiting occurs in late July to early August (Wooten and Standley 1913; Reveal 1977; Martin and Hutchins 1980; Fleteher et al. 1984). Seed dispersal probably also oceurs in August. The species reproduces both by producing seed and also asexually by producing clone rosettes from rhizomes or rootsprouts. Seed production has been observed (Spellenberg 1977), but seedlings are rarely seen and most propagation oceurs by asexual reproduction, or during infrequent climatic episodes suitable for seed germination and seedling establishment (Knight 1993, Spellenberg 1977).

Gypsum wild-buckwheat was federally listed as threatened on January 19, 1981 (46 FR 5730). At the same time, critical habitat was designated in Eddy County, New Mexico, on BLM-administered land. The gypsum wildbuckwheat is an extremely rare plant that is restricted to one locality of approximately 500 acres in size. With such a limited distribution this species is sensitive to both limited scale projects as well as those of regional impact. All gypsum wild buckwheat habitat occurs in areas with high potential for mineral extraction and associated development, especially oil and gas. This potential threat is eurrently mitigated by BLM Special Management Areas on significant portions of each gypsum wild buckwheat population, and these Special Management Area preseriptions will be needed as long as there is potential for mineral development on gypsum wild buckwheat habitats. The species is a candidate for delisting if these protections remain in place. (USFWS 2007f).

\section{Lee Pincushion Cactus}

Lee pincushion eactus (Coryphantha sneedii var. leei) occurs in semi-desert grassland in the high Chihuahuan Desert of Carlsbad Canyon National Park in the Guadalupe Mountains, Eddy County, New Mexico. The species is restricted to limestone substrates on terraces and rimrock, with the majority of the plants growing in cracks in the rocks on north facing slopes between 5,000 and 5,900 feet in elevation (Martin and Hutchins 1980; Fleteher et al. 1984; New Mexico Department of Natural Resources 1985). Plants occur in an agave-juniper association, which is dominated by large almost arboreseent shrubs. Associated species include muhly, prairie clover, Pinchot's juniper, common sotol, yucea, Texas sacahuista, oak, cactus apple, and Apache plume (Heil and Brack 1985). Plants are 
usually sparsely distributed among the scrubby vegetation, and rarely occur under cover (Martin and Hutchins 1980; Fleteher et al. 1984; Heil and Brack 1985; New Mexico Department of Natural Resources 1985).

Lee pincushion cactus is long-lived succulent perennial species. Reproduction is sexual, and although plants can be propagated vegetatively for eutting, they have no natural mechanism for doing so. Lee pincushion eactus plants bud in early to mid-April, flowers are produced in early May, and fruit is developed in late summer. The seeds are thought to be dispersed in October, with germination taking place in late May to early June (Heil and Brack 1985). Pollinating agents are believed to be bees, and seed dispersal agents are thought to be rodents and ants.

Lee pincushion cactus was federally listed as threatened on Oetober 25, 1979 (44 FR 61554). Critical habitat has not been designated. The subspecies is threatened by illegal collecting by eactus enthusiasts (Heil and Brack 1985, New Mexico Department of Natural Resourees 1985, USFWS 1985d). Plants are relatively tough, not being affected by many of the fungi and insect predators that other eacti are susceptible to. The recovery potential of the Lee pincushion cactus appears to be quite high.

\section{Sneed Pincushion Cactus}

Snced pincushion cactus (Coryphantha sneedii var. sneedii) is restricted to limestone substrates on terraees, ridgetops, hillsides, and ledges in the high Chihuahuan Desert of the Franklin, Guadalupe, and Organ mountains of Texas and New Mexico. Plants occur primarily in cracks in the limestone substrate or in shallow pockets of loamy soil on hillsides and ridgetops between 3,900 and 7,700 feet in elevation (USFWS 1985d). The subspeeies typically oceurs in semi-desert grasslands or woodlands, in an agave-juniper association. In the Guadalupe Mountains it extends upward in elevation to the lower pinyon-juniper woodland. Like the Lee pincushion cactus (discussed in the previous species account), it usually occurs in sparsely vegetated areas with shrubby species, but is rarely under cover. Associated plant species include lechuguilla, sideoats grama, whiteeolumn foxtail eaetus, eommon sotol, longleaf jointfir, Apache plume, Pinchot's juniper, Texas sacahuista, eaetus apple, oak, and pinyon pine (New Mexico Department of Natural Resourees 1985, USFWS 1985d).

Sneed pincushion caetus is a long-lived succulent perennial species. Reproduction is sexual; although plants can be propagated vegetatively for cutting, they have no natural mechanism for doing so. Sneed eaetus plants likely germinate from late May to early June, but do not begin blooming until after 3 to 4 years of age. The plants bud in March and April, flower in mid- to late April, and fruit from August to November. Pollinating agents are believed to be bees, and seed dispersal agents are thought to be rodents and ants.

Sneed pincushion cactus was federally listed as endangered on November 7, 1979 (44 FR 64741). Critieal habitat has not been designated. The taxon is threatened by illegal eollecting by cactus enthusiasts (Heil and Brack 1985, New Mexico Department of Natural Resources 1985, USFWS 1985d). Plants are relatively tough, not being affected by many of the fungi and insect predators that other cacti are susceptible to. The recovery potential of the Sneed pincushion cactus appears to be quite high.

\section{Pecos Sunflower}

The primary references for this section are:

USFWS. 1999b. Determination of Threatened Status for the Plant Helianthus paradoxus (Pecos Sunflower). Federal Register 64(202):56581-56590.

and

USFWS. 2008e. Endangered and Threatened Wildlife and Plants; Designation of Critical Habitat for Helianthus paradoxus (Pecos Sunflower). Federal Register 73(63):17762-17807.

References cited in this section are internal to the above-referenced documents. A complete list of these references is available from the USFWS New Mexico Ecological Services Field Office, Albuquerque, New Mexico. 
Pecos sunflower (Helianthus paradoxus) is dependent on desert wetlands for its survival. The species grows in permanently saturated soils, and though it is found most commonly in desert wetlands associated with springs, it may also occur along stream and lake margins. Habitat requirements include silty clay or fine sand soils that contain high organic content, are saline or alkaline, are permanently saturated within the root zone (top 20 inches of the soil profile), and have salinity levels ranging from 10 to 40 parts per thousand; and a less than 10 percent woody shrub or canopy cover directly around the plant. Plants commonly associated with Pecos sunflower include Transpecos sealavender, limewater brookweed, clasping yellowtops, Olney bulrush, common reed, saltgrass, alkali sacaton, alkali muhly, Mexican rush, Pursh seepweed, and saltcedar (Poole 1992, Sivinski 1995). All of these species are good indicators of saline soils.

Pccos sunflower is an annual member of the sunflower family that flowers from September to November. It is very similar in appearance to the common sunflower, with large, bright yellow flowers. It is known from 22 sites in Cibola, Valencia, Guadalupe, and Chaves Counties, New Mexico, and from three sites in Peeos and Reeves Counties, Texas. Various federal, state, tribal, municipal, and private interests own and administer the Pecos sunflower sites. Federal ageneies include the BLM and National Park Service.

Pecos sunflower was federally listed as endangered on Oetober 20, 1999 (64 FR 56583). In 2007, the USFWS designated 1,305 acres in Chaves, Cibola, and Guadalupe Counties, New Mexico, and in Pecos County, Texas, as eritical habitat (73 FR 17762). The loss or alteration of wetland habitats is the main threat to the Pecos sunflower. The lowering of water tables through aquifer withdrawals and diversion of water from wetlands for irrigation, livestock, or other uses; wetland filling; and invasion of saltcedar and other non-native species continue to destroy or degrade desert wetlands. Mowing of some municipal properties and highway ROWs regularly destroys some plants. Livestock will eat Pecos sunflowers, particularly if other green forage is searee. There has been some unregulated commercial sale of Pecos sunflowers in the past, and some plant collection for breeding programs to improve commereial sunflowers. Peeos sunflower will naturally hybridize with common sunflower, and it is possible that backerosses from hybrids could affect the genetic integrity of small Pecos sunflower populations.

\section{Acuña Cactus}

The primary reference for this section is:

USFWS. 2012a. Endangered and Threatened Wildlife and Plants; 12-Month Finding for the Lemmon Fleabane; Endangered Status for the Acuña Cactus and the Fickeisen Plains Cactus and Designation of Critical Habitat; Proposed Rule. Federal Register 77(192):60509-60579.

References cited in this section are internal to the above-referenced document. A complete list of these references is available from the USFWS Arizona Ecological Services Field Office, Phoenix, Arizona.

The acuña cactus (Echinomastus erectocentrus var. acunensis) is a small, spherical cactus that occurs in valleys and on small knolls and gravel ridges of the Sonoran Desert serub, at elevations from 1,198 to 3,773 feet. Populations are known from Maricopa, Pima, and Pinal Counties, Arizona, and from Sonora, Mexico (AGFD 2004). Plants occur on BLM lands in western Pima County, Maricopa County, and Pinal County. The current range of the species does not appear to differ substantially from its historic range.

The acuña cactus grows on soil overlaying various bedrock types. Soil texture in locations where plants oceur varies between bedrock and coarse- and fine-textured substrates (Rutman 2007). Associated plant species include ereosote bush, ironwood, palo verde, triangle-leaf bursage, and catclaw. The acuña cactus is often noted growing under the protective canopy of these or other associated species (Phillips et al. 1982; Butterwick 1982 to 1992 ; Felger 2000; USFWS $2011 \mathrm{a}$, b), which may act as nurse plants that shelter seedlings from extreme temperatures and provide some protection from mechanical disturbance (Nobel 1984; Suzan et al. 1996).

The acuña cactus blooms during March. It relies solely on the production of seeds for reproduction, with pollination highly linked to survival, as the species cannot fertilize itself. Acuña cacti are pollinated by bees, predominantly the leafcutter bee and cactus bee (Johnson 1992). The species is believed to be long-lived, although the lifespan of its seeds is unknown, and may be short. 
The acuña cactus was federally listed as endangered on October 1, 2013 (78 FR 60607). At the time of listing, the USFWS indicated that designation of eritical habitat for this species was prudent, and is fortheoming. Recent surveys of populations of this species have found considerable mortality and low numbers of juvenile plants. The species is threatened by long-term drought, the effects of climate change, ongoing and future activities at the U.S.Mexieo border, and future non-native, invasive species issues. Invasive species have been located in the vicinity of several populations of the species, and are projected to invade these populations within the next 5 to 20 years (Morawe 2012).

\section{Gierisch Mallow}

The primary reference for this section is:

USFWS. 2013b. Endangered and Threatened Wildlife and Plants; Determination of Endangered Status for Sphaeralcea gierischii (Gierisch Mallow) Throughout its Range. Federal Register 78(156):49149-49165.

References cited in this section are internal to the above-referenced document. A complete list of these references is available from the Arizona Ecological Services Office, Phoenix, Arizona.

The Gierisch mallow (Sphaeralcea gierischii) is a perennial plant that is only found on gypsum outerops in northern Mojave County, Arizona, and adjacent Washington County, Utah (Atwood and Welsh 2002). No information about the historical range of this species is available. Currently, there are 18 documented populations of the Gierisch mallow, restricted to an area less than approximately 460 acres in Arizona and Utah. Of these, 17 populations are on lands managed by the BLM and one is on lands managed by the Arizona State Land Department. The main populations in Arizona are located south of the Black Knolls, approximately 12 miles southwest of the BLM's Arizona Strip Field Office in St. George, Utah. The Utah population in located on BLM lands near the Arizona-Utah state line.

The Gierisch mallow is associated with the Harrisburg Member, which is the topmost exposed geologic layer of the Kaibab Formation. The Harrisburg Member is known for its soils containing high levels of gypsum (Bick and Hayden 2007). The surrounding plant community is warm desert serub. The Gieriseh mallow appears to be associated with biological soil crusts within the gypsum deposits (Frates 2012), and may, like other rare plants of this association, be excluded from areas where natural crosion or other man-made factors have destroyed the heavy cover of cryptogamic plants (Nelson and Harper 1991). The BLM has observed Gierisch mallow populations on hillsides and steep slopes, although the species has been documented growing on all slopes and aspects.

Because the Gierisch mallow was recently (2002) identified as a new species, little information about its life history is known. Other species of globemallow are pollinated by globemallow bees, which occur within the range of the Gierisch mallow (Spies and Tepedino 2005, Sipes and Wolf 2001) and are therefore likely pollinators of this species. Plants appear to grow from seeds stored in the seed bank (Hughes 2009). Plants are perennial, dying back to the ground during winter and resprouting from the base during late winter and spring (January to March), depending on daytime temperatures and rainfall.

The Gierisch mallow was federally listed as endangered on August 13, 2013 (78 FR 49149). On the same date, The USFWS designated approximately 12,822 acres in Mohave County, Arizona, and Washington County, Utah, as critical habitat (78 FR 49165). Critical habitat includes 9,406 acres of BLM lands in Arizona and 1,982 acres of BLM lands in Utah. Threats to the species include habitat destruction, modification, and degradation resulting from gypsum mining operations; livestock grazing; the spread of non-native species; increased risk of wildfire; herbivory during drought years and during the reproductive period; and small population size and restricted range.

\section{Subtropical Steppe Ecoregion Division}

The Subtropical Steppe Ecoregion Division is located in a large portion of northern Arizona, New Mexico, and Texas, and a small portion of southern Utah and Colorado. Composed of plateaus and high plains, and occurring at a higher elevation than the warm deserts to the south, this ecoregion is typified by a semiarid steppe climate. Grassland vegetation predominates, with locally developed shrubs and woodlands. Common plant community 
types found in the Subtropical Steppe Ecoregion Division include pinyon-juniper woodlands, perennial grasslands, ehaparral and other shrublands, with ponderosa pine and other evergreen forests occurring in the mountainous regions.

\section{Brady Pincushion Cactus}

The primary reference for this section is:

Arizona Game and Fish Department. 2001c. Pediocactus bradyi. Unpublished Abstraet Compiled and Edited by the Heritage Data Management System, Arizona Game and Fish Department. Phoenix, Arizona.

References eited in this section are internal to the above-refereneed document. They are included in the Bibliography.

Brady pineushion cactus (Pediocactus bradyi) is endemie to Marble Canyon, Coconino County, Arizona. Plants oeeur in Great Basin desert scrub habitats, on gently sloping benehes and terraces with very specific soil eharacteristies. Although the speeies does not exhibit a preferenee for a specific soil type, it is always found on Kaibab limestone ehips overlaying soil derived from shale, mudstone, and siltstone. Plants are typieally found in open, exposed habitats with sparse vegetation characterized by seattered low shrubs (saltbush, snakeweed, jointfir), grasses (grama, dropseed), and annuals (globemallow, buckwheat).

Seattered populations oceur along both sides of the rim of Marble Canyon and tributary canyons for a distance of about 25 miles, from below Lee's Ferry to the vieinity of Bedroek Canyon on the west side, to Tanner Wash on the east side. The densest populations oceur along the rims of Soap Creek and Rider Canyon, and nearby portions of the rim of Marble Canyon. Total potential habitat has been estimated to be 17,000 aeres, though only 10 to 20 pereent appears to be occupied. Known populations of plants oceur on land administered by the BLM, the Bureau of Indian Affairs, and the National Park Service (Glen Canyon National Recreation Area).

Brady pincushion eaetus is a globose sueeulent perennial that flowers from late Mareh to April. On sunny days, flowers open mid-morning and elose in the evening, and may open for 4 or 5 sueeessive days (Spenee 1992). There is some evidenee that this speeies is an obligate out-erosser, and that flowers are pollinated by insects, primarily native bees. Fruits mature in late May to early June. A mature fruit may contain 15 seeds, and the total number produced by a single plant over its life is relatively small. The roots of the Brady pincushion eactus are associated with beneficial microorganisms ealled mycorrhizal fungi. Under cool temperatures and wet eonditions, the speeies is highly susceptible to root rot.

Brady pineushion cactus was federally listed as endangered on October 26, 1979 (44 FR 61784). Critieal habitat has not been designated. The speeies is highly desired for its ornamental value in the eaetus and suceulent trade, and cultivation difficulties make wild populations a target for collectors. In addition, highway and road maintenance has affected at least one population, and trampling assoeiated with livestock grazing has also had loeal impacts on this species. Additional threats include OHV usage and impaets from dispersed reereation. Many Brady pineushion eacti are eaten by rodents, especially under drought conditions (Hughes 1991).

\section{Peebles Navajo Cactus}

The primary reference for this section is:

USFWS. 2009k. Pcebles Navajo Cactus (Pediocactus peeblesianus var. peeblesianus) 5-Year Review Summary and Evaluation. U.S. Fish and Wildlife Service New Mexico Ecological Field Serviees Office. Albuquerque, New Mexieo.

References eited in this section are internal to the above-referenced document. They are ineluded in the Bibliography.

Peebles Navajo cactus (Pediocactus peeblesianus var. peeblesianus) is endemic to Arizona and occupies a very small geographic area ( 7 miles in length by 1 mile in width) extending northwest to southeast within the immediate vicinity of Joseph City and Holbrook, Navajo County, Arizona (USFWS 1984b). The Peebles Navajo eactus 
occupies low hills in the Plains and Great Basin Grassland biotic eommunity from near Joseph City extending northwest to the Mareou Mesa region northwest of Holbrook (Brown and Lowe 1980, ARPC 2001, Arizona Game and Fish Department 2004). Populations oceur between 5,100 and 5,650 feet on gentle slopes on all facing aspects (Stuart et al. 1972; USFWS 1984b; Arizona Game and Fish Department 2004). Approximately 30 pereent of Peebles Navajo eaetus populations oecur on public lands administered by the BLM or the Arizona State Lands Department, with the remaining populations oecurring on private lands.

Populations of this taxon oceur in the Plains and Great Basin grassland, near the eeotone with the Great Basin serub (Brown et al. 1980). The plants in these communities are generally low in stature, and vegetative cover is sparse, characterized by low shrubs, grasses, and seasonal annuals (USFWS 1984b). Occasional junipers, associated with Peebles Navajo eacti, are about 10 feet tall, and the eanopy is open. The soils are shallow to deep, well drained to excessively well drained and formed in mixed alluvium. Peebles Navajo cactus oeeurs in the mixed rangeland land use/land cover associations, specifically in the desert grasslands forest/rangeland associations. Dominant plants in these associations are snakeweed, shadscale, four-winged saltbush, rabbitbrush, sagebrush (Bigelow and big), Mormon tea, Cutler's jointfir, and galleta. Caetus assoeiates are beehive eactus, whipple devil claw, and several prickly pear speeies.

Peebles Navajo eactus is a succulent perennial that germinates in early April. Flowering oceurs from mid-April to early May, and fruiting oceurs approximately 1 month later, in May. Seed/fruit dispersal oceurs within days of the fruit opening. Seeds do not germinate immediately after they are shed (June) because eonditions are too hot and dry. Some will germinate the following spring, but optimum germination oecurs after 2 to 3 years. Germination depends upon proper moisture at the right time, and all phenological dates are dependent on environmental conditions (Phillips et al. 1979). Seed dispersal is by wind, rainwater, and ants, and tends to produee relatively seattered colonies with fairly high densities (Heil et al. 1981). Disturbance of the habitat by overgrazing or OHVs causes erosion and compaction of soil, and influences the success of seed dispersal to suitable habitats (Phillips et al. 1979). Limiting factors for Peebles Navajo eactus include its specialized soil needs, eold winters, moist, cool springs, and drying out periods (Phillips et al. 1979; Heil et al. 1981; Benson 1982; USFWS 1984b).

Peebles Navajo eactus was federally listed as endangered on Oetober 26, 1979 (44 FR 61922). Critical habitat has not been designated. Persistent drought and increased small mammal herbivory have been the most signifieant threats to the species in reeent years and may increase due to the effeets of elimatic warming in the southwest. Development and associated land use activities are also considered significant threats to the continued existence of Peebles Navajo eactus in the foreseeable future. Peebles Navajo eactus is also in demand by collectors of rare cacti (Fleteher 1979a; Newland 1979a, b). Cattle trample plants on BLM and State of Arizona lands as well as on private grazing lands, espeeially during wet seasons when the ground is muddy and the plants are emergent (Phillips et al. 1979; USFWS 1984b). In addition, OHVs cause damage to the plants and their habitat through erushing of plants, erosion, and soil compaction.

\section{Welsh's Milkweed}

The primary referenee for this section is:

USFWS. 1992b. Welsh’s Milkweed (Asclepias welshii) Recovery Plan. Denver, Colorado.

References cited in this section are internal to the above-referenced document. They are included in the Bibliography.

Welsh's milkweed (Asclepias welshii) occurs on active acolian sand dunes in Kane County, Utah, and Coconino County, Arizona. Populations occur on "islands" of suitable habitat that are surrounded by vegetated, stabilized sands, sandstone slickrock, or various exposed shales and other fine-grained rock types or their developed soils. The plant community in which Welsh's milkweed occurs is dominated by sand mule's-ear, with prominent groves of ponderosa pine and clumps of gambel. Other plant species commonly associated with Welsh's milkweed include blowout grass, sand dropseed, giant dropseed, Indian ricegrass, giant dunegrass, sand hill muhly, sand-spurge, silvery sophora, dune scurfpea, Kanab yucca, rubber rabbit-brush, and winged wild-buckwheat. The vegetation surrounding the sand dune habitat is dominated by pinyon-juniper (Utah juniper) woodlands with big sagebrush 
parks. Plants are found at elevations ranging from approximately 5,000 to 6,500 feet, with the largest population of this species occurring on the Coral Pink Sand Dunes, loeated about 7.5 miles west of Kanab, Utah.

Welsh's milkweed is a tall, herbaceous plant in the milkweed family. Reproduetion in this species is both sexual and asexual. Flowering oeeurs from May to June, and fruit and seed development and dispersal oecur from July to September. Self-pollination is impossible in this speeies, and the highly-evolved floral structures appear to be pollinated by eertain bees, wasps, butterflies, and moths. Welsh's milkweed has a deep-seated clustered root and stem system, a dense tomentum, and very large seeds, all of which are adaptations that allow this species to survive on the unusual sand dune habitat to which it is restricted. However, beeause Welsh's milkweed has a very low rate of fruit development (Wyatt 1976), vegetative reproduction by sprouting from rhizomes is also important.

Welsh's milkweed was federally listed as threatened on Oetober 28, 1987 (52 FR 41435). At the same time, critical habitat was designated for this species, including the entire Coral Pink Sand Dunes west of Kanab, Utah, as well as the area of the Sand Hills about 10 miles north of Kanab, Utah. Because of its very limited speeifie habitat requirements and its small population size, Welsh's milkwced is vulnerable to any event that eould eause the local extirpation of one or more of its isolated populations. Realized and potential threats to this species stem primarily from recreational OHV use. Mineral and energy development, road building, and livestock grazing are minor threats.

\section{Jones Cycladenia}

The primary reference for this seetion is:

Utah Conservation Data Center. No Date(e). Faet Sheet for Jones' Cycladenia. State of Utah Natural Resourees, Division of Wildlife Resources. Available at: http://utahdc.usu.edu.

The 2008 reeovery outline for the Jones Cycladenia (USFWS 2008f) was eonsulted for updated information on this spceies.

Jones cycladenia (Cycladenia humilis var. jonesii) is restricted to the canyonlands of the Colorado Plateau in Emery, Garfield, Grand, and Kane Counties, Utah, and in adjacent Coconino and Mohave Counties, Arizona. Plants grow in salty clay and gypsum soils that are derived from the Summerville, Cutler, and Chinle Formations. These soils are shallow, fine textured, and intermixed with roek fragments. Jones eyeladenia ean be found in wild buckwheat-Mormon tea, mixed desert shrub, and seattered pinyon-juniper communities, at elevations ranging from approximately 4,390 to 6,000 feet. The plant is known from 26 sites in five general arcas: Joe Huteh Creek, San Rafael, Moab, and Greater Circle Cliffs in Utah, and Pipe Springs in Arizona, and has an estimated population of approximately 1,100 individual plants. Populations oeeur on BLM, National Park Service, and tribal lands.

Jones cycladenia is a long-lived rhizomatous perennial in the dogbanc family, with round, somewhat succulent leaves, and small, pink, trumpet-shaped flowers that bloom from mid-April to early June. This plant has very low sexual reproductive success, resulting from low rates of pollinator visitation and frequent abortion of fruit. However, the individual plants spread by underground rhizomes and can form clones up to 35 feet across with dozens of stems.

Jones' cycladenia was federally listed as threatened on May 5, 1986 (5I FR 16526). Critical habitat has not been designated. Off-highway vehicle activity and the presence of mining claims and oil and gas leases on or immediately adjaeent to known sites are the biggest threats to this species. In addition, the relatively small number of populations make the speeies especially vulnerable to natural and human-caused disturbances. The arid climate and harsh soils of the ecosystem in which the Jones cycladenia is found make it fragile and slow to reeover from surface disturbance. 


\section{Siler Pincushion Cactus}

The primary referenees for this section is:

USFWS. 2008g. Siler Pincushion Cactus (Pediocactus sileri) 5-Year Review: Summary and Evaluation. U.S. Fish and Wildlife Service Arizona Ecological Services Office. Phoenix, Arizona.

References cited in this section are internal to the above-referenced document. They are included in the Bibliography.

Siler pineushion eactus (Pediocactus sileri) ranges from southeast of Fredonia, in extreme northwestern Coconino County, Arizona, westward for about 70 miles to north-eentral Mohave County, Arizona. It also includes about 3 miles of southern Utah in Washington and Kane Counties. The majority of the habitat oceurs on lands managed by the BLM (Arizona Strip and Cedar City Distriets), with smaller amounts of land managed by the Kaibab-Paiute Indian Tribe, Arizona and Utah State trust lands, and lands in private ownership. The species is ecologically restricted to gypsiferous and ealcareous sandy or elay soils derived from the various members of the Moenkopi Formation or the nearly identical Kaibab Formation. Plants grow on rolling hills, often with a badlands appearanee, in warm desert shrub, sagebrush-grass, and, at its upper limits, pinyon-juniper communities. This speeies oceurs at elevations ranging from approximately 2,800 to 5,400 feet.

Siler pincushion cactus is a small, solitary or occasionally clustered, globose cactus about 4 inches tall, but that may in exeeptional eases reach 18 inches tall. Yellowish flowers bloom during March and April (USFWS 1986b).

Siler pincushion eactus was federally listed as endangered in 1979 (44 FR 61786). Since that time, many more plants were discovered, and the species was reclassified as threatened on December 27, 1993 (58 FR 68476). Critical habitat has not been designated. This species and its habitat are vulnerable to disturbanee from OHV use, trampling by livestock, and mining. In addition, illegal collection has negatively affected some populations.

\section{Navajo Sedge}

Navajo sedge (Carex specuicola) occurs in the canyons of Kane County and San Juan County, Utah, and in Apache, Coconino, and Navajo Counties, Arizona. The species is restrieted to hanging garden habitats within the Great Basin conifer woodland of the Colorado Plateau (Brown and Lowe 1980). Plants grow in moist sandy to silty soils of seep-spring hanging gardens (Phillips et al. 1981; USFWS 1987b). These hanging gardens are found in pinyon-juniper woodlands on south-facing Navajo Sandstone Formation eliffs, at slopes ranging from 80 to 90 percent. Plants oceur at elevations between approximately 5,700 and 6,000 feet. Hanging gardens are produced by water percolating through the porous sandstone, contacting an impervious stratum along which it flows laterally, forming a drip or spring-line along the cliff face. It is on or under this drip line or spring that hanging gardens are developed (Smith 1977).

Plant communities in hanging gardens differ in composition and in kinds of species, not only along an apparent north-south climatic gradient and along an elevational gradient, but also from one garden to another on the same cliff face (Welsh and Toft 1981; Brotherson et al. 1978). Plant species commonly associated with Navajo sedge include monkey flower, helleborine, sand bluestem, and common reed (USFWS 1987b).

Navajo sedge is a perennial herb that flowers in June and July. Plants are pollinated by wind. Seed dispersal occurs in late July.

Navajo sedge was federally listed as threatened on May 8, 1985 (50 FR 19370). At the same time, critical habitat was designated in three areas of moist, sandy to silty soils at shady seep-springs within the Navajo Sandstone Formation, Navajo Indian Reservation, Coconino County, Arizona. Most species of sedge are palatable to livestock, and it is suspected that domestic livestock (horses, sheep, goats, and cows) as well as wildlife graze the plants. The two major threats to the species are grazing and a lowering of the water table from water development for livestock. Water is vital to the survival of the species; thus, any change in the water table level will have an effect on the populations (USFWS 1987b). Other potential threats to the species include use of OHVs and illegal collection. 


\section{Kodachrome Bladderpod}

The primary reference for this section is:

USFWS. 20091. Revised Reeovery Outline for the Kodaehrome Bladderpod (Lesquerella tumulosa). Utah Ecological Services Field Offiee. West Valley City, Utah.

References eited in this section are internal to the above-referenced document. They are included in the Bibliography.

Kodaehrome bladderpod (Lesquerella tumulosa) is an endemic found only in Kane County, Utah. The species is restricted to one population of seattered occurrences in the Kodachrome Flats area of the Paria River drainage, in an area about 2.5 miles long and 0.75 mile wide. A 1989 survey in the Kodachrome Basin, Little Dry Valley, and Rock Springs Creek areas documented 20,000 individuals covering approximately 700 aeres (M.C. Franklin 1990). Morc than 90 percent of the spccies' known range now oceurs on the Grand Stairease-Esealante National Monument, whieh is managed by the BLM (A. Hughes 2009, pers. comm.). Private landowners and the Kodachrome Basin State park comprise the rest of the range.

Plants are restricted to very xcric shale outerops at elevations ranging from approximately 5,600 to 6,050 feet. Kodachrome bladderpod occupies sites with very little vegctative eover. Two commonly associated plants are bitterbrush and yellow eryptantha (Van Buren and Harper 2001), as well as pinyon pine, Utah juniper, Indian ricegrass wild buckwheat, and hyaline herb (Van Buren and Harper 2002).

A member of the mustard family, this speeics is a perennial herb that forms denscly matted and depressed mounds. It has a many-branched woody base, and produees yellow flowers. The plants begin flowering in late April and continuc through May, with sced dispersal oecurring in June (M.C. Franklin 1990).

Kodachrome bladderpod was federally listed as endangered on October 6, 1993 (58 FR 52027). Critieal habitat has not been designated. The small population size of the Kodachrome bladderpod and its restricted habitat make the species vulnerable to human-caused and natural environmental disturbances. It occurs at locations that are subjeet to OHV use and domestic livestock grazing. In addition, the shale soils on whieh this plant grows are being actively quarried, and its habitat is threatened by mineral exploration and mining elaim assessment work.

\section{Winkler Cactus}

The primary references for this section are:

USFWS. 1998b. Final Rule To Determine the Plant Pediocactus winkleri (Winkler Cactus) to be a Threatened Speeies. Federal Register 63(161):44587-44595.

and

USFWS. 2007a. Recovery Outline for San Rafael Cactus (Pediocactus despainii) and Winkler Caetus (Pediocactus winkleri). U.S. Fish and Wildlife Serviee Utah Field Office. West Valley City, Utah.

References cited in this seetion are internal to the above-referenced documents. A complete list of references is available from the USFWS Salt Lake City Field Office, Salt Lake City, Utah.

Winkler cactus (Pediocactus winkleri) is endemie to lower elevations of the Colorado Plateau in south-central Utah. Plants typically grow on the tops and sides of rocky hills or benehes in saltbush-dominated desert shrub communities (Heil 1984). The species grows in alkaline silty loam or clay loam soils derived primarily from the Dakota formation, the Brushy Basin member of the Morrison formation, and the Emery sandstone member of the Mancos formation (Heil 1984, Necse 1987, USFWS 1997b).

Winkler cactus is known from four populations including Notom, North Fremont, Hartnet, and Cathedral Vallcy, with a total estimated population sizc of 24,000 plants occurring on widely separated pareels of habitat between 2.4 aercs and 48 acres in size. The species' range includes north central Wayne County along the eastern boundary of 
Capitol Reef National Park from the vicinity of Highway 24 north to extreme southwest Emery County. Most of the habitat and population is on federal lands managed by the BLM, with a significant portion of the species' habitat and population within Capitol Reef National Park. Additional population sites occur on scattered sections of State of Utah land administered by the School and Institutional Trust Lands Administration.

Winkler cactus is a small globose cactus with stems 1 to 2.5 inches tall and up to 2 inches in diameter, and clusters of small radial spines. Its flowers are urn-shaped, and its fruits are barrel-shaped, opening along vertical slits and expelling seeds. The size and longevity of the soil seedbank is unknown. Germination and seedling cstablishment may be episodic cvents (Clark 2007b).

Winkler cactus was federally listed as threatened on August 20, 1998 (63 FR 44587). Critical habitat has not been designated. Populations are in decline, and threats include illegal collecting, OHV use, livestock trampling, insect parasitism (cactus borer beetle), and an extended drought (England 1997; Clark 2007a, 2007b).

\section{Mesa Verde Cactus}

The primary reference for this section is:

USFWS. $2011 \mathrm{~h}$. Mesa Verde Cactus (Sclerocactus mesae-verdae) 5-Year Review: Summary and Evaluation. U.S. Fish and Wildlife Service New Mexico Ecological Services Field Office. Albuquerque, New Mexico.

References cited in this section are internal to the above-referenced document. Full citations are included in the Bibliography.

Mesa Verde cactus (Sclerocactus mesae-verdae) is restricted to sparsely vegetated badlands of clay loam soils derived from upper Cretaccous Mancos shale in Colorado, and Mancos and Fruitland shale in New Mexico (USFWS 1984c). Populations are located in a narrow strip of land between Cortez, Colorado, and Sheep Springs, New Mexico, at elevations ranging from 4,600 to 6,560 feet (Heil and Porter 1994, Coles and Naumann 2003). These formations erode easily, forming low, rolling hills where plants are found on hilltops and benches, but less so in basins or swales (Cully et al. 1993; Coles and Naumann 2003). Soils are alkaline and have low permeability. Principle vegetation types associated with $S$. mesae-verdae are those of the Great Basin Desert Scrub (Saltbush Series) and Desert Grassland Ecotone communities (Dick-Peddie 1993). Vegetative associates, though low in total percent ground cover (5 to 18 percent), include valley saltbush and mat saltbush in New Mexico, and shadscale saltbush, Gardner's saltbush, and bud sagebrush in Colorado (Cully et al. 1993; Coles and Naumann 2003). The most common perennial grasses (less than 1 percent cover) are Indian ricegrass and galleta grass (Cully et al. 1993; Coles and Naumann 2003). The non-native cheatgrass and Russian thistle are found with the cactus in New Mexico (Navajo Natural Heritage Program 2004).

Mesa Verde cactus occurs in diffuse population complexes composed of widely scattered loci of individuals and clustered plants. It is not uncommon to walk a quarter of a mile between individual plants. The usual situation encountered is a grouping of 3 to 50 plants scattered over several acres forming a population center and connected to the next population center in the complex by a web of individual plants spread several hundred yards apart. Of the known populations of Mesa Verde cactus, at least 80 percent of these occur on Navajo Nation lands, 15 percent on Ute Mountain Ute lands, and 5 percent on small blocks of BLM and New Mexico State lands (Sivinski 2000). Current estimates place the total population at around 4,204 plants (USFWS 2011h).

Mesa Verde cactus is a perennial desert plant that grows slowly and has a lifespan of approximately 20 years (Colorado Natural Areas Program 2005). This low growing, globe-shaped cactus is often single-stemmed with a branched taproot (Heil and Porter 1994), although multi-stemmed individuals may occur if the stem is damaged (Cully et al. 1993; Colorado Natural Areas Program 2005). Stems begin producing flowers when they are about 0.8 inches in diameter or about 8 years old and begin to flower each year after reaching 1.6 inches in diameter (New Mexico State Forestry Division 2007). Plants bloom from late April into early May, and flowers open daily for up to five days (Heil and Porter 1994). Seeds produced by this species are large and difficult to germinate, often requiring several years of the proper growth conditions for germination to occur. Repeated freezing and thawing, 
seed eoat scarifieation, and the proper temperature and moisture are required for successful germination (USFWS 1984c). Reproduction in this species is entirely sexual.

The Mesa Verde cactus was federally listed as threatened on October 30, 1979 (44 FR 62471). Critieal habitat has not been designated. Human caused threats pertaining to highway and transmission line construction, oil and gas exploration and production, OHV use, and commercial and residential development are increasing in intensity rangewide. Apart from the human impaets, this species it is also beset by a variety of insect predators whose larval stages inflict heavy damage upon the cactus, often resulting in death. The species also appears to be vulnerable to drought, although the speeies drought adaptations ineluding potential dormaney are poorly understood.

\section{Mancos Milk-vetch}

The primary referenee for this section is:

USFWS. 2011 i. Mancos Milkvetch/Astragalus humillimus 5-Year Review: Summary and Evaluation. USFWS New Mexieo Eeological Services Office. Albuquerque, New Mexico.

References cited in this seetion are internal to the above-referenced document. Full citations are included in the Bibliography.

Mancos milk-veteh (Astragalus humillimus) is a narrow endemic known only from the Four Corners region of San Juan County New Mexieo and the adjaeent Montezuma County in Colorado. The species oeeupies bowl-like sandy depressions on nearly flat sheets of exposed sandstone bedrock from Mancos Canyon, Colorado, southward to just south of the San Juan River in San Juan County, New Mexieo, within pinyon-juniper woodland and desert serub eommunities (Dick-Peddie 1993). It is also found in eraeks and fissures in the sandstone and at the base of gentle sliekroek inclines (Knight and Housc 1986). The plants grow on level or near-level sites with full exposure to the sun. Runoff from the surrounding bare rock surfaces tends to concentrate moisture in the ereviees and depressions that the plants occupy. The vegetation at the population sites is very sparse, and includes small trees and shrubs, scattered forbs, and grasses. Overall eover is probably less than 5 pereent, and vegetation is largely concentrated in the sandy depressions on the bedroek. Dominant assoeiated speeies are Indian rieegrass, snakeweed, yucea, and big sagebrush (Barneby 1964). Also present are seattered small trees, ineluding single leaf ash, Utah juniper, and pinyon pine. Plants are found at elevations ranging from 5,000 to 6,000 feet. Prior to 1989, there were a total of 13 known populations, with 3 of these located on Ute Mountain Ute tribal lands in Colorado. Additional populations are on BLM, state, and Navajo Nation lands in New Mexico. Population surveys from 2007 to 2008 estimate the total population at 386 plants.

Mancos milk-vetch is a long-lived, slow-growing perennial herb. The leaves and buds of this species appear in the early spring, and may also occur in the fall. Flowering occurs anytime from late April to carly May, and fruit (a pod) begins to appear in late May and may last until mid-Junc. Seed dispersal begins in late June and continues on into July (Barneby 1964, New Mexico Native Plants Protection Advisory Committee 1984, USFWS 1985e, Knight and House 1986). Two native bees are the most common pollinator for the species, and the painted lady butterfly, honey bees, and other inseets are also potential pollinators. Sced dissemination agents are not definitely known, but are likely to inelude sheet erosion and perhaps rodents (USFWS 1985e, Knight and House 1986). The disjunct distribution of the speeies impedes the flow of genetic matcrial and the broad general dissemination of seeds.

Mancos milk-veteh was federally listed as endangered on June 27, 1985 (50 FR 26568). Critieal habitat has not been designated. The species is narrowly endemic to a small area, and eonsists of a very low number of plants, which increases the possibility that one catastrophie disturbance could destroy a substantial portion of the speeies (USFWS 1985e). Furthermore, plants do not tolerate disturbance well. The major serious threats to Mancos milkveteh are disturbanee and habitat destruetion. The range of the speeies ineludes an oil field, and is in the vicinity of drilling pads, oil wells, pipelines, and roads, where the possibility of future exploration and drilling is high. Disturbed areas within the speeies' habitat that resulted from the construction of transmission powerlines have not been recolonized. Plants underncath the powerlines have been driven over by either maintenance vehieles or offhighway reereational vehicles. 


\section{Knowlton's Cactus}

The primary reference for this section is:

USFWS. 2009m. Knowlton's Cactus (Pediocactus knowltonii) 5-Year Review Summary and Evaluation. U.S. Fish and Wildlife Service New Mexico Ecological Field Services Office. Albuquerque, New Mexico.

References cited in this section are internal to the above-referenced document. Full citations are included in the Bibliography.

Knowlton's cactus (Pediocactus knowltonii) occurs in pinyon-juniper communities on the Colorado plateau of northwestern New Mexico. The species is endemic to San Juan County, New Mexico. Plants grow on rolling, gravelly hills between 6,400 and 7,200 feet in elevation. The habitat is an open-spaced woodland with pinyon pine and Rocky Mountain juniper pinyon as dominants, and big sagebrush as the subdominant species (Brown 1982). The natural habitat of Knowlton's eactus is mostly confined to a single population within a 25 -acre preserve that was donated by the Public Service Company of New Mexico to The Nature Conservaney. Fewer than 50 cacti occur on adjoining BLM land within 33 feet of the boundary fence. In 2008, the population estimate was about 6,100 eacti (Sivinski 2008), about half of the 1992 population estimate of 12,000 individuals.

Knowlton's eactus is a tiny plant, with solitary or elustered stems measuring up to 2.2 inches tall and 1.2 inches in diameter. Flowering peaks in early May and fruits ripen in June and July. The species is a stem sueculent with no permanent visible leaves. Plants undergo both sexual and vegetative reproduction. The species is unusual because it initiates its flower primordia in the early autumn months, which over-winter as small buds. Flowering then oceurs from mid-April to early May. Flowers open by mid-morning and close in the late afternoon. Typically, they last 2 to 3 days. Plants fruit from late May to early June, and seeds are dispersed in mid- to late June (USFWS 1985f). The most common pollinators seen on its flowers are small native bees and most flowers produce seedfilled fruits (Robert Sivinski, personal observations, 1990 to 2008). Fruit predation by rodents (probably Peromyscus sp.) is very severe and few seeds of Knowlton's eactus are left to mature (Sivinski and MeDonald 2007).

Knowlton's cactus was federally listed as endangered on October 29, 1979 (44 FR 62244). Critical habitat has not been designated. Knowlton's cactus is one of the rarest eactus species in the United States. Since its discovery, the plant has been over-collected by botanists and cactus dealers. In recent years, collecting pressures have not been as great and some recovery has been observed. However, at the present population level, it is easily conceivable that the act of one collector could eliminate the species. The Los Pinos River Valley has excellent potential for recreational development. Although Knowlton's cactus habitat itself would not be sold for such development, the influx of people to the area could have negative effects on the eactus (Heil and Porter 1985).

\section{Zuni Fleabane}

A primary reference for this section is:

USFWS. 2007g. Zuni Fleabane (Erigeron rhizomatus) 5-Year Review: Summary and Evaluation U.S. Fish and Wildlife Service New Mexico Ecological Services Field Office. Albuquerque, New Mexico.

References cited in this section are internal to the above-referenced document. Full citations are included in the Bibliography.

Zuni fleabane (Erigeron rhizomatus) occurs in pinyon-juniper woodlands in Catron and McKinley Counties, New Mexico, and Apache County, Arizona. Zuni fleabane habitats are outcrops of coarse-textured shales on the Baca Formation in west-central New Mexico and the Chinle Formation in northwestern New Mexico and northeastern Arizona. These soils often have a strong odor of selenium and sometimes support species of seleniphytic plants. Occupied habitats range in elevation from 7,500 to 8,400 feet and in size from less than 1 acre to 260 acres. Shaley outcrops of suitable habitat are often nearly barren, but occur within and contain scattered vegetation from pinyonjuniper woodland to lower transitional forest of ponderosa pine and Douglas-fir. 
Zuni fleabane is often a rather diffusely distributed species. A dense population might contain a few hundred plants spread over several acres. The species is known to occur at 39 locations, consisting of three metapopulations. Local populations of Zuni fleabane range in number from 9 to greater than 5,000 plants and occupied habitats range in size from less than 1 acre to 260 acres (Sivinski and Lightfoot 1991, Christie 2004). Population size is positively correlated to the size of the geologic outerop providing suitable habitat, although some adjacent outerops that may appear suitable are not occupied (Christie 2004). The primary limiting factor for this species is the presence or absence of its preferred microhabitat, which is highly specific and very susceptible to disturbance. Habitat requirements include the proper substrate, at the right elevation, on a gentle slope with the right exposure, as deseribed above. However, even if all of these conditions are met, the plant might not oecur on the site.

Zuni fleabane is a long-lived herbaceous perennial that forms large rhizomatus clumps (Cronquist 1947). The plant reproduces sexually, as well as asexually by pronouneed spreading rhizomes that lead to the formation of localized clonal groups. The germination date is likely early spring, and leaves appear from late March to early April. Budding oceurs from late April through May, and flowers are produced from late May through June, with fruit noticeable between mid-June and August. Seed dispersal oeeurs from late June through August (Cronquist 1947, USFWS 1986c). This species is pollinated by a varicty of insects, and seeds are wind- and possibly animal- and/or bird-dispersed.

Zuni fleabane was federally listed as threatened on April 26, 1985 (50 FR 16680), but eritical habitat has not been designated. The chief eause of mortality for this species is surface disturbanee. This species seems to be intimately associated with formations that contain known reserves of uranium, and plants are therefore threatened by disturbanees caused by exploration, mining, transportation and processing of uranium ore (i.e., habitat destruction and heavy equipment resulting in surface disturbanee; USFWS 1986e). The soil on which the Zuni fleabane grows is a highly erodable elay that can be disturbed by such activities as trampling associated with grazing, and OHV traffic.

\section{Sacramento Prickly Poppy}

The primary reference for this section is:

Agyagos, J., A. Telles, and R. Fleteher. 2001. Biological Assessment and Evaluation: Wildland Urban Interface Fuel Treatment. Forest Service, Southwestern Region. Albuquerque, New Mexico.

Sacramento prickly poppy (Argemone pleiacantha ssp. pinnatisecta) is a robust perennial species that oceurs in canyons of the west side of the Sacramento Mountains in New Mexico. The species favors disturbed areas that are either semi-riparian or have a reliable seasonal provision of water. Thus, it appears particularly adapted to the periodic flooding of normally dry to intermittently perennial canyons. The plant is also often found at springs, and appears to be able to withstand permanently wet sites as long as the soils are well drained. Mature plants are often found in drier sites such as terraces above the normal level of flood flows. The Sacramento prickly poppy is known to oceur in seven canyon systems: Fresnal, Dry, Alamo, Mule, San Andres, Dog, and Escondido. In total, approximately 80 pereent of the species' range is on National Forest system lands, 18 pereent is on privately owned land, and the remainder is on lands administered by the BLM.

Sacramento prickly poppy is adapted to withstand some scouring by summer floods, which may encourage seed germination. However, loss of riparian vegetation in Alamo Canyon as a result of water diversion has increased the scouring intensity of flood events, rendering much of the active channel either less suitable or unsuitable for the species. Loss of the system's ability to capture fine material also makes the channels drier, reducing survivability of seedlings that do germinate. Seedlings are readily desiceated, and survival is limited to sites with higher moisture availability or to periods of above average precipitation. With the capture of most perennial flows on the west face of the Sacramento Mountains for use in the valley below, the amount of suitable habitat has been much reduced. Pipeline ROWs and roadsides provide the reduced vegetative competition and increased moisture the plant requires, and frequently serve as artificial habitat for a substantial number of plants. Once established, plants can survive for years in places that are ordinarily too dry for seedling germination and survival. 
Sacramento prickly poppy was federally listed as endangered on August 24, 1989 (54 FR 35302). Critical habitat has not been designated for this species. It is likely that most of the remaining plants occupy the extreme margins of what can be considered suitable habitat. It is not known how mueh occupied habitat was depopulated when water was developed for human use. The loss of at least seasonal flows out of the eanyon and across the bajadas of the west slope could have resulted in the loss of at least as many plants as exist today in the degraded conditions of the eanyon proper.

\section{Kuenzler Hedgehog Cactus}

Kuenzler hedgehog cactus (Echinocereus fendleri var. kuenzleri) occurs in the central highlands of New Mexico. Populations are found in Chaves, Eddy, Lincoln, and Otero Counties, on the southern side of the Capitan Mountains, on the eastern and northwestern lower sides of the Sacramento Mountains, and on the northern end of the Guadalupe Mountains. Kuenzler hedgehog eactus is normally found on gentle slopes or near the shoulders of hilltops or hillsides, at elevations from 5,800 to 6,400 feet (Fleteher 1979b). This species is a minor component of the lower fringes of pinyon-juniper woodland, a broad-ranging and stable eommunity (Fleteher 1979b, USFWS $1985 \mathrm{~g}$ ). Within the range of Kuenzler hedgehog eactus, the dominant speeies include yerba de pasmo, blue grama, plains lovegrass, Harvard's buckwheat, eggleaf silktassle, ribbed false pennyroyal, alligator juniper, oneseed juniper, trong bladderpod, little nipple cactus, pinyon pine, and mealycup sage. Current population estimates for the species range from 3,000 to over 12,000 individuals, based on extrapolation from known populations (USFWS 2005a).

Kuenzler hedgehog eactus reproduces exclusively by sexual reproduction, and is unable to reproduce vegetatively by fragmentation like other species of eactus. There are no defined germination dates for this species. It appears that it can germinate during any part of the spring, summer, or fall if sufficient rainfall is present. Budding oceurs in April, and flowering normally oecurs in early May, although the species ean flower earlier in warm, wet years. Fruits form in August, and the dispersal of seeds, which typically oceurs in September and October, is dependent on the abundance of summer rainfall. If the summer season is good, and the fall food supply for rodents is high, then seed dispersal may be prolonged. Conversely, if the summer is dry, and food supplies are low, then rodents will attack the fruit as soon as it matures. Pollinators are primarily bees, and to a lesser degree beetles and butterflies. Seed dissemination agents include rodents, wind, and water. Seeds are over 90 percent viable, and survive about 5 years (USFWS 1985g).

Kuenzler hedgehog eactus was federally listed as endangered on October 26, 1979 (44 FR 61924). Critical habitat has not been designated. It appears that there are few natural threats to the species, and that individuals protected from man-made factors die from old age. Although most of the area in which the species occurs is relatively open with little ground cover, it is believed that at one time stands of grass covered the region, which may have acted as a crucial element in eatehing seeds and hiding seedlings from herbivores. The removal of grass and forb eover from the pinyon-juniper woodland appears to be the major factor eontributing to the overall deeline of this species. However, the construction of highways throughout the region also resulted in loss of habitat. At present, the major cause of mortality is destruction by grazing, as cattle, sheep, and other grazers remove essential grass cover. The species is also sensitive to trampling associated with grazing activities. Other threats to the species include illegal collection and development.

\section{Todsen's Pennyroyal}

The primary references for this section are:

USFWS. 2001b. Todsen's Pennyroyal (Hedeoma todsenii) Revised Recovery Plan. Albuquerque, New Mexico.

and

USFWS. 2011 j. Todsen's Pennyroyal (Hedeoma todsenii) 5-Year Review: Summary and Evaluation. U.S. Fish and Wildlife Service Region 2 Ecological Services Field Office. Albuquerque, New Mexico.

References cited in this section are internal to the above-referenced documents. Full citations are included in the Bibliography. 
Todsen's pennyroyal (Hedeoma todsenii) is a rare, regionally endemic mint that oecurs only in the San Andres and Sacramento Mountains in Otero and Sierra Counties of south-central New Mexico, where it oceurs in loose gypseous-limestone soils. The speeies oecurs in the Great Basin eonifer woodland eommunity where pinyon pine and oneseed juniper are the dominant speeies (Brown and Lowe 1980). Other common associates inelude mountain mahogany, yellowleaf silktassle, wavyleaf oak, white ragweed, snakeweed, and muhly grass. The speeies grows in the shade of pinyon pines and junipers, and in woodland openings with thin grasses. Most plants are on steep (20 to 70 degree) north-facing slopes, with a surface of seree or gravelly eobble. The substrates have a thin layer of conifer litter over a mixture of limestone and finer materials. In general, these gypsum-derived soils appear to retain more moisture than other soils in similar situations (New Mexico Forestry and Researeh Conservation Division 1992).

There are 17 known loeations in the Sacramento Mountains and 15 loeations in the San Andres Mountains. All 32 known populations of this speeies occur on federal lands ineluding BLM-administered lands, Lincoln National Forest, and the White Sands Missile Range. The total number of plants is unknown, but Todsen's pennyroyal loealities range from a few thousand plants growing in patches that eover small areas of usually less than 1 acre, to localities supporting a few dozen plants. Beeause of the rhizomatous nature of the species, it is not known how many individual plants comprise each oecurrence. Although infrequently monitored, these small eolonies of plants appear to be persisting as stable populations that are free of unusual diseases or predators. No invasive, non-native plant species have been found in Todsen's pennyroyal habitats.

Todsen's pennyroyal exhibits low sexual reproduetion, with less than 20 pereent of clumps flowering per season (New Mexico Forestry and Research Conservation Division 1992). Seed set is also low. The speeies flowers from June to September, with most flowers produeed from late August to early September, concurrent with the period of highest rainfall. The flowers appear to be specialized for hummingbird pollination; however, hummingbirds only rarely visit plants (New Mexico Forestry and Research Conservation Division 1992, Ulaszek 1993). Flowers that are purposely hand-pollinated make few or no viable seeds, suggesting genetic constraints that limit sexual reproduction. Because most reproduetion is asexual through an underground rhizome, a population of this speeies can potentially oceupy all suitable habitat at a specifie locality. Although these large populations are probably able to survive droughts, floods, and other natural disasters, if a population were eradicated, the species would be unlikely to recolonize that locality because of low seed production and poor seed dispersal.

Todsen's pennyroyal was federally listed as endangered on January 19, 1981 (46 FR 5730). At the same time, two pareels of eritical habitat, each 0.6 square mile in size, were designated on the White Sands Missile Range. However, most of the populations of this speeies were discovered after eritical habitat was designated and do not oceur on eritical habitat. The relatively remote or inacessible locations of Todsen's pennyroyal afford the speeies some protection. Yet, beeause of the fragile nature of the habitat and the small size of some populations, aceidental disturbanees or ehanges in land use could destroy them. Potential threats to the species include livestock grazing, future military aetivities, mammal and inseet herbivory, and low genetic diversity. There is no information on how fire affeets Todsen's pennyroyal. The speeies would be expeeted to resprout after fire, and a potential deerease in competition for light, water, and nutrients could result in greater vigor. However, inereased erosion and reduced soil moisture could negatively affect populations.

\section{Fickeisen Plains Cactus}

The primary reference for this section is:

USFWS. 2012a. Endangered and Threatened Wildlife and Plants; 12-Month Finding for the Lemmon Fleabane; Endangered Status for the Acuña Cactus and the Fickeisen Plains Cactus and Designation of Critical Habitat; Proposed Rule. Federal Register 77(192):60509-60579.

References eited in this seetion are internal to the above-referenced document. A complete list of these references is available from the USFWS Arizona Ecological Services Field Office, Phoenix, Arizona.

The Fickeisen plains eactus (Pediocactus peeblesianus var. fickeiseniae) is a narrow endemic restrieted to exposed layers of Kaibab limestone on the Colorado Plateau. It is found only in Coeonino and Mohave Counties, Arizona. 
The range of the Fickeisen plains cactus encompasses the Arizona Strip (i.e., the area north of the Colorado River to the Arizona-Utah border) from Mainstreet Valley in Mohave County to House Rock Valley in Coconino County, along the canyon rims of the Colorado River and Little Colorado River, to the area of Gray Mountain, and along the canyon rims of Cataract Canyon on the Coconino Plateau. The majority of the populations are small, some consisting of just a few individuals. Populations are widely scattered over a broad range and separated by topography.

Plants are found in shallow, gravelly loam soils or Acolian deposits derived from limestone. Most populations occur on the margins of canyon rims, on flat terraces or benches, or on the toe of well-drained hills with less than 20 percent slope. Plants are found at elevations between 4,200 and 5,950 feet (Arizona Rare Plant Guide Committee 2001, ADFG 2011b). The habitat of the Fickeisen plains cactus is within the Plains and Great Basin grasslands and Great Basin desert scrub vegetation (Benson 1982, NatureServe 2011). Associated native plant species in these communities include sagebrush, four-wing saltbush, shadscale, black grama, bluc grama, brome, rabbitbush, Mormon tea, winterfat, broom snakeweed, James's galleta, Indian ricegrass, globemallow, and needlegrass (Brown 1994, Turner 1994, Hughes 1996b, Goodwin $2011 \mathrm{a}$, NatureServe 2011). There seems to be abundant suitable habitat that is unoccupied by the plant for reasons unknown.

The Fickcisen plains cactus is a small cactus that retracts into the soil after flowering and fruiting. Plants are coldand drought-adapted, retracting into the soil during winter (cold) and summer (dry) scasons. Plants emerge when temperatures begin to rise in the spring, and with adequate rainfall. Flowers bloom from mid-April to mid-May, opening in the mid-morning for 1 to 2 days. Fruits are produced in mid-May. Plants set seed in June. The lifespan of the species is estimated at 10 to 15 years (Phillips et al. 1982). Reproduction has not specifieally been studied, but based on other speeics in the genus, reproduction oceurs by cross pollination (Pimienta-Barrios and del Castillo 2002). Pollinators include native bees, hover flies, and bee flics.

The Fickeisen plains cactus was federally listed as endangered on October 1, 2013 (78 FR 60607). At the time of listing, the USFWS indicated that designation of critical habitat for this speeies was prudent, and is forthcoming. The primary threats to the species are due to the effects of drought and climate change, and insect predation. These threats are exacerbated at local scales by off-road excursions by cross-border violators and border patrol and law enforcement response. Species populations are likely to be impacted by non-native, invasive plants in the future.

\section{Temperate Steppe Ecoregion Division}

The Temperate Steppe Ecoregion Division includes areas with a semiarid continental climate (i.e., evaporation typically exceeds precipitation) in the Rocky Mountains and Great Plains regions. Important communities in this ecoregion division include the shortgrass and mixed grass prairies of the Great Plains, the Northwest bunchgrass prairies (also called Palouse grasslands), and evergreen and deciduous forests, woodlands, and shrublands.

\section{Western Prairie Fringed Orchid}

The primary reference for this section is:

USFWS. 1996a. Platanthera praeclara (Western Prairie Fringed Orchid) Recovery Plan. Fort Snelling, Minnesota.

References cited in this section are internal to the above-referenced document. They are included in the Bibliography.

The 2010 5-year review for the western prairic fringed orchid (USFWS 2010d) was consulted for updated information on this species.

Western prairic fringed orchid (Platanthera praeclara) is a perennial orchid of the North American tallgrass prairie that is found most often on unplowed, calcareous prairies and sedge meadows. This species may also occur at disturbed sites in successional communities, such as borrow pits, old fields, and roadside ditches (Minnesota Department of Natural Resources 1979 to present, Nebraska Games and Parks Commission 1987 to present, 
Freeman and Brooks 1989). Populations occur in six states: North Dakota, Minnesota, Iowa, Nebraska, Kansas, and Missouri.

Western prairie fringed orchid occurs in several kinds of fire- and grazing-adapted eommunities dominated by grass speeies. The tallgrass prairies in which the orehid oecurs are typieally dominated by big bluestem, little bluestem, and Indiangrass, with tufted hairgrass and switchgrass common assoeiates in wetter sites. These prairies generally support a great variety of annual and perennial forbs and grasses, with few shrubs unless fire or grazing is suppressed. The orchid generally occurs within the wetter areas of such prairies or in associated sedge meadows. Sedge meadows oeeur in seasonally hydric to wet-mesie eonditions, and are dominated by sedges and spikerushes. A variety of annual and perennial grasses and forbs also occurs in this eommunity type, with shrubs becoming inereasingly prevalent northward.

Root systems of the genus Platanthera, including western prairie fringed orchid, are tubers that regenerate during the growing season by forming a new tuber and a bud, which gives rise to vegetative shoots the following season. This asexual reproduction is the main mode of perpetuation of established populations. Vegetative shoots develop from a bud and emerge from the soil in the late spring after a period of soil warming, which usually oecurs from mid-April in the southern portion of the species' range to late May in the northern portion (Pleasants 1995). Two months of vegetative growth may pass before an inflorescence will fully develop into a flowering plant. Studies suggest that it is also common for the orehid to remain vegetative throughout the entire growing season (Sather and Smith 1994, Sieg and King 1995). Sexual reproduetion is believed to be the principal means of recruitment of new individuals into populations (Bowles 1983, Bowles and Duxbury 1986), and various sphinx moths are the likely pollinators. Plants bloom from mid-June in the southern portion of the range to late July in the northern portion. Individual flowers last up to 10 days, and infloreseences may produee flowers for up to 3 weeks.

Pollination is required for seed production, with moths thought to be the primary pollinators (USFWS 2010d). Seeds mature on the plant in eapsules and are released in early fall (Bowles and Duxbury 1986). A single capsule may produee thousands of seeds. Therefore, under ideal circumstances for germination and survivorship, the reproduetive potential of a small population could be very large. Seeds are wind-dispersed, and may also be adapted for dissemination through the soil profile by water (Bowles 1983). Growth of orchid seedlings in natural eonditions requires assoeiation with soil-inhabiting myeorrhizal fungus (Cronquist 1981; Bowles and Duxbury 1986; Currah et al. 1990). Seedling establishment may also be linked to the availability of suitable microhabitats, edaphic factors controlling soil myeorrhizae, and interspecific competition.

Habitat management, such as burning, grazing, or mowing, could have a positive or negative effect on recruitment and survivorship, depending on its frequeney, intensity, and timing. It has been suggested that flowering may be suppressed by plant litter accumulation and stimulated by fire (Bowles 1983, Bowles and Duxbury 1986). The effeet of fire on flowering is probably influeneed by the intensity and timing of the burn and weather conditions both at the time of the burn and the time of flowering.

Western prairie fringed orchid was federally listed as threatened on September 18, 1989 (54 FR 39857). Critieal habitat has not been designated. The prairie fringed orchids have declined substantially throughout their ranges as a result of conversion of most of their habitats to cropland, overgrazing, intensive hay mowing, drainage, and fire protection; these and related threats continue. Other factors threatening the species include herbieide use, poor reproduction, collection, alteration of the water regime, and competition with non-native and other invasive speeies including reed eanarygrass. 


\section{Blowout Penstemon}

The primary references for this seetion are:

USFWS. 1992c. Blowout Penstemon (Penstemon haydenii) Recovery Plan. Denver, Colorado.

and

Fertig, W. 2000. Status of Blowout Penstemon (Penstemon haydenii) in Wyoming. Prepared for the Wyoming Cooperative Fish and Wildlife Rescareh Unit, U.S. Fish and Wildlife Serviec, and Wyoming Game and Fish Department. Wyoming Natural Diversity Database, University of Wyoming. Laramie, Wyoming.

References eited in this section are internal to the above-referenced documents. Full citations have been ineluded in the Bibliography.

Blowout penstemon is a perennial herb that occurs naturally only within the Sandhills region of north-central Nebraska (Weedon et al. 1982a) and the Ferris dunes area in northwest Carbon County, eentral Wyoming. The species is restricted to sparsely vegetated, carly-sucecssional communities, in areas with shifting sands. In Nebraska, plants are found on dune blowouts, which are depressions on windward sandy slopes caused by wind erosion, where plant composition is distinetly different than that of the adjacent noneroding areas (Stubbendicck et al. 1989). Commonly associated plant species include blowout grass, lemon seurfpea, sandhill muhly, prairie sandreed, and birdegg milk-vetch. Blowout penstemon is a primary invader of blowouts, disappearing from the site onee secondary invasion of the blowout begins (Tolstead 1942; Weedon et al. 1982b; Flessncr 1988). In Wyoming, the blowout penstemon is found on blowouts and the steep, unstable slopes of active, blowout-like sand dunes. Associated species include blowout grass, thickspike wheatgrass, and lemon scurfpea. The species is dependent on continuing wind erosion, or some other souree of new blowouts. The stems of blowout penstemon root adventitiously, stabilizing the plant in shifting sands.

Blowout penstemon is a short-lived perennial, frequently occurring in large, multi-stemmed clumps containing flowering and vegetative stems. Vegetative stems are commonly up to 1 foot tall, but can sometimes reach nearly 2 feet. Plants typically flower in the second or third year (Kottas 2008), and individual plants live for 6 to 8 years (Stubbendieck et al. 1997). The number of seeds in the seedbank is typically low, due mainly to predation by small mammals at the time of seed fall (Kottas 2008). Blowout penstemon reproduces primarily by rhizomes, and naturally oecurring seedlings arc relativcly rare (Stubbendieck et al. 1983, 1984; Stubbendieck and Weedon 1984). It appears that the species is dependent on vegetative reproduction for survival. In Nebraska, plants flower from mid-May through mid- to late June, develop fruits from late May through early July, and begin dispersing seeds in late July or early August. Flowering occurs later in Wyoming, from late June to early July. The species is commonly pollinated by insects, primarily bees (Flessner and Stubbendieck 1992).

Blowout penstemon was federally listed as endangered on September 1, 1987 (52 FR 32926). Critical habitat has not been designated. The species is threatened by the natural suecession of sand-stabilizing vegetation, and the removal of sand dunes. Because the Nebraska Sandhill region is used primarily for eattle grazing, range management in the area focuses on stabilizing the sand dunes with later suceessional species. These activities result in a reduction in available blowout penstemon habitat and numbers of plants. Use of OHVs in penstemon habitat is an additional minor threat to the species.

\section{Colorado Butterfly Plant}

The primary referenee for this section is:

USFWS. 2000a. Threatened Status for the Colorado Butterfly Plant (Gaura neomexicana ssp. coloradensis) from Southeastern Wyoming, Northeentral Colorado, and Extreme Western Nebraska. Federal Register 65(202):6230262310.

References cited in this section are internal to the above-referenced document. A complete list of these references is available from the USFWS Wyoming Field Office, Cheyenne, Wyoming. 
Colorado butterfly plant (Gaura neomexicana ssp. coloradensis) is endemie to moist soils in mesie or wet meadows of floodplain areas in north eentral Colorado, extreme western Nebraska, and southeastern Wyoming. This subspeeies oeeurs primarily in habitats ereated and maintained by streams aetive within their floodplains, with vegetation that is relatively open and not overly dense or overgrown. Colonies are often found in low depressions or along bends in wide, aetive, meandering stream ehannels a short distanee upslope of the aetual ehannel. The plant requires early- to mid-sueeessional riparian habitat. It eommonly oeeurs in eommunities dominated by redtop and Kentueky bluegrass on wetter sites, and wild lieoriee, Flodman's thistle, eurlytop gumweed, and smooth seouring rush on drier sites.

Colorado butterfly plant is a perennial herb in the evening primrose family that lives vegetatively for several years before bearing fruit onee and then dying. Only a few flowers are open at any one time, and these are loeated below the rounded buds and above the hard, nutlike fruits. Nonflowering plants eonsist of a stemless, basal rosette of leaves. Colorado butterfly plant is an early sueeessional plant that is adapted to use periodieally disturbed stream ehannel sites. Historieally, flooding was probably the main eause of disturbanees in the plant's habitat, although wildfire and grazing by native herbivores also may have been important. Although flowering and fruiting stems may undergo inereased mortality beeause of these events, vegetative rosettes appear to be little affeeted (Mountain West Environmental Serviees 1985). In addition, the establishment and survival of seedlings appears to be enhaneed at sites where tall and dense vegetation has been removed by some form of disturbanee. In the absenee of oeeasional disturbanee, the plant's habitat ean beeome ehoked out by dense growth of willows, grasses, and nonnative plants.

All eurrently known populations are within a small area (17,000 aeres) in southeastern Wyoming, western Nebraska, and north-eentral Colorado. Two of the populations oeeur on F.E. Warren Air Foree Base in Cheyenne, Wyoming, and five small populations on state land (Chambers Preserve, Colorado; Oliver Reservoir State Reereation Area, Nebraska; and state sehool trust land, Wyoming). One population oeeurs on the Meadow Springs Raneh, northern Colorado (owned by City of Fort Collins). The remaining populations oeeur on privately owned lands.

Colorado butterfly plant was federally listed as threatened on Oetober 18, 2000 (65 FR 62302). On January 5, 2005 (70 FR 1940), the USFWS designated 8,486 aeres along approximately 113.1 stream miles in Laramie and Platte eounties, Wyoming; Kimball County in Nebraska; and Weld County in Colorado, as eritieal habitat. Threats inelude the indiseriminate spraying of broadleaf herbieides and the disturbanee of riparian areas that eontain native grasses, water diversions, ehannelization, and urban development.

\section{North Park Phacelia}

North Park phaeelia (Phacelia formosula) is a narrow endemie found only in the North Park valley in northern Colorado's Jaekson County. The speeies is limited to barren exposures where the Coalmont Formation forms outerops of sandy soil or ledges eontaining poekets of sandy soil. Vegetative eover is very low, and the barren outerops are contained in a matrix of sagebrush eommunities (Peterson and Wiley-Eberle 1984, Colorado Department of Wildlife 1985). The area is eonsidered rangeland. North Park phaeelia appears to prefer steep-sided ravines, although relatively flat areas support the speeies in low numbers if the soil is nearly pure sand and is nearly devoid of vegetative eover. Slopes and aspeets are variable and elevations range from 7,940 to 8,260 feet. North Park phaeelia is dominant or eo-dominant on the sites on whieh it is found. Commonly assoeiated plants inelude speeies of blazingstar, rabbitbrush, rieegrass, sandwort, buekwheat, beardtongue, rose, sagebrush, and phlox.

North Park phaeelia is a biennial herb that does not reproduee by vegetative means. Most seedlings germinate in the spring; however, a seeond reeruitment event ean oeeur in the fall, if there is enough rain. (USFWS 2011k). Flowering and fruiting oeeurs from July to August, and seeds are dispersed from July to September (Peterson and Wiley-Eberle 1984, Colorado Department of Wildlife 1985). North Park phaeelia plants ean self-pollinate, but are typieally pollinated by a variety of bees. Seed produetion is direetly dependent on the number of plants maturing in any partieular year. Sinee the speeies is a biennial or short-lived perennial, the elimate 2 years prior to any seed erop is the primary faetor influeneing seed produetion. 
North Park phacelia was federally listed as endangered on September 1, 1982 (47 FR 38540). Critical habitat has not been designated. The sandy areas in which it occurs are vulnerable to habitat destruction beeause of their extremely friable nature and very sparse vegetation eover. Cattle tend to disrupt the sand, causing plants to be uprooted, and plants are trampled by grazing animals. Off-highway vehicle usage at one of the two largest occurrences of this species has resulted in severe disturbance of the site (Wiley-Eberle 1979; Peterson and WileyEberle 1984). Road work around the known sites, eattle trampling, and OHVs have added to erosion, yet another factor causing loss of habitat and individuals. The rarity of the species itself is a threat, and some populations are so small that the gene pool is restrieted. Finally, the area of oecurrence has potential for low-grade eoal and oil and gas production. These activities, as well as seismic and geothermal exploration, may become important, should exploration and extraction become profitable in the future.

\section{Spalding's Catchfly}

The primary referenees for this section are:

USFWS. 2001c. Final Rule to List Silene spaldingii (Spalding's Catchfly) as Threatened. Federal Register 66(196):51598-51606.

and

U.S. Fish and Wildlife Service. 2007h. Recovery Plan for Silene spaldingii (Spalding's Catchfly). Portland, Oregon.

References cited in this section are internal to the above-referenced doeuments. Full citations have been included in the Bibliography.

Spalding's catchfly (Silene spaldingii) is a regional endemic found predominantly in bunchgrass grasslands and sagebrush-steppe, and oceasionally in open pine communities, in eastern Washington, northeastern Oregon, westcentral Idaho, western Montana, and barely extending into British Columbia, Canada. Occupied habitat ineludes five regions: the Palouse Grasslands in west-central Idaho and southeastern Washington; the Channeled Seablands in eastern Washington; the Blue Mountain Basins in northeastern Oregon; the Canyon Grasslands of the Snake River and its tributaries in Idaho, Oregon, and Washington; and the Intermontane Valleys of northwestern Montana. In general the species is found in open, mesic (moist) grassland communities or sagebrush-steppe eommunities. However, the species is occasionally found within open pine forests. The bunehgrass grasslands where the speeies primarily oceurs are characterized by either Idaho fescue or Idaho fescue with bluebunch wheatgrass, except in Montana where the dominant bunchgrass is rough fescue. The plant is found at elevations ranging from 1,200 to 5,300 feet, usually in fine, deep, windblown, productive soils (loess soils). Plants are generally found in swales or on northwest to northeast facing slopes where soil moisture is relatively higher.

There are currently 100 known populations of Spalding's catchfly, with two thirds of these composed of fewer than 100 individuals each. There are an additional 23 populations with at least 100 or more individuals apiece, and the 10 largest populations are each made up of more than 500 plants.

Spalding's catchfly is a long-lived perennial herb in the pink family, which ranges from 8 to 24 inches in height (Lichthardt 1997). The species does not possess rhizomes or other means of vegetative reproduction, and reproduces by seed only. Plants are typically pollinated by bumblebees, which appear to be critical to population viability (Lesica 1993).

Spalding's catchfly was federally listed as threatened on October 10, 2001 (66 FR 51597). At the time of listing, designation of critical habitat was deemed prudent, but was deferred until resources become available. Spalding's catchfly continues to be impacted by habitat loss due to human development, habitat degradation associated with adverse grazing and trampling by domestic livestock and wildlife, and invasions of aggressive non-native plants. In addition, a loss of genetic variability and the effects of inbreeding are a problem for many small, fragmented populations where genetic exchange is limited. Other impacts include changes in fire frequency and seasonality, OHV use, and herbicide spraying and drift. 


\section{Howell's Spectacular Thelypody}

The primary referenees for this seetion are:

USFWS. 1999e. Threatened Status for the Plant Thelypodium howellii ssp. spectabilis (Howell's Speetaeular Thelypody). Federal Register 64(101):28393-28403.

and

USFWS. 2010e. Howell's Speetaeular Thelypody (Thelypodium howellii ssp. spectabilis) 5-Year Review: Summary and Evaluation U.S. Fish and Wildlife Serviee Oregon Fish and Wildlife Offiee. Portland, Oregon.

Referenees eited in this seetion are internal to the above-refereneed doeuments. Full eitations are ineluded in the Bibliography.

Howell's speetaeular thelypody (Thelypodium howellii ssp. spectabilis) oeeurs in moist, alkaline meadow habitats at approximately 3,000 feet to 3,500 feet elevation in northeastern Oregon. The plant is eurrently known from 11 sites (five populations) ranging in size from 0.03 to 41 aeres in the Baker-Powder River Valley in Baker and Union eounties. All of the known oeeurrenees of this subspeeies are on private land. The total oeeupied habitat for this subspeeies is approximately 100 aeres, and its range lies entirely within a 13-mile radius of Haines, Oregon. Howell's speetaeular thelypody usually grows in valley bottoms around woody shrubs that dominate the habitat on the knolls, and along the edge of wet meadow habitat between the knolls. Assoeiated speeies inelude greasewood, alkali saltgrass, giant wild rye, alkali eordgrass, and alkali bluegrass (Kagan 1986). Soils are pluvial-deposited alkaline elays mixed with reeent alluvial silts, and are moderately well-drained.

Howell's speetaeular thelypody is an herbaeeous biennial that reaehes a height of approximately 2 feet, with branehes arising from near the base of the stem. Flowers are purple and borne on short stalks, and fruits are long, slender pods (Greenleaf 1980, Kagan 1986). The taxon may be dependent on periodie flooding, sinee it appears to rapidly eolonize areas adjaeent to streams that have flooded (Kagan 1986). In addition, this taxon does not eompete well with eneroaehing weedy vegetation sueh as teasel (Davis and Youtie 1995).

Howell's speetaeular thelypody was listed as threatened on May 26, 1999 (64 FR 28393). Critieal habitat has not been designated. Faetors that threaten this taxon inelude habitat destruetion and fragmentation eaused by agrieultural and urban development, grazing by domestie livestoek, eompetition from non-native vegetation, and alteration of wetland hydrology.

\section{McFarlane's Four-o'clock}

The primary referenee for this seetion is:

USFWS. 1996b. Reelassifieation of Mirabilis Macfarlanei (MaeFarlane's Four-o'eloek) from Endangered to Threatened Status. Federal Register 61(52):10693-10697.

Referenees eited in this seetion are internal to the above-refereneed doeument. A eomplete list of these referenees is available from the USFWS Snake River Basin Offiee, Boise, Idaho.

The 2009 5-year review for the MaeFarlane's four-o'eloek (USFWS 2009n) was eonsulted for updated information on this speeies.

MaeFarlane's four-o'eloek (Mirabilis macfarlanei) is found on talus slopes in eanyonland eorridors where the elimate is regionally warm and dry, and where preeipitation oeeurs mostly during the period from winter to spring. It ean be found in three disjunet areas in Oregon and Idaho that are assoeiated with the Snake, Salmon, and Imnaha Rivers (USFWS 2009n). The speeies oeeurs as seattered plants on open, steep (50 pereent) slopes of sandy soils, whieh generally have a west to southeast aspeet. Talus roek underlies the soil in whieh the plants are rooted. Although a variety of soils support this plant throughout its range, the more eommon sandy soils are quite suseeptible to displaeement by wind and water erosion. 
The plant community in which MacFarlane's four-o'clock oceurs is a transition zone between bluebunch wheatgrass-Sandberg bluegrass and smooth sumac-bluebunch wheatgrass, consisting of bluebunch wheatgrass, downy brome, sand dropseed, scorpion weed, desert parsley, hackberry, smooth sumac, yarrow, and rabbit bush (Franklin and Dyrness 1973).

One geographic unit of MacFarlane's four-o'clock includes approximately 25 acres along 6 miles of Hells Canyon on the banks and canyonland slopes above the Snake River in Idaho County, Idaho, and Wallowa County, Oregon. The second geographic unit includes approximately 68 acres along 18 miles of banks and canyonland slopes above the Salmon River in Idaho County, Idaho. The third geographic unit includes about 70 acres of habitat along 3 miles of canyonland slopes over the Imnaha River in Wallowa County, Oregon. The species is known from nine occurrenees in Idaho and four in Oregon.

MacFarlane's four-o'clock is a perennial plant with a stout, deep-seated taproot. Flowering occurs from early May to early June, and peaks in mid-May.

MacFarlane's four-o'clock was federally listed as endangered on October 26, 1979 (44 FR 61912). After additional populations were discovered, the plant was reclassified as threatened on March 15, 1996 (61 FR I0693). Critical habitat has not been designated. Threats to the species include lack of plant recruitment in some areas, insect predation, invasions of non-native plants (often as a result of grazing practices), and the small size of some populations. On federal land, habitat plans are in place and populations are monitored. On non-federal lands, populations are managed and conserved (USFWS 2009n).

\section{Osterhout Milk-vetch}

The primary reference for this section is:

USFWS. 1992d. Osterhout Milk-veteh and Penland Beardtongue Recovery Plan. Denver, Colorado.

References cited in this section are internal to the above-referenced document. They are included in the Bibliography.

Osterhout milk-vetch (Astragalus osterhoutii) is endemic to Middle Park, a high-elevation sagebrush park located near Kremmling, Colorado, in Grand County. Middle Park is located at an elevation of approximately 7,500 feet and surrounded by various ranges of the Rocky Mountains. Osterhout milk-vetch occurs in seattered colonies over a 15-mile range, from 3 miles east of Troublesome Creek to a few miles west of Muddy Creek. A majority of plants oceur on land administered by the BLM, although important colonies also oceur on privately owned land.

Plants are restricted to badlands of shale and siltstone sediments. These badlands are characterized by open, grassy vegetation with scattered shrubs of big sagebrush, rabbitbrushes, bitterbrush, horsebrush, winterfat, snowberry, and/or mountain mahogany. Common perennials include lupine and wild buckwheat. Where shrubs-particularly big sagebrush-have increased in density, resulting in a more closed shrubland vegetation type, Osterhout milkveteh is reduced in density. This species shows evidence of light grazing, and can be found on old road cuts and fills, indicating some tolerance for disturbance (Bio-West, Inc. 1989).

Osterhout milk-vetch has white flowers and long, pendulous fruits. Flowers are pollinated by bees.

Osterhout milk-vetch was federally listed as endangered on July 13, 1989 (54 FR 29658). Critical habitat has not been designated. Osterhout milk-vetch is a naturally rare species, limited to the small existing area of available habitat in the desert badlands. In addition, it is disjunct 150 miles from its nearest relatives; expansion and migration to potentially suitable habitats elsewhere is blocked by the high mountains surrounding Middle Park. Threats to the Osterhout milk-vetch include water projects along Muddy Creek, grazing, and oil and gas exploration and development. In addition, the density of Osterhout milk-vetch has been observed to be lower in big sagebrush stands than in the adjacent open benchlands where it normally grows. It may be that the past grazing history has caused an increase in big sagebrush density with a resultant increase in competition for soil moisture. 
Osterhout milk-vetch may then be outcompeted and populations reduced in numbers or lost entirely where big sagebrush dominates.

\section{Penland Beardtongue}

The primary reference for this seetion is:

USFWS. 1992d. Osterhout Milk-veteh and Penland Beardtongue Recovery Plan. Denver, Colorado.

References eited in this seetion are internal to the above-refereneed document. They are included in the Bibliography.

Penland beardtongue (Penstemon penlandii), like the Osterhout milk-vetch discussed in the previous species account, is endemic to Middle Park, Colorado, in Grand County. Penland beardtongue is rarer than the Osterhout milk-vetch, and is only known to oceur along Troublesome Creek. A majority of plants oceur on land administered by the BLM, although important colonies of the species also oceur on privately owned land. Penland beardtongue is limited to siltstone sediments in badlands. These badlands where these species grow are characterized by open, grassy vegetation with seattered shrubs of big sagebrush, rabbitbrushes, bitterbrush, horsebrush, winterfat, snowberry, and/or mountain mahogany. Common perennials include lupine and wild buckwheat.

Little is known about the reproductive biology of Penland beardtongue, except that it must be visited by animals (including several native bee species) to reproduce sexually.

Penland beardtongue was federally listed as endangered on July 13, 1989 (54 FR 29658). Critical habitat has not been designated. The Pendland beardtongue, like the Osterhout milk-veteh, is a naturally rare species, limited to the small existing area of available habitat in the desert badlands. It is also disjunet 150 miles from its nearest relatives, and expansion and migration to potentially suitable habitats elsewhere is blocked by the high mountains surrounding Middle Park. Threats to the species include water projects along Muddy Creek, grazing, and oil and gas exploration and development.

\section{Penland Alpine Fen Mustard}

The primary reference for this section is:

USFWS. 1993d. The Plant Eutrema penlandii (Penland Alpine Fen Mustard) Determined to be a Threatened Species. Federal Register 58(143):40539-40547.

References cited in this section are internal to the above-referenced document. They are included in the Bibliography.

Penland alpine fen mustard (Eutrema penlandii) oceurs in alpine tundras of Colorado, where small populations of the plant are distributed in a 25 -mile stretch of the Continental Divide. The speeies is habitat-speeifie, growing only in oligotrophic (nutrient deficient), rheotrophic (groundwater fed) alpine marshes (Weber and Shushan 1955). It grows in a macroclimate of long, cold, wet winters and cool, windy summers, and a microclimate of relatively protected, wet, springy bogs (Johnston et al. 1981). Major components of its microenvironment inelude mosscovered peat fens, perennial subirrigation, and high elevations (above 12,150 feet).

The peat mats on which the alpine fen mustard grows form on small, flat to gently sloping benehes in steep-walled, rounded glacial valleys. Water required for the development and sustenance of these peat mats comes from snowfields that persist through the summer. Conditions for maintaining these persistent snowfields exist along the east-west trending portion of the Continental Divide, where the plant is found on slopes (Sehwendinger et al. 1991). The alpine fen mustard is found on deep organic soils in moist areas that are usually adjacent to elear running water from snowmelt. Plant emergence at a site appears to be dependent on the availability and timing of sufficient water to continuously moisten the mosses in which the plants are rooted, but not so mueh water as to flood them. 
Penland alpine fen mustard is a small, herbaceous, perennial plant that grows up to about 3 inches in height. Clusters of small, white flowers grow atop the plants' stems. A plant of the Colorado alpine tundra, the alpine fen mustard grows in a harsh environment, with a growing season that may only last 70 days per year (Colorado Native Plant Society 1989). In addition, freezing and thawing soil, drying winds, and windblown snow and ice crystals diminish plant productivity (Zwinger and Williard 1972).

Penland alpine fen mustard was federally listed as threatened on July 28, 1993 (58 FR 40539). Critical habitat has not been designated for the species. The wetland habitat in which the species occurs is fragile, and sensitive to watershed alterations that divert flows of surface water. Direct impacts to plants and habitats occur from mining, and from OHV use and other forms of recreation. In addition, the few small populations of the species on small areas of specialized habitat make it particularly vulnerable to human disturbances as well as random environmental occurrences.

\section{Pagosa Skyrocket}

The primary reference for this section is:

USFWS. 2011e. Endangered and Threatened Wildlife and Plants; Determination of Endangered Status for Ipomopsis polyantha (Pagosa Skyrocket) and Threatened Status for Penstemon debilis (Parachute Beardtongue) and Phacelia submutica (DeBeque Phacelia). Federal Register 76(144):45054-45075.

References cited in this section are internal to the above-referenced document. A complete list of these references is available from the Western Colorado Ecological Services Field Office, Grand Junetion, Colorado.

The Pagosa skyrocket (Ipomopsis polyantha) is a rare plant endemic to shale outcrops around the town of Pagosa Springs in Archuleta County, Colorado. The two known oceurrences of this species are within about 13 miles of each other, and collectively occupy about 388 acres of habitat within a range that includes approximately 6.5 square miles. Approximately 2.5 percent of the occupied habitat is on BLM-administered land.

The Pagosa skyrocket occurs on Pagosa-Winifred soils derived from Mancos shale, which have a nearly neutral to slightly alkaline pH. Plants oecur at elevations of 6,750 to 7,775 feet (USFWS 2011e), in diseontinuous colonies as a pioneer species in open shale, or as a climax species along the edge of forested areas (ponderosa pine, mixed ponderosa pine and Rocky mountain juniper, or mixed Utah juniper and Gambel oak). Currently, the Pagosa skyrocket is mostly found on sites that are infrequently disturbed by grazing, such as road ROWs that are fenced, lightly grazed pastures, and undeveloped lots (Anderson 2004). The species has been observed successfully colonizing barren Mancos shale.

The Pagosa skyrocket is a biennial species that shows great differences in plant numbers from year to year. Seeds of this species germinate rapidly in Maneos shale soil (Collins 1995), forming rosettes that produce flowering stalks during the next growing season, or that persist for a year or more until conditions are right for flowering. Plants produce abundant fruits and seeds, but have no known mechanism for long-distance dispersal. After the seeds mature, the plants dry up and die. It is not known how long seeds remain viable. Pollination by bees is the most common means of reproduction.

The Pagosa skyrocket was federally listed as endangered on July 27, 2011 (76 FR 45054). On August 13, 2012, the USFWS designated 9,641 acres as critical habitat for the species (77 FR 48367). Threats to the species include destruction of plants and habitat due to commercial, residential, municipal, and agricultural property development, and associated new utility installations and access roads; heavy livestock use; inadequacy of existing regulatory mechanisms; fragmented habitat; and prolonged drought conditions. Ongoing and planned land development overlaps 95 percent of the species' known habitat, and therefore puts the species in danger of extinction.

\section{Mediterranean Ecoregion Division}

The Mediterranean Ecoregion Division includes most of California and a portion of southern Oregon. The Mediterranean climate in this region is characterized by dry, hot summers and wet, mild winters. Chaparral, a fire- 
and drought-adapted vegetation type that is comprised of hard-leaved evergreen trees and shrubs, is endemic to the Mediterranean Ecoregion Division. A number of TEP plant species occur in chaparral communities. Chaparral eommunities, which have been altered by fire suppression, often pose a threat to encroaching human populations because of the large amount of highly flammable fuels found in these communities. Vernal pools, seasonal ponds that fill during winter rains and dry up during the summer drought, also provide habitat for TEP species in this ecorcgion. Other communities include grasslands that once supported perennial native grasses but now support primarily non-native annuals, sagebrush, coastal scrub, and the forests and woodlands of the Sierra Nevada Mountains and surrounding foothills.

Mediterranean climates have numerous rare, locally endemic species. For this reason, more TEP plant species with the potential to be affected by BLM treatment activities occur in the Mediterranean Ecoregion Division than in any other division.

\section{Gentner's Fritillary}

The primary reference for this section is:

USFWS. 1999d. Final Endangered Status for the Plant Fritillaria gentneri (Gentner's fritillary). Federal Register 64(237):69195-69203.

References cited in this section are internal to the above-referenced document. A complete list of these references is available from the USFWS Oregon Fish and Wildlife Officc, Portland, Oregon.

Gentner's fritillary (Fritillaria gentneri), an herb of the lily family, is restricted to southwestern Oregon, where it is known only from scattered localitics in the Rogue and Illinois River drainages in Josephine and Jackson Counties. The species occurs in dry, open woodlands of fir or oak at elevations below approximately 4,450 feet. The species is highly localized within a 30-mile radius of Jacksonville Cemetery, and 73 pereent of the known plants are in a central cluster located within a 7 -mile radius of the cemetery. The remaining plants occur as single individuals or occasional clusters of individuals sparsely distributed across the landscape. Plants occur on lands managed by the Medford District of the BLM, the Oregon State Department of Transportation, Southern Oregon University, and the City of Jacksonville, as well as on privately owned land (about half of the plant's current distribution).

Gentner's fritillary is found in three habitats-oak woodlands dominated by Oregon white oak; mixed hardwood forest dominated by California black oak, Oregon white oak, and madronc; and coniferous forcsts dominated by madrone and Douglas-fir. Gentner's fritillary typically grows in or on the edge of open woodlands, with Oregon white oak and madrone as the most common overstory plants. The species can also grow in open chaparral/grassland habitat, which is often found within or adjacent to the mixed hardwood forest type, but always where some wind or sun protection is provided by other shrubs. It does not grow on extremely droughty sites. For unknown reasons, a substantial amount of potential habitat within the species range is unoccupied. Gentner's fritillary often grows in places that have experienced human disturbance and eventually bccame revegetated (e.g., old road cuts, alongside trails, bulldozer routes, old mounds left from past mining or other earth-moving activities; Rolle 1988). The species seems to require some infrequent, but regular level of disturbance such as the historic pattern of fire frequency in the Rogue and Illinois River Valleys. It is not an early colonizer of these sites but eventually takes advantage of the opening or edge effect created. It appears to be a mid-successional species in that it cstablishes after other plants have colonized a disturbed area, but before taller vegetation becomes established and shades it out.

Gentner's fritillary is a perennial species that reproduces asexually by bulblets. The bulblets break off and form new plants. The flowering season for this specics is April-June. However, many of the plants remain dormant for several years and do not produce above-ground stems and flowers. Even though some Gentner's fritillary plants may form fruits and seeds if pollinated, no good evidence exists that the secds produced are fertile or viable (Guerrant 1997). Hummingbirds or bumblebees are presumed to be the primary pollinators (Guerrant 1998). It is possible that Gentner's fritillary is sterile and that the plant is largely reproducing asexually; however, sexual reproduction of the plant needs to be better documented. 
Gentner's fritillary was federally listed as endangered on Deeember 10, 1999 (64 FR 69195). Critieal habitat has not been designated. The speeies is threatened by residential development, agrieultural aetivities, logging, road and trail improvement, OHV use, eolleetion for gardens, and problems assoeiated with small population size. In addition, all three of the habitats in whieh Gentner's fritillary oeeurs are threatened by urban and agrieultural development and fire suppression.

\section{Ione Manzanita and Ione Buckwheat}

The primary referenees for this seetion are:

USFWS. 1999e. Determination of Endangered Status for the Plant Eriogonum apricum (Inelusive of vars. apricum and prostratum; Ione Buekwheat) and Threatened Status for the Plant Arctostaphylos myrtifolia (Ione Manzanita). Federal Register 64(101):28403-28413.

and

USFWS. 2010f. Eriogonum apricum (Inelusive of vars. apricum and prostratum) (Ione Buekwheat $=1$ rish Hill Buekwheat) Arctostaplyylos myrtifolia (Ione Manzanita) 5-Year Review: Summary and Evaluation. Saeramento Fish and Wildlife Offiee. Saeramento, California.

Referenees eited in this seetion are internal to the above-refereneed doeuments. A eomplete list of the Federal Register referenees is available from the USFWS Saeramento Field Office, Saeramento, California. Referenees from the 5-year review are ineluded in the Bibliography.

Ione manzanita (Arctostaphylos myrtifolia) is restrieted to the Ione Formation in Amador and Calaveras Counties, along an approximate 19.5-mile streteh, with the eentral distribution being the large exposure of the Ione Formation in western Amador County around the City of Ione in the eentral Sierra Nevada foothills of California. Most populations oeeur at elevations between 295 and 918 feet. The speeies oceurs primarily on lone soils, whieh are eoarse-textured and exhibit soil properties typieal of those produeed under tropieal elimates, sueh as high aeidity, high aluminum eontent, and low fertility (Singer 1978). In addition, these soils and their assoeiated sedimentary deposits eontain large amounts of eommereially valuable minerals (quartz sands, kaolinitie elays, lignite [low-grade eoal], and possible gold-bearing gravels; Chapman and Bishop 1975).

The vegetation in the lone area is distinetive enough to reeeive a speeial designation as "Ione ehaparral" (Holland 1986). This plant eommunity type has been eharaeterized as an eeologieal island, a relatively small area with elimatic and eeologieal features that differ substantially from the surrounding areas (Stebbins 1993). The entire extent of this eommunity type is estimated at 6,002 aeres (California Natural Diversity Database 1997). Beeause they oeeur only on very aeidie, nutrient-poor, eoarse soils, Ione ehaparral eommunities are eomprised of lowgrowing, heath-like shrubs and seattered herbs that are tolerant of these growing eonditions (Holland 1986). The dominant shrub is Ione manzanita, whieh is narrowly endemie to the area. A reeent mapping effort to deteet the extent of lone manzanita from high-resolution aerial photographs and field verifieation identified 1,196 acres of Ione manzanita in Amador and Calaveras Counties (Holzman and Meyer 2004; Meyer 2005).

Ione manzanita is an evergreen shrub of the heath family with a low and spreading appearanee that typieally attains a height of less than 3.9 feet. The shrub's bark is red, smooth, and waxy with narrowly elliptie olive green leaves 0.2 to 0.6 inches long. The white or pinkish urn-shaped flowers appear from January to February with fruit that is more or less eylindrical. The species depends almost entirely on periodic fire events to promote seed germination (Wood and Parker 1988). As the dominant and characteristic species of Ione chaparral, lone manzanita occurs in pure stands on outcrops of the lone Formation. The species also occurs in ecotonal habitat with surrounding taller chaparral types, but does not persist if it is shaded (Woodward 1994). Populations range in elevation from 190 to 1,900 feet, with the largest populations occurring at elevations between 280 and 900 feet (Wood and Parker 1988). It is estimated that lone manzanita occurs in about 100 individual areas that cover a total of about 1,000 acres (Woodward 1994). Ione manzanita occurs primarily on private or non-federal lands. However, three occurrences are at least partially on public lands, including one occurrence within the Ione Manzanita ACEC. Populations also 
oceur on the state-owned Aprieum Hill Eeologieal Reserve managed by the California Department of Fish and Game (Wood and Parker 1988).

Ione manzanita was federally listed as threatened on May 26, 1999 (64 FR 28403). Critieal habitat has not been designated. Faetors that threaten populations of Ione manzanita inelude mining, elearing of vegetation for agrieulture and fire proteetion, habitat fragmentation, residential and eommereial development, ehanges in fire frequeney, and ongoing erosion (Bollinger 1994, Wood 1994, California Natural Diversity Database 1997). Disease also appears to be a major faetor in the deelining abundanee and health of Ione manzanita. It is estimated that over 300 aeres of Ione manzanita have been lost sinee 1980 to diseases whieh are responsible for diebaek and mortality of this speeies (USFWS 2005b).

Ione buekwheat (Eriogonum apricum), like Ione manzanita deseribed above, is found in Ione ehaparral eommunities of the eentral Sicrra Nevada foothills of California, at elevations between 295 and 918 feet. The entire extent of Ione ehaparral is estimated at 6,002 aeres (California Natural Diversity Database 1997). Beeause they oeeur only on very aeidie, nutrient-poor, eoarse soils, Ione ehaparral eommunities are eomprised of low-growing, heath-like shrubs and seattered herbs that are tolerant of these growing eonditions (Holland 1986). The dominant shrub is Ione manzanita, whieh is narrowly endemie to the area.

There are two varieties of lone buekwheat that oeeur in Ione ehaparral: Eriogonum apricum var. apricum and E. apricum var. prostratum. Both varieties are perennial herbs in the buekwheat family. Currently ninc oeeurrenees of Eriogonum apricum var. apricum and two of E. apricum var. prostratum are still believed to be extant (California Natural Diversity Database 2008) and together represent seven distinet population eenters (Holzman and Meyer 2004, Meyer 2005). E. apricum var. prostratum is eurrently believed to have a patehy distribution in an area of about 10 aeres at Irish Hill, and, more extensively, on possibly 25 aeres north of Irish Hill in the area known as the Paeifie Clay Property. Eriogonum apricum ean be found in barren surfaees of the Ione Formation. The plants sometimes eolonize disturbed sites, sueh as elay pits, spoil piles, elay stoekpiles, and abandoned roads, at times growing on near-vertieal walls of almost pure elay. Often little, if any, other vegetation is present within the Ione buekwheat oeeurrenees (Myatt 1970). Ione manzanita is a eommon assoeiate, but where dense stands of Ione manzanita or other manzanitas oeeur, Ione buekwheat is usually absent.

Ione buekwheat is a perennial herb in the buekwheat family (Polygonaecae). E. apricum var. apricum is smooth and grows upright to 3 to 8 inehes tall. Its leaves are basal, round to oval, 0.1 to 0.4 inehes wide and it flowers from July to Oetober. The outer flowers are white with reddish midribs. E. apricum var. prostratum has smaller leaves, prostrate infloreseenees and an earlier flowering time, typieally June and July. In their natural environment, the two varieties of Ione buekwheat generally do not eo-oeeur. Both varieties of Ione buekwheat are prolifie seeders. Sinee the fruit of Ione buekwheat drops from the plant along with the dried floral parts, this allows for limited seed dispersion via floatation on surfaee water runoff (Myatt 1987).

Both varieties of Ione buekwheat were federally listed as endangered on May 26, 1999 (64 FR 28403). Critieal habitat has not been designated for either speeies. Ione buekwheat is threatened by mining, elearing of vegetation for agrieulture and for fire protection, habitat fragmentation, inereased residential development, and erosion.

\section{Stebbins' Morning-glory}

The primary referenee for this seetion is:

USFWS. 1996e. Determination of Endangered Status for Four Plants and Threatened Status for One Plant from the Central Sierran Foothills of California. Federal Register 61(203):54346-54358.

Referenees eited in this seetion are internal to the above-refereneed doeument. A eomplete list of these referenees is available from the USFWS Saeramento Field Offiee, Saeramento, California.

Stebbins' morning-glory (Calystegia stebbinsii) oeeurs in ehaparral in western El Dorado County, California. The Pine Hill intrusion, where the speeies found, is an area of approximately 25,700 aeres that ranges in elevation from 
453 to 2,060 feet. In addition, Stebbins' morning-glory has a few known isolated occurrenees in El Dorado, Nevada, and/or Tuolumne counties, California.

Stebbins' morning-glory is a leafy perennial herb in the morning-glory family with stems that range up to 3.3 feet in length and generally lie flat on the ground. Flowers appear on stalks in May through June, and the fruit is a slender capsule. Most oceurrences of this species are discontinuously seattered within two population eenters in the northern and southern portions of the Pine Hill intrusion. In EI Dorado County, the species is associated with chaparral on gabbro-derived soils. In Nevada County it oceurs on serpentine soils. Gabbro-derived soils originate from mafic rocks (gabbrodiorite) that are mildly acidic, are rich in iron and magnesium, and often contain other heavy metals such as chromium (Wilson 1986). Serpentine-derived soils are formed through a similar process, but are derived from ultramafic rocks (e.g., serpentinite, dunite, and peridotite). They tend to have high concentrations of magnesium, chromium, and nickel, and low concentrations of calcium, nitrogen, potassium, and phosphorus (Kruckeberg 1984). Stebbins' morning-glory occurs primarily on privately owned land, although the BLM administers land harboring some occurrences. Development has extirpated at least one-third of the known oceurrenees (California Department of Fish and Game 1990).

Stebbins' morning-glory was federally listed as endangered on October 18, 1996 (61 FR 54346). Critical habitat has not been designated for this speeies. Loss and fragmentation of habitat, and alteration of natural ecosystem processes have resulted from residential and eommercial development in the Pine Hill intrusion area. Housing and commercial development, road maintenanee, grading, change in fire frequency, unauthorized dumping, OHV use, overgrazing practices, herbicide spraying, mining, competition from invasive, non-native vegetation, and other human-caused conditions threaten the remaining occurrences of these plants. As Stebbin's morning-glory oceurs within a fire-adapted plant community, changes in fire frequency have altered natural proeesses. Historically, fire occurred in chaparral on the average of 3 to 5 times every 100 years (Boyd 1985). Fire is important for seed germination and seedling reestablishment by eliminating competition and shading, as well as replenishing nutrients to the soil. Without periodic fires, ehaparral species either do not reproduce by seed or may become shaded by other plants.

\section{Pine Hill Ceanothus}

The primary referenees for this section are:

USFWS. 1996c. Determination of Endangered Status for Four Plants and Threatened Status for One Plant from the Central Sierran Foothills of California. Federal Register 61(203):54346-54358.

and

USFWS 2002b. Recovery Plan for Gabbro Soil Plants of the Central Sierra Nevada Foothills. Portland, Oregon.

References cited in this seetion are internal to federal register listing document. A complete list of these referenees is available from the USFWS Sacramento Field Office, Sacramento, California.

Pine Hill ceanothus (Ceanothus roderickii) is another species of the Pine Hill intrusion, where it is found in chaparral communities. This species is restricted to gabbro-derived soil in openings in chaparral or, more infrequently, on previously disturbed sites within chaparral (Wilson 1986). The species is restricted to one localized area of approximately 10 known extant occurrences discontinuously scattered in the Pine Hill intrusion (California Natural Diversity Database 1996). Pine Hill ceanothus occurs primarily on private land. The BLM administers part of one site and the California Department of Forestry administers another site. Residential and commercial development, OHV use, road-widening, changes in fire frequency, and other human-caused conditions are responsible for the decline of this species.

Pine Hill ceanothus is a prostrate evergreen shrub of the buckthorn family that generally grows to about 10 feet in diameter. The branches radiate from a central axis, and root when they come into contact with the ground. Small whitish flowers tinged with blue appear from May through June, and the fruit is a globe-shaped capsule. It does not resprout from its crown after a fire as do most chaparral shrub species, and therefore depends on re-establishment 
from seeds after a fire. Without fire, germination is low. The pollination of Pine Hill ceanothus is primarily by inseets from the orders Diptera (flies and gnats) and Hymenoptera (bees and wasps; USFWS 2002b).

Pine Hill ceanothus was federally listed as endangered on October 18, 1996 (61 FR 54346). Critical habitat has not been designated. Loss and fragmentation of habitat, and alteration of natural eeosystem processes have resulted from residential and commercial development in the Pine Hill intrusion area. Housing and eommercial development, road maintenance, grading, change in fire frequency, unauthorized dumping, OHV use, overgrazing practices, herbicide spraying, mining, competition from invasive, non-native vegetation, and other human-eaused conditions threaten the remaining occurrences of these plants. Pine Hill ceanothus oeeurs within a fire-adapted plant community, where ehanges in fire frequency have altered natural processes. Historically, fire oceurred in ehaparral on the average of 3 to 5 times every 100 years (Boyd 1985). Fire is important for seed germination and seedling reestablishment by eliminating eompetition and shading, as well as replenishing nutrients to the soil. Without periodic fires, chaparral species either do not reproduce by seed or may become shaded by other plants.

\section{Pine Hill Flannelbush}

The primary referenee for this section is:

USFWS. 1996e. Determination of Endangered Status for Four Plants and Threatened Status for One Plant from the Central Sierran Foothills of California. Federal Register 61(203):54346-54358.

References eited in this section are internal to the above-referenced document. A complete list of these referenees is available from the USFWS Sacramento Field Office, Sacramento, California.

Pine Hill flannelbush (Fremontodendron californicum ssp. decumbens) is another species of the Pine Hill intrusion, where it is found in the transition area between chaparral and oak woodland. The taxon occurs on scattered roeky outcrops either in chaparral or in the ecotone between woodland and chaparral. It is only known from one localized area near Pine Hill in western El Dorado County, seattered within an area of approximately 5,000 acres. It occurs primarily on private land, but one site is on BLM-administered land, and the California Department of Forestry and California Department of Fish and Game administers another site.

Pine Hill flannelbush is a branched spreading shrub that grows up to 4 feet tall. This subspeeies blooms from late April to early July, bearing showy light-orange to reddish-brown flowers. Its fruit is a eapsule. Seeds are dispersed by ants (Boyd 1996), and the plant depends on fire to promote seed germination.

Pine Hill flannelbush was federally listed as endangered on October 18, 1996 (61 FR 54346). Critical habitat has not been designated. Loss and fragmentation of habitat, and alteration of natural ecosystem processes have resulted from residential and commercial development in the Pine Hill intrusion area. Housing and eommereial development, road maintenance, grading, change in fire frequency, unauthorized dumping, OHV use, overgrazing praetices, herbieide spraying, mining, competition from invasive, non-native vegetation, and other human-eaused conditions threaten the remaining oeeurrenees of these plants. Pine Hill flannelbush occurs within a fire-adapted plant community, where changes in fire frequency have altered natural processes. Historically, fire occurred in ehaparral on the average of 3 to 5 times every 100 years (Boyd 1985). Fire is important for seed germination and seedling reestablishment by eliminating competition and shading, as well as replenishing nutrients to the soil. Without periodic fires, chaparral species either do not reproduce by seed or may become shaded by other plants.

\section{El Dorado Bedstraw}

The primary reference for this seetion is:

USFWS. 1996c. Determination of Endangered Status for Four Plants and Threatened Status for One Plant from the Central Sierran Foothills of California. Federal Register 61(203):54346-54358.

Referenees cited in this section are internal to the above-referenced document. A complete list of these references is available from the USFWS Sacramento Field Office, Sacramento, California. 
El Dorado bedstraw (Galium californicum ssp. sierrae) is another species of the Pinc Hill intrusion, where it occurs in oak woodland habitat. The taxon is restricted to Pinc Hill and the surrounding ridges to the west (Baad and Hanna 1987). El Dorado bedstraw is a perennial herb that flowers in May and June. It grows in oak woodland areas, including sites with ponderosa pine and gray pine (Wilson 1986). El Dorado bedstraw occurs primarily on privately-owned land, although the BLM administers the land where at least one population occurs, and the California Department of Forestry and California Department of Fish and Game administer onc site as well.

El Dorado bedstraw was federally listed as endangered on October 18, 1996 (61 FR 54346). Critical habitat has not been designated. Loss and fragmentation of habitat, and alteration of natural ecosystcm processes have resulted from residential and commercial development in the Pine Hill intrusion area. Housing and commercial devclopment, road maintenance, grading, change in fire frequency, unauthorized dumping, OHV use, overgrazing practices, herbicide spraying, mining, competition from invasive, non-native vegetation, and other human-caused conditions threaten the remaining occurrences of these plants. Oak woodlands are a firc-adapted plant community, where changes in fire frequency have altered natural processes. Without periodic fires, El Dorado bedstraw may become shaded by other plants.

\section{Layne's Butterweed}

The primary reference for this section is:

USFWS. 1996c. Determination of Endangered Status for Four Plants and Threatencd Status for One Plant from the Central Sierran Foothills of California. Federal Register 61(203):54346-54358.

References cited in this section arc internal to the above-referenced document. A complete list of these references is available from the USFWS Sacramento Field Office, Sacramento, California.

Layne's butterweed (Senecio layneae) is another species of the Pinc Hill intrusion, where it occurs in chaparral and oak woodland habitats. The species also has a few known isolated occurrences in El Dorado, Nevada, and/or Tuolumnc Counties, California. Layne's butterweed grows in open rocky areas within chaparral plant communities, primarily on gabbro-derived soil formations and occasionally on serpentine soils. Most known sites are scattered within a 40,000-acre area in western El Dorado County that includes the Pinc Hill intrusion and adjacent areas. A few other colonies occur in the Eldorado National Forest in El Dorado County and in the BLM Red Hills Management Area in Tuolumne County (BioSystems Analysis, Inc. 1989). One sitc is on land administered by the California Department of Forestry and California Department of Fish and Game, although the species primarily occurs on privately owned land.

Layne's butterweed is a perennial herb of the aster family that sprouts from a rootstock. It flowers between April and June, each plant producing several orange-yellow flower heads 2 to 3 inches wide.

Layne's butterweed was federally listed as threatened on October 18, 1996 (61 FR 54346). Critical habitat has not been designated for this spccies. Loss and fragmentation of habitat, and alteration of natural ecosystem processes have resulted from residential and commercial development in the Pine Hill intrusion area. Housing and commercial development, road maintenance, grading, change in fire frequency, unauthorized dumping, OHV use, overgrazing practices, herbicide spraying, mining, competition from invasive, non-native vegetation, and other human-caused conditions threaten the remaining occurrences of these plants. Layne's butterweed occurs within a fire-adapted plant community, where changes in fire frequency have altered natural processes. Fire is important for seed germination and seedling reestablishment by eliminating competition and shading, as well as replenishing nutrients to the soil. 


\section{Braunton's Milk-vetch}

The primary reference for this section is:

USFWS. 2006b. Endangered and Threatened Wildlife and Plant; Designation of Critieal Habitat for Astragalus brauntonii and Pentachaeta lyonii. Federal Register 71(219):66374-66423.

References eited in this seetion are internal to the above-referenced documents. A eomplete list of these referenees is available from the USFWS Ventura Field Office, Ventura, California.

The 2009 5-year review for Braunton's milk-veteh (USFWS 2009o) was consulted for updated information on this species.

Braunton's milk-veteh (Astragalus brauntonii) is a robust, short-lived perennial in the pea family that oeeurs in the Los Angeles basin. This species is eurrently known from 20 oceurrenees in five disjunet areas in Ventura, Los Angeles, and Orange Counties including: Simi Hills in eastern Ventura and western Los Angeles Counties; eastern Santa Monica Mountains in Los Angeles County; western Santa Monica Mountains near Pacifie Palisades, Los Angeles County; San Gabriel Mountains in Monrovia, Los Angeles County; and Santa Ana Mountains in Orange County (California Natural Diversity Database 2007). Braunton's milk-veteh is associated with chaparral and coastal sage serub plant eommunities and generally oceurs along the tops of knolls ranging from 800 to 2,100 feet, in habitat dominated by chamise, yueea, and the rare Teeate cypress (Fotheringham and Keeley 1998, Landis 2005, California Natural Diversity Database 2007). The species is considered a limestone endemie, and rarely oceurs on non-limestone substrates.

Fire is a natural requirement for the survival of this speeies. The natural frequency of fire in the habitat of Braunton's milk-veteh is unknown, but estimates range from 12 to over 100 years, with an average of 70-year intervals (Radtke et al. 1982; Minnich 1989; O’Leary 1990). Higher fire frequeneies have resulted from inereasing human populations in southern California, mostly in the form of arson-caused fires. This species has a life span of 2 to 3 years but viable seeds may persist in the soil for many years. Depending on fire interval, a given population appears only once in 20 to 50 or more years. Because reproduction of Braunton's milk-veteh is stimulated by fire events, the total number of individuals varies with eurrent fire eyeles. In most eases, the number of plants within a population is in the hundreds to thousands following a disturbanee, and deelines to fewer than ten plants within a few years (California Natural Diversity Database 2007).

Thirty percent of the known populations of Braunton's milk-veteh are on private land in areas with expanding development. Forty pereent are on loeal ageney lands (eity and regional parks), 20 pereent are on state lands in Topanga and Chino Hills State Parks and Coal Canyon Ecological Reserve; the remaining 10 pereent are on federal lands in the Santa Monica Mountains National Reereation Areas (California Natural Diversity Database 2007).

Braunton's milk-veteh was federally listed as endangered on January 29, 1997 (62 FR 4172) and the USFWS designated 3,300 acres of eritical habitat in Ventura and Orange Counties, California, in 2006 (71 FR 66374). This species is threatened by direet loss from urban development, fragmentation of habitat and reduced eapabilities for sustained ecological processes, fragmented ownership of single populations resulting in different landscape treatments, alteration of fire eycles, and extinetion resulting from naturally oceurring events due to small population sizes and low numbers of individuals (Mistretta 1992, California Natural Diversity Database 1994).

\section{Nevin's Barberry}

The primary reference for this section is:

USFWS. 1998e. Endangered or Threatened Status for Three Plants from the Chaparral and Serub of Southwestern California. Federal Register 63(197):54956-54971.

References eited in this seetion are internal to the above-referenced document. A complete list of these references is available from the USFWS Carlsbad Field Office, Carlsbad, California. 
The 2009 5-Year review for Nevin's barberry (USFWS 2009p) was consulted for updated information on this species.

Nevin's barberry (Berberis nevinii) oceurs in restricted, localized populations in the interior foothills of California. It is found in chaparral and alluvial serub associated with rocky slopes and sediments and sandy washes in Los Angeles, Riverside, and San Bernardino Counties (Boyd 1987, Mistretta 1989).

Chaparral habitats of the interior foothill region of southern California are dense shrub associations of moderate height dominated by chamise, California lilac, redberry, manzanita, California scrub oak, sugar bush, laurel sumae, toyon, California buckwheat, and black sage (Holland 1986). Chaparral oceurs on many different soil types, but Nevin's barberry typically oceurs in elay soils derived from gabbro (mineral) or metavoleanie bedrock (Boyd 1991, Oberbauer 1991, California Natural Diversity Data Base 1997). Clay soils have unique physical and ehemical properties that contribute to the disproportionately large number of rare plants found on this substrate, as eompared to other soil types.

Alluvial serub, found in eertain floodplain systems in southern California, eomprises an open vegetation community of drought-deciduous and evergreen shrubs (Smith 1980; Hanes et al. 1989). Alluvial serub is characterized by porous, infertile soils subject to periodie intense flooding and erosion assoeiated with the outwash environment (Hanes et al. 1988). This vegetation type includes life-forms of desert and coastal affinities such as California redberry, sealebroom, mountain mahogany, California buekwheat, and oecasionally California juniper (Hanes et al. 1988). Urbanization and industrial development are eliminating this plant community (Smith 1980).

Nevin's barberry is a rhizomatous evergreen shrub ranging from 3 to 12 feet in height. It flowers from Mareh through April, and then produees juicy, yellowish to red berries. The species is long-lived (more than 50 years) (Mistretta and Brown 1989) with low reproduetive rates likely due to sporadie production of fertile seed. Nevin's barberry is found in two habitat types: gravelly wash margins in alluvial serub, and on eoarse soils in ehaparral (Niehaus 1977, Boyd 1987). The typieal elevation range for this speeies is between 900 and 2,000 feet. The native range of Nevin's barberry currently extends from the foothills of the San Gabriel Mountains of Los Angeles County to near the foothills of the Peninsular Ranges of southwestern Riverside County. The population eenter for Nevin's barberry is located near Vail Lake in southwestern Riverside County. One of the two largest known populations of Nevin's barberry oeeurs in this area (Boyd 1987, California Natural Diversity Data Base 1997), and the other large population of Nevin's barberry is in San Franeisquito Canyon on the Angeles National Forest in Los Angeles County (Boyd et al. 1989). The majority of Nevin's barberry plants found outside the Vail Lake and Angeles National Forest sites oeeur as isolated populations in San Bernardino and Los Angeles Counties. In 2009, the total number of individuals was reportedly fewer than 500 and possibly fewer than 200 , in 14 oceurrences. The majority of oceurrenees of this species are on private lands in the Vail Lake region, Outside of the Vail Lake/Oak Mountain area, only four isolated, native Nevin's barberry occurrenees remain: two in the foothills of the San Gabriel Mountains in Los Angeles County, and two in the Loma Linda Hills in southern San Bernardino County. All of these occurrenees outside of the Vail Lake/Oak Mountain area consist of one individual, with the exception of one oceurrence in a side canyon off of San Timoteo Canyon in the Loma Linda hills area, which has three individuals remaining.

Nevin's barberry was federally listed as endangered on October 13, 1998 (63 FR 54956). The USFWS designated 6 acres in Riverside County, California as critical habitat in March 2008 ( 73 FR 8412). Nevin's barberry is threatened by destruction, degradation and fragmentation of habitat by urbanization, encroachment by exotic plant species, low seed production, altered fire regime, and OHV use. 


\section{Mexican Flannelbush}

The primary referenee for this seetion is:

USFWS. 1998e. Endangered or Threatened Status for Three Plants from the Chaparral and Serub of Southwestern California. Federal Register 63(197):54956-54971.

Referenees cited in this seetion are internal to the above-refereneed doeument. Full eitations are available from the USFWS Carlsbad Field Offiee, Carlsbad, California.

The 5-year review for the Mexiean flannelbush (USFWS 2009q) was consulted for updated information on this speeies.

Mexican flannelbush (Fremontodendron mexicanum), like Nevin's barberry, oeeurs in restrieted, loealized populations in the interior foothills of California. Mexiean flannelbush is known from ehaparral and elosed-eone eoniferous forest dominated by Teeate cypress in San Diego County and northwestern Baja California, Mexieo. Chaparral habitats of the interior foothill region of southern California are dense shrub associations of moderate height dominated by chamise, California lilae, redberry, manzanita, California serub oak, sugar bush, laurel sumae, toyon, California buckwheat, and blaek sage (Holland 1986). In the United States, Mexiean flannelbush is eurrently found in three adjaeent eanyons on the northwest side of Otay Mountain in southern San Diego County, California, in an area approximately 3.0 miles from north to south and 3.5 miles from east to west. The Otay Mountain population is estimated to be approximately 6,000 plants, ineluding populations on BLM land and on private lands. There is a single population in northwestern Baja California, Mexieo, whieh is estimated to have fewer than 20 plants.

Mexiean flannelbush is a small tree or shrub, 5 to 19 feet tall, with evergreen leaves and showy, orange to dark yellow flowers. Native populations of this speeies oeeur primarily in elosed-eone eoniferous forest and southern mixed ehaparral, often in assoeiation with metavoleanie soils (Oberbauer 1991, Reiser 1996) at elevations between sea level and 3,000 feet. The speeies grows on alluvial benehes assoeiated with ephemeral drainages and also on the assoeiated eanyon slopes. Mexiean flannelbush is a perennial plant species that flowers from March to June (Munz 1974); however, no studies on the longevity of this speeies have been eondueted. Eaeh year the plants flower and produee seed. The seeds are held on the plants in dry pods until the fall and winter months when the eapsules open to release seeds. The showy nature of the flower and the presenee of neetar pits at the base of the sepals suggest that pollen is transferred from flower to flower by inseet pollinators.

Mexican flannelbush was federally listed as endangered on Oetober 13, 1998 (63 FR 54956), and approximately 228 aeres of federal land were designated as eritieal habitat in San Diego County, California on September 27, 2007 ( 72 FR 54984). The speeies is threatened by its small population size and altered fire regime, as well as nonnative invasive speeies and impaets from border eontrol aetivities (USFWS 2009q).

\section{San Benito Evening-primrose}

The primary referenees for this seetion are:

USFWS. 1985h. Endangered and Threatened Wildlife an Plants: Determination of Threatened Status for "Camissonia benitensis" (San Benito Evening Primrose). Federal Register 50(29):5755-5759.

and

USFWS. 2006e. Reeovery Plan for Camissonia benitensis (San Benito Evening-Primrose). California/Nevada Operations Offiee. Saeramento, California.

Referenees eited in this seetion are internal to the above-refereneed doeuments. Complete eitations are ineluded in the Bibliography.

San Benito evening-primrose (Camissonia benitensis) is found only on serpentine alluvial terraees in the San Benito Mountain/Clear Creek region of California (Raven 1969; Griffin 1977, 1978a, 1978b; Kiguehi 1983, 1984, 
1985; Florence and Kiguchi 1986). It grows in loose alluvial soil in openings in chaparral, under the sparse understory of the San Benito Forest, or in relatively barren deposits of alluvial gravel. Although not found in damp areas along streams, the species oecasionally grows in dry soils immediately adjacent to streams (Kiguchi 1983, 1984, 1985; Florence and Kiguchi 1986). Its dependence on riparian influence seems to relate mainly to the deposition of alluvial soil and talus rather than on the aquatic habitat itself. The San Benito Forest is a unique combination of digger pine, Jeffrey pine, Coulter pine, and incense eedar (Griffin 1974). Along alluvial terraees, the forest tends to be sparse, blending in with serpentine chaparral. Throughout the serpentine area, it forms a complex mosaic with chaparral and barren talus slopes.

San Benito evening-primrose has been found at elevations ranging from approximately 2,500 to 4,600 feet (Kiguchi 1983, 1984, 1985). It seems to prefer relatively flat terraces with slight to moderate slope. Plants grow in open areas, often with full sun exposure throughout the day. There are 69 total known populations, ineluding 65 on BLM lands and 4 on private land (USFWS 2009r).

San Benito evening-primrose is an annual herb (Raven 1969), with a life eycle limited to the period from late winter/early spring (February through March) through early to mid-summer (June through July; Kiguehi 1983, 1984, 1985). Germination oceurs in late winter to early spring, flowering from mid-April to early June, and fruiting occurs from late April to mid-June, with seed and fruit dispersal oeeurring from late May to July (Raven 1969; Griffin 1977, 1978a; Kiguchi 1983, 1984, 1985a; Florence and Kiguchi 1986). The species is self-fertile. Flooding may be an agent in seed dissemination (Florence and Kiguchi 1986). In a large sense, availability of suitable habitat is a limiting factor for this species. However, the presence of potential habitat that does not support evening primrose populations (Kiguehi 1984, 1985) indicates that other factors such as seed dispersal or moisture requirements may also be involved.

San Benito evening-primrose was federally listed as threatened on February 12, 1985 (50 FR 5755). Critieal habitat has not been designated. The San Benito region is mined for gravel, asbestos, and minerals. The Clear Creek Management Area is subject to seasonally heavy use by OHVs and associated impaets of eamping (USDOI BLM $1983,1984,1985,1986)$. The BLM has taken steps to protect the evening-primrose populations on public land, by installing chain fences or pipe barriers around all of the populations to prevent vehicle trespass (Florence and Kiguchi 1986). Future threats to the species are likely to be similar to existing threats, with the additional possibility of interspeeific competition from other plants, such as introdueed grasses in disturbed areas.

\section{Morro Manzanita}

The primary reference for this section is:

USFWS. 1994b. Endangered or Threatened Status for Five Plants and the Morro Shoulderband Snail from Western San Luis Obispo County, California. Federal Register 59(240):64613-64623.

References cited in this section are internal to the above-referenced document. A complete list of these references is available from the USFWS Ventura Field Office, Ventura, California.

The 2013 recovery plan for the Morro manzanita (USFWS 2013c) was consulted for updated information on this species.

Morro manzanita (Arctostaphylos morroensis) occurs as components of several coastal plant communities in western San Luis Obispo County, California. The distribution of this plant has been tied to the presence of soils derived from ancient sand dunes. These soils, referred to as Baywood fine sands, were deposited during the Pleistocene epoch when sea levels 300 feet lower than current levels allowed large volumes of sand to blow inland into the Los Osos Valley. Morro manzanita is found in association with coastal dune serub, maritime chaparral, and coast live oak woodland communities on sites with no or low to moderate slopes. On steeper slopes, particularly on the north-facing slopes of the Irish Hills, the species occurs in almost pure stands. Much of the area supporting the required habitat for Morro manzanita has been subject to urban development. At the time of listing, approximately 65 percent of the remaining habitat was within private ownership, with the remaining 35 percent on publicly owned 
lands within Montana de Oro State Park and two small preserves administered by California Department of Fish and Game. Since that time, an additional 400 acres have been secured from development (USFWS 2013e).

Morro manzanita is a shrub of the heath family that reaches 5 to 13 feet in height. The seeds of this species require breaking, scratehing, or softening of the seed coat to allow germination. Maintenance and regeneration of this species are dependent on mass germination triggered by fire. Fire breaks seed dormaney and ereates open areas where seedlings ean germinate and individuals cstablish (USFWS 2013c).

Morro manzanita was federally listed as threatened on December 15, 1994 (59 FR 64613). Critical habitat has not been designated for this species. Morro manzanita oecurs in communities that have undergone changes resulting from both human-caused aetivities and natural oceurrences. The rapid urbanization of the surrounding area has already eliminated the species in portions of its range. In addition, the configuration of Morro Bay itself has been altered by the construction of a breakwater and a marina, the deposition of sediments from the Los Osos Creek and Chorro Creek watersheds, and the dredging of waterways within the Bay (Gerdes et al. 1974). Further urban development and other activities such as recreation, grazing, and utility construction threaten the remaining occurrences of Morro manzanita. The habitat of the Morro manzanita is threatened by the non-native veldt grass (Erharta calycina), which is bccoming naturalized in native plant communities. Altered plant composition is likcly altering the fire cycle, potentially incrcasing the frequeney of fires and decreasing the viability of existing seed banks (USFWS 2013e).

\section{Indian Knob Mountain Balm}

The primary referenees for this section are:

USFWS. 1994b. Endangered or Threatened Status for Five Plants and the Morro Shoulderband Snail from Western San Luis Obispo County, California. Federal Register 59(240):64613-64623.

and

USFWS. 1998t. Recovery Plan for the Morro Shoulderband Snail and Four Plants from Western San Luis Obispo County, California. Portland, Oregon.

Referenees cited in this section are internal to the above-referenced documents. References from the Recovery Plan are included in the Bibliography. A complete list of references from the Federal Register listing is available from the USFWS Ventura Field Office, Ventura, California.

The 2009 5-Year Review and Summary (USFWS 2009s) for the Indian Knob mountain balm was eonsulted for updated information on this species.

Indian Knob mountain balm (Eriodictyon altissimum), like Morro manzanita discussed above, occurs as a component of coastal plant communities in western San Luis Obispo County, California. This species oceurs within coastal maritime chaparral and oak woodlands and co-oceurs with Morro manzanita in several locations. Only six stands of Indian Knob mountain balm are known, ranging from the south end of Morro Bay to Indian Knob, between San Luis Obispo and Arroyo Grande. Two of the sites are in Morro Bay State Park; the remaining sites are on private land. Indian Knob mountain balm oceurs in soils derived from marine sandstones containing tar deposits referred to as "tar sands" and, in the northern part of its range, on Baywood fine sands and weathered ancient dune soils. As with other members of its genus, Indian Knob mountain balm is thought to be adapted to ecological disturbanee, specifically to periodic firc within the chaparral community. Most extant populations are mature or seneseent and may need preseribed fire to revitalize the stands (Bittman 1985; John Chesnut, personal communication 1997; Keil, personal communication 1997).

Indian Knob mountain balm is a long-lived, diffusely branched evergreen shrub in the waterleaf family that reaches a height of about 7 to 13 feet. This species produces small lavender flowers that are arranged in coiled elusters and produce numerous tiny seeds. A variety of non-specialist inseets have been observed visiting the flowers and may serve as pollinators. The species is a fire-adapted, and produces new growth primarily from rhizomatous suckers. 
Indian Knob mountain balm was federally listed as endangered on Deeember 15, 1994 (59 FR 64613). Critical habitat has not been designated. The species occurs in communities that have undergone a number of ehanges resulting from both human-caused activities and natural occurrences. The rapid urbanization of the surrounding area has already eliminated the Indian Knob mountain balm in a portion of its ranges. In addition, the configuration of Morro Bay itself has been altered by the construetion of a breakwater and a marina, the deposition of sediments from the Los Osos Creek and Chorro Creek watersheds, and the dredging of waterways within the Bay (Gerdes et al. 1974). Since the time of listing, all extant individuals have been protected from the threat of habitat loss due to development, surface mining, and drilling. The biggest eurrent threat to this species appears to be the lack of disturbance (attributable to fire suppression in the urban interface) that is needed to regenerate and revitalize populations (USFWS 2009s).

\section{Orcutt's Spineflower}

The primary reference for this section is:

USFWS. 2007i. Chorizanthe orcuttiana (Oreutt's Spineflower) Five-Year Review: Summary and Evaluation. Carlsbad Fish and Wildlife Office. Carlsbad, California.

References cited in this section are internal to the above-referenced document. Full citations are included in the bibliography.

Oreutt's spineflower (Chorizanthe orcuttiana) is restricted to small areas of suitable habitat, generally in openings in southern maritime chaparral. Southern maritime chaparral is a unique plant association that occurs only in coastal southern California along the immediate coast of San Diego and Orange Counties and northwestern Baja California, Mexico. Currently there are eonsidered to be four extant oecurrenees of Oreutt's spineflower, one at Oak Crest Park in Encinitas and three on Point Loma and all within San Diego County. Recent plant counts for all of the extant oceurrences combined range from a high of about 3,000 to a low of about 470 plants, although population estimates for this annual species are subject to significant fluctuations from year to year. The species is endemic to south-central and coastal San Diego County and primarily restricted to weathered sandstone bluffs in association with or in microhabitats within southern maritime chaparral (USFWS 1996d). The occurrenees are small patehes often with constricted connectivity to adjacent patehes. The habitat was deseribed as loose sandy soils in openings in coastal or maritime chaparral (Bauder 2000). Southern maritime chaparral is a low, fairly open chaparral typically dominated by wart-stemmed ceanothus, mission manzanita, chamise, Nuttall's serub oak, bush rue, red berry, Mojave yucea, and oceasionally bush poppy (Holland 1986).

Oreutt's spineflower is a low, yellow-flowered annual of the buckwheat family with small clustered yellow flowers that produce a single seed. The success of germination is highly dependent on factors such as rainfall, which often differ significantly from one year to the next in southern California. Germination usually takes place over a period of time, with more plants apparent later in the growing season.

Orcutt's spineflower was federally listed as endangered on Oetober 7, 1996 (61 FR 52370). Critical habitat has not been designated for the species. The rapid urbanization of southern Orange County and south-eentral San Diego County has already eliminated a substantial portion of the southern maritime chaparral. Small population size, invasive plants, and disruption of natural fire cycles are threats to Orcutt's spineflower. Local populations are still relatively to extremely small. Invasive non-native plants are a significant threat to the species, especially at Point Loma, and are the focus of a management plan. Because of its proximity to developed areas, fire suppression efforts in southern maritime chaparral are considerable. This may lead to encroachment of openings in suitable habitat by native shrubs and forbs. 


\section{Encinitas Baccharis}

The primary references for this section is:

USFWS. 1996d. Determination of Endangered or Threatened Status for Four Southern Maritime Chaparral Plant Taxa from Coastal Southern California and Northwestern Baja California, Mexico. Federal Register 61(195):52370-52384.

Referenees eited in this section are internal to the above-referenced document. A eomplete list of these referenees is available from the USFWS Carlsbad Field Offiee, Carlsbad, California.

The 2011 5-Year Review (USFWS 20111) for the Encinitas baecharis was eonsulted for updated information on this species.

Encinitas baccharis (Baccharis vannesae), oecurs in several types of eoastal southern chaparral habitats distributed below 3,000 fect where maritime climatc prevails. Southern maritime ehaparral is a low, fairly open chaparral typieally dominated by wart-stemmed ceanothus, mission manzanita, ehamise, Nuttall's scrub oak, bush rue, red berry, Mojave yucea, and oceasionally bush poppy (Holland 1986, Kehlcr-Wolf 1993, OGDEN 1993). The distribution of southern maritime chaparral in Orange County is disjunct, and the species composition is slightly different from that found in San Dicgo County and Mexico (Gray and Bramlet 1992). At the time of listing, there were 19 populations distributed aeross eoastal northern San Diego County, from Carlsbad east to Poway. The speeies is now presumed extant at 30 oeeurrenees, with a southward extension of its range into the Otay Mountain arca (USFWS 20111). Mueh of the remaining southern maritime ehaparral is loeated on Carmel Mountain, Torrey Pines State Park, and in the citics of Carlsbad and Encinitas in San Dicgo County. Therc are 30 known extant populations of the specics.

The speeies oecurs in southern maritime chaparral in the vicinity of Encinitas, eentral San Diego County, California, and extends inland to Mount Woodson and Poway, California, where it is assoeiated with dense southern mixed ehaparral. There are seattered populations of this species from Encinitas cast through the Del Dios highlands and Lake Hodges area to Mount Woodson and south to Otay Mountain in San Diego County, California. The majority of the remaining populations of this species are on privatcly owned lands.

Encinitas baeeharis is a slender stemmed broom-like shrub in the sunflower family that grows to heights of about 1.5 to 4.5 fect. The species is dioeeious, meaning separate plants of both sexes must be in close proximity for pollination and subsequent seed production to occur. The speeies blooms between August and November (California Native Plant Society [CNPS] 2010, San Diego County Plant Atlas 2010), and is probably pollinated by both wind and insects. Most baceharis species appcar to depend on disturbances - such as stream and gully crosion, landslides, or as in the case of encinitas baccharis, fires-for colonization and population recruitment opportunities.

Encinitas baecharis was federally listed as threatened, on Oetober 7, 1996 (61 FR 52370). Critical habitat has not been designated for the speeies. The rapid urbanization of southern Orange County and south-central San Diego County has already eliminated a substantial portion of the southern maritime chaparral. In addition, the advent of widespread urbanization and the disruption in natural fire cycles potentially threatens the remaining southern maritime chaparral. In the past, populations of Encinitas baceharis have been subjected to a eonsiderable degree of fragmentation, and threatened by trampling by farm workers or reereational activities; fuel modification; competition from non-native plant species; and habitat destruction due to residential, agricultural, commercial, and recreational development. At present, less than half of the occurrences are threatened by habitat loss. Current threats include altered firc rcgimes, impacts from non-native species, trampling, and threats associated with a small population sizc (USFWS 20111). 


\section{Slender-horned Spineflower}

The primary referenee for this section is:

$2010 \mathrm{~g}$. Dodecahema leptoceras (Slender-horned Spineflower) 5-Year Review: Summary and Evaluation. U.S. Fish and Wildlife Service Carlsbad Fish and Wildlife Office. Carlsbad, California.

References eited in this section are internal to the above-referenced document. Full citations are included in the Bibliography.

Slender-horned spineflower (Dodecahema leptoceras) is endemic to southwestern California, from northern Los Angeles County east to San Bernardino County, and south to southwest Riverside County in the foothills of the Transverse and Peninsular ranges at elevations ranging from 656 to 2,296 feet (Hickman 1993). There are eurrently 20 extant slender-horned spineflower oceurrences distributed among the three counties where it oceurs. The habitat that supports most oecurrences of the species has generally been eategorized as alluvial scrub (Smith 1980; Hanes et al. 1989; Rey-Vizgirdas 1994; Barbour and Wirka 1997). This shrub habitat is found on sandy and gravelly soils in sandy wash systems where intermittent, seouring flood events occur. plants are typically found in alluvial fan serub on benches and terraces away from active ehannels in areas receiving little surface disturbance from flooding, but subject to sheet or overland flows (Rey-Vizgirdas 1994, Wood and Wells 1997). The association of the species with older alluvial benches and terraces indicates the need or tolerance of infrequent flood events to maintain suitable habitat eonditions. A few oceurrenees of this species are found on low alluvial benehes or braids within active channels. the species also oceurs in openings in chaparral or with coast live-oak or western sycamore woodlands on sedimentary soils often associated with a erust of lichens and mosses (eryptobiotic soil).

Slender-horned spineflower is a diminutive annual herb in the buekwheat family, with a distinetive basal rosette of leaves ranging from 1.2 to 3.1 inches in diameter. The lcaves frequently beeome reddish at maturity. Germination oceurs in late February from a long-lived seed bank, with the highest survival rates oceurring during unusually cool and wet seasons. The species produees small, white to pink flowers in April through June, but is most distinet in June and early July after the basal rosette and eertain branches have turned a characteristic dark red color. A native wasp is a potential pollinator. Seed production varies depending on seasonal conditions.

Slender-horned spineflower was federally listed as endangered on September 28, 1987 (52 FR 36265). Critical habitat has not been designated. The primary threats to this speeies are development, mining activities, flood control measures, and trash dumping.

\section{Santa Ana River Woolly-star}

The primary references for this seetion is:

USFWS. 2010h. Eriastrum densifolium ssp. sanctorum (Santa Ana River Woolly-Star) 5-Year Review: Summary and Evaluation. U.S. Fish and Wildlife Service Carlsbad Fish and Wildlife Office. Carlsbad California.

References in this section are internal to this document. Full citations are included in the Bibliography.

Santa Ana River woolly-star (Eriastrum densifolium ssp. sanctorum) is endemic to the Santa Ana River drainage of southern California. This subspecies was formerly a conspicuous shrub in the alluvial fan sage scrub community on the higher floodplain terraces of the Santa Ana River and its tributaries in Orange, Riverside, and San Bernardino Counties. The species thrives in open, well-lighted areas of sandy alluvial terraces, where shrublands persist between infrequent flood events (Zembal and Kramer 1984; Burk et al. 1988; Wheeler 1988) The perennial vegetative cover where the species occurs is relatively low, and seldom exceeds 50 percent. Annual cover is also low. The species is found in disjunct stands within this habitat and tends to occupy areas with slight surface disturbance. The species is a pioneer subspecies that colonizes washed sand deposits created by sporadic stream flow action. Between major llood events, these deposits typically exist as terraces above the high water mark of the river and associated tributaries (Zembal and Kramer 1984). The known range is comprised of 21 extant occurrences dispersed across private and local government lands (California Natural Diversity Database 2010). 
Santa Ana River woolly-star is a short-lived, perennial subshrub on the phlox family, occasionally reaching as much as 3.3 feet in height. Plants have an average life span of 5 years, but may live as long as 10 . Plants are most readily detectable when in flower, typically from May through August, but most heavily in June. The primary pollinators include the solitary digger bee, giant flower-loving fly, California bumblebee, white-lined sphinx moth, black-chinned hummingbird, and Anna's hummingbird. The relative importance of these pollinators appears to vary with location (Muñoz 1991). Fruiting ean extend from mid-July to mid-Oetober. Seeds germinate within 48 to 72 hours following fall storms (after roughly 1 inch of rainfall). Seedling survivorship is highest in areas with lower cover of annual plants, grasses, and litter, and areas of more bare ground or those surfaces created by flooding (Wheeler 1991).

Santa Ana River woolly-star was federally listed as endangered on September 28, 1987 (52 FR 36265). Critical habitat has not been designated. The biggest threat to the eontinued existence of the speeies stems from the construetion of the Seven Oaks dam, which will substantially reduee floodplain areas necessary to support the species. Without habitat-rejuvenating flooding events, open, sandy substrates will eventually become covered with vegetation, which would likely make these areas unsuitable for woolly-stars. Upstream watershed management and upstream preseribed fire can also alter downstream hydrology. Additional threats impaeting habitat oeeupied by the Santa Ana River woolly-star inelude aggregate mining and OHV use.

\section{La Graciosa Thistle}

The primary referenees for this section are:

USFWS. 2000b. Final Rule for Endangered Status for Four Plants from South Central Coastal California. Federal Register 65(54):14888-14898.

and

USFWS. 2001d. Proposed Designation of Critical Habitat for Cirsium loncholepis (La Graciosa Thistle), Eriodictyon capitatum (Lompoe Yerba Santa), and Deinandra increscens ssp. villosa (Gaviota Tarplant). Federal Register 66(221):57559-57600.

References cited in this seetion are internal to the above-refereneed doeuments. A complete list of these references is available from the USFWS Ventura Field Office, Ventura, California.

The 2011 5-year review for the La Graciosa thistle (USFWS $2011 \mathrm{~m}$ ) was eonsulted for updated information on this speeies.

La Graciosa thistle (Cirsium scariosum var. loncholepis) has limited distribution in southwestern San Luis Obispo County and northwestern Santa Barbara County, California, within a unique geomorphic area known as the Santa Maria Basin (Hunt 1993). The Santa Maria Basin stretehes along a 39-mile seetion of the coastal region of eentral California and is dominated by a system of dune eomplexes that are interspersed with the drainages and tributaries of four major watersheds in this area: Arroyo Grande Creek, Santa Maria River, San Antonio Creek, and Santa Ynez River. The speeies is associated with two dune complexes (the Santa Maria Valley Dune Complex and the Santa Ynez Valley Dune Complex). On this landscape, prevailing northwest winds are a major factor in shaping the terrain and creating the dunes such that the active dune and swale systems are aligned with these winds (Hunt 1993). The swales between two parallel dunes and behind the foredunes are often at or near the water table, ereating the wetlands and back dune lakes (Hunt 1993) that are essential for La Graciosa thistle.

The species is found in wet soils surrounding the dune lakes and in the moist dune swales, where it is often associated with rush, tule, willow, poison oak, salt grass, and eoyote brush (Hendrickson 1990). Since the speeies was listed in 2000 it has experienced considerable decline, and as of 2011, there were eight known occurrences for La Graciosa thistle at four locations: southern Callender Dune Lakes, Oso Flaco, southern Guadalupe Dunes, and Santa Maria River (USFWS $2011 \mathrm{~m}$ ). Many of the oceurrenees are small, isolated, and showed a reduced reproductive vigor. All but one population of La Graciosa thistle - a small population in the Los Padres National Forest in southern Monterey County-oeeur on private lands. Observed declines in this species are apparently the 
result of changes in habitat as riparian willows and other vegetation invade the areas that previously supported this wet meadow plant (Chesnut 1998).

La Graciosa thistle is a short-lived member of the aster family that blooms once, sets seed, and dies. Plants are from 4 to 40 inches in height, with one to several stems that bear clusters of whitish-purple flowering heads.

La Graciosa thistle was federally listed as endangered on March 20, 2000 (65 FR 14888). On May 7, 2002 (67 FR 30641 ), the USFWS designated approximately 44,000 acres of land in areas that support La Graciosa thistle as critical habitat. Ongoing threats to this species include groundwater pumping, oil field development, and competition from non-native plants (Hendrickson 1990, California Department of Fish and Game 1992). Other threats include the loss of connectivity between and among populations, water quality issues, trampling of plants from cattle, and climate change (USFWS $2011 \mathrm{~m}$ ).

\section{Lompoc Yerba Santa}

The primary references for this section are:

USFWS. 2000b. Final Rule for Endangered Status for Four Plants From South Central Coastal California. Federal Register 65(54):14888-14898.

and

USFWS. 2001d. Proposed Designation of Critical Habitat for Cirsium loncholepis (La Graciosa Thistle), Eriodictyon capitatum (Lompoc Yerba Santa), and Deinandra increscens ssp. villosa (Gaviota Tarplant). Federal Register 66 (221):57559-57600.

References eited in this seetion are internal to the above-refereneed documents. A complete list of these referenees is available from the USFWS Ventura Field Office, Ventura, California.

Lompoc yerba santa (Eriodictyon capitatum), like the La Graciosa thistle discussed in the previous section, oceurs in a narrow area along the south-eentral California coast, in sensitive or altered habitats (Holland 1986, Schoenherr 1992). Inland from the active dunes of the Guadalupe Dune region (diseussed in the previous speeies aceount), a weakly cemented sandstone has weathered to produce a sandy, extremely well drained, and nearly infertile soil (Davis et al. 1988). The habitat that occurs on these sand hills has been ealled the central coast maritime chaparral (Ferren et al. 1984; Davis et al. 1988; Philbriek and Odion 1988; Davis et al. 1989; Odion et al. 1992). Seven local endemic plant species, including Lompoc yerba santa, and at least 16 other uneommon plant species, are components of this habitat. Central coast maritime chaparral is considered threatened and sensitive by the California Department of Fish and Game's Natural Heritage Division (Holland 1986).

Lompoc yerba santa occurs in maritime chaparral with bush poppy, scrub oaks, and buck brush, and in southern Bishop pine forests that intergrade with chaparral (manzanita and black sage [Smith 1983]). The five known locations of this species occur in southwestern Santa Barbara County, in three geographically distinct areas: Solomon Hills, west Burton Mesa, and Santa Ynez Mountains. Two of these locations are on Vandenberg Air Force Base, and the other three are on private land in the oilfields south of Orcutt and at the western end of the Santa Ynez Mountains.

Lompoc yerba santa is a shrub in the borage family with sticky stems up to 10 feet tall. Colonies of this species appear to be multiclonal, where the vegetative spread of the root system of a single plant produces many stems. Lompoc yerba santa is self-incompatible (i.e., it requires pollen from genctically different plants to produce seed), and its fruits appear to be parasitized by an insect (Elam 1994). Plants have been observed to resprout from the base after a prescribed fire, although living stems also die.

Lompoc yerba santa was federally listed as endangered on March 20, 2000 (65 FR I4888). On November 7, 2002 (67 FR 67968), the USFWS designated approximately 8,500 acres of land occupied by Lompoc yerba santa as critical habitat. Factors that threaten the species include fire management practices, invasive non-native plant species, low seed productivity, and naturally occurring catastrophic events. 


\section{Monterey Spineflower}

The primary reference for this section is:

USFWS. 200le. Proposed Designation of Critical Habitat for Chorizanthe pungens var. pungens (Monterey Spineflower). Federal Register 66(32):10440-10469.

References eited in this section are internal to the above-referenced document. A complete list of these refcrences is available from the USFWS Ventura Field Office, Ventura, California.

The 2009 5-year review for the Monterey spineflower (USFWS 2009t) was consulted for updated information on this species.

Monterey spineflower (Chorizanthe pungens var. pungens) is endemic to sandy soils in coastal areas in southern Santa Cruz and northern Monterey Counties, and in the Salinas Valley in interior Monterey County. It is found in a variety of seemingly disparate habitat types, including active coastal dunes, grassland, scrub, chaparral, and woodland types on interior upland sites, and interior floodplain dunes. However, all of these habitat types include microhabitat characteristics that are favored by the taxon. All sites are on sandy soils and are relatively open and free of other vegetation. Within grassland communities, plants occur along roadsides, in firebreaks, and in other disturbed sites, while in oak woodland, chaparral, and serub communities, they occur in sandy openings between shrubs. In grassland and oak woodland communities, abundant annual grasses may outcompete the Monterey spineflower, whilc managcment of grass species, either through grazing, mowing or fire, may allow the spineflower to persist. In scrub and chaparral communities, the taxon does not occur under dense oak or shrub stands, but will occur betwcen more widely spaced trees and shrubs. Prior to onset of human use of this area, the Monterey spineflower may have been restricted to openings created by wildfires within these communities (USFWS 1998). In addition, at the former Fort Ord, the highest densities of plants are located in the central portion of the firing rangc, where disturbance is the most frequent.

Monterey spineflower is generally distributed along the rim of Monterey Bay in southern Santa Cruz and northern Monterey Counties, and inland along the coastal plain of the Salinas Valley. At coastal sites ranging from the Monterey Peninsula north to Manresa State Beach, it is found in active coastal dune systems, and on coastal bluffs upon which windblown sand has been deposited. On coastal dunes, the distribution of suitable habitat is subject to dynamic shifts caused by patterns of dune mobilization, stabilization, and successional trends in coastal dune scrub that increase in cover over time. Accordingly, individual colonies of Monterey spineflower, found in gaps between stands of serub, shift in distribution and size over time. Native plants associated with the taxon include beach bur, coastal sagewort, mock heather, Monterey Indian paintbrush, and beach pea. At some northern Monterey County locations, Monterey spincflower oceurs in elose proximity to the endangered Monterey gilia, Menzies' wallflower, and in areas used by a threatened bird, the snowy plover. The species appears to be well distributed within the coastal portions of its range and able to colonize disturbed sites where sandy soils are present as long as a seed source is prescnt, and as long as both native and non-native invasive species do not become abundant (USFWS 2009t).

Monterey spineflower is a prostrate annual species in the buckwheat family. It has long, somewhat wiry branching stems supporting aggregates of small white to pinkish flowers, each of which produces one seed. The species germinates well under most winter conditions, and plants can be found above ground as early as December (Fox et al. 2006). Flowering oceurs from April through June. Although pollination ecology has not been studied for this taxon, it is likely visited by a wide array of pollinators. Seed dispersal is facilitated by the involucral spines, which attach the seed to passing animals. While animal vectors most likely facilitate dispersal between colonies and populations, the prevailing coastal winds undoubtedly play a part in seattering seed within colonies and populations. The species does not develop an extensive persistent soil seed bank; however, under some conditions, a soil seed bank that persists for several years may be present and substantial enough to repopulate a site.

Monterey spineflower was federally listed as threatened on February 4, 1994 (59 FR 5499). On May 29, 2002 (67 FR 37498), the USFWS designated approximately 18,830 acres of land (in Santa Cruz and Monterey Counties) at four coastal sites and six inland sites where the taxon is known to occur. Portions of the coastal dune and coastal 
scrub communities that support the Monterey spineflower have been eliminated or altered by recreational use, industrial and urban development, and military activities. Dune communities have also been altered in composition by the introduction of non-native species, especially sea-fig or iceplant and European beachgrass, in an attempt to stabilize shifting sands. The species is threatened by residential development, agricultural land conversion, sand mining, military activities, and encroachment by non-native plant species.

\section{Howell's Spineflower}

The primary reference for this section is:

USFWS. $201 \mathrm{ln}$. Chorizanthe howellii (Howell's Spineflower) 5-Year Review: Summary and Evaluation. Areata Fish and Wildlife Office. Arcata, California.

Referenees cited in this section are internal to the above-referenced document. They are included in the Bibliography.

Howell's spineflower (Chorizanthe howellii) is restricted to the Ten Mile Dunes along the coast of Mendocino County, California, from the Ten Mile River south approximately 7 miles south to 1.5 miles south of Virgin Creek in the City of Fort Bragg, and as much as 0.5 mile inland from the Paeific Ocean. Overall, greater than 95 pereent of the distribution is expected to lie within MacKerricher State Park. The remainder of the distribution is in private ownership (USFWS 1998d, California Natural Diversity Database 2011), spread aeross multiple parcels at the eastern extent of the dune sheets, both north and south of Ward Avenue. Much of that habitat is severely impacted by invasive species, or otherwise marginally occupied by Howell's spineflower, likely a result of fragmentation by development, proximity to invasive species strongholds, and isolation from dune-forming processes (c.g., wind). Population estimates for the species are as high as 3 million individuals in 2011.

Howell's spineflower occurs in several vegetation alliances associated with semi-stabilized near-shore dunes and backdunes. It also occurs in disturbed areas of coastal prairie, on relatively fertile, finer-textured soils associated with some of the coastal bluffs in the south portion of MacKerricher State Park (Imper 2005; Pickart and Barbour 2007; Sawyer et al. 2009). Its habitat is generally charaeterized as early successional. Disturbance in the form of wind exposure and sand deposition, or limited foot traffic appears necessary to prevent encroaehment by other species, both native and non-native, which may cause a steep decline in Howell's spineflower (Imper 2005). For example, much of the occupied habitat oceurs on the edges of pedestrian or horse trails. However, some of the largest stands are located within semi-stabilized dune swales, which appear to receive little foot traffic. Howell's spineflower in general does not tolerate a high level of competition for seedling establishment. In some cases, Howell's spineflower rapidly colonizes areas in which iceplant has died or been pulled, if the remaining mulch is not too deep (Imper 2005, Warner 2006).

Howell's spineflower is an herbaceous annual member of the buckwheat family. It blooms between May and June. Seed dispersal is facilitated by "spines" that attach to passing animals. As an annual species, Howell's spineflower responds almost immediately to changes in its environment and is capable of rapid exploitation of habitat, such as following removal of invasive species like iceplant. However, much of its habitat has been eliminated by invasive species, including iceplant and European beachgrass.

Howell's spineflower was federally listed as endangered on June 22, 1992 (57 FR 27848). Critical habitat has not been designated. Threats to the species include loss of habitat from invasive species and recreational impacts on habitat. 


\section{Menzies' Wallflower}

The primary referenees for this scetion are:

USFWS. 1992e. Six Plants and Myrtle's Silverspot Butterfly From Coastal Dunes in Northern and Central California Determined to be Endangered. Federal Register Volume 57:27848-27859.

and

USFWS 2008h. Menzies' Wallflower (Erysimum menziesii) 5-Year Review: Summary and Evaluation. Arcata Field Offiee. Areata, California.

Referenees cited in this seetion are internal to the above-referenced doeuments. Full eitations are ineluded in the Bibliography.

Menzies' wallflower (Erysimum menziesii) is another speeies that is endemie to the coastal dunes of northern and central California. The listing ineludes three subspecies: E. m. ssp. eurekense, E. $m$. ssp. menziesii, and E. $m$. ssp. yadonii). Menzies' wallflower is known from at least 16 extant oeeurrenees, distributed predominately in the nearshore dune eommunity of four disjunet dune systems in northern and eentral California: Humboldt Bay in Humboldt County, Ten Mile River in Mendoeino County, the Marina Dunes at Monterey Bay, and the Monterey Peninsula in Monterey County (Priec 1993).

The distribution of E.m. ssp. enrekense extends from the mouth of the Mad River south approximately 12 miles to the southern tip of the Samoa Peninsula (North Spit) of Humboldt Bay (Piekart et al. 2000), where it oeeurs in the dune mat eommunity, on the flanks or crests of dunes, in open sand areas, on sparsely vegetated dunes, and in the borders of lupine serub.

Erysimum menziesii ssp. menziesii exhibits a very disjunet distribution in Monterey and Mendoeino Counties (California Natural Diversity Database 2006). The Mendocino County population occupies the Ten Milc Dunes, extending from the Ten Mile River approximately 5.4 miles south nearly to Fort Bragg, and up to 0.5 miles inland. Virtually the entire Mendoeino County distribution oecurs within MaeKerrieher State Park, with a relatively small number of plants loeated on private property east of the park (Imper 2005). Currently oeeupied dunes within the park are estimated at about 240 aeres. In Monterey County, the subspeeies is known from four isolated dune exposures on the west edge of the Monterey Peninsula, extending from Point Pinos about 5 miles south to Cypress Point. Populations are known or suspeeted at the former Point Pinos Coast Guard station/lighthousc, Asilomar State Beaeh, the Spanish Bay dunes, and Signal Hill dunes (California Natural Diversity Database 2006). This subspecies oeeupies habitat similar to E.m. ssp. eurekense, on eoastal strand, close to the high tide line and proteeted from wave aetion, as well as in bluff serub and on open, sparsely vegetated dunes. E. m. ssp. yadonii oeeurs approximately 7 miles north of the Monterey peninsula. The entire eurrent and historical distribution oeeurs between the mouth of the Salinas River and the former Fort Ord military reservation, some 8 miles to the south. The only two known, naturally oeeurring sites are at Marina State Beaeh and a sand mine site, whieh oeeupy a eoastal strip of less than 3 miles on the west side of the City of Marina.

Menzies' wallflower is a low, sueeulent, rosette-forming, perennial herb in the mustard family whieh produces flowers and seeds onee during its lifespan, then dies. The wallflower forms a basal rosette of leaves that may persist for up to 8 years before flowering. Blooming typieally oeeurs from Mareh through April, although it may begin as early as late February. The speeics able to produce seed either by self-pollination, or by pollination by other plants. E. $m$. ssp. eurekense is pollinated by a solitary bee speeics in Humboldt County (USFWS 1998d). The fruits mature by mid-June. However, seeds remain attaehed to the fruit walls after dehiseenee and disperse over a long period, primarily in eonjunction with winter storm events that dislodge the mature infloreseences and seatter them by way of a wind-driven tumbling aetion (Piekart and Sawyer 1998). Germination follows the first rains in fall or early winter. Individual plants produec numerous seeds; however, the wallflower does not have a persistent sced bank in the soil (Carothers 1996), and secdling survivorship is low, with 98.3 pereent mortality shown to oeeur in the first year (Pickart and Sawyer 1998). Reproduetion may also be hindered by infestation of a fungus 
that eauses white rust disease, at least in Erysimum menziesii ssp. eurekense. Disease symptoms are more prevalent on reproductive individuals, where they ean reduce seed number or viability (Pickart and Sawyer 1998).

Menzies' wallflower was federally listed as endangered on June 22, 1992 (57 FR 27848). Critical habitat has not been designated. As diseussed in the previous species aceount (Howell's spineflower), many non-native plants have invaded these dune communities. In some eases, these non-native species have outcompeted and largely supplanted the native dune vegetation, including Menzies' wallflower. Aside from the impact of exotie vegetation, many of the areas harboring populations of the species are threatened by proposed commercial and residential development. The historical use of some dune systems by the military has resulted in heavy damage to these systems (Cooper 1967). Other OHV use has also damaged the fragile plant communities in these dune systems and remains a major threat to rare dune plants on both public and privately owned lands. Trampling of the native flora by equestrians, hikers (Brown 1987), and perhaps livestock (Clark and Fellers 1986) also threatens plants in the community. Other factors negatively affecting coastal dunes species include sand mining, disposal of dredged material from adjacent bays and waterways, and perhaps stochastic extinetion by virtue of the small isolated nature of the remaining populations.

\section{Monterey Gilia}

The primary reference for this section is:

USFWS. 2008i. Monterey Gilia (Gilia tenuiflora ssp. arenaria) 5-Year Review: Summary and Evaluation. Ventura Fish and Wildlife Office. Ventura, California.

References eited in this seetion are internal to the above-refereneed documents. Full citations are included in the Bibliography.

Monterey gilia (Gilia tenuiflora ssp. arenaria) is a small annual plant that is endemic to the coastal portion of Monterey County between the Salinas River in the north and the Monterey Peninsula in the south. It is found within two distinet geographic habitat types, coastal dune habitats and an inland maritime chaparral habitat; all of the latter oceurs at former Fort Ord. Of the coastal oceurrences, 3 of the 17 that are listed in the California Natural Diversity Data Base are likely extirpated. Approximately half of the potentially extant coastal oceurrences oceur on state, federal, and local ageney lands, and half oceur on private lands. In addition to populations along the immediate coast, the species is found in 13 oceurrenees on sandy soils remaining from Pleistocene-era dunes, which form a dune sheet that extends from the immediate coast into the interior in the vicinity of former Fort Ord over a distance of 8 miles (USFWS 1998d). The species is generally found in sparse serub communities, and does not compete well in the denser vegetation structure often exhibited by many non-native species. In addition, nonnative grasses may be detrimental to the survival of this subspecies due to exeessive soil stabilization and litter accumulation, both of which lead to more advanced soil development.

Monterey gilia is an annual herbaceous plant in the phlox family. Individual plants are less than 7 inches tall, with a basal rosette of leaves and white and purple funnel-shaped flowers. As an annual plant, Monterey gilia can go through large changes in number of individuals from year to year, and late-season rainfall can markedly affect germination and growth (Dorrell-Canepa 1994; Fox et al. 2006). The number of individuals at Marina State Beach has fluctuated from a low of 5,000 individuals in 1987 to a high of 25,000 individuals in 1993; the number of individuals at Salinas River State Beach has fluctuated from a low of 1,665 individuals in 1987 to a high of 13,500 individuals in 1993 (California Natural Diversity Database 2006). Monterey gilia may have long-lived seeds which create a relatively persistent soil seed bank (Fox et al. 2006). Monterey gilia requires semi-open areas of sandy soil to germinate and to thrive. The taxon is generally found in sparse scrub communities, and does not compete well in the denser vegetation structure often exhibited by many non-native species. In addition, non-native grasses may be detrimental to the survival of this subspecies due to excessive soil stabilization and litter accumulation, both of which lead to more advanced soil development.

Monterey gilia was federally listed as endangered on June 22, 1992 (57 FR 27848). Critical habitat has not been designated. The primary threats to Monterey gilia relate to habitat destruction due to development and an increase in cover by invasive, non-native plant species which inhibit germination and colonization of this taxon. The interior 
sites are generally more at risk than eoastal populations. Development is a threat primarily at Fort Ord, while invasive species are a threat throughout the species' range. The coastal populations on state park lands are relatively more protected than interior sites at this time, although non-native plant control is required at virtually all sites and repeated out-plantings have had to be used to maintain numbers and expand population areas.

\section{Beach Layia}

The primary reference for this section is:

USFWS. 20110. Layia carnosa (Beaeh Layia) Draft 5-Year Review: Summary and Evaluation. Areata Fish and Wildlife Office. Areata, California.

References cited in this section are internal to the above-referenced documents. They are ineluded, in part, in the Bibliography. A full list of referenees is available from the Areata Fish and Wildlife Office.

Beach layia (Layia carnosa), a low, glandular winter annual, is another species that is endemie to the coastal dunes of northern and central California. The species' distribution includes occurrenees spread aeross six very isolated dune systems, over about 500 miles of shoreline in northern and central California. Dune systems include Freshwater Lagoon, Humboldt Bay, the mouth of the Mattole River, Point Reyes, Monterey Peninsula, and Vandenberg, a part of the Guadalupe-Nipomo Dunes. Beaeh layia is restrieted to openings in eoastal sand dunes ranging in elevation from 0 to more than 100 feet, where it colonizes sparsely vegetated, semi-stabilized dunes and blowouts. The species often occurs in narrow bands of moderately disturbed habitat along the edges of trails and roads. Common associated speeies inelude: eoast buckwheat, beach pea, beach sandwort, dune bluegrass, dune goldenrod, sand verbena, and beaeh-bur (USFWS 1998d). Overall, an estimated 456 acres of near-shore dunes habitat is currently known to support beaeh layia (Imper 2011).

Beach layia is a sueeulent annual herb with fleshy leaves belonging to the sunflower family. The unbranched to highly branched plants range up to 6 inches tall and 16 inehes aeross. As a winter annual, beach layia germinates during the rainy season between fall and mid-winter, blooms in spring (April to June), and eompletes its life eyele before the dry season. Populations tend to be patehy and subjeet to large annual fluetuations in size and dynamic changes in loeal distribution assoeiated with the shifts in dune blowouts, remobilization, and natural dune stabilization that occur in the coastal dune ecosystem. Colonies often occur where sparse vegetation traps winddispersed seeds, but causes minimal shading. Seeds are dispersed by wind mostly during late spring and summer months (USFWS 1998d).

Beach layia was federally listed as endangered on June 22, 1992 (57 FR 27848). Critical habitat has not been designated. As diseussed in the species account for Howell's spineflower, many non-native plants have invaded dune eommunities. In some cases, these non-native speeies have outcompeted and largely supplanted the native dune vegetation, ineluding beach layia, and the species remains vulnerable to the persistent encroachment by invasive speeies, and overstabilization of its near-shore dunes habitat. Oeean-level rise associated with elimate ehange poses another threat. A minor, but significant portion of the populations of beach layia at Humboldt Bay and the Mattole River, and the Freshwater Lagoon population, may be vulnerable to destruetion from frequent inundation and increased erosion resulting from oeean rise.

\section{Western Lily}

The primary references for this section are:

USFWS. 1998e. Reeovery Plan for the Endangered Western Lily (Lilium occidentale). Portland, Oregon.

and

USFWS. 2009u. Lilium occidentale (Western Lily) 5-Year Review: Summary and Evaluation. Areata Field Office. Areata, California.

Citations in this section are internal to the above referenced documents. Full citations and are included in the Bibliography. 
Western lily (Lilium occidentale) is restricted to a narrow strip along the immediate Pacific Coast between Coos Bay, Oregon, and Eureka, California where it occupies a variety of early successional habitats, including freshwater wetlands, coastal prairie and scrub, and the edges of Sitka spruce forest. It occurs in one of two soil conditions: mineral soils that possess an impermeable layer that serves to maintain moisture late into the growing scason; or organic marsh soils in whieh a fluctuating water table exposes the bulb during a critical portion of the growing season. The species is especially attractive to deer and small mammal browsers, which limit the reproductive output of the plant at many sites. It also appears well adapted to moderate levels of ungulate grazing and fire, both of which were undoubtedly important historieal faetors in maintaining its habitat across the range. Seedling and juvenile stage plants ean survive in shade, in some cases for long periods, if adequate moisture is available. Reproductive plants require relatively open conditions (Sehultz 1989, Imper 1997, Bencie and Kalt 2007).

The plants grow at low elevations, from almost sea level to about 300 feet, and from ocean-facing bluffs to about 4 miles inland. Common plant associates include the shrubs salal, western wax myrtle, western spiraea, huckleberry, blackberry, black twinberry, and glandular Labrador tea. Common tree associates include shore pine, Sitka sprucc, red alder, Port Orford cedar, and willow. Common herbaceous associates inelude Pacifie reed-grass, slough sedge, bunchberry, staff gentian, bracken fern, peat moss, and western tofieldia.

Western lily appears to require a habitat that maintains a balance between having some shrubbery and having too much. Vegetation less than 3 feet tall can be beneficial to the lily by sheltering juvenile plants from browsing by large mammals, providing structural support, and by providing shelter from the heat in July and August. This protection is most critical during spring and carly summer, becausc seedlings appear to tolerate dieback of aboveground parts later in the growing season. Dense, tall shrub growth reduces reproduction and survivorship, and closure of the forest canopy will eventually eliminate a population entirely.

Western lily is an attractive perennial member of the lily family that dies back to an underground bulb in the winter. The species reproduces primarily by seed, but asexual reproduction is possible from detached bulb scales growing into new plants. Shoots emerge primarily in March and April, although they can emerge as early as January in some locations. Flowers bloom in May to July. Rhizomes may produce one or more flowering shoots per year, cach typically with one to three, but up to 25, pendant flowers. Flowers often emerge above the surrounding shrubs, where they are available to pollinators such as hummingbirds. Capsular fruits become erect and may produce over 100 seeds when mature. Seeds are dispersed primarily by wind and gravity, generally within a radius of about 13 feet. Each year the aboveground portion of the plants die back and individuals overwinter underground as rhizomes/bulbs.

Western lily was federally listed as endangered on August 17, 1994 (59 FR 42171). Critical habitat has not been designated. The species is known or assumed to be extirpated in at least nine historical sites, as a result of forest suecession, cranberry farm development, livestock grazing, deer and mammal herbivory, highway construction, and other development. These factors continue to threaten the western lily, with development taking a primary role. Populations of the western lily appear to have been maintained in the past by occasional fires, at least at some sites in Oregon, and by grazing. Among the most serious threats to this species is loss of habitat as a result of ecological succession facilitated by aggressive fire suppression.

\section{San Diego Ambrosia}

The primary references for this section are:

USFWS. 1999f. Proposed Endangered Status for Ambrosia pumila (San Diego Ambrosia) from Southern California. Federal Register 64(249):72993-73003.

and

USFWS. 2010i. Endangered and Threatened Wildlife and Plants; Final Rule Designating Critical Habitat for Ambrosia pumila (San Diego ambrosia). Federal Register 75(229):74546-74604. 
References cited in this section are internal to the above-referenced documents. A complete list of these references is available from the USFWS Carlsbad Field Office, Carlsbad, California.

San Diego ambrosia (Ambrosia pumila) is distributed in southern California from northwestern Riverside County, south through western San Diego County, to northwestern Baja California, Mexico. It is generally found at or below elevations of 1,600 feet in Riverside County, and 600 feet in San Diego County (California Natural Diversity Database 2010). The species is found primarily on sandy loam or clay soils (Dudek 2000, California Natural Diversity Database 2010); native oceurrences of the plant are always found on upper river terraces with flat or gently sloping areas or within the watersheds of vernal pools. The species is primarily associated with native and non-native grassland and ruderal communities, and openings in coastal sage scrub. Associated native plant taxa include saltgrass, California Oreutt grass, mule-fat, and turkey-mullein. Populations of San Diego ambrosia occur on federal, state, and local government lands, and on private lands in western San Diego County, western Riverside County, and in the northern state of Baja California, Estado de Baja California, Mexico.

San Diego ambrosia is an herbaceous perennial that arises from a branched system of rhizome-like roots. This rhizomatous perennial habit results in groupings of aerial stems, often termed elones, that are, or at least were at one time, all attached to one another. The aerial stems sprout in early spring after the winter rains and deteriorate in late summer. Therefore, the plant may not be evident from late summer to early spring. This species is monoecious, with separate male and female flowers on the same plant, and is wind-pollinated. This species flowers from May through Oetober. Because it is clonal, the numbers of genetically different individuals in an oceurrence, especially small oceurrences, could be very low. It is possible that an oecurrenee that supports even 1,000 aerial stems may consist of very few plants. This suggests that the low genetic diversity within the smaller oceurrences may relegate these occurrences to extinetion (Barrett and Kohn 1991). The majority of the oceurrenees of this species are in San Diego County, with the remainder in western Riverside County.

San Diego ambrosia was listed as an endangered species on July 2, 2002 (67 FR 44372). On November 30, 2010 , the USFWS designated 783 acres in Riverside and San Diego Counties, California as eritical habitat for this species (75 FR 74546). San Diego ambrosia is threatened by the destruction, fragmentation, and degradation of habitat by recreational and commercial development; highway construction and maintenance; construetion and maintenance activities associated with a utility easement; competition from non-native plants; trampling by horses and humans; and OHV use.

\section{San Diego Thornmint}

The primary reference for this section is:

USFWS. 1998f. Determination of Endangered or Threatened Status for Four Plants from Southwestern California and Baja California, Mexico. Federal Register 63(197):54937-54956.

References eited in this section are internal to the above-referenced document. A complete list of these references is available from the USFWS Carlsbad Field Office, Carlsbad, California.

The 2009 5-year review for the San Diego thornmint (USFWS 2009v) was consulted for updated information on this species.

San Diego thornmint (Acanthomintha ilicifolia) is an annual aromatic herb of the mint family that usually occurs on heavy clay soils in openings within coastal sage scrub, chaparral and native grassland of coastal San Diego County, and in isolated populations south to San Telmo in northern Baja California, Mexico (Beauchamp 1986; Reiser 1996; USFWS, unpublished data). The species is frequently associated with gabbro soils which are derived from igneous rock, and also occurs in calcareous marine sediments. At the time of its listing in 1998, there were 32 known populations of the San Diego thornmint in the United States, ranging from San Mareos east to Alpine and south to Otay Mesa in San Diego County (Reiser 1996, California Native Natural Diversity Database 1997, Roberts 1997a), and covering an estimated 400 acres. As of 2009, there were records for 80 oceurrences, 55 of which were considered to be extant (USFWS 2009v). Four major populations of this species are located within the Multiple Species Conservation Program planning subregion of southern San Diego County, California. The 
remaining major populations are located either north or east of the Multiple Species Conservation Program subregion, either on lands administered by the Forest Service (on Viejas and Poser mountains), or on privately owned lands (California Native Natural Diversity Database 1997, Roberts 1997a).

San Diego thornmint was federally listed as threatened on October 13, 1998 (63 FR 54938). On August 26, 2008, the USFWS designated approximately 671 acres of land in San Diego County as eritical habitat for this species (73 FR 50454). Most of the population increases in Southern California have oceurred within or near sites historically occupied, in part, by coastal sage scrub. Habitat destruction and modification have negatively affected species native to this area by reducing population densities and contributing to habitat fragmentation. Currently, the most pervasive rangewide threat for the San Diego thornmint is non-native plant species. An influx of non-native plant species has been shown to alter the open character of the species' habitat. Additionally, experiments have shown significant reductions in size and reproductive output of plants that are crowded by non-native plant species. The species is also negatively affected by OHV use, increased erosion, grazing, and trampling by humans (USFWS 2009v).

\section{Otay Tarplant}

The primary reference for this section is:

USFWS. 1998f. Determination of Endangered or Threatened Status for Four Plants from Southwestern California and Baja California, Mexico. Federal Register 63(197):54937-54956.

References eited in this section are internal to the above-referenced document. A complete list of these references is available from the USFWS Carlsbad Field Office, Carlsbad, California.

The 2009 5-year review for the Otay tarplant (USFWS 2009w) was also consulted for updated information on this species.

Otay tarplant (Deinandra conjugens) is an annual in the aster family. The distribution of this species is highly correlated with the distribution of clay soils or clay subsoils (Morey 1994), and plants are typically found growing in clay soils or on clay intrusions on slopes and mesas within native and mixed (native and non-native) grassland or open coastal sage serub habitats. Clay soils offering suitable habitat for the Otay tarplant have been much reduced in acreage, primarily by urbanization and cultivation. There are 34 extant native occurrenees distributed discontinuously across 900 acres in southwestern San Diego County, California near Otay Mesa, and there is also one known population near the United States border in Baja California, Mexico (California Department of Fish and Game 1994, Morey 1994, Reiser 1996, California Natural Diversity Database 1997, Roberts 1997b, USFWS $2009 \mathrm{w}$ ). The five largest populations of Otay tarplant are Horseshoe Bend-Gobblers Knob (Rancho San Miguel), Rice Canyon, Poggi Canyon, Proctor Valley, and Dennery Canyon (OGDEN 1992a, Morey 1994, Stone 1994, San Diego Gas and Electric 1995, City of San Diego and USFWS 1996b, Roberts 1997b). All populations of this species in the U.S. are on private lands. The Otay tarplant appears to tolerate mild levels of disturbance such as light grazing, which create sites necessary for germination (Tanowitz 1977, Hogan 1990).

Bees are the most likely pollinators, and overall levels of pollinators are higher in native coastal sage shrub habitat in comparison to sites dominated by non-native species. Like all annual species, population numbers can vary widely from year to year depending on seed bank conditions and local weather.

Otay tarplant was federally listed as threatened on October 13, 1998 (63 FR 54938). On December 10, 2002 (67 FR 76030), the USFWS designated approximately 2,560 acres in San Diego, California, as critical habitat. Most of the population increases in Southern California have occurred within or near sites historically occupied, in part, by coastal sage scrub. About 220,000 acres of coastal sage scrub remain in San Diego County (USFWS 1996). Habitat destruction or modification negatively affects species native to this area by reducing population densities and contributing to habitat fragmentation. Rapid urbanization and agricultural conversion in Orange and San Diego Counties has already affected populations of the San Diego thornmint, and habitat loss and fragmentation is expected to continue as the human population expands, although significant amounts of habitat for the species has 
been protected in preserves and other conservation areas. The species is also negatively affected by the invasion of non-native plants, OHV use, increased erosion, grazing, and trampling by humans (USFWS 2009w).

\section{Otay Mesa-mint}

The primary reference for this section is:

USFWS. 1993e. Determination of Endangered Status for Three Vernal Pool Plants and the Riverside Fairy Shrimp. Federal Register 58(147):41384-41392.

References cited in this section are internal to the above-referenced documents. A complete list of references from is available from the USFWS Carlsbad Ficld Office, Carlsbad, California.

The 2010 5-ycar rcview for the Otay mesa-mint (USFWS 2010j) was also consulted for updated information about this species.

Otay mesa-mint (Pogogyne nudiuscula) occurs in vernal pool habitat on Otay Mcsa in San Dicgo County. Little species-specific information detailing habitat requircments is available, cxccpt that the species is found exclusively associated with vernal pools. It is often found with other federally listed species, including San Diego buttoncclery, California Orcutt grass, and Riverside fairy shrimp. Vernal pools arc specific habitats that form in areas with Mediterranean climates, where slight depressions become seasonally wet or inundated following fall and winter rains. The presence of an impervious layer such as hardpan, clay, or basalt beneath the soil surface causes water to remain in these pools for a few months at a time. In the spring, gradual drying occurs (Holland 1976). The pools form on mesa tops or valley floors and are interspersed among very low hills (Zedler 1987). The distribution of Otay mesa-mint has decrased since it was listed in 1993 and it may now be extant at only three locations (USFWS 2010j).

Otay mesa-mint is an crect annual that usually blooms in May and Junc when water is absent from its vernal pool habitat (Munz 1974). The plants then produce fruit, dry out, and scnesce during the hot, dry summer months. Therc is little documented information regarding pollination and sced dispersal mechanisms of the species, but observations suggest that native syrphid flics and bee flies are the most common pollinators. Eurasian honeybees have also bcen seen pollinating Otay mesa-mint (USFWS 2010j). A member of the mint family, this plant is aromatic, with bright purple flowers occurring on spikes.

Otay mesa-mint was federally listed as cndangered on August 3, 1993 (58 FR 41384). Critical habitat has not been designated. Agricultural development is widespread and increasing in areas where vernal pool habitat is typically found (Moran 1981). Alteration of the watcrshed, habitat fragmentation, OHV usc, trampling, road projects, human access and disturbance, firc and fire suppression, and climatc change threaten the continued existence of the Otay mesa-mint, and the small range and narrow habitat tolerances of Otay mesa-mint make this specics particularly vulncrable.

\section{California Orcutt Grass}

The primary refercnce for this section is:

USFWS. 1993e. Determination of Endangered Status for Three Vernal Pool Plants and the Riverside Fairy Shrimp. Federal Register 58(147):41384-41392.

References citcd in this section are internal to the above-referenced document. A complete list of references is availablc from the USFWS Carlsbad Field Office, Carlsbad, California.

The 2011 5-year review for California Orcutt grass (USFWS $2011 \mathrm{p}$ ) was also consulted for updated information about this species.

California Orcutt grass (Orcuttia californica) is an inconspicuous annual grass restricted to southern California and few historical occurrences in northern Baja California, Mexico. This species is closely associated with deep ephemeral vernal pools underlain by clay soils. The specics is currently cxtant in Ventura, Los Angeles, Riverside, 
and San Diego Counties from 28 occurrences (USFWS 201 lp). It is variously associated with other federally listed vernal pool taxa including San Diego button celery, San Diego mesa-mint, Otay mesa-mint, spreading navarretia, San Diego fairy-shrimp, and Riverside fairy-shrimp. California Oreutt grass occurs in vernal pools on The Nature Conservancy's Santa Rosa Plateau Preserve, in a vernal pool within Salt Creek drainage near Hemet (D. Bramlet 1992), and in the Skunk Hollow pool in Riverside County (Lathrop 1976). In San Diego County, this species is present in pools on Otay Mesa (Bauder 1986). One population of California Orcutt grass is present in a vernal pool in Woodland Hills of Ventura County, California.

California Orcutt grass is a member of the grass family that is associated with deeper pools of water than Otay mesa-mint. It is a tufted annual grass 2 to 8 inches tall. Its seeds germinate in the deepest portion of vernal pools and plants are at first nearly prostrate. The plants produce more ereet glandular pubescent stems when they are exposed as the pool dries up and subsequently produce flowers and seeds.

California Orcutt grass was federally listed as endangered on August 3, 1993 (58 FR 41384). Critieal habitat has not been designated. Agricultural development is widespread and increasing in areas where vernal pool habitat is typically found (Moran 1981). Habitat loss and degradation due to urban and agricultural development, livestock grazing, OHV use, trampling, invasion from weedy non-native plants, and other factors threaten the continued existence of California Oreutt grass.

\section{Hairy Orcutt Grass}

The primary reference for this section is:

USFWS. 1997b. Determination of Endangered Status for Three Plants and Threatened Status for Five Plants from Vernal Pools in the Central Valley of California. Federal Register 62(58):14338-14352.

References eited in this section are internal to the above-referenced doeument. A complete list of these referenees is available from the USFWS Sacramento Field Offiee, Sacramento, California.

The 2007 5-year review for hairy Oreutt grass (USFWS 2007j) was consulted for updated information on this species.

Hairy Orcutt grass (Orcuttia pilosa) is found in the basins and margins of vernal pools of the Central Valley of California. It oecurs in northern basalt flow, northern claypan, and northern hardpan vernal pools (Sawyer and Keeler-Wolf 1995) within annual grasslands (California Natural Diversity Database 2003), from 85 feet to 400 feet in elevation. Similar to the vernal pools found in other geographic areas, these pools are typically small, seasonally aquatic ecosystems that are inundated with water in the winter and dry slowly in the spring and summer, ereating a harsh, unique environment. Within the Central Valley (a geographic area that consists of the Sacramento Valley in the northern half of the state and the San Joaquin Valley in the southern half), vernal pools are found in four physiographic settings, each possessing an impervious soil layer relatively close to the surface: high terraces with iron-silicate or volcanic substrates, old alluvial terraces, basin rims with claypan soils, and low valley terraces with silica-carbonate claypans. Due to local topography and various geological populations, vernal pools are usually clustered into pool complexes. The vernal pool habitats and the threatened and endangered species found therein occur over a very limited, discontinuous, fragmented area within the Central Valley. As of 2007, 23 natural and 1 introduced occurrence were presumed extant; of these, 13 are on privately owned land and have no protected status and 11 are on land that is protected. (USFWS 2007j).

Hairy Orcutt grass was federally listed as endangered on March 26, 1997 (62 FR 14338). On August 6, 2003 (68 FR 46684), the USFWS designated approximately 1,184,513 acres of vernal pool habitat as critical habitat for this and other vernal pool species. In August, 2005 (70 FR 46924), this acreage was reduced to 858,846 acres, and in February 2006 (71 FR 7118), the designation was revised to identify critical habitat for each individual species. Factors that imperil the continued existence of Central Valley vernal pool species include habitat loss and degradation as a result of urbanization, agricultural land conversion, livestock grazing, OHV use, a flood control project, a highway project, altered hydrology, landfill projects, and competition from weedy, non-native plants. 


\section{Greene's Tuctoria}

The primary referenee for this seetion is:

USFWS. 1997b. Determination of Endangered Status for Three Plants and Threatened Status for Five Plants from Vernal Pools in the Central Valley of California. Federal Register 62(58):14338-14352.

Referenees eited in this seetion are internal to the above-refereneed doeument. A eomplete list is available from the USFWS Saeramento Field Offiee, Saeramento, California.

The 2007 5-year review for Greene's tuetoria (USFWS 2007k) was eonsulted for updated information on this speeies.

Greene's tuetoria (Tuctoria greenei), like hairy Oreutt grass diseussed previously, is found in the basins and margins of vernal pools of the Central Valley of California. Greene's tuetoria is a tufted, annual grass that grows 2 to 6 inehes tall. The present range of this speeies eovers 258 miles, with 21 extant populations known from Tehama, Butte, Glenn, and Mereed Counties. The largest eoneentration of the presumed extant loealities are loeated in the Vina Plains area, in Tehama and Butte Counties, where 11 loealities are presumed extant. The next largest eoneentration of loealities is in eastern Mereed County, where five loealities are presumed extant (USFWS 2007k). The only proteeted loealities inelude five within The Nature Conservaney's Vina Plains Preserve, in Tehama and Butte Counties, and one at the Drayer Raneh Conservation Bank, in Mereed County. Greene's tuetoria frequently eo-oeeurs with sueh native plants as Great Valley button eelery and hairy water elover (Alexander and Sehlising 1997), Vasey's eoyote thistle, and stalked popeorn flower. Other federally listed plants that eo-oeeur with Greene's tuetoria at one or more loeations inelude Hoover's spurge, hairy Oreutt grass, San Joaquin Valley Oreutt grass, slender Oreutt grass, and Colusa grass (USFWS 2007k).

Greene's tuetoria was federally listed as endangered on Mareh 26, 1997 (62 FR 14338). On August 6, 2003 (67 FR 59884), the USFWS designated approximately $1,184,513$ aeres of vernal pool habitat as eritieal habitat for this and other vernal pool speeies. In August, 2005 (70 FR 46924), this aereage was redueed to 858,846 aeres, and in February 2006 (71 FR 7118), the designation was revised to identify eritieal habitat for eaeh individual speeies. Faetors that imperil the eontinued existenee of Central Valley vernal pool speeies inelude eonversion of habitat to agrieulture, intensive grazing during the plant's flowering season (May to June), eompetition from weedy invasive plants, and possibly grasshopper predation (USFWS 2007k).

\section{Fleshy Owl's-clover}

The primary referenee for this seetion is:

USFWS. 2011q. Castilleja campestris spp. succulenta (Fleshy Owl's-Clover) 5-Year Review: Summary and Evaluation. Saeramento Fish and Wildlife Offiee. Saeramento, California.

Referenees eited in this seetion are internal to the above-refereneed doeument. Full eitations are ineluded in the Bibliography.

Fleshy owl's-elover (Castilleja campestris ssp. succulenta), is found primarily in vernal pools, and only in the lower rolling foothill areas of the eastern San Joaquin Valley in the Southern Sierra Foothills Vernal Pool Region (USFWS 2005e). The speeies oeeurs in northern elaypan and northern hardpan vernal pools (Sawyer and KeelerWolf 1995) within annual grassland eommunities (California Natural Diversity Database 2009). The speeies has an affinity toward loams with some possibility of oeeurring in elay soils. Ninety oeeurrenees of this speeies were extant as of 2009. The majority of the extant oeeurrenees - approximately 69 pereent-oeeur in the eastern seetion of Mereed County. Twelve known oeeurrenees (or 13 pereent of the total presumed extant oeeurrenees) are loeated in Madera County, and 11 oceurrenees (12 pereent) are loeated in Fresno County, with additional oeeurrenees in southeastern San Joaquin and Stanislaus Counties. Plants most eommonly reported as oeeurring with fleshy owl'selover are Fremont's goldfields (EIP Assoeiates 1999), downingia, three-eolored monkey-flower, vernal pool popeorn flower, and eoyote thistle. Other plants that have been reported growing with fleshy owl's-elover inelude Colusa grass, San Joaquin Valley Oreutt grass), hairy Oreutt grass, Boggs Lake hedge-hyssop (EIP Assoeiates 1999, California Natural Diversity Database 2005); and spiny-sepaled button-eelery (EIP Assoeiates 1994). 
Fleshy owl's-clover is a partly parasitic, annual herb with stems that are generally 2 to 10 inches tall. It produces bright yellow to white flowers in April and May. Many different plants can serve as hosts for this plant. Seeds of the fleshy owl's-clover do not require the presence of a host to germinate, as they form root connections only after reaching a seedling stage.

Fleshy owl's-clover was federally listed as threatened on March 26, 1997 (62 FR 14338). On August 6, 2003 (67 FR 59884), the USFWS designated approximately 1,184,513 acres of vernal pool habitat as critical habitat for this and other vernal pool species. In August, 2005 (70 FR 46924), this aereage was reduced to 858,846 acres, and in February 2006 (71 FR 7118), the designation was revised to identify critical habitat for each individual species. Factors that imperil the continued existenee of Central Valley vernal pool species include habitat loss and degradation as a result of urbanization, agricultural land conversion, livestock grazing, OHV use, a flood control project, a highway project, altered hydrology, landfill projects, the small size of existing populations, and competition from weedy, non-native plants.

\section{Hoover's Spurge}

The primary reference for this section is:

USFWS. 2009x. Chamaesyce hooveri (Hoover's Spurge) 5-Year Review: Summary and Evaluation. Sacramento Fish and Wildlife Office. Sacramento, California.

References cited in this seetion are internal to the above-referenced document. Full citations are included in the Bibliography.

Hoover's spurge (Chamaesyce hooveri) is known from a few widely separated populations. The core habitat areas are distributed among four vernal pool regions: Northeastern Sacramento Valley, Solano-Colusa, San Joaquin Valley, and Southern Sierra Foothills. The main area of concentration is within the Northeastern Sacramento Valley Vernal Pool Region. The Vina Plains of Tehama and Butte Counties contain 15 (56 pereent) of the 27 presumed extant sites for Hoover's spurge (California Natural Diversity Database 2007) in an area of about 35 square miles (Stone et al. 1988). One other site in the same region is near Chico in Butte County. Seven of the extant occurrences are in the Southern Sierra Foothills Vernal Pool Region, including five in the Visalia-Yettem area of Tulare County and two in the Hickman-La Grange area of Stanislaus County. Three other oecurrenees are on the Sacramento National Wildlife Refuge in Glenn County, which is in the Solano-Colusa Vernal Pool Region. The one other extant oceurrenee is on the Bert Crane Ranch in Mereed County, which is within the San Joaquin Valley Vernal Pool Region (Keeler-Wolf et al. 1998; California Natural Diversity Database 2007).

This species is currently found in three types of vernal pools: northern basalt flow, northern claypan, and northern hardpan on both low and high terraces (Stone et al. 1988). Vernal pools supporting Hoover's spurge typically oceur on alluvial fans or terraces of ancient rivers or streams, with a few on the rim of the Central Valley basin. In addition, the species has been reported from several pools that were formed artificially when small ponds were created in appropriate soil types (California Natural Diversity Database 2007). This species may oceur along the margins or in the deepest portions of the dried pool-bed (Stone et al. 1988; Alexander and Schlising 1997). Deeper pools apparently provide better habitat for this species because the duration of inundation is longer and the deeper portions are nearly devoid of other vegetation, thus limiting competition from other plants (Stone et al. 1988; Stebbins 2000). Throughout its range, two of the most frequent associates of Hoover's spurge are the rare vernal pool grasses Greene's tuctoria and hairy Orcutt grass.

Hoover's spurge is a summer annual member of the spurge family, and forms gray-green mats from a few inches to a few feet across. Flowering occurs in July. It tends to oceur where competition from other species has been reduced by prolonged seasonal inundation or other factors.

Hoover's spurge was federally listed as threatened on March 26, 1997 (62 FR 14338). On August 6, 2003 (67 FR 59884), the USFWS designated approximately 1,184,513 acres of vernal pool habitat as critical habitat for this and other vernal pool species. In August, 2005 (70 FR 46924), this acreage was reduced to 858,846 acres, and in February 2006 (71 FR 7118), the designation was revised to identify critical habitat for each individual species. 
Faetors that imperil the eontinued existenee of Central Valley vernal pool species inelude habitat loss and degradation as a result of urbanization, agrieultural land conversion, livestoek grazing, OHV use, a flood control projeet, a highway project, altered hydrology, landfill projeets, and competition from weedy, non-native plants. Drought, elimate change, and small population sizes may also threaten the speeies.

\section{San Joaquin Valley Orcutt Grass}

The primary referenee for this seetion is:

USFWS. 1997b. Determination of Endangered Status for Thrce Plants and Threatened Status for Five Plants from Vcrnal Pools in the Central Valley of California. Federal Register 62(58):14338-14352.

San Joaquin Valley Orcutt grass (Orcuttia inaequalis), like the speeies diseussed in the previous four speeies aeeounts, is found in the basins and margins of vernal pools of the Central Valley of California. San Joaquin Vallcy Oreutt grass is a tufted annual that reaehes 2 to 6 inches in height. Most of the remaining populations of this speeies are diseontinuously seattered over a 36-mile area in southeastern San Joaquin Valley, in Fresno, Mereed, and Madera Counties. Two populations are on federal land, one on land administered by the BLM and one transplanted population on land administered by the Bureau of Reclamation. The remaining populations are found on privately owncd lands.

San Joaquin Valley Orcutt grass was federally listed as threatened on Mareh 26, 1997 (62 FR 14338). On August 6, 2003 (67 FR 59884), the USFWS designated approximately 1,184,513 aeres of vernal pool habitat as critieal habitat for this and other vernal pool speeies. In August, 2005 (70 FR 46924), this aereage was reduced to 858,846 acres, and in February 2006 (71 FR 7118), the designation was revised to identify eritical habitat for eaeh individual speeies. Faetors that imperil the continued existenee of Central Valley vernal pool speeies include habitat loss and degradation as a result of urbanization, agrieultural land eonversion, livestoek grazing, OHV use, a flood eontrol projeet, a highway project, altered hydrology, landfill projeets, and eompetition from weedy, nonnative plants.

\section{Slender Orcutt Grass}

The primary refercnce for this seetion is:

USFWS. 1997b. Determination of Endangered Status for Three Plants and Threatened Status for Five Plants from Vernal Pools in the Central Valley of California. Federal Register 62(58):14338-14352.

The 2009 5-year review for slender Oreutt grass (USFWS 2009y) was eonsulted for updated information on this speeies.

Slender Oreutt grass (Orcuttia tenuis), like the speeies diseussed in the previous five speeies aecounts, is endemie to vernal pools of the Central Valley of California. Disjunet oeeurrenees are found in vernal pools on remnant alluvial fans, high stream terraees and reeent basalt flows from the Modoe Plateau in northeastern California, west to Lake County, and south through the Central Valley to Saeramento County, with populations in Lake, Lassen, Plumas, Saeramento, Shasta, Siskiyou, and Tehama Counties. The majority of these populations are on privately owned lands. The City of Redding owns lands eontaining two populations, and the remaining populations are found on land administered by the Forest Serviee and the BLM. The speeies has also been reported from other natural and artifieial seasonal wetlands, although most sueh loeations are altered vernal pool habitats. The speeies oeeurs aeross a wide range of elevations ( 90 to 5,761 feet) but is associated primarily with vernal pool habitat on northern voleanie ashflow and northern voleanie mudflow substrates. The speeies is typieally assoeiated with larger or deeper vernal pools that have relatively long periods of inundation followed by gradual desieeation. The speeies is known to oeeur in 86 loeations, though populations of this annual species ean vary greatly from year to year (USFWS 2009y).

Slender Oreutt grass is a weakly-tufted annual grass that grows to about 2 to 6 inehes in height, produeing one to several ereet stems that often braneh from the upper nodes. 
Slender Oreutt grass was federally listed as threatened on March 26, 1997 (62 FR 14338). On August 6, 2003 (67 FR 59884), the USFWS designated approximately 1,184,513 acres of vernal pool habitat as critical habitat for this and other vernal pool species. In August, 2005 (70 FR 46924), this acreage was reduced to 858,846 acres, and in February 2006 ( 71 FR 7118), the designation was revised to identify critical habitat for each individual species. Factors that imperil the continued existence of Central Valley vernal pool species include habitat loss and degradation as a result of urbanization, agricultural land conversion, livestock grazing, OHV use, a flood control project, a highway project, altered hydrology, landfill projects, and competition from weedy, non-native plants.

\section{Colusa Grass}

The primary reference for this section is:

USFWS. 2005c. Recovery Plan for Vernal Pool Ecosystems of California and Southern Oregon. Region 1 U.S. Fish and Wildlife Service. Portland, Oregon.

References cited in this section are internal to the above-referenced document. Full citations are included in the Bibliography.

Colusa grass (Neostapfia colusana) is endemic to the vernal pool ecosystems of California, where the majority of occurrences are in the Southern Sierra Foothills Vernal Pool Region, primarily northeast of the City of Merced in Merced County and east of Hickman in Stanislaus County. The species also oceurs in the San Joaquin Valley Vernal Pool Region in central Merced County, and in the Solano-Colusa Vernal Pool Region in southeastern Yolo and central Solano Counties (Stone et al. 1988; Keeler-Wolf et al. 1998; California Natural Diversity Database 2003). It is believed to be extirpated from Colusa County.

Colusa grass has a broad ecological range, occurring on the rim of alkaline basins, as well as on acidic soils of alluvial fans and stream terraces. It is found at elevations from 18 feet to 350 fect (California Natural Diversity Database 2003).

Colusa grass is an annual species, with adaptations for living in vernal pool habitats. Seeds germinate underwater, and juvenile plants have eylindrical leaves that are clustered into a basal rosette. After the pool dries, terrestrial leaves with flattened blades form along the stem (Keeley 1998). Plants flower during the summer months, and are wind pollinated. Seeds are dispersed by water, which breaks up inflorescences (Reeder 1965, Crampton 1976, Griggs 1980, 1981). The seeds remain dormant for at least 3 years, and germinate underwater after prolonged periods of immersion (Crampton 1976, Griggs 1980, Keeley 1998). Population sizes vary depending on the amount of rainfall in a given year.

Colusa grass was federally listed as threatened on March 26, 1997 (62 FR 14338). On August 6, 2003 (67 FR 59884), the USFWS designated approximately 1,184,513 acres of vernal pool habitat as critical habitat for this and other vernal pool species. In August, 2005 (70 FR 46924), this acreage was reduced to 858,846 acres, and in February 2006 (71 FR 7118), the designation was revised to identify critical habitat for each individual species. Threats to Colusa grass include general threats to the vernal pool ecosystems: habitat loss and fragmentation as a result of urbanization, agricultural conversion, and mining; and habitat alteration and degradation as a result of changes to natural hydrology, invasive species, incompatible grazing regimes, infrastructure projects, recreational activities, erosion, climatic and environmental change, and contamination. Agricultural conversion and urbanization are the two greatest threats to Colusa grass. Additional threats to the species include inundation by poultry manure, damage by herbicide applications, and contaminations of groundwater by industrial chemicals.

\section{Contra Costa Goldfields}

The primary reference for this section is:

USFWS. 2008j. Contra Costa Goldfields (Lasthenia conjugens) 5-Year Review: Summary and Evaluation. Sacramento Fish and Wildlife Office. Sacramento, California.

References cited in this section are internal to the above-referenced document. A complete list of these references is available from the USFWS Sacramento Field Office, Sacramento, California. 
Contra Costa goldfields (Lasthenia conjugens) typically grows in vernal pools, swales, moist flats, and depressions within a grassland matrix (California Natural Diversity Database 2007), and has been found in three types of vernal pools: northern basalt flow, northern claypan, and northern volcanic ashflow (Sawyer and Keeler-Wolf 1995). Contra Costa goldficlds typically occurs at elevations up to 200 feet, although one population has been recorded at 1,460 feet. As of 2007, there were 20 extant occurrences in 10 California counties, including Alameda, Contra Costa, Marin, Mendocino, Monterey, Napa, Santa Barbara, Santa Clara, Solano, and Sonoma. Nine of the occurrences are protected; all other populations are on privately owned lands. The two most commonly reported associates are Italian ryegrass and popcorn flower. Other plant species that occur at several Contra Costa goldfield sites include brass buttons, valley downingia, California eryngo, smooth goldfields, common mousetail, and California semaphore grass. Other rare plants that co-occur with Contra Costa goldfields include alkali milk-vetch, few-flowered navarretia, and Grecne’s legenere (California Natural Diversity Database 2007).

Contra Costa goldficlds is a showy spring annual in the aster family that grows 4 to 12 inches tall and is usually branched. It flowers from March to June, producing yellow flowers in terminal heads.

Contra Costa goldfields was fcderally listed as endangered on June 18, 1997 (62 FR 33029). On August 6, 2003 (67 FR 59884), the USFWS designated approximately $1,184,513$ acres of vernal pool habitat as critical habitat for Contra Costa goldfields and other vernal pool species. In August, 2005 ( 70 FR 46924), this acreage was reduced to 858,846 acres, and in February 2006 (71 FR 7118), the designation was revised to identify critical habitat for each individual species. The primary factors threatening the continued existence of the Contra Costa goldfields are habitat loss and degradation. Damage or destruction of vernal pool habitat happens quickly and easily due to the extremely crumbly nature of the soil and the dependency of the pool upon an intact durapan or impermeable subsurfacc soil layer. Threats to the Contra Costa goldfields are posed by urbanization, agricultural land conversion, wetland drainage, trampling by cattle, vernal pool and pond construction, ditch construction, OHV use, road maintenance, or random natural events.

\section{Cook's Lomatium}

The primary references for this spccies are:

USFWS. 2002c. Determination of Endangered Status for Lomatium cookii (Cook's Lomatium) and Limnanthes floccosa ssp. grandiflora (Largc-flowered Woolly Meadowfoam) from Southern Oregon. Federal Register 67(216):68003-68015.

and

USFWS. 2010k. Endangered and Threatened Wildlife and Plants; Designation of Critical Habitat for Limnanthes floccosa ssp. grandiflora (Large-Flowered Woolly Meadowfoam) and Lomatium cookii (Cook's Lomatium). Federal Register 75(139):42490-42570.

References cited in this scction are internal to the above-referenced documents. A complete list of these references is available from the Oregon Fish and Wildlife Office, Portland, Oregon.

The 2011 5-year review for Cook's lomatium (USFWS 2011r) was consulted for additional information about this species.

Cook's lomatium (Lomatium cookii) occurs in vernal pool habitats in a small area of Jackson County, within the Rogue River Valley in southwestern Oregon. It is also known to occur in seasonally wet habitats at sites in the Illinois River Valley in Josephine County, the adjacent county to the west. Cook's lomatium is known to occur at about 13 sites in Jackson County and at about 38 sites in Josephine County (USFWS 2011 r).

Cook's lomatium occurs within a 32-square-mile landform in southwestern Oregon known as the Agate Desert in Jackson County. This landform is characterized by shallow soils, a relative lack of trees, sparse prairie vegetation, and agates commonly found on the soil surface (Oregon Natural Heritage Program 1997). Vernal pools in the Agate Desert vary in size from 3 to 100 feet across, and attain a maximum depth of about 12 inches (Oregon 
Natural Heritage Program 1997). Common associated native species in these vernal pools include popcorn flower, a rush, navarretia, common woolly meadowfoam, and annual hairgrass.

Cook's lomatium also occurs in another area of about 4 square miles in adjacent Josephine County. This area, referred to as French Flat, is located within the Illinois Valley near the Siskiyou Mountains. In this area, Cook's lomatium grows in wet meadow areas underlain with floodplain bench deposits that contain sufficient clay to form a clay pan at 24 to 35 inches below the soil surface (U.S. Department of Agriculture 1983). The clay pan creates seasonally wet areas similar to the vernal pools of the Agate Desert, but mostly lacking in mound-swale topography. Common associated species include California oatgrass, popeorn flower, horkelia, mariposa lily, and trout lily. The surrounding forest contains ponderosa pine and Jeffrey pine.

Cook's lomatium is a perennial forb in the carrot family that grows from a slender, twisted taproot. The species is adapted to grow, flower, and set seed during the short time that water is available in the spring, finishing its life cycle before the dry hot summers.

Cook's lomatium was federally listed as endangered on November 7, 2002 (67 FR 68004). Critical habitat for this species, which was designated on July 21, 2010 (75 FR 42490), includes 6,289 acres in Jackson and Josephine Counties. The primary threat to Cook's lomatium is the destruetion of vernal pool habitat by industrial and residential development, including road and powerline construction and maintenance. Agricultural conversion, certain grazing practices, and OHV use also contribute to population declines and local extirpations. Recent evidence also indicates that non-native annual grasses, particularly medusahead, are a greater problem than previously believed. Unlike native perennial bunchgrasses that originally oecupied the area, annual grasses die back each year, creating a buildup of thatch from the dead leaves that interferes with the seed germination of native species. Current observations indicate that, without control of annual grasses through mowing, grazing, or prescribed burns, populations tend to decrease over time, and could be extirpated within a relatively short time frame as a result of competition with non-native grasses (Borgias 2002). Additionally, Cook's lomatium sites in Josephine County are threatened by habitat alteration associated with gold mining and woody species encroachment resulting from fire suppression.

\section{Large-flowered Woolly Meadowfoam}

The primary reference for this species is:

USFWS. 2002c. Determination of Endangered Status for Lomatium cookii (Cook's Lomatium) and Limnanthes floccosa ssp. grandiflora (Large-flowered Woolly Meadowfoam) from Southern Oregon. Federal Register 67(216):68003-68015.

References cited in this section are internal to the above-referenced document. A complete list of these references is available from the State Supervisor, USFWS, Oregon Fish and Wildlife Office, Portland, Oregon.

Large-flowered woolly meadowfoam (Limnanthes floccosa ssp. grandiflora), like Cook's lomatium discussed in the previous species account, occurs in vernal pool habitats in a small area of Jackson County, southwestern Oregon. The species is known to oceur at about 15 sites in Jackson County (Oregon Natural Heritage Information Center Database 2002, USDOI BLM 2002).

The large-flowered woolly meadowfoam occurs within the Agate Desert, a landform that was described in the previous species account. This landform is characterized by shallow soils, a relative lack of trees, sparse prairic vegetation, and agates commonly found on the soil surface (Oregon Natural Heritage Program 1997). Vernal pools in the Agate Desert vary in size from 3 to 100 feet across, and attain a maximum depth of about 12 inches. Common associated native species in these vernal pools include popcorn flower, a rush, navarretia, common woolly meadowfoam, and annual hairgrass.

The large-flowered woolly meadowfoam is a delicate annual of the meadowfoam family that is covered with short, fuzzy hairs. Like Cook's desert-parsley, plants are adapted to grow, flower, and set seed during the short time that 
water is available in the spring, finishing their life eycle before the dry hot summers. Each year, plant populations exhibit some natural variation in numbers, related primarily to temperature and rainfall conditions for that year.

The large-flowered woolly meadowfoam was federally listed as endangered on November 7, 2002 (67 FR 68004). The USFWS designated 5,840 aeres of eritical habitat for the speeies on July 21, 2010 (75 FR 42490). The primary threat to the large-flowered woolly meadowfoam is the destruetion of vernal pool habitat by residential, urban, and commercial development; aggregate and mineral mining; agrieultural development (including leveling, ditching, tilling, and stock pond construction or water impoundments); road construction and maintenance; OHV use that affects surface hydrology; vandalism (related to OHV use); incompatible grazing practices; and encroachment by non-native plants, particularly medusahead (USFWS 2010k).

\section{Butte County Meadowfoam}

The primary references for this section is:

USFWS. 2008k. Limnanthes floccosa ssp. californica (Butte County Meadowfoam). 5-Year Review: Summary and Evaluation. U.S. Fish and Wildlife Service Sacramento Fish and Wildlife Office. Sacramento, California.

References eited in this seetion are internal to the above-referenced document. They are included in the Bibliography.

Butte County meadowfoam (Limnanthes floccosa ssp. californica) is a narrowly distributed annual plant in the meadowfoam or false mermaid family. The range of the subspecies lies entirely within Butte County, California. Limnanthes floccosa ssp. californica is found primarily on the margins of vernal swales and to a lesser extent on the margins of vernal pools located on alluvial terraces in annual grasslands with mima mound topography. Mima mounds are soil mounds of unknown origin that are a few feet in height. The species is restrieted to a narrow 28mile strip along the eastern flank of the Sacramento Valley from northwestern to eentral Butte County (California Natural Diversity Database 2007). There are 20 natural, extant Butte County meadowfoam oceurrences and one introduced oceurrence that are found between 165 and 1,167 feet in elevation (McNeill and Brown 1979, Sellers 2006, California Natural Diversity Database 2007).

Butte County meadowfoam is a densely pubescent, herbaceous winter annual. The plant begins to produce white flowers with dark yellow veins in February, reaches peak flowering in March, and may continue flowering into April if conditions are suitable. Seeds are produced in March and April, and the plants die back by early May (Jokerst 1989). Seeds then germinate in the late fall after the rainy season begins. The plant has floral adaptations that allow for cross-pollination by inseets, but self-pollination mechanisms take over to ensure seed set if inseet pollination is unsuceessful. Potential pollinators include native burrowing bees, honeybees, beetles, flies, true bugs, butterflies, and moths. This species has poor seed dispersal, making it poorly equipped to escape chance catastrophes.

Butte County meadowfoam was federally listed as endangered on June 8, 1992 (57 FR 24192). On August 6, 2003, the USFWS designated approximately $1,184,513$ acres of vernal pool habitat as eritical habitat for the Butte County meadowfoam and other vernal pool species. In August, 2005 (70 FR 46924), this acreage was reduced to 858,846 acres, and in February 2006 (71 FR 7118), the designation was revised to identify eritical habitat for each individual species. The species is threatened by land conversion to urban development, habitat loss and fragmentation, impacts from surrounding land use, adjacent road widening, eompetition with non-native plant species, potential changes to hydrology, introduetion of pesticides and herbicides, off-road vehicles, stochastic extinetion, and other human activities. In partieular, all four oceurrences in the Doe Mill core area are threatened by proposed development projects. Secondarily, lack of management of invasive plants, ineluding inappropriate levels of grazing, is also a major threat. 


\section{Munz's Onion}

The primary references for this section are:

USFWS. 1998g. Determination of Endangered or Threatened Status for Four Southwestern California Plants from Vernal Wetlands and Clay Soils. Federal Register 63(197):54975-54994.

and

USFWS. 2005d. Endangered and Threatened Wildlife and Plants; Designation of Critical Habitat for Allium munzii (Munz's onion). Federal Register 70(108):33015-33033.

References eited in this seetion are internal to the above-referenced documents. A complete list of these referenees is available from the USFWS Carlsbad Field Office, Carlsbad, California.

Munz's onion (Allium munzii) is restrieted to mesie elay soils in western Riverside County, California, along the southern edge of the Perris basin. This speeies is frequently found in association with southern needlegrass grassland, mixed grassland, and grassy openings in coastal sage serub or, oecasionally, in eismontane juniper woodlands (California Department of Fish and Game 1989, Mistretta 1993). Currently, 16 populations of this plant are known to exist.

Munz's onion, a member of the lily family, is a perennial herb, 0.5 to 1.2 feet tall, originating from a bulb. The flower cluster consists of 10 to 35 white flowers that beeome red with age. In response to rainfall and other factors, perennial bulbs may not produce aerial leaves or flowers in a given year or may produce only leaves. As a result, fluetuations in numbers of observed individuals can be misleading.

Munz's onion was federally listed as endangered on Oetober 13, 1998 (63 FR 54975). On June 7, 2005 (70 FR 33015 ) the USFWS designated 176 aeres of federal land in within Cleveland National Forest in western Riverside County, California, as eritical habitat for the species. On April 16, 2013 (78 FR 22625) this designation was revised to exclude much of this acreage, so that the current total is 98.4 acres in Riverside County. Factors that threaten the species include habitat destruetion and fragmentation from agricultural and urban development, pipeline construction, alteration of wetland hydrology by draining or excessive flooding, channelization, OHV activity, cattle and sheep grazing, weed abatement, fire suppression practiees, and competition from alien plant species. Habitat loss eontinues to be the greatest threat to Munz's onion.

\section{San Jacinto Valley Crownscale}

The primary references for this section are:

USFWS. 1998g. Determination of Endangered or Threatened Status for Four Southwestern California Plants from Vernal Wetlands and Clay Soils. Federal Register 63(197):54975-54994.

and

USFWS. 2005e. Endangered and Threatened Wildlife and Plants; Designation of Critical Habitat for Atriplex coronata var. notatior (San Jacinto Valley Crownscale). Federal Register 70(197) 59952-59974.

References eited in this section are internal to the above-referenced documents. A complete list of these references is available from the USFWS Carlsbad Field Office, Carlsbad, California.

The 2008 5-year review for the San Jacinto Valley crownscale (USFWS 20081) was consulted for updated information on this species.

San Jacinto Valley crownscale (Atriplex coronata var. notatior) is restricted to the San Jacinto, Perris, Menifee, and Elsinore Valleys of western Riverside County. It is found only in highly alkaline, silty-clay soils in association with the Traver-Domino-Willows soil association. Common habitat types include seasonal wetlands that are 
typically flooded by winter rains, such as alkali sink scrub, alkali playa, vernal pools, and, to a lesser extent, annual alkali grassland communities (Bramlet 1993a, Roberts 1993b). The duration and extent of flooding are extremely variable from onc year to the next. Populations of San Jacinto Valley crownscale are primarily associated with the San Jacinto River and Old Salt Creek tributary drainages (Roberts 1993b, 1997; McMillan 1997). The majority of the population eenters are located on privately owned lands. This plant is not known to occur on federal lands. The four locations where the taxon is known to occur rely on seasonal localized flooding and ponding from surrounding watershed areas (Bramlet 2004, Roberts 2004) and the wetlands and associated hydrology continue to provide essential biological and physical features necessary for this taxon at all four locales. All remaining occurrence complexes have been impacted by agrieultural activities (Bramlet 1993, Roberts and McMillan 1997, California Natural Diversity Database 2003). The species has a soil seed bank that may persist even though plants are removed or fail to germinate in a particular year and which persists within disturbed lands, including agricultural areas. This persistent seed bank results in population estimates that range from several thousand to several hundred thousand plants from year to year.

San Jacinto Valley crownseale is an erect annual that grows to a height of 4 to 12 inches. The species germinates after the water has receded. It usually flowers in April and May and sets fruit by May or June (Bramlet 1992). The species can persist in the seed bank within disturbed lands, including agricultural areas, and will often germinate in these areas in years when disturbanees do not occur. Because the species is an annual and has the ability to persist in the seed bank, population size in a given year varies widely depending on localized site hydrology and disturbance, though significant seed bank reserves are likely.

San Jacinto Valley erownscale was federally listed as endangercd on October 13, 1998 (63 FR 54975). The USFWS excluded this species from critical habitat designation in 2005 because all habitat with essential features for the species is loeated either within the areas to be conserved and managed by the approved Western Riverside Multiple Species Habitat Conservation Plan on existing Public/Quasi-Publie Lands, or within areas where the plan will ensure that future projects will not adversely alter essential hydrological processes. This decision was reaffirmed in April 2013 (78 FR 22625). Faetors that threaten the species include habitat destruction and fragmentation from agricultural and urban development, pipeline construction, alteration of wetland hydrology by draining or excessive flooding, ehannelization, OHV activity, cattle and sheep grazing, weed abatement, fire suppression practiees, and competition from alien plant species (USFWS 20081).

\section{Thread-leaved Brodiaea}

The primary reference for this section is:

USFWS. 1998g. Determination of Endangered or Threatened Status for Four Southwestern California Plants from Vernal Wetlands and Clay Soils. Federal Register 63(197):54975-54994.

References cited in this scction are internal to the above-referenced document. A complete list of these references is available from the USFWS Carlsbad Field Office, Carlsbad, California.

The 2009 5-year review for the thread-leaved brodiaea (USFWS 2009z) was consulted for updated information on this species.

Thread-leaved brodiaca (Brodiaea filifolia) occurs on gentle hillsides, vallcys, and floodplains in mesic, southern needlegrass grassland and alkali grassland plant communities in association with clay, toamy sand, or alkaline silty-clay soils (California Department of Fish and Game 1981, Bramlet 1993a). This species is usually found in herbaeeous plant communities such as valley needlegrass grassland, valley sacaton grassland, non-native grassland, alkali playa, southern interior basalt vernal pools, San Diego mesa hardpan vernal pools, and San Diego mesa elaypan vernal pools (Holland 1986). Sites occupied by this speeies are frequently intermixed with, or near, vernal pool eomplexes, such as near San Marcos (San Diego County), the Santa Rosa Plateau, and southwest of Hemet in Riverside County.

Sixty-eight discontinuous occurrences are distributed across southern California from the foothills of the San Gabriel Mountains at Glendora (Los Angeles County), east to Arrowhead Hot Springs in the western foothills of 
the San Bernardino Mountains (San Bernardino County), and south through eastern Orange and western Riverside Counties to Rancho Santa Fe in eentral San Diego County, California. This species is usually found in herbaceous plant eommunities that oeeur in open areas on elay soils, soils with a clay subsurfaee, or elay lenses within loamy, silty loam, loamy sand, silty deposits with eobbles, or alkaline soils; they may range in elevation from 100 feet to 2,500 feet, depending on the soil series.

Thread-leaved brodiaea is a perennial herb with an underground bulb-like storage stem (eorm). Individual plants are less than 16 inehes tall, with narrow, basal leaves, and saucer-shaped violet flowers arranged in a loose umbel. The flowering period extends from March to June (CNPS 2001). Corms and vegetatively produeed cormlets are the prineipal means of perpetuation from one growing season to another (Niehaus 1971), although the speeies also sets seeds. This species is known to hybridize with other brodiaea speeies in its range (Oreutt's brodiaea, dwarf brodiaea, and possibly chaparral brodiaea), where these speeies eoexist (Boyd et al. 1992; Morey 1995; California Natural Diversity Database 1997).

Thread-leaved brodiaea was listed as threatened on Oetober 13, 1998 (63 FR 54975). On February 8, 2011 (76 FR 6848), the USFWS designated approximately 2,947 aeres of land in 10 units in Los Angeles, San Bernardino, Orange, Riverside, and San Diego Counties, California. Thread-leaved brodiaea and its habitat have been substantially reduced by urbanization, agrieultural eonversion, and disking for fire and weed control. In Riverside County, most of the annual alkaline grassland near the San Jacinto River and southwest of Hemet has been urbanized or eonverted to dryland farming or more intensive eultivation. Additionally, thread-leaved brodiaea is vulnerable to deep disking or repeated disking. Thus, areas that were disked and have partially reeovered after being left fallow for a period of time tend to support reduced and gradually declining populations of the species, if any have survived. The most important threats to this speeies include urbanization, alteration of hydrological conditions and ehannelization, disking, unauthorized OHV aetivity, grazing, manure dumping, mowing, and nonnative plants (USFWS 2009z).

\section{Hartweg's Golden Sunburst}

The primary reference for this seetion is:

USFWS. 1997e. Determination of Endangered Status for Pseudobahia bahiifolia (Hartweg's Golden Sunburst) and Threatened Status for Pseudobahia peirsonii (San Joaquin Adobe Sunburst), Two Grassland Plants from the Central Valley of California. Federal Register 62(25):5542-5551.

The 2007 5-year review for Hartweg's golden sunburst (USFWS 20071) was consulted for updated information on this species.

Hartweg's golden sunburst (Pseudobahia bahiifolia) is a speeies of sunflower that is endemic to the eastern San Joaquin Valley in Stanislaus, Madera, Merced, and Fresno Counties. The speeies is found almost exelusively in non-native grasslands associated with mima mound topography. Mima mounds are small hilloeks a few feet in height that have formed in dense eoneentrations, interspersed with shallow basins that may pond water during the rainy season. The plants are nearly always found on the north or northeast-facing slopes of the mounds, with highest plant densities on the upper slopes where grass eover is minimal. The oecurrences are found at an elevation of 50 to 460 feet on Amador soil series in Stanislaus County, Rocklin soil series in Fresno and Madera Counties, and Valley Springs soil formation in Merced County. These soil series generally consist of shallow, well-drained, medium-textured soils that exhibit strong mound mierorelief. As of 2007, 19 oceurrences were presumed to be extant. Population numbers can fluctuate widely from one year to another, apparently in response to annual climatic conditions (seasonal rainfall) and competition from non-native plants (USFWS 2007l).

Hartweg's golden sunburst is a few-branched annual 2 to 6 inches tall. The bright yellow flower heads, produced in March or April, are solitary at the ends of branches.

Hartweg's golden sunburst was federally listed as endangered on February 6, 1997 (62 FR 5542). Critical habitat has not been designated. All of the remaining occurrences are threatened by one or more of the following: the vulnerability of the small and fragmented populations; the conversion of habitat from cattle ranches to urban and 
residential development, vineyards, and orchards; and competition from non-native invasive grasses and forbs (USFWS 2007l).

\section{San Joaquin Adobe Sunburst}

The primary reference for this section is:

USFWS. 1997c. Determination of Endangered Status for Pseudobahia bahiifolia (Hartweg's Golden Sunburst) and Threatened Status for Pseudobahia peirsonii (San Joaquin Adobe Sunburst), Two Grassland Plants from the Central Valley of California. Federal Register 62(25):5542-5551.

References cited in this section are internal to the above-referenced document. A complete list of these references is available from the USFWS Sacramento field office, Sacramento, California.

The 2007 5-year review for the San Joaquin adobe sunburst (USFWS 20071) was consulted for updated information on this species.

San Joaquin adobe sunburst (Pseudobahia peirsonii), like Hartweg's golden sunburst discussed in the previous species account, is a sunflower species that is endemic to the non-native grassland and grassland-blue oak woodland community ecotone of the California's central valley. The mierohabitat preferred by the San Joaquin adobe sunburst is areas of heavy adobe clay soils between mima mounds, where the water retention properties are high (vernal pools).

San Joaquin adobe sunburst is an ereet annual herb in the aster family, about 4 to 18 inches tall, that produces bright yellow infloreseences. This species occurs only on heavy adobe clay soils over a range of approximately 120 miles through Fresno, Tulare, and Kern Counties, California. This restrietion is likely associated with the ability of these clay soils to retain moisture longer into the summer dry season (Stebbins 1991). These soils are mainly distributed in the valleys and flats near the foothills of the southeastern San Joaquin Valley. The San Joaquin adobe sunburst is concentrated in three major locations: east of Fresno in Fresno County; west of Lake Success in Tulare County; and northeast of Bakersfield in Kern County. One population occurs on land administered by the Fresno Flood Control Distriet; two populations oceur on land administered by the U. S. Army Corps of Engineers; and all other populations occur on privately owned land (California Natural Diversity Database 1996). The intrusive and aggressive characteristies of herbaceous weedy species appear to be detrimental to habitat quality of this rare plant. Some of the common non-native associates of this species include wild oat, charlock mustard, soft brome, red brome, and redstem stork's bill.

San Joaquin adobe sunburst was listed as threatened on February 6, 1997 (62 FR 5542). Critical habitat has not been designated. Extant occurrences of the species are threatened primarily by competition with non-native invasive grasses and forbs, and by the vulnerability of the small and fragmented populations. Flooding has destroyed portions of two oceurrences of the species and still threatens occurrences at two locations (USFWS 20071).

\section{Purple Amole}

The primary reference for this section is:

USFWS. 2008m. Purple Amole (Chlorogalum purpureum) Five-year Review: Summary and Evaluation. Ventura Fish and Wildlife Office. Ventura, California.

References cited in this section are internal to the above-referenced document. Full citations are included in the Bibliography.

Purple amole (Chlorogalum purpureum var. purpureum) is endemic to the Santa Lucia Range of Monterey and San Luis Obispo Counties, California. The species is known from two properties: seattered over approximately 986 acres on Fort Hunter Liggett, southern Montercy County; and at one location on Camp Roberts in northern San Luis Obispo County. Surveys along the eastern boundary of Fort Hunter Liggett suggested that the species may occur on the adjacent private properties (Wilken 2000). Purple amole oceurs in the rain shadow of the Santa Lucia 
Range (California Army National Guard 2001a, National Park Service 2007). The taxon is known from the lower elevations on the eastern side of the range, at approximately 700 to 1,336 feet. The species oceurs in seattered clusters on both deep and relatively thin soils. Most of the soils are loamy, underlain by clay, and with fine gravel on the surface (Wilken 2000). Most sites where the species occurs are associated with flat topography or gentle slopes of less than 10 percent. Purple amole is associated with cryptogamic crusts - a layer of nonvascular photosynthetic plants (primarily cyanobacteria, lichens, mosses, and fungi) that form a crust on the soil surface (Beymer and Klopatek 1992) and enhance the habitat conditions by protecting soil from erosion, fixing atmospheric nitrogen, contributing to soil organic matter (Eldridge and Green 1994), retaining soil moisture, discouraging annual weed growth (Belnap et al. 2001), and providing favorable sites for the growth of vaseular plants (Lesica and Shetly 1992).

The plants grow in open grasstand and grassland surrounded by scattered oak woodland (California Army National Guard 2001a, 2001b). On Fort Hunter Liggett, there are hundreds of diseontinuous patches of purple amole in grassland, oak savanna, and oak woodland eommunities where they oecur in association with gravelly, clay soils. The purple a mole grows in both undisturbed sites and sites disturbed by past military training activities (U.S. Army 2004a, 2004b). The purple amole typieally occurs in association with low growing, annuat, native plants such as: rusty popcornflower, miniature lupine, annual agoseris, and California goldfields; and with non-native plants such as soft brome and stork's bill. Wavyleaf soap plant, yellowflower tarweed, and bigflower agoseris are also frequently-occurring associates. Total population is in excess of 250,000 plants based on population counts in 2001.

Purple amole is a bulb-forming perennial herb in the lily family. It has a basal rosette of linear leaves and a widely branehing stem that supports bluish-purple flowers. Reproduction in this species is primarily by seed. The species is reported to be self-compatible, and insect pollination appears to result in increased seed set. Clonalty, reproduction by longitudinal splitting of the bulbs is rare (Hoover 1940a). Like other members of the lily family, this species probably forms mycorrhizal relationships (root-hyphen relationships with a fungus), which ean aid in nutrient and water uptake by the host plant and can alter growth and eompetitive interactions between species.

Purple amole was federally listed as threatened on April 19, 2000 (65 FR 14878). On April 24, 2003 (68 FR 20083), the USFWS designated approximately 20,000 acres of land in Monterey and San Luis Obispo Counties, California, as critical habitat for two varieties of purple amole. The primary threats to this plant are displacement by non-native annual grasses, and potentially by alteration of fire cycles due to military training. Livestock grazing and associated habitat ehanges may threaten this taxon if grazing is resumed in occupied habitat in the future.

\section{Keck's Checker-mallow}

The primary reference for this section is:

USFWS. 2000c. Determination of Endangered Status for Sidalcea keckii (Keck's Cheeker-mallow) from Fresno and Tulare Counties, California. Federal Register 65(32):7757-7764.

The 2007 5-year review for Keck's checker-mallow (USFWS 2007m) was consulted for updated information on this species.

Keck's checker-mallow (Sidalcea keckii) is a slender, annual herb associated with serpentine-derived clay soils in the foothill annual grasslands of the central western Sierra Nevada Mountains. It occurs toward the southern end of the San Joaquin Valley in Tulare and Fresno Counties, California. The species grows in relatively open areas on grassy slopes, and like many serpentine species, appears to compete poorly with densely growing non-native annual grasses. Currently, only one population of Sidalcea keckii is known to be extant. Most of this population is on the Sierra Foothill Conservancy's Tivy Mountain Preserve, with small portions on land administered by the U.S. Burcau of Reclamation The plants occur between 600 and 1,000 feet in elevation. Associated plants include soft chess, blue dicks, bird's eye gilia, pretty face, Ithuriel's spear, milkweed, and tarweed species (USFWS $2007 \mathrm{~m})$. 
Keek's eheeker mallow is a slender, ereet annual herb belonging to the mallow family. The species grows 6 to 13 inehes tall, and produees deep pink flowers in April and May, and the seed appears able to persist in the seedbank for a number of years. However, speeifie requirements for seed germination in the wild and typieal germination dates are not known.

Keek's eheeker-mallow was federally listed as endangered on February 16, 2000 (65 FR 7757). On Mareh 18, 2003 (68 FR 12863), the USFWS designated approximately 1,085 aeres in Fresno and Tulare Counties as eritieal habitat for the speeies. The speeies is threatened by urban development, agrieultural land eonversion (particularly to eitrus orehards), and eompetition from non-native grasses. The remaining population is also vulnerable to random events beeause it is small in size (USFWS $2007 \mathrm{~m}$ ).

\section{California Jewelflower}

The primary referenee for this seetion is:

Sandoval, T.M., and E.A. Cypher. 1996. California Jewelflower, Caulanthus californicus. Endangered Speeies Profiles, Speeies Featured in Reeovery Plan for San Joaquin Valley Arid Upland and Riparian Communities. Endangered Speeies Reeovery Program. Fresno, California. Available at: http://esrp.esustan.edu/speeiesprofiles/.

California jewelflower (Caulanthus californicus) is an annual plant that is endemie to California. The speeies is found in several plant eommunities, ineluding non-native grassland, Upper Sonoran subshrub serub, and eismontane juniper woodland and serub. Herbaeeous eover is dense at most California jewelflower sites. Native plant speeies, sueh as annual feseue, elovers, red maids, and goldfields eomprise a high proportion of the vegetation at many of the known loeations. On the Carrizo Plain, California jewelflower oeeurs primarily on the burrow systems of giant kangaroo rats, another endangered speeies. California jewelflower has been reported from elevations ranging from approximately 250 to $2,950 \mathrm{feet}$, and from level terrain to 25 pereent slopes. Primary soil types at known sites are subalkaline, sandy loams. The historieal range of the California jewelflower ineluded the floor of the San Joaquin Valley in Fresno, Kern, and Tulare Counties; the Carrizo Plain (San Luis Obispo County) and the Cuyama Valley (Santa Barbara and Ventura Counties); the Sierra Nevada foothills at the eastern margin of the San Joaquin Valley in Kern County; and foothills west of the San Joaquin Valley, in Fresno, Kern, and Kings Counties. As of 1986, all natural oeeurrenees of California jewelflower on the San Joaquin and Cuyama Valley floors had been extirpated. Today, known populations are confined to three areas in hilly terrain west of the San Joaquin Valley: the Carrizo Plain, Santa Barbara Canyon (adjacent to the Cuyama Valley in Santa Barbara County), and the Kreyenhagen Hills (Fresno County). The Carrizo Plain and Kreyenhagen Hills populations are on publie land administered by the BLM, as is approximately 10 pereent of the Santa Barbara Canyon population. Additional populations of California jewelflower may persist in the foothills of Fresno, Kern, and Kings Counties, where potential habitat remains in private rangeland. Several experimental introduetions of California jewelflower have been attempted in Kern, Santa Barbara, and Tulare Counties, but none of the populations have persisted.

Seeds of California jewelflower begin to germinate in the fall when the rainy season begins, but additional seedlings may continue to emerge for several months. The seedlings develop into rosettes during the winter months, and the stem elongates as flower buds begin to appear in February or Mareh. Flowering and seed set eontinue until the plants die, whieh may oeeur as late as May in years of favorable rainfall and temperatures. The flowers are pollinated by inseets. Seed-dispersal agents are not known, but may inelude gravity, seed-eating animals, wind, and water. California jewelflower probably forms a persistent seed bank.

California jewelflower was federally listed as endangered on July 19, 1990 (55 FR 29361). Critieal habitat has not been designated. The primary reason for its deeline was habitat destruetion by eonversion to agrieulture and urbanization. Oilfield aetivity may have eliminated a few sites in the foothills at the western margin of the San Joaquin Valley. Potential threats to the remaining populations inelude eompetition from introdueed plant speeies, pestieide effeets on pollinators, and small population size. Populations on private land in the upper portion of Santa Barbara Canyon are subjeet to eattle grazing throughout the growing season, but the magnitude of threat posed by livestoek is unknown. Residential development also threatens the privately owned portion of the Santa Barbara Canyon population. 


\section{San Joaquin Woolly-threads}

The primary reference for this section is:

Brown, N. L., and E. A. Cypher. 1997a. San Joaquin Woolly-threads, Lembertia congdonii. Endangered Species Profiles, Species Featured in Reeovery Plan for San Joaquin Valley Arid Upland and Riparian Communities. Endangered Species Recovery Program. Fresno, California. Available at: http://esrp.esustan.edu/speeiesprofiles/.

The 2010 5-year review for San Joaquin woolly-threads (USFWS 20101) was consulted for updated information on this species.

San Joaquin woolly-threads (Monolopia congdonii, formerly Lembertia congdonii) is an annual herb that occurs in non-native grassland, valley saltbush scrub, Interior Coast Range saltbush scrub, and Upper Sonoran subshrub scrub in California. Historically, the species occurred primarily in the San Joaquin Valley, with a few oceurrenees in the hills to the west and in the Cuyama Valley of San Luis Obispo and Santa Barbara Counties. Sinee 1986, many new occurrenees have been discovered in the hills and plateaus west of the San Joaquin Valley. The largest extant metapopulation occurs on the Carrizo Plain Natural Area in San Luis Obispo County. As of 2010, 66 occurrences of San Joaquin woolly-threads were presumed extant scattered in Fresno, Kings, Kern, San Benito, San Luis Obispo, and Santa Barbara Counties (USFWS 20101).

San Joaquin woolly-threads occurs on sandy, sandy loam, or silty soils with neutral to subalkaline pH, at elevations ranging from approximately 197 to 2,625 feet. The species typically occupies microhabitats with less than 10 percent shrub cover, although herbaceous eover may be either sparse or dense. Plant species that often oeeur with San Joaquin woolly-threads inelude red brome, red-stemmed filaree, goldfields, Arabian grass, and mouse-tail fescue.

The phenology of San Joaquin woolly-threads varies with weather and site conditions. In years of below-average precipitation, few seeds of this species germinate, and those that do typically produce tiny plants. Seed germination may begin as early as November, but usually occurs in Deeember and January. The species typically flowers between late February and early April, but flowering may continue into early May if conditions are optimal. Populations in the northern part of the range flower earlier than those farther south. Each plant may have from 1 to more than 400 flower heads. Seed production depends on plant size and the number of flower heads, and can range from 10 to 2,500 seeds per individual. The seeds are shed immediately upon maturity, and all trace of the plants disappears after death in April or May. Seed dispersal agents are unknown, but possible candidates include wind, water, and animals. Seed dormancy mechanisms apparently allow the formation of a substantial seed bank in the soil.

San Joaquin woolly-threads was federally listed as endangered on July 19, 1990 (55 FR 29361). Critical habitat has not been designated. Habitat loss was responsible for the decline of the species, with the majority of the occurrences in the San Joaquin and Cuyama Valleys extirpated by intensive agriculture. In addition, several sites in and around Bakersfield were eliminated by urban and intensive oilfield development. Current threats to San Joaquin woolly-threads include commercial and agricultural development, increased intensity of land use in oilfields or pastures, and competition from introduced plants (USFWS 20101).

\section{Bakersfield Cactus}

The primary reference for this section is:

Brown, N.L., and E.A. Cypher. 1997b. Bakersfield Cactus, Opuntia basilaris var. treleasei. Endangered Species Profiles, Species Featured in Recovery Plan for San Joaquin Valley Arid Upland and Riparian Communities. Endangered Species Recovery Program. Fresno, California. Available at: http:/esrp.csustan.edu/speciesprofiles/.

The 2007 5-year review for Bakersfield cactus (USFWS 2007n) was consulted for updated information on this species.

Bakersfield cactus (Opuntia treleasei) is a long-lived perennial plant with fleshy, flattened, green stems (pads), endemic to a limited area of central Kern County in the vicinity of Bakersfield, California. The species is 
eharacteristie of the Sierra-Tehachapi saltbush scrub plant eommunity, but populations near Caliente are in blue oak woodland, and the Cottonwood Creek population is in riparian woodland. Many sites for Bakersfield eactus support a dense growth of red brome and other annual grasses. Sand Ridge is characterized by sparse vegetation and a preponderanee of native speeies sueh as California filago and yellow pincushion. Soils supporting the speeies typieally are sandy, although gravel, eobbles, or boulders also may be present. Known populations oeeur on flood plains, ridges, bluffs, and rolling hills, and oeeur at elevations between 396 and 1,800 feet. Twenty-nine presumed extant oeeurrenees exist. As of 1987, the northern, southern, eastern, and western limits of the known range of this speeies, respeetively, were Granite Station, Comanehe Point, Caliente, and Oildale, California. The majority of oeeupied habitat is on private land that is not proteeted (USFWS 2007n).

Few details on the life history of Bakersfield eaetus are available. The fleshy stems, tiny, short-lived leaves, shallow root systems, and speeialized physiology are adaptations to growth in arid environments. Known to typieally flower in May, the reproduetive biology of this taxon has not been studied. Certain other speeies of Opuntia (prieklypear) speeies require eross-pollination for seed-set, and many are pollinated by bees. One potential pollinator of Bakersfield eaetus is a native solitary bee Diadasia australis ssp. california, whieh is known to oeeur in Kern County and which speeializes in eolleeting pollen from Opuntia speeies. Vegetative reproduetion is eommon in Bakersfield eaetus and several related species. Fallen pads easily root if suffieient water is available, although the eaetus does not survive prolonged inundation. Seeds, whieh are produeed infrequently, require warm, wet eonditions to germinate, a eombination whieh is extremely rare in the Bakersfield area. Pads may be dispersed by flood waters, but seed dispersal agents are unknown.

Bakersfield eaetus was federally listed as endangered on July 19, 1990 (55 FR 29361). Critieal habitat has not been designated. The primary reason for the deeline of the speeies was habitat loss. The formerly extensive traets of Bakersfield eaetus near Edison and Lamont, California were destroyed by eonversion to row erops and eitrus groves; mueh of the eonversion oeeurred prior to 1931. Residential development, petroleum produetion, sand and gravel mining, and OHV aetivity also have eontributed to habitat loss and fragmentation of this plant, and eontinue to threaten the existing populations. Other threats inelude eompetition from introdueed grasses, air pollution, and low genetie diversity (USFWS 2007n).

\section{Kern Mallow}

The primary referenee for this seetion is:

USFWS. 1998h. Reeovery Plan for Upland Speeies of the San Joaquin Valley, California. Portland, Oregon.

Referenees eited in this seetion are internal to the above-refereneed doeument. Full eitations are ineluded in the Bibliography.

Kern mallow (Eremalche kernensis) typieally oeeurs in valley saltbush serub habitats in the San Joaquin Valley, California. The speeies grows under and around spiny and eommon saltbushes and in patehes with other herbaeeous plants, rather than in the intervening alkali sealds. Assoeiated herbs inelude red brome, red-stemmed filaree, woolly goldfields, and white Sierran layia. Kern mallow typieally grows on alkaline sandy loam or elay soils at elevations of 315 to 900 feet (Wolf 1938, California Department of Fish and Game 1995), in areas where shrub eover is less than 25 pereent (Taylor and Davilla 1986). The amount of herbaeeous eover varies with rainfall and mierohabitat.

Kern mallow has always had a highly-restrieted distribution, oeeurring only in western Kern County, north of MeKittriek. At present, the speeies oeeurs intermittently within an area of 40 square miles in Lokern, a loeal name for the area between Buttonwillow and MeKittriek (Taylor and Davilla 1986). This oecurrenee is best deseribed as a single metapopulation.

The seeds of Kern mallow typieally germinate in January and February, and the plants begin flowering in Mareh. Fruit produetion begins within a few days after flowers appear, and may eontinue into May if suffieient moisture is available. The seeds fall from the fruit as soon as they are mature. Seeds are eapable of germinating in the following growing season, but at least some of them remain ungerminated. The duration of seed viability in the soil 
is not known. Seed dispersal agents are unknown, but probably inelude animals and wind (Taylor and Davilla 1986; Mazer et al. 1993). Additionally, inseets are thought to facilitate reproduction of the species. On oeeasion, Kern mallow has reinvaded disturbed sites when existing populations remained in adjacent areas to provide sourees of seed (Mitehell 1989, E. Cypher unpublished observation).

Kern mallow was federally listed as endangered on July 19, 1990 (55 FR 29361). Critical habitat has not been designated. Loss and degradation of habitat in the Lokern area have been responsible for the deeline of the species. Approximately 85 pereent of the Kern mallow habitat in Lokern is privately owned, and is thus vulnerable to development for many potential uses (Taylor and Davilla 1986, Presley 1994, California Department of Fish and Game 1995). Oil exploration and maintenance of pipelines and utility eorridors eontinue to disturb oecupied habitat. Grazing may threaten the population by redueing reproduetive output of the species (Mazer et al. 1993), but light to moderate grazing may reduce eompetition in areas that are dominated by aggressive exoties (Cypher 1994). Another potential threat to the speeies is the reduetion of pollinator populations caused by the use of Malathion and other pestieides.

\section{Springville Clarkia}

The primary referenee for this section is:

USFWS. 1996e. Determination of Threatened Status for Four Plants from the Foothills of the Sierra Nevada Mountains in California. Federal Register 63(177):49022-49035.

The 2009 5-year review for the Springville elarkia (USFWS 2009aa) was consulted for updated information on this species.

Springville elarkia (Clarkia springvillensis) is found on granitie soils in sunny sites from 1,080 to 4,000 feet in elevation, and grows mostly on the uphill slope of roadbanks, on small decomposing granitic domes, and in openings within the blue oak woodland eommunity in the foothills of the southern Sierra Nevada Mountains of Tulare County, California. All populations of this speeies but one are found within about a 15-mile range, with the remaining population oecurring 16 miles to the northwest. One site is partially proteeted by the California Department of Fish and Game, one is on publie land, eight are on Forest Serviee-administered land, and five are on privately owned land. The largest population oeeurs on the 4.5 -aere preserve administered by the California Department of Fish and Game. Populations along roadsides have beeome restrieted to a narrow band just above a zone of herbieide use and just below heavily grazed terrain. The population size for this annual plant varies signifieantly depending on seasonal weather conditions and the soil seed bank, with wet years showing signifieantly higher counts than dry years. The known populations of the speeies contain from several hundred to several thousand plants, with one population estimated to eontain over 100,000 plants at its maximum size. Eleven oceurrenees are loeated on federal land (USFWS 2009aa).

Springville elarkia is an ereet annual herb in the primrose family that ean reach 3 feet tall. It produces lavenderpink flowers, which appear in May to July.

Springville elarkia was federally listed as threatened on September 14, 1998 (63 FR 49022). Critical habitat has not been designated. The speeies is threatened by urban development, intense livestock grazing, and roadway maintenance activities. Because it has low numbers of populations and small population sizes, it is also vulnerable to extirpation from random events (USFWS 2009aa).

\section{Red Hills Vervain}

The primary reference for this section is:

USFWS. 1998i. Determination of Threatened Status for Four Plants from the Foothills of the Sierra Nevada Mountains in California. Federal Register 63(177):49022-49035.

References cited in this section are internal to the above-referenced document. A complete list of these references is available from the USFWS Sacramento Field Office, Sacramento, California. 
The 2007 5-year review for the Red Hills vervain (USFWS 2007o) was consulted for updated information on this speeies.

Red Hills vervain (Verbena californica) is an ereet perennial herb that is restrieted to intermittent and perennial streams within serpentine areas of the Red Hills of Tuolumne County, California, at elevations of between 850 and 1,150 feet. Soil moisture is the primary faetor influeneing the distribution and reproduetion of this speeies (Knox 1998). Within this narrow range, the total area oeeupied by the known populations is estimated to be 90 acres (California Natural Diversity Database 1997). All 11 oeeurrenees are either on BLM lands or California Department of Transportation lands purehased for the proteetion of the speeies, with most oeeurrenees within the Red Hills ACEC (USFWS 2007o). The majority of populations oeeur in drainages that feed into Don Pedro Reservoir, primarily Six Bit Guleh and its tributaries. Another population is on Andrew Creek, whieh feeds into the Tulloek Reservoir (California Department of Fish and Game 1993, California Natural Diversity Database 1997). Sedges, rushes, and hoary eoffeeberry have been identified as the best indieators of suitable habitat for the speeies.

Red Hills vervain is a narrowly distributed biennial or perennial herb belonging to the vervain family. The speeies blooms from May through September. Blossoms are white to purple, with one to five flowers growing at the top of each spike.

Red Hills vervain was federally listed as threatened on September 14, 1998 (63 FR 49022). Critieal habitat has not been designated. Hydrologieal ehanges due to impaets from adjaeent development, reereational mining, grazing, trampling from livestoek, eompetition from non-native plants, and the risk of extirpation from random demographie, environmental, or genetie events still threaten the speeies.

\section{Cushenbury Milk-vetch}

The primary referenee for this seetion is:

USFWS. 2002d. Proposed Designation of Critieal Habitat for Five Carbonate Plants from the San Bernardino Mountains in Southern California. Federal Register 67(29):6577-6612.

Referenees eited in this seetion are internal to the above-refereneed doeument. A eomplete list of these referenees is available from the USFWS Carlsbad Fish and Wildlife Offiee, Carlsbad, California.

The 2009 5-year review for the Cushenbury milk-veteh (USFWS 2009bb) was eonsulted for updated information on this speeies.

Cushenbury milk-veteh (Astragalus albens) is restrieted primarily to earbonate deposits and their derived soils in San Bernardino County, California. The area of the San Bernardino Mountains in whieh the speeies oeeurs eontains outerops of earbonate substrates, primarily limestone and dolomite, in several bands running on an eastwest axis along desert-faeing slopes, and is generally known as the earbonate belt. Cushenbury milk-veteh oeeurs over about 1,201 aeres of oeeupied habitat distributed across approximately 15 miles from Furnaee Canyon southeast to the head of Lone Valley (USFWS 1994). The speeies is typieally found within singleleaf pinyon-Utah juniper, blaekbush serub, singleleaf pinyon, pinyon woodland, pinyon-juniper woodland, and Joshua tree woodland vegetation eommunities (Gonella 1994, Gonella and Neel 1995, Neel 2000). Plants elosely assoeiated with the Cushenbury milk-veteh inelude flannelbush, blaekbush, mound eaetus, desert almond, and Mojave yueea (Gonella 1994, Gonella and Neel 1995). Cushenbury milk-veteh is typieally found on earbonate soils derived direetly from deeomposing limestone bedroek along roeky washes. It is generally found in areas with an open eanopy eover, little aeeumulation of organie material, roeky substrate eover exeeeding 75 pereent, and gentle to moderate slopes (Neel 2000). Most oeeurrenees of the speeies are at elevations between 5,000 and 6,600 feet. Most of the oceurrenees below about 5,000 feet are found in roeky washes with limestone outwash from erosion (California Natural Diversity Database 2001, San Bernardino National Forest GIS Data 2001). Soils at sites supporting the Cushenbury milk-veteh have a higher pereentage of ealeium than soils that do not support this speeies (Gonella and Neel 1995). At the time of listing in 1994, the population was estimated at 5,000 to 10,000 plants. 
Cushenbury milk-vetch is a small, silvery-white, short-lived herb in the pea family. Individual plants are annual to sometimes perennial (Spellenberg 1993). It is not known whether the plants typically flower and fruit the first year, how long they live, or what conditions might cause them to act as annuals in some cases or perennials in other cases. Flowering oceurs from late March to mid-June, and the pink-purple flowers oceur in racemes on long peduncles. Pods ripen at least as early as May, and become stiff and papery with long hairs as they mature. It is thought that most Cushenbury milk-vetch reproduction occurs by seeds, which have been found to have high viability. Vegetative reproduction has never been reported. Pollinators are probably small bees.

Carbonate-restricted plants do not appear to be specifically linked to early vegetation successional stages after disturbanee; however, they are found on some surfaces that are naturally disturbed by landslides and substrate upheaval. For the most part, they oceur in habitat that is undisturbed by human activities.

Cushenbury milk-vetch was federally listed on August 24, 1994 (59 FR 43652). On December 24, 2002 (50 FR 59239), the USFWS designated approximately 4,365 aeres in San Bernardino County as critical habitat for the species. The primary threat to Cushenbury milk-vetch and other earbonate plants is limestone mining, as 97 pereent of the species' known habitat is under mining claim. Speeific threats include population reduction and habitat loss, degradation, and habitat fragmentation from surface mining activities. Additional threats include OHV use, and projects related to energy development (USFWS 2009bb).

\section{Parish's Daisy}

The primary references for this section are:

USFWS. 2002d. Proposed Designation of Critical Habitat for Five Carbonate Plants from the San Bernardino Mountains in Southern California. Federal Register 67(29):6577-6612.

and

USDOI BLM. 2001a. Biological Evaluation on Effeets of California Desert Conservation Area Plan as Amended and Proposed to be Amended by the NEMO and NECO Preferred Alternatives and With Other Interim Measures on Ten Threatened and Endangered Plants. California Desert Distriet, BLM. Riverside, California.

References cited in this seetion are internal to the above-referenced documents. References from the BLM (200la) are included in the Bibliography. A complete list of references from USFWS (2002d) is available from the USFWS Carlsbad Fish and Wildlife Office, Carlsbad, California.

The 2009 5-year review for Parish's daisy (USFWS 2009ec) was consulted for updated information on this speeies.

Parish's daisy (Erigeron parishii), like the Cushenbury milk-veteh discussed in the previous species aceount, is restricted primarily to carbonate deposits and their derived soils in San Bernardino County, California. Parish's daisy is typically associated with singleleaf pinyon-Utah juniper, singleleaf pinyon, pinyon-juniper woodlands, blackbush serub, and creosote bush-bursage scrub vegetation communities (Neel 2000, Neel and Ellstrand 2001). Plants closely associated with Parish's daisy include singleleaf pinyon, California juniper, Joshua tree, and Cushenbury milk-vetch (Gonella 1994, Gonella and Neel 1995, California Natural Diversity Database 2001). Parish's daisy typically grows on limestone or dolomite soils occurring on dry, rocky slopes, shallow drainages, and outwash plains. Some plants grow on a granite/limestone interface, usually when granitic parent material has been overlaid with limestone materials washed down from upstope. The species is generally found at elevations between 3,842 and 6,400 feet (the lower elevations of the carbonate belt; Neel 2000).

Parish's daisy has a range that spans approximately 35 miles along the carbonate belt in the northeastern San Bernardino Mountains, extending from Pioneertown in the east to Furnace Canyon in the west. This distribution includes occurrences on Tip Top Mountain and in Arctic, Cushenbury, Arrastre, and Rattlesnake Canyons (Krantz 1979, Barrows 1988a, California Natural Diversity Database 2001). Carbonate-restricted plants do not appear to be specifically linked to early vegetation successional stages after disturbance; however, they are found on some surfaces that are naturally disturbed by landslides and substrate upheaval. For the most part, they oceur in habitat that is undisturbed by human activities. 
Parish's daisy is an herbaceous perennial with a long simple taproot that extends for a distance of approximately 20 inches into the loose earbonate alluvium that the speeies favors. The stems are ereet or ascending and may be either numerous or rather few on each plant, but on mature plants are typically at least 20 in number. The flower heads are solitary on bracted stalks, commonly with two to four stalks per stem. The total number of heads on a mature plant can easily equal 50 in a given season. The heads bear lavender ray flowers and yellow disk flowers.

The method of pollination is unknown, but is certainly by inseets, based on the conspicuously colored flowers. Likely eandidates include bees, butterflies, or long-tongued flies. Seed dispersal is unstudied, as is the relative importanee of seeds versus possible vegetative spread in the maintenance and expansion of populations, though seedlings have been reported at several sites (Krantz 1979) and are probably the predominant mode of reproduction. Flowering is reported to occur from May to July, but the peak of flowering seems to be from midMay to mid-June. At least in some years a few plants continue flowering into July and some even into August (Provance 1998). Flower heads have been found to be attaeked by insect larvae, but the extent and effect of such damage is unknown (Krantz 1979).

Parish's daisy was federally listed on August 24, 1994 (59 FR 43652). On December 24, 2002 (67 FR 78570), the USFWS designated approximately 4,420 aeres in San Bernardino County as eritical habitat for the species. The primary threat to Parish's daisy and other carbonate plants is limestone mining. Specific threats include population reduetion and habitat loss, degradation, and habitat fragmentation from surface mining activities. Other threats include fire suppression activities and the effeets associated with global climate change (USFWS 2009ce).

\section{Cushenbury Buckwheat}

The primary references for this section are:

USFWS. 2002d. Proposed Designation of Critical Habitat for Five Carbonate Plants from the San Bernardino Mountains in Southern California. Federal Register 67(29):6577-6612.

and

USDOI BLM. 2001a. Biological Evaluation on Effects of California Desert Conservation Area Plan as Amended and Proposed to be Amended by the NEMO and NECO Preferred Alternatives and With Other Interim Measures on Ten Threatened and Endangered Plants. California Desert District, BLM. Riverside, California.

References eited in this section are internal to the above-refereneed documents. References from the BLM (2001 c) are included in the Bibliography. A complete list of references from USFWS (2002d) is available from the USFWS Carlsbad Fish and Wildlife Office, Carlsbad, California.

The 2009 5-year review for the Cushenbury buckwheat (USFWS 2009dd) was consulted for updated information on this species.

Cushenbury buekwheat (Eriogonum ovalifolium var. vineum), like the species discussed in the previous two speeies accounts, is restricted primarily to carbonate deposits and their derived soils in San Bernardino County, California. Cushenbury buckwheat oceurs in the northeastern San Bernardino Mountains extending from White Mountain in the west to Rattlesnake Canyon in the east, a distance of approximately 25 miles. Included are occurrenees in Aretic and Cushenbury Canyons, Terrace and Jacoby Springs, along Nelson Ridge, and southeast to near Onyx Peak (Barrows 1988b, Brown 1992, Tierra Madre Consultants 1992, Gonella and Neel 1995, California Natural Diversity Database 2001). This species inhabits open areas in singleleaf pinyon-Utah juniper, singleleaf pinyon-mountain juniper, singleleaf pinyon, pinyon, pinyon-juniper, Joshua tree woodlands, and blackbush scrub vegetation communities (Gonella 1994, Gonella and Neel 1995, Neel 2000). Plants closely associated with the Cushenbury buckwheat include flannelbush, big-berry manzanita, green-leaf manzanita, Douglas' phacelia, Joshua tree, singleleaf pinyon, Cushenbury milk-veteh, and Parish's daisy (Gonella 1994, Gonella and Neel 1995, California Natural Diversity Database 2001).

Cushenbury buckwheat typically grows with soils derived from limestone or other earbonate substrates (Hickman 1993, California Natural Diversity Database 2001). It is generally found on gentle slopes between 10 and 25 
percent, mostly with north or west aspects. Other habitat characteristics include open areas with powdery fine soils and little accumulation of organic material, a canopy cover generally less than 15 percent, and rock cover exceeding 50 percent. Its elevational range is between 4,600 and 7,900 feet (Neel 2000).

Cushenbury buckwheat plants are very compact, with short woody stems spreading a few centimeters over the ground. The foliage mounds seldom rise more than 4 inches above the surrounding rocks or soil. However, when the plants begin flowering, they send up inflorescences 1 to 5 inches above the foliage. The several to many short woody stems spread and ascend over a very small patch of ground from a thick woody base above a deep and welldeveloped woody taproot. The foliage of the plant is densely covered with tangled, white hairs on both surfaces. The leaves eover the upper parts of the stems, and are densely grouped so that the ground is generally not visible through the plant. This overall plant density is partly eaused by the dried leaves, which do not fall from the plant, but simply turn a dark brown color and eling to the older parts of the stem. This adaptation presumably provides insulation for the plant as well as added protection from water loss through the stems.

Cushenbury buckwheat is a perennial of open areas and appears intolerant of extensive shading, preferring full sunlight, and typically occurs between shrubs rather than under them (White 1997). Although not well adapted to competing for light, the species is very competitive on sites where tall and fast growing species are excluded by moisture deficiencies, wind, winter cold, or nutrient deficiencies. The compact "cushion" habit probably serves to reduce moisture loss on windy ridges as is true for other species of similar life form (Walter 1973). The short annual growth intervals and eonsequent low stature makes these plants poor competitors on sites that are capable of supporting tall or dense vegetation. However, sites where moisture stress is combined with high insulation are highly favorable for plants such as this one. The nutrient deficiencies of limestone soil, exacerbated by the high pH which interferes with mineral uptake, doubtless serve to further reduce competition by fast growing species.

The inflorescence consists of a leafless flowering stem, which bears a single head-like umbel of large, eream-white to reddish flowers. Cushenbury buckwheat flowers primarily in May and June, although later flowering sometimes occurs, and fruits from this main flowering period ripen in July. Pollination of this plant has only recently been studied, and small insects are almost certainly its pollinators (Morita 1998). Both wind and birds appear to play a role in dispersing seeds, although given the extremely restricted distribution of Cushenbury buckwheat, longdistance dispersal is uncommon.

Carbonate-restricted plants do not appear to be specifically linked to carly vegetation successional stages after disturbance; however, they are found on some surfaces that are naturally disturbed by landslides and substrate upheaval. For the most part, they occur in habitat that is undisturbed by human activities.

Cushenbury buckwheat was federally listed on August 24, 1994 (59 FR 43652). On December 24, 2002 (67 FR 78570), the USFWS designated approximately 6,955 acres in San Bernardino County as critical habitat for the species. The primary threat to the Cushenbury buckwheat and other carbonate plants is limestone mining. Specific threats include population reduction and habitat loss, degradation, and habitat fragmentation from surface mining activities (USFWS 2009dd).

\section{Cushenbury Oxytheca}

The primary references for this section are:

USFWS. 2002d. Proposed Designation of Critical Habitat for Five Carbonate Plants from the San Bernardino Mountains in Southern California. Federal Register 67(29):6577-66I2.

and

USDOI BLM. 200Ia. Biological Evaluation on Effects of California Desert Conservation Area Plan as Amended and Proposed to be Amended by the NEMO and NECO Preferred Alternatives and With Other Interim Measures on Ten Threatened and Endangered Plants. California Desert District, BLM. Riverside, California. 
Referenees eited in this seetion are internal to the above-refereneed documents. Referenees from the USDOI BLM (2001e) are ineluded in the Bibliography. A eomplete list of referenees from the Federal Register listing is available from the USFWS Carlsbad Fish and Wildlife Office, Carlsbad, California.

The 2009 5-year review for the Cushenbury oxytheea (USFWS 2009ee) was eonsulted for updated information on this speeies.

Cushenbury oxytheea (Oxytheca parishii var. goodmaniana), like the speeies diseussed in the three previous speeies aeeounts, is restrieted primarily to earbonate deposits and their derived soils in San Bernardino County, California. The Cushenbury oxytheea is seattered along the earbonate belt in the northeastern San Bernardino Mountains extending from White Mountain in the west to Rattlesnake Canyon in the east. This distribution ineludes oeeurrenees near Cushenbury Spring; Cushenbury, Marble, Aretie, Wild Rose, and Furnaee Canyons; Blaekhawk, Mineral, and Tip Top Mountains; Terrace Springs; and Rose Mine and Green Lead Gold Mine (Gonella and Neel 1995, California National Park Serviee 2001, California Natural Diversity Database 2001).

Cushenbury oxytheea is typieally found in singleleaf pinyon-Utah juniper, singleleaf pinyon-mountain juniper, singleleaf pinyon, and eanyon live oak woodland vegetation eommunities (Neel 2000). Closely assoeiated plant speeies inelude mountain mahogany, big-berry manzanita, yellow rabbitbrush, and needlegrass (California Natural Diversity Database 2001). The Cushenbury oxytheea is typieally found on soils derived from limestone, dolomite, or a mixture of limestone and dolomite substrates (Tierra Madre Consultants 1992, Neel 2000). It generally oeeurs in areas with gentle slopes between 10 and 25 degrees, with no apparent preferenee for aspeet, and at elevations between 4,724 and 7,782 feet ( Neel 2000).

Cushenbury oxytheea is an annual plant and a member of the buekwheat family. The speeies germinates in the fall following the first rains and exists as a vegetative rosette through the winter months. The plant has a relatively long, straight taproot, which presumably taps into supplies of soil moisture below the surfaee. The basal rosette eonsists of relatively broad leaves, whieh are followed in the spring by a slender, leafless infloreseenee. As the infloreseenee matures, the leaves wither and dry, so that by the time of late flowering or fruit ripening the plant typieally has no living leaves at all. Cushenbury oxytheea flowers in May and June, produeing white flowers with a reddish midrib that are apparently pollinated by inseets. Speeifie pollinators, germination requirements, seed longevity, and most other aspeets of the biology of this speeies are largely unknown. Beeause Cushenbury oxytheea is an annual, the number of individual plants present fluetuates from year to year, depending on the seed bank dynamies, rainfall, and temperature. It also has few oeeurrenees, and the total number of individuals at some oeeurrenees is often low, possibly making this speeies more suseeptible to extinetion from random environmental events than the other three earbonate plant speeies.

Carbonate-restrieted plants do not appear to be speeifieally linked to early vegetation sueeessional stages after disturbanee; however, they are found on some surfaees that are naturally disturbed by landslides and substrate upheaval. For the most part, they oeeur in habitat that is undisturbed by human aetivities.

Cushenbury oxytheea was federally listed on August 24, 1994 (59 FR 43652). On Deeember 24, 2002 (67 FR 78570), the USFWS designated approximately 3,150 aeres in San Bernardino County as eritical habitat for the speeies. The primary threat to Cushenbury oxytheea and other earbonate plants is limestone mining. Speeifie threats inelude population reduetion and habitat loss, degradation, and habitat fragmentation from surfaee mining aetivities. Fire suppression aetivities and elimate ehange also threaten this speeies (USFWS 2009ee).

\section{Yreka Phlox}

The primary referenee for this seetion is:

USFWS. 2000d. Determination of Endangered Status for the Plant Yreka Phlox from Siskiyou County, California. Federal Register 65(23):5268-5275.

Referenees eited in this seetion are internal to the above-refereneed doeument. A eomplete list of the referenees is available from the USFWS Saeramento Field Offiee, Saeramento, California. 
The 2007 5-year review for the Yreka phlox (USFWS 2007p) was consulted for updated information on this species.

Yreka phlox (Phlox hirsuta) is endemic to Siskiyou County, California, where it grows on serpentine slopes in the vicinity of the City of Yreka (California Native Plant Society 1985). Serpentine soils are rocky mineral soils consisting mostly of rocks with unusually large amounts of magnesium and iron. These rocks are found diseontinuously throughout California, in the Sierra Nevada, and in the Coast Ranges from Santa Barbara County, California, to British Columbia. Serpentine soils have eharacteristic physical and chemical properties, such as high concentrations of magnesium, chromium, and nickel, and low concentrations of calcium, nitrogen, potassium, and phosphorus. In addition, serpentine soils alter the pattern of vegetation and plant species composition nearly everywhere they oceur.

The species is found on serpentine soils at elevations from 2,800 to 4,400 feet, in association with Jeffrey pine, incense cedar, and junipers (California Native Plant Society 1985, California Department of Fish and Game 1986, California Natural Diversity Database 1997). Yreka phlox is known from only five locations in the vicinity of Yreka, California. The locations are referred to as the "China Hill," "Soap Creek Ridge," "Cracker Gulch," "Greenhorn Creek," and "Jackson Street" occurrences. Occurrences are found on a mixture of privately owned land, City of Yreka land, and Forest Service-administrated lands (California Natural Diversity Database 1997).

Yreka phlox is a perennial subshrub that grows approximately 2 to 6 inches tall from a stout, woody base. Pink to purple flowers appear from April to June. The species is not thought to self-pollinate, instead relying on inseets to vector pollen to set fruit and produce seed. Little or no information exists on seed dispersal, seed germination, or seedling establishment in the wild, or even how long individual plants typically live (USFWS 2007p).

Yreka phlox was federally listed as endangered on February 3, 2000 (65 FR 5268). The USFWS has determined that future designation of eritical habitat is prudent, as resourees beeome available. Current and potential threats are alteration or destruetion of habitat resulting from residential development, logging, fire suppression activities, ongoing highway maintenance or construction activities, off-road vehicle use, illegal collection, and vandalism. Other threats include competition with exotic plants, herbicide application, grazing by domestic animals, inadequate existing regulatory mechanisms, and potential extirpation as a result of random events due to the small number of populations and small range of the species (USFWS 2007p).

\section{Metcalf Canyon Jewelflower}

The primary reference for this species is:

USFWS. 1995b. Determination of Endangered Status for Ten Plants and Threatened Status for Two Plants from Serpentine Habitats in the San Franciseo Bay Region of California. Federal Register 60:6671-6685.

References cited in this section are internal to the above-referenced document. A complete list of these references is available from the USFWS Sacramento Field Office, Sacramento, California.

Metealf Canyon jewelflower (Streptanthus albidus ssp. albidus) is endemic to serpentine soils in the region of the San Franciseo Bay in California. Serpentine soils are found in discontinuous outerops in the Sierra Nevada and in the Coast Ranges from Santa Barbara County, California, to British Columbia. The chief constituent of the parent rock is some variant of iron-magnesium silicate. Because most serpentine soils are formed in place over the parent rock, they tend to be shallow, rocky, and highly erodible. In addition, they tend to have high coneentrations of magnesium, chromium, and nickel and low concentrations of calcium, nitrogen, potassium, and phosphorus (Kruckeberg 1984). These characteristics make serpentine soil inhospitable for the growth of most plants. Nevertheless, serpentine soils often support a high diversity of plants, including many rare species (McCarten 1988). Over 200 taxa in California are endemic to serpentine soils (Kruckeberg 1984).

Metealf Canyon jewelflower is an annual herb of the mustard family that reaches up to 3 feet in height. This plant is found on serpentine barrens, areas of minimal soil development and extensive exposed rock that support a distinctive community of a few species, growing at low densities. Because Metcalf Canyon jewelflower is endemic 
to these outcrops with little soil development, it has always been rare. It can be locally abundant but its range is limited, extending less than 20 miles from San Jose south to Anderson Lake, which lies northeast of Morgan Hill. Furthermore, the serpentine outerops on whieh the subspeeies occurs are patchily distributed and comprise only a small percentage of the area within its range.

Metealf Canyon jewelflower was federally listed as endangered on February 3, 1995 (60 FR 6671). Critical habitat has not been designated for this speeies. The human population of the San Francisco Bay region has grown rapidly over the last several decades, and urban development has drastically reduced the amount of serpentine habitat. The increasing numbers of people also place an ever greater strain on undeveloped wildlands, through activities sueh as pedestrian and OHV traffic, unauthorized garbage dumping, and changes in the pattern of wildland fires. Serpentine habitats, beeausc of their often limited vegetative eover, may appear to the uninitiated as unoccupicd space, and so they arc especially likely to be subject to disturbanees. Recreational activities may directly impact plants; or may result in increased crosion and facilitate the invasion of alicn speeies ineluding many introduced annual grasses that are common in California. The destruction of serpentine habitats as a result of urban development also has increased the fragmentation of rare plant populations, thus increasing the risks of extinction due to chanee events such as fire, pest or discasc outbrcaks, reproduetive failure, or other natural or human-caused disaster.

\section{McDonald's Rock-cress}

McDonald's rock-cress (Arabis medonaldiana) appears to be restrieted to serpentine soils in northern California and immediately adjacent southwestern Oregon. The specics occurs at Red Mountain, a dome of red colored rock forming an island of peculiar vegetation protruding through the earpet of mixed cvergreen forcst indigenous to the Coast Ranges of northern California. The majority of roek-eress populations occupy conspicuously open habitats, scrce slopes, rocky ridges, and barren rocky outcrops devoid of competing vegetation and cxposed to full sun. This spceies appears to show long-term stability in open roeky habitats devoid of compctition from other plant speeies. The densest populations oceur in areas of north and east exposures or in sheltered saddles, which probably have the most persistent aeeumulations of snow. Roek-cress roots penetrate rock crevices, and arcas of substantial shect erosion appear to bc poor areas of cstablishment. Temporarily suceessful at this sitc, McDonald's rock-cress is likely a transitional member of this rapidly changing chaparral community (Baad 1985).

The vegetation covering the crest of Red Mountain is notably sparse, eonsisting of an open forcst of sugar pine, ponderosa pine, Jeffrey pinc, and incense-cedar. An understory of ehaparral spceies forms a patchy mosaie of dense cover alternating with cxtensive park-like expanses of open forest. Frequent herbaceous associates inelude Red Mountain buckwheat and Red Mountain stoneerop (Baad 1985). McDonald's rock-eress is found at clevations of 3,200 to 4,100 fect.

McDonald's rock-cress is a pcrennial herb whose aboveground parts remain alive ycar-round (Rollins 1941, 1973; Baad 1985). Germination commences with fall rains. Flowcring occurs from April through June, and fruiting occurs from July through August, with dispersal from August through mid-Scptcmber (Baad 1985). A number of insect visitors appear to be potential pollinators of rock-cress, including Syrphid flics, solitary bees, and bumblcbces. Individual plants producc a variable number of fruits, which split open in August.

McDonald's rock-cress was federally listed as cndangered on September 28, 1978 (43 FR 44810). Critical habitat has not been designated. Although approximately two-thirds of the plants oecur on publie land, all populations are potentially endangered by plans to mine exploitable nickel and chromium deposits occurring within this area. A large-scalc surface mining operation immediately adjacent to the total distribution of the spceics represents a serious threat to the survival of McDonald's rock-cress. 


\section{Chorro Creek Bog Thistle}

The primary reference for this section is:

USFWS. 1994b. Endangered or Threatened Status for Five Plants and the Morro Shoulderband Snail From Western San Luis Obispo County, California. Federal Register 59(240):64613-64623.

References eited in this seetion are internal to the above-referenced document. A complete list of these references is available from the USFWS Ventura Field Office, Ventura, California.

The 2007 5-year review for the Chorro Creek bog thistle (USFWS 2007q) was consulted for updated information.

Chorro Creek bog thistle (Cirsium fontinale var. obispoense) is a rugged short-lived perennial herb of the aster family that is restrieted to open seep areas on serpentine soil outerops in western San Luis Obispo County, California. The taxon has probably never been abundant beeause of these narrow habitat requirements. Currently, the Chorro Creek bog thistle is known from only 12 locations; 11 are to the south and west of San Luis Obispo, 1 is 30 miles to the northwest near San Simeon. The last range-wide surveys (1986) documented approximately 3,000 individuals; at that time, two populations (at Laguna Lake Park and Pennington Creek) were made up of about 1,000 plants each and the other populations were 50 to several hundreds of individuals each.

Chorro Creek bog thistle typically lives 2 to 3 years. In the first year, it forms a rosette of leaves that ean reach up to 3 feet in diameter. The majority of seedlings that survive the first winter increase in size rapidly during that winter and the following spring, producing a branched, flowering stalk up to 6 feet in height (Chipping 1994). The species usually flowers during the second spring. In most cases, the plants die after flowering, but if suffieient reserves remain after flowering, some plants may persist into a third year (Chipping 1994). Generally, the flowering period is May through July, oecasionally extending into September or Oetober (USFWS 2007q).

Chorro Creek bog thistle was federally listed as endangered on December 15, 1994 (59 FR 64613). Critical habitat has not been designated. Extant populations are threatened by trampling from eattle, proposed water diversions, and road maintenance. Prolonged periods of drought conditions may also cause declines in Chorro Creek bog thistle populations. In addition, two non-native species that are invading bog thistle habitat at several sitesEuropean broom and eucalyptus - may pose a threat to this species (Wikler and Morey 1992).

\section{Marcescent Dudleya}

The primary reference for this section is:

USFWS. 1997e. Determination of Endangered Status for Two Plants and Threatened Status for Four Plants from Southern California. Federal Register 62(19):4172-4183.

References cited in this section are internal to the above-referenced document. A complete list of these referenees is available from the USFWS Ventura Field Office, Ventura, California.

The 2009 5-year review for the marcescent dudleya (USFWS 2009ff) was consulted for updated information.

Marcescent dudleya (Dudleya cymosa ssp. marcescens) is endemic to the Santa Monica Mountains in California and is known from a 15-mile streteh between Hidden Valley and Malibu Creek State Park (Raven et al. 1986). The total area that encompasses all of the known oecurrences is approximately 88 square miles. Sites are grouped along two watersheds, Little Syeamore Canyon and Malibu Creek, with all other oecurrences scattered between these two locations. There are approximately 12,000 individuals throughout its range.

Suitable habitat for marcescent dudleya is generally located on the lower reaches of volcanic rock outcrops adjacent to streams, chaparral, and coast live oak woodland. In most locations, the topographic relief has prevented deep soil formation; therefore, this species may be the only flowering plant occurring in a microhabitat that is otherwise dominated by mosses, lichens, and ferns. The mosses and lichens may play a crucial role in trapping marcescent dudleya seeds and allowing them to germinate and establish on the volcanic outcrops (USFWS 2009ft). 
Mareeseent dudleya is a sueeulent, perennial herb in the stoneerop family, with a thiekened rootstock, rosette leaves, and thiek flowering stems with flowers that are bright yellow, to yellow with red markings, to bright red (Munz 1974). The leaves wither during the summer but remain attached to the plant. Seeds generally germinate in the winter following the start of the wet season (Dorsey 2007). Flowering generally oeeurs between May and June; the speeies is pollinated by hummingbirds and bees, and produees an abundant amount of small seeds. Pollination serviees to Mareeseent dudleya may be less than for other Dudleya taxa beeause they grow on roek faees with no other flowering plants to attraet pollinators. Compared with other members of the same genus, Mareeseent dudleya has relatively low seed produetion and germination sueeess. Individual plants and seeds are long-lived.

Mareeseent dudleya was federally listed as endangered on January 29, 1997 (62 FR 4172). Critieal habitat has not been designated. Half of the 13 populations of the subspeeies oeeur on lands administered by the California Department of Parks and Reereation; two loeations are administered by the National Park Serviee- one on an administrative easement where the landowner has drastieally altered the native vegetation (pine plantings in a eleared oak grove), and another in an area that reeeives unsupervised reereational use. The remaining seven populations are on lands in private ownership, several of whieh are threatened by development (California Natural Diversity Database 1994, Skinner and Pavlik 1994). On the California Department of Parks and Reereation and National Park Serviee lands, the plant is threatened by reereational use, partieularly roek elimbing, foot traffie, eolleetion, and fire.

\section{Yellow Larkspur}

The primary referenee for this seetion is:

USFWS. 2003a. Endangered and Threatened Wildlife and Plants; Final Designation of Critieal Habitat for Two Larkspurs From Coastal Northern California. Federal Register 68(52):12834-12863.

Referenees eited in this seetion are internal to the above-refereneed doeument. A eomplete list of these referenees is available from the USFWS Saeramento Fish and Wildlife Offiee, Saeramento, California.

The 2011 5-year review for the yellow larkspur (USFWS 2011s) was consulted for updated information on this speeies.

Yellow larkspur (Delphinium luteum) is a perennial herb that grows from thin, tuberous roots. It oeeurs in northwestern Marin and southwestern Sonoma Counties of California, in eoastal prairie and eoastal serub areas with a laek of overstory vegetation at elevations ranging from sea level to 300 feet (California Natural Diversity Database 2001). Generally, yellow larkspurs are found on moderate to steep slopes, near areas that have experieneed ground disturbanee (Guerrant 1978, California Natural Diversity Database 2001). It is adapted to live in soils that are suseeptible to erosion. As of the 5-year status review in 2011 (USFWS 2011s), there were 12 total doeumented oeeurrenees of the speeies, 1 to 5 of which are possibly extinet.

Yellow larkspur flowers from Mareh to May. It is believed that the speeies is pollinated by hummingbirds, whieh have been observed visiting flowers (CNPS 1977). The fruit is a folliele.

Yellow larkspur was federally listed as endangered on January 26, 2000 (65 FR 4156). On Mareh 18, 2003 (68 FR 12834), the USFWS designated approximately 2,525 aeres in Marin and Sonoma Counties, California as eritieal habitat for the speeies. Mueh of the eoastal prairie within the range of the yellow larkspur has supported livestoek grazing for more than a eentury, and non-native speeies are prevalent in these habitats. Yellow larkspur typieally oeeurs near other native plant speeies, whieh are indieative of the eeologieal proeesses that ereate suitable habitat for the larkspur. Threats to the speeies vary by population, and inelude overcollection, road widening, inadequately managed sheep grazing, fire suppression, and hybridization with another Delphinium speeies (B. Guggolz, California Native Plant Soeiety 1995, pers. eomm.; California Natural Diversity Database 2001). Additionally, the speeies is at risk for extirpation from random natural events, ineluding fire, as a result of small, isolated populations, narrow range, and restrieted habitat (Shaffer 1981, Primaek 1993). 


\section{Willowy Monardella}

The primary reference for this section is:

USFWS. 2012b. Endangered and Threatened Wildlife and Plants; Revised Endangered Status, Revised Critieal Habitat Designation, and Taxonomic Revision for Monardella linoides ssp. viminea; Final Rule Federal Register 77(44):13394-13447.

References cited in this section are internal to the above-referenced doeument. A complete list of these references is available from the Carlsbad Fish and Wildlife Office, Carlsbad, California.

Willowy monardella (Monardella viminea) was previously federally listed as an endangered species under the taxon Monardella linoides ssp. viminea (63 FR 54938), which was split into two distinct species. Only M. viminea currently retains protection under the ESA. Willowy monardella oceurs in coastal sage and riparian scrub habitats in San Diego County, California. Populations of this species are concentrated in the Miramar area of San Diego County.

Willow monardella is found in washes in coastal sage scrub or riparian scrub vegetation; terraced seeondary beaches, channel banks, and stabilized sand bars; soils with a high content of eoarse-grained sand and low eontent of silt and clay; and open ground eover, less than half of which is herbaceous vegetation (Scheid 1985, USFWS 1998, Elvin and Sanders 2003, Kelly and Burraseano 2006). The species is most often found on the first abovewater sandbar in intermittent streambeds where water runs for 24 to 48 hours after heavy rain events (Elvin and Sanders 2003, Kelly and Burraseano 2006). Plants generally oceur on soil types with high sand eontent, often characterized by sediment and cobble deposited by flood events (Scheid 1985, Rebman and Dossey 2006). Willowy monardella requires open to semi-open canopy cover, with limited herbaceous understory. The species is most commonly associated with California buckwheat and desertbroom (Scheid 1985, lnec 2010).

Willowy monardella is a perennial species that blooms from June to August. Pollinators include numerous bees and butterflies, and likely a diverse array of other insects.

As discussed previously, willow monardella was previously federally listed as an endangered taxon in 1998, as the subspeeies $M$. linoides ssp. viminea. On November 8, 2006 (71 FR 65662), the USFWS designated approximately 73 acres in San Diego County, California as eritical habitat for the subspecies. The revised eritical habitat designation on March 6, 2012 (77 FR 13394), separates $M$. viminea from $M$. stoneana, whieh no longer requires protection under the ESA. On this date, the USFWS designated 122 acres in San Diego County as critieal habitat for $M$. viminea. The primary threat to the willow monardella is modifieation and destruction of habitat, particularly through severe alteration of hydrology in Carroll Canyon, Lopez Canyon, and western portions of San Clemente Canyon. Additional threats to the species include habitat degradation due to frequent fire, invasions of non-native plant species into canyon habitats, and small population size.

\section{Mariposa Pussypaws}

The primary reference for this section is:

USFWS 2007r. Mariposa Pussypaws (Calyptridium pulchellum) 5-Year Review: Summary and Evaluation. Sacramento Fish and Wildlife Office. Sacramento, California.

References cited in this section are internal to the above-referenced document. They are included in the Bibliography.

Mariposa pussypaws (Calyptridium pulchellum) is a species of the western foothills of the Sierra Nevada in California. As of 2006, the species occurred in nine or ten occurrences in Mariposa, Madera, and Fresno Counties, California, occurring within a range of approximately 40 miles (California Natural Diversity Database 2006). The main center of distribution is in Mariposa County, south of the town of Mariposa. It is believed that the current range is the same as the historical range. 
Mariposa pussypaws grows in sparsely-vegetated areas, such as granite domes and gravelly openings within foothill woodland communities (California Natural Diversity Database 2006). The species is believed to be restricted to eertain soil types (deeomposed granitie sands) because it eompetes poorly with other species on more fertile soils. It oecurs at elevations from 1,450 feet to 3,600 feet. Mariposa pussypaws typically grows in association with the rare species orange lupine, Mariposa lupine, and Layne's monkeyflower. Other frequent associates include harlequin lupine, varied-leaved jewelflower, Mariposa manzanita, and Mimulus gracilipes (Hoover 1940b, Hamon 1981, California Natural Diversity Database 2006).

Mariposa pussypaws is a small, rosette-forming, annual herb. It flowers between May and August.

Mariposa pussypaws was federally listed as a threatened species on September 14, 1998 (63 FR 49022). Critieal habitat has not been designated for this speeies. The primary threats to the speeies are urban development, OHV use, and the small size and number of populations. Competition from non-native weed species and eneroachment by native live oak are also threats to the species.

\section{Coyote Ceanothus}

The primary reference for this section is:

USFWS 2011t. Ceanothus ferrisiae (Coyote eeanothus) 5-Year Review: Summary and Evaluation Saeramento Fish and Wildlife Offiee. Saeramento, California.

References cited in this seetion are internal to the above-referenced doeument. They are included in the Bibliography.

Coyote ceanothus (Ceanothus ferrisae) is an evergreen shrub that grows on slopes in Morgan Hill, California, within Santa Clara County. It is known from only three locations, all of whieh oecur within approximately 4 to 5 miles of one another.

Coyote eeanothus is found on arid slopes in serpentine chaparral, valley, and foothill grasslands below about 1,000 feet in elevation (Munz and Keek 1959). Rare species associated with Coyote ceanothus inelude Santa Clara Valley dudleya, and most beautiful jewelflower. It is also associated with bigberry manzanita, California eoffee berry, California sagebrush, eommon yarrow, foothill pine, leather oak, and toyon (Evens and San 2004). However, some occurrences are nearly pure stands of coyote ceanothus.

Coyote ceanothus is a perennial speeies that flowers from January to Mareh (Munz and Keek 1959). Seed dispersal begins in May and can last though late Oetober. It is an obligate seeder and most likely self-ineompatible. The species is insect-pollinated mostly by generalist native and some non-native bee taxa (Kremen et al. 2002; Thorp et al. 2002). Based on observations of mass seedling germination following fire and other information, it is believed that periodic fire events are erucial for regeneration of senescent stands (Keeley 2002, Pfeiffer and Ortiz 2007).

Coyote eeanothus was federally listed as endangered on February 3, 1995 (60 FR 6671). Critical habitat has not been designated for this species. Threats to the speeies include eonsistently low numbers of individuals, few existing populations, low recruitment, urbanization, habitat loss and fragmentation, isolation, altered fire regime, and limited insect-mediated gene flow.

\section{Robust Spineflower}

The primary reference for this section is:

USFWS 2010m. Chorizanthe robusta var. robusta (Robust Spineflower) 5-Year Review: Summary and Evaluation. Ventura Fish and Wildlife Office. Ventura, California.

References eited in this section are internal to the above-refereneed document. They are included in the Bibliography. 
The robust spineflower (Chorizanthe robusta var. robusta) occurs in sandy soils along the coast and in near-coastal areas in Santa Cruz County, California. Historically, the subspecies oceurred as far north as San Francisco and Alameda Counties, and south into Monterey County, with inland occurrences documented in and around San Jose and Los Gatos in Santa Clara County. Currently, the subspecies is restricted to 11 populations over a range of approximately 21 miles in Santa Cruz County (USFWS 2004a).

Key habitat components for the robust spineflower include sandy soils associated with active coastal dunes and inland sites with sandy soils; plant communities that support associated species and that have openings between dominant elements, including coastal dune, coastal scrub, grassland maritime chaparral, and oak woodland communities; plant communities that contain little or no cover by non-native species; and physical processes, such as occasional soil disturbance, that support natural dune dynamies along coastal areas (USFWS 2004a).

The robust spineflower is a short-lived annual species. Germination oceurs during winter months. The seedling survival rate of this subspecies is fairly low, with causes of mortality including desiccation prior to flowering, herbivory, and uprooting by gophers (Baron 1998). Flowering oceurs from April through June, and in some cases throughout the summer. Plants are pollinated by a variety of insects, and are also capable of self-pollination. However, it is thought that pollinators may enhance the overall fitness of the species by resulting in a larger seed set (Murphy 2003). Therefore, protection of pollinator habitat may be a necessary component for survival of the subspecies (Schemske et al. 1994; Murphy 2003). Plants dry through the summer months, eventually breaking apart in the fall. Small mammals and birds are the most likely seed dispersers, although wind also plays a part (USFWS 2004a).

The robust spineflower was federally listed under the name Chorizanthe robusta on February 4, 1994 (59 FR 5499 ), but C. robusta var. robusta was later separated out into a separate listable entity. On May 28, 2002, the USFWS designated 469 acres in Santa Cruz County as eritical habitat for the subspecies (67 FR 36822). The primary threats to this species include development, recreation, encroachment (and/or shade-out) by invasive, nonnative and native species, road maintenance, vegetation management, human disturbance, and random events.

\section{Gaviota Tarplant}

The primary reference for this section is:

USFWS 2010n. Deinandra increscens ssp. villosa (Gaviota Tarplant) 5-Year Review: Summary and Evaluation. Ventura Fish and Wildlife Office. Ventura, California.

References cited in this section are internal to the above-referenced document. They are included in the Bibliography.

Gaviota tarplant (Deinandra increscens ssp. villosa) is endemic to the mainland portion of Santa Barbara County, California. It has a highly localized distribution in the western portion of the county, with 26 occurrences in seven main populations, ranging from the coastal terraces on the bluffs at Lion's Head near Point Sal to the mountains of the Western Transverse Ranges, to the coastal terraces on the bluffs at Point Conception and Gaviota (USFWS 2000b, 2002e; California Natural Diversity Database 2010; Consortium of California Herbaria 2010; Baldwin 2009; Elvin 2010a, b).

Gaviota tarplant occurs on marine terraces and uplifted marine sediments ranging from 150 feet in elevation along the lowest terraces to 1,000 feet and fractured shales in the Tranquillion Mountain and Sudden Peak area (Hendrickson et al. 1998; Wilken 1998; California Natural Diversity Database 2010). It occurs mostly on acidic sandy loam, clay loam, loamy sand, and loam soils; duneland; and rock outcrop complexes (USDA Soil Conservation Service 1972, 1981). Gaviota tarplant is associated with grasslands comprised of native needlegrass, non-native species such as wild oats and ripgut brome, and other herbs and grasses. Throughout the range of the species, the grasslands are interspersed with coastal sage scrub generally dominated by California sagebrush, coyote brush, sawtooth golden bush, and California buckwheat (California Natural Diversity Database 2010 ). 
Gaviota tarplant is a self-sterile annual plant that blooms in June through September. The subspecies depends on its seed bank for long-term persistence. Once produced, seeds may germinate immediately or disperse to new areas, become lost to predation, or become stored in a soil seed bank. Seeds are most likely dispersed by adhesion to animal fur or feathers. Seed banks contribute to the long-term persistence of a species by sustaining populations through periods when conditions are not conducive to adequate germination. The precise length of time that Gaviota tarplant seed banks remain viable is unknown.

Gaviota tarplant was federally listed as endangered on March 20, 2000 (65 FR 14888). On November 7, 2002, the USFWS designated 16,110 acres in Santa Barbara County as critical habitat for the subspecies (67 FR 67968). Threats to the subspecies include degradation and loss of habitat due to agriculture and urban development, invasion of non-native species, oil extraction activitics, wind energy development, and climate change.

\section{Yadon's Piperia}

The primary reference for this section is:

USFWS 2009gg. Piperia yadonii (Yadon's Piperia) 5-Year Review: Summary and Evaluation. Ventura Fish and Wildlife Office. Ventura, California.

References cited in this section are internal to the above-referenced document. They are included in the Bibliography.

Yadon's piperia is an orchid that is endemic to Monterey pine forests and maritime chaparral communities in Monterey County, California. Its center of distribution is the Monterey Peninsula, where plants are found throughout the larger undeveloped tracts of Monterey pine forest. To the north, the range of Yadon's piperia extends to the Los Lomas area, near the border of Santa Cruz County. To the south, plants have been found near Palo Colorado Canyon.

Yadon's piperia has been found in two primary habitat types: Monterey pine forest with an herbaceous, sparse understory; and ridges in maritime chaparral growing beneath dwarfed Hooker's manzanita shrubs in shallow soils (Morgan and Ackerman 1990, Allen 1996, Doak and Graff 2001). In the Monterey pine forest habitat, the species grows through pine needle duff among sparse herbaccous vegetation. It grows in filtered sun on soils with a shallow clay hard pan that becomes very dry during the flowering season. Overall, the species favors a welldrained sandy soil substrate and conditions that retain moisture during the rainy season but are not subject to inundation. In some Monterey pine forest locations, Yadon's piperia plants occur among dense stands of the nonnative quaking grass (Doak and Graff 2001). In maritime chaparral habitat in northern Monterey County, plants grow on sandstone ridges where soils are shallow. They are commonly found under the edges of prostrate mats of Hooker's manzanita. Like other orchid species, Yadon's piperia does not appear to be an early successional species but is able to colonize trails and road banks within dwarf maritime chaparral or Monterey pine forest once a decade or more has passed and if light and moisture regimes are favorable (Allen 1996).

The blooming season of Yadon's piperia is brief, usually starting in mid-June and ending in early August (Colcman 1995, Doak and Graff 200 I). Individuals that flower in one year may not flower in the next, and a portion of the population may be completely dormant in any given year. As observed with other orchids, germination of seeds is believed to involve a symbiotic relationship with fungus. Following germination, orchid seedlings typically grow below ground for I to several years before producing their first basal leaves, and may produce only vegetative growth for several years before producing flowers (Rasmussen 1995). In mature Yadon's piperia plants, basal leaves typically emerge sometime after fall or winter rains and wither by May or June. Consistent with what is known of other orchid species, only a small percentage of the plants in a population may flower in any year (Allen 1996).

Yadon's piperia was federally listed as endangered on August 12, 1998 (63 FR 43100). On October 24, 2007, the USFWS designated 2,117 acres in Monterey County, California, as critical habitat for the species (72 FR 60410). The primary threats to the species are habitat fragmentation and development. Additionally, the species is 
threatened by factors that reduce the reproductive potential of the species, including herbivory, disease, and low rates of seed set.

\section{Marine Ecoregion Division}

The Marine Ecoregion Division includes habitats in the maritime climate of the Cascade and Coast Ranges of western Washington and Oregon along the Pacific Coast. The vegetation in this ecoregion is predominantly coniferous and mixed forests, with non-forested meadows and grasslands occurring over a small area. The TEP plant species found in this ecoregion typically oceur in these rarer open habitats, many of which are threatened by forest suceession and the encroachment of woody plants.

\section{Bradshaw's Desert-Parsley}

The primary references for this section are:

USFWS. 1993f. Lomatium bradshawii (Bradshaw's Lomatium) Recovery Plan. Portland, Oregon.

and

USFWS. 2010o. Recovery Plan for the Prairie Species of Western Oregon and Southwestern Washington. U.S. Fish and Wildlife Service, Portland, Oregon.

References eited in this section are internal to the above-referenced documents. They are included in the Bibliography.

Bradshaw's desert-parsley, or Bradshaw's lomatium (Lomatium bradshawii), is known from Marion, Linn, Benton, and Lane Counties in Oregon and Clark County in Washington. The Washington populations, though few in number, are large in population size, with one site estimated to have over 800,000 individuals (USFWS unpublished data). There are currently more than 60 sites with Bradshaw's desert-parsley, coneentrated in three population centers, in Oregon. Most of these populations are small, ranging from about 10 to 1,000 individuals, although the two largest sites each have over 100,000 plants (Oregon Natural Heritage Information Center 2007). The total area of occupied habitat is about 742 acres.

Bradshaw's lomatium oceurs in two very distinet habitats. The rarest are the shallow, stream-covered basalt areas found in Marion and Linn Counties near the Santiam River. At these sites, the plants oecur in areas with almost no soil, usually in vernal wetlands or along stream channels. The majority of the species' populations oceur on seasonally saturated or flooded prairies, which are common by creeks and small rivers in the southern Willamette Valley. They oceur in areas with deep, pluvial clays, usually in a matrix with alluvial silts. The slowly permeable clay layer results in a perched water table in winter and spring, so soils are generally saturated to the surface or slightly inundated during the wet season. This relic wetland prairie has been deseribed as the tufted hairgrass valley prairie, which ranges from fairly wet areas with high sedge and rush cover, to drier bunchgrass prairie. In the wet areas, Bradshaw's lomatium occurs on the edges of tufted-hairgrass or sedge bunches, in patehes of bare or open soil. In the drier areas, it is found in low areas, such as small depressions, trails, or seasonal channels, also with open, exposed soils.

Bradshaw's lomatium blooms in the spring, usually in April and early May. The plant is pollinated by insects; more than 30 species of solitary bees, flies, wasps, and beetles have been observed visiting the flowers (Kaye and Kirkland 1994, Jackson 1996). A typical population of Bradshaw's lomatium is composed of many more vegetative plants than reproductive plants. The species generally responds positively to disturbance. Low intensity fire and annual fall mowing both appear to stimulate population growth of Bradshaw's lomatium.

Bradshaw's lomatium was federally listed as endangered on September 30, 1988 (53 FR 38448). Critical habitat has not been designated. The species' habitat is presently being destroyed or modified by numerous factors: invasion of prairie vegetation by trees and shrubs; hydrologic alterations including changes in flooding patterns and water movement (which may be critical to seedling establishment); urban development; and agricultural or rural 
development. In addition, disease caused by a fungal parasite, and insect predation of plants and fruit may threaten smaller populations. Finally, natural faetors sueh as inbreeding or limited pollinator availability may reduee feeundity, and therefore reproduetive eapaeity of the speeies.

\section{Willamette Daisy}

The primary referenees for this seetion is:

USFWS. 1997e. Endangered Status for Erigeron decumbens var. decumbens (Willamette Daisy) and Fender's Blue Butterfly (Icaricia icarioides fenderi) and Threatened Status for Lupinus sulphureus ssp. kincaidii (Kineaid's Lupine). Federal Register 65(16):3875-3890.

Referenees eited in this seetion are internal to the above-refereneed doeument. A eomplete list of these referenees is available from the USFWS Oregon State Offiee, Portland, Oregon.

Willamette daisy (Erigeron decumbens var. decumbens) is restrieted primarily to the Willamette Valley of Oregon. The valley is an alluvial floodplain that is 130 miles long and 20 to 40 miles wide, with an overall northward gradient (Orr et al. 1992). The valley is narrow and flat at its southern end, widening and beeoming hilly near its northern end at the eonfluenee of the Willamette and Columbia Rivers. The alluvial soils of the Willamette Valley and southern Washington host a mosaie of grassland, woodland, and forest eommunities. The Willamette daisy oeeupies native grassland habitats within the Willamette Valley. The vast majority of Willamette Valley grasslands require natural or human-indueed disturbanee for their maintenanee (Franklin and Dryness 1973), and would likely be forested if left undisturbed (Johannessen et al. 1971). Prior to the 1850s, the Kalapooya Indians engaged in patterns of annual burning to maintain extensive wet and dry prairie grasslands (Johannessen et al. 1971). However these fires were eurtailed in the wake of European settlement and grasslands have largely eonverted to forest, shrubland, agrieulture, or developed uses.

The primary habitat for Willamette daisy is native prairie. This habitat is eharaeterized by early sueeessional stage upland prairie, wet prairie, or oak savanna habitat with a mosaie of low-growing grasses and wildflowers, spaees to establish seedlings or new vegetative growth, and an absenee of dense eanopy vegetation. Today the speeies oeeupies about 233 aeres of habitat in Benton, Lane, Linn, Marion, and Polk Counties, Oregon. It oeeurs in both wet prairie grasslands and drier upland prairie sites. The wet prairie grassland eommunity is typieally dominated by tufted hairgrass, California oatgrass, and a number of Willamette Valley endemie forbs. It is a flat, open, seasonally wet prairie with bare soil between the elumps of the tufted hairgrass (Kagan and Yamamoto 1987). On drier upland prairie sites, assoeiated speeies eommonly inelude Hall's aster, Roemer's feseue and western poison oak (Meinke 1982; Clark et al. 1993). Willamette daisy prefers heavier soils.

Willamette daisy is a perennial herb, 6 to 24 inehes tall, with ereet to sometimes prostrate stems at the base. Flowering typieally oeeurs in June and July, with pollination earried out by flies and bees. Seeds are released in July and August. Although the seeds are wind-dispersed, the short stature of this speeies likely prevents the longdistanee travel of many of these seeds. Willamette daisy is eapable of vegetative spreading and is eommonly found in large elumps seattered throughout a site (Clark et al. 1993).

Willamette daisy was federally listed as endangered on January 25, 2000 (65 FR 3875), and eritieal habitat was designated on Oetober 31, 2006 (71 FR 63862), with eritieal habitat units in Benton, Lane, Linn, Marion and Polk Counties, Oregon. The Willamette daisy likely onee was widespread throughout the historie native prairie. Currently, the speeies is threatened by habitat loss due to urban and agrieultural development, sueeessional eneroaehment into its habitat by trees and shrubs, eompetition with non-native weeds, and small population sizes (Kagan and Yamamoto 1987; Clark et al. 1993; Gisler 2004). The USFWS (20100) estimates that habitat loss is oeeurring at 80 pereent of the remaining 84 remnants of native prairies oeeupied by Willamette Valley daisy. 


\section{Kincaid's Lupine}

The primary references for this section are:

USFWS. 1997e. Endangered Status for Erigeron decumbens var. decumbens (Willamette Daisy) and Fender's Blue Butterfly (Icaricia icarioides fenderi) and Threatened Status for Lupinus sulphureus ssp. kincaidii (Kincaid's Lupine). Federal Register 65(16):3875-3890.

and

USFWS. 20100. Recovery Plan for the Prairie Species of Western Oregon and Southwestern Washington. Portland, Oregon.

References eited in this section are internal to the above-referenced documents. References from the Recovery Plan are included in the Bibliography. A complete list of references from the Federal Register listing document is available from the USFWS Oregon State Office, Portland, Oregon.

Kincaid's lupine (Lupinus sulphureus ssp. kincaidii), is found in dry upland prairies from Lewis County, Washington in the north, south to the foothills of Douglas County, Oregon; however, most of the known and historical populations are found in the Willamette Valley. Kincaid's lupine oceurs in small populations at widely scattered native upland prairie remnants, where red feseue and/or Idaho fescues are dominant species, and with Tolmie's mariposa, Hooker's eatehfly, broadpetal strawberry, rose checker-mallow, and lomatium species serving as herbaceous indicator species (Hammond and Wilson 1993). It appears to prefer heavier, generally well-drained soils. The species is currently known to oceur at about 164 sites, comprising about 608 acres.

Kincaid's lupine is a long-lived perennial species that reproduces by seed and vegetative spread. It is able to spread extensively through underground growth. Individual clones can be several centuries old (Wilson et al. 2003), and become quite large with age, producing many flowering stems. Individual plants are capable of spreading by rhizomes, producing clumps of plants exceeding 33 feet in diameter. The long rhizomes do not produce adventitious roots (secondary roots growing from stem tissue) and apparently do not separate from the parent clump, and the clumps may be short-lived, regularly dying back to the crown (Kuykendall and Kaye 1993a). Pollination is largely accomplished by small native bumblebees, solitary bees, and oceasionally European honey bees (Wilson et al. 2003). Insect pollination appears to be eritical for successful seed production (Wilson et al. 2003). Reproduction by seed is common in large populations where inbreeding depression is minimized and ample numbers of seeds are produced. In small populations, seed production is reduced, which may be linked to inbreeding depression (Severns 2003). Seeds are dispersed from fruits that open explosively upon drying. Kincaid's lupine is the host plant of the federally endangered Fender's blue butterfly.

Kincaid's lupine was federally listed as threatened on January 25, 2000 (65 FR 3875). On October 31, 2006 (71 FR 63862) the USFWS designated 585 acres as critical habitat in Benton, Lane, Polk and Yamhill Counties, Oregon, and Lewis County, Washington. Kincaid's lupine likely once oceurred over a large distribution throughout the historic native prairie. However, native prairie vegetation in the Willamette Valley was decimated by the rapid expansion of agriculture from the 1850 s to the present. In addition, fire suppression allowed shrub and tree species to overtake grasslands, while agricultural practices hastened the decline of native prairie species through habitat loss and increased grazing (Johannessen et al. 1971; Franklin and Dyrness 1973). Currently, Kincaid's lupine is threatened by commercial and/or residential development, agriculture, silvicultural practices, road improvement, collection, herbicide use, and naturally occurring demographic and random environmental events. 


\section{Nelson's Checker-mallow}

The primary referenees for this seetion are:

USFWS. 1998j. Reeovery Plan for the Threatened Nelson's Cheeker-mallow (Sidalcea nelsoniana). Portland, Oregon.

and

USFWS. 2010o. Reeovery Plan for the Prairie Speeies of Western Oregon and Southwestern Washington.

Portland, Oregon.

Referenees eited in this seetion are internal to the above-refereneed doeuments. Full eitations are ineluded in the Bibliography.

Nelson's eheeker-mallow (Sidalcea nelsoniana) oeeurs as seattered populations in two distinet eeologieal regions: the northern Coast Range and the Willamette Valley of Oregon (ineludes two outlying populations in the Puget Trough of Washington). The speeies is not restrieted to a single habitat type. Rather, it oeeupies a broad range of soils that vary in texture, drainage, and disturbanee regimes (CH2M Hill 1986b). Plants appear to favor primary drainages, or those that reeeive mostly ground flow of stormwater runoff, rather than drainages fed by stream sourees.

Although oeeasionally oeeurring in the understory of woodlands or among woody shrubs, populations of Nelson's eheeker-mallow in the Willamette Valley usually oeeupy open habitats that support early sueeessional speeies (i.e., plants that eolonize openings and then disappear as trees shade them out). These habitats are frequently represented by margins of sloughs, ditehes, and streams; roadsides; fenee rows; drainage swales; native prairie remnants; and fallow fields. Most sites have been densely eolonized by invasive weeds, espeeially introdueed forage grasses. Commonly assoeiated plant speeies inelude: tall feseue, rose, eommon rush, Canada thistle, eommon St. Johnswort, blaekberry, sedge, timothy, velvet grass, yarrow, veteh, western spiraea, bird's-foot trefoil, ox-eye daisy, eolonial bent-grass, meadow foxtail, reed eanarygrass, Douglas' hawthorn, wild earrot, large-leaved avens, geranium, and Oregon ash (Oregon Department of Agrieulture 1995).

Populations of Nelson's eheeker-mallow in the Coast Range generally oeeur in open, wet-to-dry meadows, intermittent stream ehannels, and along the margins of eoniferous forests. These areas typieally support larger eomponents of native vegetation than the Willamette Valley sites. Commonly assoeiated plant speeies inelude tansy ragwort, spear-head seneeio, strawberry, velvet grass, timothy, rush, sedge, and yarrow.

Nelson's eheeker-mallow is an herbaeeous perennial plant speeies in the mallow family. In the Willamette Valley, flowering begins as early as mid-May, and eontinues through August to early September, depending on the moisture and elimatie eonditions of eaeh site. Coast Range populations experienee a shorter growing season and generally flower later and go dormant earlier. Seeds are deposited loeally at or near the base of the parent plant, and may be shed immediately or persist into winter within the dry flower parts that remain attaehed to the dead stems. Seed dissemination eould eoneeivably be aeeomplished through ingestion by deer and elk, partieularly in the Coast Range. Aboveground portions of the plant die baek in the fall, usually followed by some degree of regreening at the base. It is not uneommon for some plants to eontinue produeing flowers into the fall and early winter. Sexual reproduetion appears to be aeeomplished entirely by inseet pollinators.

Nelson's eheeker-mallow was federally listed as threatened on February 12, 1993 (58 FR 8235). Critieal habitat has not been designated. Prior to European settlement, Nelson's eheeker-mallow habitats were likely maintained and kept free of overgrowth and woody vegetation by natural wildfires, fires set by Native Amerieans (Johannessen et al. 1971; Franklin and Dyrness 1973; Boyd 1986), and sporadie flooding. The landseape and proeesses sueh as flooding and fire have been dramatieally altered sinee the onset of European settlement. Today, no natural prairie remains in the Willamette Valley without evidenee of livestoek grazing, agrieulture, and fire suppression (Moir and Mika 1972). Urbanization and eonversion of the native prairies into intensively managed eroplands and pastures have eliminated and fragmented grasslands to the extent that Nelson's ehecker-mallow is 
now restrieted to sparsely distributed patches within narrow highway and country road ROWs, undeveloped tracts, ditches, fence rows, abandoned fields, parks, and wildlife refuges. Populations in the Willamette Valley are threatened by roadside maintenance, herbicide application and mowing, soil eultivation, ditching, and other habitat modifications.

Land threats are less extreme in the Coast Range, where the meadows occupied by Nelson's checker-mallow are isolated from agricultural and urban development. Potential threats to these populations inelude a planned water impoundment project, herbicide application associated with timber harvest, and motoreyclists. Other threats to the species as a whole are competition with invasive plant species, the encroachment of trees and shrubs, limited seed production, and the species' small population size and fragmentation.

\section{Wenatchee Mountains Checker-mallow}

The primary referenees for this section are:

USFWS. 1999g. Determination of Endangered Status for Sidalcea oregana var. calva (Wenatehee Mountains Checker-mallow). Federal Register 64(245):71680-71687.

and

USFWS. 2001f. Final Designation of Critical Habitat for Sidalcea oregana var. calva (Wenatchee Mountains Checker-mallow). Federal Register 66(173):46536-46548.

The 2007 5-year review for the Wenatehee Mountains checker-mallow (USFWS 2007s) was consulted for updated information on this species.

Wenatehee Mountains cheeker-mallow (Sidalcea oregana var. calva) is endemie to the Wenatchee Mountains of Chelan County in central Washington. The plant is most abundant in moist meadows that have surfaee water or saturated upper soil profiles during spring and early summer, but it also oceurs in open conifer stands dominated by ponderosa pine and Douglas-fir and on the margins of shrub and hardwood thickets. Populations are found at elevations ranging from 1,600 to 3,300 feet. The soils are typieally elay loams and silty loams with low moisture permeability. Associated speeies include quaking aspen, black hawthorn, common snowberry, serviceberry, fewflowered peavine, northern mule's-ear, sticky purple geranium, and California false hellebore.

Wenatchee Mountains checker-mallow is a perennial plant with a stout taproot that branches at the root-erown and gives rise to several stems that are 8 to 60 inches tall. Flowering begins in the middle of June and peaks in the middle to end of July. The taxon is known to occur at five sites (populations), one on Washington Department of Natural Resourees lands, one within the Wenatchee National Forest, and the remaining three on private lands.

The physical and biological habitat features essential to the conservation of this species include open meadows with surface water or saturated upper soil profiles in the spring and early summer, and the hydrologie processes on which these areas depend; open conifer forests dominated by ponderosa pine and Douglas-fir; and the margins of shrub and hardwood thickets. All of these habitats have surface water or saturated soils well into the early summer. The species is generally found on flats or benches, but may also oceur in small ravines and occasionally on gently sloping uplands. The species may be fire dependent or require open habitat, and has responded positively to applications of prescribed fire.

Wenatchee Mountains checker-mallow was federally listed as endangered on December 22, 1999 (64 FR 7I680). Approximately 6,135 acres in Chelan County, Washington, were designated as critical habitat on September 6, 2001 (66 FR 46536). The greatest threats to the species are: low numbers of individuals in most of the populations; vulnerability of the species to competition from non-native invasive plants and native woody plants; landscapelevel fire suppression; seed predation by weevils and other insects; and the potential loss of habitat due to human development (USFWS 2007s). 


\section{Applegate's Milk-vetch}

The primary reference for this seetion is:

USFWS. 2009hh. Astragalus applegatei (Applegate's Milk-veteh) 5-Year Review: Summary and Evaluation. Klamath Falls Fish and Wildlife Office. Klamath Falls, Oregon.

References eited in this section are internal to the above-referenced document. Full citations are included in the Bibliography.

Applegate's milk-vetch (Astragalus applegatei) is a narrow endemic, known only from the Lower Klamath Basin near the eity of Klamath Falls in southern Oregon. It is restricted to flat-lying, seasonally moist, strongly alkaline soils (USFWS 1998k). The vegetative community in which Applegate's milk-vetch sites occurs is elassified as interior alkali grassland (The Nature Conservancy 1999). Most of the habitat for this natural community has been converted to agriculture or pasture, and developed or disturbed such that the existing sites are now dominated by non-native, weedy spceies. The speeies' habitat was historieally characterized by sparse, native bunehgrasses and patches of bare soil. Applegate's milk-vetch was believed to be extinet until its rediscovery in 1983 (Yamamoto 1985). Currently, there are six known populations of the species, which oceur over a total area of less than 10 acres, and which form a total metapopulation of approximately 33,000 individuals, including three large populations and three small ones. Of the six populations, one is on land leased by The Nature Conservaney, one is on state land, and one is on airport land belonging to the City of Klamath Falls and targeted for airport expansion. The remaining populations are on private land. There are no populations on federal lands.

Applegate's milk-veteh is limited to a very speeifie soil regime, resulting in a very speeific habitat type. It appears to be dependent on the seasonal flooding that oeeurs at sites where it is found, whieh may limit the dominance of other species and ereate favorable openings for the establishment of new plants. Applegate's milk veteh hosts an unknown species of bectle larvae, and is pollinated by ground-nesting beetles.

Applegate's milk-vetch was federally listed as endangered on July 28, 1993 (58 FR 40547). Critical habitat has not been designated. The primary threats to this species include invasion of habitat by exotic species sueh as quaekgrass and downy brome, urban development, and road eonstruction. Low population numbers, loss of habitat, wildlife grazing (rabbits), and management eontrols that alter natural wildfire and flooding regimes all pose serious threats to this species.

\section{Rough Popcornflower}

The primary references for this section are:

USFWS. 2000e. Endangered Status for the Plant Plagiobothrys hirtus (Rough Popeornflower). Federal Register $65(16): 3866-3875$.

and

USFWS. 2010p. Plagiobothrys hirtus (Rough Popcornflower). Endangered. 5-Year Review: Summary and Evaluation. U.S. Fish and Wildlife Service Roseburg Field Office. Roseburg, Oregon.

Referenees eited in this section are internal to the above-refereneed documents. A complete list of references from the Federal Register listing is available from the USFWS Oregon State Office, Portland, Oregon. Referenees from the 5-year review are ineluded in the Bibliography.

The rough popeornflower (Plagiobothrys hirtus) oecurs in habitat that is seasonally saturated and often where there is presence of native wetland plants, within the interior valley of the Umpqua River in southwestern Oregon. The plant grows at elevations ranging from 98 to $886 \mathrm{feet}$, in open microsites within interior valley grasslands. Common associates include one-sided sedge, meadow barley, tufted hairgrass, American slough grass, great camas, water foxtail, Baltic rush, wild mint, Willamette downingia, and bentgrass (Gamon and Kagan 1985). Nonnative invasive plants that are common in rough popeornflower occurrences include teasel, pennyroyal, English 
hawthorn, and pear. Pennyroyal has been shown to have inhibitory effects on the germination and vigor of the rough popeornflower seeds and seedlings.

The rough popcornflower is a member of the borage family, and grows as an annual herb on drier sites or occasionally as a perennial herb on wetter sites (Amsberry and Meinke 1997a). Individual plants range from 2.75 to 23.6 inches tall, with narrow hairy leaves along hairy stems. They grow in scattered groups and reproduce largely by inseet-aided cross-pollination and partially by self-pollination. The taxon is considered dependent on seasonal flooding and/or fire to maintain open habitat and to limit competition with invasive native and non-native plant species, such as Himalayan blackberry, Oregon ash, teasel, and pennyroyal (Gamon and Kagan 1985, Almasi and Borgias 1996).

A total of 36 distinet habitat patehes, within 14 extant rough popeornflower oceurrenees, are distributed discontinuously from Yoncalla Creek, near Rice Hill, Oregon, south to the Sutherlin Creek, near Wilbur Oregon, in the Umpqua River watershed, Douglas County (Maddux and Meyers 2008). Of the 14 oceurrenees, five introduced populations have been established in the southern range of the population. Two naturally occurring populations have also been augmented with additional rough popcornflower. Suitable habitat includes open vernally wet meadows, seasonally-ponding mud-flats, or Oregon ash-swale openings dominated by native wetland-associated herbs and graminoids in valley lowlands.

Fifteen of the 17 oceupied habitat patches oceur on private or commercial land. Three of these parcels are owned and managed by The Nature Conservaney. The other 12 have no protective management for the species and are at risk of extirpation from development, incompatible grazing and farming practices, and recreational activities (Kagan 1997, Meinke 1997). The two remaining known sites oecur on public land owned by the Oregon Department of Transportation, with a portion of one site partially oceurring on private land as well.

The rough popeornflower was federally listed as endangered on January 25, 2000 (65 FR 3866). Critical habitat has not been designated for this species. Draining of wetlands for urban and agricultural uses and road and reservoir construction, however, has altered the original hydrology of the valley to such an extent that the total area of suitable habitat for the species has been substantially reduced. In addition to the ongoing threat of direet loss of habitat from conversion to urban and agricultural uses, hydrological alterations, and fire suppression, other threats to the species include spring and summer livestock grazing, roadside mowing, spraying, competition with nonnative vegetation, and landscaping (Gamon and Kagan 1985, Kagan 1995).

\section{Showy Stickseed}

The primary referenee for this species is:

USFWS. 2002f. Determination of Endangered Status for the Washington Plant Hackelia venusta (Showy Stickseed). Federal Register 67(25):5515-5525.

References cited in this seetion are internal to the above-referenced document. A complete list of these references is available from the USFWS Western Washington Fish and Wildlife Office, Lacey, Washington.

The 2011 5-year review for the showy stickseed (USFWS 2011u) was consulted for additional information on this species.

Showy stickseed (Hackelia venusta) is a narrow endemic restricted to less than 1 acre of unstable talus, on the lower slopes of Tumwater Canyon, Chelan County, Washington. Clusters of plants are concentrated in open, unstable areas of granitic sand and talus, and on ledges and eracks of vertical granite cliffs (USFWS 201lu). The species is shade-intolerant (Carr 1998) and grows in openings within ponderosa pine and Douglas-fir forest types. Showy stickseed plants are found on open, steep slopes (minimum of 80 percent inclination) of loose, well-drained, granitic weathered and broken rock fragmented soils at an elevation of about 1,600 feet. There is currently only one small population of approximately 300 plants, which occurs on land in the Wenatchee National Forest, in an area designated as the Tumwater Botanical Area. 
Showy stickseed is a perennial herb of the borage family that ranges from 8 to 16 inches tall. It has large, showy white to bluish flowers, and its fruit is a nutlet. As the common name suggests, seeds are dispersed by clinging to passing animals. The fruits of the showy stiekseed are spurred and covered with stout hairs that cling to the hair and bodies of animals. The species relies on insects for pollination most of the time (USFWS $201 \mathrm{lu}$ ).

Showy stiekseed was federally listed as endangered on February 6, 2002 (67 FR 5515). Critical habitat has not been designated for this speeies. Major threats to the showy stickseed include collection, physical disturbanee to the plants and their habitat by humans, competition and shading from native trees and shrubs, encroachment onto the site by non-native noxious weed species, wildfire, fire suppression and associated activities, and low seedling establishment. Highway maintenanee activities, sueh as the spreading of salt and the use of de-icers during the winter months also threaten the species. Application of herbicides may also pose a threat. In addition, reproductive vigor may be depressed because of the plant's small population size and limited gene pool. A single natural or human-eaused random environmental disturbance (sueh as wildfire), could destroy a large percentage of the population.

\section{Marsh Sandwort}

The primary reference for this species is:

USFWS 2008n. Arenaria paludicola (Marsh Sandwort) 5-Year Review: Summary and Evaluation. Ventura Fish and Wildlife Office Ventura, California.

References cited in this section are internal to the above-referenced document. Full citations have been ineluded in the Bibliography.

Marsh sandwort is a coastal species that was historically known to occur in marshes and other perennially moist areas (i.e., streams, creeks) from central Washington (Pierce County) to southern California (Los Angeles County). Currently, it is believed that its primary habitat consists of boggy areas in freshwater marshes and swamps below 560 feet in elevation (Hartman 1993; Skinner and Pavlik 1994; CNPS 2001; Hartman et al. 2005; California Natural Diversity Database 2007; University of California Herbarium 2007). Soils in these habitats are saturated, acidic bog soils that are predominantly sandy and have a high organic content.

Presently, there is only one known wild population of this species in the United States, in San Luis Obispo County, California, at Oso Flaco Lake. Twenty-five plants were reported from the site in 2005. Marsh sandwort has been listed by the Washington Natural Heritage Program as "possibly extirpated" in Washington State. Nonetheless, it is thought that suitable habitat for the species remains in Washington State, and that populations eould exist there now or in the future. As this species occurs on the BLM's Washington/Oregon special status species list, but not on the California list, it is unlikely that this species presently oceurs on public lands.

Marsh sandwort is an herbaceous perennial in the pink family. It has trailing stems that can be up to 39 inches long and are often supported by surrounding vegetation. It has small, white flowers that are borne singly on long stalks arising from the leaf axils. This species can also reproduee asexually. It can produce adventitious roots on the trailing stems that eome in contact with suitable conditions. It generally blooms from May to August.

Because there are so few individuals of the marsh sandwort remaining, studying the life history of this species has been difficult. Although plants have been observed flowering and fruiting minimally, and a viable seed bank has been identified, information about the species' pollinators, seed germination and dispersal, and seedling recruitment is lacking.

Marsh sandwort was federally listed as endangered on August 3, 1993 (58 FR 41378). Critical habitat has not been designated. Threats to the species include encroaehing vegetation (both native and non-native) assoeiated with lowered water tables, agricultural and residential development, and OHV use. In addition, the very low number of individuals in the remaining population puts this species at a great risk of extinction as a result of random, naturally occurring events. 


\section{Species in Multiple Ecoregions}

Two TEP species addressed by this BA have a large geographic distribution and therefore do not fit into one primary ecoregion eategory. Both water howellia and Ute ladies'-tresses are wetland species that appear to be more dependent on hydrology and general habitat features than on regional climate.

\section{Water Howellia}

The primary reference for this section is:

Hudson, B., J. Augsburger, M. Hillis, and P. Boehne. 2000. Draft Biological Assessment for the Interior Columbia River Basin Ecosystem Management Project Final Environmental Impact Statement. BLM and Forest Service. Boise, Idaho.

Water howellia (Howellia aquatilis) is an annual aquatic plant with a seattered distribution in the Pacific Northwest. The speeies is known to be extant in Idaho, Montana, and Washington, but is also historically known from California and Oregon. Sites in California and Oregon have not been recently relocated, despite intensive field surveys in both states. Within its current range, water howellia is known from a total of 110 occurrences. There are two main eenters of distribution within this range: one in the Swan River Valley in Montana, and one in the vicinity of Spokane, Washington. Populations of water howellia in these centers range from 1 to 1,000 plants, and oceur mostly on publicly-owned land, and at elevations of 400 to 2,320 feet. Two oceurrences are known in northern Idaho, in private ownership, and two others are found in western Washington. The total known oceupied habitat for this species is less than 100 acres.

Water howellia is restrieted to small pothole ponds or the quiet water of shallow, abandoned river oxbows. These wetland habitats typically occur in a matrix of dense forest vegetation, and all known sites have at least some deciduous tree cover around a portion of the pond. Ponderosa pine forests typically surround the ponds, and redosier dogwood is usually present around the perimeters. The bottom surfaces of the wetlands consist of firm, consolidated clay and organic sediments. These wetlands are generally filled by snowmelt runoff and spring rains, but then dry out to varying degrees by late summer or early fall, depending on annual patterns of temperature and precipitation. The ponds are typically shallow, averaging 1 to 2 feet in depth during the middle of summer.

The bloom period of water howellia varies by geographic location, but typically oceurs in May and June. The drying of the wetland habitat in late summer is eritical to the species' life eycle; the seeds will only germinate if they are exposed to the atmosphere. After the seedlings appear, usually in Oetober, they overwinter under the snowpack. In late spring and early summer, the plants resume growth in the water that accumulates in the ponds. This ecological relationship has a profound influence on the size of oceurrenees from year to year; the summer climate determines the degree of pond drying, and thus the amount of seed germination in the fall. During years when seed germination is reduced, few plants are present the following summer.

Water howellia was listed as threatened on July 14, 1994 (59 FR 35860). Critical habitat has not been designated. The highly specialized ecological adaptations of the species make it vulnerable to both short- and long-term natural environmental changes, such as succession or climate change. Land management activities and habitat destruction have also affected this species. Development, construction of dams, livestock grazing and trampling, timber harvesting, and road building are some of the human activities that alter the habitat of this species. Competition with introduced plant species, such as reed canarygrass and purple loosestrife, is also a threat.

\section{Ute Ladies'-tresses}

The primary reference for this section is:

USFWS. 1992f. Final Rule to List the Plant Spiranthes diluvialis (Ute Ladies'-tresses) as a Threatened Species. Federal Register 57(12):2048-2054.

References cited in this section are internal to the above-referenced document. They are included in the Bibliography 
Ute ladies'-tresses (Spiranthes diluvialis) occurs along riparian edges, gravel bars, old oxbows, high flow ehannels, and moist to wet meadows along perennial streams. It typically occurs in stable wetland and seepy areas associated with old landscape features within historical floodplains of major rivers. It also is found in wetland and seepy areas near freshwater lakes or springs (USFWS 2010q). The species oceurs primarily in areas where the vegetation is relatively open and not overly dense, overgrown, or overgrazed (Coyner 1989, 1990; Jennings 1989, 1990). At the time of its listing in 1992, populations of the species were only known to oceur in riparian meadows in three geographic areas: near Boulder Creek in Colorado, in the Colorado River drainage of eastern Utah, and in the eastern Great Basin of Western Utah and adjacent Nevada. The orehid also has been discovered in southwestern Montana and in the Okanogan area and along the Columbia River in north-central Washington (USFWS 2010q). The species is now known to oceur in Colorado, Idaho, Montana, Nebraska, Nevada, Utah, Washington, and Wyoming.

Ute ladies'-tresses is a perennial orchid with stems that arise from thickened roots. The bloom consists of 3 to 15 small white or ivory colored flowers elustered into a spike arrangement at the top of the stem. Depending on location, the species may flower as early as early July or as late as early October (Sheviak 1984, Jennings 1989, Coyner 1990). Mature plants may remain dormant for 1 or more growing seasons without producing aboveground shoots, or may exhibit vegetative shoots only. Bumblebees are apparently required for pollination.

Ute ladies'-tresses was federally listed as threatened on January 17, 1992 (57 FR 2048). Critical habitat has not been designated for this species. The species is threatened primarily by habitat loss and modification, though its small populations and low reproductive rate also make it vulnerable to other threats. Urban development and watershed alterations in riparian and wetland habitat negatively affect this species. Exotic plant species, such as purple loosestrife, whitetop, and reed canarygrass may also impact populations of Ute ladies'-tresses. Other potential threats include grazing during periods of flowering or fruiting, and recreational use.

\section{Effects of Herbicide Treatments on Plants}

For this analysis, all TEP plant species and their critical habitat located within the project area are considered as a whole. Although the plant species listed in Table 1-I occupy a wide range of habitat types and account for a wide range of life forms, considering them as a single group is suitable for a programmatic analysis. In general, vegetation treatments have the potential to affect most plant species in much the same way: all are intended to cause mortality or injury to target plants, and effeets may vary in intensity and extent. Therefore, TEP plant speeies are particularly at risk for adverse effects from herbicide treatments. Where TEP plants are present within or near proposed treatment areas, the BLM must design treatment programs to avoid effeets from direet spray, herbicide drift and runoff from treatment sites, and deposition of wind-blown dust. When information about species tolerance is unavailable or is inconclusive, local offices must assume an adverse effect to plant populations, and protect those populations from direct or indirect exposure to the treatment in question.

All other aspects of analysis being equal, species present in low numbers or that have a limited distribution are the most sensitive to impacts. Information about population size and distribution has been provided in the background section, and should be referred to, as appropriate.

The potential effeets of herbicide treatments with aminopyralid, fluroxypyr, and rimsulfuron on TEP plant species would vary depending on a number of factors. The location of the application in relation to TEP plant species, and the type of application method utilized, would determine, in part, whether TEP species would be exposed to chemicals. In addition, the type of chemical formulation used (i.e., selective vs. non-selective; pre-emergence vs. post-emergence) and the timing of the application in relation to the phenology of the species of eoneern would be important factors to consider. Use of herbicides, and potential effects to TEP plant species that oceur in each proposed treatment area, would be considered in detail at the local level prior to initiating an herbicide treatment. At the programmatic level, this BA provides a general analysis of the potential for aminopyralid, fluroxypyr, and rimsulfuron to affect TEP plant species, as determined in ERAs completed by the BLM (see Chapter 2 of this BA and Appendix C of the 2007 PEIS [USDOI BLM 2007a] for more information). Both terrestrial and aquatic plants 
are considered in this analysis. Aquatic plants are assumed to come into contact with herbicides via the water. Therefore, for plant species that root in water but have foliage that extends above the surface of the water, exposure seenarios for both aquatic and terrestrial plants may be applicable. In these cases, the effects discussions for both groups of plants should be considered.

\section{Direct Effects}

If herbicide treatments were to oceur in habitats where TEP plant species occur, plants could be crushed by trucks and/or ATVs and UTVs during ground applications. Injury or mortality to plants could oceur. These impacts could be minimized by avoiding populations of TEP speeies when implementing vegetation treatments.

Ecological risk assessments predicted the potential for terrestrial and aquatic TEP plant species to suffer adverse effects as a result of exposure to the herbicides proposed for use by the BLM. Modes of exposure include direet spray of plants, aceidental spill of herbicides into a water body with aquatic TEP plants, off-site drift, surface runoff, and wind transport of soils from treatment sites.

In the ERAs, measurable changes in plants as a result of exposure to herbicides included such adverse effects as mortality and reduced growth, reproduction, or other ecologieally important sublethal processes (AECOM 2014ac). It is expected that possible adverse effeets to non-target TEP plant species as a result of exposure to herbicides could include one or more of the following: mortality, loss of photosynthetic foliage, redueed vigor, abnormal growth, or redueed reproductive output. Beeause many TEP plant species have populations that are small, and/or fragmented, they are expected to be more sensitive to many of these effeets than plant species with secure populations. One or more of these effects, depending on its extent and severity, could result in the extirpation of a sensitive population. Less severe effects eould reduce the size of a population further, reduee its ability to compete with other, more vigorous species, or increase its degree of fragmentation. These population-level effects eould in turn reduce the ehances of species reeovery, or increase the likelihood of a future extirpation due to natural stochastic events, such as catastrophic wildfire or drought. In this discussion, the term "adverse effects," as it pertains to exposure to herbicides, includes any of the above-mentioned effects to individual TEP plants, populations, and/or species.

\section{Direct Spray}

Aceording to the ERAs, all three of the herbicides proposed for use by the BLM would potentially have adverse effeets on terrestrial TEP plant species, should a direct spray of plants oceur. Adverse effeets to upland TEP plants were assumed as a result of direct spray by one or more of these herbicides. Therefore, populations of TEP plants will require protection through the use of buffers or other measures during herbicide treatments.

\section{Accidental Spill}

In the case of an accidental spill of herbicides into an aquatic habitat, fluroxypyr, and rimsulfuron would potentially have adverse effects on non-target aquatic plants, including TEP species, based on information provided in ERAs. However, the ERAs determined that a spill of aminopyralid would not pose risks to sensitive non-target aquatic plants under the modeled spill scenarios.

\section{Off-site Drift}

Non-target TEP plants could also be exposed to herbicides directly during off-site drift from a nearby treatment site. Off-site drift seenarios under which adverse effects to TEP plants were predicted by ERAs are summarized in Tables 4-I (terrestrial species) and 4-2 (aquatic species).

According to the ERAs, adverse effects to terrestrial TEP plants would be possible as a result of off-site drift of all three proposed herbicides, with adverse effects predicted at distances ranging from 100 feet from the treatment site for certain ground applications at the typical application rate to 2,000 feet or greater for certain aerial applications at the maximum application rate. Therefore, protective buffers are required for all applications of these herbicides in treatment areas adjacent to habitats that support terrestrial TEP plant species. 


\section{TABLE 4-1}

Summary of Effects' to Terrestrial Threatened, Endangered, and Proposed Plant Species as a Result of Offsite Drift of Herbicides, as Predicted By Risk Assessments

\begin{tabular}{|c|c|c|}
\hline Herbicide & Ground Application & Aerial Application $^{2}$ \\
\hline Aminopyralid & $\begin{array}{l}\text { Low boom, typieal application rate: adverse } \\
\text { effects within } 100 \text { feet. } \\
\text { Low boom, maximum application rate: } \\
\text { adverse effeets within } 400 \text { feet. } \\
\text { High boom, typieal applieation rate: adverse } \\
\text { effects within } 400 \text { feet. } \\
\text { High boom, maximum applieation rate: } \\
\text { adverse effects within } 600 \text { feet. }\end{array}$ & $\begin{array}{l}\text { Plane, typical applieation rate: adverse effects } \\
\text { within } 1,800 \text { feet. } \\
\text { Plane, maximum application rate: adverse } \\
\text { effeets within } 2,000 \text { feet. } \\
\text { Helicopter, typical application rate: adverse } \\
\text { effects within } 1,600 \text { feet. } \\
\text { Helieopter, maximum application rate: } \\
\text { negative effects within } 1,700 \text { feet. }\end{array}$ \\
\hline Fluroxypyr & $\begin{array}{l}\text { Low boom, typical application rate: adverse } \\
\text { effeets within } 100 \text { feet. } \\
\text { Low boom, maximum application rate: } \\
\text { adverse effeets within } 600 \text { feet. } \\
\text { High boom, typieal application rate: adverse } \\
\text { effeets within } 400 \text { feet. } \\
\text { High boom, maximum application rate: } \\
\text { adverse effeets within } 700 \text { feet. }\end{array}$ & $\begin{array}{l}\text { Plane, typieal application rate: adverse effects } \\
\text { within 1,200 feet. } \\
\text { Plane, maximum application rate: adverse } \\
\text { effects within } 1,500 \text { feet. } \\
\text { Helieopter, typical applieation rate: adverse } \\
\text { effects within } 900 \text { feet. } \\
\text { Helieopter, maximum applieation rate: } \\
\text { adverse effeets within } 1,500 \text { feet. }\end{array}$ \\
\hline Rimsulfuron & $\begin{array}{l}\text { Low boom, typieal application rate: adverse } \\
\text { effects within } 200 \text { feet. } \\
\text { Low boom, maximum application rate: } \\
\text { adverse effeets with in } 400 \text { feet. } \\
\text { High boom, typical application rate: adverse } \\
\text { effects within } 400 \text { feet. } \\
\text { High boom, maximum application rate: } \\
\text { adverse effeets within } 700 \text { feet. }\end{array}$ & $\begin{array}{l}\text { Plane, typieal application rate: adverse effects } \\
\text { within 1,600 feet. } \\
\text { Plane, maximum application rate: adverse } \\
\text { effects within 1,900 feet. } \\
\text { Helicopter, typical application rate: adverse } \\
\text { effects within 1,400 feet. } \\
\text { Helieopter, maximum application rate: } \\
\text { adverse effects within } 1,600 \text { feet. }\end{array}$ \\
\hline \multicolumn{3}{|c|}{$\begin{array}{l}{ }^{1} \text { Both acute and chronic effeets were eonsidered, and "adverse cffeets" inelude either aeute or chronic effects, or both. For more } \\
\text { information on acute vs. chronic effects, please see Appendix C of the } 2007 \text { PEIS (USDOI BLM 2007a). } \\
{ }^{2} \text { Aerial applications may occur at different heights, depending on whether the treatment area is forested or non-forested; both } \\
\text { forested and non-forested scenarios were considered by risk assessments. The largest distance at which adverse effects to non- } \\
\text { target TEP plants was predicted by risk assessments has becn presented in this table. }\end{array}$} \\
\hline \multicolumn{3}{|c|}{$\begin{array}{l}\text { Note: The ERAs provided information about the closest modeled distance for which ncgative effects were predicted }(25,100, \text { or } 900 \\
\text { feet for ground applications, and } 100,300 \text {, or } 900 \text { feet for aerial applications). Distances provided in this table were obtained by } \\
\text { plotting the risk quotients for the modeled distances, fitting a curve to the data, and then determining the distanee at which the risk } \\
\text { quotient was equivalent to the acute endangered species LOC for terrestrial plants (risk quotient of } 1 \text { ). The curve was extcnded } \\
\text { beyond the largest modeled distanec to extrapolate buffers beyond } 900 \text { feet. }\end{array}$} \\
\hline Sources: Eeological & ssessments for Herbieides (AECOM 2014a-c). & \\
\hline
\end{tabular}

The ERAs determined that there would be no risks to aquatie TEP plants assoeiated with off-site drift of aminopyralid or fluroxypyr for broadeast applications at distanees of 25 feet and greater (Table 4-2). For ground broadeast applieations of rimsulfuron, adverse effeets to aquatie TEP plants within 100 to 300 feet of the applieation site eould oeeur, depending on the type of aquatie habitat (pond or stream) and whether the typieal or maximum applieation rate is used. For aerial applieations of rimsulfuron, adverse effeets to aquatie TEP plants within 200 to 1,800 feet of the applieation site eould oceur, depending on the type of aquatie habitat and the applieation rate used. The greatest risks to TEP aquatie plants would be assoeiated with helieopter applieations over non-forested terrain and plane applieations over all habitat types. Proteetive buffers are required for all aerial and ground applieations of rimsulfuron in treatment areas adjaeent to habitats that support aquatie TEP plant species.

Based on the information provided in the risk assessments, minimum buffer distanees to proteet aquatie TEP plants have been established and ineorporated into eonservation measures listed at the end of this scetion. These buffer distanees may be ehanged at the loeal level if additional information is made available. 
TABLE 4-2

Summary of Effects ${ }^{1}$ to Aquatic Threatened, Endangered, and Proposed Plant Species as a Result of Off-site Drift of Herbicides, as Predicted By Risk Assessments

\begin{tabular}{|c|c|c|}
\hline Herbicide & Ground Application & Aerial Application ${ }^{2}$ \\
\hline Aminopyralid & $\begin{array}{l}\text { No adverse effects predicted (distances of } \\
25 \text { feet and greater considered). }\end{array}$ & $\begin{array}{l}\text { No adverse effects predicted (distances of } \\
100 \text { feet and greater considered). }\end{array}$ \\
\hline Fluroxypyr & $\begin{array}{l}\text { No adverse cffects predicted (distances of } \\
25 \text { feet and greater considered). }\end{array}$ & $\begin{array}{l}\text { No adverse effects predicted (distances of } \\
100 \text { feet and greater considered). }\end{array}$ \\
\hline \multirow{2}{*}{ Rimsulfuron } & \multicolumn{2}{|c|}{ Aquatic Plants in Ponds } \\
\hline & $\begin{array}{l}\text { Low boom, typical application rate: adverse } \\
\text { effects within } 100 \text { feet. } \\
\text { Low boom, maximum application rate: } \\
\text { adverse effects within } 100 \text { feet. } \\
\text { High boom, typical application rate: } \\
\text { adverse effects within } 200 \text { feet. } \\
\text { High boom, maximum application rate: } \\
\text { adverse effects within } 300 \text { feet. }\end{array}$ & $\begin{array}{l}\text { Plane, typical application rate: adverse } \\
\text { effects within } 1,300 \text { feet. } \\
\text { Plane, maximum application rate: adverse } \\
\text { effects within } 1,400 \text { feet. } \\
\text { Helicopter, typical application rate: } \\
\text { adverse effects within } 1,000 \text { feet. } \\
\text { Helicopter, maximum application rate: } \\
\text { negative effects within } 1,800 \text { feet }\end{array}$ \\
\hline \multicolumn{3}{|c|}{$\begin{array}{l}\text { "Both acute and chronic effects were considered, and "adverse effects" include cither acute or chronic effects, or both. For more } \\
\text { information on acute vs. chronic effects, please see Appendix C of the } 2007 \text { PEIS (USDOI 2007a). "No adverse effects predicted" } \\
\text { indicates that ERAs did not predict risks to TEP aquatic plants under the modeled scenario at the typical or maximum application } \\
\text { rate. }\end{array}$} \\
\hline \multicolumn{3}{|c|}{$\begin{array}{l}{ }^{2} \text { Aerial applications may oceur at different heights, depending on whether the treatment area is forested or non-forested; both } \\
\text { forested and non-forested scenarios were considered by risk assessments. The largest distance at which adverse effects to non- } \\
\text { target TEP plants was predicted by risk assessments has been presented in this table. }\end{array}$} \\
\hline \multicolumn{3}{|c|}{ Sources: Ecological Risk Assessments for Herbicides (AECOM 2014a-c). } \\
\hline
\end{tabular}

\section{Surface Runoff}

Risk assessments analyzed the risks to TEP plant species as a result of exposure to herbicides via surface runoff from an upslope treatment site. Potential effects are summarized in Table 4-3. Based on the predictions presented in Table 4-3, adverse effects to terrestrial TEP plants should not occur as a result of surface runoff of any of the three herbicides. Risks to aquatic TEP plant species were not predicted for surface runoff of aminopyralid and fluroxypyr. However, adverse effects to aquatic TEP plants in streams and ponds would be possible as a result of surface runoff into a water body from an upslope area treated by rimsulfuron under certain site conditions, particularly areas that receive a large amount of rainfall. Therefore, a local-level analysis must be conducted to determine site-specific risks associated with the use of this active ingredient and to develop appropriate conservation measures, if needed. 
TABLE 4-3

Summary of Effects ${ }^{1}$ to Threatened, Endangered, and Proposed Plants as a Result of Surface Runoff of Herbicides, as Predicted by Risk Assessments

\begin{tabular}{|c|c|c|}
\hline Herbicide & Effects to Terrestrial TEP Plants & Effects to TEP Aquatic Plants \\
\hline Aminopyralid & No adverse effeets predieted & No adverse effeets predicted \\
\hline Fluroxypyr & No adverse effeets predieted & No adverse effects predieted \\
\hline Rimsulfuron & No adverse effeets predieted & $\begin{array}{l}\text { Sand soils: adverse effeets where annual } \\
\text { precipitation is greater than } 10 \text { inches per } \\
\text { year. } \\
\text { Loam soils: adverse effects in areas where } \\
\text { preeipitation is greater than } 25 \text { inehes per } \\
\text { year. } \\
\text { All soils: adverse effeets in areas where } \\
\text { precipitation is greater than } 50 \text { inches per } \\
\text { year. }\end{array}$ \\
\hline \multicolumn{3}{|c|}{$\begin{array}{l}\text { 'Both acute and chronie effeets were considered, and "adverse effects" include cither acute or chronic cffeets, or both. For mor } \\
\text { information on acute vs. ehronic effeets, please sce Appendix C of the } 2007 \text { PEIS (USDOI } 2007 \text { a). "No adverse effeets predietcd } \\
\text { indicates that ERAs did not prediet risks to TEP plants under the modeled scenario at the typieal or maximum applieation rate. }\end{array}$} \\
\hline Sources: Eeological r & ments for herbieides (AECOM 2014a-c). & \\
\hline
\end{tabular}

\section{Wind Erosion}

Risk assessments analyzed the potential for soil exposed to herbicide treatments to be earried by the wind and affect TEP plant speeies off site. The models provided results for three representative watersheds (one in Montana, one in Oregon, and one in Wyoming). According to ERAs, adverse effeets to TEP species were predicted at the elosest modeled distanee from the treatment site: 0.9 miles ( 1.5 kilometers) for all three herbicides applied at the typieal or maximum application rate in the sample Oregon watershed. Additionally, adverse effects to TEP species were predieted at a distance of 0.9 miles from the site of an application with fluroxypyr at the maximum applieation rate in the sample Wyoming watershed. Based on analysis of intermediate modeled distances for these seenarios, all of the RQs drop off to below the level indieating adverse effects at a distance of 1.2 miles (2 kilometers).

\section{Indirect Effects}

Use of herbieides to treat vegetation on public lands could have indirect effects on TEP plant species by altering the species composition of treated areas. Elimination or reduction of non-native species from a site could increase its suitability for TEP plant speeies, especially those that eompete with, have been displaced by, or are otherwise threatened by non-native species. Provided herbieide treatment programs are able to avoid adversely affecting populations of TEP plant species on or near the treatment site, long-term benefits to these populations eould potentially occur. Herbicides can also indirectly affect TEP plant species if populations of pollinator insects arc impacted, especially if a TEP plant species has highly specific pollinator requirements and the pollinating species are adversely impaeted by treatments. Removal of unwanted non-native vegetation ean also affect the frequency of wildfire, which may in turn benefit some TEP plant species or harm others, depending on whether the fire frequency increases or decreases, the species, and habitat.

\section{Effects from Tank Mixes}

The effects of tank mixes were not evaluated by the ERAs. However, for the 2007 BA, ERAs evaluated the cffects of tank mixes on plants, using the assumption that the products in the tank mix would act in an additive manner. A similar exercise was completed for this BA, evaluating three pre-mixcs/tank mixes, two involving aminopyralid and one involving fluroxypyr. The predicted RQs for two active ingredicnts were summed for each individual exposure scenario to see if the eombined impaets resulted in additional RQs elevated above the corresponding LOCs. These evaluations determined that ccrtain for certain tank mixes, reeeptors were at a higher risk for adverse 
effects as a result of exposure to a tank mix than to one or more of the tank mix chemicals alone. In other cases, the same level of risk as either chemical alone was predicted. These results suggest that effects from tank mixes are specific to each tank mix. Terrestrial and aquatic TEP plants may be at greater risk from the tank mix application than from the active ingredient alone, and potential additive effects from multiple active ingredients should be taken into account at the local level when determining conservation measures. There is some uncertainty in this evaluation because herbicides in tank mixes may not interact in an additive manner; this may overestimate risk if the interaction is antagonistic, or it may underestimate risk if the interaction is synergistic. In addition, other products in tank mixes may also contribute to the potential risk.

\section{Cumulative Effects}

Cumulative effects include the effects of future state, tribal, local, or private actions that are reasonably certain to occur in the action area considered in this BA. Future federal actions that are unrelated to the proposed action are not considered in this section because they require separate consultation pursuant to Section 7 of the ESA.

Because the three herbicides assessed in this BA are being added to an existing vegetation management program (which was covered in the 2007 BA; USDOI BLM 2007d), BLM lands receiving treatments with the three new herbicides could also receive other types of vegetation treatments, including treatments with other approved herbicides, manual treatments, mechanical treatments, fire, and biological control. In some cases, a combination of treatment types may be used in concert to achieve a desired effect (e.g., preseribed fire followed by post-burn herbicide treatment). Therefore the cumulative effects of multiple treatment methods on TEP plant species should be considered when designing treatment programs at the local level. The conservation measures listed at the end of this section apply only to treatments with aminopyralid, fluroxypyr, and rimsulfuron. Where a combination of treatment methods is employed, pertinent conservation measures listed in the 2007 Vegetation Treatments BA for other methods or herbicides must also be implemented.

Since activities on public lands would constitute federal actions, most activities with the potential to impact populations of TEP plants on public lands are not considered in this cumulative effects analysis. However, state, private, local, or tribal actions off of public lands could affect adjacent populations of these species. For instance actions that spread noxious weeds into adjacent habitats (such as OHV use and livestock grazing) may lead to the spread of these weeds onto BLM-administered lands. Herbicide treatments on nearby agricultural lands or rangelands could drift onto public lands and harm TEP plant species. A wildfire originating off public lands could spread onto public lands. In wetland and riparian areas, TEP plant species could be impacted if recreational activities were to impact water flows or quality in or near the vicinity of the population. Impacts could result from spills of petroleum products from vehicles, from material found in animal feces, or from other factors entering a nearby water body and impacting the habitat of the TEP plant species. Some TEP plant populations may occur partially within and partially off of public lands; in these eases actions that cause mortality of or otherwise adversely affect a portion of a population could reduce the health and vigor of the entire population.

Given the programmatic nature of this BA, it is outside the scope of the analysis to identify specific non-federal actions that might result in cumulative impacts to TEP plant species when considered together with BLM vegetation treatment activities. This type of site-specific analysis would be done at the local level, using information about the location of individual treatment projects, and information about non-federal activities reasonably certain to occur in the action area. Cumulative effects might result from agriculture (use of herbicides), livestock grazing (trampling, spread of invasive species), mining, oil and gas, and ROW development, and timber harvest and vegetation management. Tribal actions that could harm TEP plant populations include collection of these species for traditional lifeway uses (although this was not identified as a concern requiring discussion in this $\mathrm{BA})$.

\section{Conservation Measures}

As dictated in BLM Manual 6840 (Special Status Species Management), local BLM offices are required to develop and implement management plans and programs that will conserve listed species and their habitats. In addition, 
NEPA doeumentation related to treatment aetivities (i.e., projeets) will be prepared that identify any TEP plant speeies or their critieal habitat that are present in the proposed treatment areas, and that list the measures that will be taken to proteet them.

Many local BLM offiees already have management plans in plaee that ensure the proteetion of these plant speeies during aetivities on publie land. However, a diseussion of these existing plans is outside the seope of this programmatie BA. The following general guidanee applies to all management plans developed at the loeal level:

- A survey of all proposed aetion areas within potential habitat by a qualified biologist, botanist, or eeologist to determine the presenee/absenee of the speeies.

- Establishment of site-speeifie no-aetivity buffers by a qualified botanist, biologist, or eeologist in areas of oeeupied habitat within the proposed projeet area. To proteet oeeupied habitat, herbieide treatment aetivities would not oeeur within these buffers.

- Colleetion of baseline information on the existing eondition of TEP plant speeies and their habitats in the proposed projeet area.

- Establishment of pre-treatment monitoring programs to traek the size and vigor of TEP populations and the state of their habitats. These monitoring programs would help in antieipating the future effeets of herbieide treatments on TEP plant speeies.

- Assessment of the need for site revegetation post treatment to minimize the opportunity for noxious weed invasion and establishment.

More information is provided in the 2007 BA. All management plans that address herbieide treatments must inelude SOPs (listed in Appendix A) for proteeting TEP and other non-target plant speeies. Additionally, to avoid adverse effeets to TEP plant speeies from off-site drift, surfaee runoff, and/or wind erosion, suitable buffer zones must be established between treatment sites and populations (eonfirmed or suspeeted) of TEP plant speeies, and site speeifie preeautions must be taken. Based on the information provided in the ERAs for aminopyralid, fluroxypyr, and rimsulfuron, minimum buffer distanees to proteet TEP plants have been developed for herbieide treatments involving the three new aetive ingredients under various applieation seenarios. In many eases, buffer distanees that fall between modeled distanees were determined using regression analysis based on the existing modeling data, and inereased to the nearest 100 feet to obtain a eonservative estimate. Among the formulations proposed for use eontaining aminopyralid and fluroxypyr, several also eontain other herbieide aetive ingredients (Table 2-3). For those multiple aetive ingredient formulations, eonservation measures for all aetive ingredients in the produet should be eonsidered prior to implementation. In general, buffers for the formulated produet will be based on the aetive ingredient that requires the greatest buffer distanee. Additional analysis may be neeessary at the loeal level that eonsiders information in ERAs and for loeal site eonditions (e.g., soil type, annual preeipitation, vegetation type, treatment method), and potential additive effeets from multiple aetive ingredients, to more preeisely ealeulate buffers for some herbieides and formulations. Buffers eould be altered at the loeal level based on loeal eonditions and the habitat needs of loeal speeies. Deviations from the speeified buffers would require eonsultation with the Serviees at the loeal level. For the buffer distanees speeified below, unless an alternative has been agreed upon by the Serviees and the BLM, typieal applieation rate buffers will be used for applieations involving the typieal rate or lower, and maximum applieation rate buffers will be used for applieations above the typieal applieation rate, up to the maximum rate.

\section{Aminopyralid}

Ground Application

- If using a low boom at the typieal applieation rate, do not apply within 100 feet of TEP terrestrial plants ${ }^{1}$.

- If using a low boom at the maximum applieation rate or a high boom at the typieal applieation rate, do not apply within 400 feet of TEP terrestrial plants.

- If using a high boom at the maximum applieation rate, do not apply within 600 feet of TEP terrestrial plants.

\footnotetext{
${ }^{1}$ Note that buffers for terrestrial plants may be appropriate for plant speeies that root in water but have foliage extending above the surface of the water.
} 
Aerial Application Over Forested Land

- Do not apply by airplane at the typical application rate within 1,700 feet of TEP terrestrial plants.

- Do not apply by airplane at the maximum application rate within 1,900 feet of TEP terrestrial plants.

- Do not apply by helicopter at the typical or maximum application rate within 300 feet of TEP terrestrial plants.

Aerial Application Over Non-Forested Land

- Do not apply by airplane at the typical application rate within 1,800 feet of TEP terrestrial plants.

- Do not apply by airplane at the maximum application rate within 2,000 feet of TEP terrestrial plants.

- Do not apply by helicopter at the typical application rate within 1,600 feet of TEP terrestrial plants.

- Do not apply by helicopter at the maximum application rate within 1,700 feet of TEP terrestrial plants.

General

- In areas where wind erosion is likely, do not apply within 1.2 miles of TEP plant speeies (an alternative suitable buffer may be developed at the loeal level based on an analysis of site eonditions).

\section{Fluroxypyr}

Ground Application

- If using a low boom at the typical application rate, do not apply within 100 feet of TEP terrestrial plants.

- If using a low boom at the maximum application rate, do not apply within 600 feet of TEP terrestrial plants.

- If using a high boom at the typieal applieation rate, do not apply within 400 feet of TEP terrestrial plants.

- If using a high boom at the maximum application rate, do not apply within 700 feet of TEP terrestrial plants.

Aerial Application Over Forested Land

- Do not apply by airplane at the typieal applieation rate within 1,200 feet of TEP terrestrial plants.

- Do not apply by airplane at the maximum application rate within 1,400 feet of TEP terrestrial plants.

- Do not apply by helicopter at the typical application rate within 200 feet of TEP terrestrial plants.

- Do not apply by helicopter at the maximum applieation rate within 400 feet of TEP terrestrial plants.

Aerial Application Over Non-Forested Land

- Do not apply by airplane at the typical application rate within 1,100 feet of TEP terrestrial plants.

- Do not apply by helieopter at the typical application rate within 900 feet of TEP terrestrial plants.

- Do not apply by airplane or helicopter at the maximum application rate within 1,500 feet of TEP terrestrial plants.

General

- In areas where wind erosion is likely, do not apply within 1.2 miles of TEP plant species (an alternative suitable buffer may be developed at the local level based on an analysis of site conditions).

\section{Rimsulfuron}

Ground Application

- If using a low boom at the typieal application rate, do not apply within 200 feet of TEP terrestrial plants.

- If using a low boom at the maximum application rate or a high boom at the typical application rate, do not apply within 400 feet of TEP terrestrial plants.

- If using a high boom at the maximum application rate, do not apply within 700 feet of TEP terrestrial plants.

Aerial Application Over Forested Land

- Do not apply by airplane at the typical application rate within 1,600 feet of TEP terrestrial plants.

- Do not apply by airplane at the maximum application rate within 1,700 feet of TEP terrestrial plants.

- Do not apply by helicopter at the typical or application rate within 300 feet of TEP terrestrial plants.

Aerial Application Over Non-Forested Land

- Do not apply by airplane at the typical application rate within 1,600 feet of TEP terrestrial plants. 
- Do not apply by airplane at the maximum application rate within 1,900 feet of TEP terrestrial plants.

- Do not apply by helicopter at the typical application rate within 1,400 feet of TEP terrestrial plants.

- Do not apply by airplane or helicopter at the maximum application rate within 1,600 feet of TEP terrestrial plants.

\section{General}

- In areas where wind erosion is likely, do not apply within 1.2 miles of TEP plant species (an alternative suitable buffer may be developed at the local level based on an analysis of site conditions).

- Do not use in watersheds where annual precipitation excceds 50 inches.

- In watersheds where annual precipitation exceeds 10 inches, prior to use of rimsulfuron conduct a local-level analysis of site conditions and develop suitable conservation measures for protection of TEP plant species from surface runoff.

If a tank mix of one of these chemicals with another approved herbicide is desired, an additional asscssment of potential effects to non-target TEP species must be made with the assumption that effects of the herbicides are at a minimum additive. Larger buffers may be warranted.

At the local level, the BLM must make determinations as to the suitability of herbicide treatments for the populations of TEP species that are managed by local offices. The following information should be considered: the timing of the treatment in relation to the phenology of the TEP plant species; the intensity of the treatment; the duration of the treatment; and the tolerance of the TEP species to the treatment. When information about species tolerance is unavailable or is inconclusive, local offices must assume an adverse effect to plant populations, and protect those populations from direct or indirect cxposure to the treatment in question.

Treatment plans must also address the presence of and expected impacts on noxious weeds on the project site. These plans must be coordinated with BLM weed experts and/or appropriate county weed supervisors to minimize the spread of weeds.

As discussed in Chapter 2, this BA assumes that the BLM would continuc to follow the conscrvation measures listed in the $2007 \mathrm{BA}$, or other comparable measures that would be developed by the field offices based on local site conditions and included in local-level consultations. General conscrvation measures for all herbicide treatments would be applicable for use of aminopyralid, fluroxypyr, and rimsulfuron. A list of key conservation measures for TEP plants is presented at the end of this seetion, with a complete list provided in Appendix A. Conscrvation measures pertaining to other types of vegetation treatments can be found in the 2007 BA (USDOI BLM 2007d). This document is available on-line at http://www.blm.gov/wo/st/en/prog/more/veg_eis.html.

\section{Key Conservation Measures for TEP Plant Species from the 2007 BA}

- Do not conduct herbicide treatments in areas where TEP plants may be subject to direet spray by herbicides during treatments.

- Follow all instructions and SOPs to avoid spill and dircct spray scenarios into aquatic habitats that support TEP plant species.

- Treated areas that are prone to downy brome or noxious weed invasions should be seeded with an appropriate seed mixturc to reduce the probability of noxious weeds or other undesirable plants becoming cstablishcd on the site.

- In suitable habitat for TEP plant species, do not use non-native species for revegetation.

- Vehicles and other equipment used during treatment activities should be washed prior to arriving at a new location to avoid the transfer of noxious weeds.

When BAs are drafted at the local level for treatment programs, additional conservation measures developed through consultation with the Services may be added to this list. Where BLM plans that consider the effects of vegetation treatments on TEP plant species already exist, these plans should be consulted, and incorporated (e.g., any guidance or conservation mcasures they provide) into local-level BAs for vegetation treatments. 


\section{Determination of Effects}

Given the assumption at the programmatic level that treatments with the three herbicides proposed for use eould occur anywhere on public lands (contingent on whether the usage meets local projeet-level eriteria), herbicide treatments with aminopyralid, fluroxypyr, and rimsulfuron have the potential to adversely affect TEP plant species and their eritical habitats. Following the conservation measures in the 2007 BA, and SOPs for use and handling of herbicides and for surveying for TEP species prior to treatments would help the BLM avoid or minimize adverse effects to non-target terrestrial and aquatic vegetation. The conservation measures presented in this chapter inelude buffer zones that were developed to reduce the ehance of adverse effects oecurring to the point where the likelihood of such effects would be discountable, or to reduce any potential effects to the point where they would be insignificant to the species or their critical habitats, and would never reach the scale where take oceurs. As a result, the action may affeet, but would be Not Likely to Adversely Affect listed plant species or their federally designated critical habitats at the programmatic level. Similarly, the action is not likely to jeopardize proposed species or adversely modify proposed critieal habitat. Given BLM mandates for use of integrated pest management (including vegetation management), and given that it is not possible to foreeast site-specific vegetation management needs below the programmatic level, additional evaluations of situation specific effects will be the subject of step-down Seetion 7 evaluations and subsequent consultations. In this manner, any additional specifie conservation measures necessary to accommodate site or situation-specifie peculiarities not predictable at the programmatic level will be developed at the local level and incorporated into Pestieide Use Proposals prior to local implementation of vegetation management activities that involve the use of herbicides eonsidered in this BA. 


\section{CHAPTER 5}

\section{AQUATIC ANIMALS}

\section{Background Information}

This BA eonsiders a total of 83 fish speeies (ineluding subspeeies and Evolutionary Signifieant Units [ESUs]), 11 mollusks, and 8 aquatie arthropods that are listed as threatened or endangered, or that are proposed for listing. Baekground information is presented, speeies by speeies, in the seetion that follows. For the most part, speeies aeeounts have been arranged by eeoregion. However, some speeies (e.g., salmonids) travel over a wide geographie area to eomplete their life history eyeles, and therefore may fall into multiple eeoregions. These speeies have been diseussed separately.

Most of the information eontained in this seetion was obtained direetly from Federal Register doeuments, speeies reeovery plans, BAs and biologieal evaluations, and other sourees of information. Where primary referenee(s) was/were used for speeies baekground and listing information, full eitations are listed in the individual seetions for eaeh speeies. In some instanees, eitations were used from the primary referenee(s), and the eomplete eitations were not available from the primary referenee(s) for inelusion in the Bibliography (Chapter 7). In the instanees where eomplete eitations were not available, information on where eomplete eitations ean be found (e.g., USFWS Sacramento Field Offiee, Saeramento, California) is provided.

\section{Marine/Anadromous Species}

Fish speeies that migrate to the oeean to eomplete a portion of their life eyele are presented here, independent of the eeoregion divisions that are used to group freshwater speeies. Most of these speeies migrate through several eeoregions during the eompletion of their life history eyele.

The primary referenees for this seetion are:

Washington State Joint Natural Resourees Cabinet. 1999. Statewide Strategy to Reeover Salmon. Olympia, Washington.

and

National Marine Fisheries Serviee. 2005a. Updated Status of Federally Listed ESUs of West Coast Salmon and Steelhead. National Oeeanie and Atmospherie Administration Teehnieal Memorandum NMFS-NWFSC-66. Northwest Fisheries Seienee Center and Southwest Fisheries Seienee Center. Seattle, Washington and Santa Cruz, California.

The life eyeles of salmonids vary widely. However, eommon habitat requirements exist for all speeies. Freshwater salmonid habitat eonsists of four major eomponents: habitat for spawning and ineubation, juvenile rearing habitat, juvenile and adult migration eorridors, and adult holding habitat. Estuarine and marine nearshore areas provide habitats for estuarine and oeean rearing, and for juvenile and adult migration.

Two of the most important features of freshwater habitat for spawning, rearing, and migration are a suffieient quantity of water, and good quality water. Salmon require eool, elean water that is of suffieient depth and veloeity to allow passage, migration, and spawning, where floods do not seour ehannels. In addition, they seek out slow veloeity areas adjaeent to faster water for feeding, resting, and growing. Temperature affeets growth rates and the timing of life history events, and turbidity and sediments ean affeet the abundanee of food, as well as impaet 
spawning and incubation habitats. Salmon also require a high level of dissolved oxygen, and are affected by other chemical aspects of the water.

Salmon life cycles are very sensitive to changes in stream flow, and have adapted over thousands of years to the natural flow regime in their individual watersheds. Natural low flows are important for the establishment of vegetation along stream banks. High flows add gravel, flush sediments from gravel, create new rearing channels, and perform other important functions.

Within the stream channel, salmon require sufficient clean and appropriately sized cobbles and gravel for spawning and incubation. Riffles, rapids, pools, and floodplain connectivity are important for produetion, rearing, cover, and aeration. Riparian vegetation provides shade, moderates the temperature of the stream, stabilizes banks, and controls soil erosion and sedimentation. It also provides nutrients to the stream and contributes large woody debris, which increases channel complexity, ereates backwater habitats, and increases the water depth of pools. Aquatic plants and organic litter provide food for salmon, and can be influenced by riparian vegetation, temperature, streamflow, and substrate. Finally, salmon require unobstructed access both downstream and upstream for migration and feeding. Factors that obstruet passage include physical structures, inadequate streamflow, and high temperatures.

Nearshore marine habitats (e.g., marine tidal marshes, tidal channels, eelgrass beds, and kelp beds) provide salmon with spawning, rearing, and feeding grounds and shelter. They also proteet the shoreline from erosion, filter pollutants, and reduce flooding by retaining stormwater during high-flow periods. Estuaries are important habitats for anadromous salmon transitioning from juvenile to adult, and from fresh to salt water and back again. Salmon pass through estuaries as juveniles on their downstream migration to the oeean, and as adults on their upstream migration to spawn. Some species are also dependent on estuaries as rearing areas. There are several important features of estuarine and marine habitats: water quality, espeeially temperature; adequate food and eover; a saltwater/fresh water transition zone; marine vegetation and algae; adequate river or stream discharge; and migration pathways.

The term ESU is used by NMFS to refer to any distinct group of salmon populations, and to further clarify the meaning of subspecies under the ESA. Each salmonid species under the jurisdietion of NMFS is divided into several ESUs for the purposes of management, proteetion, and listing under the ESA. The following sections also list eounties with critical habitat. For several ESUs, critical habitat may have been designated in areas where the ESU was found historically, but is now absent.

\section{Coho Salmon}

Coho salmon (Oncorhyncus kisutch) oceurs in most major river basins around the Pacific Rim from Monterey Bay in California north to Point Hope, Alaska; through the Aleutians; and from the Anadyr River in Russia south to Korea and northern Hokkaido, Japan (Laufle et al. 1986). In the project area, there are four listed ESUs of eoho salmon: Central California Coast, Oregon Coast, Southern Oregon/Northern California, Lower Columbia River, and Oregon Coast.

With the exception of spawning habitat, which consists of small streams with stable gravels, summer and winter freshwater habitats most preferred by coho salmon consist of quiet areas with low flow, such as backwater pools, beaver ponds, dam pools, and side channels (Reeves et al. 1989). Habitats used during winter generally have greater water depth and greater amounts of large woody debris than those used in summer.

West Coast coho smolts typically leave freshwater in the spring (April to June), re-enter freshwater from September to November when sexually mature, and spawn from November to December and occasionally into January (Sandercock 1991). Stocks from British Columbia, Washington, and the Columbia River often have very early runs (entering rivers in July or August) or late runs (spawning into March), in addition to normally timed runs. Coho spend approximately the first half of their life cycle rearing in streams and small freshwater tributaries. The remainder of their life cycle is spent foraging in estuarine and marine waters of the Pacific Ocean, prior to 
returning to their stream of origin to spawn and die. Most fish return to spawn at 3 years old, although some precocious males may do so at 2 years of age.

\section{Central California Coast}

The Central California Coast ESU was federally listed as threatened on October 31, 1996 (61 FR 59028), and relisted as endangered in June 2005 (70 FR 37160). This ESU ineludes all naturally-spawned populations of coho salmon from Punta Gorda in northern California south to and ineluding the San Lorenzo River in eentral California, as well as populations in tributaries to San Franeisco Bay, excluding the Saeramento-San Joaquin River system and four artifieial propagation programs. Critical habitat for this ESU, which was designated on May 5 , 1999, includes all accessible river reaehes from Punta Gorda to the San Lorenzo River, including Mill Valley (Arroyo Corte Medare Del Presidio) and Corte Madera Creeks, whieh are tributaries to San Franeiseo Bay. Excluded from this designation are areas above speeifie dams or above longstanding, naturally impassable barriers, sueh as natural waterfalls. Major river basins eontaining spawning and rearing habitat for this ESU eomprise approximately 4,152 square miles in California. The following eounties lie partially or wholly within these basins: Lake, Marin, Mendoeino, San Mateo, Santa Clara, Santa Cruz, and Sonoma. Counties with eritieal habitat are Marin, Mendoeino, Napa, San Mateo, Santa Cruz, and Sonoma; BLM-administered lands are found in all eounties with eritical habitat, exeept Marin County.

\section{Oregon Coast}

The Oregon Coast ESU was first federally listed as threatened on August 10, 1998 (63 FR 42587). The decision was set aside in 2001, and a final determination listing the ESU as threatened was made on February 11, 2008 (73 FR 7816). This ESU includes all naturally spawned populations of eoho salmon in Oregon coastal streams south of the Columbia River and north of Cape Blaneo, Oregon, including the Cow Creek coho hatehery program. Critical habitat, which was designated on February 11, 2008 (70 FR 37160), includes approximately 6,568 stream miles and 15 square miles of lake habitat within the geographical area presently occupied by the ESU. Counties with eritieal habitat are Benton, Clatsop, Columbia, Coos, Curry, Douglas, Lane, Oregon, Lincoln, Polk, Tillamook, Washington, and Yamhill Counties, Oregon.

\section{Southern Oregon/Northern California Coasts}

The Southern Oregon/Northern California Coasts ESU was federally listed as threatened on May 6, 1997 (62 FR 33038 ), and its threatened status was reaffirmed on June 28, 2005 (70 FR 37160). This ESU includes all naturally spawned populations occurring in coastal streams between Cape Blanco, Oregon, and Punta Gorda, California, as well as three artificial propagation programs (the Cole Rivers Hatchery, Trinity River Hatchery, and Iron Gate Hatchery programs). Critical habitat (designated on May 5, 1999; 64 FR 24049) includes all river reaches accessible to listed coho salmon between Cape Blanco, Oregon and Punta Gorda, California. Inaecessible reaches are those above specific dams or above longstanding, naturally impassable barriers. Major river basins containing spawning and rearing habitat for this ESU eomprise approximately 18,090 square miles in California and Oregon. Counties that lie partially or wholly within watersheds inhabited by this ESU include Del Norte, Glenn, Humboldt, Lake, Mendocino, Siskiyou, and Trinity Counties in California, and Coos, Curry, Douglas, Jaekson, Josephine, and Klamath Counties in Oregon. Counties with critical habitat are Del Norte, Glenn, Humboldt, Lake, Mendocino, Siskiyou, and Trinity Counties in California, and Curry, Douglas, Jackson, Josephine, and Klamath Counties in Oregon; BLM-administered lands are also found in these counties.

\section{Lower Columbia River}

The Lower Columbia River ESU was federally listed as threatened on June 28, 2005 (70 FR 37160). This ESU includes all naturally spawned populations occurring in the Columbia River and its tributaries in Washington and Oregon, from the mouth of the Columbia River up to and including the Big White Salmon and Hood Rivers. This ESU also includes the Willamette River to Willamette Falls, Oregon, as well as 25 artificial propagation programs. Critical habitat for this ESU was proposed on January 14, 2013 (78 FR 2726). Critical habitat includes approximately 2,288 miles of freshwater and estuarine habitat in Oregon and Washington. 


\section{Chinook Salmon}

Chinook salmon (Oncorhynchus tshawytscha) are found from the Bering Strait south to Southern California. Historically, they ranged as far south as the Ventura River in California. There are 17 ESUs of Chinook salmon along the west coast of the United States, which range from southern California to the Canadian border and east to the Rocky Mountains. In the project area, there are eight listed ESUs: Sacramento Winter-run, Snake River Fallrun, Snake River Spring/Summer-run, Lower Columbia River, Upper Willamette River, Upper Columbia River Spring-run, Central Valley Spring-run, and California Coastal.

Chinook salmon are the largest of any salmon, with adults often exceeding 40 pounds. Like coho salmon, they are anadromous and spawn only once before dying. Chinook salmon exhibit diverse and complex life history strategies. There are two distinet races of Chinook salmon: stream-type and ocean-type. Stream-type Chinook have a longer freshwater resideney and perform extensive offshore migrations before returning to their natal streams in the spring and summer months. Ocean-type Chinook, which are commonly found in eoastal streams, typically migrate to sea within the first 3 months of emergence, but may spend up to a year in fresh water prior to emigration. They also spend their ocean life in coastal waters, utilizing estuaries and eoastal areas more extensively for juvenile rearing.

Adult female Chinook prepare spawning beds in stream areas with suitable gravel eomposition, water depth, and velocity. The female then lays eggs, which she guards for a brief period before dying. Eggs hateh between 90 and 150 days after deposition, depending on water temperatures. The following spring, young salmon fry emerge, and may spend from 3 months to 2 years in freshwater before migrating to estuarine areas as smolts, and then into the ocean to feed and mature. Chinook salmon remain at sea for 1 to 6 years, with the exeeption of a small number of yearling males that mature in freshwater, or return after 2 to 3 months in salt water.

\section{Sacramento Winter Run}

The Sacramento River winter-run Chinook salmon ESU was federally listed as threatened on November 30, 1990 (55 FR 49623), and then reclassified as an endangered species on March 23, 1994 (59 FR 13836). This ESU includes populations of winter-run Chinook salmon in the Sacramento River and its tributaries in California, as well as two artificial propagation programs (winter-run Chinook from the Livingston Stone National Fish Hatchery, and winter-run Chinook in a captive broodstock program maintained at the same fish hatchery and the University of California Bodega Marine Laboratory).

On June 16, 1993, NMFS designated critical habitat for the Sacramento winter-run Chinook from Keswick Dam (Sacramento river mile 302) to the Golden Gate Bridge (58 FR 33212). The designated habitat ineludes the area from the Sacramento River at Keswick Dam downstream to the San Francisco Bay. The open ocean was considered important, but was not designated as eritical habitat beeause degradation of the open ocean did not appear to have substantially contributed to the decline of the species. The essential features of the critical habitat include 1) the river water; 2) the river bottom, including those areas used as spawning substrate; 3 ) the adjacent riparian zone used for rearing; and 4) the estuarine water column and essential foraging habitat and food resources of the Delta and Bay, used for juvenile emigration and adult upmigration. Major river basins containing spawning and rearing habitat for this ESU comprise approximately 9,329 square miles in California. The following counties lie partially or wholly within these basins: Butte, Colusa, Contra Costa, Glenn, Napa, Nevada, Placer, Plumas, Sacramento, Shasta, Solano, Sutter, Tehama, Trinity, Yolo, and Yuba. Counties with critical habita include Butte, Colusa, Contra Costa, Glenn, Sacramento, Shasta, Solano, Sutter, Tehama, and Yolo. BLM-administered lands are found in all counties with critical habitat except Sutter.

\section{Snake River Fall Run}

The Snake River Fall-run ESU was federally listed as a threatened species on April 22, 1992 (57 FR 14653). This ESU includes all natural populations occurring in the mainstem Snake River below Hells Canyon Dam, and in the Tucannon River, Grande Ronde River, Imnaha River, Salmon River, and Clearwater River, as well as four artificial propagation programs (the Lyons Ferry Hatchery, Fall Chinook Acclimation Ponds Program, Nez Perce Tribal Hatchery, and Oxbow Hatchery fall-run Chinook hatchery programs). 
Critical habitat (designated on December 28, 1993; 58 FR 68543) includes all river reaches presently or historically accessible (except reaches above impassable natural falls, and Dworshak and Hells Canyon Dams) in the Columbia River, from a straight line connecting the west end of the Clatsop jetty (south jetty, Oregon side) and the west end of the Peacock jetty (north jetty, Washington side). Critical habitat also includes all Columbia River estuarine areas and river reaches proceeding upstream to the confluence of the Columbia and Snake Rivers. On the Snake River, all reaches from the confluenec of the Columbia River, upstream to Hells Canyon Dam are included. Also included are the Palouse River from its confluence with the Snake River upstream to Palouse Falls; the Clearwater River from its confluence with the Snake River upstream to its confluence with Lolo Creek; and the North Fork Clearwater River from its confluence with the Clearwater River upstream to Dworshak Dam. Major river basins containing spawning and rearing habitat for this ESU comprise approximately 13,679 square miles in Idaho, Oregon, and Washington. The following counties lie partially or wholly within these basins: Idaho-Adams, Benewah, Clearwater, Idaho, Latah, Lewis, Nez Peree, and Shoshone Valley; Oregon-Baker, Union, and Wallowa; and Washington-Adams, Asotin, Columbia, Franklin, Garfield, Walla Walla, and Whitman. Counties with eritical habitat are: Idaho-Adams, Clearwater, Idaho, Latah, Lemhi, Lewis, and Nez Peree; Oregon-Baker, Clatsop, Columbia, Gilliam, Hood River, Morrow, Multnomah, Sherman, Umatilla, Wallowa, and Wasco; and Washington-Adams, Asotin, Benton, Clark, Columbia, Cowlitz, Franklin, Garficld, Klickitat, Lincoln, Pacific, Skamania, Spokane, Wahkiakum, Walla Walla, and Whitman. BLM-administered lands are found in all counties with critical habitat except Wahkiakum County.

\section{Snake River Spring/Summer Run}

The Snake River Spring/Summer-run ESU was federally listed as a threatened species on April 22, 1992 (57 FR 14653), and the threatened status was reaffirmed on June 28, 2005 (70 FR 37160). Included in this ESU are all natural populations oceurring in the mainstem Snake River and the Tucannon River, Grande Ronde River, Imnaha River, and Salmon River subbasins, as well as 15 artificial propagation programs.

Critical habitat was designated on December 28, 1993 (58 FR 68543), and revised on Oetober 25, 1999 (64 FR 57399). Critical habitat includes the Columbia River from a straight line conneeting the west end of the Clatsop jetty (south jetty, Oregon side) and the west end of the Peacock jetty (north jetty, Washington side) and including all Columbia River estuarine areas and river reaches proceeding upstream to the confluence of the Columbia and Snake rivers; and all Snake River reaches from the confluence of the Columbia River upstream to Hells Canyon Dam. Critical habitat also includes river reaches presently or historically accessible (except reaches above impassable natural falls (ineluding Napias Creek Falls) and Dworshak and Hells Canyon Dams) to Snake River spring/summer Chinook salmon in the following hydrologic units: Hells Canyon, Imnaha, Lemhi, Little Salmon, Lower Grande Ronde, Lower Middle Fork Salmon, Lower Salmon, Lower Snake-Asotin, Lower Snake-Tucannon, Middle Salmon Chamberlain, Middle Salmon-Panther, Pahsimeroi, South Fork Salmon, Upper Middle Fork Salmon, Upper Grande Ronde, Upper Salmon, Wallowa. Critical habitat borders on or passes through the following counties in Oregon: Baker, Clatsop, Columbia, Gillium, Hood River, Morrow, Multnomah, Sherman, Umatilla, Union, Wallowa, Waseo; the following counties in Washington: Asotin, Benton, Clark, Columbia, Cowlitz, Franklin, Garfield, Klickitat, Pacific, Skamania, Wahkiakum, Walla, Whitman; and the following counties in Idaho: Adams, Blaine, Custer, Idaho, Lemhi, Lewis, Nez Peree, Valley.

\section{Lower Columbia River}

The Lower Columbia River ESU was federally listed as threatened on March 24, 1999 (64 FR 14308), and was reaffirmed on June 28, 2005 (70 FR 37160). Included in this ESU are all naturally-spawned populations of Chinook salmon from the Columbia River and its tributaries, from its mouth at the Pacific Ocean upstream to a transitional point between Washington and Oregon east of the Hood River and the White Salmon River. This ESU also includes populations in the Willamette River to Willamette Falls, Oregon, exclusive of spring-run Chinook salmon in the Clackamas River, as well as 17 artificial propagation programs.

On September 2, 2005, NMFS designated critical habitat for this species (70 FR 52630) in Clackamas, Clatsop, Columbia, Hood River, Multnomah, Waseo counties in Oregon; and Clark, Cowlitz, Klickitat, Lewis, Pacific, Pierce, Skamania, Wahkiakum, and Yakima Counties in Washington. Major river basins that contain spawning and rearing habitat for this ESU comprise approximately 6,338 square miles in Oregon and Washington. 
Approximately 1,311 stream miles and 33 square miles of lake habitat within this ESU are designated as critical habitat. The following counties lie partially or wholly within these basins, or contain migration habitat for the ESU: Oregon-Clackamas, Clatsop, Columbia, Hood River, Marion, Multnomah, Waseo, and Washington; and Washington-Clark, Cowlitz, Klickitat, Lewis, Pacific, Pierce, Skamania, Wahkiakum, and Yakima. Critical habitat is found in the following counties: Oregon-Clackamas, Clatsop, Columbia, Hood River, and Multnomah; and Washington-Clark, Cowlitz, Klickitat, Lewis, Pacific, Skamania, and Wahkiakum. BLM-administered lands are found in all counties with critical habitat except Pierce and Wahkiakum.

\section{Upper Willamette River}

The Upper Willamette River Chinook salmon ESU was federally listed as threatened on March 24, 1999 (64 FR 14308), and the status was reaffirmed on June 28, 2005 (70 FR 37160). This ESU includes all naturally spawned populations of spring-run Chinook salmon in the Clackamas River and in the Willamette River, and its tributaries, above Willamette Falls, Oregon, as well as seven artificial propagation programs.

On September 2, 2005 (70 FR 52630), NMFS designated approximately 1,472 stream miles and 18 square miles of lake habitat as eritieal habitat for this ESU. Major river basins containing spawning and rearing habitat for this ESU comprise approximately 8,575 square miles. The following counties lie partially or wholly within these basins (or contain migration habitat for the species): Oregon-Benton, Clackamas, Clatsop, Columbia, Douglas, Lane, Lincoln, Linn, Marion, Multnomah, Polk, Tillamook, Washington, and Yamhill; and Washington-Clark, Cowlitz, Pacific, and Wahkiakum. Critical habitat has been designated in the following counties: Oregon-Benton, Clackamas, Clatsop, Columbia, Lane, Linn, Marion, Multnomah, Polk, and Yamhill; and Washington-Clark, Cowlitz, and Wahkiakum. BLM-administered lands are found in all counties with eritieal habitat exeept Wahkiakum County.

\section{Upper Columbia River Spring Run}

The Upper Columbia River Spring-run ESU was federally listed as endangered on Mareh 24, 1999 (64 FR 14308), and this status was reaffirmed on June 28, 2005 (70 FR 37160). Included in this ESU are all naturally spawned populations of spring Chinook salmon occurring in all aceessible river reaches in Columbia River tributaries upstream of the Rock Island Dam and downstream of Chief Joseph Dam in Washington, as well as six artificial propagation programs (the Twisp River, Chewuch River, Methow Composite, Winthrop National Fish Hatehery, Chiwaha River, and White River spring-run Chinook hatchery programs).

On September 2, 2005 (70 FR 52630), NMFS designated approximately 974 stream miles and 4 square miles of lake habitat as critical habitat for this ESU. Major river basins containing spawning and rearing habitat for this ESU comprise approximately 7,003 square miles in Oregon and Washington. The following counties lie partially or wholly within these basins (or contain migration corridors for the species): Oregon-Clatsop, Columbia, Hood River, Gilliam, Morrow, Multnomah, Sherman, Umatilla, and Wasco; and Washington-Benton, Chelan, Clark, Cowlitz, Douglas, Franklin, Grant, Klickitat, Kittitas, Okanogan, Pacific, Skamania, Wahkiakum, Walla Walla, and Yakima. Critical habitat for this ESU is found in the following counties: Oregon-Clatsop, Columbia, Gilliam, Hood River, Morrow, Multnomah, Sherman, Umatilla, and Waseo; and Washington-Benton, Chelan, Clark, Cowlitz, Douglas, Franklin, Grant, Kittitas, Klickitat, Okanogan, Pacific, Skamania, Wahkiakum, Walla Walla, and Yakima. BLM-administered lands are found in all counties with critical habitat except Wahkiakum County.

\section{Central Valley Spring Run}

The Central Valley Spring-run ESU of Chinook salmon was federally listed as a threatened species on September 16, 1999 (64 FR 50394). This ESU includes all naturally-spawned populations of spring-run Chinook occurring in the Sacramento River and its tributaries in California, including the Feather River, as well as the Feather River Hatchery spring-run Chinook program.

On September 2, 2005 (70 FR 52488), NMFS designated approximately 1,158 stream miles and 254 square miles of estuarine habitat as critical habitat for this ESU, in Tehama, Butte, Glenn, Shasta, Yolo, Sacramento, Solano, Colusa, Yuba, Sutter, Trinity, Alameda, San Joaquin, and Contra Costa Counties, California. Major river basins containing spawning and rearing habitat for this ESU comprise approximately 9,329 square miles in California. 
The following counties lie partially or wholly within these basins (or contain migration habitat for the speeies): Alameda, Butte, Colusa, Contra Costa, Glenn, Marin, Napa, Nevada, Plaeer, Sacramento, San Francisco, San Mateo, Shasta, Solano, Sonoma, Sutter, Tehama, Yolo, and Yuba. BLM-administered lands are found in all eounties with eritical habitat except Sutter County.

\section{California Coast}

The California Coast ESU of Chinook salmon was federally listed as threatened on September 16, 1999 (64 FR 50394), and the status was reaffirmed on June 28, 2005 (70 FR 37160). This ESU ineludes all naturally spawned populations of Chinook salmon oeeurring in rivers and streams south of the Klamath River to the Russian River, California, as well as seven artificial propagation programs (the Humboldt Fish Action Council, Yager Creek, Redwood Creck, Hollow Tree, Van Arsdale Fish Station, Mattole Salmon Group, and Mad River Hatchery fall-run Chinook hatchery programs).

On Scptcmber 2, 2005 (70 FR 52488), NMFS designated approximately 1,475 strcam miles and 25 square miles of estuarine habitat as critieal habitat for this ESU, in Humboldt, Trinity, Mendocino, Sonoma, Lake, Napa, Glenn, Colusa, and Tehama Counties, California. Major river basins containing spawning and rearing habitat for this ESU comprise approximately 8,061 square miles in California. The following countics lic partially or wholly within these basins (or contain migration habitat for the species): Glenn, Humboldt, Lake, Marin, Mendocino, Sonoma, and Trinity. All counties with critieal habitat also have BLM-administered lands.

\section{Chum Salmon}

Chum salmon (Oncorhynchus keta) have the widest natural geographie and spawning distribution of any Paeific salmonid, with a range that extends farther along the shores of the Aretic Occan. Historically, chum salmon were distributed as far south as Montcrey, California, and may have been the most abundant of all salmonids. Presently, however, major spawning populations are found only as far south as Tillamook Bay on the northern Orcgon coast. There are four ESUs of ehum salmon along the west coast of the United States, and two listed ESUs: the Hood Canal Summer-run ESU and the Columbia River ESU.

Chum salmon spawn primarily in freshwater, and arc apparently obligatorily anadromous, as therc are no recorded landlocked or naturalized populations. They spend more of their life history in marine waters than other Pacific salmonids. They spawn in the lowermost reaches of rivers and strcams, typically within about 60 miles of the ocean. Unlike most other salmonids, they migratc almost immediately after hatching to estuarine and ocean waters. Therefore, the survival and growth of juveniles depends less on freshwater conditions than on favorable estuarine and marine eonditions. Another bchavioral difference between chum salmon and most species that rear extensively in fresh water is that chum salmon form schools, presumably to reduce predation. Most chum salmon mature at between 3 and 5 years of age. The speeies has only a single form (sea-run) and does not reside in fresh water.

\section{Columbia River}

The Columbia River ESU was federally listed as threatened on March 25, 1999 (64 FR 14508), and the status was reaffirmed on June 28, 2005 (70 FR 37160). This ESU includes all naturally spawned populations of chum salmon occurring in the Columbia River and its tributaries in Washington and Orcgon, as well as thrce artificial propagation programs (the Chinook River, Grays River, and Washougal River/Duncan Creek chum hatchery programs).

On September 2, 2005 (70 FR 52630), NMFS designated approximatcly 708 stream miles as critical habitat for this ESU. Major river basins containing spawning and rearing habitat for this ESU comprise approximatcly 4,426 square miles in Oregon and Washington. The following counties lic partially or wholly within these basins (or contain migration habitat for the species): Oregon-Clatsop, Columbia, Multnomah, and Washington; and Washington-Clark, Cowlitz, Lewis, Pacific, Skamania, and Wahkiakum. Critical habitat is found in the following countics: Oregon-Clatsop, Columbia, Hood River, and Multnomah; and Washington-Clark, Cowlitz, Klickitat, Lewis, Pacific, Skamania, and Wahkiakum. BLM-administercd lands are found in all eountics with critical habitat except Wahkiakum. 


\section{Hood Canal Summer-Run}

The Hood Canal summer-run ESU was federally listed as threatened on March 25, 1999 (64 FR 14508), and the status was reaffirmed on June 28, 2005 (70 FR 37160). This ESU includes all naturally spawned populations of summer-run ehum salmon in Hood Canal and its tributaries, and populations in Olympic Peninsula rivers between Hood Canal and Dungeness Bay, Washington, as well as eight artificial propagation programs (the Quilcene National Fish Hatehery, Hamma Hamma Fish Hatehery, Lilliwaup Creek Fish Hatehery, Union River/Tahuya, Big Beef Creek Fish Hatchery, Salmon Creek Fish Hatehery, Chimaeum Creek Fish Hatehery, and the Jimmycomelately Creek Fish Hatehery summer-run ehum hatchery programs). Critical habitat, which was designated on September 2, 2005 (70 FR 52630), includes 79 miles of stream and 377 miles of nearshore marine areas in the following counties in Washington: Clallam, Jefferson, Kitsap, and Mason. BLM-administered lands are found in Clallam and Jefferson Counties.

\section{Sockeye Salmon}

Sockeye salmon (Oncorhyncus nerka) on the Pacifie coast inhabit riverine, marine, and lake environments, from the Columbia River and its tributaries north and west to the Kuskokwim River in western Alaska. There are seven ESUs of sockeye salmon along the west coast of the United States, two of which are federally listed. Of these, only the endangered Snake River ESU is found within the projeet area.

Sockeye salmon exhibit a wide variety of life history patterns that refleet varying dependeney on the freshwater environment. With the exception of eertain river-type and sea-type populations, the vast majority of sockeye salmon spawn in inlet or outlet streams of lakes or in lakes themselves or near lakes. The juveniles of these "laketype" soekeye salmon rear in lake environments for 1 to 3 years, migrate to sea, and return to natal lake systems to spawn after 1 to 4 years in the ocean. For this reason, the major distribution and abundance of large sockeye salmon stocks are elosely related to the location of rivers that have aceessible lakes in their watersheds for juvenile rearing. Oceasionally, a proportion of the juveniles in an anadromous sockeye salmon population will remain in their rearing lake environment throughout life, and will be observed on the spawning grounds together with their anadromous siblings. Some soekeye salmon populations spawn in rivers without juvenile lake-rearing habitat. Juveniles of these populations rear in slow velocity sections of rivers for 1 or 2 years (river-type) or migrate to sea as underyearlings, and thus rear primarily in salt water (sea-type; Wood 1995). As with lake-type sockeye salmon, they return to natal spawning habitat after 1 to 4 years in the ocean.

Certain self-perpetuating, nonanadromous populations of the species that become resident in lake environments over long periods of time are ealled kokanee in North America. Sockeye salmon and kokanee exhibit a suite of heritable differences in morphology, early development rate, seawater adaptability, growth, and maturation, which appear to have arisen from differenees associated with anadromous versus nonanadromous life histories.

The Snake River ESU of sockeye salmon was federally listed as endangered on November 20, 1991 (56 FR 58620 ), and this status was reaffirmed on June 28, 2005 (70 FR 37160). This ESU includes all anadromous and residual sockeye salmon from the Snake River Basin, Idaho, as well as artificially propagated sockeye salmon from the Redfish Lake captive propagation program.

Critical habitat, designated on December 28, 1993 (58 FR 68543), includes presently or historically accessible river reaches (except reaches above impassable natural falls, and Dworshak and Hells Canyon dams) in the Columbia River, from a straight line connecting the west end of the Clatsop jetty (south jetty, Oregon side) and the west end of the Peacock jetty (north jetty, Washington side) and including all Columbia River estuarine areas and river reaches upstream to the confluence of the Columbia and Snake Rivers. Also included are all Snake River reaches from the confluence of the Columbia River upstream to the confluence of the Salmon River; all Salmon River reaches from the confluence of the Snake River upstream to Alturas Lake Creek; Stanley, Redfish, Yellow Belly, Pettit, and Alturas Lakes (including their inlet and outlet creeks); Alturas Lake Creek, and the portion of Valley Creek between Stanley Lake Creek and the Salmon River. Watersheds containing spawning and rearing habitat for this ESU comprise approximately 510 square miles in Idaho. The watersheds lie partially or wholly within Blaine and Custer Counties. Critical habitat has been designated in the following counties: Idaho-Blaine, Custer, Idaho, Lemhi, Lewis, Nez Perce, and Valley; Oregon-Clatsop, Columbia, Gilliam, Hood River, Morrow, Multnomah, 
Sherman, Umatilla, Wallowa, and Waseo; and Washington-Asotin, Benton, Clark, Columbia, Cowlitz, Franklin, Garfield, Kliekitat, Paeific, Skamania, Wahkiakum, Walla Walla, and Whitman. All eounties with critieal habitat also have BLM-administered lands exeept Wahkiakum.

\section{Steelhead Trout}

Along the west eoast, steelhead trout (Oncorhynchus mykiss) are distributed aeross about 15 degrees of latitude from the U.S. Canada border south to the mouth of Malibu Creek, California. In some years, steelhead may be found as far south as the Santa Margarita River in San Diego County. There are 11 listed steelhead ESUs, 10 of whieh are found in the project area: Southern California, South Central California Coast, California Central Valley, Northern California, Central California Coast, Snake River Basin, Upper Willamette River, Upper Columbia River, Lower Columbia River, and Middle Columbia River.

Steelhead have the greatest diversity of life history patterns of any Pacifie salmonid speeies, ineluding varying degrees of anadromy, differenees in reproduetive biology, and plastieity of life history between generations. Within the range of West Coast steelhead, spawning migrations oeeur throughout the year, with seasonal peaks of aetivity. In any given river basin there may be one or more peaks of migration activity; some rivers may have multiple runs, and fish are divided into either winter, spring, summer, or fall run steelhead. North Ameriean steelhead eommonly spend 2 years in the ocean before entering fresh water to spawn. Summer steelhead enter fresh water up to a year prior to spawning. Steelhead may spawn more than onee. The resident freshwater forms of steelhead are usually ealled rainbow or redband trout. In some eases, the separation between anadromous steelhead and rainbow or redband trout is obseured.

Within the range of West Coast steelhead, spawning migrations oeeur throughout the year, with seasonal peaks of aetivity. In a given river basin there may be one or more peaks in migration activity; beeause these runs are usually named for the season in whieh the peak occurs, some rivers may have runs known as winter-, spring-, summer-, or fall-run steelhead. For example, large rivers, sueh as the Columbia, Rogue, and Klamath Rivers, have migrating adult steethead at all times of the year. Loeal variations in the names identify the seasonal runs of steelhead; in northern California, some biologists have retained the terms spring- and fall-run steelhead to deseribe what others would eall summer-run steelhead.

Steelhead ean be divided into two basic reproduetive eeotypes, based on the state of sexual maturity at the time of river entry and duration of spawning migration (Burgner et al. 1992). The stream-maturing type (summer-run steelhead in the Pacific Northwest and northern California) enters freshwater in a sexually immature eondition between May and October and requires several months to mature and spawn. The oeean-maturing type (winter-run steelhead in the Pacific Northwest and northern California) enters freshwater between November and April and spawns shortly thereafter. In basins with both summer and winter steelhead runs, the summer run appears to oeeur where habitat is not fully used by the winter run or where a seasonal hydrologie barrier, sueh as a waterfall, separates them. Coastal streams are dominated by winter-run steelhead, whereas inland steelhead of the Columbia River basin are almost exelusively summer-run steelhead.

\section{Southern California}

The Southern California ESU was federally listed as endangered speeies on August 18, 1997 (62 FR 43937), and this status was reaffirmed on January 5, 2006 (71 FR 834). This ESU ineludes all naturally spawned anadromous populations of steelhead below natural and manmade impassable barriers in streams from the Santa Maria River, San Luis Obispo County, California (inelusive) to the U.S.-Mexieo border. On September 2, 2005 (70 FR 52488), NMFS designated approximately 708 stream miles as critieal habitat for this ESU.

\section{South-central California Coast}

The South-eentral California Coast ESU was federally listed as threatened on June 17, 1998 (63 FR 32996), and this status was reaffirmed on January 5, 2006 (71 FR 834). This ESU ineludes all naturally spawned populations of steelhead below natural and manmade impassable barriers in streams from the Parajo River (inelusive) to, but not ineluding the Santa Maria River, California. On September 2, 2005 (70 FR 52488), NMFS designated approximately 1,250 stream miles and 3 square miles of estuarine habitat as eritieal habitat for this ESU. Critieal 
habitat oceurs in Los Angeles, Orange, San Luis Obispo, Santa Barbara, and Ventura Counties. BLM-administered lands are found in all of these counties except Orange County.

\section{Central California Coast}

The Central California Coast ESU was federally listed as threatened on August 18, 1997 (62 FR 43937). This ESU includes all naturally-spawned steelhead populations below natural and manmade impassable barriers in California streams from the Russian River (inclusive) to Aptos Creek (inclusive), and the drainages of San Francisco, San Pablo, and Suisun Bays, eastward to Chipps Island at the confluence of the Sacramento and San Joaquin Rivers. The ESU also includes tributary streams to Suisun Marsh, including Suisun Creek, Green Valley Creek, and an unnamed tributary to Cordelia Slough, exeluding the Sacramento-San Joaquin River Basin, as well as two artificial propagation programs (the Don Clusen Fish Hatchery and Kinfisher Flat Hatehery/Seott Creek steelhead hatehery programs).

On September 2, 2005, NMFS designated approximately 1,465 stream miles and 386 square miles of estuarine habitat as critical habitat for this ESU. Major river basins containing spawning and rearing habitat for this DPS comprise approximately 6,516 square miles in California. The following counties lie partially or wholly within these basins (or contain migration habitat for the species): Alameda, Contra Costa, Marin, Mendocino, Napa, San Francisco, San Mateo, Santa Clara, Santa Cruz, Solano, and Sonoma. Critical habitat is found in the following counties: Alameda, Marin, Mendocino, Napa, San Francisco, San Mateo, Santa Clara, Santa Cruz, Solano, and Sonoma. BLM-administered lands are found in all of these counties except Marin and San Franciseo.

\section{Upper Columbia River}

The Upper Columbia River ESU was first federally listed as endangered on August 18, 1997 (62 FR 43937), and has since been upgraded to threatened (most recently on August 24, 2009 [74 FR 42605]). This ESU includes all naturally spawned anadromous populations of steelhead below natural and man-made impassable barriers in streams in the Columbia River Basin upstream from the Yakima River, Washington, to the U.S.-Canada border, as well as six artificial propagation programs (the Wenatchee River, Wells Hatehery, Winthrop National Fish Hatchery, Omak Creek, and Ringold Steelhead hatehery programs). On September 2, 2005 (70 FR 52630), NMFS designated approximately 1,262 stream miles and 7 square miles of lake habitat as eritical habitat for this ESU. Major river basins containing spawning and rearing habitat for this ESU comprise approximately 9,545 square miles in Oregon and Washington. The following counties lie partially or wholly within these basins (or contain migration habitat for the species): Oregon-Clatsop, Columbia, Gilliam, Hood River, Morrow, Multnomah, Sherman, Umatilla, and Waseo; and Washington-Benton, Chelan, Clark, Cowlitz, Douglas, Franklin, Gilliam, Grant, Kittitas, Klickitat, Okanogan, Pacific, Skamania, Wahkiakum, Walla Walla, and Yakima. Critical habitat is found in the following counties: Oregon-Clatsop, Columbia, Gilliam, Hood River, Morrow, Multnomah, Umatilla, and Wasco; and Washington-Adams, Benton, Chelan, Clark, Cowlitz, Douglas, Franklin, Grant, Kittitas, Klickitat, Okanogan, Skamania, Wahkiakum, Walla Walla, and Yakima. BLM-administered lands are found in all counties with eritical habitat except Wahkiakum.

\section{Snake River Basin}

The Snake River Basin ESU of steelhead was federally listed as threatened on August 18, 1997 (62 FR 43937). This ESU includes all naturally spawned populations of steelhead below natural and manmade impassable barriers in streams in the Snake River Basin of southeast Washington, northeast Oregon, and Idaho. The ESU also includes six artificial propagation programs (the Tucannon River, Dworshak National Fish Hatchery, Lolo Creek, North Fork Clearwater, East Fork Salmon River, and the Little Sheep Creek/Imnaha River Hatchery steelhead hatchery programs). On September 2, 2005 (70 FR 52630), NMFS designated approximately 8,049 stream miles and 4 square miles of lake habitat as critical habitat for this ESU. Major river basins containing spawning and rearing habitat for this ESU comprise approximately 29,282 square miles in Idaho, Oregon, and Washington. The following counties lie partially or wholly within these basins (or contain migration habitat for the species): Idaho-Adams, Blaine, Boise, Clearwater, Custer, Idaho, Latah, Lemhi, Lewis, Nez Perce, and Valley; Oregon-Baker, Clatsop, Columbia, Hood River, Morrow, Mulnomah, Sherman, Umatilla, Union, Wallowa, and Wasco; and Washington-Asotin, Benton, Clark, Columbia, Cowlitz, Franklin, Garfield, Gilliam, Klickitat, Skamania, Wahkiakum, Walla Walla, and Whitman. Critical habitat is found in the following counties: 
Idaho-Adams, Blaine, Clearwater, Custer, Idaho, Latah, Lemhi, Lewis, Nez Peree, and Valley; Oregon-Clatsop, Columbia, Gilliam, Hood River, Morrow, Multnomah, Sherman, Umatilla, Union, Wallowa, and Wasco; and Washington-Asotin, Benton, Clark, Columbia, Cowlitz, Franklin, Garfield, Klickitat, Skamania, Wahkiakum, Walla Walla, and Whitman. BLM-administered lands are found in all counties with critical habitat except Wahkiakum.

\section{Lower Columbia River}

The Lower Columbia River ESU was federally listed as threatened on March 19, 1998 (63 FR 13347), and this status was reaffirmed on January 5, 2006 (71 FR 834). This ESU includes all naturally spawned anadromous steelhead populations below natural and man-made impassable barriers in streams and tributaries to the Columbia River between the Cowlitz and Wind Rivers, Washington (inclusive), and the Willamette and Hood Rivers, Oregon (inclusive). The ESU also includes ten artificial propagation programs (the Cowlitz Trout Hatchery, Kalama River Wild (winter- and summer-run), Clackamas Hatchery, Sandy Hatchery, and Hood River (winter- and summer-run) steelhead hatehery programs. Excluded are populations in the upper Willamette River Basin above Willamette Falls, Oregon, and from the Little and Big White Salmon Rivers, Washington.

On September 2, 2005, NMFS designated approximately 2,324 stream miles and 27 square miles of lake habitat as critical habitat for this ESU. Major river basins containing spawning and rearing habitat for this ESU comprise approximately 5,017 square miles in Oregon and Washington. The following counties lie partially or wholly within these basins (or contain migration habitat for the species): Oregon-Clackamas, Clatsop, Columbia, Hood River, Marion, Multnomah, and Washington; and Washington-Clark, Cowlitz, Lewis, Pacific, Skamania, and Wahkiakum. Critical habitat is found in the following counties: Oregon-Clackamas, Clatsop, Columbia, Hood River, Marion, and Multnomah; and Washington-Clark, Cowlitz, Klickitat, Lewis, Skamania, and Wahkiakum. BLM-administered lands are found in all counties with critical habitat except Wahkiakum.

\section{Central Valley, California}

The Central Valley, California, ESU was federally listed as threatened on March 19, 1998 (63 FR 13347), and this status was reaffirmed on January 5, 2006 (71 FR 834). This ESU includes all naturally spawned anadromous steelhead populations below natural and man-made impassable barriers in the Sacramento and San Joaquin Rivers and their tributarics, as well as two artificial propagation programs (the Coleman National Fish Hatchery, and Feather River Hatchery steclhead hatchery programs). Excluded from the ESU are steelhead from San Francisco and San Pablo bays and their tributaries. On September 2, 2005 (70 FR 52488), NMFS designated approximately 2,308 stream miles and 254 square miles of estuarinc habitat as critical habitat for this ESU. Major river basins containing spawning and rearing habitat for this ESU comprisc approximately 13,096 square miles in California. The following counties lie partially or wholly within these basins (or contain migration habitat for the species): Alameda, Amador, Butte, Calaveras, Colusa, Contra Costa, Glenn, Marin, Mereed, Nevada, Placer, Sacramento, San Francisco, San Joaquin, Shasta, Solano, Sonoma, Stanislaus, Sutter, Tehama, Tuolumne, Yolo, and Yuba. Critical habitat is found in the following counties: Butte, Calaveras, Colusa, Contra Costa, Glenn, Marin, Merced, Nevada, Placer, Sacramento, San Francisco, San Joaquin, Shasta, Solano, Stanislaus, Sutter, Tehama, Tuolumne, Yolo, and Yuba. BLM-administcred lands are found in all counties with critical habitat except Marin, San Francisco, and Sutter.

\section{Upper Willamette}

The Upper Willamette ESU of steelhead was federally listed as threatened on Mareh 25, 1999 (64 FR 14517), and this status was reaffirmed on January 5, 2006 (71 FR 834). The ESU includes all naturally spawned anadromous steelhead populations below natural and manmade impassable barriers in the Willamette River, Oregon, and its tributaries upstrcam from Willamette Falls to the Calapooia River (inclusive).

On September 2, 2005, NMFS designated approximately 1,276 stream miles and 2 square miles of lake habitat critical habitat for this ESU. Major river basins containing spawning and rearing habitat for this DPS comprise approximately 4,872 square miles in Oregon and Washington. The following counties lie partially or wholly within these basins (or contain migration habitat for the species): Oregon-Benton, Clackamas, Clatsop, Columbia, Lincoln, Linn, Marion, Multnomah, Polk, Tillamook, Washington, and Yamhill; and Washington-Clark, Cowlitz, 
Pacific, and Wahkiakum. Critical habitat is found in the following counties: Oregon-Benton, Clackamas, Clatsop, Columbia, Linn, Marion, Multnomah, Polk, Tillamook, Washington, and Yamhill; and Washington-Clark, Cowlitz, and Wahkiakum. BLM-administered lands are found in all counties with eritical habitat except Wahkiakum.

\section{Middle Columbia River}

The Middle Columbia River ESU was federally listed as threatened on Mareh 25, 1999 (64 FR 14517), and this status was reaffirmed on January 5, 2006 (71 FR 834). This ESU includes all naturally spawned anadromous steelhead populations below natural and manmade impassable barriers in streams from above the Wind River, Washington, and the Hood River, Oregon (exclusive), upstream to, and ineluding, the Yakima River, Washington, excluding steelhead from the Snake River Basin. The ESU ineludes seven artificial propagation programs (the Touchet River Endemic, Yakima River Kelt Reconditioning Program, Umatilla River, and Deschutes River steelhead hatchery programs). Critical habitat for this ESU, which was designated on September 2, 2005 (70 FR 52630), includes approximately 5,815 stream miles. Major river basins containing spawning and rearing habitat for this ESU comprise approximately 26,739 square miles in Oregon and Washington. The following counties lie partially or wholly within these basins (or contain migration habitat for the species): Oregon-Clatsop, Columbia, Crook, Gilliam, Grant, Harney, Hood River, Jefferson, Morrow, Multnomah, Sherman, Umatilla, Union, Wallowa, Waseo, and Wheeler; and Washington-Benton, Clark, Columbia, Cowlitz, Franklin, Kittitas, Kliekitat, Paeific, Skamania, Wahkiakum, Walla Walla, and Yakima. Critical habitat is found in the following eounties: Oregon-Clatsop, Columbia, Crook, Gilliam, Grant, Hood River, Jefferson, Morrow, Multnomah, Sherman, Umatilla, Union, Wallowa, Wasco, and Wheeler; and Washington-Benton, Clark, Columbia, Cowlitz, Franklin, Kittitas, Kliekitat, Skamania, Wahkiakum, Walla Walla, and Yakima. BLM-administered lands are found in all counties with critical habitat except Wahkiakum.

\section{Northern California}

The Northern California ESU was federally listed as threatened on June 7, 2000, and this status was reaffirmed on January 5, 2006 (71 FR 834). This ESU oceurs in California eoastal river basins from Redwood Creek south to the Gualala River, inclusive. NMFS designated critical habitat for this ESU on September 2, 2005 (70 FR 52488). Approximately 3,028 stream miles and 25 square miles of estuarine habitat has been designated as critical habitat. Major river basins containing spawning and rearing habitat for this ESU comprise approximately 6,672 square miles in California. The following counties lie partially or wholly within these basins: Del Norte, Glenn, Humboldt, Lake, Mendocino, Sonoma, and Trinity. Critical habitat is found in the following counties: Glenn, Humboldt, Mendocino, Sonoma, and Trinity. BLM-administered lands are also found in those eounties with critical habitat.

\section{Threats to Pacific Salmon}

Salmonid species on the West Coast of the United States have experienced dramatie declines in abundance during the past several decades as a result of human-induced and natural factors. Water storage, withdrawal, conveyanee, and diversions for agriculture, flood control, domestic, and hydropower purposes have greatly reduced or eliminated historically accessible habitat and/or resulted in direct entrainment mortality of juvenile salmonids. Modification of natural flow regimes has resulted in increased water temperatures; changes in fish community structures; and a depletion of the flows necessary for migration, spawning, rearing, flushing of sediments from spawning gravels, gravel recruitment, and transport of large woody debris. Physical features of dams, such as turbines and sluiceways, have resulted in increased mortality of both adults and juvenile salmonids. Attempts to mitigate negative impacts of these structures have, to date, met with limited success.

Natural resource use and extraction leading to habitat modification can have substantial direct and indirect impacts to salmon populations. Land use activities associated with logging, road construction, urban development, mining, agriculture, and recreation have significantly altered fish habitat quantity and quality. Impacts associated with these activities include: alteration of streambanks and channel morphology; alteration of ambient stream water temperatures; degradation of water quality; reduction in available food supply; elimination of spawning and rearing habitat; fragmentation of available habitats; elimination of downstream recruitment of spawning gravels and large woody debris; removal of riparian vegetation resulting in increased stream bank erosion; and increased 
sedimentation input into spawning and rearing areas, resulting in the loss of channel complexity, pool habitat, suitable gravel substrate, and large woody debris. In most westem states, about 80 to 90 percent of the historic riparian habitat has been eliminated. It has also been estimated that Washington and Oregon's wetlands have been diminished by one third, and that California has experienced a 91 percent loss of its wetland habitat.

Other factors that have led to the decline of salmon and continue to threaten remaining populations include loss of spatial and temporal connectivity and complexity, recreational and commercial fishing, introduction of non-native species, and natural environmental conditions (e.g., floods, drought, climatic shifts) that exacerbate the problems associated with degraded and altered riverine and estuarine habitats (NMFS, no date).

\section{Bull Trout}

The primary reference for this section is:

USFWS. 1999h. Determination of Threatened Status for Bull Trout in the Coterminous United States Final Rule. Federal Register 64(210):58909-58933.

References cited in this section are internal to the above-referenced document. A complete list of these references is available from the USFWS Snake River Basin Field Office, Boise, Idaho.

The 20085 -year review for the bull trout (USFWS 20080) was consulted for updated information on this species.

Bull trout (Salvelimus confluentus) are native to the Pacific Northwest and westem Canada. They historically occurred in major river drainages in the Pacific Northwest, from the southem limits in the McCloud River in northern California and the Jarbidge River in Nevada, north to the headwaters of the Yukon River in Northwest Ferritories, Canada (Cavender 1978, Bond 1992). To the west, the range of the bull trout includes the Puget Sound, and various coastal rivers of Washington, British Columbia, Canada, and southeast Alaska (Bond 1992, Leary and Allendorf 1997). Bull trout are relatively dispersed throughout tributaries of the Columbia River Basin, including its headwaters in Montana and Canada. Bull trout also occur in the Klamath River Basin of south-central Oregon. East of the Continental Divide, they are found in the headwaters of the Saskatchewan River in Alberta and the MacKenzie River system in Alberta and British Columbia (Cavender 1978, Brewin and Brewin 1997).

Bull trout exhibit both resident and migratory life-history strategies through much of their current range (Riernan and McIntyre 1993). Resident bull trout complete their life cycles in the tributary streams in which they spawn and rear. Migratory bull trout spawn in tributary streams, and juvenile fish rear from 1 to 4 years before migrating to either a lake (adfluvial), river (fluvial), or in certain coastal areas, saltwater (anadromous), to mature (Fraley and Shepard 1989, Goetz 1989). Anadromy is the least studied life-history stage in bull trout, and some biologists believe the existence of true anadromy in bull trout is still uncertain (McPhail and Baxter 1996). Resident and migratory forms may be found together, and bull trout may produce offspring exhibiting either resident or migratory behavior (Rieman and McIntyre 1993).

Compared to other salmonids, bull trout have more specific habitat requirements (Rieman and McIntyre 1993) that appear to influence their distribution and abundance. Critical parameters include water temperature, cover, channel form and stability, valley form, spawning and rearing substrates, and migratory corridors (Oliver 1979; Pratt 1984, 1992; Fraley and Shepard 1989; Goetz 1989; Hoelscher and Bjornn 1989; Sedell and Everest 1991; Howell and Buchanan 1992; Rieman and MeIntyre 1993, 1995; Rich 1996; Watson and Hillman 1997). Watersheds must have specific physical characteristics to provide the necessary habitat requirements for bull trout spawning and rearing. although these characteristics are not necessarily ubiquitous throughout watersheds in which bull trout occur. Because bull trout exhibit a patchy distribution, even in undisturbed habitats (Rieman and McIntyre 1993), fish would not likely occupy all available habitats simultaneously (Rieman et al. 1997).

Bull trout are typically associated with the colder streams in a river system, although fish can occur throughout larger river systems (Fraley and Shepard 1989; Rieman and McIntyre 1993, 1995; Buchanan and Gregory 1997; Rieman et al. 1997). Spawning areas are often associated with cold-water springs, groundwater infiltration, and the coldest streams in a given watershed (Pratt 1992; Rieman and McIntyre 1993; Rieman et al. 1997). All life history 
stages of bull trout are associated with complex forms of cover, including large woody debris, undercut banks, boulders, and pools (Oliver 1979, Fraley and Shepard 1989, Goetz 1989, Hoelscher and Bjornn 1989, Sedell and Everest 1991, Pratt 1992, Thomas 1992, Rich 1996, Sexauer and James 1997, Watson and Hillman 1997). Maintaining bull trout populations requires stream channel and flow stability (Rieman and McIntyre 1993). Juvenile and adult bull trout frequently inhabit side channels, stream margins, and pools with suitable cover (Sexauer and James 1997). These areas are sensitive to activities that directly or indirectly affect stream channel stability and alter natural flow patterns.

Preferred spawning habitat generally consists of low gradient stream rcaches, which are often found in high gradient streams that have loose, clean gravel (Fraley and Shepard 1989) and water temperatures of 41 to $48{ }^{\circ} \mathrm{F}$ in late summer to early fall (Goetz 1989). The size and age of maturity for bull trout is variable depending on lifehistory strategy. Growth of resident fish is generally slower than that of migratory fish; resident fish tend to be smaller at maturity and less fecund (productive; Fraley and Shepard 1989, Goetz 1989). Bull trout normally reach sexual maturity in 4 to 7 years, and can live 12 or more years. Biologists report repeat and alternate year spawning, although repeat spawning frequency and post-spawning mortality are not well known (Leathe and Graham 1982, Fraley and Shepard 1989, Pratt 1992, Rieman and McIntyre 1996). Bull trout typically spawn from August to November during periods of decreasing water temperatures. However, migratory bull trout may begin spawning migrations as early as April, and move upstream as far as 155 miles to spawning grounds in some areas of their range (Fraley and Shepard 1989, Swanberg 1997). Depending on the water temperature, egg incubation is normally 100 to 145 days (Pratt 1992), and juveniles remain in the substrate after hatehing. Fry normally emerge from early April through May, depending on water temperatures and increasing stream flows (Pratt 1992, Ratliff and Howell 1992).

Bull trout are opportunistic feeders, with food habits primarily a function of size and life-history strategy. Resident and juvenile bull trout prey on terrestrial and aquatic insects, macro-zooplankton, amphipods, mysids, crayfish, and small fish (Wyman 1975, Rieman and Lukens 1979 cited in Rieman and McIntyre 1993, Boag 1987, Goetz 1989, Donald and Alger 1993). Adult migratory bull trout are primarily piscivorous, known to feed on various trout and salmon species, whitefish, yellow perch and sculpin (Fraley and Shepard 1989, Donald and Alger 1993).

The bull trout was federally listed as threatened throughout its entire range in the coterminous United States on November 1, 1999 (64 FR 17110). Critical habitat for the bull trout was first designated on October 6, 2004 (69 FR 59995), and after various additional designations and revisions, the most recent revised designation of critical habitat for the bull trout was made on October 18, 2010 (75 FR 63898). This designation includes 19,729 miles of streams (including 754 miles of marine shoreline) and 488,252 acres of reservoirs and lakes in Washington, Oregon, Nevada, ldaho, and Montana. The decline of bull trout is primarily attributable to habitat degradation and fragmentation, blockage of migratory corridors, poor water quality, past fisheries management practices, and the introduction of non-native species. Currently the primary threats to the species are a lack of habitat connectivity, and predation, competition, and hybridization with non-native fish (USFWS 2008n).

\section{Pacific Eulachon}

The primary reference for this section is:

NMFS. 2011. Endangered and Threatened Species; Designation of Critical Habitat for the Southern Distinct Population Segment of Eulachon; Final Rule. Fedcral Register 76(203):65323-65352.

References cited in this section are internal to the above-referenced document. They are available from the NMFS Protected Resources Division, Northwest, Region, Portland, Oregon.

Pacific eulachon (Thaleichthys pacificus) are endemic to the northeastern Pacific Ocean, ranging from northern California to southwest and south-Central Alaska and into the southeastern Bering Sea (McAllister 1963; Scott and Crossman 1973; Willson et al. 2006). The distribution coincides closely with the distribution of the coastal temperate rain forest on the west coast of North America. South of the Canadian border, most eulachon production originates in the Columbia River basin, with the major and most consistent spawning runs returning to the mainstem of the Columbia and Cowlitz Rivers (Gustafson et al. 2010). Spawning also occurs in other tributaries to 
the Columbia River, and has historically occurred in the Klamath River in northern California and the Umpqua River in Oregon.

Eulachon typically spend 3 to 5 years in salt water before returning to fresh water to spawn from late winter through early summcr. Eulachon generally spawn in rivers that are glacier- or snowmelt-fed and have a pronounced peak freshet (a sudden rise in stream level) in spring. Spawning grounds are typically in the lower reaches of larger rivers fed by snowmelt (Hay and McCarter 2000). Spawning typically occurs at night, over sand, coarse gravel, or detrital substratcs. Spawning generally occurs in January, February, and March in the Columbia River, the Klamath River, and the coastal rivers of Washington and Oregon, and April and May in the Fraser River (Gustafson et al. 2010). Shortly after hatching, the larvae are carried downstream and dispersed by estuarine, tidal, and ocean currents. Larval eulachon may remain in low salinity, surface waters of estuaries for several weeks or longer (Hay and McCarter 2000) bcfore entering the ocean. Once juvenile eulachon enter the ocean, they movc from shallow nearshore arcas to deeper areas over the continental shelf. Larvae and young juveniles become widely distributed in coastal waters, where they are typically found near the ocean bottom in waters 66 to 292 fcet deep (Hay and McCarter 2000).

Eulachon larvae and juveniles eat a variety of prey items, including phytoplankton, copepods, copepod eggs, mysids, barnacle larvae, and worm larvac (Barraclough 1967; Barraclough and Fulton 1967; Robinson et al., 1968a, 1968b). Eulachon adults feed on zooplankton. Adults and juveniles commonly forage at moderate depths (66 to 292 feet) in nearshore marine waters (Hay and McCarter 2000). Eulachon adults do not feed during spawning (McHugh 1939, Hart and McHugh 1944).

The Southern DPS of Pacific eulachon was federally listed as threatened on March 18, 2010 (75 FR 13012). In October 2011, NMFS designated critical habitat for the species in 16 areas within California, Oregon, and Washington (76 FR 65323). Critical habitat areas include a combination of freshwater creeks and rivers and their associated estuaries, totaling approximately 335 miles. The most significant threat to eulachon and their habitats is changes in ocean conditions due to climate change. Ocean warming trends may alter prey, spawning, and rearing success. Climate-induced change to freshwater habitats is also a moderate threat. The other primary threat to Southern DPS eulachon is habitat loss and degradation, particularly in the Columbia River basin.

\section{Green Sturgeon}

The primary references for this section are:

NMFS. 2005b. Endangered and Threatened Wildlife and Plants: Proposed Threatened Status for Southern Distinct Population Segment of North American Green Sturgeon. Federal Register 70(65): 17386-17401.

and

NMFS. 2009. Endangered and Threatened Wildlife and Plants: Final Rulemaking To Designate Critical Habitat for the Threatened Southern Distinct Population Segment of North American Green Sturgeon. Federal Register 74(195):52300-52351.

References cited in this section are internal to the above-referenced documents. They are available from the NMFS Protected Resources Division, Southwest, Region, Ocean Beach, California.

The green sturgeon (Acipenser medirostris) is a long-lived anadromous fish that occurs on the west coast of the U.S., ranging from Alaska to Mexico. It is the most widely distributed species of the sturgeon family and the most marine-oriented of the sturgeon species. Green sturgeon occur in in nearshore marine waters and are commonly observed in bays and estuaries along the coast, with particularly large concentrations entering the Columbia River estuary, Willapa Bay, and Grays Harbor during the late summer (Moyle et al. 1992). The Southern DPS consists of populations originating from coastal watersheds south of the Eel River, with the only known spawning population in the Sacramento River. Southern DPS green sturgeon occur throughout their natal river systems (the Sacramento River, lower Feather River, and lower Yuba River), but are believed to be restricted to the estuaries in non-natal river systems (i.e., north of an including the Eel River). 
Subadult and adult green sturgeon spend most of their lives in coastal marine and estuarine waters. They spawn in deep pools in large, turbulent freshwater river mainstems (Moyle ct al. 2002). Eggs are likely broadcast over large cobble substrates, but spawning can occur over a range of substrate types, from sand to clean bedrock (Moyle et al. 1995). Cold, clean water is likely important for proper embryonic development. Adult green sturgeon return to freshwater when they are about 15 years of age and more than 4 feet in size. Spawning is believed to occur every 2 to 5 years (Moyle 2002). Adults typically migrate into fresh water beginning in late February, and spawning occurs from March through July, with peak activity in April through June (Moyle et al. 1995). Juveniles spend a few years in fresh and estuarine waters before they disperse in the ocean. Adult green sturgeon are known to feed on invertebrates (shrimp, amphipods, mollusks) and small fish, although feeding data are limited.

The Southern DPS of the green sturgeon was federally listed as threatened on April 7, 2006 (71 FR 17757). On October 9, 2009, NMFS designated as critical habitat approximately 320 miles of freshwater river habitat, 897 square miles of marine habitat, 487 miles of habitat in the Sacramento-San Joaquin Delta, and 135 square miles of habitat within the Yolo and Sutter bypasses (Sacramento River; 74 FR 52300). The principal factor in the decline of the southern DPS is the reduction of its spawning area to a limited section of the Sacramento River. Other threats to the species include insufficient freshwater flow rates in spawning areas, pesticides and other contaminants, bycatch in fisheries, potential poaching, entrainment by water projects, influence of exotic species, small population size, impassable barriers, and elcvated water temperatures.

\section{Temperate Desert Ecoregion}

The Temperate Desert Ecoregion is a cool desert region, with low precipitation and a relatively high elevation. This region more or less corresponds to the Great Basin and the Colorado Plateau. Much of this area is made up of separate interior basins; only a small part of it drains to the sea (Bailey 1995). The lower parts of many basins have heavy accumulations of alkaline and saline salts. Streams are rare and few are permanent. Important aquatic habitats include terminal lakes (e.g., Mono Lake and the Great Salt Lake), marshes, or sinks that are warm and saline (Moyle 1976). The northern half of this ecoregion division also includes portions of the Snake, Columbia, Yakima, and Platte Rivers.

\section{Foskett Speckled Dace}

The Foskett speckled dace (Rhinichthys osculus ssp.) is endemic to Foskett Spring in south-central Oregon, a small spring system in the Coleman Basin on the west side of Warner Valley. Habitat is a small springhole and overflow rivulets that occur in what appears to be mixed rangeland at the edge of an alkali playa. The wet areas at the spring, along the course of the rivulets, and at the sump on the edge of the playa supports grasses and some aquatic vegetation, including cattails. The main population is in the springhole, which is about 6 feet in diameter and mostly 6 to 12 inches deep. Individuals also live in tiny outflow rivulets that are at times only a few inches wide and deep. Some are found in cattle tracks into which water seeps continuously (Bond 1974). Cover utilized includes overhanging bank edges, grass, exposed grass roots, and filamentous algae. Water in the spring is clear, and the current is slow. The bottom is primarily mud. The dace was introduced into Dace Spring, an excavated area at a spring source located on public land about 1 mile south of Foskett Spring. This artificial habitat is muddy and well-vegetated (Armantrout 1985). However, that population was extirpated after 17 years (USFWS 2009ii). Although individuals have been collected from shallow water habitats associated with filamentous algae, exposed grass roots, and emergent aquatic vegetation, this habitat is not believed to be optimal. Based on conditions under which other speckled dace live, it is likely that deeper water with moderate vegetative cover would be better habitat.

The Foskett speckled dace appears to feed primarily on invertebrates. Extensive migration is not known, but larval and early juvenile dace have been observed only in the marsh at the edge of the lake bed (Hayes 1980), so there is either a migration of adults downstream to spawn, or a migration of the hatched larvae from the spring hole or rivulets to the marsh (a distance of about 6 to 12 feet). Like other dace populations, it is likely that the Foskett speckled dace requires a hard substrate for egg deposition (Moyle 1976). Reproduction apparently occurs in the second year of age, and spawning is believed to occur between late May and early July (Hayes 1980). 
The Foskett speckled dace was federally listed as threatened on March 28, 1985 (50 FR 12302). Critical habitat has not been designated. The subspecies apparently became isolated in Foskett Spring about 9,000 to 10,000 years ago, when Lake Warner went dry (Hubbs and Miller 1948). Its main natural habitat has been overrun by vegetation or heavily trampled by cattle. The BLM has acquired and fenced off both Foskett and Dace Springs, although numerous Foskett speckled dace occur outside of the exclusion fence (USFWS 2009ii). Apart from its small, isolated population, the primary threat to the Foskett speckled dace is the encroachment of vegetation (cattails and possible rushes), and the resulting decrease in dissolved oxygen. Pumping of groundwater or channelization (via heavy equipment, such as a backhoe) at either site could impact the habitat as well (USFWS 1985i). Both Foskett and Dace springs are in a known geothermal area, so there is also a potential future threat of encrgy development.

\section{Warner Sucker}

The primary reference for this section is:

USFWS. 19981. Recovery Plan for the Native Fishes of the Warner Basin and Alkali Subbasin. Portland, Oregon.

References cited in this section are internal to the above-referenced document. They are included in the Bibliography.

The 2010 5-year review for the Warner sucker (USFWS 2010r) was consulted for updated information on this species.

The Warner sucker (Catostomus warnerensis) is endemic to the Warner Basin of southeastern Oregon, northeastern California, and northwestern Nevada. The historic range of this species includes the basin's three permanent lakes (Pelican, Crump, and Hart), ephemeral lakes, and all the sloughs and canals connecting these lakes, Warner suckers also reside in the three major stream basins that are tributaries to these lakes (Deep Creek, Twentymile Creek, and Honey Creek; USFWS 2010r).

There are two phenotypic variations, or morphs of the Warner sucker, which correspond to the two generally continuous aquatic habitat types provided by the Warner Basin. Stream morphs occur in the temporally stable stream environments, and lake morphs occur in the temporally less stable lake environments. Individual fish can opportunistically change from one morph to another based on the types of habitat that are available. Suckers residing in streams can migrate downstream and repopulate lakes that have refilled after desiccation due to drought. This life history strategy is believed to be a key survival mechanism in an area that can experience both prolonged drought which can result in drying up of the lake habitat, or scouring flows which can affect the stream habitat.

The feeding habitats of the Warner sucker depend to a large degree on habitat and life history stage, with adult suckers becoming more generalized than juveniles and young-of-year. Larvae have terminal mouths and short digestive tracts, enabling them to feed selectively in midwater or at the surface. Invertebrates, particularly planktonic crustaceans, make up most of their diet. As the suckers grow, they develop subterminal mouths and longer digestive tracts, and gradually become benthic feeders, eating diatoms, filamentous algae, and detritus. Adult stream morph suckers forage nocturnally over a wide variety of substrates, such as boulders, gravel, and silt. Adult lake morph suckers are thought to have a similar diet, though they feed over predominantly muddy substrates (Tait and Mulkey 1993a, b).

Spawning usually occurs in April and May in streams, although variations in water temperature and stream flows may result in either earlier or later spawning. Temperature and flow cues appear to trigger spawning, with most taking place at 57 to $68^{\circ} \mathrm{F}$ when stream flows are relatively high. Suckers spawn in sand or gravel beds in slow pools (White et al. 1990, 1991; Kennedy and North 1993). In years when access to stream spawning areas is limited by low flow or by physical in-stream blockages, suckers may attempt to spawn on gravel beds along the lake shorelines.

Larvae are found in shallow backwater pools or on stream margins where there is no current, often among or near macrophytes. Young-of-year are often found over still, deep water from midwater to the surface, but also move 
into faster flowing water near the heads of pools (Coombs et al. 1979). Juveniles (1 to 2 years old) are usually found at the bottom of deep pools or in other habitats that are relatively eool or permanent, such as near springs. In general, adults use stretehes of streams where the gradient is sufficiently low to allow the formation of long (167 feet or longer) pools. These pools tend to have undercut banks, large beds of aquatic macrophytes, root wads or boulders, a surface to bottom temperature differential of at least $36^{\circ} \mathrm{F}$, a maximum depth greater than 5 feet, and overhanging vegetation.

The Warner sucker was federally listed as threatened on September 27, 1985, with critical habitat designated at the time of listing (50 FR 39117). Critical habitat for this species includes the following areas: 1) Twentymile Creek from the confluence of Twelvemile and Twentymile Creeks upstream for about 4 miles; 2) Twentymile Creek starting about 9 miles upstream of the confluence of Twelvemile and Twentymile Creeks and extending downstream for about 18 miles; 3) Spillway Canal north of Hart Lake and continuing about 2 miles downstream; 4) Snyder Creek from the eonfluence of Snyder and Honey Creeks upstream for about 3 miles; and 5) Honey Creek from the confluence of Hart Lake upstream 16 miles.

Warner suckers are vulnerable to predation by exotic fish and are affected by modification to habitat through the continued operation of water diversions and barriers that restrict movement and migration of the species. Prolonged drought, particularly desiccation of lakes from drought and irrigation use and the drying or reduced stream flow of stream channels from irrigation water removal, greatly impaet Warner suckers' viability and recovery.

\section{June Sucker}

The primary reference for this section is:

USFWS. 1999i. June Sucker (Chasmistes liorus) Recovery Plan. Denver, Colorado.

References cited in this section are internal to the above-referenced document. Full citations have been included in the Bibliography.

The June sucker is a lake sucker that is endemic to Utah Lake, which is located about 45 miles south of the Great Salt Lake, Utah. Historically, the species was found in Utah Lake throughout the year, and in Provo River and other tributaries to Utah Lake during its annual spawning migration. In addition to the small remaining Utah Lake population, five other locations have been stocked with June suckers for the purposes of study and increasing overall population numbers. The historic habitat of Utah Lake was typified by relatively stable water levels, which allowed for long-term maintenance of macrophyte beds. These macrophyte beds are commonly used as nursery habitat by native fish speeies. Spawning habitat preferred by the June sucker is riverine habitat with braided, slow, meandering channets, providing a diversity of habitat conditions for different age-elasses of fish. Like other lake suckers, the June sueker is thought to be a mid-water planktivore (Miller and Smith 1981). However, food habits of this species in Utah Lake are difficult to verify.

June suckers are thought to be a long-lived species, maturing at 5 to 10 years of age. During the reproductive period, beginning in April and May, adults concentrate in and around the mouth of the Provo River (Radant and Hickman 1984). In the second and third weeks of June, the spawning migration typically begins. The exact date of migration is dependent on environmental conditions. Most spawning is completed within a span of 5 to 8 days. After hatching, emergent June sucker larvae drift downstream in the river during nighttime hours (Modde and Muirhead 1990; Crowl and Thomas 1997; Keleher et al. 1998). During the larval stage, abundant aquatic vegetation is utilized for cover and refugia.

The June sucker was federally listed as endangered on April 30, 1986 (51 FR 10851). Critical habitat, which was designated on the same date, includes the lower 4.9 miles of the main channel of the Provo River, from the Tanner Race diversion downstream to Utah Lake. Decline in abundance of June suckers can be attributed to habitat alteration through dewatering, channelization of tributary streams, and degradation of water quality; competition with and predation by non-native species; commercial fishing; and killing of adults during the spawning run. 


\section{Borax Lake Chub}

The permanent habitat of the Borax Lake chub (Gila boraxobius) is a 10-acre thermal lake and adjacent wetlands located in the Alvord Basin of Harvey County, Oregon (USFWS 2009jij). This lake, which is shallow and fed by hot and cool springs, is perehed about 30 feet above the desert floor in a "pedestal" of deposited salts. The saline lake bottom is inhospitable to rooted plants, although some of the precipitated minerals are finely divided and siltlike. Irrigation channels have been dug from the lake to supply water for hay fields, and the chub may also be found in these channels. In the past, the Borax Lake chub was also found in the Lower Borax Lake, an artificial pond, during wet years, but this area currently has no fish (USFWS 2009jj). All of the Borax Lake chub's known habitats in southeastern Oregon comprise approximately 640 acres.

The Borax Lake chub is found at surface water temperatures ranging from 61 to 100 degrees Farenheit $\left({ }^{\circ} \mathrm{F}\right.$; higher temperatures can result in fish kills (Scopettone et al. 1995). The Borax Lake chub is an opportunistic omnivore (Hudson et al. 2000). Spawning can occur year-round, but primarily occurs in the fall and spring. Spawning oceurs primarily in gravel, rock outcrop, and sand habitats, which comprise only 16 percent of the substrate of Borax Lake (Perkins et al. 1996).

The Borax Lake chub was federally listed as endangered on October 5, 1982 (47 FR 43957). At the same time, critical habitat was designated in Harney County, Oregon, including all 640 acres of habitat in Township 37 South, Range 33 East (Borax Lake, marsh areas to the south and southwest, Lower Borax Lake, and hot springs north of Borax Lake). Because the lake depends upon several subterranean springs for its water supply, lowering the rim of the lake or tapping and diverting the springs could have severe effects on the species. Borax Lake is in a known geothermal resource area, and both diversion and geothermal exploration appear to constitute a threat to the species. Other threats include modification of the fragile lake shorelines, which diverts water away from the lake, overgrazing by livestock (although the area is currently fenced in), and damage of the fragile salt-crust by off-road vehicle use (USFWS 2009jj).

\section{Hutton Tui Chub}

The following information, taken from Moyle (1976), refers to tui chubs in general. Tui chubs oceur in a wide variety of habitats, most commonly in the weedy shallows of lakes and quiet waters in sluggish rivers. They do well in a wide variety of water conditions from warm to cold, and clear to cutrophic. In the fall, they seek out deeper water and may spend winters in a semi-dormant state on the bottom of lakes. Tui chubs are opportunistic omnivores concentrating on invertebrates associated with bottom or aquatic plants (i.c., clams, insect larvae, insects, crayfish), as well as algae and plant material.

Tui chub usually spawn from late April to late June; eggs adhere to plants or the bottom and hatch in 9 days. In large deep lakes, they tend to form large schools in shallow water frequently associated with beds of aquatic vegetation. In shallow lakes, with heavy aquatic growth, schooling is less noticeable. Tui chubs tend to disperse amongst the vegetation, presumably as protection from predators. They also appear to be able to adapt to the severe long- and short-term climatic fluctuations characteristic of the interior basins where they are most common. The minnow family in general has been successful because they have a well-developed sense of hearing, release a fear scent when injured (a warning signal to others), have a broad diet, and exhibit high fecundity. Despite these advantages, many native minnows are declining in numbers as their environment deteriorates beyond their ability to cope with the changes or they are displaced by more aggressive introduced species.

The Hutton tui chub (Gila bicolor ssp.) is endemic to springs in Lake County, south-central Oregon (NatureServe 2010). The current known range of the Hutton tui chub is limited to Hutton Spring and 3/8 Mile Spring, and possibly a third spring nearby (USFWS $2008 \mathrm{p}$ ). These springs are located in a grassy rangeland bordered to the north and west by shrubby rangeland and to the east and south by the lake bed of pluvial Alkali Lake. Available habitat in Hutton Spring is unvegetated open water, surrounded by bull rush marsh, and encroachment of aquatic vegetation may be limiting availability of habitat (Scheerer and Jacobs 2005 cited in USFWS 2008p). Available habitat in 3/8 Mile Spring is two small pools (USFWS 2008p). 
The Hutton tui chub was federally listed as threatened on Mareh 28, 1985 (50 FR 12302). Critical habitat has not been designated. The current isolation of the Hutton tui chub was eaused by the desiceation of pluvial Alkali Lake (Snyder 1908a, Hubbs and Miller 1942). Present status is in part a result of past aecess by eattle to the springs in which the Hutton tui chub oceurs (Franzreb 1985). Threats include pumping of water from the springs, which occurred in the past but is no longer occurring (Bond 1974, Franzreb 1985), and contamination of groundwater by dispersal of ehemicals from a nearby herbicide-manufacturing residue disposal site (Franzreb 1985). Modifieation of the springs by heavy equipment (eausing siltation, erosion, vegetation eover loss, water diversion and drawdown) has also had detrimental effects on the ehub population. The primary threats to the species remain its vulnerability as a result of extremely limited distribution and low numbers, and the potential for degradation of habitat from localized events (USFWS 2008p).

\section{Owens Tui Chub}

The Owens tui chub (Gila bicolor snyderi) is associated with streams in the Owens Valley of California that have slow eurrent, mud bottoms, and abundant submerged vegetation. The Owens Basin consists of three valleys; Long Valley and Adobe Valley in the north drain into Owens Valley to the south. The Owens Basin contains a variety of springs, lakes, and flowing water habitats, many of which were inhabited by the Owens tui chub at one time. However, much of the natural habitat has been modified for irrigation purposes, impounded to ereate reservoirs, or dewatered to provide for the needs of Los Angeles. The subspecies is restricted to six isolated sites, all of which have been artificially ereated or altered in some fashion (USFWS $2009 \mathrm{kk}$ ).

The Owens tui chub oeeurs in low-velocity waters with well-developed beds of aquatic vegetation, rocks, and undercut banks (Luenda et al. 2005). Vegetation is likely important to Owens tui ehubs for predator avoidance, reproduction, food, and redueed water velocity (MeEwan 1990, 1991, Conservation Management Institute 1996, Geologica 2003). Aquatie vegetation is espeeially important as it provides plant food and habitat for aquatic invertebrates, the main food item of the Owens tui chub (MeEwan 1990, 1991). Water temperature is usually fairly constant at spring sites, but ean fluctuate from 36 to $78^{\circ} \mathrm{F}$ in a river (Geologica 2003).

The Owens tui chub is an opportunistic omnivore, consuming aquatic inseets, vegetation, and detritus (MeEwan 1991). It feeds mainly by gleaning and grazing within submerged vegetation, and diet varies seasonally (McEwan 1990). Spawning oecurs from late winter to early summer in spring habitats, usually over gravel substrate or aquatic vegetation. Females can produce large numbers of eggs, and there are multiple spawning bouts. Hatehing time is likely influeneed by water temperature, with eggs hatehing earlier in warmer water (Cooper 1978).

The Owens tui chub was federally listed as endangered on August 5, 1985 (50 FR 31592). At the same time, critical habitat for the subspecies was designated in portions of Hot Creek (Seetion 35, Township 35 South, Range 28 East) and Owens River (Seetions 19 through 25 and 36, Township 4 South, Range 30 East) in Mono County, California. Over the past 3 to 4 decades, habitats have been modified, streams have been diverted, and rivers have been dammed, as a result of increased water demands. Introduction of exotic fishes has also been a major factor in the decline of the Owens tui chub. Predation by trout has impacted populations, and hybridization with the Lahontan tui chub has oceurred extensively throughout the Owens Basin. Current threats inelude the potential for further destruetion and alteration of a greatly reduced habitat; predation by non-native aquatic species; inadequacy of existing laws and regulations to conserve and protect the remaining habitat for the species; hybridization with introduced Lahontan tui chubs; demographic, genetic, and environmental stochasticity; catastrophic events; and climate change (USFWS 2009kk).

\section{Aquatic Snails of the Snake River}

The primary references for this section are:

USFWS. 1995c. Snake River Aquatic Species Recovery Plan. Snake River Basin Office, Ecological Services. Boise, Idaho.

and

USFWS. 2002g. Recovery Plan for the Bruneau Hot Springsnail (Pyrgulopsis bruneauensis). Portland, Oregon. 
References cited in this seetion are internal to the above-referenced documents. Full citations have been included in the Bibliography.

The 2009 5-year review for the Bliss Rapids snail (USFWS 200911), the 2007 5-year review for the Bruneau hot springsnail (USFWS 2007t), and the 2006 5-year review for the Banbury Springs limpet (USFWS 2006d) were eonsulted for updated information on these speeies.

The Snake River physa snail (Physa natricina), Bliss Rapids snail (Taylorconcha serpenticola), and Banbury Springs limpet (Lanx sp.) are part of the native mollusk fauna of the Snake River of Idaho, whieh eharaeteristieally require eold, fast water or lotie habitats. These three speeies are unique in that, unlike many other mollusk speeies, which are widely distributed and somewhat tolerant of pollution, they are primarily limited to the Snake River basin below Ameriean Falls Dam, and are generally intolerant of pollution. The loeations and habitats of eaeh of these speeies are deseribed below. Very little is known about their life history.

\section{Snake River Physa Snail}

The Snake River physa snail oeeurs on the undersides of gravel-to-boulder sized substrate in swift eurrent in the mainstem Snake River. Living speeimens have been found on boulders in the deepest aeeessible part of the river at the margins of rapids. The historie range of this speeies is believed to have extended from Grandview through the Hagerman Reaeh (Taylor 1988). Its eurrent distribution has been eonfirmed to as far upstream as Minidoka Dam.

\section{Bliss Rapids Snail}

The Bliss Rapids snail oeeurs on stable eobble-to-boulder sized substrate in flowing water of unimpounded reaehes of the mainstem Snake River, and in a few spring habitats in the Hagerman Valley. The speeies is dependent on eold water springs and spring outflows. The speeies does not burrow in sediments and normally avoids surfaees with attaehed plants. Known river populations of the Bliss Rapids snail oeeur only in areas assoeiated with spring influenees or rapids-edge environments, and tend to flank shorelines. They are found at varying depths if dissolved oxygen and temperature requirements persist, and are found in shallow (less than 0.5 inehes deep), permanent eold springs (Frest and Johannes 1992). The speeies is eonsidered moderately intolerant of light, and resides on the lateral sides and undersides of roeks during daylight (Bowler 1990). The speeies ean be loeally quite abundant, espeeially on smooth roek surfaees with eommon enerusting red algae.

The Bliss Rapids snail was known historieally from the mainstem Snake River and assoeiated springs between Indian Cove Bridge and Twin Falls (Hershler et al. 1994). Based on live eolleetions, the speeies eurrently exists as diseontinuous populations within its historie range. These eolonies are primarily eoneentrated in the Hagerman Reaeh, in tailwaters of Bliss and Lower Salmon Dams, and several unpolluted streams: Thousand Springs, Banbury Springs, Box Canyon Springs, and Niagara Springs.

\section{Banbury Springs Limpet}

The Banbury Springs limpet has been found only in spring-run habitats with well-oxygenated, elear, eold (59 to 61 $\left.{ }^{\circ} \mathrm{F}\right)$ waters, on boulder or eobble-size substrate. All known loeations have relatively swift eurrents. They are found most often on smooth basalt, and avoid surfaees with large aquatie maerophytes or filamentous green algae. The speeies may be found in water as shallow as 2 inehes, but is most eommon at depths up to 6 inehes (Frest and Johannes 1992). All limpets are partieularly affeeted by dissolved oxygen fluetuations, sinee respiration is aeeomplished only through the mantle; lungs, gills, and other speeialized respiratory struetures are laeking. The Banbury Springs limpet is known to oeeur only in four eoldwater spring eomplexes along 6 river miles of the middle Snake River: Thousand Springs, Box Canyon Springs, Banbury Springs, and Briggs Springs (USFWS 2006d).

The Snake River physa snail and Banbury Springs limpet were federally listed as endangered on Deeember 14 , 1992 (57 FR 59244). The Bliss Rapids snail was federally listed as threatened on the same date. Critieal habitat has not been designated for any of these speeies. With the advent of exploration and development, the Snake River eeosystem has undergone a substantial transformation from a primarily free-flowing, eold-water system to a slower-moving, warmer system. The human-indueed environmental stressors to the Snake River inelude numerous 
point and nonpoint pollution sourees, diversion of water for irrigation or hydropower, and construction of several mainstem dams. Therefore, threats to these speeies include activities that deplete oxygen or reduce water quality, such as agricultural runoff, and activities that cause changes or fluctuations in water level, such as impoundments, pumping, or water diversion projects. Competition from introduced snail species is also a threat.

\section{Bruneau Hot Springsnail}

The Bruneau hot springsnail (Pyrgulopsis bruneauensis) is another aquatic snail that is restricted to the state of Idaho. It is a thermal species, restricted to the lower reaches of Hot Spring, a tributary of the Bruneau River in the southwestern portion of the state. This speeies inhabits flowing geothermal springs and seeps that range in temperature from 60 to $98.5^{\circ} \mathrm{F}$, and is an opportunistic grazer that feeds primarily on algae and diatoms on the floor of the riverbed. Its complete range includes a 5-mile portion of the Bruneau River and the lower third of Hot Spring. Most of the occupied springs are located along the Bruneau River at the confluence of and upstream of Hot Creek, on lands administered by the BLM. Some additional springsnail habitats located downstream of the Indian Bathtub and Hot Creek are on privately owned land. In this area, there has been a decline in the number of springs oceupied by the Bruneau hot springsnail (from 146 in 1991 to 66 in 2006), as well as in the relative density of the species (Myler 2006). Additionally, declining geothermal water levels have led to fragmentation of the remaining geothermal spring sites, and an associated fragmentation of the Bruneau hot springsnail into smaller colonies (USFWS 2007t).

Bruneau hot springsnails are found on the exposed surfaces of various substrates, ineluding rocks, gravel, sand, mud, and algal film, within geothermal habitats (Mladenka 1992). However, during the winter period of cold ambient temperatures and ieing, the springsnails are most often located on the underside of flow substrates, habitats that are exposed least to cold temperatures. Reproduction occurs throughout the year, except when limited by high or low water temperatures. Sexual maturity oceurs at approximately 2 months. Bruneau hot springsnails are dioecious (reproductive organs are located in separate male and female specimens), and lay single eggs on hard surfaces, such as rock substrates or the shells of other snails.

The Bruneau hot springsnail was listed as endangered on January 25, 1993 (58 FR 5938). Critical habitat has not been designated. The species is threatened by the reduction and/or loss of geothermal habitats eaused by the depletion of the regional geothermal aquifer underlying the Bruneau Valley area (Hudson et al. 2000). Discharge from many of the geothermal springs along Hot Creek and the Bruneau River has either ceased flowing or has exhibited a much reduced flow, thus restricting springsnail habitat (Young et al. 1979; Mladenka 1992; Berenboek 1993; Mladenka and Minshall 1996; Myler and Minshall 1998). Introduced predators, flash floods, and grazing also impact this species.

\section{Lahontan Cutthroat Trout}

The Lahontan cutthroat trout (Oncorhyncus clarki henshawii) is endemic to the Lahontan Basin of northern Nevada, eastern California, and southern Oregon (USFWS 2008q). In the first half of the 1800s the species oceupied extensive lake and stream habitat in the area, but species occurrence began changing with settlement of the region in the late $19^{\text {th }}$ century (USFWS 1995d). Currently, the subspecies is found in approximately 125 streams and five historic lakes within the Lahontan Basin, as well as numerous lakes and streams outside the historic range (USFWS 2008q). The subspecies has been introduced into habitats outside of its range for recreational fishing purposes (USFWS 1995d).

Stream-dwelling Lahontan cutthroat trout are found in small streams with cool water, in areas with well vegetated and stable stream banks, pools near cover and breaks in velocity, and rocky, relatively silt-free substrates with riffles (USFWS 1995d). Lake dwelling Lahontan eutthroat trout are typically found in rocky areas, riffles, deep pools, and habitats near overhanging logs, shrubs, or banks (McA fee 1966 and Sigler and Sigler 1987 cited in USFWS 1995d). Historically, the species occurred in large, terminal alpine lakes; slow, meandering rivers; mountain rivers; and small headwater tributary streams (USFWS 2008q).

All Lahontan cutthroat trout spawn in streams. Spawning typically occurs from April through July, although it varies based on stream flow, elevation, and water temperature (USFWS 2008q). Eggs are deposited in small 
gravels within riffles or pool crests, eggs hatch within 4 to 6 weeks, and fry emerge 13 to 23 days after hatehing Stream-dwelling fish feed opportunistically on drift organisms, mostly terrestrial and aquatic insects (Moyle 1976 and Coffin 1983 in USFWS 1995d). Small lake-dwelling fish feed on insects and zooplankton, and larger lakedwelling fish feed on other fish (Calhoun 1942, McAfee 1966, and Lea 1968 in USFWS 1995d).

The Lahontan eutthroat trout was federally listed as endangered in 1970 (35 FR 16047), and then reclassified as threatened in 1975 (40 FR 17847). There is no designated eritical habitat for the subspecies. Major impacts to habitat and abundanee have included reduction and alteration of stream discharge; degradation of water quality; reduction of lake levels and eoncentrated chemical eomponents in natural lakes; and introduetions of non-native fish (USFWS 1995d). Activities that have eontributed to these impacts include agriculture, livestock and feral horse grazing, mining, urban development, logging, highway and road construction, dam building, and discharge of effluent from wastewater treatment facilities. Populations of the subspecies continue to be impacted by non-native species interaetions, habitat fragmentation and isolation, degraded habitat conditions, drought, and fire (USFWS $2009 \mathrm{~mm})$.

\section{Desert Dace}

The desert dace (Eremichthys acros) inhabits eight major thermal springs and approximately 3 miles of outflow ereeks in Humboldt County, Nevada (USFWS 2010s). The speeies oeeurs in warm springs and their outflows, including small irrigation ditches, within an area of approximately 3,830 acres. Outflows from the numerous small springs either terminate in marshy areas or coalesce into Mud Meadow Wash, which eventually terminates in the Black Rock Desert. Occupied habitats include spring pools up to 8 feet in depth, with peripheral emergent vegetation and little or no current; outflow streams typically less than 1 foot deep; alkali marsh areas with overland flow among cattails, hardstem bulrush, and other herbaceous plants, artifieial impoundments, and earthen irrigation ditches. Substrate eomposition in the spring pools and outflow streams is variable and includes silt, sand, pebbles, and rocks (USFWS 2010s). The species prefers water temperatures between 73 and $84{ }^{\circ} \mathrm{F}$, but tolerates temperatures of 64 to $104{ }^{\circ} \mathrm{F}$. Temperatures of 70 to $75^{\circ} \mathrm{F}$ are required for spawning, which apparently oeeurs throughout early and mid-summer (Sigler and Sigler 1987), and possibly year round (Matthews and Moselcy 1990). The dace is apparently primarily herbivorous in its feeding habits.

The desert dace was federally listed as threatened on Deeember 10, 1985 (50 FR 50304). At the same time, eritical habitat for the species was designated in the thermal springs and their surrounding riparian areas for a distanee of 50 feet from these springs and outflows in Seetions 5, 8, 18, and 19, Township 40 North, Range 25 East; and Sections 23 through 26, Township 40 North, Range 24 East, of Humboldt County, Nevada. Many of the spring outflows have been diverted from their natural channels into man-made ditches for irrigation, domestie use, and providing water for livestock (La Rivers 1962, Nyquist 1963, USFWS 1985j). These diversions have reduced habitat available to the desert dace, and are expeeted to continue in the foreseeable future. Potential threats to the species inelude geothermal development, groundwater depletion, and introduction of exotic fishes. Thermal springs and their outflow crecks inhabited by the desert dace oceur on private lands. The local landowner has modified much of the speeies' habitat for livestock grazing, and has diverted water away from natural ehannels into manmade ditches for stock watering. Grazing also poses the threat of trampling and overgrazing.

\section{Cui-ui}

Cui-ui (Chasmistes cujus) are obligate lacustrine suckers with a very restrieted distribution, oceurring only in the lower Truckee River and Pyramid Lake, Nevada, within the Pyramid Lake Paiute Reservation. In the spring (between March and June), adults migrate from Pyramid Lake up the lower Truckee River to reproduce, and return to Pyramid Lake immediately after spawning. Migrating adults must be passed through the Marble Bluff Fish Facility and above Marble Bluff Dam to access suitable spawning habitat (USFWS 2010t).

Eggs hatch 1 to 2 weeks after spawning, and larval cui-ui drift downstream to Pyramid Lake shortly after hatehing (La Rivers 1962; Scoppettone et al. 1983; Sigler et al. 1985; Scoppettone et al. 1986). Timing of spawning migration depends on river water temperature and flow characteristies (USFWS 2010t). Habitat of adults in Pyramid Lake is the inshore benthie region. They are generally found in near-shore areas at depths less than 75 feet. Adult cui-ui spawn in Truckee River over predominately gravel substrate, at water depths ranging from 8 to 
43 inches, and stream velocities ranging from 0.9 to 4.6 feet per second. Cui-ui spawning has also been reported in Pyramid Lake at the entrance of freshwater streams on fine to coarse gravel (Koch 1973, 1982) and in the Marble Bluff fishway where the substrate is predominately compacted soil (Seoppettone et al. 1986). Upstream migrating prespawning adults require pool environments, typically log jam pools, as refugia during the day (Scoppettone et al. 1981). Koch (1982) recommended a safe maximum temperature for adult eui-ui of 68 to $71{ }^{\circ} \mathrm{F}$. Adults feed primarily on zooplankton, filamentous algae, and aquatic insects (Nevada Fish and Game Commission 1958, La Rivers 1962).

The cui-ui was federally listed as endangered on Mareh 11, 1967 (32 FR 4001). Critieal habitat has not been designated. The reproductive cycle of this species was blocked by the construction of the Derby Dam on the Truckee River in 1905. In the past, this speeies has also been impacted by channelization projects that removed protective cover, deep pools, and shade required by the species. Livestock have removed riparian vegetation and increased the potential for erosion. Faetors pereeived as future threats to this speeies inelude upstream passagc of migrating adults over Marble Bluff Dam, adequate Truckee River flows for migrating adults and larvae, proper river water temperatures for incubating embryos and out-migrating larvae, stream bank and channel erosion, increases in Pyramid Lake salinity and Truekee River water quality, and nutrient loading to Pyramid Lake (Galat 1983; Sigler et al. 1985; Coleman 1986). Additionally, low water conditions and/or sand bars can render the delta at the mouth of the Truckee River impassable (USFWS 2010t).

\section{White River Spinedace}

The White River spinedace (Lepidomeda albivallis) occurs in cool springs that represent remnant segments of the ancient White River of eastern Nevada. The species was historically found throughout the upper White River drainage in seven spring systems (USFWS 2010u). Presently, it is found only in 1.6 miles of habitat within the Kirch Wildlife Management Area. Habitats oceupied by the White River spinedaee are eharaeterized by relatively cool temperatures (64 to $72{ }^{\circ} \mathrm{F}$ ) and elear water (Miller and Hubbs 1960). Spinedaee occur in both deep water souree pools and shallower effluent streams, and may prefer areas with moderate to swift flows over gravel substrates (Miller and Hubbs 1960, La Rivers 1962). Aquatic vegetation found in springs inhabited by White River spinedace include pondweed and watereress, while rushes and cattails are abundant near shoreline areas (Miller and Hubbs 1960).

White River spinedace consume a variety of food items, which indicates that the species is a habitat and dietary generalist. Analysis of stomach contents and observations of actively feeding spinedace suggest that they feed on drifting invertebrates and plant material (Scoppettone et al. 2004).

Spawning in the elosely related Virgin River spinedace, occurs in shallow tailout areas of pools over a substrate of fine gravel (Rinne 1971). The White River spinedace spawns throughout the summer (Minekley and Carufel 1967, Minckley 1973). Sexual maturity is reached after 1 year (Rinne 1971), and spawning takes plaee in fish that are 1 year or older.

The White River spinedace was federally listed as endangered on September 12, 1985 (50 FR 37194). At the same time, critical habitat was designated in the following springs and outflows, as well as surrounding land areas for a distance of 50 feet from the springs and outflows, in White Pine County: Preston Big Spring (Section 2, Township 12 North, Range 61 East) and Lund Spring (in portions of Section 4, Township 11 North, Range 62 East and Section 33, Township 12 North, Range 62 East); and Nye County: Flagg Springs (in portions of Sections 32 and 33, Township 7 North, Range 62 East), Nevada. Habitat deterioration has been attributed to channelization and piping of spring outflows, diversion of water from spring sources, and use of copper sulfate to control aquatic vegetation (Hardy 1980; Courtney et al. 1985; Williams et al. 1985). Further alteration of spring habitats in such a manner would thus be detrimental to existing spinedace populations. Introduced species, including guppies, and mosquitofish, compete with and in some instances prey on spinedace, and are present in one of the two locations where the White River spinedace now exists (Courtney et al. 1985). Any further modifications of spring habitats (e.g., channelization, water diversion, and reductions of water quality) where the White River spinedace occurs would bring about further population declines and possible extinction of this species (Hardy 1980). Additional introductions, or increases in existing populations, of exotic species would have similar negative effects (Hardy 
1980, USFWS 1985k). The ever inereasing demand of water from the Las Vegas Valley could further ehange the flow system in the White River valley. Additionally, fire and climate change have been identified as two threats that could reduce or eliminate spinedaee populations (USFWS 2010u).

\section{Clover Valley Speckled Dace and Independence Valley Speckled Dace}

The primary reference for this seetion is:

USFWS. 1998m. Recovery Plan for the Endangered Speckled Dace of Clover and Independence Valleys (Rhinichthys osculus lethoporus and Rhinichthys osculus oligoporus). Portland, Oregon.

References cited in this seetion are internal to the above-referenced document. Full citations have been included in the Bibliography.

The 2009 5-year review for the Independenee Valley speckled dace (USFWS 2009nn) was consulted for updated information on this speeies.

The Clover Valley speckled daee (Rhinichthys osculus oligoporus) is restricted to three springs and outflows in the Clover Valley, located in Elko County, Nevada: Bradish Spring, Clover Valley Warm Springs, and Wright Spring Ranch. The Independence Valley speekled daee (Rhinichthys osculus lethoporus) is found only in the marsh of the largest spring system in Independenee Valley, whieh is also located in Elko County, Nevada. This spring system is known as the Independence Valley Warm Springs.

No other freshwater fish oceupies a more widely distributed or variety of habitats than the speckled dace species (Moyle 1976). They are found throughout all major western drainage systems from the Colorado River south to Sonora, Mexieo. Speekled daee primarily inhabit cool, flowing, permanent streams and rivers, but are also sueeessful in a variety of other habitats. Throughout their range, they are found primarily among rocks in riffles in streams and on rocky or sandy bottoms stirred by wave action in lakes.

Clover Valley speckled dace are found primarily in reservoirs and outflows of the three spring systems identified above. There do not appear to be any marshes assoeiated with these springs, only the outflows that have been heavily modified. Details of the subspeeies' seasonal habitat requirements, population size, distribution over time, reproductive potential, and available habitat are unknown.

Independence Valley speckled dace are found in a temperate, permanent desert stream/marsh fed by numerous springs. The subspeeies is found primarily in the shallow waters of the marsh of this spring system, among the sedges and grasses. It is believed that speckled dace also historieally oeeupied the stream, but were forced out by predation by non-native species. Currently, Independence Valley speekled daee are found throughout most of the wetted areas of the Warm Springs marsh, but are not found in the springs and eanals that are oeeupied by predatory largemouth bass and bluegill (USFWS 2009nn).

Generally, speckled dace are eharacterized as diurnal (active during the daytime), bottom browsers that feed primarily on small invertebrates (sueh as aquatic insects), plant material, and zooplankton. However, they will also feed on large, flying insects at the water's surface, and oceasionally on the eggs and larvae of other minnows when available. Seasonal diet changes have been noted (Jhingram 1948, Miller 1951); dace most often eat algae and detritus in the fall, bottom-dwelling inseets in the winter and spring, and flying inseets in the summer. Based on the habitat they occupy, the Clover Valley and Independence Valley speekled daee probably have similar food preferences.

Specific reproductive patterns of the two dace subspecies have not been examined. Generally, speekled dace mature in their second summer. They are capable of spawning throughout the summer, but peak activity usually occurs in the months of June and July at water temperatures of $65^{\circ} \mathrm{F}$ (Moyle 1976, Sigler and Sigler 1979). Males congregate in spawning areas from which they remove debris to expose a bare patch of rock or gravel. Males surround the female when entering a spawning area. Eggs are deposited underneath roeks, into spaces in the gravel, 
or close to the bottom, and fertilized. Eggs hateh in 6 days on average, and the larval fish remain in the gravel for 7 to 8 days. After emerging from the gravel, the young tend to concentrate in the warm shallows of streams.

The Clover Valley speckled daee and the Independence Valley speckled dace were federally listed as endangered on Oetober 10, 1989 (54 FR 41448). Critical habitat has not been designated for either species. The primary faetors that threaten these subspecies include irrigation, the potential for habitat manipulation on surrounding private lands, and competition with and predation by non-native sport fishes. In addition, their small population sizes and limited distribution make them vulnerable to catastrophic events such as drought and fire (USFWS 2009nn).

\section{White River Springfish and Hiko White River Springfish}

The primary reference for this section is:

USFWS. 1998n. Reeovery Plan for the Aquatic and Riparian Species of Pahranagat Valley. Portland, Oregon.

References cited in this section are internal to the above-refereneed document. Full citations have been ineluded in the Bibliography.

The 2012 5-Year review for the Hiko White River springfish and White River springfish (USFWS 2012c) was consulted for updated information on these species.

The White River springfish (Crenicthys baileyi baileyi) and Hiko White River springfish (Crenicthys baileyi grandis) are endemic to the Pahranagat Valley, located in south-central Lincoln County, Nevada, approximately 92 miles north of Las Vegas. White River springfish are currently restricted to spring pools and outflows at Ash Springs, but are locally abundant in these areas. Hiko White River springfish occupy the pools of Hiko and Crystal Springs, and have been introduced into Blue Link Spring in Mineral County, Nevada. Since 2006, the estimated springfish population at Hiko Spring has been between 300 and 1,000 fish (USFWS 2012c). The population has declined substantially since 2000 , when red swamp crayfish appeared in the system.

The plant eommunity of the Pahranagat Valley is typical of the Mojave Desert, and is dominated by the creosote bush-burroweed vegetation association (Kanim 1986). Livestock grazing is a principle land use in Pahranagat Valley, and pastures with a variety of grasses and legumes have been established in the valley bottom. Very little information is available on the life history and habitat requirements of either subspecies of White River springfish. However, it is assumed that this subspecies has a similar life history and habitat needs that are comparable to other Crenicthys subspecies. Adults are found at varying depths, from 1.3 to 5.6 feet, but prefer deeper water (3.6 feet). Juveniles will also use all depths, but generally oceur in shallower $(2.1$ feet) water and are more vertically dispersed. Larval springfish restrict their movement to the top of the water column ( 0 to 2 feet), and are found most frequently at 1.1 feet. All age classes are present in areas of calm water (Tuttle et al. 1990).

White River springfish are feeding generalists (Deacon and Minckley 1974, Williams and Williams 1982, Wilde 1989). Invertebrates, especially amphipods (small crustaceans), appear to be important items in their diet (Wilde 1989). Springfish may also be highly herbivorous, ingesting filamentous algae, vascular plants, and diatoms (Williams and Williams 1982). Differences in diet probably result from differences in habitat that dietate food item availability. Herbivory may be most common in the winter when invertebrates are not abundant (Wilde 1989). Springfish forage along the substrate and in plants, as evidenced by the ingestion of bottom-dwelling invertebrates, plant fragments, and detritus. They are active only in the daytime, with peaks occurring in the morning and afternoon.

Both White River springfish subspecies are uniquely adapted for surviving in environments of extreme temperatures and low dissolved oxygen content (Hubbs and Hettler 1964). The ability of springfish to actively thermoregulate by moving in and out of areas of extreme temperatures, which would be lethal under extended exposure, and to live in water with a broad range of temperatures, has enabled them to survive in areas deemed too hostile for other fish species. 
Springfish are asynehronous, whieh means that individual females will spawn at different times of the year. Most females average 2 spawning periods a year, while the spawning season of the entire population extends over a long period of time eaeh year. Another subspeeies of White River springfish spawns year-round, with peak spawning aetivity from April through August (Seoppettone et al. 1987). The period of spawning aetivity may be regulated by the primary produetivity in the spring system (Sehoenherr 1981).

The White River and Hiko White River springfish were federally listed as endangered on September 27, 1985 (50 FR 39123). Critieal habitat was designated for both subspeeies at the same time. Critieal habitat for the White River springfish ineludes Ash Springs, its outflow, and surrounding land areas for a distanee of 50 feet from these areas. Critieal habitat for the Hiko White River springfish ineludes the two springs historieally oeeupied by the subspeeies, along with their outflows and surrounding land areas for a distance of 50 feet from these springs. For both subspeeies, eonstituent elements inelude warm water springs and their outflows and surrounding land areas that provide vegetation for eover and habitat for inseets and other invertebrates on whieh the subspeeies feed. The White River springfish is threatened by failing springs and non-native fish (USFWS 2010v). The Hiko White River springfish is threatened by habitat modifieation, and eompetition, predation, and parasitism from exotie speeies (USFWS 2010w). Interaetions with non-native speeies may influenee life history traits of springfish, and may eause a shift in habitat use by native fish (USFWS 2012e).

\section{Railroad Valley Springfish}

The primary referenee for this seetion is:

USFWS. 1996f. Railroad Valley Springfish (Crenichthys nevadae) Recovery Plan. Portland, Oregon.

Referenees eited in this seetion are internal to the above-refereneed doeument. Full eitations have been ineluded in the Bibliography.

The 2009 5-year review for the Railroad Valley springfish (USFWS 200900) was eonsulted for updated information on this speeies.

The Railroad Valley springfish (Crenichthys nevadae) is the only fish speeies native to the thermal spring systems of Railroad Valley, Nye County, Nevada. The speeies historieally oeeurred in six spring systems, representing the remnants of pluvial Lake Railroad. It was extirpated from one of the spring systems in 2003, but restored to the area in 2007 (USFWS 200900). The speeies is uniquely adapted to survive in an environment of high water temperature ( 86 to $100^{\circ} \mathrm{F}$ at the spring souree) and low dissolved oxygen eontent ( 1.5 to 6.0 parts per million $[\mathrm{ppm}]$ ). This eombination of metabolie stresses is well beyond the toleranee levels of most other fish speeies (Hubbs and Hettler 1964). In their natural environment, Railroad Valley springfish will oeeupy habitats with water temperatures at the extremes of their toleranee limits $\left(57\right.$ or $\left.104{ }^{\circ} \mathrm{F}\right)$ for limited amounts of time. They adjust their body temperatures by moving in and out of areas where the water temperature would be lethal under extended exposure (Williams 1986).

Railroad Valley springfish are opportunistie feeders, ingesting a wide variety of foods (Williams 1986). There is evidenee that the speeies is predominantly herbivorous during the spring, eonsuming primarily filamentous algae. By summer, the speeies shifts to earnivory, when animal foods, primarily seed shrimp, eonstitute a majority of the diet. Railroad Valley springfish have been observed diving into algal mats, as if for speeifie food items, and also drift feeding (Deaeon et al. 1980).

Reproduetive behavior has never been studied, but it is believed to be similar to that of White River springfish. Springfish typieally spawn from spring through summer and into early fall, when water temperatures are between 82 and $95^{\circ} \mathrm{F}$. Females release 10 to 15 eggs in eaeh spawning event, and larval springfish hateh after 5 to 7 days of ineubation (USFWS 2009oo).

The Railroad Valley springfish was federally listed as threatened on Mareh 31, 1986 (51 FR 10857). Critieal habitat was designated for the speeies on the same date. Critieal habitat ineludes the six springs that were historieally oeeupied by the speeies, along with their pools, portions of the outflow streams and marshes, and a 50- 
foot riparian zone around all such areas. Constituent elements for critical habitats include elear, unpolluted thermal spring waters ranging in temperature from 84 to $97^{\circ} \mathrm{F}$ in pools, flowing channels, and marshy areas with aquatic plants, insects, and mollusks. The historical populations have been impacted to various degrees by habitat loss and modification resulting from water diversion, non-native fish introductions, and groundwater depletion. Currently, the primary potential threat to the speeies is groundwater withdrawal in the region (USFWS 200900).

\section{Pahranagat Roundtail Chub}

The primary reference for this seetion is:

USFWS. 1998n. Recovery Plan for the Aquatic and Riparian Species of Pahranagat Valley. Portland, Oregon.

Most references cited in this section are internal to the above-referenced document. Full eitations have been included in the Bibliography.

The Pahranagat roundtail chub (Gila robusta jordani) is endemie to thermal waters in the Pahranagat Valley. Historically, it oceurred in outflows from Crystal, Hiko and Ash Springs, and in the Pahranagat River. The eurrent known distribution in the wild is limited to an approximately $3 / 4$-mile reach of the Pahranagat River below the Ash Springs outflow on private property (Nevada Department of Wildlife and USFWS 2007). Below that point the flow is confined to a conerete irrigation diteh from which water can be diverted for use on crops and pasture. The Pahranagat roundtail chub is generally found in a single microhabitat in the lower portion of the natural channel (from about 6,400 to 7,400 feet below Ash Springs), which is a generally broad, straight channel (Hardy 1982). There are seattered dense stands of willow and grape along the stream margin with some ash and cottonwood. Root projeetions, fallen branches (and logs), and overhanging branches provide aquatic cover. The substrate is sand, silt and mud. Runs and pools comprise about 92 and 8 pereent of the available habitat, respectively. There are no riffles in this segment. Stream gradient is low, banks are not well-defined and the ehannel is about 20 feet in width.

The relative seareity of deep, slow run/pool habitats with associated cover may impose some limitation on population size in this last remaining habitat available to the species. Temperature throughout mueh of the summer remains above $81^{\circ} \mathrm{F}$ throughout the available habitat.

In the outflow of Ash Spring the breeding season may occur in February and March when adults leave their sheltered pool (Hardy 1982). This period coincides with annual thermal minimum temperatures. Juveniles have been observed in the outflow from March through September, disappearing rapidly from the population during October through January. Adults, therefore, appear to live through at least 2 winters prior to spawning.

The Pahranagat roundtail ehub was federally listed as endangered on October 13, 1970 (35 FR 16047). Critical habitat has not been designated for this subspecies. Its present endangered status is a result of habitat loss and predation and competition with introduced exotic species. The species was extirpated from Crystal Springs, possibly as a result of the introduction of largemouth bass into the system. The subspecies is threatened by habitat loss and degradation related to dams, diversions, groundwater pumping, mining, development, recreation, improper livestock grazing, and competition and predation from non-native fishes (USFWS 2010x).

\section{Big Spring Spinedace}

The primary reference for this section is:

USFWS. 1993g. Big Spring Spinedace, Lepidomeda mollispinis pratensis, Reeovery Plan. Portland, Oregon.

References eited in this section are internal to the above-referenced document. Full citations have been included in the Bibliography.

The Big Spring spinedace (Lepidomeda mollispinis pratensis) is one of three native fishes occupying the stream habitat of Meadow Valley Wash in Lincoln County, Nevada. Big Spring spinedace are restricted to a 5-mile section of stream, which flows through privately owned and public lands in Condor Canyon, north of Panaca, Nevada. 
The primary known constituent elements of Big Spring spinedace critical habitat include: 1) clean, permanent, flowing, spring-fed stream habitat with deep pool areas and shallow marshy areas along the shore; and 2) the absence of non-native fishes. The subsepecies occurs in high velocity waters, typieally at runs near the base of riffles or in plunge pools (USFWS 2010y).

Food preferences and feeding habitat are unknown, but closely-related spinedace are opportunistic drift feeders, feeding primarily on aquatic insect larvac, but consuming algae and other plant material when insects are searce (Rinne 1971, Minekley 1973). It has been suggested that vegetation, espeeially watereress, is important in providing habitat for aquatie inseet and invertebrate foods for the Big Spring spinedace (Allan 1985). It is believed that Big Spring broadeast spawn over gravel substrate (USFWS 2010y).

The Big Spring spinedace was federally listed as threatened on Mareh 28, 1985 (50 FR 12298). On the same date, critieal habitat was designated for the species along 4 stream miles of the Meadow Valley Wash, and a 50 foot riparian zone on either side of the stream. Introdueed, non-native species and the diversion of water and other hydrologic alterations of its habitat threaten the subspecies. Because of its limited distribution, it is vulnerable to events that may severely reduce or extirpate its extant population. Other activities that disturb riparian habitat or alter water quality ean also impact the subspecies. Fires and associated siltation from runoff decreases habitat available for spawning, and also allows vegetation such as cattails to establish, which in turn increases the amount of sediment deposited in the stream and provides habitat for non-native species (USFWS 2010y).

\section{Subtropical Steppe/Subtropical Desert Ecoregions}

Subtropieal steppes are hot, semi-arid regions that border and grade into more arid subtropical deserts, located in the Great Basin and Southwestern areas of the U.S. Because of the dry elimate, in whieh annual losses of water through evaporation exceed annual gains through precipitation, no permanent streams originate in these eeoregions. However rivers that originate in more northern states, sueh as the Colorado River and the Rio Grande and their tributaries, run through these regions, and support aquatic life. Other important aquatie habitats include springs and other desert wetlands, which are often fragile and isolated, and provide the only suitable habitat for rare aquatic species in an otherwise dry landscape.

Because of the similarity in aquatic habitats in subtropical steppes and subtropical deserts, and because many of the river systems in which TEP species are found run through both ecoregion divisions, it is diffieult to separate speeies out from one region or the other. Although some species do occur solely in the subtropieal desert ecoregion, there are only two species (Little Colorado spinedaee and Kanab ambersnail) that occur solely in the subtropical steppe ecoregion. Numerous species are found in both.

\section{Little Colorado Spinedace}

The primary referenee for this section is:

USFWS. 1998o. Little Colorado River Spinedace Recovery Plan. Parker Fisheries Resouree Office. Parker, Arizona.

References cited in this section are internal to the above-referenced document. Full citations have been ineluded in the Bibliography.

The 2008 5-year review for the Little Colorado spinedace (USFWS 2008r) was consulted for updated information on this species.

The Little Colorado spinedace (Lepidomeda vittata) is a minnow that is endemie to the Little Colorado River Basin, and native to most of the north-flowing tributaries and headwaters of the Little Colorado River (Miller 1963). The species is currently restricted to north-flowing tributaries of the Little Colorado River in Apache, Coconino, and Navajo Counties of castern Arizona. 
Suitable habitat for the Little Colorado spinedace is characterized by clear, flowing pools with slow to moderate currents, moderate depths, and gravel substrates (Miller 1963, Minckley and Carufel 1967). Cover provided by undercut banks or large rocks is often a feature. Spinedace have also been found in pools and flowing water conditions over a variety of substrates, with or without aquatie vegetation, in turbid and clear water. Water temperatures in occupied habitats range from 58 to $78^{\circ} \mathrm{F}$ (Miller 1963). Both mountain streams and lower gradient streams and rivers have provided habitat for the Little Colorado spinedace. Residual pools and spring areas are important refuges during periods of normal low water or drought. In the past, spinedace have been able to reeolonize other stream reaches during wetter periods from these refugial areas (USFWS 2008r).

The diet of the Little Colorado spinedace varies seasonally, and consists of mostly aquatic and terrestrial insects. Adult aquatic insects are eaten preferentially. This species forages opportunistically, and is able to switch diets based on food availability (Blinn and Runck 1990). Spinedaee mature at around 2.3 inches and are prolific spawners; they may spawn more than onee a year. Spawning primarily occurs in spring and early summer, but ean also occur sporadically throughout the summer and fall months (Minckley and Carufel 1967, Minckley 1984, Blinn and Runck 1990). Spawning products are broadeast over the bottom, on aquatic vegetation, or on debris (Minckley 1973). Growth is rapid, with individuals reaehing the size of sexual maturity within 3 months. The life span of spinedace is about 3 years.

The Little Colorado spinedace was federally listed as threatened on September 16, 1987 (52 FR 53034). At the same time, eritieal habitat was designated in the following areas in Arizona: 31 miles of East Clear Creek (Coconino County) from its confluence with Leonard Canyon upstream to Blue Ridge Reservoir, and from the upper end of Blue Ridge Reservoir to Potato Lake; 8 miles of Chevelon Creek (Navajo County), from the confluence with the Little Colorado River upstream to the confluence of Bell Cow Canyon; and 5 miles of Nutrioso Creek (Apache County), from the Apache-Sitgreaves National Forest's boundary upstream to Nelson Reservoir Dam. The eritical habitat designation includes only the stream eourse. The main threats to the subspeeies' habitat continue to be water development resulting from increased human demand for water (including both groundwater pumping and surfaee water collection), drought, and the continued effects of invasive aquatic species (USFWS 2008r).

\section{Kanab Ambersnail}

The primary reference for this section is:

USFWS. 1995e. Kanab Ambersnail (Oxyloma haydeni kanabensis) Recovery Plan. Denver, Colorado.

References cited in this section are internal to the above-referenced document. Full eitations have been included in the Bibliography.

The 2011 5-year review for the Kanab ambersnail (USFWS 2011v) was consulted for updated information on this species.

The Kanab ambersnail (Oxyloma haydeni kanabensis) is a rare terrestrial snail that is endemic to permanently wet areas within small wetlands of the Colorado Plateau. It lives in marshes watered by springs and seeps at the base of sandstone or limestone cliffs (Clarke 1991, Spamer and Bogan 1993). It is restricted to a permanently wet soil surface or shallow standing water. The snails are also frequently seen just within the mouths of vole burrows. However, none have been found in the drier micro-habitats commonly frequented by other land snails. Cattails, dense sedge and grass, and other vegetation may provide crucial vegetative cover (i.e., protection from predators) and food resources for the snails (Clarke 1991).

The subspecies is known from two naturally occurring populations (Vasey's Paradise along the Colorado River in the Grand Canyon in Coconino County, Arizona, and Three Lakes, about 6 miles north-northwest of Kanab in Kane County, Utah) and one introduced extant population (Upper Elves Canyon, Arizona; USFWS $2011 \mathrm{v}$ ).

The Kanab ambersnail has a life span of up to 18 months (Stevens et al. 1997). Peak reproduction occurs in midsummer (Stevens et al. 1997; Nelson 2001). Cross-fertilized snails lay eggs on the undersides of host plant stems 
and leaves, or in moist soil (Nelson 2001). Kanab ambersnails begin winter dormaney in October and emerge from dormancy in March (Stevens et al. 1997). During this period the snails attach the aperture of their shells to a firm substrate such as host plant stems and leaves, rocks, sticks, or bark. There is a large die-off of individuals during the dormaney period (25 to 80 percent; Stevens et al. 1997).

The Kanab ambersnail was emergeney listed on August 8, 1991 (56 FR 37668), and a final rule listing it as an endangered species was published on April 17, 1992 (57 FR 13657). Critical habitat has not been determined or designated for this speeies. Threats to the subspeeies stem primarily from loss and/or negative modification of its wetland habitat. Flooding in particular can affect populations by altering habitat through siltation and scouring. The Vasey's Paradise population is threatened by habitat loss eaused by eontrolled flooding of the Colorado River below Glen Canyon Dam. Current information on population trends is not available for the Kanab ambersnail (USFWS 2011v).

\section{Mohave Tui Chub}

The primary referenees for this section are:

California Department of Fish and Game. 2000a. The Status of Rare, Threatened, and Endangered Animals and Plants of California, Mohave Tui Chub. California Department of Fish and Game Habitat Conservation and Planning Branch. Sacramento, California.

and

USFWS. 1983a. Reeovery Plan for the Mohave Tui Chub, Gila bicolor mohavensis. Portland, Oregon.

Referenees eited in this seetion are internal to the above-referenced documents. Full eitations have been ineluded in the Bibliography.

The 2009 5-year review for Mohave tui chub (USFWS 2009pp) was consulted for updatcd information on this species.

The Mohave tui chub (Gila bicolor mohavensis) occurred historieally the Mojave River in California, from the confluence of the east and west forks at the base of the San Bernardino Mountains to its terminus at Soda Dry Lake. It is the only native fish in this river system. Formerly found in deep pools and slough-like areas of the Mojave River, this species now oeeurs only in highly modified refuge sites in San Bernardino County, California. With the cxception of one subpopulation, all existing populations arc introductions outside the historical rangc of the subspecies. Currently, there are only three populations of Mohave tui chubs: Soda Springs and Camp Cady Wildlife Area in San Bcrnardino County, and Lark Scep at China Naval Air Weapons Station, Kern County. All populations occur in small, man-made and /or maintained laeustrine habitats (USFWS 2009pp).

The Mojave tui chub occurs in ponds or pools with a minimum water depth of 4 feet, with flow of fresh water into the pool or pond. Aquatic plants provide habitat for a variety of native, aquatic invertcbrates, a primary food souree. They also provide a substrate for fish egg attachment. Limited amounts of riparian or wetland vegetation are necessary to provide shade from sunlight and intense tempcratures. A moderate amount of aquatic and wetland vegetation is needed to prevent cxcessive aerobic digestion of detritus and nocturnal plant respiration, which can produce anoxic conditions. As the only fish native to the Mojave River, the Mohave tui chub evolved without aquatie eompetitors or predators, and it requires habitats that are free of excessive predation from arroyo ehubs and other non-native, aquatic, faunal species. Mohave tui occur at tempcratures from 37 to $97{ }^{\circ} \mathrm{F}$ (Feldmeth et al. 1985, Archbold 1996), and in habitats with dissolved oxygen grcater than 2 ppm, and salinities of 40 to 323 milliosmols/liter (McClanahan et al. 1986).

Mohave tui chub typically spawn from March/April to Oetober. Females lay approximately 4,000 to 50,000 eggs over aquatic vegetation. Once hatehed, the fry will sehool in the shallows, while medium-sized tui ehub ( 1 to 3 inches) school in water 1 to 2 inches deep. Large chub are typically solitary and found in deeper water. Mohave tui ehub feed on insect larvae and detritus. 
The Mohave tui chub was federally listed as endangered on October 13, 1970 (35 FR 16047). Critical habitat has not been designated. Habitat modifieations, including damming of the headwaters and withdrawals of the river's underflow, and hybridization with an introduced species, the arroyo chub, contributed to the decline of the species. During the 1930s, arroyo chub were illegally introduced into the headwater reservoirs of the Mojave River as a baitfish. The arroyo chub quickly spread throughout the drainage. Mohave tui chub population numbers began to decrease as a result of competition and hybridization with the arroyo chubs. By 1979, species replacement was complete in their natural habitat. Current threats include genetic contamination, introduction of other exotic species, habitat loss and degradation from improper maintenance of water flows and cattails, and parasitism from the Asian tapeworm. If re-established in the Mojave River, threats to the subspecies would include hybridization with the arroyo chub, habitat alteration and loss, predation from non-native, aquatic species, climate change, and parasitism from the Asian tapeworm (USFWS 2009pp).

\section{Virgin River Chub}

The primary referenee for this section is:

USFWS. 1994c. Virgin River Fishes Recovery Plan. Salt Lake City, Utah.

Most references eited in this section are internal to the above-referenced document. Full citations have been included in the Bibliography.

The 2008 Virgin River fishes 5-year review (USFWS 2008s) was eonsulted for updated information on this species.

The Virgin River chub (Gila seminuda) oceurs in the Virgin River Basin, within the Moapa River in Nevada, and within the mainstem Virgin River from Pah Tempe Springs, Utah, downstream to the Mesquite Diversion, located near the Arizona-Nevada border. Virgin River chubs are most often associated with deep runs or pool habitats of slow to moderate velocities with large boulders or instream eover, such as root snags. Adults and juveniles are often associated together within these habitats; however, the larger adults are collected most often in the deeper pool habitats within the river. Chubs are generally found in stream waters in velocities ranging up to 2.5 feet per second.

Virgin River chubs are omnivorous, showing considerable dietary shifts with age. In general, Virgin River chubs feed mainly on debris and chironomids in February; Cladophora and debris in June; debris and Spyrogyra and Cladophora in September; and unidentified drift animals, dragonfly larvae, debris, and Cladophora in Deeember. Young fish feed almost entirely on macroinvertebrates, while adults feed almost exclusively on algae and debris (Greger and Deacon 1988).

Very little is known about the reproductive biology of the Virgin River chub. The exact time of spawning for this species is not known, although ripe males and females have been reported in April, May, and June (USFWS 2008s). However, it is known that Virgin River chubs suecessfully spawn in both artificial pond habitats and the mainstem Virgin River (Utah Division of Wildlife Resources and Dexter National Fish Hatchery and Technology Center, unpublished data). Longer lived Virgin River chub appear to reproduce suceessfully in most years, and some level of recruitment to the adult population appears to oceur on a frequent basis (USFWS 2008s).

The Virgin River chub was federally listed as endangered on August 24, 1989 (54 FR 35305). Critical habitat was designated for the species on January 26, 2000 (65 FR 4I40), and includes the 87.5 miles on the mainstem Virgin River and its 100-year floodplain (only those portions that contain at least one of the primary constituent elements for critical habitat), extending from the confluence of La Verkin Creek to Halfway Wash. The critical habitat designation represents approximately 66 percent of the speeies' historical habitat within the Virgin River Basin. It also consists of the species' remaining occupied habitat, which flows through both public and private lands. The major limiting factors for the Virgin River chub are modification and loss of habitat, and the introduction and establishment of non-native fish, particularly red shiner. Building of dams and associated reservoirs, water diversion structures, canals, laterals, aqueducts, and the dewatering of streams causes loss or degradation of available habitat. 


\section{Woundfin}

The primary reference for this section is:

USFWS. 2000f. Designation of Critical Habitat for the Woundfin and Virgin River Chub. Federal Register $65(17): 4140-4156$.

References cited in this section are internal to the above-referenced document. A eomplete list of these references is available from the USFWS Salt Lake City Field Office, Salt Lake City, Utah.

The 2008 Virgin River fishes 5-year review (USFWS 2008s) was consulted for updated information on this species.

The original range of the woundfin (Plagopterus argentissimus) extended from near the junction of the Salt and Verde Rivers at Tempe, Arizona, to the mouth of the Gila River at Yuma, Arizona (Gilbert and Scofield 1898, Minekley 1973). Woundfin were also found in the mainstem Colorado River from Yuma (Jordan and Evermann 1896, Meek 1904, Follett 1961) upstream to the Virgin River in Nevada, Arizona, and Utah and into La Verkin Creck, a tributary of the Virgin River in Utah (Gilbcrt and Seofield 1898, Snyder 1915, Miller and Hubbs 1960 , Cross 1975). However, becausc no barricrs or habitat considcrations exist that would have precluded woundfin from existing further upstream in thesc rivers, it is bclieved that the woundfin likcly oeeurred further upstrcam in the Verde, Salt, and Gila rivers in Arizona. With the exception of the mainstem of the Virgin River, woundfin are cxtirpated from most of their historical range. Over the course of the past 30 years, woundfin have generally declined throughout their oecupied range (USFWS 2008s). They presently range from Pah Tcmpe Springs (also called La Verkin Springs) on the mainstem of the Virgin River and the lower portion of La Verkin Creck in Utah, downstrcam to Lake Mcad. Populations in Utah, partieularly those upstream of the influenee of red shiner, have persisted better than anywhere else.

Adult and juvenile woundfin inhabit runs and quiet waters adjacent to riffles with sand and sand/gravel substrates. Adults are generally found in habitats with water depths between 0.5 and 1.4 feet, with veloeities between 0.8 and 1.6 feet per second. Juveniles select arcas with slower and decper water, whilc larvac are found in baekwaters and stream margins, which are often associated with growths of filamcntous algac. Spawning occurs from April to July, depending on the timing of snow melt runoff, which should be during the period of declining spring flows.

The woundfin was federally listed as cndangered on October 13, 1970 (35 FR 16047). Critical habitat was designated for the species on January 26, 2000 (65 FR 4140). This designation includes the mainstem Virgin River and its 100-year floodplain (only those portions that contain at least onc of the primary constituent elements for eritical habitat), extending from the conflucnec of La Verkin Crcek, Utah, to Halfway Wash, Ncvada, and ineludes 37.3 miles in Utah, 31.6 miles in Arizona, and 18.6 miles in Nevada. This designation includes a total of 87.5 miles of the mainstem Virgin River, which represents approximatcly 13 percent of the woundfin's historical habitat. The area of the Virgin River designated as critical habitat consists of the remaining occupicd habitat for the woundfin, which flows through both publie and private lands. The primary threats to this specics are competition and predation from non-native spccics (primarily red shiner) and degraded habitat conditions (reduced flow/high temperatures; USFWS 2008s).

\section{Moapa Dace}

The Moapa dacc (Moapa coriacea) is endemic to the warm spring arca at the headwaters of the Moapa (Muddy) River, in northern Clark County, southeastern Ncvada. The speeies is restricted to warm springs, thcir outflows, and the warm waters of the upper mainstrcam Muddy River. The Moapa dace prefers habitat within local headwaters where water temperatures are between 82 and $90^{\circ} \mathrm{F}$ and turbidity is low. Velocity flow is variable, but in many arcas can be swift. Moapa dacc arc usually found in watcrs no cooler than $81^{\circ} \mathrm{F}$, although thcy have bcen taken below the low head dam in waters as cool as $67^{\circ} \mathrm{F}$ (Dcacon and Bradley 1972). Dissolved oxygen conecntrations in Moapa dace habitat have been reeorded between 1.6 and 8.9 ppm (Dcaeon and Wilson 1967), although concentrations below $2.4 \mathrm{ppm}$ seem to be uncommon (Hubbs and Hettler 1964; Hubbs et al. 1967; USFWS 1984d). Streamside vegetation is dense throughout most of the Moapa daee habitat, frequently forming a complctc canopy over the strcam and filling the channel with snags and brush (Bradley and Dcacon 1967, Deacon 
and Bradley 1972, USFWS 1984d). Streamside vegetation eonsists of ash, cottonwood, screwbean mesquite, willow, tamarisk, grape vines, and a variety of shrubs, grasses and, herbs.

The Moapa dace appears to be predominantly earnivorous, feeding on invertebrates, and lesser amounts of detritus and filamentous algae. Direct observation of feeding indicates that the species feeds relatively indiseriminately on drift. Fish tend to congregate at dawn and dusk in swift water near snags, and dash up into the current to pick off drift material passing by. Observations of feeding behavior in pool habitats indicate Moapa dace will consume benthic invertebrates directly off the bottom. Larvae, living in shallower, more slowly moving water, probably feed on the mueh smaller microcrustacea.

Moapa daee can reproduce throughout the year in the nearly constant temperatures of their habitat. Peak reproduction probably oecurs from February to April followed by peak emigration of the young in May (USFWS 1984d). This species has been observed spawning on sandy substrate in a water depth of 6 to 7.5 inches, and a near-bed velocity of 0.1 to 0.3 feet per second. Preliminary measurements of fecundity indicate a range of 97 to 386 eggs produced per adult female.

The Moapa daee was federally listed as endangered on Mareh 11, 1967 (32 FR 4001). Critical habitat has not been designated. A study by the USFWS (1984d) indicates that the Moapa dace oceupies only 10 percent of its original range. The population of the species deelined from 1,172 individuals in 2007 to 459 individuals in 2008 (USFWS $2009 \mathrm{qq}$ ). In the mid-1980s, the population ranged from 2,600 to 2,800 (Seoppettone et al. 1992). The most important factor limiting the distribution and abundance of the Moapa dace within its former range may be turbidity eaused by irrigation return flows into the formerly clear water. The feeding ability of the Moapa dace may have been severely curtailed by this inereased turbidity. Other apparent reasons for the species' deeline include competitive interactions with introduced exotic species (USFWS 1983b), parasites (eommonly assoeiated with aquarium fishes and introduced through these exotic fish; La Rivers 1962, Hubbs and Deacon 1964, Bradley and Deacon 1967, Minekley and Deaeon 1968, USFWS 1983b), and declining water quality (chemical parameters and physical parameters) from channelization and irrigation for agrieultural development (Cross 1976, USFWS 1983b). Current threats to the species inelude habitat loss and degradation due to altered water flow characteristies, presence of non-native predators and competitors, and habitat fragmentation. Over the long term the speeies is threatened by a drop in groundwater leading to a deeline in spring discharge (USFWS 2009qq).

\section{Ash Meadows Naucorid}

The primary reference for this section is:

USFWS. 1990d. Recovery Plan for the Endangered and Threatened Species of Ash Meadows, Nevada. Portland, Oregon.

References eited in this section are internal to the above-referenced document. Full eitations have been included in the Bibliography.

The Ash Meadows naucorid (Ambrysus amargosus) is a small, flightless insect that oecurs in aquatic habitats in Ash Meadows, Nevada, the sole habitat for 33 unique plants and animals. Ash Meadows is a large oasis in southwestern Nevada, situated at approximately 2,200 feet in elevation in the Mojave Desert, 40 miles east of Death Valley National Monument headquarters at Furnace Creek, California, and 90 miles northwest of Las Vegas, Nevada. The area includes approximately 50,000 acres of desert uplands and spring-fed oases that straddle the California-Nevada border. Its nearly 50 seeps and springs discharge about 17,000 acre-feet of water annually (Walker and Eakin 1963; Bateman et al. 1974). This water formerly flowed into an extensive marsh, which was drained in the mid-1960s. Thunderstorms occasionally caused floodwaters to discharge from Ash Meadows into the Amargosa River, which terminates in the floor of Death Valley. The Ash meadows nancorid is restricted to several stream channels that are less than 1 foot wide and 33 feet long, all of which occur on the Ash Meadows National Wildlife Refuge.

A creosote bush vegetation community predominates in the surrounding region. On the nearly level terrain near the springs, vegetation is dominated by groves of velvet ash trees and screwbean mesquite in association with seep 
willow. Sand dunes in the area are dominated by western honey mesquite. Shadscale and alkali goldenbush dominate areas away from the direet influenee of the spring waters. Large areas of seasonally wet, salt-encrusted soils are eovered with saltgrass. Creosote bush dominates the better-drained soils on the surrounding slopes. Discharge from springs maintains soil moisture in the lowlands, while the uplands receive water only from rainfall that averages less than 3 inches annually.

The Ash Meadows naucorid lives entirely underwater. Within Ash Meadows, the species is known to oceupy an extremely restricted habitat where flowing water passes over roek and pebble substrates at Point of Roeks Springs (La Rivers 1953). The naucorids eling to roeks in riffle habitat and hunt a variety of aquatic insects and crustaceans. Reproduction occurs during early spring and summer. Female naueorids deposit eggs that adhere to the substrate during ineubation (Usinger 1946). The Ash Meadows naucorid has several instars, and both juvenile and adult forms.

The Ash meadows naucorid was listed as threatened on May 20, 1985 (50 FR 20777). Approximately 10 acres at Point of Roeks Springs have been designated as eritieal habitat for this speeies. The small size and vulnerability of its habitats make the species highly suseeptible to extirpation. The species is threatened by altered surface drainage patterns that reduee or eliminate surface water, lower the water table, or interfere with groundwater reeharge.

\section{Ash Meadows Speckled Dace}

The Ash Meadows speekled dace (Rhinichthys osculus nevadensis) is endemic to spring systems and aquatic habitats formed by spring waters at Ash Meadows, in Nye County, Nevada. Although formerly more widespread in the area, the species is eurrently restrieted to Jackrabbit Spring, Big Spring, the two westernmost springs of the Bradford Springs group, and the outflows of these springs (NatureServe 2010). The species is restricted by its cold water intolerance. The Ash Meadows speckled dace is known to oceur in headwater spring pools, spring outflow ereeks (including areas of the creek up to a mile or more from their spring sources), and marshes formed by spring flows (Soltz and Naiman 1978, Hardy 1980, Williams and Sada 1985). The subspecies also oeeurs in irrigation ditehes and eanals that utilize the spring flows for irrigation. The Ash Meadows speekled daee appears to be rather general in its habitat requirements, utilizing areas of rather fast stream eurrent, as well as quiet spring pools.

Speekled dace are typically omnivores (Moyle 1976). They often feed on bottom materials, ineluding aquatic inseet larvae, crustaceans, attached diatoms, snails, and algae. Some mid-water foods or even an oceasional surface inseet will be taken (Moyle 1976, Williams and Williams 1982). Terrestrial inseets that fall in the water may also be consumed.

Speekled daee generally become mature in their seeond summer (Moyle 1976). Spawning oecurs in early spring and again in late summer (Matthews and Moseley 1990). Speekled dace typically spawn on the gravel edge or riffles in stream habitats. No pair bonds are formed; rather, when a female enters a spawning area during the breeding season, several males may swim out to spawn with her. Eggs hateh in approximately 6 days (at water temperatures of 64 to $66^{\circ} \mathrm{F}$ ).

Human development in the area consists primarily of small, scattered residenees with which subsistenee gardens, small orehards, or agrieultural fields may be associated. During the early 1970s, a large farm began operating in Ash Meadows. Development of the farm involved extensive removal of natural vegetation, land leveling, eonstruetion of irrigation wells, ditehes, and fenees, and other aetivities neeessary for commercial farming (Worts 1963, Dudley and Larson 1976). The former major threats from dewatering and development were eliminated with the establishment of the Ash Meadows National Wildlife Refuge. However, some of the spring outflows that were diverted into ditehes in the past remain today.

The Ash Meadows speekled dace was federally listed as endangered on September 2, 1983 (48 FR 40178). Critical habitat has been designated in Nye County, Nevada in Seetion 11 Township 18 South, Range 50 East and Seetions 18 and 19 in Township 18 South, Range 51 East. The primary threats to the Ash Meadows speekled dace are predation by tilapia and habitat loss due to declining water flows. Water development aetivities that eliminate or degrade habitat threaten the subspecies. Beeause of the aequisition of many spring areas by the USFWS, the major 
threats in the future will most likely consist of additional exotic species introductions rather than physical habitat alteration.

\section{Pahrump Poolfish}

The Pahrump poolfish (also commonly referred to as the Pahrump killfish; Empetrichthys latos) was extirpated from its original range in the Pahrump Valley of Nevada, as a result of groundwater pumping and competition from non-native goldfish (USFWS 2004b). This species is now maintained in three refugia where it has been reintroduced: Corn Creek Springs on the Desert National Wildlife Refuge, Spring Mountain Ranch State Park (in western Clark County), and Shoshone Ponds Natural Area (White Pine County). The Shoshone Ponds Natural Area is a BLM-administered native fish sanetuary. All three areas are bordered by natural desert vegetation and are protected from excessive public disturbance. Adult poolfish feed on debris, insect parts, sand, insect larvae, snails, eggs, and plants. Juveniles and young probably depend on zooplankton algae and debris as their primary food sources.

Isolated in desert springs, the Pahrump poolfish is a non-migratory species. Spawning of Pahrump poolfish in constant-temperature natural springs probably can occur throughout the year, as is common with desert spring fishes (Deacon and Minckley 1974). Poolfish maintain their populations in desert springs containing no other fish species. They survive and reproduce well in these stable habitats with a diversity of plant and invertebrate speeies (Soltz and Naiman 1978; Deacon et al. 1980).

The Pahrump poolfish was federally listed as endangered on March 11, 1967 (32 FR 4001). In 1993, the USFWS proposed a reclassification of its status to threatened, but this proposal was withdrawn on April 2, 2004 (69 FR 17383). Excess pumping of groundwater for agricultural irrigation is seen as the primary cause of habitat destruction for this species (Minckley and Deacon 1968, Soltz and Naiman 1978, Deacon 1979). All native habitats of the Pahrump poolfish have been destroyed, and locations where transplanted populations occur are likely to require management intervention to maintain healthy populations. Current threats to the species include potential introductions of non-native aquatic predators, and habitat destruction and loss due to limited water supply as a result of demands on limited water sources (USFWS 2004a).

\section{Gila Topminnow and Yaqui Topminnow}

The primary references for this section are:

USFWS, 1994d. Yaqui Fishes Recovery Plan. Albuquerque, New Mexico.

and

USFWS. 1999j. Gila Topminnow, Poeciliopsis occidentalis occidentalis, Revised Recovery Plan. Albuquerque, New Mexico.

References cited in this section are internal to the above-referenced documents. Full citations have been included in the Bibliography.

There are two listed subspecies of the Sonoran topminnow ( $P$. occidentalis): the Gila topminnow $(P$. $O$. occidentalis) and the Yaqui topminnow (P.o.sonoriensis). The Gila topminnow (Poecilioposis occidentalis) is a small, live-bearing minnow that historically occurred throughout the entire Gila River basin in Arizona, New Mexico, and northern Sonora, Mexico, below 4,000 feet in elevation. It was once the most common fish found throughout the Gila River drainage in Arizona, but is now limited to isolated habitats in Arizona and Mexico. It has been extirpated from New Mexico. In Arizona, most of the remaining populations are in the Santa Cruz River system, in Gila, Pinal, Graham, Yavapai, Santa Cruz, Pima, Maricopa, and La Paz Counties (U.S. Geological Survey [USGS] 2012a). The Yaqui topminnow occurs in the Rio Yaqui Basin, a drainage that (in the United States) includes parts of Cochise County, Arizona, and Hidalgo County, New Mexico.

Topminnows have fairly broad habitat requirements. They prefer shallow, warm, fairly quiet waters, but can adjust to a rather wide range of conditions, living in quiet to moderate currents. Topminnows live in a wide variety of 
water types. The Gila topminnow occurs in small streams, springs, and eienagas, primarily in shallow areas with aquatic vegetation and debris for cover. They ean tolerate relatively high water temperatures and low dissolved oxygen. The Yaqui topminnow lives in shallow, warm, quiet waters, and occasionally in moderate to relatively swift currents (Galat and Robertson 1988, 1992). Preferred habitats usually include dense mats of algae and debris along stream margins or in eddies below riffles, typically over sandy substrates covered with organic muds and debris. Yaqui topminnows become most abundant in marshes, especially those fed by thermal springs or artesian outflows (Sims and Simms 1992). Topminnows have a fairly generalized diet, eating detritus, living vegetative material, amphipod crustaceans, and aquatic insect larvae, including mosquitoes (Minckley 1973, Gerking and Plantz 1980).

The breeding season for the Gila topminnow speeies lasts from January to August, but a few pregnant femalcs are present throughout the year, and young are produced even in winter. Sexual maturity may occur in a few weeks to many months after birth, depending largely upon the time of year the individual is born. Female Yaqui topminnows may have over 20 young per brood, with broods produced at intervals of approximately 20 days. Reproduction occurs year-round where winter temperatures are ameliorated by the inflow of springs, but under conditions of fluctuating temperature reproduction begins in early April and ends in October (Mincklcy 1973; Galat and Robertson 1988, 1992). Topminnows are not thought to live longer than a year under natural conditions (Minckley 1973).

The Gila topminnow and Yaqui topminnow were federally listed as endangered on March 11, 1967 (32 FR 4001). Critical habitat has not been designated for these subspceics. Factors that led to alteration and distraction of Gila topminnow habitat include heavy overgrazing and wood cutting in riparian habitats, which led to erosion, flooding, lowering of water tables, and other habitat modifications. Groundwater pumping, construction of water diversions and dams, land use practices, and development continucd to modify habitats (USFWS 1998p). These altered habitat conditions continue to threaten the spccies. Some populations are supported in habitats constructed or modified by man and require periodic maintenance for support of the population. Additionally, because of the presence of barriers to movement, Gila topminnows can no longer re-distributc from their remaining isolated and widely scparated populations to colonize formerly oceupied habitats, even during years with above average rainfall.

The Rio Yaqui watershed has been heavily utilized for cattle grazing and farming, changing the diversity of natural landscapes in the region. Severe grazing pressure has led to the incision of stream channels, desiccation of cienegas, and excessive exploitation of underground aquifers. The introduction of non-indigenous fish species into the system has also contributed to a further general decline in aquatic communitics. These factors continue to threaten the Yaqui topminnow.

\section{Beautiful Shiner}

The bcautiful shiner (Cyprinella formosa) occurs in several basins in southeastern Arizona and northwestern Mexico. It is most common in riffles of small streams, and presumably uses pools of intermittent streams for refugia (Minckley 1985). This species is not eommon in rivers but has been found in rapids with water velocities exceeding 3.3 feet per second, in addition to earthen tanks and ponds on the San Bernardino Ranch. The species has also sueessfully reproduecd in earthen ponds at the Dexter National Fish Hatehery.

Historic habitat for this species in the Mimbres River has been described as a lagoon-like system of deep pools with undercut banks (Antisell 1856). The species occurs mainly in pools of small to medium streams with sand, gravel, and rock bottoms, and has been introduced into man-made ponds. It is believed that reproduction occurs primarily from May through July, and that spawning in this species consists of spreading the eggs over aquatic vegetation, brush, other cover, or the bottom of the aquatic habitat. The beautiful shiner is an omnivore and feeds on drifting aquatic and terrestrial invertebrates (Arizona Game and Fish Department 200ld). What little is known about the cover/shelter requirements for this species indicates that pools of intermittent streams are used as refugia.

The beautiful shincr was federally listed as threatened on August 31, 1984 (49 FR 34490). Critical habitat has been designated in aquatic habitats of the San Bernardino National Wildlife Refuge. Primary reasons for the decline of 
this species include arroyo cutting caused by overgrazing and the removal of riparian vegetation, pumping of groundwater, damming of watercourses, and the introduetion of exotic species (USFWS 1984e). More specifically, within the U.S., capping of the artesian well leading to what is now Twin Ponds on the San Bernardino National Wildlife Refuge in about 1970 destroyed a short spring-fed run and cienega that served as a breeding habitat and refuge for the beautiful shiner. Capping of the well forced the shiner into a pond inhabited by predatory bluegill, black crappie, and largemouth bass, causing the extinetion of the minnow within the United States. The species has since been reintroduced to ponds in the San Bernardino National Wildlife Refuge.

\section{Pecos Bluntnose Shiner}

The primary references for this species are:

USFWS. 1992g. Pecos Bluntnose Shiner Recovery Plan. Region 2. Albuquerque, New Mexico.

and

USFWS. 1987c. Endangered and Threatened Wildlife and Plants; Notropis simus pecosensis (Pecos Bluntnose Shiner). Federal Register 52(34):5295-5303.

References cited in this section are internal to the about refereneed documents. A complete list of these references is available from the USFWS, Albuquerque, New Mexico.

The 2010 5-year review for the Pecos bluntnose shiner (USFWS 2010z) was consulted for updated information on this species.

Pecos bluntnose shiner (Notropis simus pecosensis) is a moderate-sized shiner separable from co-occurring shiners by its robust body, blunt and rounded snout, and large, slightly subterminal mouth that usually extends even with the pupil. The Peeos bluntnose shiner oeeupies most major habitats within the Pecos River, but is most eommon in the main channel. It is typically found in low velocity water, 7 to 16 inches deep, over sand substrate (Hateh et al. 1985). Historically, the Pecos bluntnose shiner inhabited the mainstream Peeos River from Santa Rosa downstream to the vicinity of Carlsbad, New Mexico (Hateh et al. 1985). However, this species has decreased drastically in abundance and range. The current occupied range of the Pecos bluntnose shiner is from the confluence of Taiban Creek with the Pecos River to Brantley Reservoir (USFWS 2010z).

Female Pecos bluntnose shiners release non-adhesive, semi-buoyant eggs that float in the water column (Platania and Altenbach 1998). The spawning season extends from late April through September, with the primary period occurring from June to August (Platania 1993, 1995a). Spawning is cued by substantial increases in diseharge, including flash floods and block releases of water (Platania 1993, Dudley and Platania 1999). Young Pecos bluntnose shiners likely consume zooplankton primarily, while Pecos bluntnose shiners of increasing size rely upon terrestrial and aquatic insects (Platania 1993, Propst 1999). The Pecos bluntnose shiner's diet is indieative of drift foraging (a feeding strategy in which individuals wait in a favorable position and capture potential food items as they float by; Starrett 1950, Griffith 1974, Mendelson 1975). Drift foragers depend on frequent delivery of food to offset the energy required to maintain a position in the current (Fausch and White 1981). Water velocity must be adequate to deliver drift (Chapman and Bjornn 1969, Mundie 1969) but also of low enough speed to form refugia where the fish can rest within striking distance of target items (Fausch and White 1981, Fausch 1984).

The Pecos bluntnose shiner was listed as threatened on February 20, 1987 (52 FR 5295). At the same time, the USFWS designated two noncontiguous river reaches, totaling approximately 101 miles of the Pecos River, as critical habitat. The primary reason for the decline of the Pecos bluntnose shiner is the modification of habitat and establishment of non-native fish species. Hatch et al. (1985) presented information that indicated stream desiccation, due to dam and reservoir operations, river pumping, and the proliferation of the non-native salt cedar (Tamarix pentandra), to be the main reason for decline in the Pecos River. It is likely that other physical habitat modifications, pollution, and non-native predators/competitors also have contributed to the decline of the species in the Pecos River drainage (Brooks et al. 1991). Currently, the biggest threat to the species is intermittent flows in 
river habitats. Although golden algae is not eurrently a threat to Peeos bluntnose shiner, with climate ehange (deereases in flow, greater proportion of flow eoming from agrieultural return, leading to inereased nutrient and salt eoneentrations) golden algae eould beeome an issue in portions of the river in the future (USFWS 2010z).

\section{Loach Minnow}

The primary referenee for this speeies is:

USFWS. 2012d. Endangered and Threatened Wildlife and Plants; Endangered Status and Designations of Critieal Habitat for Spikedaee and Loaeh Minnow. Federal Register 77(36):10810-10932.

Referenees eited in this seetion are internal to the about refereneed doeuments. A eomplete list of these referenees is available from the USFWS Arizona Eeologieal Serviees Offiee, Phoenix, Arizona.

The loaeh minnow (Tiaroga cobitis) is found in small to large perennial streams in portions of New Mexieo and Arizona. In Arizona, the speeies persists in Aravapai Creek and its tributaries, Turkey and Deer Creeks, in the upper reaehes of White River, and in limited reaehes of the Blaek River, Blue River and tributaries, Campbell Blue and Little Blue Creeks, Eagle Creek, and in the San Franeiseo River between Clifton and the New Mexieo border (Propst et al. 1985). In New Mexieo, the loaeh minnow still oeeurs in the upper Gila River, ineluding the East, Middle, and West forks, and in the Cliff-Gila Valley reaeh of the Gila River, the San Franeiseo and Tularosa Rivers and their tributaries, and Paee and Frieborn ereeks. Loaeh minnows are generally absent downstream of the Cliff-Gila Valley (Propst et al. 1988; Propst and Bestgen 1991). Loaeh minnows use shallow, turbulent riffles with primarily eobble substrate and swift eurrents (Miekley 1973; Propst et al. 1988; Rinne 1989; Propst and Bestgen 1991). They use the spaees between and on the sheltered side of roeks for resting and spawning. The speeies does not oeeur in areas where fine sediments fill these interstitial spaees (Propst and Bestgen 1991).

Loaeh minnows feed exelusively on aquatie inseets (Abarea 1987). They are opportunistie, benthie inseetivores, largely deriving their food supplies from among riffle-dwelling larval mayflies, blaekflies, and midges. Loaeh minnows appear to aetively seek their food among bottom substrates rather than pursuing animals entrained in the stream drift. Spawning typieally oeeurs in the spring when water temperatures exeed $60{ }^{\circ} \mathrm{F}$. The first spawn oeeurs in the minnow's seeond year of life, primarily during Mareh through May (Britt 1982; Propst et al. 1988). However, under eertain eireumstanees, loaeh minnows also spawn in the autumn (Vives and Minekley 1990). Eggs typieally hateh in 5 to 6 days.

The loaeh minnow was federally listed as threatened on Oetober 28, 1986 (51 FR 39468). Critieal habitat was first designated in 1994 (59 FR 10896). On February 23, 2012 (77 FR 10810), the USFWS ehanged the status to endangered, and revised the eritieal habitat designation. Approximately 610 miles in Apaehe, Coehise, Gila, Graham, Greenlee, Pinal, and Yavapai Counties, Arizona, and Catron, Grant, and Hidalgo Counties in New Mexieo were designated as eritieal habitat for loaeh minnow. Critieal habitat oeeurs on BLM lands in both Arizona and New Mexieo. The speeies is threatened by water withdrawals as a result of growing water demands, ehannelization of streams for flood eontrol, degradation of water quality, reereational aetivities, ereetion of roads and bridges, livestoek grazing, and elimate ehange.

\section{Gila Trout}

The primary referenee for this seetion is:

USFWS. 2005f. Reelassifieation of the Gila Trout From Endangered to Threatened with Regulations. Federal Register 70(90):24750-24763.

Referenees eited in this seetion are internal to the above-refereneed doeument. A eomplete list of these referenees is available from the New Mexieo Eeologieal Serviees Field Offiee, Albuquerque, New Mexieo.

The Gila trout (Oncorhynchus gilae) is a moderate-sized salmonid that is native to the headwaters of the Gila River, New Mexieo. The speeies historieally oeeurred in mountain stream habitats in Sierra, Grant, and Catron Counties in New Mexieo, and Grenlee, Apaehe, Graham, Gila, and Yavapai Counties in Arizona. As of 2000, the speeies inhabits approximately 65 miles of habitat in 14 streams. Over the years, range reduetions have oeeurred 
from local extirpations caused by high-intensity forest fires and hybridization with rainbow trout, and range expansions have resulted from establishing new populations by stocking by resource management agencies.

Habitat of Gila trout consists of perennial montane streams ranging from 400 feet to over 9,200 feet in elevation (Propst and Stefferud 1997). Streams with suitable habitat are found in eoniferous and mixed woodland, montane coniferous forest, and subalpine coniferous forest (Dick-Peddic 1993). Suitable nursery and rearing habitat, or areas used by larval and juvenile Gila trout, occurs in areas with slow eurrent velocity such as stream margins, seeps, shallow bars, and side channels (Behnke 1992). Absence of predation by non-native trout, particularly brown trout, is another essential element of nursery and rearing habitat. Subadult Gila trout oceur primarily in riffles (shallow water flowing over cobbles), riffle-runs, and runs, while adults are found mainly in pools (Rinne 1978). Cover (large woody debris, undereut banks, boulders, deep water, and overhanging woody and herbaceous vegetation) is an important component of subadult and adult habitat (Stefferud 1994). The quantity and quality of adult habitat typically limits the trout population biomass (Behnke 1992). Absence of competition with non-native trout (brown and rainbow) for foraging habitat is also an essential element of subadult and adult habitat. Overwintering habitat (November through February) ineludes deep water with low current velocity and protective cover (Behnke 1992). Barriers to fish movement (e.g., waterfalls, dry stream bed) that prevent fish from accessing overwintering habitat may impact populations of Gila trout. Gila trout are now restricted to small headwater streams that typieally have fewer deep pools and less suitable overwintering habitat than do larger streams (Harig and Fausch 2002).

Spawning oceurs mainly in April (Rinne 1980), when temperatures are 43 to $46^{\circ} \mathrm{F}$; however, day length may also be an important cue. Young fish emerge from gravel nests 56 to 70 days after egg deposition (Rinne 1980). On average, for every $100 \mathrm{eggs}$ that hateh, only two fish will survive to become adults (Brown et al. 2001). The majority of female Gila trout only spawn once, and most males only spawn two or three times. Like many salmonids, Gila trout are opportunistie earnivores, consuming a large variety of aquatic and terrestrial inseets entrained in the stream drift. Large Gila trout oeeasionally eat other fish (Van Eimeren 1988).

The Gila trout was federally listed as endangered on March 11, 1967 (32 FR 4001), and on July 18, 2006, its status was reclassified to threatened (71 FR 40657). Critieal habitat has not been designated. The continued deeline in this species and its available habitat is attributable to a number of factors, ineluding the introduction of non-native salmonids and land management practices (overgrazing, fires, lumbering, and mining) that have caused habitat loss and modifieation.

\section{Gila Chub}

The primary reference for this section is:

USFWS. 2002h. Listing the Gila Chub as Endangered With Critical Habitat. Federal Register 67(29):6459-6479.

References cited in this section are internal to the above-referenced document. A complete list of these references is available from the USFWS Arizona Ecological Services Field Office, Phoenix, Arizona.

The Gila chub (Gila intermedia) is a fish in the minnow family that inhabits pools in smaller streams, springs, and cienegas, and can survive in small artificial impoundments (Miller 1946, Minckley 1973, Rinne 1975). Historically found throughout the Gila River basin in southern Arizona, southwestern New Mexieo, and northeastern Sonora, Mexico, Gila chub have been extirpated or reduced in numbers and distribution throughout much of this range (Minckley 1973; Weedman et al. 1996). Numerous events, oceurring nearly a century ago, led to long-term stream, cienega, and riparian habitat degradation throughout southern Arizona and northern Mexico, and the ecosystem has not fully recovered, and in some areas may never recover. Approximately 85 to 90 percent of the Gila chub's habitat has been degraded or destroyed, and much of it is unrecoverable.

Gila chub are highly secretive, preferring quiet deeper waters, especially pools, or remaining near eover including terrestrial vegetation, boulders, and fallen logs (Rinne and Minckley 1991). Undercut banks created by overhanging terrestrial vegetation with dense roots growing into pool edges provide ideal cover (Nelson 1993). Gila chub can survive in larger stream habitats such as the San Carlos River, and artificial habitats, like the 
Buckeye Canal (Stout et al. 1970; Rinne 1976). Gila chub interaet with spring and small stream fishes regularly (Meffe 1985), but prefer deeper waters (Minckley 1973). Adults often are found in deep pools and eddies below areas with swift eurrent, as in the Gila chub habitats found in Bass Canyon and Hot Springs in the Muleshoe Preserve area. Young-of-the-year inhabit shallow water among plants or eddies, while older juveniles use higherveloeity stream areas (Minckley 1973, 1991).

Gila ehub are omnivorous (Griffith and Tiersch 1989), although adults appear to be prineipally carnivorous, feeding on large and small aquatic and terrestrial invertebrates and sometimes other small fishes (Rinne and Minckley 1991). Smaller individuals often feed on organic debris and aquatic plants, espeeially filamentous (threadlike) algae, and less intensely on diatoms (unicellular or colonial algae). Bottom feeding may also oceur.

Spawning probably oecurs over beds of submerged aquatie vegetation or root wads. Warmer water temperatures ( 68 to $75.2^{\circ} \mathrm{F}$ ) appear to contribute to a sueeessful spawn (Nelson 1993). For the roundtail chub, a close relative of the Gila ehub, spawning oecurs when water temperatures are approximately $68^{\circ} \mathrm{F}$, and temperature appears to be the most important environmental factor triggering spawning (Bestgen et al. 1985).

The USFWS listing the Gila chub as endangered on November 2, 2005 (70 FR 66664). At the same time, approximately 160.3 river miles of critical habitat were designated in Grant County, New Mexico; and in Yavapai, Gila, Greenlee, Graham, Cochise, Santa Cruz, Pima, and Pinal Counties in Arizona. Primary threats to the speeies include predation by and eompetition with non-native organisms, including fish in the sunfish and bass family, other fish species, bullfrogs, and erayfish; and habitat degradation from surfaee water diversions and groundwater withdrawals. Secondary threats inelude habitat alteration, destruction, and fragmentation (USFWS 2005g). The species exists as a few, small, isolated populations, whieh makes it highly suseeptible to these threats.

\section{Spikedace}

The primary reference for this section is:

USFWS. 2007u. Designation of Critieal Habitat for the Spikedace (Meda fulgida) and Loaeh Minnow (Tiaroga cobitis). Federal Register 72(54):13356-13422.

Referenees eited in this seetion are internal to the above-refereneed doeument. A complete list of these references is available from the Arizona Ecological Services Office, Phoenix, Arizona.

The spikedace (Meda fulgida) is a stream-dwelling member of the minnow family that was onee eommon in large and moderate-sized rivers throughout the upper Gila River Basin of Arizona and New Mexico. The speeies was onee eommon throughout much of the Gila River basin, including the mainstem Gila River upstream of Phoenix, and the Cerde, Agua Fria, Salt, San Pedro, and San Francisco subbasins. It occupies suitable habitat in both the mainstem reaehes and moderate-gradient tributaries, up to approximately 6,500 feet in elevation (Cope and Yarrow 1875, Gilbert and Seofield 1898, Chamberlain 1904, Miller and Hubbs 1960).

Spikedace are found in moderate to large perennial streams, where they inhabit shallow riffles with sand, gravel, and rubble substrates (Barber and Minekley 1966; Propst et al. 1986; Rinne and Kroeger 1988). Recurrent flooding and a natural hydrograph (physical conditions, boundaries, flow, and related characteristies of water) are very important in maintaining the habitat of spikedace and in helping the species maintain a competitive edge over invading non-native aquatic species (Propst et al. 1986; Minekley and Meffe 1987).

Spikedace feed primarily on aquatic and terrestrial insects (Barber and Minckley 1983; Marsh et al. 1989), although the species will feed on fry of other fish during certain seasons. The aquatic insects consumed by the spikedace oceur mainly in riffle habitats, whieh provide the elean and relatively stable eonditions they require. The spikedace's diet is highly dependent on the type of habitat and time of year (Minekley 1973). Spikedace feed by picking off food items entrained in stream drift. Spawning oceurs from Mareh through May, but there is some yearly and geographic variation (Barber et al. 1970; Anderson 1978; Propst et al. 1986). Breeding is initiated in response to a combination of declining stream diseharge and increasing water temperatures. Young grow rapidly, 
attaining adult size by November of the year spawned. Spikedace live approximately 2 years, with reproduction typically occurring in 1-year-old fish.

The spikedace was federally listed as threatened on July 1, 1986 (51 FR 23769). Its status was changed to endangered on February 23, 2012 (77 FR 10810). Critical habitat was first designated on April 25, 2000 (65 FR 24328) and has since been revised, with the most recent revision on February 23, 2012 (77 FR 10810). The current designation of critical habitat includes 630 miles in Arizona and New Mexico. The primary causes of this species' continued decline are habitat destruction and competition with and predation by non-native aquatic species. Current potential threats include water withdrawals, stream channel alteration, water quality impacts, recreation, roads and bridges, livestock grazing, and climate change (USFWS 2012d).

\section{Socorro Isopod}

The primary reference for this section is:

USFWS. 2009rr. Socorro Isopod (Thermosphaeroma thermophilus) 5-Year Review: Summary and Evaluation. Albuquerque, New Mexico.

References eited in this section are internal to the above-referenced document. Full citations have been included in the Bibliography.

The Socorro isopod (Thermosphaeroma thermophilus) is endemic to eentral New Mexico (Pennak 1978). It is known to oceur in only one spring located on private land in Socorro, County, New Mexico. The habitat consists of two concrete pools and the plumbing system of an abandoned bathhouse supplied with water from Sedillo Spring. This species lives in thermal habitats, requiring warm springs that are less than a foot deep. Water temperatures throughout the system oceupied by the Socorro isopod range from 77 to $91^{\circ} \mathrm{F}$ (New Mexico Department of Game and Fish 1995), and the water surface is eovered by algae (USFWS 1982e). Socorro isopods burrow into the substrates and hide in eracks or under vegetation during the day. The floor of the smaller pool is composed of 0.8 to 2.4 inches of sediment into which the isopods burrow.

The life span of a Socorro isopod is 1 year or less (Shuster 1981). Females have many reproductive cycles over their lifetime and breed throughout the year, with peak reproduction occurring in the spring and fall. Males guard females prior to copulation, through the molting period. Gestation lasts approximately 3 weeks.

Socorro isopods graze on vegetative matter (the thin film of blue-green algae covering most surfaces within the pool or organic debris that falls into their habitat), or engage in predatory feeding frenzies, in which 10 to 30 isopods attack an injured isopod, an apparently healthy isopod, or an insect larva (Shuster 1981). Food in the pools appears to be the limiting factor for the species. The species appears to be primarily nocturnal, avoiding direct sunlight. Activity inereases toward late afternoon, reaching a peak about an hour before sunset, and remaining high until just before dawn.

The Socorro isopod was federally listed as endangered on March 27, 1978 (43 FR 12690). Critical habitat has not been designated. In August 1988, the entire population died out at the spring, when the flow of water beeame occluded and the habitat dried out. However, a population of the isopod housed at the University of New Mexico saved the species from extinetion, and a transplant has restored it to Sedillo Spring (New Mexico Department of Game and Fish 1988). Threats to the Socorro isopod include vandalism of its extremely limited habitat, any activity that alters the thermal spring or reduces its flow, and any activity that alters either the physical or chemical quality of the spring water. The effects of climate change, if they include widespread drought, decreased spring discharge, or a change in water chemistry is a newly recognized threat that could eliminate the species. 


\section{Alamosa Springsnail and Socorro Springsnail}

The primary referenee for this seetion is:

USFWS. 1993h. Alamosa Springsnail (Tyronia alamosae) and Soeorro Springsnail (Pyrgulopsis neomexicana) Draft Reeovery Plan. Albuquerque, New Mexieo.

Referenees eited in this seetion are internal to the above-refereneed doeument. Full eitations have been ineluded in the Bibliography.

The 2008 5-year review for the Soeorro springsnail (USFWS 2008t) was eonsulted for updated information on this speeies.

The Alamosa springsnail (or Caliente tryonia; Tryonia alamosae), and the Soeorro springsnail (Pyrgulopsis neomexicana) are two speeies of aquatie snail that are endemic to thermal habitats in eentral New Mexieo. Both speeies require a eontinued supply of free-flowing thermal spring water that is free of pollutants, bordered by a zone of organie detritus and vegetation that is suffieient to support their biologieal and habitat requirements.

The Alamosa springsnail is endemie to eentral New Mexieo. The speeies is known only from a thermal spring eomplex in Soeorro County, New Mexieo, whieh eonsists of five individual springheads that flow together. The speeies also oeeurs in minor rivulets out of the main ehannel in the eanyon where the springs arise (Taylor 1987).

The Alamosa springsnail is found primarily where minor rivulets flow out of the main ehannel downstream of the springhead (Taylor 1987). In these situations, there is a mat of watereress and filamentous green algae, over water 1 to 2 inehes deep and flowing over fine gravel and sand among eobbles and roeks. The speeies is found in areas of slow-moving eurrent, on gravel and among vegetation, and is most abundant where an organie film eovers the pebbles and eobbles. As spring runs join and form a narrow, swifter, flowing brook, snails beeome less numerous. Water temperature at the springheads remains between 81 and $82.5^{\circ} \mathrm{F}$. It appears that seasonal fluetuations in water flow and temperature do not oeeur.

The Alamosa springsnail is herbivorous, feeding on algae and other materials that oeeur in the organie film on plants and debris. The speeies eontains a series of embryos in various stages of development, and eggs hatch within the female parent or immediately after being foreed from the parent. Beeause the Alamosa springsnail lives in a thermally eonstant environment, reproduetion is probably not seasonal, and population size likely remains relatively stable (New Mexico Department of Game and Fish 1985).

The Soeorro springsnail is known from only one spring on privately owned property in Soeorro County, New Mexieo, where it was first found in 1979. Aeeess to this spring has been denied sinee 1995, and population numbers and status of habitat are unknown (USFWS 2008t). The souree of this spring has been impounded, redueing the flowing-water habitat to a very small pool. One tiny spring souree having a small, improved pool, with a water temperature of $63^{\circ} \mathrm{F}$ remains. The speeies is abundant on rootlets in this pool, but is not found in the ditehes and ponds radiating from the spring into irrigation struetures. Like the Alamosa springsnail, the Soeorro springsnail oeeurs in slow-veloeity water near spring sourees, on stones and among aquatie plants. The speeies is also herbivorous, and feeds on algae and other materials in organie film. The Soeorro springsnail produees eggs that develop and hateh after being laid, probably in the spring and summer.

The Alamosa and Soeorro springsnails were listed as endangered on September 30, 1991 (56 FR 49646). Critieal habitat has not been designated for either speeies. The limited ranges of both springsnails make them vulnerable to habitat loss or alteration. Potential threats to the speeies inelude all aetivities that would substantially reduee spring flow or the food souree that supports the springsnails. Alterations of the watersheds, springs, or assoeiated runs eould eause a reduetion in water flow, a ehange in water temperature or water quality, or a modification in habitat or food sourees, thus having a devastating impaet on existing populations. It is believed that the greatest threat to these speeies is the potential loss of water flow. Exeessive pumping from the aquifer that supplies water to the springs could destroy the springs and the speeies. Pollution of the springs eould also negatively impaet these speeies. Other threats inelude introduetion of non-native fishes and other aquatie organisms, and eolleetion. The 
Socorro springsnail may be threatened by widespread drought, decreased spring discharge, and changes in water chemistry. Lack of cooperation by the landowner may also be a threat (USFWS 2008t).

\section{Pecos Gambusia}

The Peeos gambusia (Gambusia nobilis) is a fish that oceurs abundantly in springs within a small range in the Pecos River Basin, New Mexico and Texas. However, the species also occurs in areas with little spring influence, but with abundant overhead cover, sedge-covered marshes, and gypsum sinkholes. The species prefers elear, vegetated waters in springs and sinkholes (USGS 2012b). The Pecos gambusia is found from the surface to depths of about 10 feet (USFWS 1983e). All populations, ineluding those at historic, present, and introduction sites, oceur in habitats between 2,700 feet and 3,900 feet in elevation. The species prefers water temperatures of 70 to $77^{\circ} \mathrm{F}$ in the morning and 79 to $86^{\circ} \mathrm{F}$ in the afternoon. In contrast, a potential competitor, western mosquitofish, is more tolerant of higher water temperatures. The Pecos gambusia is essentially restrieted to stenothermal (having only a small range of temperature), clear water, lotic habitats. It lives in a variety of habitats in Bitter Lake National Wildlife Refuge (Bouma 1984). Lands surrounding the habitats are elassified as Texas savanna and shrub/brush rangelands or mixed rangelands. Like other gambusia species, the Pecos gambusia is considered to be a carnivorous surface feeder (Bednarz 1979). It appears to be an opportunistie feeder, eating a variety of small invertebrates and filamentous algae. This species bears live young, primarily in shallow areas.

The Pecos gambusia was federally listed as endangered on Oetober 13, 1970 (35 FR 14067). Critical habitat has not been designated. The speeies faees two major threats-loss of habitat and the inability to interact suecessfully with non-native fish species, especially other gambusia species (USFWS 1983e).

\section{Pecos Assiminea Snail, Roswell Springsnail, Koster's Springsnail, and Noel's Amphipod}

The primary referenee for this seetion is:

USFWS. 2005h. Listing Roswell Springsnail, Koster's Springsnail, Pecos Assiminea, and Noel's Amphipod as Endangered With Critical Habitat. Federal Register 70(152):46304-46333.

References eited in this seetion are internal to the above-referenced document. A complete list of these references is available from the USFWS New Mexico Ecological Services Field Office, Albuquerque, New Mexieo.

The 2010 5-year review for the Roswell springsnail, Koster's springsnail, Noel's amphipod, and Pecos assiminea snail (USFWS 2010aa) was eonsulted for updated information on these species.

The Roswell springsnail (Pyrgulopsis roswellensis), Koster's springsnail (Juturnia kosteri), and Pecos assiminea snail (Assiminea pecos) oceur at sinkholes, springs, and associated spring runs and wetland habitats in New Mexico and Texas. These species are assoeiated with the Roswell Basin, which has a surface area of around 12,000 square miles and is located in southeastern New Mexico. The Roswell Basin contains two major aquifers, which are the sources of springs inhabited by these rare snail species. The action of water on soluble rocks, such as limestone and dolomite, has formed abundant physical features, including sinkholes, caverns, springs, and underground streams (White et al. 1995).

The Roswell springsnail occurs at several locations on the Bitter Lake National Wildlife Refuge in Chaves County, New Mexico. This species was formerly known from several other springs in the Roswell area, but these habitats have dried up, apparently as a result of groundwater pumping (Cole 1981; Taylor 1983, 1987). Koster's springsnail also occurs on the Bitter Lake National Wildlife Refuge, and potentially at North Spring on privately owned land east of Roswell. Like the Roswell springsnail, the species was formerly found at several other springs in the Roswell area that have since dried up as a result of groundwater pumping. The Pecos assiminea snail is currently known from sites at Bitter Lake National Wildlife Refuge; from a large population at Diamond Y Spring and its associated drainage in Pecos County, Texas; and at East Sandia Spring in Reeves County, Texas.

The Roswell springsnail, Koster's springsnail, and Pecos assiminae are all aquatic species. As with other snails in the family, the Roswell springsnail and Koster's springsnail are completely aquatic but can survive in seepage areas, as long as flows are perennial and within the species' physiological tolerance limit. These two snails occupy 
springs with variable water temperatures $\left(50\right.$ to $68^{\circ} \mathrm{F}$ ) and slow to moderate water veloeities, over eompact substrate ranging from deep organic silts to gypsum sands and gravel and eompaet substrates (New Mexieo Department of Game and Fish 1998). In eontrast, the Peeos assiminea snail seldom oceurs immersed in water, but prefers a humid mierohabitat ereated by wet mud or the undersides of vegetation mats, typieally within an inch or so of rumning water.

Like most snails, the Roswell springsnail. Koster's springsnail, and Peeos assiminea snail feed on algae, baeteria, and deeaying organie material (New Mexieo Department of Game and Fish 1988). They will also aceidentally ingest small invertebrates while grazing on algae and detritus.

These three snail speeies have life spans of 9 to 15 months, and reproduee several times during the spring through fall breeding season (Taylor 1987, Pennak 1989, Brown 1991). All three speeies belong to a family of snails that are sexually dimorphie, with females eharaeteristieally larger and longer-lived than males.

Noel's amphipod (Gammarus desperatus) is a small freshwater erustacean that eommonly inhabits shallow, eool, well-oxygenated waters of streams, ponds, ditehes, sloughs, and springs (Holsinger 1976, Pennak 1989). Noel's amphipod is one of three speeies of endemie amphipods of the Peeos River Basin oeeurring from Roswell, New Mexieo, south to Fort Stoekton, Texas. Noel's amphipod is eurrently known from multiple sites at Bitter Lake National Wildlife Refuge, as well as in several springs just outside the National Wildlife Refuge boundary on private property owned by the City of Roswell (USFWS 2010aa).

Beeause they are light-sensitive, bottom-dwelling amphipods are aetive mostly at night and feed on algae, submergent vegetation, and deeaying organie matter (Holsinger 1976, Pennak 1989). Young amphipods depend on mierobial foods, sueh as algae and baeteria, assoeiated with aquatie plants (Covieh and Thorp 1991).

Most amphipods complete their life eyele in 1 year and breed from February to Oetober, depending on water temperature (Pennak 1978). Amphipods form breeding pairs that remain attached for 1 to 7 days at or near the substrate while eontinuing to feed and swim (Bousfield 1989). They ean produce from 15 to 50 offspring, forming a brood.

The Roswell springsnail, Koster's springsnail, Peeos assiminea snail, and Noel's amphipod were federally listed as endangered on August 9, 2005 (70 FR 46304). Critieal habitat, designated on June 7, 2011, ineludes approximately 523 aeres in Chaves County, New Mexieo and Peeos and Reeves Counties, Texas (76 FR 33036). Critieal habitat ineludes areas within the Bitter Lake National Wildlife Refuge, as well as land owned by the City of Roswell and The Nature Conservaney. Primary constituent habitat elements for these speeies include permanent, flowing, unpolluted fresh to moderately saline water; slow to moderate veloeities of water over substrates ranging from deep organie soils to limestone eobble and gypsum substrates; presenee of algae, submergent vegetation, and detritus in the substrata; and water temperatures ranging from 50 to $68^{\circ} \mathrm{F}$, with natural diurnal and seasonal variation slightly above and below that range. All four speeies have an exeeedingly limited distribution and are imperiled by loeal and regional groundwater depletion, surface and groundwater eontamination, oil and gas extraetion aetivities within the supporting aquifer and watershed, and direet loss of their habitat (e.g., through burning or removing marsh vegetation, eementing, or filling of habitat).

\section{Devil's Hole Pupfish, Warm Springs Pupfish, and Ash Meadows Amargosa Pupfish}

The primary referenee for this seetion is:

USFWS. 1990d. Reeovery Plan for the Endangered and Threatened Speeies of Ash Meadows, Nevada. Portland, Oregon.

Referenees eited in this seetion are internal to the above-refereneed doeument. Full eitations have been ineluded in the Bibliography.

The 2010 5-Year Status Review for the ash meadows amargosa pupfish (USFWS 2010bb) has been eonsulted for updated information on this speeies. 
The Devil's Hole pupfish (Cyprinodon diabolis), Warm Springs pupfish (C. nevadensis pectoralis), and Ash Meadows Amargosa pupfish (C. nevadensis mionectes) oceur in aquatic habitats in Ash Meadows, located in the Mojave Desert in California and Nevada. The area can be described as a watered island in an expansive desert. Aquatic habitats are spring-fed. The surrounding uplands receive less than 2.75 inches of rainfall a year and are primarily comprised of creosote bush plant communities.

The Devil's Hole pupfish is restricted to a limestone cave located on the east eentral border of Ash Meadows, in addition to small refugia populations that have been established. The Ash Meadows population is dependent on a legal requirement to maintain a minimum water level within Devil's Hole, although levels are not currently high enough to meet recovery eriteria. Essential habitat for this species includes 21,760 acres encompassing the area where groundwater removal most influences the water level in Devil's Hole.

The Devil's Hole pupfish is a primarily annual species with a fluctuating population. Spawning oceurs throughout the year, but peaks during the spring (Minckley and Deacon 1975). Eggs are deposited singly onto the substrate and then fertilized.

The Warm Springs pupfish oceupies six small springs within an area encompassing less than 0.77 square miles situated approximately 0.62 miles west of Devil's Hole (Miller and Deacon 1973). All of the species' habitats are isolated from other aquatic environments. Spring discharge is minimal, and flows less than 1.25 miles before disappearing into the soil. All of the Warm Springs pupfish populations are believed to be quite small because of the limited available habitat.

The peak spawning period for the Warm Springs pupfish is in the spring, and the size of populations fluetuates substantially throughout the course of a year. Threats to the species include the vulnerability of habitat to alteration, and predatory and/or competing species. Essential habitat for the species includes 2,240 acres surrounding all of its habitat (USFWS 1976), and represents the area in which groundwater pumping is most likely to negatively affeet spring discharge.

The Ash Meadows Amargosa pupfish oecurs in nearly all of the surface waters within the Ash Meadows Refuge, inholdings, and adjacent land in the Amargosa Valley in Nye County, Nevada (USFWS 2010bb). Most habitats are spring sources and outflow channels of varying sizes. The aquatic habitats that support this species have been altered by diversion into earthen or conerete channels, impoundment, drying eaused by pumping of groundwater, and/or, elimination of riparian vegetation during ground leveling. Introduced organisms are also a threat. The spawning of the Ash Meadows Amargosa pupfish is believed to be similar to that of the Warm Springs pupfish.

The Devil's Hole pupfish was federally listed as endangered on March 11, 1967 (32 FR 4001). Critical habitat has not been designated. The Warm Springs pupfish was federally listed as endangered on Oetober 13, 1970 (35 FR 16047). Critical habitat has not been designated. The Ash Meadows Amargosa pupfish was federally listed as endangered on September 2, 1983 (48 FR 40178), after an emergency listing in May 1982 (47 FR 19995). At the same time, several springs and associated outflows in Nye, County, Nevada were designated as eritical habitat for the species.

\section{Desert Pupfish}

The primary reference for this section is:

USFWS. 1993i. Desert Pupfish Recovery Plan. Phoenix, Arizona.

References cited in this section are internal to the above-referenced document. Full citations have been included in the Bibliography.

The 2009 5-year review for the desert pupfish (USFWS 2009ss) was consulted for updated information on this species. 
The desert pupfish (Cyprinodon macularis) was once widespread and abundant in portions of Southern Arizona, Southeastern California, and adjacent Mexico (Miller 1943). Historical habitats, which varied in size, complexity, character, and permanence, included cienegas, springs, strcams, and margins of larger lakes and rivers (Minckley 1973). Naturally occurring populations in the U.S. are now restricted to two tributary streams to the Salton Sea, as well as a few shoreline pools and irrigation drains, in California. They also occur in a wash near Hot Mineral Spa when conditions are suitable. No natural populations of the species remain in Arizona, although numerous captive and wild reestablished populations currently exist. These populations have becn established on private, municipal, county, state, and federal lands (USFWS 2009ss).

The descrt pupfish is remarkably tolerant of extreme environmental conditions (Dcacon and Minckley 1974), such as high temperature, low dissolved oxygen (Barlow 1958), and high salinity (Lowe et al. 1967). Pupfish are opportunistic omnivores, consuming whatever algae, plants, invertebrates, and detritus are available (Cox 1966, 1972; Naiman 1979).

Under conditions of abundant food and suitable temperature, desert pupfish may become sexually mature as early as six weeks of age (Moylc 1976). Most do not begin to breed until their second summer. Male pupfish are highly aggressive, establishing and defending territories, while females swim in loose schools until they are rcady to spawn (Cowles 1934, Barlow 1961).

The desert pupfish was federally listed as endangered on March 31, 1986 (51 FR 10842). At the same time, critical habitat was designated at Quitobaquito Spring, Organ Pipc Cactus National Monument, Pima County, Arizona; and along portions of San Felipe Creek, Carrizo Wash, and Fish Creek Wash, Impcrial County, California. The species is threatened with extinction throughout its native range, primarily because of habitat loss and modification, pollution, and introduction of exotic fishes (USFWS 1986d). The Salton Sca, Quitobaquito Springs, and the Rio Sonoyta have suffered water level declines and associated habitat loss, fragmentation, and degradation. Water availability to the desert pupfish will continue to interact with predicted trends for warmer, drier, and more extreme hydrological conditions associated with climatc change. New non-native aquatic species continue to establish within the desert pupfish's range, and previously existing non-native species increasc in numbers and distribution (USFWS 2009ss).

\section{Temperate Steppe Ecoregion}

The Temperate Steppe Ecoregion supports a semiarid climate with cold, dry winters and warm, hot summers. This region includes the Rocky Mountains, in which the headwaters of a number of major river systems (e.g., the Colorado, Green, Missouri, Snake, Platte, and Rio Grande) are located. Most of the TEP aquatic species that occur in this ccoregion are large river-dwelling fish species.

\section{Kootenai River White Sturgeon}

The primary reference for this section is:

USFWS. 2008u. Critical Habitat Revised Designation for the Kootenai River Population of White Sturgeon (Acipenser transmontanus). Federal Register 73(132):39506-39523.

References cited in this section are internal to the above-referenced document. A complete list of these references is available from the USFWS Upper Columbia Fish and Wildlife Office, Spokane, Washington.

The Kootenai River population of white sturgeon (Acipenser transmontanus) is restricted to approximately 168 river miles of the Kootenai River in Idaho, Montana, British Columbia, Canada. The range of this land-locked population extends from below Libby Dam, Montana, downstream through Kootenay Lake to Corra Linn Dam at the outflow from Kootenay Lake in British Columbia. The downstream waters of the Kootenay Lake drain into the Columbia River system. Habitat in the Kootenai River can be divided into the canyon reach, canyon reach, which extends from Kootenai Falls at river mile 193.9 in Montana to river mile 159.7 below the confluence with the Moyie River in ldaho; the braided reach, which begins at the end of the canyon reach and extends downstream to 
river mile 152.6 at Bonners Ferry; and the meander reach, which extends from the end of the braided each at river mile 152.61 downstream to the confluence with Kootenay Lake in British Columbia at river mile 74.6.

The canyon reach is characterized by rocky substrates and a relatively high water surface gradient. Downstream the valley broadens, and the river forms the low-gradient braided reach as it courses through multiple shallow channels over gravel and cobbles (Barton et al. 2005; Berenbrock 2005a). The meander reach is characterized by primarily sandy substrate, a low water-surface gradient, a series of deep holes, and low water velocities under present river operations. A deep hole near Ambush Rock at approximately river mile 151.7 (Berenbrock 2005b) is frequented by sturgeon in spawning condition. Both adult and juvenile sturgeon forage in and migrate freely throughout the lower Kootenai River, but apparently no longer commonly oceur upstream of Bonners Ferry, Idaho (Partridge 1983; Apperson and Anders 1990, 1991), although there are no apparent physical barriers to sturgeon migration within these three geomorphic reaches of the Kootenai River.

White sturgeon are considered opportunistic feeders, and have been observed feeding on a variety of prey items, including clams, snails, aquatic insects, and fish. They are generally long-lived, with females living from 34 to 70 years (Pacific States Marine Fisheries Commission 2008). Kootenai sturgeon males and females do not reach sexual maturity until 28 and 30 years, respectively (Paragamian et al. 2005). Thereafter, females spawn at 4- to 6year intervals.

Many Kootenai sturgeon spend part of their lives in Kootenay Lake in British Columbia and migrate upstream to spawn in the Kootenai River. The sturgeon have been described as having a unique two-step pre-spawning migration process, migrating first from the lower river and Kootenay Lake during autumn to staging reaches in the Kootenai River, then migrating in spring to the spawning reach near Bonners Ferry, ldaho (Paragamian et al. 2001, 2002). Suceessful reproduction is dependent upon Kootenai sturgeon spawning at sites where the eggs can settle in an area that supports their viability, and where the free embryos that emerge from the eggs have appropriate habitat for development and protection from predators. For the Kootenai sturgeon, these needs appear to be met by rocky substrates for spawning and attachment of eggs, and meeting in-water minimum flow, depth, and temperature requirements on at least an intermittent basis during the spawning period.

Spawning oceurs when the physical environment permits egg development and cues ovulation. White sturgeon are broadeast spawners, releasing their eggs and sperm in fast water. Kootenai River white sturgeon spawn during peak flows, from May through July (Apperson and Anders 1991), when high water velocities disperse and prevent clumping of the adhesive eggs. Following fertilization, eggs adhere to the river substrate and hateh after a relatively brief incubation period of 8 to 15 days, depending on the water temperature (Brannon et al. 1984). Upon hatching, embryos become "free embryos" (a life stage with continued dependence on yolk materials for energy). If adequate cover is available, free embryos swim into the inter-gravel spaces in the substrate, which provide shelter and cover during this hiding phase (USFWS $2011 \mathrm{w}$ ). As the yolk sac is depleted, free embryos become free swimming foraging larvae, which are entirely dependent on forage for food and energy and that initiate a downstream dispersal.

Although Kootenai sturgeon continue to spawn annually in the Kootenai River, this spawning has not resulted in significant levels of recruitment for over 30 years. Although most eggs are being fertilized (Paragamian et al. 2001 ), it is estimated that on average, a total of only about 10 juvenile sturgeon currently may be naturally produced in the Kootenai River annually (Paragamian et al. 2005). This recruitment failure is attributed largely to the spawning of Kootenai sturgeon over unsuitable sandy substrates (Paragamian et al. 2001) after the construction of the Libby Dam.

The USFWS listed the Kootenai River population of white sturgeon as endangered on September 6, 1994 (59 FR 45989). This population has been in general decline since the mid-1960s, when the Libby Dam began operation. Human activities have modified the natural flows of the Kootenai River, thereby altering the spawning, egg incubation, and rearing habitats of white sturgeon, and reducing overall biological productivity. These factors have contributed to the general lack of recruitment in the white sturgeon population since the mid-1960s. Currently, the 
primary threat to this population is a laek of nutrients neeessary for survival of larval to age-2 Kootenai sturgeon (USFWS 2011w).

\section{Pallid Sturgeon}

The primary referenee for this seetion is:

Duffy, W.G., C.R. Berry, and K.D. Keenlyne. 1996. Biology of the Pallid Sturgeon with an Annotated Bibliography through 1994. South Dakota Cooperative Researeh Unit Teehnieal Bulletin Number 5. South Dakota State University. Brookings, South Dakota.

Referenees eited in this seetion are internal to the above-referenced doeument. Full eitations have been ineluded in the Bibliography.

The 2007 5-year review for the pallid sturgeon (USFWS 2007v) was eonsulted for updated information on this speeies.

The pallid sturgeon (Scaphirhyncus albus) is found at the sandy or rocky bottoms of swift, large, turbid and freeflowing rivers in the Missouri and Mississippi river drainages of central North Ameriea. It is one of the largest freshwater fish in North Ameriea. Redueed from its historie range, the present distribution of this species includes the Missouri River to Fort Benton, Montana; the lower Mississippi River from New Orleans to its juneture with the Missouri River; the Atchafalaya River to its connection with the Mississippi River; and the lower Yellowstone River from the mouth of the Tongue River to its juncture with the Missouri River. At present, the eomplete range of the pallid sturgeon is approximately 3,500 miles.

Pallid sturgeon prefer turbid, flowing riverine habitat with roeky or sandy substrate and water depths of 13 to 16 feet (Erickson 1992). They inhabit floodplains, baekwaters, ehutes, sloughs, islands, sandbars, and main ehannel waters. In the Missouri River, sturgeon have been captured in the main ehannels along sandbars at the inside of river bends and behind wing dikes with deeply seoured trenches (Carlson et al. 1985). Fish eolleeted in the Missouri River have been loeated primarily upstream of reservoirs, and show a preferenec for riverine-like eonditions, if they exist (Kallemeyn 1983). The pallid sturgeon eats a range of foods, from aquatie inseets to fish, depending on life stage (USFWS 2007v).

Males reach sexual maturity between 5 and 7 years of age, and females become sexually mature at 15 years of age (Keenlyne and Jenkins 1993). Pallid sturgeon may spawn as early as April in the lower portion of their range, or as late as early June in the extreme northern portion of their range. Reproduetion eoineides with natural high river flows. Under wild eonditions, males do not spawn every year, and females may take up to 10 years between spawnings, depending on the quality and quantity of food available in their natural habitat. Therefore, feeundity of a female may vary eonsiderably, with an individual female spawning only a few times during the normal life span. Larval fish produced during spawning events drift downstream from the hatehing site and begin to settle from the lower portion of the water eolumn 11 to 17 days post hateh (USFWS 2007v).

The pallid sturgeon was federally listed as endangered on June 9, 1990 (55 FR 36641). Critieal habitat has not been designated. Over the years, the habitat of the pallid sturgeon has been dramatieally altered. The most apparent ehange is the series of impoundments on the main stem of the upper Missouri River and ehannelization of the lower Missouri and Mississippi Rivers. The upper Missouri River dams have ereated physieal bloekages that prohibit normal migration patterns, alter habitat charaeteristies, and restriet riverine fish to limited flowing river reaches (Hesse et al. 1989). Approximately 51 pereent of the range of the pallid sturgeon has been ehannelized, 28 pereent has been impounded, and the remaining 21 percent is affeeted by upstream impoundments that alter flow regimes and modify both turbidity and water temperatures (Kennlyne 1989). These forms of habitat alteration have ehanged river parameters such as eurrent veloeity, seasonal flows, turbidity, temperature, and nutrient supply paths within the food ehain (Hesse 1987). These modifieations negatively affeet the pallid sturgeon by blocking movements to spawning and/or feeding areas, destroying spawning areas, altering conditions or flows of potential remaining spawning areas, and redueing food sourees or the ability to obtain food (Keenlyne 1989). The speeies 
continues to be threatened by habitat loss and inadequate regulatory mechanisms in all or portions of its range, and certain water quality contaminants may have an effect on reproduction (USFWS 2007v).

\section{Greenback Cutthroat Trout}

The greenback cutthroat trout (Oncorhyncus clarki stomias) historically occurred in the sourees of the South Platte River and Arkansas River in Colorado, from the headwaters to the foothills, and in a few headwater tributaries of the South Platte River in a small area of southeastern Wyoming (Behnke 1992). The present distribution of the subspecies includes areas in the South Platte Drainage: east slope drainages of Rocky Mountain National Park (Cow and Hidden Valley Creeks; Pear Reservoir; West and Fern Creeks; Fern, Bear, Caddis, and Odessa lakes; Big Thompson River); Como Creek, South Boxelder Creek, South Fork of the Cache La Poudre River, and Black Hollow Creek. Greenback eutthroat trout are also found in the Arkansas River drainage: South Huerfano and Cascade Creeks in San Isabel National Forest, Hourglass Creek, and Lake Fork above Turquoise Lake.

All of the present habitat where the subspecies occurs is essentially undisturbed headwaters of drainages from 7,000 to 11,000 feet elevation in the Rocky Mountain National Park, on Forest Service-administered lands (Roosevelt, San Isabel, and Pike National Forest), and in one spring-fed pond on Fort Carson. With the exception of the Fort Carson pond, all habitats are associated with montane conifer forests and meadows. Some streams contain beaver dams and beaver ponds. There is nothing unique about greenback habitat, and the subspecies is able to live in any habitat and tolerate any water quality that supports other species of trout. However, greenback cutthroat trout eannot coexist with other species because of competition and/or hybridization (Behnke and Zarn 1976; Behnke 1976, 1979). Thus, any trout habitat can be greenback trout habitat if no other species of trout are present.

There is no evidence to suggest that greenback trout have feeding preferences that distinguish them from other trout species. Therefore, it can be assumed that a greenback trout of similar size and existing in similar habitat as other trout species will feed on similar food items-predominantly aquatic insects in streams, and zooplankton and benthic crustaceans and insects in lentic environments.

Cover and shelter requirements are similar to those of other trout species. Young and juvenile fish select shallower, more open habitats, and larger, older fish select deeper areas with more cover (boulders, log jams, particularly undercut streambanks). Present habitat of most greenback populations are very small streams, from 5 to 20 feet wide (Behnke and Zarn 1976, USFWS 1983d). Reproductive site requirements are similar to those of other trout species-suitable gravel substrate ( 0.25 to 2.0 inches in size) with adequate flow to maintain oxygen requirements of incubating eggs is necessary for successful reproduction (Behnke and Zarn 1976). No innate migration patterns exist, only movements during spawning to the nearest site with suitable spawning substrate.

Greenback trout attain sexual maturity at 2 or 3 years of age. Spawning in steams oceurs annually after first maturation, in spring and early summer, peaking when daily water temperature exceeds $45{ }^{\circ} \mathrm{F}$. The female construets a spawning bed in gravel, and several males are usually in attendance, with the dominant male constantly driving away subdominant males. The dominant male fertilizes most of the eggs during the spawning act, but smaller, subdominant males may dart in, shedding sperm, and fertilize some eggs. The female may construct and spawn in two or three spawning beds over several days. On average, females lay 700 to 1,000 eggs per pound of body weight (Behnke and Zarn 1976). After the eggs are spawned and fertilized, the female covers them with gravel. After this, no additional parental eare is given to eggs or of fspring. Maximum life span in small streams is typically 4 or 5 years, although in lakes greenbacks may live 8 to 10 years.

The greenback cutthroat trout was federally listed as endangered on April 18, 1978 (43 FR 16343). Critical habitat has not been designated. In the late $19^{\text {th }}$ century the greenback cutthroat trout was greatly reduced in abundance by toxic mine pollution, and irrigation diversions for agriculture. Problems that have added to the decline of the trout include water drawdown, water temperature alteration, siltation, and erosion (linked to grazing and general agricultural practices). Other factors that have impacted the subspecies include timber removal; hydroelectric power diversions; man-made pollution caused by effluents from industrial, human sewage, and agricultural practices; and physical damage to watersheds caused by such construction activities as highways, ski areas, and 
housing developments (Behnke 1976, Behnke and Zarn 1976, USFWS 1977). Non-native trout (brook, rainbow, brown and other subspeeies of cutthroat trout) have also been widely introdueed throughout the range of the greenbaek. All pure populations of the greenback eutthroat trout oecur in tiny headwater streams above barriers to upstream migration that proteet the subspecies from non-native trout. Any impaet on trout habitat, sueh as the loss of riparian vegetation, flow depletion, and aeeelerated erosion, would affect a greenback trout population in the same manner as it would other species of trout. Low-level threats to the speeies inelude the ongoing negative effeets of past mining operations on water quality; the impaets of grazing, logging, and road and trail construction use on riparian streambanks and erosion; and the eo-oeeurrenee of non-native salmonids with greenbaek populations. The potential risk of eatastrophic wildfire to destroy habitat, or the potential for fish to be killed by fire retardants used to fight wildfires, has inereased since the species was listed. Climate ehange is also a potential threat to the species (USFWS 2009tt).

\section{Kendall Warm Springs Dace}

The Kendall Warm Springs dace (Rhinichthys osculus thermalis) is assoeiated with the numerous seeps and springs of the Kendall Warm Springs area and its outflow stream located along the north faee of a small limestone ridge. The Kendall Warm Springs, which are hydrologieally linked to the Green River, are located within the BridgerTeton National Forest in Sublette County, Wyoming. Although this National Forest is managed by the Forest Service, the speeies oeeurs on the BLM's list of TEP speeies beeause the BLM manages subsurfaee resourees in the area. However, none of the proposed vegetation treatments would oceur in or near habitat oeeupied by the Kendall Warm Springs daee. Therefore, this speeies will not be discussed further in this BA.

\section{Mediterranean Ecoregion}

Aquatie habitats in the Mediterranean Eeoregion, loeated along the Paeifie Coast and including most of California and a portion of Oregon, are influeneed by a number of faetors. Rivers along the eoast reeeive medium to high inputs from rainfall. Surface runoff in the region is rapid, water storage is relatively short, and rivers are prone to low flows during times of drought (Myers et al. 1998). The Sicrra Nevada mountains receive predominantly winter rain, and eontain the headwaters for the Rogue, Klamath, and Saeramento Rivers. The hills in the rainshadow of the eoastal mountains experienee relatively low annual rainfall, and support tributary rivers to the Saeramento and San Joaquin rivers. The Saeramento and San Joaquin Rivers run through California's Central Valley, a region that is heavily influeneed by agrieultural praetiees. These rivers have peak flows in February and experienee low flows in September and Oetober after the summer drought. They are also the main migratory corridors for a number of anadromous salmon speeies, and empty into the Pacifie Ocean via the San Franeisco Bay. The Mediterranean Ecoregion also supports vernal pool habitats, whieh provide habitat for a number of rare mollusk speeies.

\section{Modoc Sucker}

The Modoe sueker (Catostomus microps) is known from a few widely separated tributary systems to the upper Pit River in northeastern California (the Rush-Ash Creek system and the Washington-Turner-Hulbert system [Moyle 1976, Ford 1977]) and the Goose Lake sub-basin in southern Oregon and northern California. The eurrent distribution of the species ineludes populations in ten streams in three sub-drainages (USFWS 2009uu). This speeies oeeurs primarily in seetions of stream with low or intermittent flow, or pools of the meadowlands (Moyle and Marioehi 1975, Moyle 1976, Ford 1977). In general, sites where Modoe suekers have been found are eharaeterized by the following: low flows (intermittent in some); largely shallow pools; muddy bottoms; partial shade trees, shrubs, boulders, or undereut banks; abundant eover from riparian vegetation and undereut banks; and moderately elear water (Moyle and Marioehi 1975). Water temperatures (summer and fall) in Modoc sucker habitat range from $46{ }^{\circ} \mathrm{F}$ (fall) to $74^{\circ} \mathrm{F}$ (summer; Ford 1977). Modoc suekers are omnivorous, feeding on detritus, diatoms, filamentous algae, ehironomid larvae, erustaceans, and aquatie insect larvae. Adult suckers usually remain on the bottom or elose to it (Martin 1972).

Spawning usually oecurs from mid-April to the last week in May or the first week in June (Boeeone and Mills 1979). Spawning oeeurs over eoarse fine gravel in the lower end of pools with abundant eover. Water temperatures range from 56 to $61{ }^{\circ} \mathrm{F}$. There is some evidenee from Johnson and Washington Creeks of upstream migration by Modoc suekers to small intermittent tributaries, sueh as Higgins and Riee flats, during spawning season. Also, a 
possible spawning migration of Modoc suckers has been observed from Moon (Lake) Reservoir upstream into Cedar Creck.

The Modoc sucker was federally listed as endangered on June 11, 1985 (50 FR 24526). At the same time, eritical habitat was designated in Modoc County, California. Designated habitat includes intermittent and permanent water and adjacent land areas that provide vegetation for cover and protection from soil erosion of all or portions of: Turner Creek, Hulbert Creek, Cedar Creek, Washington Creek, Coffee Mill Gulch, Johnson Creek, Higgins and Riee flats, and Rush Creek, Modoc County, California. The original reasons for listing were the species' very restrieted distribution combined with destruetion of habitat. However, habitat eonditions have shown substantial improvements, and the population of the species is showing an upward trend. The principal remaining threat to the Modoe sueker is predation by non-native fishes, in particular brown trout in the Ash Creek sub-drainage and largemouth bass in the Turner subdrainage. While the Modoc sucker has survived for deeades in the presenee of non-native fish, if left unchecked, introduced fish predators have the potential to threaten the Modoc sucker with loeal extinction in at least one of three sub-drainages (USFWS 2009uu).

\section{Owens Pupfish}

The primary reference for this section is:

USFWS. 1998q. Owens Basin Wetlands and Aquatic Speeies Reeovery Plan, Inyo and Mono Counties, California. Portland, Oregon.

Referenees eited in this section are internal to the above-referenced document. Full eitations have been included in the Bibliography.

The 2009 5-year review for the Owens pupfish (USFWS 2009vv) was reviewed for updated information on this species.

The Owens pupfish (Cyprinodon radiosus) occurs in aquatic habitats in the Owens Basin, which is located in east central California in the rain shadow of the Sierra Nevada. The species inhabits areas where water is relatively warm and food is plentiful. Historically, the species occurred in aquatic habitats throughout the Owens Valley, but populations declined as a result of competition and predation by non-native species and water diversion from the Owens River and its tributaries. Currently, there are four populations of the Owens pupfish: Fish Slough, Mule Springs, Well 368, and Warm Springs (USFWS 2009vv). The latter three were established after listing. Two subpopulations at Fish slough, the population at Mule Springs, and the population at Well 368 are all managed by the BLM (USFWS 2009vv).

Compared to habitats occupied by other pupfish species in the southwest, the Owens pupfish occurs in habitats that are generally colder and lower in conductivity and salinity (Cole 1981). They oeeupy most aquatic habitats where water is relatively warm and food is plentiful (USFWS 2009vv). They eongregate in small schools and feed mostly on aquatic insects. However, they are opportunistic omnivores; their diet typically includes invertebrates and plants that are most abundant in the environment.

Females begin producing eggs when water temperatures are near $57^{\circ} \mathrm{F}$, and spawning oecurs over soft substrates in the spring and summer (Mire 1993). Eggs incubate for approximately 6 days before hatehing in water temperatures ranging from 75 to $81{ }^{\circ} \mathrm{F}$. Juveniles grow to sexual maturity in 3 to 4 months (Barlow 1961) and usually spawn before their first winter; their lifespan is rarely greater than I year (Soltz and Naiman 1978), although they may live as long as 3 years in refuge habitats (Mire 1993).

The Owens pupfish was federally listed as endangered on March 11, 1967 (32 FR 4001). Critical habitat has not been designated. All of the refuges in which populations of the species occur are managed to isolate the pupfish from non-native fishes. Current major threats to the Owens pupfish include habitat encroachment by aquatic vegetation, predation by non-native species, and stochastic factors. 


\section{Shasta Crayfish}

The primary reference for this seetion is:

USFWS. 1998r. Reeovery Plan for the Shasta Crayfish (Pacifastacus fortis). Portland, Oregon.

The Shasta erayfish (Pacifastacus fortis) is the only surviving speeies of erayfish endemic to California. Populations of this speeies are limited to the midseetions of the Pit River drainage, primarily the Fall River and Hat Creek subdrainages in Shasta County. The greatest densities of Shasta erayfish are found in the pristine headwater springs of the Fall River, a few of whieh support loeally abundant isolated populations. The distribution of this speeies is tied to the distribution of lava eobbles and boulders that originated in the voleanie geology of the Modoe Plateau.

Shasta erayfish are generally found in eold, elear, spring-fed headwaters. In general, suitable habitat is defined by the availability of eover, or refugia, provided by elean lava eobbles and boulders on gravel or sand. Although potential food resourees, temperature, and water ehemistry eonstituents (e.g., dissolved oxygen, ealeium, pH) may also limit the distribution of the Shasta erayfish, the range of eonditions under whieh the speeies is found is eonsiderable.

Shasta erayfish are aetive only at night, remaining hidden during the day. In general, they eome out from hiding after dark to browse on the periphyton (i.e., the eommunity of plants, animals, and associated detritus, or debris) that adhere to and form a surfaee eoating on the abundant lava roeks. Crayfish that are found in the open during daylight have generally either been disturbed from their refuge or appear ill.

The primary food of the Shasta erayfish appears to be the periphyton and invertebrates that are abundant in the speeies' native environment. Other potential food resourees inelude trout, sueker, and seulpin eggs, whieh are seasonally abundant. Although some of the items the erayfish will eonsume are known, nothing is known about the speeies' aetual nutritional requirements.

Shasta erayfish are long-lived and slow-growing, and take approximately 5 years to reach sexual maturity. Mating oeeurs in Oetober or November, when the male deposits a eapsule eontaining sperm, or spermatophore, on the underside of the female. Shortly afterwards, the female lays 10 to 70 eggs, whieh she fertilizes with sperm from the spermatophore and then attaehes to the underside of her abdomen or tail. In the spring, the eggs hateh into immature larval forms, or first instars, that are attaehed to the undersides of the female's abdomen by threads to the inner egg membrane. These first instars then molt into seeond instars, miniatures of the adult that elasp the female with their tiny elaws. After a seeond molt, the third instars grow in size and eventually beeome free-living.

The Shasta erayfish was federally listed as endangered without eritieal habitat on September 30, 1988 (53 FR 38460). The limited distribution of the speeies, eoupled with its apparent deeline, led to its endangered status. Overall, Shasta erayfish have a low abundanee and fragmented distribution, with migration and genetie exehange between populations limited by hydroeleetrie development, natural barriers, and loss of habitat. The primary threats to the speeies are the introduetion and expansion of non-native speeies, and disturbanees related to land use praetiees.

\section{Unarmored Threespine Stickleback}

The unarmored threespine stieklebaek (Gasterosteus aculeatus williamsoni) has been extirpated from most of its range in Southern California, and is now limited to a small, remnant range. The subspeeies is eurrently restrieted to three areas: the upper Santa Clara River and its tributaries in Los Angeles County, San Antonio Creek on Vandenberg Air Foree Base in Santa Barbara County, and the Shay Creek vieinity in San Bernardino County. San Felipe Creek in San Diego County (a site of a transplant of the subspeeies) is another area that may support the subspeeies, although its eurrent status in this loeation is unknown (USFWS 2009ww). Unarmored threespine stieklebaeks oeeur in shallow (less than 3.3 feet deep) eoastal streams often flowing through riparian woodlands within dry mixed rangeland. The streams always have a very low gradient, and usually do not support rainbow trout or speekled daee, whieh often oeeur in higher gradient reaehes of the same drainages, sometimes along with low plated stieklebaeks. Observations of the Soledad Canyon population indieate that the speeies prefers areas of 
moderate flow with vegetation for cover. Riffles and ponds are the major habitats available, and sticklebacks tend to be most numerous in small ponds with moderate flow. Most breeding takes place in small, man-made pools. Natural cover includes stream banks, rocks, sunken logs and, most importantly, vegetation (vascular plants and filamentous algae; Baskin 1974). Fry generally are found in vegetation, and presumably depend on it for protection from predatory fishes and invertebrates.

Although seasonal migrations are well documented for some threespine stickleback populations, freshwater sticklebacks, including those in southern California are not known to undertake migrations. However, they actively disperse as the aquatic habitat expands in the late fall, and they apparently are washed downstream during flooding (Baskin 1974; Bell 1974-1979; Irwin 1982).

Unarmored threespine sticklebacks reproduce throughout the year. Reproduction occurs in areas with adequate aquatic vegetation and slow-moving water, where males establish and vigorously defend territories (USFWS $2009 \mathrm{ww}$ ). In general, the males tend to establish territories and build nests on the bottom in shallow, still water near cover. The nests normally are construeted of decaying aquatic plant fibers, but males appear to accept a wide range of vegetation types for nest construction. Nests, which are built in shallow pits dug in sandy, muddy substrate, are generally construeted in or near vegetation (Kynard 1979). The male courts all females that enter his territory; a single nest may contain the eggs of several families (USFWS 2009ww). The female is courted, deposits eggs in the nest, and is then driven out of the territory. The male then returns to fertilize the eggs. Following spawning, the males care for the eggs and newly hatched fry and guard the nest and surrounding territory from predators.

The unarmored threespine stickleback was federally listed as endangered on October 13, 1970 (35 FR 16047). Critical habitat has not been designated. The following factors have been identified as persistent threats to the species: channelization, groundwater and surface water use (drawdown); introductions of exotic aquatic organisms; industrial and residential (urban) construction; agricultural development; the development of recreational parks in Soledad Canyon; and excessive growth of aquatic vegetation, which may reduce dissolved oxygen through plant respiration and decomposition. Currently, the most critical threats to the habitat of the unarmored threespine stickleback are urbanization, eutrophication, stream channelization, addition of water, groundwater removal, and water quality factors (USFWS $2009 \mathrm{ww}$ ).

\section{Santa Ana Sucker}

The primary reference for this section is:

USFWS. 2009xx. Endangered and Threatened Wildlife and Plants; Revised Critical Habitat for the Santa Ana Sucker (Catostomus santaanae); Proposed Rule. Federal Register 74(235):65056-65087.

References cited in this section are internal to the above-referenced document. A complete list of these references is available from the USFWS Carlsbad Fish and Wildlife Office, Carlsbad, California.

The Santa Ana sucker (Catostomis santaanae) is a small, short-lived fish that oceurs in the watersheds draining the San Gabriel and San Bernardino Mountains of southern California. They historically occupied diverse freshwater habitats from upper watershed areas to the Pacific Ocean (Moyle 2002; Swift et al. 1993). The species generally inhabits perennial streams with water from a few inches to several feet deep (Haglund and Baskin 2003). They are most abundant in unpolluted, clear water that is typically less than $72{ }^{\circ} \mathrm{F}$ (Moyle and Yoshiyama 1992). They prefer streams with coarse substrates and a combination of shallow riffle area and deeper runs and pools (Haglund et al. 2001; Haglund and Baskin 2003). Tributary streams also provide habitat, including shallow water refugia for larvae and fry from predators, and for juveniles and adults during storms. The species is eurrently known to occur in the Santa Ana River (San Bernardino, Riverside, and Orange Counties) and the San Gabriel River and Big Tujunga Creek, as well as tributary streams.

Santa Ana suckers feed primarily on algae, zooplankton, and detritus found on the surfaces of rocks and other hard substrates. A small amount of aquatic insect larvae, fish scales, and fish eggs are also consumed (Greenfield et al. 1970). 
Santa Ana suckers become reproductively mature during spring following hatching (Greenfield et al. 1970). Spawning typically oceurs in the spring, generally beginning in mid-March, peaking in April, and concluding by early July (Moyle 2002). Spawning may be dependent on loeal eonditions in each watershed (e.g., water temperature, stream size, or pattern of seasonal runoff). Females deposit eggs in gravel substrate without construeting any type of nest, with the eggs well camouflaged in the gravel. Eggs adhere to the substrate (Greenfield et al. 1970). Eggs hatch within approximately 15 days of fertilization. Females lay large quantities of eggs at a time, allowing the species to quickly repopulate streams following periodie flooding events, provided refuge is available within the stream.

The Santa Ana sueker was federally listed as threatened on April 12, 2000 (65 FR 19686). Critical habitat was originally designated in 2005 (70 FR 426), and was revised on December 14, 2010 (75 FR 77962) to include approximately 9,331 acres of habitat in the Santa Ana River, San Gabriel River, and Big Tujunga Creek. Threats to the species inelude potential habitat destruction, natural and human-induced changes in streamflows, urban development and related land-use praetiees, intensive recreation, introduction of non-native competitors and predators, and demographics associated with small populations. Their habitats are naturally subject to periodic, severe, flooding, and extended periods of drought that reduee the amount of perennial water flow in the species' habitats.

\section{Tidewater Goby}

The primary reference for this section is:

USFWS. 2009yy. Endangered and Threatened Wildlife and Plants; Designation of Critical Habitat for Tidewater Goby. Federal Register 78(25):8746-8819.

Referenees eited in this section are internal to the above-referenced document. A complete list of these referenees is available from the USFWS Ventura Fish and Wildlife Office, Ventura, California.

The tidewater goby (Eucyclogobius newberryi) is a small, short-lived speeies of fish that oeeurs along the eoast of California, in lagoons, estuarics, baekwater marshes, and freshwater tributaries. Historically, it oceurred from near the California-Oregon border to 44 miles north of the United States-Mexico border. Currently, the southernmost known, occupied locality is the San Luis Rey River in San Diego County. Its overall distribution has become patchy and fragmented, and the speeies is now found in six distinet areas in California: 1) Tillas Slough (Smith River) in Del Norte County to Lagoon Crcek in Mendocino County (North Coast (NC) Reeovery Unit); 2) Salmon Creek in Sonoma County to Bennett's Slough in Montercy County (Greater Bay (GB) Recovery Unit); 3) Arroyo del Oso to Morro Bay in San Luis Obispo County (Central Coast (CC) Recovery Unit); 4) San Luis Obispo Creek in San Luis Obispo County to Rincon Creck in Santa Barbara County (Conception Recovery Unit); 5) Ventura River in Ventura County to Topanga Creek in Los Angeles County (Los Angeles-Ventura Recovery Unit); and 6) San Pedro Harbor in Los Angeles County to Los Penasquitos Lagoon in San Diego County (South Coast Recovery Unit).

The habitats oecupied by the tidewater goby are dynamic and subjeet to eonsiderable fluctuations on a seasonal and annual basis. Wetland habitats are created through movement and deposition of sand along the eoast; these habitats are then scoured out by high flows associated with winter rains. The wetland habitats move up and down the coast, and inland or coastward in response to the movement of sand. Habitat for the tidewater goby may be a few acres in size, extending only a few hundred feet inland, or hundreds of acres in size, extending many miles inland.

Tidewater gobies feed mainly on maeroinvertebrates (Irwin and Soltz 1984; Swift et al. 1989; Swenson 1995). They have been observed spawning in every month of the year except Deeember (Swenson 1999). Reproduction peaks in late April to July, and can continue into November, depending on seasonal temperature and rainfall. Spawning aetivities have been documented at water temperatures between 48 and $77^{\circ} \mathrm{F}$, and at salinities between 1 and 30 parts per thousand (Swenson 1995). Salinities less than 10 parts per thousand are preferred (Moyle 2002).

The tidewater goby was federally listed as endangered on February 4, 1994 (59 FR 5494). Critical habitat for the species was designated in 2000 (65 FR 69693) and again in 2008 (74 FR 5920). Revised critical habitat for the 
species was designated on February 6, 2013 (78 FR 8745), and includes approximately 12,156 acres in Del Norte, Humboldt, Mendocino, Sonoma, Marin, San Mateo, Santa Cruz, Monterey, San Luis Obispo, Santa Barbara, Ventura, Los Angeles, Orange, and San Diego Counties. No critical habitat has been designated on BLM lands. Threats to the speeies inelude coastal development projects, water diversions and alterations, groundwater overdrafting, channelization of rivers, discharge of agrieultural and sewage effluents, eattle grazing and feral pig activity, introduced predator speeies, inadequacy of existing regulatory mechanisms, drought conditions, competition with introduced species, and loss of genetic diversity.

\section{Delta Smelt}

The primary reference for this section is:

USFWS. 2010ee. Endangered and Threatened Wildlife and Plants; 12-Month Finding on a Petition to Reclassify the Delta Smelt From Threatened to Endangered Throughout Its Range. Federal Register 75(66):17667-17680.

References eited in this seetion are internal to the above-refereneed doeument. A complete list of these references is available from the USFWS Sacramento Fish and Wildlife Office, Sacramento, California.

The delta smelt (Hypomesus transpacificus) is endemic to the San Franeiseo Bay and Saeramento-San Joaquin Delta Estuary (Delta) in California, found only from the San Pablo Bay upstream through the Delta in Contra Costa, Sacramento, San Joaquin, Solano, and Yolo Counties (Moyle 2002). Historically, they were very common in the upper Delta. Populations have been observed to populations fluetuate wildly since the 1970s, but are now at their lowest level ever.

The species requires specific environmental conditions (freshwater flow, water quality) and habitat types (shallow open waters) within the estuary for migration, spawning, egg ineubation, rearing, and larval and juvenile transport from spawning to rearing habitats (Moyle 2002). Delta smelt tolerate a wide range of salinities (but rarely more than 12 parts per thousand) and temperatures $\left(45\right.$ to $\left.78^{\circ} \mathrm{F}\right)$. It is thought that the species relies on certain levels of baekground turbidity for eertain behaviors, such as feeding. Delta smelt feed primarily on small free-floating crustaceans and oecasionally inseet larvae (Moyle 2002). They are thought to require a turbid environment for efficient, suceessful foraging.

Spawning has never been observed in the wild, but it is believed to oecur from late January through late June or early July, at water temperatures ranging from 45 to $59^{\circ} \mathrm{F}$ (Moyle 2002). In laboratory conditions, eggs typically hateh after 9 to 14 days, and larvae begin feeding 5 to 6 days later (Mager et al. 2004). Larvae are most abundant in the Delta from mid-April through May (Bennett 2005). After several weeks of development, larvae move downstream until they reach nursery habitat in the low salinity zone ( 2 to 7 parts per thousand). They reach adulthood in September or October and migrate back to freshwater areas where spawning is thought to oceur.

The delta smelt was federally listed as threatened on March 5, 1993 (58 FR 12854), with eritical habitat designated on December 19, 1994 (59 FR 65256), including 1,752 acres on BLM lands. Threats to the species include modification of habitat by operation of upstream reservoirs, inereased water exports, and upstream diversions. These factors have altered the location and extent of the low-salinity zone, concentrating delta smelt in an area with competing fish species. Entrainment by state and federal water export facilities, and introduced species, are also threats. 


\section{Vernal Pool Shrimp}

The primary references for this section are:

USFWS. 1994e. Final Rule: Endangered and Threatened Wildlife and Plants; Determination of Endangered Status for the Conservancy Fairy Shrimp, Longhorn Fairy Shrimp, and the Vernal Pool Tadpole Shrimp; and Threatened Status for the Vernal Pool Fairy Shrimp. Final Rule. Federal Register 59(180):48136-48153

and

USFWS. 2005i. Reeovery Plan for Vernal Pool Ecosystems of California and Southern Oregon. Region 1. Portland, Oregon.

References eited in this section are internal to the above-refereneed doeuments. A eomplete list of the Federal Register referenees is available from the USFWS Saeramento Field Office, Saeramento, California.

The Conservancy fairy shrimp (Branchinecta conservatio), longhorn fairy shrimp (B. longiantenna), vernal pool fairy shrimp (B. lynchi), and vernal pool tadpole shrimp (Lepidurus packardi) are aquatic crustaceans that are endemic to vernal pools in California. The vernal pools in whieh these species oeeur are found in the Central Valley, the Coast Range, and a limited number of sites in the Transverse Range and Santa Rosa Plateau. All four species are sporadie in their distribution, often inhabiting only one or a few pools in vernal pool complexes that are quite widespread (Eng 1990, Brusca 1992, King 1992, Simovich 1992). None are known to occur in riverine waters, marine waters, or other permanent bodies of water.

The three fairy shrimp and the vernal pool tadpole shrimp are eeologieally dependent on seasonal fluetuations in their habitat, sueh as absenee or presenee of water during speeifie times of the year, duration of inundation, and other cnvironmental faetors that inelude speeifie salinity, conduetivity, dissolved solids, and pH levels.

The Conservancy fairy shrimp occurs as a few isolated populations distributed over a large portion of California's Central Valley and in southern California. It occurs in vernal pools found on several different landforms, geologic formations, and soil types. It is often found in pools that are large in size, with low eonduetivity, total dissolved solids, and alkalinity (Barelay and Knight 1984; Eng et al. 1990). The Conservaney fairy shrimp is usually collected at eool temperatures and appears to be relativcly long-lived (Patton 1984; Simovich et al. 1992). This species has been observed from November to early April. The Conservancy fairy shrimp eo-oecurs with the vernal pool fairy shrimp and the vernal pool tadpole shrimp.

The longhorn fairy shrimp inhabits clear to turbid, grass-bottomed vernal pools in grasslands, and clear-water pools in sandstone depressions. The water in grassland pools inhabited by this species has very low eonductivity, total dissolved solids, and alkalinity (Eng et al. 1990). This species is only known from only a small number of widely seattered populations. Vernal pools inhabited by this species are filled by winter and spring rains, and may remain inundated until June. The longhorn fairy shrimp has been observed from late December until late April.

The vernal pool fairy shrimp, although it has a relatively wide range, primarily occurs in vernal pools with clear to tea-colored water, most commonly in grass- or mud-bottomed swales, or in basalt flow depression pools in unplowed grasslands. However, one population occurs in sandstone rock outcrops, and another population occurs in alkaline vernal pools. The water in pools inhabited by this specics has low total dissolved solids, conduetivity, alkalinity, and chloride (Collie and Lathrop 1976). Vernal pool fairy shrimp have been collected from early Deccmber to early May.

The vernal pool fairy shrimp occurs in a wide range of vernal pool habitats in the southern and Central Valley of California and the Klamath Mountains Vernal Pool Region in Jaekson County, Oregon. The species has a sporadic distribution within vernal pool complexes (Patton 1984; County of Sacramento 1990; Jones and Stokes 1992, 1993; Stromberg 1993; Sugnet and Associates 1993b), wherein the majority of pools in a given eomplex are not inhabited by the speeies. The species is typically found at low population densities (Simovich et al. 1992), and only rarely 
does it co-occur with other fairy shrimp species. Adaptations of the vernal pool fairy shrimp to ephemeral habitats include a short life span and eggs that can remain dormant in the soil when the pools are dry.

The vernal pool tadpole shrimp inhabits vernal pools containing clear to highly turbid water, and ranging in size from 54 square feet to 89 acres. Pools have low conductivity, alkalinity, and total dissolved solids (Barclay and Knight 1984; Eng et al. 1990). These pools are located most commonly in grass-bottomed swales of grasslands in old alluvial soils underlain by hardpan, or in mud-bottomed pools containing highly turbid water. The vernal pool tadpole shrimp is distributed across the Central Valley of California and in the San Francisco Bay area. Vernal pools within its range occupy a small portion of their former area and are fragmented and isolated (Holland 1998).

The life history of the vernal pool tadpole shrimp is linked to the phenology of the vernal pool habitat. After winter rainwater fills the pools, the populations are re-established from eggs that have been dormant in the dry pool sediments (Lanway 1974, Ahl 1991). Eggs hatch shortly after inundation, with sexually reproductive adults appearing in about 3 to 4 weeks after hatching (Ahl 1991). A female surviving to large size may lay up to six clutches of eggs, which are sticky, and readily adhere to plant matter and sediment particles (Simovich et al. 1992). A portion of the eggs hatch immediatcly, and the rest become dormant and remain in the soil to hatch during later rainy seasons (Ahl 1991). The vernal pool tadpole shrimp matures slowly and is a long-lived species (Alexander 1976, Ahl 1991). Adults are often present and reproductive until the pools dry up in the spring (Ahl 1991, Simovich 1992).

Nearly all fairy shrimp feed on algae, bacteria, protozoa, rotifers, and bits of detritus (Pennak 1989). The females carry eggs in an oval or elongate ventral brood sac. The eggs are either dropped to the pool bottom or remain in the brood sac until the female dies and sinks. The "resting" or "summer" eggs are capable of withstanding heat, cold, and prolonged desiccation. When the pools refill in the same or subsequent seasons some, but not all, of the eggs may hatch. The egg bank in the soil may be comprised of the eggs from several ycars of breeding (Donald 1983). The eggs hatch when the vernal pools fill with rainwater. The early stages of the fairy shrimp develop rapidly into adults. These non-dormant populations often disappear early in the season long before the vernal pools dry up.

Tadpole shrimp are primarily benthic animals that swim with their legs down. They elimb or scramble over objects, as well as plow along in bottom sediments, and their diet consists of organic detritus and living organisms, such as fairy shrimp and other invertebrates (Fryer 1987, Pennak 1989). Female tadpole shrimp deposit their eggs on vegetation and other objects on the bottom. Vernal pool tadpole shrimp populations pass the dry summer months as dormant eggs in pool sediments. Some of the eggs hatch as the vernal pools are filled with rainwater in the fall and winter of subsequent seasons.

The Conservancy fairy shrimp, longhorn fairy shrimp, and vernal pool tadpole shrimp were listed as endangered on September 19, 1994 (59 FR 48136). The vernal pool fairy shrimp was listed as threatened on the same date. On August 6, 2003 (68 FR 46833), the USFWS designated critical habitat for these and other vernal pool species. The critical habitat designated was revised on August 11, 2005 (70 FR 46924), with species-specific unit designations published on February 10, 2006 (71 FR 7118). Critical habitat currently includes 161,786 acres for the Conservancy fairy shrimp, 13,557 acres for the longhorn fairy shrimp, 587,821 acres for the vernal pool fairy shrimp, and 228,785 acres for the vernal pool tadpole shrimp. Urban, water, flood control, highway, and utility projects, as well as conversion to agricultural use, have eliminated vernal pools in southern California (Riverside and San Diego Counties), the Central Valley, and the San Francisco Bay area (Jones and Stokes Associates 1987). Factors that threaten these species include changes in hydrologic patterns, overgrazing, OHV use, and any human activities that alter the watershed of the vernal pools. For some species, continued development could destroy existing habitat.

\section{Marine Ecoregion}

The Marine Ecoregion Division, which is located in western Oregon and Washington, includes such aquatic systems as the Puget Sound region, the western portion of the Columbia River Basin (including its confluence with the Pacific Ocean), and the Willamette River Basin of Western Oregon. Only three TEP aquatic species that could 
potentially be affected by vegetation treatments on public lands occur loeally in this ecoregion. The ranges of these two of these species (the Lost River and shortnose suckers) extend into the Mediterranean Ecoregion, which begins in southern Oregon.

Although few speeies of concern to this project are permanent residents of this ecoregion, numerous ESUs of Pacifie Northwest salmon migrate through the Marine Ecoregion on their way to and from the ocean phases of their life eyeles. A diseussion of these species begins on page 5-1.

\section{Oregon Chub}

The primary referenee for this section is:

USFWS. 1998s. Oregon Chub (Oregonichthys crameri) Recovery Plan. Portland, Oregon.

References cited in this seetion are internal to the above-referenced doeument. Full citations have been included in the Bibliography.

The 2008 5-year review for the Oregon ehub (USFWS 2008v) was reviewed for updated information on this species.

The Oregon ehub (Oregonichthys crameri) is a small minnow that is endemie to the Willamette River Basin in western Oregon. The speeies was formerly distributed throughout the Willamette River Valley in off-channel habitats such as beaver ponds, oxbows, side ehannels, backwater sloughs, low gradient tributaries, and flooded marshes (Snyder 1908b). As of 2008, the eurrent distribution of the Oregon chub consisted of 34 populations in the Willamette Basin (USFWS 2008v). Fifty-six pereent of these populations have a low probability of annual floodplain connectivity due to isolation.

Oregon ehub are found in slack water off-ehannel habitats such as beaver ponds, oxbows, side channels, baekwater sloughs, low gradient tributaries, and flooded marshes. These habitats usually have little or no water flow, silty and organie substrate, and eonsiderable aquatie vegetation as eover for hiding and spawning (Pearsons 1989; Markle et al. 1991). The average depth of Oregon chub habitats is typically less than 6 feet, and the summer temperatures typieally exceed $61^{\circ} \mathrm{F}$. Adult Oregon chub seek dense vegetation for cover and frequently travel in the mid-water column in beaver channels or along the margins of aquatic plant beds. Larval chub congregate in nearshore areas in the upper layers of the water eolumn in shallow areas (Pearsons 1989). Juveniles venture farther from shore into deeper areas of the water eolumn. In the winter months, ehub ean be found buried in the detritus or concealed in aquatie vegetation. Fish of similar size elasses sehool and feed together. In the early spring, Oregon ehub are most aetive in the warmer, shallow areas of the ponds.

Oregon chub are obligatory sight feeders. They feed throughout the day and stop feeding after dusk (Pearsons 1989). Chub feed mostly on water eolumn fauna, primarily minute crustaccans such as copepods, cladoeerans, and chironomid larvae (Markle et al. 1991).

Oregon chub spawn from mid-May through August, with peak activity and July (USFWS 2008v). Before and after spawning season, ehub are social and non-aggressive. Spawning behavior begins with the male establishing a territory in or near dense aquatic vegetation (Pearsons 1989). Behaviors associated with reproduction and courtship include territorial behavior between males, head rubbing, directing of females by males, and twirling of both fish during the release of egg and sperm. Spawning aetivity has only been observed at temperatures exceeding $61^{\circ} \mathrm{F}$.

The Oregon chub was federally listed as endangered on October 18, 1993 (58 FR 53800), but was downlisted to threatened on April 23, 2010 (75 FR 21179). On March 10, 2010, approximately 1,232 acres of aquatie habitat in Benton, Lane, Linn, and Marion Counties, Oregon, were designated as critical habitat (75 FR 11010). The species evolved in a dynamic network of slack water habitats in the floodplain of the Willamette River. Major alteration of the Willamette River for flood control and navigation improvements has eliminated most of the river's historic floodplain. This alteration has also impaired or eliminated the environmental conditions in which the Oregon ehub evolved. Remaining suitable habitats have been invaded by non-native fish predators and competitors. Current 
threats to the species include continued habitat alteration; the proliferation of non-native fish and amphibians; accidental ehemical spills; runoff from herbicide or pesticide application on farms or along roadways, railways, and powerline ROWs; desiceation of habitats; unauthorized water withdrawals, diversions, or fill and removal activities; and siltation resulting from timber harvesting in the watershed. Additionally, there are potential genetic coneerns about the long-term viability of the species if a significant proportion of the populations remain isolated from one another (USFWS 2008v).

\section{Lost River and Shortnose Suckers}

The primary reference for this section is:

USFWS. 2011x. Draft Revised Recovery Plan for the Lost River Sucker and Shortnose Sucker (Deltistes luxatus and Chasmistes brevirostris). Pacific Southwest Region. Sacramento, California.

References eited in this section are internal to the above-refereneed document. They are included in the Bibliography.

The Lost River sucker (Deltistes luxatus) and shortnose sucker (Chasmistes brevirostris) are large, long-lived suckers endemic to the upper Klamath Basin of Oregon and California. Historieal records indicate that the two speeies were once widespread and abundant within their range. The present distribution of the Lost River sueker includes Upper Klamath Lake and its tributaries, Clear Lake Reservoir and its tributaries, Tule Lake, Lost River, Link River, and the Klamath River mainstem, including Keno, J.C. Boyle, Copeo, and Iron gate Reservoirs (Moyle 2002). The present distribution of the shortnose sucker includes Upper Klamath Lake and its tributaries, Klamath River downstream to Iron Gate Reservoir, Clear Lake Reservoir and its tributaries, Gerber Reservoir and its tributaries, the Lost River, and Tule Lake. The distribution of shortnose sucker overlaps with that of Lost River sucker, but shortnose suckers also oceur in Gerber Reservoir and upper Willow Creek, a tributary to Clear Lake Reservoir (Buettner and Scoppettone 1991, Moyle 2002).

Lost River and shortnose suekers have complex life histories that include stream/river, lake, marsh, and shoreline habitats. Both species spawn during the spring over gravel substrates in habitats less than 4 feet deep in tributary streams and rivers. A smaller but signifieant number of Lost River sueker also spawn over gravel substrates at shoreline springs along the margins of Upper Klamath Lake. Larvae spend relatively little time in rivers or streams before drifting downstream to the lakes by mid-summer. Larval habitat is generally along the relatively shallow shoreline where emergent vegetation provides cover from predators, protection from eurrents and turbulence, and abundant food (including zooplankton, macroinvertebrates, and periphyton). Juvenile suckers utilize a wide variety of near- and off-shore habitat, including emergent wetlands and non-vegetated areas. They inereasingly move offshore into the lake as they grow. Adults oceupy open water habitats. Adult Lost River and shortnose suckers usually spend relatively little time in tributary streams and migrate back to the lake after spawning. Adults appear to prefer areas with relatively low densities of algae and good water quality in terms of $\mathrm{pH}$ and dissolved oxygen, such as areas of the lake near inflows from streams or springs. Lost River and shortnose suckers are omnivores that feed primarily on zooplankton and insects.

The Lost River and shortnose sucker were federally listed as endangered on July 18, 1988 (53 FR 27130). On December 11, 2012, the USFWS designated approximately 146 miles of streams and 117,848 aeres of lakes and reservoirs for Lost River sucker as critical habitat (77 FR 73739). At the same time, the USFWS designated approximately 136 miles of streams and 123,590 acres of lakes and reservoirs as critical habitat for shortnose sucker. Critical habitat for these species oecurs in Klamath and Lake Counties, Oregon, and Modoc County, California. Critical habitat on BLM land occurs in Upper Klamath Lake and the Lost River Basin. The limited distribution of both sucker species, combined with the level of agricultural development and associated water and land use threats within the drainage, make these fishes suseeptible to past and present habitat loss and degradation throughout their distribution. The rate of habitat loss has slowed during recent years; nevertheless, only a fraction of the original habitat remains. Reductions in habitat quality compound the effects of reduced habitat quantity and availability on Lost River sucker and shortnose sucker abundance. Current factors limiting species recovery also include high mortality of larvae and juveniles due to minimal rearing habitat, entrainment in water management structures, poor water quality, and negative interactions with introduced species. Adult populations are limited by 
the negligible reeruitment to the population, as well as high levels of stress and mortality associated with severely impaired water quality. As a whole, the species are potentially limited by the laek of habitat conneetivity.

\section{Species in Multiple Ecoregions}

\section{Arkansas River Shiner}

The primary referenees for this seetion are:

USFWS. 1998t. Final Rule to List the Arkansas River Basin Population of the Arkansas River Shiner (Notropis girardi) as Threatened. Federal Register 63(225):64771-64799;

and

USFWS. 2001 g. Final Designation of Critieal Habitat for the Arkansas River Basin Population of the Arkansas River Shiner. Final Rule. Federal Register 66(65):18001-18034.

Referenees eited in this seetion are internal to the above-refereneed doeuments. A eomplete list of these referenees is available from the USFWS Oklahoma Eeologieal Serviees Field Offiee, Tulsa, Oklahoma.

The Arkansas River shiner (Notropis girardi) is a small fish found in the Canadian River in New Mexieo, Oklahoma, and Texas, and the Cimarron River in Kansas and Oklahoma, whieh are both rivers in the Arkansas River Basin. This speeies utilizes a broad range of mierohabitat features. However, adults are uneommon in quiet pools or baekwaters, and almost never oeeur in tributaries having deep water and bottoms of mud or stone (Cross 1967).

Arkansas River shiners are generalist foragers, feeding on both items suspended in the water eolumn and items lying on the substrate (Bonner et al. 1997). In the Peeos River, fly larvae, eopepods, immature mayflies, inseet eggs, and seeds were the dominant items in the speeies' diet (Gido 1997). The Arkansas River shiner spawns in July, usually eoineiding with flood flows following heavy rains (Moore 1944). It appears to be in peak reproduetive eondition throughout the months of May, June, and July (Polivka and Matthews 1997), and may aetually spawn several times during this period (Wilde 1998). Arkansas River shiner eggs are non-adhesive and drift with the swift eurrent during high flows. Hatehing oeeurs within 24 to 48 hours after spawning. The larvae are eapable of swimming within 3 to 4 days; they then seek out baekwater pools and quiet water at the mouth of tributaries where food is more abundant (Moore 1944). Adult shiners attain a maximum length of 2 inehes.

Historieally, Arkansas River shiners inhabited the main ehannels of wide, shallow, sandy-bottomed rivers and larger streams of the Arkansas River Basin (Gilbert 1980), and were onee widespread and abundant throughout the western portion of the Arkansas River Basin in Kansas, New Mexieo, Oklahoma, and Texas. The speeies is now almost entirely restrieted to about 508 miles of the Canadian River in Oklahoma, Texas, and New Mexieo. An extremely small population may also still persist in the Cimarron River in Oklahoma and Kansas. In addition, a non-native population of the Arkansas River shiner has beeome established in the Peeos River of New Mexieo within the last 20 years (Bestgen et al. 1989), but is not federally listed.

The Arkansas River shiner was federally listed as threatened on November 23, 1998 (63 FR 64772). Critieal habitat for the speeies was first designated on April 4, 2001 (66 FR 18002). However, this eritieal habitat was vaeated by a subsequent eourt ruling. On Oetober 13, 2005, approximately 532 miles of rivers, ineluding 300 feet of adjacent riparian areas, were designated as eritieal habitat (70 FR 59808). This eritieal habitat ineludes portions of the Canadian River in New Mexieo, Texas, and Oklahoma, the Beaver/North Canadian River in Oklahoma, the Cimarron River in Kansas and Oklahoma, and the Arkansas River in Kansas.

The primary reason for the deeline of this speeies is the inundation and modifieation of stream diseharge by impoundments, ehannel desieeation by water diversion and exeessive groundwater pumping, stream ehannelization, and introduetion of non-native speeies. The Arkansas River basin population is threatened by habitat destruetion and modifieation from stream dewatering or depletion due to diversion of surfaee water and 
groundwater pumping, construetion of impoundments, and water quality degradation. Water levels in the High Plains Aquifer continue to decline, and salt eedar eneroachment into the Canadian and Cimarron basin eontinues (USFWS 2009zz). Competition with the non-indigenous Red River shiner contributes to diminished distribution and abundance in the Cimarron River. Ineidental capture of the species during pursuit of commercial bait fish species may also contribute to reduced population sizes. Drought and other natural factors also threaten the existence of the Arkansas River Shiner.

\section{Humpback Chub}

The humpback chub (Gila cypha) is restrieted to the Colorado River system, where it once ranged from western Colorado and southwestern Wyoming to northern Arizona and possibly California (NatureServe 2010). Currently, the species is found only in the Little Colorado River and adjacent portions of the Colorado River. The species has been associated with a variety of habitats, ranging from pools with turbulent to little or no current; substrates of silt, sand, boulder or bedroek; and depth ranging from 3 feet to 50 feet (USFWS $2010 \mathrm{dd}$ ).

The humpback chub reaches sexual maturity between 2 and 3 years of age. Spawning occurs from May to July, when water temperatures are between 57 and $75^{\circ} \mathrm{F}$, at depths of 6 to 12 feet, over boulder, sand, and possibly gravel substrates (USFWS 2010dd).

The humpback ehub was federally listed as endangered on March 11, 1967 (32 FR 4001). On March 21, 1994 (59 FR 13374), the USFWS designated 1,980 miles of river in the Colorado River basin in portions of Colorado, New Mexico, Utah, Arizona, Nevada, and California as eritical habitat for the humpback chub and three other speeies (razorbaek sucker, Colorado pikeminnow, and bonytail chub; USFWS 1994f). The Colorado River has been altered by the construction of mainstream dams, whieh have ehanged the water quality from muddy and turbulent to elear and cold. Alteration of the flow and temperature regime of the Colorado River by development projects (i.e., dams, irrigation, dewatering and channelization projects) is eited as the primary reason for the decline of the humpback chub and for its precarious position today (Minckley 1973, Kaeding and Zimmerman 1983, USFWS 1984f). The proliferation of introduced species (Tyus et al. 1982) and the resultant eompetition and predation may have contributed to the decline of the species (Behnke and Benson 1983). Pollution (pesticides), eutrophication, and other faetors such as parasitism (a parasitie erustacean-Lernaea), changes in the food base, and fishing pressure also may have attributed to the species' decline (USFWS 1984f). The fragmentation of the Colorado River system by dams has served to isolate subpopulations of the humpback chub, thus reducing gene flow and the ability of subpopulations to adapt to changing conditions.

\section{Bonytail Chub}

The bonytail chub (Gila elegans) is restrieted to the Colorado River system, where it presently exists in very low numbers in its natural riverine and manmade reservoir habitat. Formerly abundant throughout the Colorado River and its larger tributaries, currently no self-sustaining populations of the species exist in the wild (USFWS 2002i). No young individuals have been found in recent years, and the species is eonsidered functionally extinet (USFWS 2010ee). Captures of wild adult bonytail chubs have oceurred in Lakes Powell, Mohave, Havasu, and in rivers of the Upper Colorado River Basin (USFWS 2002i). In riverine areas, the species is considered a "big-river" or mainstream fish, since few have ever been captured in small tributaries (USFWS 19851). However, in rivers bonytails tend to use pools and eddies instead of areas of faster eurrent, and in reservoirs they are found more in lacustrine rather than riverine habitat (Vanicek 1967, Minckley 1973). They prefer backwaters with rocky or muddy bottoms and flowing pools, although they have been reported in swiftly moving water. They are predominantly restricted to rocky eanyons, but were historically abundant in the wide downstream sections of rivers (USFWS 2010ee).

The bonytail chub is generally considered to be an insectivore (Valdez and Clemmer 1982); however, little information is available on specific food habits. Young chubs presumably eat chironomid larvae and mayfly nymphs in the Green River, where juveniles consume terrestrial and aquatic insects and the adults consume terrestrial insects, plant debris, and filamentous algae (Vanicek 1967). No other information is known on river feeding preferences, but the species is reported to eat plankton and algae in reservoir habitats (Minckley 1973). The breeding behavior of bonytail chubs has been observed in Lake Mojave (Jonez and Sumner 1954), where 
approximately 500 fish congregated over a gravel bar in 29.5 feet of water. Females were eseorted by 3 to 5 males, and deposited eggs randomly with no indication of parental care.

The bonytail chub was federally listed as endangered April 23, 1980 (45 FR 27710). On Mareh 21, 1994 (59 FR 13374), the USFWS designated 1,980 miles of river in the Colorado River basin in portions of Colorado, New Mexico, Utah, Arizona, Nevada, and California as critieal habitat for the bonytail chub and three other species (razorbaek sueker, Colorado pikeminnow, and humpback ehub; USFWS 1994f). The primary reasons for the decline of this speeies include flow depletions, loss of riverine habitat, dams, mining impacts and the resulting siltation, incidental eapture, and the introduction of exotic fish. Presently, the fish is very rare, and its low population numbers impact the ability of the species to effectively reproduee. In addition, ehanges in the river flow regimes may be forcing the roundtail chub and the bonytail chub to reproduee in closer proximity (USFWS 19851). Threats to the species include streamflow regulation, habitat modification, eompetition with and predation by nonnative fish speeies, hybridization, and pesticides and pollutants (USFWS 2002i).

\section{Rio Grande Silvery Minnow}

The primary referenee for this seetion is:

USFWS. 2010ff. Rio Grande Silvery Minnow Reeovery Plan (Hybognathus amarus). First Revision. Southwest Region. Albuquerque, New Mexico.

Referenees cited in this section are internal to the above-referenced document. Full citations have been ineluded in the Bibliography.

The Rio Grande silvery minnow (Hybognathus amarus) is native to the Rio Grande Basin, historieally oceurring in the Rio Grande River from Espanola, New Mexico, to the Gulf of Mexieo and in the Pecos River, a major tributary of the Rio Grande, from Santa Rosa, New Mexieo, to its confluenee with the Rio Grande in South Texas. The speeies is now known to oecur only in one reach of the Rio Grande in New Mexico, a 174-mile stretch from Coehiti Dam to the headwaters of Elephant Butte Reservoir. Its eurrent range also includes a small portion of the lower Jemez River, a tributary to the Rio Grande north of Albuquerque. Its eurrent habitat is limited to about 7 pereent of its former range. In December 2008, silvery minnows were introduced into the Rio Grande near Big Bend, Texas as a nonessential, experimental population. This experimental population is being monitored to determine whether it has been sueeessful.

The Rio Grande silvery minnow uses only a small portion of the available aquatie habitat. In general, the species most often uses silt substrates in areas of low or moderate water velocity (e.g., eddies formed by debris piles, pools, and baekwaters). The Rio Grande silvery minnow is rarely found in habitats with high water velocities, such as main channel runs, which are often deep and swift. The species is most eommonly found in depths of less than 7.9 inehes in the summer and 12 to 16 inehes in the winter. Few use areas with depths greater than 20 inches. The species is herbivorous, with algae apparently an important food source.

The Rio Grande silvery minnow is a pelagic spawner (Platania 1995b) that produees thousands of semibuoyant, non-adhesive eggs that passively drift while developing (Platania and Altenbaeh 1998). Each female may produee 3 to 18 elutches of eggs in a 12-hour period. Mean elutch size is about 270 eggs. Following fertilization, the eggs drift with the eurrent for up to 50 hours, remaining suspended in the water column (Platania 1995b). Egg hatehing time is temperature dependent but rapid, and generally occurs in 24 to 48 hours (Platania 2000). Reeently hatehed, passively drifting larval fish remain a part of the drift by swimming vertieally in the water column. Free-swimming larvae are capable of swimming horizontally and appear to aetively seek low velocity habitats (Platania and Altenbach 1998). Spawning is associated with high and/or increased flow events sueh as spring runoff or summer rainstorms, and typically occurs over a relatively brief period (1 month) in May or June, although spawning can oecur later or earlier in the season when temperature and flows are suitable. Spawning takes place in the water eolumn when the water temperature is 64 to $75^{\circ} \mathrm{F}$ (Platania and Dudley 2006).

The Rio Grande silvery minnow was federally listed as endangered on July 20, 1994 (59 FR 36988). Critical habitat was first designated on August 5, 1999 (64 FR 39560), but as a result of a court order it was set aside, and a 
new designation of eritical habitat was made on February 19, 2003 (68 FR 8088). Throughout much of its historic range, the decline of the Rio Grande silvery minnow is attributed primarily to destruction and modification of its habitat due to dewatering and diversion of water, water impoundment, and modification of the river (channelization). Competition and predation by introduced non-native species, water quality degradation, and other factors also have contributed to its decline.

\section{Razorback Sucker}

The primary reference for this section is:

USFWS. 2002j. Razorback Sucker (Xyrauchen texanus) Recovery Goals: Amendment and Supplement to the Razorback Sucker Recovery Plan. Mountain Prairie Region. Denver, Colorado.

References cited in this section are internal to the above-referenced document. Full citations have been included in the Bibliography.

The razorback sucker (Xyrauchen texanus) was historically widely distributed in warm-water reaches of the Colorado River Basin, from Mexico to Wyoming. However, this range has been much reduced. Razorback sucker are currently found in the Green River, upper Colorado River, and San Juan River subbasins; lower Colorado River between Lake Havasu and Davis Dam; reservoirs of Lakes Mead and Mohave; and in small tributaries of the Gila River subbasin. They were also recently rediscovered in the Grand Canyon (National Park Service 2013). No substantial recruitment to any population has been documented in recent years. Juveniles are most often collected from irrigation eanals in Arizona and California. Intensive management in some locations has helped to offset the decline of the razorback sucker, such as the capture and protective rearing of larvae in Lake Mohave for release at larger sizes, and raising of young in predator-free environments (Marsh 2000).

Habitats required by adults in rivers include deep runs, eddies, backwaters, and flooded off-channel environments in spring; runs and pools often in shallow water associated with submerged sandbars in summer; and low-velocity runs, pools, and eddies in winter. Spring migrations of adult razorback sucker were associated with spawning in historic accounts, and a variety of local and long-distance movements and habitat-use patterns have been documented. Spawning in rivers occurs over bars of cobble, gravel, and sand substrates during spring runoff at widely ranging flows and water temperatures. Spawning also occurs in reservoirs over rocky shoals and shorelines. Young require nursery environments with quiet, warm, shallow water such as tributary mouths, backwaters, or inundated floodplain habitats in rivers, and coves or shorelines in reservoirs.

Razorback suckers breed in spring (mostly April to June), when flows in riverine environments are high. During the breeding season, adult razorback suckers congregate in flooded bottomlands and gravel pits, backwaters, and impounded tributary mouths near spawning sites. Relatively large aggregations of razorback suckers have been observed in these types of environments, usually upstream of areas with broad floodplains (Tyus et al. 1982; Valdez et al. 1982; Modde et al. 1996; Muth 1995). Razorback sucker adults occupy such habitats both before and after spawning, presumably for feeding, resting, gonadal maturation, and other activities associated with their reproductive cycle (Tyus and Karp 1990, Osmundson and Kaeding 1991, Modde and Wick 1997, Modde and lrving 1998).

Larvae and juveniles suffer very high mortality from predation, particularly from non-native species. For the first period of life, larval razorback suckers are nocturnal, hiding during the day. Their diet during this period consists mostly of plankton (Marsh and Langhorst 1988). Young fish grow fairly quickly, but growth slows once adult size is reached (McCarthy and Minckley 1987). The diet of adults consists of midge larvae, planktonic crustaceans, diatoms, filamentous algae, and detritus. For the most part, razorback suckers are bottom feeders, but they do contain mouthparts that are characteristic of planktonic and detrital feeding habits.

The razorback sucker was federally listed as endangered on October 23, 1991 (56 FR 54957). In addition, on March 21, 1994, critical habitat for the species was designated in 15 river reaches containing about 49 percent of the species' historic habitat (1,724 miles) within the Colorado River Basin and its 100-year floodplain (59 FR 13374). The decline of this species is primarily attributable to the impoundment of large portions of the Colorado 
River and its tributaries. These impoundments have altered habitat, substantially reducing flows in some reaches and modifying temperature regimes in others. In addition, recruitment of the species is limited by extreme predation pressure from introduced, fish-eating predators. The primary threats to razorback sucker populations are streamflow regulation and habitat modification (including cold-water dam releases, habitat loss, and blockage of migration corridors); competition with and predation by non-native fish species; and pesticides and pollutants.

\section{Colorado Pikeminnow}

The primary reference for this section is:

USFWS. 2002k. Colorado Pikeminnow (Ptychochelius lucius) Recovery Goals: Amendment and Supplement to the Colorado Squawfish Recovery Plan. Denver, Colorado.

References cited in this section are internal to the above-refereneed document. Full citations have been included in the Bibliography.

The 2011 5-year review for the Colorado pikeminnow (USFWS 2011y) was consulted for updated information on this species.

The Colorado pikeminnow (formerly Colorado squawfish; Ptychochelius lucius) is endemic to the Colorado River basin, where it was once widespread and abundant in warm-water rivers and tributaries (Tyus 1991, Quartarone 1995). It was common in the lower basin in California and Arizona, where it was commercially harvested in the early 1900s (Minckley 1973). Currently, wild populations are found only in the upper basin, and the species occupies only about 25 pereent of its historic range basin-wide. It is common only in the Green-Yampa River system of northwestern Colorado and northeastern Utah (Tyus 1990, 1991; Propst 1999). Natural reproduction occurs in the Green, Yampa, upper Colorado, Gunnison, and San Juan Rivers.

The Colorado pikeminnow is a long-distanee migrator; adults move hundreds of kilometers to and from spawning areas, and require long sections of river with unimpeded passage. Adults require pools, deep runs, and eddy habitats maintained by high spring flows. These high spring flows maintain channel and habitat diversity, flush sediments from spawning areas, rejuvenate food production, form gravel and cobble deposits used for spawning, and rejuvenate backwater nursery habitats. Spawning occurs after spring runoff, at water temperatures typically between 64 and $73{ }^{\circ} \mathrm{F}$. After hatehing and emerging from spawning substrate, larvae drift downstream to nursery backwaters that are restruetured by high spring flows and maintained by relatively stable base flows.

Juveniles of this species feed on insects and crustaceans, while individuals over 1.2 inches in length feed on fish. As adults, Colorado pikeminnows are almost exclusively fish-eaters, and are the main native predator of the Colorado River basin (Vanicek and Kramer 1969, Minckley 1973, Holden and Wick 1982). Spawning activity begins after the peak of spring runoff, during June through August, at water temperatures typically $61{ }^{\circ} \mathrm{F}$ or warmer (Vanicek and Kramer 1969; Hamman 1981; McAda 2000; Muth et al. 2000). Colorado pikeminnows are broadeast spawners that scatter adhesive eggs over cobble substrate, which incubate in interstitial spaces. Larvae emerge from spawning cobbles 3 to 15 days after hatching and drift downstream to nursery areas. Migration is an important component in the reproductive cycle, and Colorado pikeminnows have been observed migrating more than 186 miles to specific river reaches to spawn (Tyus 1985, 1986).

The Colorado pikeminnow was federally listed as endangered on March 11, 1967 (32 FR 4001). In Mareh, 1994 , the USFWS designated 1,148 miles (29 percent of the species' historical range) as critical habitat (59 FR 13374). Six reaches of the upper Colorado River basin were included, five of which are located in Colorado and Utah and a sixth on the San Juan River in New Mexico. This species was nearly driven to extinction, primarily by water development programs, such as dams, that have altered stream morphology, flow patterns, temperatures, water chemistry, and silt loads of most major streams throughout the Colorado River Basin. Aceess to most spawning areas have also been blocked by dams. Interactions with non-native fishes may be an important factor in the continued survival or success of reintroduced populations of the Colorado pikeminnow. Current threats to the species include streamflow regulation, habitat modification, competition with and predation by non-native fish species, and pesticides and pollutants. 


\section{Effects of Herbicide Treatments on Aquatic Species}

This analysis considers TEP aquatic animal species and their critical habitat that are located within the project area. Similar to the $2007 \mathrm{BA}$ for herbicide treatments, this BA considers all aquatic species together for the purposes of analyzing impacts. The ERAs, which analyze the toxicological risk of aminopyralid, fluroxypyr, and rimsulfuron to TEP aquatic species under various exposure scenarios, consider four general groups of receptors: fish that inhabit streams, fish that inhabit ponds, aquatic invertebrates that inhabit streams, and aquatic invertebrates that inhabit ponds. Additionally, this BA addresses indirect effects eaused by altering aquatic habitats, which would have the potential to affect TEP speeies found in those habitats. In the case of pond scenarios, the ERAs assumed instantaneous mixing into a $1 / 4$-acre, 1 -meter-deep pond. The pond concentration calculated by the model does not consider herbicide degradation, sorption, or dissipation, and likely overestimates actual concentrations.

Given the programmatic nature of this document, the effects analysis that follows is necessarily general in nature, providing an overview of the sorts of effects that are likely to oceur to aquatic species as a result of herbicide treatments. Loeal BLM offices, which have been monitoring many of these speeies and their habitats for years, have additional information about TEP aquatic species and their habitat requirements that will allow a more detailed analysis of effects than is feasible at the programmatie level.

Impacts from the proposed treatments may affect one or more specific life history requirements of the TEP species considered in this BA. For instance, the spawning, rearing, and feeding requirements of a particular TEP speeies may be very specific within that species' habitat. Therefore, effects must eonsider multiple life stages and thus multiple habitat needs of a particular species.

All else being equal, the potential impacts to TEP aquatic species that are narrowly endemie may be greater than the potential impacts to species that are more broadly ranging. However, project-level eonsultation will often be able to provide more specific guidance for avoiding or minimizing impacts to narrow endemics. For this reason, it is likely that vegetation treatments could be better fine-tuned to ensure that these narrow endemics would not be adversely affected.

\section{Effects of Herbicide Treatments}

Aquatic TEP species could potentially come into contact with herbieides if sprayed formulations were to enter aquatic habitats during the application process. Since all thrce of the herbicides proposed for use are terrestrial herbicides, mechanisms by which the herbieides eould enter aquatic habitats include accidental spray or off-site drift or surface runoff of herbicides sprayed in nearby upland habitats into aquatic habitats. Chemicals could also enter aquatic habitats during an accidental spill of herbicides before, during, or after the treatment. Additionally, depending on how they are applied, herbicides could result in removal of riparian vegetation, which would have the potential to alter aquatic habitats. Projects involving herbicide treatments would be implemented with the objective of improving the habitats of TEP species, and would therefore have a long-term beneficial effect on these species, if successful.

\section{Direct Effects - Active Ingredients}

Based on information from the risk assessments, the three new herbicide active ingredients would pose a low toxicological risk to aquatic species. Of the three herbicides, only fluroxypyr is associated with risks to aquatic species, and only under accidental spill scenarios. Tables 5-1 through 5-4 summarize the risks to aquatic organisms associated with exposure to herbicides via the modeled exposure pathways.

For more information on the methodology used to complete the risk assessments, see Chapter 2 of this BA and Appendix C of the 2007 PEIS (USDOI BLM 2007a). 


\section{Direct Spray}

Based on the findings of the ERAs, none of the herbicides proposed for use would result in adverse health effects to fish and aquatic invertebrates if sprayed directly into aquatic habitats (Tables 5-1 through 5-4). Since the three herbicides are only approved for use in terrestrial habitats, direct spray into aquatie habitats would constitute an accidental release scenario, which is unlikely to occur.

\section{Accidental Spill}

No effeets to fish or aquatic invertebrates were predieted as a result of an aceidental spill of aminopyralid or rimsulfuron into aquatic habitats. However the ERAs predicted adverse effects to fish and aquatie invertebrates as a result of an aecidental spill of fluroxypyr into a water body (pond or stream; Tables 5-1 through 5-4). These adverse effeets could include mortality or sublethal effects, such as altered behavior, stunted growth, reduced reproductive sueeess, and physiologieal ehanges that make the organism more suseeptible to environmental stresses (Spence et al. 1996). For TEP fish and aquatie invertebrates, it is assumed that adverse health effects eould lead to population-levcl effeets, as many of thesc species already have reduced, sensitive populations. Mortality, reprodueed reproductive output, and increased sensitivity to environmental stresses (such as predation and exposure to harsh environmental eonditions) eould all increase the risk of future extirpations of populations.

TABLE 5-1

\section{Summary of Effects ${ }^{1}$ to Threatened, Endangered, and Proposed Fish from Exposure to Herbicides in Ponds, as Predicted By Risk Assessments}

\begin{tabular}{|l|l|l|l|l|}
\hline \multicolumn{1}{|c|}{ Herbicide } & \multicolumn{1}{c|}{ Direct Spray } & \multicolumn{1}{c|}{ Off-site Drift } & \multicolumn{1}{c|}{ Spill ${ }^{2}$} & \multicolumn{1}{c|}{ Surface Runoff } \\
\hline Aminopyralid & No effects & No effects & No effects & No effects \\
\hline Fluroxypyr & No effects & No effects & Adverse effects & No effects \\
\hline Rimsulfuron & No effects & No effects & No effects & No effects \\
\hline${ }^{1}$ Both acutc and chronic effects were considcred, and "adverse effects" inelude cither acute or chronie effects, or both. For more \\
information on acute vs. chronie effeets, plcasc sce Appendix C of the 2007 PEIS (USDOI 2007a). "No effects" indicates that \\
ERAs did not predict risks to TEP fish under the modeled scenario at typieal or maximum application rates. \\
${ }^{2}$ Accidental spill scenarios only eonsidered a truek or helicopter spilling an cntire load of herbicide prepared for the maximum \\
application rate. \\
Sources: Ecological risk assessments for herbicides (AECOM 2014a-c). \\
\hline
\end{tabular}

TABLE 5-2

Summary of Effects ${ }^{1}$ to Threatened, Endangered, and Proposed Fish from Exposure to Herbicides in Streams, as Predicted By Risk Assessments

\begin{tabular}{|c|c|c|c|c|}
\hline Herbicide & Direct Spray & Off-site Drift & Spill $^{2}$ & Surface Runoff \\
\hline Aminopyralid & No effects & No effects & No effects & No effects \\
\hline Fluroxypyr & No effects & No effects & Adverse effects & No effects \\
\hline Rimsulfuron & No effects & No effects & No effects & No effects \\
\hline \multirow{2}{*}{\multicolumn{5}{|c|}{$\begin{array}{l}{ }^{1} \text { Both acute and chronic effeets were eonsidered, and "adverse effects" include either acute or chronie effeets, or both. For mor } \\
\text { information on aeutc vs. chronic cffeets, pIcase see Appendix C of the } 2007 \text { PEIS (USDOI BLM 2007a). "No effeets" indieate } \\
\text { that ERAs did not predict risks to TEP fish under the modelcd sccnario at typical or maximum application rates. } \\
2 \text { Sinee the ERAs did not assess the risks associated with spills into a stream, results for spills into a pond are presented herc } \\
\text { Accidental spill sccnarios only considered a truek or helieopter spilling an entire load of herbicide prepared for the maximum } \\
\text { application rate. }\end{array}$}} \\
\hline & & & & \\
\hline \multicolumn{5}{|c|}{ Sourees: Ecological risk assessments for herbicides (AECOM 2014a-e). } \\
\hline
\end{tabular}

The risk asscssments only considered spills into ponds, and only eonsidered scenarios in which a truck or helicopter spilled an entire load of the herbicide prepared for the maximum application rate. Therefore, risk asscssments are eonservative. Additionally, an aecidental spill into an aquatic habitat is an unlikely occurrenee. Herbieide treatments would follow the SOPs and guidelines listed in the 2007 PEIS (Appendix A; USDOI BLM 2007a: 2-22 to 2-25), which would minimize the risks of spills into aquatie habitats. Relevant SOPs include 
preparing a spill contingency plan in advance of treatments, mixing and loading herbicide products in an area where an aceidental spill would not reach a water body, not rinsing spray tanks in or near water bodies, following product labels for use and storage, and having licensed applicators apply the herbicides. Project design criteria also require the BLM to consider TEP species that oecur near potential treatment areas when developing site-specific vegetation treatment programs.

TABLE 5-3

Summary of Effects ${ }^{1}$ to Threatened, Endangered, and Proposed Aquatic Invertebrates from Exposure to Herbicides in Ponds, as Predicted By Risk Assessments

\begin{tabular}{|c|c|c|c|c|}
\hline Herbicide & Direct Spray & Off-site Drift & Spill & Surface Runoff \\
\hline Aminopyralid & No effects & No effects & No effects & No effects \\
\hline Fluroxypyr & No effects & No effects & Adverse effects & No effects \\
\hline Rimsulfuron & No effects & No effects & No effects & No effects \\
\hline \multirow{2}{*}{\multicolumn{5}{|c|}{$\begin{array}{l}\text { "Both acute and chronic effects were considered, and "adverse effects" include either acute or chronic effects, or both. For more } \\
\text { information on acute vs. chronic effects, please see Appendix C of the } 2007 \text { PEIS (USDOI BLM 2007a). "No effects" indicates } \\
\text { that ERAs did not prediet risks to TEP aquatic invertebrates under the modeled scenario at typical or maximum application rates. } \\
2 \text { Accidental spill scenarios only considered a truck or helicopter spilling an entire load of herbicide prepared for the maximum } \\
\text { application rate. }\end{array}$}} \\
\hline & & & & \\
\hline \multicolumn{5}{|c|}{ Sources: Ecological risk assessments for herbicides (AECOM 2014a-c). } \\
\hline
\end{tabular}

TABLE 5-4

Summary of Effects ${ }^{1}$ to Threatened, Endangered, and Proposed Aquatic Invertebrates From Exposure to Herbicides in Streams, as Predicted By Risk Assessments

\begin{tabular}{|c|c|c|c|c|}
\hline Herbicide & Direct Spray & Off-site Drift & Spill $^{2}$ & Surface Runoff \\
\hline Aminopyralid & No effects & No effects & No effects & No effects \\
\hline Fluroxypyr & No effects & No effects & Adverse effects & No effects \\
\hline Rimsulfuron & No effects & No effects & No effects & No effects \\
\hline \multirow{2}{*}{\multicolumn{5}{|c|}{$\begin{array}{l}\text { 'Both acute and chronic effects were considered, and "adverse effects" include either acute or chronic effects, or both. For more } \\
\text { information on acute v. chronic effects, please see Appendix C of the } 2007 \text { PEIS (USDOI BLM 2007a). "No effects" indicate } \\
\text { that ERAs did not predict risks to TEP fish under the modeled scenario at typical or maximum application rates. } \\
{ }^{2} \text { Since the ERAs did not assess the risks associated with spills into a stream, results for spills into a pond are presented here } \\
\text { Accidental spill seenarios only considered a truek or helicopter spilling an entire load of herbicide prepared for the maximum } \\
\text { application rate. }\end{array}$}} \\
\hline & & & & \\
\hline \multicolumn{5}{|c|}{ Sources: Ecological risk assessments for herbicides (AECOM 2014a-c). } \\
\hline
\end{tabular}

\section{Off-site Drift and Surface Runoff}

None of the herbicides considered in this BA would have the potential to cause adverse health effects to aquatic TEP species as a result of off-site drift or surface runoff into nearby aquatic habitats, based on ERAs (Tables 5-1 through 5-4).

\section{Indirect Effects - Removal of Vegetation}

Aminopyralid, fluroxypyr, and rimsulfuron would not be used to target aquatic vegetation. However, they could be used in upland areas adjacent to streams, including riparian areas. Removal of riparian vegetation would have the potential to impact adjacent aquatic habitats, particularly if widespread removal of vegetation were to occur. These potential effects, which are discussed in more detail in the $2007 \mathrm{BA}$, include loss of necessary habitat components (i.e., cover and food), increased sedimentation into aquatic habitats, altered nutrient dynamics, and increased water temperature due to a reduction in shade. However, based on the likely usage of the three new active ingredients, wide-scale removal of riparian vegetation is unlikely to occur. Out of the three herbicides, fluroxypyr and rimsulfuron would typically not be used near water, except possibly for spot treatments of certain target species. Aminopyralid would be used in riparian treatments for selective removal certain species (e.g., knapweeds), but extensive removal of riparian vegetation would be unlikely. Additionally, aminopyralid would provide an 
alternative to glyphosate, which is less selective and more likely to result in removal of non-target riparian vegetation.

Mortality of plants that provide key habitat for aquatic species could have short-term effects on TEP species, such as salmon, which rely on overhanging vegetation for cover. Chapter 4 of this BA provides more specific information on the means by which aminopyralid, fluroxypyr, and rimsulfuron would potentially affect non-target terrestrial and aquatic plants. Indirect effects to aquatic species through loss of key riparian vegetation would typically last only until the next growing season, but could last longer if large riparian plants were lost as a result of the application. In some cases, fish and invertebrates would be able to readily move to another area with appropriate habitat components. The degree of the effects would vary by the location, amount of plant material removed, and distance from the aquatic habitat. The risk for these effects would be minimized during the project planning phase, when local site characteristics and potential for damage to non-target vegetation would be considered. Projects would include revegetation, as needed, to stabilize streambanks and promote recovery of native species.

While some TEP fish species could be indirectly affected by herbicides through a potential reduction in prey items (i.e., aquatic invertebrates and smaller fish), based on the risk assessment information presented in Tables 5-1 through $5-4$, the three new herbicides would also have a low toxicity to prey species. Only an accidental spill of fluroxypyr would be likely to impact prey items and have a potential to reduce food availability of TEP fish species. As discussed previously, spill scenarios represent a worst-case and unlikely herbicide release scenario, and are highly conservative as far as predicting impacts to receptors. Additionally, project planning and design and relevant SOPs would further minimize the risk of an accidental spill occurring. Any adverse effects to prey items would be temporary in nature.

Over the long term, treatments that remove non-native and competing vegetation are likely to have a beneficial effect on the habitat of aquatic species, provided that native or other desirable plant species are returned to those habitats after the treatments. Noxious weeds can have substantial adverse effects on riparian areas by outcompeting more desirable riparian vegetation, reducing biodiversity, altering aquatic habitats (e.g., reducing streambank protection, undercut bank cover, overhanging vegetation cover, pool depth and volume, and detrital and nutrient inputs; and increasing erosion and fine sediment deposition, stream width, and thermal relationships), and altering natural ecosystem processes (National Fire Plan Technical Team 2002). Herbicide treatments that target plant communities adjacent to aquatic habitats should result in conditions that would be more suitable for supporting aquatic species. Therefore, these treatments would eventually increase the amount of suitable habitat, potentially leading to an increase in TEP species populations.

\section{Effects from Adjuvants, Degradates, Inert Ingredients, and Tank Mixes}

\section{Adjuvants}

The herbicides being considered in this BA utilize various adjuvants, which may impact aquatic species. Aminopyralid formulations use nonionic surfactants. Fluroxypyr formulations use methylated sced oils (a low toxic type of adjuvant) for the control of kochia, but not for other weeds. Rimsulfuron formulations use several types of spray adjuvants, such as nonionic surfactants, petroleum crop oil concentrates, modified seed oils, ammonium nitrogen fertilizer, and combination adjuvant products.

The GLEAMS model was used to estimate the potential portion of an adjuvant that might reach an adjacent water body via surface runoff. In addition, sources (Muller 1980; Lewis 1991; Dorn et al. 1997; Wong et al. 1997) generally suggest that the acute toxicity of surfactants and anti-foam agents to aquatic life ranges from 1 to 10 $\mathrm{mg} / \mathrm{L}$, and that chronic toxicity ranges as low as $0.1 \mathrm{mg} / \mathrm{L}$. At the application rate recommended for non-ionic surfactants and the maximum ground application rate recommended for aminopyralid, the concentration of the adjuvant compound would be well below the chronic toxicity value for nonionic surfactants and the range for behavioral and physiological effects. For fluroxypyr, the maximum predicted concentration of the adjuvant was just above the chronic toxicity value for the adjuvant type, and within the range for behavioral and physiological effects. For rimsulfuron, the maximum predicted concentration of the representative adjuvant was well below the 
chronic toxicity value for nonionic surfactants, and in the low end of the range for behavioral and physiological effects. See the ERAs for additional information (AECOM 2014a-c).

Selection of adjuvants is under the control of BLM land managers, and land managers will follow all label instructions and abide by any warnings stated on both the herbicide and adjuvant labels. Selection of adjuvants with limited toxicity and low volumes is recommended to reduce the potential for the adjuvant to influence the toxicity of the herbicide.

\section{Degradates}

Degradates may be more or less mobile and more or less toxic in the environment than their source herbicides (Battaglin et al. 2003). Differenees in environmental behavior (e.g., mobility) and toxicity between parent herbicides and degradates makes prediction of potential impacts challenging. For example, a less toxic, but more mobile bioaccumulative, or persistent degradate may have a greater adverse impact due to residual concentrations in the environment. According to one study of 60 herbicides and 485 associated degradation products, 70 percent of degradates had either similar or reduced toxicity to fish, daphnids, and algae than the parent pesticide, with 30 pereent of degradates more toxic (including a degradation product of rimsulfuron; Sinclair and Boxall 2003). There is a lack of available data on the toxicity of degradates of aminopyralid and fluroxypyr, which represents a source of uncertainty in the risk assessment for these active ingredients.

\section{Inert Ingredients}

The ERAs do not provide toxicity information pertaining to inert ingredients.

A BLM scientist received elearance from the USEPA to review Confidential Business Information on inert compounds for aminopyralid, fluroxypyr, and rimsulfuron. The information received listed the inert ingredients, their chemical abstract number, supplier, percentage of the formulation, and purpose in the formulation. This information is confidential and is therefore not disclosed in this document. In reviewing the data, it was found that all of the inert ingredients identified in the formulations of aminopyralid, fluroxypyr, and rimsulfuron are in the Food and Nonfood Use category. These are inert ingredients approved for use in pesticide products applied to food.

As discussed in Chapter 2, the BLM requires that inert ingredients found in herbicide formulations and adjuvants be listed in either the Nonfood Use or Food and Nonfood Use categories.

\section{Tank Mixes}

Use of tank mixtures can result in changes to the toxic effects of the herbicides in the mixture. Herbicide interactions can be additive, synergistic, or antagonistic, and the mixture may have more or less toxicity than either of the individual products. In addition, other products may also be included in tank mixes, and may contribute to the potential risk. The BLM ERAs did not conduct a quantitative evaluation of potential tank mixes for any of the herbicides being considered in this BA. However, based on simulations of tank mixes in risk assessments completed for the 2007 PEIS, and a similar exercise completed for mixtures involving the active ingredients considered in this BA, aquatic receptors may be at greater risk from exposure to a tank mix than from exposure to any of the three herbicides on its own. There is some uncertainty in this evaluation because herbicides in tank mixes may not interact in an additive manner. Thus, the evaluation may overestimate risk if the interaction is antagonistic, or it may underestimate risk if the interaction is synergistic. In addition, other products may also be included in tank mixes that may contribute to the potential risk. Typical tank mixes of the three herbicides proposed for use are listed in Table 2-3.

Selection of tank mixes, like adjuvants, is under the control of BLM land managers. To reduce uncertainties and potential negative impacts, it is required that land managers follow all label instructions and abide by any warnings, including conservation measures and SOPs identified in this BA and in the $2007 \mathrm{BA}$. Labels for all tank mixed products should be thoroughly reviewed, and mixtures with the least potential for negative effects should be selected. This is especially relevant when a mixture is applied in a manner that may have increased potential for risk. Use of a tank mix under these conditions increases the level of uncertainty in risk to the environment. Measures to mitigate for risks associated with use of tank-mixed products, such as buffers between treatment areas 
and TEP speeies and their habitats, may require analysis at the loeal level. These local-level analysis may include use of information in ERAs and local site conditions (e.g., soil type, annual preeipitation, vegetation type, treatment method, application rate, and potential additive effects from multiple active ingredients) to more precisely calculate buffer distances to minimize effeets to TEP species.

\section{Cumulative Effects}

Cumulative effects include the effeets of future state, tribal, local, or private actions that are reasonably certain to oceur in the action area considered in this BA. Future federal aetions that are unrelated to the proposed action are not considered in this section because they require separate eonsultation pursuant to Section 7 of the ESA. The cumulative effeets of local treatments will be individually evaluated in future project-level eonsultations.

Beeause the three herbieides assessed in this BA are being added to an existing vegetation treatment program (whieh was covered in the 2007 BA; USDOI BLM 2007d), BLM lands reeeiving treatments with these herbicides eould also receive other types of vegetation treatments, ineluding treatments with other approved herbicides, manual treatments, mechanical treatments, fire, and biological control. In some eases, a eombination of treatment types may be used in coneert to aehieve a desired effect (e.g., preseribed fire followed by post-burn herbieide treatment). Therefore the cumulative effects of multiple treatment methods on TEP aquatic species should be eonsidered when designing treatment programs at the loeal level. The eonservation measures listed at the end of this section apply only to treatments with aminopyralid, fluroxypyr, and rimsulfuron. Where a eombination of treatment methods is employed, pertinent eonservation measures listed in the 2007 BA (available at http://www.blm.gov/wo/st/en/prog/more/veg_eis.html) for other methods or herbicides must also be implemented.

State, tribal, local, and private aetions oeeurring on or near publie lands eould affeet fish and other aquatic organisms diseussed in this BA. Beeause aquatic habitats that oeeur on publie lands often extend onto land under other types of ownership, non-federal activities could oecur within the action area for aquatie species, and would have the potential to be additive to those associated with BLM vegetation treatment activities. Given the programmatic nature of this BA, it is outside the scope of the analysis to identify speeific non-federal actions that might have eumulative impaets to aquatie TEP speeies when eonsidered together with BLM vegetation treatment activities. This type of site-specifie analysis would be done at the loeal level, using information about the loeation of individual BLM treatment projeets, and information about non-federal activities reasonably certain to oceur in the aetion area. Cumulative effects might result from agriculture (use of herbicides and pesticides), livestock grazing (trampling, erosion, degradation of water quality, loss of forage and eover, removal of water) recreation (fishing, injury/mortality associated with OHV use), mining, oil and gas and ROW development, and timber harvest. Industrial activities may lead to loss of habitat, surface disturbanee and assoeiated water quality impaets, changes in water quantity, pollution, and introduetion of noxious weeds into aquatic and riparian habitats. Vegetation management programs at industrial sites might involve additional use of herbieides within the action area. Tribal aetions that could harm TEP aquatic species include fishing and netting of animals for traditional lifeway uses.

\section{Conservation Measures}

Many local BLM offices already have management plans in place that ensure the protection of these species, and have eompleted formal or informal consultations on similar treatment aetivities. These consultations have identified protection zones alongside aquatic habitats that support these species. Additionally, herbicide application SOPs (listed in Appendix A) include measures to protect aquatic species and their habitats, such as practices to prevent and respond to spills.

As discussed in Chapter 2, this BA assumes that the BLM would eontinue to follow the conservation measures listed in the $2007 \mathrm{BA}$, or other comparable measures that would be developed by the field offices based on local site conditions and included in local-level consultation. General conservation measures for all herbieide treatments would be applieable for use of aminopyralid, fluroxypyr, and rimsulfuron. A list of key conservation measures for aquatic species is presented at the end of this seetion, with a eomplete list provided in Appendix A. Conservation 
measures pertaining to other types of vegetation treatments can be found in 2007 BA (USDOI BLM 2007d). This document is available at: http://www.blm.gov/wo/st/en/prog/more/veg_eis.html.

Given the low toxicity of the three new herbicides to aquatic TEP species, likely uses of the herbicides, and SOPS for minimizing the risk of spills into aquatic habitats, no new conservation measures have been developed for herbicide treatments using aminopyralid, fluroxypyr, or rimsulfuron. No buffers to protect fish and aquatic organisms from direet effects from the herbicides have been identified. However, if these active ingredients are used in a tank mixture or formulation that includes previously approved active ingredients, any applicable buffers developed at the project level through consultation with the Services for protecting TEP aquatic speeies would apply. Additionally, the BLM has SOPs that include minimum buffers widths for aquatic habitats (100 feet for aerial spraying, 25 feet for ground applications by vehicle, and 10 feet for hand spray applications; see Appendix A), which would also apply.

\section{Key Conservation Measures for Aquatic TEP Species from the 2007 BA}

- Maintain equipment used for transportation, storage, or application of chemicals in a leak proof condition.

- Do not store or mix herbicides, or conduct post-application cleaning within riparian areas.

- Ensure that trained personnel monitor weather conditions at spray times during application.

- Strictly enforce all herbicide labels.

- Do not broadcast spray within 100 feet of open water when wind velocity exceeds $5 \mathrm{mph}$.

- Do not broadeast spray when wind velocity exceeds $10 \mathrm{mph}$.

- Do not spray if precipitation is oceurring or is imminent (within 24 hours).

- Do not spray if air turbulenee is sufficient to affect the normal spray pattern.

- Do not broadcast spray herbicides in riparian areas that provide habitat for TEP aquatic species. Determine appropriate buffer distances at the local level to ensure that overhanging vegetation that provides habitat for TEP species is not removed from the site. Buffer distanees provided as conservation measures in the assessment of effects to plants (Chapter 4 of this BA) should be consulted as guidance.

- Follow all instructions and SOPs to avoid spill and direct spray scenarios into aquatic habitats.

If a tank mix of more than one approved herbicide is desired, an additional assessment of potential effects to nontarget TEP species must be made with the assumption that effects of the herbicides are at a minimum additive. Larger buffers, if warranted, will be applied.

\section{Determination of Effects}

Based on the ERAs, the only scenarios by which any of the three non-aquatic herbicides would potentially have adverse effects on TEP aquatic organisms are an accidental spill of fluroxypyr directly into aquatic habitats or through removal of riparian vegetation that provides important habitat attributes. Following SOPs for handling, transport, and use of these chemicals would help minimize the risk of an aceidental spill or direet spray into aquatic habitats. The conservation measures discussed in this chapter would further reduce the potential risks to aquatic habitats associated with using these herbicides. As a result, the action would be Not Likely to Adversely Affect listed aquatic species or their federally designated or critical habitats at the programmatic level. Similarly, the action is not likely to jeopardize proposed species or adversely modify proposed critical habitat. Given BLM mandates for use of integrated pest management (including vegetation management), and given that it is not possible to forecast site-specific vegetation management needs below the programmatic level, additional evaluations of situation-specific effects will be the subject of step-down Section 7 evaluations and subsequent consultations. In this manner, any additional specific conservation measures necessary to accommodate site or situation-specific peculiarities not predictable at the programmatic level will be developed at the local level and incorporated into Pesticide Use Proposals prior to local implementation of vegetation management activities that involve the use of herbicides considered in this BA. 


\section{CHAPTER 6}

\section{TERRESTRIAL ANIMALS}

This BA ehapter considers a total of 77 terrestrial animal species that are listed as threatened or endangered, or that are proposed for listing. Background information is presented for eaeh species by taxonomie grouping beginning with mollusks and ending with mammals. Within each grouping, speeies are further grouped, as appropriate, on the basis of habitat needs. Groupings, and species within these groupings, are ordered roughly by ecoregion.

Most of the information contained in this section was obtained directly from Federal Register documents, species reeovery plans, biologieal assessments and evaluations, and other sources of information. Where primary reference(s) was/were used for spceies baekground and listing information, full citations are listed in the individual sections for each speeies. In some instanees, eitations were used from the primary reference(s), and the complete citations were not available from the primary referenee(s) for inelusion in the Bibliography (Chapter 7). In the instanees where complete citations were not available, information on where there eomplete eitations ean be found (e.g., USFWS Sacramento Field Office, Sacramento, California) is provided.

\section{Terrestrial Mollusks}

Only one listed speeies of terrestrial mollusk oceurs or eould potentially oeeur within the project area: the Morro shoulderband snail. This speeies oceurs in the Mediterranean Ecoregion division, in the same habitat as several listed plant species diseussed elsewhere in this document.

\section{Morro Shoulderband Snail}

The primary reference for this section is:

USFWS. 1998u. Recovery Plan for the Morro Shoulderband Snail and Four Plants from Western San Luis Obispo County, California. USFWS. Portland, Oregon.

References eited in this seetion are internal to the above-referenced document. Full citations have been ineluded in the Bibliography.

The 2006 5-year review for the Morro shoulderband snail (USFWS 2006e) was consulted for updated information on this speeies.

The Morro shoulderband snail (Helminthoglypta walkeriana), also known as the banded dune snail, is a land snail that is endemie to the western portion of San Luis Obispo County, California. The species is found in coastal dune, coastal dune serub, and maritime chaparral plant communities on the south end of Morro Bay, mostly in back dune and stabilized dune eeosystems (USFWS 2006e). Throughout most of the species' range, the dominant shrub associated with the snail's habitat is mock heather. Other prominent shrub and sueeulent species are buckwheat, giant woolly-star, chamisso bush lupine, dudleya, and in more inland locations, California sagebrush and black sage (Roth 1985). The Morro shoulderband snail has also been found under mats of non-native fig-marigold (also known as iceplant).

Away from the immediate coast, immature scrub in earlier sueeessional stages may offer more favorable shelter sites than mature senescent stands of eoastal dune serub. The immature shrubs provide eanopy cover for the snail, whereas the lower limbs of larger older shrubs may be too far off the ground to offer good shelter (Roth 1985). In addition, mature stands produce twiggy litter low in food value. No studies or documented observations exist on 
the feeding behaviors of the Morro shoulderband snail, although it has been suggested that the species feeds on fungal material growing on decaying plant litter (Hill 1974).

The Morro shoulderband snail was federally listed as endangered on December 15, 1994 (59 FR 64613). On February 7, 2001 (66 FR 9233), the USFWS designated approximately 2,566 acres in San Luis Obispo County, California, as critieal habitat for the species. While many threats to the species have been eliminated or shown to not be oceurring, populations are still threatened by continued development and lack of habitat management. It appears that the population of this species is currently stable or increasing, rather than decreasing (USFWS 2006e).

\section{Effects of Herbicide Treatments on the Morro Shoulderband Snail}

\section{Direct Effects}

During herbicide treatments in areas inhabited by the Morro shoulderband snail, use of trucks/ATVs/UTVs to apply herbicides, as well as walking or riding a horse through the area, could crush and injure or kill snails. However, some trampled snails would likely be pushed into the sandy soils rather than erushed.

If an herbicide applieation were to oceur in or near shoulderband snail habitat, snails eould be exposed to herbicides by direet spray during the treatment, or by dermal contact with sprayed vegetation following the treatment. Based on information from the risk assessments, the three new active ingredients would pose a low toxicological risk to snails. Of the three herbieides proposed for use, only fluroxypyr is associated with risks to terrestrial invertebrates, and only under direct spray scenarios (see Table 6-1). Adverse health effects assoeiated with direet spray by fluroxypyr (at the typical or maximum application rate) could include mortality, reduced reproductive output, behavioral modification, and/or increased susceptibility to environmental stresses. Beeause the remaining populations of the Morro shoulderband snail are small and isolated, these toxicological effects could lead to a further decrease in the size and viability of the affected population, and possibly lead to extirpation of the population.

TABLE 6-1

Summary of Effects ${ }^{1}$ to Threatened, Endangered, and Proposed Terrestrial Invertebrates from Dermal Exposure to Herbicides, as Predicted by Risk Assessments

\begin{tabular}{|l|l|c|c|c|}
\hline \multicolumn{1}{|c|}{ Herbicide } & Direct Spray & Level of Risk & $\begin{array}{c}\text { Dermal Contact with } \\
\text { Sprayed Vegetation }\end{array}$ & Level of Risk $^{2}$ \\
\hline Aminopyralid & No effects & -- & No effects & -- \\
\hline Fluroxypyr & Adverse effects & $\begin{array}{c}\text { Typical rate: L } \\
\text { Maximum rate: } \mathrm{L}\end{array}$ & No effects & -- \\
\hline Rimsulfuron & No effects & -- & No effects & -- \\
\hline $\begin{array}{l}{ }^{1} \text { Both acute and chronic effects were considered, and "adverse effects" include either acute or chronic effects, or both. For more } \\
\text { information on acute vs. chronic effects, please see Appendix C of the 2007 PEIS (USDOI BLM 2007a). "No effects" indicates } \\
\text { that ERAs did not predict risks to TEP terrestrial invertebrates under the modeled scenario at typical or maximum application rates. } \\
{ }^{2} \text { L=Low risk; and -- means there is no level of risk, since no effects were predicted. } \\
\text { Sources: Ecological risk assessments for herbicides (AECOM 2014a-c). }\end{array}$ \\
\hline
\end{tabular}

There are no toxicological risks to Morro shoulderband snails associated with use of aminopyralid or rimsulfuron, and no toxicological risks associated with dermal contact with vegetation sprayed by any of the three herbicides at the typical or maximum application rate. Dermal contact entails much lower exposure levels than direct spray scenarios, and is a more likely exposure pathway.

For more information on the methodology used to determine risk levels, see Chapter 2 of this BA and Appendix C of the 2007 PEIS (USDOI BLM 2007a). 


\section{Indirect Effects}

Since the Morro shoulderband snail oceurs in native coastal dune scrub communities, and its habitat is degraded by the invasion of non-native plant species, herbieide treatments that successfully reduce the cover of non-native species in existing or potential snail habitats would be expeeted to benefit the speeies. However, since the species relies on vegetation for food and eover, use of herbieides in snail habitat could adversely affect the snail by redueing the eover of native vegetation. Although vegetation losses would be short term in nature, snail populations could decline. Use of herbieides to treat vegetation in habitats that are not eurrently suitable for snails, especially those near existing snail habitat, eould benefit the species by inereasing the amount of habitat and potentially allowing populations to expand in size.

\section{Conservation Measures}

As diseussed in Chapter 2, this BA assumes that the BLM would eontinue to follow the eonservation measures listed in the $2007 \mathrm{BA}$, or other comparable conservation measures that would be developed by the field offiees.

Given the low toxicity of aminopyralid and rimsulfuron to terrestrial invertebrates, no new conservation measures have been developed for herbieide treatments involving these active ingredients. Because there would be a low risk to terrestrial invertebrates under seenarios involving direet spray of fluroxypyr, the following eonservation measures have been developed for this aetive ingredient:

- When eondueting herbicide treatments in or near Morro shoulderband snail habitat, avoid use of fluroxypyr, where feasible. If pre-treatment surveys determine the presence of the Morro shoulderband snail, do not use fluroxypyr to treat vegetation.

- Do not broadeast spray fluroxypyr in habitats oceupied by Morro shoulderband snails, and do not broadeast spray fluroxypyr in areas adjaeent to Morro shoulderband snail habitat under eonditions when spray drift onto Morro shoulderband snail habitat is likely.

Key Conservation Measures from the $2007 \mathrm{BA}$

- Survey treatment sites within the range of the Morro shoulderband snail for the presence of the snail, prior to formulating treatment programs (should be condueted by a qualified biologist).

- Do not use broad-speetrum herbicides in habitats oeeupied by snails.

- Do not perform herbieide treatments in habitats oeeupied by snails that will result in a substantial reduetion of plant (and espeeially native plant) cover; where feasible, spot treat vegetation rather than spraying.

If the new aetive ingredients are used in a tank mixture or formulation that includes previously approved aetive ingredients, any applicable conservation measures for these chemicals from the 2007 BA would also apply.

\section{Determination of Effects}

Based on the information provided in the risk assessments, there are no toxicological risks to Morro shoulderband snails assoeiated with the use of aminopyralid and rimsulfuron. Conservation measures in the $2007 \mathrm{BA}$ include surveys of treatment sites for snail presence, and a restrietion on herbieide treatments that would result in a substantial loss of vegetation. These measures (or other eomparable measures developed by field offices) would allow the BLM to avoid Morro shoulderband snails during treatments, and to avoid adverse effeets to the speeies' habitat. Fluroxypyr has a low level of risk to the species under direct spray scenarios. The conservation measures diseussed in this chapter were designed to reduce the chance of adverse effects occurring to the point where the likelihood of sueh effects would be discountable, or to reduee any potential effects to the point where they would be insignificant to the speeies or their eritieal habitats, and would never reach the seale where take occurs. As a result, with application of these eonservation measures, the aetion would be Not Likely to Adversely Affect Morro shoulderband snails or their federally designated critical habitat at the programmatic level. Given BLM mandates for use of integrated pest management (including vegetation management), and given that it is not possible to forecast site-speeific vegetation management needs below the programmatic level, additional evaluations of situation-specific effects will be the subjeet of step-down ESA Seetion 7 evaluations and subsequent eonsultations. In this manner, any additional speeifie conservation measures necessary to aeeommodate site or situation-speeifie peculiarities not predictable at the programmatic level will be developed at the loeal level and 
incorporated into Pesticide Use Proposals prior to local implementation of vegetation management activities that involve the use of herbicides considered in this BA.

\section{Arthropods - Butterflies and Moths}

A total of eight TEP butterfly and moth species oceur within the project area. These species occur in various ccoregions throughout the west (apart from the subtropical ecoregions, or hot climates), but have similar general habitat requirements: open conditions and the presence of larval host plants and nectar sources.

Carson wandering skipper - Temperate Desert

Pawnee montane skipper - Temperate Steppe

Uncompahgre fritillary - Temperate Steppe

Quino checkerspot - Mediterranean

Kern primrose sphinx moth - Mediterranean

Oregon silverspot - Mediterranean/Marine

Fender's blue - Marine

Taylor's checkerspot - Marine

\section{Carson Wandering Skipper}

The primary reference for this section is:

USFWS. 2007w. Recovery Plan for the Carson Wandering Skipper (Pseudocopaeodes eumus obscurus). California/Nevada Operations Office. Sacramento, California.

References cited in this section are internal to the above-referenced document. Full citations have been included in the Bibliography.

The Carson wandering skipper (Pseudocopaeodes eunus obscurus) is locally distributed in grassland habitats on alkaline substrates in eastern California and western Nevada. As of 2007, the subspecies was known from four populations: two in Washoe County, Nevada, one along the Carson River in Douglas County, Nevada, and one in Lassen County, California. Habitat for this subspecies is characterized as lowland grassland habitats on alkaline substrates. Occupied areas are characterized by an elevation of less than 5,000 feet, and presence of saltgrass (Hickman 1993) and neetar sourees in open areas near springs or water, and possible association with geothermal activity.

The larval host plant for the Carson wandering skipper is saltgrass, which is a common species in the saltbushgreasewood plant communities of the intermountain west. It is likely that suitable larval habitat is related to the depth of the water table, with saltgrass needing to be above the water table for larval survival. In dry years, survival is probably related to the timing of senescence of the host plant. Microtopographic variation is likely important for survival. Adult Carson wandering skippers require nectar sources that are in bloom during the spring/summer flight season for food. If alkaline-tolerant plant species are not present but there is a freshwater source to support alkaline-intolerant nectar sources adjacent to the larval host plant, the area may provide suitable habitat (Brussard et al. 1999). Nectar sites used by the Carson wandering skipper may change from year to year.

Carson wandering skipper females lay their eggs on saltgrass, the larval host plant for the subspecies (Garth and Tilden 1986, Scott 1986). The early life stages of the Carson wandering skipper are not well known. However, the subspecies' life cycle is probably similar to other species in the grass skipper sublamily. Larvae live in silked-leaf nests, and some species make their nests partially underground. Pupae generally rest in the nest, and larvae generally hibernate during winter (Scott 1986). Some larvae may be able to extend their hibernation period for more than 1 year, depending on the conditions. The pupae emerge as adult butterflies in late spring/early summer. The life span of an adult Carson wandering skipper is possibly 1 to 2 weeks but they may live longer where 
abundant nectar sources exist with minimal habitat disturbanee (Sanford 2006). Carson wandering skippers are thought to produee one brood per year during June to mid-July (Austin and Emmel 1998).

The Carson wandering skipper was federally listed as endangered on August 7, 2002 (67 FR 51116), after an emergeney listing in 2001 (66 FR 59537). Critieal habitat was found to be "not determinable" at the time of listing, and henee has not been designated. Beeause of the small, isolated nature of the known populations of this subspeeies, extinetion eould oeeur from naturally oeeurring events or other threats. These threats inelude habitat destruetion, degradation, and fragmentation resulting from urban and residential development; wetland habitat modifieation; gas and geothermal development; and the invasion of non-native speeies. Other threats inelude colleeting, livestoek trampling,/grazing water exportation projeets, road eonstruetion, reereation, and pestieide drift.

\section{Pawnee Montane Skipper Butterfly}

The primary referenee for this seetion is:

USFWS. 1998v. Pawnee Montane Skipper Butterfly (Hesperis leonardus montana) Reeovery Plan. Denver, Colorado.

Referenees eited in this seetion are internal to the above-refereneed doeument. Full eitations have been ineluded in the Bibliography.

The 2012 5-year review for the Pawnee montane skipper (USFWS 2012e) was eonsulted for updated information on this speeies.

The Pawnee montane skipper butterfly (Hesperis leonardus montana) is a small, brownish-yellow butterfly that oeeurs only on the Pikes Peak Granite Formation in the South Platte River drainage system in Colorado. Its range, whieh has been estimated at 23 miles long and 5 miles wide, ineludes portions of Jefferson, Douglas, Teller, and Park Counties. The total known habitat within this range was originally estimated to be 37.9 square miles. However, oeeasional observations of Pawnee montane skippers have been made outside of, but in elose proximity to this mapped range (USFWS 2012e). The area oeeupied by the skipper is owned and/or administered by the Forest Serviee (Pike National Forest), Jefferson County, Colorado State Land Board, the BLM, the Denver Water Department, and private individuals.

Pawnee montane skippers oeeur in dry, open ponderosa pine woodlands at an elevational range of 6,000 to 7,500 feet. The slopes are moderately steep, with soils derived from Pikes Peak granite. The understory is limited in the pine woodlands. Blue grama grass, the larval food plant, and the prairie gayfeather, the primary neetar plant, are two neeessary eomponents of the ground cover strata. Small elumps of blue grama oeeur throughout the warm, open slopes inhabited by skippers, and prairie gayfeather oeeurs throughout the ponderosa pine woodlands. Skippers are uneommon in pine woodlands that have a tall shrub understory (Keenan et al. 1986), or where young eonifers dominate the understory (ERT Company 1986).

The vegetative eommunity preferred by the skipper is a northernmost extension of the ponderosa pine/blue grama grass habitat type doeumented from southern California and northern New Mexieo. However, prairie gayfeather does not oeeur in similar habitats to the south. The northeastern limit of the ponderosa pine/blue grama grass eommunity overlapping with the southwestern limit of the prairie gayfeather may eontribute to the maintenanee of the speeies in this limited area.

Pawnee montane skippers emerge from their pupae as adult butterflies in late July, whieh is apparently the same time that the prairie gayfeather flowers. Adults spend most of their short existenee feeding and mating. Adult females deposit eggs singly and direetly on the leaves of blue grama grass (Seott and Stanford 1982, MeGuire 1982, Opler 1986). The speeies overwinters as young larvae, and little is known about the larval and pupal stages. Pupation is generally short (12 to 23 days) in most butterfly speeies. The skipper eompletes its life eyele (egg to 
larva to pupa to adult butterfly to egg) annually (Keenan et al. 1986). Adult skippers probably fly until a major killing frost occurs (ERT Company 1986).

The prairie gayfeather apparently requires openings from single event disturbances, such as logging or fire, but does not tolerate continuous disturbanee. However, the skipper apparently does not colonize fire-ereated areas for at least several years after disturbance and regeneration. Populations of the species are low following mid- to highseverity burns (USFWS 2012e). Besides the prairie gayfeather, other plants that have been used as nectar sources include musk thistle (which is classified as a noxious weed by Jefferson County), smooth blue aster, Canada thistle, beebalm, pineywoods geranium, sunflower, and broomlike ragwort.

The Pawnee montane skipper was federally listed as threatened on September 25, 1987 (52 FR 36176). Critical habitat has not been designated. Encroachment of conifers and subsequent loss of grasses and prairie gayfeather reduces the quality and quantity of skipper habitat. Suppression of fire in ponderosa pine/Douglas-fir forests has reduced habitat quality for Pawnee montane skippers and inereased the risk of large-seale, stand-replacing fires (USFWS 2012e). Beeause of the limited habitat and range of the Pawnee montane skipper, unexpected random events could have major deleterious effeets on the population. Climate change is considered a threat to the species, and could potentially eause increased drought, habitat alteration, and more frequent and severe wildfires (USFWS 2012e). Invasion by noxious weeds that may outcompete blue grama and prairie gayfeather, such as knapweed, is also a serious threat to the skipper. The Forest Service currently uses seleetive herbicides to treat noxious weeds in Pawnee montane skipper habitat, but it is not considered to have a significant effect on the species or its habitat (USFWS 2012e).

\section{Uncompahgre Fritillary Butterfly}

The primary reference for this section is:

USFWS. 1994g. Uneompahgre Fritillary Butterfly Recovery Plan. Denver, Colorado.

References eited in this seetion are internal to the above-referenced document. Full citations have been included in the Bibliography.

The 2010 5-year review for the Uncompahgre fritillary butterfly (USFWS 2010gg) was reviewed for updated information on this species.

The Uncompahgre fritillary butterfly (Boloria acrocnema) has the smallest total range of any North American butterfly species. Its habitat is limited to 11 eolonies in the San Juan Mountains and southern Sawatch Range in Gunnison, Hinsdale, and Chaffee Counties in southwestern Colorado. Colonies are associated with patches of snow willow, which provides larval food and cover, and are located above 12,500 feet. The species has been found only on northeast-facing slopes, which are the coolest and wettest microhabitat available in the San Juan Mountains (Scott 1982, Brussard and Britten 1989). Adults nectar on a range of flowering alpine plants (Seidl 1993).

The females usually lay their eggs on snow willow plants, or in litter within snow willow patehes. It is believed that the species has a biennial life history, requiring 2 years to complete its life cycle (Scott 1982, Brussard and Britten 1989). Eggs laid in even years are caterpillars during the following odd year, and then mature into adults during the following even year. Although odd- and even-year broods may function as essentially separate populations, evidence of gene flow between the two (Brussard and Britten 1989) suggests that at times, larvae hatched early in the summer can develop into adults the following year.

The Uncompahgre fritillary was federally listed as endangered on June 24, 1991 (56 FR 28712). Critical habitat has not been designated. Since the species was listed, the number of confirmed colonies and population estimates have increased. Overcollection was initially considered the greatest human-caused threat to the species, but it has been reduced to some degree by maintaining collecting closures around two well-known colonies. Use of nearby hiking trails and sheep grazing and trailing have minimal impacts to habitat, but are not considered a threat to the Uncompahgre fritillary butterfly (USFWS $2010 \mathrm{gg}$ ). 


\section{Quino Checkerspot Butterfly}

The primary referenee for this section is:

USFWS. 20021. Designation of Critical Habitat for the Quino Checkerspot Butterfly (Euphydryas editha quino). Federal Register 67(72):18355-18395.

References eited in this section are internal to the above-refereneed doeument. A complete list of these referenees is available from the USFWS Carlsbad Fish and Wildlife Offiee, Carlsbad, California.

The 2009 5-year review for the Quino checkerspot butterfly (USFWS 2009aaa) was reviewed for updated information on this species.

The Quino checkerspot butterfly (Euphydryas editha quino) is a subspeeies of Edith's checkerspot that is locally distributed in sunny openings within chaparral and eoastal sage shrublands in the interior foothills of Riverside and San Diego Counties in California, and in adjaeent Mexieo. Like other subspeeies of Edith's checkerspot, the Quino checkerspot shows a habitat preference for low-growing vegetation interspersed with barren spots (Osborne and Redak 2000). The thermodynamie requirements of the butterfly and its natural avoidance of shaded areas deter flight below the canopy of vegetation (Singer 2001). Male Quino checkerspot butterflies and, to a lesser extent, females, are frequently observed on hilltops and ridgelines (Osborne 2001).

The distribution of the Quino checkerspot is highly dependent on the availability of its primary larval host plant, dwarf plantain. Typieally, butterflies occur where there are high densities of this plant, although other species of host plant are also used. Above the elevational limits of dwarf plantain (approximately 9,750 feet), woolly plantain and white snapdragon appear to be the primary host plants utilized by the butterfly (Pratt 2001). All host plant species occur in coastal sage serub, open ehaparral, grassland, and similar open-eanopy plant eommunities. Dwarf plantain is often associated with soils with fine-textured clay or with cryptogamie crusts.

Edith's checkerspot butterflies use a much wider range of plant species for adult neetar feeding than for larval foliage feeding. The butterflies frequently take neetar from lomatium, goldenstar, yarrow, fiddleneek, goldfields, popeornflowers, gilia, California buekwheat, onion, and yerba santa (Murphy and Pratt 2000). Chia may also be used for nectar feeding (Orsak 1978, Osborne 2001), but is probably not preferred (Pratt and Murphy 2001). Quino checkerspot butterflies have been observed flying several hundred feet from the nearest larval habitat patch to nectar sourees.

The life eycle of the Quino checkerspot butterfly includes four distinet life stages: egg, larva (eaterpillar), pupa (chrysalis), and adult, with the larval stage divided into five to seven instars (periods between molts, or shedding skin). There is typieally one generation of adults per year, with a 4- to 6-week flight period beginning between late February and May, depending on weather conditions (Emmel and Emmel 1973).

Quino checkerspot butterflies deposit eggs on plants loeated in full sun, preferably surrounded by bare ground or sparse, low-growing vegetation (Weiss et al. 1987, 1988; Osborne and Redak 2000). Eggs deposited by adults on host plants hatch in 10 to 14 days. Primary host plants must remain edible for approximately 8 weeks to support pre-diapause larvae if no secondary host plants are available (Singer 1972, Singer and Ehrlich 1979). Quino cheekerspot butterfly larvae may undergo as many as seven molts prior to pupation. Newly hatehed larvae spin a web and feed in elusters on the plant where their eggs were deposited. If larvae have accumulated sufficient energy reserves, they enter diapause as host plants age and beeome dry and inedible, and usually remain in diapause until December or January. Although the exact location of diapausing Quino checkerspot butterfly larvae is not known, clusters of post-diapause larvae found near dense grass and shrub cover indicate that they may diapause in these areas (Osborne and Redak 2000). Sufficient rainfall, usually during November or December, stimulates germination and growth of host plants, and apparently causes larvae to break diapause. Post-diapause larvae undergo from two to as many as four instars prior to pupating in webbed shelters near ground level. Adults emerge from pupae after approximately 10 days, depending on the weather (Mattoni et al. 1997). 
Distributions of patches of Quino checkerspot habitat are defined by a matrix of adult resources (all larval resources are found within areas of adult movement), primarily nectar plants, oviposition plants, and basking sites. Habitat patch fragmentation occurs when land use changes eompromise adult movement patterns and frequently results from habitat destruction that reduces resouree availability. Such fragmentation may substantially reduce the ability of habitat patches to support local populations. Most Quino eheekerspot butterfly populations are part of a larger metapopulation strueture. Isolated habitat patches are not sufficient to ensure the long-term persistenee of butterfly metapopulations (Hanski 1999). A local habitat patch population may be expected to persist on the time scale of years (Harrison 1989); however, persistence of metapopulations for longer terms results from the interaction among sets of local habitat patch populations at larger geographic scales. Maintenance of landseape conneetivity (habitat patches linked by intervening dispersal areas) is essential in order to maintain metapopulation resilience. Land use ehanges that block dispersal between habitat patches and isolate local populations by compromising landscape connectivity ean be just as detrimental to metapopulation survival as those that destroy or reduce the size of habitat patehes.

The Quino checkerspot was listed as endangered on January 16, 1997 (62 FR 2313). Critical habitat was designated on April 15, 2002 (67 FR 18356), and revised on June 17, 2009 (74 FR 28776), and includes approximately 62,125 acres of land in Riverside and San Diego Countics. The Quino checkerspot butterfly is threatened primarily by eonversion of native vegetation to non-native annual grassland, urban and agricultural development, nitrogen deposition, and climate change-induced habitat modification (USFWS 2009aaa). These threats destroy and degrade the quality of habitat and result in the extirpation of local Quino eheekerspot populations. Activities resulting in habitat fragmentation or host or nectar plant removal reduce habitat quality and inerease the probability of local Quino checkerspot butterfly population extirpation and specics extinction.

\section{Kern Primrose Sphinx Moth}

The Kern primrose sphinx moth (Euproserpinus euterpe) occurs in the Walker Basin, the Carizzo Plain, and the Cutama Valley in Kern and San Louis Obispo Counties, California. Two of the Carrizo Plain populations are located on BLM lands (USFWS 2007x). The species is associated with sandy washes with the following essential habitat clements: open soil for morning basking, young alluvial sandy soils that support the speeics' food plant, field primrose, and that are loose enough to allow larval burrows, and sufficiently dense stands of field primrose that allow larvac to travel from stand to stand while feeding (Jump et al. 2006). Suitable host plants for adults vary by site.

Adult populations of Kern primrose sphinx moth vary in size from year to year, but the timing of biological factors is not well known (Osborne 2005). The breeding period is coincident with the adult flight season, which appears to vary based on the elevation of the population, and occurs in late winter or early spring (USFWS 2007x). Adults lay cggs on field primrose plants, but will also deposit eggs on the filaree, a naturalized exotic plant. At least 11 days are required for the eggs to hatch, and there are five larval instars before pupation oeeurs (USFWS 1983d). Pupation occurs in the soil, and a pupation chamber is constructed near the surface, perhaps under rocks or other objects. The adults may emerge the following year, or may remain in the pupal stage for an undetermined number of years. Pupal emergence is correlated with climatic cues associated with relatively wet and productive years. Extended dormancy is a means of avoiding the loss of many larvae during drought years when populations of host plants may be low (Powell 1986).

The Kern Primrose sphinx moth is a day flier, with adults flying during the warmer parts of the day, usually between 10:00 a.m. and 2:30 p.m. (Tuskes and Emmel 1981). In the morning, males and females frequently bask on bare patches of soil, dirt roads, or rodent mounds. As the afternoon winds increase, adult basking locations change to areas protected from wind, such as washes, behind knolls, or on the ground among bushes.

The Kern primrose sphinx moth was federally listed as threatened on April 8, 1980 (45 FR 24088). Critical habitat has not been designated. Human activity probably has affected the population levels of the Kern primrose sphinx moth in at least three ways: 1) the introduction and establishment of non-native plants, particularly filaree, may have had a substantial impact on the ability of the moth to locate and oviposit on the correct host plant; 2) land use 
practiees probably have directly influenced the survival of the moth and/or its host plant; and 3) flight eharaeteristics of the moth result in higher mortality of females than males by colleetors, which negatively affects the population's reproductive potential. Loss of habitat resulting from eonflicting land uses (OHV use, certain agricultural praetiees, residential development) is still considered a serious threat to the species (USFWS 2007x).

\section{Oregon Silverspot Butterfly}

The primary reference for this section is:

USFWS. 2001h. Oregon Silverspot Butterfly (Speyeria zerene hippolyta) Revised Recovery Plan. Portland, Oregon.

References eited in this section are internal to the above-refereneed document. Full eitations have been ineluded in the Bibliography.

The 2011 5-year review for the Oregon silverspot butterfly (USFWS 2011z) was reviewed for updated information on this speeies.

The Oregon silverspot butterfly (Speyeria zerene hippolyta) oceurs at disjunet sites near the Paeifie eoast, from Del Norte County, California, north to Long Beaeh Peninsula, Washington. The subspeeies occupies three types of grassland habitat: marine terrace and coastal "salt spray" meadows, stabilized dunes, and montane grasslands. The first two habitats are strongly influeneed by proximity to the oecan, with mild temperatures, high rainfall, and persistent fog. Of the two, the dune habitat tends to have lower relief, highly porous soils, and less exposure to winds. Conditions at the montane sites inelude colder temperatures, frequent eloud eover, substantial snow accumulations, less coastal fog, and no salt spray.

As of 2011, only five populations of Oregon silverspot butterfly were known to oecur: one is in Del Norte County, California (Lake Earl), two are in Lane County, Oregon (Rock Creek-Big Creek and Bray Point), and two are in Tillamook County, Oregon (Caseade Head and Mount Hebo; USFWS 2011 y).

Eaeh type of habitat must provide the Oregon silverspot with host plants, neetar sourees, and other suitable environmental eonditions. Caterpillars feed primarily on early blue violets. Stands of violets that are large enough to provide enough food for larval butterflies on the Oregon coast oceur only in relatively open and low-growing grasslands, where violets may be an abundant eomponent of the plant eommunity (Hammond and MeCorkle 1984). Apart from early blue violets, Oregon silverspot eaterpillars are also known to feed on a few other violet speeies, sueh as yellow stream violets and Aleutian violets. Neetar plants most frequently used by Oregon silverspot butterflies are members of the aster family, including the following native species: Canada goldenrod, dune goldenrod, California aster, pearly everlasting, dune thistle, and yarrow. They are also known to neetar on two eommon introduced species: tansy ragwort and false dandelion. The flowering seasons of these species overlap, providing an array of nectar choiees for adult butterflies throughout the flight season.

The Oregon silverspot butterfly goes through six larval instars and a pupal stage before metamorphosing into an adult. Newly hatehed first-instar larvae immediately enter diapause after eating the lining of the eggshell. They remain in diapause until host plants send up new growth in spring, and feed until pupation in the summer. Very little is known about the biology of the caterpillar or pupae. Adult emergence starts in July and extends into September, with many males appearing several weeks before females appear. Mating usually takes plaee in relatively sheltered areas. Adults will often move long distanees for neetar or to eseape windy and foggy conditions.

The Oregon silverspot butterfly was federally listed as threatened on July 2, 1980 (45 FR 44935), and eritical habitat was designated at the same time. Lands ineluded in the eritical habitat designation are those that were known to be oceupied by the butterfly at the time: portions of Seetion 15 and the south half of Seetion 10 that are west of a line parallel to and about 1,500 feet west of the eastern seetion boundaries of Sections 10 and 15 , Township 16 South, Range 12 West, Lane County, Oregon. Invasion by exotie species, natural suecession, fire 
suppression, and land development have resulted in the loss and modifieation of the species' habitat. Land use practices have altered disturbance regimes needed to maintain existing habitats and create new habitats for species expansion. Other threats to the subspecies include OHVs, grazing, erosion, road kill, and pesticides. The Oregon silverspot butterfly is also sought by collectors. Currently, lack of suitable habitat continues to be the most signifieant threat to the species. At all sites where the species oecurs, invasive plant species have degraded habitat quality, and control of these species has been inadequate. The use of herbieides is likely needed to successfully restore enough suitable habitat for the species to preserve existing populations and provide habitat for reintrodueed populations (USFWS $2011 \mathrm{y}$ ).

\section{Fender's Blue Butterfly}

The primary referenee for this section is:

USFWS. 2010o. Recovery Plan for the Prairie Species of Western Oregon and Southwestern Washington. Portland, Oregon.

Referenees eited in this section are internal to the above referenced document. They are included in the bibliography.

The Fender's blue butterfly (Icaricia icarioides fenderi) is endemic to upland prairies of the Willamette Valley in Oregon. Although the precise historic distribution of this subspecies is unknown, recent surveys have indicated that the insect is confined to the Willamette Valley and eurrently (as of 2010) persists in less than 20 populations on remnant prairies in Yamhill, Polk, Benton, and Lane Counties. Populations oceur on upland prairies historieally charaeterized by native bunch grasses, as a result of the subspecies' dependenee on Kincaid's lupine. However, wet prairies are used for neetaring and dispersal habitat. Fender's blue butterflies oeeupy sites predominantly loeated almost exelusively on the western side of the Willamette Valley, within 21 miles of the Willamette River.

The primary habitat requirement for the Fender's blue butterfly is its host plant, Kineaid's lupine, which is the larval food souree, although spurred lupine and sickle keeled lupine may be secondary food plants used by the inseet (Hammond and Wilson 1993). The Fender's blue butterfly also requires native wildflowers for adult neetar food sources. At least 12 aeres of high quality habitat are neeessary to support a population (Crone and Schultz 2003, Schultz and Hammond 2003), and in degraded, low-quality prairies, a mueh larger area is probably required.

Adult Fender's blue butterflies live approximately 10 to 15 days, and rarely travel farther than 1.2 miles over their entire life span (Sehultz 1998). It is thought that the life eycle of Fender's blue butterfly is similar those of related subspecies (Hammond and Wilson 1993). Adult butterflies lay their eggs on the host plant, which serves as a food source for the caterpillars during May and June. Newly hatched larvae feed for a short time, reaching their second developmental stage in the early summer, at which point they enter an extended diapause (maintaining a state of suspended activity). Diapausing larvae remain in the leaf litter at or near the base of the host plant through the fall and winter, and may become active again in March or April of the following year. Some larvae may be able to extend diapause for more than one season depending upon the individual and environmental conditions. Once diapause is broken, the larvae feed and grow through three to four additional developmental stages, enter their pupal stage, and then emerge as adult butterflies in April and May (Schultz and Hammond 2003). A Fender's blue butterfly may complete its life cycle in 1 year.

The Fender's blue butterfly was federally listed as endangered on January 25, 2000 (65 FR 3875). On October 31, 2006, the USFWS designated approximately 3,010 acres of critical habitat for the subspecies in Benton, Lane, Polk, and Yamhill Counties, Oregon (71 FR 63862). The primary threats are habitat loss from agriculture and urban development, encroachment into prairie habitats by shrubs and trees as a result of fire suppression, fragmentation, the invasion of non-native plant species into prairie habitat, and elimination of natural disturbance regimes. Pesticide use may also impact this subspecies. 


\section{Taylor's Checkerspot Butterfly}

The primary reference for this section is:

USFWS. 2012f. Endangered and Threatened Wildlife and Plants; Listing Taylor's Checkerspot Butterfly and Streaked Horned Lark and Designation of Critical Habitat; Proposed Rule. Federal Register 77(197):61937-62058.

References cited in this section are internal to the above-referenced document. A complete list of these references is available from the Washington Fish and Wildlife Office, Lacey, Washington.

Taylor's checkerspot butterfly (Euphydryas editha taylori) is a medium-sized butterfly that is found in open habitats dominated by grassland vegetation. Taylor's checkerspot butterflies were historically known to oceur in British Columbia, Washington, and Oregon, and were likely distributed throughout grassland habitat found on prairies, shallow-soil balds, grassland bluffs, and grassland openings within a forested matrix in south Vancouver Island, the northern Olympic Peninsula, the Puget Sound region, and the Willamette Valley. Their distribution has been reduced from more than 80 locations rangewide to 13 , and there are now only ten populations in Washington, two populations in Oregon, and one population in British Columbia, Canada.

In Washington, Taylor's checkerspot butterflies inhabit glacial outwash prairies in the south Puget Sound region; shallow soil balds, roadsides, and former clear-cut areas within a forested matrix on the northeastern Olympic Peninsula; and a coastal stabilized dune site near the Straits of Juan de Fuca (Stinson 2005). In Oregon, they are found on grassland hills in the Willamette Valley.

Taylor's eheckerspot butterflies produce one brood per year. They overwinter in the fourth or fifth developmental phase, and as adults typically have a flight period of 10 to 14 days. The flight period usually oceurs in May, although depending on climatic conditions the flight period may begin in late April and extend into early July, and can last for as long as 45 days (Ross 2008). Female Taylor's checkerspot butterflies and their larvae utilize plants that contain defensive chemicals. As maturing larvae feed, they accumulate these defensive chemical compounds from the host plant into their bodies, which appears to deter predation (Bowers 1981). Larval host plants include members of the Broomrape family, such as paintbrushes and owl's clover, as well as members of the Plantain family. Additional food plants may also be utilized by larvae.

Taylor's checkerspot butterfly was federally listed as endangered on October 3, 2013 (78 FR 61451). On the same date, the USFWS designated 1,941 acres in Island, Clallam, and Thurston Counties in Washington, and in Benton County in Oregon, as eritical habitat for the taxon (78 FR 61505). The primary threats to Taylor's checkerspot butterfly are development and impacts to habitat from conversion to other uses (agriculture), the isolation and limited distribution of the species, military training, recreation, habitat fragmentation, habitat disturbance, and long-term fire suppression.

\section{Effects of Herbicide Treatments on Butterflies and Moths}

\section{Direct Effects}

During herbicide treatments in areas where listed butterflies and moths occur, trucks and/or ATVs/UTVs used to apply herbicides could crush larvae, eggs, and adults. Workers on foot with backpack sprayers could also trample butterflies and moths in the treatment area, resulting in injury or mortality.

Inadvertent exposure of TEP butterflies and moths to herbicides would be likely if treatments were to oceur in areas where these species oceur. Reasonable exposure pathways include direct spray (particularly during sedentary phases of the life cycle) and dermal contact with vegetation that has been treated with herbicides. According to ERAs, of the three herbicides proposed for use, only fluroxypyr is associated with risks to terrestrial invertebrates, and only under direct spray seenarios (see Table 6-1). Adverse health effects associated with direct spray could include mortality, reduced reproductive output, behavioral modification, and/or increased susceptibility to environmental stresses. These toxicological effects could lead to a further decrease in the size and viability of 
affeeted populations. Small, fragmented populations could potentially be extirpated or become more susceptible to future extirpation by environmental stresses and other factors.

There are no toxieological risks to TEP butterflies and moths associated with use of aminopyralid or rimsulfuron, and no toxicologieal risks associated with dermal eontact with vegetation sprayed by any of the three herbicides at typical or maximum application rates (Table 6-1).

\section{Indirect Effects - Removal of Vegetation}

Listed butterfly and moth species could suffer indireet effects from herbicide treatments if non-target host and neetar plants were sprayed by herbicides. Effects to non-target plant species are predieted as a result of direct spray by all three herbicides. In addition, non-target plants eould be impaeted by off-site drift of the herbicides under certain seenarios, and surface runoff of rimsulfuron under certain scenarios (see Tables 4-1 through 4-4 for more information). Localized elimination or a reduction in numbers of host and/or neetar plants could result in adverse population-level effeets to the listed butterfly or moth speeies that rely on these plants for survival.

Herbicide treatments that inerease the amount of open habitat on the site would be expeeted to have long-term positive effects on these species, provided that the needed larval food plants and nectar plants are present on the site. Creation of open areas adjacent to known locations of TEP species would also have the potential to inerease the size and range of existing populations in some instances.

The removal of non-native plant species from habitats in which these species oceur, or in nearby habitats, would also be expected to have positive effeets. Non-native species can exclude larval food plants and neetar sources, which butterflies and moths are dependent upon for survival and the eompletion of their life eyele. Non-native species can also change the habitat strueturally so that adults are unable to forage adequately.

\section{Conservation Measures}

Many local BLM offices already have management plans in place that ensure the protection of these species during activities on publie lands. As diseussed in Chapter 2, this BA assumes that the BLM would eontinue to follow the conservation measures listed in the $2007 \mathrm{BA}$, or other comparable eonservation measures that would be developed by the field offices based on local site conditions and included in local-level consultation. A list of key conservation measures for TEP butterflies and moths is presented at the end of this seetion, with a complete list provided in Appendix A. These measures include restrictions on broadeast spray of herbicides to avoid direet spray seenarios. Because there would be a low risk to terrestrial invertebrates under seenarios involving direct spray of fluroxypyr, the following conservation measure has been developed for this active ingredient:

- When condueting herbicide treatments in or near habitat used by TEP butterflies or moths, avoid use of the fluroxypyr, where feasible. If pre-treatment surveys determine the presenee of TEP butterflies or moths, do not use fluroxypyr to treat vegetation.

\section{Key Conservation Measures from the $2007 \mathrm{BA}$}

- Use an integrated pest management approach when designing programs for managing pest outbreaks.

- Survey treatment areas for TEP butterflies/moths and their host/nectar plants (suitable habitat) at the appropriate times of year.

- Minimize the disturbance area with a pre-treatment survey to determine the best access routes. Avoid areas with butterfly/moth host plants and/or nectar plants.

- To protect host and nectar plants from herbicide treatments, follow recommended buffer zones and other conservation measures for TEP plant species when conducting herbicide treatments in areas where populations of host and nectar plants occur.

- Do not broadcast spray herbicides in habitats occupied by TEP butterflies or moths; do not broadcast spray herbicides in areas adjacent to TEP butterfly/moth habitat under conditions when spray drift onto the habitat is likely. 
Each local BLM office is required to draw up management plans related to treatment activities that identify any TEP butterfly or moth species or their critical habitat that are present in the proposed treatment areas, as well as the measures that will be taken to protect these species.

\section{Determination of Effects}

Based on the information provided in the risk assessments, there are no toxicological risks to TEP butterflies and moths associated with the use of aminopyralid and rimsulfuron. Conservation measures in the $2007 \mathrm{BA}$ include steps to identify the presence of TEP butterfly and moth species in proposed treatment areas, and to protect host and nectar plants. These measures (or other comparable measures developed by field offices), would allow the BLM to avoid populations of these specics, and minimize impacts to habitat. Fluroxypyr has a low level of risk to the species under direct spray sccnarios. The conservation measures discussed in this chapter were designed to reduce the chance of adverse effects occurring to the point where the likelihood of such effects would be discountable, or to reduce any potential effects to the point where they would be insignificant to the species or their critical habitats, and would never reach the scale where take occurs. As a result, with application of these conservation measures, the action would be Not Likely to Adversely Affect TEP butterflies and moths or their federally designated critical habitat at the programmatic level. Given BLM mandates for use of integrated pest management (including vegetation management), and given that it is not possible to forecast site-specific vegetation management needs below the programmatic level, additional evaluations of situation-specific effects will be the subject of step-down ESA Section 7 evaluations and subsequent consultations. In this manner, any additional specific conservation measures necessary to accommodate site or situation-specific peculiaritics not predictable at the programmatic level will be developed at the local level and incorporated into Pesticide Use Proposals prior to local implementation of vegetation management activities that involve the usc of herbicides considered in this BA.

\section{Arthropods - Other Terrestrial Insects}

Apart from butterflies and moths, only one listed terrestrial insect occurs or could potentially occur within the project area: the valley clderberry longhorn bectle. The valley elderberry longhorn beetle occurs in the Mediterranean Ecoregion Division.

\section{Valley Elderberry Longhorn Beetle}

The primary reference for this section is:

USFWS. 1984g. Valley Elderberry Longhorn Beetle Recovery Plan. Portland, Oregon.

References cited in this section are internal to the above-referenced document. Full citations have becn included in the Bibliography.

The 2006 5-year review for the valley elderberry longhorn beetle (USFWS 2006f) was reviewed for updated information on this species.

The valley elderberry longhorn bectle (Desmocerus californicus dimorphus) is endemic to remnants of moist valley oak woodlands associated with riparian systems in the lower Sacramento and upper San Joaquin valleys of California, where its food plant, elderberry, grows (Linsley and Chemsak 1972, Arnold 1983). The species currently inhabits the Central Valley from southern Shasta County south to Fresno County in the San Joaquin Valley (Barr 1991). The riparian forest remnants that contain the valley elderberry longhorn beetle are difficult to characterize because they occur in many different forms throughout the valley. Under ideal conditions, they eonsisted of several canopy layers with a dense undergrowth (Katihah 1983). Fremont cottonwood, California sycamore, willow, and valley oak were common overstory species. The intermediate canopies consisted of California boxelder, Oregon ash, elder, and various species of willow. Vines were abundant in all canopy layers of the riparian forest. Undergrowth vegetation was quite diverse, and today includes a number of exotic weeds. As a result of urban and agricultural development within the beetle's range, elderberry today grows in a number of 
unnatural areas (e.g., urban parks, power-line corridors, agricultural land) that formerly were riverine floodplains, but which now represent lands reclaimed by man.

Eggs are laid in May on elderberry stems greater than 1 inch in diameter, on healthy plants. Larvae bore into stems and feed on the soft eore of the plant, remaining in larval form inside excavated passages within the stem for as long as 2 years before emerging as adults. Adults feed on elderberry flowers and possibly foliage (Linsley and Chemsak 1972, Arnold 1983), and are present from March through early June (Barr 1991).

The valley elderberry longhorn beetle was federally listed as threatened on August 8, 1980 (45 FR 52803 ). At the same time, critical habitat was designated in the City of Sacramento, in the American River Parkway, and in Goethe Park, Sacramento County, California. Sinee the time of listing the valley elderberry longhorn beetle has been identified in numerous new locations, and loss of riparian habitat throughout the Central Valley has slowed. In 2006, the USFWS recommended delisting the valley elderberry longhorn beetle (USFWS 2006f), and a proposed rule to delist the species was made on October 2, 2012 (77 FR 60237).

\section{Effects of Herbicide Treatments on the Valley Elderberry Longhorn Beetle}

\section{Direct Effects}

Injury or mortality of longhorn beetles could oceur during herbicide applications, as a result of trucks/ATVs/UTVs, horses, or people crushing beetles and eggs. In addition, longhorn beetles could be exposed to herbicides during treatments, either by being directly sprayed during the treatment or by coming into contact with treated vegetation after the spraying oceurred. According to ERAs, of the three herbicides proposed for use, only fluroxypyr is associated with risks to terrestrial invertebrates, and only under direet spray seenarios (see Table 6-1). Adverse health effects could include mortality, reduced reproductive output, behavioral modification, and/or increased susceptibility to environmental stresses. These toxicological effects could lead to a further decrease in the size and viability of affected populations. Small, fragmented populations could potentially be extirpated or become more susceptible to future extirpation by environmental stresses and other factors.

No effeets were predicted for direct spray by aminopyralid or rimsulfuron, or for exposures involving dermal contact with vegetation sprayed with any of the three herbicides at the typical or maximum application rate (Table 6-1).

\section{Indirect Effects}

Removal of non-native plant species would likely benefit the valley elderberry longhorn beetle, since it is most prevalent in native plant communities, and excessive weed growth is a known threat to the beetle and its host plant (USFWS 1984g). However, if host elderberry plants were to become injured or suffer mortality as a result of herbicide treatments, it is likely that populations of longhorn beetles would be adversely affected. Additionally, since the species occurs in dense riparian habitats, any herbicide treatment resulting in a large-seale removal of plant cover would likely have an adverse impact on the species. All three of the herbicides proposed for use could potentially be used for terrestrial applications in riparian habitats. However, based on the likely usage of these herbicides, wide-scale removal of riparian vegetation is unlikely to occur. Out of the three herbicides, fluroxypyr and rimsulfuron would not typically be used near water, except possibly for spot treatments of certain target species. Aminopyralid would be used in riparian treatments for selective removal of certain species (e.g., knapweeds), but extensive removal of riparian vegetation would be unlikely. Additionally, aminopyralid would provide an alternative to glyphosate, which is less selective and more likely to result in removal of non-target riparian vegetation.

\section{Conservation Measures}

As discussed in Chapter 2, this BA assumes that the BLM would continue to follow the conservation measures listed in the $2007 \mathrm{BA}$, or other comparable conservation measures that would be developed by the field offices based on local site conditions and included in local-level consultation. A list of key conservation measures from the $2007 \mathrm{BA}$ is presented at the end of this seetion, with a complete list provided in Appendix A. These include surveys for the species and its host plant, and a requirement to follow the recommended buffers identified for TEP 
plant species to protect vegetation in valley elderberry longhorn beetle habitat. The buffers identified for aminopyralid, fluroxypyr, and rimsulfuron in Chapter 4 of this BA would also need to be followed. Additionally, the following eonservation measures would help minimize the potential for a direet spray of this speeies by fluroxypyr:

- When conducting herbieide treatments in or near habitat used by the valley elderberry longhorn beetle, avoid the use of fluroxypyr, where feasible. If pre-treatment surveys determine the presenee of valley elderberry longhorn beetles, do not use fluroxypyr to treat vegetation.

No additional eonservation measures for aminopyralid or rimsulfuron are neeessary, as these species do not pose a toxicologieal risk to the valley elderberry longhorn beetle. However, if the new active ingredients are used in a tank mix or formulation that ineludes previously approved active ingredients, any applicable eonservation measures for these chemieals from the 2007 BA would also apply.

\section{Key Conservation Measures from the $2007 \mathrm{BA}$}

- Survey proposed treatment sites within the range of the valley elderberry longhorn beetle for the presence of the beetle and its elderberry host plant (should be condueted by a qualified biologist).

- To protect host elderberry plants from herbieide treatments, follow reeommended buffer zones and other conservation measures for TEP plant speeies when eonducting herbieide treatments in areas where populations of elderberry occur.

- Do not broadcast spray herbicides in suitable valley elderberry longhorn beetle habitat; do not broadeast spray herbicides in areas adjacent to suitable habitat under eonditions when spray drift onto the habitat is likely.

\section{Determination of Effects}

Based on the information provided in the risk assessments, there are no toxicological risks to the valley elderberry longhorn beetle assoeiated with the use of aminopyralid and rimsulfuron. Conservation measures in the 2007 BA include surveys of treatment sites for the speeies and its host plant, and a restrietion on herbieide treatments that would result in a substantial loss of vegetation. These measures (or other comparable measures developed by field offices) would allow the BLM to avoid directly spraying valley elderberry longhorn beetles during treatments, and to avoid adverse effeets to the speeies' habitat. Fluroxypyr has a low level of risk to the speeies under direet spray scenarios. The conservation measures discussed in this ehapter were designed to reduce the ehanee of adverse effects occurring to the point where the likelihood of sueh effeets would be diseountable, or to reduce any potential effeets to the point where they would be insignificant to the species or their eritical habitats, and would never reach the scale where take oeeurs. As a result, with applieation of these conservation measures, the action would be Not Likely to Adversely Affect valley elderberry longhorn beetles or their federally designated critical habitat at the programmatic level. Given BLM mandates for use of integrated pest management (ineluding vegetation management), and given that it is not possible to forecast site-specific vegetation management needs below the programmatic level, additional evaluations of situation-specific effects will be the subjeet of step-down ESA Section 7 evaluations and subsequent consultations. In this manner, any additional speeific eonservation measures necessary to accommodate site or situation-specific peculiarities not predictable at the programmatie level will be developed at the local level and ineorporated into Pesticide Use Proposals prior to loeal implementation of vegetation management activities that involve the use of herbieides eonsidered in this BA.

\section{Amphibians and Reptiles}

Listed (and proposed) amphibian and reptile species predominantly occur in the Subtropical Desert habitats of the southwest, and in California, in the Mediterranean Eeoregion. A notable exception is the Wyoming toad, which occurs in the Temperate Steppe Ecoregion of Wyoming.

\section{Amphibians:}

Desert slender salamander - Subtropical Desert

Sonora tiger salamander - Subtropical Desert 
Chiricahua leopard frog - Subtropical Desert/Subtropical Steppe

Wyoming toad - Temperate Steppe

California tiger salamander - Mediterranean

Arroyo toad - Mediterranean

California red-legged frog-Mediterranean

Sierra Nevada yellow-legged frog - Mediterranean

Mountain yellow-legged frog - Mediterranean

Yosemite toad - Mediterranean

Oregon spotted frog - Marine

\section{Reptiles:}

Coachella Valley fringe-toed lizard - Subtropical Desert

Desert tortoise - Subtropical Desert

New Mexican ridge-nosed rattlesnake - Subtropical Desert

Northern Mexican garter snake - Subtropieal Desert/Subtropical Steppe

Narrow-headed garter snake - Subtropieal Deserv/Subtropical Steppe

Giant garter snake - Mediterranean

Blunt-nosed leopard lizard - Mediterranean

\section{Desert Slender Salamander}

The desert slender salamander (Batrachoseps aridus) is a small, subterranean amphibian with moist skin that must remain in moist environments. It is constrained to perennial sceps and springs in the desert slopes of the Santa Rosa Mountains in Riverside County, California (USFWS 2009bbb). It is found in moist subterranean spaees such as erevices between limestone sheets and under limestone slabs and other roeks along the base of eliffs where continuous water seepage occurs (California Department of Fish and Game 2000b), and in the burrows of other animals and earthworms (USFWS 2009bbb). The only known locations of this species are in Hidden Palm Canyon, a tributary of Deep Canyon, a large gorge draining desert stopes of the Santa Rosa Mountains (USDOI BLM 2001b), and in Guadalupe Canyon, on land administered by the BLM (Giuliani 1981).

The most important struetural eomponent of the desert slender salamander's habitat is believed to be the limestone sheeting that eovers portions of the canyon wall at both sides. The material has built up over a period of years as a result of seepage and precipitation of the solutes. By possessing a moist interior environment when other nearby retreats dry out, the sheeting may be a refuge of last resort for the salamander. Decay of plant roots and developmental patterns of the sheeting may account for the tunnels and pockets that provide retreats for salamanders. Erosion of this sheeting down to bedrock during severe tropical storms of 1976 resulted in a loss of approximately one-third of the available salamander habitat at the site. Desert slender salamanders feed on small arthropods, which they catch with a special projectile tongue (USFWS 2009bbb).

This species is a terrestrial breeder, presumably laying eggs in an underground chamber, in a crevice, or under a rock. However, little is known about the breeding habits or courtship of any species of slender salamander, and the eggs of the desert slender salamander have never been observed.

The desert slender salamander was federally listed as endangered on June 4, 1973 (38 FR 14678). Critical habitat has not been designated for the species. The continued existence of the species is threatened by a variety of factors, including its extremely restricted distribution. The Hidden Palm Canyon population has not been found recently, and the Guadalupe Canyon population, which is restricted to a very small area, has not been surveyed recently (USFWS 2009bbb). Since salamanders require moist conditions, desiceation of habitat during a prolonged drought could result in extirpation of the species. Maintenance of the habitat at Hidden Palm Canyon is dependent on seepage from groundwater originating in the watershed above the box canyon. Therefore, future groundwater pumping or diversion projects in this watershed could indirectly impact salamander habitat. The Guadalupe Canyon site, however, is more secure, since it is more remote, and the watershed is administered by the BLM and 
Forest Service (San Bernardino National Forest). Another potential threat is erosion caused by severe storms. Additionally, disease and climate change are threats that have recently been identified (USFWS 2009bbb).

\section{Sonora Tiger Salamander}

The primary referenee for this section is:

USFWS. 2002m. Sonora Tiger Salamander (Ambystoma tigrinum stebbinsi) Reeovery Plan (Draft). Albuquerque, New Mexico,

References eited in this section are internal to the above-refereneed doeument. They have been included in the Bibliography.

The 2007 5-year review for Sonora tiger salamander (USFWS 2007y) was eonsulted for updated information on this speeies.

The Sonora tiger salamander (Ambystoma tigrinum stebbinsi) oceurs in a limited number of wetland habitats in the San Rafael Valley of Arizona and Mexico, and the adjacent foothills of the Patagonia and Huaehuea Mountains. The most important habitat requirement for Sonora tiger salamanders is the availability of standing water for breeding from January through June. Historically, the subspecies probably inhabited springs, eienegas, and possibly backwater pools where permanent or nearly permanent water allowed survival of bronehiate adults. With the disappearance of natural standing water habitats, ponds ereated by ranehers for watering their eattle are now almost the only suitable breeding sites remaining. The historical habitats of the subspecies have either disappeared or are oceupied by non-native fishes with which Sonora tiger salamanders cannot eoexist (USFWS 2007y). Aquatic breeding habitats are used by all life stages; however, upland habitats are also used by terrestrial adults when not in the breeding ponds.

Sonora tiger salamanders are tolerant of a wide range of temperatures. Temperatures in ponds range from less than 41 to $86^{\circ} \mathrm{F}$. Temperatures in the terrestrial environment range from below freezing to over $95^{\circ} \mathrm{F}$. Mammal burrows or loosened soils outside the pond likely provide refugia for metamorphosed salamanders in the terrestrial environment, enabling them to burrow underground to avoid extreme environmental conditions.

Sonora tiger salamanders may begin breeding as early as January, and eggs are laid until early May. Eggs are attached to aquatic vegetation, roeks, or other substrate in elumps of up to 50, and hatch within 2 to 4 weeks. Larvae that hateh in permanent water often develop into branehiate adults and spend their entire lives in the water; all larvae that hateh in ephemeral waters metamorphose into the terrestrial form and return to aquatie habitats only to breed. Sexual maturity is reached in 5 to 6 weeks. Populations of the Sonora tiger salamander are dynamic. In particular, drought and disease periodieally extirpate or greatly reduee populations. Branchiate adult tiger salamanders prey on zooplankton and a variety of macroinvertebrates, and eat salamander eggs and larvae during the breeding season (Holomuzki 1986). In the pond, metamorphosed individuals eat aquatic macroinvertebrates and terrestrial insects that fall in the water. Outside the pond, they consume terrestrial insects and other macroinvertebrates (Whiteman et al. 1994). Metamorphs are the only life history stage that ean disperse from pond to pond and establish new populations.

The Sonora tiger salamander was listed as endangered on January 6, 1997 (62 FR 665), but eritical habitat has not been designated. A variety of factors threaten the subspeeies. Disease and predation by introduced non-native fishes and bullfrogs are probably the most serious and immediate threats, both of whieh have been implicated in the elimination of aquatie populations. Tiger salamanders also are widely used in Arizona as fishing bait, a use that poses additional threats. Other subspecies of tiger salamander introduced into habitats of the Sonora tiger salamander for bait propagation or by anglers could, through interbreeding, genetieally swamp distinet populations of this subspecies. Additional threats include habitat destruction, reduced fitness resulting from low genetie diversity, and inereased probability of ehanee extirpation, which is charaeteristic of small populations. 


\section{Chiricahua Leopard Frog}

The primary references for this section are:

USFWS. 2002n. Listing of the Chiricahua Leopard Frog (Rana chiricahuensis). Federal Register 67(114):4079040811.

and

USFWS. 2007z. Chiricahua Leopard Frog (Rana chiricatmensis) Final Recovery Plan. Albuquerque, New Mexico.

References cited in this section are internal to the above-referenced documents. A complete list of these references is available from the USFWS Arizona Ecological Services Field Office, Phoenix, Arizona.

The 2011 5-year review for the Chiricahua leopard frog (USFWS 2011 aa) was reviewed for updated information on this species.

The Chiricahua leopard frog (Rama chiricahuensis; Lithobates chiricahuaensis) is known from cienegas, pools, livestock tanks, lakes, reservoirs, streams, and rivers at elevations of 3,281 to 8,890 feet. The species is a habitat generalist that historically was found in a variety of aquatic habitats, but is now limited to the comparatively few aquatic systems that support few or no non-native predators (e.g., American bullfrogs, fishes, and crayfishes). The species occurs in central and southeastern Arizona, west-central and southwestern New Mexico, and in Mexico (Platz and Mecham 1979, 1984; McCranie and Wilson 1987; Degenhardt et al. 1996; Sredl et al. 1997). The range of the species is divided into two parts: a southern group of populations (the majority of the species' range) located in mountains and valleys south of the Gila River in Arizona, New Mexico, and Mexico; and a group of northern montane populations in west central New Mexico and along the Mogollan Rim in central and eastern Arizona (Platz and Mccham 1979). As of 2011, it was estimated that Chiricahua leopard frogs were likely extant at about 29 sites New Mexico and in 92 sites in Arizona (USFWS 2011z).

The Chiricahua leopard frog occurs in permanent or semi-permanent aquatic habitats (which arc required for reproduction), typically with abundant aquatic vegetation, at elcvations from approximately 3,300 to 8,500 feet. The species also requires water that is characterized by low levels of contaminants and moderate $\mathrm{pH}$, and may be excluded or exhibit periodic die-offs where a pathogenic fungus is present. Leopard frogs nest in densely vegetated areas, with high canopy cover and dense foliage from ground level to about 13 feet. Chiricahua leopard frogs breed from spring to late summer, depending on elevation. The life cycle of the species is complex, consisting of eggs and larvae that are entirely aquatic and adults that are primarily aquatic. Females produce egg masses that adhere, suspended just above the water surface, to vegetation growing in water 6 to 14 inches deep, near the shore of ponds and streams. Eggs are laid mainly from February into October, with most masses found in the warmer months. Hatching time ranges between 8 and 14 days, depending on water temperature. Upon hatching, tadpoles are mainly herbivorous and remain in the water, where they feed and grow, with growth rates faster in warmer conditions. Tadpoles have a long larval period, from 3 to 9 months, and may overwinter. After metamorphosis, Chiricahua leopard frogs eat an array of invertebrates and small vertebrates, and are generally inactive between November and February.

The Chiricahua leopard frog was federally listed as threatened on July 15, 2002 (67 FR 40790). On March 20, 2012, the USFWS designated approximately 10,300 acres as critical habitat for the species, in Apache, Cochise, Gila, Graham, Greenlee, Pima, Santa Cruz, and Yavapai Counties, Arizona; and Catron, Grant, Hidalgo, Sierra, and Socorro Counties, New Mexico (77 FR 16324). At the same time, the USFWS listed the revised taxonomic description of the species (Lithobates chiricahuaensis) as threatened. The species is now absent from more than 75 percent of its known historical sites, and from numerous mountain ranges, valleys, and drainages within its former range. In areas where the Chiricahua leopard frog is still present, populations are often small, widely scattered, and occupy marginal and dynamic habitats. Threats to this species include predation by non-native organisms; the fungal disease chytridiomycosis; drought; floods; habitat loss and degradation as a result of water diversions and groundwater pumping; livestock management that degrades frog habitats; catastrophic wildfire resulting from a 
long history of fire suppression, mining, development, and other human activities; disruption of metapopulation dynamics; increased chance of extirpation or extinction resulting from small numbers of populations and individuals existing in dynamic environments; and environmental contamination such as runoff from mining operations and airborne contaminants from copper smelters. Loss of Chiricahua leopard frog populations fits a pattern of global amphibian decline, suggesting other regional or global causes of decline may be important as well, such as elcvated ultra-violet radiation, pesticides or other contaminants, and climate change.

\section{Wyoming Toad}

The Wyoming toad (Bufo baxteri) is restricted to a very small range in the Laramie Basin of southeastern Wyoming. The current distribution of the species includes Mortenson Lake National Wildlife Refuge and possibly Hutton Lake Wildlife Refuge (Laramie Rivers Conservation Distriet and USFWS 2004). The Laramie Basin is a semi-arid, intermountain basin characterized by a predominant vegetation of short grasses and sagebrush, located at an elevation of between 7,200 and 7,500 feet. Since settlement and development of agriculturc, the central lower portions of the basin have been irrigated using water diverted from the two major rivers, the Big and Little Laramie (Baxter 1952). The species occurs in floodplains and the short grass edges of ponds and lakes. The habitats once utilized by the Wyoming toad were floodplains ponds, small ponds and lakes produced by irrigation runoff, and the many small seepage lakes in the basin.

The Wyoming toad needs vegetative cover such as sedges and grasses, in a moist situation, throughout the summer to protect against the high evaporative power of the air in the relatively arid climate of the Laramie Basin. It probably utilizes any soft carth, such as pocket gopher burrows and sand dunes, to burrow to below the frost line for winter dormancy (Baxter 1952). The Wyoming toad requires warm (over $60^{\circ} \mathrm{F}$ ), shallow ponds or lake margins for reproduction; these ponds must remain filled during the period from late May until at least mid-August for completion of the tadpole stage. Adult toads are insectivorous and opportunistic in selection of food. It is unlikely that availability of food for either adults or larvae has ever been limiting for this toad.

During daylight hours in June and early July, adults and subadults are abundant and active in the sedges and grasses on the floodplain during Junc and early July. During late July, adults disappear, probably becoming largely nocturnal during the dry part of the summer and remaining beneath the surface of the ground during the day (Baxter 1952). In the period during which this toad was common in the Laramie Basin, adult toads cmerged from winter dormancy in late May or early June, after daily air temperatures approach $80^{\circ} \mathrm{F}$. Eggs were laid in the warm, shallow floodplains. Tadpoles normally completed their transformation to adults by early August. Drying up of the floodplain ponds was a noticeable cause of mortality to the tadpoles (Baxter 1952).

The Wyoming toad was federally listed as endangered on January 17, 1984 (49 FR 1992). Critical habitat has not been designated. The species was determined to be extinet in 1994, and captive-raised larvae and toadlets were released at Lake George, Rush Lake, and Mortenson Lake, Wyoming, in 1995. The toad was also reintroduced to a small research project site in the Laramie Plains in 2003, and private land in Centennial, Wyoming in 2005. Reasons for the population's decline are not entirely clear, although aerial applications of pesticides for mosquito control, predation, and agricultural practices related to irrigated hay meadows have been implicated as possible causes. Currently, the primary threat to the specics is the amphibian chytrid fungus, which is present at Mortensen Lake and has been implicated in the declines and extinctions of amphibian species worldwide. Other factors that threaten the species include water diversion, infectious disease, predation, pesticide use, grazing and irrigation practices, weather events, climate change, and lack of genetic diversity (USFWS 2009cec). 


\section{California Tiger Salamander}

The primary reference for this section is:

USFWS. 2004c. Determination of Threatened Status for the California Tiger Salamander; and Special Rule Exemption for Existing Routine Ranching Activities. Federal Register 69(149):47212-47248.

References eited in this seetion are internal to the above-referenced document. A complete list of these references is available from the USFWS Sacramento Fish and Wildlife Office in Sacramento, California.

The California Tiger Salamander (Ambystoma californiense) oceurs in grasslands, oak savannahs, and coastal scrub communities of lowlands and foothill regions where aquatic sites are available for breeding. Along the Coast Ranges, the species occurs in the Santa Rosa area of Sonoma County, southern San Mateo County south to San Luis Obispo County, and the vicinity of northwestern Santa Barbara County. In the Central Valley and surrounding Sierra Nevada foothills and Coast Range, the species oceurs from northern Yolo County (Dunnigan) southward to northwestern Kern County and northern Tulare and Kings Counties.

Breeding sites are areas where California tiger salamanders successfully breed in years of normal rainfall and survive during the dry months of the year. California tiger salamanders oecur in vernal pools, seasonal and perennial ponds, and surrounding upland areas from sea level to approximately 3,600 feet in elevation (Stebbins 1989; Shaffer et al. 1993; Jennings and Hayes 1994; Petranka 1998). Aquatic habitats required by the species include standing bodies of fresh water (including natural and manmade water bodies) that typically support inundation during winter rains and hold water for a minimum of 12 eonsecutive weeks. Spring rains maintain pool inundation, allowing larvae the time in water to grow into juveniles that ean survive in upland habitats. Juveniles and adults are primarily terrestrial. Upland habitats containing underground refugia (small mammal burrows or other underground struetures) have features that are essential for the survival of these life forms. The burrows provide proteetion from the hot, dry weather typical of California in the nonbreeding season. California tiger salamanders have been observed up to 1.3 miles from breeding ponds.

Onee established in underground burrows, California tiger salamanders may move short distances within burrows or overland to other burrows, generally during wet weather. Dispersal distance is elosely tied to precipitation; California tiger salamanders travel further in years with more preeipitation. As with migration distanees, the number of ponds used by an individual over its lifetime is dependent on landscape features. Migration to breeding ponds is coneentrated during a few rainy nights early in the winter, with males migrating before females (Twitty 1941; Shaffer et al. 1993; Loredo and Van Vuren 1996; Trenham 1998; Trenham et al. 2000).

Adult California tiger salamanders mate in vernal pools and similar water bodies, and females lay their eggs in the water (Twitty 1941; Shaffer et al. 1993; Petranks 1998). Females attach their eggs singly or, in rare cireumstances, in groups of two to four, to twigs, grass, stems, vegetation, or debris (Storer 1925, Twitty 1941). In ponds with little or no vegetation, females may attach eggs to objects such as rocks and boards on the bottom (Jennings and Hayes 1994). After breeding, adults leave the pool and return to small mammal burrows in the surrounding uplands (Loredo et al. 1996; Trenham 1998a). The eggs hateh in 10 to 14 days, and larvae are aquatic. The larval stage usually lasts 3 to 6 months, beeause most seasonal ponds and pools dry up during the summer (Petranka 1998). After the larvae reach the appropriate size, they metamorphose to the terrestrial stage (Wilbur and Collins 1973). Larvae feed on zooplankton, small crustaceans, and aquatic insects for about 6 weeks after hatching, when they switch to larger prey (J. Anderson 1968). Larger larvae will consume smaller tadpoles of Pacific treefrogs and California red-legged frog (J. Anderson 1968).

The Santa Barbara population segment of the California tiger salamander was federally listed as endangered on September 21, 2000 (65 FR 57242). On July 22, 2002, the Sonoma County population segment was emergency listed as endangered ( $67 \mathrm{FR} 47726$ ). On August 4, 2004, all other populations of the species were federally listed as threatened (69 FR 47212). Critical habitat has been designated for the Sonoma County population of the California tiger salamander, with the most recent revised designation on August 31, 2011 of 47,383 acres of land (76 FR 54346). Although California tiger salamanders still exist across most of their historic range, the habitat available to 
them has been greatly reduced. The breeding ponds and the associated upland habitats inhabited by salamanders have been degraded and redueed in number and area through changes in agriculture practices, urbanization, building of roads and highways, ehemical applieations, and overgrazing (Sweet 1993, 1998a, b; Gira et al. 1999; Santa Barbara County Planning and Development 2000). The primary threats to this species are destruction and modification of habitat, predation and eompetition by introduced or non-native species, habitat fragmentation, contamination of aquatie habitats, and overgrazing.

\section{Arroyo Toad}

The primary references for this section are:

USFWS. 1994h. Determination of Endangered Status for the Arroyo Southwestern Toad. Federal Register 59(241):64859-64867.

and

USFWS. 2001i. Final Designation of Critical Habitat for the Arroyo Toad. Federal Register 66(26):13656-13671.

Referenees eited in this seetion are internal to the above-refereneed doeuments. A complete list of these references is available from the USFWS Carlsbad Fish and Wildlife Office, Carlsbad, California.

The 2009 5-year review for the Arroyo toad (USFWS 2009ddd) was reviewed for updated information on this species.

The Arroyo toad (also commonly called the Arroyo southwestern toad; Bufo californicus; recently recognized as Anaxyrus californicus) is a small toad that is restricted to rivers that have shallow, gravelly pools adjacent to sandy terraces. Historieally, this speeies was found along the length of drainages in southern California from San Luis Obispo to San Diego County, and south into Mexieo. However, urbanization and dam eonstruetion throughout the $20^{\text {th }}$ eentury has destroyed and degraded habitat, limiting the oeeurrenee of this species in the U.S. to small, isolated populations in the headwater areas of streams (USFWS 2009ddd).

The Arroyo toad exhibits a breeding habitat specialization that favors shallow pools and open sand and gravel channels along low-gradient reaehes of medium to large-sized streams (USFWS 1999). These streams ean have either intermittent or perennial streamflow, and typically experience periodie flooding that scours vegetation and replenishes fine sediments. In at least some portions of its range, the speeies also breeds in smaller streams and eanyons where low-gradient breeding sites are more sporadieally distributed. Populations in smaller drainages are likely to be smaller and at greater risk of extirpation than those in larger streams and in larger habitat patehes.

Arroyo toads also require, and spend most of their adult life in, upland habitats. Individual toads have been observed as far as 1.2 miles from the streams where they breed, but are most commonly found within 0.3 miles of those streams (Griffin et al. 1999; USFWS 1999; Holland and Sisk 2000; D. Holland, Camp Pendleton Amphibian and Reptile Survey, Fallbrook, California, unpublished data). Arroyo toads typieally burrow underground during periods of inactivity, and thus tend to utilize upland habitats that have sandy, friable (readily crumbled) soils. Although the upland habitat use patterns of this speeies are poorly understood, aetivity probably is eoneentrated in the alluvial flats (areas ereated when sediments from the stream are deposited) and sandy terraces found in valley bottoms of eurrently active drainages (Griffin et al. 1999; Sweet 1999; USFWS 1999; Holland and Sisk 2000; Ramirez 2000).

Arroyo toads breed from late Mareh until mid-June, in large streams with persistent water (Sweet 1989). Eggs are deposited and larvae develop in shallow pools with minimal eurrent and little or no emergent vegetation. The substrate is sand or pea gravel overlain with floceulent silt. Larvae metamorphose in June or July, and juvenile toads remain on the bordering gravel bars until the pool no longer persists, typically 3 to 8 weeks (Sweet 1992). Sandy terraces with cottonwoods, oaks, and willows, and almost no grass and herbaceous cover at ground level provide optimal foraging habitat for juveniles and adults. 
The Arroyo toad was listed as endangered on December 16, 1994 (59 FR 64859). Critical habitat for the speeies was first designated in 2001 (66 FR 9414), and then underwent a series of revisions. The most recent revised eritical habitat designation, on February 9, 2011 (76 FR 7245), designated a total of approximately 98,366 acres in Santa Barbara, Ventura, Los Angeles, San Bernardino, Riverside, Orange, and San Diego Counties, California, as critical habitat. Critieal habitat includes rivers or streams that support the appropriate habitat requirements for breeding activities and all life phases of the toad, and upland habitats of sufficient width and quality to provide foraging or living areas for subadult and adult arroyo toads. Threats to this species include habitat destruction and alteration by human factors (urbanization, agriculture, overgrazing, recreation, OHV use, and mining activities) and natural factors (drought, wildfires); alteration of habitat by non-native plants (e.g., tamarisk); predation by introduced fish and bullfrogs; chytrid fungus disease; and wildfire suppression activities (USFWS 2009ddd).

\section{California Red-legged Frog}

The primary reference for this section is:

USFWS. 2002o. Reeovery Plan for the California Red-Legged Frog (Rana draytonii). Portland, Oregon.

References cited in this section are internal to the above-referenced document. Full citations have been included in the Bibliography.

The California red-legged frog (Rana draytonii) is endemic to California and Baja California, Mexieo. Its known elevational range extends from near sea level to approximately 5,200 feet. The species has been extirpated from 70 pereent of its former range, and is now found primarily in eoastal drainages of Central California, from Marin County south into Mexico, and in isolated drainages in the Sierra Nevada, northern Coast, and northern Transverse ranges. Populations remain in approximately 256 streams or drainages in 28 counties.

California red-legged frogs use a variety of habitat types, including various aquatic, riparian, and upland habitats. They include, but are not limited to, ephemeral ponds, intermittent streams, seasonal wetlands, springs, seeps, permanent ponds, perennial creeks, man-made aquatic features, marshes, dune ponds, lagoons, riparian corridors, blackberry thiekets, non-native annual grasslands, and oak savannas. Among the variety of habitats where California red-legged frogs have been found, the only common faetor is association with a permanent water source. Apparently, California red-legged frogs can use virtually any aquatic system, provided a permanent water souree, ideally free of non-native predators, is nearby.

Breeding sites include a variety of aquatic habitats. California red-legged frogs may complete their entire life cycle in a particular area (i.e., a pond that is suitable for all life stages) or utilize multiple habitat types. These variable life-history characteristics enable California red-legged frogs to change habitat use in response to varying conditions. During a period of abundant rainfall, the entire landscape may become suitable habitat. Conversely, habitat use may be drastically confined during periods of prolonged drought. Breeding adults are often associated with deep, still or slow moving water and dense, shrubby riparian or emergent vegetation (Hayes and Jennings 1988). During periods of wet weather, starting with the first rains of fall, some individuals make overland excursions through upland habitats, mostly at night. Long-distance movements of more than 2 miles have been observed. California red-legged frogs rest and feed in riparian vegetation when it is present. During the summer, they often disperse from their breeding habitat to forage and seek summer habitat if water is not a vailable, such as spaces under boulders or rocks and organic debris, industrial debris, and agricultural features like drains, watering troughs, abandoned sheds, or hay-ricks.

California red-legged frogs breed from November through April. Most adults lay their eggs in March. Eggs are laid and fertilized while attached to a emergent vegetation or roots and twigs, and the egg masses float on the surface of the water (Hayes and Miyamoto 1984). The eggs hateh in 6 to 14 days, depending on the water temperature (Jennings 1988). Egg predation is infrequent, and most mortality probably occurs during the tadpole stage (Licht 1974), although eggs are susceptible to being washed away by high stream flows. Tadpoles require 11 to 20 weeks to develop into terrestrial frogs (Storer 1925; Wright and Wright 1949; Bobzien et al. 2000). 
The diet of California red-legged frogs is highly variable. Larvae probably eat algae, while the most common food item of adults is invertebrates (Hayes and Tennant 1985). Larger frogs also eat vertebrates such as Pacific tree frogs and California mice. Feeding typically oecurs along the shoreline and on the surface of the water. Juveniles appear to forage during both daytime and nighttime, and subadults and adults appear to feed at night (Hayes and Tennant 1985).

The California red-legged frog was listed as threatened on May 23, 1996 (61 FR 25813). Critical habitat was first designated on March 13, 2001 (66 FR 14626). On Mareh 17, 2010, the USFWS issued a revised designation of eritical habitat that includes approximately 1,637,000 acres in 27 California eounties ( 75 FR 12816). The species is threatened within its remaining range by aetivities that destroy, degrade, and fragment habitat, such as urban eneroachment, construetion of reservoirs and water diversions, contaminants, agriculture, and livestoek grazing. The introduction of non-native predators and eompetitors also continues to threaten the viability of many California red-legged frog populations.

\section{Sierra Nevada Yellow-legged Frog and Mountain Yellow-legged Frog}

The primary reference for this seetion is:

USFWS. 2013d. Endangered and Threatened Wildlife and Plants; Endangered Status for the Sierra Nevada Yellow-Legged Frog and the Northern Distinct Population Segment of the Mountain Yellow-Legged Frog, and Threatened Status for the Yosemite Toad; Proposed Rule. Federal Register 78(80):24471-24514.

Referenees eited in this seetion are internal to the above-refereneed document. A eomplete list of these references is available from the Saeramento Fish and Wildlife Office, Sacramento, California.

The Sicrra Nevada yellow-legged frog (Rana sierrae) and mountain yellow-legged frog (Rana muscosa) are two species of mountain frog inhabiting the Sierra Nevada. They were onee thought to be two subspeeies of the foothill yellow-legged frog $(R$. boylii), but subsequent genetic analysis indieated that they are two distinet species that occupy separate geographic ranges within the montane regions of the Sierra Nevada of California. The Sierra Nevada yellow-legged frog oecurs in the northern portion of the Sierra Nevada, north of the Kern River watershed and over the eastern erest of the mountains into Inyo County, California at its most southern extent. The mountain yellow-legged frog occurs in the Kern River watershed to the west of the Sierra Nevada erest, along with populations inhabiting southern California (Vredenburg et al. 2007). The ranges of the two species meet each other roughly along the Monarch Divide to the north and along the crest of the Sierra Nevada to the east. Where information in this section refers to both species, the term "mountain yellow-legged frog" will be used.

Throughout their range, mountain yellow-legged frogs historically inhabited lakes, ponds, marshes, meadows, and streams at elevations ranging from 4,500 to 12,000 feet (CDFG 2011b). Current distributions of the Sierra Nevada yellow-legged frog and the northern DPS of the mountain yellow-legged frog are restrieted primarily to publiely managed lands at high elevations, including streams, lakes, ponds, and meadow wetlands located within National Forests and National Parks.

Mountain yellow-legged frogs are highly aquatic, and are generally not found more than 3.3 feet from water (Stebbins 1951; Mullaly and Cunningham 1956a; Bradford et al. 1993). Adults are typically found sitting on rocks along the shoreline, usually where there is little or no vegetation (Mullaly and Cunningham 1956a). They use a variety of shoreline habitats, but are most common at open shorelines that gently slope up to shallow waters of only 2 to 3 inches in depth (Mullaly and Cunningham 1956a, Jennings and Hayes 1994). In the Sierra Nevada, mountain yellow-legged frogs are most abundant in high-elevation lakes and slow-moving portions of streams (Zweifel 1955, Mullaly and Cunningham 1956a). As tadpoles overwinter multiple years before metamorphosis, they require lakes and ponds that do not dry out in the summer and are also deep enough that they do not completely freeze or become oxygen depleted in winter.

Adult mountain yellow-legged frogs breed in the shallows of ponds or in inlet streams (Vredenburg et al. 2005). Adults emerge from overwintering sites immediately following snowmelt, and will even move over ice to reach 
breeding sites (Pope 1999a; Vredenburg et al. 2005). Mountain yellow-legged frogs deposit their eggs underwater in elusters, which they attach to rocks, gravel, or vegetation, or which they deposit under banks (Wright and Wright 1949, Stebbins 1951). Cluteh size varies from 15 to 450 eggs per egg mass (Livezey and Wright 1945; Vredenburg et al. 2005). Egg development is temperature dependent, with egg hatehing time ranging from 18 to 21 days (Zweifel 1955). Tadpoles may take more than 1 year (Wright and Wright 1949), and often require 2 to 4 years, to reach metamorphosis (Cory 1962b; Bradford 1983; Bradford et al. 1993; Knapp and Matthews 2000), depending on local elimate conditions and site-specific variables. The time required to reach reproductive maturity in mountain yellow-legged frogs is thought to vary between 3 and 4 years post metamorphosis (Zweifel 1955). Longevity is unknown, but under normal eireumstanees, adult survivorship from year to year is high. Therefore, mountain yellow-legged frogs are presumed to be long-lived (Pope 1999a). Available evidenee suggests that mountain yellow-legged frogs display strong site fidelity and return to the same overwintering and summer habitats from year to year (Pope 1999a).

The Sierra Nevada yellow-legged frog and the mountain yellow-legged frog were listed as endangered speeies on April 29, 2014 (79 FR 24255). On April 25, 2013, the USFWS proposed designation of 1,105,400 acres of eritical habitat for the yellow-legged frog in Butte, Plumas, Lassen, Sierra, Nevada, Plaeer, El Dorado, Amador, Calaveras, Alpine, Mariposa, Mono, Madera, Tuolumne, Fresno, and Inyo Counties, California; and 221,498 acres eritieal habitat for the northern DPS of the mountain yellow-legged frog in Fresno and Tulare Counties, California (78 FR 24515). Threats to the speeies inelude habitat degradation and fragmentation, predation and disease, elimate change, inadequate regulatory protections, and the interaetion of these various stressors impaeting small remnant populations. There has been a rangewide reduetion in abundance and geographic extent of these species following deeades of fish stocking and habitat fragmentation, and a reeent disease epidemie.

\section{Yosemite Toad}

The primary referenee for this seetion is:

USFWS. 2013d. Endangered and Threatened Wildlife and Plants; Endangered Status for the Sierra Nevada Yellow-Legged Frog and the Northern Distinet Population Segment of the Mountain Yellow-Legged Frog, and Threatened Status for the Yosemite Toad; Proposed Rule. Federal Register 78(80):24471-24514.

References eited in this section are internal to the above-referenced document. A complete list of these references is available from the Sacramento Fish and Wildlife Offiee, Saeramento, California.

The Yosemite toad (Anaxyrus canorus) is a moderate-sized toad that inhabits wet meadow habitats in east eentral California. The historical range of the Yosemite toad extended from the Blue Lakes region north of Ebbetts Pass in Alpine County, to just south of Kaiser Pass in the Evolution Lake/Darwin Canyon area in Fresno County (Jennings and Hayes 1994), at elevations from 4,790 to 11,910 feet (Stebbins 1985). The eurrent range of the species is similar to the historieal range, although toad habitats within this range have been degraded and may be deereasing in area as a result of eonifer eneroachment and livestock grazing. The vast majority of the Yosemite toad's range is on federal lands.

Yosemite toads are found in wet meadow habitats and lake shores surrounded by lodgepole or whitebark pines (Camp 1916). They are most often found in areas with thick meadow vegetation or patches of low willows (Mullaly 1953). The species appears to have an affinity for high elevations and relatively flat sites with a southwesterly aspeet (Liang 2010). These areas receive higher solar radiation and are capable of sustaining wet, seasonally ponded, and moist breeding and rearing habitat. Breeding habitat includes the edges of wet meadows and slow-flowing streams (Jennings and Hayes 1994). Tadpoles have also been observed in shallow ponds and shallow areas of lakes (Mullaly 1953). Adults are most often observed near water, but only occasionally in water (Mullaly and Cunningham 1956b). Moist upland areas, such as seeps and springheads, are important summer nonbreeding habitats for adult toads (Martin 2002). The majority of a Yosemite toad's life is spent in upland habitats near breeding meadows, where they use rodent burrows for temporary refuge during the summer (Jennings and Hayes 1994). They also use spaces under surface objects, including logs and rocks, for temporary refuge (Stebbins 1951). 
Adults are thought to be long-lived (up to 15 years), allowing them to persist in variable conditions and in more marginal habitats where only periodic good years allow high reproductive suceess (USFWS et al. 2009). Females begin breeding at ages 3 to 5 . Yosemite toads tend to breed at a single site, and appear to have high site fidelity, although individuals will move between breeding areas (Liang 2010). They are prolific breeders, laying many eggs immediately in snowmelt, to coincide with suitable water levels in meadow habitats and ephemeral pools. Eggs hatch within 3 to 15 days, depending on ambient water temperatures (Sherman 1980, Jennings and Hayes 1994). Tadpoles typically metamorphose approximately 40 to 50 days after fertilization, and are not known to overwinter (Jennings and Hayes 1994). Tadpoles tend to eongregate together in warm shallow waters during the day (Cunningham 1963) and then retreat to deeper waters at night (Mullaly 1953). Rearing through metamorphosis takes approximately 5 to 7 weeks after eggs are laid (USFS et al. 2009).

The Yosemite toad was federally listed as a threatened speeies on April 29, 2014 (79 FR 24255). On April 25, 2013, the USFWS proposed designation of 750,926 aeres of eritieal habitat in Alpine, Mono, Tuolumne, Mariposa, Madera, Fresno, and Inyo Counties, California (78 FR 24515). Critieal habitat designations have not been finalized to date. The speeies is primarily threatened by habitat loss assoeiated with degradation of meadow hydrology following stream ineision resulting from historie land management activities (e.g., livestock grazing). It is also threatened by the anticipated effects of climate ehange on its habitat. Disease is another threat to this species.

\section{Oregon Spotted Frog}

The primary reference for this seetion is:

USFWS. 2013e. Endangered and Threatened Wildlife and Plants; Threatened Status for Oregon Spotted Frog. Proposed Rule. Federal Register 78(168):53581-53623.

Referenees cited in this seetion are internal to the above-referenced document. A complete list of these referenees is available from the Washington Fish and Wildlife Offiee, Laeey, Washington.

The Oregon spotted frog (Rana pretiosa) is a medium-sized frog that inhabits emergent wetland habitats in forested landseapes in the Paeifie Northwest. Historieally, the species was also associated with lakes in the prairie landseape of the Puget lowlands (MeAllister and Leonard 1997). The species onee ranged from British Columbia to the Pit River basin in northeastern California (Hayes 1997, McAllister and Leonard 1997). Currently, it is found from extreme southwestern British Columbia south through the Puget Trough, and in the Caseades Range from southcentral Washington to at least the Klamath Basin in southern Oregon. Of the 61 doeumented historieal loealities of the Oregon spotted frog, only 13 were confirmed to still support the species as of the 1990s (Hayes 1997, MeAllister and Lconard 1997). Therefore, it is estimated that the species may no longer occur in 76 to 90 pereent of its historieal range.

Habitat components required for completion of the Oregon spotted frog life cycle include shallow water areas for egg and tadpole survival, perennially deep, moderately vegetated pools for adult and juvenile survival in the dry season, and perennial water for protecting all age classes during eold, wet weather (Watson et al. 2003). Oregon spotted frogs occur in forested landseapes, but are not typically found under forest canopy. They are the most aquatie native frogs in the Pacifie Northwest, as all other species have a terrestrial life stage. They are almost always found in or near a perennial body of water, such as a spring, pond, lake, sluggish stream, irrigation canal, or roadside diteh (Engler 1999). They have been found at elevations ranging from near sea level in the Puget Trough lowlands in Washington to approximately 5,000 feet in the Oregon Caseades in western Oregon.

Oregon spotted frogs breed in shallow pools ( 2 to 12 inches deep) that are near flowing water, or which may be eonnected to larger bodies of water during seasonally high water or at flood stage. Characteristic vegetation includes grasses, sedges, and rushes, although eggs are laid where the vegetation is low and sparse, so that it will not shade eggs (McAllister and Leonard 1997). Traditional egg-laying sites are of limited availability; for this reason the speeies may be particularly vulnerable to modification of egg-laying sites (Hayes 1994). After breeding, during the dry season, Oregon spotted frogs move to deeper, permanent pools or ereeks for overwintering (Watson et al. 2003). When they are inaetive during periods of prolonged or severe cold, Oregon spotted frogs burrow in 
mud, silty substrate, clumps of emergent vegetation, woody accumulations within the ereek, and holes in the creek banks (McAllister and Leonard 1997; Hallock and Pearson 2001; Watson et al. 2003).

Breeding in Oregon spotted frogs oceurs in February or March at lower elevations, and between early April and early June at higher elevations (Leonard et al. 1993). Females may deposit their egg masses at the same loeations in successive years. Eggs are extremely vulnerable to desiccation and freezing. Adult Oregon spotted frogs begin to breed by 1 to 3 years of age, depending on sex, elevation, and latitude. Tadpoles metamorphose into froglets during their first summer (Leonard et al. 1993, Pearl and Bowerman 2005). Tadpoles are grazers that have rough tooth rows for seraping plant surfaces and ingesting plant tissue and bacteria. They also consume algae, detritus, and probably carrion (Licht 1974, McAllister and Leonard 1997). Post-metamorphic Oregon spotted frogs are opportunistic predators that prey on live animals, primarily insects, found in or near the water.

The Oregon spotted frog was federally listed as a threatened speeies on August 29, 2014 (79 FR 51657). On August 29, 2013, the USFWS proposed designating 68,192 acres in Washington and Oregon as critical habitat (78 FR 53537), but has not made a final critical habitat designation to date. The Oregon spotted frog currently remains in isolated populations. These populations are vulnerable to threats that include modifieation and destruetion of habitat through loss of wetlands and hydrologic changes, changes in water temperature and vegetation structure resulting from invasions of non-native species, and water quality impacts associated with livestock grazing. The species is also threatened by predation by introduced fish and bullfrogs, and insufficient protection of habitat through existing regulatory mechanisms.

\section{Coachella Valley Fringe-toed Lizard}

The Coaehella Valley fringe-toed lizard (Uma inornata) is a narrow endemic, restricted to areas of fine, windblown sand deposits in the sandy plains, sand hummocks, and mesquite dunes of the Coachella Valley in Riverside County, California (California Department of Fish and Game 2000c). The speeies requires fine, loose sand for burrowing for shelter during cold temperatures and extreme heat. The sand dunes on which the species oceurs are referred to as blowsand habitat, and consist of the fine sand that accumulates at the bottom of drainages during flood events, and that is transported aeross the Coachella Valley by high winds that continually blow through the area. Typically, vegetation in these sand dune habitats is scaree, eonsisting of creosote bush and other types of scrubby growth (Stebbins 1985). However, lizards do rely on some plants (mostly perennials) for shelter and food (Durtsche 1995).

Coachella Valley fringe-toed lizards hibernate during the winter, and are most active during the daylight hours. When summer temperatures reach or exceed limits that could be lethal to lizards, lizards escape the heat by burrowing beneath the sand and restricting their activities to the early morning and late afternoon hours. In May, flowers and plant-dwelling arthropods are the primary foods for the Coachella Valley fringe-toed lizard (NatureServe 2010). After the breeding season is over in the summer, when food abundance is low, the diet broadens to include ground-dwelling arthropods and foliage (Durtsche 1992, 1995). Lizard hatchlings are also eaten, when available. Coachella Valley fringe-toed lizards breed from late April through mid-August. Little is known about the location and timing of egg laying; however, hatchlings begin to appear from late June to early September.

The Coachella Valley fringe-toed lizard was federally listed as threatened on September 25, 1980 (45 FR 63812). On the same date, the USFWS designated approximately 20,000 acres of land as eritical habitat. This eritical habitat includes the areas with the highest concentrations of lizards, as well as a source for the blowsand habitat on which the lizard depends. The species continues to be impacted by threats from urban development, non-native, invasive plant species, obstructions to sand transport systems, OHVs, small population size, alteration of hydrology, and climate change. Since listing, the species' distribution has decreased by more than 60 percent, and only 43 percent of suitable habitat remains (USFWS 2010hh). 


\section{Desert Tortoise}

The primary referenee for this seetion is:

USFWS. $2011 \mathrm{bb}$. Revised Recovery Plan for the Mojave Population of the Desert Tortoise (Gopherus agassizii). Paeifie Southwest Region. Saeramento, California.

Referenees eited in this seetion are internal to the above-refereneed doeument. They are ineluded in the Bibliography.

The desert tortoise (Gopherus agassizii) oeeurs in desert regions of the southwestern U.S. and northwestern Mexieo. Populations of this speeies are found in the Mojave and Sonoran Deserts. The so-ealled Mojave population, whieh ineludes desert tortoises north and west of the Colorado River, is eurrently listed under the ESA. Prior to European settlement of the Mojave Desert region, the desert tortoise's range ineluded the Mojave and Sonoran deserts in southern California, southern Nevada, western Arizona, the southwestern tip of Utah, and Sonora and Sinaloa, Mexieo. This speeies is also found on Tiburon Island in the Sea of Cortez (Linsdale 1940). The desert tortoise is now eonsiderably redueed in numbers throughout mueh of this area, and has been extirpated from parts of its historie range (Berry 1978a, b; Spang et al. 1988).

Desert tortoises are adapted to the highly variable and often harsh desert environment. They spend mueh of their lives in burrows, even during seasons of aetivity. They over-winter and emerge from burrows in late winter or early spring to feed and mate, and typieally remain aetive through fall. During these aetivity periods, desert tortoises eat a wide variety of herbaeeous plants, partieularly grasses and the flowers of annual plants (Berry 1974, Luekenbaeh 1982, Esque 1994). During periods of inaetivity, they reduee their metabolism and water loss and eonsume very little food, and ean survive for more than a year without aeeess to free water. Desert tortoise home ranges ean be as large as 200 aeres for males, and over its lifetime, eaeh desert tortoise may use more than 1.5 square miles of habitat (Berry 1986).

Within the varied vegetational eommunities of the Mojave Desert region, desert tortoises ean potentially survive and reproduee where their basie habitat requirements are met. These requirements inelude suffieient suitable plants for forage and eover, and suitable substrates for burrow and nest sites. Throughout most of the Mojave Desert region, desert tortoises oeeur primarily on gently sloping terrain with sandy-gravel soils where there is sparse eover of low-growing shrubs, whieh allows establishment of herbaeeous plants. Desert tortoises are also found on roeky terrain and slopes in parts of the Mojave Desert region, and there is substantial geographie variation in the way tortoises use available resourees. Soils must be suitable for digging burrows, but firm enough so that burrows do not eollapse.

Desert tortoises exhibit delayed maturity (13 to 20 years) and live a long life. Mating oeeurs during spring, summer, and fall. Adults have low reproduetive rates over a long period of reproduetive potential (Turner et al. 1984). Eggs and hatehlings are quite vulnerable, and pre-reproduetive adult mortality averages 98 pereent (Turner et al. 1987; Wilbur and Morin 1988). Adults, however, are well-proteeted against most predators (apart from humans) and other environmental hazards (Turner et al. 1987; Germano 1992). Their longevity helps eompensate for their variable annual reproduetive sueeess, whieh is eorrelated with environmental eonditions.

The Mojave population of desert tortoise (ineluding any Sonoran Desert tortoises outside of their normal range) was federally listed as threatened on April 2, 1990 (55 FR 12178). On February 8, 1994, the USFWS designated approximately 6.4 million aeres in portions of the Mojave and Colorado Deserts as eritieal habitat for this speeies (59 FR 5820). The Mojave population was listed in response to preeipitous deelines in desert tortoise numbers in many areas. For the most part, these deelines have been attributed to direet and indireet human-eaused mortality, eoupled with the inadequaey of existing regulatory meehanisms to proteet desert tortoises and their habitat. Impaets sueh as the destruetion, degradation, and fragmentation of habitat result from urbanization, agrieultural development, livestoek grazing, mining, and roads. Furthermore, direet mortality to tortoises is eaused by numerous human aetivities. Finally, an upper respiratory traet disease is an additional major eause of mortality and population deeline, partieularly in the western Mojave Desert. 


\section{New Mexican Ridge-nosed Rattlesnake}

The New Mexican ridge-nosed rattlesnake (Crotalus willardi obscurus) is a subspecies that is endemic to the Animas and Peloncillo Mountains of southern New Mexico and Arizona, and the Sierra de San Luis Mountains of Mexico. The population of this subspecies within its restricted range has been reduced by collection, as it is commercially very valuable and much sought after by private herpetoculturists (New Mexico Department of Game and Fish 1994). Habitat for the New Mexican ridge-nosed rattlesnake is high elevation pine-oak woodlands and pine-fir forests, as well as foothill canyons in pinyon-juniper woodland (NatureServe 2010). Rattlesnakes seek cover and shelter to escape from bad weather and predators. Winter retreats are probably talus areas and other labyrinthian formations (e.g., rock outcrops, cliffs/ledges) that allow the snakes to move below the frost line. Similar sites may be used at other times of the year, although in warm weather the species is often found on or near vegetated areas (Applegarth et al. 1980). New Mexican ridge-nosed rattlesnakes hide in leaf litter among cobbles and rocks, and may climb into trees and shrubs (New Mexico Department of Game and Fish 1994). They are inactive in cold temperatures and in extreme heat, with most activity occurring during daylight hours from July through September (Ernst 1992). In the summer, activity peaks during warm humid mornings, and in the fall, activity peaks during the afternoon.

The bulk of New Mexican ridge-nosed rattlesnakes' diets are presumed to consist of small vertebrates, such as lizards, small mammals and birds (Vorhies 1948). Invertebrates may also be taken on oceasion. The most frequently recorded prey species include the Yarrow's spiny lizard, the Arizona alligator lizard (Klauber 1949, Woodin 1953), and the brush mouse (Woodin 1953, Klauber 1972).

Rattlesnakes are ovoviviparous, with fertilized eggs being retained in the female until hatching oceurs (Klauber 1972). The gestation period for the species is 13 months. Young disperse immediately after birth.

The New Mexican ridge-nosed rattlesnake was federally listed as threatened on August 4, 1978 (43 FR 34476). At the same time, critical habitat was designated in Hidalgo County, New Mexico, at elevations between 6,200 and 8,532 feet in Bear, Indian, and Spring Canyons in the Animas Mountains. Threats to this species include overcollecting and factors that alter habitat, such as heavy livestock grazing, the misuse of controlled fire (NatureServe 2010, New Mexico Department of Game and Fish 1994), development, OHV use, pollution, mining, and timber harvesting.

\section{Northern Mexican Garter Snake and Narrow-headed Garter Snake}

The primary reference for this section is:

USFWS. 2013f. Endangered and Threatened Wildlife and Plants; Threatened Status for the Northern Mexican Gartersnake and Narrow-headed Gartersnake; Proposed Rule. Federal Register 78(132):4 I499-41547.

References cited in this section are internal to the above-referenced document. A complete list of these references is available from the Arizona Ecological Services Field Office, Phoenix, Arizona.

The northern Mexican garter snake (Thamnophis eques megalops) oceurs in riparian areas at elevations from 130 to 8,497 feet, in various subbasins in Arizona. Historically, the U.S. distribution was predominantly in Arizona, where the species was found in every county and nearly every subbasin in the state. It had a limited distribution in New Mexico, in seattered locations throughout the Upper Gila watershed in Grant and western Hidalgo Counties. Populations may have also historically occurred in Colorado and Nevada. Only five populations of the northern Mexican garter snake in the U.S. are currently considered likely viable, all of which occur in Arizona (Big Williams River, Tonto Creek, Upper Verde River, Oak Creek, and Upper Santa Cruz River/San Rafael Valley).

The northern Mexican garter snake is a riparian obligate (restricted to riparian areas when not engaged in dispersal behavior). It occurs chiefly in the following general habitat types: source-area wetlands (e.g., cienegas or stock tanks); large river riparian woodlands and forests; and streamside gallery forests (as defined by well-developed broadleaf deciduous riparian forests with limited, if any, herbaceous ground cover or dense grass; Hendrickson and 
Minekley 1984, Rosen and Sehwalbe 1988). The species has been observed in protected backwaters, braided side channels and beaver ponds, isolated pools near the river mainstem, and on the edges of dense emergent vegetation that offer cover and foraging opportunities (Emmons and Nowak 2013).

The northern Mexican garter snake is active on the surface at air temperatures ranging from 71 to $91{ }^{\circ} \mathrm{F}$, and forages along the banks of water bodies. It is estimated that northern Mexiean garter snakes spend 60 pereent of their time moving, 13 percent basking, and 9 percent under surface eover (Rosen 1991). In the northernmost portion of its range, the species is most active during July and August, followed by June and September. Northern Mexican garter snakes are aetive predators, and are belicved to depend heavily upon a native prey base (Rosen and Schwalbe 1988). They forage along vegetated banklines, searching for prey in water and on land (Alfaro 2002). The diet generally consists of amphibians and fishes.

Sexual maturity in northern Mexican garter snakes oeeurs at 2 to 3 years of age (Rosen and Schwalbc 1988). They are viviparous, giving birth to live young rather than bringing forth eggs. Mating has been doeumented in April and May, followed by the live birth of between 7 and 38 ncwborns in July and August (Rosen and Sehwalbe 1988, Nowak and Boyarski 2012). However, mating may also oceur during the fall.

The narrow-headed garter snake (Thamnophis rufipunctatus) is a nonpoisonous snake found in and near eool, elear headwater streams of the Southwest. The historieal distribution of the speeies ranged aeross the Mogollan Rim and along its assoeiated percnnial drainages, from eentral and eastern Arizona southeast to southwestern New Mexico, at elevations ranging from 2,300 to 8,000 feet (Rosen and Schwalbe 1988; Rossman et al. 1996; Holycross et al. 2006). As of 2011, narrow-headed garter snakes werc detected in only 5 of 16 historical localities (Whitewater Creek, Tularosa River, Diamond Creek, and Middle fork Gila River in New Mexieo; and Oak Creek Canyon in Arizona). Populations in Whitewater Creek and the Middle Fork Gila River may have been adversely affeeted by a fire in June of 2012, and the eurrent viability of these populations is unknown.

The narrow-headed garter snake is one of the most aquatic of the garter snakes (Drummond and Mareias Gareia 1983; Rossman et al. 1996). It is strongly assoeiated with elear, roeky streams, and uses predominantly pool and riffle habitat that ineludes eobbles and boulders (Rosen and Sehwalbe 1988; Degenhardt et al. 1996; Rossman et al. 1996; Ernst and Ernst 2003). It also uses lake shoreline habitat. Narrow-headed garter snakes occur at elevations from 2,300 to 8,200 feet, and inhabit eonifer forest, conifer woodland, chaparral, and Sonoran desert serub eommunities (Rosen and Sehwalbe 1988, Brennan and Holycross 2006). Where narrow-headed garter snakes are typieally found in the water, little aquatic vegetation exists (Rosen and Sehwalbe 1988). They usually bask in areas where a quick eseape ean be made. They opportunistieally forage within dammed reservoirs formed by streams (Fleharty 1967).

The narrow-headed garter snake is generally aetive on the surfaee between March and November (Nowak 2006). It is presumed to be rather eold-tolerant, and forages in elear, eold streams at higher elevations. The primary prey of the speeies is various speeies of fish. Narrow-headed garter snakes are belicved to be mainly visual hunters that are heavily dependent on visual eues when foraging (Hibbitts and Filzgerald 2005). They are considered to be ambush predators (Brennan and Holyeross 2006; Pieree et al. 2007).

Sexual maturity in narrow-headed garter snakes oeeurs at 2 to 2.5 years of age (Deganhardt et al. 1996). They are viviparous, and have a reproductive eycle that is apparently longer than that of other garter snake species. Females begin the development of follieles in early Mareh, and gestation takes longer (Rosen and Sehwalbe 1988). They breed annually and give birth to 4 to 17 offspring from late July into early August (and possibly earlier).

The northern Mexiean garter snake and narrow-headed garter snake were federally listed as threatened speeies on July 8, 2014 (79 FR 38677). On July 10, 2013, the USFWS proposed the designation of 421,423 aeres as eritieal habitat for the northern Mexiean garter snake, and 210,189 aeres as eritieal habitat for the narrow-headed garter snake ( 78 FR 41549). However, a final critieal habitat designation has not yet been made. The primary threat to these speeies is harmful non-native speeies, whieh have substantially impacted these listed species and their prey bases. Native aquatie communities, and speeifieally the native prey bases for northern Mexiean and narrow-headed 
garter snakes, have been significantly weakened to the point of near collapse as a result of the cumulative effeets of disease and non-native species, such as bullfrogs, crayfish, and spiny-rayed fish. Harmful non-native species have been intentionally introduced or have naturally moved into virtually every subbasin throughout the distribution of northern Mexican and narrow-headed garter snakes in the United States and Mexico. Other threats to the species include degradation and dewatering of aquatic habitats, land use activities, drought, and wildfires.

\section{Giant Garter Snake}

The primary reference for this section is:

USFWS. 1993j. Determination of Threatened Status for the Giant Garter Snake. Federal Register 58(201):5405354066.

References cited in this section are internal to the above-refereneed document. A complete list of these references is available from the USFWS Sacramento Field Office, Sacramento, California.

The 20065 -year review for the giant garter snake (USFWS 2006g) was consulted for updated information on this species.

The giant garter snake (Thamnophis gigas) is endemic to valley floor wetlands in the Sacramento and San Joaquin Valleys of California. The species inhabits marshes, sloughs, ponds, small lakes, low gradient streams, and other waterways and agricultural wetlands (e.g., irrigation and drainage canals and rice fields). The range of the species extends from the City of Chico to the north, to the Mendota Wildlife Area in Fresno County to the south (USFWS $2006 \mathrm{~g}$ ). Species populations within this range are largely isolated from one another and from remaining suitable habitat.

Giant garter snakes require adequate water during the active season (carly spring through mid-fall), emergent herbaceous wetland vegetation for eseape cover and forage habitat, grassy banks and openings in vegetation for basking, and higher elevation uplands that provide refuge and cover from flood waters during the winter dormant season. Giant garter snakes are absent from larger rivers and other water bodies that support introduced populations of large, predatory fish. They are also absent from wetlands with sand, gravel, or rock substrates (Hansen 1980, 1988; Rossman and Stewart 1987; Brode 1988). In addition, riparian woodlands do not offer suitable habitat because of their excessive shade, the lack of basking sites, and the absence of prey populations (Hansen 1980). Giant garter snakes feed on small fishes, tadpoles, and frogs (Fitch 1941; Hansen 1980, 1988).

The giant garter snake inhabits small mammal burrows and other soil crevices above prevailing flood elevations throughout its winter dormaney period, which oceurs from November to mid-March (Hansen 1991). Snakes typically select burrows with sunny aspects and west-facing slopes. Upon emergence, males immediately begin wandering in search of mates. The breeding season extends through March and April, and females give birth to live young from late July through early September (Hansen and Hansen 1990). Brood size is variable, ranging from I0 to 46 young, with an average of about 23 . Young immediately scatter into dense cover and absorb their yolk sacs, after which they begin feeding on their own.

The giant garter snake was federally listed as threatened on October 20, 1993 (58 FR 54053). Critical habitat has not been designated. This species is threatened by habitat loss from urbanization, flooding, contaminants, agricultural and maintenance activities, and introduced predators. Habitat loss and degradation continue to be the greatest threats to the species, although habitat for the species has also been protected, restored, and created (USFWS 2006g). 


\section{Blunt-nosed Leopard Lizard}

The primary referenee for this section is:

USFWS. 1998h. Reeovery Plan for Upland Speeies of the San Joaquin Valley, California. Region 1. Portland, Oregon.

Referenees eited in this seetion are internal to the above-referenced document. Full citations have been included in the Bibliography.

The 2010 5-year review for the blunt-nosed leopard lizard (USFWS 2010ii) was reviewed for updated information on this species.

The blunt-nosed leopard lizard (Gambelia silus) is endemie to the San Joaquin Valley of central California (Stejneger 1893; Smith 1946; Montanucei 1965, 1970; Tollestrup 1979a). As a result of widespread agrieultural development, the eurrent distribution of the speeies is less than 15 pereent of its historic range. In its remaining habitats, the species oceurs in alkali sink scrub, saltbush scrub, and native and non-native grasslands on the Valley floor and in the surrounding foothills areas (USFWS 2010ii).

Blunt-nosed leopard lizards inhabit open, sparsely vegetated areas of low relief (Smith 1946, Montanueei 1965). On the valley floor, they are most eommonly found in the non-native grassland and valley sink serub communities deseribed by Holland (1986). The valley sink serub is dominated by low, alkali-tolerant shrubs of the chenopod family, sueh as iodine bush and seepweeds. The soils are saline and alkaline lake bed or playa elays that often form a white salty erust and are oeeasionally eovered by introduced annual grasses. Valley needlegrass grassland, nonnative (annual) grassland, and alkali playa also provide suitable habitat for the lizard on the Valley floor. Valley needlegrass grassland is dominated by native perennial bunehgrasses, whieh are assoeiated with native and introdueed annual plants. Blunt-nose leopard lizards also inhabit valley saltbush serub, a low shrubland, with an annual grassland understory, that oceurs on the gently sloping alluvial fans of the foothills of the southern San Joaquin Valley and the adjacent Carrizo Plain.

Blunt-nosed leopard lizards feed primarily on inseets (mostly grasshoppers, eriekets, and moths) and other lizards, although some plant material is eaten rarely, or perhaps consumed unintentionally with animal prey. The lizard appears to feed opportunistieally on animals, eating whatever is available in the size range they can overeome and swallow. Young of its own species are also eaten (Montanucei 1965; Kato et al. 1987; Germano and Williams 1994a).

Breeding activity begins within a month of emergenee from dormancy and lasts from the end of April through the end of June. During this period, and for a month or more afterward, the adults often are seen in pairs and frequently oceupy the same burrow system (Germano and Williams 1994b, Montanucei 1965). Male territories may overlap those of several females, and a given male may mate with several females. Copulation may oeeur as late as June (Montanucci 1965). Females lay two to six eggs in June and July, in a chamber either exeavated speeifieally for a nest or already existing within the burrow system (Montanueei 1965, 1967). Females typically produce only one clutch of eggs per year, but some may produee three or more under favorable environmental conditions (Montanucei 1967; USFWS 1985m; Germano and Williams 1992; Willams et al. 1993a). After about 2 months of incubation, young hateh from July through early August, and rarely to September. Sexual maturity is reached at between 9 and 21 months, depending on the sex and environmental conditions (USFWS 1985m).

The blunt-nosed leopard lizard was federally listed as endangered in 1967 (32 FR 4001). Critical habitat has not been designated. The greatest threats to this species are habitat disturbanee, destruetion, and fragmentation. Conversion of land for agrieultural purposes continues to be the most eritical threat (USFWS 2010ii). Construction of facilities related to oil and natural gas production, such as well pads, wells, storage tanks, sumps, pipelines, and their associated service roads degrade habitat and cause direet mortality to leopard lizards, as do oil leakage from pumps, transport pipes, and storage facilities, surfaee mining, and OHV traffic (Madrone Assoeiates 1979, Chesemore 1980, Mullen 1981, USFWS 1985m, Kato and O'Farrell 1986). Livestock grazing can result in the 
removal of herbaceous vegetation and shrub cover, destruction of rodent burrows used by lizards for shelter, and associated soil erosion if the stocking rate is too high or animals are left on the range too long after annual plants have died (Chesemore 1981, Williams and Tordoff 1988). However, unlike the cultivation of row crops, which precludes use by leopard lizards, light or moderate grazing may be beneficial (Chesemore 1980, USFWS 1985m, Germano and Williams 1993). The lizards are believed to prefer lightly-grazed grasslands, which are dominated by a low, sparsely growing annual grass, rather than the taller, denser, introduced red brome that dominates ungrazed sites. The use of pesticides may directly and indirectly affect lizards. In addition, lizard mortality is known to oceur as a result of automobile traffic and OHV use (Tollestrup 1979b; Uptain et al. 1985; Williams and Tordoff 1988). Roads also bisect remaining fragments of habitat, increasing the risks of mortality by vehicles and increasing the effects of isolation of populations. Altered vegetation communities (due to grazing, non-native grasses, and altered wildfire regime), vehicle strikes, waterfowl blinds, broad-scale pesticide application, rodenticide application, and climate change continue to impact populations of blunt-nosed leopard lizards.

\section{Effects of Herbicide Treatments on Amphibians and Reptiles}

\section{Direct Effects}

Herbicide treatments in upland habitats could result in the erushing of herpetofauna, primarily by vehicles, which could injure or kill individuals. Although most herpetofauna would attempt to escape herbicide applicators and equipment, many individuals would do so by seeking eover in shallow burrows, where they would not necessarily be protected from crushing. Most animals in such hiding places would not be exposed directly to herbicides during the application, but direct spray of some animals could occur. Reptiles and amphibians in terrestrial life history stages could potentially be exposed to direct spray of chemicals, come into contact with sprayed vegetation after a treatment, or ingest sprayed prey items after a treatment. Amphibians in aquatic environments could be exposed to herbicides entering the water through various exposure pathways (accidental direct spray of herbicides directly into a water body, off-site drift of herbicides applied to adjacent uplands into a water body, runoff from upland areas, or an accidental spill of herbicides directly from a truck/ATV/UTV or helicopter into a water body). Amphibian TEP species that oceur in aquatic habitats for at least a portion of their lives include all the amphibians addressed in this $\mathrm{BA}$, with the exception of the desert slender salamander.

Based on information from the risk assessments, the three new herbicide active ingredients would pose a low toxicological risk to herpetofauna. There are no toxicological risks to terrestrial herpetofauna under any of the modeled exposure scenarios. For aquatic herpetofauna, only fluroxypyr is associated with toxicological risks, and only under accidental spill scenarios. Risk assessment results are discussed in more detail in the following sections.

\section{Terrestrial Scenarios}

For scenarios evaluating dermal contact with herbicides (direct spray or contact with contaminated foliage), ERAs primarily utilized small mammals to represent terrestrial vertebrate species for risk calculations. Data pertaining to reptiles and amphibians is largely unavailable, so a more accurate calculation of risk to TEP herpetofauna was not possible. However, since ERAs utilize very conservative assumptions (e.g., 50 pereent of the animal's surface would be exposed to direct spray, and 100 percent of the herbicide would be absorbed through the skin), it is unlikely that they would underestimate risks to reptiles and amphibians. Therefore, the analysis for the terrestrial vertebrates and for birds was used to extrapolate risks for TEP reptiles and amphibians. For more information on the methodology used to determine risk levels, see Chapter 2 of this BA and Appendix C of the 2007 PEIS (USDOI BLM 2007a).

As discussed in ERAs completed by the BLM, very few laboratory studies have been conducted to assess the adverse effects of herbicides on reptiles and amphibians (AECOM 2014a-c). However, it is assumed that the types of potential toxicological effects of herbicides on reptiles and amphibians would be similar to those on other terrestrial species, and would include mortality and sublethal effects. According to the limited laboratory data that are available, sublethal effects may include behavioral alteration, slowed growth, developmental effects, and illness (Sparling et al. 2000). It is assumed that sublethal effects could also include reduced reproductive success. In addition, it is assumed that for TEP reptiles and amphibians, these adverse health effects would potentially result in population-level effects for the species in question. Because many TEP herpetofauna species already have reduced, 
sensitive populations, mortality of individuals or reduced reproductive output could reduce the size of affected populations further, perhaps even leading to extirpation. Furthermore, if individuals were to become more physiologically predisposed to mortality from environmental stresses (such as predation or exposure to harsh environmental conditions), the risk for future population-level effects, including extirpations, would be increased.

For scenarios that assess the risks of ingesting contaminated food, ERAs used animals of a similar trophic guild as surrogates to assess risks. For herpetofauna species that consume more than one type of food (e.g., small mammals and invertebrates), more than one surrogate specics was used in the analysis.

Based on information in the ERAs, none of the herbicides evaluated in this BA would eause adverse health effects to herpetofauna as a result of direct spray (Table 6-2), dermal contact with sprayed vegetation (Table 6-2), or ingestion of contaminated food sources (Table 6-3).

TABLE 6-2

Summary of Effects ${ }^{1}$ to Threatened, Endangered, and Proposed Terrestrial Vertebrates from Dermal Exposure to Herbicides, as Predicted By Risk Assessments

\begin{tabular}{|c|c|c|c|c|}
\hline Herbicide & Direct Spray & Level of Risk & $\begin{array}{c}\text { Dermal Contact } \\
\text { with Sprayed } \\
\text { Vegetation }\end{array}$ & Level of Risk \\
\hline Aminopyralid & No effects & -- & No effects & -- \\
\hline Fluroxypyr & No effects & -- & No effects & -- \\
\hline Rimsulfuron & No effects & -- & No effects & -- \\
\hline \multicolumn{5}{|c|}{$\begin{array}{l}{ }^{1} \text { Both acute and chronic effects were considered. "No effects" indicates that ERAs did not predict risks to TEP terrestrial } \\
\text { vertcbrates under the modeled scenario at typical or maximum application rates. }\end{array}$} \\
\hline \multicolumn{5}{|c|}{ Sources: Ecological risk assessments for herbicides (AECOM 2014a-c). } \\
\hline
\end{tabular}

\section{Aquatic Scenarios}

For aquatic scenarios, fish were used as surrogates to predict risk to amphibian species. Available toxicity information for some herbicides indicates that amphibians and fish have a similar sensitivity to herbicides (Berrill et al. 1997). Given the conservative approach taken in completing risk assessments, it was assumed that fish calculations were suitable for predicting risks to amphibians, even for species that are slightly more sensitive to the herbicides analyzed than fish. As discussed in the effects analysis for aquatic organisms, ERAs addressed the potential for effects to aquatic species via multiple cxposure pathways (i.e., direct spray, off-site drift, surface runoff, and accidental spill). None of the threc herbicides considered in this BA are aquatic herbicides, so direct spray into aquatic habitats would not occur under normal eircumstanees. However, they could be used in dry soils adjacent to aquatic habitats, so spray drift, runoff, and accidental spray/spill into aquatic habitats could occur.

\section{Direct Spray}

Based on information provided in the ERAs (see Tables 5-1 through 5-4), none of the herbicides proposed for use would result in adverse effects to aquatic amphibians if sprayed directly into aquatic habitats. Since the three herbicides are only approved for usc in terrestrial habitats, direct spray into aquatic habitats would constitute an accidental release scenario. With SOPs in place, such a release is unlikely to occur.

\section{Accidental Spill}

According to the ERAs, an accidental spill of fluroxypyr into a water body could potentially result in adverse health effects to the aquatic amphibian species addressed in this BA. No effects to aquatic amphibians were predicted for accidental spills of aminopyralid or rimsulfuron. The risk assessments only considered spills into ponds, and only considered seenarios in which a truck or helicopter spilled an entire load of the herbicide prepared for the maximum application rate. Therefore, risk assessments are conservative. Additionally, an accidental spill of this magnitude into an aquatic habitat is an unlikely occurrence. Herbicide treatments would follow the SOPS and guidelines listed in the 2007 PE1S (Appendix A; USDOI BLM 2007a: 2-22 to 2-25), which would minimize the 
risks of spills into aquatic habitats. Relevant SOPs include preparing a spill contingency plan in advance of treatments, mixing and loading herbicide products in an area where an accidental spill would not reach a water body, not rinsing spray tanks in or near water bodies, following product labels for use and storage, and having licensed applicators apply the herbicides. Project design criteria also require the BLM to consider TEP species that occur near potential treatment areas when developing site-specific vegetation treatment programs.

TABLE 6-3

Summary of Effects to Threatened, Endangered, and Proposed Herpetofauna From Ingestion of Food Contaminated by Herbicides, as Predicted By Risk Assessments

\begin{tabular}{|c|c|c|}
\hline Species & $\begin{array}{c}\text { Food } \\
\text { (During Terrestrial Stage) }\end{array}$ & Summary of Effects ${ }^{1}$ \\
\hline Desert slender salamander & Arthropods & No effects \\
\hline Chirieahua leopard frog & Invertebrates & No effeets \\
\hline Wyoming toad & Insects & No effects \\
\hline California tiger salamander & Invertebrates & No effects \\
\hline Coachella valley fringe-toed lizard & Arthropods & No effects \\
\hline Desert tortoise & Herbaceous plants & No effects \\
\hline New Mexican ridge-nosed rattlesnake & Vertebrates and invertebrates & No effects \\
\hline Giant garter snake & Fish, vertebrates, and invertebrates & No effects \\
\hline Blunt-nosed leopard lizard & Insects and lizards & No effects \\
\hline
\end{tabular}

\section{Off-Site Drift and Surface Runoff}

None of the herbicides considered in this BA would have the potential to cause adverse health effects to TEP aquatic amphibians as a result of off-site drift or surface runoff into nearby aquatic habitats, based on information provided in the ERAs (see Tables 5-1 through 5-4).

\section{Indirect effects}

Treatment of upland sites with herbicides could result in a substantial, though temporary, reduction in vegetative cover, particularly if a site was broadeast sprayed with a broad-spectrum formulation. Such a loss of vegetation could indirectly impact TEP reptiles and amphibians by removing cover. However, based on the likely usage of the three new active ingredients, wide-scale removal of riparian vegetation is unlikely to occur. Furthermore, other important components for cover, such as duff and woody debris would be maintained, and could even increase in quantity. It is possible that prey items, such as invertebrates, could also be reduced temporarily as a result of crushing, toxicity from spraying, or loss of habitat. However, long-term adverse effects to habitat should not oceur. Treatments to reduce weedy species could benefit herpetofauna by returning habitat to a more native state, and treatments that reduce the risk of a future catastrophic wildfire would likely have positive long-term effects on habitat components.

\section{Conservation Measures}

Many local BLM offices already have management plans in place that ensure the protection of these species during activities on public lands. Additionally, the BLM would follow all pertinent SOPs (listed in Appendix A), which include practices for use, transport, and handling of herbicides, and other measures that would help protect herpetofauna, such as practices to prevent and respond to spills.

As discussed in Chapter 2, this BA assumes that the BLM would continue to follow the conservation measures listed in the $2007 \mathrm{BA}$, or other comparable measures that would be developed by the field offices based on local 
site conditions and included in local-level consultation. General conservation measures for all herbicide treatments would be applicable for use of aminopyralid, fluroxypyr, or rimsulfuron. A list of key conservation measures for herpetofauna is presented at the end of this section, with a complete list provided in Appendix A.

Given the low toxicity of the three new herbicides to herpetofauna, likely uses of the herbicides, and SOPs for minimizing the risk of spills into aquatic habitats, no new conservation measures have been developed for herbicide treatments using aminopyralid, fluroxypyr, or rimsulfuron. However, if these active ingredients are used in a tank mixture or formulation that includes previously approved active ingredients, any conservation measures specific to the previously approved ingredients would apply.

Key Conservation Measures for TEP herpetofauna from the 2007 BA:

- Survey all areas that may support TEP amphibians and/or reptiles prior to treatments.

- In habitats where aquatic herpetofauna occur, implement all conservation measures identified for aquatic organisms.

- Do not broadeast spray herbicides in riparian areas or wetlands that provide habitat for TEP herpetofauna.

- In desert tortoise habitat, conduct herbicide treatments during the period when desert tortoises are least active.

- To the greatest extent possible, avoid desert tortoise burrows during herbicide trcatments.

- When conducting herbicide treatments in upland areas adjacent to aquatic or wetland habitats that support TEP herpetofauna, do not broadcast spray during conditions under which off-site drift is likely.

- Follow all instructions and SOPs to avoid spill and direct spray scenarios into aquatic habitats that support TEP herpetofauna.

\section{Determination of Effects}

Based on the ERA, the only scenarios by which any of the three herbicides would potentially have adverse effects on TEP herpetofauna are an accidental spill of fluroxypyr into a pond inhabited by a TEP aquatic amphibian species, or through alteration of habitat. Following SOPs for handling, transport, and use of these chemicals would help minimize the risk of an accidental spill into aquatic habitats. The conservation measures discussed in this chapter would further reduce the potential risk to species habitats associated with herbicide treatments. As a result, the action would be Not Likely to Adversely Affect amphibians and reptiles or their federally designated critical habitats at the programmatic level. Similarly, the action is not likely to jeopardize proposed species or adversely modify proposed eritical habitat. Given BLM mandates for use of integrated pest management (including vegetation management), and given that it is not possible to forecast site-specific vegetation management nceds below the programmatic level, additional evaluations of situation-specific effects will be the subject of step-down ESA Section 7 cvaluations and subsequent consultations. In this manner, any additional specific conservation measures necessary to accommodate site or situation-specific peculiarities not predictable at the programmatic level will be developed at the local level and incorporated into Pesticide Use Proposals prior to local implementation of vegetation management activities that involve the use of herbicides considered in this BA.

\section{Birds}

The following birds, and the ecoregion they are typically found in, are considered in this BA:

Steller's cider - Tundra

Spectacled eider - Tundra

Northern Aplomado falcon - Subtropical Desert

Yuma clapper rail - Subtropical Desert

Southwestern willow flycatcher - Various in Southwest

Mexican spotted owl - Numerous in Southwest

Gunnison sagc-grousc - Temperate Desert

Greater sage-grouse - Temperate Desert

Least tern (interior) - Temperatc Steppe 
Piping plover - Temperate Steppe

Lesser prairic-chicken - Temperate Steppe

Western snowy plover - Mediterranean/Marine

Least Bell's vireo - Mediterranean

Inyo California towhee - Mediterranean

Coastal California gnatcatcher - Mediterranean

California condor - Mediterranean

Northern spotted owl - Mediterranean/Marine

Streaked horned Lark - Marine

Marbled murrelet - Numerous on Pacific Coast

Whooping crane - Numerous

Yellow-billed cuckoo - Numerous

Note: In the discussions that follow, the general term "adverse health effects" is used in reference to exposure to certain herbicides under certain scenarios. The potential toxicological effects of herbicides on terrestrial wildlife, which were examined in ERAs, include mortality and sublethal effeets. Examples of sublethal effects include harm to vital organs, changes in body weight, reduced reproductive success, and altered behavior, which may increase the animal's susceptibility to predation (USDA Forest Service 2005). Sublethal effects to an animal's health may also increase the severity of impacts associated with unrelated environmental stresses and other disturbances. In all of the effects assessments for birds found in this chapter, the term "adverse health effects" refers to the abovementioned or similar toxicological effects at the level of the organism. In addition, it is assumed that for TEP birds, these adverse health effects would potentially result in population-level effects for the species in question. Because many TEP bird species already have reduced, sensitive populations, mortality of individuals or reduced reproductive output could reduce the size of affected populations further, perhaps even leading to extirpation. Furthermore, if individuals were to become more physiologically predisposed to mortality from environmental stresses (such as predation or exposure to harsh environmental conditions), the risk for future population-level effects, including extirpations, would be inereased. For more information on the methodology used to determine risk levels, see Chapter 2 of this BA and Appendix C of the 2007 PEIS (USDOI BLM 2007a).

\section{Alaskan Waterfowl: Steller's Eider and Spectacled Eider}

\section{Steller's Eider}

The primary references for this section are:

USFWS. 1997f. Threatened Status for the Alaska Breeding Population of the Steller's Eider. Federal Register 62(112):31748-31757.

and

USFWS. 2002p. Steller's Eider Recovery Plan. Fairbanks, Alaska.

References cited in this section are internal to the above-referenced Federal Register document. A complete list of these references is available from the USFWS, Ecological Services Fairbanks Field Office, Fairbanks, Alaska.

The Steller's eider (Polysticta stelleri) is a sea duck that spends the majority of the year in shallow, near-shore marine waters where it feeds by diving and dabbling for mollusks and crustaceans (Petersen 1980). Three breeding populations of Steller's eiders are recognized: two in Aretic Russia and one in Alaska (USFWS 2002p). The current breeding distribution of the Steller's eider in Alaska encompasses the Arctic coastal regions of northern Alaska from Wainwright to Prudhoe Bay up to 54 miles inland (King and Brackney 1993). The majority of Steller's eiders nest in Arctic Russia (Palmer 1976, Bellrose 1980).

Steller's eiders in Alaska nest on tundra adjacent to small ponds or within drained lake basins, generally near the coast, but ranging at least as far as 56 miles inland. They nest in a small depression in the vegetation that is lined with a thick bed of down, incubating one to eight eggs for about 25 days. Young hatch in late June, although many 
nests are partially or completely depredated during incubation by foxes, ravens, jaegers, or other predators. Shortly after hatching, ducklings are led by females to nearby wetlands to feed, until they are capable of flight at about 40 days (Obritschkewitsch et al. 2001). After the nesting season, Steller's eiders return to marine habitats where they undergo a complete molt (Jones 1965; Petersen 1980, 1981). Individuals remain flightless for about 3 weeks.

In Alaska, Steller's eiders molt in various locations in southwest Alaska, but the largest numbers congregate in four areas along the north side of the Alaska Peninsula: Izembek Lagoon, Nelson Lagoon, Port Heiden, and Seal Islands (Gill et al. 1981; Peterson 1981; Metzner 1993). Molting areas where large numbers congregate tend to be characterized by extensive shallow areas with eelgrass beds and intertidal sand flats and mudflats.

Principal foods in marine areas include bivalves, crustaceans, polychaete worms, and mollusks (Petersen 1980, Troy and Johnson 1987, Metzner 1993). In inland areas, aquatic insects (primarily chironomid larvae), plant materials, crustaceans, and mollusks are important dietary components (Cottam 1939, Quakenbush and Cochrane 1993).

The Alaska breeding population of Steller's eider was federally listed as threatened on June 11, 1997 (62 FR 31748). On February 2, 2001, the USFWS designated approximately 24,954,638 acres on the Yukon-Kuskokwim (Y-K) Delta, in Norton Sound, Ledyard Bay, and the Bering Sea between St. Lawrenee and St. Matthew Islands as critical habitat for the population (66 FR 8850). The primary threats to this population are the substantial decrease in the species' nesting range in Alaska and the reduction in the number of Steller's eiders nesting in Alaska, which result in increased vulnerability of the remaining breeding population to extirpation. Additionally, predation, hunting, ingestion of spent lead shot in wetlands, and changes in the marine environment could affect food or other resources. Exposure to oil or other contaminants near fish processing facilities in Southwest Alaska is another potential threat (USFWS 2002p).

\section{Spectacled Eider}

The primary reference for this section is:

USFWS. 2001j. Final Determination of Critical Habitat for the Spectacled Eider. Federal Register 66(25):91469185.

References eited in this section are internal to the above-referenced document. A complete list of these referenees is available from the USFWS, Ecological Services Anchorage Field Office, Anchorage, Alaska.

The 2010 5-year review for the spectacled eider (USFWS 2010ij) was consulted for updated information on this species.

The spectacled eider (Somateria fischeri) is a large sea duck, a type of waterfowl that spends at least part of its life at sea or on large water bodies. In the U.S., speetacled eiders historically had a discontinuous nesting distribution from the Nushagak Peninsula in southwestern Alaska north to Barrow and east nearly to the Canadian border. Today, two breeding populations remain in Alaska. The remainder of the species breeds in Aretic Russia. On the Y-K Delta, spectacled eiders breed mostly within 9.3 statute miles of the coast, from Kigigak Island north to Kokechik Bay (USFWS 1996), with smaller numbers nesting south of Kigigak Island to Kwigillingok and north of Kokechik Bay to the mouth of Uwik Slough. The coastal fringe of the Y-K Delta is the only subaretic breeding habitat where spectacled eiders occur at high density (1.2 to 2.6 birds per square mile; USFWS 1996).

Spectacled eiders are diving ducks that spend most of the year in marine waters, where they primarily feed on bottom-dwelling mollusks and crustaceans. From November through March or April, they remain in open sea or other areas of open water in the sea ice of the northern Bering Sea, at water depths of less than 240 feet (Peterson et al. 2000). In winter foraging areas, the availability of ice as a resting platform may be important for energy conservation (Lovvorn et al. 2009).

As open water becomes available in the spring, breeding pairs move to nesting areas on wet coastal tundra (Peterson et al. 2000; Bart and Earnst 2005). Nesting is restricted to the vegetated intertidal zone, which is 
dominated by low wet-sedge and grass marshes and has numerous small shallow water bodies. Nests are established near shallow ponds or lakes, usually within 10 feet of water. During the breeding season, hens and broods feed in freshwater ponds and wetlands, eating aquatic insects, crustaceans, and vegetation (Peterson et al. 2000). Males return to the marine environment after ineubation begins. When moving between nesting and molting areas, spectacled eiders travel along the coast up to 36 miles offshore. Molting flocks gather in relatively shallow coastal water, ustually less than 120 feet deep. Presumably, nonbreeding birds remain at sea year-round until they attempt to breed at age 2 or 3 . It is unknown which areas at sea are important to nonbreeding spectacled eiders.

On Alaska's North Slope, nearly all spectacled eiders breed north of $70^{\circ}$ latitude between ley Cape and the Shaviovik River. Within this region, most spectacled eiders oceur between Cape Simpson and the Sagavanirktok River (USFWS 1996). Spectacled eiders on the North Slope oceur at low densities within about 50 miles of the coast. During pre-nesting and early nesting, they oceur most commonly on large shallow produetive thaw lakes, usually with convoluted shorelines or small islands (Larned and Balogh 1997). Such shallow water bodies with emergent vegetation and low islands or ridges appear to be important as eider nesting and brood-rearing habitat on the North Slope (Derksen et al. 1981; Warnock and Troy 1992; Andersen et al. 1998).

Within the U.S., spectacled eiders molt in Norton Sound and Ledyard Bay, where they congregate in large, dense flocks that may be particularly susceptible to disturbance and environmental perturbations. During their time on the molting grounds (early July through October), each bird is flightless for a few weeks. During winter, speetacled eiders congregate in exceedingly large and dense flocks in pack ice openings between St. Lawrenee and St. Matthew islands in the eentral Bering Sea (Larned et al. 1995c). Spectacled eiders from all three known breeding populations use this wintering area (USFWS 1999a); no other wintering areas are currently known.

The spectaeled eider was federally listed as threatened on May 10, 1993 (58 FR 27474). On February 6, 2001, the USFWS designated approximately $24,954,638$ acres on the Y-K Delta, in Norton Sound, Ledyard Bay, and the Bering Sea between St. Lawrence and St. Matthews islands as critical habitat for the species (66 FR 9146). Threats to the species on its breeding grounds are thought to include lead contamination, illegal harvest, and predation (USFWS 2010jj).

\section{Effects of Herbicide Treatments on Steller's Eider and Spectacled Eider}

\section{Direct Effects}

It is very unlikely that the BLM would use herbicides in eider breeding areas. However, if herbicides were applied in eider breeding areas, nests, eggs, or newborn birds could be crushed by workers and vehicles. It is likely that adults would flee the area, but breeding activities could be disturbed. Eiders, and especially newborn birds and eggs, could inadvertently be sprayed during herbicide application, and birds could ingest food items exposed to herbicides. Eiders primarily eat aquatic invertebrates, as well as some plant materials, so indireet exposure to herbicides could oceur if an eider were to consume animals or plants that have been sprayed by herbicides during vegetation treatments.

Based on information from the risk assessments, none of the three new herbicides proposed for use would pose a toxicological risk to birds through exposure scenarios involving direct spray, dermal contact of sprayed vegetation, or ingestion of sprayed food items (Table 6-4). For all ingestion exposure scenarios, ERAs assume that 100 percent of the animal's diet would come from contaminated vegetation, which is unlikely given that vegetation is a relatively minor component of eider diets.

\section{Indirect Effects}

Loss of vegetation in nesting habitats as a result of herbicide treatments would likely have an adverse effect on eiders by reducing plant cover that helps to hide nests from predators, potentially resulting in increased predation during nesting, and reduced reproductive success at the population level. Effects would be greatest if treatments occurred just before or during the breeding season. 


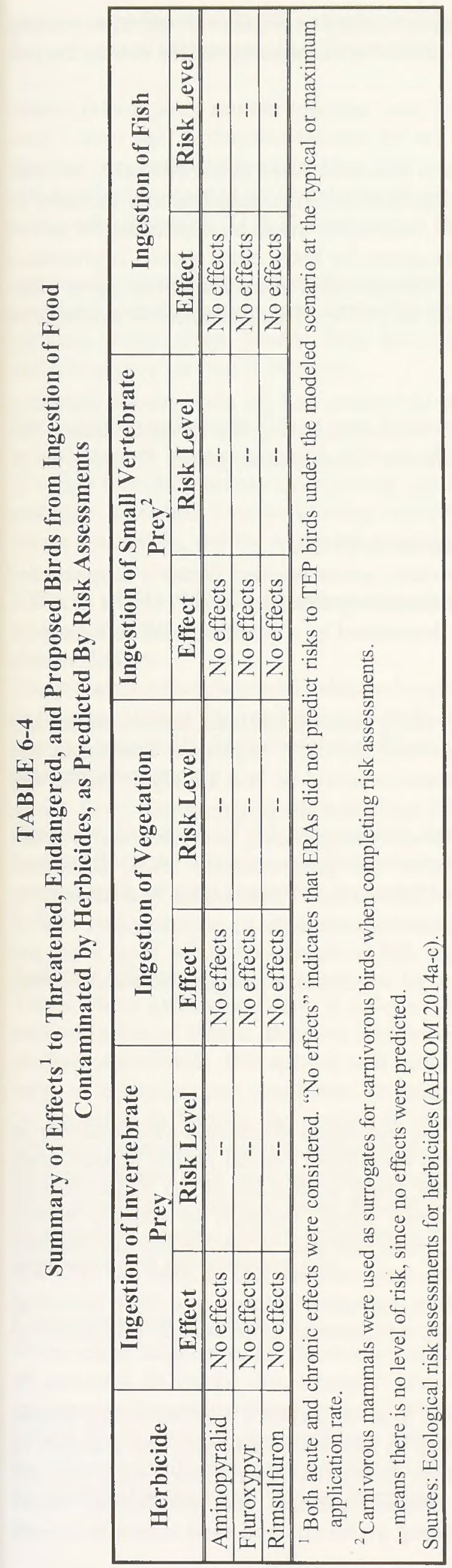


Treatments that reduce hazardous fuels could benefit eiders by reducing the risks that wildfire would burn nesting habitat in the future. Removal of non-native species would also benefit ciders by maintaining native habitat for use in nesting.

\section{Conservation Measures}

This BA assumes that the BLM would continue to follow the conservation measures listed in the $2007 \mathrm{BA}$, or other comparable measures that would be developed by the field offices based on local site conditions and included in local-level consultation. General conservation measures for all herbicide treatments would be applicable for use of aminopyralid, fluroxypyr, and rimsulfuron. A list of key conservation measures for listed eider species is presented at the end of this section, with a complete list provided in the appendix. Conservation measures pertaining to other types of vegetation treatments ean be found in the 2007 BA (USDOI BLM 2007d). This document is available at http://www.blm.gov/wo/st/en/prog/more/veg_eis.html.

Given the lack of a toxicological risk to birds from use of the three new herbicides, and the conservation measures from the $2007 \mathrm{BA}$ to determine eider use of treatment areas and avoid treatments during the breeding season, no new conservation measures have been developed for herbicide treatments using aminopyralid, fluroxypyr, or rimsulfuron.

\section{Key Conservation Measures for Steller's and Spectacled Eiders from the 2007 BA}

- Prior to developing management plans associated with treatment activities, assess whether Steller's or spectacled eiders are likely to use areas proposed for treatment for nesting or brood-rearing activities.

- Do not conduct vegetation treatments during the breeding season (as determined by a qualified wildlife biologist).

\section{Determination of Effects}

Based on the ERAs, none of the three herbicides would be likely to adversely affeet listed eider species under any of the modeled exposure scenarios. Following the conservation measures from the 2007 Vegetation Treatments BA would help minimize adverse impacts to these species. As a result, the action would be Not Likely to Adversely Affect Steller's and spectacled eiders or their federally designated critical habitats at the programmatic level. Given BLM mandates for use of integrated pest management (ineluding vegetation management), and given that it is not possible to forecast site-specific vegetation management needs below the programmatic level, additional evaluations of situation-specific effects will be the subject of step-down ESA Section 7 evaluations and subsequent consultations. In this manner, any additional specific conservation measures necessary to accommodate site or situation-speeific peculiarities not predictable at the programmatic level will be developed at the local level and incorporated into Pesticide Use Proposals prior to local implementation of vegetation management activities that involve the use of herbicides considered in this BA.

\section{Northern Aplomado Falcon}

The northern aplomado falcon (Falco femoralis septentrionalis) inhabits the desert grasslands and savannas of Latin America. In the United States, the subspecies historically occurred throughout coastal prairie habitat along the southern Gulf coast of Texas, and in savanna and grassland habitat along both sides of the Texas-Mexico border, southern New Mexico, and southeastern Arizona. Falcons were fairly common in suitable habitat throughout these areas until the 1940s, but declined rapidly. Since 1952, only one pair of falcons has successfully nested in the U.S. Captive-bred falcons have been released in Texas with some success, and in 2006, the USFWS, BLM, and the Peregrine Fund began a program to reintroduce northern aplomado falcons into their historical habitat in southern New Mexico for the purpose of establishing a viable, nonessential experimental population in New Mexico and Arizona (USFWS 2006h).

Northern aplomado falcon habitat consists of open terrain with scattered trees or shrubs. Other necessary habitat components include moderately low ground cover, an abundance of small to medium sized birds, and a supply of nesting platforms (e.g., large bromeliads and stick nests; USFWS 1990e). In Mexico, they inhabit palm and oak savannas, open tropical deciduous woodlands, seasonally flooded coastal savannas and marshlands, desert grasslands, and upland pine parklands. In the U.S., they were found along yucca-covered sand ridges in coastal 
prairies, riparian woodlands in open grasslands, and in desert grasslands with scattered mesquite and yucca (U.S. Department of Defense and USFWS 2007).

Mated falcon pairs remain together year-round and hunt cooperatively. Nesting typically occurs in birds greater than 1 year old. Aplomado falcons do not build their own nests, but take over nests of other raptors or corvids. Nesting oeeurs from Mareh to June. The average clutch size is 2.6 to 2.8 eggs, and the average brood size is 1.6 to 2.4. Incubation lasts 31 to 33 days, and both sexes participate in ineubation. Young birds leave the nest about 4 to 5 weeks after hatehing (U.S. Department of Defense and USFWS 2007).

Aplomado faleons prey primarily on other birds (e.g., euckoos, doves, woodpeekers, blackbirds, flyeatchers, and thrushes), supplementing their diet with insects, small mammals, and herpetofauna (e.g., grasshoppers, butterflies, crickets, wasps, frogs, lizards, bats, and rodents; USFWS 1992h). Falcons typieally initiate hunting in flight, but will chase prey on foot if necessary.

The northern aplomado faleon was federally listed as endangered on February 25, 1986 (51 FR 6686). Critical habitat has not been designated. Causes of decline inelude widespread shrub eneroaehment resulting from eontrol of range fires and intense overgrazing, agricultural development in grassland habitats used by the subspeeies, and pestieide exposure. Faetors limiting recovery of the species include long-term drought, shrub eneroaehment into desert grasslands, and the inereased presence of the predator the great horned owl (USFWS 2006h).

\section{Effects of Herbicide Treatments on the Northern Aplomado Falcon}

\section{Direct Effects}

The presenee of workers and vehicles in aplomado falcon habitats could cause some minor, temporary disturbances to faleons. During the application of herbicides, most birds would be able to flee the area to avoid contact with the sprayed chemieals. However some faleons, ineluding young flightless birds, might be unable to avoid sueh an inadvertent exposure.

Based on the results of risk assessments, none of the three new herbicides proposed for use would result in adverse health effects to northern aplomado falcons under any of the modeled exposure seenarios (direet spray, dermal contact with sprayed vegetation, or ingestion of prey items that have been direetly sprayed by the herbicides; Table 6-2).

\section{Indirect Effects}

The northern aplomado faleon is a desert grassland species that has lost large areas of suitable habitat through the encroachment of shrubs. Beeause it requires an open landscape, with seattered trees and an abundanee of small- to medium-sized birds, this speeies will benefit from any treatment that removes shrubby plants from its habitat and helps to maintain open eonditions for foraging. Therefore, herbicide treatments in aplomado falcon habitats would be expeeted to benefit the species if they ereate more open grassland conditions. Additionally, redueing the presenee of invasive species should help to restore grassland structure and function, which would benefit not only falcons, but also their prey species. If herbicide treatments were to reduce overall bird populations in faleon habitat, adverse effeets to falcons eould inelude reduced prey and reduced nesting opportunities. However, conservation measures to proteet faleon populations from the 2007 BA (listed below) should be protective of other bird populations on the treatment site.

\section{Conservation Measures}

When using aminopyralid, fluroxypyr, and rimsulfuron in vegetation treatment programs, the BLM would follow all pertinent SOPs for use, transport, and handling of herbicides. The BLM would also continue to follow the conservation measures listed in the $2007 \mathrm{BA}$, or other eomparable measures that would be developed by the ficld offices based on loeal site conditions and included in local-level consultation. No additional eonservation measurcs have been identified that are specific to the three new herbieides. However, additional conservation measures may be identified at the local level, as neeessary. 


\section{Key Conservation Measures for Northern Aplomado Falcon from the 2007 BA}

- Prior to conducting vegetation treatments, survey the project area for northern aplomado falcon nests.

- Avoid conducting vegetation treatments in northern aplomado falcon habilat during the nesting period.

- Avoid broadcast spraying herbicides in areas where future falcon nesting trees occur.

\section{Additional Conservation Measure for Northern Aplomado Falcon}

- Where surveys detect breeding birds, do not implement herbicide treatments during the breeding scason.

\section{Determination of Effects}

Based on the ERAs, none of the three herbicides would be likely to adversely affect northern aplomado falcons under any of the modeled exposure seenarios. Following the conservation measures from the $2007 \mathrm{BA}$ and this BA would help minimize adverse impacts to this species. As a result, the action would be Not Likely to Adversely Affect northern aplomado falcons at the programmatie level. Given BLM mandates for use of integrated pest management (including vegetation management), and given that it is not possible to forecast site-speeific vegetation management needs below the programmatie level, additional evaluations of situation-speeifie effects will be the subjeet of step-down ESA Section 7 cvaluations and subsequent consultations. In this manner, any additional specific conservation measures necessary to accommodate site or situation-specific peculiarities not predictable at the programmatic level will be developed at the loeal level and ineorporated into Pestieide Use Proposals prior to local implementation of vegetation management activities that involve the use of herbicides considered in this BA.

\section{Yuma Clapper Rail}

The primary reference for this seetion is:

USFWS. 2010kk. Yuma Clapper Rail Recovery Plan (Rallus longirostris yumanensis). Draft First Revision. Southwest Region. Albuquerque, New Mexico.

References eited in this section are internat to the above-referenced document. Full eitations have been ineluded in the Bibliography.

The clapper rail (Rallus longirostris) is a large marsh bird generally found in salt- to brackish-water marshes, mangrove swamps, and other tidal wetlands on the Atlantic, Caribbean, and Pacific Coasts of North, Central, and northern South America (Eddleman and Conway 1998). The Yuma clapper rail (Rallus longirostris yumanensis) is a subspecies of elapper rail that occurs in inland habitats in the southwestern United States. The Yuma elapper rail occurs along the lower Colorado River and tributaries in Arizona, California, Nevada, and Utah; the Salton Sea in California; and the Cienaga de Santa Clara and Colorado River Delta in Mexico.

Yuma clapper rails are secretive birds that live in freshwater marshes dominated by cattail and bulrush, with a mix of riparian trees and shrubs along the shoreline of the marsh. Optimum habitat appears to consist of a mosaic of emergent vegetation averaging greater than 6 feet tall (Anderson and Ohmart 1985, Eddleman 1989); shallow open water areas either as channels or pools with minimal daily water fluctuation (Tomlinson and Todd 1973, Gould 1975); open dry ground between water, vegetation, or marsh edge for foraging and movement (Gould 1975; Anderson and Ohmart 1985; Eddleman 1989; Conway et al. 1993); and a band of riparian vegetation on the higher ground along the fringes of the marsh that provides cover and buffer areas that may be used seasonally (Eddleman 1989). Home ranges are smallest ( 17 to 20 acres) during the early and late breeding seasons (March through July) and largest (up to 60 acres) in the post breeding (August through October) and late winter (January through February) periods (Conway et al. 1993).

The diet of the Yuma clapper rail is dominated by crayfish, with small fish, tadpoles, clams, and other aquatic invertebrates also eaten (Anderson and Ohmart 1985, Todd 1986, Eddleman 1989, Conway 1990). Yuma clapper rails are sight-feeders with an excellent sense of smell. Prey items are taken by surface gleaning or shallow probing on open mudflats, shallow open waters, vegetated areas with low emergent stem densities, and the water/emergent vegetation interface (Todd 1986, Eddleman 1989). 
Yuma clapper rails form pair bonds starting in February, which last for the breeding season. Nesting begins in March and peaks in May or June (Abbot 1940, Bennett and Ohmart 1978, Eddleman and Conway 1998). Nests are construeted on stable substrates (bases of emergent plant clumps or trees, on or in deep mats of residual vegetation) and may be near-shore in shallow water or in the interior of marshes over deeper water (Abbot 1940, Bennett and Ohmart 1978). The cattail stems provide overhead cover for nests, and generally additional tree or shrub cover is not needed (Eddleman 1989). Clutch size is from 5 to 10 (Bennett and Ohmart 1978, Eddleman 1989) and incubation ranges from 23 to 28 days (Eddleman 1989). Adults remain with the chicks, protecting them at night in brooding nests and accompanying them on foraging trips, for approximately 6 weeks post-hatching (Eddleman and Conway 1998).

The Yuma clapper rail was federally listed as endangered on March 11, 1967 (32 FR 4001). Critical habitat for this subspecies has not been designated. Water diversions along the lower Colorado river destroyed the cattail/bulrush marsh habitat historically utilized by this species. Existing habitats primarily are either human-made or formed behind dams and diversions. The entire habitat is threatened by natural succession processes. The greatest threat to the Yuma clapper rail is the permanent loss of these habitat areas without active management and protection of water sources supporting the habitat. Other threats to this species include continuing land use changes in floodplains, human activities, environmental contaminants (particularly increases in selenium levels), and reductions in conncctivity betwecn core habitat areas.

\section{Effects of Herbicide Treatments on the Yuma Clapper Rail}

\section{Direct Effects}

The presence of workers and vehicles associated with herbicide treatments would likcly cause a temporary disturbance to Yuma clapper rails on site, which would cause minor behavioral modifications. Many birds would likely flee the site and so avoid direct exposure to herbicides during the treatment; however birds that have not fledged would be unable to flee and could be directly sprayed by herbicides. Since the Yuma clapper rail occurs in marsh habitats, and the three herbicides are only suitable for non-aquatic uses, the chance of direct spray would be minimal. Since the three herbicides would not be sprayed direetly in the aquatic habitats in which Yuman clapper rails forage for food, the risk of ingesting food items contaminated by herbicides is low. However, spray drift of herbicides onto food sources from adjacent upland areas is possible.

Based on the results of the ERAs, none of the herbicides considered in this BA would result in adverse health effects to Yuma clapper rails under dircet spray, dermal contact with sprayed vegetation, or ingestion of sprayed food exposure scenarios (sce Tables 6-2 and 6-4).

\section{Indirect Effects}

Since Yuma clapper rails nest in aquatic habitats, herbicide treatments with the three herbicides should have little to no effect on nesting habitats. No direct spray of these aquatic habitats would occur, although accidental direct spray or spray drift from nearby upland areas could occur. Yuma clapper rails arc associated primarily with dense marsh vegetation (USFWS 1997i). Therefore, any reduction in the cover of herbaceous vegetation in clapper rail habitats would be expected to negatively affect the specics. Effects would be greatest if treatments during the nesting season exposed nests, eggs, and/or newly-hatched birds. Over the long term, removal of non-native plant species such as tamarisk would be expected to make treated areas more suitable for Yuma clapper rails.

\section{Conservation Measures}

When using aminopyralid, fluroxypyr, and rimsulfuron in vegetation treatment programs, the BLM would follow all pertinent SOPs for use, transport, and handling of herbicides. The BLM would also continue to follow the conservation measures listed in the $2007 \mathrm{BA}$, or other comparable measures that would be developed by the field offices based on local site conditions and included in local-level consultation. No additional conservation mcasures specific to the three new herbicides have been identified in this BA. However, additional conservation measures may be identified at the local level, as necessary. 
Key Conservation Measures for the Yuma Clapper Rail from the 2007 BA

- Conduct surveys prior to vegetation treatments within potential or suitable habitat.

- Where surveys detect birds, do not implement treatments during the breeding season.

- In habitats where Yuma clapper rails occur, follow the riparian/aquatic habitat protection measures discussed in Chapter 5.

- Closely follow all application instruetions and use restrictions on herbieide labels (including aquatic and wetland habitat use restrictions).

\section{Determination of Effects}

Based on the ERAs, none of the three herbicides would be likely to adversely affect Yuma clapper rails under any of the modeled exposure scenarios. Following the conservation measures from the 2007 BA would help minimize adverse impacts to this speeies. As a result, the action would be Not Likely to Adversely Affect Yuma elapper rails at the programmatic level. Given BLM mandates for use of integrated pest management (including vegetation management), and given that it is not possible to forecast site-specific vegetation management needs below the programmatic level, additional evaluations of situation-specific effects will be the subject of step-down ESA Section 7 evaluations and subsequent eonsultations. In this manner, any additional specific conservation measures necessary to aecommodate site or situation-specific peculiarities not predietable at the programmatie level will be developed at the local level and ineorporated into Pesticide Use Proposals prior to local implementation of vegetation management activities that involve the use of herbicides considered in this BA.

\section{Sand and Bare Ground Nesters: Western Snowy Plover, Piping Plover, Least Tern, and Streaked Horned Lark}

\section{Western Snowy Plover}

The primary reference for this section is:

USFWS 2007aa. Recovery Plan for the Pacific Coast Population of the Western Snowy Plover (Charadrius alexandrinus nivosus). California/Nevada Operations Offiee. Sacramento, California.

References eited in this section are internal to the above-referenced document. They are included in the Bibliography.

There are two distinet populations of western snowy plover (Charadrius nivosus nivosus, formerly Charadrius alexandrinus nivosus), only one of whieh is federally listed. The Pacific coast population of the western snowy plover, which is genetically isolated from interior-breeding western snowy plovers, is defined as those individuals that nest within 50 miles of the Pacific Ocean on the mainland coast, peninsulas, offshore islands, bays, estuaries, or rivers of the U.S. and Baja California, Mexico (USFWS 1993k). It is the Pacific coast population that is addressed in this document. In the U.S., four breeding areas currently exist in southern Washington, and nesting birds have been recorded in 14 locations in Oregon. In California, eight geographic areas support more than threequarters of the breeding population in that state: San Francisco Bay, Monterey Bay, Morro Bay, the CallendarMussel Rock Dunes area, the Point Sal to Point Conception area, the Oxnard lowland, Santa Rosa Island, and San Nicolas Island (Page et al. 1991).

The coastal population of the western snowy plover consists of both resident and migratory birds. Some birds winter in the same areas used for breeding, while other birds migrate either north or south to wintering areas, the majority of which are south of Bodega Bay, California. Pacific coast western snowy plovers breed primarily on coastal beaches from southern Washington to Mexico. It is estimated that, at most, about 2,000 snowy plovers breed along the U.S. Pacific Coast (Page et al. 1995).

Nest sites occur in flat, open areas with sandy or saline substrates, usually in areas where vegetation and driftwood are sparse or absent (Widrig 1980; Wilson 1980; Stenzel et al. 1981). Nesting habitat is unstable and ephemeral as a result of unconsolidated soil characteristics influenced by high winds, storms, wave action, and colonization by plants. Other, less common nesting habitats include salt pans, coastal dredged spoil disposal sites, dry salt ponds, 
and salt pond levees. Sand spits, dune-backed beaehes, unvegetated beaeh stands, open areas around estuaries, and beaches at river mouths are the preferred habitats for nesting (Wilson 1980; Stenzel et al. 1981). The nesting season along the west eoast extends from early Mareh through late September. Western snowy plovers eoneentrate in suitable habitat, with the number of adults at eoastal breeding loeations ranging from 1 to 315 , depending, in part, on the size of the area. The largest number of breeding birds oceurs from south San Franeiseo Bay to southern Baja California (Page and Stenzel 1981; Palaeios et al. 1994).

Wintering western snowy plovers may remain at their breeding sites or move north or south to other wintering sites along the Paeifie eoast. Additionally, both eoastal and interior populations use eoastal loeations during winter. Wintering habitat ineludes eoastal areas from southern Washington to Central Ameriea (Page et al. 1995). In Washington, there are two wintering loeations. In Oregon, at least nine loeations have been used by wintering western snowy plovers between 1990 and 2005. The majority of wintering western snowy plovers on the California eoast are found from Bodega Bay, Sonoma County, southward (Page et al. 1986).

Snowy plovers forage on invertebrates in the wet sand and among surf-east kelp within the intertidal zone; in dry, sandy areas above the high tide; on salt pans; at spoil sites; and along the edges of salt marshes and salt ponds. Their food eonsists of immature and adult aquatie and terrestrial invertebrates.

The Paeifie eoast population of the snowy plover was federally listed as threatened on Mareh 5, 1993 (58 FR 12864). Critieal habitat was originally designated on Deeember 7, 1999 (64 FR 68508), and then revised on September 29, 2005 to inelude 32 areas totaling 12,145 aeres in Washington, Oregon, and California (70 FR 56970). On June 19, 2012, the USFWS revised the eritieal habitat designation to inelude approximately 24,527 aeres in these three states ( 77 FR 36727). Deelines in snowy plover populations have been attributed to poor reproduetive sueeess resulting from human disturbanee, predation, and inelement weather, eombined with habitat loss resulting from urban development and the eneroaehment of introdueed European beaehgrass. These faetors eontinue to threaten eoastal populations of this speeies.

\section{Piping Plover}

The primary referenee for this seetion is:

USFWS. 2001k. Final Determination of Critieal Habitat for Wintering Piping Plovers. Federal Register 66(132):36037-36086.

Referenees eited in this seetion are internal to the above-refereneed doeument. A eomplete list of these referenees is available from the USFWS, Eeologieal Serviees Field Offiee, Corpus Christi, Texas.

The 2009 5-year review for the piping plover (USFWS 2009eee) was reviewed for updated information on this speeies.

The piping plover (Charadrius melodus) is a small North Ameriean shorebird. Piping plovers breed in three diserete areas of North Ameriea: The northern Great Plains, the Great Lakes, and the Atlantie Coast. There is only one breeding population in the projeet area: the northern Great Plains population. The northern Great Plains breeding range extends from southern Alberta, northern Saskatehewan, and southern Manitoba, south to eastern Montana, the Dakotas, southeastern Colorado, lowa, Minnesota, and Nebraska, and east to north-eentral Minnesota. The majority of the U.S. pairs in this population are in the Dakotas, Nebraska, and Montana (USFWS 1994). Oeeasionally, Great Plains birds nest in Oklahoma and Kansas. Generally, piping plovers favor open sand, gravel, or eobble beaehes for breeding. Breeding sites are generally found on islands, lakeshores, eoastal shorelines, and river margins.

Piping plovers winter in eoastal areas of the U.S. from North Carolina to Texas. They also winter along the eoast of eastern Mexieo and on Caribbean islands from Barbados to Cuba and the Bahamas (Haig 1992). Wintering habitats inelude beaehes, mud flats, sand flats, algal flats, and washover passes (areas where breaks in the sand dunes result in an inlet). Wintering areas for Northern Great Plains plovers are predominantly in eoastal Mississippi, Louisiana, and Texas, although there is no exelusive partitioning of the wintering range among populations (USFWS 
2009eee). Piping plovers demonstrate high fidelity to winter regions where they use a mosaie of habitats within their home ranges.

Except at inland sites, piping plover migration routes and habitats overlap breeding and wintering habitats (USFWS 2009eee). Piping plovers begin arriving on the wintering grounds in July, with some late-nesting birds arriving in September. A few individuals can be found on the wintering grounds throughout the year, but sightings are rare in late May, June, and early July. Most of the time on wintering grounds is spent foraging (Nicholls and Baldassarre 1990b; Drake 1999a, 1999b), which usually takes place on moist or wet sand, mud, or fine shell. In some cases, this substrate may be covered by a mat of blue-green algae. Primary prey ineludes polyehaete marine worms, various crustaceans, inseets, and occasionally bivalve mollusks (Nieholls 1989, Zonick and Ryan 1995). When not foraging, plovers can be found roosting, preening, bathing, in aggressive encounters (with other piping plovers and other species), and moving among available habitat locations (Zonick and Ryan 1996). Individual plovers tend to return to the same wintering sites year after year (Nicholls and Baldassarre 1990b, Drake 1999a). In late February, piping plovers begin leaving the wintering grounds to migrate back to breeding sites. Northward migration peaks in late March, and by late May most birds have left the wintering grounds (Eubanks 1994).

The population of piping plovers that breeds in the Great Lakes states is listed as endangered, while all other piping plovers are threatened species (50 FR 50726). All piping plovers are considered threatened species when on their wintering grounds. Critical habitat has been designated for breeding and wintering populations of piping plover. On September 11, 2002, 183,422 acres of prairie alkali wetlands and inland and reservoir lakes, and portions of four rivers totaling approximately 1,208 river miles in Minnesota, Montana, Nebraska, North Dakota, and South Dakota were designated as eritical habitat (67 FR 57639). Additionally, 139,029 acres of wintering habitat in Texas have been designated as eritical habitat (95 FR 23476). No other designated eritical wintering habitat oecurs within the states covered by this BA. Breeding census results show a marked decline of the population breeding in the northern Great Plains of the U.S. (Plissner and Haig 1997). Shoreline development, river flow alteration, channelization, and reservoir construction have all resulted in the loss of plover breeding habitat. Overall winter habitat loss is difficult to document; however, a variety of human-eaused disturbance factors have been noted that may affect plover survival or utilization of wintering habitat (Nicholls and Baldassarre 1990a, Haig and Plissner 1993). These faetors include recreational activities (motorized and pedestrian), inlet and shoreline stabilization, dredging of inlets that can affect spit (a small point of land, espeeially sand, running into water) formation, beach maintenance and renourishment (renourishing the beach with sand that has been lost to erosion), and pollution (e.g., oil spills; USFWS 1996). Piping plovers eontinue to be threatened by loss and degradation of habitat due to sand placement projects, inlet stabilization, sand mining, groins, seawalls and revetments, exotic and invasive vegetation, and wrack removal. Additionally the species is threatened by inadequate management of beach recreationists, and associated disturbance to breeding birds (USFWS 2009cee).

\section{Least Tern (Interior)}

The primary reference for this section is:

Lackey, J. 1997. The Interior Least Tern, an Endangered Species. NEBRASKAland Magazine and the Nebraska Game and Parks Commission. Lincoln, Nebraska.

The least tern (Sterna antillarum), the smallest member of the tern family, is represented by three distinct subspecies. The interior least tern (Sterna a. athalassos) breeds locally along the major tributaries of the Mississippi River drainage basin from eastern Montana south to Texas and east to western Illinois, Missouri, Arkansas and Louisiana. The interior least tern has distinct breeding and wintering areas. Most breeding occurs on interior rivers, and wintering is thought to occur on beaches along the Central American coast and along the northern coast of South America from Venezuela to northeastern Brazil. Wintering least terns have been reported in Guyana, El Salvador, and Guatemala. The occurrence of breeding least terns is localized and is highly dependent on the presence of dry, exposed sandbars and favorable river flows that support a forage fish supply and isolate the sandbars from the riverbanks. Characteristic riverine nesting sites are dry, flat, sparsely vegetated sandbars and gravel bars within a wide, unobstructed, water-filled river channel. 
Interior least terns consume small fish captured in the shallow water of rivers and lakes. They hunt by hovering, searching, and then diving from a height of a few feet to 30 feet above the surface to snateh small fish in their bill. Interior least terns nesting at sandpits and other off-river sites often fly up to 2 miles to forage at river sites. Interior least terns nesting on riverine sandbars usually forage close to the nesting colony. Fish of 1 to 3 inches long are consumed by adults.

Interior least terns usually arrive on their breeding grounds in early to mid-May and begin to establish feeding and nesting territories. During the breeding season, the terns' home range is generally limited to a 2-mile streteh of river assoeiated with the nesting eolony. Interior least terns nesting at sandpits along rivers use the adjoining river as well as the sandpit lake itself for foraging. Interior least terns are semi-eolonial nesters that benefit from the antipredator behavior exhibited by the entire eolony when the nesting territory is invaded. The piping plover, a state and federally threatened shorebird speeies, is often found nesting in the midst of interior least tern eolonies in Nebraska. Presumably the piping plover benefits from the defensive group behavior of the nesting terns as well.

Upon arrival on breeding grounds, interior least terns begin to engage in aerial courtship displays. During the ground phase of courtship, male terns offer small fish to females to help secure the pair bond. Courtship feeding is one of the most important parts of the courtship process and is continued through the incubation period. Nests are initiated only after spring and early summer flows reede and dry areas on sandbars are exposed, usually on higher elevations away from the water's edge. Artifieially ereated nesting sites, such as sand and gravel pits, dredge islands, reservoir shorelines, and power plant ash disposal areas, also are used.

Soon after pair formation, both sexes participate in making many shallow nest serapes dispersed in open, gravelly or sandy areas. Although several serapes might be built by each pair, only one is used for nesting. Nest serapes are sometimes loeated near small pieees of wood or debris or near elusters of small stones. After the female selects a suitable serape, two or three eggs are laid on consecutive days. Both adults begin to alternate incubation duties after the first egg is laid. If a first cluteh of eggs is lost, interior least terns will renest up to two times, eaeh renesting attempt taking place at a new site. Incubation lasts about 21 days, after whieh the eggs begin to hateh on eonseeutive days. The newly hatehed young are weak and helpless and are continuously brooded by the adults during the first day. The nesting season ends by early August, and departure from breeding areas usually is eomplete by early September.

Following the breeding season, interior least terns gather in small flocks along rivers to feed and prepare for migration. In fall they probably follow the same migration routes that they use in spring, but their movements are less regular and more casual.

The interior least tern was federally listed as endangered on May 28, I985 (50 FR 21784). Critical habitat has not been designated. Loss of habitat has eontributed to the decline of this species. River channelization, irrigation diversions, and the construetion of dams have contributed to the destruetion of much of the terns' sandbar nesting habitat. In addition, human-related disturbanees (e.g., foot traffic, unleashed pets, swimmers, eanocists, and OHVs) ean limit the reproductive suecess of this species.

\section{Streaked Horned Lark}

The primary reference for this seetion is:

USFWS. 2012f. Endangered and Threatened Wildlife and Plants; Listing Taylor's Checkerspot Butterfly and Streaked Horned Lark and Designation of Critical Habitat; Proposed Rule. Federal Register 77(197):61937-62058.

References eited in this section are internal to the above-refereneed document. A complete list of these referenees is available from the Washington Fish and Wildlife Offiee, Laeey, Washington.

The streaked horned lark (Eremophila alpestris strigata) is a small, ground-dwelling bird that is a subspeeies of the wide-ranging horned lark (E. alpestris). It is endemic to the Paeifie Northwest (British Columbia, Washington, and Oregon; Altman 2011). The breeding range of the subspecies historically extended from Southern British Columbia, Canada, south through the Puget Lowlands and outer coast of Washington, along the lower Columbia 
River, through the Willamette Valley, along the Oregon coast, and into the Umpqua and Rogue River Valleys of southwestern Oregon. The subspecies has been extirpated as a breeding species throughout much of its former range, and eurrently is only found in three regions: the south Puget Sound in Washington, the Washington eoast and lower Columbia River islands, and the Willamette Valley of Oregon. The majority of streaked horned larks winter in the Willamette Valley (72 pereent) and on the islands in the lower Columbia River (20 percent). The rest winter on the Washington coast or in the south Puget Sound (Pearson et al. 2005b).

Habitat used by streaked horned larks is generally flat, with substantial areas of bare ground and sparse, low-stature vegetation, primarily eomprised of grasses and forbs (Pearson and Hopey 2005). Suitable habitat generally has 16 to 17 pereent bare ground, with vegetation less than 13 inehes in height (Altman 1999, Pearson and Hopey 2005). Historically, the nesting habitat of streaked horned larks was found on grasslands, estuaries, and sandy beaches in British Columbia, in dune habitats along the coast of Washington, in western Washington and western Oregon prairies, and on the sandy beaches and spits along the Columbia and Willamette Rivers. Today, the subspeeies nests in a broad range of habitats, ineluding native prairies, coastal dunes, fallow and active agricultural fields, wetland mudflats, sparsely-vegetated edges of grass fields, reeently planted Christmas tree farms with extensive bare ground, moderately-to-heavily grazed pastures, gravel roads or gravel shoulders of lightly traveled roads, airports, and dredge deposition sites in the lower Columbia River (Altman 1999, Pearson and Altman 2005, Pearson and Hopey 2005, Moore 2008). Streaked horned lark populations are found at nearly every airport within the range of the subspecies, beeause airport maintenanee requirements provide the desired open landseape eontext and short vegetation structure. Wintering streaked horned larks use habitats that are very similar to breeding habitats (Pearson et al. 2005b).

Horned larks forage on the ground in low vegetation or on bare ground, feeding mainly on grass and weed seeds, but also some inseets (Beason 1995). They appear to seleet habitats based on the strueture of the vegetation rather than the presenee of any speeifie food plants (Moore 2008).

Horned larks form pairs in the spring. They ereate nests in shallow depressions in the ground and line them with soft vegetation (Beason 1995). They establish their nests in areas of extensive bare ground, with nests plaeed adjacent to elumps of vegetation or other objeets (Moore and Kotaich 2010). There is evidenee that streaked horned larks have strong natal fidelity to nesting sites, returning each year to the place they were born (Pearson et al. 2008). The nesting season for the subspecies begins in mid-April and ends in the early part of August. Clutehes range from 1 to 5 eggs, with a mean of 3 eggs. After the first nesting attempt, they will often re-nest in late June or early July (Pearson and Hopey 2004). Young leave the nest by the end of the first week after hatehing, and beeome independent at about 4 weeks old (Beason 1995).

The streaked horned lark was federally listed as threatened on Oetober 3, 2013 (78 FR 61451). On the same date, the USFWS designated 4,629 acres of eritical habitat for the species in Grays Harbor, Pacifie, and Wahkiakum Counties in Washington, and in Clatsop, Columbia, Marion, Polk, and Benton Counties in Oregon (78 FR 61505). Throughout the entirety of the streaked horned lark's range, its habitat is threatened by loss of natural disturbance regimes, succession of woody plants and the invasion of non-native plants that alter habitat structure, and incompatible management practices.

\section{Effects of Herbicide Treatments on the Western Snowy Plover, Piping Plover, Least Tern, and Streaked Horned Lark}

\section{Direct Effects}

The presence of workers and vehicles in plover, tern, or streaked horned lark habitats during herbicide treatments would temporarily disturb some birds. If treatments were to occur near nesting birds, adverse effects to breeding suecess could occur. Although most birds would flee the area, some birds (particularly young, flightless birds) could inadvertently be exposed to direct spray of herbicides. Given that the three herbicides would not be used in aquatic habitats, direct spray of plant materials or prey items utilized by listed plovers or terns should not occur. In the case of the streaked horned lark, direct spray of plant materials, and insects used as food sources could occur. For all three species, spray drift from adjacent treatment areas is possible, and in the case of the plovers and the 
least tern, aceidental direct spray of aquatie habitats, is possible. Should aminopyralid receive an aquatie registration in the future, aquatic habitats could also be subject to accidental overspray of this aetive ingredient during herbieide treatments. Therefore, food sources of all three speeies could be sprayed under various exposure seenarios considered by the ERAs.

Based on the results of the ERAs, none of the herbieides eonsidered in this BA would result in adverse health effects to listed plovers, terns, or streaked horned larks under direct spray, dermal spray, or ingestion of sprayed food exposure seenarios (see Tables 6-2 and 6-4).

\section{Indirect Effects}

The western snowy plover, piping plover, and interior least tern all nest in sparsely vegetated, sandy habitats next to water, and require bare sand for nesting. Populations of streaked horned lark along the Washington Coast nest in the same habitats as western snowy plovers (USFWS 2012f), but they also nest much further inland, in sparsely vegetated flat areas. In some places, the invasion of non-native beach grasses, or other vegetation (ineluding native speeies) that eneroaehes onto suitable nesting areas has redueed the amount of available breeding habitat for plovers and terns. Non-native speeies have also impacted breeding habitat for streaked horned larks, whieh currently nest in disturbed areas where cover of vegetation is sparse. Vegetation removal through herbieide treatments would be unlikely to adversely affect the habitat of these listed bird speeies. Furthermore, treatments that eontrol invasive plant speeies to maintain or recover the open conditions favored by these species could have a long-term beneficial effect by inereasing the suitability of habitat.

\section{Conservation Measures}

When using aminopyralid, fluroxypyr, and rimsulfuron in vegetation treatment programs, the BLM would follow all pertinent SOPs for use, transport, and handling of herbicides. The BLM would also continue to follow the eonservation measures listed in the $2007 \mathrm{BA}$, or other eomparable measures that would be developed by the field offices based on loeal site eonditions and included in local-level consultation. As the streaked horned lark was not listed at the time of the $2007 \mathrm{BA}$, the eonservation measures listed in that document must be expanded to inelude this species. No additional conservation measures specific to the three new herbicides have been identified in this BA. However, additional, project-speeifie eonservation measures would be developed at the local level, as appropriate.

\section{Key Conservation Measures from the $2007 \mathrm{BA}$}

- Survey for western snowy plovers, piping plovers, interior least terns, and streaked horned larks (and their nests) in suitable areas of proposed treatment areas, prior to developing treatment plans.

- Do not treat vegetation in nesting areas during the breeding season (as determined by a qualified biologist).

- Do not allow human disturbance within $1 / 4$ mile of nest sites during the nesting period.

- Conduct beachgrass treatments during the plant's flowering stage, during periods of active growth.

- Closely follow all applieation instructions and use restrictions on herbicide labels (ineluding aquatic and wetland habitat use restrictions).

\section{Determination of Effects}

Based on the ERAs, none of the three herbicides would be likely to adversely affeet western snowy plovers, piping plovers, least terns, or streaked horned larks under any of the modeled exposure scenarios. Following the conservation measures from the $2007 \mathrm{BA}$ would help minimize adverse impacts to these species. As a result, the action would be Not Likely to Adversely Affect western snowy plover, piping plover, least tern, and streaked horned lark or their federally designated critical habitats at the programmatic level. Given BLM mandates for use of integrated pest management (including vegetation management), and given that it is not possible to forecast sitespecifie vegetation management needs below the programmatic level, additional evaluations of situation specific effects will be the subject of step-down ESA Seetion 7 evaluations and subsequent eonsultations. In this manner, any additional specifie conservation measures necessary to accommodate site or situation-speeific peculiarities not predietable at the programmatic level will be developed at the loeal level and incorporated into Pestieide Use Proposals prior to local implementation of vegetation management activities that involve the use of herbieides considered in this BA. 


\section{Riparian Species: Least Bell's Vireo, Inyo California Towhee, Southwestern Willow Flycatcher, and Yellow-billed Cuckoo}

\section{Least Bell's Vireo}

The primary reference for this section is:

USFWS. 1998w. Draft Recovery Plan for the Least Bell's Vireo (Vireo bellii pusillus). Portland Oregon.

References eited in this section are internal to the above-referenced doeument. Full citations have been included in the Bibliography.

The 2006 5-year review for the least Bell's vireo (USFWS 2006i) was reviewed for updated information on this species.

The least Bell's vireo (Vireo bellii pusillus) is a subspecies of the Bell's vireo that oceurs in riparian habitats in the southwestern U.S. and northwestern Mexico. It is dependent on riparian habitats for breeding. This subspecies was onee widespread and abundant throughout the Central Valley and other low elevation riverine areas of California. Historically, the least Bell's vireo ranged from the interior of northern California (near Red Bluff, Tehama County), south to northwestern Baja California, Mexico. Its breeding distribution is restrieted to a few loealities in southern California and northwestern Mexieo (Franzreb 1989). The least Bell's vireo winters primarily in Baja California, with occasional individuals remaining through the winter in cismontane southern California. Since its listing the subspeeies' population in the U.S. has increased ten-fold, with the population from Ventura County southward inereasing significantly but the population from Santa Barbara northward deelining (USFWS 2006i).

Least Bell's vireos typically inhabit structurally diverse woodlands along watereourses. They oceur in various riparian habitats, including cottonwood-willow woodlands/forests, oak woodlands, and mule fat scrub. Essential habitat features apparently include dense eover within 3 to 6 feet of the ground for nesting, and a dense, stratified canopy for foraging (Goldwasser 1978, Gray and Greaves 1984). Although least Bell's vireos typically nest in willow-dominated areas, plant species composition does not appear to be as important a determinant of nesting site selection as habitat structure. Ideal breeding habitat conditions are typically found in early successional habitats.

Least Bell's vireos forage in riparian and adjoining upland habitats (Kus and Miner 1987, Salata 1987). The subspecies is not exclusively dependent on riparian habitat in its wintering areas.

The least Bell's vireo arrives on its breeding grounds in mid-March (Brown 1993), with males arriving slightly before females (Nolan 1960, Barlow 1962). Nesting takes place from early April through the end of July, and two broods are usually attempted during this period. Nests are suspended from forks in dense bushes or small trees, usually willows, although over 60 speeies of plants have been used for nest sites (Brown 1993). Most birds depart the nesting grounds by September, although some may remain until late November (Rosenberg et al. 1991).

The least Bell's vireo was federally listed as endangered on May 2, 1986 (5I FR 16474). On February 2, 1994, about 38,000 acres of land in ten localities of six counties in Southern California were designated as critical habitat (59 FR 4845). Ineluded are areas along the Santa Ynez River in Santa Barbara County; the Santa Clara River in Ventura and Los Angeles Counties; the Santa Ana River in San Bernardino and Riverside Counties; and the Santa Margarite, San Luis Rey, San Diego, Sweetwater, and Tijuana Rivers and Coyote and Jamul-Dulzura Creeks in San Diego County. The reduction of least Bell's vireo numbers and distribution is associated with widespread loss of riparian habitats and brood parasitism by the brown-headed cowbird. Factors that have caused loss or degradation of habitat include agricultural, urban, and suburban development, flood control efforts, military activities, fires, OHV use, livestock activities, and the invasion of non-native plant species. Since its listing, the rapid destruction and modification of habitat has been curtailed significantly, and nest parasitism by cowbirds is now the primary threat to the species (USFWS 2006i). To sustain the least Bell's vireo, continued cowbird control and exotic plant removal in riparian areas must continue. 


\section{Inyo California Towhee}

The primary reference for this section is:

USFWS. 1998x. Recovery Plan for the Inyo California Towhee. Portland, Oregon.

References cited in this section are internal to the above-referenced document. Full citations have been included in the Bibliography.

The 2008 5-year review for the Inyo California towhee (USFWS 2008w) was reviewed for updated information on this species.

The Inyo California towhee (Pipilo crissalis eremophilus) is an isolated subspecies of the California towhee that is only found in riparian habitats on the west and east slopes of the southern Argus Mountains of Inyo County, California (USFWS 2008w). The Inyo California towhee is a relict population of a species that was historically widespread in the southwestern U.S. and northern Mexico (Davis 1951). The subspecies became restricted to mountain areas on the northern Mojave Desert as a result of prehistoric climatic changes. Inyo California towhees are non-migratory, holding their territories year-round.

Inyo California towhees nest and forage in areas of dense riparian vegetation dominated by willows, Fremont cottonwood, and desert olive, with associated rubber rabbit brush and squaw waterweed. They also nest in shrubs of the upland community adjacent to riparian habitat, and use the upland habitat as their principal foraging grounds. This habitat consists of Mojave creosote bush scrub or Mojave mixed woody scrub. Plants associated with the creosote bush community include burro brush, allscale, and indigo bush. The mixed shrub community consists of a wide variety of plants, including antelope brush, green ephedra, Nevada ephedra, bush lupine, blackbrush, bush pea, big sagebrush, bladder sage, and brittlebush (LaBerteaux 1994).

Inyo California towhees are omnivorous, opportunistic feeders, foraging primarily in open, rocky and sandy desert hillsides on just about any seed or invertebrate they encounter. They will also forage on the low branches of large shrubs and in the leaf litter and foliage of dense riparian vegetation (LaBerteaux 1989). When foraging, towhees primarily peck and glean, but will also engage in scratehing, fly catching, chasing, and harvesting to find or capture food.

Inyo California towhees mate for life, and only when one bird dies does the other pursue another mate. Sexual maturity is generally attained in the first breeding season after hatching. Initiation of nesting coincides with local plant growth and flowering periods, which are influenced by rainfall and temperature, factors that also affect insect abundance. Inyo California towhees nest in riparian habitats and in a variety of desert shrubs in adjacent upland communities. Their nests are bulky cups made of thin twigs, grasses, and forb stems with leaves and flower heads. The nests are lined with fine stems, grasses, and hairs. Nests are constructed in a variety of plants, such as shining willow, arroyo willow, desert olive, antelope brush, bladder sage, four-winged saltbush, and green ephedra (Cord and Jehl 1979, LaBerteaux 1989). These plant types help provide nest sites off the ground that offer protection from ground predators, as well as dense canopies that hide nests from aerial predators. These trees also provide shade from extreme desert temperatures.

The breeding season generally starts early in spring, with courtship and nest building commencing in March. The first clutches are typically laid in April, although they may be laid as early as late March. Replacement clutches may be laid as late as May or early June. If the first clutch fails, the pair will recycle, but brecding behavior usually ceases for the pair when the first clutch is successful.

Clutch sizes range from two to four eggs. Only the female incubates the eggs, but both parents share in the brooding and feeding of the young. Eggs hatch after 14 days of incubation, and the young fledge 8 days after hatching. Parents continue to feed the young for at least 4 weeks after fledging. The young are fully independent of the parents at 6 weeks, but remain within their natal nest area through the following fall and winter (LaBerteaux 1989). 
The Inyo California towhee was federally listed as threatened, and eritical habitat was designated, on August 3 , 1987 (52 FR 28780). Critical habitat for the Inyo California towhee encompasses approximately 5,600 acres of habitat near springs, streambeds, and uplands in the following areas: Margaret Ann Springs, Snooky Spring, Ruby Spring, Quail Spring, Benko Spring, Bainter Spring, Indian Joe Spring, Great Falls Basin, Mountain Springs Canyon, Mumford Springs, Austin Springs, and three unnamed springs. At the time of listing, the primary threat to the continued existence of this subspecies was the degradation and destruction of riparian habitat by the export of water, mining, recreational and military aetivities, rural development, controlled burns, and grazing. Since the vast majority of the Inyo California towhees remaining habitat is on federally managed land, measures to reduce or eliminate these activities has resulted in a marked improvement in towhee habitat and an increase in abundance. The subspecies was recommended for delisting in 2008 (USFWS 2008w).

\section{Southwestern Willow Flycatcher}

The primary referenee for this section is:

USFWS. 2002q. Southwestern Willow Flyeatcher Recovery Plan. Albuquerque, New Mexico.

References eited in this section are internal to the above-referenced document. Full citations have been ineluded in the Bibliography.

The southwestern willow flyeateher (Empidonax traillii extimus) is a subspecies of willow flycatcher that breeds in southern California, southern Nevada, southern Utah, Arizona, New Mexico, western Texas, and southwestern Colorado, and extreme northwestern Mexico (Hubbard 1987, Unitt 1987, Browning 1993). The historical breeding range is similar to the eurrent breeding range, but the quantity of suitable habitat within it is reduced. All willow flycatchers are migratory, wintering in southern Mexico, Central America, and northern South America.

The southwestern willow flycatcher breeds in relatively dense riparian tree and shrub eommunities assoeiated with rivers, swamps, and other wetlands, ineluding lakes. Most of these habitats are elassified as forested or serub-shrub wetlands. Throughout the range of the subspecies, these riparian habitats tend to be rare, small, and/or linear locales, widely separated by vast expanses of arid lands. Breeding habitats are typically near or adjacent to surface water or underlain by saturated soil.

Flyeatchers nest in thickets of trees and shrubs approximately 6 to 98 feet in height, with dense foliage up to approximately 13 feet above the ground, and often a high pereentage of eanopy eover. The diversity of nest site plant species may be low or comparatively high, and nest site vegetation may be even- or uneven-aged, but is usually dense and structurally homogeneous (Brown 1988; Whitfield 1990; Sogge et al. 1993; Muiznieks et al. 1994; Stoleson and Finch 1999). Although the southwestern willow flyeatcher historieally nested in native plant communities, and still does so when such vegetation is available, the species is now known to nest in thickets dominated by the non-native species tamarisk and Russian olive, and in habitats where native and non-native trees and shrubs are present in essentially even mixtures (Hubbard 1987; Brown 1988; Sogge et al. 1993; Muiznieks et al. 1994; Sferra et al. 1997; Sogge et al. 1997; Paradzick et al. 1999).

The southwestern willow flycatcher is an insectivore, eatching insects while flying, gleaning them from foliage, and occasionally capturing them on the ground. Flycatchers forage within and above the canopy, along the pateh edge, in openings within the territory, and above water, and glean food from tall trees and herbaceous ground cover (Bent 1960, McCabe 1991). It is assumed that the diet of southwestern willow flycatchers is similar to that of other North American flycatehers in the same genus, consisting of small to medium sized insects (Beal 1912). Willow flycatchers commonly eat wasps, bees, flies, beetles, butterflies/moths and caterpillars, spittlebugs, and negligible amounts of plant material (Beal 1912, Roberts 1932, Imhof 1962, McCabe 1991).

Southwestern willow flycatchers typically arrive at breeding sites between early May and early June, and establish a territory by singing and interacting aggressively with other flycatchers (Ligon 1961; Maynard 1995; Skaggs 1996; Sferra et al. 1997). Birds typically construct nests in the fork of small-diameter vertical or nearly vertical branches, at varying heights. Typically, there is dense vegetation above and around the nest. The nest is a compact cup constructed of leaves, grass, fibers, feathers, and animal hair, with coarser materials in the base and body and 
finer materials in the nest cup (Bent 1960). Incubation of eggs lasts 12 to 13 days, and nestlings fledge 12 to 15 days after hatehing. Pairs may attempt to renest if the first nest is lost or abandoned, or if the young fledge from the first nest by late June or very early July. Dispersal after nesting is poorly understood. Unpaired males may leave the breeding site as early as mid-July, and adults that suceessfully raise young may remain at the site until midAugust or early September (Sogge 1995; Sogge et al. 1997b).

The southwestern willow flycatcher was federally listed as endangered on February 27, 1995 (60 FR 10695). On October 19, 2005, 737 river miles of waterways and their adjacent riparian habitats (nearly 121,000 acres) in Arizona, California, Nevada, New Mexico, and Utah were designated as critical habitat (70 FR 60886). On January 3,2013 , the USFWS revised the eritical habitat designation to include a total of approximately 1,227 stream miles and associated habitat (totaling 208,973 acres; 78 FR 343). Extensive loss and modification of this subspecies' breeding habitat has oceurred through reduction or elimination of surface and subsurface water caused by diversion and groundwater pumping, changes in flood and fire regimes as a result of dams and stream channelization, elearing and control of vegetation, livestock grazing, disruption of natural hydrologic eycles, and establishment of non-native plants. In addition, brood-parasitism by the brown-headed cowbird has inhibited reproductive suecess and reduced population levels.

\section{Yellow-billed Cuckoo}

The primary referenee for this section is:

USFWS. 2013g. Endangered and Threatened Wildlife and Plants; Proposed Threatened Status for the Western Distinet Population Segment of the Yellow-billed Cuckoo (Coccyzus americanus); Proposed Rule. Federal Register 78(192):61621-61666.

References cited in this section are internal to the above-referenced document. A complete list of these references is available from the Sacramento Fish and Wildlife Office, Sacramento, California.

The yellow-billed cuckoo (Coccyzus americanus) is a neotropical migrant bird that winters in South America and breeds in North America. The breeding range of the species formerly ineluded most of North Ameriea, from southeastern and western Canada to the Greater Antilles and northern Mexico (AOU 1957, 1983, 1998). In the United States, the breeding range of the western DPS (western yellow-billed cuckoo) includes the area west of the Continental Divide, south through Montana, Wyoming, and Colorado, and along the watershed divide between the upper and middle Rio Grande and Pecos Rivers in New Mexico and Texas, south to Big Bend in southwestern Texas, and extending to the states of the west coast. It is believed that the population of the speeies has declined by several orders of magnitude over the past 100 years, and that this decline is continuing.

The western yellow-billed cuckoo nests almost exclusively in low to moderate elevation riparian woodlands that cover 50 acres or more within arid to semiarid landseapes (Hughes 1999). The large majority of nests are placed in willow trees, but alder, cottonwood, mesquite, walnut, box elder, sycamore, and tamarisk are also used (Jay 1911; Hanna 1937; Laymon 1980; Halterman and Laymon 1995; Holmes et al. 2008). Most nests are placed on wellfoliaged horizontal branches at sites with dense canopy cover above the nest (Laymon et al. 1997). Western yellow-billed cuckoos require large blocks of riparian habitat for breeding. Little is known about foraging, migratory, and wintering habitat of the species.

The western yellow-billed cuckoo generally arrives on its breeding grounds in mid-June. The breeding season varies regionally with the availability of its preferred food. Nesting peaks in mid-June through August, and may be triggered by an abundanee of cicadas, katydids, caterpillars, or other large prey items that form the bulk of the species' diet (Hamilton and Hamilton 1965; Rosenberg et al. 1982). Up to three broods can be raised in a season if the prey base is sufficient (Laymon et al. 1997; Halterman 2009). In mid-August, the birds begin their southbound migration, and most have left the breeding grounds by mid-September (Gaines and Laymon 1984).

Yellow-billed cuckoos build an open cup nest with a loose saucer-shaped stick construction. Both parents build the nest, incubate, and tend the young. Cluteh size varies from two to five eggs, depending the available food supply. 
Eggs hatch in 11 to 12 days, and young fledge in 5 to 7 days. Nesting success is high in comparison to other opencup nesting birds (Laymon et al. 1997).

The western DPS of the yellow-billed cuckoo was federally listed as a threatened species on October 3, 2014 (79 FR 59992). On August 15, 2014, approximately 546,335 acres were proposed as eritical habitat for the western DPS of the yellow-billed cuckoo in Arizona, California, Colorado, Idaho, Nevada, New Mexico, Texas, Utah, and Wyoming (79 FR 48548). The yellow-billed cuckoo is threatened by habitat destruction, modification, and degradation from dam construetion and operations; water diversions; riverflow management; stream channelization and stabilization; conversion to agricultural uses; urban and transportation infrastructure; and increased incidence of wildfire. These factors also eontribute to fragmentation and promote conversion to non-native plant species, particularly tamarisk.

\section{Effects of Herbicide Treatments on the Least Bell's Vireo, Inyo California Towhee, Southwestern Willow Flycatcher, and Yellow-billed Cuckoo}

\section{Direct Effects}

Although the three herbicides would not be applied to standing water, they could be used in riparian habitats where water is not present. The presence of workers and vehicles in habitats that support riparian TEP bird species would result in temporary disturbances to birds. The severity of these effects would depend on the season, and the vicinity of disturbances to nesting habitat. Although adult birds would be able to fly away from treatment sites, some birds could inadvertently be exposed to herbicides, as could nests, eggs, and young, flightless birds. Birds also could be exposed to herbicides indireetly through contact with plants that have been sprayed, or by consuming food items that have been sprayed by herbicides.

Based on the results of the ERAs, none of the herbicides considered in this BA would result in adverse health effects to riparian TEP bird species under direct spray, dermal spray, or ingestion of sprayed food exposure scenarios (see Tables 6-2 and 6-4).

\section{Indirect Effects}

Herbicide treatments in habitats that support the least Bell's vireo, Inyo California towhee, southwestern willow flycatcher, or yellow-billed cuckoo could negatively affect these habitats if substantial loss of vegetation oceurred. Thinning of understory vegetation, for example, may reduce the suitability of a riparian site for nesting, as birds generally require dense vegetation above and around the nest for cover. Effects would be greatest if vegetation around nests was injured or killed. However, based on the likely usage of the three new active ingredients, widescale removal of riparian vegetation is unlikely to occur. Out of the three herbicides, fluroxypyr and rimsulfuron would typically not be used near water, except possibly for spot treatments of certain target species. Aminopyralid would be used in riparian treatments for selective removal of certain target species, but excessive removal of riparian vegetation would be unlikely. Indireet effects would likely be short-term in nature, unless older trees and shrubs were killed. The three bird species could also be adversely affected by a short-term reduction in food items, such as seeds and berries. A treatment program that reduces invasive species, allowing natives (such as cottonwoods and willows) to increase in abundance, would be expected to have a long-term positive effect on riparian bird habitat.

\section{Conservation Measures}

When using aminopyralid, fluroxypyr, and rimsulfuron in vegetation treatment programs, the BLM would follow all pertinent SOPs for use, transport, and handling of herbicides. The BLM would also continue to follow the conservation measures listed in the $2007 \mathrm{BA}$, or other comparable measures that would be developed by the field offices based on local site conditions and included in local-level consultation. No additional conservation measures specific to the three new herbicides have been identified in this BA. However, project-specific conservation measures may be developed at the local level, as appropriate, to ensure protection of these species during and following treatments with the new active ingredients. 


\section{Key Conservation Measures from the $2007 \mathrm{BA}$}

- Conduct surveys prior to vegetation treatments within potential or suitable habitat.

- Where surveys detect birds, do not broadeast spray herbieides.

- Do not eonduct vegetation treatments within $1 / 2$ mile of known nest sites or unsurveyed suitable habitat during the breeding season (as determined by a qualified wildlife biologist).

- Adjust spatial and temporal seales of treatments so that not all suitable habitat is affeeted in any given year.

- Following treatments, replant or reseed treated areas with native species, if needed.

- Closely follow all applieation instruetions and use restrietions on herbieide labels (ineluding aquatic and wetland habitat use restrietions).

\section{Determination of Effects}

Based on the ERAs, none of the three herbieides would be likely to adversely affeet the least Bell's vireo, Inyo California towhee, southwestern willow flyeateher, or ycllow-billed cuckoo under any of the modeled exposure scenarios. Following the eonservation measures from the $2007 \mathrm{BA}$ would help minimize adverse impaets to these speeies. As a result, the action would be Not Likely to Adversely Affect Bell's vireo, Inyo California towhee, southwestern willow flyeateher, and yellow-billed cuckoo or their federally designated eritieal habitats at the programmatie level. Given BLM mandates for use of integrated pest management (including vegetation management), and given that it is not possible to forecast site-specific vegetation management needs below the programmatic level, additional evaluations of situation-speeifie effeets will be the subjeet of step-down ESA Section 7 evaluations and subsequent consultations. In this manner, any additional speeifie eonservation measures neeessary to aceommodate site or situation-specifie peeuliarities not predictable at the programmatie level will be developed at the local level and incorporated into Pesticide Use Proposals prior to local implementation of vegetation management aetivities that involve the use of herbieides eonsidered in this BA.

\section{Gunnison Sage-grouse, Greater Sage-grouse, and Lesser Prairie-chicken}

\section{Gunnison Sage-grouse and Greater Sage-grouse}

The primary references for this seetion are:

USFWS. 2013h. Endangered and Threatened Wildlife and Plants; Endangered Status for Gunnison Sage-Grouse; Proposed Rule. Federal Register 78(8):2485-2538.

and

USFWS. 2013i. Endangered and Threatened Wildlife and Plants; Threatened Status for the Bi-State Distinet Population Segment of Greater Sage-Grouse With Speeial Rule; Proposed Rule. Federal Register 78(208):6435764384.

Referenees eited in this seetion are internal to the above-refereneed documents. A complete list of these references is available from the Western Colorado Field Offiee, Grand Junction, Colorado (Gunnison sage-grouse) and the Nevada Fish and Wildlife Offiee, Reno, Nevada (greater sage-grouse).

The Gunnison sage-grouse (Centrocercus minimus) and the greater sage-grouse (Centrocercus urophasianus) are two species of sage-grouse, ground-nesting birds found in sagebrush habitats in the western U.S. The greater sagegrouse is found throughout the western states (Washington, Oregon, Idaho, Montana, North Dakota, eastern California, Nevada, Utah, western Colorado, South Dakota, and Wyoming) and portions of Canada. However, only the Bi-State DPS, found in eastern California and western Nevada, is proposed for listing and eonsidered in this BA. The Gunnison sage-grouse is found only in Colorado and Utah. Greater sage-grouse currently occupy approximately 56 percent of their historical range, and Gunnison sage-grouse currently oeeupy an area that represents approximately 7 pereent of the species' potential historieal range. Approximately 42 pereent of habitats oceupied by Gunnison sage-grouse are on BLM-administered land. A large eomponent of habitats oeeupied by greater sage-grouse are also on BLM-administered land. 
Sage-grouse are reliant on sagebrush, and exploit numerous habitat types in the sagebrush eeosystem across broad landscapes to successfully complete their life eycles. Sage-grouse exhibit strong site fidelity (loyalty to a particular area) to seasonal habitats, including breeding, nesting, brood-rearing, and wintering areas, even when a partieular area may no longer be of value (Connelly et al. 2004). Sage-grouse require sagebrush and herbaceous vegetation year-long for escape and hiding cover from predators (Schroeder et al. 1999; Connelly et al. 2000b; GSGRC 2005; Connelly et al. 2011).

Sage-grouse require large, interconnected expanses of sagebrush eommunities that contain a healthy understory composed primarily of native, herbaceous vegetation (Patterson 1952; Knick et al. 2003; Connelly et al. 2004; Knick and Connelly 2011; Pyke 2011; Wisdom et al. 2011). While considered sagebrush obligates, they may use a variety of habitats, including riparian meadows, riparian areas with a shrub eomponent, agricultural lands, and steppe dominated by native grasses and forbs. The diet of sage-grouse is comprised of nearly 100 pereent sagebrush in the winter, while forbs, inseets, and sagebrush are important dietary components during the remainder of the year (Wallestad et al. 1975; Barnett and Crawford 1994; Schroeder et al. 1999; Young et al. 2000).

Sage-grouse are long-lived, but also have low reproduetive rates, whieh make populations slow-growing (Schroeder et al. 1999; Connelly et al. 2000a). They exhibit natural, eyclical variability in abundance. In the spring, they gather for mating at communal breeding areas called leks. Lek sites ean be loeated on areas of bare soil, windswept ridges, exposed knolls, low sagebrush, meadows, and other relatively open sites with good visibility and low vegetation structure (Connelly et al. 1981; Gates 1985; Klott and Lindzey 1989; Connelly et al. 2004). In addition, leks are usually loeated on flat to gently sloping areas of less than 15 percent grade (Patterson 1952, Giezentanner and Clark 1974, Wallestad 1975, Autenrieth 1981). Leks are often surrounded by denser shrub-steppe eover, which is used for escape, and thermal and feeding eover.

Sage-grouse typically seleet nest sites under sagebrush cover with some forb and grass cover, with successful nests found in areas of higher shrub density and greater forb and grass cover than unsuceessful nests (Young 1994).

The Gunnison sage-grouse was federally listed as a threatened speeies on November 20, 2014 (79 FR 69191). At the same time, approximately 1,429,551 acres of critical habitat were designated in Delta, Dolores, Gunnison, Hinsdale, Mesa, Montrose, Ouray, Saguache, and San Miguel Counties in Colorado, and in Grand and San Juan Counties in Utah (79 FR 69311). The Bi-State DPS of the greater sage-grouse was proposed for federal listing as a threatened species on October 28, 2013 (78 FR 64357). On the same date, the USFWS proposed the designation of 1,868,017 acres of eritical habitat in Carson City, Lyon, Douglas, Mineral, and Esmeralda Counties, Nevada; and Alpine, Mono, and Inyo Counties, California (78 FR 64327).

The principal threat to the Gunnison sage-grouse is habitat loss due to residential, exurban (beyond the suburbs), and commercial development and associated infrastructure (e.g., roads and power lines). Other threats include improper grazing management, predation, genetic risks, and inadequate regulatory mechanisms. Threats to the BiState DPS of greater sage-grouse include urbanization and habitat conversion; infrastructure; mining; renewable energy development and associated infrastructure; grazing; non-native and native invasive species (e.g., cheatgrass and pinyon-juniper encroachment); wildfires and altered fire regime; and small population size and population structure.

\section{Lesser Prairie-chicken}

The primary reference for this section is:

USFWS. 2012g. Endangered and Threatened Wildlife and Plants; Listing the Lesser Prairie-Chicken as a Threatened Species; Proposed Rule. Federal Register 77(238):73827-73888.

References eited in this section are internal to the above-referenced document. A complete list of these references is available from the Oklahoma Ecological Services Field Office, Tulsa, Oklahoma.

The lesser prairie-chicken (Tympanuchus pallidicinctus) is a grassland bird endemic to the southern plains of the United States. It is a species of prairic grouse known from southeastern Colorado, western Kansas, eastern New 
Mexico, western Kansas, eastern New Mexico, western Oklahoma, and the Texas Panhandle. The currently occupied range of the species is estimated at 27,259 square miles, which is believed to be about 16 percent of its historical range.

The preferred habitat of the lesser prairie-chicken is native short- and mixed-grass prairies with a shrub component dominated by sand sagebrush or shinnery oak (native rangeland; Donaldson 1969, Taylor and Guthery 1980a, Giese 1998). Small shrubs are important for summer shade, winter protection, and as supplemental foods (Johnsgard 1979). Outside of the grasslands in Kansas, lesser prairie-chickens are primarily found in the sand sagebrush dominated rangelands of Colorado, Kansas, Oklahoma, and Texas, and in the shinnery oak-bluestem grasslands of New Mexico, Oklahoma, and Texas.

Lesser prairie-chickens are polygynous (i.e., a male mates with more than one female in a single breeding season) and exhibit a lek mating system. A lek is a place where males traditionally gather to conduct a communal, competitive courtship display. The males use specialized plumage and vocalizations to attract females for mating. Male lesser prairie-chickens gather to display on leks at dawn and dusk, beginning as early as late January, and continuing through mid-May (Copelin 1963, Hoffman 1963, Crawford and Bolen 1976a, Sell 1979, Merchant 1982). Male birds may remain on the lek for up to 4 hours (Copelin 1963, Crawford and Bolen 1975, Giesen 1998), with females typically departing the lek following successful copulation (Sharpe 1968). Male lesser prairiechickens exhibit strong site fidelity; once a lek site is selected, males persistently return to that lek year after year (Wiley 1974), and may remain faithful to that site for life. They will continue to use these areas, even when the surrounding habitat has declined in value, and may not immediately demonstrate a population response when faced with environmental change.

Female lesser prairie-chickens tend to nest within 1.5 miles of a lek (Giesen 1994a). Within 1 to 2 weeks of successful mating, the hen will select a nest site, construct a nest, and lay a clutch of 8 to 14 eggs (Bent 1932; Copelin 1963; Merehant 1982; Fields 2004; Hagen and Giesen 2005; Pitman et al. 2006a). Nesting is generally initiated in mid-April and concludes in late May (Copelin 1963, Snyder 1967, Merchant 1982, Haukos 1988). Hens most commonly lay one egg per day and initiate incubation onee the eluteh is complete (Hagen and Giesen 2005). Incubation lasts 24 to 27 days (Coats 1955; Sutton 1968; Pitman et al. 2006a), with hatching generally peaking in late May through mid-June (Copelin 1963; Merchant 1982; Pitman et al. 2006a). Hens typically leave the nest within 24 hours after the first egg hatches (Hagen and Giesen 2005). Nests generally consist of bowl-shaped depressions in the soil that are lined with dried grasses, leaves, and feathers. Adequate herbaceous cover, including residual cover from the previous growing season, is an important factor influencing nest success, primarily by providing concealment (Suminski 1977; Riley 1978; Riley et al. 1992; Giesen 1998). Availability of food and cover are key factors that affect chick and juvenile survival.

Leks are normally located on the tops of wind-swept ridges, exposed knolls, sparscly vegetated duncs, and similar features in areas having low vegetation height or bare soil and enhanced visibility of the surrounding area (Copelin 1963, Jones 1963a, Taylor and Guthery 1980a). Areas that have been previously disturbed by humans, such as infrequently used roads, abandoned drilling pads, abandoned farmland, recently cultivated fields, and livestock watering sites also can be used as lek sites (Crawford and Bolen 1976b; Davis et al. 1979; Sell 1979; Taylor 1979). However, ongoing human activity, such as presence of humans or noise, may discourage lekking by causing birds to flush, and, in some instances, may cause lek sites to be abandoned (Hunt and Best 2004). Leks often are surrounded by taller, denser cover that is used for escape, thermal cover, and feeding eover. New leks can be formed opportunistically at any appropriate site within or adjacent to nesting habitat.

Lesser prairie-chickens forage during the day, usually during the early morning and late afternoon, and roost at night (Jones 1964). The diet of the lesser prairie-chicken is very diverse, primarily consisting of insects, seeds, leaves, and buds, and varies by age, location, and season (Giesen 1998). Lesser prairie-chickens forage on the ground and within the vegetation layer (Jones 1963b) and are known to consume a variety of invertebrate and plant materials. 
The lesser prairie-chicken was federally listed as a threatened species on April 10, 2014 (79 FR 19974). Critical habitat has not been designated for the species. The primary threats to the species are conversion of grasslands to agricultural and other uses, encroachment by invasive woody plants, wind energy development, petroleum production, roads, and the presence of man-made vertical structures, such as utility lines, fences, turbines, wells, and buildings. Populations are also vulnerable to the effects of elimate change, disease, and predation.

\section{Effects of Herbicide Treatments on the Gunnison Sage-grouse, Greater Sage-grouse, and Lesser Prairie-chicken}

\section{Direct Effects}

Human presence associated with herbicide treatments in sage-grouse and prairie-chicken habitats would be expected to cause a short-term disturbance to birds in the vicinity, particularly during important activities such as lekking, mating, nest selection, and foraging for food. Lesser prairie-chickens actively avoid areas of human activities and noise (USFWS 2012g), and human disturbance during the peak of breeding may reduce breeding success by sage-grouse (USFWS 2013h). Disturbances associated with herbicide application and associated treatment and restoration activities would be short-term in duration.

Sage-grouse and prairie-chickens could be exposed to herbicides by direct spray, although most adult birds would likely be able to flee the immediate treatment site. Other possible routes of exposure to herbicides would include dermal contact with vegetation that has been sprayed, and consuming food items that have been sprayed by herbicides. Based on the results of the ERAs, none of the herbicides considered in this BA would result in adverse health effects to sage-grouse or prairie chickens under direct spray, dermal contact with sprayed vegetation, or ingestion of sprayed food exposure scenarios (see Tables 6-2 and 6-4).

\section{Indirect Effects}

Use of herbicides in sage-grouse and lesser prairie-chicken habitats can adversely affect habitat through impacts to non-target plants, which may include sagebrush, native forbs and other vegetation or insects that provide a food source to these species. The risk for native vegetation to be harmed by herbicide treatments would be greatest during broadeast spray treatments that cover a wide area, and would be lowest during targeted spot treatments. Over the long-term, however, herbicide treatments would be expected to benefit sage-grouse and lesser prairiechicken habitats. Sage-grouse, for example, rely on a variety of native forbs and the insects associated with them for ehick survival, and sagebrush is used exclusively throughout the winter for food and cover (USFWS 2013h). Invasive plants adversely affect habitats by outcompeting these native species. In addition, fire-adapted invasives such as cheatgrass can cause long-term changes in fire cycles, which threatens sagebrush in particular. Sagebrush species are generally killed by fire and may take decades to recover. Therefore, herbicide treatments that eontrol noxious weeds and other invasive species would have a long-term beneficial effect on sage-grouse habitats.

\section{Conservation Measures}

When using aminopyralid, fluroxypyr, and rimsulfuron in vegetation treatment programs, the BLM would follow all pertinent SOPs for use, transport, and handling of herbicides. As the Gunnison sage-grouse, greater sage-grouse, and lesser prairie-chicken had not yet been listed or proposed for listing at the time of the publication of the 2007 $\mathrm{BA}$, no conservation measures were previously developed for these species. The conservation measures listed below would help protect the Gunnison sage-grouse, greater sage-grouse, and lesser prairie-chicken from being adversely affected by herbicide treatments with aminopyralid, fluroxypyr, and rimsulfuron (no measures specific to these three herbicides are identified). The BLM must also implement suitable protective measures during treatments with the eurrently approved herbicides, which should be based on measures identified for similar species in the $2007 \mathrm{BA}$, to include avoidance of active ingredients and application methods with a risk of impacting these species or their habitats. Project-specific conservation measures will be developed at the local level, as appropriate, to ensure protection of these species during and following herbicide treatments. 


\section{Conservation Measures for Gunnison Sage-grouse and Bi-State DPS of Greater Sage-grouse}

- Conduct surveys prior to vegetation treatments within potential or suitable habitat.

- Where surveys detect birds, or in known habitats, do not broadcast spray herbieides.

- Coordinate with state wildlife management agencies prior to conducting vegetation treatments in suitable sagegrouse habitat.

- Avoid eondueting vegetation treatments within 4 miles of known lek sites. If vegetation treatments are necessary within 4 miles of a lek, treatments must demonstrate a net conservation value to the speeies.

- Avoid condueting vegetation treatments in areas that eontain features of sage-grouse winter habitat.

- Where local data on aetual distribution of nesting habitats are available, the 4-mile buffer may be modified as appropriate if the project impacts will still not eontribute to a negative effect on the speeies. Additionally, temporal restrietions may also be modified if loeal data indicate a different window of oecupaney by breeding birds and ehieks. Where such data are lacking, striet adherenee to the programmatic standards should be enforced.

- Adjust spatial and temporal scales of treatments so that not all suitable habitat is affected in any given year.

- Following treatments, replant or reseed treated areas with native speeies, if needed.

- Closely follow all application instruetions and use restrictions on herbicide labels.

\section{Conservation Measures for Lesser Prairic-chicken}

- Conduet surveys prior to vegetation treatments within potential or suitable habitat.

- Where surveys detect birds, or in known habitats, do not broadeast spray herbieides.

- During the eritieal period of nesting and brood rearing (Mareh $1^{\text {st }}$ to July $15^{\text {th }}$ ) avoid eonducting vegetation treatments within 3 miles of deteetions (i.e., loeations where Lesser Prairie Chiekens have been deteeted within the last 5 years) or suitable habitat. If vegetation treatments are neeessary within 3 miles of a deteetion or suitable habitat and demonstrate a net conservation value to the species, they may be permitted following completion of a local-level consultation.

- Adjust spatial and temporal seales of treatments so that not all suitable habitat is affeeted in any given year.

- Following treatments, replant or reseed treated areas with native species, if needed.

- Closely follow all application instructions and use restrictions on herbicide labels.

\section{Determination of Effects}

Based on the ERAs, none of the three herbicides would be likely to adversely affect the Gunnison sage-grouse, greater sagc-grouse, or lesser prairie-ehicken under any of the modeled exposure scenarios. Short-term effects to habitat are likely to be offset by long-term benefits associated with the reduction in noxious weeds and fire-adapted invasive speeies. Following the eonservation measures listed in this BA would help minimize the risk for unintentional adverse impaets to these listed and proposed bird species. As a result, the action would be Not Likely to Adversely Affect Gunnison sage-grouse or lesser prairie-ehieken, or their critical habitat, at the programmatie level. Additionally, the action would not jeopardize the eontinued existence of the Bi-State DPS of sage-grouse, or result in destruetion or adverse modification of proposed critieal habitat. Should this taxon be listed in the future, the proposed aetion would be Not Likely to Adversely Affect the Bi-State DPS of greater sage-grouse or its critieal habitat at the programmatic level. Given BLM mandates for use of integrated pest management (including vegetation management), and given that it is not possible to forecast site-specific vegetation management needs below the programmatic level, additional evaluations of situation-specific effects will be the subjeet of step-down ESA Section 7 evaluations and subsequent consultations. In this manner, any additional speeifie conservation measures necessary to accommodate site or situation-specific peculiarities not predictable at the programmatic level will be developed at the local level and incorporated into Pestieide Use Proposals prior to local implementation of vegctation management activities that involve the use of herbicides eonsidered in this BA. 


\section{Coastal California Gnatcatcher}

The primary reference for this section is:

USFWS. 2000h. Final Determination of Critical Habitat for the Coastal California Gnateateher. Federal Register 65(206):63679-63743.

References eited in this section are internal to the above-referenced document. A complete list of these references is available from the USFWS Carlsbad Fish and Wildlife Office, Carlsbad, California.

The 2010 5-year review for the coastal California gnateatcher (USFWS 201011) was consulted for updated information on this species.

The coastal California gnateatcher (Polioptila californica californica), a subspecies of the California gnateateher, is a small, insectivorous songbird that typically occurs in various coastal sage scrub plant communities. These habitats are composed of relatively low-growing, dry-season deciduous, and sueculent plants. Characteristic plant species include coastal sagebrush, various species of sage, California buckwheat, lemonadeberry, California encelia, and prickly pear and cholla cactus. The gnatcatcher exhibits a strong affinity to coastal sage scrub vegetation dominated by coastal sagebrush, although in some portions of its range (e.g., western Riverside County) other plant species may be more abundant. Sage serub often occurs in a patchy, or mosaic, distribution pattern throughout the range of the subspecies. Gnatcatehers also use chaparral, grassland, and riparian habitats where they oceur in proximity to sage scrub. Availability of these non-sage scrub areas may be essential during certain times of the year for dispersal, foraging, or nesting, particularly during drought conditions and following disturbance of habitat from fire.

The coastal California gnateatcher is non-migratory and defends breeding territories ranging in size from 2 to 14 acres (Atwood 1990). Reported home ranges vary in size from 13 to 39 acres for this species (Mock and Jones 1990). The breeding season extends from late February through July, with the peak of nest initiations oceurring from mid-March through mid-May. Nests are composed of grasses, bark strips, small leaves, spider webs, down, and other materials, and are often located in California sagebrush about 3 feet above the ground. Clutch size averages four eggs, and incubation and nestling periods encompass about 14 and 16 days, respectively. Both sexes participate in all phases of the nesting eycle. Juveniles are dependent upon, or remain elosely associated with, their parents for up to several months following departure from the nest and dispersal from their place of birth territory. Dispersal of juveniles generally requires a corridor of native vegetation providing certain foraging and shelter requisites to link larger patches of appropriate sage serub vegetation (Soule 1991).

This subspecies is restricted to coastal southern California and northwestern Baja California, Mexico, from Ventura and San Bernardino Counties, California, south to approximately El Rosario, Mexico (American Ornithologists' Union 1957, Garrett and Dunn 1981, Atwood 1991, Banks and Gardner 1992), although the southern end of its range cannot be precisely defined (USFWS 201011). In the mid-1940s, the subspecies was considered locally common, but by the 1960 s had apparently experienced a substantial population decline in the U.S. resulting from the widespread loss and fragmentation of its habitat.

The coastal California gnateateher was federally listed as threatened on March 30, 1993 (58 FR I6742). A total of approximately 513,650 acres in Los Angeles, Orange, Riverside, San Bernardino, and San Diego Counties, California, were designated as eritical habitat for the subspecies on October 24, 2000 (65 FR 63680). On December 19,2007 , the critical habitat designation was reduced to include only 197,303 of the originally designated land area (72 FR 72010). Critical habitat includes BLM-administered lands. The species remains threatened by habitat type conversion caused by wildland fire conversion and other stressors. Non-native plants are also a factor in habitattype conversion for this species. Wildland fire is regarded as the largest threat to this species, with lesser magnitude threats that include grazing, nest predation, and brood parasitism by brown-headed cowbirds (USFWS 201011). 


\section{Effects of Herbicide Treatments on the Coastal California Gnatcatcher}

\section{Direct Effects}

Although most birds would be able to fly out of an area to avoid an herbicide application, some birds could be exposed to direct spray of herbicides inadvertently. Given the location of coastal California gnateatcher nests (approximately 3 feet above the ground), young birds and eggs could be sprayed during a treatment if nests were present in the area. Coastal California gnatcatchers could also be exposed to herbicides through contact with sprayed foliage, or through ingestion of sprayed insects.

Based on the results of the ERAs, none of the herbicides considered in this BA would result in adverse health effects to coastal California gnatcatchers under direct spray, dermal spray, or ingestion of sprayed food cxposure scenarios (sce Tables 6-2 and 6-4).

\section{Indirect Effects}

Indiscriminate use of herbicides in coastal California gnatcatcher habitat, such that mortality of multiple plant species occurred over a large area, could result in a loss of key habitat components. Habitat for this species is small and fragmented. Should equally or more suitable habitat not be available nearby, lasting population-level effects could occur, despite the temporary nature of the reduction in vegetative cover. Given their very limited, fragmented habitat, coastal California gnatcatchers may be unable to disperse to other areas if a core habitat area is degraded. In their final determination of critical habitat for the coastal California gnatcatcher, the USFWS (2000h) identifics the following as activitics that may directly or indirectly affect critical habitat: "removing, thinning, or destroying coastal California gnatcatcher habitat, whether by burning or mechanical, chemical, or other means (e.g., woodcutting, grubbing, grading, overgrazing, construction, road building, mining, hcrbicide application, etc.)."

Over the long-term, treatment methods that reduce the coverage of non-native species would be likely to have a beneficial effect on coastal California gnateatchers by helping to return habitats to a more native condition. Nonnative species, such as red brome, invade coastal sites and exclude the shrubs and native grasses found in coastal sage scrub habitat. Reduction of non-native species in areas that do not currently support coastal California gnatcatchers could also potentially benefit the species by increasing the amount of suitable habitat.

\section{Conservation Measures}

When using aminopyralid, fluroxypyr, and rimsulfuron in vegetation treatment programs, the BLM would follow all pertinent SOPs for use, transport, and handling of herbicides. The BLM would also continuc to follow the conservation measures listed in the $2007 \mathrm{BA}$, or other comparable measures that would be developed by the ficld offices based on local site conditions and included in local-level consultation. No additional conscrvation measures specific to the three new herbicides have been identified in this BA. However, conservation measures may be developed, as appropriatc, during the preparation of project-level NEPA documents and management plans.

\section{Key Conservation Measures for the Coastal California Gnatcatcher from the 2007 BA}

- Prior to implementing vegetation treatments, survey areas in which trcatments would occur for coastal California gnatcatchers.

- Where gnatcatchers occur, do not conduct trcatments during the breeding season (as determined by a qualificd wildlife biologist).

- Revegetatc coastal sage habitats with native species.

- Do not broadcast spray herbicides in arcas where coastal California gnatcatchers occur.

\section{Determination of Effects}

Based on the ERAs, none of the three herbicides would be likely to adversely affect the coastal California gnatcatcher under any of the modeled exposure scenarios. Following the conservation measures from the $2007 \mathrm{BA}$ would help minimize adverse impacts to this species. As a result, the action would be Not Likely to Adversely Affect coastal California gnatcatchers or their federally designated critical habitat at the programmatic level. Given BLM mandates for use of integrated pest management (including vegetation management), and given that it is not 
possible to forecast site-specific vegetation management needs below the programmatic level, additional evaluations of situation-specific effects will be the subject of step-down ESA Section 7 evaluations and subsequent consultations. In this manner, any additional specific conservation measures necessary to aeeommodate site or situation-speeific peculiarities not predictable at the programmatic level will be developed at the local level and incorporated into Pesticide Use Proposals prior to loeal implementation of vegetation management aetivities that involve the use of herbicides considered in this BA.

\section{California Condor}

The primary referenec for this section is:

USFWS. 1996g. California Condor Recovery Plan, Third Revision. Portland, Oregon.

References cited in this section are internal to the above-referenced document. Full citations have been included in the Bibliography.

At the time of the arrival of European man in western North America, the California condor (Gymnogyps californianus) occupied a narrow Pacific coastal strip from British Columbia, Canada to Baja California Norte, Mexico (Koford 1953, Wilbur 1978). Prior to the eapture of the last free-flying, wild eondor in 1987, the species used a wishbone-shaped area encompassing six counties just north of Los Angeles, California. Following several years of increasingly successful eaptive breeding, captive-produced condors were first released back to the wild in early 1992. The wishbone-shaped area remains an important habitat area, and has been designated as the range of primary coneern by the California Condor Reeovery Team.

California condors nest in various types of rock formations, ineluding crevices, overhung ledges, and potholes, and, more rarely, in cavities of giant sequoia trees (Snyder et al. 1986). The faetors influeneing the ehoice of nest sites is poorly understood. Nest sites share the following charaeteristies: entranees large enough for the birds to fit through; a eeiling height of at least 15 inches at the egg position; fairly level floors with some loose surface substrate; unconstricted space for incubating adults; and short distance accessibility to a landing point.

California condors are opportunistic scavengers, feeding only on the eareasses of dead animals. Typical foraging behavior includes long-distance reconnaissance flights, lengthy circling flights over a carcass, and hours of waiting at a roost or on the ground near a eareass. Most foraging occurs in the open terrain of foothill grassland and oak savannah habitats. Steep terrain and brush interfere with foraging, and eondors apparently do not loeate food by olfaetory cues (Stager 1964). It has been estimated that 95 percent of the condor's diet once consisted of cattle, domestic sheep, ground squirrels, mule deer, and horses (Koford 1953).

Depending on weather conditions and the hunger of the bird, a California condor may spend most of its time perched at a roost. Cliffs and tall conifers, ineluding snags, are generally used as roost sites in nesting areas. Birds often use traditional roosting sites near important foraging grounds (USFWS 1984h). Although most roost sites are near nesting or foraging areas, scattered roost sites are located throughout the range. While at a roost, birds devote considerable time to preening and other maintenance activities. Roosts may also serve some social function, as it is common for two or more birds to roost together and leave a roost together. California condors will tolerate more disturbance at a roost than at a nest, although the preservation of both requires isolation from human intrusion.

Based on observations of the wild condor population prior to 1987 , courtship and nest site selection by breeding adults occurs from December through the spring months. Reproductively mature pairs normally lay a single egg between late January and early April. The egg is incubated by both parents and hatches after approximately 56 days. Both parents share responsibilities for feeding the nestling. At 2 to 3 months of age, condor chicks leave the actual nest cavity, but remain in the vicinity of the nest, where they are fed by their parents. The chick takes its first flight at about 6 to 7 months of age, but may not become fully independent of its parents until the following year. California condors often nest successfully only every other year (Koford 1953), although if the nestling fledges relatively early (in late summer or early fall), its parents may nest again in the following year (Snyder and Hamber 
1985). Adults may lay a replacement clutch if their first (Harrison and Kiff 1980) or even their second egg is lost (Snyder and Hamber 1985).

The California condor was federally listed as endangered on March 11, 1967 (32 FR 4001). Nine years later, the USFWS established critieal habitat for the speeies on September 24, 1976 (41 FR 41914). Despite decades of research, it is not known with certainty which mortality factors have been dominant in the overall decline of the species. However, there is evidence that two anthropogenic factors, lead poisoning and shooting, have eontributed disproportionately to the decline of the speeies in reeent years. In addition, thinning and ultrastructural abnormalities in eggshells, likely caused by the pesticide DDT, have resulted in reduced reproductive success in the speeies. The biggest threats to experimentally released populations appear to be eollisions with power lines and other manmade objeets, indieating that future releases should be conducted in areas remote from human settlements.

\section{Effects of Herbicide Treatments on the California Condor}

\section{Direct Effects}

Human presence and usc of vehieles assoeiated with herbieide treatments could disturb condors, eausing behavioral modification. This disturbanee would be temporary. It is unlikely that a California eondor would be sprayed during an herbicide applieation inadvertently, since eondors would be able to flee the area, and typically nest and roost in cliffs and tall conifers. Additionally, condors would likcly have minimal contact with foliage in sprayed arcas, but such indirect exposure to herbicides could occur. Condors might consume carrion that is contaminated by herbieides.

Based on the results of the ERAs, none of the herbieides eonsidered in this BA would result in adverse health effects to California condors under direct spray, dermal eontaet with sprayed vegetation, or ingestion of sprayed food exposure scenarios (see Tables 6-2 and 6-4).

\section{Indirect Effects}

Use of herbicides to control vegetation in California eondor habitat would be unlikely to have a negative effect on the quality of the habitat. Removal of non-native speeies eould ereate more open habitat eonditions, potentially allowing condors to foragc more easily. Condors require open eonditions to search the surrounding area for food. A more open habitat would increase the quality of foraging, as condors prefer to forage on ridges and in areas with short vegetation so that they ean easily loeate prey and for facilitation of takeoff and approaeh (Verner 1978; Lowe et al. 1990).

\section{Conservation Measures}

When using aminopyralid, fluroxypyr, and rimsulfuron in vegetation treatment programs, the BLM would follow all pertinent SOPs for usc, transport, and handling of herbicides. The BLM would also continue to follow the conservation measures listed in the $2007 \mathrm{BA}$, or other eomparable mcasures that would be developed by the ficld offices based on local sitc conditions and included in local-level eonsultation. No additional conscrvation measures specific to the three new herbieides have been identified in this BA. However, additional conservation measures may be developed at the projeet level, as appropriate.

\section{Key Conservation Measures for the California Condor from the $2007 \mathrm{BA}$}

- Restriet human activity within 1.5 miles of California condor nest sites (Snyder et al. 1986).

\section{Determination of Effects}

Based on the ERAs, none of the three herbicides would be likely to adversely affect the California condor under any of the modeled exposure scenarios. Following the conservation measures from the 2007 BA would help minimize adverse impacts to these speeies. As a result, the action would be Not Likely to Adversely Affect California eondors or their federally designated critical habitat at the programmatie level. Given BLM mandates for use of integrated pest management (including vegetation management), and given that it is not possible to forecast sitc-specific vegetation management needs below the programmatic level, additional cvaluations of situation- 
specific effeets will be the subject of step-down ESA Section 7 evaluations and subsequent consultations. In this manner, any additional specific conservation measures neeessary to accommodate site or situation-specific peculiarities not predictable at the programmatie level will be developed at the local level and ineorporated into Pesticide Use Proposals prior to local implementation of vegetation management activities that involve the use of herbicides considered in this BA.

\section{Mature-forest Nesters: Marbled Murrelet, Northern Spotted Owl, and Mexican Spotted Owl}

\section{Marbled Murrelet}

The primary reference for this seetion is:

USFWS, 1992i. Determination of Threatened Status for the Washington, Oregon, and California Population of the Marbled Murrelet. Federal Register 57(191):45328-45337.

References eited in this section are internal to the above-referenced document. A complete list of these referenees is available from the USFWS Portland Field Office, Portland, Oregon.

The 2009 5-year review for the marbled murrelet (USFWS 2009fff) was consulted for updated information on this species.

The marbled murrelet (Brachyramphus marmoratus) is a small seabird found on the Pacific Coast of North America. Marbled murrelets are generally found in nearshore waters (within about 3 miles of shore) near their nesting sites. They nest in a narrow range along the Pacifie, from the Aleutian Islands of Alaska south through British Columbia, Washington, and Oregon, to central California. The speeies generally oeeupies nesting areas on a year-round basis, although in eertain places in Alaska and British Columbia, birds move to more protected waters during the winter. This species ean also be found wintering south of its breeding range, along the coast of southern California to extreme northwestern Baja California. The states of California, Oregon, and Washington eneompass roughly one-third of the geographic area occupied by this speeies, eomprising an important portion of its range. The amount of nesting habitat has undergone a tremendous decline sinee the late $1800 \mathrm{~s}$ (most of which has taken place during the last 30 to 40 years), especially in the coastal areas of all three states. Therefore, the marbled murrelet is listed only in these three states, which together constitute a DPS of the eastern Pacifie subspeeies.

Marbled murrelets feed primarily on fish and invertebrates in nearshore marine waters. During the summer, major food items include Pacifie sand lanee, northern anchovy, Pacific herring, and other small schooling fish, while during the winter, krill, amphipods, and herring are major prey items. Marbled murrelets usually forage alone, or in pairs, and are active in search of food both day and night. Although the majority of birds are found within or adjacent to the marine environment, there have been detections of marbled murrelets on rivers and inland lakes (Carter and Sealy 1986). Marbled murrelets spend the majority of their lives on the ocean, and come inland to nest, although they visit some inland stands during all months of the year. There are records of marbled murrelets up to 50 miles inland in Washington (Hamer and Cummins 1991), 35 miles inland in Oregon (Nelson 1990), 22 miles inland in northern California (Carter and Erickson 1988, Paton and Ralph 1990), and 11 miles inland in central California (Paton and Ralph 1990). However, the majority of deteetions were reeorded eloser to the coast. Marbled murrelets are semi-colonial in their nesting habits, and simultaneous detections of more than one bird are frequently made at inland sites. Nesting birds are often aggregated, with separate nests located close together.

Marbled murrelets do not reach sexual maturity until their second year, and adults have a variable reproductive rate (i.e., not all adults may nest every year). They produce one egg per nest, which the female lays on the limb of an old-growth conifer tree. Nesting oceurs over an extended period from mid-April to late September (Carter and Sealy 1987). Incubation lasts about 30 days, and fledging takes another 28 days (Simons 1980; Hirsch et al. 1981). Both sexes incubate the egg in alternating 24-hour shifts (Simons 1980; Singer et al. 1991). Flights from ocean feeding areas to inland nest sites oceur most often at dusk and dawn (Hamer and Cummins 1991). The adults feed the chick at least once per day, carrying one fish at a time (Carter and Sealy 1987; Hamer and Cummins 1991; 
Nelson 1992; Singer et al. 1992). Before leaving the nest, the young molt into a distinctive juvenile plumage. Fledglings appear to fly direetly from the nest to the sea, rather than exploring the forest environment first (Hamer and Cummins 1991).

In California, Oregon, and Washington, marbled murrelets use older forest stands near the coastline for nesting. These forests are generally characterized by large trees (32 inches diameter at breast height or larger), a multistoried stand, and a moderate to high canopy closure. In certain parts of the range, marbled murrelets are also known to use mature forests with an old-growth component. In order to provide suitable nest platforms, trees must have large branches or deformities (Binford et al. 1975; Carter and Sealy 1987; Hamer and Cummins 1990, 1991; Singer et al. 1991, 1992). Marbled murrelets tend to nest in the oldest trees in the stand. Observations of nests indicate that they tend to be located high above ground, usually with good overhead protection, in locations that allow easy access to the exterior of the forest. In Oregon and Washington, nests are located in stands dominated by Douglas-fir, and in California they are located in old-growth redwood stands.

In California, the species is restricted to old-growth redwood forests in Del Norte, Humboldt, San Mateo, and Santa Cruz Counties (Paton and Ralph 1988). In northwest Washington, marbled murrelets are mostly found at oldgrowth/mature sites (Hamer and Cummins 1990), and in Oregon, they occupy stands dominated by larger trees more often than those dominated by smaller trees (Nelson 1990). Large geographic gaps in offshore marbled murrelet numbers oecur between central and northern California (a distance of 300 miles), and between Tillamook County, Oregon, and the Olympic Peninsula (a distance of about 120 miles), where nearly all older forest has been removed near the coast.

The marbled murrelet was federally listed as threatened in California, Oregon, and Washington on October 1, 1992 (57 FR 45337). Critical habitat was designated on May 24, 1996 (61 FR 26257), and then revised on October 5 , 201 I (76 FR 61599). Currently, approximately 3,698,100 acres in California, Washington, and Oregon are designated as critical habitat. Primary constituent elements include individual trees with potential nesting platforms, and forested areas within 0.5 miles of these trees, with a canopy height of at least one-half the sitepotential tree height. Between 2002 and 2008, the marbled murrelet population declined by an estimated 26 pereent across its listed range (USFWS 2009fff). The principal factor affecting the marbled murrelet in the three-state area, and the main cause of population decline, has been the extensive removal of late-successional and old-growth coastal forest and associated nest sites. Additional factors in its decline include high nest-site predation rates and human-induced mortality in the marine environment from disturbance, gillnets, and oil spills. In addition, murrelet reproductive suceess is strongly correlated with the abundance of mid-trophic level prey. Effects to the marine environment that impact the availability of that prey can occur through overfishing or oceanographic variation from weather or climate events. Affects to adults in the marine environment from disturbance events like underwater detonations or pile driving can also impact their ability to forage and successfully provide for their young. Climate change is also a potential threat to the species (USFWS 2009fff).

\section{Northern Spotted Owl}

The primary reference for this section is:

U.S. Fish and Wildlife Service. 2011 cc. Revised Recovery Plan for the Northern Spotted Owl (Strix occidentalis caurina). Region I U.S. Fish and Wildlife Service. Portland, Oregon.

References cited in this section are internal to the above-referenced document. They are included in the Bibliography.

The northern spotted owl (Strix occidentalis caurina) is one of three subspecies of the spotted owl, a nocturnal bird of forest habitats. The species occupies complex forested habitats from southwest British Columbia through the Cascade Mountains, coastal ranges, and intervening forested lands in Washington, Oregon, and California. The actual number of currently occupied spotted owl locations across the species' range is unknown because many areas remain unsurveyed (Thomas et al. 1993). Based on a recent model of population change, there is evidence that populations are declining in 7 of 11 study areas, and stable in the others (Forsman et al. 2011). 
The northern spotted owl is known from most of the major types of coniferous forests in the Pacific Northwest (Forsman et al. 1984). Extensive studies of spotted owls during the last 20 years have shown the species to be strongly assoeiated with late-suecessional forests throughout mueh of its range. However, landseape-level analyses suggest that a mosaic of late-successional habitat interspersed with other seral conditions may benefit the species more than large, homogeneous expanses of older forests (Meyer et al. 1998; Franklin et al. 2000; Zabel et al. 2003).

Older forests contain the structures and charaeteristics required for northern spotted owl nesting, roosting, and foraging. Features that support nesting and roosting include moderate to high canopy closure (60 to 90 percent); a multi-layered, multi-species eanopy dominated by large (greater than 30 inches diameter at breast height) overstory trees; a high incidence of large trees with various deformities (e.g., large cavities, broken tops, mistletoe infections, and other evidence of decadence); numerous large snags; large accumulations of fallen trees and other woody debris on the ground; and sufficient open space below the canopy for owls to fly (Thomas et al. 1990). Usually, the features eharacteristie of owl habitat are most commonly associated with old-growth forests or mixed stands of oldgrowth and mature trees, which do not assimilate these attributes until 150 to 200 years of age. Dispersal habitat consists of stands that have large enough trees and enough canopy closure to provide protection from avian predators and some foraging opportunities.

Although a secretive and mostly nocturnal bird, the northern spotted owl is relatively unafraid of human beings (Forsman et al. 1984). The adult spotted owl maintains a territory year-round; however, individuals may shift their home ranges between the breeding and nonbreeding season. Northern spotted owls are perch-and-dive predators; more than 50 percent of their prey items are arboreal or semi-arboreal specics. They subsist on a variety of mammals, birds, reptiles, and insects, with small mammals (e.g., flying squirrels, red tree voles, and dusky-footed woodrats) making up the bulk of the food items throughout the range of the species (Forsman et al. 1984; Barrows 1985).

Spotted owls are territorial and monogamous, with home ranges with median sizes that vary from approximately 3,000 to 14,000 acres (Thomas et al. 1990). Most spotted owl pairs usually do not nest every year, and nesting pairs are not successful every year (Forsman et al. 1984; Anthony et al. 2006). Nesting behavior begins in February to Mareh, with nesting occurring from March to June. The timing of nesting and fledging varies with latitude and elevation (Forsman et al. 1984). The number of eggs in a clutch ranges from one to four, with two eggs being most eommon. Fledging occurs from mid-May to late June, with parental care continuing into September. Females are capable of breeding in their second year, but it is likely that most do not breed until their third year (Barrows 1985; Miller and Meslow 1985; Franklin et al. 1986). Males do most of the foraging during incubation, and assist with foraging during the fledging period.

The northern spotted owl was federally listed as a threatened species on June 26, 1990 (55 FR 26114), and critieal habitat was designated in Washington, Oregon, and California in January 1992 (57 FR 1796). This designation was revised in August 2008 to include a reduced acreage (5.3 million acres; 73 FR 47326). On December 4, 2012, the USFWS revised the eritical habitat to include a total of 9,577,969 acres (77 FR 71875). Throughout its range, the northern spotted owl is threatened by competition from the barred owl and the loss and modification of suitable habitat as a result of timber harvesting. These threats are exacerbated by risks of catastrophic events such as fire, volcanic eruption, and wind storms.

\section{Mexican Spotted Owl}

The primary reference for this section is:

USFWS. 2011 dd. Draft Recovery Plan for the Mexican Spotted Owl, First Revision (Strix occidentalis lucida). Southwest Region. Albuquerque, New Mexico.

References cited in this section are internal to the above-referenced document. Full citations have been included in the Bibliography. 
The Mexiean spotted owl (Strix occidentalis lucida) occupies a broad geographic area, in forested mountains and canyonlands throughout the southwestern United States and Mexico. It ranges from Utah, Colorado, Arizona, New Mexieo, and the western portions of Texas south into several States of Mexico. Within this range, the species oecurs non-uniformly in disjunct areas that correspond with isolated mountain ranges and canyon systems. In the United States, the majority of owls are found in National Forests; however, in some areas of the Colorado Plateau Ecologieal Management Unit, owls are found only in rocky-eanyon habitats, whieh primarily occur on National Park Serviee and BLM lands.

Mexican spotted owls nest, roost, forage, and disperse in a diverse array of biotic communities. Nests and roosts occur in late seral forests or roeky canyons. Forests used for roosting and nesting often eontain mature or oldgrowth stands with eomplex strueture. These forests are typically uneven-aged and multistoried, and have high canopy cover. Nest trees are typieally large, although owls roost in both large and small trees (Ganey 1988; Seamans and Gutierrez 1995; Ganey et al. 2000; May and Gutierrez 2002; May et al. 2004). Douglas-fir is the most common nest tree in many arcas (SWCA, Ine. 1992). In other portions of its range, the Mexican spotted owl oeeupies a variety of steep, rocky-canyon habitats (Ganey and Balda 1989, Rinkevich and Guttierrez 1996, Mullet 2008). Within these eanyons, owls nest and roost on eliff faces, using proteeted eaves and rocky ledges.

Mexican spotted owls forage in a variety of habitats: managed and unmanaged forests, pinyon-juniper woodlands, mixed-conifer and ponderosa pine forests, on eliff faces and terraces between eliffs, and along riparian zones (Ganey and Balda 1994; Ganey et al. 2003). Mexiean spotted owls typically locate prey from an elevated perch by sight or sound, then pounee on the prey and eapture it with their talons. In general, owls appear to forage more in unlogged forests than in scleetivcly logged forests (Ganey and Balda 1994). Common prey items inelude speeies of rodent, bat, bird, reptile, and arthropod that use unique habitats. Thus it appears that diverse habitats for prey speeies provide owls with a diverse prey base.

Mexiean spotted owls nest on eliff ledges and eaves, in stiek nests built by other birds, on debris platforms in trees, and in tree eavities (Ganey 1988; Gutiérrez et al. 1995; Seamans and Gutiérrez 1995; Johnson 1997). The breeding period of the subspeeics varies slightly throughout its range, but generally begins in March. Eggs arc laid in late Mareh or early April. Females normally lay one to three eggs. Renesting following nest failure is uncommon but has been observed in Mexiean spotted owls (Kroel and Zwank 1992; Gutiérrez et al. 1995). Eggs usually hatch in early May (Ganey 1988). Nestling owls (owlets) generally fledge in early to mid-June, 4 to 5 weeks after hatehing (Ganey 1988).

The Mexiean spotted owl was federally listed as a threatened specics on April 15, 1993 (58 FR 14248). On August 31, 2004, the USFWS designated approximately 8.6 million acres on federal lands in Arizona, Colorado, New Mexieo, and Utah as critical habitat for the subspecies (69 FR 53182). Threats the U.S. population of Mexican spotted owl have shifted from commereial-based timber harvest to the risk of stand-replacing wildfire. Southwestern forests have experienced larger and more severe wildfires from 1995 to the present than at other times in reeorded history. Climate variability eombined with unhealthy forest eonditions may result in increased adverse effects to habitat from firc. The intensification of natural drought eyeles and the ensuing stress placed upon overstocked forested habitats eould result in cven larger and more severe fires in owl habitat. Scveral mortality factors have been identified as potentially important to the Mexican spotted owl, including predation, starvation, accidents, discase, and parasites.

\section{Effects of Herbicide Treatments on the Marbled Murrelet, Northern Spotted Owl, and Mexican Spotted Owl}

\section{Direct Effects}

Herbicide treatments would involve workers and the use of vehicles (trucks/ATVs/UTVs) or aircraft, which could potentially disturb murrelets or spotted owls. Disturbanee would be temporary, and effects would be greatest during the breeding scason, when reproductive sueeess eould be reduced. While it is unlikely that murrclets or owls would bc exposed to herbieides during treatments, it is conceivable that inadvertent direet exposure to herbicide 
spray could oceur. Murrelets and spotted owls also could be exposed to herbicides by touching contaminated vegetation or ingesting contaminated prey.

According to the ERAs, none of the herbicides considered in this BA would result in adverse health effects to marbled murrelets or spotted owls under direct spray, dermal contact with sprayed vegetation, or ingestion of sprayed food exposure scenarios (see Tables 6-2 and 6-4).

\section{Indirect Effects}

Herbicide treatments should not have a substantial effect on spotted owl or murrelet habitat. Nesting trees would not be targeted during herbicide applications. Some alteration of the composition of lower canopy layers could oceur, but key habitat components such as snags and woody debris would be unaffected.

Although treatments may have negative effects on prey species and their habitat in the short term, the proposed treatments may inerease the diversity of vegetative conditions, which would in turn provide for a diverse prey base. The prey of marbled murrelets, which feed on fish in marine habitats, would be unaffected by treatment aetivities.

\section{Conservation Measures}

When using aminopyralid, fluroxypyr, and rimsulfuron in vegetation treatment programs, the BLM would follow all pertinent SOPs for use, transport, and handling of herbicides. The BLM would also continue to follow the conservation measures listed in the $2007 \mathrm{BA}$, or other comparable measures that would be developed by the field offices based on local site conditions and included in local-level consultation. No additional conservation measures specific to the three new herbicides have been identified in this BA. However, additional conservation measures may be developed at the project level, as necessary, to fine-tune protection of these species.

\section{Key Conservation Measures from the 2007 BA}

- Survey for marbled murrelets, northern spotted owls, and Mexican spotted owls (and their nests) on suitable proposed treatment areas, prior to developing treatment plans.

- Do not allow human disturbance within $1 / 4$ mile of protected activity centers during the nesting period (as determined by a local biologist).

- Protect and retain the structural components of known or suspected nest sites during treatments; evaluate each nest site prior to treatment and protect it in the most appropriate manner.

- Maintain sufficient dead and down material during treatments to support spotted owl prey species (minimums would depend on forest types, and should be determined by a wildlife biologist).

- Do not conduct treatments that alter forest structure in old-growth stands.

- Follow all instructions and SOPs to avoid spill and direct spray scenarios into aquatic habitats, particularly marine habitats where murrelets forage for prey.

\section{Determination of Effects}

Based on the ERAs, none of the three herbicides would be likely to adversely affect the marbled murrelet, northern spotted owl, or Mexican spotted owl under any of the modeled exposure scenarios. Following the conservation measures from the 2007 Vegetation Treatments BA would help minimize adverse impacts to these species. As a result, the action would be Not Likely to Adversely Affect marbled murrelet, northern spotted owl, and Mexican spotted owl or their federally designated critical habitat at the programmatic level. Given BLM mandates for use of integrated pest management (including vegetation management), and given that it is not possible to forecast sitespecific vegetation management needs below the programmatic level, additional evaluations of situation-specific effects will be the subject of step-down ESA Section 7 evaluations and subsequent consultations. In this manner, any additional specific conservation measures necessary to accommodate site or situation-specific peculiarities not predictable at the programmatic level will be developed at the local level and incorporated into Pesticide Use Proposals prior to local implementation of vegetation management activities that involve the use of herbicides considered in this BA. 


\section{Whooping Crane}

The primary referenees for this section are:

USFWS. 1994i. Whooping Crane Reeovery Plan. Albuquerque, New Mexieo.

and

Canadian Wildlife Service and USFWS. 2007. International Recovery Plan Whooping Crane (Grus americana), Third Revision. Ottawa, Canada, and Albuquerque, New Mexico.

References cited in this seetion are internal to the above-referenced doeuments. Full citations have been ineluded in the Bibliography.

The 2012 5-year review for the whooping erane (USFWS 2012h) was reviewed for updated information on this species.

The whooping erane (Grus americana) is a wetland bird that currently exists in four wild populations and at eaptive breeding loeations. Historically, more than 10,000 whooping eranes oeeurred in North Ameriea, ranging east of the Rocky Mountains from Canada to Mexico and the Rocky Mountains to the East Coast. Population declines were caused primarily by shooting and destruetion of prairie habitat as a result of agricultural development. By the mid-1900s only a few birds remained, nesting in the Wood Buffalo National Park and wintering in South Texas at what is now the Aransas National Wildlife Refuge. Currently, whooping cranes nest in and near Wood Buffalo National Park, migrate through Alberta, Saskatchewan, and oeeasionally Manitoba in the spring and fall, and stage in the fall in southern Saskatchewan. Spring and fall migration oeeurs in the eentral Great Plains of the U.S. The cranes winter on the central Gulf Coast of Texas at the Aransas National Wildlife Refuge and vicinity. Reintroduction attempts that were made in the Rocky Mountains from 1975 to 1989, and in 1997, failed. In 1993, captive-reared birds were used to introduce a non-migratory flock in the Kissimmee Prairie and surrounding area in eentral Florida. Another attempt to establish a migratory floek between eentral Wiseonsin and the central Gulf Coast of Florida began in 2001. The population estimate in April 2011 was 279 birds (USFWS $2012 h)$.

The whooping erane breeds, migrates, winters, and forages in a varicty of habitats, including coastal marshes and estuaries, inland marshes, lakes, ponds, wet meadows and rivers, and agrieultural fields. Whooping eranes prefer sites with minimal human disturbance for nesting (USFWS 2012h). The eurrent nesting habitat for the main wild population in the Wood Buffalo National Park, Alberta, lies between the headwaters of the Nyarling, Sass, Klewi, and Little Buffalo Rivers. The area is poorly drained and interspersed with numerous potholes. Wetlands vary eonsiderably in size, shape, and depth, and most possess soft bottoms. These wetlands are separated by narrow ridges that support an overstory of white spruce, black spruce, tamarack, and willows; and an understory of dwarf birch, Labrador tea, and bearberry. Bulrush is the dominant emergent in the potholes used for nesting, although cattail, sedge, and other aquatie plants are common (Allen 1956; Novakowski 1965, 1966; Kuyt 1976a, 1976b, 1981a). Nest sites are located in the rushes or sedges of marshes, sloughs, or along lake margins (Bent 1926). It is believed that mollusks and frogs are important prey items for breeding adults and their offspring (Allen 1956).

Whooping eranes use a variety of habitats during migration (Howe 1987, 1989; Lingle 1987; Lingle et al. 1991). They have been observed feeding in a variety of croplands and roosting in marshy wetlands (Howe 1987, 1989). Whooping eranes also roost in riverine habitat, most notably the Platte River, Middle Loup River, and Niobrara River in Nebraska; the Cimarron River in Oklahoma; and the Red River in Texas. Cranes roost on submerged sandbars in wide unobstructed ehannels that are isolated from human disturbance (Armbruster 1990). Large palustrine wetlands are used for roosting and feeding during migration.

The prineipal wintering grounds (salt flats on Aransas National Wildlife Refuge and adjacent islands) eonsist of marshes dominated by salt grass, saltwort, smooth cordgrass, glasswort, and sea ox-eye. Inland margins of the flats are dominated by Gulf cordgrass. Interior portions of the refuge are gently rolling and sandy, and are eharacterized 
by oak brush, grassland, swales, and ponds. Typical plants include live oak, redbay, and bluestem (Stevenson and Griffith 1946, Allen 1952, Labuda and Butts 1979).

Whooping cranes are omnivorous (Walkinshaw 1973), probing the soil subsurface with their bills and taking foods from the soil surface or vegetation. Young chicks are fed by their parents, and gradually become more independent in their feeding until they separate from the parents preecding the next breeding season. Summer foods include large nymphal or larval forms of inseets, frogs, rodents, small birds, minnows, and berries (Allen 1956, Novakowski 1966). Foods utilized during migration are poorly doeumented, but include frogs, fish, plant tubers, crayfish, insects, and waste grains in harvested fields. Animal foods and the plant wolfberry predominate in the winter diet. Most foraging occurs in brackish bays, marshes, and salt flats lying between the mainland and barrier islands.

Whooping cranes are monogamous, but will re-mate, sometimes within only a few weeks, following the death of their mate (Blankinship 1976, Stehn 1992). Most pairs return to the nesting area in late April, and begin ncst eonstruction and egg laying. Expcrienced pairs arrive first, show considerable fidelity to their breeding territories, and normally nest in the same general vicinity each year. From the initiation of laying until chicks are a few weeks of age, the activities of pairs and family groups are restricted to the breeding territory. Eggs (from one to three per clutch) are normally laid in late April to mid-May, and hatching occurs about 1 month later. The ineubation period is from 29 to 31 days. Whooping cranes may re-nest if their first clutch is destroyed or lost before mid-ineubation (Erickson and Derrickson 1981, Derrickson and Carpenter 1981, Kuyt 1981b). Whooping cranes generally nest annually, but occasional pairs skip a nesting season for no apparent reason. When nesting habitat conditions are unsuitable, some pairs do not attempt to nest. Autumn migration normally begins in mid-September, with most birds arriving on the wintering grounds between late October and mid-November. Occasionally, stragglers may not arrive until late December.

The whooping erane was listed as endangered, exeept where designated as an experimental population, on March 11, 1967 (32 FR 4001). On May 15, 1978 (43 FR 20938), critical habitat was designated for the species at nine sites in six states: Monte Vista National Wildlife Refuge, Colorado; Alamosa National Wildlife Refuge, Colorado; Grays Lake National Wildlife Refuge and vieinity, Idaho; Cheyenne Bottoms State Watcrfowl Management Area, Kansas; the Platte River bottoms between Lexington and Dehman, Nebraska; Bosque del Apaehe National Wildlife Refuge, New Mexico; Salt Plains National Wildlife Refuge, Oklahoma; and Aransas National Wildlife Refuge and vicinity, Texas. Historic population declines occurred as a result of destruction of wintering and breeding habitat, collisions with powerlines and fences, shooting, specimen eollcetion, and human disturbance. Current threats include limited genetics of the population, loss and degradation of migration stopover habitat, construction of additional power lines, degradation of eoastal ecosystems, shooting, predators, disease, severe weather, and the potential for chemical spills in Texas (USFWS 2012h).

\section{Effects of Herbicide Treatments on the Whooping Crane}

\section{Direct Effects}

The three herbicides would not be used in aquatic habitats where whooping cranes oceur, but could be used in adjacent habitats where no standing water is present. Human presence and vehicles associated with nearby herbicide treatments could disturb whooping cranes, particularly during roosting and foraging activities. In addition, use of trucks/ATVs/UTVs in whooping crane habitat could destroy nests or harm eggs, flightless young, or molting adults. It is possible that some cranes could be exposed inadvertently to a direct spray of herbicides. Whooping cranes also could be exposed to herbicides by coming into contact with contaminated vegetation or ingesting contaminated food, such as fish, plant materials or other prey (e.g., frogs). Since aquatic habitats would not be directly sprayed, these prey items would only be exposed via spray drift or accidental direct spray.

Based on the results of the ERAs, none of the herbicides considered in this BA would result in adverse health effects to whooping cranes under direct spray, dermal contact with sprayed vegetation, or ingestion of sprayed food exposure scenarios (see Tables 6-2 and 6-4). Risk predictions assume that 100 percent of the animal's diet consists of the type of food item in question. 


\section{Indirect Effects}

Whooping cranes in the project area commonly occur in wetlands and some agricultural fields along their migration route. Activities that reduce the cover of non-native plant species in resting and feeding areas along this route would be likely to have at least a minor beneficial effect on cranes by helping to restore/maintain the native qualities of these habitats. Cranes roost in standing water in wetlands to avoid terrestrial predators, and nest in emergent vegetation in various aquatic and wetland habitats. The three herbicides would not be used in sites with standing water, and should have minimal effect on roosting and nesting habitat. Removal of vegetation from direct spray via adjacent upland habitats, should it occur, eould benefit roosting habitat by making it more open. However, removal of vegetation from nesting habitat during the breeding/nesting season could make eggs and ehicks more susceptible to predation (USFWS 1980).

\section{Conservation Measures}

When using aminopyralid, fluroxypyr, and rimsulfuron in vegetation treatment programs, the BLM would follow all pertinent SOPs for use, transport, and handling of herbicides. The BLM would also continue to follow the conservation measures listed in the $2007 \mathrm{BA}$, or other comparable measures that would be developed by the field offices based on local site conditions and included in local-level consultation. No additional conservation measures speeific to the three new herbicides have been identified in this BA. However, additional, site-specific conservation measures would also be developed at the local level, as appropriate.

\section{Key Conservation Measures for the Whooping Crane from the 2007 BA}

- Do not allow human disturbance within 1 mile of occupied whooping crane habitat (nesting, roosting foraging) or potential nesting habitat where whooping cranes have been observed within the past 3 years during periods when eranes may be present (as determined by a qualified biologist).

- Do not conduct herbicide treatments in whooping erane habitat during the breeding season.

- Closely follow all application instructions and use restrictions on herbicide labels (including aquatic and wetland habitat use restrictions).

\section{Determination of Effects}

Based on the ERAs, none of the three herbicides would be likely to adversely affeet whooping eranes under any of the modeled exposure scenarios. Following the conservation measures from the 2007 BA would help minimize adverse impacts to this species. As a result, the action would be Not Likely to Adversely Affect whooping cranes or their federally designated critical habitat at the programmatic level. Given BLM mandates for use of integrated pest management (including vegetation management), and given that it is not possible to forecast site-specific vegetation management needs below the programmatic level, additional evaluations of situation-specific effects will be the subject of step-down ESA Section 7 evaluations and subsequent consultations. In this manner, any additional specific conservation measures necessary to accommodate site or situation-specific peculiarities not predictable at the programmatic level will be developed at the local level and incorporated into Pesticide Use Proposals prior to local implementation of vegetation management activities that involve the use of herbicides considered in this BA.

\section{Mammals}

The following mammals, and the ecoregion they are typically found in, are considered in this BA:

Pygmy rabbit - Temperate Desert

Columbian white-tailed deer - Temperate Desert/Marine

Lesser long-nosed bat - Subtropical Desert

Mexican long-nosed bat - Subtropical Desert

Ocelot - Subtropical Desert

Jaguar - Subtropical Desert

Sonoran pronghorn - Subtropical Desert

Amargosa vole - Subtropical Desert 
Hualapai Mexican vole - Subtropical Steppe

New Mexico meadow jumping mouse - Subtropical Steppe

Utah prairie dog - Subtropical Steppe/Temperate Desert

Preble's meadow jumping mouse - Temperate Steppe

Northern Idaho ground squirrel - Temperate Steppe

Woodland earibou - Temperate Steppe (mountainous areas)

Grizzly bear - Marine/Temperate Steppe (mountainous areas)

Canada lynx - Marine/Temperate Steppe (mountainous areas)

San Joaquin kit fox - Mediterranean

Giant kangaroo rat - Mediterranean

Fresno kangaroo rat - Mediterranean

Tipton kangaroo rat - Mediterranean

San Bernardino Merriam's kangaroo rat - Mediterranean

Stephens' kangaroo rat - Mediterranean

Morro Bay kangaroo rat - Mediterranean

Bighorn sheep - Mediterranean

Riparian (San Joaquin Valley) woodrat - Mediterranean

Buena Vista Lake ornate shrew - Mediterranean

Black-footed ferret - various

Gray Wolf - various

Note: In the discussions that follow, the general term "adverse health effects" is used in reference to exposure to certain herbicides under eertain scenarios. The potential toxicological effects of herbicides on terrestrial wildlife, which were examined in ERAs, include mortality and sublethal effects. Examples of sublethal effects include harm to vital organs, changes in body weight, reduced reproductive suceess, and altered behavior, which may increase the animal's suseeptibility to predation (USDA Forest Service 2005). Sublethal effects to an animal's health may also increase the severity of impacts associated with unrelated environmental stresses and other disturbanees. In all of the effects assessments for birds found in this chapter, the term "adverse health effects" refers to the abovementioned or similar toxicological effects at the level of the organism. In addition, it is assumed that for TEP birds these adverse health effeets would potentially result in population-level effects for the species in question. Because many TEP mammal species already have reduecd, sensitive populations, mortality of individuals or reduced reproductive output could reduce the size of affected populations further, perhaps even leading to extirpation. Furthermore, if individuals were to become more physiologically predisposed to mortality from environmental stresses (such as predation or exposure to harsh environmental conditions), the risk for future population-level effects, including extirpations, would be increased. For more information on the methodology used to determine risk levels, see Chapter 2 of this BA and Appendix C of the 2007 PEIS (USDOI BLM 2007a).

\section{Pygmy Rabbit}

The primary reference for this section is:

USFWS. 20011. Emergency Rule to List the Columbia Basin Distinet Population Segment of the Pygmy Rabbit (Brachylagus idahoensis) as Endangered. Federal Register 66(231):59734-59749.

References cited in this section are internal to the above-referenced document. A complete list of these references is available from the USFWS Upper Columbia Fish and Wildlife Office, Spokane, Washington.

The 2010 5-year review for the Columbia Basin DPS of the pygmy rabbit (USFWS 2010mm) was reviewed for updated information on this species.

The pygmy rabbit (Brachylagus idahoensis) was once distributed throughout much of the semi-arid, shrub steppe region of the Great Basin and adjacent intermountain zones of the conterminous western U.S. (Green and Flinders 1980a). It's historical range likely included portions of Montana, Idaho, Wyoming, Utah, Nevada, California, Oregon, and Washington. The Columbia Basin DPS of the species has been physically and genetically discrete 
from the remainder of the species populations for at least 10,000 years (USFWS 2010mm). Pygmy rabbits are not and have never been continuously distributed, typically occurring only in areas where sagebrush cover is sufficiently tall and dense, and where soils are suffieiently deep and loose to allow burrowing (Bailey 1936, Green and Flinders 1980a, Weiss and Verts 1984, Washington Department of Fish and Wildlife [WDFW] 1995). The local distribution of these habitat patches likely shifts across the landseape in response to various sources of disturbanee (e.g., fire, flooding, grazing, and erop produetion), combined with long- and short-term weather patterns. Historieally, more dense vegetation along permanent and intermittent stream corridors, alluvial fans, and sagebrush plains probably provided travel corridors or dispersal habitat for pygmy rabbits between appropriate use areas.

Pygmy rabbits typically are found in areas of tall, dense sagebrush cover, and are highly dependent on sagebrush to provide both food and shelter throughout the year (Orr 1940, Green and Flinders 1980a, WDFW 1995). The winter diet of pygmy rabbits is composed of up to 99 percent sagebrush (Wilde 1978), which is unique among Leporids (hares and rabbits; White et al. 1982). During spring and summer, their diet eonsists of roughly 51 percent sagebrush, 39 percent grasses (partieularly native bunchgrasses, such as wheatgrass and bluegrass), and 10 pereent forbs (Green and Flinders 1980b). There is evidence that pygmy rabbits preferentially seleet native grasses as forage during this period in comparison to other available foods. In addition, total grass eover relative to forbs and shrubs may be reduced within pygmy rabbit colonies as a result of its use as a food source during spring and summer.

The pygmy rabbit is believed to be one of only two Leporids in North America that digs its own burrows (Nelson 1909, Green and Flinders 1980a, WDFW 1995). Pygmy rabbit burrows typically are found in relatively deep, loose soils of wind-borne or water-borne origin, and the species oceasionally makes use of burrows abandoned by other speeies, such as the yellow-bellied marmot or badger. Burrows may also occur in areas of shallower or more compact soils that support sufficient shrub cover (Bradfield 1974). During winter, pygmy rabbits make extensive use of snow burrows to aecess sagebrush forage (Bradfield 1974, Katzner and Parker 1997), using them as proteetion from predators and inelement weather (Bailey 1936, Bradfield 1974). The burrows frequently have multiple entranees, some of whieh are conecaled at the base of larger sagebrush plants (WDFW 1995). Burrows are relatively simple and shallow, often no more than 6.6 feet long and usually less than 3.3 feet deep with no distinct chambers (Bradfield 1974, Green and Flinders 1980a, Gahr 1993).

Pygmy rabbits may be active at any time of the day or night and appear to be most aetive during mid-morning. Pygmy rabbits maintain a low stance, have a deliberate gait, and are relatively slow and vulnerable in more open areas. They ean evade predators by maneuvering through the dense shrub eover of their preferred habitats, often along established trails, or by escaping into their burrows (Bailey 1936, Severaid 1950, Bradfield 1974). Predation is the main eause of pygmy rabbit mortality (Green 1979). Potential predators include badgers, long-tailed weasels, coyotes, bobeats, great horned owls, long-eared owls, ferruginous hawks, and northern harriers (Janson 1946; Gashwiler et al. 1960; Green 1978; Wilde 1978; WDFW 1995).

Pygmy rabbits begin breeding in their seeond year and, in Washington, breeding occurs from February through July (WDFW 1995). Females may have up to three litters per year and average six young per litter (Green 1978, Wilde 1978). Breeding appears to be highly synchronous in a colony, and juveniles are often identifiable to eohorts (Wilde 1978). No evidence of nests, nesting material, or lactating females with young has been found in burrows (Bradfield 1974, Gahr 1993, WDFW 1995). Individual juveniles have been found under elumps of sagebrush, although it is not known precisely where the young are born in the wild or if they may be routinely hidden at the bases of scattered shrubs or within burrows (Wilde 1978). Reeent information on captive and wild pygmy rabbits indicates that females excavate specialized natal burrows for their litters in the vicinity of their regular burrows ( $P$. Swenson 2001; Shipley 2001, USFWS $2010 \mathrm{~mm}$ ). Females begin to dig and supply nesting material (e.g., grass clippings) to these burrows several days prior to giving birth, and may give birth and nurse their young at the ground surface in a small depression near the burrow's entrance. After nursing, the young return to the burrow and the female refills the burrow entrance with loose soil and otherwise disguises the immediate area to avoid detection. 
The Columbia Basin population of the pygmy rabbit was federally listed as endangered on Mareh 5, 2003 (68 FR 10388). Critical habitat has not been designated or proposed for this species. Once thought to be extirpated from the State of Washington, pygmy rabbits were again loeated in Washington in 1979. Intensive surveys in 1987 and 1988 resulted in the diseovery of five small colonies of pygmy rabbits in southern Douglas County; three of whieh oceurred on State lands and two of which oceurred on privately-owned lands (WDFW 1995). With the exception of a single site record from Benton County in 1979, pygmy rabbits have been found only in southern Douglas and northern Grant Counties, Washington, sinee 1956 (WDFW 2000a). The last known wild subpopulation of pygmy rabbits within the Columbia Basin became extirpated by early 2004, although other as yet unknown wild subpopulations may still be present (USFWS $2010 \mathrm{~mm}$ ).

The Columbia Basin pygmy rabbit is imminently threatened by this reeent decrease in population, which has caused it to be susceptible to the combined influenee of catastrophic environmental events, habitat or resource failure, disease, predation, and loss of genetic heterogeneity. Captive breeding programs and reintroduetion efforts are hampered by disease and habituation in the eaptive population, as well as potential outbreeding depression in wild pygmy rabbits following proposed reintroduetion efforts (USFWS 2010mm).

\section{Effects of Herbicide Treatments on the Pygmy Rabbit}

\section{Direct Effects}

Use of trucks/ATVs/UTVs to apply herbieides could eause some injury and/or mortality to pygmy rabbits by crushing burrows and potentially the animals inside them. Young rabbits would be most at risk. It is also possible that disturbanees assoeiated with herbieide applieation procedures would have temporary behavioral effeets on pygmy rabbits.

Although it is likely that pygmy rabbits would flee or retreat into burrows during herbieide applications, it is possible that some animals would be unintentionally exposed to these chemicals, either by direet spray or by contaet with sprayed vegetation. Additionally, pygmy rabbits could ingest vegetation sprayed by the herbicides.

Based on the results of the ERAs for terrestrial vertebrate speeies, none of the herbieides considered in this BA would result in adverse health effeets to pygmy rabbits via direet spray or dermal eontaet with sprayed vegetation exposure seenarios (Table 6-2). Additionally, the ERAs determined that there is no toxicological risk to small mammals from ingestion of vegetation treated by aminopyralid, fluroxypyr, or rimsulfuron (Table 6-5). Risk assessments conservatively assume that all of a rabbit's diet would eome from eontaminated vegetation.

\section{Indirect Effects}

Use of ATVs/UTVs and trueks to apply herbieides, in addition to applications on foot, could result in damage to pygmy rabbit burrow systems. In addition, the physical disturbanee associated with herbicide applications could cause struetural damage to pygmy rabbit habitat.

Pygmy rabbits are highly dependent on sagebrush to provide food and cover throughout the year, and feed on other types of vegetation during the spring and summer. Therefore, any treatment that removes large amounts of vegetation from pygmy rabbit habitats is likely to adversely affect the species temporarily. Additionally, use of herbicides could cause a temporary reduction in food items. However, over the long term, a reduction in non-native species would likely improve the quality of treated areas, making them more suitable for supporting pygmy rabbit populations. Treatments that target non-native species would be expected to improve pygmy rabbit habitats. Areas with dense cover of downy brome are apparently avoided by pygmy rabbits (Weiss and Very 1984 cited in USFWS 20011). Therefore, use of rimsulfuron to control downy brome in pygmy rabbit habitat would likely have a beneficial effect on the species. As pygmy rabbits are unlikely to be present in areas with a high coverage of nonnative species, treatments that restore these areas to more native conditions could potentially improve the availability of habitat for future occupation by pygmy rabbits. 
TABLE 6-5

Summary of Effects to Threatened, Endangered, and Proposed Mammals From Ingestion of Food, As Predicted By Risk Assessments

\begin{tabular}{|c|c|c|c|c|}
\hline Herbicide & $\begin{array}{l}\text { Ingestion of } \\
\text { Vegetation - } \\
\text { Small Mammals }\end{array}$ & $\begin{array}{l}\text { Ingestion of } \\
\text { Vegetation - } \\
\text { Large Mammals }\end{array}$ & $\begin{array}{l}\text { Ingestion of Small } \\
\text { Vertebrate Prey }\end{array}$ & $\begin{array}{c}\text { Ingestion of } \\
\text { Invertebrate Prey }\end{array}$ \\
\hline Aminopyralid & No effeet & No effeet & No cffect & No effeet \\
\hline Fluroxypyr & No cffect & No cffect & No effeet & No effect \\
\hline Rimsulfuron & No effeet & No cffeet & No cffect & No effect \\
\hline \multicolumn{5}{|c|}{$\begin{array}{l}\text { 'Both acute and chronic effects were considered. For more information on acute vs. chronie effects, please see Appendix C of the } 2007 \text { PEIS } \\
\text { (USDOI BLM 2007a). "No effects" indicates that ERAs did not predict risks to TEP mammals under the modeled scenario at the typical of } \\
\text { maximum application rate. }\end{array}$} \\
\hline \multicolumn{5}{|c|}{${ }^{2}$ Insectivorous birds were used as surrogates for insectivorous mammals when completing risk assessments. } \\
\hline \multicolumn{5}{|c|}{ Note: Risks to mammals from ingesting contaminated fish are assumed to be the same as those to birds (see Table 6-4). } \\
\hline \multicolumn{5}{|c|}{ Sources: Ecological risk assessments for herbicides (AECOM 2014a-c). } \\
\hline
\end{tabular}

\section{Conservation Measures}

When using aminopyralid, fluroxypyr, and rimsulfuron in vegetation treatment programs, the BLM would follow all pertinent SOPs for use, transport, and handling of herbieides. The BLM would also continue to follow the eonservation measures identified in the $2007 \mathrm{BA}$, or other eomparable measures that would be developed by the field offices based on local site conditions and ineluded in local-level consultation. Although only the Columbia Basin DPS of the pygmy rabbit is currently listed, these mitigation measures should be eonsidered for treatments throughout the species' entire range, and implemented as appropriate. No additional eonservation measures have been identified that are specifie to the three new herbicides. However, projeet-level eonservation measures may be developed, as necessary, by loeal BLM offiees during the development of NEPA doeuments for sitc-specifie treatment projects.

Key Conservation Measures for Pygmy Rabbits from the 2007 BA

- Prior to treatments, survey all suitable habitat for pygmy rabbits.

- Address pygmy rabbits in all management plans prepared for treatments within the range of the species' historical habitat.

- Where feasible, spot treat vegetation in pygmy rabbit habitat rather than broadeast spraying, to avoid impaeting important food sources.

\section{Determination of Effects}

Based on the ERAs, none of the three herbicides would be likely to adversely affect pygmy rabbits under any of the modeled exposure scenarios. Following the conservation measures from the 2007 BA would help minimize adverse impacts to this speeies. As a result, the action would be Not Likely to Adversely Affect pygmy rabbits at the programmatic level. Given BLM mandates for use of integrated pest management (including vegetation management), and given that it is not possible to forecast site-specific vegetation management needs below the programmatie level, additional evaluations of situation-speeifie effects will be the subject of step-down ESA Section 7 evaluations and subsequent consultations. In this manner, any additional speeific conservation measures neeessary to accommodate site or situation-specific peculiarities not predietable at the programmatic level will be developed at the local level and ineorporated into Pesticide Use Proposals prior to local implementation of vegetation management aetivities that involve the use of herbieides considered in this BA. 


\section{Columbian White-tailed Deer}

The primary reference for this section is:

USFWS. 2002r. Supplemental Proposed Rule to Remove the Douglas County Population of Columbian Whitetailed Deer From the Federal List of Endangered and Threatened Wildlife. Federal Register 67(120):42217-42229.

References eited in this seetion are internal to the above-referenced document. A complete list of these references is available from the USFWS, Oregon Fish and Wildlife Office, Portland, Oregon.

The Columbian white-tailed deer (Odocoileus virginianus leucurus) is the westernmost representative of 30 subspecies of white-tailed deer in North and Central America. The subspecies was formerly distributed throughout the bottomlands and prairie woodlands of the lower Columbia, Willamette, and Umpqua River basins in Oregon and southern Washington (Bailey 1936, Verts and Carraway 1998). It is believed that this deer was locally common, particularly in riparian areas along major rivers (Gavin 1978). With the arrival and settlement of pioneers in the fertile river valleys, the decline in Columbian white-tailed deer numbers was rapid (Gavin 1978). By 1940, a population of 500 to 700 animals along the lower Columbia River in Oregon and Washington, and a disjunet population of 200 to 300 in Douglas County, Oregon survived (Crews 1939, Gavin 1984, Verts and Carraway 1998).

Columbian white-tailed deer in Douglas County (Douglas County DPS) are most often associated with riparian habitats, though the deer also uses a variety of lower elevation habitat types (c.g., grassland, grass shrub, oak savanna, oak-hardwood woodland, oak-hardwood savanna shrub, oak-hardwood conifer, conifer, and urban/suburban yards; Rieca 1999). Open areas are used for feeding between dusk and dawn. The Columbia River population (Columbia River DPS) oceurs in wet bottomlands and dense forest swamps where there is little elevational relief, and which receive a large amount of precipitation. The diet of Columbian white-tailed deer consists of forbs, shrubs, grasses, and a variety of other foods, such as lichens, mosses, ferns, seeds, and nuts (Whitney 2001).

Like other types of deer, Columbian white-tailed deer breed in the winter, primarily in November and Deeember. Most fawns are born between mid-May and mid-June. Columbian white-tailed deer first breed as yearlings (18 months), and young females typically give birth to a single fawn. After 2 years of age, twins are more common.

The Columbian white-tailed deer was federally listed as endangered on Mareh 11, 1967 (32 FR 4001). On July 24, 2003, the Douglas County DPS was delisted due to recovery (68 FR 43647). The Douglas County DPS population has more than doubled in size since listing (USFWS 2003b). The Columbia River population remains listed as endangered. This species is primarily threatened by a lack of suitable habitat. Logging has degraded forest habitat in some areas. In addition, periodic flooding of the Columbia River, and residential development along the North Umpqua River are also threats to the subspecies.

\section{Effects of Herbicide Treatments on the Columbian White-tailed Deer}

\section{Direct Effects}

Although deer would readily flee people and equipment associated with herbicide applications, it is possible that some animals would inadvertently be exposed to herbicides used on public lands. Columbian white-tailed deer could also be exposed to herbicides through contact with sprayed vegetation or ingestion of sprayed plant materials.

According to the ERAs, none of the herbicides considered in this BA would result in adverse health effects to Columbian white-tailed deer under direct spray, dermal contact with sprayed vegetation, or ingestion of sprayed food items exposure scenarios (Tables 6-2 and 6-5). Risk assessments conservatively assume that 100 percent of the animal's diet would consist of contaminated vegetation, which would be unlikely unless all of the animal's habitat was treated. 


\section{Indirect Effects}

The three herbieides eould be used in dry riparian habitats. Removal of vegetation from riparian vegetation can cause degradation of these habitats (see the effects analysis for aquatic speeies in Chapter 5) and indirectly affect Columbian white-tailed deer populations. However, based on the likely usage of the three new active ingredients, wide-seale removal of riparian vegetation is unlikely to oeeur. Herbieide treatments eould temporarily reduce the availability of forage plants. Becausc deer are mobile and often graze in a variety of habitats, these effects would be unlikely to affect deer populations unless a very extensive area was sprayed or few alternate foraging sites were available. Reduetion in forage could also affeet deer populations if treatments oceurred during a time when forage was already limited. Over the long term, a reduetion in non-native plant species could inerease the quality of deer forage.

\section{Conservation Measures}

When using aminopyralid, fluroxypyr, and rimsulfuron in vegetation treatment programs, the BLM would follow all pertinent SOPs for use, transport, and handling of herbicides. The BLM would also continue to follow the eonservation measures identified in the 2007 Vegetation Trcatments BA, or other eomparable measures that would be developed by the field offiees based on local site conditions and included in loeal-level eonsultation. No additional conservation measures have becn identified that are specific to the three new herbicides. However, sitespecific and project-specifie eonservation measures may be developed by local BLM offices, as necessary to ensure protection of the Columbian white-tailed decr.

\section{Key Conservation Measures for the Columbian White-Tailed Deer from the $2007 \mathrm{BA}$}

- Prior to treatments, survey for evidence of Columbian white-tailed deer usc of areas in which treatments are proposed to oeeur.

- Address the proteetion of Columbian white-tailed decr in local management plans developed in assoeiation with treatment programs.

- In areas that are likely to support Columbian white-tailed deer, protect riparian areas from degradation by avoiding them altogether, or utilizing SOPs. Consult Chapter 5 for appropriate conservation measures to be used in proteeted riparian areas.

- Closely follow all application instructions and usc restrietions on herbieide labels (ineluding aquatie and wetland habitat use restrictions).

- Avoid broadcast spray treatments in areas where Columbian white-tailed deer are known to forage.

\section{Determination of Effects}

Based on the ERAs, nonc of the three herbieides would bc likely to adversely affect Columbian white-tailed deer under any of the modeled exposure seenarios. Following the conscrvation measures from the 2007 BA would help minimize adverse impacts to this species. As a result, the action would be Not Likely to Adversely Affect Columbian white-tailed deer at the programmatie level. Given BLM mandates for use of integrated pest management (including vegetation management), and given that it is not possiblc to forecast site-speeifie vegctation management needs below the programmatic level, additional evaluations of situation-speeific effeets will be the subject of step-down ESA Seetion 7 evaluations and subsequent eonsultations. In this manner, any additional specific conservation measures necessary to aeeommodate site or situation-specific peculiarities not predictable at the programmatic level will be developed at the loeal level and incorporated into Pesticide Usc Proposals prior to local implementation of vegetation management aetivities that involve the use of herbicides considered in this BA.

\section{Bats: Lesser Long-nosed Bat and Mexican Long-nosed Bat}

\section{Lesser Long-nosed Bat}

The primary referenee for this scetion is:

USFWS. 1995f. Lesser Long-nosed Bat Recovery Plan. Albuquerque, Ncw Mexico.

References cited in this scction are internal to the above-referenced doeument. Full citations have been included in the Bibliography. 
The 2007 5-year review for the lesser long-nosed bat (USFWS 2007bb) was consulted for updated information on this species.

The lesser long-nosed bat (Leptonycteris curosoae yerbabuenae) is a nectar-, pollen-, and fruit-eating bat that migrates seasonally from Mexico to southern Arizona and southwestern New Mexico. It has been found in southern Arizona from the Picacho Mountains southwest to the Agua Dulce Mountains and southeast to the Chiricahua Mountains. It has also been found in far southwestern New Mexico in the Animas and Peloneillo Mountains, and throughout the drier parts of Mexico. The subspecies is a seasonal resident in Arizona, usually arriving in early April and departing in mid- to late September. It apparently resides in New Mexico only from mid-July to early September (Hoyt et al. 1994).

Two sets of resourees are critical for the lesser long-nosed bat: suitable day roosts and suitable concentrations of food plants. It is unclear precisely what factors identify potential roost sites as "suitable," but maternity roosts tend to be very warm and poorly ventilated, at least where the young are actually raised. Such roosts reduce the energetic requirements of adult females while they are raising their young (Arends et al. 1995). Lesser long-nosed bats have been found living in eaves and mines displaying a variety of microclimates (e.g., dry and hot, wet and hot, dry and cool, wet and cool). They are found in well-ventilated eaves as well as those that are poorly ventilated and filled with strong ammonia fumes. The subspecies sometimes co-oceurs with other species of bats. fndependent of its day-roosting location, the subspecies appears to be sensitive to human disturbance, and bats may temporarily abandon their roosts and move to another in response to a single brief human visit.

The lesser long-nosed bat has specialized food requirements. Columnar eactus flowers and fruits and agave flowers are believed to represent this bat's core diet. Its consumption of nectar and pollen produced by paniculate agave flowers is well-known (e.g., Howell 1974, 1976, 1979). Important also are nectar, pollen, and fruit produced by a variety of columnar eacti (Howell 1974; Cockrum 1991; Fleming et al. 1993). Flowers and fruits of two to three species of columnar cacti (pachycereus, saguaro, and organ pipe cactus) provide nearly all of the energy and nutrients obtained by pregnant and lactating females roosting in the Sonoran Desert in the spring and early summer. By eating nectar, pollen, and fruit, lesser long-nosed bats are important pollinators and seed dispersers of their food plants.

Female lesser long-nosed bats are thought to bear only a single young per year, and the timing of mating and parturition likely varies geographically. It is thought that periods of birth and lactation coincide with peak flower availability. Young bats have well-developed feet and are left to hang in the day roost from the day of birth while the mother leaves the roost to forage. Young probably are nursed for about 6 weeks, begin to fly at 4 weeks, and begin to leave the roost on evening flights at 6 to 7 weeks.

The lesser long-nosed bat was federally listed as endangered on September 30, 1988 (53 FR 38456). Critical habitat has not been designated for the subspecies. Primary threats include human and other disturbances at roosting colonies, and loss and degradation of foraging habitat. The current population numbers of this subspecies exceed the levels known and recorded at the time of listing, and trend in overall numbers has been stable or increasing in both the U.S. and Mexico. However, the number of roost sites has not significantly increased (USFWS 2007bb).

\section{Mexican Long-nosed Bat}

The primary reference for this section is:

USFWS. 1994j. Mexican Long-nosed Bat (Leptonycteris nivalis) Recovery Plan. Albuquerque, New Mexico.

The Mexican long-nosed bat (Leptonycteris nivalis), also a migratory species, ranges from southern Mexico to southern Texas and New Mexico. It is found at medium to high elevations (1,550 to 9,330 feet) in desert scrub, open conifer-oak woodlands, and pine forest habitats in the Upper Sonoran and Transitional life zones. The Mexican long-nosed bat is a colonial species that usuafly roosts in caves, but can also be found in mines, culverts, and hollow trees. 
The species feeds primarily on the nectar from agave plants and also on pollen from cacti flowers and some soft fruits. Bats become active in late evening, leaving roosts in search of their night blooming food plants. The Mexican long-nosed bat is considered a vital pollinator for some plant species, such as the agave.

Reproductive information for the Mexican-long nosed bat is limited. Most young are born in May. However, some studies indicate that this species might have two birth peaks a year, the first in spring and the second peak in September. It is suggested that the migratory nature of this species is derived from the mutualistic relationship it shares with the agave plants on which it feeds. Although the agaves, which flower only once before dying, ean reproduce vegetatively by sending shoots from the bottom to the main stem, they rely on the Mexican long-nosed bat and other nectar feeders for eross-pollination to keep up an adequate amount of gene flow. The bat's migratory pattern suggests that it follows the onset of flowering agaves northward, seasonally. When elimatic conditions severely limit the number of agaves that flower in any given year, the bat will range farther for additional food sources.

The Mexican long-nosed bat was federally listed as endangered on September 30, 1988 (53 FR 38456). Critical habitat has not been designated for this speeies. The primary threats to this species are modification or destruction of roost sites and foraging habitat. A lack of suitable roost sites for this species may be a limiting factor. Other potential threats include pesticides, competition for roosts and nectar, natural catastrophes, disease, and predation. The population status of the Mexican long-nosed bat is unknown for certain, but it is suspected to be declining. Population estimates are difficult, given the migratory nature and rarity of the species, and the probability that seasonal movements are connected with elimactic conditions that stimulate agave flower blooming (Texas Parks and Wildlife Department 2003).

\section{Effects of Herbicide Treatments on the Lesser Long-nosed Bat and the Mexican Long-nosed Bat}

\section{Direct Effects}

Because lesser and Mexican long-nosed bats roost in covered areas during the day and are active in the evening, direct spray of bats during herbicide treatments would be unlikely. More likely exposure scenarios would be dermal contact with sprayed plant materials or ingestion of these materials after an herbicide application.

According to the ERAs, none of the herbicides considered in this BA would result in adverse health effeets to listed bat speeies under any of the modeled exposure secnarios (direet spray, dermal contact with sprayed vegetation, or ingestion of sprayed food items; Tables 6-2 and 6-5).

\section{Indirect Effects}

Adverse effects to non-target plant species are predicted as a result of direct spray by aminopyralid, fluroxypyr, or rimsulfuron. In addition, non-target plants could be impacted by off-site drift of all three herbicides (see Tables 4-1 through 4-4 for more information on potential effects to vegetation). Sinee lesser and Mexican long-nosed bats depend on neetar plants for food, inadvertent mortality or reduced reproduetive output of these cactus species as a result of herbicide treatments would adversely affect lesser and Mexican long-nosed bats.

Herbicide treatments that reduce the coverage of invasive shrub species would be expected to have a positive effeet on the habitat of these two bat species. Weed removal activities would likely improve habitat for neetar plants, such as agave and eactus species. In addition, some of the most common invasive species found in bat habitat areas are fire tolerant species, such as red brome, that increase the potential for a severe wildfire by adding to the fuels base (USDOI BLM 1996b). Since a large fire could destroy large stands of neetar plants, herbicide treatments that reduee these fuel species would benefit the bat species.

\section{Conservation Measures}

When using aminopyralid, fluroxypyr, and rimsulfuron in vegetation treatment programs, the BLM would follow all pertinent SOPs for use, transport, and handling of herbicides. The BLM would also continue to follow the conservation measures identified in the $2007 \mathrm{BA}$, or other comparable measures that would be developed by the 
field offices based on local site conditions and included in local-level consultation. These measures include practices to protect nectar plants and roost trees. No additional conservation measures have been identified that are specific to the three new herbicides. However, local BLM offices would develop site-specific conservation measures, as needed, to protect these species during and following herbicide treatments.

Key Conservation Measures for the Lesser Long-Nosed Bat and Mexican Long-Nosed Bat from the 2007 BA

- Prior to treatments, survey all potentially suitable habitat for the presence of bats or their nectar plants.

- At the local level, incorporate protection of lesser and Mexican long-nosed bats into management plans developed for proposed treatment programs.

- Instruet all field personnel on the identification of bat nectar plants and the importance of their protection.

- Protect nectar plants from modification by treatment activities to the greatest extent possible. Do not remove nectar plants during treatments. Avoid driving over plants.

- To protect nectar plants and roost trees from herbicide treatments, follow recommended buffer zones for the herbicides, and other conservation measures for TEP plant species, in areas where populations of neetar plants and roost trees occur.

- If condueting spot treatments of herbicides in lesser or Mexican long-nosed bat habitats, avoid potential roost sites.

\section{Determination of Effects}

Based on the ERAs, none of the three herbicides would be likely to adversely affeet lesser or Mexican long-nosed under any of the modeled exposure seenarios. However, indireet effects to the species could oceur if neetar plants or roost trees are harmed by herbicide treatments. Following the conservation measures from the 2007 Vegetation Treatments BA, and incorporating the appropriate non-target plant buffer distances for aminopyralid, fluroxypyr, and rimsulfuron, would help minimize adverse impacts to these species. As a result, the action would be Not Likely to Adversely Affect lesser and Mexican long-nosed bats or their federally designated eritical habitat at the programmatic level. Given BLM mandates for use of integrated pest management (including vegetation management), and given that it is not possible to forecast site-specific vegetation management needs below the programmatic level, additional evaluations of situation-specifie effects will be the subject of step-down ESA Section 7 evaluations and subsequent consultations. In this manner, any additional specific conservation measures necessary to aceommodate site or situation-specific peculiarities not predictable at the programmatic level will be developed at the local level and ineorporated into Pesticide Use Proposals prior to local implementation of vegetation management activities that involve the use of herbicides considered in this BA.

\section{Desert Cats: Ocelot and Jaguar}

\section{Ocelot}

The primary reference for this section is:

USFWS. 2010nn. Ocelot Recovery Plan (Leopardus pardalis) Draft First Revision. Southwest Region. Albuquerque, New Mexico.

Referenees cited in this section are internal to the above-referenced document. Full citations have been included in the Bibliography.

The ocelot (Leopardus pardalis) is a medium-sized spotted cat that ranges from southern Texas and Arizona through Central and South America into northern Argentina and Uruguay. In the U.S., ocelots occur in two populations in southern Texas: one in Willacy and Kenedy Counties, primarily on private ranches (Navarro-Lopez 1985 ) and the other in eastern Cameron County primarily on the Laguna Atascosa National Wildlife Refuge (Laack 1991). Both populations are isolated from each other by at least 19 miles and occupy remnant habitat fragments. As of February 2010, there were fewer than 25 individuals total in these two populations, with the possibility that more inhabit surrounding ranches. The species has been infrequently sighted in Arizona, as recently as 2010.

Habitats used by the ocelot throughout its range vary from tropical rainforest, pine forest, gallery forest, riparian forest, semi-deciduous forest, and dry tropical forest, to savanna, shrublands, and marshlands. In south Texas, the 
ocelot inhabits dense thornserub eommunities. Although the speeies use a variety of habitats throughout its range, its spatial patterns are strongly linked to dense cover or vegetation. Although greater than 75 percent canopy cover is required, in Texas the species prefers areas with 95 percent cover in the shrub layer. Resacas, rivers, irrigation canals, irrigation drains, natural drainages, shorelines, feneelines, and road verges all provide suitable travel eorridors for ocelots, espeeially as density and percent eover of thornserub vegetation increase (Tewes et al. 1995).

Ocelots are primarily active at dusk and at night, spending the day in heavy brush (Leopold 1959, Grzimek 1975, Tewes and Everett 1982). Ocelots make dens in caves, hollow trees, and other similar openings. Their prey consists primarily of rabbits, rodents, birds, and lizards.

Wild oeelots probably first produee young at about 18 to 30 months of age (Eaton 1977, Tewes and Schmidly 1987). Gestation lasts about 70 to 80 days, and in Texas breeding reaehes a peak during autumn (Tewes and Sehmidly 1987). Usually, one or two kittens are born, but litter sizes of up to four have been reported (Hall and Kelson 1959, Cahalane 1961, Morris 1965, Eaton 1977, Seager and Demorest 1978, Nowak and Paradiso 1983).

The ocelot was federally listed as endangered on July 21, 1982 (47 FR 31670). Critical habitat has not been designated. Lack of suitable habitat has been eited as an important reason for the endangered status of the oeelot in the U.S. (Tewes and Everett 1986, Tewes and Miller 1987). More than 95 pereent of the suitable habitat for this speeies in the Lower Rio Grande Valley has been altered for agricultural and urban development (Jahrsdoerfer and Leslie 1988). Populations in many areas apparently eontinue to decline, and the primary threats to the species currently are habitat conversion, fragmentation, and loss. Small population sizes in Texas and isolation from conspeeifies in Mexico threaten the ocelot in Texas with inbreeding. Conneetivity among oeelot populations or colonization of new habitats is inhibited by road mortality among dispersing ocelots. Issues assoeiated with border barrier development and patrolling the boundary between the United States and Mexico further exacerbate the isolation of Texas and Arizona oeelots from those in Mexico.

\section{Jaguar}

The primary referenee for this section is:

USFWS. 1997g. Final Rule to Extend Endangered Status for the Jaguar in the United States. Federal Register 62(140):39147-39157.

References eited in this seetion are internal to the above-refereneed doeument. A complete list of these referenees is available from the USFWS, Arizona Ecological Services Field Office, Phoenix, Arizona.

The jaguar (Panthera onca) is the largest species of cat native to the Western Hemisphere. 1ts range in North America includes Mexieo and portions of the southwestern United States (Hall 1981). Jaguars are known from a variety of habitats (Seymour 1989, Nowak 1991). They show a high affinity to lowland wet habitats, typieally swampy savannas or tropieal rain forests. However, they also oceur, or once did, in upland habitats in warmer regions of North and South Ameriea. Within the United States, jaguars have been recorded most commonly from Arizona, but there are also records from California, New Mexico, and Texas, and reports from Louisiana. Currently there is no known resident population of jaguars in the United States, though they still oceur in northern Mexico. Nonetheless, there have been recent, confirmed records of jaguar in the United States from the New Mexieo/Arizona border area and in southeentral Arizona. Most recent sightings have been within 40 miles of the United States/Mexico border. Between 1996 and 2009, four or five jaguars have been doeumented in the U.S. (USFWS 201000).

Jaguars breed year-round range-wide, but at the southern and northern ends of their range there is evidenee for a spring breeding season. Gestation is about 100 days, and litters range from one to four cubs (usually two). Cubs remain with their mother for nearly 2 years. Females begin sexual aetivity at 3 years of age, males at 4 . The list of prey taken by jaguars range-wide includes more than 85 species (Seymour 1989), such as pecearies (javelina), armadillos, turtles, and various birds and fish. Javelina and deer are presumably mainstays in the diet of jaguars in the United States and Mexico borderlands. 
The jaguar was originally listed as endangered from the United States and Mexico border southward to include Mexico and Central and South America. On July 22, 1997, the jaguar was also listed as endangered in the United States (62 FR 39147). The USFWS has proposed the designation of 858,137 acres in Pima, Santa Cruz, and Cochise Counties, Arizona, and Hidalgo County, New Mexico as critical habitat for this species (77 FR 50213). Loss and modification of the jaguar's habitat are likely to have contributed to its decline. The presence of the species in the United States is believed to be dependent on the status of the jaguar in northern Mexico. In the United States, a primary threat to this speeies is illegal shooting (USFWS 201000).

\section{Effects of Herbicide Treatments on the Ocelot and Jaguar}

\section{Direct Effects}

Herbicide treatments would be unlikely to directly affect to ocelots or jaguars. These species are unlikely to oceur in the project area, and would likely move out of an area being treated by herbicides. Unintentional direct spray of these mammals is not anticipated, although contact with sprayed foliage or ingestion of sprayed prey items could conceivably occur. According to the ERAs, none of the herbicides considered in this BA would result in adverse health effects to ocelots or jaguars under any of the modeled exposure scenarios (direet spray, dermal eontact with sprayed vegetation, or ingestion of sprayed food items; Tables 6-2 and 6-5).

\section{Indirect Effects}

Populations of ocelots and jaguars generally oceur south of the United States, in Mexico and South America, although there is a population of ocelots in Texas. In the project area, these species are only known to oecur as seattered individuals in Arizona and New Mexico, which are believed to be transients from Mexico. Therefore, it is unlikely that herbicide treatments would indirectly affect ocelots or jaguars. However, there is some chanee that modification of lands near the Arizona and New Mexico southern borders could make them either more or less suitable for supporting these species.

\section{Conservation Measures}

The proposed vegetation treatments are unlikely to cause adverse effects to the ocelot or jaguar, or their habitats, sinee these species are unlikely to oceur in the project area. The 2007 BA included one conservation measure associated with use of a single herbicide (2,4-D) in areas where recent sightings of these species have occurred. No additional conservation measures have been identified that are specific to the three new herbicides.

\section{Determination of Effects}

Given the rarity of these speeies in the United States and the infrequency of sightings in Arizona and New Mexico where public lands oecur, vegetation treatments with the thee new herbicides would be Not Likely to Adversely Affect the ocelot or jaguar. However, at the local level, BLM offices should still inelude ocelots and/or jaguars in their vegetation management plans if the species have been observed in the project area in the past.

\section{Sonoran Pronghorn}

The primary reference for this section is:

USFWS. 1998y. Final Revised Sonoran Pronghorn Recovery Plan. Albuquerque, New Mexico.

References cited in this section are internal to the above-referenced document. Full citations have been included in the Bibliography.

The 2010 Federal Register document establishing a nonessential experimental population (USFWS 2010pp) was consulted for updated information on this subspecies.

The Sonoran pronghorn (Antilocapra americana sonoriensis), one of five subspecies of pronghorn (Nowak and Paradiso 1983), inhabits southwestern Arizona in the U.S. and northwestern Sonora in Mexico. Currently, there are three geographically isolated populations of the subspecies (USFWS 2010pp). Two of seven identified subdivisions of the Sonoran desert encompass the habitat of this subspecies: the Lower Colorado River Valley and 
the Arizona Upland. Common plant speeies found in the Lower Colorado River Valley include creosote bush, white bursage, ironwood, blue palo verde, and mesquite. Common species in the Arizona Upland inelude foothill palo verde, catelaw acacia, jumping cholla, and teddy bear cholla. Pronghorn appear to use flat valleys and isolated hills to a greater degree than other topographic features of the Sonoran Desert (Arizona Game and Fish Department 1985).

Washes flow briefly after rains during the monsoon season and after sustained winter rains. The network ereated by these washes provides important thermal cover for Sonoran pronghorn during the hot summer season. Drainages and bajadas are used during spring and summer, with bajadas used as fawning areas during the spring. Pronghorn appear to use palo verde, ironwood, and mesquite for cover. Playas provide abundant forbs during the spring, especially during good rain years. Pronghorn vacate these areas later in the season when forbs dry up (Hughes and Smith 1990). Some of the sandy areas provide a greater variety of seasonal vegetation. The openness of these areas appears to be attractive for pronghorn, as the annuals, grasses, and shrubs provide good forage species, particularly in the spring. These areas have long been considered important Sonoran pronghorn habitat in the U.S. However, the decreased palatability of annuals as summer approaches and a lack of sufficient woody vegetation for nutrition and thermal protection requirements drive pronghorns to bajada habitat in the southeast portion of the range by early summer.

The diet of Sonoran pronghorns consists of forbs, shrubs, cacti, trees, and grasses. Sonoran pronghorns drink minimal amounts of water, even when it is available. It is belicved that water consumption varies inverscly with the quantity and succulence of plants consumed (Beale and Smith 1970).

Sonoran Pronghorn does become sexually mature at 16 months, and bucks become mature at 1 year of age (Kitchen and O'Gara 1974). Bucks eongregate in the summer for breeding and to pursue females. Does break off from groups to search for fawning areas. Gestation is approximately 240 days, and fawns are born between February and May, and parturition appears to coincide with spring forage abundanec. Does usually have twins, and fawns appcar to suckle for about 2 months, fceding on vegetation soon after. Fawning areas have been documented in the Mohawk Duncs and the bajadas of the Sierra Pintas, Mohawk, Bates, and Growler mountain ranges.

The Sonoran pronghorn was federally listed as endangered on March 11, 1967 (32 FR 4001). Critical habitat has not been designated for the subspecies. The decline of the subspecics is attributable to a number of factors, including a lack of recruitment, insufficient foragc and/or water, drought coupled with predation, difficulties for population expansion due to barriers to historical habitat, illegal hunting, degradation of habitat from livestock grazing, the diminishing size of the Gila and Sonoyta rivers, and human eneroachment. Current threats to the subspecies include highways, fences, and other man-made features that block aceess to essential forage or water resources; human activities (e.g., livestock grazing, military activities, recreation) that disturb pronghorn or degrade habitat; frequent wildfires; drought and associated limited food and water; and small population sizc and random changes in demographies (USFWS 2010pp). In 2002 the U.S. population of Sonoran pronghorn declined by 83 percent, to 21 animals, as a result of severe drought.

\section{Effects of Herbicide Treatments on the Sonoran Pronghorn}

\section{Direct Effects}

Although pronghorns would readily flee areas in which herbicide applications were occurring, it is possible that an accidental spray of Sonoran pronghorns could occur. Since pronghorns are a large, readily visible species, the likelihood of an aceidental direet spray is low. Pronghorns could also eome into dermal contact with sprayed foliage, or ingest sprayed vegetation after the application. According to the ERAs, none of the herbicides considered in this BA would result in adverse health effects to Sonoran pronghorns under any of these potential exposure scenarios (Tables 6-2 and 6-5).

\section{Indirect Effects}

Over the short term, herbicide treatments could reduce the cover of forage in pronghorn habitat. Sonoran pronghorns rely on riparian areas as habitat corridors. The three herbieides could be used in dry riparian habitats. 
Herbicide treatments in riparian areas used by pronghorns as corridors could reduce the overall plant cover in these areas, making them less desirable for use as corridors, although based on the likely usage of the three new active ingredients wide-seale removal of riparian vegetation is unlikely to oceur. Over the long term, the quality of forage would improve, as non-native plant species would likely be less prevalent. The Sonoran pronghorn oeeurs in desert habitats, many of which have been impacted by non-native plant species. The invasion of exoties typically oecurs at the expense of native plant species, including Sonoran pronghorn forage plants. Therefore, any treatments that aid in returning native conditions to habitat should have a beneficial effect on the species.

\section{Conservation Measures}

When using aminopyralid, fluroxypyr, and rimsulfuron in vegetation treatment programs, the BLM would follow all pertinent SOPs for use, transport, and handling of herbicides. The BLM would also continue to follow the conservation measures identified in the $2007 \mathrm{BA}$, or other comparable measures that would be developed by the field offices based on local site conditions and ineluded in local-level consultation. No additional eonservation measures have been identified that are specific to the three new herbicides. However, additional project-specific conservation measures may be developed and applied at the local level, as neeessary, to minimize effects to the species.

\section{Key Conservation Measures for the Sonoran Pronghorn from the 2007 BA}

- Prior to treatments, survey all suitable habitat in areas proposed for treatment for Sonoran pronghorns.

- Avoid fawning areas during treatments.

- Closely follow all application instruetions and use restrictions on herbicide labels (ineluding aquatic and wetland habitat use restrietions).

- Avoid broadeast spraying herbicides in key pronghorn foraging areas.

\section{Determination of Effects}

Based on the ERAs, none of the three herbicides would be likely to adversely affect Sonoran pronghorn under any of the modeled exposure seenarios. Following the conservation measures from the $2007 \mathrm{BA}$ would help minimize adverse impacts to this species. As a result, the action would be Not Likely to Adversely Affect Sonoran pronghorns at the programmatic level. Given BLM mandates for use of integrated pest management (ineluding vegetation management), and given that it is not possible to forecast site-specific vegetation management needs below the programmatic level, additional evaluations of situation-specific effects will be the subject of step-down ESA Section 7 evaluations and subsequent eonsultations. In this manner, any additional specifie conservation measures necessary to accommodate site or situation-specific peculiarities not predictable at the programmatic level will be developed at the local level and ineorporated into Pesticide Use Proposals prior to local implementation of vegetation management activities that involve the use of herbicides considered in this BA.

\section{Small Wetland Mammals: Hualapai Mexican Vole, Amargosa Vole, Preble's Meadow Jumping Mouse, New Mexico Meadow Jumping Mouse, Riparian Woodrat, and Buena Vista Lake Ornate Shrew}

\section{Hualapai Mexican Vole}

The primary reference for this section is:

USFWS. 1991b. Hualapai Mexican Vole Reeovery Plan. Albuquerque, New Mexico.

References cited in this section are internal to the above-referenced document. Full citations have been included in the Bibliography.

The Hualapai Mexican vole (Microtus mexicanus hualpaiensis) is a subspecies of the Mexican vole (Microtus mexicanus) that occurs in the Hualapai Mountains of Arizona. The subspecies has been found at elevations between approximately 5,400 and 8,400 feet, and is generally associated with woodland forest types containing grasses and grass-sedge habitats. Habitats tend to be dry, although when it is the only vole species present, it oecurs in moister habitats as well (Spicer et al. 1985). The Hualapai vole is associated with moist grass-sedge areas along 
permanent or semi-permanent waters fed by springs or seeps in either open forest or chaparral. Good eover of grasses, sedges, and forbs is characteristie of this waterside vole habitat, which is usually found in narrow bands paralleling the watercourse.

Although there is little information on Hualapai vole food habitats, the diet of most vole speeies usually ineludes green plant material, when available. It is likely that the Hualapai vole utilizes a typical vole diet of lush forbs and grasses. The subspeeies has been observed during both day and night (Spicer et al. 1985), and is believed to be active year-round. Burrows and runways may be present within suitable habitat.

It is believed that the life history of the Hualapai vole is similar to that of other Mexican vole subspecies, whieh have small litters. Pregnant females are present from at least late spring through summer. Like other vole speeies, population levels may fluctuate on annual and perennial eyeles. These cycles may eorrespond with precipitation and resulting growth of vegetation (Spicer et al. 1985).

The Hualapai Mexiean vole was federally listed as endangered on October 1, 1987 (52 FR 36776). Critical habitat has not been designated. It is assumed that when grassy and herbaceous habitats were more abundant in the Hualapai Mountains, the Hualapai vole was more eommon and widespread than it is today. In addition, the waterside habitats were onee more extensive and intereonneeted than they are today. Grazing, mining, road construetion, and recreational uses have eontributed to the elimination and destruction of vole habitat in the Hualapai Mountains. Primary threats to the vole and its habitat are grazing and reereation use and development. All remaining habitat areas are small and isolated from each other and are easily degraded by grazing, drought, and reereational use.

\section{Amargosa Vole}

The primary referenee for this seetion is:

USFWS. 1997h. Amargosa Vole (Microtus californicus scirpensis) Recovery Plan. Portland, Oregon.

References eited in this seetion are internal to the above-referenced document. Full eitations have been ineluded in the Bibliography.

The 2009 5-year review for the Amargosa vole (USFWS 2009ggg) was consulted for updated information on this speeies.

The Amargosa vole (Microtus californicus scirpensis) is a desert subspecies of the widely distributed California vole (Microtus californicus) with a highly localized range in the central Mojave Desert of California. The subspeeies has been found in isolated wetland habitats where bulrush is a dominant perennial overstory speeies. These wetlands form continuous bands along the Amargosa River, and are broken by more "eharacteristie" desert vegetation dominated by creosote bush, burro bush, and desert holly. Perennial tributary spring sourees interspersed along this seetion of the Amargosa River additionally ereate mesic habitat "islands" of eattails and bulrush, ranging in size from less than 1 to over 5 acres.

The historical range of the Amargosa vole apparently was limited to wetland pockets extending from the desert community of Shoshone, Inyo County, to the Amargosa Canyon, Inyo County, California. The largely subterranean Amargosa River and an associated series of small tributary springs maintain an isolated 10-linear mile streteh of perennial surface water. Within this range, the current distribution of the vole appears to coineide prineipally with isolated bulrush-eattail pockets that are not subjected to regular inundation during heavy summer thunderstorms.

Little is known about the life history of the Amargosa vole; however, it is probably similar to that of the California vole, whieh is described below.

Voles are primary eonsumers and often the prineipal herbivores within oeeupied habitats (Rose and Birney 1985). They may excavate an extensive underground network of runways and tunnels (Wolff 1985), and in dense cover 
frequently develop extensive surface runways (Taitt and Krebs 1985). The inability to concentrate urine and conserve water is a major reason for the vole's distributional restriction to mesic and wetland habitats (Getz 1985). Voles lack physiological or morphological characteristics that would allow them to tolerate high temperatures (Rose and Birney 1985). Therefore, they require a regular intake of large amounts of water, meeting or exeeeding 10 percent of body weight per day (Batzli and Pitelka 1971).

California voles are active throughout the year. Activity usually occurs in daylight hours during winter months, although animals my become crepuscular and nocturnal through the summer (Madison 1985). The main food items consumed by voles are grasses and forbs, as well as seeds (Heske et al. 1984). When seasonally available, green emergent vegetation comprises the bulk of the diet; grass seeds predominate in the diet during the summer and autumn (Batzli and Pitelka 1971).

Reproduction may occur at any time of year, but is primarily influenced by factors, such as temperature and precipitation, that determine the availability of food and water (Hoffman 1958, Seabloom 1985). In central California, vole populations peak during the spring and begin declining in late summer (Hoffmann 1958). Reproduetive maturity is reached when females attain a weight of 0.9 to 1.1 ounces and males a weight of 1.2 to 1.4 ounces. Vole nests are composed of dried grass and may be placed above or below ground (Wolff 1985). In central California, litter size increases from about three at the beginning of the breeding season in the fall, to a peak of about six in the spring (Hoffman 1958). Mean litter size for the species is 4.7 (Nadeau 1985). Young are born after a gestation of 21 days, and are weaned after 14 days. California vole populations are subject to booms and crashes on a 2- to 4-year cycle.

The Amargosa vole was federally listed as endangered with eritical habitat on November 15, 1984 (49 FR 45160). Critical habitat for the species encompasses an area of 4,520 acres in southeastern Inyo County, California. Within critical habitat areas the major constituent elements that are known to require special management consideration or protection are marsh vegetation (primarily bulrushes), springs, and some open water along the Amargosa River, which provide escape cover and an adequate food supply. The main eause for listing was loss of habitat as a result of livestock grazing, marsh burning, and diversion and channelization of spring outflows. The BLM and other landowners have helped to minimize these threats; the BLM has established an ACEC and managed its land uses to minimize impacts to habitat. Nonetheless, factors that continue to threaten the subspecies include localized burning of marsh vegetation on private land, salt cedar invasion of Amargosa volc habitat, diversion of spring outflows, predation by domestic cats, interspecific competition with house mice, and the genetic consequences of small, fragmented populations (USFWS 2009ggg).

\section{Preble's Meadow Jumping Mouse}

The primary reference for this section is:

USFWS. 2002s. Designation of Critical Habitat for the Preble's Meadow Jumping Mouse (Zapus hudsonius preblei). Federal Register 67(137):47153-47210.

References cited in this section are internal to the above-referenced document. A complete list of these references is available from the USFWS Colorado Ecological Services Field Office, Lakewood, Colorado.

Preble's meadow jumping mouse (Zapus hudsonius preblei) is found along the foothills in southeastern Wyoming, southward along the eastern edge of the Front Range of Colorado to Colorado Springs, El Paso County (Hall 1981; Clark and Stromberg 1987; Fitzgerald et al. 1994). The subspecies is likely an Ice Age relict (Hafner et al. 1981; Fitzgerald et al. 1994) that was confined to riparian systems where moisture was more plentiful after the glaciers receded from the Front Range of Colorado and the foothills of Wyoming and the climate became drier. The semiarid climate in southeastern Wyoming and eastern Colorado limits the extent of riparian corridors and restricts the range of the Preble's meadow jumping mouse in this region. The eastern boundary for the subspecies is likely defined by the dry shortgrass prairie, which may present a barrier to eastward expansion (Beauvais 200I). The western boundary of Preble's range in both states appears related to elevation along the Laramie Range and Front Range; the general upward limit of the subspecies' habitat in Colorado is 7,600 feet (USFWS 1998). 
Typical habitat for the Preble's meadow jumping mouse comprises well-developed plains riparian vegetation with adjacent, undisturbed grassland communities and a nearby water source. Well-developed plains riparian vegetation typically includes a dense combination of grasses, forbs, and shrubs; a taller shrub and tree canopy may be present (Bakeman 1997). When present, the shrub canopy is often willow, although shrub species including snowberry, chokecherry, hawthorn, gambel oak, gray alder, river birch, skunkbrush, wild plum, lead plant, red-osier dogwood, and others also may oceur (Bakeman 1997, Shenk and Eussen 1998). Preble's meadow jumping mice regularly use uplands at least as far out as 330 feet beyond the 100-year floodplain for feeding and resting (Ryon 1999, Shenk 2002). The subspecies can also move considerable distances along streams, as far as 1 mile in one evening (Ryon 1999, Shenk and Sivert 1999a).

The abundance of Preble's meadow jumping mice at a given location is not likely to be driven by the diversity of plant species, but by the density of riparian vegetation. The tolerance of Preble's meadow jumping mice for exotic plant species is not well understood. However, there is particular concern about non-native species such as leafy spurge that may form a monoculture, displacing native vegetation and thus reducing available habitat.

The Preble's meadow jumping mouse construets day nests composed of grasses, forbs, sedges, rushes, and other available plant material. They may be globular in shape or simply raised mats of litter, and are most commonly above ground, but also can be below ground. They are typically found under debris at the base of shrubs and trees, or in open grasslands (Ryon 2001). An individual mouse can have multiple day nests in both riparian and grassland communities (Shenk and Sivert 1999a), and may abandon a nest after approximately a week of use (Ryon 2001). Hydrologic regimes that support Preble's habitat range from large perennial rivers such as the South Platte River to small temporary drainages only 3 to 10 feet in width, as at Rocky Flats and in montane habitats. Flooding is a common and natural event in the riparian systems along the Front Range of Colorado. This periodic flooding helps create a dense vegetative community by stimulating resprouting from willow shrubs, and allows herbs and grasses to take advantage of newly-deposited soil. Fire is also a natural component of the Colorado Front Range and Wyoming foothills, and Preble's meadow jumping mouse habitat naturally decreases in size in response to a firc event, and then increases in size again until the next fire. Within shrubland and forest, intensive fire may result in adverse impacts to Preble's populations. However, grassland fires on small mammals may have little effect, or even a positive effect.

Preble's meadow jumping mice eat insects, fungus, moss, pollen, willow, lamb's quarters, Russian thistle, sunflowers, sedge, mullein, brome, fescue, bluegrass, dropseed, wheatgrass, bladderpod, scouring rush, and assorted seeds (Shenk and Eussen 1998, Shenk and Sivert 1999a). The diet shifts seasonally, consisting primarily of insects and fungus after emerging from hibernation, and shifting to fungus, moss, and pollen during midsummer (July to August), with insects again added in September (Shenk and Sivert 1999a). The shift in diet along with shifts in mouse movements suggests that the Preble's meadow jumping mouse may require specific seasonal diets, perhaps related to the physiological constraints imposed by hibernation. The Preble's meadow jumping mouse is a true hibernator, usually entering hibernation in September or October and emerging the following May, after a potential hibernation period of 7 or 8 months. Adults are the first age group to enter hibernation because they accumulate the necessary fat stores earlier than young of the year. Similar to other subspecies of meadow jumping mouse, Preble's meadow jumping mouse do not store food, but survive on fat stores accumulated prior to hibernation (Whitaker 1963). Preble's meadow jumping mice are primarily nocturnal or erepuscular but also may be active during the day, when they have been seen moving around or sitting still under a shrub (Shenk 1998).

Preble's meadow jumping mice usually have two litters per year, but there are records of three litters per year. An average of five young are born per litter, but the size of a litter ean range from two to eight young (Quimby 1951, Whitaker 1963). The Preble's meadow jumping mouse is long-lived for a small mammal, in comparison with many species of mice and voles that seldom live a full year. However, like many small mammals, the subspecies' annual survival rate is low. The Preble's meadow jumping mouse has a host of known predators, including garter snakes, prairie rattlesnakes, bullfrogs, red and grey foxes, house eats, long-tailed weasels, and red-tailed hawks (Shenk and Sivert 1999a, Schorr 2001). Other potential predators include coyotes, barn owls, great horned owls, screech owls, long-eared owls, northern harriers, and large predatory fish. Other mortality factors of the Preble's meadow jumping mouse include drowning and vehicle collision. Mortality factors known for the meadow jumping mouse, 
such as starvation, exposure, disease, and insufficient fat stores for hibernation, also are likely causes of death for the Preble's meadow jumping mouse (Whitaker 1963).

The Preble's meadow jumping mouse was federally listed as threatened on May 13, 1998 (63 FR 26517). On June 23, 2003, the USFWS designated river and stream habitat in Colorado and Wyoming as critical habitat (68 FR 37276). On December 15, 2010, the designation was revised, and the total coverage of eritical habitat now includes 411 miles of streams and 34,935 acres in Boulder, Broomfield, Douglas, El Paso, Jefferson, Larimer, and Teller Counties, Colorado (75 FR 78430). The Preble's meadow jumping mouse is closely associated with riparian ecosystems that are relatively narrow and represent a small pereentage of the landscape. If habitat for the Preble's meadow jumping mouse is destroyed or modified, populations in those areas will decline or be extirpated. Thus, the decline in the extent and quality of Preble's meadow jumping mouse habitat is considered the main factor threatening the subspecies (Hafner et al. 1998; Shenk 1998; USFWS 1998). Habitat alteration, degradation, loss, and fragmentation resulting from urban development, flood control, water development, agriculture, and other human land uses have negatively impacted Preble's meadow jumping mouse populations. The subspecies is threatened by current and future human development; a decline in the extent and quality of habitat is the main factor threatening the Preble's meadow jumping mouse (USFWS 2010qq).

\section{New Mexico Meadow Jumping Mouse}

The primary reference for this section is:

USFWS. 2013j. Endangered and Threatened Wildlife and Plants; Listing Determination for the New Mexico Meadow Jumping Mouse. Proposed Rule. Federal Register 78(119):37363-37369.

References cited in this section are internal to the above-referenced document. A complete list of these references is available from the New Mexico Ecological Services Field Office, Albuquerque, New Mexico.

The New Mexico meadow jumping mouse (Zapus hudsonius luteus) is a small mammal that is endemic to New Mexico, Arizona, and a small area of southern Colorado. Its historical distribution likely included riparian wetlands along streams in the Sangre de Cristo and San Juan Mountains, from southern Colorado to central New Mexico, and into parts of the White Mountains in eastern Arizona. Based on more recent data about its distribution and abundance, the New Mexico meadow jumping mouse has declined significantly rangewide, with most local extirpations occurring since the late 1980s to the early 1990s. Since 2005, 29 remaining populations have been documented, nearly all of which are isolated and widely separated. Some of these populations may currently be compromised.

The New Mexico jumping mouse occurs in specialized habitats characterized by tall (averaging 24 inches or more), dense riparian herbaceous vegetation, primarily composed of sedges and forbs. This suitable habitat is found only when wetland vegetation achieves full growth potential associated with perennial flowing water. The vegetation provides food sourees (insects and seeds), as well as the structural material for building day nests that are used for shelter from predators. Jumping mice also need intact upland areas adjacent to riparian and wetland areas to build nests or use burrows to give birth to young in the summer and hibernate over winter.

The New Mexico jumping mouse is generally nocturnal. It hibernates 8 or 9 months out of the year, and is only active during 3 or 4 months in the summer, during which time it must breed, birth and raise young, and store up sufficient fat reserves to survive the next year's hibernation period. The period of activity coincides with the growing season of the grasses and forbs on which it depends. Preparation for hibernation seems to be triggered by day length. Jumping mice only live up to 3 years. They have one small litter of up to seven young annually.

The New Mexico meadow jumping mouse was federally listed as an endangered species on June 10, 2014 (79 FR 331 19). On June 20,2013, the USFWS proposed the designation of 193 miles of eritical habitat for the subspecies within Bernalillo, Colfax, Mora, Otero, Rio Arriba, Sandoval, and Socorro Counties in New Mexico; Las Animas, Archuleta, and La Plata Counties in Colorado; and Greenlee and Apache Counties in Arizona (78 FR 37327). No final determination of eritical habitat has been made to date. The primary threats to the subspecies are loss of habitat from grazing pressure and water management use, lack of water due to drought, and wildfires. Additional 
sources of habitat loss are likely to occur from scouring floods, loss of beaver ponds, highway reconstruction, residential and commercial development, coalbed methane development, and unregulated recreation.

\section{Riparian Woodrat}

The primary reference for this section is:

USFWS. 1998h. Recovery Plan for Upland Species of the San Joaquin Valley. Portland, Oregon.

References cited in this section are internal to the above-referenced document. Full citations have been included in the Bibliography.

The riparian woodrat (Neotoma fuscipes riparia), also called the San Joaquin Valley woodrat, is 1 of 11 subspecies of the dusky-footed woodrat (Hooper 1938). There is currently only one known population of the riparian woodrat, which occurs in riparian forest on the Stanislaus River in Caswell Memorial State Park, California. Riparian woodrats are found in stands of deciduous valley oaks, and are most numerous where shrub cover is dense and least abundant in open areas. The highest densities of woodrats are often encountered in willow thickets with an oak overstory (Linsdale and Tevis 1951). For the most part, woodrats are generalist herbivores, consuming a wide variety of nuts, fruits, fungi, and foliage, as well as some forbs.

Riparian woodrats make large houses out of sticks and other litter, which range from 2 to 5 feet in height, and from 4 to 8 feet in basal diameter. These houses are typically placed in the ground, against or straddling a log or exposed roots of a standing tree, and are often located in dense brush. Nests are also placed in the crotehes and cavities of trees and in hollow logs.

Riparian woodrats live in loosely-cooperative societies, and a maternal-based social structure (Kelly 1990). Whereas adjacent females are usually elosely related, males disperse away from their birth den and are highly territorial and aggressive, especially during the breeding season. The effective population size (i.c., successful breeders) of riparian woodrats is generally much smaller than the actual population size.

The riparian woodrat was federally listed as endangered on February 23, 2000 (65 FR 8881). Critical habitat has not been designated. As for many species occurring in the San Joaquin Valley of California, loss and fragmentation of habitat are the principal reasons for the decline of the riparian woodrat. The remaining population of the species is at an increased risk for extinetion because of its small size. In addition, the population is vulnerable to flooding of the Stanislaus River, which can severely damage woodrat houses.

\section{Buena Vista Lake Ornate Shrew}

The primary referenees for this section are:

USFWS. 1998h. Recovery Plan for Upland Species of the San Joaquin Valley. Portland, Oregon.

and

USFWS. 2005j. Final Rule to Designate Critical Habitat for the Buena Vista Lake Shrew (Sorex ornatus relictus). Federal Register 70(14):3438-3461.

References cited in this seetion are internal to the recovery plan refereneed above. Full citations have been included in the Bibliography.

The Buena Vista Lake ornate shrew (Sorex ornatus relictus) is one of nine subspecies of the ornate shrew (Sorex ornatus; Merriam 1895, Hall 1981, Junge and Hoffman 1981). The species formerly oceurred in wetlands around Buena Vista Lake, and presumably throughout the Tulare Basin (Grinnell 1932, 1933; Williams and Kilburn 1984; Williams 1986), but little is known about its current distribution. The shrew is known to oceur in areas with dense wetland vegetative cover and an abundant layer of decomposed vegetation (Center for Conservation Biology 1990 , Maldonado 1992), and like other ornate shrews may be more associated with the structure of the vegetation in suitable habitats, rather than the plant species composition. The dominant plant species present in areas where the 
shrew has recently been eaptured include Fremont cottonwood, willows, glasswort, alkali heath, wild-rye grass, and Baltic rush. Although the specifie feeding and foraging habits of Buena Vista Lake ornate shrews are not known, it is likely that, like other shrews, they feed on inseets and other invertebrates (Harris 1990, Maldonado 1992). Shrews are thought to burrow (Rudd 1953) and utilize the burrows of other animals (Pearson 1959).

Although details of the shrews reproduction and mating are not known, it is believed that the breeding season for this subspecies may begin in autumn and end when the dry season begins in May or June. In areas where wetlands do not dry up during the dry season, the breeding season may last longer (Center for Conservation Biology 1990). Up to two litters, each containing four to six young, are produeed per year (Owen and Hoffman 1983).

The Buena Vista Lake ornate shrew was listed as endangered on March 6, 2002 (67 FR 10101). On January 24, 2005, the USFWS originally designated approximately 84 acres within the Central Valley floor of Kern County, California, as eritical habitat for the species (70 FR 3438). On July 2, 2103, the eritical habitat designation was revised to in include approximately 2,485 aeres in Kings and Kern Counties, California (78 FR 39836). The major causes for the deeline of the shrew are loss and fragmentation of habitat as a result of converting lands to agriculture and diverting fresh water supplies (Williams and Kilburn 1984, 1992). It is believed that there may be a single remaining population of this subspecies, existing in a very small area of suitable habitat. Threats to the species include natural or human-eaused changes to the remaining habitat for this speeies, selenium poisoning, and a lack of other viable populations in the area to recolonize the site should an extirpation of the population oeeur.

\section{Effects of Herbicide Treatments on the Hualapai Mexican Vole, Amargosa Vole, Preble's Meadow Jumping Mouse, New Mexico Meadow Jumping Mouse, Buena Vista Lake Ornate Shrew, and Riparian Woodrat}

\section{Direct Effects}

Use of ATVs/UTVs, trucks, or horses to apply herbicides could eause some mortality or injury to these small TEP mammals as a result of erushing. Since the Hualapai Mexican vole, Amargose vole, Preble's meadow jumping mouse, New Mexico meadow jumping mouse, riparian woodrat, and Lake Buena Vista ornate shrew all utilize vegetation for cover from predators, and may have above-ground nests, it is conceivable that some animals eould be sprayed inadvertently during herbieide treatments. These small mammals may also come into eontaet with or ingest sprayed vegetation following a treatment with one or more of the new herbicides.

According to the ERAs, none of the herbicides considered in this BA would result in adverse health effects to these species under any of the modeled exposure seenarios (direet spray, dermal contact with sprayed vegetation, or ingestion of sprayed food items; Tables 6-2 and 6-5).

\section{Indirect Effects}

Removal of vegetation from the habitat of these five speeies would be expected to have short-term adverse effeets. All five of these mammals rely on dense vegetation for cover from predators, even utilizing habitat with a large component of non-native plant species. The Preble's meadow jumping mouse, for example, utilizes habitats where Canada thistle, toadflax, and smooth brome are present (Colorado Natural Heritage Program 1999). Herbicide treatments in mouse, vole, shrew or woodrat habitat could reduce vegetative cover, temporarily exposing animals to increased predation. In addition, the availability of food could be reduced temporarily. However, based on the likely usage of the three new active ingredients, wide-seale removal of riparian vegetation is unlikely to occur. Use of trucks or ATVs/UTVs could crush aboveground nests present on the treatment site.

Removal of non-native species would have long-term benefits. In riparian and wetland habitats, where these species occur, invasion and spread of non-native plant species typically results in degraded habitat. In the case of the Amargosa vole, the invasion of habitat by tamarisk is a threat because it displaces native plant species, such as bulrush, and because salt exudation from tamarisk leaves reduces the prevalence of a lower canopy flora, on which voles rely for food and cover (USFWS 1997h). Tamarisk also contributes to water loss, and can reduce the coverage of wetlands. Russian olive and knapweed are non-native species that can potentially replace critical components of Preble's meadow jumping mouse habitat (Colorado Natural Heritage Program 1999). Treatments 
that reduce the coverage of non-native plant species could also increase the suitability of wetland and riparian areas within the speeies' ranges, potentially increasing the acreage of habitat available for these speeies in the future.

\section{Conservation Measures}

When using aminopyralid, fluroxypyr, and rimsulfuron in vegetation treatment programs, the BLM would follow all pertinent SOPs for use, transport, and handling of herbieides. The BLM would also continue to follow the conservation measures identified in the $2007 \mathrm{BA}$, or other comparable measures that would be developed by the field offices based on local site eonditions and included in local-level consultation. No additional eonservation measures have been identified that are speeifie to the three new herbicides. However, additional projeet-speeifie conservation measures may be developed at the local level, if appropriate.

\section{Key Conservation Measures from the 2007 BA}

- $\quad$ Survey suitable habitat for these species prior to developing treatment programs at the local level.

In areas where surveys indicate that the Hualapai Mexiean vole, Amargosa vole, Preble's meadow jumping mouse, New Mexico meadow jumping mouse, riparian woodrat, or Buena Vista Lake ornate shrew oeeur:

- Address Hulalpai Mexican voles, Amargosa voles, Preble's meadow jumping mice, New Mexieo meadow jumping miee, riparian woodrats, and Buena Vista Lake ornate shrews in all management plans prepared for treatments within areas that eontain habitat for these speeies.

- Use manual spot applieation of herbieides rather than broadeast treatments.

- Closely follow all applieation instruetions and use restrietions on herbicide labels (ineluding aquatic and wetland habitat use restrictions).

\section{Determination of Effects}

Based on the ERAs, none of the three herbicides would be likely to adversely affect Hualapai Mexican vole, Amargosa vole, Preble's meadow jumping mouse, New Mexieo meadow jumping mouse, riparian woodrat, or Buena Vista Lake ornate shrew under any of the modeled exposure seenarios. Following the conservation measures from the $2007 \mathrm{BA}$ would help minimize adverse impacts to these species. As a result, the action would be Not Likely to Adversely Affect Hualapai Mexican vole, Amargosa vole, Preble's meadow jumping mouse, or Buena Vista Lake ornate shrew or their federally designated critical habitats at the programmatic level. Similarly, the action is not likely to jeopardize the continued existence of the New Mexieo meadow jumping mouse or result in the destruetion or adverse modification of proposed critieal habitat. Should this speeies be listed in the future, the proposed action would be Not Likely to Adversely Affect the New Mexieo meadow jumping mouse or its eritical habitat. Given BLM mandates for use of integrated pest management (ineluding vegetation management), and given that it is not possible to forecast site-speeific vegetation management needs below the programmatic level, additional evaluations of situation-specific effects will be the subjeet of step-down ESA Section 7 evaluations and subsequent eonsultations. In this manner, any additional specific conservation measures neeessary to aceommodate site or situation-specific peculiarities not predictable at the programmatic level will be developed at the local level and incorporated into Pesticide Use Proposals prior to local implementation of vegetation management activities that involve the use of herbieides considered in this BA.

\section{Northern Idaho Ground Squirrel}

The primary reference for this section is:

USFWS. 2000i. Determination of Threatened Status for the Northern Idaho Ground Squirrel. Federal Register $65(66): 17779-17786$.

References eited in this section are internal to the above-referenced document. A eomplete list of these references is available from the USFWS Snake River Basin Office, Boise, Idaho.

The 2011 5-year review for the northern Idaho ground squirrel (USFWS 2011ee) was consulted for updated information on this species. 
The northern Idaho ground squirrel (Spermophilus brunneus brunneus) has one of the smallest ranges of any North American mainland mammal (Gill and Yensen 1992), and is known from 36 sites in Adams and Valley Counties, Idaho. Populations occur at elevations ranging from 3,800 to 5,200 feet, and are associated with xeric meadows surrounded by ponderosa pine and Douglas-fir forest. However, the ground squirrel is not abundant in meadows that are surrounded by high densities of small young trees (Sherman and Yensen 1994). Soil texture and depth ean be a primary factor in determining species distribution for the northern Idaho ground squirrel (Brown and Harney 1993). The subspecies often digs burrows under logs, rocks, or other objeets (Sherman and Yensen 1994). Dry vegetation sites with shallow soil horizons of less than 20 inches depth above basalt bedrock to develop burrow systems are preferred (Yensen et al. 1991). Nesting burrows are found in well-drained soils greater than 3 feet deep, in areas not covered with trees or used by Columbian ground squirrels.

The northern Idaho ground squirrel eats small seeds and grain seasonally, and ingests large amounts of bluegrass and other grass seeds to store energy for the winter. The subspecies will also consume the roots, bulbs, leaf stems, and flower heads of another 45 to 50 plant species that are major eomponents of the diet during key periods of the spring and summer. Therefore, a diverse component of forbs and grass species present appears to be important for conservation of the species (USFWS 2011 ee).

The northern Idaho ground squirrel emerges in late March or early April, remains active above ground until late July through early September (Yensen 1991, USFWS 2011ee), and spends the rest of the year in hibernation underground (Yensen 1999). Seasonal torpor (a state of sluggishness or inactivity) generally oceurs in early to midJuly for males and females, and late July to early August for juveniles. The subspecies normally becomes reproductively aetive within the first 2 weeks of emergenee (Yensen 1991). Females that survive the first winter live, on average, nearly twice as long as males (3.2 years for females and 1.7 years for males). During the mating period, males move considerable distances in search of receptive females for mating, and often fight with other males for copulations, thereby exposing themselves to predation by raptors.

The northern Idaho ground squirrel was federally listed as threatened on April 5, 2000 (65 FR 17780). Critical habitat for the squirrel was deemed prudent, but has not yet been designated. The estimated population of the subspecies decreased rapidly between 1985 and 2002, but has since increased and the current trend is an increasing population with an expanding distribution across the landscape (USFWS $2011 \mathrm{ee}$ ). The subspecies is primarily threatened by habitat loss resulting from forest encroachment into former suitable meadow habitats. Logging and fire suppression have led to increased dense stands of trees lacking an understory. Such forest encroachment results in habitat fragmentation, eliminates dispersal corridors, and restriets the squirrel's population into small, isolated habitat areas. The northern Idaho ground squirrel is also threatened by loss of habitat due to land use changes, illegal recreational shooting, predation, inadequacy of existing regulatory information regarding private land development, competition with Columbian ground squirrels, and small populations and naturally occurring events (USFWS 2011 ee).

\section{Effects of Herbicide Treatments on the Northern Idaho Ground Squirrel}

\section{Direct Effects}

During herbicide treatments, any northern Idaho ground squirrels unable to flee the area could be inadvertently injured or killed by trucks or ATVs/UTVs used to apply herbicides. Although direet spray of northern Idaho ground squirrels is unlikely, it could potentially oceur during herbicide treatment programs in the species' habitat outside of the hibernation period. Additionally, ground squirrels could come into contact with foliage after spraying has oceurred. Another possible herbicide exposure pathway is through consumption of vegetation that has been sprayed by an herbicide.

Based on the results of the ERAs, none of the three herbicides considered in this BA pose a risk to the northern Idaho ground squirrel via exposure scenarios involving direct spray, dermal contact with sprayed vegetation, or ingestion of sprayed vegetation (Tables 6-2 and 6-5). 


\section{Indirect Effects}

A large portion of the diet of the northern Idaho ground squirrel consists of seeds from native bunchgrasses. These fire-resistant plants, in the absenee of fire, have been overwhelmed by non-native invaders, which are a poorer food source for the squirrel, and which degrade the quality of habitat. Herbieide treatments in northern Idaho ground squirrel habitat could affect populations if the eover of native bunchgrasses were reduced. Over the long term, however, herbicide treatments would likely improve ground squirrel habitat, sinee native bunchgrasses would benefit from the removal of weeds. In addition, removal of non-native species in already-degraded habitats where the squirrel no longer oceurs may inerease their suitability for supporting this species in the future. Thus, herbicide treatments eould also potentially increase the aereage of northern Idaho ground squirrel habitat.

\section{Conservation Measures}

When using aminopyralid, fluroxypyr, and rimsulfuron in vegetation treatment programs, the BLM would follow all pertinent SOPs for use, transport, and handling of herbicides, as well as all of the applicable eonservation measures for herbicide use that were identified in the 2007 BA. The BLM would also eontinue to follow the eonservation measures identified in the $2007 \mathrm{BA}$, or other comparable measures that would be developed by the field offices based on loeal site conditions and included in local-level consultation. No additional conservation measures have been identified that are specific to the three new herbicides. However, at the time of projeet-level NEPA review, loeal BLM offices would develop additional eonservation measures, if needed, that are speeifie to both the projeet and the site.

\section{Key Conservation Measures for the Northern Idaho Ground Squirrel from the 2007 BA}

- Prior to conducting treatments, survey the area to be treated for northern Idaho ground squirrels.

- At the loeal level, address northern Idaho ground squirrels and their habitat when developing management plans for proposed treatments.

- Where squirrels are detected, conduct vegetation treatments during the hibernation season, where feasible.

- Design treatments so that only a portion of northern Idaho ground squirrel habitat is in a state of reeovery at any one time.

- Design treatments to avoid injury to native bunehgrasses in northern Idaho ground squirrel habitat; consult plant buffer distanees and other eonservation measures for sensitive plants in Chapter 4 for guidance.

\section{Determination of Effects}

Based on the ERAs, none of the three herbicides would be likely to adversely affect northern Idaho ground squirrel under any of the modeled exposure seenarios. Following the eonservation measures from the 2007 BA would help minimize adverse impacts to this species and its habitats. As a result, with applieation of these conservation measures, the action would be Not Likely to Adversely Affect Northern Idaho ground squirrel at the programmatie level. Given BLM mandates for use of integrated pest management (ineluding vegetation management), and given that it is not possible to foreeast site-speeifie vegetation management needs below the programmatie level, additional evaluations of situation-specifie effeets will be the subjeet of step-down ESA Section 7 evaluations and subsequent consultations. In this manner, any additional specifie conservation measures necessary to aceommodate site or situation-specific peculiarities not predictable at the programmatic level will be developed at the local level and ineorporated into Pesticide Use Proposals prior to local implementation of vegetation management activities that involve the use of herbicides eonsidered in this BA.

\section{Woodland Caribou}

The primary referenee for this seetion is:

USFWS. 1994k. Recovery Plan for Woodland Caribou in the Selkirk Mountains. Portland, Oregon.

References eited in this seetion are internal to the above-references document. Full citations have been ineluded in the Bibliography.

The woodland earibou (Rangifer tarandus caribou) primarily oecurs in Canada, but there is a small population-the Selkirk Mountain population-that extends into the northwestern United States. This population is 
generally found at elevations above 4,000 feet in the Selkirk Mountains, in Engelmann spruee/subalpine fir and western red cedar/western hemlock forest types. Prior to 1900, woodland earibou were distributed throughout northeastern, northeentral, and northwestern United States. However, since the $1960 \mathrm{~s}$, the last remaining population in the United States has restricted its range to the Selkirk Mountains of northeastern Washington and northern Idaho (in addition to southeastern British Columbia in Canada). The southern Selkirk Mountains woodland caribou population is now the southernmost extant population of mountain caribou and the last remaining mountain earibou population in the U.S. The most reeent estimate for the southern Selkirk Mountains population is less than 50 animals, nearly all of which oceur in Canada (USFWS 2011ff).

Woodland earibou, in general, do not make the long, mass migrations for which tundra earibou are famous. However, seasonal movements and migrations are characteristic of many, though not all, woodland caribou herds (Shoesmith and Storey 1978; Bloomfield 1980; Símpson et al. 1985; Antifeau 1987; Cichowski 1989; Servheen and Lyon 1989). Generally, the mountain ecotype of woodland caribou exhibit five distinet seasonal movements. In early winter, caribou shift to lower elevation habitats best characterized by mature to old-growth subalpine fir/Engelmann spruce and western hemloek/western red cedar forest types, and the ecotone between them, on moderate slopes with a high density of reeently windthrown arboreal lichen-bearing trees. During early winter, these dense-canopied habitats intercept snow, reducing snow depth on the forest floor and providing green forage later in the season than more exposed forest communities at higher elevations.

The movement from early winter to late winter habitats (taking place anywhere between mid-December and midJanuary) oceurs as snow accumulates and hardens, allowing easier movement and lifting the earibou into the lichen-bearing canopy. The Engelmann spruce/subalpine fir forests used during this period are characterized by open eanopies, and are generally above 6,000 feet in elevation (Servheen and Lyon 1989). Areas with moderate slopes on all aspects are most suitable for caribou during this period. Caribou are often located on ridge tops or open slopes with open, old-growth forests.

In spring, caribou move to areas of new growth, which are typically located at mid-elevation in open-canopied areas, often adjacent to mature forest (Seott and Servheen 1985, Servheen and Lyon 1989). These areas provide high quality forage in early spring, allowing earibou to reeover from the effects of winter. Pregnant females move to typical spring habitat in April or May, then move back to snow-eovered areas, often at higher elevations, to calve in early June. The areas selected for calving by the Selkirk Mountain earibou typically support old noneommercial forests with high lichen densities, open canopies, and small trees. Lichen again beeomes the primary food source because green forage is unavailable at these elevations in carly June (Servheen and Lyon 1989).

Caribou spend the summer in alpine and subalpine vegetative zones, primarily in areas of high forage availability. In early summer, open-canopied stands provide an abundance of forbs and huckleberry leaves (Seott and Servheen 1985), and as summer progresses the caribou move to more elosed-canopy forest stands supporting forbs that mature later in the season (Servheen and Lyon 1989). In the fall, caribou shift to lower elevations and more densely canopied forest in the southern Selkirk Mountains.

Although caribou eat a wide range of foods, winter foraging is limited almost exclusively to arboreal lichens. Selkirk Mountain caribou may depend on arboreal lichens for up to 6 months of the year. During the remainder of the year, the caribou feed extensively on blackberry leaves, Sitka valerian, boxwood, and smooth woodrush.

Caribou generally have a low reproductive rate. Females usually give birth to their first ealf when they are 3 years old, and single calves are the norm. The breeding season peaks in early to mid-October, and calves are born in May or June. Calf mortality during the first few months of life is high, often approaching 50 percent or greater. Common causes of calf mortality include inclement weather, predation, abandonment, and accidents. Selkirk Mountain caribou are polygamous, with adult males defending harems of six to ten cows with calves. The breeding season is unusually short, and peaks during early or mid-October. 
The woodland caribou was federally listed as endangered on February 29, 1984 (49 FR 7390). On November 28, 2012, the USFWS designated approximately 30,010 aeres in Boundary and Bonner Counties, Idaho, and Pend Oreille County, Washington, as eritical habitat (76 FR 74018). The primary long-term threat to the southern Selkirk Mountains earibou is the ongoing loss and fragmentation of contiguous old-growth forest habitats due to a combination of timber harvest, wildfires, and road development (USFWS $2011 \mathrm{ff}$ ). Other potential threats to the speeies include predation by wolves, and low reproductive potential, overhunting and poaehing, eollisions with motor vehicles, and disease and genetic problems from inbreeding.

\section{Effects of Herbicide Treatments on the Woodland Caribou}

\section{Direct Effects}

Although caribou would readily flee areas in which herbieide applieations were oceurring, it is possible that some animals could be sprayed inadvertently. Woodland caribou could also come into dermal contact with sprayed foliage, or ingest sprayed vegetation after the application.

Based on the results of the ERAs, none of the herbieides eonsidered in this BA would result in adverse health effects to woodland caribou under any of the modeled exposure seenarios (direet spray, dermal eontaet with sprayed vegetation, or ingestion of sprayed food items; Tables 6-2 and 6-5).

\section{Indirect Effects}

Herbicide treatments in woodland earibou habitat eould temporarily reduce the cover of available forage. Effeets would be greatest if treatments oeeurred just before or during a period when forage was searee. Over the long term, herbicide treatments could potentially improve the quality of forage in earibou habitat by reducing the cover of non-native species.

Creation of aceess routes into habitat could negatively affect caribou populations. Predation is thought to be the major souree of mortality in caribou populations (Kinley and Apps 2001). Given the already fragmented habitat of the species, any activity that inereases the ability of predators to find caribou (c.g., aceess routes, increased visibility) would likely exaeerbate this problem.

\section{Conservation Measures}

When using aminopyralid, fluroxypyr, and rimsulfuron in vegetation treatment programs, the BLM would follow all pertinent SOPs for use, transport, and handling of herbicides. The BLM would also eontinue to follow the eonservation measures identified in the $2007 \mathrm{BA}$, or other comparable measures that would be developed by the field offices based on local site conditions and included in local-level eonsultation. These measures include practices to proteet neetar plants and roost trees. No additional conservation measures have been identified that are speeific to the three new herbieides. However, local offices may determine that additional project- and site-specific eonservation measures are neeessary during the preparation of project-level NEPA documentation.

\section{Key Conservation Measures for the Woodland Caribou from the $2007 \mathrm{BA}$}

- At the local level, prepare a management plan for all proposed treatment activities that eould potentially oeeur on land utilized by woodland caribou. This management plan must be eompleted with the assistance of a wildlife biologist and a forest ecologist, and must specifically address caribou and earibou habitat.

- Time major herbicide treatments in woodland caribou habitats sueh that they do not oceur during the season when caribou rely on the treatment area for forage.

\section{Determination of Effects}

Based on the ERAs, none of the three herbicides would be likely to adversely affect the woodland caribou under any of the modeled exposure seenarios. Following the conservation measures from the 2007 BA would help minimize adverse impaets to this species. As a result, with application of these eonservation measures, the aetion would be Not Likely to Adversely Affect woodland earibou at the programmatic level. Given BLM mandates for use of integrated pest management (including vegetation management), and given that it is not possible to foreeast site-specific vegetation management needs below the programmatie level, additional evaluations of situation- 
specific effects will be the subject of step-down ESA Section 7 evaluations and subsequent consultations. In this manner, any additional specific conservation measures necessary to accommodate site or situation-speeific peculiarities not predictable at the programmatic level will be developed at the local level and incorporated into Pesticide Use Proposals prior to local implementation of vegetation management activities that involve the use of herbieides considered in this BA.

\section{Grizzly Bear}

The primary reference for this seetion is:

USFWS. 19931. Grizzly Bear Recovery Plan. Missoula, Montana.

References cited in this section are internal to the above-referenced document. Full citations have been included in the Bibliography.

The 2011 5-year review for the grizzly bear (USFWS 2011gg) was reviewed for updated information on this species.

The grizzly bear (Ursus arctos horriblis) was originally distributed in various habitats throughout western North America from Central Mexico to the Arctic Ocean. Its current distribution is reduced to less than 2 percent of its former range south of Canada in five, and perhaps six, small populations. Four regions in the contiguous United States that accommodate grizzly populations: the Northern Continental Divide and Cabinet/Yaak in Montana, the Selkirk Mountains of Idaho and Washington, and the North Caseades of Washington. There is also a population in the Yellowstone ecosystem, and a possible sixth population in the Bitterroot ecosystem in Idaho. In Alaska, where the grizzly bear is more commonly ealled brown bear, populations are healthy (over 30,000 animals), and the species is classified as a game species. In the lower 48 states, it is estimated that there are approximately 1,500 grizzly bears (USFWS $2011 \mathrm{gg}$ ).

The grizzly bear has a broad range of habitat toleranee. Most areas in which the species remains are characterized by contiguous, relatively undisturbed mountainous habitat with a high level of topographic and vegetative diversity. Grizzly bears prefer areas of dense forest cover. In the winter, when there is deep snow, low ambient air temperatures, and an unavailability of food, bears hibernate in den sites. Excavation of dens starts as early as September, though it may occur just prior to entry in late November. Dens are usually dug on steep slopes where wind and topography eause an accumulation of deep snow, but where the snow is unlikely to melt during warm periods. Bears exhibit no overt defense of their dens, and several have been reported to abandon them because of human disturbance.

Seven essential characteristics of grizzly bear habitat have been defined: space, isolation, sanitation, denning, safety, vegetation types, and food (Craighead et al. 1982). Each of these eharacteristics contributes to the overall suitability of an area to provide habitat for grizzly bears. If one characteristic is absent from an area, or severely depleted, the ability of the entire ecosystem to sustain a grizzly bear population is much reduced.

Grizzly bears have an adaptive flexibility in food habits. Although the digestive system is essentially that of a carnivore, bears are successful omnivores, and in some areas may be almost entirely herbivorous. Bears feed on animal matter or vegetable matter that is highly digestible and high in starch, sugars, protein, and stored fat (Stebler 1972; Mealey 1975; Hamer et al. 1977). Grizzly bears must avail themselves of foods rich in protein or carbohydrates in excess of maintenance requirements in order to survive denning and post-denning periods. Herbaceous plants are eaten as they emerge from the soil, when crude protein levels are highest. Grizzly bears are opportunistic feeders and will prey or scavenge on almost any available food, including ground squirrels, ungulates, carrion, and garbage (Murie 1944, Hamer 1974). In areas where animal matter is less available, roots, bulbs, tubers, fungi, and tree cambium may be important in meeting protein requirements (Hamer 1974, Pearson 1975, Singer 1978). 
The search for food has a prime influence on grizzly bear movements. Upon emergence from the den they seek the lower elevations, drainage bottoms, avalanche chutes, and ungulate winter ranges where their food requirements can be met. Throughout the late spring and early summer they follow plant phenology back to higher elevations. In late summer and fall, there is a transition to fruit and nut sources, as well as herbaceous materials.

Mating in grizzly bears appears to oceur from late May through mid-July, with a peak in mid-June and estrus lasting from a few days to over a month (Craighead et al. 1969; Herrero and Hamer 1977). Females in estrus are receptive to practically all adult males (Hornocker 1962). Age of first reproduction and litter size varies, and may be related to nutritional state (Herrero 1978; Russell et al. 1978). Age at first reproduction varies from 3.5 to 8.5 years, with an average of 5.5 years. Litter size varies from one to four eubs, with an average of approximately two throughout much of the range of the species. Reproductive intervals for females average 3 years. The time lapse from conception to birth of eubs is between 229 and 266 days (Banfield 1974). Dispersing young grizzly bears establish home ranges within or overlapping their mother's. which makes dispersal across landseapes a slow process (USFWS $2011 \mathrm{gg}$ ).

The grizzly bear was federally listed as threatened on July 28, 1975 (40 FR 31734). Critical habitat has not been designated. The decline in numbers of this species is attributable to habitat loss and indirect human-caused mortality. Any bear-human interaction is a potential threat to either the bear or the human. The rate of grizzly bear mortality resulting from such interactions often exceeds birth rates (Craighead and Mitchell 1982). Factors that threaten the continued survival of this species include human predation and increased aceess by humans to wilderness. Additionally, increasing genetic and demographic fragmentation is occurring, which could lead to a loss of connectivity between U.S. and Canadian grizzly bears (USFWS $2011 \mathrm{gg}$ ).

\section{Effects of Herbicide Treatments on the Grizzly Bear}

\section{Direct Effects}

During treatments, human activity and use of vehicles could disturb any denning bears nearby. The herbicides themselves are unlikely to directly affect grizzly bears. A scenario in which a grizzly bear would be sprayed inadvertently during herbicide application would be unlikely, sinee grizzly bears would avoid these sites during treatments, and such a large animal is not likely to be overlooked by operators of herbicide application equipment. If an inadvertent spray of one or more grizzly bears by herbicides did oceur, none of the chemicals considered in this BA would cause adverse health effects under normal treatment scenarios, as addressed in the ERAs (see Table 6-2). Additionally, none of the herbicides would eause negative health effects as a result of dermal contact with sprayed foliage (see Table 6-2) or ingestion of contaminated plants or animals (see Table 6-5).

\section{Indirect Effects}

Herbicide treatments would be unlikely to have a substantial effeet on grizzly bear habitat, unless a key food source (such as a berry patch) was eliminated. There is also some indication that invasive species have displaced some food plants utilized by grizzly bears. Therefore, any activity that reduces the cover of non-native speeies would be likely to have an indirect positive effect on habitat over the long term.

Grizzly bears typically oceur in remote areas, away from human disturbance. Creation of access routes for herbicide treatments in remote areas would increase the likelihood of aceess to those areas in the future. The presence of human food in grizzly bear habitat attracts bears and results in the loss of natural fear and avoidance of humans (USFWS 1993n). Such habituation may result in "problem" bears that could eventually become a threat to humans and that often must be destroyed. Thus, any treatment activity involving the presence of humans in grizzly bear habitat, or the ereation of aceess routes into habitat would be expected to have an adverse effect on bears.

\section{Conservation Measures}

When using aminopyralid, fluroxypyr, and rimsulfuron in vegetation treatment programs, the BLM would follow all pertinent SOPs for use, transport, and handling of herbicides. The BLM would also continue to follow the conservation measures identified in the $2007 \mathrm{BA}$, or other eomparable measures that would be developed by the field offices based on local site conditions. No additional conservation measures have been identified that are 
specific to the three new herbicides. However, analysis of potential site-specific impacts to grizzly bears would occur at the project level, and any additional eonservation measures deemed necessary would developed to ensure that potential effects were minimized or avoided.

\section{Key Conservation Measures for the Grizzly Bear from the $2007 \mathrm{BA}$}

- Within the Recovery Zone, ensure that all treatment activities comply with the Interagency Grizzly Bear Guidelines (Interageney Grizzly Bear Committee 1987) and the Final Conservation Strategy for the Grizzly Bear in the Yellowstone Ecosystem (Interagency Conservation Strategy Team 2003).

To minimize the potential for displacement/mortality risk during treatments:

- Within the Recovery Zone (defined in Grizzly Bear Recovery Plan, USFWS 19931), ensure that any vehicular travel off highway or on restrieted roads adheres to access standards/directions as provided in local or regional interagency agreements, biological opinions, or local land use plans.

- Within the Recovery Zone, do not conduct vegetation treatment activities in riparian meadows and stream corridors between April 1 and July 1, or complete these activities in 1 day.

- Within the Recovery Zone, do not implement vegetative treatments that would substantially change the vegetative community in huckleberry producing sites.

To minimize the potential for habituation/human conflict:

- Within the Recovery Zone, ensure that all treatment activities adhere to interagency grizzly bear guidelines and standards for sanitation measures and storage of potential attractants, and enforee food storage and garbage disposal stipulations.

- Ensure all workers at treatment sites are aware of appropriate personal safety measures and behavior in grizzly bear habitat.

\section{Determination of Effects}

Based on the ERAs, none of the three herbicides would be likely to adversely affeet grizzly bears under any of the modeled exposure scenarios. Following the conservation measures from the 2007 Vegetation Treatments BA would help minimize adverse impacts to this species. As a result, the action would be Not Likely to Adversely Affect grizzly bears at the programmatic level. Given BLM mandates for use of integrated pest management (including vegetation management), and given that it is not possible to forecast site-specific vegetation management needs below the programmatic level, additional evaluations of situation-specific effects will be the subject of step-down Section 7 evaluations and subsequent consultations. In this manner, any additional specific conservation measures necessary to accommodate site or situation-specific peculiarities not predictable at the programmatic level will be developed at the local level and incorporated into Pesticide Use Proposals prior to local implementation of vegetation management activities that involve the use of herbicides considered in this BA.

\section{Canada Lynx}

The primary reference for this section is:

USFWS. 2000j. Determination of Threatened Status for the Contiguous U.S. Distinct Population Segment of the Canada Lynx and Related Rule. Federal Register 65(58):16051-16086.

References cited in this section are internal to the above-referenced document. A complete list of these references is available from the USFWS Montana Field Office, Helena, Montana.

The 2005 recovery outline for the Canada lynx (USFWS 2005k) was consulted for updated information on this species.

Lynx occur in moist coniferous forests that provide a prey base of snowshoe hare (Quinn and Parker 1987; Koehler 1990; Koehler and Brittell 1990; Mowat et al. 1999). In the contiguous United States, the Canada lynx (Lynx canadensis) historically occurred in the Cascades Range of Washington and Oregon; the Rocky Mountain Range in 
Montana, Wyoming, Idaho, eastern Washington, eastern Oregon, northern Utah, and Colorado; the western Great Lakes Region; and the northeastern United States region from Maine southwest to New York (McCord and Cardoza 1982, Quinn and Parker 1987). This distribution associated with the southern boreal forest, comprising of subalpine coniferous forest in the West and primarily mixed coniferous/deciduous forest in the East (Aubry et al. 1999). In Canada and Alaska, however, lynx inhabit the elassic boreal forest ecosystem known as the taiga (MeCord and Cardoza 1982; Quinn and Parker 1987; Agee 1999; MeKelvey et al. 1999b). Within these general forest types, lynx are most likely to persist in areas that receive deep snow, for which the lynx is highly adapted (Ruggiero et al. 1999b).

The lynx population in the contiguous U.S. is considered by the USFWS to be part of a larger metapopulation whose eore is located in the northern boreal forest of central Canada (Buskirk et al. 1999b; McKelvey et al. 1999a, 1999b). The boreal forest extends south into the contiguous United States along the Caseade and Rocky Mountain ranges in the West, the western Great Lakes Region, and along the Appalachian Mountain Range of the northeastern United States. At its southern margins, the boreal forest becomes naturally fragmented into patehes of varying size as it transitions into other vegetation types. These southern boreal forest habitat patehes are small relative to the extensive northern boreal forest of Canada and Alaska, which eonstitutes the majority of the lynx range. Many of these southern boreal forest habitat patehes within the contiguous U.S. are able to support resident populations of lynx and snowshoe hare. It is likely that some of the habitat patches act as sources of lynx (reeruitment is greater than mortality) that are able to disperse and potentially colonize other patehes (McKelvey et al. 1999a). Other habitat patehes act as "sinks" where lynx mortality is greater than recruitment and lynx are lost from the overall population. The ability of naturally dynamic habitat to support lynx populations may change as the habitat undergoes natural suecession following natural or manmade disturbances (i.e., fire, cleareutting). In addition, fluctuations in the prey populations may cause some habitat patches to change from being sinks to sourees and vice versa.

It is believed that historic and current lynx densities in the contiguous U.S. are naturally low relative to lynx densities in the northern boreal forest. At present, in the western states, resident populations eurrently exist only in Montana and Washington, and populations that are no longer self-sustaining occur in Oregon, Idaho, Wyoming, Utah, and Colorado. Because the lynx is a seeretive animal, there are no reliable population estimates for this species. However, sightings of lynx throughout the U.S. have continued to decrease over the years.

Lynx are highly specialized predators whose primary prey is the snowshoe hare, a species that has evolved to survive in areas that receive deep snow (Bittner and Rongstad 1982). Snowshoe hares use forests with dense understories that provide forage, cover to eseape from predators, and protection during extreme weather (Wolfe et al. 1982; Monthey 1986; Hodges 1999a, 1999b). Generally, earlier successional forest stages have greater understory structure than do mature forests and therefore support higher hare densities (Hodges 1999a, 1999b) However, mature forests can also provide snowshoe hare habitat as openings develop in the canopy of mature forests when trees succumb to disease, fire, wind, ice, or inseets, and the understory grows (Buskirk et al. 1999b). Lynx concentrate their hunting activities in areas where hare activity is relatively high (Kochler et al. 1979; Parker 1981; Ward and Krebs 1985; Major 1989; Murray et al. 1994; O’Donoghue et al. 1997, 1998a). Lynx also prey opportunistically on other small mammals and birds, particularly when hare populations decline (Nellis et al. 1972: O’Donoghue 1997, 1998a). Red squirrels are an important alternate prey (Apps 1999; Aubry et al. 1999). However, a shift to alternate food sources may not compensate for the decrease in hares eonsumed (Koehler and Aubry 1994). In northern regions, when hare densities deeline, the lower quality diet causes sudden decreases in the productivity of adult female lynx and decreased survival of kittens, which eauses the numbers of breeding lynx to level off or decrease (Nellis et al. 1972; Brand et al. 1976; Slough and Mowat 1996; O’Donoghue et al. 1997).

The breeding period for Canada lynx is late winter to early spring, with adult females producing one litter every 1 to 2 years. The gestation period typically lasts from 62 to 74 days, and the litter size is 3 to 4 kittens, on average. Females may reach reproductive maturity by as early as 1 year (Brainerd 1985).

Lynx use large woody debris, such as downed logs and windfalls, to provide denning sites with security and thermal cover for kittens (MeCord and Cardoza 1982, Koehler 1990, Koehler and Brittell 1990, Squires and 
Laurion 1999, Organ 1999). For lynx den sites, the age of the forest stand does not seem as important as the amount of downed, woody debris available (Mowat et al. 1999). The size of lynx home ranges varies by the animal's gender, abundance of prey, season, and the density of lynx populations (Hatler 1988; Kochler 1990; Poole 1994; Slough and Mowat 1996; Aubry et al. 1999; Mowat et al. 1999). Home ranges vary from 12 to 83 square miles (USFWS 2005k).

The population of the Canada lynx occurring in the contiguous U.S. was federally listed as threatened on March 24, 2000 (65 FR 16053). Critical habitat was designated in 2006 (71 FR 66008) and then revised on February 25, 2009 (74 FR 8616) and September 12, 2014 (79 FR 54782). Critical habitat for this species currently includes approximately 36,632 square miles of land in Maine, Minnesota, Montana, Wyoming, ldaho, and Washington. On September 12, 2014 (79 FR 54782), the USFWS changed the definition of the lynx DPS so that it includes lynx throughout the contiguous U.S., which would include lynx in New Mexico. At the time of listing, the primary factor affecting lynx in the contiguous U.S. was the lack of guidanee for conservation of lynx in federal land management plans. The associated impacts of timber harvest and fire on lynx populations have since been reduced as a result of conservation agreements between the USFS, BLM, and USFWS. Currently, the predominant land uses affecting the Canada lynx are timber harvest, recreation, and their related activities. Climate change may also be a threat to lynx by eventually causing the boreal forests in the contiguous U.S. to reeede north and/or to higher elevations (USFWS 2005k).

\section{Effects of Herbicide Treatments on the Canada Lynx}

Lynx oceurring in the project area may be affected by management activities that reduce or degrade essential habitat elements used by lynx for denning, foraging, and recruitment, or that increase habitat fragmentation and lynx mortality.

\section{Direct Effects}

Herbicide treatments would be unlikely to direetly affect Canada lynx that occur on public lands, since lynx would readily avoid areas in which herbicide treatments were occurring. Unintentional spray of lynx would be highly unlikely. Dermal contact with foliage sprayed by herbicide, or consuming prey items that have been exposed to herbicide are more likely exposure scenarios.

According to the ERAs, none of the herbicides considered in this BA would result in adverse health effects to the Canada lynx species under any of the modeled exposure scenarios (direct spray, dermal contact with sprayed vegetation, or ingestion of sprayed food items; Tables 6-2 and 6-5).

\section{Indirect Effects}

Herbicide treatments could potentially affect snowshoe hares, although ERAs did not prediet adverse effects to small mammals for any of the herbicides under any of the exposure pathways.

The invasion of non-native species into lynx habitat can be a risk factor to the species if it occurs at a large scale. The associated habitat degradation and the potential changes in understory vegetation can both have indirect effects on the Canada lynx by changing the structure of stands or reducing the availability of food for prey sources. Therefore, herbicide treatments that reduce the cover of non-natives or thwart their establishment would have a long-term positive effect on lynx habitat.

The use of herbicide treatments in lynx habitat could negatively affect the species by creating new access routes for humans and competitors, and potentially fragmenting habitat. Construetion of roads has been observed to increase the likelihood of human-lynx interactions, the vulnerability of lynx to legal and illegal harvest, and the amount of lynx harassment (Washington Department of Wildlife 1993).

\section{Conservation Measures}

When using aminopyralid, fluroxypyr, and rimsulfuron in vegetation treatment programs, the BLM would follow all pertinent SOPs for use, transport, and handling of herbicides. The BLM would also continue to follow the 
conservation measures identified in the $2007 \mathrm{BA}$, or other comparable measures that would be developed by the field offices based on local site conditions and included in local-level consultation. No additional conservation measures have been identified that are specific to the three new herbicides. However, the BLM may develop and implement additional conservation measures, if necessary, during project-level analysis at the local level.

\section{Key Conservation Measures for the Canada Lynx from the 2007 BA}

- Prior to vegetation treatments, map lynx habitat within areas in which treatments are proposed to occur. Identify potential denning and foraging habitat, and topographic features that may be important for lynx movement (major ridge systems, prominent saddles, and riparian corridors).

- Design vegetation treatments in lynx habitat to approximate historical landscape patterns and disturbance processes.

- Ensure that no more than 30 percent of lynx habitat within a Lynx Analysis Unit (as defined in Ruediger et al. 2000) would be in an unsuitable condition at any time.

- Give particular consideration to amounts of denning habitat, condition of summer and winter foraging habitat, as well as habitat linkages, to ensure that that treatments do not negatively impact lynx. If there is less than 10 pereent lynx habitat in a Lynx Analysis Unit, defer vegetation treatments that would delay development of denning habitat strueture. Protect habitat connectivity within and between Lynx Analysis Units.

\section{Determination of Effects}

Based on the ERAs, none of the three herbicides would be likely to adversely affect the Canada lynx under any of the modeled exposure seenarios. Following the conservation measures from the 2007 BA would help minimize adverse impacts to this species. As a result, the action would be Not Likely to Adversely Affect Canada lynx at the programmatic level. Given BLM mandates for use of integrated pest management (including vegetation management), and given that it is not possible to forecast site-specific vegetation management needs below the programmatic level, additional evaluations of situation-specific effects will be the subject of step-down ESA Section 7 evaluations and subsequent consultations. In this manner, any additional specific conservation measures necessary to aceommodate site or situation-specific peculiarities not predictable at the programmatic level will be developed at the loeal level and ineorporated into Pesticide Use Proposals prior to local implementation of vegetation management activities that involve the use of herbicides considered in this BA.

\section{San Joaquin Kit Fox}

The primary reference for this section is:

USFWS. 1998h. Recovery Plan for Upland Species of the San Joaquin Valley, California. Region 1. Portland, Oregon.

Referenees eited in this seetion are internal to the above-refereneed document. Full citations have been included in the Bibliography.

The 2010 5-year review for the San Joaquin kit fox (USFWS 2010rr) was consulted for updated information on this species.

The San Joaquin kit fox (Vulpes macrotis mutica) is endemic to California's San Joaquin Valley and surrounding foothills. Prior to 1930, kit foxes inhabited most of the San Joaquin Valley from southern Kern County north to Tracy, San Joaquin County, on the west side, and near LaGrange, Stanislaus County, on the east side. The habitat of this species has been much reduced as a result of urban development and eultivation for agriculture. The largest populations of kit foxes are in the Bakersfield, western Kern County, and Carrizo Plains areas, with the Bakersfield population apparently the most stable (USFWS 2010rr).

Kit foxes are adapted to arid land and typically oceur in desert-like habitats in North America, which are characterized by sparse or absent shrub cover (Cypher 2006). Historically, San Joaquin kit foxes oceurred in several native plant communities of the San Joaquin Valley, some of which are only represented by small, degraded remnants today. Other habitats in which kit foxes are found have been extensively modified by humans. 
These habitats include grasslands and scrublands with active oil fields, wind turbines, and an agricultural matrix of row erops, irrigated pasture, orehards, vineyards, and grazed annual grasslands. Other plant communities in the San Joaquin Valley providing habitat for the species include vernal pools and alkali meadows and playas. In the southernmost portion of its range, the kit fox is associated with valley sink scrub, valley saltbush serub, upper Sonoran subshrub serub, and annual grassland. In the central portion of its range, the species is associated with valley sink scrub, interior Coast Range saltbush serub, upper Sonoran subshrub scrub, annual grassland, and the remaining native grasslands. In the northern portion of its range, the species is associated with annual grassland (Hall 1983) and valley oak woodland (Bell 1994).

Kit foxes prefer loose-textured soils (Grinnell et al. 1937; Hall 1946; Egoseue 1962; Morrell 1972), but are found on virtually every soil type. Dens appear to be searee in areas with shallow soils because of the proximity to bedrock (O'Farrell and Gilbertson 1979; O'Farrell et al. 1980), high water tables (MeCue et al. 1981), or impenetrable hardpan layers (Morrell 1972). However, kit foxes will occupy soils with high clay content, where they modify burrows dug by other animals (Orloff et al. 1986). Current understanding of kit fox habitat indicates that habitat with slopes of less than 5 percent is optimal for the kit fox, while habitat with slopes of 5 to 15 percent is suitable and habitat with slopes of greater than 15 percent is unsuitable (Cypher 2006).

The diet of kit foxes varies geographically, seasonally, and annually, based on variation in abundance of potential prey. In the southern portion of their range, kangaroo rats, pocket mice, white-footed mice, and other nocturnal rodents comprise about one-third or more of their diets. Kit foxes there also prey on California ground squirrels, black-tailed hares, San Joaquin antelope squirrels, desert cottontails, ground-nesting birds, and insects (Scrivner et al. 1987). Vegetation and inseets are also eaten, with grass being the most commonly ingested plant material (Morrell 1971). In the central portion of their range, known prey species include white-footed mice, insects, California ground squirrels, black-tailed hares, and chukar (Jensen 1972, Archon 1992). In the northern part of their range, kit foxes consume California ground squirrels most frequently (Orloff et al. 1986), and also prey upon black-tailed hares, pocket mice, and kangaroo rats (Hall 1983).

Kit foxes can breed when 1 year old, but may not breed during their first year of adulthood (Morrell 1972). Adult pairs remain together all year, sharing the home range, but not neeessarily the same den. During September and Oetober, adult females begin to clean and enlarge natal or pupping dens. Mating and conception take place between late December and Mareh (Egoseue 1956; Morrell 1972; Zoellick et al. 1987). The median gestation period is estimated to range from 48 to 52 days, and litters of between two and six pups are born sometime between February and late March. The pups emerge above ground at slightly more than 1 month of age. After 4 to 5 months, usually in August or September, the family bonds begin to dissolve and the young begin dispersing.

The San Joaquin kit fox was federally listed as endangered on Mareh 11, 1967 (32 FR 4001). Critical habitat has not been designated. The primary factors associated with the decline of this species were loss, degradation, and fragmentation of habitats as a result of agricultural, industrial, and urban developments in the San Joaquin Valley (Laughrin 1970, Morrell 1971, Jensen 1972, Knapp 1978). Since listing, loss of natural habitat to agricultural development has continued on the floor of the San Joaquin Valley and the associated valleys of the Coast Range. Agricultural and urban development now threaten the remaining foraging and dispersal habitat along the east and west sides of the valley. Other threats to the species include pesticide exposure, competitive exclusion by other eanids, the highly fluctuating population dynamic of most populations, the isolation and loss of small subpopulations due to stochastic events and habitat fragmentation, OHV use, and loss of prey (UFWS 2010rr).

\section{Effects of Herbicide Treatments on the San Joaquin Kit Fox}

\section{Direct Effects}

It is unlikely that kit foxes would be inadvertently sprayed by herbicides during chemical treatments. Foxes would readily flee the treatment area or run into underground burrows. More likely means of exposure would be contact with sprayed vegetation and ingestion of prey items and vegetation that have been sprayed by herbicides. 
According to the ERAs, none of the herbicides considered in this BA would result in adverse health effects to San Joaquin kit foxes under any of the modeled exposure scenarios (direct spray, dermal contact with sprayed vegetation, or ingestion of sprayed food items; Tables 6-2 and 6-5).

\section{Indirect Effects}

Herbicide treatments would have minimal effects on kit fox habitat over the short term. A temporary reduction in vegetative cover could benefit foxes by increasing their ability to locate prey items. Over the long term, use of herbicides to return kit fox habitats to more native conditions would likely benefit the species. However, given the ability of the fox to adapt to altered landseapes, these benefits may be minimal.

\section{Conservation Measures}

When using aminopyralid, fluroxypyr, and rimsulfuron in vegetation treatment programs, the BLM would follow all pertinent SOPs for use, transport, and handling of herbicides. The BLM would also continue to follow the conservation measures identified in the $2007 \mathrm{BA}$, or other comparable measures that would be developed by the field offices based on local site conditions and included in local-level consultation. The 2007 BA included a few conservation measures associated with use of previously approved herbicides, which are not applicable to treatments with the three herbicides being addressed in this BA. No additional conservation measures have been identified that are specific to the three new herbicides. However, during project-level analysis, the BLM would develop and implement any necessary conservation measures, based on a detailed analysis of site-specific treatments.

\section{Determination of Effects}

Based on the ERAs, none of the three herbicides would be likely to adversely affect the San Joaquin kit fox under any of the modeled exposure scenarios. Additionally, indirect effects to the species through removal of vegetation are unlikely. Therefore, the action would be Not Likely to Adversely Affect the San Joaquin kit fox at the programmatic level. Given BLM mandates for use of integrated pest management (including vegetation management), and given that it is not possible to forecast site-specific vegetation management needs below the programmatic level, additional evaluations of situation specific effects will be the subject of step-down ESA Section 7 evaluations and subsequent consultations. In this manner, any additional specific conservation measures necessary to accommodate site or situation-specific peculiarities not predictable at the programmatic level will be developed at the local level and incorporated into Pesticide Use Proposals prior to local implementation of vegetation management aetivities that involve the use of herbicides considered in this BA.

\section{Grassland Ground-Burrowing Mammals: Kangaroo Rats, Utah Prairie Dog, and Black-footed Ferret}

\section{Kangaroo Rats}

The primary reference for the next three sections is:

USFWS. 1998h. Recovery Plan for Upland Species of the San Joaquin Valley, California. Region 1. Portland, Oregon.

References cited in these sections are internal to the above-referenced document. Full eitations have been included in the Bibliography.

The 2010 5-year review for the giant kangaroo rat (USFWS 2010ss), the 2010 5-year review for the Fresno kangaroo rat (USFWS 2010tt), and the 2010 5-year review for the Tipton kangaroo rat (USFWS 2010uu) were consulted for updated information on these species.

\section{Giant Kangaroo Rat}

The giant kangaroo rat (Dipodomys ingens) is found in grassland and shrubland communities in the southern San Joaquin Valley of California. Below about 1,300 feet, the species oceurs in annual grassland and saltbush serub. At higher elevations, it is found in Upper Sonoran subshrub serub associations. Giant kangaroo rats are most 
numerous where annual grasses and forbs predominate. The species population is currently fragmented into six major geographic units. These major units are in turn fragmented into more than 100 smaller populations, many of which are isolated by steep terrain with plant communities unsuitable as habitat, or by agricultural, industrial, or urban land that provides poor habitat for this species.

Giant kangaroo rats are primarily seed eaters, but also eat green plants and inseets. They forage on the surface from around sunset to near sunrise, though most activity takes place in the first 2 hours after dark. Foraging activity is greatest in the spring as seeds of annual plants ripen. The ability to transport large quantities of seeds and other foods in their eheek pouches, and highly developed caching behaviors, coupled with relatively high longevity of adults with established burrow systems, probably allow giant kangaroo rats to endure severe drought for 1 or 2 years without great risk of population extinetion (Williams et al. 1993b).

Giant kangaroo rats have an adaptable reproductive pattern that is affected by both population density and availability of food. During times of relatively high density, females have a short, winter reproductive season with only one litter produced, and there is no breeding by young-of-the-year. However, if there is sufficient food and space, females can breed the year of their birth, and some may have two to three litters per year. In most years, females are reproductive between December and March or April, but in colonies with low densities, reproduction ean extend into August or September (Williams et al. 1993b). Young disperse at about 11 to 12 weeks after birth. However, in years of high density, when most or all burrow systems are occupied, most young appear to remain in their natal burrows until the opportunity to disperse arises or they are finally driven off by the mother or one of the siblings.

The giant kangaroo rat was federally listed as endangered on January 5, 1987 (52 FR 283). Critical habitat has not been designated. Since the time of listing, eonversion of habitat for agricultural purposes has slowed substantially, as most tillable land has already been cultivated. However, urban and industrial developments, petroleum and mineral exploration and extraction, and other activities continue to destroy habitat and increase threats to the speeies by reducing and further fragmenting populations. In addition, populations are small and vulnerable to extinetion from demographie and random catastrophie events (drought, flooding, fire), and inappropriate land uses that can degrade or destroy habitat.

\section{Fresno Kangaroo Rat}

The Fresno kangaroo rat (D. nitratoides exilis), a subspecies of the San Joaquin kangaroo rat, oceupies sands and saline sandy soils in chenopod scrub and annual grassland communities on the San Joaquin Valley floor. The current distribution of this subspeeies is unknown. Recently, they have been found only in alkali sink communities located between 200 and 300 feet in elevation. Habitat is on elevated grassy patehes on alkali plains or in grassy terrain with scattered alkali patches, which are characterized by easily dug friable soils for burrowing. The primary food source for the subspecies is seeds from native and non-native forbs and grasses. Seeds are a staple in their diet, but they also eat some types of green, herbaceous vegetation, and inseets. Fresno kangaroo rats shelter in ground burrows, which are usually found in relatively light, crumbly soils in raised areas. In all species of San Joaquin kangaroo rats, each burrow system is typically occupied by a single adult individual.

Little is known about the mating behavior of Fresno kangaroo rats in the wild, although breeding is probably initiated in the winter after the onset of the rainy season. In captivity, gestation is 32 days, and young are weaned at 21 to 24 days. Average litter size is two (Culbertson 1946, Eisenberg and Isaac 1963). Young are born in the burrow, and remain there until they are fully furred and able to move about easily. Foraging is believed to start at about 6 weeks (Culbertson 1946).

The Fresno kangaroo rat was federally listed as endangered on January 30, 1985 (50 FR 4222). On the same date, approximately 857 acres were designated as critical habitat for the species. Critical habitat is located in the Mendota Wildlife Area, the Alkali Sink Ecological Reserve, and on privately owned land. Loss of habitat to cultivation, year-round grazing, and conversion of land to other uses continue to diminish the size and quality of extant, historical habitat. Coupled with the resulting fragmentation and isolation of habitat, these developments increase the probability of extinction. No populations of Fresno kangaroo rat have been found since 1998, despite 
surveys in previously occupied habitats. It is believed that the subspecies could be extirpated from survey areas, although several unsurveyed locations may contain persisting populations (USFWS 2010tt). The Fresno kangaroo rat continues to be threatened by degradation of habitat from ongoing modification and conversion of existing habitat to agriculture, water banking projects, and development.

\section{Tipton Kangaroo Rat}

The Tipton kangaroo rat (D. nitratoides nitratoides), another subspecies of the San Joaquin kangaroo rat, is limited to arid-land communities occupying the valley floor of the Tulare Basin in level or nearly level terrain. The subspecies occupies alluvial fan and floodplain soils ranging from fine sands to clay-sized particles with high salinity. Today, much of the occupied remnants of the subspecies' range contain one or more species of sparsely scattered woody shrubs and a ground cover of mostly introduced and native annual grasses and forbs. Current occurrences are limited to scattered, isolated areas in Kings, Tulare, and Kern Counties (USFWS 2010uu).

Burrows of Tipton kangaroo rats are commonly located in slightly elevated mounds, the berms of roads, canal embankments, railroad beds, and at the bases of shrubs and fences where windblown soils accumulate above the level of surrounding terrain. Most aspects of food and foraging are identical to those of Fresno kangaroo rats.

Reproduction in Tipton kangaroo rats is similar to that of the Fresno kangaroo rat. Reproduction commenees in winter and peaks in late March and early April. Most females appear to have only a single litter, though some adult females have two or more, and females born early in the year also may breed.

The Tipton kangaroo rat was federally listed as endangered on July 8, 1988 (53 FR 25608). Critical habitat has not been designated. The principle reason for the decline of this subspecies was the loss of habitat as a result of agricultural conversion. Industrial and agricultural development, thatch accumulation from exotic grasses, urbanization, and flooding have been identified as the specific mechanisms that drive habitat loss (USFWS 2010uu). Potential new threats to the species include climate change and illegal application of rodenticides. Current threats come from industrial and agricultural-related developments, cultivation, the formation of heavy thatch by exotic grasses, urbanization, and flooding. Overall, Tipton kangaroo rat populations continue to decline.

\section{San Bernardino Merriam's Kangaroo Rat}

The primary reference for this section is:

USFWS. 2007cc. Endangered and Threatened Wildlife and Plants; Revised Critical Habitat for the San Bernardino Kangaroo Rat (Dipodomys merriami parvus). Federal Register 72(117):33808-33842.

References cited in this sections are internal to the above-referenced document. Full citations are available from the USFWS Carlsbad Fish and Wildlife Office in Carlsbad, California.

The San Bernardino Merriam's kangaroo rat (D. merriami parvus) occurs primarily on alluvial fans with appropriate physical and vegetative characteristies in San Bernardino and Riverside Counties in California (Lidicker 1960; Hall 1981; Williams et al. 1993). The historical range of the subspecies extends from the San Bernardino Valley in San Bernardino County to the Menifee Valley in Riverside County (Hall and Kelson 1959, Lidicker 1960). Prior to 1960, the San Bernardino Merriam's kangaroo rat was known from more than 25 localities within this range (McKernan 1997; McKernan 1993).

Alluvial fans, washes, and associated floodplain areas with sand, loamy sand, sandy loam, and loam soils provide burrowing habitat necessary for shelter and rearing offspring, storing food in caches, and movement between occupied patehes. San Bernardino Merriam's kangaroo rats use adjacent alluvial sage serub habitat and associated vegetation with up to 50 percent canopy cover, which provides protection from predators as well as bare ground and open areas for foraging and movement. The subspecies may also be found in more marginal habitat in agricultural lands, inactive mining areas, and urban/wildland interfaces.

San Bernardino Merriam's kangaroo rats dig simple, shallow burrow systems where they spend approximately 75 perecnt of their lives (Reynolds 1958). Burrows consist of one or two chambers and average 6 inches in depth 
(Reynolds 1960). They obtain food resources from the alluvial sage shrub plant community. They are generally granivorous, and feed primarily on the seeds of alluvial sage scrub species, but green vegetation and insects are also eaten. They emerge from their burrow systems at sunset and feed at night, when they are most active. Like most Merriam's kangaroo rats, they often store large quantities of seeds in surface pits for later consumption (Reynolds 1958; Reichman and Price 1993). Availability of food is linked to reproductive output. Based on observations of pregnant females, reproduction is thought to occur throughout much of the year. Some females may produce more than one litter per year. Litter size averages between two and three young (Eisenberg 1993).

The San Bernardino Merriam's kangaroo rat was federally listed as endangered on September 24, 1998 (63 FR 51005). Critical habitat for the species was originally designated in 2002, but revised critical habitat was designated on October 17, 2008 (73 FR 61936). Critical habitat includes approximately 7,779 acres in San Bernardino and Riverside Counties. The majority of all remaining suitable habitat, and the long-term persistence of the San Bernardino Merriam's kangaroo rat, is threatened by the direct and indireet effeets of: sand and gravel mining; construction, operation, and maintenance of flood control structures; water conservation activities; urban and industrial development; agricultural activities; and off-road vehicle activity. These threats inerease with the increase and expansion of the human population in the area.

\section{Stephens' Kangaroo Rat}

The primary reference for this section is:

USFWS. 2010vv. 12-Month Finding on a Petition to Remove the Stephens' Kangaroo Rat from the Federal List of Endangered and Threatened Wildlife. Federal Register 75(160):51204-51223.

References cited in this sections are internal to the above-referenced document. Full citations are available from the USFWS Carlsbad Fish and Wildlife Office in Carlsbad, California.

The Stephens' kangaroo rat (Dipodomys stephensi) occurs at elevations below about 2,000 feet in flat or gently rolling, often degraded, annual grassland. The entire geographic range of this species, which is estimated at approximately 1,000 square miles, is eentered in the San Jacinto and Perris Valleys of western Riverside County, California, with minor extensions south into San Diego County and north into San Bernardino County. Stephens' kangaroo rats are associated with locations where grass cover and bare ground are abundant, but where bush and rock are uncommon. The subspecies prefers grassland communities dominated by forbs rather than by annual grasses, as the forbs provide critical greens in the spring, furnish temporary cover, produce large seeds, and rapidly disintegrate after drying, resulting in substantial patches of bare ground (O'Farrell and Clark 1987, O'Farrell and Uptain 1989) that provide suitable habitat conditions. Highest densities of Stephens' kangaroo rats oceur in grassland communities dominated by forbs and characterized by moderate to high amounts of bare ground, moderate slopes, and well drained soils (O'Farrell and Uptain 1987, O'Farrell 1990, Anderson and O'Farrell 2000). Rainfall is an important factor in the species' ecology: Stephens' kangaroo rats show 10-fold fluctuations in population density related to regional rainfall.

Stephens' kangaroo rats construct burrows to serve as sleeping quarters and nesting sites (Bleich 1973), which are frequently found clustered in burrow complexes (Brock and Kelt 2004). Stephens' kangaroo rats are nocturnal, typically emerging from burrows after sunset and spending very little time (less than 1 hour) above ground each day. They are seed-eaters that extract seeds from the soil by digging with their forefeet and balancing on hind legs (Reichman and Price 1993), direct clipping seed stalks, or harvesting seeds directly from fruit near the ground. Stephens' kangaroo rats often store large quantities of seeds. Seed caching may enable survival during temporary shortages of food. They seldom drink water because they are able to use water resulting from the chemical breakdown of their food. They also conserve moisture by coming out of their burrows at night when the humidity is highest.

Reproductively active individuals have been found in every month of the year, although onset of estrus in females appears to be triggered by the growth of vegetation subsequent to winter rain (McClenaghan and Taylor 1993, Price and Kelly 1994). Late spring to early summer breeding is common. Multiple litters may be possible during 
favorable conditions (O'Farrell and Clark 1987). The number of young per litter averages about 2.5. Weaning takes place at 18 to 22 days.

The Stephens' kangaroo rat was federally listed as endangered on September 30, 1988 (53 FR 38465). Critical habitat has not been designated for this species. By 1938, only about 37 percent of the species' original habitat was estimated to have remained, and its range had become greatly fragmented. Aceelerating urban development has led to further degradation of available habitat. While many of the threats to this subspecies have been reduced, habitat that is not being protected by a conservation program continues to be impacted by urban and agrieultural development. Over the long-term, non-native species, OHVs, and potential impacts associated with climate change pose threats to Stephens' kangaroo rats (USFWS $2011 \mathrm{hh}$ ). The Stephens' kangaroo rat is eurrently threatened by urban development.

\section{Morro Bay Kangaroo Rat}

The Morro Bay kangaroo rat (Dipodomys heermanni morroensis), one of nine subspecies of Heermann's kangaroo rat, occurs on old, stabilized sand dunes in the vicinity of Los Osos and San Luis Obispo Counties, California. The range of the species is restricted to an area of approximately 4.8 square miles generally corresponding to the distribution of Baywood fine sand south and southeast of Morro Bay (USFWS 2011ii). The subspeeies has not been observed in the wild since 1986, and no longer oceurs in captivity, and therefore is possibly extinet. However, pockets of suitable habitat remain, and not all private properties have been surveyed, so isolated colonies may still persist (USFWS 2011ii).

Morro Bay kangaroo rats are essentially found only in disturbed areas; optimum habitat consists of the earlier suceessional stages of the coastal sagebrush community which oceur on the old, stabilized dune terraces on the south and southeast sides of Morro Bay. Typical vegetation in this habitat is herbaceous annuals, with seattered woody perennial shrubs (coastal sagebrush, coyotebrush, yellow bush lupine and chamisso bush lupine, and buekwheat) no more than 2 feet in height. Shrub eover may be totally absent, or range as high as 60 pereent; ground cover may vary from practically zero to 100 pereent (Stewart 1958; Stewart and Roest 1960; Condon 1971, 1975; Roest 1973; Toyoshima 1978, 1979). Early suceessional stages inhabited by kangaroo rats exist until about 15 to 30 years after an area has been cleared of vegetation, depending on the specific site. Succession involves a gradual inerease in size and coverage of brushy species, and after 20 to 30 years the brush is too tall and dense for kangaroo rats. In earlier times, vegetation was cleared and succession restarted as a result of fires intentionally set by Native Americans. More recently, brushy areas have been eleared by bulldozers for either development or cultivation. The animals quickly move into such areas, usually within the first year after clearing. If the area is cultivated, they move in after the first harvest of oats or other grain, or within the first year, if the land is allowed to lie fallow (Stewart 1958; Stewart and Roest 1960; Roest 1973; Toyoshima 1978, 1979). Prescribed burning is one means of potential restoring habitat for this subspeeies (USFWS 2011ii).

Morro Bay kangaroo rats use and maintain multiple burrow systems in sandy soils with slopes of less than 15 degrees (Gambs and Holland 1988). They are nocturnal, solitary, and territorial (USFWS 1982d, Roest 1991). Trapping records indicate year-round activity (i.e., no dormancy period), with juveniles captured from March through November. Gestation is approximately 30 days, and sexual maturity is attained at approximately 4 months of age (Roest 1984). Reported sizes of litters ranged from one to four pups (Stewart and Roest 1960, Roest 1991). Longevity in the wild is probably 2 to 3 years (USFWS 1982d).

Morro bay kangaroo rats feed on vegetation, obtaining sustenance primarily from seeds, but also from the leaves, stems, and fruits of plants (Stewart 1958, Stewart and Roest 1960). The subspecies is strictly nocturnal, and is active early in the evening, sometimes with another active period before davn (Toyoshima 1979, Roest 1985).

The Morro Bay kangaroo rat was federally listed as endangered in 1970 (35 FR 16047). On August 11, 1977, the USFWS designated critical habitat for the taxon in San Luis Obispo County (42 FR 40685). The two primary causes for the decline of the subspecies are direet loss of habitat associated with development in the vicinity of Los Osos, and succession of optimal habitat into dense, mature plant communities in the absence of fire. Other threats 
include predation by cats, habitat fragmentation, stochastic events, invasive plant species, competition with other burrowing rodents, and extreme weather events.

\section{Utah Prairie Dog}

The primary reference for this section is:

USFWS. 2010ww. Utah Prairie Dog Draft Revised Recovery Plan. Utah Ecological Services Office and Utah Prairie Dog Recovery Team. West Valley City, Utah and Denver, Colorado.

References eited in this section are internal to the above-referenced document. Full citations have been included in the Bibliography.

The Utah prairie dog (Cynomys parvidens) inhabits arid grassland in southwest Utah, and has the most restrieted range of all prairie dog species in the United States. It is thought that the species' range onee extended across the desert almost to the Nevada-Utah state line. Currently, Utah prairie dogs are limited to the central and southwestern quarter of Utah in Beaver, Garfield, Iron, Kane, Piute, Sevier, and Wayne Counties. They oceur at elevations of 6,200 to 9,180 feet (MeDonald 1993), in seattered colonies, some of which are isolated and some of which function as metapopulations (Ritchie and Brown 2005).

Because prairie dogs get most of their water from plants, there is a positive correlation between available moisture and prairie dog abundance and density. Prairie dogs appear to prefer swale type formations where moist herbage is available even during drought periods. Soil characteristics are an important factor in the location of Utah prairie dog colonies. A well-drained area is neeessary for home burrows. The soil should be deep enough to allow burrowing to depths sufficient to provide protection from predators and insulation from environmental and temperature extremes. Prairie dogs must be able to inhabit a burrow system 3.3 feet underground without beeoming wet. The vegetation height within the prairie dog colony must be low enough to allow standing prairie dogs to sean their environment for predators. Utah prairie dogs avoid areas where brushy species dominate, and eventually deeline or disappear in areas invaded by brush (Collier 1975, Player and Urness 1983). Open habitats are important for foraging, visual surveillance to eseape predators, and intraspecific interactions (Player and Urness 1983).

Prairie dogs are predominantly herbivores, with grasses the preferred food items during all seasons. The flowers and seeds of forbs such as alfalfa also are preferred. Although forbs other than alfalfa are not always highly preferred items, they may be eritical to a prairie dog colony's survival during drought. Prairie dogs have also been observed eating the flowering parts of shrubs, especially during the fall.

Because of the high mortality rate for juvenile males resulting from confliets with other males, approximately twothirds of the adult population is female. Female Utah prairie dogs are capable of giving birth annually to litters that average three to four young. The young are usually born in April, after a gestation period of about 30 days. Juvenile prairie dogs appear above ground at an age of 5 to 7 weeks. They attain adult size by Oetober and reach sexual maturity at the age of 1 year.

Utah prairie dogs hibernate by spending 4 to 6 months underground each year during the winter months (Hoogland 2001). Adult males cease surface activity during August and September, and females follow suit several weeks later. Juvenile prairie dogs remain above ground 1 to 2 months longer than adults, and usually hibernate by late November. Few prairie dogs are above ground from the first of November through mid-February, although they are not completely dormant in the winter. Utah prairie dogs emerge from hibernation in late February or early March, with males emerging 2 to 3 weeks prior to females (Hoogland 2003). Mating begins soon after females emerge from hibernation (Hoogland 2003).

The Utah prairie dog was federally listed as endangered on June 4, 1973 (38 FR 14678), and was reclassified as threatened on May 29, 1984 (49 FR 22330) because of increases in population numbers. Critical habitat has not been designated. The Utah prairie dog once maintained an ecological relationship with bison, which maintained shortgrass habitat, interspaced with patches of forbs and bare ground. However, the replacement of bison with cattle resulted in long-term overgrazing on prairic dog habitat, which has resulted in a reduction in habitat quality 
and a reduetion in moisture availability in the vegetation. Past control programs targeting prairie dogs also eontributed to the decline of the species. Habitat loss and poor habitat quality are immediate eoneerns for the remaining Utah prairie dogs. Most of the species' distribution occurs on privately owned lands that are or will be largely developed for agrieultural production and housing. The speeies is vulnerable to habitat loss, plague, ehanging elimatie eonditions, unauthorized take, and disturbanee from reereational and eeonomie land uses. Current speeies population trends are stable to inereasing, with an estimated 5,000 to 6,000 individuals (as of 2009). Observations indieate that individual eolonies erash and reeolonize, sometimes repeatedly. Causes of erashes may be plague, forage eompetition, habitat alteration, self-indueed population regulation, and unlawful eontrol. Larger eolonies are more likely to persist beeause they have a lower probability of erashing (Ritehie and Brown 2005).

\section{Black-footed Ferret}

The primary referenee for this seetion is:

USFWS. 2000k. Establishment of a Nonessential Experimental Population of Blaek-footed Ferrets in NorthCentral South Dakota.

Referenees eited in this seetion are internal to the above-refereneed doeument. Full eitations have been ineluded in the Bibliography.

The 2008 5-year review for the blaek-footed ferret (USFWS 2008x) was reviewed for updated information on this speeies.

The blaek-footed ferret (Mustela nigripes) is the only ferret speeies native to North Ameriea. Its historieal range extended from southern Canada south through the Great Plains, mountain basins, and semi-arid grasslands of the western U.S. Blaek-footed ferrets depend almost exelusively on prairie dogs for food, shelter, and denning (Henderson et al. 1969; Forrest et al. 1985). The range of the ferret eoineides with that of three prairie dog speeies (Anderson et al. 1986), and ferrets with young have been doeumented only in the vieinity of aetive prairie dog eolonies. Historieally, blaek-footed ferrets have been reported in assoeiation with blaek-tailed prairie dog, whitetailed prairie dog, and Gunnison's prairie dog towns.

Prairie dogs make up the vast majority of the blaek-footed ferret's diet, and ferrets oeeupy underground prairie dog burrows during periods of inaetivity. Other food sourees are miee, rabbits, rats, birds, reptiles, inseets, and earrion. Breeding oeeurs during Mareh and April. The gestation period is 41 to 45 days, after whieh a litter of three to four young is produeed. Ferrets develop quiekly, reaehing sexual maturity by September.

Substantial reduetions in both prairie dog numbers and distribution oeeurred during the last eentury as a result of widespread poisoning of prairie dogs, the eonversion of native prairie to farmland, and outbreaks of sylvatie plague, partieularly in the southern portions of prairie dog ranges in North Ameriea. Sylvatie plague, whieh arrived from Asia in approximately 1900, is an exotie disease foreign to the evolutionary history of prairie dogs, which have little or no immunity to it. Blaek-footed ferrets also are highly suseeptible to sylvatie plague. This severe reduetion in the availability of the ferret's prineipal prey, in eombination with other faetors sueh as seeondary poisoning from prairie dog toxieants, resulted in the near extinetion of the blaek-footed ferret in the wild by 1980 . In 1974, a remnant wild population of ferrets in South Dakota, originally diseovered in 1964, abruptly disappeared. Afterwards, the speeies was believed to be extinet; however, in 1981 a small population of ferrets was diseovered near Meeteetse, Wyoming. In 1985 to 1986, the Meeteetse population deelined to only 18 animals due to outbreaks of sylvatie plague and eanine distemper. Following this eritieal deeline, the remaining individuals were taken into eaptivity in 1986 to 1987 to serve as founders for a eaptive-propagation program. Sinee that time, eaptive-breeding efforts have been highly sueeessful and have faeilitated ferret reintroduetions in several areas of formerly oeeupied range. These reintroduetions, however, have met with limited sueeess. No wild populations of blaek-footed ferrets have been found sinee the eapture of the last Meeteetse ferret, despite extensive and intensive range wide searehes, and it is unlikely that any undiseovered wild populations remain (USFWS 2008x). 
The black-footed ferret was federally listed as endangered on March 11, 1967 (32 FR 4001). This endangered status applies to the entire range of the species, except where reintroduced and designated as a non-essential experimental population. Such populations occur in Arizona, Colorado, Montana, South Dakota, Utah, and Wyoming. Critical habitat has not been designated for the species. Threats to the species inelude habitat modification and curtailment, plague, and poisoning of prairie dogs (USFWS 2008x).

\section{Effects of Herbicide Treatments on Kangaroo Rats, the Utah Prairie Dog, and the Black- footed Ferret}

\section{Direct Effects}

Direct spray of listed kangaroo rats, prairie dogs, or black-footed ferrets would be unlikely during herbicide applications, since these animals would be able to flee the site or run into underground burrows. These small mammals would be more likely to be exposed to herbicides through contact with treated vegetation or ingesting treated vegetation or prey items following an application.

Aceording to the ERAs, none of the herbicides considered in this BA would result in adverse health effects to listed kangaroo rats, prairie dogs, or black-footed ferrets under any of the modeled exposure scenarios (direct spray, dermal eontact with sprayed vegetation, or ingestion of sprayed food items; Tables 6-2 and 6-5).

\section{Indirect Effects}

Herbieide treatments could affect the habitat of kangaroo rats and prairie dogs by temporarily reducing the amount of forage available to these speeies. Removal of non-native vegetation is likely to have either a positive effect or no effect, depending on the species. Kangaroo rats ean thrive in annual grasslands that have a large component of nonnative species, including red brome. However, excessive amounts of non-native species, espeeially shrubby species, can degrade habitat used by these small mammals. The invasion of vegetation onto Fresno kangaroo rat habitat has been linked to deelines in species numbers (Morrison et al. 1996). In desert shrubland and grassland habitats, the invasion of woody speeies as a result of fire suppression has eliminated suitable prairie dog and blackfooted ferret habitat (USDOI BLM 2003). For all of the speeies considered in this section, the control of shrubs and other weedy species that invade grassland habitats and reduce the degree of openness would have a long-term positive effect on habitat.

Black-footed ferrets eould suffer indirect effeets if prairie dog populations were affected. However, since the ERAs determined that herbicides would not result in adverse effects to small mammals under any of the modeled exposure scenarios, no indirect effects to blaek-footed ferrets associated with prairie dog mortality or reduced reproductive vigor should occur.

\section{Conservation Measures}

When using aminopyralid, fluroxypyr, and rimsulfuron in vegetation treatment programs, the BLM would follow all pertinent SOPs for use, transport, and handling of herbicides. The BLM would also continue to follow the conservation measures identified in the $2007 \mathrm{BA}$, or other comparable measures that would be developed by the field offices based on local site conditions and included in loeal-level consultation. No additional conservation measures have been identified that are specific to the three new herbicides. Individual projects would be subject to review at the local level, during which additional conservation measures could be identified, as neeessary to protect these species.

\section{Key Conservation Measures from the $2007 \mathrm{BA}$}

- Prior to conducting vegetation treatments, survey areas scheduled to receive treatments for listed kangaroo rats, Utah prairie dogs, and black-footed ferrets.

- Incorporate these species and their habitat into management plans developed for treatment activities.

- Avoid vegetation treatments during drought conditions.

- Where possible, perform treatments during the hibernation period. 


\section{Determination of Effects}

Based on the ERAs, none of the three herbicides would be likely to adversely affect listed kangaroo rats, the Utah prairie dog, or the black-footed ferret under any of the modeled exposure scenarios. Following the eonservation measures from the $2007 \mathrm{BA}$ would help minimize adverse impaets to these species. As a result, the aetion would be Not Likely to Adversely Affect kangaroo rats, the Utah prairie dog, and the blaek-footed ferret or their federally designated critical habitats at the programmatic level. Given BLM mandates for use of integrated pest management (including vegetation management), and given that it is not possible to forecast site-speeifie vegetation management needs below the programmatie level, additional evaluations of situation-specifie effects will be the subjeet of step-down ESA Section 7 evaluations and subsequent consultations. In this manner, any additional specifie eonservation measures neeessary to aceommodate site or situation-specific peeuliarities not predictable at the programmatie level will be developed at the loeal level and ineorporated into Pesticide Use Proposals prior to local implementation of vegetation management activities that involve the use of herbieides considered in this BA.

\section{Bighorn Sheep}

The primary references for this seetion are:

USFWS. 20001. Final Rule To List the Sierra Nevada Distinet Population Segment of the California Bighorn Sheep as Endangered. Federal Register 65(1):20-30.

and

USFWS. 1998z. Endangered Status for the Peninsular Ranges Population Segment of the Desert Bighorn Sheep in Southern California. Federal Register 63(52):13134-13150.

References eited in this section are internal to the above-refereneed documents. A complete list of these referenees is available from the USFWS, Ventura Field Office, Ventura, California; and the Carlsbad Field Office, Carlsbad, California.

The 2008 5-year review for the Sierra Nevada bighorn sheep (USFWS 2008y) and the 2011 5-year review for the Peninsular Ranges bighorn sheep (USFWS $2011 \mathrm{jj}$ ) were eonsulted for updated information on these species.

Two populations of bighorn sheep oceur in the projeet arca: Peninsular Ranges bighorn sheep (Ovis canadensis ssp. nelsoni), whieh inhabit the Peninsular Mountain Ranges of southern California and Mexico, and Sierra Nevada bighorn sheep (O. canadensis ssp. sierrae), which occupy the Sierra Nevada mountain range loeated along the eastern boundary of California. Peninsular bighorn sheep is a DPS of desert bighorn sheep.

The Peninsular Ranges bighorn sheep oecurs on open slopes in hot and dry desert regions where the land is rough, roeky, sparsely vegetated, and eharaeterized by steep slopes, canyons, and washes. In general, sheep inhabit elevations ranging between 300 and 4,000 feet, in areas where annual precipitation averages less than 4 inches and daily high temperatures in the summer average $104{ }^{\circ} \mathrm{F}$. Sheep use caves and roek outerops as shelters during inclement weather, and ridge benehes or eanyon rims adjacent to steep slopes or esearpments as lambing areas. From May through October, populations aggregate near water sourees and engage in breeding activities.

Bighorn sheep are diurnal, with a daily activity pattern that consists of both feeding and resting periods. The primary source of food for desert-assoeiated bighorn sheep is browse, which includes such species as brittlebrush, mountain mahogany, Russian thistle, bursage, mesquite, and palo verde. Sheep may also eat the pulp and fruits of various caetus species and graze on native grasses.

Bighorn sheep have a gestation period of 5 to 6 months, and produce one lamb per year. Lambing oceurs between January and June, peaking between February and May. Ewes with their lambs frequently inhabit areas where there are a diversity of slopes and exposures for escape cover and shelter from heat. Lambs are weaned between 1 and 7 months of age, and are independent of ewes by their second spring (Cowan and Geist 1971). 
Sierra Nevada bighorn sheep use habitats ranging from the highest elevations along the crest of the Sierra Nevada $(13,120$ feet and up) to winter ranges at the eastern base of the range as low as 4,760 feet. They are found in alpine and subalpine zones during the summer months, and on high, windswept ridges or lower elevation sagebrushsteppe habitat in the winter. Habitats utilized by the subspecies range from alpine to Great Basin sagebrush serub. Primary elements of preferred habitats are visual openness and close proximity to steep rocky terrain used to escape from predators. Forage resourees vary greatly across habitats. Of particular importance to population parameters is the nutrient content of forage. Nutrient quality of diets varies greatly with season and elevation and is limited primarily by effects of temperature and soil moisture on plant growth and population density. Because of the relationship between elevation and temperature, low-elevation winter ranges provide an important souree of high quality forage early in the growing season.

Summer habitat is primarily open areas that are rough, rocky, sparsely vegetated, and characterized by steep slopes and eanyons (Wehausen 1980, Sierra Nevada Bighorn Sheep Interagency Advisory Group 1997), at elevations between 10,000 and 14,000 feet. In the winter, the sheep exhibit a preference for south-facing slopes. The steep, rugged terrain is necessary for eseape, lambing, and bedding, and adjacent areas of low growing vegetation are required for food. An adequate supply of water is also necessary, as are travel routes that link all of the habitat areas. The sheep also require areas that are free of competition from other grazing ungulates, in particular domestic sheep. Sierra Nevada bighorn sheep are primarily grazers, but may browse woody vegetation as well, and their diet commonly includes a mixture of grasses and other herbaceous plants, as well as shoots, twigs, and leaves of trees and shrubs.

The general reproductive eycle is the same as that of Peninsular Ranges populations; however, in Sierra Nevada populations, breeding takes place in November, and lambing oceurs from late April to early July, peaking in May or June.

The Peninsular Ranges population segment was federally listed as endangered on Mareh 18, 1998 (63 FR 13134), and the Sierra Nevada population segment was federally listed as endangered on January 3, 2000 (65 FR 20). Critical habitat for the Peninsular Ranges bighorn sheep was originally designated in 2001 (66 FR 8650), but on April 14, 2009 was reduced (74 FR 17288). Currently, approximately 376,938 acres in Riverside, San Diego, and Imperial Counties, California, are designated eritical habitat for the Peninsular Ranges bighorn sheep. On August 5, 2008, approximately 417,577 acres in Tuolumne, Mono, Fresno, Inyo, and Tulare Counties, California, were designated as critical habitat for the Sierra Nevada bighorn sheep (73 FR 45534).

The Sierra Nevada population declined in the 1980s and early 1990s, hitting a low of about 100 individuals in 1995 (Sierra Nevada Bighorn Sheep Foundation, no date). Since, listing, however, the population size has increased to approximately 400 individuals (USFWS 2008y). The population of the Peninsular Ranges bighorn sheep decreased from about 1,100 individuals (in 1974) to as few as 300 individuals (USDOI BLM 2002b). In 2010, the population was estimated at approximately 981 individuals, a nearly three-fold increase sinee the time of listing (USFWS $201 \mathrm{ijj}$ ). Threats to the Peninsular Ranges population include the synergistic effeets of disease; low recruitment; habitat loss, degradation, and fragmentation; non-adaptive behavioral responses associated with residential and commereial development; and high predation rates eoineiding with low bighorn sheep population numbers. Additionally, the presence of invasive, non-native plants has increased rangewide, causing a change in forage quality and increasing the risk of wildfire at low elevations (USFWS 2011jij). Primary threats to the Sierra Nevada population continue to be small population size, mountain lion predation, abandonment of winter range, and the potential for disease transmission from domestic sheep. Roadkills and capture-related deaths also contribute to mortality (USFWS 2008y).

\section{Effects of Herbicide Treatments on Bighorn Sheep}

\section{Direct Effects}

Because bighorn sheep are large, mobile animals, it is unlikely that they would be sprayed inadvertently during herbicide treatments. However, bighorn sheep could come into contact with sprayed foliage after an herbicide application, or ingest plant materials at a treatment site shortly following the herbicide application. According to 
the ERAs, none of the herbicides considered in this BA would result in adverse health effects to bighorn sheep under any of the modeled exposure scenarios (direct spray, dermal contact with sprayed vegetation, or ingestion of sprayed food items; Tables 6-2 and 6-5).

\section{Indirect Effects}

Because bighorn sheep occur in sparsely vegetated habitats, herbicide treatments could indirectly affect the species by further reducing the amount of forage available. These effects would be temporary, but during a particularly sparse year could affect sheep populations. Over the long term, however, control of non-native species should improve the quality of forage in these habitats. Because bighorn sheep inhabit remote areas, vegetation treatments could affect habitat suitability by increasing the accessibility of habitat areas by humans. Creation of roads to access remote areas for treatments, should this oceur, would decrease their remoteness and could result in an increased human intrusion into sheep habitat.

\section{Conservation Measures}

When using aminopyralid, fluroxypyr, and rimsulfuron in vegetation treatment programs, the BLM would follow all pertinent SOPs for use, transport, and handling of herbicides. The BLM would also continue to follow the conservation measures identified in the $2007 \mathrm{BA}$, or other comparable measures that would be developed by the field offices based on local site conditions and included in local-level consultation. No additional conservation measures have been identified that are specific to the three new herbicides. However, additional project-specific conservation measures may be identified at the local level, as appropriate.

\section{Key Conservation Measures for Bighorn Sheep from the 2007 BA}

- Prior to treatment activities, survey suitable habitat for evidence of use by bighorn sheep.

- When planning vegetation treatments, minimize the creation of linear openings that could result in permanent travel ways for competitors and humans.

- Obliterate any linear openings construeted within bighorn sheep habitat in order to deter future uses by humans and competitive species.

- Where feasible, time vegetation treatments such that they do not coincide with seasonal use of the treatment area by bighorn sheep.

- Do not broadeast spray herbicides in key bighorn sheep foraging habitats.

\section{Determination of Effects}

Based on the ERAs, none of the three herbicides would be likely to adversely affeet bighorn sheep under any of the modeled exposure seenarios. Following the conservation measures from the 2007 BA would help minimize adverse impacts to this species. As a result, the action would be Not Likely to Adversely Affect bighorn sheep or their federally designated critical habitat at the programmatic level. Given BLM mandates for use of integrated pest management (including vegetation management), and given that it is not possible to forecast site-specific vegetation management needs below the programmatic level, additional evaluations of situation-specific effects will be the subject of step-down ESA Section 7 evaluations and subsequent consultations. In this manner, any additional specific conservation measures necessary to accommodate site or situation-specific peculiarities not predictable at the programmatic level will be developed at the local level and incorporated into Pesticide Use Proposals prior to local implementation of vegetation management activities that involve the use of herbicides considered in this BA.

\section{Gray Wolf}

The primary reference for this section is:

USFWS. 2000m. Proposal to Reclassify and Remove the Gray Wolf From the List of Endangered and Threatened Wildlife in Portions of the Coterminous United States; Proposal To Establish Three Special Regulations for Threatened Gray Wolves; Proposed Rule. Federal Register Volume 65(135):43449-43496.

References cited in this section are internal to the above-referenced document. A complete list of these references is available from the USFWS Region 3 Office, Fort Snelling, Minnesota. 
Gray wolves (Canis lupus) are the largest wild members of the dog family. The species historically occurred across most of North America, Europe, and Asia. In North America, wolves oceurred from the northern reaches of Alaska, Canada, and Greenland to the eentral mountains and the high interior plateau of southern Mexico. The only areas of the contiguous U.S. that apparently lacked gray wolves are much of California and the Gulf and Atlantic coastal plain south of Virginia. In addition, wolves were generally absent from the extremely arid deserts and the mountaintops of the western United States (Goldman 1944, Hall 1959, Mech 1974). The cultural attitudes of European settlers, coupled with pereeived and real conflicts between wolves and human activities along the frontier, led to widespread persecution of wolves. Poisons, trapping, and shooting - spurred by federal, state, and local government bounties-resulted in extirpation of the species from more than 95 percent of its range in the 48 coterminous states.

Wolves are predators of large animals. Wild prey speeies in North America include white-tailed deer, mule deer, moose, elk, woodland caribou, barren ground caribou, bison, musk ox, bighorn sheep, Dall sheep, mountain goat, beaver, and snowshoe hare, with small mammals, birds and large invertebrates sometimes being taken (Mech 1974, Stebler 1944, Wisconsin Department of Natural Resources 1999a). Wolves may also feed on domestic animals (Paul 1999).

Wolves are social animals, normally living in packs of two to ten members. Packs are primarily family groups consisting of a breeding pair, their pups from the current year, offspring from the previous year, and occasionally an unrelated wolf. Packs occupy, and defend from other packs and individual wolves, a territory of 20 to 214 square miles (though typically larger in the Rocky Mountains). Normally, only the top-ranking male and female in each pack breed and produce pups. Litters are born from early April into May; they can range from 1 to 11 pups, but generally contain 4 to 6 pups (USFWS 1992a, Michigan Department of Natural Resources 1997). Yearling wolves frequently disperse from their natal packs, although some remain with their pack. Dispersers may become nomadic and cover large areas as lone animals, or they may locate suitable unoceupied habitat and a member of the opposite sex and begin their own territorial pack. Dispersal movements of over 500 miles have been documented (Fritts 1983).

As many as 24 distinet subspecies of gray wolf have been recognized, and federal listings were originally at the subspecies level. On March 9, 1978, the gray wolf was relisted as endangered throughout the conterminous 48 States and Mexico (43 FR 9607). In Minnesota, however, the gray wolf was reclassified to threatened. In addition, critical habitat was designated in Isle Royale National Park, Michigan, and Minnesota. After numerous listing revisions and determinations, the current U.S. status of the gray wolf is listed as endangered, with various populations recently delisted or classified as experimental non-essential populations. Within the area covered by this BA, populations of the gray wolf are listed as endangered in California, Colorado, Kansas, Nebraska, Nevada, Oklahoma; portions of Arizona, New Mexico, and Texas not included in an experimental population; and portions of North Dakota, Oregon, South Dakota, Utah, and Washington (USFWS 2012i). On June 13, 2013, the USFWS determined that Canis lupus is not a valid species under the ESA (78 FR 35664) and proposed delisting of the species. Of the various subspecies that are eligible for listing, Canis lupus baileyi (Mexican wolf) is proposed for listing as endangered. This subspecies continues to be threatened by illegal shooting, inbreeding, loss of adaptive potential, and small population size (USFWS 2013k).

\section{Effects of Herbicide Treatments on Wolves}

\section{Direct Effects}

It is unlikely that wolves would be directly exposed to herbicides, since animals would avoid treatment sites, and are large enough that herbicide applicators should be able to see them. More likely exposure pathways would be dermal exposure to foliage sprayed by herbicide, or ingestion of prey items contaminated by herbicide. According to the ERAs, none of the herbicides considered in this BA would result in adverse health effects to wolves under any of the modeled exposure scenarios (direct spray, dermal contact with sprayed vegetation, or ingestion of sprayed food items; Tables 6-2 and 6-5). 


\section{Indirect Effects}

Habitat preferences by wolves appear to be more dependent on the availability of desired prey than on cover type. Although herbicide treatments could result in some modification of wolf habitat, it is the changes in the habitats of prey species that would have the most effect on wolves. Since some prey species prefer open habitat and others prefer dense habitat, treatments could benefit some species while negatively affecting others (Agyagos et al. 2001). In addition, treatments that reduee the cover of non-native species should have some long-term benefits by helping to restore native plant communities to wolf habitats, possibly increasing the diversity of food sourees.

\section{Conservation Measures}

When using aminopyralid, fluroxypyr, and rimsulfuron in vegetation treatment programs, the BLM would follow all pertinent SOPs for use, transport, and handling of herbicides. The BLM would also continue to follow the conservation measures identified in the $2007 \mathrm{BA}$, or other comparable measures that would be developed by the field offices based on loeal site conditions and included in local-level consultation. No additional conservation measures have been identified that are specific to the three new herbicides. However, additional or more speeifie guidanee would be provided at the project level, as appropriate.

\section{Key Conservation Measures for Gray Wolves from the 2007 BA}

- Avoid human disturbance and/or associated activities within 1 mile of a den site during the breeding period (as determined by a qualificd biologist).

- Avoid human disturbance and/or associated activities within 1 mile of a rendezvous site during the breeding period (as determined by a qualified biologist).

\section{Determination of Effects}

Based on the ERAs, none of the three herbicides would be likely to adversely affect gray wolves under any of the modeled exposure seenarios. Following the conservation measures from the 2007 BA would help minimize adverse impacts to this species. As a result, the action would be Not Likely to Adversely Affect gray wolf or their federally designated critical habitat at the programmatie level. Given BLM mandates for use of integrated pest management (including vegetation management), and given that it is not possible to forecast site-specific vegetation management needs below the programmatic level, additional evaluations of situation-specific effects will be the subject of step-down ESA Section 7 evaluations and subsequent consultations. In this manner, any additional specific conservation measures necessary to accommodate site or situation-specific peculiarities not predictable at the programmatic level will be developed at the loeal level and ineorporated into Pesticide Use Proposals prior to local implementation of vegetation management aetivities that involve the use of herbicides eonsidered in this BA.

\section{Cumulative Effects for Terrestrial Animals}

Private, tribal, and non-federal agency aetions occurring on or ncar public lands could affect terrestrial animals discussed in this BA. Future federal actions that are unrelated to the proposed action are not considered in this section because they require separate consultation pursuant to Section 7 of the ESA. The cumulative effects of local treatments will be individually evaluated in future project-level consultations.

Because the three herbicides assessed in this $\mathrm{BA}$ are being added to an existing vegetation treatment program (which was eovered in the 2007 BA; USDOI BLM 2007d), BLM lands receiving treatments with the three new herbicides could also receive other types of vegetation treatments, including treatments with other approved herbicides, manual treatments, mechanical treatments, fire, and biological control. In some cases, a combination of treatment types may be used in coneert to achieve a desired effect (e.g., preseribed fire followed by post-burn herbicide treatment). Therefore the eumulative effeets of multiple treatment methods on TEP terrestrial animal species should be considered when designing treatment programs at the local level. The conservation measures listed at the end of effects analysis sections for terrestrial animal species (or groups of species) apply only to treatments with aminopyralid, fluroxypyr, and rimsulfuron. Where a combination of treatment methods is 
employed, pertinent conservation measures listed in the 2007 BA (available at http://www.blm.gov/wo/st/en/prog/more/veg_eis.html) for other methods or herbicides must also be implemented.

State, tribal, local, and private actions occurring on or near public lands could affect the terrestrial organisms discussed in this BA. Many of the species eonsidered have habitats or home ranges that extend off of BLM lands, onto lands of other types of ownership, and could be impacted by non-federal activities in these areas. Given the programmatic nature of this BA, it is outside the scope of the analysis to identify specific non-federal actions that might contribute to cumulative impacts to TEP terrestrial species when considered together with BLM vegetation treatment activities. This type of site-specific analysis would be done at the local level, using information about the location of individual BLM treatment projects, and information about non-federal activities reasonably certain to occur in the action area. Cumulative effects might result from agriculture (use of herbicides and pesticides), livestock grazing (trampling, erosion, loss of forage and cover), mining, oil and gas, and ROW development, and timber harvest. Industrial activities may lead to loss of habitat, mortality of individuals, and spread of noxious weeds. Vegetation management programs at adjacent or nearby sites might involve additional use of herbicides within the action area. Tribal actions that could harm TEP terrestrial animals include hunting and collecting of animals for traditional lifeway uses. 


\section{CHAPTER 7}

\section{BIBLIOGRAPHY}

Abarca, F.J. 1987. Seasonal and Diel Patterns of Feeding in Loach Minnow, Tiaroga cobitis Girard. Proceedings of the Desert Fishes Council 19(1987):20.

Abbot, C.G. 1940. Notes from the Salton Sea, California. Condor 42(5):264.

AECOM. 2013. Final Scoping Summary Report for the Vegetation Treatments Using Aminopyralid, Fluroxypyr, and Rimsulfuron on Bureau of Land Management Lands in 17 Western States Programmatic Environmental Impact Statement. Prepared for the USDOI BLM. Seattle, Washington.

. 2014a. Final Aminopyralid Ecological Risk Assessment Final Report. Prepared for the USDOI BLM. Manchester, New Hampshire.

2014b. Final Fluroxypyr Ecological Risk Assessment Final Report. Prepared for the USDOI BLM. Manchester, New Hampshire.

2014c. Final Rimsulfuron Ecological Risk Assessment Final Report. Prepared for the USDOI BLM. Manchester, New Hampshire.

Agee, J.K. 1999. Fire Ecology of Pacific Northwest Forests. Island Press. Washington, D.C.

Agyagos, J., A. Telles, and R. Fletcher. 2001. Biological Assessment and Evaluation: Wildland Urban Interface Fuel Treatment. Forest Service, Southwestern Region. Albuquerque, New Mexico.

Alexander, D.G., and R.A. Schlising. 1997. Vernal Pool Ecology and Vernal Pool Landscape Management as Illustrated by Rare Macroinvertebrates and Vascular Plants at Vina Plains Preserve, Tehama County, California. Unpublished Report to the California Department of Fish and Game. Redding, California.

Allan, R.C. 1985. A Field Survey of the Endemic Fishes of the Pluvial White River and Carpenter River Systems. Unpublished Report. Nevada Department of Wildlife. Reno, Nevada.

Allen, D. 1996. Results of Two Consecutive Ycars of Surveys for Yadon's Piperia (Piperia yadonii). Ventura, California.

Allen, R.P. 1952. The Whooping Crane. National Audubon Society Resouree Report 3.

1956. A Report on the Whooping Cranes' Northern Breeding Grounds. National Audubon Society Supplemental Resouree Report 3.

Amsberry, K., and R.J. Meinke. 2007. Status Evaluation of Astragalu tricarinatus (Triple-ribbed Milk-vetch). Agreement No. PO485100. California Department of Fish and Game. Sacramento, California.

Anderson, B.W., and R.D. Ohmart. 1985. Habitat Use by Clapper Rails in the Lower Colorado River Valley. Condor 87(1):116-126. 
Anderson E., S.C. Forrest, T.W. Clark, and L. Richardson. 1986. Paleobiology, Biogeography, and Systematies of the Black-footed Ferret Mustela nigripes (Audubon and Bachman), 1851. Great Basin Naturalist Memoirs 8:11-62.

Anderson, J.L. 1982. Regional Resouree Planning; Dwarf Bear-poppy (Arctomecon humilis). USFWS. Denver, Colorado.

Anderson, R.M. 1978. The Distribution and Aspeets of the Life History of Meda fulgida in New Mexieo. M.S. Thesis, New Mexico State University. Las Cruees, New Mexico.

Anthony, R.G., E.D. Forsman, A.B. Franklin, D.R. Anderson, K.P. Burnham, G.C. White, C.J. Schwarz, J. Nichols, J.E. Hines, G.S. Olson, S.H. Ackers, S. Andrews, B.L. Biswell, P.C. Carlson, L.V. Diller, K.M. Dugger, K.E. Fehring, T.L. Fleming, R.P. Gerhardt, S.A. Gremel, R.J. Gutierrez, P.J. Happe, D.R. Herter, J.M. Higley, R.B. Horn, L.L. Irwin, P.J. Loschi, J.A. Reid, and S.G. Sovern. 2006. Status and Trends in Demography of Northern Spotted Owls 1985-2003. Wildlife Monograph No. 163.

Antifeau, T.D. 1987. The Signifieance of Snow and Arboreal Liehens in the Winter Eeology of Mountain Caribou (Rangifer tarandus caribou) in the North Thompson Watershed of British Columbia. M.S. Thesis, University of British Columbia. Vaneouver, British Columbia.

Antisell, T. 1856. Geologieal Report. Pacific Railroad Exploration Survey 7:1-204.

Apperson, K.A., and P.A. Anders. 1991. Kootenai River White Sturgeon Investigations and Experimental Culture. Annual Progress Report FY 1990. Contraet No. DE-A179-88BP93497; Projeet No. 88-65. Idaho Department of Fish and Wildlife and Bonneville Power Administration. Portland, Oregon.

Applegarth, J.S., J.C. Bednarz, and M.A. Williamson. 1980. The Ridge-nosed Rattlesnake in New Mexico: A Review of Existing Information and a Seareh for Suitable Habitat on Public Lands. Unpublished Report to the BLM. Las Cruees, New Mexieo.

Archbold, C.A. 1996. Habitat Evaluation for the Mohave Tui Chub (Gila bicolor mohavensis). M.S. Thesis, California State University, Fullerton, California.

Archon, M. 1992. Ecology of the San Joaquin Kit Fox in Western Mereed County, California. M.A. Thesis, California State University. Fresno, California.

Arends, A., F.J. Bonaccorso, and M. Genoud. 1995. Basal Rates of Metabolism of Nectarivorous Bats (Phyllostomidae) from a Semiarid Thorn Forest in Venezuela. Journal of Mammalogy 76:947-956.

Arizona Game and Fish Department. 1985. Interim Report on the Sonoran Pronghorn Antelope (Antilocapra americana sonoriensis). Oetober 1983 to Mareh 1985. Phoenix, Arizona.

. 1996. Wildlife of Special Concern in Arizona. Phoenix, Arizona.

- 1997. Amsonia kearneyana. Unpublished Abstraet Compiled and Edited by the Heritage Data Management System, Arizona Game and Fish Department. Phoenix, Arizona.

1999. Echinocactus horizonthalonius var. nicholii. Unpublished Abstract Compiled and Edited by the Heritage Data Management System, Arizona Game and Fish Department. Phoenix, Arizona.

2001a. Coryphantha robbinsorum. Unpublished Abstract Compiled and Edited by the Heritage Data Management System, Arizona Game and Fish Department. Phoenix, Arizona. 
- 2001b. Purshia subintegra. Unpublished Abstract Compiled and Edited by the Heritage Data Management System, Arizona Game and Fish Department. Phoenix, Arizona.

- 2001c. Pediocactus bradyi. Unpublished Abstraet Compiled and Edited by the Heritage Data Management System, Arizona Game and Fish Department. Phoenix, Arizona.

- 2001d. Cyprinella formosa. Unpublished Abstract Compiled and Edited by the Heritage Data Management System, Arizona Game and Fish Department. Phoenix, Arizona.

2004. Pediocactus pebblesianus var. peeblesianus. Unpublished Abstract Compiled and Edited by the Heritage Data Management System, Arizona Game and Fish Department. Phoenix, Arizona.

Arizona Rare Plant Committee (ARPC). 2001. Arizona Rare Plant Field Guide. A Collaboration of Agencies and Organizations. U.S. Government Printing Office. Washington, D.C.

Armantrout, N. 1985. Agency Report: BLM. Pages 34-37 in Proceedings of the Desert Fishes Council (E.P. Pister ed.). Volume XIII. 13th Symposium 1981.

Armbruster, M.J. 1990. Charaeterization of Habitat Used by Whooping Crancs during Migration. Biological Report 90(4):1-16.

Armstrong, V., and K.T. Harper. 1991. Astragalus holmgreniorum and Astragalus ampullarioides Status Report. Unpublished Report on File with the USDOI BLM. Salt Lake City, Utah.

Arnold, R.A. 1983. Valley Elderberry Longhorn Beetle Recovery Plan. Ageney Review Draft. USFWS. Portland, Oregon.

Austin, G.T., and J.F. Emmel. 1998. New Subspecies of Butterflies (Lepidoptera) from Nevada and California. Pages 501-522 in T. C. Emmel (Editor), Systematies of Western North Ameriean Butterflies. Mariposa Press, Gainesville, Florida.

Avery, J. 2008. Personal Communication. Fish and Wildlife Biologist, United States Fish and Wildlife Serviee, Carlsbad, California.

Baad, M.F. 1985. Population Biology of Arabis medonaldiana on Red Mountain, Mendoeino County, California. Progress Report No. 2. USDOI BLM. Ukiah, California.

Bagley, M. 1989. Scnsitive Plant Speeies Survey on a Portion of the Proposed Fort Irwin National Training Center Expansion Area, San Bernardino County, California. Report for Miehael Brandman Assoeiation, Santa Ana, California, to U.S. Army Corps of Engincers. Los Angeles, California.

Bailey, R.G. 1995. Description of the Ecoregions of the United States. $2^{\text {nd }}$ Edition, Revised and Expanded $\left(1^{\text {st }}\right.$ Edition 1980). Miseellaneous Publication Number 1391 (rev.), USDA Forest Serviee.

Baldwin, B.G. 2009. Morphologieal and Molecular Reconsideration of Deinandra increscens subsp. villosa. Final Report on File at Ventura Fish and Wildlife Offiee. Ventura, California.

Balestreri, A.N. 1981. Status of the San Joaquin Kit Fox at Camp Roberts, California, 1981. Unpublished Report, U.S. Department of the Army, Engineering, Environmental, and Natural Resources Offiee. California Polytechnic State University. San Luis Obispo, California.

Banfield, A.W.F. 1974. The Mammals of Canada. University of Toronto Press for Museum of Natural Science and the National Museums of Canada. Toronto, Canada. 
Barber, W.E., and W.L. Minckley. 1966. Fishes of Aravaipa Creek, Graham and Pinal Counties, Arizona. Southwestern Naturalist 11(3):313-324.

, and 1983. Feeding Ecology of a Southwestern Cyprinid Fish, the Spikedace, Meda fulgida

Girard. Southwestern Naturalist 28(1):33-40.

, D.C. Williams, and W.L. Minckley. 1970. Biology of the Gila Spikedace, Meda fulgida, in Arizona. Copeia 1970(1):9-18.

Barbour, M.G., and A.F. Johnson. 1977. Beach and Dune. Pages 223-261 in Terrestrial Vegetation of California (M.G. Barbour and J. Major, Editors). John Wiley and Sons. New York, New York.

, and J. Wirka. 1997. Classification of Alluvial Serub Vegetation in Los Angeles, Riverside, and San Bernardino Counties. Unpublished Document Prepared for Mary Myer, California Department of Fish and Game. San Diego, California.

Barlow, G.W. 1958. Daily Movements of Desert Pupfish, Cyprinodon macularins, in Shore Pools of the Salton Sea, California. Ecology 39:580-587.

1961. Social Behavior of the Desert Pupfish, Cyprinodon macularius, in the Field and the Aquarium. American Midland Naturalist 65:330-359.

Barlow, J.C. 1962. Natural History of the Bell Vireo, Vireo bellii Audubon. University of Kansas Publications of the Museum of Natural History 12:241-296.

Barneby, R.C. 1964. Atlas of North American Astragalus. Memoirs of the New York Botanical Garden Volume 13(2):597-1188.

Baron, S. 1998. A Demographic Study of Four Annual Plants of Maritime Chaparral. Senior Thesis, University of California. Santa Cruz, California.

Barr, C.B. 1991. The Distribution, Habitat and Status of the Valley Elderberry Longhorn Beetle, Desmocerus californicus dimorphus. U.S. Fish and Wildlife Service. Sacramento, California

Barrows, C.W. 1985. Breeding Suceess Relative to Fluctuations in Diet for Spotted Owls in California. In Ecology and Management of the Spotted Owl in the Pacific Northwest. Gutierrez, R.J., and A.B. Carey [Editors]. General Technical Report PNW-185. U.S. Department of Agriculture, Forest Service, Pacific Northwest Forest and Range Experiment Station. Portland, Oregon.

Barrows, K. 1987. Element Conservation Plan for Astragalus tricarinatus. In-house document. The Nature Conservancy. San Francisco, California.

Bart, J., and S.L. Earnst. 2005. Breeding Ecology of Spectacled Eiders Somateria fischeri in Northern Alaska. Wildfowl 55:85-100.

Bartlett, T., P. Coin, H. Nendick-Mason, and B. Moisset. 2008. Family Halictidae - Sweat Bees-Bug Guide.Net. Original Contribution by Troy Bartlett on February 16, 2004. Additional Contributions by Patrick Coin, Hannah Nendick-Mason, and Beatriz Moisset. Last updated September 16, 2008. Available at: http://bugguide.net.

Baskin, J.N. 1974. Survey of the Unarmored Threespine Stickleback (Gasterosteus aculeatus williansoni) in the Upper Santa Clara River Drainage. Final Report for Bureau of Sport Fisheries and Wildlife Contract No. 14-16-001-5387SE, USFWS. Washington, D.C. 
Bateman, R.L., A.L. Mindling, and R.L. Naff. 1974. Development and Management of Ground Water in Relation to Preservation of Desert Pupfish in Ash Meadows, Southern Nevada. Technical Report Series HW, Center for Water Resources Research Publication 17, University of Nevada. Reno, Nevada.

Battaglin, A.W., E.M. Thurman, S.J. Kalkhoff, and S.D. Porter. 2003. Herbicides and Transformation Products in Surface Waters of the Midwestern United States. Journal of the American Water Resources Association.

Batzli, G.O., and F.A. Pitelka. 1971. Condition and Diet of Cycling Populations of the California Vole, Microtus californicus. Journal of Mammalogy 52(1):141-163.

Bauder, E.T. 2000. Recovery and Management of Orcutt's Spineflower (Chorizanthe orcuttiana) Final Report. Unpublished Report Prepared for California Department of Fish and Game, South Coast Region. San Diego, California.

Baxter, G.T. 1952. The Relation of Temperature to the Altitudinal Distribution of Frogs and Toads in Southwestern Wyoming. Unpublished Ph.D. Thesis. University of Michigan. Ann Arbor, Michigan.

Beal, F.E.L. 1912. Food of Our More Important Flycatchers. U.S. Burcau of Biological Survey, Bulletin 4. Washington, D.C.

Beale, D.M., and A.D. Smith. 1970. Forage Use, Water Consumption, and Productivity of Pronghorn Antelope in Western Utah. Journal of Wildlife Management 34(3):570-582.

Beatley, J.C., 1977. Endangered Plant Species of the Nevada Test Site, Ash Meadows and Central-Southern Nevada. Contract E (11-1)-2307, U.S. Energy Research and Development Administration.

Bednarz, J.C. 1979. Ecology and Status of the Pecos Gambusia, Gambusia nobilis (Poeciliidae), New Mexico. Southwest Naturalist 24:311-322.

Beedlow, P.A., J.G. Carter, and F.J. Smith. 1980. Primula maguirei L. Wms. (Primulaceae), a Preliminary Report on the Population Biology of an Endemic Plant. Unpublished Report on File with USFWS. Salt Lake City, Utah.

Behnke, R.J. 1976. Summary of Information on the Status of the Greenback Cutthroat Trout, Salmo clarki stomias. Report Prepared for USFWS. Salt Lake City, Utah.

1979. Monograph of the Native Trouts of the Genus Salmo of Western North America. Prepared for the USFWS. Denver, Colorado.

1992. Native Trout of Western North America. American Fisheries Society, Monograph No. 6.

, and D.E. Benson. 1983. Endangered and Threatened Fishes of the Upper Colorado River Basin. Colorado State University, Cooperative Extension Service Bulletin 503A. Fort Collins, Colorado.

, and M. Zarn. 1976. Biology and Management of Threatened and Endangered Western Trouts. Forest Service General Technical Report RM-28. Fort Collins, Colorado.

Bell, H.M. 1974-1979. Unpublished Data. Field Notebook. Department of Ecology and Evolution, State University of New York. Stoney Brook, New York.

. 1994. Analysis of Habitat Characteristics of the San Joaquin Kit Fox in its Northern Range. M.A.

Thesis, California State University. Hayward, California. 
Belnap, J., J H. Kaltenecker, R. Rosentreter, J. Williams, S. Leonard, and D. EIdridge. 2001. Biological Soil Crusts: Ecology and Management. Technical Reference 1730-2. Bureau of Land Management. Denver, Colorado.

Bencie, R., and J. Kalt. 2007. 1998-2005 Summary Report, Western Lily Vegetation Strategy, Crescent City Marsh Wildlife Area and Table Bluff Ecological Reserve. Unpublished Report Prepared under Interagency Agreement California State University and California Department of Fish and Game. Redding, California.

Bennett, W.W., and R.D. Ohmart. 1978. Habitat Requirements and Population Characteristies of the Clapper Rail (Rallus longirostris yumanensis) in the Imperial Valley of California. University of California, Lawrence Livermore Laboratory. Livermore, California.

Benson, L. 1982. The Cacti of the United States and Canada. Stanford University Press. Stanford, California.

Bent, A.C. 1926. Life Histories of North Ameriean Marsh Birds. U.S. National Museum Bulletin 135:219-231.

1960. Life Histories of North American Flyeatchers, Larks, Swallows, and Their Allies. Dover Press, New York, New York.

Berenbrock, C. 1993. Effeets of Well Discharges on Hydraulic Heads in Spring Discharges from the Geothermal Aquifer System in the Bruneau Area, Owyhee County, Southwestern Idaho. Water Resourees Investigations, U.S. Geological Survey. Reston, Virginia.

Berrill, M., S. Bertram, and B. Pauli. 1997. Effects of Pesticides on Amphibian Embryos and Larvae. Pages 233245 in Amphibians in Decline: Canadian Studies of a Global Problem (D.M. Greed, Editor). Society for the Study of Amphibians and Reptiles. Salt Lake City, Utah.

Berry, K.H. 1974. Desert Tortoise Relocation Project: Status Report for 1972. Division of Highways, State of California, Desert Tortoise Relocation Project. Contract Number F-9353.

1978a. State Report - California. Pages I5-17 in Proeeedings of the Symposium of the Desert Tortoise Council.

. 1978b. Livestock Grazing and the Desert Tortoise. In Transactions of the $43^{\text {rd }}$ North American Wildlife and Natural Resourees Conference; 1978 March 18-22; Phoenix, Arizona. Wildlife Management Institute. Washington, D.C.

- 1986. Incidence of Gunshot Deaths in Desert Tortoise Populations in California. Wildlife Society Bulletin 14:127-132.

Beschta, R.L., J.R. Boyle, C.C. Chambers, W.P. Gibson, S.V. Gregory, J. Grizzel, J.C. Hagar, J.L. Li, W.C. McComb, M.L. Reiter, G.H. Taylor, and J.E. Warila. 1995. Cumulative Effects of Forest Practices in Oregon. Oregon State University, Corvallis, Oregon. Prepared for the Oregon State Department of Forestry. Salem, Oregon.

Beymer, R.J., and J.M. Klopatek. 1992. Effects of Grazing on Cryptogamic Crusts in Pinyon Juniper Woodlands in Grand Canyon National Park. American Midland Naturalist 127:139-148.

Biosystems Analysis, Inc. 1989. Endangered Species Alert Program Manual: Species Accounts and Procedures. Southern California Edison Environmental Affairs Division. Rosemead, California.

Bio-West, Inc. 1989. Biological Assessment for the Rock Creek/Muddy Creek Reservoir Project. Routt and Grand Counties, Colorado. 
. 2008. Ash Meadows National Wildlife Refuge Vegetation Mapping and Rare Plant Survey. Draft Progress Report Submitted to U.S. Fish and Wildlife Service by Bio-West, Inc. Logan, Utah.

.2011. Ash Meadows National Wildlife Refuge: Vegetation Community Mapping and rare Plant Survey; Final Report. Report submitted to U.S. Fish and Wildlife Serviee by Bio-West, Ine., Logan, Utah.

Bittman, R. 1985. Element Preservation Plan for Eriodictyon altissimum. The Nature Conservaney. San Franciseo, California.

Blankinship, D.R. 1976. Studies of Whooping Cranes on the Wintering Grounds. Pages 197-206 in Proceedings of the International Crane Workshop (J.C. Lewis, Editor). Oklahoma State University Press. Stillwater, Oklahoma.

Blinn, D.W., and C. Runck. 1990. Importanee of Predation, Diet, and Habitat on the Distribution of Lepidomeda vittata: a Federally Listed Speeies of Fish. Final Report Submitted to Coconino National Forest. Flagstaff, Arizona.

Bloomfield, M. 1980. Patterns of Seasonal Habitat Seleetion Exhibited by Mountain Caribou in Central British Columbia, Canada. Pages 10-18 in Proceedings of the $2^{\text {nd }}$ International Reindeer/Caribou Symposium (E. Reimers, E. Gaare, and S. Skjenneberg, Editors). Roros, Norway.

Bobzien, S., J.E. DiDonato, and P.J. Alexander. 2000. Status of the California Red-Legged Frog (Rana aurora draytonii) in the East Bay Regional Park District, California. Oakland, California.

Boccone, V., and T. Mills. 1979. Spawning Bchavior and Spawning Substrate Preferenee of the Modoe Sueker, Catostomus microps (Rutter). Inland Fisheries Endangered Species Program Special Publieation 79-2, California Department of Fish and Game. Saeramento, California.

Bond, C.E. 1974. Endangered Plants and Animals of Oregon: I. Fishes. Oregon Agriculture Experiment Station Special Report 205.

Bouma, R. 1984. A Contribution to the Management of Gambusia nobilis at Bitter Lake National Wildlife Refuge. Report to USFWS. Albuquerque, New Mexico.

Bowers, J.E. 1996. Seedling Emergence on Sonoran Desert Dunes. Journal of Arid Environments 33:63-72.

Bowler, P.A. 1990. The Rapid Spread of the Freshwater Hydrobiid Snail Potomopyrgus antipodarum (Gray) in the Middle Snake River, Idaho. Proceedings of the Desert Fishes Couneil 21:173-182.

Bowles, M.L. 1983. The Tallgrass Prairic Orchids: Platanthera leucuphaea (Nutt.) Lindl. and Cypripedium Candidum Muhl. Ex Willd.: Some Aspects of Their Status, Biology, and Ecology, and Implications toward Management. Natural Areas Journal 3(4):14-37.

, and A. Duxbury. 1986. Report on the Status of Platanthera praeclara Sheviak and Bowles in Oklahoma, Kansas, Nebraska, South Dakota, and North Dakota. Unpublished Report to USFWS. Denver, Colorado.

Bowlin, W.R., V.J. Tepedino, and T.L. Griswold. 1993. The reproductive biology of Eriogonum pelinophilum (Polygonaceae). In: R. C. Sivinski and K. Lightfoot, Editors. 1993. Proceedings of the Southwestern Rare and Endangered Plants Conference. Santa Fe, New Mexico.

Boyd, R. 1986. Strategies of Indian Burning in the Willamette Valley. Canadian Journal of Anthropology 5:65-84. 
Bradley, W.G., and J.E. Deacon. 1967. The Biotic Communities of Southern Nevada. Nevada State Museum Anthropological Papers 13(4):201-295.

Brandt, C.A., W.H. Rickard, and N.A. Cadoret. 1997. Vegetation Studies: National Training Center, Fort Irwin, California. Report for U.S. Army National Training Center, by Pacific Northwest National Laboratory. Fort Irwin, California.

Brannon, E.L., C.L. Melby, and S.D. Brewer. 1984. Columbia River White Sturgeon Enhancement. Final Report to Bonneville Power Administration. Contract No. DEA179-84BP18952; Project No. 83-316. Portland, Oregon.

Britt, K.D. 1982. The Reproductive Biology and Aspects of Life History of Tiaroga cobitis in Southwestern New Mexico. M.S. Thesis, New Mexico State University. Las Cruces, New Mexico.

Brotherson, J.D., G. Nebeker, M. Skougard, and J. Fairchild. 1978. Plants of Navajo National Monument. Great Basin Naturalist 38(1):19-30.

Brown, B.T. 1988. Breeding Ecology of a Willow Flycatcher Population in Grand Canyon, Arizona. Western Birds 19:25-33.

. 1993. Bell's Vireo (Vireo bellii). No. 35. In Birds of North America (A.F. Poole and F.B. Gill, Editors.). Academy of Natural Science of Philadelphia and American Ornithological Union. Washington, D.C.

Brown, D.E. (Editor). 1982. Biotic Communities of the American Southwest-United States and Mexico. Desert Plants 4(1-4):1-342.

, and C.H. Lowe. 1980. Biotic Communities of the Southwest. General Technical Report RM-78, Roeky Mountain Forest and Range Experiment Station, U.S. Department of Agriculture Forest Service. Fort Collins, Colorado.

, and C.P. Pase. 1980. A Digitized Systematic Classification for Ecosystems with an Illustrated Summary of the Natural Vegetation of North Ameriea. U.S. Department of Agrieulture/Forest Service General Technical Report RM-73. Rocky Mountain. Forest and Range Experiment Station. Fort Collins, Colorado.

Brown, D.R. 1987. The Effect of Human Trampling on Dune-mat Vegetation of the Lanphere-Christensen Dunes Preserve. Unpublished Preliminary Report, The Nature Conservancy, California Field Office. San Francisco, California.

Brown, N.L., and E.A. Cypher. 1997a. San Joaquin Woolly-threads, Lembertia congdonii. Endangered Species Profiles. Species Featured in Recovery Plan for San Joaquin Valley Arid Upland and Riparian Communities. Endangered Species Recovery Program. Fresno, California. Available at: http://arnica.csustan.edu/esrpp.

, and

- 1997b. Bakersfield Cactus, Opuntia basilaris var. treleasei. Endangered Species Profiles. Species Featured in Recovery Plan for San Joaquin Valley Arid Upland and Riparian Communities. Endangered Species Recovery Program. Fresno, California. Available at: http://arnica.csustan.edu/esrpp.

Browning, M.R. 1993. Comments on the Taxonomy of Empidonax traillii (Willow Flycatcher). Western Birds 24:241-257. 
Brussard, P.F., and H. Britten. 1989. The Status of the Uncompahgre Fritillary (Boloria acrocnema). Final Report Prepared for the Forest Service, BLM, and USFWS. Montana State University. Bozeman, Montana.

Brussard, P., B. Neill, and G.T. Austin. 1999. Report on the Distribution, Genetics, and Conservation Status of the Carson Wandering Skipper, Pseudocopaeodes eunus obscurus. University of Nevada, Reno. Unpublished Report Submitted to the USFWS Nevada Fish and Wildlife Office. Reno, Nevada.

Buettner, M., and G. Scoppettone. 1991. Distribution and Information on the Taxonomic Status of the Shortnose Sucker, Chasmistes brevirostris, and Lost River Sucker, Deltistes luxatus, in the Klamath Basin, California. Completion Report. California Department of Fish and Game Contract FG-8304.

Burk, J.H., C.E. Jones, J. Wheeler, and S. DeSimone. 1988. The Ecology of Eriastrum densifolium ssp. sanctorum (Milliken) Mason. Design Memorandum No. 1: Phase II GDM on the Santa Ana River Mainstem Including Santiago Creek. Vol. 8: Environmental. Prepared for U.S. Army Corps of Engineers, Los Angeles District. Prepared by Environmental Audit Inc.. Placentia, California.

Cahalane, V. 1961. Mammals of North America. MacMillan Company. New York, New York.

Calhoun, A.J. 1942. The Biology of the Black-Spotted Trout (Salmo clarki henshawi) (Gill and Jordan) in Two Sierra Nevada Lakes. Ph.D. Dissertation. Stanford University. Palo Alto, California.

California Army National Guard. 2001a. Camp Roberts Training Center, Monterey and San Luis Obispo Counties California: Integrated Natural Resourees Management Plan, November 2001, for Plan Period FY 2002-2006. Sacramento, California.

. 2001b. Purple Amole 2001 Census Data. Camp Roberts, California.

California Department of Fish and Game. 1990. Draft Recommendations to the California Fish and Game Commission. Natural Heritage Division. Sacramento, California.

. 1995. California Natural Diversity Database, Electronic Form. Sacramento, California.

- 1997. Natural Diversity Database Rare Find Element Occurrence Reports. California Department of Fish and Game Natural Heritage Division. Sacramento, California.

. 2000a. The Status of Rare, Threatened, and Endangered Animals and Plants of California: Mohave Tui Chub. California Department of Fish and Game Habitat Conservation and Planning Branch. Sacramento, California. Available at: http://www.dfg.ca.gov.

. 2000b. The Status of Rare, Threatened, and Endangered Animals and Plants of California: Desert Slender Salamander. State of California Habitat Conservation Planning Branch. Sacramento, California. Available at: http://www.dfg.ca.gov.

2000c. The Status of Rare, Threatened, and Endangered Animals and Plants of California: Coachella Valley Fringe-toed Lizard. State of California Habitat Conservation Planning Branch. Sacramento, California. Available at: http://www.dfg.ca.gov.

California Native Plant Society (CNPS). 2001. Inventory of Rare and Endangered Plants of California, 6th edition. Special Publication No. I. Sacramento, California. 
. 2010. Inventory of Rare and Endangered Plants (Online Edition, v7-10b). California Native Plant Socicty. Sacramento, California. Accessed on January 20, 20I0. Available at: http://www.enps.org/inventory.

California Natural Diversity Database. Multiple years. Database Records for Various Species. Sacramento, California. Available at: http://www.dfg.ca.gov/biogeodata/enddb/.

Canadian Wildlife Service and USFWS. 2007. International Recovery Plan Whooping Crane (Grus americana), Third Revision. Ottawa, Canada, and Albuquerque, New Mexico.

Carlson, D.M., W.L. Pfleiger, L. Trial, and P.S. Haverland. 1985. Distribution, Biology and Hybridization of Scaphirlyncus albus and S. platorynchus in the Missouri and Mississippi River, Missouri. The Sturgeon Symposium. Environmental Biology of Fishes 14:141-225.

Carothers, S. 1996. Sampling to Deteet a Persistent Seed Bank for the Endangered Humboldt Bay Wallflower (Erysimum menziesii ssp. eurekeuse). Unpublished report. The Nature Conservancy. Arcata, California.

Center for Conservation Biology. 1990. An Investigation of the Distribution and Abundance of the Buena Vista Shrew, Sorex ornatus relictus, at Kern Lake Preserve. Final Report, The Nature Conservancy, Stanford University. Stanford, California.

CH2M Hill. 1986a. Factors Affecting the Distribution of Eriogonum ovalifolium var. williamsae at Steamboat Springs. Report to Western States Geothermal Company.

- 1986b. Studies of Sidalcea nelsoniana. Unpublished Annual Research Report and Technical Memorandum Prepared by CH2M Hill for MeMinnville Water and Light, Submitted to the USFWS.

Chapman, D.W., and T.C. Bjornn. 1969. Distribution of Salmonids in Streams, with Special Reference to Food and Feeding. Pages 153-176 in T.G. Northeote (Editor). Symposium on Salmon and Trout in Streams. Institute of Fisheries, University of British Columbia. Vancouver, British Columbia.

Chesemore, D.L. 1980. Impact of Oil and Gas Development on Blunt-nosed Leopard Lizards. BLM, Final Report, Contract Number YA-512-CT9-118. Bakersfield, California.

. 1981. Blunt-nosed Leopard Lizard Inventory Final Report. BLM, Contract Number YA-553-CTO-5I. Bakersfield, California.

Chipping, D. 1994. Chorro Creek Bog Thistle Recovery Project. Final Report Submitted to the California Department of Fish and Game. Natural Heritage Division. Sacramento, California.

Christie, K. 2004. Erigeron rhizomatus Survey and Status Report for the Navajo Nation. Submitted to the Navajo Natural Heritage Program. Window Rock, Arizona.

Cichowski, D.B. 1989. Seasonal Movements, Habitat Use, and Winter Feeding Ecology of Woodland Caribou in West-central British Columbia. M.S. Thesis, University of British Columbia. Victoria, British Columbia.

Clark, D. 1997. Annual Report - "Expeditions into the Parks" Rare Plant Survey at Capitol Reef National Park. Unpublished Report Prepared for the National Park Foundation and Canon U.S.A.

- 1999. 1999 Survey Results for Barneby's Reed-Mustard (Schoenocrambe barnebyi). Unpublished Report by the 1999 Interagency Rare Plant Team, Prepared for the Capitol Reef National Park and the Bureau of Land Management. Richfield, Utah. 
. 2001. 2001 Survey Results for Wright Fishhook Cactus (Sclerocactus wrightiae). Capitol Reef National Park. Torrey, Utah; Bureau of Land Management. Richfield Field Office. Richfield, Utah.

. 2002a. Summary of the Interagency Rare Plant Inventory Project 1999 through 2002. Dixie National Forest, Teasdale District. Teasdale, Utah; Bureau of Land Management. Richfield Field Office. Richfield, Utah; Capitol Reef National Park. Torrey, Utah; and Fish Lake National Forest, Supervisor's Office. Richfield, Utah.

. 2002b. 2002 Survey Results for Wright Fishhook Cactus (Sclerocactus wrightiae). Bureau of Land Management, Richfield Field Office. Richfield, Utah.

, K.K. Finley, and C.A. Ingersoll. 1993. Status Report for Erigeron decumbens var. decumbens. Report to Conservation Biology Program. Oregon Department of Agriculture. Salem, Oregon.

, and C. Groebner. 2003. Summary of Survey Results for Wright Fishhook Cactus 2000 through 2003 (Sclerocactus wrightieae). Bureau of Land Management Richficld Field Office. Richfield, Utah.

G. Lenhart, and C. Craig. 2004. Survey Results for Wright Fishhook Cactus 2004 (Sclerocactus wrightiae). Capitol Reef National Park and Bureau of Land Management. Price Field Office. Price, Utah.

Clark, R.A., and G.M. Fellers. 1986. Rare Plants of Point Reyes National Seashore. Cooperative National Park Resources Studies Unit, Technical Report No. 22. University of California. Davis, California.

Clarke, A.H. 1991. Status Survey of Seleeted Land and Freshwater Gastropods in Utah. Unpublished Report Prepared for the USFWS. Denver, Colorado.

Cochrane, S. 1981. Field Survey Report for Grindelia Fraxino-pratensis 20 Oetober 1981. California Natural Diversity Database. Sacramento, California.

Cockrum, L.E. 1991. Seasonal Distribution of Northwestern Populations of the Long-nosed Bats, Leptonycteris sanborni Family Phyllostomidae. Annals of the Institute of Biology; Universidad Nacional Autonoma de Mexico, Serie Zoologia 60:181-202.

Coffin, P.D. 1983. Lahontan Cutthroat Trout Fishery Management Plan for the Humboldt River Basin. Federal Aid to Fish Restoration Project Report F-20-17. Study IX, Job No. 1-P-1. Nevada Department of Wildlife. Reno, Nevada.

Cole, G.A. 1981. Habitats of North American Desert Fishes. Pages 472-492. In Fishes in North American Deserts. R.J. Naiman and D.L. Soltz (Editors). Wiley Interseience. New York, New York.

Coleman, M.E. 1986. Evaluation of Spawning Runs at the Marble Bluff Fish Facility Nixon, Nevada 1978 to 1985. USFWS. Report. FR1/FAO-86-11. USFWS. Reno, Nevada.

Coleman, R.A. 1995. The Wild Orehids of California. Cornell University Press. Ithaca, New York.

Coles, J., and T. Naumann. 2003. Long-Term Demographic Monitoring of the Mesa Verde Cactus in Colorado. Unpublished Manuseript.

Collier, G.D. 1975. The Utah Prairic Dog: Abundance, Distribution, and Habitat Requirements. Publication Number 75-10. Utah Division of Wildlife Resources. Salt Lake City, Utah. 
Colorado Department of Wildlife. 1985. Colorado Natural Areas Inventory Database; Field Survey of Jackson County, Colorado. Department of Wildlife. Denver, Colorado.

Colorado Native Plant Society. 1989. Rare Plants of Colorado. Estes Park, Colorado.

Colorado Natural Areas Program. 1986-2005. Performance Reports for Population Biology and Habitat Protection of Sclerocactus mesae-verdae. Colorado State Parks. Grand Junction, Colorado.

Colorado Natural Heritage Program. 1999. Conservation and Management Plan for Preble's Meadow Jumping Mouse. Prepared for the United States Air Foree Academy, Colorado. Fort Collins, Colorado.

2006. Biodiversity Tracking and Conservation System (BIOTICS). Colorado Natural Heritage Program. Colorado State University. Fort Collins, Colorado.

Commission for Environmental Cooperation. 2000. Biodiversity Conservation of Migratory and Transboundary Species: Species of Common Conservation Concern in North America (Working Draft). Montreal, Canada.

Condon, J.D. 1971. Population Estimate and Distribution of the Morro Bay Kangaroo Rat. Special Report for California Department of Fish and Game, WMB Administrative Report 71-11.

1975. Status of the Endangered Morro Bay Kangaroo Rat. Journal of Mammalogy 56:679-683.

Conservation Management Institute. 1996. Fish and Wildlife Information Exchange, Owens Tui Chub. College of Natural Resources, Virginia Polytechnic Institute and State University. Blacksburg, Virginia.

Consortium of California Herbaria. 2010. Information Regarding Deinandra increscens ssp. villosa Herbarium Specimens Deposited in the Following Herbaria: JEPS, NY, POM, RSA, SBBG, SD, SDSU, UCSB. Available at: http://ucjeps.berkeley.edu/che_form.html. May 7, 2010.

Conway, C.J. 1990. Seasonal Changes in Movements and Habitat Use by Three Sympatric Species of Rails. M.S. Thesis, University of Wyoming. Laramie, Wyoming.

, W.R. Eddleman, S.H. Anderson, and L.R. Hanebury. 1993. Scasonal Changes in Yuma Clapper Rail Vocalization Rate and Habitat Use. Journal of Wildlife Management 57(2):282-290.

Coombs, C.I., C.E. Bond, and S.F. Drohan. 1979. Spawning and Early Life History of the Warner Sucker (Catostomus warnerensis). Unpublished Report to the USFWS.

Cooper, J.J. 1978. Contributions to the Life History of the Lahontan Tui Chub, Gila bicolor obese (Girard), in Walker Lake, Nevada. M.S. Thesis, University of Nevada. Reno, Nevada.

Cooper, W.S. 1967. Coastal Dunes of California. Geological Society of America 104:1-125. Boulder, Colorado.

Cord, B., and J.R. Jehl, Jr. 1979. Distribution, Biology, and Status of a Relict Population of Brown Towhee (Pipilo fuscus eremophilus). Western Birds 10:131-156.

Courtenay, W.R., Jr., J.E. Deacon, D.W. Sada, R.C. Allan, and G.L. Vinyard. 1985. Comparative Status of Fishes along the Course of the Pluvial White River, Nevada. Southwest Naturalist 30(4):503-524.

Cowles, R.B. 1934. Notes on the Ecology and Breeding Habits of the Desert Pupfish, Cyprinodon macularius Baird and Girard. Copeia 1934: 40-42. 
Cox, T.J. 1966. A Behavioral and Ecologieal Study of the Desert Pupfish (Cyprinodon macularius) in Quitobaquito Springs, Organ Pipe Caetus National Monument, Arizona. Dissertation, University of Arizona. Tueson, Arizona.

1972. The Food Habits of Desert Pupfish (Cyprinodon macularius) in the Quitobaquito Springs, Organ Pipe Caetus National Monument, Arizona. Journal of the Arizona-Nevada Aeademy of Seienee 7:25-27.

Coyner, J. 1989. Status Cheek on Reported Historie Populations of Spiranthes diluvialis. Memorandum, USFWS. Salt Lake City, Utah.

1990. Report for Population Study Spiranthes diluvialis. Unpublished Report. BLM and Red Butte Gardens, University of Utah. Salt Lake City, Utah.

Craighead, J.J., and J.A. Mitchell. 1982. Grizzly Bear. In Wild Mammals of North Ameriea: Biology, Management, and Eeonomies (J. Chapman and G. Feldhamer, Editors). Johns Hopkins University Press. Baltimore, Maryland.

, M.G. Hornocker, and F.C. Craighead, Jr. 1969. Reproduetive Biology of Young Female Grizzly Bears. Journal of Reproduetion and Fertility, Supplement 6:447-475.

, J.S. Sumner, and G.B. Scaggs. 1982. A Definitive System for Analysis of Grizzly Bear Habitat and other Wilderness Resourees Utilizing LANDSAT Multispeetral Imagery and Computer Teehnology. Wildlife-Wildlands Institute Monograph No. 1. University of Montana Foundation, University of Montana. Missoula, Montana.

Crampton, B. 1976. Rare Grasses in a Vanishing Habitat. Fremontia 4(3):22-23.

Crocker-Bedford, D.C. 1975. Quarterly Report for January-Mareh. Utah Cooperative Wildlife Researeh Unit, Utah State University. Logan, Utah.

Crone, E.E., and C.B. Schultz. 2003. Movement Behavior and Minimum Pateh Size for Butterfly Population Persistenee. Pages 561-576 in: Butterflies: Eeology and Evolution Taking Flight (C. Boggs, W. Watt, and P. Ehrlieh, Editors). University of Chieago Press. Chieago, Illinois.

Cronquist, A. 1947. A Revision of the North Ameriean Speeies of Erigeron, North of Mexieo. Brittonia 6:274275.

1981. An Integrated System of Classifieation of Flowering Plants. Columbia University Press. New York, New York.

, A.H. Holmgren, N.H. Holmgren, and J.L. Reveal. 1972. Intermountain Flora, Volume 1. Hafner Publishing Company. New York, New York and London, England.

Cross, J.N. 1976. Status of the Native Fish Found in the Moapa River, Clark County, Nevada. Transaetions of the Ameriean Fisheries Soeiety 105(4):503-508.

Crowl, T.A., and H.M. Thomas. 1997. June Sueker Studies - 1995 to 1996: Provo River and Utah Lake Fisheries Management Studies. Annual Report Submitted to Utah Division of Wildlife Resourees. Salt Lake City, Utah.

Culbertson, A.E. 1946. Observations on the Natural History of the Fresno Kangaroo Rat. Journal of Mammalogy 27:189-203. 
Cully, A., P. Knight, R. Sivinski, M. Olwell, D.E. House, and K. Lightfoot. 1993. Preliminary Results from a Long-Term Study of Mesa Verde Cactus (Sclerocactus mesae-verdae). In: Proceedings of the Southwestern Rare and Endangered Plants Conferenee 1992. (R. Sivinski and K. Lightfoot, Editors). Miseellaneous Publieation No. 2. New Mexieo Forestry and Resourees Conservation Division. Santa Fe, New Mexico.

Currah, R.S., E.A. Smreciu, and S. Hambleton. 1990. Myeorrhizae and Mycorrhizal Fungi of Boreal Species of Platanthera and Coeloglossum (Orehidaceae). Canadian Journal of Botany 68:1171-1181.

Cypher, B.L. 2006. Kit Fox Conservation in the San Luis Drainage Study Unit. Unpublished Report to the U.S. Bureau of Reelamation South-Central California Area Offiee. California State University, Stanislaus, Endangered Speeies Reeovery Program. Fresno, California.

Cypher, E.A. 1994. Progress Report on 1994 Grazing Studies for Kern Mallow and San Joaquin Woolly-threads. BLM, Unpublished Report. Bakersfield, California.

Davis, J. 1951. Distribution and Variation of the Brown Towhees. University of California Publications in Zoology 52:1-120.

Davis, J.S., and B. Youtie. 1995. Site Information and Analysis: North Powder Thelypodium howellii ssp. spectabilis Preserve. Prepared for The Nature Conservaney, Oregon Field Offiee. Portland, Oregon.

Deacon, J.E. 1979. Endangered and Threatened Fishes of the West. Great Basin Naturalist 3:41-64.

, and B.L. Wilson. 1967. Daily Activity Cyeles of Crenichthys baileyi, a Fish Endemic to Nevada. Southwestern Naturalist 12(1):31-44.

, and W.G. Bradley. 1972. Eeologieal Distribution of the Fishes of Moapa (Muddy) River in Clark County, Nevada. Transactions of the Ameriean Fisheries Soeiety 101(3):408-419.

, and W.L. Minckley. 1974. Desert Fishes. Pages 385-487 in Desert Biology (G.W. Brown, Jr., Editor). Volume 2. Academic Press. New York, New York.

, T.B. Hardy, J. Pollard, W. Taylor, J. Landye, J. Williams, C. Williams, P. Greger, and M.

Conrad. 1980. Environmental Analysis of Four Aquatic Habitats in East-eentral Nevada: June-September, 1980. Interim Final Summary Report to HDR Seienees.

Decker, K., A. Lavender, J. Handwerk, and D.G. Anderson. 2006. Modeling the Potential Distribution of Three Endemic Plants of the Northern Piceance and Uinta Basins. Unpublished Report Prepared for U.S. Fish and Wildlife Serviee by the Colorado Natural Heritage Program. Colorado State University. Fort Collins, Colorado.

Derrickson, S.R., and J.W. Carpenter. 1981. Whooping Crane Production at the Patuxent Wildlife Research Center, 1967-1981. Pages 190-198 in Proceedings of the 1981 International Crane Workshop (J.C. Lewis, Editor). National Audubon Society. Tavernier, Florida.

Dick-Peddie, W. 1993. New Mexieo Vegetation. University of New Mexico Press. Albuquerque, New Mexico.

DiTerlizzi, T., B. Moiset, and J.S. Ascher. 2008. Family Andrenidae - Mining Bees - BugGuide. Net. Original Contribution by Tony DiTerlizzi on July 18, 2004. Additional Contributions by Beatriz Moisset and John S. Ascher. Last updated October 7, 2008. 
Doak, D.F., and A. Graff. 2001. Reproductive Biology and Pollination Eeology of the Federally Endangered Yadon's Piperia (Piperia yadonii, Orchidaeeae) in Monterey County, California. Unpublished Report Prepared for U.S. Fish and Wildlife Serviee, Ventura Field Offiee. Ventura, California.

Dorn, P.B., J.H. Rodgers, Jr., W.B. Gillespie, Jr., R.E. Lizotte, Jr., and A.W. Dunn. 1997. The Effects of C1213 Linear Aleohol Ethoxylate Surfaetant on Periphyton, Maerophytes, Invertebrates and Fish in Stream Mesoeosms. Environmental Toxieology and Chemistry 16(8):1634-1645.

Dorrell-Canepa, J. 1994. Population Biology of Gilia tenuiflora ssp. arenaria (Polemoniaeeae). Unpublished M.S. Thesis, San Jose State University. San Jose, California.

Dorsey, A. 2007. Dudleya, with Speeial Referenee to Those Growing in the Santa Moniea Mountains. In Flora and Eeology of the Santa Moniea Mountains. (D. A. Knapp, Editor). Southern California Botanists Speeial Publieation No. 4.

Dudley, R.K., and S.P. Platania. 1999. Downstream Transport Rates of Drifting Semibuoyant Cyprinid Eggs and Larvae in the Peeos River, NM. DRAFT Reports to U.S. Bureau of Reelamation. Albuquerque, New Mexieo.

Dudley, W.W., Jr., and J.D. Larson. 1976. Effeet of Irrigation Pumping on Desert Pupfish Habitats in Ash Meadows, Nye County, Nevada. U.S. Geologieal Survey Professional Paper 927:1-52.

Duffy, W.G., C.R. Berry, and K.D. Keenlyne. 1996. Biology of the Pallid Sturgeon with an Annotated Bibliography through 1994. South Dakota Cooperative Researeh Unit Teehnieal Bulletin Number 5. South Dakota State University. Brookings, South Dakota.

Durtsche, R.D. 1992. Feeding Time Strategies of the Fringe-toed Lizard, Uma inornata, during Breeding and Non-Breeding Seasons. Oeeologia 89:85-89.

1995. Foraging Eeology of the Fringe-toed Lizard, Uma inornata, during Periods of High and Low Food Abundanee. Copeia 1995:915-26.

Eaton, R. 1977. Breeding Biology and Propagation of the Oeelot (Leopardus [Felis] pardalis). Zoologisehe Garten 47:9-23.

ECOS, Inc. 1990. Habitat Charaeterization and Sensitive Speeies Monitoring Plan for Vegetation in the Algodones Dunes, Imperial County, California. Unpublished Report Prepared for USDOI BLM, El Centro Resouree Area. El Centro, California.

Eddleman, W.R. 1989. Biology of the Yuma Clapper Rail in the Southwestern U.S. and Northwestern Mexieo. Final Report to Bureau of Reelamation, Yuma Projeets Offiee and Fish and Wildlife Serviee, Region 2. Wyoming Cooperative Fish and Wildlife Researeh Unit, University of Wyoming. Laramie, Wyoming.

, and C.J. Conway. 1994. Clapper Rail. In Pages 167-179 of Management of Migratory Shore and Upland Game Birds in North Ameriea (T.C. Taeha and C.E. Braun, Editors). International Assoeiation of Fish and Wildlife Ageneies. Washington, D.C.

Egoscue, H.J. 1956. Preliminary Studies of the Kit Fox in Utah. Journal of Mammalogy 37:351-357.

1962. Eeology and Life History of the Kit Fox in Tooele County, Utah. Eeology 43:481-497. 
E1P Associates. 1994. University of California San Joaquin Campus Site Selection Draft Environmental Impact Report. Volume 2: Project Description/Environmental Analysis. Unpublished Report to the University of California Office of the President. San Joaquin, California.

1999. UC Merced/UC Community Planning Area 1999 Special-Status Plant Survey Report. Unpublished report to the University of California and Mereed County. Sacramento, California.

Eisenberg, J.F., and D.E. Isaac. 1963. The Reproduction of Heteromyid Rodents in Captivity. Journal of Mammalogy 44:61-67.

Eldridge, D.J., and R.S.B. Greene. 1994. Microbiotic Soil Crusts: a Review of Their Roles in Soil and Ecological Processes in the Rangelands of Australia. Australian Journal of Soil Research 32:389-415.

Elvin, M.A. 2010a. Unpublished Data, Field Notes Regarding Government Point Site Visit with Mary Meyer of California Department of Fish and Game, Jessica Peak of Padre and Associates, and Brian Dugas of Padre and Associates to Examine Deinandra increscens subsp. villosa. August 17, 2010. U.S. Fish and Wildlife Service. Ventura, California.

. 2010b. Unpublished Data, Field Notes Regarding Vandenberg Air Foree Base Site Visit with Luanne Lum of Vandenberg Air Forec Base. September 7, 2010. U.S. Fish and Wildlife Service. Ventura, California.

ENSR. 2004. Vegetation Treatments Programmatic EIS Ecological Risk Assessment Methodology. Prepared for the USDOI BLM, Nevada State Office, Reno, Nevada. Westford, Massachusetts.

Erickson, J.D. 1992. Habitat Selection and Movement of Pallid Sturgeon in Lake Sharpe, South Dakota. M.S. Thesis. South Dakota State University. Brookings, South Dakota.

Erickson, R.C., and S.R. Derrickson. 1981. Whooping Crane (Grus americana). Pages 104-118 in Crane Research Around the World (J.C. Lewis and H. Masatomi, Editors). International Crane Foundation. Baraboo, Wisconsin.

Ernst, C.H. 1992. Venomous Reptiles of North America. Smithsonian Institute Press. Washington, D.C.

ERT Company. 1986. Status Report on the Pawnee Montane Skipper (Hesperia leonardus montana Skinner). Prepared for the Denver Water Department. Denver, Colorado.

Esque, T.C. 1994. Diet and Diet Selection of the Desert Tortoise (Gopherus agassizii) in the Northeastern Mojave Desert. Master's Thesis. Colorado State University. Fort Collins, Colorado.

Evens, J., and S. San. 2004. Vegetation Associations of a Serpentine Area: Coyote Ridge, Santa Clara County, California. California Native Plant Society. Sacramento, California.

Fausch, K.D. 1984. Profitable Stream Positions for Salmonids: Relating Specific Growth Rate to Net Energy Gain. Canadian Journal of Zoology 62:441-451.

, and R.J. White. 1981. Competition Between Brook Trout (Salvelimus fontinalis) and Brown Trout (Salmo trutta) for Positions in a Michigan Stream. Canadian Journal of Fisheries and Aquatic Science 38:1220-1227.

Feldmeth, R., D. Soltz, L. MeClanahan, J. Jones, and J. Irwin. 1985. Natural Resources of the Lark Seep System (China Lake, CA0 with Special Emphasis on the Mohave Chub (Gila bicolor mohavensis). Proceedings of the Desert Fishes Council 13-15:356-358. 
Fertig, W. 2000. Status of Blowout Penstemon (Penstemon haydenii) in Wyoming. Prepared for the Wyoming Cooperative Fish and Wildlife Research Unit, U.S. Fish and Wildlife Service, and Wyoming Game and Fish Department. Wyoming Natural Diversity Database, University of Wyoming. Laramie, Wyoming.

Fleming, T.H., R.A. Nunez, and L.S.L. Sternberg. 1993. Seasonal Changes in the Diets of Migrant and Nonmigrant Nectarivorous Bats as Revealed by Carbon Stable Isotope Analysis. Oecologia 94:72-74.

Flessner, T.R. 1979a. Status Report on Pediocactus peeblesianus var. peeblesianus. Unpublished Report on File at the USDA Forest Service, Region 3. Albuquerque, New Mexico.

- 1979b. Status Report on Echinocereus fendleri var. kuenzleri. USDA Forest Service. Albuquerque, New Mexico.

1988. Propagation, Establishment, and Ecological Characteristics of Penstemon haydenii S. Watson. M.S. Thesis, University of Nebraska. Lineoln, Nebraska.

, and J. Stubbendieek. 1992. Pollination Charaeteristies of Blowout Penstemon (Penstenon haydenii S. Wats.). Transactions of the Nebraska Academy of Sciences.

, W. Isaaes, and P. Knight. 1984. A Handbook of Rare and Endemic Plants of New Mexico. University of New Mexico Press. Albuquerque, New Mexico.

Florenee, S., and L.M. Kiguehi. 1986. Sensitive Plant Survey: Clear Creek Recreation Area, San Benito Mountain Natural Area. Unpublished Report for the BLM, Hollister Resouree Area. Hollister, California.

Ford, T. 1977. Status Summary Report on the Modoc Sucker (Catostomus microps Rutter). Unpublished Report. Modoe National Forest. Alturas, California.

Forrest, S.C., T.W. Clark, L. Riehardson, and T.M. Campbell III. 1985. Black-footed Ferret Habitat: Some Management and Reintroduction Considerations. Wyoming BLM, Wildlife Technical Bulletin, No. 2.

Forsman, E.D., E.C. Meslow, and H.M. Wight. 1984. Distribution and Biology of the Spotted Owl in Oregon. Wildlife Monographs 87:1-64.

, R.G. Anthony, K.M. Dugger, E.M. Glenn, A.B. Franklin, G.C. White, C.J. Sehwarz, K.P. Burnham, D.R. Anderson, J.D. Niehols, J.E. Hines, J.B. Lint, R.J. Davis, S.H. Ackers, L.S. Andrews, B.L. Biswell, P.C. Carlson, L.V. Diller, S.A. Gremel, D.R. Herter, J.M. Higley, R.B. Horn, J.A. Reid, J. Roekweit, J. Schaberl, T.J. Snetsinger, and S.G. Sovern. 2011. Population Demography of Northern Spotted Owls: 1985-2008. Studies in Avian Biology. Cooper Ornithological Society. Berkeley, California.

Fotheringham, C., and J. Keeley. 1998. Ecology and Distribution of Braunton's Milk-Vetch (Astragalus brauntonii) and Lyon's Pentachaeta (Pentachaeta lyonii). Prepared for California Department of Fish and Game, USFWS Section 6 Contract No. FG5636-R5. Los Angeles, California.

Fox, L., H. Steele, K. Holl, and M. Fusari. 2006. Contrasting Demographies and Persistence of Rare Annual Plants in Highly Variable Environments. Plant Ecology Volume 183, Number 1.

Franklin, A. 2007. BLM Botanist, Folsom Resourec Area. Electronic Mails to Kirsten Tarp, U.S. Fish and Wildlife Service. Sacramento, California. 
Franklin, A.B., J.P. Ward, and R.J. Gutierrez. 1986. Population Ecology of the Northern Spotted Owl (Strix occidentalis canrina) in Northwestern California: Preliminary Results. Unpublished Report Submitted to the California Department of Fish and Game. Sacramento, California.

, D.R. Anderson, R.J. Gutierrez, and K.P. Burnham. 2000. Climate, Habitat Quality, and Fitness in Northern Spotted Owl Populations in Northwestern California. Ecological Monographs 70:539-590.

Franklin, J., and C.T. Dyrness. 1973. Natural Vegetation of Oregon and Washington. Oregon State University Press. Corvallis, Oregon.

Franklin, M.A. 1990. Report for 1990 Challenge Cost Share Project, Manti-LaSal National Forest. Target Species: Astragalus desereticus. Unpublished Report Prepared by the Utah Natural Heritage Program. Salt Lake City, Utah.

1992. Schoenocrambe argillacea. Unpublished Report Prepared by the Utah Natural Heritage Program. BLM. Vernal, Utah.

Franklin, M.C. 1990. Report for 1989 Challenge Cost Share Project USDOI BLM Target Species: Xylorhiza cronquistii (Cronquist Woodyaster), Lesquerella tumulosa (Kodachrome Bladderpod), Lepidium montamum var. stellae (Kodachrome Pepper-grass). Utah Natural Heritage Program. Salt Lake City, Utah.

Franzreb, K.E. 1985. Endangered and Threatened Wildlife and Plants; Determination of Threatened Status for Hutton Tui Chub and Foskett Speckled Dace. Federal Register 50:12302-12306.

1989. Ecology and Conservation of the Endangered Least Bell's Vireo. USFWS Biological Report 89.

Freeman, C.C., and R.E. Brooks. 1989. Status Report on Platanthera praeclara Sheviak and Bowles (Western Prairie Fringed Orchid) in Kansas, Nebraska, and South Dakota. Unpublished Report to USFWS. Denver, Colorado.

Frest, T.J., and E.J. Johannes. 1992. Distribution and Ecology of the Endemic Relict Molluse Fauna of Idaho The Nature Conservancy's Thousand Springs Preserve. Final Report to the Idaho Nature Conservaney. Sun Valley, Idaho.

Galat, D.L. 1983. Study Concepts Paper. Sewage Effluent in the Lower Truckee River Pyramid Lake: Toxicity to Fish and Biostimulation to Aquatic Plants. Colorado Cooperative Fishery Unit. Colorado State University. Fort Collins, Colorado.

, and B. Robertson. 1988. Interactions between Poeciliopsis occidentalis sonoriensis and Gambusia affinis (Pisces: Poeciliidae) in the Rio Yaqui Drainage, Arizona. Report to the USFWS, Albuquerque, New Mexico, Arizona State University, Tempe, and USFWS, San Bernardino National Wildlife Refuge.

, and 1992. Response of Endangered Poeciliopsis occidentalis sonoriensis in the Rio Yaqui Drainage, Arizona, to Introduced Gambusia affinis. Environmental Biology of Fishes 33:249-264.

Gambs, R.D., and V.L. Holland. 1988. Ecology of the Morro Bay Kangaroo Rat (Dipodomys heermanmi morroensis). Final Report Submitted to the U.S. Fish and Wildlife Service. Sacramento, California.

Gamon, J. 1991. Report on the Status of Arenaria paludicola Robinson. Prepared for the U.S. Fish and Wildlife Service, Boise Field Office. Boise, Idaho.

Ganey, J.L. 1988. Distribution and Habitat Ecology of Mexican Spotted Owls in Arizona. M.S. Thesis, Northern Arizona University. Flagstaff, Arizona. 
, and R.P. Balda. 1989. Distribution of Habitat Use of Mexican Spotted Owvls in Arizona. Condor 91:355-361.

, and - 1994. Habitat Selection by Mexican Spotted Owls in Northern Arizona. Auk $111(1): 162-169$.

, and R.M. King. 2000. Roost Sites of Radio-Marked Mexican Spotted Owls in Arizona and New Mexico: Sources of Variability and Deseriptive Characteristics. Journal of Raptor Researeh 34:270278.

, W.M. Block, and S.H. Ackers. 2003. Struetural Characteristies of Forest Stands Within Home Ranges of Mexican Spotted Owls in Arizona and New Mexico. Western Journal of Applied Forestry 18:189-198.

Garth, J. S., and J.W. Tilden. 1986. California Butterflies. California Natural History Guides: 51. University of California Press. Berkeley, California.

Geologica. 2003. Evaluation of Owens Tui Chub Habitat, Long Valley Caldera, Mono County, California. Report Submitted to County of Mono, Department of Economic Development and Special Projects. Mammoth Lakes, California.

Gerking, S.D., and D.V. Plantz, Jr. 1980. Size-biased Predation by the Gila Topminnow, Poeciliopsis occidentalis (Baird and Girard). Hydrobiologia 72:179-191.

Germano, D.J. 1992. Longevity and Age-size Relationships of Populations of Desert Tortoises. Copeia 1992(2):367-374.

, and D.F. Williams. 1992. Gambelia sila (Blunt-Nosed Leopard Lizard). Reproduction. Herpetological Review 23:117.

, and

1993. Recovery of the Blunt-nosed Leopard Lizard: Past Efforts, Present Knowledge, and Future Opportunities. Transactions of the Western Seetion of The Wildlife Society 28:38-47.

, and - 1994a. Gambelia sila (Blunt-nosed Leopard Lizard): Cannibalism. Herpetological

Review 23:117.

, and

. 1994b. Population Ecology of Blunt-nosed Leopard Lizards in 1994 on the Elkhorn Plain, San Luis Obispo County, California. BLM. Bakersfield, California.

Getz, L.L. 1985. Habitats. Pages 286-309 in Biology of New World Microtus (R.H. Tamarin, Editor). Special Publication Number 8, American Society of Mammology. Boston, Massachusetts.

Gill, R.E., M.R. Petersen, and P.D. Jorgensen. 1981. Birds of the Northcentral Alaska Peninsula, 1978-1980. Arctic 34:286-306.

Gisler, S.D. 2004. Developing Biogeographically Based Population Introduction Protocols for At-Risk Willamette Valley Plant Species. Report to U.S. Fish and Wildlife Service, Portland, Oregon. Native Plant Conservation Program, Oregon Department of Agriculture. Salem, Oregon.

Giuliani, D. 1981. An Investigation of Pre-selected Springs and Seepages for Additional Populations of the Desert Slender Salamander, Batrachoseps aridus, in the Santa Rosa Mountains, Riverside County, California. BLM Contract Report CA-060-CT1-2. Riverside, California. 
Goldwasser, S. 1978. Distribution, Reproductive Success and Impact of Nest Parasitism by Brown-headed Cowbirds on Least Bell's Vireo. Project Report W-54-R-10, California Department of Fish and Game. Sacramento, California.

Gould, G. 1975. Yuma Clapper Rail Study - Censuses and Distribution. California Department of Fish and Game, Wildlife Management Report 75-2. Saeramento, California.

Gray, M.V., and J. Greaves. 1984. Riparian Forest as Habitat for the Least Bell's Vireo. Pages 605-611 in California Riparian Systems: Ecology, Conservation, and Productive Management (R. Warner and K. Hendrix, Editors). University of California Press. Davis, California.

Greenleaf, J. 1980. Status Report for Thelypodium howellii Wats ssp. spectabilis (Peck).

Greger, P., and J.E. Deacon. 1988. Food Partitioning Among the Fishes of the Virgin River. Copeia 1988(2):314323.

Grier, J.W. 1969. Bald Eagle Behavior and Productivity Responses to Climbing Nests. Journal of Wildlife Management 33:961-966.

Griffin, J.R. 1974. A Strange Forest in San Benito County. Fremontia 2:11-15.

1977. California Native Plant Society Rare Plant Status Report, Camissonia benitensis.

1978a. California Native Plant Society Rare Plant Status Report, Cantissonia benitensis.

- 1978b. Survey of Rare and Endangered Plants, Clear Creek Recreation Area, San Benito-Fresno County. Report Prepared for the BLM.

Griffith, J.S., Jr. 1974. Utilization of Invertebrate Drift by Brook Trout (Salvelinus fontinalis) and Cutthroat Trout (Salmo clarki) in Small Streams in Idaho. Transaetions of the American Fisheries Society 103:440-447.

Griggs, F.T. 1980. Population Studies in the Genus Orcuttia (Poaceae). Ph.D. dissertation, University of California. Davis, California.

1981. Life histories of Vernal Pool Annual Grasses. Fremontia 9(1):14-17.

GrinnelI, J. 1932. A Relic Shrew from Central California. University of California Publications in Zoology 38:387-388.

1933. Review of the Recent Mammal Fauna of California. University of California Publications in Zoology 40:71-234.

, J.S. Dixon, and J.M. Linsdale. 1937. Fur-bearing Mammals of California Volume 2. University of California Press. Berkeley, California.

Grzimek, B. 1975. Grzimek's Animal Life Encyclopedia, Volume 12. Van Nostrand Reinhold Company. New York, New York.

Gutiérrez, R.J., A.B. Franklin, and W.S. LaHaye. 1995. Spotted Owl (Strix occidentalis). The Birds of North America, Number 179. The Academy of Natural Sciences Philadelphia and the American Ornithologists Union. Washington, D.C.

Hall, E.R. 1946. Mammals of Nevada. University of California Press. Berkeley, California. 
. 1981. The Mammals of North America. Volume II. John Wiley and Sons. New York, New York.

, and K.R. Kelson. 1959. The Mammals of North America, Volume II. John Wiley and Sons. New York, New York.

Hall, F.A. 1983. Status of the San Joaquin Kit Fox, Vulpes macrotis mutica, at the Bethany Wind Turbine Generating Site, Alameda County, California. Unpublished Report, California Department of Fish and Game. Sacramento, California.

Hamer, J.D. 1974. Distribution, Abundance, and Management Implieations of the Grizzly Bear and Mountain Caribou in the Mountain Creek Watershed of Glacier National Park, British Columbia. M.S. Thesis. University of Calgary. Calgary, Alberta.

, S. Herrero, and R.T. Ogilvie. 1977. Ecological Studies of the Banff National Park Grizzly Bear. Project Report 1978.

Hamman, R.L. 1981. Spawning and Culture of Colorado Squawfish in Raceways. Progressive Fish-Culturist 43:173-177.

Hammond, P.C., and D.V. McCorkle. 1984. Ecological Investigations of Viola adunca. USDA Forest Serviee, Siuslaw National Forest.

, and M.V. Wilson. 1993. Status of the Fender's Blue Butterfly. Unpublished Report to the U.S. Fish and Wildlife Serviee. Portland, Oregon.

Hamon, D. 1981. Calyptridium pulchellum (Eastw.) Hoov. (Portulacaceae). Madroño 28:188.

Hanes, T.L., R.I. Friesen, and K. Keane. 1989. Alluvial Serub Vegetation in Coastal Southern California. Presented at the California Riparian Systems Conference, September 1988, Davis, California. USDA Forest Service Gen. Tech. Rep. PSW-110.

Hardy, T. 1980. The Inter-basin Area Report - 1979. Proceedings of the Desert Fishes Couneil 11:5-21.

- 1982. Ecological Interaetions of the Introduced and Native Fishes in the Outflow of Ash Springs, Lincoln County, Nevada. M.S. Thesis, University of Nevada. Las Vegas, Nevada.

Harper, K., and R. Van Buren. 1998. Field Report - 1996, Rare Loco Weeds of Washington County, Utah. Unpublished Report on File with the BLM. Salt Lake City, Utah.

Harris, J. 1990. Ornate Shrew, Sorex ornatus. Pages 12-13 in California's Wildlife Volume III: Mammals (D.C. Zeiner, W.F. Laudenslayer, Jr., K.E. Meyer, and M. White, Editors). California Department of Fish and Game. Saeramento, California.

Harrison, E.N., and L.F. Kiff. 1980. Apparent Replacement Clutch Laid by Wild California Condor. Condor $82: 351-352$.

Hartman, R.L. 1993. Arenaria. Pages 478-483 In: The Jepson Manual, Higher Plants of California. University of California Press. Berkeley, California.

, R.K. Rabeler, and F.H. Utech. 2005. Arenaria. In: Flora of North America, eFloras. Missouri Botanical Garden. St. Louis, Missouri. Harvard University Herbaria. Cambridge, Massachusetts. Available at: http://www.efloras.org. Accessed April 10 and 13, 2007. 
Hayes, J. 1980. Fish of Warner Valley. Pages 120-129 in Analysis of the Aquatic Habitats of Warner Valley with Relation to Land Use Patterns (C. Gilman, Editor). Department of Fish and Wildlife. Oregon State University Final Report 78-03490 to the National Science Foundation.

Hayes, M.P., and M.R. Jennings. 1988. Habitat Correlates of Distribution of the California Red-Legged Frog (Rana aurora draytonii) and the Foothill Yellow-Legged Frog (Rana boylii): Implications for Management. Pp. 144-158. In Proceedings of the Symposium on the Management of Amphibians, Reptiles, and Small Mammals in North America. (R. Sarzo, K.E. Severson, and D.R. Patton, Technical Coordinators). USDA Forest Service General Technical Report RM-166.

, and M.M. Miyamoto. 1984. Biochemical, Behavioral and Body Size Difference Between Rana aurora aurora and R.a. draytonii. Copeia 1984(4):1018-1022.

, and M.R. Tennant. 1985. Diet and Feeding Behavior of the California Red-legged Frog Rana aurora draytonii (Ranidae). The Southwestern Naturalist 30(4):601-605.

Heil, K. 1989. A Vegetation Study of Capitol Reef National Park - Endangered, Threatened, Rare, and Other Plants of Concern at Capitol Reef National Park. National Park Service. Torrey, Utah.

1992. Survey to Determine the Distribution of: Schoenocrambe barnebyi on BLM Lands in Utah. BLM. Moab, Utah.

, and S. Brack. 1985. The Rare and Sensitive Cacti of Carlsbad Caverns National Park. National Park Service.

, and J.M. Porter. 1985. Endangered and Threatened Plant Inventory: Pediocactus knowltonii Distribution and Habitat. BLM. Contract \#NM-010-CT4-0010. On File at USFWS, Office of Endangered Species. Washington, D.C.

, and . 1994. Sclerocactus (Cactaceae) A revision. Haseltonia 2:20-46.

, and . 2004. Sclerocactus. In Flora of North America Editorial Committee, Editors. 1993+. Flora of North America North of Mexico. Volume 4. New York, New York and Oxford, England.

, B. Armstrong, and D. Schleser. 1981. A Review of the Genus Pediocactus. Cactus and Succulent Journal 53:17-39.

Henderson, F.R., P.F. Springer, and R. Adrian. 1969. The Black-footed Ferret in South Dakota. South Dakota Department of Game, Fish and Parks, Technical Bulletin 4:1-36.

Hendrickson, B., W.R. Ferren Jr., and T. Klug. 1998. Botanical Resources of the Hollister Ranch, Santa Barbara County, California. Environmental Report No. 10. Prepared for Hollister Ranch Conservancy. Museum of Systematics and Ecology, Department of Ecology, Evolution, and Marine Biology, University of California. Santa Barbara, California.

Herrero, S. 1978. A Comparison of Some Features of the Evolution, Ecology, and Behavior of Black and Grizzly/Brown Bears. Carnivore 1:7-17.

, and D. Hamer. 1977. Courtship and Copulation of a Pair of Grizzly Bears, with Comments on Reproductive Plasticity and Strategy. Journal of Mammalogy 58:441-444. 
Hershler, R., T.J. Frest, E.J. Johannes, P.A. Bowler, and F.G. Thompson. 1994. Two New Genera of Hydrobiid Snails (Prosobranchia: Rissooidea) From the Northwestern United States. The Veliger $37(3): 221-243$.

Heske, E.J., R.S. Ostfield, and W.Z. Lidicker, Jr. 1984. Competitive Interactions Between Microtus californicus and Reithrodontomys megalotis during Two Peaks of Microtus Abundance. Journal of Mammology 65(2):271-280.

Hesse, L.W. 1987. Taming the Wild Missouri River: What Has it Cost? Fisheries 12(2):2-9.

, J.C. Schmulbach, J.M. Carr, K.D. Keenlyne, D.G. Unkenholz, J.S. Robinson, and G.E. Mestl. 1989. Missouri River Resourees in Relation to Past, Present, and Future Stresses. Pages 352-371 in Proceedings of the International Large River Symposium (D.P. Dodge, Editor). Canadian Special Publications in Fisheries and Aquatic Science 106.

Hickman, J.C. 1993. The Jepson Manual: Higher Plants of California. Berkeley, University of California Press. Berkeley, California.

Hill, D.L. 1974. Helminthoglypta walkeriana: A Rare Endangered Land Molluse. Unpublished Senior Thesis, California Polytechnic State University. San Luis Obispo, California.

Hoffman, R.S. 1958. The Role of Reproduction and Mortality in Population Fluctuations of Voles (Microtus). Ecological Monographs 28(1):79-107.

Holden, P.B., and E.J. Wick. 1982. Life History and Prospects for Recovery of Colorado Squawfish. Pages 98108 in Fishes of the Upper Colorado River System: Present and Future. (W.H. Miller, H.M. Tyus, and C.A. Carlson, Editors). Western Division, American Fisheries Society. Bethesda, Maryland.

Holland, R.F. 1986. Preliminary Deseriptions of the Terrestrial Natural Communities of California. California Department of Fish and Game. Sacramento, California.

Holmgren, N.H. 1972. Plant Geography of the Intermountain Region in the Intermountain Flora Volume 1. Hafer Publishing Company, Inc. New York, New York.

Holomuzki, J.R. 1986. Variation in Microhabitat Use and Trophic Patterns of Larval Tiger Salamanders (Ambystoma tigrinum nebulosum) in Arizona. Ph.D. Dissertation, Arizona State University. Tempe, Arizona.

Holzman, B., and T. Meyer. 2004. Conservation and Recovery of Ione Endemic Plants: Mapping the Ione Plant Community. San Francisco State University. San Francisco, California.

Hoogland, J.L. 2001. Black-tailed, Gunnison's, and Utah Prairie Dogs All Reproduce Slowly. Journal of Mammalogy 82:917-927.

2003. Sexual Dimorphism in Five Species of Prairie Dogs. Journal of Mammalogy 84:1254-1266.

Hooper, E.T. 1938. Geographical Variation in Wood Rats of the Species Neotoma fuscipes. University of California Publications in Zoology 42:213-246.

Hoover, R.F. 1940a. A Monograph of the Genus Chlorogalum. Madrono 5:137-147.

. 1940b. New Information regarding Calyptridium and Spraguea. Leaflets of Western Botany 2:222-225. 
Hornocker, M.G. 1962. Population Characteristies and Social Reproductive Behavior of the Grizzly Bear in Yellowstone National Park. M.S. Thesis. University of Montana. Missoula, Montana.

Howe, M.A. 1987. Habitat Use by Migrating Whooping Cranes in the Aransas-Wood Buffalo Corridor. Pages 303 311 in Proceedings of the 1985 Crane Workshop (J.C. Lewis and J.W. Ziewitz, Editors). Platte River Whooping Crane Habitat Maintenance Trust and USFWS. Grand Island, Nebraska.

1989. Migration of Radio-marked Whooping Cranes from the Aransas-Wood Buffalo Population: Patterns of Habitat Use, Behavior, and Survival. USFWS Technical Report 21.

Howell, D.J. 1974. Bats and Pollen: Physiological Aspeets of the Syndrome of Chiropterophily. Comparative Biochemical Physiology 48:263-276.

1976. Plant-loving Bats, Bat-loving Plants. Natural History 85(2):52-59.

1979. Flock Foraging in Nectar-feeding Bats: Advantages to the Bats and to the Host Plants. American Naturalist 114:23-49.

Hoyt, R.A., J.S. Altenbach, and D.J. Hafner. 1994. Observations on Long-nosed Bats (Leptonycteris) in New Mexico. Southwest Naturalist 39:175-179.

Hubbard, J.P. 1987. The Status of the Willow Flycateher in New Mexico. Endangered Species Program, New Mexico Department of Game and Fish. Santa Fe, New Mexico.

Hubbs, C., and R.R. Miller. 1942. Fish of Catlow Valley. Page 152 in Archeological Researehes of the Northern Great Basin (L.S. Cressman, Editor). Carnegie Institute of Washington Publication Number 538.

, and

- 1948. The Zoological Evidence of Correlation between Fish Distribution and Hydrographic History in the Desert Basins of Western United States. Pages 17-166 in The Great Basin, with Emphasis on Glacial and Postglacial Times. Bulletin of the University of Utah 30.

, and J.E. Deacon. 1964. Additional Introductions of Tropical Fishes into Southern Nevada. Southwestern Naturalist 9(4):249-251.

, and W.F. Hettler. 1964. Observations of the Toleration of High Temperatures and Low Dissolved Oxygen in Natural Waters by Crenichthys baileyi. The Southwestern Naturalist 9(4):245-248.

, R.C. Baird, and J.W. Gerald. 1967. Effeets of Dissolved Oxygen Concentration and Light Intensity on Activity Cycle of Fishes Inhabiting Warm Springs. American Midland Naturalist 77(1):104-115.

Hudson, B., J. Augsburger, M. Hillis, and P. Boehne. 2000. Draft Biological Assessment for the Interior Columbia River Basin Ecosystem Management Project Final Environmental Impact Statement. USDOI BLM and USDA Forest Service. Boise, Idaho.

Hughes, A. 2009. Personal Communication. Botanist for Grand Staircase-Escalante National Monument, Escalante Field Office. Subject: Review and Discussion of Final Recovery Outline. August 2009.

Hughes, K.S., and N.S. Smith. 1990. Sonoran Pronghorn Use of Habitat in Southwest Arizona. Final Report. 1416-009-1564 RWO \#6. Arizona Cooperative Fish and Wildlife Research Unit. Tucson, Arizona.

Hughes, L. 1991. Status Report. BLM. Arizona Strip District. St. George, Utah. 
Hunt, L.E. 1993. Origin, Maintenance and Land Use of Aeolian Sand Dunes of the Santa Maria Basin, California. Unpublished report. For The Nature Conservaney. Sacramento, California.

Imhof, T.A. 1962. Alabama Birds. University of Alabama Press, Tusealoosa, Alabama.

Imper, D.K. 1997. Ecology and Management of the Endangered Western Lily (Lilium occidentale) in Northwestern California. Pages 23-33 in Conservation and Management of Native Plants and Fungi (Kaye, T.N., A. Liston, R.M. Love, D.L. Luoma, R.J. Meinke, and M.V. Wilson, Editors). Native Plant Society of Oregon. Corvallis, Oregon.

. 2005. Personal Observations and Field Notes, MacKerricher State Park and Environs. U.S. Fish and Wildlife Serviee, Areata Fish and Wildlife Office. Areata, California.

. 2011. Computations and Unpublished Data Related to Layia carnosa oeeupied habitat. U.S. Fish and Wildlife Serviee, Areata Fish and Wildlife Offiee, Areata, California.

Interagency Conservation Strategy Team. 2003. Final Conservation Strategy for the Grizzly Bear in the Yellowstone Ecosystem. Missoula, Montana.

Interagency Grizzly Bear Committee. 1987. Interageney Grizzly Bear Guidelines. Missoula, Montana.

Intermountain Ecosystems. 2002. Challenge Cost Share Status Report. Target Species: Cruetzfeldtii-Flower (Cryptantha creutzfeldiii) and Wright Fishhook Cactus (Sclerocactus wrightiae). Prepared for BLM, Priee Field Office. Price, Utah.

Irwin, J.F. 1982. The Distribution and Natural History of the Unarmored Threespine Stickleback. Gasterosteus aculeatus williamsoni (Girard) in San Antonio Creek, California. Contraet No. 11310-1289-80, USFWS. Sacramento, California.

Jackson, S.A. 1996. Reproduetive Aspects of Lomatium bradshawii and Erigeron decumbens of the Willamette Valley, Oregon. Master's Thesis. University of Oregon. Eugene, Oregon.

Jahrsdoerfer, S.E., and D.M. Leslie, Jr. 1988. Tamaulipan Brushland of the Lower Rio Grande Valley of South Texas: Deseription, Human Impacts, and Management Options. USFWS Biological Report 88(36).

Jennings, M. 1988. Natural History and Decline of Native Ranids in California. Pages 61-72 in Proceedings of the Conferenee on California Herpetology (H.F. DeLisle, P.R. Brown, B. Kaufman, and B.M. MeGurty, Editors). Southwestern Herpetologists Society Special Publieation (4):1-143.

Jennings, W.F. 1989. Final Report. Species Studied: Eustoma grandiflorum, Spiranthes diluvialis, Malaxis brachypoda, Hypoxis hirsuta, Physaria bellii, Aletes humilis. Unpublished Report Prepared for The Nature Conservaney under the Colorado Natural History Small Grants Program. The Nature Conservaney. Boulder, Colorado.

. 1990. Final Report. Species Studies: Spiranthes diluvialis, Sisyrinchium pallidum. Unpublished Report Prepared for The Nature Conservaney Under the Colorado Natural History Small Grants Program. The Nature Conservancy. Boulder, Colorado.

Jensen, C.C. 1972. San Joaquin Kit Fox Distribution. USFWS Unpublished Report. Saeramento, California.

Jhingram, V.G. 1948. A Contribution to the Biology of the Klamath Blaek Dace, Rhinichthys osculus klamathensis (Evermann and Meek). Ph.D. Thesis, Stanford University. Stanford, California. 
Johannessen, C.L., W.A. Davenport, A. Millet, and S. McWilliams. 1971. The Vegetation of the Willamette Valley. Annals of the Association of American Geography 61:286-302.

Johnson, C.L. 1997. Distribution, Habitat, and Ecology of the Mexican Spotted Owl in Colorado. M.S. Thesis, University of Northern Colorado. Greeley, Colorado.

Johnston, B.C., J.S. Peterson, and W. Harmon. 1981. Status Report Eutrema penlandii Rollins. Unpublished Report. Department of Natural Resources, Colorado Natural Areas Program. Denver, Colorado.

Jokerst, J.D. 1989. A Draft Plan for the Conservation of Butte County Meadowfoam in the City of Chieo, Limnanthes floceosa ssp. californica. Unpublished Report, Jones and Stokes Associates, Inc.. Sacramento, California.

Jonez, A., and R.C. Sumner. 1954. Lakes Mead and Mohave Investigations, a Comparative Study of an Established Reservoir as Related to a Newly Created Impoundment. Federal Aid Project F-1-R. Nevada Fish and Game Department. Reno, Nevada.

Jump, P.M., T. Longcore, and C. Rich. 2006. Eeology and Distribution of a Newly Discovered Population of the Federally Threatened Euproserpinus euterpe (Sphingidae). Journal of the Lepidopterists' Society 60(1): 41-50.

Junge, J.A., and R.S. Hoffman. 1981. An Annotated Key to the Long-tailed Shrews (Genus Sorex) of the United States and Canada, with Notes on Middle American Sorex. Oceasional Papers of the Museum of Natural History, University of Kansas 94:1-48.

Kaeding, L.R., and M.A. Zimmerman. 1983. Life History and Ecology of the Humpback Chub in the Little Colorado and Colorado Rivers of the Grand Canyon. Transaetions of the American Fisheries Society 112:577-594.

Kagan, J.S. 1986. Status Report for Thelypodium howellii ssp. spectabilis. Oregon Natural Heritage Data Base. Portland, Oregon.

, and S. Yamamoto. 1987. Status Report for Erigeron decumbens subsp. decumbens. Unpublished Report to the U.S. Fish and Wildlife Service. Portland, Oregon.

Kallemeyn, L.W. 1983. Status of the Pallid Sturgeon, Scaphirhyneus albus. Fisheries 8(1):3-9.

Kanim, N.R. 1986. Organic Energy Budget of a Thermal Stream Ecosystem: The Pahranagat Ditch, Nevada. M.S. Thesis, University of Las Vegas. Las Vegas, Nevada.

Kass, R.J. 1990. Final Report-habitat Inventory of Threatened and Endangered and Candidate Plant Species in the San Rafael Swell, Utah. BLM. Salt Lake City, Utah.

Katihah, E.F. 1983. A Brief History of the Riparian Forests in the Great Central Valley of California. Pages 23-29 in California Riparian Systems: Ecology Conservation and Productive Management (R.E. Warner and K.M. Hendrix, Editors). University of California Press. Berkeley, California.

Kato, T.T., and T.P. O'Farrell. 1986. Biological Assessment of the Effects of Petroleum Production at Maximum Efficient Rate, Naval Petroleum Reserve \#I (Elk Hills), Kern County, California, on the Endangered Blunt-nosed Leopard Lizard, Gambelia silus. U.S. Department of Energy Topical Report Number EGG 10282-2108, Santa Barbara Operations, EG \& G Energy Measurements. Goleta, California. 
, B.R. Rose, and T.P. O'Farrell. 1987. Diet of the Blunt-nosed Leopard Lizard, Gambelia silus, on Naval Petroleum Reserves \#1 and \#2, Kern County, California. U.S. Department of Energy Final Report Number 10282-2188, Santa Barbara Operations, EG \& G Energy Measurements. Goleta, California.

Kaye, T.N., and M. Kirkland. 1994. Population Biology of Lomatium bradshawii II. Insect Interactions, Phenology, and Breeding System. Oregon Department of Agriculture. Sảlem, Oregon; and BLM Eugene District. Eugene, Oregon.

Keeler-Wolf, T., D.R. Elam, K. Lewis, and S.A. Flint. 1998. California Vernal Pool Assessment Preliminary Report. California Department of Fish and Game. Sacramento, California.

Keeley, J.E. 1998. C4 Photosynthetic Modifications in the Evolutionary Transition from Land to Water in Aquatic Grasses. Oecologia 116:85-97.

- 2002. Native Ameriean Impaets on Fire Regimes of the California Coastal Ranges. Journal of Biogeography 29:303-320.

Keenan, L.D., R.E. Stanford, S.L. Ellis, and B. Drummond. 1986. Status Report on: Pawnee Montane Skipper. Prepared for Denver Water Department. Denver, Colorado.

Keenlyne, K.D. 1989. A Report on the Pallid Sturgeon. USFWS, MRC-89-1. Pierre, South Dakota.

, and L.G. Jenkins. 1993. Age at Sexual Maturity of the Pallid Sturgeon, Scaphirhyncus albus. Proceedings of the South Dakota Academy of Science 72:41-49.

Keleher, C.J., L.D. Lentsch, and C.W. Thompson. 1998. Evaluation of Flow Requirements for June Sucker (Chasmistes liorus) in the Provo River: An Empirical Approaeh. Publieation Number 99-06. Utah Division of Wildlife Resources. Salt Lake City, Utah.

Kelly, P.A. 1990. Population Ecology and Soeial Organization of Dusky-footed Woodrats, Neotoma fuscipes. Ph.D. Dissertation, University of California. Berkeley, California.

Kennedy, T.B., and J.F. North. 1993. 1992 Report: Drift Behavior and Distribution of the Warner Sucker (Catostomus warnerensis) and Preliminary Assessment of Stream Habitat Conditions in the Warner Valley, Oregon. Unpublished Report to the BLM and Oregon Department of Fish and Wildlife.

Kiguchi, L.M. 1983. Sensitive Plant Survey: Clear Creek Recreation Area, San Benito Mountains Natural Area. Unpublished Report for the BLM, Hollister Resource Area.

- 1984. Sensitive Plant Survey: Clear Creek Recreation Area, San Benito Mountains Natural Area. Unpublished Report for the BLM, Hollister Resouree Area.

- 1985. Sensitive Plant Survey: Clear Creek Recreation Area, San Benito Mountains Natural Area. Unpublished Report for the BLM, Hollister Resource Area.

Kinley, T.A., and C.D. Apps. 2001. Mortality Patterns in a Subpopulation of Endangered Mountain Caribou. Wildlife Society Bulletin 29(1):158-164.

Kitchen, D.W., and B.W. O'Gara. 1974. Social Behavior and Ecology of the Pronghorn. Wildlife Monographs 38.

Klauber, L.M. 1949. The Subspeeies of the Ridge-nosed Rattlesnake, Crotalus willardi. Transactions of the San Diego Society of Natural History 11(8):121-140. 
1972. Rattlesnakes: Their Habits, Life Histories, and Influence on Mankind, 2nd Edition. University of California Press. Berkeley, California.

Knapp, D.K. 1978. Effeets of Agricultural Development in Kern County, California, on the San Joaquin Kit Fox in 1977. Nongame Wildlife Investigation Unpublished Report. California Department of Fish and Game. Sacramento, California.

Knight, P.J. 1993. A Status Review of Gypsum Wild Buckwheat. Submitted to USFWS, Region 2. Albuquerque, New Mexico.

, and D. House. 1986. Maneos Milk-vetch Astragalus humillimus Gray ex. Brand. Recovery Plan Draft. Prepared for USFWS, Region 2. Albuquerque, New Mexico.

Knox, A.E. 1998. The Ecology of Verbena californica, a Serpentine Endemic in the Red Hills of Tuolumne County, California. M.S. Thesis, California State University. Sacramento, California.

Koch, D.L. 1973. Reproductive Characteristies of the Cui-Ui Lakesucker (Chasmistes cujus Cope) and its Spawning Behavior in Pyramid Lake, Nevada. Transactions of the American Fisheries Society 102:145149.

. 1982. Temperature Tolerance Evaluation of Various Life Phases of the Cui-Ui. Report to Pyramid Lake Indian Tribal Enterprise. Koch and Associates. Reno, Nevada.

Koehler, G.M., and J.D. Brittell. 1990. Managing Spruce-fir Habitat for Lynx and Snowshoe Hares. Journal of Forestry 88:10-14.

Koford, C.B. 1953. The California Condor. National Audubon Society Research Report 4:1-154.

Kottas, K.L. 2008. Life History and Modeling of an Endangered Plant, Penstemon haydenii. Ph.D. Dissertation. University of Nebraska. Lincoln, Nebraska.

Krantz, T.P. 1979. A Botanical Investigation of Erigeron parishii. Unpublished Report Prepared for Forest Service, San Bernardino National Forest.

Kremen, C., R.L. Bugg, N. Nicola, S.A. Smith, R.W. Thorp, and N.M. Williams. 2002. Native Bees, Native Plants, and Crop Pollination in California. Fremontia 30:41-49.

Kroel, K.W., and P.J. Zwank. 1992. Renesting of Mexican Spotted Owl in Southern New Mexico. Journal of Raptor Research 26:267-268.

Kus, B.E., and K.L. Miner. 1987. Foraging Behavior of the Least Bell's Vireo: Use of Riparian and Non-riparian Habitats. Unpublished Report, San Diego State University. San Diego, California.

Kuyt, E. 1976a. Whooping Cranes: The Long Road Back. Nature Canada 5:2-9.

. 1976b. The Continuing Story of the Whooping Crane. Pages 109-111 in Proceedings of a Symposium on Canada's Threatened Species and Habitats (T. Mosquin and C. Suchal, Editors). Canada National Federal Special Publications 6. Ottawa, Canada.

1981a. Population Status, Nest Site Fidelity, and Breeding Habitat of Whooping Cranes. Pages 119-125

in Crane Research Around the World (J.C. Lewis and H. Masatomi, Editors). International Crane Foundation. Baraboo, Wisconsin. 
- 1981b. Cluteh Size, Hatehing Sueeess, and Survival of Whooping Crane Chieks, Wood Buffalo National Park, Canada. Pages 126-129 in Crane Researeh Around the World (J.C. Lewis and H. Masatomi, Editors). International Crane Foundation. Baraboo, Wisconsin.

Kynard, B.E. 1979. Nest Habitat Preferenee in Low Plate Morphs in Threespine Sticlebacks (Gasterosteus aculeatus). Copeia 1979:525-528.

Laack, L.L. 1991. Eeology of the Ocelot (Felis pardalis) in South Texas. M.S. Thesis, Texas A\&I University, Kingsville, Texas.

LaBerteaux, D.L. 1989. Morphology, Foraging Behavior, and Nesting Biology of the Inyo California Towhee (Pipilo crissalis eremophilus). M.S. Thesis, Northern Arizona University. Flagstaff, Arizona.

- 1994. Management Plan Recommendations for the Inyo California Towhee (Pipilo crissalis eremophilus) on Naval Air Weapons Station, China Lake, California. Naval Air Weapons Station Contract N60530-90-0071 (0018), Commanding Officer (CO8081). China Lake, California.

Labuda, S.E., and K.O. Butts. 1979. Habitat Use by Wintering Whooping Cranes on the Aransas National Wildlife Refuge. Pages 152-157 in Proeeedings of the 1978 International Crane Workshop (J.C. Lewis, Editors). Colorado State University Printing Serviee. Fort Collins, Colorado.

Lackey, J. 1997. The Interior Least Tern, an Endangered Species. NEBRASKAland Magazine and the Nebraska Game and Parks Commission. Lineoln, Nebraska.

La Doux, T. 2007. Administrative Direetor, Granite Mountains Desert Researeh Center. Kelso, California. E-mail addressed to Scott White, Scott White Biological Consulting Services, and Gary Wallace, USFWS, dated August 17, 2007. Subject: Astragalus tricarinatus loeation.

Landis, E. 2005. Powerpoint Presentation of Results of Soil Samples Taken at 20 Astragalus brauntonii Locations, and Known Predators of $A$. brauntonii, provided to C. Hamilton, Ventura Fish and Wildlife Office. California Native Plant Soeiety. Los Angeles/ Santa Monica Mountains Chapter. Van Nuys, California.

Lane, M. 1993. Genus Grindelia. In: Hickson, J.C. (Editor). The Jepson Manual. University of California Press. Berkeley, California.

Laramie Rivers Conservation District and USFWS. 2004. Safe Harbor Agreement Between Laramie Rivers Conservation Distriet and U.S. Fish and Wildlife Serviee for Wyoming Toad. Wyoming Eeologieal Serviees Field Offiee. Cheyenne, Wyoming.

La Rivers, I. 1953. New Gelastocorid and Naueorid Reeords and Miseellaneous Notes, with a Deseription of the New 121 Speeies, Ambrysus amargosus (Hemiptera: Naueoridae). The Wasmann Journal of Biology. Volume II:83-96.

. 1962. Fish and Fisheries of Nevada. Nevada State Fish and Game Commission. Carson City, Nevada.

Laufle, J.C., G.B. Pauley, and M.F. Shepard. 1986. Speeies Profiles. Life Histories and Environmental Requirements of Coastal Fishes and Invertebrates (Paeifie Northwest): Coho Salmon. USFWS Biologieal Report 82(11.48).

Laughrin, L. 1970. San Joaquin Kit Fox: Its Distribution and Abundanee. California Department of Fish and Game, Saeramento Wildlife Management Braneh, Administrative Report Number 70-2. Saeramento, California. 
Lea, T.N. 1968. Ecology of the Lahontan Cutthroat Trout, Salmo clarki henshawi, in Independence Lake, California. M.S. Thesis. University of California. Berkeley, California.

Lee and Ro Consulting Engineers. 1986. Endangered and Sensitive Species Survey and Defieiency Tabulation, Fort Irwin National Training Center and Goldstone Space Communications Complex. Report for Director of Engineering and Housing, Fort Irwin, National Training Center, Contract No. DACA09-84-C-0097. Fort Irwin, California.

Leopold, A.S. 1959. Wildlife of Mexico: The Game Birds and Mammals. University of California Press. Berkeley, California.

Lesica, P. 1993. Loss of Fitness Resulting from Pollinator Exclusion in Silene spaldingii (Caryophyllaceae). Madroño 40:193-201.

, and J.S. Shelly. 1992. Effects of Cryptogamic Soil Crust on the Population Dynamics of Arabis fecunda (Brassicaceae). American Midland Naturalist 128:53-60.

Lewis, M. 2010. Annual Report on Shoenocrambe suffrutescens Research. Report on File at Vernal BLM. M.S. Student, Utah State University. Logan, Utah.

Lewis, M.A. 1991. Chronic and Sublethal Toxicities of Surfaetants to Aquatic Animals: A Review and Risk Assessment. Water Research. 25(1):101-113.

Licht, L.E. 1974. Survival of Embryos, Tadpoles, and Adults of the Frogs Rana aurora aurora and Rana pretiosa pretiosa Sympatrie in Southwestern British Columbia. Canadian Journal of Zoology 52(5):613-627.

Lichthardt, J. 1997. Revised Report on the Conservation Status of Silene spaldingii in Idaho. Conservation Data Center, Idaho Department of Fish and Game. Boise, Idaho.

Ligon, J.S. 1961. New Mexico Birds and Where to Find Them. University of New Mexico Press. Albuquerque, New Mexico.

Lingle, G.R. 1987. Status of Whooping Crane Migration Habitat within the Great Plains of North America. Pages 331-340 in Proceedings of the 1985 Crane Workshop (J.C. Lewis and J. Zewitz, Editors). Platte River Whooping Crane Habitat Maintenance Trust and USFWS. Grand Island, Nebraska.

, G.A. Wingfield, and J.W. Ziewitz. 1991. The Migration Ecology of Whooping Cranes in Nebraska, U.S.A. Pages 395-401 in Proceedings of the 1987 International Crane Workshop (J. Harris, Editor). International Crane Foundation. Baraboo, Wisconsin.

Linsdale, J.M. 1940. Amphibians and Reptiles in Nevada. Proceedings of the American Academy of Arts and Sciences 73:197-257.

, and L.P. Trevis. 1951. The Dusky-footed Wood Rat. University of California Press. Berkeley, California.

Linsley, E.G., and J.A. Chemsak. 1972. Cerambycidae of North America. Part VI, No. 1. Taxonomy and Classification of the Subfamily Lepturinae. University of California Publications in Entomology 69:1-138.

Lovvorn, J.R., J.M. Grebmeier, L.W. Cooper, J.K. Bump and S.E. Richman. 2009. Modeling Marine Protected Areas for Threatened Eiders in a Climactically Changing Bering Sea. Ecological Applications 19:1596-1613. 
Lowe, C.H., D.S. Hinds, and E.A. Halpern. 1967. Experimental Catastrophic Selection and Tolerance to Low Oxygen Concentrations in Native Arizona Freshwater Fishes. Ecology 48:1013-1017.

Lowe, D.W., J.R. Matthews, and C.J. Moseley (Editors). 1990. The Official World Wildlife Fund Guide to Endangered Species of North America. Beacham Publishing, Inc.. Washington, D.C.

Luckenbach, R.A. 1982. Eeology and Management of Desert Tortoise (Gopherus agassizii) in California. in North American Tortoises: Conservation and Ecology. Wildlife Resources Report 12:1-37. USDA Forest Serviee. Washington, D.C.

Luenda, P.M., R. Miranda, J. Madoz, S. Parmenter, Y. Chen, and B. May. 2005. Threatened Fishes of the World: Siphateles bicolor snyderi (Miller, 1973) (Cyprinidac). Environmental Biology of Fishes 73:109110 .

Maddux, T., and S. Meyers. 2008. Plagiobothrys hirtus Survey. Native Plant Conservation Program, Oregon Department of Agriculture at Orcgon State University. Salem, Oregon. Prepared for the U.S. Fish and Wildlife Serviee. Grant No. OR-EP-2, Scgment 18.

Madison, D.M. 1985. Aetivity Rhythms and Spacing. Pages 373-419 in Biology of New World Microtus (R. H Tamarin, Editor). Special Publieation Number 8, American Soeiety of Mammology. Boston, Massachusetts.

Madrone Associates. 1979. Liquid Products Pipeline, Storage and Railroad Loading Facility (Dcpartment of Energy Project 12) Biological Assessment, Blunt-nosed Leopard Lizard (Crotaphytus [-Gambelia] silus), Naval Petroleum Reserve Number 1 (Elk Hills), Kern County, California. U.S. Department of the Navy, Final Projeet Report. San Bruno, California.

Maldonado, J.E. 1992. A Review of the Populations of the Buena Vista Lake Shrew (Sorex ornatus relictus). University of California. Los Angeles, California.

Markle, D.F., T.N. Pearsons, and D.T. Bills. 1991. Natural History of Orcgonichthys (Pisces: Cyprinidac), with a Deseription of a Ncw Speeies from the Umpqua River of Oregon. Copcia 1991(2):277-293.

Marsh, P.C. 2000. Fish Population Status and Evaluation in the Cibola High Levee Pond. Final Rcport to U.S. Bureau of Reclamation. Boulder City, Nevada.

, and D.R. Langhorst. 1988. Feeding and Fate of Wild Larval Razorback Sucker. Environmental Biology of Fishes 21:59-67.

, F.J. Abarca, M.E. Douglas, and W.L. Minckley. 1989. Spikedace, Meda fulgida, and Loach Minnow, Tiaroga cobitis, Relative to Introduced Red Shiner, Cyprinella lutrensis. Final Report to Arizona Game and Fish Department. Phoenix, Arizona.

Martin, M. 1972. Morphology and Variation of the Modoc Sucker, Catostomus microps Rutter, with Notes on Feeding Adaptations. California Fish and Game 58(4):277-284.

Martin, W.C., and C.R. Hutchins. 1980. A Flora of New Mexico. J. Kramer Press. Hirschberg, Germany.

Matthews, J.R., and C.J. Moseley (Editors). 1990. The Official World Wildlife Fund Guide to Endangered Species of North America. Volume 1. Plants, Mammals. Volume 2. Birds, Reptiles, Amphibians, Fishes, Musscls, Crustaceans, Snails, Insects, and Srachnids. Bcacham Publications, Inc. Washington, D.C. 
May, C.A., and R.J. Gutiérrez. 2002. Habitat Associations of Mexican Spotted Owl Nest and Roost Sites in Central Arizona. Wilson Bulletin 114:457-466.

, M.L. Petersburg, and R.J. Gutiérrez. 2004. Mexican Spotted Owl Nest- and Roost-Site Habitat in Northern Arizona. Journal of Wildlife Management 68:1054-1064.

Maynard, W.R. 1995. Summary of 1994 Survey Efforts in New Mexico for the Southwestern Willow Flycateher (Empidonax traillii extimus). New Mexico Department of Game and Fish Report. Contract \#94-5I 6-69.

Mazer, S.J., G. LeBuhn, and D.E. Meade. 1993. Demography and Reproductive Biology of Kern Mallow (Eremalche kernensis: Malvaceae). California Department of Fish and Game. Sacramento, California.

McAda, C.W. 2000. Flow Recommendations to Benefit Endangered Fishes in the Colorado and Gunnison Rivers. Draft Final Report of U.S. Fish and Wildlife Service, Grand Junetion, Colorado, to Upper Colorado River Endangered Fish Recovery Program. Denver, Colorado.

McAfee, W.R. 1966. Lahontan Cutthroat Trout. Pages 225-231 in Inland Fisheries Management. A. Calhoun, Editor. California Department of Fish and Game. Sacramento, California.

McCabe, R.A. 1991. The Little Green Bird: Ecology of the Willow Flycateher. Palmer Publications, Inc.. Amherst, Wisconsin.

McCarthy, M.S., and W.L. Minckley. 1987. Age Estimation for Razorback Sucker from Lake Mojave, Arizona and Nevada. Journal of Arizona-Nevada Academy Seienees 21:87-97.

McClanahan, L.L., C.R. Feldmeth, J. Jones, and D.L. Soltz. 1986. Energeties, Salinity, and Temperature Tolerance in the Mohave Tui Chub, Gila bicolor mohavensis. Copeia 1986(1):45-52.

McCue, P.M., T. Kato, M.L. Sauls, and T.P. O'Farrell. 1981. Inventory of San Joaquin Kit Fox on Land Proposed as Phase II. Kesterson Reservoir, Mereed County, California. Report Number EGG 1183-2426, EG\&G Energy Measurements. Goleta, California.

McDonald, K.P. 1993. Analysis of the Utah Prairie Dog Recovery Program, 1972-1992. Publication No. 93-16. Utah Division of Wildlife Resources. Cedar City, Utah.

McEwan, D. 1990. Utilization of Aquatic Vegetation and Some Aspects of the Owens Tui Chub (Gila bicolor snyderi) in the Hot Creek Headsprings, Mono County, California. M.S. Thesis, California State University. Sacramento, California.

, 1991. Microhabitat Selection of the Owens Tui Chub, Gila bicolor snyderi, in the Hot Creek Headsprings, Mono County, California. Desert Fishes Council Proceedings 20:1 1-23.

McGuire, W.D. 1982. New Oviposition and Larval Host Plant Records for North American Hesperia (Rhopalocera: Hesperiidae). Bulletin of the Allyn Museum, Number 72.

McIntosh, M.E., L.A. McDade, A.E. Boyd, and P.D. Jenkins. 2007. Patterns of Growth and Mortality in the Endangered Nichol's Turk's head cactus (Echinocactus horizonthalonius var. nicholii L. Benson; Cactaceae) in Southeastern Arizona. In: Southwestern Rare and Endangered Plants: Proceedings of the Fourth Conference (P. Barlow-Irick, J. Anderson, C. McDonald, Technical Editors). March 22-26, 2004; Las Cruces, New Mexico. Proceedings. RMRS-P-48CD. USDA Forest Service. Rocky Mountain Research Station. Fort Collins, Colorado. 
MeNeill, C., and C. Brown. 1979. Rare Plant Status Report: Limnanthes floccosa Howell ssp. californica Arroyo. California Native Plant Society. Sacramento, California.

Mealy, S. 1975. The Natural Food Habits of Free Ranging Grizzly Bears in Yellowstone National Park. M.S. Thesis. Montana State University. Bozeman, Montana.

Meinke, R.J. 1982. Threatened and Endangered Vascular Plants of Oregon: An Illustrated Guide. Unpublished Report by the Oregon Department of Agriculture for the U.S. Fish and Wildlife Serviee, Region 1. Portland, Oregon.

, K. Amsberry, R.E. Currin, S.C. Meyers, and B. Knaus. 2007. Evaluating the Biological Conservation Status of the Coachella Valley Milkvetch (Astragalus lentiginosus var. coachellae).

Mendelson, J. 1975. Feeding Relationships Among Species of Notropis (Pisees: Cyprinidae) in a Wiseonsin Stream. Ecological Monographs 45:199-230.

Merriam, C.H. 1895. Synopsis of the American Shrews of the Genus Sorex. North American Fauna 10:57-98.

Metzner, K.A. 1993. Eeologieal Strategies of Wintering Steller's Eiders on Izembek Lagoon and Cold Bay, Alaska. M.S. Thesis, University of Missouri. Columbia, Missouri

Meyer, J.S., L.L. Irwin, and M.S. Boyce. 1998. Influenee of Habitat Abundance and Fragmentation on Northern Spotted Owls in Western Oregon. Wildlife Monographs 139:1-51.

Meyer, T.J. 2005. The Arctostaphylos myrtifolia and Eriogonum apricum Plant Community: Its Distribution, Abundance and Conservation. M.S. Thesis, San Franeiseo State University. San Franciseo, California.

Miller, G.S., and E.C. Meslow. 1985. Dispersal Data for Juvenile Spotted Owls: the Problem of Small Sample Size. In Eeology and Management of the Spotted Owl in the Paeifie Northwest (R.J. Gutierrez and A.B. Carey, Editors). USDA Forest Service General Teehnical Report GTR-PNW-185. Portland, Oregon.

Miller, R.G. 1951. The Natural History of Lake Tahoe Fishes. Ph.D. Thesis. Stanford University. Stanford, California.

Miller, R.R. 1943. The Status of Cyprinodon macularis and Cyprinodon nevadensis, Two Desert Fishes of Western North Ameriea. Oeeasional Papers of the Museum of Zoology, University of Miehigan 473:1-25.

1963. Distribution, Variation, and Ecology of Lepidomeda vittata, a Rare Cyprinid Fish Endemic to Eastern Arizona. Copeia 3:401-422.

, and C.L. Hubbs. 1960. The Spiny-Tayed Vyprinid Gishes (Plagopterini) of the Colorado River System. Miscellaneous Publication of the Museum of Zoology, University of Michigan, Number 115.

, and J.E. Deacon. 1973. New Localities of the Rare Warm Springs Pupfish, Cyprinodon nevadensis pectoralis, from Ash Meadows, Nevada. Copeia 1973:137-140.

, and G.R. Smith. 1981. Distribution and Evolution of Chasmistes (Pisces: Catastomidae) in Western North America. Occasional Papers of the Museum of Zoology, University of Michigan. Ann Arbor, Michigan.

Minckley, C.O., and J.E. Deacon. 1975. Foods of the Devil's Hole Pupfish, Cyprinodon diabolis (Cyprinotondiac). The Southwestern Naturalist 20(1):105-111. 
Minckley W.L. 1973. Fishes of Arizona. Arizona Game and Fish Department. Phocnix, Arizona.

1985. Native Fishes and Natural Aquatic Habitats in USFWS Region 11 West of the Continental Divide. Report on File with USFWS. Albuquerque, New Mexico.

, and L.H. Carufel. 1967. The Little Colorado River Spinedace, Lepidomeda vittata, in Arizona. Southwest Naturalist 12(3):291-302.

, and J.E. Deacon. 1968. Southwestern Fishes and Enigma of "Endangered Speeies." Scienee 159:14241432.

Minnesota Department of Natural Resourees. 1979 to Present. Plant Element Occurrence Records: Platanthera praeclara. Minnesota Natural Heritage Program. St. Paul, Minnesota.

Mire, J.B. 1993. The Behavioral Ecology and Conservation Biology of the Owens Pupfish, Cyprinodon radiosus. Unpublished Ph.D. Dissertation, University of California. Berkeley, California.

Mistretta, O., and W.J. Brown. 1989. Species Management Guide for Mahonia nevinii (Gray) Fedde. Technical Report No. 4. Rancho Santa Ana Botanic Garden. Claremont, California.

Mitehell, D.L. 1989. Geophysical Survey Line Plant Study: Lokern Area, Kern County, California. Unpublished Report. Chevron U.S.A., Inc. Bakersfield, California.

Mladenka, C.G. 1992. The Ecological Life History of the Bruneau Hot Spring Snail (Pyrgulopsis bruneauensis). Stream Ecology Center, Department of Biological Sciences, Idaho State University, Pocatello, Idaho. Final Report to the USFWS, Boise Field Office. Boise, Idaho.

, and G.W. Minshall. 1996. Report on the Re-survey of the Bruneau Hot Springsnail Sites. Prepared for the USFWS by Stream Ecology Center, Department of Biological Sciences, Idaho State University. Pocatello, Idaho.

Modde, T., K.P. Burnham, and E.J. Wiek. 1996. Population Status of the Razorback Sueker in the Middle Green River. Conservation Biology 10:110-119.

, and D.B. Irving. 1998. Use of Multiple Spawning Sites and Seasonal Movement by Razorback Sucker in the Middle Green River, Utah. North American Journal of Fisheries Management 18:318-326.

, and N. Muirhead. 1990. Emergence Patterns and Feeding Behavior of Larval June Sucker. Final Report. Utah Division of Wildlife Resources Contract 90-0081. Salt Lake City, Utah.

, and E.J. Wick. 1997. Investigations of Razorback Sucker Distribution Movements and Habitats Used During Spring in the Green River, Utah. Final Report of U.S. Fish and Wildlife Service, Vernal, Utah, to Upper Colorado River Endangered Fish Recovery Program. Denver, Colorado.

Moir, W., and P. Mika. 1972. Prairie Vegetation of the Willamette Valley, Benton County, Oregon. Unpublished Report on File at USDA Forest Service, Forestry Science Laboratory. Corvallis, Oregon.

Montanucci, R.R. 1965. Observations on the San Joaquin Leopard Lizard, Crotaphytus wislizenii silus Stejneger. Herpetologica 21:270-283.

- 1967. Further Studies on Leopard Lizards, Crotaphytus wislizenii. Herpetologica 23:119-126. 
- 1970. Analysis of Hybridization between Crotaphytus wislizenii and Crotaphytus silus (Sauria: Iguanidae) in California. Copeia 1970:104-123.

Morefield, J.D.. 2001. Nevada Rare Plant Atlas: Enceliopsis nudicaulis var. corrugata. Report submitted to the U.S. Fish and Wildlife Service by the Nevada Natural Heritage Program. Carson City, Nevada.

Morey, S.C. 1995. Recovery Workshop Summary, Thread-leaved Brodiaca (Brodiaea filifolia), February 22, 1995. Unpublished Report. California Department of Fish and Game.

Morgan, R., and J.D. Ackerman. 1990. Two Ncw Pipcrias (Orchidaccac) from Western North America. Lindleyana 5(4):205-211.

Morrell, S.H. 1971. Life History of the San Joaquin Kit Fox. California Department of Fish and Game. Special Wildlife Investigation, Unpublished Report. Sacramento, California.

- 1972. Life History of the San Joaquin Kit Fox. California Department of Fish and Game. Sacramento, California.

Morris, D. 1965. The Mammals: A Guide to Living Species. Harper and Row Publishers, Ine. New York, New York.

Morrison, M.L., L.S. Mills, and A.J. Kuenzi. 1996. Study and Management of an Isolated, Rare Population: The Fresno Kangaroo Rat. Wildlife Soeiety Bulletin 24(4):602-606.

Moyle, P.B., and A. Mariochi. 1975. Biology of the Modoc Sucker, Catostomus microps, in Northcastcrn California. Copeia 3:556-560.

1976. Inland Fishes of California. University of California Press. Berkeley, California.

. 2002. Inland Fishes of California. University of California Press. Berkeley, California.

Mozingo, H.N. 1977. Nitrophila mohavensis Munz and Roos. Mentzelia 3:24.

, and M. Williams. 1980. Threatened and Endangercd Plants of Nevada. Report Submitted to the U.S. Fish and Wildlife Scrvicc. Portland, Oregon; and Bureau of Land Management. Reno, Nevada.

Muiznicks, B.D., S.J. Sferra, T.E. Corman, M.K. Sogge, and T.J. Tibbitts. 1994. Arizona Partncrs in Flight Southwestern Willow Flycateher Survey, 1993. Draft Report: Nongame and Endangered Wildlife Program, Arizona Game and Fish Department. Phoenix Arizona.

Mullen, R.K. 1981. Elk Hills Endangered Species Program. Environmental Assessment of the Blunt-nosed Lcopard Lizard, Crotaphytus silus, Phasc 2, 1980. U.S. Department of Energy Topical Report Number EGG 1183-2417, Santa Barbara Operations, EG \& G Energy Mcasurements. Golcta, California.

Muller, R. 1980. Fish Toxicity and Surface Tension of Non-ionic Surfactants: Investigations of Anti-foam Agcnts. Journal of Fish Biology 16:585-589.

Mullet, T.C. 2008. Evaluation of Two GIS Habitat Models and 1nitial Charactcrization of Nesting and BreedingSeason Roosting Microhabitat for Mcxican Spotted Owls in the Guadalupe Mountains. M.S. Thesis, Sul Ross State University. Alpine, Texas. 
Mundie, J.H. 1969. Ecological Implications of the Diet of Juvenile Coho in Streams. In: Symposium on Salmon and Trout in Streams (T.G. Northeote, Editor). Institute of Fisheries, University of British Columbia. Vancouver, British Columbia.

Muñoz, A.A. 1991. Reproductive Biology of the Endangered Santa Ana River Woolly-Star, Eriastrum densifolium ssp. sanctorum (Milliken) Mason (Polemoniaceae). Unpublished Master of Arts in Biology thesis. Department of Biological Science, California State University. Fullerton, California.

Munz, P.A. 1974. A Flora of Southern California. University of California Press. Berkeley, California. , and D.D. Keck. 1959. A California Flora. University of California Press. Berkeley, California.

Murie, A. 1944. The Wolves of Mount MeKinley. U.S. Government Printing Office. Washington, D.C.

Murphy, K.A. 2003. Pollination Ecology of the Robust Spineflower (Chorizanthe robusta var. robusta) in Santa Cruz County. A Report to the U.S. Fish and Wildlife Serviee, Region 8. Ventura, California.

Muth, R.T. 1995. Conceptual Framework Doeument for Development of a Standardized Monitoring Program for Basin-Wide Evaluation of Restoration Activities for Razorback Sucker in the Green and Upper Colorado River Systems. Final Report of Colorado State University Larval Fish Laboratory to Upper Colorado River Endangered Fish Recovery Program. Denver, Colorado.

, L.W. Crist, K.E. LaGory, J.W. Hayse, K.R. Bestgen, T.P. Ryan, J.K. Lyons, and R.A. Valdez. 2000. Flow and Temperature Recommendations for Endangered Fishes in the Green River Downstream of Flaming Gorge Dam. Final Report to Upper Colorado River Endangered Fish Recovery Program. Denver, Colorado.

Myatt, R.G. 1970. A New Prostrate Varicty of Eriogonum apricum (Polygonaceae). Madrono 20:320-321.

- 1987. Germination and Seedling Establishment of the Ione Buckwheat. In Conservation and Management of Rare and Endangered Plants (T.S. Elias, Editor). Conference Proceedings. California Native Plant Society. Sacramento, California.

Myers, J.M., R.G. Kope, G.J. Bryant, D. Teel, L.J. Lierheimer, T.C. Wainwright, W.S. Grant, F.W. Waknitz, K. Neely, S.T. Lindley, and R.S. Waples. 1998. Status Review of Chinook Salmon from Washington, Idaho, Oregon, and California. U.S. Department of Commeree, National Oceanic and Atmospheric Administration Technical Memo NMFS-NWFSC-35.

Myler, C.D. 2006. Report on the Re-survey of the Bruneau Hot Springsnail Sites for 2005 and 2006 Monitoring Years. Report to the U.S. Fish and Wildlife Service. Boise, Idaho.

, and G.W. Minshall. 1998. Report on the 1998 Re-survey of the Bruneau Hot Springsnail Sites. Prepared for the USFWS, Boise, Idaho by Stream Ecology Center, Department of Biological Sciences, Idaho State University. Pocatello, Idaho.

Nadeau, J.H. 1985. Biology of New World Microtus. Pages 254-285 in Special Publication Number 8, American Society of Mammology (R.H. Tamarin, Editor). Boston, Massachusetts.

Naiman, R.J. 1979. Preliminary Food Studies of Cyprinodon macularius and Cyprinodon nevadensis (Cyprinodontidae). Southwestern Naturalist 24:538-541.

National Fire Plan Technical Team. 2002. Criteria for At-Risk Salmonids: National Fire Plan Activities. Version 2.1 . 
National Marine Fisheries Service. No Date. Pacific Salmonids: Major Threats and Impacts. Available at: http://www.nmfs.noaa.gov/pr/species/fish/salmon.htm.

. 2005a. Updated Status of Federally Listed ESUs of West Coast Salmon and Steelhead. NOAA Technical Memorandum NMFS-NWFSC-66. Northwest Fisheries Seienee Center and Southwest Fisheries Science Center. Seattle, Washington and Santa Cruz, California.

. 2005b. Endangered and Threatened Wildlife and Plants: Proposed Threatened Status for Southern Distinet Population Segment of North American Green Sturgcon. Federal Register 70(65):17386-17401.

. 2009. Endangered and Threatened Wildlife and Plants: Final Rulemaking To Designate Critical Habitat for the Threatened Southern Distinet Population Segment of North Ameriean Green Sturgeon. Federal Register 74(195):52300-52351.

2011. Endangered and Threatened Species; Designation of Critieal Habitat for the Southern Distinet Population Segment of Eulachon; Final Rule. Federal Register 76(203):65323-65352.

National Park Service. 2007. Final Fort Hunter Liggett Speeial Resource Study. Oakland, California.

2013. Razorback Sucker (Xyrauchen

http://www.nps.gov/grca/naturescienee/fish-razorbaek-sueker.htm.

texanus). Available

at:

NatureServe. 2001-2012. NatureServe Explorer: An Online Encyclopedia of Life [Web Applieation]. Versions 1.6 Through 7.1. Arlington, Virginia. Available at: http://www.natureserve.org/explorer.

Navajo Natural Heritage Program. 2004. Status Assessment Report for S. mesae-verde (MesaVerde Caetus). Prepared for Navajo Natural Heritage Program. Window Rock, Arizona.

Navarro-Lopez, D. 1985. Status and Distribution of the Ocelot in South Texas. Unpublished M.S. Thesis, Texas A\&I University. Kingsville, Texas

Nebraska Game and Parks Commission. 1987 to Present. Plant Element Oceurrenee Records: Platanthera praeclara. Nebraska Natural Heritage Database. Lincoln, Nevada.

Neese, E. 1984. Field Work Performed for Colorado Natural Heritage Inventory. Salt Lake City, Utah.

- 1987. Final Report - Habitat Inventory of Sclerocactus wrightiae and Other Associated Sensitive Speeies. Volume 1 - Text and Photographs. USDOI, Bureau of Land Management. Riehfield, Utah.

Nelson, C.B. 2001. Life History of the Kanab Ambersnail on Native and Nonnative Host Plants in Grand Canyon, Arizona. Master's Thesis. Northern Arizona University Biology Department. Flagstaff, Arizona.

Nevada Department of Wildlife and USFWS. 2007. Programmatic Safe Harbor Agreement for Voluntary Enhaneement/Restoration Aetivities Benefitting White River Springfish, Hiko White River Springfish, Pahranagat Roundtail Chub, and Southwestern Willow Flycateher Within Pahranagat Valley, Lincoln County, Nevada. Las Vegas, Nevada.

Nevada Division of Forestry. No Date. Steamboat Buekwheat: A Special Nevada Plant. Available at: http://www.state.nv.us/nvnhp/reports/erovwbro.pdf.

Nevada Fish and Game Commission. 1958. Fisheries Management Report: Pyramid Lake. Lakes Walker, Pyramid and Tahoe Investigations, Dingell-Johnson Project FAF-4-R. Nevada Fish and Game Commission. Carson City, Nevada. 
Nevada Natural Heritage Program. 2001a. Rare Plant Fact Sheet for Astragalus phoenix Barneby (1970), Ash Meadows Milk Veteh. Available at: http://www.state.nv.us/nvnhp/atlas/.

2001b. Rare Plant Fact Sheet for Ivesia kingii S. Watson var. eremica Coville (1892) Ertter, Ash Meadows Ivesia. Available at: http://www.state.nv.us/nvnhp/atlas/.

. 2001c. Rare Plant Fact Sheet for Mentzelia leucophylla Brandegee (1899), Ash Meadows Blazingstar. Available at: http://www.state.nv.us/nvnhp/atlas/.

Newland, K.C. 1979a. Statement Presented at Fish and Wildlife Service Hearings on the Proposed Endangered Cacti in Arizona. Phoenix, Arizona.

. 1979b. [Letter to A.M. Phillips, III]. Evaluation of Private and Commereial Colleeting on Five Arizona Endangered Cactus Speeies, July 1979. Located at the Museum of Northern Arizona. Flagstaff, Arizona.

New Mexico Department of Game and Fish. 1985. Handbook of Species Endangered in New Mexico. Santa Fe, New Mexico.

1988. Handbook of Species Endangered in New Mexico, A-600:1-2. Santa Fe, New Mexico.

1994. Endangered Species of New Mexico - 1994 Biennial Review and Recommendations. Authority: New Mexico Wildlife Conservation Aet (NMSA 17-2-37, 1978). Santa Fe, New Mexico.

1995. Reeommended Changes: List of Endangered Speeies in New Mexieo. Santa Fe, New Mexico.

2002. Biota Information System of New Mexico (BISON). New Mexico Department of Game and Fish Electronic Database. Version 3/2002. Available at: http://nmnhp.unm.edu/bisonm/.

New Mexico Department of Natural Resources. 1985. Natural Resources Information System. Santa Fe, New Mexico.

New Mexico Forestry and Resources Conservation Division. 1992. Seetion 6 Progress Report. USFWS, Region 2. Albuquerque, New Mexico.

New Mexico Native Plants Protection Advisory Committee. 1984. A Handbook of Rare and Endemie Plants of New Mexico. University of New Mexico. Albuquerque, New Mexico.

New Mexico Rare Plant Technical Council. 1999. New Mexico Rare Plants. Albuquerque, New Mexico: New Mexico Rare Plants Home Page. Available at: http://nmrareplants.unm.edu.

New Mexico State Forestry Division. 2007. Mesa Verde Cactus: a Twenty-One Year Demographic Summary of a Waterflow, New Mexico Study Plot. R. Sivinski, Author. New Mexieo Energy, Minerals, and Natural Resourees Department. Santa Fe, New Mexico.

Niehaus, T.F. 1971. A Biosystematic Study of the Genus Brodiaea (Amaryllidaceae). University of California Publications in Botany, Volume 60. University of California Press. Berkley, California.

Nolan, V. 1960. Breeding Behavior of the Bell Vireo in Southern Indiana. Condor 62:225-240.

Novakowski, N.S. 1965. The Day We Rescued a Whooping Crane. Audubon Magazine 67:230-233.

1966. Whooping Crane Population Dynamics on the Nesting Grounds, Wood Buffalo National Park, Northwest Territories, Canada. Canadian Wildlife Service, Research Report Series. 
Nowak, R.M., and J.L. Paradiso. 1983. Walker's Mammals of the World. Pages 1230-1232 in Fourth Edition Volume II. John Hopkins University Press. Baltimore, Maryland.

Nyquist, D. 1963. The Ecology of Ermichthys acros an Edemic Thermal Species of Cyprinid Fish from Northwestern Nevada. M.S. Thesis. University of Nevada. Reno, Nevada.

Odion, D.C., R.M. Callaway, W.R. Ferren, Jr., and F.W. Davis. 1992. Vegetation of Fish Slough, an Owens Valley Wetland Ecosystem. Pages 173-197 in History of Water: Eastern Sierra Nevada, Owens Valley, White-Inyo Mountains (C.K. Hall, V. Doyle-Jones and B. Widawski, Editors). University of California Press. Berkeley, California.

O'Farrell, T.P., and L. Gilbertson. 1979. Ecology of the Desert Kit Fox Vulpes macrotis arsipus, in the Mojave Desert of Southern California. Bulletin of the Southern California Academy of Science 85:1-15.

, T.T. Kato, P.M. McCue, and M.L. Sauls. 1980. Inventory of San Joaquin Kit Fox on U.S. Bureau of Management Lands in Southern and Southwestern San Joaquin Valley - Final Report. Report Number EGG 1183-2400, EG\&G Energy Measurements. Goleta, California.

Office of Species Conservation. 2002. Letter to Mr. Robert Ruesink from Mr. James Caswell Regarding Notice and Request for Comments on the Proposed Listing of Lepidium papilliferum under 50 CFR 17. Boise, Idaho.

Opler, P.A. 1986. Letter to Fish and Wildlife Service, November 6, 1986. USFWS, Office of Information Transfer. Fort Collins, Colorado.

Oregon Department of Agriculture. 1995. Sidalcea nelsoniana: Preliminary Report of Oregon Department of Agriculture Research Results (1994) and Examination of Previous MWL-Sponsored Research. Unpublished Report Written by Oregon Department of Agriculture, Plant Conservation Biology Program.

Oregon Natural Heritage Information Center. 2007. Rare, Threatened and Endangered Species of Oregon. Oregon Natural Heritage Information Center, Oregon State University. Portland, Oregon.

Orloff, S.G., F. Hall, and L. Spiegel. 1986. Distribution and Habitat Requirements of the San Joaquin Kit Fox in the Northern Extreme of their Range. Transactions of the Western Section of the Wildlife Society 22:6070 .

Osborne, K.H. 2005. Report on the Status of the Euterpe Sphinx Moth (Euproserpimus enterpe) and Assessment of Habitats on the 660-acre DeLuea property, Walker Basin. Prepared for the U.S. Fish and Wildlife Sacramento Fish and Wildlife Office by Osborne Biological Consulting. Riverside, California.

Osmundson, D.B., and L.R. Kaeding. 1991. Recommendations for Flows in the 15-Mile Reach During OetoberJune for Maintenanee and Enhaneement of Endangered Fish Populations in the Upper Colorado River. Final Report of U.S. Fish and Wildlife Service, Grand Junetion, Colorado, to Upper Colorado River Endangered Fish Recovery Program, Denver, Colorado.

Otis Bay, Inc. 2006. Ash Meadows Geomorphic and Biological Assessment: Draft Final Report. Prepared for Ash Meadows National Wildlife Refuge. Amargosa Valley, Nevada.

Owen, J.G., and R.S. Hoffman. 1983. Sorex ornatus. Mammalian Species 212:1-5.

Padgett, W.G. 1986. Maguire Primrose Status Report. Unpublished Report Prepared by Utah Native Plant Society. Logan, Utah. 
Page, G.W., and L.E. Stenzel (Editor). 1981. The Breeding Status of the Snowy Plover in California. Western Birds 12(1): 1-40.

, F.C. Bidstrup, R.J. Ramer, and L.E. Stenzel. 1986. Distribution of Wintering Snowy Plovers in California and Adjacent States. Western Birds 17(4):145-170.

, L.E. Stenzel, W.D. Shuford, and C.R. Bruce. 1991. Distribution and Abundance of the Snowy Plover on its Western North American Breeding Grounds. Journal of Field Ornithology 62(2):245-255.

, J.S. Warriner, J.C. Warriner, and P.W.C. Paton. 1995. Snowy Plover (Charadrius alexandrianus) in The Birds of North America, No. 154 (A. Poole and F. Gill, Editors). The Academy of Natural Sciences and the American Ornithologists' Union. Philadelphia, Pennsylvania and Washington, D.C.

Palacios, E.P., L. Alfaro, and G.W. Page. 1994. Distribution and Abundance of Breeding Snowy Plovers on the Pacific Coast of Baja California. Journal of Field Ornithology 65(4):490-497.

Paradzick, C.E., R.F. Davidson, J.W. Rourke, M.W. Sumner, and T.D. McCarthey. 1999. Southwestern Willow Flyeatcher 1998 Survey and Nest Monitoring Report. Technical Report 141. Arizona Game and Fish Department. Phoenix, Arizona.

Pavlik, B., and E.A. Manning. 1986. Endangered Species Information Systems Speeies Workbook Part IISpecies Biology. Workbook Compiled for the Spring-Loving Centaury. Prepared for the Office of Endangered Species. U.S. Fish and Wildlife Service.

Pearson, A.M. 1975. The Northern Interior Grizzly Bear (Ursus arctos). Canadian Wildlife Service Report Series 34.

Pearson, O.P. 1959. A Traffic Survey of Microtus-Reithrodontomys Runways. Journal of Mammalogy 40:169180.

Pearsons, T.N. 1989. Ecology and Decline of a Rare Western Minnow: The Oregon Chub (Oregonichthys crameri). M.S. Thesis. Oregon State University. Corvallis, Oregon.

Pennak, R.W. 1978. Fresh-Water Invertebrates of the United States, Second Edition. John Wiley \& Sons, New York, New York.

Perkins, D.L., C.E. Mace, G.G. Scoppettone, and P.H. Rissler. 1996. Identification of Spawning Habitats Used by Endangered Borax Lake Chub (Gila boraxobins). United States Geological Survey, Biological Resources Division, Reno Field Station. Reno, Nevada.

Petersen, M.R. 1981. Populations, Feeding Ecology and Molt of Steller's Eiders. Condor 83:256-262.

Peterson, J.S. 1982. Abstract for Eriogonum pelinophilum. (Unpublished). Colorado Natural Areas Inventory. Denver, Colorado.

1985. Field Work Performed for the Rocky Mountain Heritage Task Force. Denver, Colorado.

, and K.L. Wiley-Eberle. 1984. Phacelia formosula Osterhout, Recovery Plan. Technical Draft. Natural Heritage Inventory. Denver, Colorado.

Pfeiffer, J.M., and E.H. Ortiz. 2007. Invasive Plants Impact California Native Plants Used in Traditional Basketry. Fremontia 35:7-13. 
Phillips, A.M., III, B.G. Phillips, and E.M. Peterson. 1979. Status Report: Pediocactus peeblesianus (Croiz.) L. Benson var. peeblesianus. USFWS. Albuquerque, New Mexieo.

, L.T. Green, I. Mazzoni, and N. Brian. 1981. Status Report for Carex specuicola. Prepared for USFWS. Albuquerque, New Mexico.

Pickart, A.J., and M.G. Barbour. 2007. Beaeh and Dune. Pages 155-179 in Terrestrial Vegetation of California (M.G. Barbour, T. Keeler-Wolf and A. Sehoenherr, Editors). University of California Press. Berkeley, California.

, and J. Sawyer. 1998. Ecology and Restoration of Northern California Coastal Dunes. California Native Plant Society. Saeramento, California.

, A.L. Eicher, M.M. Bivin, and K.F. Hayler. 2000. Changes in a Metapopulation of the Endangered Wallflower (Erysimum menziesii [Hook.] Wettst ssp. enrekense R.A. Priee) in Relation to Disease Incidenee and Management. Natural Areas Journal 20:234-242.

Platania, S.P. 1993. Pecos Bluntnose Shiner (Notropis simus pecosensis) Researeh; 1992 Annual Progress Report. University of New Mexieo in Peeos River Investigations Annual Research Report to U.S. Bureau of Reclamation. Albuquerque, New Mexico.

1995a. Peeos Bluntnose Shiner (Notropis simus pecosensis) Researeh: Larval Fish Drift Studies. 1993 Annual Progress Report, Submitted to the U.S. Bureau of Reelamation. Albuquerque, New Mexico.

- 1995b. Reproduetive Biology and Early Life-History of Rio Grande Silvery Minnow, Hybognathus amarus. Report to the U.S. Army Corps of Engineers. Albuquerque, New Mexieo.

. 2000. Effeets of Four Water Temperature Treatments on Survival, Growth, and Developmental Rates of Rio Grande Silvery Minnow (Hybognathus amarus) Eggs and Larvae. Report to U.S. Fish and Wildlife Serviee, New Mexico Ecological Services Field Office. Albuquerque, New Mexico.

, and C.S. Altenbach. 1998. Reproductive Strategies and Egg Types of Seven Rio Grande Basin Cyprinids. Copeia 1998:559-569.

, and R.K. Dudley. 2006. Spatial Spawning Periodieity of Rio Grande Silvery Minnow During 2006. Report to U.S. Bureau of Reclamation. Albuquerque, New Mexico.

Player, R.L., and P.J. Urness. 1983. Habitat Manipulation for Reestablishment of Utah Prairie Dogs in Capitol Reef National Park. Great Basin Naturalist 42(4):517-523.

Pleasants, J.M. 1995. The Effeets of Spring Burns on the Western Prairie Fringed Orehid (Platanthera praeclara). Proeeedings of the $14^{\text {th }}$ North American Prairie Conference (B.C. Hart, ed.). Kansas University Press. Manhattan, Kansas.

Poole, K.G. 1994. Characteristies of an Unharvested Lynx Population During a Snowshoe Hare Deeline. Journal of Wildlife Management 58(4):608-618.

Poole, J.M. 1992. Puzzle sunflower (Helianthis paradoxus): A Status Report Update. USFWS. Albuquerque, New Mexico.

Powell, J. 1986. Reeords of Prolonged Diapause in Lepidoptera. Journal of Researeh on the Lepidoptera. 25(2): 83-109. 
Presley, G. 1994. Draft Lokern Natural Area Conceptual Area Plan. Draft Report, California Department of Fish and Game. Visalia, California.

Price, M.V., and P.A. Kelly. 1994. An Age-structured Demographic Model for the Endangered Stephens' Kangaroo Rat. Conservation Biology 8:810-821.

Price, R.A. 1993. Erysimum. in The Jepson Manual: Higher Plants of California (J.C. Hickman, Editor). University of California Press. Berkeley, California.

Propst, D.L. 1999. Threatened and Endangered Fishes of New Mexico. Technical Report Number 1, 1999, New Mexico Department of Game and Fish. Santa Fe, New Mexico.

, and K.R. Bengston. 1991. Habitat and Biology of the Loach Minnow, Tiaroga cobitis, in New Mexico. Copeia 199(1):29-38.

, P.C. Marsh, and W.L. Minckley. 1985. Arizona Survey for Spikedace, Meda fulgida, and Loach Minnow, Tiaroga cobitis: Fort Apache and San Carlos Apache Indian Reservations and Eagle Creek, 1985. Report, USFWS. Albuquerque, New Mexico.

, K.R. Bestgen, and C.W. Painter. 1986. Distribution, Status, and Biology of the Spikedace, Meda fulgida, in New Mexico. Endangered Species Report Number 15, USFWS. Albuquerque, New Mexico.

, and 1988. Distribution, Status, Biology, and Conservation of the Loach Minnow, Tiaroga cobitis Girard, in New Mexico. Endangered Species Report Number 17, USFWS. Albuquerque, New Mexico.

Quartarone, F. 1995. Historical Accounts of Upper Colorado River Basin Endangered Fish. Information and Education Committee, Upper Colorado River Endangered Fish Recovery Program. Denver, Colorado.

Quigley, T.M., R. Haynes, R.W. Graham, and T. Russell (Technical Editors). 1996. Integrated Scientific Assessment for Ecosystem Management in the Interior Columbia Basin and Portion of the Klamath and Great Basins. Forest Service Pacific Northwest Research Station General Technical Report PNW-GTR382. Portland, Oregon.

Radant, R.D., and T.J. Hickman. 1984. Status of the June Sucker (Chasmistes liorus). Proceedings of the Desert Fishes Council $15^{\text {th }}$ Annual Symposium. Death Valley, California.

Radtke, K. W-H., A.M. Arndt, and R.H. Wakimoto. 1982. Fire History of the Santa Monica Mountains. General Technical Report, PSW-58. Pacific Southwest Forest and Range Experiment Station. U.S. Department of Agriculture. U.S. Forest Service. Berkeley, California.

Rasmussen, H.N. 1995. Terrestrial Orchids from Seed to Mycotrophic Plant. University Press. Cambridge, Great Britain.

Raven, P. 1969. A Revision of the Genus Camissonia (Onagraceae). Contential. U.S. National Herb 37:332.

, H.J. Thompson, and B.A. Prigge. 1986. Flora of the Santa Monica Mountains, California, Second Edition. Southern California Botanists, Special Publication No. 2, University of California. Los Angeles, California.

Reeder, J.R. 1965. The Tribe Orcuttieae and the Subtribes of the Pappophoreae (Gramineae). Madroño 18:18-28. 
Reeves, G.H., F.H. Everest, and T.E. Nickelson. 1989. Identification of Physical Habitats Limiting the Production of Coho Salmon in Western Oregon and Washington. General Technical Report PNW-GTR245. U.S. Forest Service, Pacifie Northwest Research Station. Portland, Oregon.

Reveal, J.L. 1973. A New Subfruticose Eriogonum (Polygonaceae) from Western Colorado. Great Basin Naturalist 33:120-122.

. 1977. Eriogonum (Polygonaceae) of Arizona and New Mexico. Phytologia 34:409-484.

. 1978a. Status Report on Nitrophila mohavensis [Munz \& Roos] (Amargosa Niterwort). Unpublished Report Submitted to the Department of the Interior.

. 1978b. Astragalus phoenix Barneby (Ash Meadows Milk-veteh). Status Report. USFWS. Portland, Oregon.

. 1978c. Mentzelia leucophylla Brandegee (Ash Meadows Stick-Leaf). Status Report. USFWS. Reno, Nevada.

, C.R. Broome, and J.C. Beatley. 1973. A New Centaurium (Gentianceae) from the Death Valley Region of Nevada and California. Bulletin of the Torrey Botanical Club 100:353-356.

Rey-Vizgirdas, E. 1994. Status and Conservation of the Endangered Slender-Horned Spineflower (Dodecahema leptoceras (Gray) Rev. \& Hardham) and Alluvial Serub Habitat in Southern California. M.A. Thesis. California State University. Fullerton, California.

Rinkevich, S.E., and R.J. Gutiérrez. 1996. Mexican Spotted Owl Habitat Characteristies in Zion National Park. Journal of Raptor Research 30:74-78.

Rinne, J.N. 1980. Spawning Habitat and Behavior of Gila Trout, a Rare Salmonid of the Southwestern United States. Transactions of the Ameriean Fisheries Society 109:83-91.

, and W.L. Minckley. 1991. Native Fishes of Arid Lands: A Dwindling Resource of the Desert Southwest. U.S. Department of Agriculture, Forest Service, General Technical Report RM-206. Rocky Mountain Forest and Range Experiment Station. Fort Collins, Colorado.

Rinne, W.E. 1971. The Life History of Lepidomeda mollispinis mollispinis (the Virgin River Spinedace) a Unique Western Cyprinid. Unpublished M.S. Thesis. Department of Zoology, University of Nevada. Las Vegas, Nevada.

Ritchie, M.E., and N. Brown. 2005. Interim Progress Report: Research Toward Recovery of the Utah Prairie Dog. Department of Fisheries and Wildlife, Utah State University. Logan, Utah.

Roberts, T.S. 1932. The Birds of Minnesota. University of Minnesota Press. Minneapolis, Minnesota.

Roest, A.I. 1973. Morro Bay Kangaroo Rat Habitat Evaluation Study. Special Report for California Department of Fish and Game, W54R6-4.

. 1984. The Morro Bay Kangaroo Rat: A Summary of Current Knowledge. Poster Session Presented at American Society of Mammology Annual Meeting, 24-28 June. Humboldt State University. Humboldt, California.

. 1985. Personal Knowledge, Observations. Biological Seiences Department, California Polytechnie State University. San Luis Obispo, California. 
1991. Captive Reproduction in Heermann's Kangaroo Rat, Dipodomys heermanni. Zoo Biology 10: 127-137.

Rollins, R.C. 1941. A Monographic Study of Arabis in Western North America. Rhodora 43:289-325, 348-411, 425-481.

1973. Purple-flowered Arabis of the Pacific Coast of North America. Contribution to the Gray Herbarium 204:149-154.

Romspert, A.P., and J.H. Burk. 1979. Algodones Dunes Sensitive Plant Project 1978-79. Prepared for the USDOI BLM, Project Number 1510 (C-961.1).

Rose, R.K., and E.C. Birney. 1985. Community Ecology. Pages 310-339 in Biology of New World Microtus (R.H. Tamarin, ed.). Special Publication Number 8, American Socicty of Mammology. Boston, Massachusetts.

Rosenberg, K.V., R.D. Ohmart, W.C. Hunter, and B.W. Anderson. 1991. Birds of the Lower Colorado River Valley. University of Arizona Press. Tueson, Arizona.

Roth, B. 1985. Status Survey of the Banded Dune Snail, Helminthoglypta walkeriana. Prepared for the USFWS, Sacramento Endangered Species Office. Sacramento, California.

Rudd, R.L. 1953. Notes on Maintenance and Behavior of Shrews in Captivity. Journal of Mammology 34:118120.

Ruediger, B., J. Claar, S. Gniadek, B. Holt, L. Lewis, S. Mighton, B. Naney, G. Patton, T. Rinaldi, J. Trick, A. Vandehey, F. Wahl, N. Warren, D. Wenger, and A. Williamson. 2000. Canada Lynx Conservation Assessment and Strategy. Forest Service, USFWS, BLM, and National Park Service. Missoula, Montana.

Russell, R.H., J.W. Nolan, N.G. Woody, G. Anderson, and A.M. Pearson. 1978. A Study of the Grizzly Bear (Ursus arctos) in Jasper National Park. Canadian Wildlife Service. Edmonton, Canada.

Salata, L. 1987. The Status of the Least Bell's Vireo at Camp Pendleton, California in 1987. Unpublished Report. U.S. Marine Corps. Camp Pendleton, California.

Sandercock, F.K. 1991. Life History of Coho Salmon (Oncorhynchus kisutch) Pages 396-445 in Pacific Salmon Life Histories (C. Groot and L. Margolis, Editors). University of British Columbia Press. Vancouver, British Columbia.

Sanders, A.C. 1999. Triple-ribbed Milk-vetch, Astragahus tricarinatus Gray. Unpublished Report.

, and Thomas Olsen Associates. 1996. A Rare Plant Survey of Five Selected Plants in the Coachella Valley. Riverside, California.

San Diego County Plant Atlas. 2010. An Online Database of the San Diego Museum of Natural History. Available at: http://www.sdplantatlas.org/(S(huph4nfxotdprf45lw5knq45))/publicsearch.aspx.

Sandoval, T.M., and E.A. Cypher. 1996. California Jewelflower, Caulanthus californicus. Endangered Species Profiles, Species Featured in Recovery Plan for San Joaquin Valley Arid Upland and Riparian Communities. Endangered Species Recovery Program. Fresno, California. Available at: http://arnica.csustan.edu/esrpp. 
Sanford, M. 2006. Biology and Conservation of the Endangered Carson Wandering Skipper (Pseudocopaeodes eunus obscurus Austin and Emmel) in Western Great Basin Saltgrass Communities. Natural Areas Journal 26:396-402.

Sather, N., and W. Smith. 1994. Results of Demographic Studies at Four Minnesota Populations of Platanthera praeclara in Minnesota. Presentation at Western Prairie Fringed Orehid Workshop, June 26-27, 1994. Crookston, Minnesota.

Sawyer, J.O., and T. Keeler-Wolf. 1995. A Manual of California Vegetation. California Native Plant Society. Sacramento, California.

, and J.M. Evans. 2009. A Manual of California Vegetation, Second Edition. California Native Plant Society Press. Sacramento, California.

Schemske, B., B.C. Husband, M.H. Ruckelshaus, C. Goodwillie, I.M. Parker, and J.G. Bishop. 1994. Evaluation Approaches to the Conservation of Rare and Endangered Plants. Ecology 75:584-606.

Schoenherr, A. 1981. The Role of Competition in the Replacement of Native Fishes by Introduced Species. In Fishes in North American Deserts (R.J. Naiman and D.L. Soltz, Editors). John Wiley and Sons. New York, New York.

Schultz, C.B. 1998. Dispersal Behavior and its Implication for Reserve Design for a Rare Oregon Butterfly. Conservation Biology 12:284-292.

, and P.C. Hammond. 2003. Using Population Viability Analysis to Develop Recovery Criteria for Endangered Insects: Case Study of the Fender's Blue Butterfly. Conservation Biology 17:1372-1385.

Schultz, S.T. 1989. Status Report on Lilium occidentale Purdy. Unpublished Report Prepared for the Endangered Species Program, Plant Division, Oregon State Department of Agriculture. Salem, Oregon.

Schwendinger, R.B., G.K. Carlson, and C.O. Spelman, Jr. 1991. Status Report on Eutrema penlandii Rollins as a Result of Field lnvestigations in Park, Summit, Gunnison, Chaffee, and Clear Creek Counties, Colorado, in July and August 1991. Unpublished Report to USFWS. Alma American Mining Corporation. Lakewood, Colorado.

Scoppettone, G.G., M. Coleman, H. Burge, and G. Wedemeyer. 1981. Cui-Ui Life History: River Phase. USFWS, an Annual Report. National Fisheries Resouree Center, Seattle, Washington, and Fisheries Assistance Office. Reno, Nevada.

, G.A. Wedemeyer, M. Coleman, and H. Burge. 1983. Reproduction by the Endangered Cui-Ui in the Lower Truckee River. Transactions of the American Fisheries Society 112:788-793.

, M. Coleman, and G.A. Wedemeyer. 1986. Life History and Status of the Endangered Cui-Ui of Pyramid Lake, Nevada. Fish and Wildlife Resourees 1. USFWS. Washington, D.C.

, H.L. Burge, P.L. Tuttle, and N.K. Parker. 1987. Life History and Status of the Moapa Dace (Moapa coriacea). USFWS, National Fisheries Research Center. Seattle, Washington.

, H.L. Burge, and P.L. Tuttle. 1992. Life History, Abundance, and Distribution of Moapa Dace (Moapa coriacea). Great Basin Naturalist 52:216-225. 
, P.H. Rissler, B. Nielsen, and M. Grader. 1995. Life History and Habitat Use of Borax Lake Chub (Gila boraxobius Williams and Bond) with Some Information on the Borax Lake Ecosystem. National Biological Service. Northwest Biological Science Center, Reno Field Station. Reno, Nevada.

, J.E. Harvey, and J. Heinrich. 2004. Conservation, Status, and Life History of the Endangered White River Spinedace Lepidomeda albivallis (Cyprinidae). Western North American Naturalist 64(1):38-44.

Scott, J.A. 1982. The Life History and Ecology of an Alpine Relict, Boloria improba acrocnema (Lepidoptera: Nymphalidae), Illustrating a New Mathematical Population Census Method. Papilio 2:1-12.

1986. The Butterflies of North America. Stanford University Press. Stanford, California.

, and R.E. Stanford. 1982. Geographic Variation and Ecology of Hesperia leonardus (Hesperiidae). Journal of Research on the Lepidoptera 20(1):18-35.

Scott, M.D., and G. Servheen. 1985. The Woodland Caribou. Audubon Wildlife Report 1985.

Scrivner, J.H., T.P. O'Farrell, T.T. Kato, and M.K. Johnson. 1987. Diet of the San Joaquin Kit Fox, Vulpes macrotis mutica on Naval Petroleum Reserve \#1, Kern County, California, 1980-1984. Report Number EGG 10282-2186, EG\&G Energy Measurements. Goleta, California.

Seabloom, R.W. 1985. Endocrinology. Pages 685-724 in Biology of New World Microtus (R.H. Tamarin, Editor). Special Publication Number 8, American Society of Mammology. Boston, Massachusetts.

Seager, S.W.J., and C.M. Demorest. 1978. Reproduction of Captive Wild Carnivores. Pages 667-706 in Zoo and Wild Animal Medicine (M.E. Fowler, Editor). W.B. Saunders Company. Philadelphia, Pennsylvania.

Seamans, M.E., and R.J. Gutiérrez. 1995. Breeding Habitat Ecology of the Mexican Spotted Owl in the Tularosa Mountains, New Mexico. Condor 97:944-952.

Seidl, A. 1993. Final Report on the Uncompahgre Fritillary Butterfly. Unpublished Report Prepared for the Forest Service, in USFWS Files. Denver, Colorado.

Sellers, C. 2006. Assistant Director, Community Services Department, City of Chico. Status of Populations of Butte County Meadowfoam (Limnanthes floccosa ssp. californica). City of Chico. Unpublished.

Servheen, G., and J.L. Lyon. 1989. Habitat Use by Woodland Caribou in the Selkirk Mountains. Journal of Wildlife Management 53(1):230-237.

Severns, P.M. 2003. Inbreeding and Small Population Size Reduce Seed Set in a Threatened and Fragmented Plant Species Lupimus sulphureus ssp. kincaidii (Fabaceae). Biological Conservation 110:221-229.

Sferra, S.J., T.E. Corman, C.E. Paradzick, J.W. Rourke, J.A. Spencer, and M.W. Sumner. 1997. Arizona Partners in Flight Southwestern Willow Flycatcher Survey: 1993-1996 Summary Report. Nongame and Endangered Wildlife Program Technical Report 113. Arizona Game and Fish Department. Phoenix, Arizona.

Sharifi, R., B. Prigge, and P. Rundel. 2006. The Effect of the Amount of Precipitation on Seedling Survival of the Lane Mountain Milk-Veteh (Astragalus jaegerianus Munz). Powerpoint Presentation Given at the Annual Department of the Army Desert Research Conference. November 7, 2006. Redlands, California.

Sheviak, C.J. 1984. Spiranthes diluvialis (Orchidaceae), a New Species from the Western United States. Brittonia $36(1): 8-14$. 
Shoesmith, M.W., and D.R. Storey. 1978. Pages 51-64 in Movements and Associated Behavior of Woodland Caribou in Central Manitoba. XIII Congress of Game Biologists.

Shultz, L.M., and K.M. Mutz. 1979. Threatened and Endangered Plants of the Willow Creek Drainage. BLM. Vernal, Utah.

Shuster, S.M. 1981. Sexual Selection in the Soeorro Isopod, Thermosphaeroma thermophilum (Cole) (Crustaeea: Peraearida). Animal Behavior 29:698-707.

Sieg, C.H., and R.M. King. 1995. Influenee of Environmental Faetors and Preliminary Demographie Analysis of a Threatened Orchid Platanthera praeclara. American Midland Naturalist 134(2):307.

Sigler, W.F., and J.W. Sigler. 1979. Fishes of the Great Basin: A Natural History. University of Nevada Press. Reno, Nevada.

, and 1987. Fishes of the Great Basin: A Natural History. University of Nevada Press. Reno,

Nevada.

, S. Vigg, and M. Bres. 1985. Life History of the Cui-Ui, Chasmistes cujus Cope, in Pyramid Lake, Nevada: A Review. The Great Basin Naturalist 45:57I-603.

Simpson, K., G.P. Woods, and K.B. Hebert. 1985. Movements and Habitats of Caribou (Rangifer tarandus cariboul in the Columbia Mountains of British Columbia. British Columbia Fish and Wildlife Branch Report. Nelson, British Columbia.

Sims, J.K., and K.M. Simms. 1992. What Constitutes Quality Habitat for Gila Topminnow (Poeciliopsis occidentalis)? An Overview of Habitat Parameters Supporting a Robust Population at Cienega Creek, Pima County, Arizona. Proeeedings of the Desert Fisheries Couneil 22(1991):82.

Sinclair, C.J., and A.B.A. Boxall. 2003. Assessing the Ecotoxicity of Pesticide Transformation Produets. Environmental Seience and Technology 37:4617-4625.

Singer, F.J. 1978. Seasonal Coneentrations of Grizzly Bears, North Fork of the Flathead River, Montana. Canadian Field Naturalist 92:283-286.

Sivinski, R. 2000. Internal Seetion 6 Report to USFWS: Draft Mesa Verde Cactus (Sclerocactus mesae-verdae) Revised Recovery Plan. Prepared by Robert Sivinski, New Mexico Forestry Division, Santa Fe, New Mexieo for Region 2, USFWS. Albuquerque, New Mexico.

. 2008. Knowlton's Cactus (Pediocactus knowltonii). Section 6, Segment 22 Progress Report (September 30,2008 ) for U.S. Fish \& Wildlife Serviee, Region 2. Albuquerque, New Mexico.

, and K. Lightfoot. 1991. Field Survey for Zuni Fleabane (Erigeron rhizomatus), Datil and Sawtooth Mountains, Cibola National Forest. Submitted to The Nature Conservancy, New Mexico Natural Heritage Program. Albuquerque, New Mexico.

, and C. McDonald. 2007. Knowlton's Cactus (Pediocactus knowltonii): Eighteen Years of Monitoring and Reeovery Actions. In: Southwestern Rare and Endangered Plants: Proceedings of the Fourth Conferenee. (Barlow-Irick, P., J. Anderson and C. McDonald, Technical Editors). Mareh 22-26, 2004. Las Cruces, New Mexico. Proceedings. RMRS-P-48CD. USFS, Rocky Mountain Research Station. Fort Collins, Colorado. 
Skaggs, R.W. 1996. Population Size, Breeding Biology, and Habitat of Willow Flycatehers in the Cliff-Gila Valley, New Mexico - 1995. New Mexico Department of Game and Fish Report. Contract \#95-516-91.

Skinner, M.W., and B.M. Pavlik (Editors). 1994. California Native Plant Society's Inventory of Rare and Endangered Vascular Plants of California. California Native Plant Soeiety Special Publication Number 1 $\left(5^{\text {th }}\right.$ edition). California Native Plant Society. Sacramento, California.

Smith, H.M. 1946. Handbook of Lizards: Lizards of the Unites States and Canada. Comstock Publishing Company. Ithaca, New York.

Smith, J.P., Jr. 1977. Vascular Plant Families. Mad River Press. Eureka, California.

Smith, R.L. 1980. Alluvial Serub Vegetation of the San Gabriel River Floodplain, California. Madrono 27(3):126138.

Snyder, J.O. 1908a. Relationships of the Fish Fauna of the Lakes of Southeastern Oregon. Bulletin of the U.S. Bureau of Fish. Volume XXVII(1907):69-102.

. 1908b. The Fishes of the Coastal Streams of Oregon and Northern California. Bulletin of the U.S. Bureau of Fisheries 27:153-189.

Snyder, N.F.R., and J.A. Hamber. 1985. Replacement-clutehing and Annual Nesting of California Condors. Condor 87:374-378.

, R.R. Ramey, and F.C. Sibley. 1986. Nest-site Biology of the California Condor. Condor 88:228-241.

Sogge, M.K. 1995. Southwestern Willow Flycatcher (Empidonax traillii extimus) Monitoring at Tuzigoot National Monument. 1995 Progress Report to the National Park Service. National Biological Service Colorado Plateau Research Station/Northern Arizona University Report.

, T.J. Tibbits, and S.J. Sferra. 1993. Status of the Southwestern Willow Flycatcher Along the Colorado River Between Glen Canyon Dam and Lake Mead - 1993. Summary Report. National Park Service Cooperative Park Studies Unit/Northern Arizona University, U.S. Fish and Wildlife Service, and Arizona Game and Fish Department Report.

, and J. Petterson. 1997. Status and Ecology of the Southwestern Willow Flycatcher in the Grand Canyon. Western Birds 28:142-157.

Soltz, D.L., and R.J. Naiman. 1978. The Natural History of the Native Fishes in the Death Valley System. Natural History Museum of Los Angeles County and Death Valley Natural History Association, Science Series 30:1-76.

Spamer, E.E., and A.E. Bogan. 1993. Mollusea of the Grand Canyon and Vicinity, Arizona: New and Revised Data on Diversity and Distribution, with Notes on Pleistocene-Holocene Mollusks of the Grand Canyon. Proceedings of the Academy of Natural Sciences of Philadelphia 144:21-68.

Spang, E.F., G.W. Lamb, F. Rowley, W.H. Radtkey, R.R. Olendorff, E.A. Dahlem, and S. Stine. 1988. Desert Tortoise Habitat Management and the Derivation of Absolute Estimates. In Ecological Methods with Particular Reference to the Study of Insect Populations.

Sparling, D.W., G. Linder, and C.A. Bishop (Editors). 2000. Ecotoxicology of Amphibians and Reptiles. Society of Environmental Toxicology and Chemistry (SETAC). Pensacola, Florida. 
Spellenberg, R. 1977. A Report on the Investigation of Eriogomm gypsophilum and Happlopappus spinulosus Subspecies laevis in the Vieinity of Brantley Reservoir. Eddy County, New Mexieo.

Spence, B.C., G.A. Lomnicky, R.M. Hughes, and R.P. Novitski. 1996. An Eeosystem Approach to Salmonid Conservation. Doeument TR-4501-96-6057. ManTeeh Environmental Researeh Services Corp. Corvallis, Oregon. (Available from the National Marine Fisheries Serviee, Portland, Oregon).

Spence, J. 1991. Status of Schoenocrambe barnebyi in Capitol Reef National Park. Unpublished Report. National Park Serviee. Torrey, Utah.

1992. A Monitoring Program for the Endangered Pediocactus bradyi L. Benson, Lee's Ferry, Glen Canyon National Reereation Area. Glen Canyon National Reereation Area. Page, Arizona.

Spicer, R.B., R.L. Glinski, and J.C. deVos, Jr. 1985. Status of the Hualapai Vole (Microtus mexicanus hralapaiensis Goldman). Unpublished Report to the USFWS by Arizona Game and Fish Department. Phoenix, Arizona.

Stager, K. 1964. The Role of Olfaetion in Food Loeation by the Turkey Vulture (Cathartes arra). Los Angeles County Museum Contributions to Seienee 81:1-63.

Starrett, W.C. 1950. Food Relationships of the Minnows of the Des Moines River lowa. Eeology 31:216-233.

Stebbins, J.C. 1991. State Survey of Two Plants Endemie to the San Joaquin Valley, Psendobahia bahiifolia and Pseudobahia peirsonii. Prepared for Jim Bartel, Offiee of Endangered Speeies, U.S. Fish and Wildlife Serviee. Saeramento, California.

. 2000. Letter to Ellen Cypher, California State University, Stanislaus, California. Endangered Speeies Reeovery Program. Bakersfield, California.

Stebbins, R.C. 1985. A Field Guide to Western Reptiles and Amphibians. Seeond Edition. Houghton Mifflin Company. Boston, Massaehusetts.

Stebler, A.M. 1972. Conservation of the Grizzly: Eeologieal and Cultural Consideration. Pages 297-303 in Bears: Their Biology and Management (S. Herrero, Editor). International Union for Conservation of Nature Publieation, New Series 23.

Steffan-Dewenter, I., and T. Tscharntke. 1999. Effeets of Habitat Isolation on Pollination Communities and Seed Set. Oeeologia. 121:432-440.

Stehn, T.V. 1992. Unusual Movements and Behaviors of Color-banded Whooping Cranes during Winter. Proeeedings of the North Ameriean Crane Workshop 6:95-101.

Stejneger, L. 1893. Annotated List of Reptiles and Batraehians Colleeted by the Death Valley Expedition in 1891, with Deseriptions of New Speeies. North Ameriean Fauna 7:159-228.

Stenzel, L.E., S.C. Peaslee, and G.W. Page. 1981. Mainland Coast. Pages 6-16 in The Breeding Status of the Snowy Plover in California (G.W. Page and L.E. Stenzel, Editors). Western Birds 12(1):1-40.

Stevens, L.E., V.J. Meretsky, F.R. Protiva, D.M. Kubly, and J. Peterson. 1997. The Impaets of an Experimental Flood from Glen Canyon Dam on the Endangered Kanab Ambersnail at Vasey's Paradise, Grand Canyon, Arizona: Final Report. Prepared for the Grand Canyon Monitoring and Researeh Center. Flagstaff, Arizona. 
Stevenson, J.O., and R. E. Griffith. 1946. Winter Life of the Whooping Crane. Condor 48:160-178.

Stewart, G. 1958. Notes on the Morro Bay Kangaroo Rat. Undergraduate Thesis. California Polytechnic State University. San Luis Obispo, California.

, and A.I. Roest. 1960. Distribution and Habits of the Kangaroo Rats at Morro Bay. Journal of Mammology 41(1):126-129.

Stoleson, S.H., and D.M. Finch. 1999. Reproductive Success of Southwestern Willow Flycatchers in the CliffGila Valley, New Mexico. Report to Phelps-Dodge Corporation. USDA Forest Service, Rocky Mountain Research Station. Albuquerque, New Mexico.

Stone, R.D., W.B. Davilla, D.W. Taylor, G.L. Clifton, and J.C. Stebbins. 1988. Status Survey of the Grass Tribe Oreuttieae and Chamaesyce hooveri (Euphorbiaceac) in the Central Valley of California. U.S. Fish and Wildlife Service Technical Report. Sacramento, California.

Storer, T.I. 1925. A Synopsis of the Amphibia of California. University of California Publications in Zoology 27:1-342.

Stuart, J.H., F.G. Poole, and R.F. Wilson. 1972. Stratiography and Origin of the Chinle Formation and Related Upper Triassic Strata in the Colorado Plateau Region. Geologic Survey Professional Paper 690. U.S. Government Printing Office. Washington, D.C.

Stubben, C. 1997. Habitat Characteristics of Astragalns holmgreniorum Barneby and Genetic Variation Among Two Rare Milkvetches in Southwestern Utah. M.S. Thesis, Brigham Young University. Provo, Utah.

Stubbendieck, J., and R.R. Weedon. 1984. Germination and Establishment of Blowout Penstemon (Penstemon haydenii S. Wats.). Abstracts of Papers, Society for Range Management 37:199.

, J. Traeger, and R.R. Weedon. 1983. Propagation of Blowout Penstemon (Penstemon haydenii S. Wats.). Proceedings of the Nebraska Academy of Sciences 93:16.

, D. Beachly, and R.R. Weedon. 1984. Germination and Propagation of Penstemon haydenii S. Wats. Proceedings of the North American Prairie Conference 9:7.

, T.R. Flessner, and R.R. Weedon. 1989. Blowouts in the Nebraska Sandhills: The Habitat of Penstemon haydenii. Pages 223-225 in Proceedings of the Eleventh North American Prairie Conference (T. B. Bragg and J. Stubbendieck, Editors). Lincoln, Nebraska.

, J.B. Fitzgerald, D.T. Lindgren, and J.A. Lamphere. 1997. Penstemon haydenii: An Update on an Endangered Species. Bulletin of the American Penstemon Society 56:3-7.

SWCA, Inc. 1992. Nest Tree and Nest Tree Habitat Characteristics of the Mexican Spotted Owl in Arizona and New Mexico. Unpublished Report, USDA Forest Service, Southwestern Region. Albuquerque, New Mexico.

Tait, C.K., and E.J. Mulkey. 1993a. Assessment of Biological and Physical Factors Limiting Distribution of Stream-resident Warner Suckers (Catostomus warnerensis). Unpublished Report to the BLM and Oregon Department of Fish and Wildlife.

, and . 1993b. Estimation of Stream-resident Warner Sucker Abundance and Total Habitat Area in Two Basins Using a Statistically Valid Sampling Design. Unpublished Report to the BLM and Oregon Department of Fish and Wildlife. 
Taitt, M.J., and C.J. Krebs. 1985. Population Dynamies and Cycles. Pages 567-620 in Biology of New World Microtus (R. H. Tamarin, ed.). Speeial Publication Number 8, American Society of Mammology. Boston, Massachusetts.

Taylor, D.W. 1987. Fresh Water Mollusks from New Mexieo and Vicinity. Bulletin 116. New Mexico Bureau of Mines and Mineral Resources. Socorro, New Mexico.

1988. New Speeies of Physa (Gastropoda: Hygrophila) from the Western United States. Malaeologieal Review 21:43-79.

, and W.B. Davilla. 1986. Status Survey of Three Plants Endemie to the San Joaquin Valley and Adjacent Areas, California. Unpublished Report. USFWS. Saeramento, California.

Tepedino, V.J. 2000. The Reproduetive Biology of Rare Rangeland Plants and Their Vulnerability to Insecticides. In Grasshopper Integrated Pest Management User Handbook (G.L. Cunningham and M.W. Sampson, Teehnical Coordinators). Teehnical Bulletin 1809. USDA. Washington, D.C.

. 2005. Final Report: Reproduetion and Pollination of Two Rare Speeies of Astragalus from Washington County, Southern Utah: A. holmgreniorum and A. ampullarioides. USDA ARS Bee Biology and Systematies Laboratory, Department of Biology, Utah State University. Logan, Utah.

Tewes, M.E., and D.D. Everett. 1982. Year End Report - Studies of the Endangered Ocelot Oceurring in Texas, Contraet \#14-16-0002-81-229. Caesar Kleberg Wildlife Researeh Institute, Texas A\&I University. Kingsville, Texas.

, and

1986. Status and Distribution of the Endangered Ocelot and Jaguarundi in Texas. Pages 147-158 in Cats of the World: Biology, Conservation, and Management. (S.D. Miller and D.D. Everett, Editors) National Wildlife Federation. Washington, D.C.

, L.L. Laack, and A. Caso. 1995. Corridor Management for Oeelots in the Southern United States and Northern Mexieo. Proeeedings of the International Wildlife Management Congress 1:444-446.

, and S.D. Miller. 1987. Future research for the Endangered Oeelot Population of the United States. Pages 164-166 in Proceedings of the Third Southeastern Nongame and Endangered Wildlife Symposium. (R.R. Odom, K.A. Riddleberger, and J.C. Ozier, Editors). Georgia Department of Natural Resources. Athens, Georgia.

, and D.J. Schmidly. 1987. The Neotropical Felids: Jaguar, Ocelot, Margay, and Jaguarundi. Pages 695712 in Wild Furbearer Management and Conservation in North America (M. Novak, J.A. Baker, M.E. Obbard, and B. Malloeh, Editors). Ministry of Natural Resources. Ontario, Canada.

Texas Parks and Wildlife Department. 2003. Nature: Mexiean Long-nosed Bat. Available at: http://www.tpwd.state.tx.us/nature/wild/mammals/.

The Nature Conservancy. 1999. Soil Analysis and Soil Surveys for Suitable Habitat for Applegate's Milk-Veteh Within the Upper Klamath Basin. Unpublished Report Submitted to Klamath Falls Fish and Wildlife Office. Klamath Falls, Oregon.

Thomas, J.W., E.D. Forsman, J.B. Lint, E.C. Meslow, B.R. Noon and J. Verner. 1990. A Conservation Strategy for the Northern Spotted Owl. Interageney Seientifie Committee to Address the Conservation of the Northern Spotted Owl. U.S. Forest Serviee, U.S. Bureau of Land Management, U.S. Fish and Wildlife Service, and U.S. National Park Serviee. Portland, Oregon. 
, M.G. RaphaeI, R.G. Anthony, E.D. Forsman, A.G. Gunderson, R.S. Holthausen, B.G. Marcot, G.H. Reeves, J.R. Sedell, and D.M. Solis. 1993. Viability Assessments and Management Considerations for Species Associated with Late-suceessional and Old-growth Forests of the Pacific Northwest. U.S. Forest Service. Portland, Oregon.

Thorp, R.W., P.C. Schroeder, and C.S. Ferguson. 2002. Bumble Bees: Boisterous Pollinators of Native California Flowers. Fremontia 30:26-31.

Todd, R.L. 1986. A Saltwater Marsh Hen in Arizona. A History of the Yuma Clapper Rail (Rallus longirostris yumanensis). Completion Report Federal Aid Project W-95-R. Arizona Game and Fish Department. Phoenix, Arizona.

Tollestrup, K. 1979a. Distribution of Gambelia silus (Blunt-nosed Leopard Lizard) in the Western Foothills of the San Joaquin Valley. USDOI BLM. Sacramento, California.

. 1979b. The Eeology, Social Structure, and Foraging Behavior of Two Closely Related Leopard Lizards, Gambelia silus and Gambelia wislizenii. Ph.D. Dissertation, University of California. Berkeley, California.

Tolstead, W.L. 1942. Vegetation of the Northern Part of Cherry County, Nebraska. Ecological Monographs 12:255-292.

Tomlinson, R.E., and R.L. Todd. 1973. Distribution of Two Western Clapper Rail Races as Determined by Responses to Taped Calls. Condor 75:177-183.

Toyoshima, J. 1978. Small Mammal Monitoring Study on the Morro Bay Eeological Reserve. Special Report for California Department of Fish and Game, S-1312.

1979. Current Population and Range of the Morro Bay Kangaroo Rat. Report Submitted to the California Department of Fish and Game.

, P.A. Medica, and C.L. Lyons. 1984. Reproduction and Survival of the Desert Tortoise (Scaptochelys agassizii) in Ivanpah Valley, California. Copeia 4:811-820.

Turner, F.B., K.H. Berry, D.C. Randall, and G.C. White. 1987. Population Ecology of the Desert Tortoise at Goffs, California. 1983-1986. Report to Southern California Edison Company. Rosemead, California.

Tuskes, P.M., and J. Emmel. 1981. The Life History and Behavior of Euproserpinus euterpe (Sphingidae). Journal of the Lepidopteran Society 35(1):27-33.

Tuttle, P., G. Scoppettone, and D. Withers. 1990. Status and Life History of Pahranagat River Fishes Completion Report. USFWS, National Fisheries Research Center. Seattle, Washington.

Tyus, H.M. 1985. Homing Behavior Noted for Colorado Squawfish. Copeia 1985:213-215.

B.D. Burdick, R.A. Valdez, C.M. Haynes, T.A. Lytle, and C.R. Berry. 1982. Fishes of the Upper Colorado River Basin: Distribution, Abundance, and Status. Pages 12-70 in Fishes of the Upper Colorado River System: Present and Future. (W.H. Miller, H.M. Tyus, and C.A. Carlson, Editors) Western Division, American Fisheries Society. Bethesda, Maryland.

- 1986. Life Strategies in the Evolution of the Colorado Squawfish (Ptychocheilus lucius). The Great Basin Naturalist 46:656-661. 
1990. Potamodromy and Reproduction of Colorado Squawfish in the Green River Basin, Colorado and Utah. Transactions of the American Fisheries Society 119:1035-1047.

1991. Ecology and Management of Colorado Squawfish. Pages 379-402 in Battle Against Extinction: Native Fish Management in the American West (W.L. Minckley and J.E. Deacon, Editors). The University of Arizona Press. Tueson, Arizona.

, and C.A. Karp. 1990. Spawning and Movements of Razorback Sucker, Xyrauchen texanus, in the Green River Basin of Colorado and Utah. Southwestern Naturalist 35:427-433.

, B.D. Burdick, R.A. Valdez, C.M. Haynes, T.A. Lytle, and C.R. Berry. 1982. Fishes of the Upper Colorado River Basin: Distribution, Abundance, and Status. Pages 12-70 in Fishes of the Upper Colorado River System, Present and Future (W.H. Miller, H.M. Tyus, and C.A. Carlson, Editors). Western Division of the American Fisheries Society. Bethesda, Maryland.

Ulaszek, E. 1993. Status Summary and Revised Reeovery Plan for Todsen's Pennyroyal (Hedeoma todsenii): Field Report to USFWS, New Mexico Ecological Services Field Office. Albuquerque, New Mexico.

Unitt, P. 1987. Empidonax traillii extimus: An Endangered Subspecies. Western Birds 18:137-162.

University of California Herbarium. 2007. Digital Images of Herbarium Specimens from the University of California Herbarium at Berkeley (UC): UC 64161, UC 120442, UC 1285071, UC 1285073, UC 1285074.

Uptain, C., W.A. Clark, and S.M. Juarez. 1985. Mark-recapture Population Estimates and Visitation Indices for the Blunt-nosed Leopard Lizard, Gambelia silus, at the Pixley National Wildlife Refuge. USFWS. Delano, California.

U.S. Army. 2004a. Integrated Natural Resourees Management Plan FY 2004-2008. U.S. Army Reserve Training Center, Fort Hunter Liggett, California. West Coast Garrison (Provisional) and Fort Hunter Liggett, California.

. 2004b. Reinitiation of Programmatic Biological Opinion \#1-8-96-F-40: Biological Assessment of the Effeets of Activities Conducted at Fort Hunter Liggett, Monterey County, California, on Federal Endangered and Threatened Species, March 2002, Amended April 2004. West Coast Garrison (Provisional) and Fort Hunter Liggett, California.

U.S. Department of Agriculture Forest Service (USDA Forest Service). 2005. Preventing and Managing Invasive Plants Final Environmental Impact Statement. Forest Service. Available at: http://www.fs.fed.us/r6/invasiveplant-eis/.

- 2008. Forest Service Reissues Southern California Forest Plans Decision. Available at: http://www.fs.fed.us/r5/sefpr/projects/lmp/.

USDA National Resource Conservation Service (NRCS). 2010. Plant Guide for Last Chance Townsendia. USDA NRCS Idaho Plant Materials Program. Aberdeen, Idaho. Available at: ftp://ftpfc.sc.egov.usda.gov/ID/programs/plant/townsendia_last chance.pdf.

USDA Soil Conservation Service. 1972. Soil Survey of Northern Santa Barbara Area, California. In Cooperation with University of California Agricultural Experiment Station. Washington, D.C.

- 1981. Soil Survey of Southern Santa Barbara Area, California. In Cooperation with University of California Agricultural Experiment Station. Washington, D.C. 
U.S. Department of Defense and USFWS. 2007. Northern Aplomado Faleon (Falco femoralis septentrionalis) Fact Sheet. Available at: http://www.fws.gov/endangered/esa-library/pdf/aplomado_falcon_fact_sheet.pdf.

U.S. Department of Interior Bureau of Land Management (USDOI BLM). 1983. Draft Hollister Planning Area Resource Management Plan and Environmental Impact Statement. U.S. Department of the Interior BLM, Bakersfield District, Hollister Research Area. Bakersficld, California.

1984. Final Hollister Planning Area Resource Management Plan and Environmental Impact Statement. U.S. Department of the Interior, BLM, Bakersfield District, Hollister Research Area. Bakersfield, California.

1985. Draft Clear Creek Management Plan and Environmental Assessment. U.S. Department of the Interior, BLM, Bakersfield District, Hollister Research Area. Bakersfield, California.

1986. Clear Creek Management Plan and Decision Record. U.S. Department of the Interior, BLM, Bakersfield District, Hollister Research Area. Bakersfield, California.

. 1991. Final EIS Vegetation Treatment on BLM Lands in Thirteen Western States. Washington, D.C.

1996a. Draft Environmental Impact Statement for the Army's Land Acquisition Project for the National Training Center, Fort Irwin, California, and Proposed Amendment to the California Desert Conservation Area Plan, BLM, California Desert Distriet. Riverside, California.

. 1996b. Biological Evaluation for the BLM Safford Distriet Grazing Program. Safford, Arizona.

. 2000. Monitoring of Special Plants in the Algodones Dunes, Imperial County, California. Results of 1998 Monitoring and Comparison with the Data from WESTEC's 1977 Monitoring Study. Unpublished Report.

2001a. Biological Evaluation on Effects of California Desert Conservation Area Plan as Amended and Proposed to be Amended by the Northern and Eastern Mojave Desert and Northern and Eastern Colorado Desert Preferred Alternatives and with Other Interim Measures on Ten Threatened and Endangered Plants. California Desert District, BLM. Riverside, California.

. 2001b. Biological Evaluation on Effects of California Desert Conservation Area Plan as Amended and Proposed to be Amended by the Northern and Eastern Mojave Desert and Northern and Eastern Colorado Desert Preferred Alternatives and with Other Interim Measures on Nine Threatened and Endangered Species. BLM California Desert District. Riverside, California.

. 2001c. Biological Evaluation on Effects of California Desert Conservation Area Plan as Amended and Proposed to be Amended by the Northern and Eastern Mojave Desert and Northern and Eastern Colorado Desert Preferred Alternatives and with Other Interim Measures on Southwestern Willow Flycateher, Least Bell's Vireo, Arroyo Southwestern Toad, and Coachella Valley Fringe-toed Lizard. BLM California Desert District. Riverside, California.

2003. Threatened and Endangered Species: Utah Prairie Dog. Cedar City Field Offiee. Cedar City, Utah. Available at: http://www.ut.blm.gov/cedarcity fo/.

2007a. Final Vegetation Treatments Using Herbicides on Bureau of Land Management Lands in 17 Western States Programmatic Environmental Impact Statement. Washington, D.C. Available at: http://www.blm.gov/wo/st/en/prog/more/veg_eis.html. 
. 2007b. Record of Decision for Vegetation Treatments Using Herbicides on Bureau of Land Management Lands in 17 Western States Programmatic Environmental Impact Statement. Washington, D.C. Available at: http://www.blm.gov/wo/st/en/prog/more/veg_eis.html.

2007c. Final Vegetation Treatments on Bureau of Land Management Lands in 17 Western States Programmatic Environmental Report. Washington, D.C. Availablc at: http://www.blm.gov/wo/st/en/prog/more/veg_eis.html.

.2007d. Biological Assessment for Vegetation Treatments on Bureau of Land Management Lands in 17 Western States. Washington, D.C. Available at: http://www.blm.gov/wo/st/en/prog/more/veg eis.html.

, and USFWS. 2000. Environmental Assessment for the Proposed Land and Mineral Withdrawal at Ash Mcadows National Wildlife Refuge, Nye County, Nevada. Report NV-056-00-16. Las Vegas, Nevada and Portland, Oregon.

U.S. Environmental Protection Agency (USEPA). 1998. Guidelines for Ecological Risk Assessment. EPA/630/R-95/002F, U.S. Environmental Protection Agency. Washington, D.C.

. 2005. Aminopyralid: Aggregate Human Health Risk Assessment for the Proposed Uses on Wheat, Grasses, Non-Cropland Areas, and Natural Areas. July 12, 2005 Memorandum from the Office of Prevention, Pesticides, and Toxic Substances. Washington, D.C.

2012. Pesticides: Regulating Pesticides. What is the Conventional Reduced Risk Pesticide Program? Available at: http://www.epa.gov/opprd001/workplan/reducedrisk.html.

2014. Endocrine Disruptor Screcning Program (EDSP). Available at: http://www.epa.gov/endo/.

U.S. Fish and Wildlife Service (USFWS). 1976. Warm Springs Pupfïsh Recovery Plan. U.S. Fish and Wildlife Service Unpublished Report. Portland, Oregon.

. 1977. Greenback Cutthroat Trout Recovery Plan. USFWS. Denver, Colorado.

- 1979. Final Environmental Assessment; Determination that Arctomecon humilis is an Endangered Species. U.S. Department of Interior. Washington, D.C.

. 1980. Whooping Crane Recovery Plan. Washington, D.C.

1982a. Phacelia argillacea Recovery Plan. U.S. Fish and Wildlife Service. Denver, Colorado.

. 1982b. Recovery Plan for the Dwarf Bear-poppy, Arctomecon humilis Coville, an Endangered Plant. Final Draft. USFWS. Denver, Colorado.

1982c. Socorro Isopod (Thermosphaeroma thermophilum) Recovery Plan. USFWS. Albuquerque, New Mexico.

. 1982d. Morro Bay Kangaroo Rat Recovery Plan. Portland, Oregon.

1983a. Recovery Plan for the Mohave Tui Chub, Gila bicolor mohavensis. Portland, Oregon.

. 1983b. Moapa Dace Recovery Plan. USFWS. Portland, Oregon.

1983c. Pecos Gambusia Recovery Plan. USFWS. Albuquerque, New Mexico. 
. 1983d. Greenback Cutthroat Trout Recovery Plan Revision. USFWS. Denver, Colorado.

1983e. Kern Primrose Sphinx Moth Recovery Plan - Agency Review Draft. USFWS. Portland, Oregon.

. 1984a. Recovery Plan for Gypsum Wild Buckwheat (Eriogonum gypsophilum). USFWS. Albuquerque, New Mexico.

- 1984b. Peebles Navajo Cactus (Pediocactus peeblesianus (Croizat) L. Benson var. peeblesianus) Recovery Plan. USFWS. Albuquerque, New Mexico.

1984c. Mesa Verde Cactus Recovery Plan. USFWS. Albuquerque, New Mexico.

- 1984d. Life History and Ecological Requirements of the Moapa Dace (Moapa coriacea). Annual Report, National Fisheries Research Center, Great Basin Complex Office. Reno, Nevada.

1984e. Yaqui Fishes Recovery Plan. Technical Review Draft. USFWS. Albuquerque, New Mexico.

1984f. Revised Humpback Chub Recovery Plan. Colorado River Fishes Recovery Team and Region 6, USFWS. Denver, Colorado.

. 1984g. Valley Elderberry Longhorn Beetle Recovery Plan. USFWS. Portland, Oregon.

. 1984h. California Condor Recovery Plan. USFWS. Portland, Oregon.

- 1985a. Wright Fishhook Cactus Recovery Plan. Prepared in Cooperation with the Wright Fishhook Cactus Recovery Committee. USFWS. Denver, Colorado.

. 1985b. Endangered and Threatened Wildlife and Plants; Final Rule to Determine Prinula maguirei (Maguire Primrose) to be a Threatened Species. Federal Register 50:33731-33737.

1985c. Final Rule for Seven Plants and One Inseet in Ash Meadows, Nevada. Federal Register 50(97).

. 1985d. Sneed and Lee Pincushion Cacti Recovery Plan. USFWS. Albuquerque, New Mexico.

. 1985e. Endangered and Threatened Wildlife and Plants, Determination of Astragalus humillimus to be Endangered. Federal Register 50(124):26568-26572.

. 1985f. Knowlton Cactus Recovery Plan. USFWS. Albuquerque, New Mexico.

. 1985g. Kuenzler Hedgehog Cactus Recovery Plan. USFWS. Albuquerque, New Mexico.

- 1985h. Endangered and Threatened Wildlife and Plants; Determination of Threatened Status for

"Camissonia benitensis" (San Benito Evening-primrose). Federal Register 50:5755-5759.

. 1985i. Endangered and Threatened Wildlife and Plants; Determination of Threatened Status for Hutton Tui Chub and Foskett Speckled Dace. Federal Register 50:12302-12306.

. 1985j. Endangered and Threatened Wildlife and Proposed Species; Determination of Threatened Status and Critical Habitat for the Desert Dace. Federal Register 50:50304- 50309.

. 1985k. Endangered and Threatened Wildlife and Plants: Determination of Endangered Status for the White River Spinedace. Federal Register 50:37194-37198. 
. 1985I. Bonytail Chub Recovery Plan. Colorado River Fishes Recovery Team and Region 6, USFWS. Denver, Colorado.

. 1985m. Blunt-nosed Leopard Lizard Revised Recovery Plan. USFWS. Portland, Oregon.

. 1986a. Recovery Plan for the Nichol Turk's Head Cactus (Echinocactus horizonthalonius Lemaire, var. nicholii L. Benson). Albuquerque, New Mexico.

- 1986b. Siler Pincushion Cactus (Pediocactus sileri) Recovery Plan. U.S. Fish and Wildlife Service. Albuquerque, New Mexico.

- 1986c. Recovery Plan for Zuni Fleabane (Erigeron rhizomatus). Technical Draft. USFWS. Albuquerque, New Mexico.

. 1986d. Endangered and Threatened Wildlife and Plants; Detcrmination of Endangered Status and Critical Habitat for the Desert Pupfish. Federal Register 51:10842-10851.

1987a. Final Rule to Determine Astragalus montii (Heliotrope milk-vetch) to be a Threatened Speeies, with Designation of Critical Habitat. Federal Register 52(215):41652-42657.

. 1987b. Navajo Sedge (Carex specuicola J.T. Howell). USFWS. Albuquerque, New Mexico.

1987c. Endangered and Threatened Wildlife and Plants; Notropis simus pecosensis (Pceos Bluntnose Shiner). Federal Register 52(34):5295-5303.

1989. Lepidium barnebyanum Supplemental Status Report. Salt Lake City, Utah.

. 1990a. Uinta Basin Hookless Cactus (Sclerocactus glaucus) Recovery Plan. Denver, Colorado.

.1990b. Schoenocrambe argillacea: Supplemental Status Report. Salt Lake City, Utah.

. 1990c. Maguire Primrose (Primula maguirei) Recovery Plan. USFWS. Denver, Colorado.

1990d. Recovery Plan for the Endangered and Threatened Species of Ash Meadows. Nevada. Portland, Oregon.

. 1990e. Northern Aplomado Falcon Recovery Plan. Albuquerque, New Mexico.

- 1991a. Autumn Buttereup (Ranunculus acriformis var. aestivalis) Reeovery Plan. USFWS. Denver, Colorado.

. 1991 b. Hualapai Mexican Vole Recovery Plan. Albuquerque, New Mexico.

1992a. Endangered and Threatened Wildlife and Plants; Proposed Rule for Seven Desert Milk-vetch Taxa from California and Nevada. Federal Register 57(90):19844-19851.

. 1992b. Welsh's Milkweed (Asclepias welshii) Reeovery Plan. USFWS. Denver, Colorado.

1992c. Blowout Penstemon (Penstemon haydenii) Recovery Plan. Denver, Colorado.

. 1992d. Osterhout Milk-veteh and Penland Beardtongue Recovery Plan. Denver, Colorado. 
- 1992e. Six Plants and Myrtle's Silverspot Butterfly from Coastal Dunes in Northern and Central California Determined to be Endangered. Federal Register 57:27848-27859.

. 1992f. Final Rule to List the Plant Spiranthes dilivialis (Ute Ladies'-tresses) as a Threatened Species. Federal Register 57(12):2048-2054.

. 1992g. Pecos Bluntnose Shiner Recovery Plan. Region 2. Albuquerque, New Mexico.

- 1992h. Threatened and Endangered Wildlife Species of Texas. Endangered Species Office. Albuquerque, New Mexico.

1992i. Determination of Threatened Status for the Washington, Oregon, and California Population of the Marbled Murrelet. Federal Register 57(191):45328-45337.

. 1993a. Barneby Ridge-eress (Lepidium barnebyanum) Recovery Plan. Denver, Colorado.

. 1993b. Last Chanee Townsendia (Townsendia aprica) Reeovery Plan. Denver, Colorado.

. 1993c. Dudley Bluffs Bladderpod and Dudley Bluffs Twinpod Reeovery Plan. Denver, Colorado.

1993d. The Plant Eutrema penlandii (Penland Alpine Fen Mustard) Determined to be a Threatened Species. Federal Register 58(143):40539-40547.

- 1993e. Determination of Endangered Status for Three Vernal Pool Plants and the Riverside Fairy Shrimp. Federal Register 58(147):41384-41392.

1993f. Lomatium bradshawii (Bradshaw's Lomatium) Recovery Plan. Portland, Oregon.

. 1993g. Big Spring Spinedace, Lepidomeda mollispinis pratensis, Recovery Plan. Portland, Oregon.

. 1993h. Alamosa Springsnail (Tryonia alamosae) and Socorro Springsnail (Pyrgulopsis neomexicana)

Drafi Recovery Plan. Albuquerque, New Mexico.

1993i. Desert Pupfish Recovery Plan. Phoenix, Arizona.

. 1993j. Determination of Threatened Status for the Giant Garter Snake. Federal Register 58(20I):5405354066.

. 1993k. Determination of Threatened Status for the Pacific Coast Population of the Western Snowy Plover. Federal Register 58(42):12864-12874.

19931. Grizzly Bear Recovery Plan. Missoula, Montana.

1994a. Utah Reed-mustards: Clay Reed-mustard (Schoenocrambe argillacea), Barneby Reed-mustard (Schoenocrambe barnebyi), Shrubby Reed-mustard (Schoenocrambe suffrutescens) Recovery Plan. Denver, Colorado.

- 1994b. Endangered or Threatened Status for Five Plants and the Morro Shoulderband Snail from Western San Luis Obispo County, California. Federal Register 59(240):64613-64623.

.1994c. Virgin River Fishes Recovery Plan. Salt Lake City, Utah.

. 1994d. Yaqui Fishes Recovery Plan. Albuquerque, New Mexico. 
1994e. Final Rule: Endangered and Threatened Wildlife and Plants; Determination of Endangered Status for the Conservaney Fairy Shrimp, Longhorn Fairy Shrimp, and the Vernal Pool Tadpole Shrimp; and Threatened Status for the Vernal Pool Fairy Shrimp. Federal Register 59(180):48136-48153.

. 1994f. Determination of Critieal Habitat for the Colorado River Endangered Fishes: Razorbaek Sueker,

Colorado Squawfish, Humpback Chub, and Bonytail Chub. Federal Register 59(54):13374-13400.

1994g. Uneompahgre Fritillary Butterfly Reeovery Plan. Denver, Colorado.

. 1994h. Determination of Endangered Status for the Arroyo Southwestern Toad. Federal Register 59(241):64859-64867.

1994i. Whooping Crane Reeovery Plan. Albuquerque, New Mexieo.

. 1994j. Mexiean Long-nosed Bat (Leptonycteris nivalis) Reeovery Plan. Albuquerque, New Mexieo.

. 1994k. Reeovery Plan for Woodland Caribou in the Selkirk Mountains. Portland, Oregon.

- 1995a. Arizona Cliffrose (Purshia subintegra) Reeovery Plan. USFWS, Arizona Eeologieal Serviees State Offiee. Phoenix, Arizona.

- 1995b. Determination of Endangered Status for Ten Plants and Threatened Status for Two Plants from Serpentine Habitats in the San Franeiseo Bay Region of California. Federal Register 60:6671-6685.

. 1995c. Snake River Aquatie Speeies Reeovery Plan. Snake River Basin Offiee, Eeologieal Serviees. Boise, Idaho.

- 1995d. Lahontan Cutthroat Trout (Oncorhyncus clarki ssp. henshawii) Reeovery Plan. Portland, Oregon.

. 1995e. Kanab Ambersnail (Oxyloma haydeni kanabensis) Reeovery Plan. Denver, Colorado.

. 1995f. Lesser Long-nosed Bat Reeovery Plan. Albuquerque, New Mexieo.

- 1996a. Platanthera praeclara (Western Prairie Fringed Orehid) Reeovery Plan. Fort Snelling, Minnesota.

- 1996b. Reelassifieation of Mirabilis Macfarlanei (MaeFarlane's Four-O'elock) from Endangered to Threatened Status. Federal Register 61(52):10693-10697.

1996c. Determination of Endangered Status for Four Plants and Threatened Status for One Plant from the Central Sierran Foothills of California. Federal Register 61(203):54346-54358.

. 1996d. Endangered and Threatened Wildlife and Plants; Determination of Endangered or Threatened Status for Four Southern Maritime Chaparral Plant Taxa from Southern California and Northwestern Baja California, Mexieo. Federal Register 61(195):52370-52383.

1996e. Determination of Threatened Status for Four Plants from the Foothills of the Sierra Nevada Mountains in California. Federal Register 63(177):49022-49035.

. 1996f. Railroad Valley Springfish (Crenichthys nevadae) Reeovery Plan. Portland, Oregon.

1996g. California Condor Reeovery Plan, Third Revision. Portland, Oregon. 
1997a. Determination of Endangered Status for Three Wetland Species Found in Southern Arizona and Northern Sonora, Mexico. Federal Register 62(3).

. 1997b. Determination of Endangered Status for Three Plants and Threatened Status for Five Plants from Vernal Pools in the Central Valley of California. Federal Register 62(58):14338-14352.

. 1997c. Determination of Endangered Status for Pseudobahia bahiifolia (Hartweg's Golden Sunburst) and Threatened Status for Pseudobahia peirsonii (San Joaquin Adobe Sunburst), Two Grassland Plants from the Central Valley of California. Federal Register 62(25):5542-5551.

. 1997d. Endangered Status for Four Plants from Vernal Pools and Mesic Areas in Northern California. Federal Register 62(117):33029-33038.

. 1997e. Endangered Status for Erigeron decumbens var. decumbens (Willamette Daisy) and Fender's Blue Butterfly (Icaricia icarioides fenderi) and Threatened Status for Lupinus sulphureus ssp. kincaidii (Kincaid's Lupine). Federal Register 65(16):3875-3890.

- 1997f. Threatened Status for the Alaska Breeding Population of the Steller's Eider. Federal Register 62(112):31748-31757.

1997g. Final Rule to Extend Endangered Status for the Jaguar in the United States. Federal Register 62(140):39147-39157.

. 1997h. Amargosa Vole (Microtus californicus scirpensis) Recovery Plan. Portland, Oregon.

. 1998a. Endangered and Threatened Wildlife and Plants; Determination of Endangered and Threatened Status for Five Desert Milk-veteh Taxa from California. Federal Register 63(193):53596-53615.

. 1998b. Final Rule To Determine the Plant Pediocactus winkleri (Winkler Cactus) to be a Threatened Species. Federal Register 63(161):44587-44595.

- 1998c. Endangered or Threatened Status for Three Plants from the Chaparral and Scrub of Southwestern California. Federal Register 63(197):54956-54971.

. 1998d. Seven Coastal Plants and the Myrtle's Silverspot Butterfly Recovery Plan. Portland, Oregon.

. 1998e. Recovery Plan for the Endangered Western Lily (Lilium occidentale). Portland, Oregon.

- 1998I. Determination of Endangered or Threatened Status for Four Plants from Southwestern California and Baja California, Mexico. Federal Register 63(197):54937-54956.

1998g. Determination of Endangered or Threatened Status for Four Southwestern California Plants from Vernal Wetlands and Clay Soils. Federal Register 63(197):54975-54994.

1998h. Recovery Plan for Upland Species of the San Joaquin Valley, California. Region 1. Portland, Oregon.

- 1998i. Determination of Threatened Status for Four Plants from the Foothills of the Sierra Nevada Mountains in California. Federal Register 63(177):49022-49035.

. 1998j. Recovery Plan for the Threatened Nelson's Checker-mallow (Sidalcea nelsoniana). Portland, Oregon. 
. 1998k. Recovery Plan for the Applegate's milk-vetch (Astragalus applegatei). Portland, Oregon.

1998I. Recovery Plan for the Native Fishes of the Warner Basin and Alkali Subbasin. Portland, Oregon.

. 1998m. Recovery Plan for the Endangered Speckled Dace of Clover and Independence Valleys (Rhinichthys osculus lethoporus and Rhinichthys osculus oligoporus). Portland, Oregon.

1998n. Recovery Plan for the Aquatic and Riparian Species of Pahranagat Valley. Portland, Oregon.

. 19980. Little Colorado River Spinedace Recovery Plan. Parker Fisheries Resource Office. Parker, Arizona.

- 1998p. Gila Topminnow (Poecilioposis occidentalis occidentalis) Revised Recovery Plan. Albuquerque, New Mexico.

- 1998q. Owens Basin Wetlands and Aquatic Species Recovery Plan, Inyo and Mono Counties, California. Portland, Oregon.

. 1998r. Recovery Plan for the Shasta Crayfish (Pacifastacus fortis). Portland, Oregon.

. 1998s. Oregon Chub (Oregonichthys crameri) Recovery Plan. Portland, Oregon.

1998t. Final Rule to List the Arkansas River Basin Population of the Arkansas River Shiner (Notropis girardi) as Threatened. Federal Register 63(225):64771-64799.

. 1998u. Recovery Plan for the Morro Shoulderband Snail and Four Plants from Western San Luis Obispo County, California. USFWS. Portland, Oregon.

. 1998v. Pawnee Montane Skipper Butterfly (Hesperis leonardus montana) Recovery Plan. Denver, Colorado.

.1998w. Draft Recovery Plan for the Least Bell's Vireo (Vireo bellii pusillis). Portland Oregon.

. 1998x. Recovery Plan for the Inyo California Towhec. Portland, Oregon.

. 1998y. Final Revised Sonoran Pronghorn Recovery Plan. Albuquerque, New Mexico.

1998z. Endangered Status for the Peninsular Ranges Population Segment of the Desert Bighorn Sheep in Southern California. Federal Register 63(52):13134-13150.

- 1999a. Final Rule to List Astragalus desereticus (Deseret Milk-vetch) as Threatened. Federal Register 64(202):56590-56596.

1999b. Determination of Threatened Status for the Plant Helianthus paradoxus (Pecos Sunflower). Federal Register 64(202):56581-56590.

. 1999c. Threatened Status for the Plant Thelypodium howellii ssp. spectabilis (Howell's Spectacular Thelypody). Federal Register 64(101):28393-28403.

1999d. Final Endangered Status for the Plant Fritillaria gentneri (Gentner's Fritillary). Federal Register 64(237):69195-69203. 
- 1999e. Determination of Endangered Status for the Plant Eriogonum apricum (Inclusive of Vars. apricum and prostratum; Ione Buckwheat) and Threatened Status for the Plant Arctostaphylos myrtifolia (Ione Manzanita). Federal Register 64(101):28403-28413.

- 1999f. Proposed Endangered Status for Ambrosia pumila (San Diego Ambrosia) from Southern California. Federal Register 64(249):72993-73003.

. 1999g. Determination of Endangered Status for Sidalcea oregana var. calva (Wenatchee Mountains Checker-mallow). Federal Register 64(245):71680-71687. Rio Grande Silvery Minnow Recovery Plan. Albuquerque, New Mexico.

. 1999h. Determination of Threatened Status for Bull Trout in the Coterminous United States; Final Rule. Federal Register 64(210):58909-58933.

. 1999i. June Sucker (Chasmistes liorus) Recovery Plan. Denver, Colorado.

. 1999j. Gila Topminnow, Poeciliopsis occidentalis occidentalis, Revised Recovery Plan. Albuquerque, New Mexico.

.2000a. Threatened Status for the Colorado Butterfly Plant (Gaura neomexicana ssp. coloradensis) from Southeastern Wyoming, Northeentral Colorado, and Extreme Western Nebraska. Federal Register 65(202):62302-62310.

. 2000b. Final Rule for Endangered Status for Four Plants from South Central Coastal California. Federal Register 65(54):14888-14898.

. 2000c. Determination of Endangered Status for Sidalcea keckii (Keck's Checker-mallow) from Fresno and Tulare Counties, California. Federal Register 65(32):7757-7764.

- 2000d. Determination of Endangered Status for the Plant Yreka Phlox from Siskiyou County, California. Federal Register 65(23):5268-5275.

. 2000e. Endangered Status for the Plant Plagiobothrys hirtus (Rough Popcornflower). Federal Register 65(16):3866-3875.

- 2000f. Designation of Critical Habitat for the Woundfin and Virgin River Chub. Federal Register 65(17):4140-4156.

.2000g. Endangered Status for Erigeron decumbens var. decumbens (Willamette Daisy) and Jcaricia icarioides fenderi (Fender's Blue Butterfly) and Threatened Status for Lupinus sulphureus ssp. kincaidii (Kincaid's Lupine). Federal Register 65(16):3875-3890.

. 2000h. Final Determination of Critical Habitat for the Coastal California Gnateateher. Federal Register 65(206):63679-63743.

2000i. Determination of Threatened Status for the Northern Idaho Ground Squirrel. Federal Register 65(66): 17779-17786.

. 2000j. Determination of Threatened Status for the Contiguous U.S. Distinct Population Segment of the Canada Lynx and Related Rule. Federal Register 65(58):16051-16086.

. 2000k. Establishment of a Nonessential Experimental Population of Black-footed Ferrets in NorthCentral South Dakota. Federal Register 65(199):60879-60889. 
- 20001. Final Rule to List the Sierra Nevada Distinct Population Segment of the California Bighorn Sheep as Endangered. Federal Register 65(1):20-30.

.2000m. Proposal to Reclassify and Remove the Gray Wolf from the List of Endangered and Threatened Wildlife in Portions of the Continental United States; Proposal to Establish Three Special Regulations for Threatened Gray Wolves; Proposed Rule. Federal Register Volume 65(135):43449-43496.

. 2001a. Determination of Endangered Status for Astragalus holmgrenorium (Holmgren Milk-veteh) and Astragalus ampullarioides (Shivwitz Milk-veteh). Federal Register 66(189):49560-49567.

. 2001b. Todsen's Pennyroyal (Hedeoma todsenii) Revised Recovery Plan. USFWS. Albuquerque, New Mexieo.

. 2001c. Final Rule to List Silene spaldingii (Spalding's Catehfly) as Threatened. Federal Register 66 (196):51598-51606.

2001d. Proposed Designation of Critical Habitat for Cirsium loncholepis (La Graeiosa Thistle), Eriodictyon capitatum (Lompoe Yerba Santa), and Deinandra increscens ssp. villosa (Gaviota Tarplant). Federal Register 66(221):57559-57600.

- 2001e. Proposed Designation of Critieal Habitat for Chorizanthe pungens var. pungens (Monterey Spineflower). Federal Register 66(32):10440-10469.

. 2001f. Final Designation of Critical Habitat for Sidalcea oregana var. calva (Wenatehee Mountains Checker-mallow). Federal Register 66(173):46536-46548.

2001g. Final Designation of Critieal Habitat for the Arkansas River Basin Population of the Arkansas River Shiner; Final Rule. Federal Register 66(65):18001-18034.

. 2001h. Oregon Silverspot Butterfly (Speyeria zerene hippolyta) Revised Reeovery Plan. Portland, Oregon.

. 2001i. Final Designation of Critieal Habitat for the Arroyo Toad. Federal Register 66(26):13656-13671.

. 2001j. Final Determination of Critieal Habitat for the Spectacled Eider. Federal Register 66(25):91469185.

- 2001k. Final Determination of Critieal Habitat for Wintering Piping Plovers. Federal Register 66(132):36037-36086.

. 20011. Emergeney Rule to List the Columbia Basin Distinet Population Segment of the Pygmy Rabbit (Brachylagus idahoensis) as Endangered. Federal Register 66(231):59734-59749.

. 2002a. Listing the Desert Yellowhead as Threatened. Federal Register 67(50):11442-11449.

. 2002b. Recovery Plan for Gabbro Soil Plants of the Central Sierra Nevada Foothills. Portland, Oregon.

. 2002c. Determination of Endangered Status for Lomatium cookii (Cook's Lomatium) and Limnanthes floccosa ssp. grandiflora (Large-flowered Woolly Meadowfoam) from Southern Oregon. Federal Register 67(216):68003-68015.

2002d. Proposed Designation of Critical Habitat for Five Carbonate Plants from the San Bernardino Mountains in Southern California. Federal Register 67(29):6577-6612. 
. 2002e. Endangered and Threatened Wildlife and Plants; Designation of Critical Habitat for Eriodictyon capitatum (Lompoe Yerba Santa) and Deinandra increscens ssp. villosa (Gaviota Tarplant). Federal Register 67(216):67968-67990.

- 2002f. Determination of Endangered Status for the Washington Plant Hackelia venusta (Showy Stickseed). Federal Register 67(25):5515-5525.

.2002g. Recovery Plan for the Bruneau Hot Springsnail (Pyrgulopsis bruneauensis). Portland, Oregon.

. 2002h. Listing the Gila Chub as Endangered With Critical Habitat. Federal Register 67(29):6459-6479.

2002i. Bonytail (Gila elegans) Recovery Goals: Amendment and Supplement to the Bonytail Chub Recovery Plan. Denver, Colorado.

2002j. Razorback Sucker (Xyranchen texanus) Recovery Goals: Amendment and Supplement to the Razorback Sucker Recovery Plan. Mountain Prairic Region. Denver, Colorado.

. 2002k. Colorado Pikeminnow (Ptychochelius lucius) Recovery Goals: Amendment and Supplement to the Colorado Squaw fish Recovery Plan. Denver, Colorado.

20021. Designation of Critical Habitat for the Quino Checkerspot Butterfly (Euphydryas editha quino). Federal Register 67(72):18355-18395.

$.2002 \mathrm{~m}$. Sonora Tiger Salamander (Ambystoma tigrinum stebbinsi) Recovery Plan (Draft). Albuquerque, New Mexico.

. 2002n. Listing of the Chiricahua Leopard Frog (Rana Chiricahuensis). Federal Register 67(114):4079040811 .

20020. Recovery Plan for the California Red-Legged Frog (Rana draytonii). Portland, Oregon.

.2002p. Steller's Eider Recovery Plan. Fairbanks, Alaska.

.2002q. Southwestern Willow Flyeateher Recovery Plan. Albuquerque, New Mexico.

. 2002r. Supplemental Proposed Rule to Remove the Douglas County Population of Columbian Whitetailed Deer from the Federal List of Endangered and Threatened Wildlife. Federal Register $67(120): 42217-42229$.

- 2002s. Designation of Critical Habitat for the Preble's Meadow Jumping Mouse (Zapus hudsonius preblei). Federal Register 67(137):47153-47210.

2003a. Endangered and Threatened Wildlife and Plants; Final Designation of Critical Habitat for Two Larkspurs From Coastal Northern California. Federal Register 68(52):12834-12863.

. 2003b. Final Rule to Remove the Douglas County Distinct Population Segment of Columbian WhiteTailed Deer from the Federal List of Threatened and Endangered Wildlife. Federal Register 68(142): 43647-43659.

. 2004a. Recovery Plan for Chorizanthe robusta var. robusta (Robust Spineflower). Ventura, California.

2004b. Withdrawal of Proposed Rule to Reclassify the Pahrump Poolfish (Empetrichthys latos) from Endangered to Threatened Status. Federal Register 69(64): 17383-17386. 
2004c. Determination of Threatened Status for the California Tiger Salamander; and Special Rule Exemption for Existing Routine Ranching Activities. Federal Register 69(149):47212-47248.

. 2005a. Kuenzler's Hedgehog Cactus (Echinocereus fendleri var. kuenzleri) 5-Year Review: Summary and Evaluation U.S. Fish and Wildlife Service New Mexico Ecological Services Field Office. Albuquerque, New Mexico.

- 2005b. Draft Recovery Plan for Plants of the lone Area and Central Sierra Nevada Foothills. Unpublished Report. Portland, Oregon.

2005c. Recovery Plan for Vernal Pool Ecosystems of California and Southern Oregon. Portland, Oregon.

2005d. Endangered and Threatened Wildlife and Plants; Designation of Critical Habitat for Allium munzii (Munz’s Onion). Federal Register 70(108):33015-33033.

- 2005e. Endangered and Threatened Wildlife and Plants; Designation of Critical Habitat for Atriplex coronata var. notatior (San Jacinto Valley Crownscale). Federal Register 70(197):59952-59974.

. 2005f. Reclassification of the Gila Trout From Endangered to Threatened with Regulations. Federal Register 70(90):24750-24763.

. 2005g. Listing Gila Chub as Threatened with Critical Habitat. Federal Register 70(211):66664-66721.

. 2005h. Listing Roswell Springsnail, Koster's Springsnail, Pecos Assiminea, and Noel's Amphipod as Endangered With Critical Habitat. Federal Register 70(152):46304-46333.

. 2005i. Recovery Plan for Vernal Pool Ecosystems of California and Southern Oregon. Region 1. Portland, Oregon.

- 2005j. Final Rule to Designate Critical Habitat for the Buena Vista Lake Shrew (Sorex ornatus relictus). Federal Register 70(14):3438-3461.

. 2005k. Recovery Outline Contiguous United States Distinet Population Segment of the Canada Lynx. Montana Field Office. Helena, Montana.

. 2006a. Astragalus holmgreniorum (Holmgren Milk-veteh) and Astragalus ampullarioides (Shivwits Milk-veteh) Recovery Plan. U.S. Denver, Colorado.

. 2006b. Endangered and Threatened Wildlife and Plants; Designation of Critical Habitat for Astragalus brauntonii and Pentachaeta lyonii. Federal Register 71(219):66374-66423.

2006c. Recovery Plan for Camissonia benitensis (San Benito Evening-Primrose). California/Nevada Operations Office. Sacramento, California.

. 2006d. Banbury Springs Lanx (Lanx sp.) (Undescribed) 5-Year Review: Summary and Evaluation. Snake River Fish and Wildlife Office. Boise, Idaho.

- 2006e. Banded Dune Snail (Helminthoglypta walkeriana) [=Morro Shoulderband Snail (Helminthoglypta walkeriana) and Chorro Shoulderband Snail (Helminthoglypta morroensis) 5-Year Review: Summary and Evaluation. Ventura Fish and Wildlife Office. Ventura, California. 
- 2006f. Valley Elderberry Longhorn Beetle (Desmocerus californicus dimorphus) 5-Year Review: Summary and Evaluation. Sacramento Fish and Wildlife Office. Sacramento, California.

. 2006g. Giant Garter Snake (Thamnophis gigas) 5-Year Review: Summary and Evaluation. Sacramento Fish and Wildlife Office. Saeramento, California.

. 2006h. Establishment of a Nonessential Experimental Population of Northern Aplomado Faleons in New Mexico and Arizona. Federal Register 71(143):42298-42315.

. 2006i. Least Bell's Vireo (Vireo bellii pusillis) 5-Year Review Summary and Evaluation. Carlsbad Fish and Wildlife Office. Carlsbad, California.

- 2007a. Recovery Outline for San Rafael Cactus (Pediocactus espainii) and Winkler Cactus (Pediocactus winkleri). U.S. Fish and Wildlife Service Utah Field Office. West Valley City, Utah.

. 2007b. Amargosa Niterwort (Nitrophila mohavensis) 5-Year Review Summary and Evaluation. U.S. Fish and Wildlife Service Nevada Fish and Wildlife Office. Las Vegas, Nevada.

- 2007c. Ash Meadows Gumplant (Grindelia fraxino-pratensis) 5-Year Review: Summary and Evaluation. U.S. Fish and Wildlife Service Nevada Fish and Wildlife Office. Las Vegas, Nevada.

. 2007d. Pima Pineapple Cactus (Coryphantha scheeri var. robustispina) 5-Year Review: Summary and Evaluation U.S. Fish and Wildlife Service Arizona Eeological Services Office. Phoenix, Arizona.

- 2007e. Cochise Pincushion Cactus (Coryphantha robbinsorum) 5-Year Review: Summary and Evaluation. U.S. Fish and Wildlife Service Arizona Eeological Serviees Offiee. Phoenix, Arizona.

. 2007f. Gypsum Wild Buckwheat (Eriogonum gypsophilum) 5-Year Review: Summary and Evaluation. U.S. Fish and Wildlife Service New Mexico Eeological Services Field Office. Albuquerque, New Mexico.

. 2007g. Zuni Fleabane (Erigeron rhizomatus) 5-Year Review: Summary and Evaluation. New Mexico Eeological Services Field Office. Albuquerque, New Mexico.

.2007h. Recovery Plan for Silene spaldingii (Spalding's Catchfly). Portland, Oregon.

- 2007i. Chorizanthe orcuttiana (Oreutt's Spineflower) Five-Year Review: Summary and Evaluation. Carlsbad Fish and Wildlife Office. Carlsbad, California.

.2007j. Hairy Orcult Grass (Orcuttia pilosa) 5-Year Review Summary and Evaluation. Sacramento Fish and Wildlife Office. Sacramento, California.

. 2007k. Greene's Tuctoria (Tuctoria greenei) 5-Year Review: Summary and Evaluation. Sacramento Fish and Wildlife Office. Sacramento, California.

. 2007I. Pseudobahia bahiifolia (Hartweg's Golden Sunburst) and Pseudobahia peirsonii (San Joaquin Adobe Sunburst) 5-Year Review: Summary and Evaluation. Sacramento Fish and Wildlife Office. Sacramento, California.

. $2007 \mathrm{~m}$. Keck's Cheekermallow (Sidalcea keckii) 5-Year Review: Summary and Evaluation. Sacramento Fish and Wildlife Office. Sacramento, California.

- 2007n. Bakersfield cactus (Opuntia treleasei $=$ Opuntia basilaris var. treleasei) 5-Year Review: Summary and Evaluation. Sacramento Fish and Wildlife Office. Sacramento, California. 
. 2007o. Red Hills Vervain (Verbena californica) 5-Year Review: Summary and Evaluation U.S. Fish and Wildlife Service Sacramento Fish and Wildlife Office. Sacramento, California.

. 2007p. Yreka Phlox (Phlox hirsuta) 5-Year Review: Summary and Evaluation. Yreka Fish and Wildlife Office. Yreka, California.

. 2007q. Chorro Creek Bog Thistle (Cirsium fontinale var. obispoense) 5-Year Review: Summary and Evaluation. Ventura Field Office. Ventura, California.

- 2007r. Mariposa Pussypaws (Calyptridium pulchellum) 5-Year Review: Summary and Evaluation. Sacramento Fish and Wildlife Office. Sacramento, California.

. 2007s. Wenatchee Mountains Checker-Mallow (Sidalcea oregana var. calva) 5-Year Review: Summary and Evaluation. Washington Fish and Wildlife Office. Lacey, Washington.

. 2007t. Bruneau Hot Springsnail (Pyrgulopsis bruneauensis) 5-Year Review: Summary and Evaluation. Snake River Fish and Wildlife Office. Boise, Idaho.

. 2007u. Designation of Critical Habitat for the Spikedace (Meda fulgida) and Loach Minnow (Tiaroga cobitis). Federal Register 72(54):13356-13422.

- 2007v. Pallid Sturgeon (Scaphirhyncus albus) 5-Year Review Summary and Evaluation. Pallid Sturgeon Recovery Coordinator. Billings, Montana.

- 2007w. Recovery Plan for the Carson Wandering Skipper (Psendocopaeodes eunus obscures). California/Nevada Operations Office. Sacramento, California.

. 2007x. Kern Primrose Sphinx Moth (Euproserpinus euterpe) 5-Year Review: Summary and Evaluation. Sacramento Fish and Wildlife Field Office. Sacramento, California.

- 2007y. Sonora Tiger Salamander (Ambystoma tigrinum stebbinsi) 5-Year Review: Summary and Evaluation. Arizona Ecological Services Field Office. Phoenix, Arizona.

- 2007z. Chiricahua Leopard Frog (Rana chiricahuensis) Final Recovery Plan. Albuquerque, New Mexico.

2007aa. Recovery Plan for the Pacific Coast Population of the Western Snowy Plover (Charadrius alexandrinus nivosus). California/Nevada Operations Office. Sacramento, California.

. 2007bb. Lesser Long-Nosed Bat (Leptonycteris curosoae yerbabuenae) 5-Year Review: Summary and Evaluation. Phoenix, Arizona.

- 2007ce. Endangered and Threatened Wildlife and Plants; Revised Critical Habitat for the San Bernardino Kangaroo Rat (Dipodomys merriami parvus). Federal Register 72(1 17):33808-33842.

2008a. Wright Fishhook Cactus (Sclerocactus wrightiae L. Benson) 5-Year Review: Summary and Evaluation. U.S. Fish and Wildlife Service Utah Field Office - Ecological Services. West Valley City, Utah.

2008b. Dudley Bluffs Bladderpod (Lesquerella congesta or Physaria congesta) and Dudley Bluffs Twinpod (Physaria obcordata) 5-Year Review Summary and Evaluation. U.S. Fish and Wildlife Service Western Colorado Field Office. Grand Junetion, Colorado. 
.2008c. Lane Mountain Milk-vetch (Astragalus jaegerianus) 5-Year Review: Summary and Evaluation

U.S. Fish and Wildlife Service Ventura Fish and Wildlife Office. Ventura, California.

. 2008d. Endangered and Threatened Wildlife and Plants; Revised Designation of Critical Habitat for Astragahus magdalenae var. peirsonii (Peirson's Milk-Vetch). Federal Register 73(31):8748-8785.

. 2008e. Endangered and Threatened Wildlife and Plants; Designation of Critieal Habitat for Helianthus Paradoxus (Pecos Sunflower). Federal Register 73(63):17762-17807.

2008f. Recovery Outline for the Jones Cycladenia (Cycladenia humilis var. jonesii). U.S. Fish and Wildlife Service Mountain-Prairie Region Utah Field Office. Salt Lake City, Utah.

.2008g. Siler Pincushion Cactus (Pediocactus sileri) 5-Year Review: Summary and Evaluation. Arizona Ecological Services Office. Phoenix, Arizona.

.2008h. Menzies' Wallflower (Erysimum menziesii) 5-Year Review: Summary and Evaluation. Areata Field Office. Areata, California.

- 2008i. Monterey Gilia (Gilia temiflora ssp. arenaria) 5-Year Review: Summary and Evaluation. Ventura Fish and Wildlife Offiee. Ventura, California.

. 2008j. Contra Costa Goldfields (Lasthenia conjugens) 5-Year Review: Summary and Evaluation. Sacramento Fish and Wildlife Offiee. Saeramento, California.

2008k. Limnanthes floccosa ssp. californica (Butte County Meadowfoam). 5-Year Review: Summary and Evaluation. Sacramento Fish and Wildlife Office. Sacramento, California.

2008I. Atriplex coronata var. notatior (San Jacinto Valley crownscale) 5-Year Review: Summary and Evaluation. Carlsbad Fish and Wildlife Office. Carlsbad, California.

. 2008m. Purple Amole (Chlorogahum purpurenm) Five-year Review: Summary and Evaluation. Ventura Fish and Wildlife Office. Ventura, California.

. 2008n. Arenaria paludicola (Marsh Sandwort) 5-Year Review: Summary and Evaluation. Ventura Fish and Wildlife Office. Ventura, California.

- 20080. Bull Trout (Salvelinus confluentus). 5-Year Review: Summary and Evaluation. Portland, Oregon.

. 2008p. Hutton Tui Chub (Gila bicolor ssp.) 5-Year Review Summary and Evaluation. Oregon Fish and Wildlife Office. Portland, Oregon.

. 2008q. Endangered and Threatened Wildlife and Plants; 90-Day Finding on a Petition to Delist the Lahontan Cutthroat Trout. Federal Register 73:52257-52260.

- 2008r. Little Colorado Spinedace (Lepidomeda vittata). 5-Year Review: Summary and Evaluation. Arizona Ecological Services Field Office. Phoenix, Arizona.

- 2008s. The Virgin River Fishes Woundfin (Plagopterus argentissimus) Virgin River Chub (Gila seminuda) 5-Year Review: Summary and Evaluation. Oregon Fish and Wildlife Office. Portland, Oregon.

- 2008t. Socorro Springsnail (Pyrgulopsis neomexicana) 5-Year Review: Summary and Evaluation. Albuquerque, New Mexico. 
- 2008u. Critical Habitat Revised Designation for the Kootenai River Population of White Sturgeon (Acipenser transmontcmus). Federal Register 73(132):39506-39523.

2008v. Oregon Chub (Oregonichthys crameri) 5-Year Review Summary and Evaluation. South Dakota Field Office. Pierre, South Dakota.

2008w. Inyo California Towhee (Pipilo crissalis eremophilus) [=Inyo Brown Towhee (Pipilo fuscus eremophilus)] 5-Year Review: Summary and Evaluation. Ventura Fish and Wildlife Office. Ventura, California.

. 2008x. Black-Footed Ferret (Mustela nigripes) 5-Year Status Review: Summary and Evaluation. South Dakota Field Office. Picrre, South Dakota.

2008y. Sierra Nevada Bighorn Shecp Ovis canadensis californiae (= Ovis canadensis sierrae) 5-Year Review: Summary and Evaluation. Ventura Fish and Wildlife Office. Ventura, California.

. 2009a. Steamboat Buckwheat (Eriogonum ovalifolium var. williamsiae) 5-Year Review: Summary and Evaluation. U.S. Fish and Wildlife Service Nevada Fish and Wildlife Office. Reno, Nevada.

2009b. Endangered and Threatened Wildlife and Plants; Listing Lepidiutn papilliferum (Slickspot Peppergrass) as a Threatened Species Throughout Its Range. Federal Register 74(194):52014-52064.

.2009c. Astragalus lentiginosus var. piscinensis (Fish Slough Milk-vetch) 5-Year Review: Summary and Evaluation. Ventura Fish and Wildlife Office. Ventura, California.

. 2009d. Eriogonum pelinophilum (Clay-loving Wild Buckwheat) 5-Year Review: Summary and Evaluation. U.S. Fish and Wildlife Service Western Colorado Ecological Services Office. Grand Junction, Colorado.

.2009e. Endangered and Threatened Wildlife and Plants; Taxonomic Change of Sclerocactus Glaucus to Three Separate Species. Federal Register 74(177):47712-47717.

- 2009f. Astragalus lentiginosus var. coachellae (Coachella Valley Milk-vetch) 5-Year Review: Summary and Evaluation U.S. Fish and Wildlife Service Carlsbad Fish and Wildlife Office. Carlsbad, California.

.2009g. Astragalus tricarinatus (Triple-Ribbed Milk-Vetch) 5-Year Review: Summary and Evaluation. U.S. Fish and Wildlife Service Carlsbad Fish and Wildlife Office. Carlsbad, California.

2009h. Astragalus phoenix (Ash Meadows Milkveteh) 5-Year Review: Summary and Evaluation. U.S. Fish and Wildlife Service Nevada Fish and Wildlife Office. Las Vegas, Nevada.

2009i. Centaurium namophilum (Spring-loving Centaury) 5 -Year Review: Summary and Evaluation.

U.S. Fish and Wildlife Service Nevada Fish and Wildlife Office. Las Vegas, Nevada.

. 2009j. Nichol Turk's Head Cactus (Echinocactus horizonthalonius var. nicholii) 5-Year Review: Summary and Evaluation U.S. Fish and Wildlife Service Arizona Ecological Services Field Office. Phoenix, Arizona.

. 2009k. Peebles Navajo Cactus (Pediocactus peeblesianus var. peeblesianus) 5-Year Review Summary and Evaluation. U.S. Fish and Wildlife Service New Mexico Ecological Field Services Office. Albuquerque, New Mexico. 
. 20091. Revised Recovery Outline for the Kodachrome Bladderpod (Lesquerella tumulosa). Utah Ecological Services Field Office. West Valley City, Utah.

. 2009m. Knowlton's Cactus (Pediocactus knowltonii) 5-Year Review Summary and Evaluation. USFWS New Mexico Ecological Field Services Office. Albuquerque, New Mexico.

2009n. MacFarlane's Four-o'clock (Mirabilis macfarlanei) 5-Year Review Summary and Evaluation. USFWS Idaho Fish and Wildlife Office. Boise, Idaho.

- 2009o. Braunton's Milk-veteh (Astragalus branntonii) 5-Year Review: Summary and Evaluation. Ventura Fish and Wildlife Office. Ventura, California.

. 2009p. Berberis nevinii (Nevin's Barberry) 5-Year Review: Summary and Evaluation. Carlsbad Fish and Wildlife Office. Carlsbad, California.

- 2009q. Fremontodendron mexicanum (Mexican Flannelbush) 5-Year Review: Summary and Evaluation. Carlsbad Fish and Wildlife Office. Carlsbad, California.

. 2009r. Camissonia benitensis (San Benito Evening-primrose) 5-Year Review: Summary and Evaluation Ventura Fish and Wildlife Office. Ventura, California.

.2009s. Eriodictyon altissimum (Indian Knob Mountainbalm) 5-Year Review: Summary and Evaluation. New Mexico Ecological Services Field Office. Albuquerque, New Mexico.

- 2009t. Monterey Spineflower (Chorizanthe pungens var. pungens) 5-Year Review: Summary and Evaluation. Ventura Fish and Wildlife Office. Ventura, California.

. 2009u. Lilium occidentale (Western lily) 5-Year Review: Summary and Evaluation. Areata Field Office. Arcata, California.

2009v. Acanthomintha ilicifolia (San Diego Thornmint) 5-Year Review: Summary and Evaluation. Carlsbad Fish and Wildlife Office. Carlsbad, California.

. 2009w. Deinandra conjugens (Otay Tarplant) 5-Year Review: Summary and Evaluation. Carlsbad Fish and Wildlife Office. Carlsbad, California.

2009x. Chamaesyce hooveri (Hoover's Spurge) 5-Year Review: Summary and Evaluation. Sacramento Fish and Wildlife Office. Sacramento, Califormia.

.2009 y. Slender Oreutt grass (Orcuttia tenuis) 5-Year Review: Summary and Evaluation. Sacramento Fish and Wildlife Office. Sacramento, California.

.2009z. Brodiaea filifolia (Thread-leaved Brodiaea). 5-Year Review: Summary and Evaluation. Carlsbad Fish and Wildlife Office. Carlsbad, California.

2009aa. Clarkia springvillensis (Springville Clarkia) 5-Year Review: Summary and Evaluation. U.S. Fish and Wildlife Service Sacramento Fish and Wildlife Office. Sacramento, California.

- 2009bb. Astragahus albens (Cushenbury Milk-vetch) 5-Year Review: Summary and Evaluation. Carlsbad Fish and Wildlife Office. Carlsbad, California.

. 2009ce. Erigeron parishii (Parish's Daisy) 5-Year Review: Summary and Evaluation. Carlsbad Fish and Wildlife Office. Carlsbad, California. 
. 2009dd. Eriogonum ovalifolium var. vineum (Cushenbury Buckwheat) 5-Year Review: Summary and Evaluation. Carlsbad Fish and Wildlife Offiee. Carlsbad, California.

- 2009ee. Acanthoscyphus (Oxytheca) parishii var. goodmaniana (Cushenbury Oxytheca) 5-Year Review: Summary and Evaluation. Carlsbad Fish and Wildlife Offiee. Carlsbad, California.

- 2009ff. Dudleya cymosa ssp. marcescens (Marcescent Dudleya) 5-Year Review: Summary and Evaluation. Ventura Fish and Wildlife Office. Ventura, California.

2009gg. Piperia yadonii (Yadon's Piperia) 5-Year Review: Summary and Evaluation. Ventura Fish and Wildlife Office. Ventura, California.

. 2009hh. Astragalus applegatei (Applegate's Milkveteh) 5-Year Review Summary and Evaluation. Klamath Falls Fish and Wildlife Office. Klamath Falls, Oregon.

. 2009ii. Foskett Speekled Daee (Rhinichthys osculus ssp.) 5-Year Review: Summary and Evaluation. Oregon Fish and Wildlife Offiee. Portland, Oregon.

- 2009jj. Speeies Fact Sheet Borax Lake Chub (Gila boraxobius). Available at: http://www.fws.gov/oregonfwo/Speeies/Data/BoraxLakeChub/. Oregon Fish and Wildlife Offiee. Last Updated: October 30, 2009.

. 2009kk. Owens Tui Chub (Siphaletes bicolor snyderi = Gila bicolor snyderi) 5-Year Review: Summary and Evaluation. Ventura Fish and Wildlife Office. Ventura, California.

2009ll. 5-Year Review Short Form Summary for the Bliss Rapids Snail (Taylorconcha serpenticola). Idaho Fish and Wildlife Offiee. Boise, Idaho.

. 2009mm. Lahontan Cutthroat Trout (Oncorhyncus clarkia henshawi) 5-Year Review: Summary and Evaluation. Nevada Fish and Wildlife Offiee. Reno, Nevada.

- 2009nn. Independence Valley Speckled Daee (Rhinichthys osculus lethoporus) 5-Year Review: Summary and Evaluation. Nevada Fish and Wildlife Offiee. Reno, Nevada.

200900. Railroad Valley Springfish (Crenichthys nevadae) 5-Year Review: Summary and Evaluation. Nevada Fish and Wildlife Office. Reno, Nevada.

. 2009pp. Mohave Tui Chub (Gila bicolor mohavensis = Siphaletes bicolor mohavensis) 5-Year Review: Summary and Evaluation. Ventura Fish and Wildlife Offiee. Ventura, California.

.2009qq. Spotlight Species Aetion Plan for the Moapa Dace (Moapa coriacea) 2010 to 2014. Nevada Fish and Wildlife Office. Las Vegas, Nevada.

. 2009rr. Socorro Isopod (Thermosphaeroma thermophilus) 5-Year Review: Summary and Evaluation. Albuquerque, New Mexico.

. 2009ss. Desert Pupfish (Cyprinodon macularius) 5-Year Review: Summary and Evaluation. Arizona Ecological Services Office. Phoenix, Arizona.

- 2009tt. Greenback Cutthroat Trout (Oncorhyncus clarki stomias) 5-Year Review: Summary and Evaluation. Ventura Fish and Wildlife Office. Ventura, California. 
.2009uu. Modoc Sucker (Catostomus microps) 5-Year Review: Summary and Evaluation. Klamath Falls Fish and Wildlife Office. Klamath Falls, Oregon.

.2009vv. Owens Pupfish (Cyprinodon radiosus) 5-Year Review: Summary and Evaluation. Ventura Fish and Wildlife Office. Ventura, California.

2009ww. Unarmored Threespine Stickleback (Gasterosteus aculeatus williamsoni) 5-Year Review: Summary and Evaluation. Ventura Fish and Wildlife Office. Ventura, California.

2009xx. Endangered and Threatened Wildlife and Plants; Revised Critical Habitat for the Santa Ana Sucker (Catostomus santaanae); Proposed Rule. Federal Register 74(235):65056-65087.

.2009yy. Endangered and Threatened Wildlife and Plants; Designation of Critical Habitat for Tidewater Goby. Federal Register 78(25):8746-8819.

. 2009zz. Spotlight Species Action Plan for the Arkansas River Shiner (Notropis girardi) 2010 to 2014. Oklahoma Ecological Services Field Office. Tulsa, Oklahoma.

- 2009aaa. Quino Checkerspot Butterfly (Euphydryas editha quino) 5-Year Review: Summary and Evaluation. Carlsbad River Fish and Wildlife Office. Carlsbad, California.

- 2009bbb. Desert Slender Salamander (Batrachoseps major aridus) 5-Year Review: Summary and Evaluation. Carlsbad Fish and Wildlife Office. Carlsbad, California.

2009cec. Spotlight Species Action Plan for the Wyoming Toad. Wyoming Ecological Services Field Office. Cheyenne, Wyoming.

. 2009ddd. Arroyo Toad (Bufo californicus (=microscaphus)) 5-Year Review: Summary and Evaluation. Ventura Fish and Wildlife Office. Ventura, California.

- 2009eee. Piping Plover (Charadrius melodus) 5-Year Review. Hadley, Massachusetts and East Lansing, Michigan.

- 2009fff. Marbled Murrelet (Brachyramphus marmoratus) 5-Year Review. Washington Fish and Wildlife Office. Lacey, Washington.

.2009ggg. Amargosa Vole (Microtus californicus scirpensis) 5-Year Review: Summary and Evaluation. Ventura Fish and Wildlife Office. Ventura, California.

2010a. Recovery Outline for Yermo Xanthocephalus (Desert Yellowhead). U.S. Fish and Wildlife Service Wyoming Field Office. Cheyenne, Wyoming.

.2010b Astragalus desereticus Deseret Milk-Vetch 5-Year Review: Summary and Evaluation. U.S. Fish and Wildlife Service Utah Field Office - Ecological Services. West Valley City, Utah.

- 2010c. Schoenocrambe suffrutescens (Shrubby Reed-mustard) 5-Year Review: Summary and Evaluation. U.S. Fish and Wildlife Service Utah Field Office - Ecological Services. West Valley City, Utah.

- 2010d. Western Prairie Fringed Orchid (Platanthera praeclara). 5-Year Review: Summary and Evaluation. Twin Cities Field Office. Bloomington, Minnesota. 
- 2010e. Howell's Spectacular Thelypody (Thelypodium howellii ssp. spectabilis) 5-Year Review: Summary and Evaluation U.S. Fish and Wildlife Serviee Oregon Fish and Wildlife Offiee. Portland, Oregon.

2010f. Eriogonmm apricum (inelusive of vars. apricum and prostratum) (lone Buekwheat = Irish Hill Buekwheat) Arctostaplyylos myrtifolia (Ione Manzanita) 5-Year Review: Summary and Evaluation. Saeramento Fish and Wildlife Offiee. Saeramento, California.

- 2010g. Dodecahema leptoceras (Slender-Horned Spineflower) 5-Year Review: Summary and Evaluation. Carlsbad Fish and Wildlife Offiee. Carlsbad, California.

.2010h. Eriastrum densifolinm ssp. sanctorum (Santa Ana River Woolly-Star) 5-Year Review: Summary and Evaluation. Carlsbad Fish and Wildlife Offiee. Carlsbad California.

. 2010i. Endangered and Threatened Wildlife and Plants; Final Rule Designating Critieal Habitat for Ambrosia pumila (San Diego ambrosia). Federal Register 75(229):74546-74604.

.2010j. Pogogyne nudiuscula (Otay mesa mint) 5-Year Review: Summary and Evaluation. Carlsbad Fish and Wildlife Offiee. Carlsbad, California.

2010k. Endangered and Threatened Wildlife and Plants; Designation of Critieal Habitat for Limnanthes floccosa ssp. grandiflora (Large-Flowered Woolly Meadowfoam) and Lomatium cookii (Cook's Lomatium). Federal Register 75(139):42490-42570.

. 20101. Monolopia (=Lembertia) congdonii (San Joaquin Woolly-threads) 5-Year Review: Summary and Evaluation. Saeramento Fish and Wildlife Offiec. Saeramento, California.

- 2010m. Chorizanthe robusta var. robusta (Robust Spineflower) 5-Year Review: Summary and Evaluation. Ventura Fish and Wildlife Offiec. Ventura, California.

.2010n. Deinandra increscens ssp. villosa (Gaviota Tarplant) 5-Year Review: Summary and Evaluation. Ventura Fish and Wildlife Offiee. Ventura, California.

2010o. Reeovery Plan for the Prairie Speeies of Western Oregon and Southwestern Washington. U.S. Fish and Wildlife Serviee. Portland, Oregon.

- 2010p. Plagiobothrys hirtus (Rough Popeornflower). Endangered. 5-Year Review: Summary and Evaluation. U.S. Fish and Wildlife Serviee Roseburg Field Offiee. Roscburg, Oregon.

- 2010q. Ute Ladies'-Tresses Orehid. Speeies Deseription. USFWS Mountain-Prairic Region website. Available at: http://www.fws.gov/mountain-prairie/speeies/plants/uteladiestress/.

2010r. Warner Sueker (Catostomis warnerensis) 5-Year Review: Summary and Evaluation. Oregon Fish and Wildlife Offiee. Portland, Oregon.

- 2010s. Desert Daee (Eremichthys acros). Nevada Fish and Wildlife Offiee. Available at: http://www.fws.gov/nevada/proteeted_speeies/fish/speeies/desert_daee.html.

- 2010t. Cui-ui (Chasmistes crims). Nevada Fish and Wildlife Offiee. Available at: http://www.fws.gov/nevada/proteeted_speeies/fish/speeies/euiui.html.

. 2010u. White River Spinedaee (Lepidomeda albivallis). 5-Year Review: Summary and Evaluation.

Nevada Fish and Wildlife Offiee. Reno, Nevada. 
2010v. White River Springfish (Crenictlys baileyi baileyi). Nevada Fish and Wildlife Office. Available at: http://www.fws.gov/nevada/protected_species/fish/species/wr_springfish.html.

2010w. Hiko White River Springfish (Crenicthys baileyi grandis). Nevada Fish and Wildlife Office. Available at: http://www.fws.gov/nevada/protected_species/fish/species/hiko_wr_springfish.html.

2010x. Pahranagat Roundtail Chub (Gila robusta jordani). Nevada Fish and Wildlife Office. Available at: http://www.fws.gov/nevada/protected_species/fish/species/pahranagat_roundtail_chub.html.

. 2010y. Big Springs Spinedace (Lepidomeda mollispinis pratensis). Nevada Fish and Wildlife Office. Available at: http://www.fws.gov/nevada/protected_species/fish/species/bs_spinedace.html.

. 2010z. Pecos Bluntnose Shiner (Notropis simus pecosensis) 5-Year Review: Summary and Evaluation. New Mexico Ecological Service Field Office. Albuquerque, New Mexico.

. 2010aa. Roswell Springsnail (Pyrgulopsis roswellensis), Koster's Springsnail (Juturnia kosteri), Nocl's Amphipod (Gammarus desperatus), and Pecos Assiminea Snail (Assiminea pecos) 5-Year Review: Summary and Evaluation. New Mexico Ecological Services Field Office. Albuquerque, New Mexico.

- 2010bb. Ash Meadows Amargosa Pupfish (Cyprinodon nevadensis mionectes) 5-Year Revicw: Summary and Evaluation. Nevada Fish and Wildlife Office. Las Vegas, Nevada.

.2010ce. Endangered and Threatened Wildlife and Plants; 12-Month Finding on a Petition to Reclassify the Delta Smelt From Threatened to Endangered Throughout Its Range. Federal Register 75(66):1766717680 .

- 2010dd. Humpback Chub (Gila cypha). Nevada Fish and Wildlife Office. Available at: http://www.fws.gov/nevada/protected_species/fish/species/humpback_chub.html.

- 2010ee. Bonytail Chub (Gila elegans). Nevada Fish and Wildlife Office. Available at: http://www.fws.gov/nevada/protected_species/fish/species/btail_chub.html.

2010ff. Rio Grande Silvery Minnow Recovery Plan (Hybognathus amarus). First Revision. Southwest Region. Albuquerque, New Mexico.

- 2010gg. Uncompahgre Fritillary Butterfly (Boloria acrocnema) 5-Year Review: Summary and Evaluation. Western Colorado Field Office. Grand Junction, Colorado.

. 2010hh. Coachella Valley Fringe-Toed Lizard (Uma inornata) 5-Year Review: Summary and Evaluation. Carlsbad Fish and Wildlife Office. Carlsbad, California.

. 2010ii. Blunt-Nosed Leopard Lizard (Gambelia silus) 5-Year Review: Summary and Evaluation. Sacramento Fish and Wildlife Office. Sacramento, California.

. 2010jj. Spectacled Eider (Somateria fischeri). 5-Year Review: Summary and Evaluation. Fairbanks Fish and Wildlife Field Office. Fairbanks, Alaska.

. 2010kk. Yuma Clapper Rail Recovery Plan (Rallus longirostris yumanensis). Draft First Revision. Southwest Region. Albuquerque, New Mexico.

- 201011. Coastal California Gnatcatcher (Polioptila californica californica) 5-Year Review: Summary and Evaluation. Carlsbad Fish and Wildlife Office. Carlsbad, California. 
.2010mm. Columbia Basin Distinet Population Segment of the Pygmy Rabbit (Brachylagus idahoensis)

5-Year Review: Summary and Evaluation. Eastern Washington Field Office. Spokane, Washington.

. 2010nn. Ocelot Recovery Plan (Leopardus pardalis) Draft First Revision. Southwest Region. Albuquerque, New Mexico.

201000. Determination that Designation of Critical Habitat is Prudent for the Jaguar. Federal Register 75(8):1741-1744.

- 2010pp. Establishment of a Nonessential Experimental Population of Sonoran Pronghorn in Southwestern Arizona. Federal Register 75(23):5732-5744.

2010qq. Revised Critical Habitat for the Prcble's Meadow Jumping Mouse in Colorado. Federal Register 75(240): 78430-78483.

. 2010rr. San Joaquin Kit Fox (Vulpes macrotis mutica) 5-Year Review: Summary and Evaluation. Sacramento Fish and Wildlife Officc. Sacramento, California.

- 2010ss. Giant Kangaroo Rat (Dipodomys ingens) 5-Year Review: Summary and Evaluation. Sacramento Fish and Wildlife Office. Sacramento, California.

. 2010tt. Fresno Kangaroo Rat (Dipodomys nitratoides exilis) 5-Year Review: Summary and Evaluation. Sacramento Fish and Wildlife Office. Sacramento, California.

- 2010uu. Tipton Kangaroo Rat (Dipodomys nitratoides nitratoides) 5-Ycar Revicw: Summary and Evaluation. Sacramento Fish and Wildlife Office. Sacramento, California.

2010vv. 12-Month Finding on a Petition to Remove the Stephens' Kangaroo Rat from the Federal List of Endangered and Threatened Wildlife. Federal Register 75(160):51204-51223.

- 2010ww. Utah Prairie Dog Draft Revised Recovery Plan. Utah Ecological Services Office and Utah Prairie Dog Recovery Team. West Valley City, Utah and Denver, Colorado.

. 2011a. Malheur Wirc Lettuce (Stephanomeria malheurensis) 5-Year Review: Summary and Evaluation U.S. Fish and Wildlife Service Oregon Fish and Wildlife Office. Portland, Oregon.

. 2011b. Lepidium barnebyamum (Barneby Ridge-cress) 5-Year Review: Summary and Evaluation. U.S. Fish and Wildlife Service Utah Field Office - Ecological Services. West Valley City, Utah.

. 2011c. Schoenocrambe argillacea (Clay Reed-mustard) 5-Ycar Review: Summary and Evaluation. U.S. Fish and Wildlife Service Utah Field Office - Ecological Services. West Vallcy City, Utah.

2011d. Schoenocrambe barnebyi (Barneby Reed-Mustard) 5-Year Review: Summary and Evaluation.

U.S. Fish and Wildlife Scrvice Utah Ficld Office - Ecological Services. West Vallcy City, Utah.

2011e. Endangered and Threatened Wildlife and Plants; Determination of Endangered Status for Ipomopsis polyantha (Pagosa Skyrocket) and Threatened Status for Penstemon debilis (Parachute Bcardtongue) and Phacelia submutica (DeBeque Phacelia). Federal Register 76(144):45054-45075.

. 2011f. Endangered and Thrcatened Wildlife and Plants; Designation of Critical Habitat for Astragalus lentiginosus var. coachellae. Federal Register 76(165):53224-53254. 
2011g. Enceliopsis nudicaulis var. corrugate (Ash Meadows Sunray) 5-Year Review: Summary and Evaluation. Nevada Fish and Wildlife Office. Reno, Nevada.

. 2011h. Mesa Verde Cactus (Sclerocactus mesae-verdae) 5-Year Review: Summary and Evaluation. New Mexico Ecological Services Field Office. Albuquerque, New Mexico.

2011i. Maneos Milkveteh/Astragalus hunillimus 5-Year Review: Summary and Evaluation. New Mexico Ecological Services Office. Albuquerque, New Mexico.

. 2011j. Todsen's Pennyroyal (Hedeoma todsenii) 5-Year Review: Summary and Evaluation. Region 2 Ecological Services Field Office. Albuquerque, New Mexico.

.2011k. Phacelia formulosa (North Park Phacelia) 5-Year Review Summary and Evaluation. Western Colorado Field Office. Grand Junction, Colorado.

. 20111. Baccharis vanessae (Encinitas Baccharis) 5-Year Revicw: Summary and Evaluation. Carlsbad Fish and Wildlife Office. Carlsbad, California.

. $2011 \mathrm{~m}$. Cirsizm loncholepis [Cirsium scariosum var. loncholepis] (La Graciosa Thistle) 5-Year Review: Summary and Evaluation. Ventura Fish and Wildlife Office. Ventura, California.

.2011n. Chorizanthe howellii (Howell's Spineflower) 5-Year Review: Summary and Evaluation. Areata Fish and Wildlife Office. Arcata, California.

20110. Layia carnosa (Beach Layia) Draft 5-Year Review: Summary and Evaluation. Areata Fish and Wildlife Office. Arcata, California.

. 2011 p. Orcuttia californica (California Orcutt Grass) 5-Year Review: Summary and Evaluation. Carlsbad Fish and Wildlife Office. Carlsbad, California.

. 2011q. Castilleja campestris spp. succulenta (Fleshy Owl's-Clover) 5-Year Review: Summary and Evaluation. Sacramento Fish and Wildlife Office. Sacramento, California.

. 2011r. 5-Year Review Short Form Summary for Lomatium cookii (Cook's Desert Parsley, Cook's Lomatium). Oregon Fish and Wildlife Office, Roseburg Field Office. Roseburg, Oregon.

. 2011s. Delphinium luteum (Yellow Larkspur) 5-Year Review: Summary and Evaluation. Sacramento Fish and Wildlife Office. Sacramento, California.

2011t. Ceanothus ferrisiae (Coyote Ceanothus) 5-Year Review: Summary and Evaluation Sacramento Fish and Wildlife Office. Sacramento, California.

. 2011 u. Hackelia venusta (Showy Stickseed) 5-Year Review: Summary and Evaluation. Washington Fish and Wildlife Office. Lacey, Washington.

2011v. Kanab Ambersnail (Oxylona haydeni kanabensis) 5-Year Review: Summary and Evaluation. Newport Field Office. Newport, Oregon.

.2011w. Kootenai River Distinct Population Segment of the White Sturgeon (Acipenser transmontamus)

5-Year Review: Summary and Evaluation. Northern Idaho Field Office. Spokane, Washington.

. 2011x. Draft Revised Recovery Plan for the Lost River Sucker and Shortnose Sucker (Deltistes luxatus and Chasmistes brevirostris). Pacific Southwest Region. Sacramento, California. 
. 2011y. Colorado Pikeminnow (Ptychochelius lucius) 5-Year Review: Summary and Evaluation. Upper Colorado River Endangered Fish Recovery Program. Denver, Colorado.

- 2011z. Oregon Silverspot Butterfly (Speyeria zerene hippolyta) 5-Year Review Summary and Evaluation. Utah Field Offiee - Ecological Serviees. West Valley City, Utah.

2011aa. Chiricahua Leopard Frog (Lithobates [-Rana] chiricahuensis) 5-Year Review: Summary and Evaluation. Arizona Ecological Serviees Office. Phoenix, Arizona.

. 2011 bb. Revised Reeovery Plan for the Mojave Population of the Desert Tortoise (Gopherus agassizii). Pacific Southwest Region. Sacramento, California.

. 2011cc. Revised Recovery Plan for the Northern Spotted Owl (Strix occidentalis caurina). Region 1

U.S. Fish and Wildlife Service. Portland, Oregon.

2011dd. Draft Recovery Plan for the Mexiean Spotted Owl, First Revision (Strix occidentalis lucida). Southwest Region. Albuquerque, New Mexieo.

2011ee. Northern Idaho Ground Squirrel (Spermophilus brunneus brunneus) 5-Year Review: Summary and Evaluation. Idaho Fish and Wildlife Office. Boise, Idaho.

2011ff. Designation of Critical Habitat for the Southern Selkirk Mountains Population of Woodland Caribou (Rangifer tarandus caribou) (Proposed Rule). Federal Register 76(230):74018-74038.

.2011gg. Grizzly Bear (Ursus arctos horriblis) 5-Year Review: Summary and Evaluation. Grizzly Bear Reeovery Offiee. Missoula, Montana.

. 2011 hh. 5-Year Review Short Form Summary for Stephens' Kangaroo Rat (Dipodomys stephensi). Carlsbad Fish and Wildlife Office. Carlsbad, California.

2011ii. Morro Bay Kangaroo Rat (Dipodomys heermanni morroensis) 5-Year Review: Summary and Evaluation. Ventura Fish and Wildlife Offiee. Ventura, California.

. 2011jj. Peninsular Bighorn Sheep (Ovis Canadensis nelsoni) 5-Year Review: Summary and Evaluation. Carlsbad Fish and Wildlife Office. Carlsbad, California.

. 2012a. Endangered and Threatened Wildlife and Plants; 12-Month Finding for the Lemmon Fleabane; Endangered Status for the Acuña Cactus and the Fickeisen Plains Cactus and Designation of Critical Habitat; Proposed Rule. Federal Register 77( 192):60509-60579.

. 2012b. Endangered and Threatened Wildlife and Plants; Revised Endangered Status, Revised Critical Habitat Designation, and Taxonomic Revision for Monardella linoides ssp. viminea; Final Rule Federal Register 77(44):13394-13447.

- 2012c. Hiko White River Springfish (Crenichthys baileyi grandis) and White River Springfish (Crenichthys baileyi baileyi) 5-Year Review: Summary and Evaluation. Nevada Fish and Wildlife Office. Reno, Nevada.

. 2012d. Endangered and Threatened Wildlife and Plants; Endangered Status and Designations of Critical Habitat for Spikedaee and Loach Minnow. Federal Register 77(36):10810-10932.

2012e. Pawnee Montane Skipper Butterfly (Hesperis leonardus montana) 5-Ycar Review: Summary and Evaluation. Colorado Field Office. Lakewood, Colorado. 
2012f. Endangered and Threatened Wildlife and Plants; Listing Taylor's Checkerspot Butterfly and Streaked Horned Lark and Designation of Critical Habitat; Proposed Rule. Federal Register 77(197): 61937-62058.

. 2012g. Endangered and Threatened Wildlife and Plants; Listing the Lesser Prairie-Chicken as a Threatened Species; Proposed Rule. Federal Register 77(238):73827-73888.

. 2012h. Whooping Crane (Grus americana) 5-Year Review: Summary and Evaluation. Aransas National Wildlife Refuge and Corpus Christi Ecological Service Field Office. Austwell, Texas and Corpus Christi, Texas.

. 2012i. Lower 48-State and Mexico Gray Wolf (Canis lupus) Listing, as Revised; 5-Year Review: Summary and Evaluation. USFWS Arlington Office. Arlington, Virginia.

. 2013a. Endangered and Threatened Wildlife and Plants; Endangered and Threatened Wildlife and Plants; 12-Month Finding and Candidate Removal for Potentilla basaltica; Proposed Threatened Species Status for Ivesia webberi. Federal Register 78(149):46889-46897.

. 2013b. Endangered and Threatened Wildlife and Plants; Determination of Endangered Status for Sphaeralcea gierischii (Gierisch Mallow) Throughout Its Range. Federal Register 78( I56):49149-49165.

- 2013c. Arctostaphylos morroensis (Morro Manzanita) 5-Year Review: Summary and Evaluation. Ventura Fish and Wildlife Office. Ventura, California.

. 2013d. Endangered and Threatened Wildlife and Plants; Endangered Status for the Sierra Nevada Yellow-Legged Frog and the Northern Distinet Population Segment of the Mountain Yellow-Legged Frog, and Threatened Status for the Yosemite Toad; Proposed Rule. Federal Register 78(80):24471-24514.

. 2013e. Endangered and Threatened Wildlife and Plants; Threatened Status for Oregon Spotted Frog. Proposed Rule. Federal Register 78(168):53581-53623.

. 2013f. Endangered and Threatened Wildlife and Plants; Threatened Status for the Northern Mexican Gartersnake and Narrow-headed Gartersnake; Proposed Rule. Federal Register 78(132):41499-41547.

. 2013g. Endangered and Threatened Wildlife and Plants; Proposed Threatened Status for the Western Distinet Population Segment of the Yellow-billed Cuckoo (Coccyzus americanus); Proposed Rule. Federal Register 78(192):61621-61666.

. 2013h. Endangered and Threatened Wildlife and Plants; Endangered Status for Gunnison Sage-Grouse; Proposed Rule. Federal Register 78(8):2485-2538.

- 2013i. Endangered and Threatened Wildlife and Plants; Threatened Status for the Bi-State Distinct Population Segment of Greater Sage-Grouse With Special Rule; Proposed Rule. Federal Register 78(208):64357-64384.

. 2013j. Endangered and Threatened Wildlife and Plants; Listing Determination for the New Mexico Meadow Jumping Mouse. Proposed Rule. Federal Register 78(1 19):37363-37369.

. 2013k. Endangered and Threatened Wildlife and Plants; Removing the Gray Wolf (Camis lupus) From the List of Endangered and Threatened Wildlife and Maintaining Protections for the Mexican Wolf (Camis lupus baileyi) by Listing It as Endangered; Proposed Revision to the Nonessential Experimental Population of the Mexican Wolf; Proposed Rules. Federal Register 78(1 14):35664-35719. 
, and National Marine Fisheries Service. 1998. Endangered Speeies Consultation Handbook: Procedures for Condueting Seetion 7 Consultations and Conferenees.

U.S. Geological Survey (USGS). 2012a. Poecilioposis occidentalis occidentalis Nonindigenous Aquatie Speeies Database. Available at: http://nas.er.usgs.gov/queries/faetsheet.aspx?SpeeiesID=866.

2012b. Gambusia nobilis Nonindigenous Aquatie Speeies Database. Available at: http://nas.er.usgs.gov/queries/faetsheet.aspx?SpeeiesID=851.

Usinger, R.L. 1946. Notes and Deseriptions of Ambrysus Stal with an Aeeount of the Life History of Ambrysus mormon Montd. (Hemiptera: Naueoridae). Bulletin of the University of Kansas, Seienee Bulletin, Volume $31(1): 185-210$.

Utah Conservation Data Center. No Date(a). Faet Sheet for San Rafael Caetus. State of Utah Natural Resourees, Division of Wildlife Resourees. Available at: http://utahde.usu.edu.

- No Date(b). Faet Sheet for Clay Phaeelia. State of Utah Natural Resourees, Division of Wildlife Resourees. Available at: http://utahde.usu.edu.

- No Date(c). Faet Sheet for Jones' Cyeladenia. State of Utah Natural Resourees, Division of Wildlife Resourees. Available at: http://utahde.usu.edu.

Utah Natural Heritage Program. 2005. Element Oeeurrenee Database, Utah Division of Wildlife Resouree. Salt Lake City, Utah.

Valdez, R.A., and G.H. Clemmer. 1982. Life History and Prospeets for Reeovery of the Humpbaek and Bonytail Chub. Pages 109-119 in Fishes of the Upper Colorado River System, Present and Future (W.H. Miller, H.M. Tyus, and C.A. Carlson, Editors). Western Division of the Ameriean Fisheries Soeiety. Bethesda, Maryland.

, P.G. Mangan, R. Smith, and B. Nilson. 1982. Upper Colorado River Investigations (Rifle, Colorado, to Lake Powell, Utah). Pages 100-279 in U.S. Fish and Wildlife Serviee. Colorado River Fishery Projeet, Final Report, Part 2: Field Investigations. U.S. Fish and Wildlife Serviee. Salt Lake City, Utah.

Van Buren, R. 1992. Astragalus Speeies Field Report. Unpublished Report on File with the Bureau of Land Management. Salt Lake City, Utah.

, and K.T. Harper. 2000a. Status Report 1999 Astragalus holmgreniorum (Holmgren Loeoweed). Unpublished Report on File with the BLM. Riehfield, Utah.

, and 2000b. Status Report 1999 Astragalus ampullarioides (Shivwitz Loeoweed). Unpublished Report on File with the USFWS. Salt Lake City, Utah.

, and _.2001. 2000 Status Report Lesquerella tumulosa. Kodaehrome Bladderpod Demography. Order No. JC-POO-3015A. Presented to the Bureau of Land Management Grand Stairease Esealante National Monument. Kanab, Utah.

, and . 2002. 2001 Status Report Lesquerella tumulosa. Kodachrome Bladderpod Demography.

Order No. JC-POO-3015A.

, and . 2003. 2002 Demography Report: Astragalus holmgrenionm and A. ampullarioides, Holmgren Milkveteh and Shivwits Milkveteh. Unpublished Report on File with the Bureau of Land Management State Offiee. Salt Lake City, Utah. 
, and

. 2004. Two-year Monitoring Report (2003 and 2004): Astragalus ampullarioides, Shivwits Milkvetch. Unpublished Report Submitted to Bureau of Land Management, St. George Field Office. St. George, Utah.

Van Eimeren, P.A. 1988. Comparative Food Habits of Gila Trout and Speckled Dace in a Southwestern Headwater Stream. Unpublished M.S. Thesis, New Mexico State University. Las Cruces, New Mexico.

Van Houten, F.B. 1964. Tertiary Geology of the Beaver Rim Area Fremont and Natrona Counties, Wyoming: Geological Survey Bulletin 1164, U.S. Government Printing Office. Washington, D.C.

Vanicek, C.D. 1967. Ecological Studies of Native Green River Fishes below the Flaming Gorge Dam; 1964-1966. Ph.D. Dissertation, Utah State University. Logan, Utah.

, and R.H. Kramer. 1969. Life History of the Colorado Squawfish Ptychocheilus lucius, and the Colorado Chub, Gila robusta, in the Green River in Dinosaur National Monument, 1964-1966. Transactions of the American Fisheries Society 98:193-208.

Verner, J. 1978. California Condors: Status of the Recovery Effort. General Technical Report PSW-28. Forest Service Pacific Southwest Forest and Range Experiment Station. Berkeley, California.

Vives, S.P., and W.L. Minckley. 1990. Autumn Spawning and Other Reproductive Notes on Loach Minnow, a Threatened Cyprinid of the American Southwest. The Southwestern Naturalist 35:451-454.

Vorhies, C.T. 1948. Food Items of Rattlesnakes. Copeia 1948:302-303.

Wagner, W.L., and D.G. Sabo. 1977. Status Report for Eriogonum gypsophilum. Unpublished Report on File at USFWS. Albuquerque, New Mexico.

Walker, G.E., and T.E. Eakin. 1963. Geology and Ground Water at Amargosa Desert, Nevada-California. Nevada Department of Conservation and Natural Resources, Water Resource Reconnaissance Series Report 14:1-45.

Walkinshaw, L.H. 1973. Cranes of the World. Winchester Press. New York, New York.

Walter, H. 1973. Vegetation of the Earth in Relation to Climate and the Eco-Physiological Conditions. SpringerVerlag. New York, New York.

Warner, P. 2006. Development of a Restoration Strategy for Howell's Spineflower, MacKerricher State Park: Progress Report, September 2006. Unpublished Report and Field Data Submitted Pursuant to ESA Section 6 - Funded Project. California Department of Parks and Recreation. Mendocino, California.

Washington Department of Fish and Wildlife (WDFW). 1995. Washington State Recovery Plan for Pygmy Rabbit. Wildlife Management Program. Olympia, Washington.

Washington Department of Wildlife. 1993. Status of the North American Lynx (Lynx canadensis) in Washington. Unpublished Report. Olympia, Washington.

Washington State Joint Natural Resources Cabinet. 1999. Statewide Strategy to Recover Salmon. Olympia, Washington.

Weber, W.A., and S. Shushan. 1955. Additions to the Flora of Colorado II. University of Colorado Studies. Series in Biology 3:65-108. 
Weedon, R.R., D.J. Norton, and J. Stubbendieck. 1982a. Blowout Penstemon ( $P$. haydenii S. Wats.): A Rare Sandhills Endemie (Nebraska). Restoration and Management Notes 1:213.

, J. Stubbendieck, and D.J. Norton. 1982b. The Botanical Contributions of Claude A. Barr, II: Penstemon haydenii S. Watson. American Penstemon Society Bulletin 41:6-9.

Welsh, S.L. 1978a. Status Rcport: Lepidium barnebyanum. Brigham Young University Herbarium. Provo, Utah.

1978b. Status Report: Arctomecon humilis. USFWS. Denver, Colorado.

1978c. Status Report: Lesquerella tumulosa. USFWS. Denver, Colorado.

1979a. Status Report Primula maguirei. Unpublished Report on File with the USFWS. Salt Lake City, Utah,

. 1979b. Illustrated Manual of Proposed Endangered and Threatened Plants of Utah. USFWS. Denver, Colorado.

, and K.H. Thorne. 1979. Illustrated Manual of Proposed Endangered and Threatened Plants of Utah. Brigham Young University Herbarium. Provo, Utah.

, and C.A. Toft. 1981. Biotie Communities of Hanging Gardens in Southeastern Utah. National Geographie Society Resources Report 13:663-681.

WESTEC Services Inc. 1977. Survey of Sensitive Plants of the Algodones Dunes. BLM Contraet No. YA-512CT7-133.

Wheeler, J. 1988. Reeent Eeologieal Investigations and Present Status of the Endangered Santa Ana River Woolly-Star, Eriastrum densifolium ssp. sanctorum (Milliken) Mason. Crossoma 14(3):1-17.

Wheeler, J.A. 1991. Seed and Seedling Ecology of Eriastrum densifolium ssp. sanctorum an Endangered Floodplain Endemic. Unpublished M.S. Thesis, California State University. Fullerton, California.

White, R.K., T.R. Hoitsma, M.A. Stern, and A.V. Munhall. 1990. Final Report on lnvestigations of the Range and Status of the Warner Sucker, Catostomus warnerensis, during Spring and Summer 1990. Unpublished Report to the BLM, Oregon Department of Fish and Wildlife, and USFWS.

, T.L. Ramsey, M.A. Stern, and A.V. Munhall. 1991. Salvage Operations and lnvestigations of the Range and Stream Habitat Charaeteristies of the Warner Sueker, Catostomus warnerensis, during Spring and Summer 1991. Unpublished Report to the BLM and Oregon Department of Fish and Wildlife.

White, S. 1997. Comments on San Bernardino Mountains Carbonate Plants Draft Recovery Plan. Submitted to USFWS.

Whiteman, H.H., S.A. Wissinger, and A.J. Bohonak. 1994. Seasonal Movement Patterns in a Subalpine Population of the Tiger Salamander, Ambystoma tigrinum nebulosum. Canadian Journal of Zoology 72:1780-1787.

Whitfield, M.J. 1990. Willow Flyeateher Reproduetive Response to Brown-Headed Cowbird Parasitism. M.S. Thesis, California State University. Chico, California.

Widrig, R.S. 1980. Snowy Plovers at Leadbetter Point: An Opportunity for Wildlife Management? Prepared for the U.S. Fish and Wildlife Service, Willapa NWR. Ilwaeo, Washington. 
Wilbur, H.M., and J.P. Morin. 1988. Life History Evolution in Turtles. Pages 387-439 in Biology of Reptilia: Defense and Life History 16(B) (C. Gans and R.B. Huey, Editors). A.R. Liss, Inc. New York, New York.

Wilbur, S.R. 1978. The California Condor, 1966-76: A Look at Its Past and Future. USFWS. North America Fauna 72:1-136.

Wilde, G.R. 1989. Foods and Feeding Periodicity of the White River Springfish, Crenichthys baileyi. Great Basin Naturalist 49(2): 249-251.

Wiley-Eberle, K. 1979. Unpublished Report. Status Report of Phacelia formosula Osterhout. USFWS.

Wilken, D. 1998. California Native Species Field Survey Forms for Deinandra increscens ssp. villosa. Dated August 18, 1998. Submitted to the Natural Diversity Database, California Department of Fish and Game. Sacramento, California.

. 2000. Rare Plant Survey at Fort Hunter Liggett: Purple Amole (Chlorogahm purpmreum), Dwarf Calycadenia (Calycadenia villosa), and Santa Lucia Mint (Pogogyne clareana). Technieai Report No. 2 , Santa Barbara Botanic Garden. Santa Barbara, California.

Williams, C.D. 1986. Life History of the Railroad Valley Springfish, Crenichthys nevadae Hubbs (Cyprinodontidae), of East-central Nevada. M.S. Thesis. California State University. Sacramento, California.

, and J.E. Williams. 1982. Summer Food Habits of Fishes from Two Springs in East-central Nevada. The Southwestern Naturalist 27(4):437-445.

Williams, D.F. 1986. Mammalian Species of Special Coneern in California. California Department of Fish and Game, Wildlife Management Division Administrative Report 86-1:1-112.

, and K.S. Kilburn. 1984. Sensitive, Threatened, and Endangered Mammals of Riparian and Other Wetland Communities in California. Pages 950-956 in California Riparian Systems Ecology, Conservation, and Productive Management (R.E. Warner and K.M. Hendrix, Editors). University of California Press. Berkeley, California.

, and W. Tordoff III. 1988. Operations and Maintenance Schedule: Elkhorn Plain Eeologieal Reserve, San Luis Obispo County, California. California Department of Fish and Game, Nongame Heritage Program. Sacramento, California.

, and K.S. Kilburn. 1992. The Conservation Status of the Endemic Mammals of the San Joaquin Faunal Region, California. Pages 329-348 in Endangered and Sensitive Species of the San Joaquin Valley, California (D.F. Williams, S. Byrne, and T.A. Rado, Editors). California Energy Commission. Sacramento, California.

Williams, J.D., D.B. Bowman, J.E. Brooks, A.A. Echelle, R.J. Edwards, D.A. Hendrickson, and J.J. Landye. 1985. Endangered Aquatic Ecosystems in North America Deserts with a List of Vanishing Fishes of the Region. Journal of the Arizona-Nevada Academy of Science 20(1):1-62.

, and D.W. Sada. 1985. Status of Two Endangered Fishes, Cyprinodon nevadensis mionectes and Rhinichthys osculus nevadensis, from Two Springs in Ash Meadows, Nevada. Southwestern Naturalist 30(4):475-484. 
Wilson, M.V., T. Erhart, P.C. Hammond, T.N. Kaye, K. Kuykendall, A. Liston, A.F. Robinson, Jr., C.B. Schultz, and P.M. Severns. 2003. Biology of Kincaid's lupine (Lupinus sulphurens spp. kincaidii [Smith] Phillips), A Threatened Species of Western Oregon Native Prairies, USA. Natural Areas Journal 23(1):7283.

, D.J. Germano, and W. Tordoff III. 1993a. Population Studies of Endangered Kangaroo Rats and Blunt-nosed Leopard Lizards in the Carizo Plain Natural Area, California. California Department of Fish and Game, Nongame Bird and Mammal Section. Report 93-01:1-114.

, and 1993b. Taxonomy. Pages 38-196 in Biology of the Hetcromyidac (H.H. Genoways and J.H. Brown, Editors). American Society of Mammalogy Special Publication 10:1-719.

Wilson, R.A. 1980. Snowy Plover Nesting Ecology on the Oregon Coast. MS Thesis, Oregon State University. Corvallis, Oregon.

Wolf, C.B. 1938. California Plant Notes: 1I. Occas. Papers Rancho Ana Botanical Garden Series 1(2):44-90.

Wolff, J.O. 1985. Behavior. Pages 340-372 in Biology of New World Microtus (R. H. Tamarin, Editor). Special Publication Number 8, American Society of Mammology. Boston, Massachusetts.

Wong, D., P.B. Dorn, and E.Y. Chai. 1997. Acute Toxicity and Structure-activity Relationships of Nine Alcohol Ethoxylate Surfactants to Fathead Minnow and Daphnia magna. Environmental Toxicology and Chemistry 16(9):1970-1976.

Wood, C.C. 1995. Life History Variation and Population Structure in Sockeye Salmon. In Evolution and the Aquatic Ecosystem: Defining Unique Units in Population Conservation. (J. L. Nielsen, Editor). American Fishcries Society Symposium 17:195-216.

Wood, Y., and S.G. Wells. 1997. Final Report: Characterizing the Habitat of Slender-Horned Spineflower (Dodecahema leptoceras): Geomorphic Analysis. Prepared for California Department of Fish and Game, U.S. Fish and Wildlife Service Contract Number FG4632-R5. Long Beach, California.

Woodin, W.H. 1953. Notes on Some Reptiles from the Huachuca Arca of Southeastern Arizona. Bullctin of the Chicago Academy of Science 9:285-296.

Wooten, E.O., and P.C. Standley. 1913. Descriptions of New Plants Preliminary to a Report upon a Flora of New Mexico. Contributions from the U.S. National Herbarium 16:109-196.

World Health Organization (WHO). 2002. International Program on Chemical Safety. Global Assessment on the State of the Seience of Endocrine Disruptors. WHO-PCS-EDC-02.2. Geneva, Switzerland.

Worts, G.F., Jr. 1963. Effect of Ground Water Development on the Pool Level in Devil's Hole, Death Valley National Monument, Nye County, Nevada. U.S. Gcological Survey, Water Resources Division. Carson City, Nevada.

Wright, A.H., and A.A. Wright. 1949. Handbook of Frogs and Toads of the United States and Canada. Comstock Publishing Company, Inc.. Ithaca, New York.

Wyatt, R. 1976. Pollination and Fruit-sct in Asclepias: A Rcappraisal. American Journal of Botany 63:845-85I.

Yamamoto, S. 1985. Status Report of Astragalus applegatei. Unpublished Report Submitted to Klamath Falls Fish and Wildlife Office. Klamath Falls, Oregon. 
Young, H.W., R.E. Lewis, and R.L. Backsen. 1979. Thermal Groundwater Diseharge and Associated Convective Heat Flux, Bruneau-Grandview Area, Southwest Idaho. U.S. Geologieal Survey Water Resources Investigations. Denver, Colorado.

Zabel, C.J., J.R. Dunk, H.B. Stauffer, L.M. Roberts, B.S. Mulder, and A. Wright. 2003. Northern Spotted Owl Habitat Models for Research and Management Application in California (USA). Ecologieal Applications 13:1027-1040.

Zembal, R., and K.J. Kramer. 1984. The Known Limited Distribution and Unknown Future of Santa Ana River Woolly-Star (Eriastrum). Crossosoma 10(5):1-6.

Zoellick, B.W., T.P. O'Farrell, P.M. McCue, C.E. Harris, and T.T. Kato. 1987. Reproduction of the San Joaquin Kit Fox on Naval Petroleum Reserve \#1, Elk Hills, California, 1980-1985. Report Number EGG 10282-2144, EG\&G Energy Measurements. Goleta, California.

Zwinger, A.H., and B.E. Willard. 1972. Land above the Trees. A Guide to American Alpine Tundra. University of Arizona Press. Tueson, Arizona. 


\section{CHAPTER 8}

\section{INDEX OF SPECIES COVERED IN THE BIOLOGICAL ASSESSMENT BY COMMON NAME}

Ambersnail, Kanab ........................................... 5-30

Ambrosia, San Diego ........................................ 4-80

Amole, Purple ................................................. 4-95

Amphipod, Noel's........................................ 5-44

Baceharis, Eneinitis ........................................ 4-71

Barberry, Nevin's............................................ 4-65

Bat, Lesser Long-nosed ................................. 6-77

Bat, Mexiean Long-nosed............................... 6-78

Bear, Grizzly............................................ 6-96

Beardtongue, Paraehute ................................. 4-17

Beardtongue, Penland ................................... 4-57

Bear-poppy, Dwarf ......................................... 4-33

Bedstraw, El Dorado.................................... 4-63

Beetle, Valley Elderberry Longhorn............... 6-13

Bladderpod, Dudley Bluffs ............................. 4-15

Bladderpod, Kodaehrome ............................... 4-43

Blazingstar, Ash Meadows ............................. 4-27

Blue-star, Kearney's .................................... 4-29

Brodiaea, Thread-leaved .................................. 4-93

Buckwheat, Cushenbury ................................ 4-103

Buckwheat, Ione .......................................... 4-60

Buckwheat, Steamboat.................................... 4-2

Buttereup, Autumn............................................ 4-5

Butterfly, Fender's Blue.................................... 6-10

Butterfly, Oregon Silverspot ............................ 6-9

Butterfly, Quino Checkerspot .......................... 6-7

Butterfly, Taylor's Checkerspot...................... 6-11

Butterfly, Uneompahgre Fritillary .................... 6-6

Butterfly Plant, Colorado .............................. 4-52

Butterweed, Layne's ...................................... 4-64

Cactus, Acuña ............................................... 4-37

Cactus, Arizona Hedgehog ............................. 4-32

Cactus, Bakersfield ..................................... 4-98

Cactus, Brady Pincushion ............................. 4-39

Cactus, Coehise Pincushion ............................. 4-31

Cactus, Colorado Hookless ................................. 4-6

Cactus, Fickeisen Plains.................................... 4-49

Cactus, Knowlton's ....................................... 4-46
Cactus, Kuenzler Hedgehog........................... 4-48

Caetus, Lee Pincushion..................................... 4-35

Cactus, Mesa Verde ...................................... 4-44

Cactus, Niehol's Turk's Head........................ 4-28

Caetus, Pariette ............................................ 4-6

Cactus, Peebles Navajo ................................. 4-39

Cactus, Pima Pineapple...................................... 4-29

Cactus, San Rafael ....................................... 4-10

Cactus, Siler Pineushion .................................. 4-42

Cactus, Sneed Pincushion .............................. 4-36

Caetus, Uinta Basin hookless.......................... 4-6

Caetus, Winkler............................................ 4-43

Caetus, Wright Fishhook ............................... 4-7

Caribou, Woodland ..................................... 6-93

Catchfly, Spalding's...................................... 4-54

Ceanothus, Coyote ....................................... 4-111

Ceanothus, Pine Hill ....................................... 4-62

Centaury, Spring-loving............................... 4-25

Cheeker-mallow, Keek's.................................. 4-96

Checker-mallow, Nelson's ............................. 4-117

Cheeker-mallow, Wenatehee Mountains ...... 4-118

Chub, Bonytail .......................................... 5-62

Chub, Borax Lake .......................................... 5-19

Chub, Gila ................................................... 5-40

Chub, Humpbaek ......................................... 5-62

Chub, Hutton Tui ............................................. 5-19

Chub, Mohave Tui ......................................... 5-31

Chub, Oregon …............................................... 5-59

Chub, Owens Tui ........................................ 5-20

Chub, Pahranagat Roundtail .......................... 5-28

Chub, Virgin River....................................... 5-32

Clarkia, Springville .................................... 4-100

Cliff-rose, Arizona ........................................... 4-31

Colusa Grass .............................................. 4-88

Condor, California ............................................ 6-62

Crane, Whooping ........................................... 6-69

Crayfish, Shasta .............................................. 5-53

Crownseale, San Jacinto Valley ..................... 4-92 
Cuckoo, Yellow-billed....................................6-53

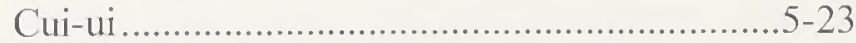

Cyeladenia, Jones ............................................4-41

Dace, Ash Meadows Speekled...........................5-35

Dace, Clover Valley Speekled...........................5-25

Dace, Desert.......................................................5-23

Dace, Foskett Speckled.......................................5-16

Dace, Independenee Valley Speckled...............5-25

Dace, Kendall Warm Springs ...........................5-51

Dace, Moapa .................................................... 5-33

Daisy, Parish's .................................................4-102

Daisy, Willamette ...........................................4-115

Deer, Columbian White-tailed..........................6-76

Desert-parsley, Bradshaw's .............................4-114

Dudleyea, Mareeseent.......................................4-108

Eider, Spectaeled ............................................6-37

Eider, Steller's .................................................. 6-36

Eulachon, Pacific ...............................................

Evening-primrose, San Benito ............................4-67

Falcon, Northern Aplomado ............................6-40

Ferret, Black-footed .......................................6-109

Flannelbush, Mexican.......................................4-67

Flannelbush, Pine Hill ....................................4-63

Fleabane, Zuni ..............................................4-46

Flycatcher, Southwestern Willow....................6-52

Four-o'eloek, Macfarlane's ..............................4-55

Fox, San Joaquin Kit......................................6-101

Fritillary, Gentner's ......................................4-59

Frog, California Red-legged .............................6-22

Frog, Chiricahua Leopard ................................6-18

Frog, Mountain Yellow-legged.........................6-23

Frog, Oregon Spotted.........................................6-25

Frog, Sierra Nevada Yellow-legged .................6-23

Gambusia, Pecos ................................................5-44

Gilia, Monterey..................................................4-78

Gnateatcher, Coastal California ........................6-60

Goby, Tidewater ................................................5-55

Goldfields, Contra Costa ................................4-88

Gumplant, Ash Meadows .................................4-26

Howellia, Water .............................................4-122

lsopod, Socorro ................................................. 5-42

Ivesia, Ash Meadows .........................................4-25

Ivesia, Webber .................................................4-17

Jaguar ............................................................. $6-81$

Jewelflower, California......................................4-97

Jewelflower, Metealf Canyon..........................4-106

Kangaroo Rat, Fresno ...................................6-104

Kangaroo Rat, Giant ........................................6-103

Kangaroo Rat, Morro Bay .............................6-107
Kangaroo Rat, San Bernardino Merriam's .... 6-105

Kangaroo Rat, Stephen's ............................. 6-106

Kangaroo Rat, Tipton .................................... 6-105

Ladies'-tresses, Canelo Hills ............................ 4-30

Ladies'-tresses, Ute....................................... 4-122

Lark, Streaked Horned ...................................... 6-47

Larkspur, Yellow ........................................... 4-109

Layia, Beach .................................................... 4-79

Lily, Western ................................................... 4-79

Limpet, Banbury Springs ................................... 5-21

Lizard, Blunt-nosed Leopard ........................... 6-31

Lizard, Coachella Valley Fringe-toed.............. 6-26

Lomatium, Bradshaw's .................................. 4-114

Lomatium, Cook's ........................................... 4-89

Lupine, Kineaid's .......................................... 4-116

Lynx, Canada .................................................. 6-98

Mallow, Gierisch ........................................... 4-38

Mallow, Kern ................................................. 4-99

Manzanita, Ione ............................................. 4-60

Manzanita, Morro ............................................. 4-68

Meadowfoam, Butte County ............................ 4-91

Meadowfoam, Large-flowered Woolly ........... 4-90

Mesa-mint, Otay ............................................. 4-83

Milk-veteh, Applegate's ............................... 4-119

Milk-vetch, Ash Meadows.............................. 4-24

Milk-vetch, Braunton's ..................................... 4-65

Milk-vetch, Coachella Valley ......................... 4-18

Milk-vetch, Cushenbury ................................ 4-101

Milk-veteh, Deseret ............................................ 4-9

Milk-vetch, Fish Slough ................................... 4-4

Milk-veteh, Heliotrope....................................... 4-14

Milk-veteh, Holmgren ..................................... 4-33

Milk-veteh, Lane Mountain .............................. 4-19

Milk-vetch, Mancos ......................................... 4-45

Milk-vetch, Osterhout ..................................... 4-56

Milk-vetch, Pierson's ................................... 4-21

Milk-veteh, Shivwitz .................................... 4-34

Milk-vetch, Triple-ribbed ................................ 4-22

Milkweed, Welsh's ...................................... 4-40

Minnow, Loach ................................................ 5-39

Minnow, Rio Grande Silvery ........................... 5-63

Monardella, Willowy .................................... 4-110

Morning-glory, Stebbins' .................................. 4-61

Moth, Kern Primrose Sphinx .............................. 6-8

Mountain Balm, Indian Knob ........................... 4-69

Mouse, New Mexico Meadow Jumping .......... 6-88

Mouse, Preble's Meadow Jumping .................. 6-86

Murrelet, Marbled............................................ 6-64

Mustard, Penland Alpine Fen ........................ 4-57 
Naucorid, Ash Meadows

Niterwort, Amargosa

4-23

Ocelot.

6-80

Onion, Munz's .

4-92

Orchid, Western Prairic Fringed.

4-50

Oreutt Grass, California ................................... 4-83

Oreutt Grass, Hairy ........................................ 4-84

Oreutt Grass, San Joaquin Valley ................... 4-87

Oreutt Grass, Slender ...................................... 4-87

Owl, Mexican Spotted .................................... 6-66

Owl, Northern Spotted .................................. 6-65

Owl's-elover, Fleshy.................................... 4-85

Oxytheea, Cushenbury .................................. 4-104

Pennyroyal, Todsen's..................................... 4-48

Penstemon, Blowout ...................................... 4-52

Peppergrass, Slickspot ................................. 4-3

Phacelia, Clay .................................................. 4-14

Phacelia, Debeque ....................................... 4-16

Phacelia, North Park ..................................... 4-53

Phlox, Yreka ............................................ 4-105

Pikeminnow, Colorado ................................... 5-65

Piperia, Yadon's.......................................... 4-1 13

Plover, Piping............................................. 6-45

Plover, Western Snowy (Pacific Population)... 6-44

Poolfish, Pahrump ........................................... 5-36

Popeornflower, Rough ................................ 4-1 19

Prairie Dog, Utah ......................................... 6-108

Prairie-Chicken, Lesser................................. 6-56

Prickly Poppy, Sacramento ............................ 4-47

Primrose, Maguire ......................................... 4-13

Pronghorn, Sonoran .................................... 6-82

Pupfish, Ash Meadows Amargosa .................. 5-45

Pupfish, Desert ............................................... 5-46

Pupfish, Devil's Hole...................................... 5-45

Pupfish, Owens .......................................... 5-52

Pupfish, Warm Springs ................................. 5-45

Pussypaws, Mariposa.................................... 4-110

Rabbit, Pygmy ............................................. 6-72

Rail, Yuma Clapper ................................... 6-42

Rattlesnake, New Mexican Ridge-nosed ........ 6-28

Reed-mustard, Barneby................................... 4-11

Reed-mustard, Clay ........................................ 4-10

Reed-mustard, Shrubby................................. 4-12

Ridge-cress, Barneby .................................... 4-8

Rock-cress, McDonald's.............................. 4-107

Sage-grouse, Greater................................... 6-55

Sage-grouse, Gunnison ................................. 6-55

Salamander, California Tiger....................... 6-20

Salamander, Desert Slender .......................... 6-16
Salamander, Sonora Tiger............................ 6-17

Salmon, Chinook ................................................ 5-3

Salmon, Chum.................................................... 5-7

Salmon, Coho ............................................... 5-2

Salmon, Soekeye ......................................... 5-8

Sandwort, Marsh ......................................... 4-121

Sedge, Navajo ............................................ 4-42

Sheep, Peninsular Bighorn ......................... 6-111

Sheep, Sierra Nevada Bighorn ....................... 6-111

Shiner, Arkansas River .................................. 5-61

Shiner, Beautiful ........................................ 5-37

Shiner, Pecos Bluntnose............................... 5-38

Shrew, Buena Vista Lake Ornate ................... 6-89

Shrimp, Conservancy Fairy............................ 5-57

Shrimp, Longhorn Fairy ................................... 5-57

Shrimp, Vernal Pool Fairy .............................. 5-57

Shrimp, Vernal Pool Tadpole.......................... 5-57

Skipper, Carson Wandering .............................. 6-4

Skipper, Pawnee Montane................................... 6-5

Skyrocket, Pagosa ....................................... 4-58

Smelt, Delta .................................................. 5-56

Snail, Bliss Rapids ....................................... 5-21

Snail, Morro Shoulderband ................................ 6-1

Snail, Pecos Assiminea ................................... 5-44

Snail, Snake River Physa ................................. 5-21

Snake, Giant Garter....................................... 6-30

Snake, Narrow-headed Garter......................... 6-28

Snake, Northern Mexican Garter ................... 6-28

Spikedace .................................................... 5-41

Spinedace, Big Spring.................................. 5-28

Spinedace, Little Colorado............................. 5-29

Spinedace, White River ............................... 5-24

Spineflower, Howell's .................................... 4-76

Spineflower, Monterey .................................... 4-75

Spineflower, Oreutt's .................................. 4-70

Spineflower, Robust...................................... 4-111

Spineflower, Slender-horned .......................... 4-72

Springfish, Hiko White River .......................... 5-26

Springfish, Railroad Valley............................. 5-27

Springfish, White River ................................. 5-26

Springsnail, Alamosa ...................................... 5-43

Springsnail, Bruneau Hot ................................. 5-22

Springsnail, Koster's..................................... 5-44

Springsnail, Roswell ........................................ 5-44

Springsnail, Socorro........................................ 5-43

Spurge, Hoover's ........................................... 4-86

Squirrel, Northern Idaho Ground...................... 6-91

Stickleback, Unarmored Threespine ................ 5-53

Stickseed, Showy ….................................... 4-120 
Sturgeon, Green …............................................ 5-15

Sturgeon, Pallid .............................................. 5-49

Sturgeon, White (Kootenai River Population) ..5-47

Sucker, June.................................................. 5-18

Sucker, Lost River ........................................... 5-60

Sucker, Modoc.................................................... 5-51

Sucker, Razorback ............................................5-64

Sucker, Santa Ana.............................................5-54

Sucker, Shortnose ............................................5-60

Sucker, Warner ................................................ 5-17

Sunburst, Hartweg's Golden ..............................4-94

Sunburst, San Joaquin Adobe ............................4-95

Sunflower, Pecos .............................................4-36

Sunray, Ash Meadows ....................................4-27

Tarplant, Gaviota .......................................... 4-112

Tarplant, Otay ................................................. 4-82

Tern, Least (Interior) ........................................6-46

Thelypody, Howell's Speetacular.....................4-55

Thistle, Chorro Creek Bog..............................4-108

Thistle, La Graciosa.......................................4-73

Thornmint, San Diego ...................................4-81

Toad, Arroyo ................................................... 6-21

Toad, Wyoming .............................................. 6-19

Toad, Yosemite................................................... $6-24$

Topminnow, Gila .............................................. $5-36$

Topminnow, Yaqui ...........................................5-36
Tortoise, Desert (Mojave population) ............. 6-27

Towhee, Inyo California .................................. 6-51

Townsendia, Last Chance ................................. 4-13

Trout, Bull................................................ 5-13

Trout, Gila........................................................ 5-39

Trout, Greenback Cutthroat ............................ 5-50

Trout, Lahontan Cutthroat ............................... 5-22

Trout, Steelhead ................................................. 5-9

Tuctoria, Greene's ........................................... 4-85

Twinpod, Dudley Bluffs ................................... 4-15

Vervain, Red Hills ....................................... 4-100

Vireo, Least Bell's ............................................ 6-50

Vole, Amargosa ............................................... 6-85

Vole, Hualapai Mexican ................................. 6-84

Wallflower, Menzies' ..................................... 4-77

Water-umbel, Huachuea .................................. 4-30

Wild-buckwheat, Clay-loving ............................ 4-5

Wild-buckwheat, Gypsum ............................... 4-35

Wire-lettuce, Malheur ........................................ 4-1

Wolf, Gray .................................................. 6-113

Woodrat, Riparian........................................... 6-89

Woolly-star, Santa Ana River ......................... 4-72

Woolly-threads, San Joaquin ............................ 4-98

Woundfin ..................................................... 5-33

Yellowhead, Desert .......................................... 4-2

Yerba Santa, Lompoe ..................................... 4-74 


\section{CHAPTER 9}

\section{INDEX OF SPECIES COVERED IN THE BIOLOGICAL ASSESSMENT BY SCIENTIFIC NAME}

Acanthomintha ilicifolia.

4-81

Acipenser medirostris

$5-15$

Acipenser transmontamis ................................ 5-47

Allitm munzii.

4-92

Ambrosia pumila...

4-80

Ambrysus amargosus .................................... 5-34

Ambystoma californiense .............................. 6-20

Ambystoma tigrinum stebbinsi....................... 6-17

Amsonia kearneyana .................................... 4-29

Anaxyrus californicus .................................. 6-21

Anaxymus canorus ......................................... 6-24

Antilocapra americana sonoriensis ............... 6-82

Arabis medonaldiana .................................. 4-107

Arctomecon humilis ................................... 4-33

Arctostaphylos morroensis.............................. 4-68

Arctostaphylos myrtifolia.................................. 4-60

Arenaria paludicola ................................... 4-121

Argemone pleiacantha ssp. pinnatisecta......... 4-47

Asclepias welshii ........................................... 4-40

Assiminea pecos .............................................. 5-44

Astragalus albens...................................... 4-101

Astragalus ampullarioides ............................. 4-34

Astragalus applegatei .................................. 4-119

Astragalus brauntonii ..................................... 4-65

Astragalus desereticus ................................... 4-9

Astragalus holmgreniorum ............................ 4-33

Astragalus humillimus .................................. 4-45

Astragalus jaegerianus ................................. 4-19

Astragalus lentiginosus var. coachellae........... 4-18

Astragalus lentiginosus var. piscinensis ........... 4-4

Astragalus magdalenae var. peirsonii ............. 4-21

Astragalus montii ........................................... 4-14

Astragalus osterhoutii.................................... 4-56

Astragalus phoenix ...................................... 4-24

Astragalus tricarinatus ................................. 4-22

Atriplex coronata var. notatior ....................... 4-92

Baccharis vanessae................................... 4-71
Batrachoseps aridus..................................... 6-16

Berberis nevinii .............................................. 4-65

Boloria acrocnema.......................................... 6-6

Brachylagus idahoensis ................................ 6-72

Brachyramphus marmoratus.......................... 6-64

Branchinecta conservatio ............................. 5-57

Branchinecta longiantenna ............................ 5-57

Branchinecta lynchi ...................................... 5-57

Brodiaea filifolia ............................................. 4-93

Bufo baxteri.................................................. 6-19

Bufo californicus ............................................ 6-21

Calyptridium pulchellum ............................. 4-110

Calystegia stebbinsii ....................................... 4-61

Camissonia benitensis..................................... 4-67

Conis lupus .............................................. 6-113

Carex specuicola.......................................... 4-42

Castilleja campestris ssp. succulenta............... 4-85

Catostomus microps ..................................... 5-51

Catostomus santaanae .................................. 5-54

Catostomus warnerensis ............................... 5-17

Caulanthus californicus ................................ 4-97

Ceanothus ferrisae...................................... 4-111

Ceanothus roderickii..................................... 4-62

Centaurium mamophilum ................................. 4-25

Centrocercus minimus ..................................... 6-55

Centrocercus urophasianus ............................ 6-55

Chamaesyce hooveri ...................................... 4-86

Charadrius melodus .......................................... 6-45

Charadrius nivosus nivosus .......................... 6-44

Chasmistes brevirostris .................................. 5-60

Chasmistes cujus ............................................. 5-23

Chasmistes liorus ............................................ 5-18

Chlorogalum purpureum var. purpureum........ 4-95

Chorizanthe howellii...................................... 4-76

Chorizanthe orcuttiana .................................... 4-70

Chorizanthe pungens var. pungens ................. 4-75

Chorizanthe robusta var. robusta ................. 4-111 
Cirsium fontinale var. obispoense .................4-108

Cirsium scariosum var. loncholepis.................4-73

Clarkia springvillensis..................................4-100

Coccyzus americanus........................................6-53

Coryphantha robbinsorum...............................4-31

Coryphantha scheeri var. robustispina.............4-29

Coryphantha sneedii var. leei ..........................4-35

Coryphantha sneedii var. sneedii......................4-36

Crenichthys baileyi baileyi ...............................5-26

Crenichthys baileyi grandis .............................5-26

Crenichthys nevadae ...................................... 5-27

Crotalus willardi obscurus ..............................6-28

Cycladenia humilis var. jonesii........................4-41

Cynomys parvidens .........................................6-108

Cyprinella formosa .........................................5-37

Cyprinodon diabolis ........................................ $5-45$

Cyprinodon macularius ....................................5-46

Cyprinodon nevadensis mionectes.....................5-45

Cyprinodon nevadensis pectoralis .....................5-45

Cyprinodon radiosus ...................................... 5-52

Deinandra conjugens.....................................4-82

Deinandra increscens ssp. villosa .................4-112

Delphineum luteum.....................................4-109

Deltistes huxatus .................................................5-60

Desmocerus californicus dimorphus ...............6-13

Dipodomys heermanni morroensis .................6-107

Dipodomys ingens...........................................6-103

Dipodomys merriami parvus ..........................6-105

Dipodomys nitratoides exilis ........................6-104

Dipodonys nitratoides nitratoides..................6-105

Dipodomys stephensi .................................6-106

Dodecahema leptoceras...................................4-72

Dudleya cymosa ssp. marcescens ..................4-108

Echinocactus horizonthalonius var. nicholli.....4-28

Echinocereus fendleri var. kuenzleri ................4-48

Echinocereus triglochidiatus var. arizonicus ...4-32

Echinomastus erectocentrus var. acunensis .....4-37

Empetrichthys latos .........................................5-36

Empidonax traillii extimus................................6-52

Enceliopsis mudicaulis var. corrugata ..............4-27

Eremalche kernensis ......................................4-99

Eremichthys acros ..............................................5-23

Eremophila alpestris strigata ........................6-47

Eriastrum densifolium ssp. sanctorum.............4-72

Erigeron decumbens var. decumbens .............4-115

Erigeron parishii ..........................................4-102

Erigeron rhizomatus .....................................4-46

Eriodictyon altissimum ..................................4-69

Eriodictyon capitatum ...................................4-74
Eriogonum apricum ..................................... 4-60

Eriogonum gypsophilum ................................ 4-35

Eriogonum ovalifolium var. vineum ............... 4-103

Eriogonum ovalifolium var. williamsiae ............ 4-2

Eriogonum pelinophilum ................................. 4-5

Erysimum menziesii ........................................ 4-77

Eucyclogobius newberryi.............................. 5-55

Euphydryas editha quino ................................... 6-7

Euphydryas editha taylori............................... 6-11

Euproserpinus enterpe .................................... 6-8

Eutrema penlandii .......................................... 4-57

Falco femoralis septentrionalis ...................... 6-40

Fremontodendron californicum spp.

decumbens..................................................... 4-63

Fremontodendron mexicanum ....................... 4-67

Fritillaria gentneri........................................ 4-59

Galium californicum ssp. sierrae................... 4-63

Gambelia silus ................................................. 6-31

Gambusia nobilis ............................................ 5-44

Gammarus desperatus ................................... 5-42

Gasterosteus aculeatus williamsoni................ 5-53

Gaura neomexicana var. coloradensis ........... 4-52

Gila bicolor mohavensis ................................ 5-31

Gila bicolor snyderi...................................... 5-20

Gila bicolor ssp........................................... 5-19

Gila boraxobius ............................................... 5-19

Gila cypha..................................................... 5-62

Gila elegans ................................................ 5-62

Gila intermedia ............................................... 5-40

Gila robusta jordani ...................................... 5-28

Gila seminuda ............................................... 5-32

Gilia tenuiflora ssp. arenaria ........................ 4-78

Gopherus agassizii.......................................... 6-27

Grindelia fraxino-pratensis ........................... 4-26

Grus americana ............................................. 6-69

Gymnogyps californiamus ............................... 6-62

Hackelia vemusta .......................................... 4-120

Hedeoma todsenii ............................................ 4-48

Helianthus paradoxus................................... 4-36

Helminthoglypta walkeriana............................ 6-1

Hesperis leonardus montana ........................... 6-5

Howellia aquatilis....................................... 4-122

Hybognathus amarus ..................................... 5-63

Hypomesus transpacificus .............................. 5-56

Icaricia icarioides fenderi .............................. 6-10

Ipomopsis polvantha.................................... 4-58

Ivesia kingii var. eremica............................... 4-25

Ivesia webberi.......................................... 4-17

Juturnia kosteri.............................................. 5-44 
Lanx sp.

Lasthenia conjugens .

4-88

Layia carnosa 4-79

Leopardus pardalis. 6-80

Lepidium barnebyamum . 4-8

Lepidium papilliferum. 4-3

Lepidomeda albivallis. 5-24

Lepidomeda mollispinis pratensis.

5-28

Lepidomeda vittata

$5-29$

Lepidurus packardi. 5-57

Leptonycteris curosoae yerbabuenae. 6-77

Leptonycyteris nivalis 6-78

Lesquerella congesta. 4-15

Lesquerella tumulosa. 4-43

Lilaeopsis schaffneriana var. recurva. 4-30

Lilinun occidentale. 4-79

Limnanthes floccosa ssp. californica. 4-91 Limnanthes floccosa ssp. grandiflora . 4-90

Lomatium bradshawii.. 4-114

Lomatium cookii 4-89

Lupinus sulphureus ssp. kincaidii. 4-116 Lynx canadensis. 6-98 Meda fulgida... 5-41

Mentzelia leucophylla ………………………... 4-27

Microtus californicus scirpensis ...................... 6-85

Microtus nexicanus hualpaiensis .................... 6-84

Mirabilis macfarlanei ……………………...... 4-55

Moapa coriacea …………………………..... 5-33

Monardella viminea...................................... 4-110

Monolopia congdonii..................................... 4-98

Mustela nigripes ………………………..... 6-109

Neostapfia colusana....................................... 4-88

Neotoma fuscipes riparia ……………………... 6-89

Nitrophila mohavensis ................................ 4-23

Notropis girardi ............................................. 5-61

Notropis simus pecosensis .............................. 5-38

Odocoileus virginianus lencurus ..................... 6-76

Oncorlynchus clarki henshawi........................ 5-22

Oncorhynchus clarki stomias........................... 5-50

Oncorhynchus gilae ……………………..... 5-39

Oncorhynchus keta ………………………..... 5-7

Oncorhynchus kisutch …….............................. 5-2

Oncorhynchus mykiss ……………………….... 5-9

Oncorlynchus nerka ....................................... 5-8

Oncorhynchus tshawytscha............................... 5-3

Opuntia treleasei.............................................. 4-98

Orcuttia californica …………………………... 4-83

Orcuttia inaequalis ......................................... 4-87

Orcuttia pilosa ............................................... 4-84
Orcuttia temis ...................................... 4-87

Oregonichythys crameri................................. 5-59

Ovis caradensis nelsoni............................... 6-111

Ovis canadensis sierrae …………………....... 6-111

Oxyloma haydeni kanabensis........................... 5-30

Oxytheca parishii var. goodmaniana ............. 4-104

Pacifastacus fortis.......................................... 5-53

Panthera onca............................................... 6-81

Pediocactus bradyi......................................... 4-39

Pediocactus despainii ....................................... 4-10

Pediocactus knowltonii .................................... 4-46

Pediocactus peeblesianus var. fickeiseniae..... 4-49

Pediocactus peeblesianus var. peeblesianus.... 4-39

Pediocactus sileri.......................................... 4-42

Pediocactus winkleri....................................... 4-43

Penstemon debilis ......................................... 4-17

Penstemon haydenii ....................................... 4-52

Penstemon penlandii ...................................... 4-57

Phacelia argillacea ......................................... 4-14

Phacelia formosula ………............................. 4-53

Phacelia submutica .......................................... 4-16

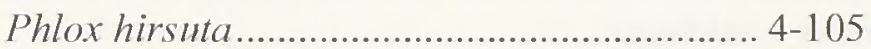

Physa natricina ............................................. 5-21

Physaria obcordata.......................................... 4-15

Piperia yadonii …………………………..... 4-113

Pipilo crissalis eremophilus .............................. 6-51

Plagiobothrys hirtus.................................... 4-119

Plagopterus argentissimus ............................... 5-33

Plantanthera praeclara................................... 4-50

Poeciliopsis occidentalis sonoriensis............... 5-36

Poeciliopsis occidentalis occidentalis.............. 5-36

Pogogyne nudiuscula ..................................... 4-83

Polioptila californica californica...................... 6-60

Polysticta stelleri ………………………....... 6-36

Primula maguirei ………………………….... 4-13

Psendobahia bahiffolia .................................... 4-94

Psendobahia peirsonii ..................................... 4-95

Psendocopaeodes emms obscurus ..................... 6-4

Ptychocheilus lucius.................................... 5-65

Purshia subintegra ......................................... 4-31

Pyrgulopsis bruneauensis ............................... 5-22

Pyrgulopsis neomexicana .............................. 5-43

Pyrgulopsis roswellensis .................................. 5-44

Rallus longirostris yumanensis ........................ 6-42

Rana chiricahmensis...................................... 6-18

Rana draytonii ............................................... 6-22

Rana muscosa ................................................ 6-23

Rana pretiosa ................................................ 6-25

Rana sierrae ................................................... 6-23 
Rangifer tarandus caribou.............................6-93

Rannuculus aestivalis ........................................4-5

Rhinichthys osculus ssp. .................................5-16

Rhinichthys osculus lethoporus .......................5-25

Rhinichthys oscuhs nevadersis ......................5-35

Rhinichthys osculus oligoporus ........................ 5-25

Rhinichthys osculus thermalis .........................5-51

Salvelints confluentus ...................................5-13

Scaphirhynchus albus .....................................5-49

Schoenocrambe argillacea ..............................4-10

Schoenocrambe barnebyi.................................4-11

Schoenocrambe suffrutescens ...........................4-12

Sclerocactus brevispinus .................................... 4-6

Sclerocactus glaucus .......................................4-6

Sclerocactus mesae-verdae .............................4-44

Sclerocactus wetlandicus ....................................4-6

Sclerocactus wrightiae.......................................4-7

Senecio layneae ...............................................4-64

Sidalcea keckii ................................................4-96

Sidalcea nelsoniana ......................................4-117

Sidalcea oregana var. calva .........................4-118

Silene spaldingii .............................................. 4-54

Somateria fischeri..........................................6-37

Sorex ornatus relictus ........................................6-89

Spermophilus brunneus brunneus.....................6-91

Speyeria zerene hippolyta ..................................6-9

Sphaeralcea gietschii .....................................4-38

Spiranthes delitescens......................................4-30
Spiranthes diluvialis ................................... 4-122

Stephanomeria malheurensis ........................... 4-1

Sterna antillarum .......................................... 6-46

Streptanthus albidus ssp. albidus................. 4-106

Strix occidentalis caurina ............................... 6-65

Strix occidentalis lucida................................ 6-66

Taylorconcha serpenticola ............................ 5-21

Thaleichthys pacificus................................... 5-14

Thamnophis eques negalops .......................... 6-28

Thamnophis gigas ........................................... 6-30

Thamnophis rufipunctatus ............................. 6-28

Thelypodium howellia ssp. spectabilis............ 4-55

Thermosphaeroma thermophilus ................... 5-42

Tiaroga cobitis .............................................. 5-39

Townsendia aprica......................................... 4-13

Tryonia alomosae ......................................... 5-43

Tuctoria greenei............................................. 4-85

Tympanachus pallidicinctus .......................... 6-56

Uma inornata .................................................. 6-26

Ursus arctos horribilis.................................. 6-96

Verbena californica ...................................... 4-100

Vireo bellii pusillus .......................................... 6-50

Vulpes macrotis mutica.................................. 6-101

Xyrauchen texanus........................................... 5-64

Yermo xanthocephalus.................................... 4-2

Zapus hudsonius luteus................................... 6-8

Zapus hudsonius preblei ................................ 6-86 
APPENDIX A

STANDARD OPERATING PROCEDURES AND CONSERVATION MEASURES 


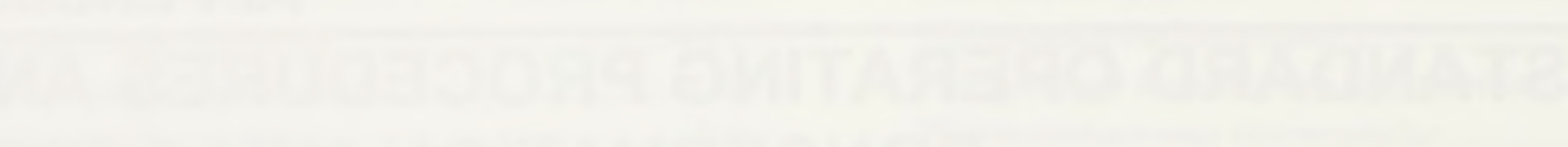
ren 
This section lists SOPs and eonservation measures that are applieable to herbicide treatments projects involving aminopyralid, fluroxypyr, and/or rimsulfuron. They do not include SOPS and eonservation measures that are speeifie to other vegetation treatment methods or herbieide treatments involving the previously approved herbicides, although these proeedures and measures would be implemented if treatments with the three new herbieides also involve other herbieides or treatment methods. A eomplete list of these SOPs and eonservation measures ean be found in the ROD for the 2007 PEIS (USDOI BLM 2007b) and the 2007 BA (USDOI BLM 2007e), whieh ean be found on-line at http://www.blm.gov/wo/st/en/prog/more/veg eis.html.

TABLE A-1

Standard Operating Procedures (Includes Applicable Mitigation from ROD for 2007 PEIS)

\begin{tabular}{|c|c|}
\hline Resource Element & Standard Operating Procedure \\
\hline Guidanee Doeuments & $\begin{array}{l}\text { BLM Handbook H-9011-1 (Chemieal Pest Control); and manuals } 1112 \text { (Safety), } 9011 \\
\text { (Chemieal Pest Control), } 9012 \text { (Expenditure of Rangeland Inseet Pest Control Funds), } \\
9015 \text { (Integrated Weed Management), and } 9220 \text { (Integrated Pest Management). }\end{array}$ \\
\hline General & 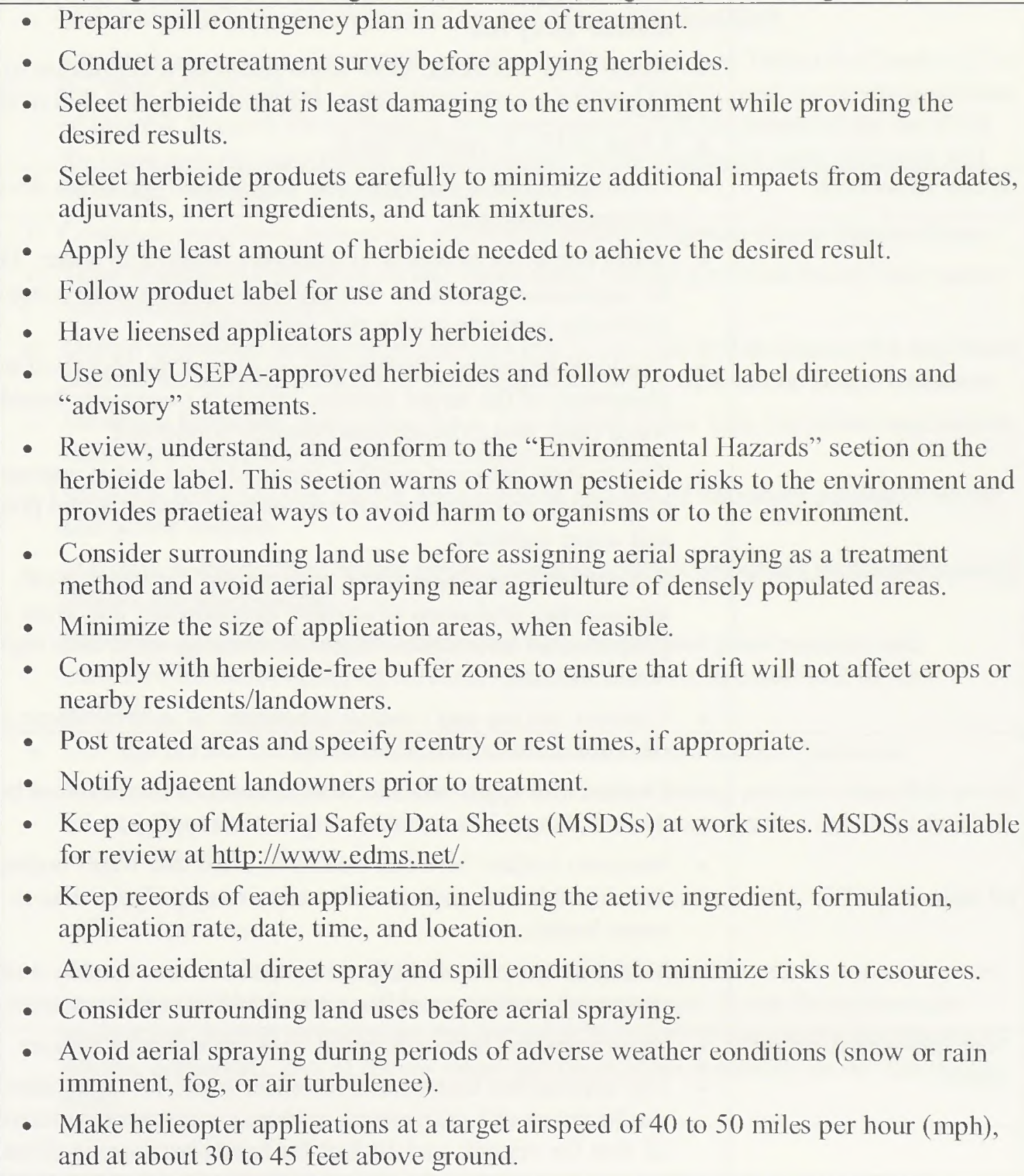 \\
\hline
\end{tabular}


TABLE A-1 (Cont.)

Standard Operating Procedures (Includes Applicable Mitigation from ROD for 2007 PEIS)

\begin{tabular}{|c|c|}
\hline Resource Element & Standard Operating Procedure \\
\hline General (cont.) & $\begin{array}{l}\text { - Take precautions to minimize drift by not applying herbicides when winds execed } \\
10 \text { mph ( greater than } 6 \text { mph for aerial applications) or a serious rainfall event is } \\
\text { imminent. } \\
\text { - Use drift control agents and low volatile formulations. } \\
\text { - Conduct pre-treatment surveys for sensitive habitat and special status species within } \\
\text { or adjacent to proposed treatment areas. } \\
\text { - Consider site characteristies, environmental conditions, and application equipment } \\
\text { in order to minimize damage to non-target vegetation. } \\
\text { - Use drift reduction agents, as appropriate, to reduce the drift hazard to non-target } \\
\text { species. } \\
\text { - Turn off applied treatments at the completion of spray runs and during turns to start } \\
\text { another spray run. } \\
\text { - Refer to the herbicide label when planning revegetation to ensure that subsequent } \\
\text { vegetation would not be injured following application of the herbicide. } \\
\text { - Clean OHVs to remove seeds. }\end{array}$ \\
\hline Water Resources & $\begin{array}{l}\text { - Consider elimate, soil type, and vegetation type when developing herbicide } \\
\text { treatment programs. } \\
\text { - Select herbicide products to minimize impacts to water. This is especially important } \\
\text { for application seenarios that involve risk from active ingredients in a particular } \\
\text { herbicide, as predieted by risk assessments. } \\
\text { - Use local historical weather data to choose the month of treatment. Considering the } \\
\text { phenology of the target species, schedule treatments based on the condition of the } \\
\text { water body and existing water quality conditions. } \\
\text { - Plan to treat between weather fronts (ealms) and at appropriate time of day to avoid } \\
\text { high winds that increase soil movements, and to avoid potential stormwater runoff } \\
\text { and water turbidity. } \\
\text { - Review hydrogeologic maps of proposed treatment areas. Note depths to } \\
\text { groundwater and areas of shallow groundwater and areas of surface water and } \\
\text { groundwater interaction. Minimize treating areas with high risk for groundwater } \\
\text { contamination. } \\
\text { - Conduct mixing and loading operations in an area where an aceidental spill would } \\
\text { not contaminate an aquatic body. } \\
\text { - Do not rinse spray tanks in or near water bodies. Do not broadeast pellets where } \\
\text { there is danger of eontaminating water supplies. } \\
\text { - Maintain buffers between treatment areas and water bodies. Buffer widths should be } \\
\text { developed based on herbicide- and site-specific criteria to minimize impacts to } \\
\text { water bodies. }\end{array}$ \\
\hline $\begin{array}{l}\text { Wetlands and Riparian } \\
\text { Areas }\end{array}$ & $\begin{array}{l}\text { Use a selective herbicide and a wick or backpack sprayer. } \\
\text { Use appropriate herbicide-free buffer zones for herbicides not labeled for aquatic } \\
\text { use based on risk assessment guidance, with minimum widths of } 100 \text { feet for aerial, } \\
25 \text { feet for vehicle, and } 10 \text { feet for hand spray applications. }\end{array}$ \\
\hline
\end{tabular}


TABLE A-1 (Cont.)

Standard Operating Procedures (Includes Applicable Mitigation from ROD for 2007 PEIS)

\begin{tabular}{|c|c|}
\hline Resource Element & Standard Operating Procedure \\
\hline Vegetation & $\begin{array}{l}\text { - Refer to the herbicide label when planning revegetation to ensure that subsequent } \\
\text { vegetation would not be injured following application of the herbicide. } \\
\text { - Use native or sterile species for revegetation projects to compete with invasive } \\
\text { species until desired vegetation establishes. } \\
\text { - Use weed-free fecd for horses and pack animals. Use weed-free straw and mulch for } \\
\text { revegetation and other activities. } \\
\text { - Identify and implement any temporary domestie livestock grazing and/or } \\
\text { supplemental feeding restrictions needed to enhance desirable vegetation recovery } \\
\text { following treatment. Consider adjustments in the existing grazing permit, needed to } \\
\text { maintain desirable vegetation on the treatment site. } \\
\text { Minimize the use of terrestrial herbicides in watersheds with downgradient ponds } \\
\text { and streams if potential impacts to aquatic plants are identified. } \\
\text { - Establish appropriate (herbicide-spceific) buffer zones (see Tables 4-12 and 4-14 in } \\
\text { the } 2007 \text { PEIS) around downstream water bodies, habitats, and species/populations } \\
\text { of interest. Consult the ecological risk assessments (ERAs) prepared for the PEIS } \\
\text { for more specific information on appropriate buffer distances under different soil, } \\
\text { moisture, vegetation, and application scenarios. }\end{array}$ \\
\hline Pollinators & $\begin{array}{l}\text { - Complete vegetation treatments scasonally before pollinator forage plants bloom. } \\
\text { - Time vegetation treatments to take place when foraging pollinators are least active } \\
\text { both seasonally and daily. } \\
\text { - Design vegetation treatment projects so that nectar and pollen sources for important } \\
\text { pollinators and resources arc treated in patches rather than in one single treatment. } \\
\text { - Minimize herbicide application rates. Use typical rather than maximum application } \\
\text { rates where there are important pollinator resources. } \\
\text { - Maintain herbicide free buffer zones around patches of important pollinator nectar } \\
\text { and pollen sourees. } \\
\text { - Maintain herbicide frec buffer zones around patehes of important pollinator nesting } \\
\text { habitat and hibernacula. } \\
\text { Maintain special note of pollinators that have single host plant speeies, and } \\
\text { minimize herbicide spraying on those plants (if invasive species) and in their } \\
\text { habitats. }\end{array}$ \\
\hline $\begin{array}{l}\text { Fish and Other } \\
\text { Aquatic Organisms }\end{array}$ & $\begin{array}{l}\text { - Use appropriate buffer zones based on label and risk assessment guidance. } \\
\text { - Minimize treatments near fish-bearing water bodies during periods when fish are in } \\
\text { life stages most sensitive to herbicide(s) used, and use spot rather than broadcast or } \\
\text { aerial treatments. } \\
\text { - Use appropriate application equipment/method near water bodies if the potential for } \\
\text { off-site drift exists. } \\
\text { - For treatment of aquatic vegetation: 1) treat only that portion of the aquatic system } \\
\text { necessary to achieve acceptable vegetation management; 2) use the appropriatc } \\
\text { application method to minimize the potential for injury to desirable vegetation and } \\
\text { aquatic organisms; and 3) follow water use restrictions presented on the herbicide } \\
\text { label. }\end{array}$ \\
\hline
\end{tabular}


TABLE A-1 (Cont.)

Standard Operating Procedures (Includes Applicable Mitigation from ROD for 2007 PEIS)

\begin{tabular}{|c|c|}
\hline Resource Element & Standard Operating Procedure \\
\hline $\begin{array}{l}\text { Fish and Other } \\
\text { Aquatie Organisms } \\
\text { (eont.) }\end{array}$ & $\begin{array}{l}\text { - Limit the use of terrestrial herbieides in watersheds with eharactcristies suitable for } \\
\text { potential surfaee runoff that have fish-bearing streams during periods when fish are } \\
\text { in life stages most sensitive to the herbieide(s) used. } \\
\text { - Consider the proximity of application areas to salmonid habitat and the possible } \\
\text { cffects of herbicides on riparian and aquatie vegetation. Maintain appropriate buffer } \\
\text { zones around salmonid-bearing streams (see Appendix C, Table C-16, of the } 2007 \\
\text { PEIS, and reeommendations in the individual ERAs). } \\
\text { - Avoid using the adjuvant R-11 }{ }^{\mathbb{B}} \text { in aquatie environments, and either avoid using } \\
\text { glyphosate formulations eontaining polyoxyethyleneamine (POEA), or seek to use } \\
\text { formulations with the least amount of POEA, to reduee risks to aquatic organisms in } \\
\text { aquatie environments. }\end{array}$ \\
\hline Wildlife & $\begin{array}{l}\text { - Use herbieides of low toxieity to wildlife, where fcasible. } \\
\text { - Use spot applications or low-boom broadeast operations where possible to limit the } \\
\text { probability of eontaminating non-target food and water sourees, especially non- } \\
\text { target vegetation over areas larger than the trcatment area. } \\
\text { - Use timing restrietions (e.g., do not treat during eritical wildlife breeding or staging } \\
\text { periods) to minimize impaets to wildlife. } \\
\text { - Avoid using glyphosate formulations that inelude } \mathrm{R}-11^{\circledR} \text { in the future, and either } \\
\text { avoid using and formulations with POEA, or seek to use the formulation with the } \\
\text { lowest amount of POEA available, to reduee risks to amphibians. } \\
\text { - Use appropriate buffer zones (see Tables } 4-12 \text { and } 4-14 \text { in Chapter } 4 \text { of the } 2007 \\
\text { PEIS) to limit eontamination of off-site vegetation, which may serve as forage for } \\
\text { wildlife. }\end{array}$ \\
\hline $\begin{array}{l}\text { Threatened, } \\
\text { Endangered, and } \\
\text { Sensitive Speeies }\end{array}$ & $\begin{array}{l}\text { - Survey for speeial status speeies before treating an area. Consider effeets to speeial } \\
\text { status species when designing herbieide treatment programs. } \\
\text { - Use a selcctive herbieide and a wiek or baekpaek sprayer to minimize risks to } \\
\text { speeial status plants. } \\
\text { - Avoid treating vegetation during time-sensitive periods (c.g., nesting and migration, } \\
\text { sensitive life stages) for speeial status speeies in an area to be treated. } \\
\text { - Implement all eonscrvation measures for special status plant and animal speeies } \\
\text { presented in the } 2007 \mathrm{BA} \text {. }\end{array}$ \\
\hline
\end{tabular}


TABLE A-2

Programmatic Conservation Measures for Herbicide Treatments with Aminopyralid, Fluroxypyr, and Rimsulfuron (including measures from 2007 BA not specific to previously approved herbicides)

\begin{tabular}{|c|c|}
\hline Species/Species Group & Programmatic Conservation Measures \\
\hline Plants & 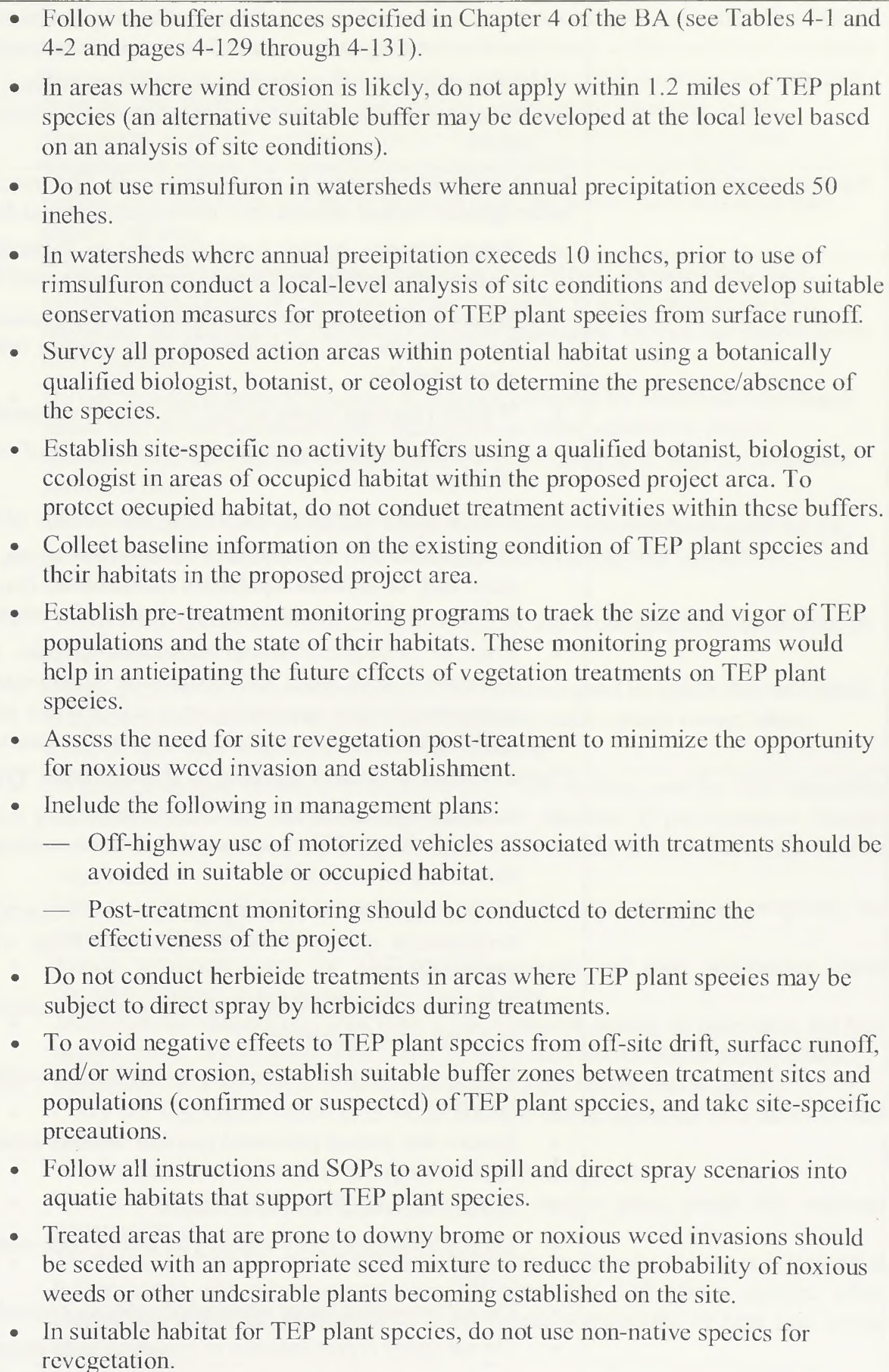 \\
\hline
\end{tabular}


TABLE A-2 (Cont.)

Programmatic Conservation Measures for Herbicide Treatments with Aminopyralid, Fluroxypyr, and Rimsulfuron (including measures from $2007 \mathrm{BA}$ not specific to previously approved herbicides)

\begin{tabular}{|c|c|}
\hline Speeies/Speeies Group & Programmatic Conservation Measures \\
\hline Plants (cont.) & $\begin{array}{l}\text { Vehicles and other equipment used during treatment activities should be washed } \\
\text { prior to arriving at a new location to avoid the transfer of noxious weeds. } \\
\text { Follow all BLM operating procedures for avoiding herbicide treatments during } \\
\text { climatic conditions that would inerease the likelihood of spray drift or surface } \\
\text { runoff. }\end{array}$ \\
\hline Aquatic Animals & 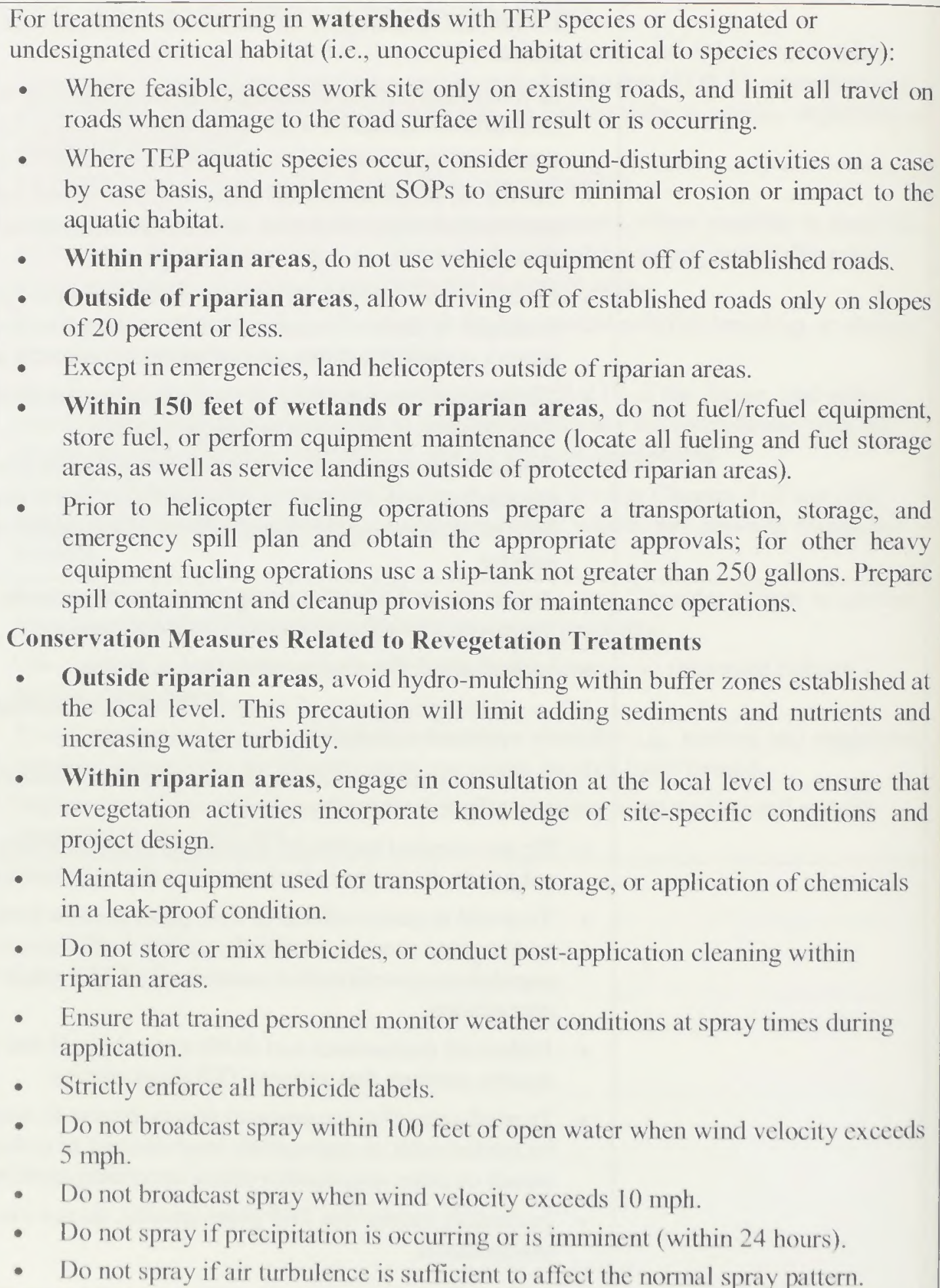 \\
\hline
\end{tabular}


TABLE A-2 (Cont.)

Programmatic Conservation Measures for Herbicide Treatments with Aminopyralid, Fluroxypyr, and Rimsulfuron (including measures from 2007 BA not specific to previously approved herbicides)

\begin{tabular}{|c|c|}
\hline Species/Species Group & Programmatic Conservation Measures \\
\hline Aquatic Animals (eont.) & $\begin{array}{l}\text { Do not broadeast spray herbieides in riparian areas that provide habitat for TEP } \\
\text { aquatie speeies. Determine appropriate buffer distanees at the loeal level to ensure } \\
\text { that overhanging vegetation that provides habitat for TEP speeies is not removed } \\
\text { from the site. Buffer distanees provided as eonservation measures in the } \\
\text { assessment of effeets to plants (Chapter } 4 \text { of the BA) and fish and aquatie } \\
\text { invertebrates should be eonsulted as guidanee (Table 5-5 of the BA). } \\
\text { Follow all instruetions and SOPs to avoid spill and direet spray seenarios into } \\
\text { aquatie habitats. }\end{array}$ \\
\hline $\begin{array}{l}\text { Morro Shoulderband } \\
\text { Snail }\end{array}$ & $\begin{array}{l}\text { When eondueting herbieide treatments in or near Morro shoulderband snail } \\
\text { habitat, avoid the use of fluroxypyr, where feasible. If pre-treatment surveys } \\
\text { determine the presenee of the Morro shoulderband snail. Do not use fluroxypyr to } \\
\text { treat vegetation. } \\
\text { - Do not broadeast spray fluroxypyr in habitats oeeupied by Morro shoulderband } \\
\text { snails, and do not broadeast spray fluroxypyr in areas adjacent to Morro } \\
\text { shoulderband snail habitat under eonditions when spray drift onto the identified } \\
\text { habitat is likely. } \\
\text { - Survey treatment sites within the range of the Morro shoulderband snail for the } \\
\text { presenee of the snail, prior to formulating treatment programs (should be } \\
\text { eondueted by a qualified biologist). } \\
\text { - Do not burn, eonduet meehanieal treatments, or use broad-speetrum herbieides in } \\
\text { habitats oeeupied by snails. } \\
\text { Do not perform herbieide treatments in habitats oeeupied by snails that will result } \\
\text { in a substantial reduetion of plant (and espeeially native plant) eover; where } \\
\text { feasible, spot treat vegetation rather than spraying. }\end{array}$ \\
\hline Butterflies and Moths & $\begin{array}{l}\text { - When eondueting herbieide treatments in or near habitat used by TEP butterflies } \\
\text { or moths, avoid the use of fluroxypyr, where feasible. If pre-treatment surveys } \\
\text { determine the presenee of TEP butterflies or moths, do not use fluroxypyr to treat } \\
\text { vegetation. } \\
\text { - Use an integrated pest management approaeh when designing programs for } \\
\text { managing pest outbreaks. } \\
\text { - Survey treatment areas for TEP butterflies/moths and their host/neetar plants } \\
\text { (suitable habitat) at the appropriate times of year. } \\
\text { Minimize the disturbanee area with a pre-treatment survey to determine the best } \\
\text { aeeess routes. Avoid areas with butterfly/moth host plants and/or neetar plants. } \\
\text { Minimize OHV aetivities on sites that support host and/or neetar plants. } \\
\text { Carry out vegetation removal in small areas, ereating openings of } 5 \text { aeres or less } \\
\text { in size. } \\
\text { - Wash equipment before it is brought into the treatment area. } \\
\text { Use a seed mix that eontains host and/or neetar plant seeds for road/site } \\
\text { reelamation. } \\
\text { To proteet host and neetar plants from herbieide treatments, follow reeommended } \\
\text { buffer zones and other eonservation measures for TEP plants speeies when } \\
\text { eondueting herbieide treatments in areas where populations of host and neetar } \\
\text { plants oeeur. }\end{array}$ \\
\hline
\end{tabular}


TABLE A-2 (Cont.)

Programmatic Conservation Measures for Herbicide Treatments with Aminopyralid, Fluroxypyr, and Rimsulfuron (including measures from $2007 \mathrm{BA}$ not specific to previously approved herbicides)

\begin{tabular}{|c|c|}
\hline Species/Species Group & Programmatic Conservation Measures \\
\hline $\begin{array}{l}\text { Butterflies and Moths } \\
\text { (cont.) }\end{array}$ & $\begin{array}{l}\text { Do not broadeast spray herbicides in habitats oecupied by TEP butterflies or } \\
\text { moths; do not broadeast spray herbicides in areas adjacent to TEP butterfly/moth } \\
\text { habitat under conditions when spray drift onto the habitat is likely. }\end{array}$ \\
\hline $\begin{array}{l}\text { Valley Elderberry } \\
\text { Longhorn Beetle }\end{array}$ & $\begin{array}{l}\text { - Survey proposed treatment sites within the range of the valley elderberry longhorn } \\
\text { beetle for the presence of the beetle and its elderberry host plant (should be } \\
\text { condueted by a qualified biologist). } \\
\text { - When conducting herbicide treatment in or near habitat used by the valley } \\
\text { elderberry longhorn beetle, avoid the use of fluroxypyr, where feasible. If pre- } \\
\text { treatment surveys determine the presence of valley elderberry longhorn beetles, do } \\
\text { not use fluroxypyr to treat vegetation. } \\
\text { - To protect host elderberry plants from herbieide treatments, follow recommended } \\
\text { buffer zones and other conservation measures for TEP plants speeies, as listed in } \\
\text { Chapter } 4 \text { of the BA, when condueting herbicide treatments in areas where } \\
\text { populations of elderberry oecur. } \\
\text { Do not broadcast spray herbicides in suitable valley elderberry longhorn beetle } \\
\text { habitat; do not broadeast spray herbicides in areas adjacent to suitable habitat } \\
\text { under conditions when spray drift onto the habitat is likely. }\end{array}$ \\
\hline Amphibians and Reptiles & $\begin{array}{l}\text { - Survey all areas that may support TEP amphibians and/or reptiles prior to } \\
\text { treatments. } \\
\text { - In habitats where aquatic herpetofauna oceur, implement all conservation measures } \\
\text { identified for aquatic organisms in Chapter } 4 \text { of the BA. } \\
\text { - Do not broadeast spray herbicides in riparian areas or wetlands that provide habitat } \\
\text { for TEP herpetofauna. } \\
\text { - In desert tortoise habitat, conduct herbicide treatments during the period when } \\
\text { desert tortoises are least aetive. } \\
\text { - To the greatest extent possible, avoid desert tortoise burrows during herbicide } \\
\text { treatments. } \\
\text { - When conducting herbicide treatments in upland areas adjacent to aquatic or } \\
\text { wetland habitats that support TEP herpetofauna, do not broadeast spray during } \\
\text { conditions under which off-site drift is likely. } \\
\text { - Follow all instructions and SOPs to avoid spill and direct spray scenarios into } \\
\text { aquatic habitats that support TEP herpetofauna. }\end{array}$ \\
\hline $\begin{array}{l}\text { Steller's and Spectacled } \\
\text { Eider }\end{array}$ & $\begin{array}{l}\text { Prior to developing management plans associated with treatment activities, assess } \\
\text { whether Steller's or spectacled eiders are likely to use areas proposed for treatment } \\
\text { for nesting or brood-rearing activities. } \\
\text { - Do not conduct vegetation treatments during the breeding season (as determined } \\
\text { by a qualified wildlife biologist). }\end{array}$ \\
\hline $\begin{array}{l}\text { Northern Aplomado } \\
\text { Falcon }\end{array}$ & $\begin{array}{l}\text { Prior to conducting vegetation treatments, survey the project area for northern } \\
\text { aplomado falcon nests. } \\
\text { - Where surveys detect breeding birds, do not implement herbicide treatments } \\
\text { during the breeding season. }\end{array}$ \\
\hline
\end{tabular}




\section{TABLE A-2 (Cont.)}

Programmatic Conservation Measures for Herbicide Treatments with Aminopyralid, Fluroxypyr, and Rimsulfuron (including measures from 2007 BA not specific to previously approved herbicides)

\begin{tabular}{|c|c|}
\hline Species/Species Group & Programmatic Conservation Measures \\
\hline $\begin{array}{l}\text { Northern Aplomado } \\
\text { Faleon (eont.) }\end{array}$ & $\begin{array}{l}\text { - Avoid eondueting vegetation treatments in northern aplomado faleon habitat } \\
\text { during the nesting period. } \\
\text { - Avoid broadeast spraying herbieides in areas where future faleon nesting trees } \\
\text { oeeur. }\end{array}$ \\
\hline Yuma Clapper Rail & $\begin{array}{l}\text { - Conduet surveys prior to vegetation treatments within potential or suitable habitat. } \\
\text { - Where surveys deteet birds, do not implement treatments during the breeding } \\
\text { season. } \\
\text { - In habitats where Yuma elapper rails oeeur, follow the riparian/aquatie habitat } \\
\text { proteetion measures diseussed in Chapter 5. } \\
\text { - Closely follow all applieation instruetions and use restrietions on herbieide labels } \\
\text { (ineluding aquatie and wetland habitat use restrietions). }\end{array}$ \\
\hline $\begin{array}{l}\text { Western Snowy Plover, } \\
\text { Piping Plover, Least Tern } \\
\text { (interior), and Streaked } \\
\text { Horned Lark }\end{array}$ & $\begin{array}{l}\text { - Survey for western snowy plovers, piping plovers, interior least terns, and streaked } \\
\text { horned larks (and their nests) in suitable areas of proposed treatment areas, prior to } \\
\text { developing treatment plans. } \\
\text { - Do not treat vegetation in nesting areas during the breeding season (as determined } \\
\text { by a qualified biologist). } \\
\text { - Do not allow human (or domestie animal) disturbanee within } 1 / 4 \text { mile of nest sites } \\
\text { during the nesting period. } \\
\text { - Conduet beaehgrass treatments during the plant's flowering stage, during periods } \\
\text { of aetive growth. } \\
\text { - Closely follow all applieation instruetions and use restrietions on herbieide labels } \\
\text { (ineluding aquatie and wetland habitat use restrietions). }\end{array}$ \\
\hline $\begin{array}{l}\text { Least Bell's Vireo, Inyo } \\
\text { California Towhee, } \\
\text { Southwestern Willow } \\
\text { Flyeateher, and Yellow- } \\
\text { billed Cuekoo }\end{array}$ & $\begin{array}{l}\text { - Conduet surveys prior to vegetation treatments within potential or suitable habitat. } \\
\text { - Where surveys deteet birds, do not broadeast spray herbieides. } \\
\text { - } \text { unsurveyed suitable habitat during the breeding season (as determined by a } \\
\text { qualified wildlife biologist). } \\
\text { - Adjust spatial and temporal seales of treatments so that not all suitable habitat is } \\
\text { affeeted in any given year. } \\
\text { - Following treatments, replant or reseed treated areas with native species, if needed. } \\
\text { - Closely follow all application instructions and use restrictions on herbicide labels } \\
\text { (including aquatic and wetland habitat use restrictions). }\end{array}$ \\
\hline $\begin{array}{l}\text { Gunnison Sage-grouse } \\
\text { and Greater Sage-grouse } \\
\text { (Bi-State DPS) }\end{array}$ & $\begin{array}{l}\text { - Conduet surveys prior to vegetation treatments within potential or suitable habitat. } \\
\text { - Where surveys deteet birds, or in known habitats, do not broadeast spray } \\
\text { herbieides. } \\
\text { - Coordinate with state wildlife management ageneies prior to eondueting vegetation } \\
\text { treatments in suitable sage-grouse habitat. } \\
\text { - Avoid eondueting vegetation treatments within } 4 \text { miles of known lek sites. If } \\
\text { vegetation treatments are neeessary within } 4 \text { miles of a lek, treatments must } \\
\text { demonstrate a net eonservation value to the speeies. } \\
\text { - Avoid eondueting vegetation treatments in areas that eontain features of sage- } \\
\text { grouse winter habitat. }\end{array}$ \\
\hline
\end{tabular}


TABLE A-2 (Cont.)

Programmatic Conservation Measures for Herbicide Treatments with Aminopyralid, Fluroxypyr, and Rimsulfuron (including measures from 2007 BA not specific to previously approved herbicides)

\begin{tabular}{|c|c|}
\hline Species/Species Group & Programmatic Conservation Measures \\
\hline $\begin{array}{l}\text { Gunnison Sage-grouse } \\
\text { and Greater Sage-grouse } \\
\text { (Bi-State DPS) (eont.) }\end{array}$ & $\begin{array}{l}\text { Where loeal data on aetual distribution of nesting habitats are available, the 4-mile } \\
\text { buffer may be modified as appropriate if the project impaets will still not } \\
\text { eontribute to a negative effect on the speeies. Additionally, temporal restrictions } \\
\text { may also be modified if loeal data indieate a different window of oeeupaney by } \\
\text { breeding birds and ehieks. Where sueh data are laeking, striet adherenee to the } \\
\text { programmatie standards should be enforced. } \\
\text { - Adjust spatial and temporal seales of treatments so that not all suitable habitat is } \\
\text { affected in any given year. } \\
\text { - Following treatments, replant or reseed treated areas with native speeies, if needed. } \\
\text { - Closely follow all applieation instruetions and use restrietions on herbieide labels. }\end{array}$ \\
\hline Lesser Prairie-ehieken & $\begin{array}{l}\text { - Conduet surveys prior to vegetation treatments within potential or suitable } \\
\text { habitat. } \\
\text { Where surveys deteet birds, or in known habitats, do not broadeast spray } \\
\text { herbieides. } \\
\text { - During the eritieal period of nesting and brood rearing (Mareh } 1^{\text {st }} \text { to July } 15^{\text {th }} \text { ) } \\
\text { avoid eondueting vegetation treatments within } 3 \text { miles of deteetions (i.e., } \\
\text { loeations where Lesser Prairie Chiekens have been detected within the last } 5 \\
\text { years) or suitable habitat. If vegetation treatments are neeessary within } 3 \text { miles of } \\
\text { a deteetion or suitable habitat and demonstrate a net eonservation value to the } \\
\text { speeies, they may be permitted following eompletion of a loeal-level consultation. } \\
\text { Adjust spatial and temporal scales of treatments so that not all suitable habitat is } \\
\text { affeeted in any given year. } \\
\text { Following treatments, replant or resecd treated areas with native speeies, if } \\
\text { needed. } \\
\text { Closely follow all applieation instruetions and use restrietions on herbicide labels. }\end{array}$ \\
\hline $\begin{array}{l}\text { Coastal California } \\
\text { Gnateatcher }\end{array}$ & $\begin{array}{l}\text { - Prior to implementing vegetation treatments, survey areas in which treatments } \\
\text { would oceur for eoastal California gnateatehers. } \\
\text { - Where gnateatehers oeeur, do not eonduet treatments during the breeding season } \\
\text { (as determined by a qualified wildlife biologist). } \\
\text { - Revegetate eoastal sage habitats with native species. } \\
\text { - Do not broadeast spray herbicides in areas where coastal California gnatcatehers } \\
\text { oceur. }\end{array}$ \\
\hline California Condor & - Restriet human aetivity within 1.5 miles of California condor nest sites. \\
\hline $\begin{array}{l}\text { Marbled Murrelet, } \\
\text { Northern Spotted Owl, } \\
\text { and Mexican Spotted Owl }\end{array}$ & $\begin{array}{l}\text { - Survey for marbled murrelets, northern spotted owls, and Mexiean spotted owls } \\
\text { (and their nests) on suitable proposed treatment areas, prior to developing } \\
\text { treatment plans. } \\
\text { - Do not allow human disturbance within } 1 / 4 \text { mile of protected activity centers during } \\
\text { the nesting period (as determined by a local biologist). } \\
\text { - Protect and retain the structural components of known or suspected nest sites } \\
\text { during treatments; evaluate each nest site prior to treatment and protect it in the } \\
\text { most appropriate manner. }\end{array}$ \\
\hline
\end{tabular}


TABLE A-2 (Cont.)

Programmatic Conservation Measures for Herbieide Treatments with Aminopyralid, Fluroxypyr, and Rimsulfuron (including measures from 2007 BA not specific to previously approved herbieides)

\begin{tabular}{|c|c|}
\hline Species/Speeies Group & Programmatic Conservation Measures \\
\hline $\begin{array}{l}\text { Marbled Murrelet, } \\
\text { Northern Spotted Owl, } \\
\text { and Mexican Spotted Owl } \\
\text { (eont). }\end{array}$ & $\begin{array}{l}\text { - Maintain suffieient dead and down material during treatments to support spotted } \\
\text { owl prey species (minimums would depend on forest types, and should be } \\
\text { determined by a wildlife biologist). } \\
\text { - Do not conduct treatments that alter forest structure in old-growth stands. } \\
\text { - Follow all instructions and SOPs to avoid spill and direct spray scenarios into } \\
\text { aquatie habitats, particularly marine habitats where murrelets forage for prey. }\end{array}$ \\
\hline Whooping Crane & $\begin{array}{l}\text { Do not allow human disturbanee within } 1 \text { mile of oceupied whooping crane habitat } \\
\text { (nesting, roosting foraging) or potential nesting habitat where whooping eranes } \\
\text { have been observed within the past } 3 \text { years during periods when eranes may be } \\
\text { present (as determined by a qualified biologist). } \\
\text { - Do not eonduet herbieide treatments in whooping erane habitat during the breeding } \\
\text { season. } \\
\text { - Closely follow all application instruetions and use restrictions on herbieide labels; } \\
\text { in wetlands and riparian habitats (ineluding aquatic and wetland habitat use } \\
\text { restrietions). }\end{array}$ \\
\hline Pygmy Rabbit & $\begin{array}{l}\text { - Prior to treatments, survey all suitable habitat for pygmy rabbits. } \\
\text { - Address pygmy rabbits in all management plans prepared for treatments within the } \\
\text { range of the species' historieal habitat. } \\
\text { - Where feasible, spot treat vegetation in pygmy rabbit habitat rather than broadeast } \\
\text { spraying. }\end{array}$ \\
\hline $\begin{array}{l}\text { Columbian White-tailed } \\
\text { Deer }\end{array}$ & $\begin{array}{l}\text { - Prior to treatments, survey for evidence of Columbian white-tailed deer use of } \\
\text { areas in whieh treatments are proposed to oceur. } \\
\text { - Address the protection of Columbian white-tailed deer in loeal management } \\
\text { plans developed in association with treatment programs. } \\
\text { - In areas that are likely to support Columbian white-tailed deer, protect riparian } \\
\text { areas from degradation by avoiding them altogether, or utilizing SOPs. Consult } \\
\text { Chapter } 5 \text { for appropriate conservation measures to be used in protected riparian } \\
\text { areas. } \\
\text { - Closely follow all application instruetions and use restrietions on herbicide labels } \\
\text { (including aquatic and wetland habitat use restrictions). } \\
\text { - Avoid broadeast spray treatments in areas where Columbian white-tailed deer } \\
\text { are known to forage. }\end{array}$ \\
\hline $\begin{array}{l}\text { Lesser and Mexiean } \\
\text { Long-nosed Bat }\end{array}$ & $\begin{array}{l}\text { Prior to treatments, survey all potentially suitable habitat for the presence of } \\
\text { bats or their neetar plants. } \\
\text { At the local level, incorporate proteetion of lesser and Mexican long-nosed bats } \\
\text { into management plans developed for proposed treatment programs. } \\
\text { - Instruct all field personnel on the identifieation of bat neetar plants and the } \\
\text { importanee of their protection. } \\
\text { Proteet neetar plants from modification by treatment aetivities to the greatest } \\
\text { extent possible. Do not remove neetar plants during treatments. Avoid driving } \\
\text { over plants. }\end{array}$ \\
\hline
\end{tabular}


TABLE A-2 (Cont.)

Programmatic Conservation Measures for Herbicide Treatments with Aminopyralid, Fluroxypyr, and Rimsulfuron (including measures from 2007 BA not specific to previously approved herbicides)

\begin{tabular}{|c|c|}
\hline Species/Species Group & Programmatic Conservation Measures \\
\hline $\begin{array}{l}\text { Lesser and Mexican } \\
\text { Long-nosed Bat (eont.) }\end{array}$ & $\begin{array}{l}\text { To protect nectar plants and roost trees from herbicide treatments, follow } \\
\text { recommended buffer zones for the herbicides, and other eonservation measures } \\
\text { for TEP plant species in areas where populations of nectar plants and roost trees } \\
\text { occur. } \\
\text { - If conducting spot treatments of herbicides in lesser or Mexican long-nosed bat } \\
\text { habitats, avoid potential roost sites. }\end{array}$ \\
\hline Sonoran Pronghorn & $\begin{array}{l}\text { Prior to treatments, survey all suitable habitat in arcas proposed for treatment for } \\
\text { Sonoran pronghorns. } \\
\text { - Avoid fawning areas during trcatments. } \\
\text { - Closely follow all application instruetions and use restrictions on herbieide labels } \\
\text { (including aquatic and wetland habitat use restrietions). } \\
\text { - Avoid broadeast spraying herbieides in key pronghorn foraging areas. }\end{array}$ \\
\hline $\begin{array}{l}\text { Hualapai Mexican Vole, } \\
\text { Amargosa Vole, Prcble's } \\
\text { Meadow Jumping Mouse, } \\
\text { New Mexico Meadow } \\
\text { Jumping Mousc, Riparian } \\
\text { Woodrat, and Buena } \\
\text { Vista Lakc Ornate Shrew }\end{array}$ & $\begin{array}{l}\text { - Survey suitable habitat for these species prior to developing treatment programs } \\
\text { at the local level. } \\
\text { In areas where surveys indicate that the Hualapai Mexiean vole, Amargosa vole, } \\
\text { Preble's meadow jumping mouse, New Mexieo meadow jumping mouse, riparian } \\
\text { woodrat, or Buena Vista Lakc ornate shrew occur: } \\
\text { - Address these species in all managcment plans preparcd for treatments within } \\
\text { areas that contain habitat for these spccies. } \\
\text { - Use manual spot applications of herbieides rather than broadcast treatments. } \\
\text { - Closely follow all application instructions and use restrictions on herbicide labels } \\
\text { (including aquatic and wetland habitat use restrictions). }\end{array}$ \\
\hline $\begin{array}{l}\text { Northern Idaho Ground } \\
\text { Squirrel }\end{array}$ & $\begin{array}{l}\text { - Prior to conducting treatments, survey the area to be treated for northern Idaho } \\
\text { ground squirrcls. } \\
\text { - At the local level, address northern Idaho ground squirrels and their habitat when } \\
\text { developing management plans for proposed treatments. } \\
\text { - Where squirrels are detected, conduct vegetation treatments during the hibernation } \\
\text { season, where feasible. } \\
\text { - Design treatments so that only a portion of northern Idaho ground squirrel habitat } \\
\text { is in a state of recovery at any one time. } \\
\text { - Design treatments to avoid injury to native bunchgrasses in northern Idaho ground } \\
\text { squirrel habitat; consult plant buffer distances and other conservation measures for } \\
\text { sensitive plants in Chapter } 4 \text { for guidance. }\end{array}$ \\
\hline Woodland Caribou & $\begin{array}{l}\text { - At the local level, prepare a management plan for all proposed treatment } \\
\text { activities that could potentially occur on land utilized by woodland caribou. This } \\
\text { management plan must be completed with the assistance of a wildlife biologist } \\
\text { and a forest ecologist, and must specifically address caribou and caribou habitat. } \\
\text { - Time major herbicide treatments in woodland caribou habitats such that they do } \\
\text { not occur during the season when caribou rely on the treatment area for forage. }\end{array}$ \\
\hline Grizzly Bear & $\begin{array}{l}\text { - Within the Recovery Zone, ensure that all treatment activities comply with the } \\
\text { Interagency Grizzly Bear Guidelines (Interagency Grizzly Bear Committee } \\
\text { 1987) and the Final Conservation Strategy for the Grizzly Bear in the } \\
\text { Yellowstone Ecosystem (Interagency Conservation Strategy Team 2003). }\end{array}$ \\
\hline
\end{tabular}


TABLE A-2 (Cont.)

Programmatic Conservation Measures for Herbicide Treatments with Aminopyralid, Fluroxypyr, and Rimsulfuron (including measures from 2007 BA not specific to previously approved herbicides)

\begin{tabular}{|c|c|}
\hline Species/Species Group & Programmatic Conservation Measures \\
\hline Grizzly Bear (cont.) & $\begin{array}{l}\text { To minimize the potential for displacement/mortality risk during treatments: } \\
\text { - Within the Recovery Zone (defined in Grizzly Bear Recovery Plan, USFWS } \\
\text { 1993), ensure that any vehicular travel off highway or on restricted roads adheres } \\
\text { to access standards/directions as provided in local or regional interagency } \\
\text { agreements, biological opinions, or local land use plans. } \\
\text { - Within the Recovery Zone, do not conduct vegetation treatment activities in } \\
\text { riparian meadows and stream corridors between April } 1 \text { and July 1, or complete } \\
\text { these activities in } 1 \text { day. } \\
\text { - Within the Recovery Zone, do not implement vegetative treatments that would } \\
\text { substantially change the vegetative community in huckleberry producing sites. } \\
\text { To minimize the potential for habituation/human conflict: } \\
\text { - Within the Recovery Zone, ensure that all treatment activities adhere to } \\
\text { interagency grizzly bear guidelines and standards for sanitation measures and } \\
\text { storage of potential attractants, and enforce food storage and garbage disposal } \\
\text { stipulations. } \\
\text { Ensure all workers at treatment sites are aware of appropriate personal safety } \\
\text { measures and behavior in grizzly bear habitat. } \\
\text { - Within the Recovery Zone, do not plant or seed highly palatable forage species } \\
\text { near roads or facilities used by humans. }\end{array}$ \\
\hline Canada Lynx & $\begin{array}{l}\text { - Prior to vegetation treatments, map lynx habitat within areas in which treatments } \\
\text { are proposed to occur. Identify potential denning and foraging habitat, and } \\
\text { topographic features that may be important for lynx movement (major ridge } \\
\text { systems, prominent saddles, and riparian corridors). } \\
\text { Design vegetation treatments in lynx habitat to approximate historical landscape } \\
\text { patterns and disturbance processes. } \\
\text { - Where possible, keep linear openings out of mapped potential habitat and away } \\
\text { from key habitat components, such as denning areas. } \\
\text { - When planning vegetation treatments, minimize the creation of linear openings } \\
\text { (fire lines, access routes, and escape routes) that could result in permanent travel } \\
\text { ways for competitors and humans. } \\
\text { Obliterate any linear openings constructed within lynx habitat in order to deter } \\
\text { future uses by humans and competitive species. } \\
\text { Ensure that no more than } 30 \text { percent of lynx habitat within a Lynx Analysis Unit } \\
\text { (see Ruediger et al. 2000) would be in an unsuitable condition at any time. } \\
\text { Give particular consideration to amounts of denning habitat, condition of summer } \\
\text { and winter foraging habitat, as well as habitat linkages, to ensure that that } \\
\text { treatments do not negatively impact lynx. If there is less than } 10 \text { percent lynx } \\
\text { habitat in a Lynx Analysis Unit, defer vegetation treatments that would delay } \\
\text { development of denning habitat structure. Protect habitat connectivity within and } \\
\text { between Lynx Analysis Units. }\end{array}$ \\
\hline
\end{tabular}


TABLE A-2 (Cont.)

Programmatic Conservation Measures for Herbicide Treatments with Aminopyralid, Fluroxypyr, and Rimsulfuron (including measures from 2007 BA not specific to previously approved herbicides)

\begin{tabular}{|l|l|}
\hline \multicolumn{1}{|c|}{ Specics/Species Group } & \multicolumn{1}{c|}{ Programmatic Conscrvation Measures } \\
\hline $\begin{array}{l}\text { Kangaroo Rats, Utah } \\
\text { Prairie Dog, and Black- } \\
\text { footed Ferret }\end{array}$ & $\begin{array}{l}\text { - Prior to conducting vegetation treatments, survey areas scheduled to reeeive } \\
\text { treatments for listed kangaroo rats, Utah prairie dogs, and black-footed ferrets. }\end{array}$ \\
- Incorporate these species and their habitat into management plans developed for \\
treatment activities. \\
- Avoid vegetation treatments during drought conditions. \\
- Where possible, perform treatments during the hibernation period.
\end{tabular}


APPENDIX B ESSENTIAL FISH HABITAT ASSESSMENT 



\section{TABLE OF CONTENTS}

Page

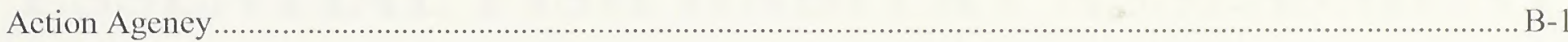

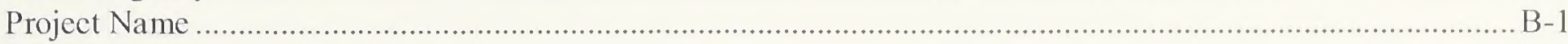

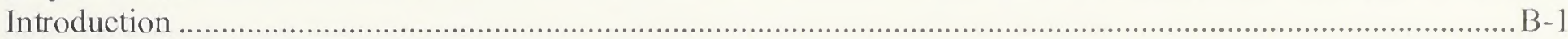

Speeies, Regions, and EFH Evaluated in this EFH Assessment ............................................................ B-5

Endangered Speeies Aet (ESA)-listed Species and Their Relationship to EFH ..............................................

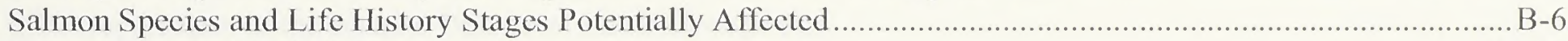

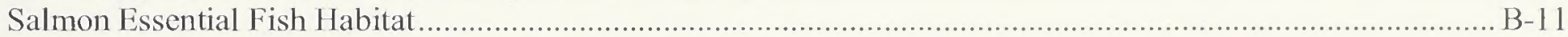

Habitat Requirements of Salmonids in Streams ........................................................................... B-12

Habitat Requirements of Salmonids in Estuaries and Other Nearshore Arcas ................................. B-13

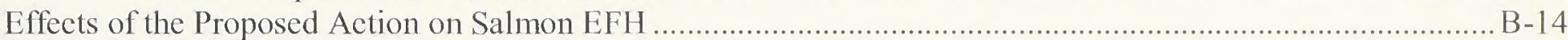

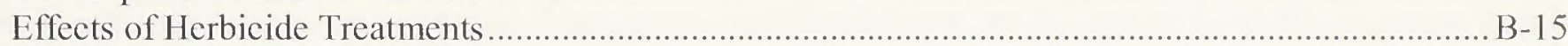

Groundfish Species and Life History Stages Potentially Affected ..................................................... B-16

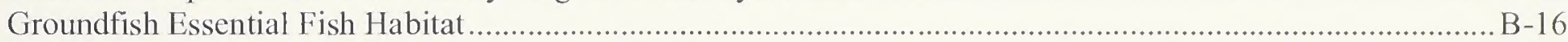

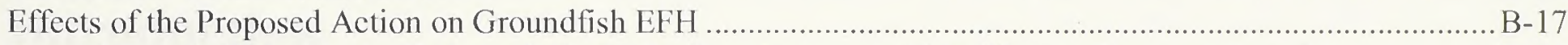

Coastal Pelagie Fish, Alaska Crab, and Alaska Seallop Speeies and Life History Stages Affected ................... B-18

Coastal Pelagie Fish, Alaska Crab, and Alaska Scallop Speeies EFH ........................................................ B-19

Effects of the Proposed Action on Coastal Pelagie Fish, Alaska Crab, and Alaska Scallop Species EFH .......... B-20

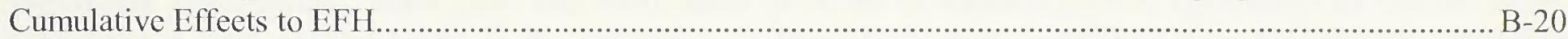

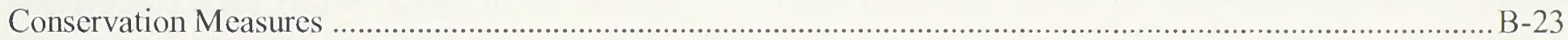

Key Conservation Measures from 2007 EFH Assessment ............................................................. B-23

Measures Speeifie to Herbieide Treatments .................................................................................... B-23

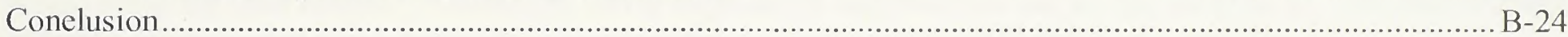

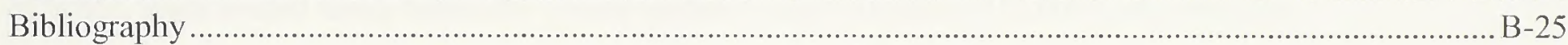

\section{List of Tables}

B-1 Species and Life Stages for Species Using Essential Fish Habitat Near Public Lands

B-3

B-2 Endangered Species Aet Status of Pacific Coast Coho and Chinook Salmon within Aetion Area ................ B-7

B-3 Current and Historie Salmon Distribution as Defined by the U.S. Geologieal Survey Hydrologic

Units

B-4 Generalized Biologieal and Habitat Requirements in Pacific Salmonids 



\section{APPENDIX B}

\section{ESSENTIAL FISH HABITAT ASSESSMENT}

\section{Action Agency}

U.S. Department of the Interior Bureau of Land Management

\section{Project Name}

Vegetation Treatments Using Aminopyralid, Fluroxypyr, and Rimsulfuron on Bureau of Land Management Lands in 17 Western States Programmatie EIS

\section{Introduction}

The U. S. Department of the Interior (USDOI) Bureau of Land Management (BLM) is proposing to add the aetive ingredients aminopyralid, fluroxypyr, and rimsulfuron to its list of approved aetive ingredients for use on BLMadministered lands (publie lands) in the western U.S. These herbieides would be integrated into the vegetation management programs that were assessed in the Biological Assessment for Vegetation Treatments on Bureau of Land Management Lands in 17 Western States (2007 BA; USDOI BLM 2007a). The addition of these herbieides would bring the total number of herbieide aetive ingredients approved for use by the BLM to 21 . The total aereage of publie lands treated using herbieides would remain at approximately 932,000 aeres annually.

The BLM administers vegetation on 247 million aeres (projeet area) in 17 states in the western U.S., ineluding Alaska (Map 1-1). These lands eneompass approximately 1 out of every 5 aeres from the Roeky Mountains to the Paeifie Oeean. The overall goal of the BLM's herbieide treatments is to improve eeosystem health. Herbieide use is one eomponent of a larger vegetation management effort by the BLM to treat up to 6 million aeres each year using several treatment methods: preseribed fire and wildland fire use for resouree benefit (fire use), meehanieal, manual, and biologieal eontrol methods, and herbieides. An Essential Fish Habitat (EFH) Assessment for the full vegetation treatment program (Appendix A of the 2007 BA) was eompleted in 2007 to deseribe the potential adverse effeets of the proposed BLM vegetation treatments program on EFH.

In 1976, Congress passed into law what is eurrently known as the Magnuson-Stevens Fishery Conservation and Management Aet (MSA). This law authorized the U.S. to manage its fishery resourees out to 200 nautieal miles off its eoast. This 200-mile area is referred to as the exelusive eeonomie zone (EEZ). Regional Couneils established by Congress under the MSA were eharged to prepare Fishery Management Plans (FMPs) for every fishery that required management. In 1996, the Sustainable Fisheries Aet (Publie Law 104-267) amended the MSA, requiring the identifieation of EFH for federally managed fishery speeies, and the implementation of measures to eonserve and enhanee the habitat of these speeies, as deseribed in federal FMPs. In 2006, the MSA was amended again, this time to end overfishing, promote market-based fisheries management, improve the quality of and ineorporate seientifie data into the management proeess, and to address illegal, unreported, and unregulated fishing and byeateh of proteeted living marine resourees.

All federal ageneies are required to eonsult with the National Oeeanie and Atmospherie Administration National Marine Fisheries Serviee (NMFS) on all aetions or proposed aetions permitted, funded, or undertaken by the ageney that may negatively affeet EFH. Adverse effeets may inelude direet (e.g., eontamination or physieal disruption), indireet (e.g., loss of prey), site-speeifie, or habitat-wide impaets. The vegetation treatments proposed by the BLM have the potential to adversely affeet EFH. 
The MSA defines EFH as "those waters and substrate necessary to fish for spawning, breeding, feeding, or growth to maturity." Rules about EFH in 1997 (interim final rule; 62 Federal Register [FR] 66551) and 2002 (final rule; I2 FR 2343) further clarify EFH with the following definitions:

- Waters - aquatic arcas and thcir associate physical, chemical, and biologieal propertics that are used by fish, and may include aquatic arcas historically used by fish, where appropriate.

- Substrate - sediment, hard bottom, struetures underlying the waters, and associated biological communities.

- Necessary - the habitat required to support a sustainable fishery and the managed species' contribution to a healthy eeosystem.

- Spawning, breeding, feeding, or growth to maturity - stages representing a speeies' full life eyclc.

The definition of EFH may include habitat for an individual species or an assemblage of species, whichever is appropriate to the FMP.

There are four components of an EFH consultation:

1. Notification - the federal agency (i.c., BLM) provides notification of an activity that "may adversely affect" EFH to NMFS.

2. EFH Assessment - The federal agency provides a description of the proposed action, an analysis, and effects determination to NMFS.

3. Conservation Recommendations - As dictated under section 305(b)(4) of the MSA, NMFS provides EFH conservation and enhancement recommendations to the federal agency for actions that may negatively affeet EFH. In turn, NMFS discusses EFH conservation recommendations with the federal agency and provides these recommendations to the federal agency, pursuant to section 305(b)(4)(A) of the MSA.

4. Federal Agency Response - The federal agency provides detailed written responses to NMFS and the appropriate Council within 30 days of receiving the conservation recommendations.

The objective of this EFH Assessment is to describe potential adverse effects of the proposed BLM vegetation treatments program in designated EFH for the federally managed Pacific Coast (including Washington, Oregon, California, and Idaho) and Alaskan salmon, groundfish, pelagic fish, crab, and scallop fisherics. This assessment also addresses potential effects to habitat areas of particular concern (HAPC), which are specific habitat areas that play a particularly important ccological role in the fish life eycle, or are especially sensitive, rare, or vulnerable. Five salmon specics are reviewed in this assessment: Chinook, coho, and pink salmon for the Pacific Coast; and Chinook, coho, ehum, pink, and sockeye salmon for Alaska (Table B-1). Forty-five Pacific Coast and 34 Alaskan groundfish species or groups are reviewed in this assessment. Groundfish are fish such as rockfish, sablefish, flatfish, and Pacifie whiting that are often (but not cxelusively) found on or near the ocean floor or other struetures. The federally managed Pacifie Coast pelagic speeies include Pacific sardine, Pacific mackerel, northern anchovy, jack mackerel, market squid, and all species of krill. Pelagic fish are found in open marine water near the surface and are not assoeiated with substrate. The assessment also reviews five Alaska crab species (blue king erab, golden king crab, red king crab, snow crab, and Tanner crab) and four Alaska scallop species (pink, rock, spiny, and weathervane). For the purposes of this EFH Assessment, groundfish, pelagic fish, crab, and scallop species are limited to those species that spend all or a portion of their lives in estuaries and other eoastal habitats. Although EFH for highly migratory speeies (i.e., important species of tunas, billfish, and sharks) is also covered under the MSA, these species are not covered under this EFH because they are generally found in open waters away from shore. 
TABLE B-1

Species and Life Stages for Species using Essential Fish Habitat near Public Lands

\begin{tabular}{|c|c|c|c|c|}
\hline \multirow{2}{*}{ Species } & \multicolumn{4}{|c|}{ Essential Fish Habitat Use by Life Stage } \\
\hline & Egg & Larvae & Juvenile & Adult \\
\hline \multicolumn{5}{|l|}{ Salmon } \\
\hline Chinook & - & - & - & - \\
\hline Chum & - & - & - & - \\
\hline Coho & - & - & - & - \\
\hline Pink & - & - & - & - \\
\hline Sockeye & $\bullet$ & - & - & - \\
\hline \multicolumn{5}{|l|}{ Groundfish-Pacific Coast } \\
\hline Big skate & & - & & - \\
\hline Black rockfish & & & - & - \\
\hline Black-and-yellow rock fish & & & - & - \\
\hline Blue rockfish & & & - & - \\
\hline Bocaccio & & - & - & - \\
\hline Brown rockfish & & - & - & - \\
\hline Cabezon & $\bullet$ & - & - & - \\
\hline Calico rockfish & & & - & \\
\hline California scorpionfish & & & - & - \\
\hline California skate & - & & - & - \\
\hline Canary rockfish & & & - & \\
\hline Chilipepper & & $\bullet$ & $\bullet$ & \\
\hline China rockfish & & & & - \\
\hline Copper rockfish & & - & - & - \\
\hline Dover sole & - & - & - & - \\
\hline English sole & - & - & - & - \\
\hline Flathead sole & - & - & - & - \\
\hline Gopher rockfish & & & - & - \\
\hline Grass rockfish & & - & 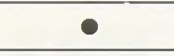 & $\cdot$ \\
\hline Kelp greenling & $\cdot$ & - & - & - \\
\hline Kelp rockfish & & $\bullet$ & $\bullet$ & $\bullet$ \\
\hline Leopard shark & & & $\bullet$ & - \\
\hline Lingcod & - & - & - & - \\
\hline Olive rockfish & & - & - & $\bullet$ \\
\hline Pacific cod & - & - & - & - \\
\hline Pacific hake & $\bullet$ & $\bullet$ & $\bullet$ & $\bullet$ \\
\hline Pacific sanddab & - & - & $\bullet$ & - \\
\hline Petrale sole & - & - & - & $\cdot$ \\
\hline Quillback rockfish & & & $\bullet$ & $\bullet$ \\
\hline Redstripe rockfish & & - & - & \\
\hline Rex sole & $\bullet$ & - & - & - \\
\hline Rock sole & - & - & - & - \\
\hline Rosethorn rockfish & & & & $\bullet$ \\
\hline Sand sole & - & - & - & $\bullet$ \\
\hline Shortbelly rockfish & & & - & \\
\hline Silvergray rockfish & & & $\bullet$ & \\
\hline Soupfin shark & & & - & $\bullet$ \\
\hline Speckled rockfish & & & $\bullet$ & \\
\hline Spiny dogfish & & & - & - \\
\hline Splitnose rockfish & & & $\bullet$ & \\
\hline Starry flounder & - & - & - & - \\
\hline
\end{tabular}


TABLE B-1 (Cont.)

Species and Life Stages for Species using Essential Fish Habitat near Public Lands

\begin{tabular}{|c|c|c|c|c|}
\hline \multirow{2}{*}{ Species } & \multicolumn{4}{|c|}{ Essential Fish Habitat Use by Life Stage } \\
\hline & Egg & Larvae & Juvenile & Adult \\
\hline Stripetail rockfish & & & $\bullet$ & \\
\hline Vermilion rockfish & & $\bullet$ & $\bullet$ & $\bullet$ \\
\hline Widow rockfish & & & $\bullet$ & \\
\hline Yellowtail rockfish & & & $\bullet$ & $\bullet$ \\
\hline \multicolumn{5}{|l|}{ Groundfish-Alaska } \\
\hline Alaska plaice & $\bullet$ & $\bullet$ & $\bullet$ & $\bullet$ \\
\hline Arrowtooth flounder & NA & $\bullet$ & $\cdot$ & $\bullet$ \\
\hline Atka mackerel & NA & $\bullet$ & NA & $\bullet$ \\
\hline Bathylagids & NA & NA & NA & NA \\
\hline Capelin & NA & NA & NA & NA \\
\hline Dover sole & $\bullet$ & $\cdot$ & $\bullet$ & $\bullet$ \\
\hline Dusky rockfish & NA & $\bullet$ & NA & $\bullet$ \\
\hline Eulachon & NA & NA & NA & NA \\
\hline Euphausiids & NA & NA & NÁ & NA \\
\hline Flathead sole & $\bullet$ & $\bullet$ & $\bullet$ & $\bullet$ \\
\hline Gonostomatids & NA & NA & NA & NA \\
\hline Greenland turbot & $\bullet$ & $\bullet$ & $\bullet$ & $\bullet$ \\
\hline Myctophids & NA & NA & NA & NA \\
\hline Northern rockfish & NA & $\bullet$ & $\bullet$ & $\bullet$ \\
\hline Octopus & NA & $\mathrm{NA}$ & NA & NA \\
\hline Pacific cod & $\bullet$ & $\bullet$ & $\bullet$ & $\bullet$ \\
\hline Pacific Ocean perch & NA & $\bullet$ & $\bullet$ & $\bullet$ \\
\hline Pholids & NA & NA & NA & NA \\
\hline Rex sole & $\bullet$ & $\bullet$ & $\bullet$ & $\cdot$ \\
\hline Rock sole & NA & $\bullet$ & $\bullet$ & $\bullet$ \\
\hline Rougheye rockfish & NA & $\bullet$ & NA & $\bullet$ \\
\hline Sablefish & $\bullet$ & $\bullet$ & $\bullet$ & $\bullet$ \\
\hline Sand fish & NA & NA & NA & NA \\
\hline Sand lance & NA & NA & NA & NA \\
\hline Sculpins & NA & NA & $\bullet$ & $\bullet$ \\
\hline Sharks & NA & NA & NA & NA \\
\hline Shortraker rockfish & NA & $\bullet$ & NA & $\bullet$ \\
\hline Skates & NA & NA & NA & $\bullet$ \\
\hline Squid & NA & NA & $\bullet$ & $\bullet$ \\
\hline Stichaeids & NA & NA & $\bullet$ & $\bullet$ \\
\hline Thornyhead rockfish & NA & $\bullet$ & $\bullet$ & - \\
\hline Walleye pollock & $\bullet$ & $\bullet$ & $\bullet$ & $\bullet$ \\
\hline Yelloweye rockfish & NA & $\bullet$ & $\bullet$ & $\bullet$ \\
\hline Yellowfin solc & $\bullet$ & $\bullet$ & $\bullet$ & $\bullet$ \\
\hline \multicolumn{5}{|l|}{ Pelagic Fish } \\
\hline Jack mackerel & $\bullet$ & $\bullet$ & $\bullet$ & - \\
\hline Krill (all species) & NA & - & $\bullet$ & $\bullet$ \\
\hline Market squid & $\bullet$ & $\bullet$ & $\bullet$ & - \\
\hline Northern anchovy & - & - & $\bullet$ & $\bullet$ \\
\hline Pacific mackeral & $\bullet$ & $\bullet$ & $\bullet$ & $\bullet$ \\
\hline Pacific sardine & $\bullet$ & $\bullet$ & - & $\bullet$ \\
\hline \multicolumn{5}{|l|}{ Crab } \\
\hline Blue king crab & $\bullet$ & NA & $\bullet$ & $\bullet$ \\
\hline Golden king crab & $\bullet$ & NA & - & - \\
\hline
\end{tabular}


TABLE B-1 (Cont.)

Species and Life Stages for Species using Essential Fish Habitat near Public Lands

\begin{tabular}{l}
\hline \multirow{2}{*}{ Species } \\
\cline { 2 - 5 }
\end{tabular}

Subsequent projeets implemented under the direction of this proposed action require environmental review under the National Environmental Policy Act (NEPA) and must be in complianee with all applicable laws and regulations prior to authorization and implementation. An assessment of potential effects to EFH will be completed as part of that evaluation. If the effects rise to the adverse level, the BLM field offiees are required to initiate eonsultation on EFH with the NMFS. If there is overlap between EFH and Endangered Spceies Act (ESA)-listed species, ficld offices may agree with NMFS to utilize the existing processes established under Section 7 of ESA to meet this consultation obligation.

\section{Species, Regions, and EFH Evaluated in this EFH Assessment}

The Northwest Region of NMFS administers NMFS programs for coastal habitats of Washington and Oregon, as well as the inland watershed habitats of Pacific salmon and steelhead in Washington, Oregon, Idaho, and Montana. The Southwest Region administers NMFS programs for coastal habitats of California and islands in the Pacific Ocean, as well as the inland watershed habitats of Pacific salmon and steclhead in California. The Alaskan Region administers NMFS programs for eoastal habitats of Alaska, the Bering Sea, and the Aleutian Islands, and inland watershed habitats of Pacific salmon and steelhead in Alaska.

For the Paeific Coast (exeluding Alaska), the Pacific Fishery Management Council (Pacific Couneil) manages federal fisheries for Washington, Oregon, Idaho, and California under four FMPs. These FMPs are the Coastal Pelagic Species Fishery Management Plan (Pacific Fishery Management Council 2011a), Pacific Coast Groundfish Fishery Management Plan (Pacifie Fishery Management Council 2011b), the Pacific Coast Salmon Fishery Management Plan (Paeific Fishery Management Couneil 2012), and the Fishery Management Plan for U.S. West Coast Fisheries for Highly Migratory Species (Pacific Fishery Management Council $2011 \mathrm{c}$ ).

For Alaska, the North Pacifie Fishery Management Council (Alaskan Council) manages federal fisheries for the Bering Sea/Aleutian Islands area and the Gulf of Alaska, under five FMPs: the Fishery Management Plan for Bering Sea/Aleutian Islands King and Tanner Crabs (North Pacific Fishery Management Council 2011 a), Fishery Management Plan for the Scallop Fishery off Alaska (North Pacific Fishery Management Council 2006), Fishery Management Plan for Groundfish of the Gulf of Alaska (North Pacific Fishery Management Couneil 2011b), Fishery Management Plan for the Groundfish of the Bering Sea and Aleutian Islands Management Area (North 
Pacific Fishery Management Council 2011c), and The Fishery Management Plan for the Salmon Fisheries in the EEZ off Alaska (North Pacific Fishery Management Council 2012). With jurisdiction over the EEZ off Alaska, the primary responsibility of the Alaskan Council is groundfish management in the Gulf of Alaska, Bering Sea, and Aleutian Islands. The Alaskan Council also makes limited decisions for halibut; however the U.S.-Canada International Pacific Halibut Commission is responsible for conservation of halibut. Salmon, crab, herring, and other large Alaska fisheries are managed primarily by the State of Alaska (North Pacific Fisheries Management Council 2013).

Essential fish habitat that could be impacted by BLM vegetation treatment activities includes upland, riverine, estuarine, and eertain marine habitats along the coast. Salmon use all four types of EFH, while groundfish and pelagic fish species, scallops, and crabs use only estuarine and coastal/marine habitats. Highly migratory species (i.e., important species of tunas, billfish, and sharks) are not included in this EFH, as they are generally found some distance from shore.

\section{Endangered Species Act-listed Species and Their Relationship to EFH}

The scope and requirements of EFH and ESA consultations differ from one another in that an EFH consultation is required for non-listed, federally managed fishery species, while an ESA consultation only addresses fishery species within the action area that are federally listed or proposed for listing. Each federally listed salmon species is broken into distinet groups, or Evolutionary Significant Units (ESUs). To be considered an ESU, a population or group of populations must: a) be substantially reproductively isolated from other populations, and b) contribute substantially to the ecological or genetic diversity of the species (Myers et al. 1998). A total of 28 ESUs of salmon have been listed as either threatened or endangered under the ESA in Washington, Oregon, Idaho, and California (Table B-2). Additionally, several species of groundfish that are covered under an FMP are also listed under the ESA. Partial overlap exists between the EFH and ESA-listed species/critical habitat in the project area, along the Pacific Coast (i.e., affected species may be listed but not managed, or managed but not listed), as only Chinook, coho, and pink salmon are managed under FMPs that cover this area. However, all four listed groundfish (bocaccio, canary rockfish, yelloweye rockfish, and eulachon) are managed under FMPs for the area. Potential impacts to ESA-listed species from BLM vegetation treatments using aminopyralid, fluroxypyr, and rimsulfuron are identified in the BA. Conservation measures identified in the EFH Assessment pertain to both ESA listed species and non-listed species in EFH areas.

\section{Salmon Species and Life History Stages Potentially Affected}

The natural ranges of the Pacific salmon species addressed within this EFH Assessment include large portions of the Pacific Rim of North America and Asia. Anadromous salmonids exhibit a significant shift in habitat, as adults migrate from the ocean to their natal streams to spawn (Groot and Margolis 1991). All anadromous salmonids follow the same general life history pattern, which includes incubation and hatching of embryos, and emergence and initial rearing of fry (a life stage of salmon between absorption of the yolk sac and juvenile salmonid) in freshwater; migration to oceanic habitats for extended periods of feeding and growth; and return to natal waters for completion of maturation, spawning, and death within a few weeks after spawning. Although all anadromous salmonids share the same general life cycle, there are substantial differences among species in the amount of time spent in freshwater and marine environments, as well as in the types of habitat they utilize for spawning and rearing (Table B-3).

Pink and chum salmon typically spawn in gravel beds along coastal streams, in close proximity to tidewaters. These species have the shortest freshwater phases of all anadromous salmon, entering the ocean within a period of days after emerging from the gravel (Salo 1991; Heard 1991; Hard et al. 1996; Spence et al. 1996). Pink salmon are mature at 2 years of age, at which time they return to freshwater to spawn (Heard 1991), while chum are more variable, spending between 2 to 5 years in the ocean before returning to their natal area to spawn (Salo 1991). 
TABLE B-2

Endangered Species Act Status of Pacific Coast Coho and Chinook Salmon within Action Area

\begin{tabular}{|c|c|c|}
\hline Common Name & Scientific Name & ESU and ESA Status' \\
\hline \multirow{9}{*}{ Chinook salmon } & \multirow{9}{*}{ Oncorhynchus tshawytscha } & Sacramento River winter-run $(\mathrm{E}-6 / 05)$ \\
\hline & & Snake River fall-run $(T-6 / 05)$ \\
\hline & & Snake River spring/summer run $(\mathrm{T}-6 / 05)$ \\
\hline & & Lower Columbia River $(T-6 / 05)$ \\
\hline & & Upper Willamette River $(T-6 / 05)$ \\
\hline & & Upper Columbia River spring run $(\mathrm{E}-6 / 05)$ \\
\hline & & Central Valley spring run $(T-6 / 05)$ \\
\hline & & California Coastal $(T-6 / 05)$ \\
\hline & & Puget Sound $(T-6 / 05)$ \\
\hline \multirow{4}{*}{ Coho salmon } & \multirow{4}{*}{ Oncorhynchus kisutch } & Central California Coast $(\mathrm{E}-6 / 05)$ \\
\hline & & Southern Oregon/Northern California Coast $(\mathrm{T}-6 / 05)$ \\
\hline & & Lower Columbia River $(\mathrm{T}-6 / 05)$ \\
\hline & & Oregon Coast $(T-6 / 11)$ \\
\hline \multirow{2}{*}{ Chum salmon } & \multirow{2}{*}{ Oncorhynchus keta } & Hood Canal summer-run $(T-6 / 05)$ \\
\hline & & Columbia River $(T-6 / 05)$ \\
\hline \multirow{2}{*}{ Sockeye salmon } & \multirow{2}{*}{ Oncorhynchus nerka } & Snake River $(E-6 / 05)$ \\
\hline & & Ozette Lake $(\mathrm{T}-6 / 05)$ \\
\hline \multirow{11}{*}{ Steelhead } & \multirow{11}{*}{ Oncorhynchus mykiss } & Southern California $(\mathrm{E}-1 / 06)$ \\
\hline & & Upper Columbia River $(\mathrm{T}-8 / 09)$ \\
\hline & & Snake River Basin $(T-1 / 06)$ \\
\hline & & Middle Columbia River $(T-1 / 06)$ \\
\hline & & Lower Columbia River $(\mathrm{T}-1 / 06)$ \\
\hline & & Upper Willamette River $(\mathrm{T}-1 / 06)$ \\
\hline & & South-central California Coast $(\mathrm{T}-1 / 06)$ \\
\hline & & Central California Coast $(T-1 / 06)$ \\
\hline & & Northern California $(\mathrm{T}-1 / 06)$ \\
\hline & & California Central Valley $(\mathrm{T}-1 / 06)$ \\
\hline & & Puget Sound $(\mathrm{T}-5 / 07)$ \\
\hline
\end{tabular}


TABLE B-3

Current and Historic Salmon Distribution as Defined by the U.S. Geological Survey Hydrologic Units

\begin{tabular}{|c|c|c|c|}
\hline Unit $\#^{1}$ & $\begin{array}{l}\text { State(s)/ } \\
\text { Province }^{2}\end{array}$ & $\begin{array}{l}\text { Current and Historic } \\
\text { Salmon Distribution }\end{array}$ & Hydrologic Unit Name \\
\hline 17080001 & OR/WA & $\mathrm{C}^{1,2}$ & Lower Columbia River - Sandy \\
\hline 17080003 & $\mathrm{OR} / \mathrm{WA}$ & $\mathrm{C}^{1,2}$ & Lower Columbia River - Clatskanie \\
\hline 17090001 & OR & $\mathrm{C}^{1}$ & Middle Fork Willamette River \\
\hline 17090002 & OR & $\mathrm{H}^{1}$ & Coast Fork Willamette River \\
\hline 17090003 & OR & $\mathrm{C}^{1,2}$ & Upper Willamette River \\
\hline 17090004 & OR & $\mathrm{C}^{1,2}$ & MeKenzie River \\
\hline 17090005 & OR & $\mathrm{C}^{1,2}$ & North Santiam River \\
\hline 17090006 & OR & $\mathrm{C}^{1,2}$ & South Santiam River \\
\hline 17090008 & OR & $\mathrm{C}^{2}, \mathrm{H}^{* 1}$ & Yamhill River \\
\hline 17090009 & OR & $\mathrm{C}^{1,2}$ & Mollala-Pudding River \\
\hline 17090010 & OR & $\mathrm{C}^{2}, \mathrm{H}^{* 1}$ & Tualatin River \\
\hline 17090011 & OR & $\mathrm{C}^{1,2}$ & Clackamas River \\
\hline 17090012 & $\mathrm{OR}$ & $\mathrm{C}^{1,2}$ & Lower Willamette River \\
\hline 17070101 & $\mathrm{OR} / \mathrm{WA}$ & $\mathrm{C}^{1,2}$ & Middle Columbia River - Lower Wallula \\
\hline 17070104 & OR & $\mathrm{H}^{1}$ & Willow \\
\hline 17070106 & WA & $\mathrm{C}^{1,2}$ & Klickitat River \\
\hline 17070301 & OR & $\mathrm{H}^{1}$ & Upper Deschutes River \\
\hline 17070303 & OR & $\mathrm{H}^{1}$ & Beaver - South Fork \\
\hline 17070304 & OR & $\mathrm{H}^{1}$ & Upper Crooked River \\
\hline 17070305 & OR & $\mathrm{H}^{1}$ & Lower Crooked River \\
\hline 17070307 & OR & $\mathrm{C}^{2}, \mathrm{H}^{* 1}$ & Trout Creek \\
\hline 17070201 & OR & $\mathrm{C}^{1}$ & Upper John Day River \\
\hline 17070202 & OR & $\mathrm{C}^{1}$ & North Fork John Day River \\
\hline 17070203 & OR & $\mathrm{C}^{\prime}$ & Middle Fork John Day River \\
\hline 17070204 & OR & $\mathrm{C}^{1}$ & Lower John Day River \\
\hline 17030001 & WA & $C^{1,2}$ & Upper Yakima River \\
\hline 17030003 & WA & $\mathrm{C}^{1,2}$ & Lower Yakima River \\
\hline 17020005 & WA & $\mathrm{C}^{1}, \mathrm{H}^{*^{2}}$ & Chief Joseph \\
\hline 17020006 & WA/BC & $\mathrm{C}^{1}$ & Okanogan River \\
\hline 17020007 & WA/BC & $\mathrm{H}^{\prime}$ & Similkameen \\
\hline 17020008 & WA & $\mathrm{C}^{1}, \mathrm{II}^{*^{2}}$ & Methow River \\
\hline 17020010 & WA & $\mathrm{C}^{1}, \mathrm{H}^{2}$ & Upper Columbia River - Entiat \\
\hline 17020016 & WA & $\mathrm{C}^{1,2}$ & Upper Columbia River - Priest Rapids \\
\hline 17020001 & WA/BC & $\mathrm{H}^{1,2}$ & F. D. Roosevelt Lake \\
\hline 17020002 & WA/BC & $\mathrm{H}^{1}$ & Kettle River \\
\hline 17020003 & WA & $\mathrm{H}^{1}$ & Colville River \\
\hline 17020004 & WA & $\mathrm{H}^{1}$ & Sanpoil River \\
\hline 17010307 & WA & $\mathrm{H}^{1,2}$ & Lower Spokane River \\
\hline 17060101 & $\mathrm{OR} / \mathrm{ID}$ & $\mathrm{C}^{1}$ & Hells Canyon \\
\hline 17060102 & OR & $\mathrm{C}^{\prime}$ & Imnaha River \\
\hline 17060103 & OR/WA/ID & $\mathrm{H}^{* 1,2}$ & Lower Snake River - Asotin Creek \\
\hline 17060106 & OR/WA & $\mathrm{C}^{1}, \mathrm{H}^{* 2}$ & Lower Grande Ronde \\
\hline 17060110 & WA & $\mathrm{C}^{1}, \mathrm{H}^{* 2}$ & Lower Snake River \\
\hline 17060201 & ID & $\mathrm{C}^{1}$ & Upper Salmon River \\
\hline 17060202 & ID & $\mathrm{C}^{1}$ & Pahsimeroi River \\
\hline 17060203 & ID & $\mathrm{C}^{\prime}$ & Middle Salmon - Panther River \\
\hline 17060204 & ID & $C^{\prime}$ & Lemhi River \\
\hline
\end{tabular}


TABLE B-3 (Cont.)

Current and Historic Salmon Distribution as Defined by the U.S. Geological Survey Hydrologic Units

\begin{tabular}{|c|c|c|c|}
\hline Unit \# & $\begin{array}{c}\text { State(s)/ } \\
\text { Province }^{2} \\
\end{array}$ & $\begin{array}{c}\text { Current and Historic Salmon } \\
\text { Distribution }^{3}\end{array}$ & Hydrologic Unit Name \\
\hline 17060205 & ID & $\mathrm{C}^{1}$ & "Upper Middle Fork Salmon River \\
\hline 17060207 & ID & $\mathrm{C}^{1}$ & Middle Salmon River - Chamberlain \\
\hline 17060209 & ID & $\mathrm{C}^{1}$ & Lower Salmon River \\
\hline 17060210 & ID & $\mathrm{C}^{1}$ & Little Salmon River \\
\hline 17060305 & ID & $\mathrm{C}^{1}$ & South Fork Clearwater River \\
\hline 17060308 & ID & $\mathrm{H}^{1}$ & Lower North Fork Clearwater \\
\hline 17050201 & OR/ID & $\mathrm{H}^{1}$ & Brownlec Rescrvoir \\
\hline 17050202 & OR & $\mathrm{H}^{1}$ & Burnt River \\
\hline 17050203 & OR & $\mathrm{H}^{1}$ & Powder River \\
\hline 17050101 & ID & $\mathrm{H}^{1}$ & C.J. Strike Reservoir \\
\hline 17050102 & $\mathrm{ID} / \mathrm{NV}$ & $\mathrm{H}^{1}$ & Bruneau River \\
\hline 17050103 & ID & $\mathrm{H}^{1}$ & Middle Snake River - Succor \\
\hline 17050104 & ID & $\mathrm{H}^{1}$ & Upper Owyhee River \\
\hline 17050105 & ID/NV/OR & $\mathrm{H}^{1}$ & South Fork Owyhee River \\
\hline 17050106 & ID/NV/OR & $\mathrm{H}^{1}$ & East Little Owyhee River \\
\hline 17050107 & ID/OR & $\mathrm{H}^{1}$ & Middle Owyhee River \\
\hline 17050108 & $\mathrm{ID} / \mathrm{OR}$ & $\mathrm{H}^{\prime}$ & Jordan Creek \\
\hline 17050109 & OR & $\mathrm{H}^{1}$ & Crooked - Rattlesnake \\
\hline 17050110 & OR & $\mathrm{H}^{1}$ & Lower Owyhee River \\
\hline 17050111 & ID & $\mathrm{H}^{1}$ & North And Middle Fork Boise River \\
\hline 17050112 & ID & $\mathrm{H}^{1}$ & Boise - Mores \\
\hline 17050113 & ID & $\mathrm{H}^{1}$ & South Fork Boise River \\
\hline 17050114 & ID & $\mathrm{H}^{1}$ & Lower Boise River \\
\hline 17050115 & ID/OR & $\mathrm{H}^{1}$ & Middle Snake River - Payette \\
\hline 17050116 & OR & $\mathrm{H}^{\mathrm{l}}$ & Upper Malheur River \\
\hline 17050117 & OR & $\mathrm{H}^{1}$ & Lower Malheur River \\
\hline 17050118 & $\mathrm{OR}$ & $\mathrm{H}^{1}$ & Bully Creek \\
\hline 17050119 & OR & $\mathrm{H}^{1}$ & Willow Creek \\
\hline 17050120 & ID & $\mathrm{H}^{1}$ & South Fork Payette River \\
\hline 17050121 & ID & $\mathrm{H}^{1}$ & Middle Fork Payette River \\
\hline 17050122 & ID & $\mathrm{H}^{1}$ & Payette River \\
\hline 17050123 & ID & $\mathrm{H}^{1}$ & North Fork Payette River \\
\hline 17050124 & ID & $\mathrm{H}^{1}$ & Weiser River \\
\hline 17040212 & ID & $\mathrm{H}^{\prime}$ & Upper Snake River - Rock \\
\hline 17040213 & ID/NV & $\mathrm{H}^{1}$ & Salmon Falls \\
\hline 17100202 & OR & $\mathrm{C}^{1,2}$ & Nehalem River \\
\hline 17100203 & OR & $\mathrm{C}^{1,2}$ & Wilson - Trask - Nestucca \\
\hline 17100204 & OR & $\mathrm{C}^{1,2}$ & Siletz - Yaquina River \\
\hline 17100205 & OR & $\mathrm{C}^{1,2}$ & Alsea River \\
\hline 17100206 & OR & $\mathrm{C}^{1,2}$ & Siuslaw River \\
\hline 17100301 & OR & $\mathrm{C}^{1,2}$ & North Umpqua River \\
\hline 17100302 & OR & $\mathrm{C}^{1,2}$ & South Umpqua River \\
\hline 17100303 & $\mathrm{OR}$ & $\mathrm{C}^{1,2}$ & Umpqua River \\
\hline 17100304 & OR & $\mathrm{C}^{1,2}$ & Coos River \\
\hline 17100305 & OR & $\mathrm{C}^{1,2}$ & Coquille River \\
\hline 17100306 & OR & $\mathrm{C}^{1,2}$ & Sixes River \\
\hline 17100307 & OR & $\mathrm{C}^{1,2}$ & Upper Rogue River \\
\hline
\end{tabular}


TABLE B-3 (Cont.)

Current and Historic Salmon Distribution as Defined by the U.S. Geological Survey Hydrologic Units

\begin{tabular}{|c|c|c|c|}
\hline Unit \#' & $\begin{array}{l}\text { State }(\mathbf{s}) / \\
\text { Province }^{2}\end{array}$ & $\begin{array}{c}\text { Current and Historic Salmon } \\
\text { Distribution }\end{array}$ & Hydrologic Unit Name \\
\hline 17100308 & $\mathrm{OR}$ & $\mathrm{C}^{1,2}$ & Middle Rogue River \\
\hline 17100309 & $\mathrm{CA} / \mathrm{OR}$ & $\mathrm{C}^{1,2}$ & Applegate River \\
\hline 17100310 & $\mathrm{OR}$ & $\mathrm{C}^{1,2}$ & Lower Rogue River \\
\hline 17100311 & $\mathrm{CA} / \mathrm{OR}$ & $\mathrm{C}^{1,2}$ & Illinois River \\
\hline 17100312 & $\mathrm{CA} / \mathrm{OR}$ & $\mathrm{C}^{1,2}$ & Chetco River \\
\hline 18010202 & $\mathrm{OR}$ & $\mathrm{H}^{1}$ & Sprague River \\
\hline 18010206 & $\mathrm{CA} / \mathrm{OR}$ & $\mathrm{C}^{1,2}$ & Upper Klamath River \\
\hline 18010207 & $\mathrm{CA}$ & $\mathrm{C}^{1,2}$ & Shasta River \\
\hline 18010208 & $\mathrm{CA}$ & $\mathrm{C}^{1,2}$ & Scott River \\
\hline 18010211 & $\mathrm{CA}$ & $\mathrm{C}^{1,2}$ & Trinity River \\
\hline 18010212 & $\mathrm{CA}$ & $\mathrm{C}^{1,2}$ & South Fork Trinity River \\
\hline 18010102 & $\mathrm{CA}$ & $\mathrm{C}^{1,2}$ & Mad-Redwood \\
\hline 18010103 & $\mathrm{CA}$ & $\mathrm{C}^{1,2}$ & Upper Eel River \\
\hline 18010104 & $\mathrm{CA}$ & $\mathrm{C}^{1,2}$ & Middle Fork Eel River \\
\hline 18010105 & $\mathrm{CA}$ & $\mathrm{C}^{1,2}$ & Lower Eel River \\
\hline 18010106 & $\mathrm{CA}$ & $\mathrm{C}^{1,2}$ & South Fork Eel River \\
\hline 18010107 & $\mathrm{CA}$ & $\mathrm{C}^{1,2}$ & Mattole River \\
\hline 18010108 & $\mathrm{CA}$ & $\mathrm{C}^{2}, \mathrm{H}^{* 1}$ & Big - Navarro - Garcia \\
\hline 18010109 & $\mathrm{CA}$ & $\mathrm{C}^{2}, \mathrm{H}^{* 1}$ & Gualala-Salmon River \\
\hline 18010110 & CA & $\mathrm{C}^{1,2}$ & Russian River \\
\hline 18040004 & $\mathrm{CA}$ & $\mathrm{H}^{* 1}$ & Lower Calaveras - Mormon Slough \\
\hline 18040008 & $\mathrm{CA}$ & $\mathrm{H}^{1}$ & Upper Merced \\
\hline 18040009 & $\mathrm{CA}$ & $\mathrm{C}^{1}, \mathrm{H}^{1}$ & Upper Tuolumne \\
\hline 18040010 & $\mathrm{CA}$ & $\mathrm{H}^{1}$ & Upper Stanislaus \\
\hline 18040011 & $\mathrm{CA}$ & $\mathrm{C}^{1}$ & Upper Calveras \\
\hline 18040012 & CA & $\mathrm{H}^{1}$ & Upper Mokelumne \\
\hline 18040013 & $\mathrm{CA}$ & $\mathrm{C}^{1}, \mathrm{H}^{1}$ & Upper Cosumnes \\
\hline 18060002 & $\mathrm{CA}$ & $\mathrm{C}^{2}, \mathrm{H}^{* 1}$ & Pajaro River \\
\hline 18050005 & $\mathrm{CA}$ & $\mathrm{C}^{2}$ & Tomales - Drake Bays \\
\hline 18050006 & CA & $\mathrm{C}^{2}$ & San Francisco-Coastal South \\
\hline 18060012 & $\mathrm{CA}$ & $\mathrm{H}^{* 2}$ & Carmel River \\
\hline \multicolumn{4}{|c|}{$\begin{array}{l}{ }^{1} \text { Unit \# designates U.S. Geological Survey Hydrologic Unit Code. } \\
{ }^{2} \mathrm{BC}=\text { British Columbia; } \mathrm{CA}=\text { California; } \mathrm{ID}=\mathrm{Idaho} ; \mathrm{NV}=\mathrm{Nevada} \text {; } \mathrm{OR}=\text { Oregon; and WA = Washington. } \\
\mathrm{C}=\text { Current habitat; } \mathrm{H}=\text { inaccessible historic habitat; } \text { and } \mathrm{H}^{*}=\text { current accessible, but unutilized historic habitat. Fish species } \\
\text { present: } 1 \text { = Chinook; and } 2=\text { Coho. } \\
\text { Source: Pacific Fishery Management Council } 1999 .\end{array}$} \\
\hline
\end{tabular}

Coho salmon generally spawn in small, low-gradient streams in both coastal and interior systems (Laufle et al. 1986; Sandercock 1991). Juveniles typically spend between 1 and 3 years in freshwater. However, in the southern portion of their range (including Washington, Oregon and California) most fish migrate to sea after just 1 year (Spence et al. 1996). Adults return after approximately 18 months at sea to spawn in natal streams (Sandercock 1991).

Chinook salmon generally spawn in various-sized rivers, from small streams to large systems such as the Columbia River (Healy 1991). Chinook salmon display two dominant life history types: ocean- and stream-types (Myers et al. 1998). Individuals exhibiting an ocean-type life history usually spend only a few months in freshwater before migrating to the ocean, whereas stream-type Chinook may spend 1 to 2 years in freshwater before their migration 
to the sea (Healey 1991; Myers et al 1998). Both ocean- and stream-type fish can reside in the oeean between 2 and 5 years before returning to spawn (Healey 1991).

Sockeye salmon most often spawn in the inlet and outlet streams of lakes (Burgner 1991; Gustafson et al. 1997). Shortly after emergenee, soekeye fry migrate into these lakes, where they reside for 1 to 3 years before migrating to the oeean. They then spend 2 to 3 years in the oeean before migrating baek to their natal spawning areas (Burgner 1991). Most soekeye are known as lake-type soekeye. However, some populations of soekeye salmon spawn in rivers without the lake rearing period, and are known as either river- or sea-type soekeye. Juvenile soekeye salmon that are river-type rear in freshwater streams for 1 to 2 years before migrating to the oeean (Gustafson et al. 1997). Sea-type soekeye salmon migrate to the oeean as underyearlings after spending only a few months in their natal river, and therefore rear primarily in saltwater (Gustafson et al. 1997).

\section{Salmon Essential Fish Habitat}

Essential fish habitat for the Paeifie Coast and Alaska salmon fishery refers to those waters and substrates that are neeessary for salmon produetion that is eapable of supporting a long-term, sustainable salmon fishery and salmon eontributions to a healthy eeosystem. For the Paeifie salmon fishery, freshwater EFH ineludes all streams, lakes, ponds, wetlands, and other viable water bodies that are aeeessible to salmon, as well as most of the habitat that was historieally aeeessible (exeluding areas upstream of longstanding naturally impassable barriers), in Washington, Oregon, Idaho, and California. In estuarine and marine areas, EFH extends from the nearshore and tidal submerged environments within state territorial waters, out to the full extent of the EEZ (200 nautieal miles) offshore of Washington, Oregon, and California, north of Point Coneeption (Paeifie Fishery Management Couneil 2012). Current and historie salmon distribution and EFH based on U.S. Geologieal Survey hydrologie units in California, Oregon, and Washington is in Table B-4.

TABLE B-4

Generalized Biological and Habitat Requirements in Pacific Salmonids

\begin{tabular}{|c|c|c|c|c|c|}
\hline \multirow{2}{*}{ Attribute } & \multicolumn{5}{|c|}{ Salmon Species } \\
\hline & Chinook & Coho & Pink & Chum & Sockeye \\
\hline Spawning sites & Mainstem & Tributaries & $\begin{array}{c}\text { Mainstem, } \\
\text { tributaries, and } \\
\text { intertidal }\end{array}$ & $\begin{array}{c}\text { Mainstem, } \\
\text { tributaries, and } \\
\text { intertidal }\end{array}$ & $\begin{array}{l}\text { Lakeshore and } \\
\text { tributaries }\end{array}$ \\
\hline $\begin{array}{l}\text { Time in grave } \\
\text { (eggs) }\end{array}$ & $\begin{array}{c}\text { Fall: } 90-150 \text { days } \\
\text { Spring: } 90-150 \\
\text { days }\end{array}$ & $80-150$ days & $\begin{array}{c}90-150 \text { days (odd } \\
\text { years only) }\end{array}$ & $90-150$ days & $90-150$ days \\
\hline Emergenee & Mareh-April & April-May & $\begin{array}{l}\text { Late January; } \\
\text { April-May }\end{array}$ & $\begin{array}{c}\text { Late February; } \\
\text { April-May }\end{array}$ & April-May \\
\hline Rearing sites & Mainstem & $\begin{array}{c}\text { Mainstem, side } \\
\text { ehannels, and slaek } \\
\text { water }\end{array}$ & Saltwater & Saltwater & Lakes \\
\hline $\begin{array}{l}\text { Time in } \\
\text { freshwater }\end{array}$ & $\begin{array}{l}\text { Fall: } 60-120 \text { days } \\
\text { Spring: } 1-2 \text { yrs }\end{array}$ & $\begin{array}{c}1-2 \text { yrs } \\
(12-14 \text { months }) \\
\end{array}$ & Several days & Several days & $1-3$ years \\
\hline $\begin{array}{l}\text { Time in marine } \\
\text { habitats }\end{array}$ & 2-6 years & $1-2$ years & 2 years & 2-3 years & 14 years \\
\hline $\begin{array}{l}\text { Return to } \\
\text { freshwater }\end{array}$ & $\begin{array}{l}\text { Spring: April } \\
\text { Summer: July } \\
\text { Fall: Nov } \\
\end{array}$ & Late fall & Early fall & Early to late fall & Mid-summer \\
\hline
\end{tabular}

For the Alaskan salmon fishery, the marine and nearshore salmon EFH generally ineludes all marine waters from the mean higher tide line to the limits of the EEZ, as salmon are found nearshore and along eoastal migration eorridors during migration as early juveniles and adults, and are distributed throughout all marine waters during late juvenile and adult life stages. Freshwater EFH generally ineludes areas above mean higher tide to the upper 
limits of freshwater systems that support salmon. These systems may include contiguous wetland areas (NMFS 2005).

Freshwater salmon systems are generally defined as those areas above mean higher tide to the upper limits of those freshwater systems supporting salmon and may include contiguous wetland areas, such as those areas hydrologically connected to the main water source via access channels to an adjacent river, stream, lake, pond, etc. Interactive mapping showing Pacific salmon freshwater EFH is available at the Alaska Department of Fish and Game Anadromous $\quad$ Fish $\quad$ Waters $\quad$ Catalog (http:/www.adfg.alaska.gov/sf/SARR/AWC/index.efm?adfg=maps.interactive).

\section{Habitat Requirements of Salmonids in Streams}

Adult Pacific salmon typically migrate upstream at temperatures between 37 and $68{ }^{\circ} \mathrm{F}$ in water between 7 and 9.5 inches deep (Bjornn and Reiser 1991). Salmon may spawn within this temperature range, although spawning typically oceurs between 39 and $52^{\circ} \mathrm{F}$ (Bell 1986 cited in Spence et al. 1996). Once spawning is complete, water temperature affects the timing of salmonid egg incubation (Iwamoto et al. 1978; Laufle et al. 1986; Healey 1991; Sandereock 1991; Spence et al. 1996; Myers et al. 1998). For example, the time to 50 percent hateh (i.e., the time it takes 50 percent of the larval salmonids to hateh) for Pacific salmon species ranges from 115 to 150 days at $39^{\circ} \mathrm{F}$ and from 35 to 60 days at $54^{\circ} \mathrm{F}$ (Bjornn and Reiser 1991). However, the alevin stage (a larval salmonid that has hatehed, but has not yet fully absorbed its yolk sac) is generally less temperature-sensitive than the embryonic stages (Spenee et al. 1996). Fry and parr (juvenile salmonids) are variable with regard to their temperature requirements, although as parrs most species are at risk when water temperatures exceed $77^{\circ} \mathrm{F}$. Although juvenile salmonids may briefly tolerate such high temperatures, high water temperatures are potentially lethal.

Higher water temperatures also contribute to the reduction of dissolved oxygen (DO) concentrations. Embryos and alevins are very susceptible to low DO levels, generally requiring levels above $8 \mathrm{ppm}$ to survive (Phillips and Campbell 1961). Low DO concentrations lead to an increased incidence of morphological abnormalities in emerging alevins (Bjornn and Reiser 1991). However, upon hatching, alevins in the gravel are able to deteet oxygen gradients and move to areas with more suitable DO levels. Salmon, when rearing in freshwater, also require a high level (6.5 to $7.0 \mathrm{ppm}$ ) of DO. They may survive when DO eoneentrations are lower (less than 5 ppm), but growth, food conversion efficiency, and swimming performance may be negatively affected.

Water temperatures can be altered by several factors, such as removal of vegetative cover over the stream, withdrawal and return of water for agricultural irrigation, or release of water from deep reservoirs. Riparian vegetation, which is vegetation growing on or near the banks of a stream, provides shade, covers salmon from predation, moderates the water temperature of a stream, stabilizes banks, and controls soil erosion and sedimentation. Furthermore, riparian vegetation provides nutrients to the stream and food for juvenile salmon, and may contribute large woody debris (LWD), which in turn inereases channel complexity, creates backwater habitats, and increases the water depth of pools. Studies have shown a correlation between the amount of LWD and salmon production (Dolloff 1983, House and Bochne 1986). For example, coho salmon production declined when LWD was removed from streams in southeast Alaska (Dolloff 1983). Not only ean riparian vegetation and stream temperature influence the quantity and quality of salmonid habitat, but the velocity of the streamflow and substrate of the stream can also play a significant role.

Adult salmonids can successfully migrate any stream reach of reasonable length if the water depth is greater than 4.7 inches when substrate particles average larger than 3 inches in diameter, or if the depth is greater than 3.5 inches when particles are less than 3 inches (Bjornn and Reiser 1991). Adult salmonids, upon reaching spawning beds, will typically deposit eggs within a range of water depths and velocities that minimize the risk of desiccation over the coming incubation period. These depths and velocities vary depending on species and run of population (i.e., spring, summer, or fall runs). However, studies suggest a depth of 7 inches and velocity of 0.98 feet per second (ft/s) meet the minimum criteria (Thompson 1972, Neilson and Banford 1983, Bjornn and Reiser 1991, Healy 1991, Heard 1991). 
Upon emerging from the substrate, fry between 0.7 and 1.4 inehes long require water veloeities of less than 0.32 $\mathrm{ft} / \mathrm{s}$, whereas juvenile salmon between 1.6 and 7 inches long usually oeeupy sites with veloeities of up to $1.3 \mathrm{ft} / \mathrm{s}$ (Bjornn and Reiser 1991). When rearing in freshwater, juvenile salmon seek out low veloeity areas adjacent to faster water for feeding, resting, and growing. Overall, veloeities required and used by juvenile salmonids vary with the size of the fish, and may ehange seasonally. By oeeupying slow veloeity areas, salmon are likely to use less energy. Invertebrate drift abundanee inereases with veloeity aeross a stream. Therefore, darting into the stream to feed, and then resuming their position in slower waters may provide a potential energy benefit for fish. Salmon use less energy maintaining their position in low veloeities, while at the same time benefiting from the inereased food abundanee provided by higher veloeities.

Within the stream ehannel, salmon require suffieient elean and appropriately-sized eobbles and gravel (ranging from 0.5 to 4 inehes) for spawning and ineubation (Spenee et al. 1996). Furthermore, riffles, rapids (a seetion of stream with eonsiderable surfaee agitation, swift eurrent, and drops up to 3 feet), pools, and floodplain conneetivity with the stream, are important for produetion, rearing, eover, and aeration.

\section{Habitat Requirements of Salmonids in Estuaries and Other Nearshore Areas}

The Pacific Coast Salmon Plan (Paeific Fishery Management Couneil 2012) and referenees eited therein summarize information on salmon use of estuarine and nearshore habitats along the Paeifie Coast. Estuaries and other nearshore areas provide habitat for salmon fry or fingerlings moving from freshwater to marine habitats, and for adults moving from marine habitats to freshwater spawning areas.

Stream-type Chinook salmon spend only a brief period in estuaries before moving into eoastal waters and the open oeean. Oeean-type Chinook salmon reside in estuaries for several months before entering eoastal waters. Chinook salmon fry prefer proteeted estuarine habitats with lower salinity, but move to less proteeted and higher salinity habitats as they grow older. Prey items include inseets and amphipods when they first enter estuaries, and larval and juvenile fish as they grow older. After leaving the estuarine environment, juvenile Chinook disperse to marine feeding areas.

The amount of time juvenile eoho salmon rear in estuaries appears to depend on latitude, with more northern populations dwelling in estuaries for several months, while those in more southerly waters may only remain in estuaries for days to several weeks. Large woody debris is an important habitat element of juvenile eoho salmon in estuaries. Juvenile salmon eonsume large planktonie or small mektonie animals, sueh as amphipods, inseets, mysids, deeapod larvae, and larval and juvenile fishes. Some juveniles migrate northwards into offshore waters, while others remain in eoastal waters near their natal stream for at least the first summer before migrating north.

Pink salmon may migrate direetly through the estuary to nearshore areas, or may reside in estuaries for 1 to 2 months before moving to the oeean. Pink salmon that reside in estuaries for extended periods use shallow, proteeted habitats sueh as tidal ehannels and eonsume a variety of prey items, sueh as insects, eladoeerans, and eopepods. Juvenile pink salmon are rarely found in estuaries beyond June. After leaving estuaries, juvenile pink salmon form sehools and tend to follow the shoreline and, at least for the first few weeks at sea, spend mueh of their time in shallow water only a few eentimeters deep.

The Fishery Management Plan for the Salmon Fisheries in the EEZ off Alaska (North Paeifie Fishery Management Couneil 2012) and Final Environmental Impact Statement for Essential Fish Habitat Identification and Conservation in Alaska (NMFS 2005) and referenees eited therein summarize information on salmon use of estuarine and nearshore habitats in Alaska and include all five speeies of Paeifie salmon: pink salmon, soekeye salmon, eoho salmon, ehum salmon, and Chinook salmon. Estuarine and marine EFH requirements for Chinook, eoho, and pink salmon are diseussed above. The following foeuses on estuarine and marine EFH requirements for soekeye and ehum salmon.

Soekeye salmon enter estuarine and nearshore environs after smoltifieation and exodus from natal river systems in spring or early summer. By autumn, they have moved offshore. Juvenile soekeye forage on eopepods, amphipods, 
euphausiids, insects, and fish larvae. After entering the open sea during their first summer, juvenile sockeye salmon remain in a band relatively close to the coast.

After cmerging from the streambed, schooling chum salmon fry migrate downstream, mostly at night, to the estuaries where they tend to feed in the intertidal grass flats and along the shore. Chum salmon use these intertidal wetlands for several months before migrating to deeper marine waters. Juvenile chum salmon forage on invertebrates, and gelatinous species.

\section{Effects of the Proposed Action on Salmon EFH}

Because of the general similarities among species of Pacific salmon with regard to life history stages and habitat requirements, this section will discuss effects of herbicide treatments on these fish as a group, rather than on a species-by-species basis. Aminopyralid, fluroxypyr, and rimsulfuron are not registered for use in aquatic habitats, and their use would be subject to applicable aquatic area buffers. However, aminopyralid may reeeive an aquatic registration in the future, at which time the BLM could use it adjaeent to aquatic habitats, and incidental overspray into water could oceur. Even with an aquatic registration, aminopyralid would not be applied directly into the water column, as it has no utility in controlling aquatic vegetation. Exeept for Alaska, where large tracts of publie land are found on the North Slope, and near Point Delgada in northern California, most public lands are inland and far from estuarine and marine habitats (although small amounts of land may be found along the coast). Although herbicides could be used in coastal areas, it is assumed that greatest potential for adverse effects to Paeific salmon EFH would be in inland aquatic habitats adjacent to herbicide treatment areas. These habitats could be exposed to aminopyralid, fluroxypyr, or rimsulfuron as a result of spray drift or aceidental spill or direct spray into aquatic habitats. Freshwater life history stages that would potentially be affected by the proposed treatments include adult migration to natal spawning areas, incubation and maturation of eggs, and rearing and migrating of juveniles to the ocean. Estuarine and marine habitats would only have the potential to be affected if herbicides applied in upland areas entered freshwater streams and then traveled downstream and entered salt water habitats.

Ecological risk assessments (ERAs) completed in support of the PEIS (AECOM 2014a-c) identify the risks to fish associated with using the three new herbicide active ingredients. The information provided in these risk assessments was used to determine the potential for effects to EFH speeies and their habitats as a result of herbicide treatments with aminopyralid, fluroxypyr, and rimsulfuron on publie lands. Risk assessments characterized exposure scenarios involving a range of surrogate species. In the case of fish, rainbow trout and bluegill sunfish were used to represent all freshwater fish species, including anadromous salmonids. The ERA considered a range of exposure pathways associated with applications on a variety of upland sites, as well as accidental aquatic releases. Additional discussion of the methods used to determine the risks to fish species as a result of herbicide use is presented in the main text of this BA, and the Vegetation Treatments Programmatic EIS Ecological Risk Assessment Methodology (ENSR 2004), which is also Appendix C of the 2007 PEIS.

The proposed treatments would follow the general timing restrictions established by NMFS. These restrictions are imposed by both the states and NMFS, for specific bodies of water, watersheds, or geographic regions, as a means of protecting salmonid species from potential habitat disturbance during spawning. Typically, activities may occur around or within streams containing salmonids during the summer months (i.e., May through Oetober); however, timing windows may vary depending on geographic location.

Since all five salmon identified in this assessment occur on public lands, they could all potentially be affected by treatments with the three new herbicides, should herbicide applications occur in a watershed where these species occur. The most likely potential impact to salmon habitat from herbicide treatments would be changes in water quality and temperature. Pacific salmonids require cool, clean water that is of sufficient depth and velocity to allow passage, migration, and spawning, where floods do not scour channels (Spence et al. 1996). 


\section{Effects of Herbicide Treatments}

Salmonids could potentially come into contact with herbicides if sprayed formulations were to enter aquatic habitats during the application process. Sinee aminopyralid, fluroxypyr, and rimsulfuron are currently not approved for use in aquatic habitats, these herbicides would not be sprayed directly into fish habitats as part of the application process. However, they could enter aquatic habitats through accidental spray, or via off-site drift of surface runoff after spray in nearby upland habitats. Depending on how they are applied, herbicides could result in the removal of riparian vegetation, which would have the potential to alter aquatic habitats. Many projects involving herbicide treatments in riparian areas would be implemented with the objective of improving the habitats of salmonid speeies, and would therefore have a long term beneficial effect on salmonids and EFH, if sueeessful.

Based on information from the ERAs, the three new herbicide active ingredients would pose a low toxicological risk to aquatic species. Of the three herbicides, only fluroxypyr is associated with risks to aquatic species, and only under aceidental spill scenarios. Tables 5-1 through 5-4 of the BA summarize the risks to aquatic organisms associated with cxposure to herbicides via the modeled exposure pathways. ERAs predicted that in a scenario involving a truck or helicopter spill of an entirc load of fluroxypyr prepared for the maximum application rate, the potential for adverse effeets to endangered and more typical fish species would be high. The BLM would follow standard operating procedures (SOPs) to minimize the risk of an accidental relcase of herbicides into aquatic habitats, such SOPs for transporting, storage, and handling of herbicides, and emergency spill plans.

Bioaccumulation is most likely to occur when salmon are exposed to persistent chemicals that have low water solubility and high lipid solubility (Norris et al. 1991). According to ERAs, bioaccumulation of aminopyralid or rimsulfuron and is not anticipated to occur (bioconcentration factor of 1), based on the physical properties of these active ingredients. However, studies have shown that fluroxypyr may bioaceumulate in fish tissue (bioconcentration factor of 62.11). Additionally, salmon may take up sublethal quantities of all three herbicides, potentially resulting sublethal effects such as reduced growth, decreased reproductive suceess, altcred behavior, and reduced resistance to stress (Beschta et al. 1995).

Removal of riparian vegetation would have the potential to impaet EFH, particularly if widespread removal of vegetation were to occur. These potential effects, which are discussed in more detail in the 2007 EFH Assessment (Appendix A of the $2007 \mathrm{BA}$ ), include loss of necessary habitat components (i.c., cover and food), inereased sedimentation into aquatic habitats, altered nutrient dynamics, and inereased water temperatures due to reduetion in shade. Beneficial indirect effects from removal of vegetation include redueing and slowing the development of deciduous trees in favor of conifers. Based on the likely usage of the three new active ingredients, however, widescale removal of riparian vegetation is unlikely to occur. Out of the three herbieides, fluroxypyr and rimsulfuron would typically not be used near water, except possibly for spot treatments of certain target species. Aminopyralid would be used in riparian treatments for sclective removal of eertain specics (c.g., knapweeds), but extensive removal of riparian vegetation would be unlikely. Additionally, aminopyralid would provide an alternative to glyphosate, which is less selective and more likcly to result in removal of non-target riparian vegetation.

Salmonid species could be indirectly affeeted by herbicides through a reduction in prey items (i.e., aquatic invertebrates and smaller fish). However, the three new herbicides would have a low toxicity to prey species (see Tables 5-1 through 5-4 of the BA). Only an accidental spill of fluroxypyr would be likely to impact prey items and have a potential to reduce food availability of EFH species. As discussed previously, spill scenarios represent a worst-case and unlikely herbicide release seenario, and are highly conservative as far as predicting impacts to reeeptors. Additionally, project planning and design and relevant SOPs would further minimize the risk of an accidental spill occurring. Any negative effects to prey items would be temporary in nature.

Over the long term, treatments that remove non-native and competing vegctation are likcly to have a benefieial impaet on salmonid EFH habitat, provided that native or other desirable plant species are returned to those habitats after the treatments. Noxious weeds can have a substantial adverse effect on riparian areas by outcompeting more desirable riparian vegetation, reducing biodiversity, altering aquatic habitats (e.g., reducing streambank protection, undercut bank cover, overhanging vegetation cover, pool depth and volume, and detrital and nutrient inputs; and 
erosion and fine sediment deposition, stream width, and thermal relationships), and altering natural ecosystem processes (National Fire Plan Technical Team 2002). Herbicide treatments that target plant communities adjacent to EFH habitats should result in conditions that would be more suitable for supporting salmonid species. Therefore, these treatments would eventually increase the amount of suitable EFH habitat, potentially leading to an increase in salmonid populations.

\section{Groundfish Species and Life History Stages Potentially Affected}

More than 90 species of groundfish are managed under the Pacific Coast Groundfish Fishery Management Plan (Pacific Fishery Management Couneil 2011b). Table B-1 lists the Pacific coast groundfish species with the greatest chance of being affected by herbicide treatments on BLM lands, based on the habitats they are associated with. These include species associated with estuaries and the intertidal zone. Specics associated with rooted macrophytes, algae, or seagrass in estuarine, intertidal, and continental shelf zones are also included, as they are HAPCs.

Groundfish in Alaska are managed under the Fishery Management Plan for Groundfish of the Bering Sea and Aleutian Islands Management Area (North Pacific Fishery Management Council 2011c) and the Fishery Management Plan for Groundfish of the Gulf of Alaska (North Pacific Fishery Management Council 2011b). The 34 species or fish groups identified in Table B-1 spend all or a portion of their lives in estuarine or marine/coastal waters with EFH, although life-history information is lacking for some species or groups.

\section{Groundfish Essential Fish Habitat}

The most recent FMP for Pacific coast groundfish was approved by NMFS in December, 2011. This plan protects more than 130,000 square miles of marine waters off the West Coast, covering a large and ecologically diverse area, as EFH for groundfish. Given the large number of species managed under the groundfish FMP, a description of the overall area identified as groundfish EFH is appropriate, with life histories and EFH identifications for each individual species provided in Appendix B of the Pacific Coast Groundfish FMP (Pacific Fishery Management Council $201 \mathrm{lb}$ ). The overall extent of groundfish EFH includes an area that spans from Canada to Mexico, and includes all waters and substrates from mean higher high water level (and parts of estuaries) to 11,483 feet in depth, seamounts in depths greater than 11,483 feet, and areas designated as HAPCs. Habitat areas of particular concern are estuaries, canopy kelp, seagrass, rocky reefs, and special areas of interest off the coasts of Washington, Oregon, and California. Information on HAPCs is taken from Pacific Fishery Management Council (2011b) and references eited therein.

Estuaries are protected nearshore areas such as bays, sounds, inlets, and river mouths, influenced by ocean and freshwater. Because of tidal cycles and freshwater runoff, salinity varies within estuaries, offering freshwater, brackish, and marine habitats. Estuaries tend to be shallow, protected, nutrient rich, and biologically productive, and provide important habitat for groundfish and other marine organisms.

Canopy kelp forests are found relatively close to the shore along the open coast. These communities provide vertically structured habitat throughout the water column - a canopy of tangled blade from the surface to a depth of 10 feet, a mid-water stipe region, and a holdfast region on the seafloor. Kelp stands provide nurseries, feeding grounds, and shelter to a variety of groundfish species and their prey.

Seagrass species found along the West Coast include eelgrass, widgeongrass, and surfgrass. These grasses are vascular plants that form dense beds of leafy shoots year-round in the lower intertidal and subtidal areas of estuaries and occasionally in other nearshore areas. These seagrass beds are among the most productive habitats in the world and provide habitat for many groundfish species. 
Rocky reefs are eomposed of bedrock, boulders, or smaller roeks, such as cobble and gravel, and are found nearshore and offshore. These habitats are some of the least abundant benthie habitats, yet are among the most important habitats for groundfish.

Areas of interest are discrete areas that are of speeial interest due to their unique geologieal and ecological characteristics. They are designated as HAPCs. They include:

- Washington - All waters and sea bottom in Washington State waters from the 3 nautical mile boundary of the territorial sea shoreward to mean higher high water.

- Oregon - Daisy Bank/Nelson Island, Thompson Seamount, and President Jackson Seamount.

- California - All seamounts, including Gumdrop Seamount, Pioneer Seamount, Guide Seamount, Taney Seamount, Davidson Seamount, and San Juan Seamount; Mendocino Ridgc; Cordell Bank; Monterey Canyon; specific areas in the federal waters of the Channel Islands National Marine Sanctuary; and specific areas of the Cowcod Conservation Area.

Washington State waters are important to juvenile roekfish, juvenile lingeod, juvenile flatfish, and English sole. Currents generated by seamounts retain roekfish larvae and zooplankton, a principal food source for roekfish. Canyons provide refuge for groundfish. Daisy Bank is an important area for roekfish; over 6,000 juvenile roekfish per hectare were observed at the site in 1990.

The Fishery Management Plan for Groundfish of the Bering Sea and Aleutian Islands Management Area (North Pacific Management Council 2011c) and The Fishery Management Plan for Groundfish of the Gulf of Alaska (North Pacific Management Council 2011b) state that EFH for groundfish species is the general distribution (95 percent of the population) of a species described by life stage. Where information is not available for a partieular life stage (see Table B-1), EFH is not described in the management plan. Aecording to NMFS, several habitat types in Alaska have important ecological functions, are sensitive and vulnerable to human impacts, and are relatively rare for groundfish. In shallow waters that could be affected by BLM vegetation management activities, these habitats include nearshore areas of intertidal and submerged vegetation, roek, and other substrates. These areas provide food and rearing habitat for juvenile groundfish and spawning habitat for adult fish. These areas also have a high potential for being affected by shore-based activities. A detailed list of important EFH habitat eomponents for groundfish is given in Appendixes D and $\mathrm{F}$ of Final EIS for Essential Fish Habitat Identification and Conservation in Alaska (NMFS 2005).

\section{Effects of the Proposed Action on Groundfish EFH}

Except for Alaska, where large traets of public land are found on the North Slope, and near Point Delgada in northern California, most public lands are inland and far from estuarinc, coastal, and marine habitats use by groundfish. Herbieides could be used in coastal areas, but based on information that was utilized for the 2007 PEIS, the BLM does not propose to treat lands on the North Slope, or lands adjacent to the coast in Alaska or along the West Coast, with herbicides.

Should there be a future need for treatments with aminopyralid, fluroxypyr, or rimsulfuron on public lands adjacent to the coast, they would have minor or no effects on groundfish. Treatments would likely be limited to onshore spot or other small-scale treatments. The BLM would not treat aquatic vegetation in estuarine or coastal waters. Types of indirect adverse effects (e.g., loss of vegetative cover near the aquatie body, sedimentation, pollution) of treatments of estuarine and marine habitats would be similar to those described above for salmon, but the magnitude of the impact would be negligible beeause: I) herbieides, sediments, and other harmful compounds associated with inland and nearshore herbicide treatments would be diluted by large amounts of water found at the mouths of streams and rivers, in estuaries, and in the oeean; and 2) because few treatments would oceur near estuarine or marine habitats, treatments would be limited in size to a few acres or less, and treatments would not 
directly impact vegetation and other habitat components favored by groundfish. The BLM would use SOPs and other mitigation measures identified below, and in the BA and PEIS, to reduce effects to EFH.

\section{Coastal Pelagic Fish, Alaska Crab, and Alaska Scallop Species and Life History Stages Affected}

Descriptions of species and life history stages of coastal pelagic species that could be affected by BLM vegetation treatments are taken from the Coastal Pelagic Species Fishery Management Plan (Pacific Fishery Management Council 2011a) and references cited therein.

Nearshore habitat areas support about 70 percent of the juvenile anchovy population. Northern anchovy are typically found in schools near the surface. They eat phytoplankton and zooplankton by either filter feeding or biting, depending upon the size of the food. Spawning can occur year-round, but most occurs during February to April. Both the eggs and larvac are found near the surface, but all life stages may be found in the surface waters where temperatures range from 54 to $71{ }^{\circ} \mathrm{F}$.

Small jack mackerel are often found near the mainland coast and islands and over shallow rocky banks, while adults are found in deeper waters. In California, jack mackerel schools are often found over rocky banks, artificial reefs, and shallow rocky coastal areas. They remain under kelp canopies during daylight and venture into deeper waters at night. Larvae feed almost exclusively on copepods, while large fish eat large zooplankton, juvenile squid, and anchovy.

Pacific sardine inhabit coastal subtropical and temperate waters. They oceur in estuaries, but are most common in the nearshore and offshore domains along the coast. Pacific sardines spawn in loosely aggregated schools in the upper 165 feet of the water column. Most sardines are found off the coast of California, but they have been seen as far north as British Columbia. Sardines are planktivores that consume both phytoplankton and zooplankton.

Pacific mackerel range from Banderas Bay, Mexico, to southeastern Alaska. Juveniles are found off sandy beaches, around kelp beds, and in open bays. Adults are commonly found near shallow banks and from the surface to depths of 1,000 feet. Pacific mackercl larvae eat copepods and other zooplankton, including fish larvae. Juveniles and adults feed on small fishes, fish larvae squid, and pelagic crustaceans.

Krill (euphasiid) species serve as the basis for the marine food chain. They are eaten by numerous species of fish managed under the MSA, as well as by whales and seabirds. Although all krill species are protected under the MSA, there are only two species for which there is substantial information pertaining to abundance, distribution, and life history characteristics. Distribution of these species within the EEZ is thought to be closely related to bathymetric, topological, and oceanographic features for retaining adults, juveniles, and larvac in optimum grazing areas. They are known to graze on microscopic plants and animals, and may also consume large quantities of phytoplankton, fish eggs, and fish larvae. Certain features have been associated with areas of high krill concentrations, including islands, banks, canyons, and promontories where circulation patterns concentrate krill and phytoplankton biomass in nutrient-rich upwelled water.

Market squid are found from the southern tip of Baja California, Mexico, to southeastern Alaska. They prefer oceanic salinities and are rarely found in bays, estuaries, or near river mouths. Known major spawning areas include shallow protected nearshore areas with sandy or mud bottoms adjacent to submarine canyons, with egg deposition occurring between 16 and 180 feet. Juvenile squid feed on copepods, while mature squid feed on euphasiids, other small crustaceans, small fish, and other squid.

King and tanner crabs are covered under The Fishery Management Plan for Bering Sea/Aleutian Islands King and Tanner Crabs (North Pacific Fishery Management Council 2011a). Red king crab are widely distributed throughout the Bering Sea and Aleutian Istands, Gulf of Alaska, Sea of Okhotsk, and along the Kamchatka shelf. Red king crabs mate when they enter shallower waters, beginning in January and continuing through June. Red 
king crabs spend 2 to 3 months in larval stages before settling to the benthic life stage. Young erabs oceur at depths of 150 feet or less and need high relief habitat or coarse substrates such as boulders, cobble, shell hass, and living substrates such as bryozoans. By age 4 , crabs move to deeper waters.

Blue king erabs oecur from Japan to southeast Alaska. Juvenile blue king erabs require cobble habitat with shell hash. These habitat areas have been found at about 130 to 200 feet. Adult blue king erabs occur at an average depth of 230 feet. Golden king erabs range from Japan to British Columbia and in the Bering Sea and Aleutian Islands are found at depths of 650 to over 3,000 feet. Tanner erabs are distributed on the eontinental shelf of the North Paeifie Oeean and Bering Sea from Kamehatka to Oregon. Snow crabs are distributed on the continental shelf of the Bering Sea, Chukchi Sea, and the western Atlantic Ocean; snow crabs are not found in the Gulf of Alaska. In the Bering Sea, snow crabs are common at depths less than 650 feet.

Alaskan scallops are covered under The Fishery Management Plan for the Scallop Fishery off Alaska (North Pacific Fishery Management Council 2006). They include the weathervane seallop, pink or reddish seallop, roek scallop, and spiny seallop. Scallops are found from intertidal waters to a depth of 650 feet. Weathervane scallops are found from Point Reyes, California, to the Pribilof Islands, Alaska. At all life stages, weathervane seallops are found at depths up to 650 feet, although abundance is greatest between 150 and 425 feet in depth. Juvenile and adult seallops use mud, sand, and gravel substrates. They appear to mature in mid-Deeember to late January and spawn in May through July. Pink seallops range from California to the Pribilof Islands. They are found in deep waters (to 650 feet deep) in areas with a soft bottom, and spawn during the winter (January to March). Spiny scallops are found from California to the Gulf of Alaska. They oceur in shallower (to 500 feet) areas characterized by a hard bottom and strong eurrents, and spawn during autumn (August to Oetober). Roek seallops range from Mexico to Alaska. These seallops attaeh themselves to rocks and attain a large size (10 inehes). They are found in relatively shallow areas (to $260 \mathrm{feet}$ ) with strong currents. Rock seallops may spawn during two distinet periods (Oetober to January and March to August).

\section{Coastal Pelagic Fish, Alaska Crab, and Alaska Scallop Species EFH}

For purposes of EFH, the coastal pelagie finfish (Pacific sardine, Pacific mackerel, northern anchovy, and jaek mackerel) and market squid are treated as a single speeies eomplex. For these speeies EFH is defined as all marine and estuarine waters from the coasts of California, Oregon, and Washington offshore to the limits of the EEZ (200 nautieal miles from shore), and above the thermoeline in the upper mixed layer, where sea surface temperatures range between 50 and $79^{\circ} \mathrm{F}$. The southern limit of the EFH is the U.S.-Mexico maritime boundary. The northern boundary is the position of the $50^{\circ} \mathrm{F}$ thermoeline, and varies seasonally based on water temperature. During the summer, the position of the $50^{\circ} \mathrm{F}$ thermoeline is off Canada and Alaska. The EFH designation for all speeies of krill extends the length of the West Coast from the shoreline to the 1,000-fathom ( $\mathrm{fm}$ ) isobath and to a depth of 1,312 feet.

Essential fish habitat for the crab species covered under The Fishery Management Plan for Bering Sea/Aleutian Islands King and Tanner Crabs (North Pacific Fishery Management Couneil 2011a) is defined for eggs (equivalent to the general distribution of egg-bearing female erabs), late juveniles, and adults. There is not enough information to define EFH for larvae and early juveniles. Essential fish habitat for late juveniles ineludes bottom habitats along the continental shelf wherever there are substrates consisting of rock, eobble, and gravel and biogenic struetures. For adults, EFH oeeurs where there are substrates consisting of sand, mud, cobble, and gravel. Essential fish habitat for juvenile blue erabs includes bottom habitats along the nearshore where there are rocky areas with shell hash, and along the continental shelf where there are roek, cobble, and gravel substrates. For adults, EFH ineludes bottom habitats along the shelf where there are sand and mud substrates adjacent to roekier areas and areas of shell hash (i.c., a mixture of sand or mud with gravel and/or unconsolidated broken shell). For late juvenile golden king erabs, EFH ineludes bottom habitats along the slope and basins where there are high-relief living habitats (e.g., coral) and vertical substrates. For adults, EFH includes similar bottom habitats along the outer shelf, slope, and basins. Golden crabs are found at depths from 650 to greater than 10,000 feet. Tanner crabs and snow erabs select 
mud habitats along the ocean floor along the inner, middle, and outer continental shelf. For late juvenile and adult tanner and snow crabs, EFH includes bottom habitats along the continental shelf where there are substrates that consist mainly of mud.

There is insufficient information for weathervane scallops to determine EFH for egg through early juvenile life stages. In general, eggs ean be found in the inner and middle continental shelf regions, from 1 to 325 feet in depth, and on the ocean bottom. Larvae are found in the inner, middle, and outer continental shelf regions within the water column (off the bottom). Late juveniles and adults are found on the sea floor of the middle and outer continental shelf at depths of 160 to 650 feet and where there are substrates of elay, mud, sand, and gravel. There is insufficient information to describe EFH for pink, spiny, and rock scallops.

\section{Effects of the Proposed Action on Coastal Pelagic Fish, Alaska Crab, and Alaska Scallop Species EFH}

Dredging in coastal waters, dredge material disposal, oil and gas exploration and production, aquaculture, wastewater discharge, discharge of oil or release of hazardous substances, and coastal development were identified as important nonfishing effects on coastal pelagic fish, and Alaska crab and scallop species EFH in their respective FMPs. Impacts to coastal pelagic fish, and Alaska crab and seallop species from proposed BLM vegetation treatments would be similar to those described for groundfish.

\section{Cumulative Effects to EFH}

Because the three herbicides assessed in this EFH are being added to an existing vegetation management program (which was covered in the 2007 BA and associated EFH Assessment; USDOI BLM 2007a), BLM-administered lands receiving treatments with the three new herbicides could also receive other types of vegetation treatments, including treatments with other approved herbicides, manual treatments, mechanical treatments, fire, and biological control. In some eases, a combination of treatment types may be used in concert to achieve a desired effect (e.g., preseribed fire followed by post-burn herbicide treatment). Therefore the cumulative effects of multiple treatment methods on salmon speeies should be considered when designing treatment projects at the local level. The conservation measures identified in the $2007 \mathrm{BA}$ and associated EFH Assessment pertinent to other treatment methods or treatments with the previously approved herbieides would continue to be implemented. Additionally, general conservation measures for herbicide treatments would apply to treatments with aminopyralid, fluroxypyr, and rimsulfuron.

In addition to effects from BLM vegetation treatments, EFH can be impacted by other activities occurring in upland, riverine, estuarine, and marine/coastal habitats that are usually of greater concern to the welfare of estuarine, coastal, and marine organisms than BLM vegetation treatment activities. These include: nonpoint source pollution; urban/suburban development; road building and maintenance; mining; dam operation; commercial and domestic water use; dredging; vessel operation; pile driving and removal; overwater structures; flood control and shoreline protection; water control structures; log transfer facilities; utility line/cables/pipeline installation; commercial utilization of habitat; point source discharge; fish processing waste; water intake structures; habitat restoration; and introduction of exotic species. These effects are summarized in Non-fishing Impacts to Essential Fish Habitat and Recommended Conservation Measures (NMFS 2003) and The Fishery Management Plan for the Groundfish Fishery of the Bering Sea/Aleutian Islands Area (NMFS 2005) and references cited therein, and are summarized below.

Nonpoint source pollution sources include agricultural runoff, timber harvest, and pesticide application. Adverse effects to EFH from agricultural and nursery runoff include nutrient loading, introduction of animal wastes, erosion, and sedimentation. Nutrient contamination can impact water quality that can result in the destruction of habitat and loss of fish. Erosion and sedimentation can impact water quality and clog and harm the gills of fish and interfere with their feeding behaviors. Timber harvest removes vegetation and converts mature forest stands to 
early seral stages. It also alters fish habitat, reduces soil permeability, increases erosion and sedimentation, alters hydrologic regimes, and impairs fish passage in areas with poorly-designed fish passage structures.

More than 800 different pesticides are registered for use in the U.S., and pesticide residues are frequently detected in freshwater and estuarine systems that provide EFH. Pesticides can adversely affect EFH through direct toxicological impact on the health of fish, indirect impairment of the productivity of aquatic systems, and loss of vegetation that provides habitat for fish.

Urban growth primarily affects EFH through loss of riparian and shoreline habitat and vegetation and from runoff. Loss of vegetative cover can increase stream temperatures and decrease the amount of protective habitat for fish, while runoff can impact water quality and fish health, as discussed above. Road building and maintenance can affect aquatic habitats by increasing rates of natural processes such as debris slides or landslides and sedimentation, introduce exotic species, alter channel configuration, introduce migration barriers such as culverts, and degrade water quality.

Mining can cause adverse modification of hydrologic conditions so as to cause erosion, removal of substrates that serve as habitat for fish and their prey, conversion of habitats and loss of vegetation, alteration of channel morphology, release of harmful or toxic materials, and increase in turbidity. Surface mining, in particular, can be particularly damaging to EFH, as it can climinate vegetation, permanently alter topography and soil and subsurface geological structurc, and disrupt surface and subsurface hydrologic regimes. Erosion for surface mining is a major threat to salmon in the western U.S. Marine mining in the Bering Sea and elsewhere can destroy habitat and significantly affect the removal, transport, and deposition of sand and gravel along shore. Mining can inerease water turbidity and affect less motile life stages of fish.

Oil and natural gas activities occur along the California and Alaska coasts and have the potential to cause pollution of habitats, loss of resources, and alteration of quality and quantity of habitats. Physical alterations to local habitats can occur because of the site and construction of offshore drilling rigs and platforms, loading platforms, or pipelines. Large oil spills can damage marine and coastal habitats, making them unsuitable for eggs, larvae, and juvenile fish and as spawning and rearing habitat. Large and chronic small oil spills can build up in sediments and affect marine resources. Disposal of drilling muds, fluids, and cuttings into the water and seabed, and dredged materials from pipeline laying or facility construction can degrade EFH.

Dams serve as impediments to anadromous fish migration, alter water flow and quality, reduce downstream water velocities and change current patterns, introduce thermal impacts, and limit sediment and woody debris transport. Withdrawal of water for commercial and domestic consumption can affect EFH by altering flows and the process associated with flow rates, affecting shoreline riparian habitats, affecting prey bases, affecting water quality, and entrapping fish. Loss of vegetation along streambanks due to fluetuating water levels can decrease fish cover and reduce bank stability.

Dredging can impact marine EFH by overburdening and covering marine habitats and organisms, destroying productive habitat, and increasing water turbidity. Dredging can also release contaminants in marine soils, including nutrients, metals, and organics, which can harm fish.

Routine vessel traffic, discharges, and accidents are potential threats to EFH. Grounding or sinking of vessels with hazardous eargo, such as oil tankers, can foul thousands of square miles of habitat. Large vesscls grounding in shallow water ean harm habitat, such as eelgrass, when the propeller is used to break free. Boat propellers can impact fish and fish habitat by killing or harming fish, resuspending sediments, and increasing turbidity. Vessels often discharge debris, sewage, and other wastes that can pollute the water and harm fish.

Pile driving ean generate intense underwater sound pressure waves that may adversely affect the ecological function of EFH. These pressure waves can kill or injure fish. Pile driving can harm habitat, and pilc removal can resuspend sediments, which may result in harmful levels of turbidity and release of contaminants contained in those sediments. 
Overwater structures primarily affect EFH by changing ambient light conditions, altering the wave and current energy regime, and through activities associated with the use and operation of structures. Shading by structures affects both plant and animal communities, and the distribution of plants, invertebrates, and fishes have been found to be severely limited in under-dock environments as compared to unshaded environments. Overwater structures provide perching platforms for avian predators. Structures can alter currents and adjacent substrates, and the flora and fauna found adjacent to the structure.

The protection of riverine and estuarine areas from flooding can change the physical, chemical, and biological characteristics of shoreline and riparian habitat. The use of dikes and berms can have long-term adverse effects in tidal marsh and estuarine habitats by cutting off tributaries feeding the marsh and preventing freshwater flushing. Other effects include subsidence, loss of estuarine habitat as these habitats are flooded by freshwater, and loss of use by marine organisms.

Water control structures, such as pump stations and tidegates, regulate water levels in nearshore and estuary arcas. These struetures can block fish and other aquatic organisms from accessing habitat, alter water ehemistry through suppressed mixing of fresh and saltwater, decrease sediment transport, and degrade water quality through thermal loading.

Estuaries and bays are used to store logs in Alaska and the Paeific Northwest. Logs can degrade water and modify habitat. Storage of logs may result in the release of soluble, organic compounds. Bark from logs may affect fish by increasing oxygen demand within the area of bark accumulation. Leaching of soluble organic compounds also leads to cumulative oxygen demand and reduced visibility. Accumulations of bark and other wood components can pile up on the ocean floor, degrade habitat, and harm organisms.

Utility line/cables/pipelinc installation can adversely affect EFH by destroying organisms and habitat, inercasing the turbidity of waters, resuspending sediments and contaminants, and causing changes in hydrology. Avoiding sensitive habitats and taking the most direct route across estuarics or marine environments can reduce impacts to marinc organisms.

Commercial utilization of habitat, including mariculture, ean adversely affect EFH because of over-enrichment of water and benthic habitat by uncaten food, feces, or other organic materials. Aecumulations on the bottom can create anaerobic conditions near mariculture sites and degrade foraging arcas for juvenile salmon and other fish. Fish processing waste from shoreside and vessel processing has occurred in marine waters since the $1800 \mathrm{~s}$, and impacts marine environments by degrading water quality. Fish parts that are ground to fine particles and become suspended can foul water and, over time, accumulate. Juvenile and adult fish are often drawn to these areas as food sources.

Point source discharges from municipal sewage treatment facilities or stormwater discharges are regulated by the U.S. Environmental Protection Ageney's mandated regulations under the Clean Water Act and by state water regulations. However, point source discharges can adversely affect EFH by reducing habitat quality and modifying plant and aquatic organism community structure. Discharges can also harm aquatic organism health, growth, survival, and behavior. Discharges are of particular coneern in sensitive aquatic communities, such as eelgrass and kelp beds, and where discharges cause scouring.

The withdrawal of riverine, estuarine, and marine waters by water intake structures is a common aquatic activity. Adverse impacts to EFH from water intake structures and effluent discharges occurs through entrainment, impingement, discharge, operation and maintenance, and construction-related activities. Egg and larval stages of aquatic organisms are most susceptible to entrainment in water withdrawn for cooling, agriculture, or other uses. Large organisms can become impinged, or stuck in intake structure screening devices. Discharges of warm water can harm aquatic organisms or their habitats

The introduction of exotic species into estuarine and marine habitats has resulted from industrial shipping, recreational boating, aquaculture, biotechnology, and aquariums. Some introductions have been intentional (for 
pest control) and others have been unintentional. Impacts from non-native speeies inelude habitat alternation, trophic alteration, gene pool alteration, spatial alteration, and introduction of diseases. Non-native plants and algae are of particular eoneern because they ean displaee or preelude the growth of native species and make habitats unsuitable for native fish.

\section{Conservation Measures}

The BLM would eontinue to follow the conservation measures listed in the 2007 BA and EFH Assessment, or other comparable eonservation measures that would be developed by the field offices based on loeal site conditions and included in the loeal-level consultation. Conservation measures were developed as part of the EFH Assessment for the 2007 vegetation treatments projeet (which ean be found in Appendix A of the 2007 BA). General conservation measures for all herbicide treatments would be applieable for use of aminopyralid, fluroxypyr, and rimsulfuron. A list of these general measures is presented at the end of this seetion. These conservation measures were identified to reduee adverse effects to salmonids, pelagic fish and groundfish, Alaskan erabs and scallops, and their habitat to the point where these adverse effeets do not reduee the quantity or quality of EFH.

Given the low toxieity of the three new herbicides to aquatie speeies, likely uses of the herbieides, and SOPs for minimizing the risk of spills into aquatic habitats, no new eonservation measures have been developed for herbicide treatments using aminopyralid, fluroxypyr, or rimsulfuron. No buffers to proteet fish and aquatie organisms from direet effects from the herbicides have been identified. However, if these aetive ingredients are used in a tank mixture or formulation that ineludes previously approved active ingredients, any applieable buffers for proteeting EFH species would apply. Additionally, the BLM has SOPs that include minimum buffers widths for aquatie habitats ( 100 feet for aerial spraying, 25 feet for ground applications by vehicle, and 10 feet for hand spray applieations; see Appendix A of the BA), which would also apply.

Riparian areas referenced in the following conservation measures inelude traditional riparian eorridors, wetlands, intermittent streams, and other areas that help maintain the integrity of aquatie ecosystems by 1) influencing the delivery of coarse sediment, organie matter, and woody debris to streams, 2) providing root strength for channel stability, 3) shading the stream, and 4) proteeting water quality. Estuarine and coastal marine EFH of partieular eoneern is described above for groundfish, pelagie fish, erabs, and seallops.

\section{Key Conservation Measures from 2007 EFH Assessment}

- Establish riparian, estuarine, and coastal buffer strips adjaeent to salmonid, groundfish and pelagic fish, and Alaskan erab and seallop habitats to reduee direet impacts to the various life stages of these speeies. Buffer widths should depend on the specific eeological function for which protection is desired (e.g., streambanks stabilization, control of sediment inputs from surface erosion, or maintenance of shade to stream channels). Loeal BLM field offiees would consult ERAs prepared for the BA and PEIS to obtain programmatic guidanee on appropriate buffer distances.

- Implement SOPs to minimize sedimentation and disturbance of riparian, estuarine, and coastal vegetation.

- To avoid erosion and future recreational uses within close vieinity of aquatie areas, limit or exelude construction of new permanent or temporary roads within the boundary of treatment riparian areas.

\section{Measures Specific to Herbicide Treatments}

- Where feasible, minimize spray operations around aquatie habitats to days when winds are greater than 10 miles per hour for ground applications, and greater than 6 miles per hours for aerial applications, to avoid wind drift or direct application of herbieides into these habitats.

- Where feasible, minimize the use of aminopyralid, fluroxypyr, and rimsulfuron in watersheds with downgradient ponds and streams if potential impaets to salmonids are of coneern. 
- Time herbicide applications near salmonid-bearing streams, and estuaries and coastal/marine habitats used by salmon and FMP species so that they do not overlap with sensitive life-history stages of these fish (would vary at the local level).

\section{Conclusion}

Based on completed EFH consultations at the project level for similar activities, the BLM anticipates that the proposed action would be Not Likely to Adversely Affect EFH for shellfish, crustaceans, groundfish, and/or pelagie species (i.e., marine stocks) of EFH-identified species. Herbicide treatments with aminopyralid, fluroxypyr, and rimsulfuron would oceur inland, and would not impact any nearshore or marine habitats. Although the groundfish EFH includes the upriver extent of saltwater intrusion in river mouths along the Pacific Coast, no public lands are located within these regions.

Based on the ERAs, the only seenarios by which any of the three herbicides would potentially have adverse effects on EFH species are a spill of fluroxypyr directly into aquatic habitats. Following SOPs for handling, transport, and use of these chemicals would help minimize the risk of an aceidental spill or direct spray into aquatic habitats. The conservation measures discussed in this chapter would further reduce the potential risks to aquatic habitats associated with using these herbicides. As a result, with application of these SOPs and conservation measures, the action would be Not Likely to Adversely Affect EFH at the programmatic level. Given BLM mandates for use of integrated pest management (including vegetation management), and given that it is not possible to foreeast sitespecific vegetation management needs below the programmatic level, additional evaluations of situation-specific effects will be the subject of step-down EFH evaluations and subsequent consultations. In this manner, any additional specific conservation measures necessary to accommodate site or situation-specific peculiarities not predictable at the programmatic level will be developed and applied prior to local implementation of herbicide treatment activities. 


\section{Bibliography}

AECOM. 2014a. Aminopyralid Ecological Risk Assessment Final Report. Prepared for the USDOI BLM. Manchester, New Hampshire.

- 2014b. Fluroxypyr Eeologieal Risk Assessment Final Report. Prepared for the USDOI BLM. Manchester, New Hampshire.

. 2014c. Rimsulfuron Eeologieal Risk Assessment Final Report. Prepared for the USDOI BLM. Manchester, New Hampshire.

Bell, M.C. 1986. Fisheries Handbook of Engineering Requirements and Biological Criteria. U.S. Army Corp of Engineers, Offiee of the Chief Engineers, Fish Passage Development and Evaluation Program, Portland, Oregon. In An Eeosystem Approaeh to Salmonid Conservation (B.C. Spence, G.A. Lomnicky, R.M. Hughes, and R.P., Novitzki, Editors). TR-4501-96-6057. Management Technology. Portland, Oregon.

Beschta, R.L., J.R. Boyle, C.C. Chambers, W.P. Gibson, S.V. Gregory, J. Grizzel, J.C. Hagar, J.L. Li, W.C. McComb, M.L. Reiter, G.H. Taylor, and J.E. Warila. 1995. Cumulative Effeets of Forest Praetiees in Oregon. Oregon State University, Corvallis. Prepared for the Oregon Department of Forestry. Salem, Oregon.

Bjornn, T.C., and D.W. Reiser. 1991. Habitat Requirements of Salmonids in Streams. Ameriean Fisheries Society Special Publication 19:83-138. Bethesda, Maryland.

Burgner, R.L. 1991. Life History of Soekeye Salmon, Oncorhynchus nerka. Pages 3-117 in Pacific Salmon Life Histories (C. Groot and L. Margolis, Editors). UBC Press. Vaneouver, B.C., Canada.

Dolloff, C.A. 1983. Effects of Stream Cleaning on Juvenile Coho Salmon and Dolly Varden in Southeast Alaska. Transactions of the American Fisheries Society 115:743-755.

ENSR. 2004. Vegetation Treatments Programmatie EIS Eeologieal Risk Assessment Methodology. Prepared for the USDOI BLM, Nevada State Offiee, Reno, Nevada. Westford, Massachusetts.

Groot, C., and L. Margolis (Editors). 1991. Paeifie Salmon Life Histories. UBC Press. Vancouver, B.C., Canada.

Gustafson, R.G., T.C. Wainwright, G.A. Winans, F.W. Waknitz, L.T. Parker, and R.S. Waples. 1997. Status Review of Soekeye Salmon from Washington and Oregon. U.S. Department of Commeree, NOAA Technical Memorandum NMFS-NWFSC-33. Seattle, Washington.

Hard, J.J., R.G. Kope, W.S. Grant, F.W. Waknitz, L.T. Parker, and R.S. Waples. 1996. Status Review of Pink Salmon from Washington, Oregon, and California. U.S. Department of Commeree, NOAA Teehnical Memorandum NMFS-NWFSC-25. Seattle, Washington.

Healey, M.C. 1991. Life History of Chinook Salmon, Oncorhynchus tshawytscha. Pages 311-394 in Pacific Salmon Life Histories (C. Groot and L. Margolis, eds.). UBC Press. Vancouver, B.C., Canada.

Heard, W.R. 1991. Life History of Pink Salmon, Oncorhynchus gorbuscha. Pages 119-230 in Pacific Salmon Life Histories (C. Groot and L. Margolis, Editors). UBC Press. Vancouver, B.C., Canada.

House, R.A., and P.L. Boehne. 1986. Effeets of Instream Enhancement Structures for Salmonid Spawning and Rearing in a Coastal Oregon Stream. North American Journal of Fisheries Management 6:283-295. 
Iwamoto, R.N., E.O. Salo, M.A. Madej, and R.L. McComas. 1978. Sediment and Water Quality: A Review of the Literature Including a Suggested Approach for Water Quality Criteria. USEPA 910/9-78-048. U.S. Environmental Protection Agency, Region X. Seattle, Washington.

Laufle, J.C., G.B. Pauly, and M.F. Shepard. 1986. Species Profile: Life Historics and Environmental Requirements of Coastal Fishes and Invertebrates (Pacific Northwest): Coho Salmon. U.S. Fish and Wildlife Service Biological Report 82(11.48).

Meehan, W.R., and T.C. Bjornn. 1991. Salmonid Distributions and Life Histories. American Fisheries Society Special Publication 19:47-82. Bethesda, Maryland.

Myers, J.M., R.G. Kope, G.J. Bryant, D. Teel, L.J. Lierheimer, T.C. Wainwright, W.S. Grant, F.W. Waknitz, K. Neely, S.T. Lindley, and R.S. Waples. 1998. Status Review of Chinook Salmon from Washington, Idaho, Oregon, and California. U.S. Department of Commerce, NOAA Technical Memorandum NMFS-NWFSC-35. Seattle, Washington.

National Fire Plan Technical Team. 2002. Criteria For At-risk Salmonids: National Fire Plan Activities. Version 2.1. Washington, D.C.

National Marine Fisheries Service (NMFS). 2005. Final Environmental Impact Statement for Essential Fish Habitat Identification and Conservation in Alaska. United States Department of Commerce National Oceanic and Atmospheric Administration National Marine Fisheries Service Alaska Region. Anchorage, Alaska.

. 2012. Status of ESA Listings and Critical Habitat Designations for West Coast Salmon and Steelhead. Available at: http://www.nwr.noaa.gov/protected species/species list/species_lists.html. Seattle, Washington.

Neilson, J.D., and C.E. Banford. 1983. Chinook Salmon (Oncorhynchus tshawytscha) Spawner Characteristics in Relation to Redd Physical Features. Canadian Journal of Zoology 6I:1254-153I.

Norris, L.A., H.W. Lorz, and S.V. Gregory. 1991. Forest Chemicals. Pages 207-296 in Influence of Forest and Rangeland Management on Salmonid Fishes and Their Habitats. Special Publication 19 (W.R. Meehan, Editor). American Fisherics Society, Bethesda, Maryland.

North Pacific Fishery Management Council. 2006. Fishery Management Plan for the Scallop Fishery off Alaska. Anchorage, Alaska.

. 2011a. The Fishery Management Plan for Bering Sea/Aleutian Islands King and Tanner Crabs. Anchorage, Alaska.

2011b. The Fishery Management Plan for the Groundfish of the Gulf of Alaska. Anchorage, Alaska.

2011c. Fishery Management Plan for Groundfish of the Bering Sea and Aleutian Islands Management

Area. Anchorage, Alaska.

2012. Fishery Management Plan for the Salmon Fisheries in the EEZ off Alaska. Anchorage, Alaska.

- 2013. North Pacific Fishery Management Council Home Page. Available at: http://www. fakr.noaa.gov/npfmc. Anchorage, Alaska. 
Pacific Fishery Management Council. 1999. Appendix A: Identification and Deseription of Essential Fish Habitat, Adverse Impacts and Recommended Conservation Measures for Salmon. Amendment 14 to the Pacific Coast Salmon Plan. Portland, Oregon.

2011a. Coastal Pelagic Species Fishery Management Plan, As Amended Through Amendment 13. Portland, Oregon.

. 2011b. Pacific Coast Groundfish Fishery Management Plan for the California, Oregon and Washington Groundfish Fishery. Portland, Oregon.

. 2011c. Fishery Management Plan for U.S. West Coast Fisheries for Highly Migratory Species. Portland, Oregon.

. 2012. Pacific Coast Salmon Fishery Management Plan for Commercial and Recreational Salmon Fisheries off the Coasts of Washington, Oregon and California As Revised Through Amendment 16. Portland, Oregon.

Phillips, R.W., and H.J. Campbell. 1961. The Embryonic Survival of Coho Salmon and Steelhead Trout as Influenced by Some Environmental Conditions in Gravel Beds. Pages 60-73 in $14^{\text {th }}$ Annual Report of the Pacific Marine Fisheries Commission. Portland, Oregon.

Salo, E.O. 1991. Life History of Chum Salmon, Oncorhynchus keta. Pages 233-309 in Pacific Salmon Life Histories (C. Groot and L. Margolis, Editors). UBC Press. Vancouver, B.C., Canada.

Sandercock, F.K. 1991. Life History of Coho Salmon, Oncorhynchus kisutch. Pages 395-445 in Pacific Salmon Life Histories (C. Groot and L. Margolis, Editors). UBC Press. Vancouver, B.C., Canada.

Spence, B.C., G.A. Lomnicky, R.M. Hughes, and R.P. Novitzki. 1996. An Ecosystem Approach to Salmonid Conservation, TR-4501-96-6057. Management Technology. Portland, Oregon.

Thompson, K. 1972. Determining Stream Flows for Fish Life. Pages 31-50 in Proceedings, Instream Flow Requirements Workshop. Pacific Northwest River Basins Commission. Vancouver, Washington.

U.S. Department of Agriculture Forest Service. 2002. Biological Assessment for the Implementation of the Preferred Alternatives for the Sierra Nevada Forest Plan Draft Environmental Impact Statement. Pacific Southwest Region. Vallejo, California.

U.S. Department of the Interior Bureau of Land Management. 2007a. Vegetation Treatments using Herbicides on Bureau of Land Management Lands in 17 Western States Programmatic Environmental Impact Statement. DES-05-56. Reno, Nevada.

- 2007b. Record of Decision for Vegetation Treatments Using Herbicides on Bureau of Land Management Lands in 17 Western States Programmatic Environmental Impact Statement. Washington, D.C.

- 2007c. Final Vegetation Treatments on Bureau of Land Management Lands in 17 Western States Programmatic Environmental Report. Washington, D.C.

. 2007d. Biological Assessment for Vegetation Treatments on Burcau of Land Management Lands in 17 Western States. Washington, D.C. 



\section{ACRONYMS, ABBREVIATIONS, AND SYMBOLS}

\begin{tabular}{ll} 
ACEC & Area of Critical Environmental Concern \\
ALS & Acetolactate synthase \\
ATV & All-terrain vehicle \\
BA & Biological assessment \\
BLM & Bureau of Land Management \\
CALPUFF & California Puff \\
CERCLA & Comprehensive Environmental Response, \\
CFR & Compensation and Liahility Act \\
CNHP & Code of Federal Regulations \\
CNPS & Calorado Natural Heritage Program Native Plant Society \\
DO & Dissolved oxygen \\
DPS & Distinct Population Segment \\
EEZ & Exclusive economic zone \\
EFH & Essential Fish Habitat \\
ERA & Ecological Risk Assessment \\
ESA & Endangered Species Act \\
ESU & Evolutionarily Significant Unit \\
FFRA & Federal fnsecticide, Fungicide, and Rodenticide Act \\
FMP & Fishery Management Plan \\
FR & Federal Register \\
Ft/s & Footfeet per second \\
GIEAMS & Groundwater Loading Effects of Agriculturat \\
HAPC & Management Systems \\
L & Habitat areas of particular concern \\
LOC & Liter \\
LWD & Lavel of Concern \\
mg & Milligram(s) \\
mg/L & Milligram(s) per Liter \\
mph & Miles per hour \\
MSA & Magnuson-Stevens Fishery Conservation and \\
& Management Act \\
\hline
\end{tabular}

\begin{tabular}{|c|c|}
\hline MSDS & Material safety data sheets \\
\hline MSO & Methylated seed oil \\
\hline NA & Not applicable or not available \\
\hline NEPA & National Environmental Policy Act \\
\hline NMFS & $\begin{array}{l}\text { National Oceanic and Almospheric } \\
\text { Administration National Marine Fisheries } \\
\text { Service }\end{array}$ \\
\hline NOAA & $\begin{array}{l}\text { Nationat Oceanic and Atmospheric } \\
\text { Administration }\end{array}$ \\
\hline NRCS & Natural Resources Conservation Service \\
\hline $\mathrm{OHV}$ & Off-highway vehicle \\
\hline PEIS & $\begin{array}{l}\text { Programmatic Environmental Impact } \\
\text { Statement }\end{array}$ \\
\hline PER & Programmatic Environmental Report \\
\hline POEA & Polyoxyethyleneamine \\
\hline ppm & Parts per miltion \\
\hline RCRA & Resource Conservation and Recovery Act \\
\hline ROD & Record of Decision \\
\hline Row & Right-of-way \\
\hline RQ & Risk quotient \\
\hline SOP & Standard operating procedure \\
\hline TEP & $\begin{array}{l}\text { Threatened, endangered, and proposed fo } \\
\text { listing }\end{array}$ \\
\hline U.S.C. & United States Code \\
\hline USDA & U.S. Department of Agriculture \\
\hline USDOI & U.S. Department of the Interior \\
\hline ISEPA & U.S. Environmental Protection Agency \\
\hline Usfws & U.S. Fish and Wildlife Service \\
\hline USGS & U.S. Geological Survey \\
\hline UTV & Utility vehicle \\
\hline WDFW & $\begin{array}{l}\text { Washington Department of Fish and } \\
\text { Wildlife }\end{array}$ \\
\hline$F$ & Degrees Fahrenheit \\
\hline
\end{tabular}






\section{Bureau of Land Management Forest, Rangeland, Riparian, and Plant Conservation Division, WO-220 1849 C Street, NW, Room 2134 LM Washington, DC 20240 202-912-7226 \\ Website address: http://b/m.gov/3vkd}

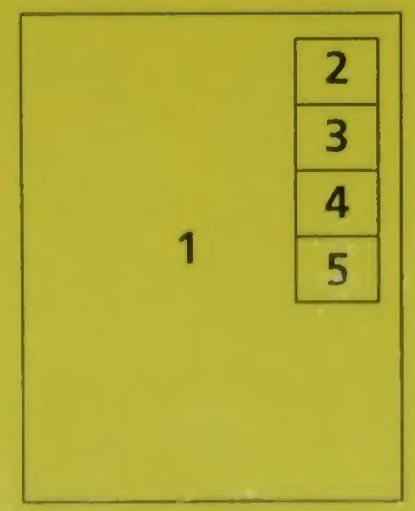

Cover photos and photo credits:

1. Red Canyon near Lander, Wyoming. Photo by Aaron Thompson, BLM.

2. Aerial spraying of mesquite in New Mexico. Photo by Eddy Williams (retired), BLM.

3. Spraying herbicide on salt cedar near the Dolores River in Utah.

4. Aerial spraying of leafy spurge at Bennett Peak, Wyoming. Photo by Ken Henke, BLM.

5. Mule sprayer at Goose Creek, Litah. Photo by Gordon Edwards, High Country Sprayers. 